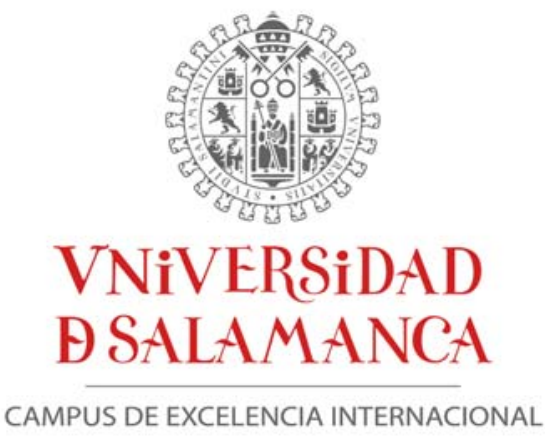

\title{
EL TRÁFICO DE PRECURSORES DE DROGAS TÓXICAS, ESTUPEFACIENTES Y SUSTANCIAS PSICOTRÓPICAS
}

TESIS DOCTORAL

\author{
Autor \\ ANÍBAL RÍOS MONTERREY \\ Director \\ EDUARDO A. FABIÁN CAPARRÓS
}

Salamanca, 2017 





\section{PRIMERA PARTE \\ ASPECTOS DE ORDEN ADMINISTRATIVO Y FENOMENOLÓGICO DEL TRÁFICO DE PRECURSORES DE DROGAS TÓXICAS, ESTUPEFACIENTES Y PSICOTRÓPICOS}

\section{CAPÍTULO I \\ LEGISLACIÓN INTERNACIONAL, SUPRANACIONAL Y NACIONAL DE LOS PRECURSORES DE DROGAS Y FISCALIZACIÓN INTERNACIONAL DE ESTAS SUSTANCIAS}

I. LEGISLACIÓN INTERNACIONAL

A.) Convenio de VIENA DE 20 DE DiCIEMBRE DE 1988 ............................................................ 3

II. ESTADO DE LA APLICACIÓN Y FUNCIONAMIENTO DE LA LEGISLACIÓN INTERNACIONAL EN MATERIA DE VIGILANCIA Y CONTROL DEL COMERCIO DE PRECURSORES DE DROGAS

A) MEDIDAS ADOPTADAS PARA LA FISCALIZACIÓN DE LOS PRECURSORES DE DROGAS ................. 10

1. Adhesión a la Convención ........................................................................................... 10

2. Presentación de informes a la Junta ................................................................................ 11

3. Presentación de datos sobre el comercio lícito ........................................................... 12

B.) PREVENCIÓN DE LA DESVIACIÓN .......................................................................................... 14

1. Notificaciones previas a la exportación ............................................................................ 14

2. Sistema de Comunicación de incidentes relacionados con precursores ................. 16

3. Actividades en el marco de la fiscalización internacional de precursores .............. 17

4. Necesidades legítimas anuales de importación de precursores de estimulantes de tipo anfetamínico .................................................................................................. 24

5. Medidas legislativas..................................................................................................... 26

6. La colaboración voluntaria con la industria química y la lista limitada de vigilancia especial internacional de las sustancias no incluidas en los cuadros 33

C.) LEGISLACIÓN SUPRANACIONAL DE LA UNIÓN EUROPEA............................................................. 40

1. El comercio de sustancias catalogadas de los Estados miembros a terceros 40 
países (extracomunitario)

2. El comercio de sustancias catalogadas entre Estados miembros de la Unión Europea (intracomunitario)

3. Estado de la aplicación y funcionamiento de la legislación comunitaria en materia de vigilancia y control del comercio de precursores de drogas

D.) REgLAMENTO MODELO PARA EL CONTROL DE SUSTANCIAS QUÍMICAS QUE SE UTILIZAN EN LA FABRICACIÓN ILÍCITA DE ESTUPEFACIENTES (OEA)

III. LEGISLACIÓN NACIONAL

A.) ANTECEDENTES DE LA REGULACIÓN ADMINISTRATIVA DEL TRÁFICO DE PRECURSORES DE DROGAS

B.) LEY 3/1996, SOBRE MEDIDAS DE CONTROL DE SUSTANCIAS QUÍMICAS CATALOGADAS, SUSCEPTIBLES DE DESVÍO PARA LA FABRICACIÓN ILÍCITA DE DROGAS

C.) LEY 4/2009, DE 15 DE JUNIO, DE CONTROL DE PRECURSORES DE DROGAS

\section{CAPÍTULO II}

LOS PRECURSORES DE DROGAS Y LAS MEDIDAS DE CONTROL ADOPTADAS SOBRE LAS SUSTANCIAS CATALOGADAS QUE SE UTILIZAN EN LA ELABORACIÓN DE LA COCAÍNA Y LA HEROÍNA

I. PRECURSORES QUE SE UTILIZAN EN LA ELABORACIÓN DE DROGAS ILÍCITAS Y SU PROCESO DE FABRICACIÓN

A.) SUSTANCIAS QUÍMICAS QUE SE USAN EN LA FABRICACIÓN DE DROGAS ILÍCITA ......................... 93

B.) EL PROCESO DE ELABORACIÓN DE DROGAS ILÍCITAS ........................................................... 106

1. El proceso de elaboración de la cocaína.............................................................................. 107

2. El proceso de elaboración de la heroína .......................................................................... 111

3. El proceso de elaboración de anfetamina y la metanfetamina .................................. 115

4. $\quad$ El proceso de elaboración del MDMA y otras sustancias análogas ........................... 118

5. Dosis callejeras de drogas fabricadas ilícitamente utilizando sustancias catalogadas (precursores)

II. PRECURSORES QUE SE EMPLEAN EN LA FABRICACIÓN ILÍCITA DE LA COCAÍNA Y LA HEROÍNA

A.) PRECURSORES QUE SE EMPLEAN EN LA FABRICACIÓN ILÍCITA DE LA COCAÍNA ........................... 121

B.) PRECURSORES UTILIZAdoS EN LA FABRICACIÓN ILÍCITA DE HERoÍNA ….................................. 145

C.) OTROS ÁCIDOS Y DISOLVENTES INCLUIDOS EN EL CUADRO II DEL CONVENIO DE 1988 .......... 174

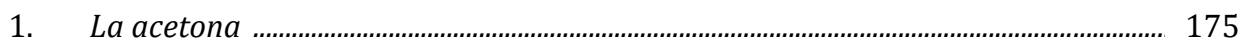

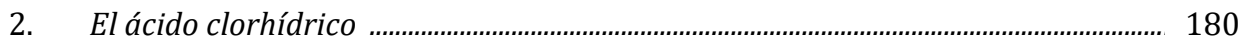

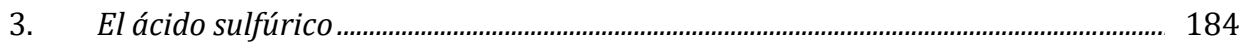

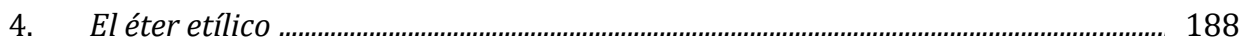

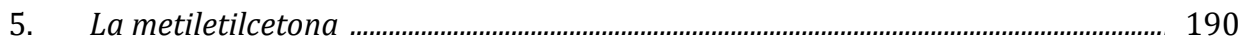

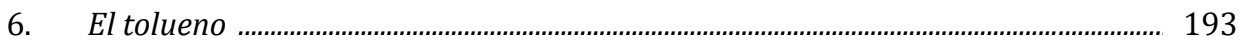




\section{CAPÍTULO III \\ PRECURSORES QUE SE EMPLEAN EN LA FABRICACIÓN ILÍCITA DE LOS ESTIMULANTES DE TIPO ANFETAMÍNICO}

I. PRECURSORES UTILIZADOS EN LA FABRICACIÓN ILÍCITA DE ESTIMU-

LANTES DE TIPO ANFETAMÍNICO (ETA ).

A.) PRECURSORES QUE SE EMPLEAN EN LA ELABORACIÓN DE ANFETAMINA Y METANFETAMINA (ANFETAMinAS)

1. Efedrina y seudoefedrina .................................................................................................. 204

2. Especial referencia a la efedra ............................................................................................... 238

3. Norefedrina ............................................................................................................. 243

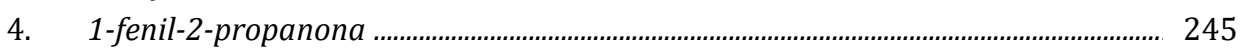

5. Ácido fenilacético ......................................................................................................... 263

B.) PRecursores que Se utilizan para Elaborar MDMA (Éxtasis), MDA (TENAmFeTAMINA O PÍLDORA DEL AMOR), MDE (EVA) Y N-HIDROXI-MDA (HIDROXILAMINA) .......... 275

1. 3,4-metilendioxifenil-2-propanona ................................................................................ 275

2. Safrol (sus derivados) y el isosafrol ........................................................................... 288

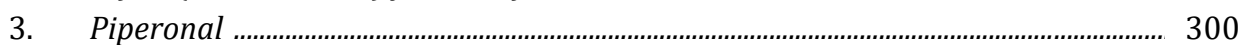

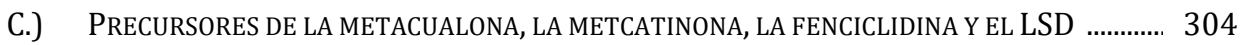

1. Precursores de la metacualona y la metcatinona .......................................................... 304

2. $\quad$ Precursores de la fenciclidina ........................................................................................ 309

3. Precursores del LSD (ergotamina, ergometrina y ácido lisérgico) ............................. 311

II. INCAUTACIONES DE PRECURSORES REALIZADAS EN ESPAÑA ............................ 317

III. MÉTODOS UTILIZADOS POR LOS NARCOTRAFICANTES PARA EL DESVÍO DE PRECURSORES DE DROGAS TÓXICAS, ESTUPEFACIENTES Y PSICOTRÓPICOS

\section{SEGUNDA PARTE \\ PENALIZACIÓN DEL DELITO DE TRÁFICO DE PRECURSORES DE DROGAS \\ CAPÍTULO IV BIEN JURÍDICO, DELITOS COLECTIVOS Y TRÁFICO DE PRECURSORES}

I. FUNCIÓN EXCLUSIVA DE PROTECCIÓN DE BIENES JURÍDICOS 333

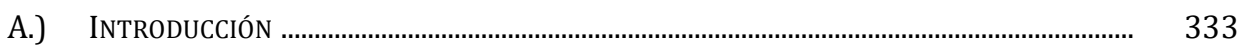

1. Las funciones del bien jurídico penal ........................................................................ 344

2. La evolución histórica del bien jurídico en la teoría del delito .............................. 346 
B.) ANÁLISIS DEL FUNCIONALISMO SISTÉMICO

1. El funcionalismo sistémico de Amelung a Jakobs ....................................................... $\quad 355$

2. Algunas reflexiones sobre la dañosidad social ...................................................... 366

C.) SOBRE LA FUENTE DEL BIEN JURÍDICO ……................................................................ 372

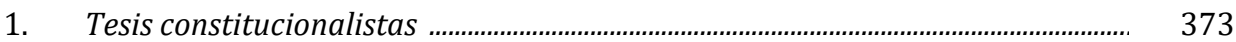

2. El constitucionalismo estricto .............................................................................. 376

3. El constitucionalismo amplio ............................................................................ 380

4. Tesis sociológicas ................................................................................................. 386

5. $\quad$ Toma de postura sobre la fuente del bien jurídico ................................................... $\quad 390$

II. LOS BIENES JURÍDICOS COLECTIVOS ...................................................................... 392

A.) LA TUTELA DE LOS BIENES JURÍDICOS COLECTIVOS ............................................................... 394

1. Sobre la expansión del Derecho Penal mediante la protección de nuevos bienes jurídicos colectivos ........................................................................................... $\quad 399$

2. Valoración sobre la legitimidad de los bienes jurídicos colectivos ........................ 409

III. TOMA DE POSTURA …….......................................................................................... 414

IV. EL BIEN JURÍDICO PROTEGIDO EN EL TRÁFICO DE DROGAS TÓXICAS, ESTUPEFACIENTES Y PSICOTRÓPICOS ................................................................. 424

A.) LA SALUD PÚBLICA ….................................................................................................. 425

B.) OtRas Posturas SOBRE EL BIEN JURÍdico PROTEGIDO EN EL DELITO DE TRÁFICO DE

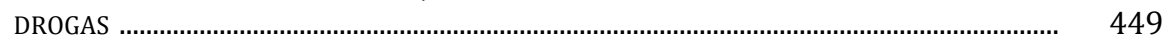

C.) ALGUNAS REFLEXIONES SOBRE LA LUCHA CONTRA EL TRÁFICO DE DROGAS ........................ 453

V. EL BIEN JURÍDICO PROTEGIDO EN EL DELITO TRÁFICO DE PRECURSORES DE DROGAS TÓXICAS ESTUPEFACIENTES Y SUSTANCIAS PSICOTRÓPICAS

\section{CAPÍTULO V LOS DELITOS DE PELIGRO}

I. INTRODUCCIÓN

A.) APROXIMACIÓN A LOS DELITOS DE PELIGRO ……............................................................... 473

B.) LOS DELITOS DE PELIGRO EN EL DERECHO PENAL MODERNO ............................................. 478

C.) LOS DELITOS CONTRA LA SEGURIDAD COLECTIVA COMO DELITOS DE RIESGO GENERAL ...... 488

II. EL CONCEPTO DE PELIGRO ................................................................................... 492

A.) TEORÍAS SUBJETIVAS. CONCEPCIÓN DEL PELIGRO COMO JUICIO ............................................ 494

B.) TEORÍAS OBJETIVAS …………..................................................................................... 497

C.) EL CONCEPTO NORMATIVO DEL PELIGRO _........................................................................ 499

III. EL DOLO DE PELIGRO _....................................................................................... 507 
IV. EL DESVALOR DE ACCIÓN Y EL DESVALOR DE RESULTADO EN LOS DELITOS DE PELIGRO .

V. LOS DELITOS DE PELIGRO CONCRETO ..

VI. LOS DELITOS DE PELIGRO ABSTRACTO …............................................................. 523

A.) NoCIÓN SOBRE LOS DELITOS DE PELIGRO ABSTRACTO ......................................................... 523

1. Esfuerzos doctrinales por dotar de legitimidad a los delitos de peligro abstracto

2. $\quad$ Posturas favorables a la expansión de los delitos de peligro abstracto .............. $\quad 559$

3. Crítica al uso indiscriminado de los delitos de peligro abstracto ........................... 567

VII. EL TRÁFICO DE PRECURSORES DE DROGAS COMO DELITO DE PELIGRO ABSTRACTO

\section{CAPITULO VI \\ PENALIZACIÓN DEL TRÁFICO DE PRECURSORES}

I. INTRODUCCIÓN

II. ANÁLISIS DE LOS ELEMENTOS DEL TIPO ……........................................................ 593

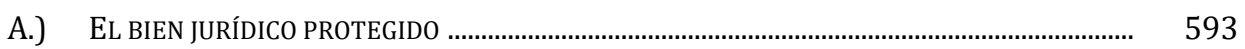

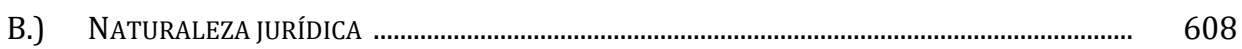

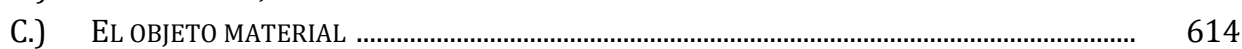

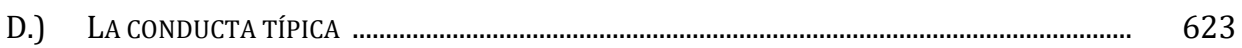

E.) EL DOLO Y EL ELEMENTO SUBJETIVO DEL INJUSTO ............................................................. 633

F.) EL ERROR EN EL DELITO DE TRÁFICO DE PRECURSORES DE DROGAS .................................. 645

G.) FORMAS DE IMPERFECTA REALIZACIÓN ……................................................................ $\quad 648$

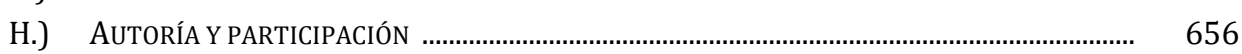

III. LA PENALIDAD .................................................................................................. 667

A.) PENA PRIVATIVA DE LIBERTAD ......................................................................................... 667

B.) DETERMINACIÓN DE LA CUANTÍA DE LA PENA DE MULTA .................................................... 685

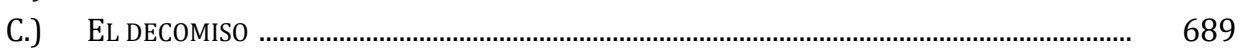

D.) PRELACIÓN EN PAGO ……….................................................................................. 692

IV. OTRAS DISPOSICIONES DEL CÓDIGO PENAL RELACIONADAS CON EL TRÁFICO DE PRECURSORES ................................................................................. 692

A.) LA PROVOCACIÓN, LA CONSPIRACIÓN Y LA PROPOSICIÓN …………………........................ 692

B.) LA REINCIDENCIA INTERNACIONAL ................................................................................ 697

C.) COLABORACIÓN CON LA JUSTICIA …………...................................................................... 698

D.) LA CIRCULACIÓN O ENTREGA VIGILADA DE DROGAS O DE SUS PRECURSORES ....................... 701

E.) EL AGENTE ENCUBIERTO _............................................................................................. $\quad 705$ 
V. CONCURSO CON OTROS DELITOS

A.) CONCURSO CON EL TRÁFICO DE DROGAS

B.) PERTENENCIA A ORGANIZACIÓN O GRUPO CRIMINAL

C.) REPRESIÓN DEL CONTRABANDO DE PRECURSORES DE DROGAS

CONCLUSIONES

BIBLIOGRAFÍA

ÍNDICE DE JURISPRUDENCIA

ANEXOS

- ANEXo I: Ley 4/2009, DE 15 DE JUNIO, DE CONTROL DE PRECURSORES DE DROGAS ....... 789

- ANEXO II: USO DE SUSTANCIAS INCLUIDAS EN LOS CUADROS PARA LA FABRICACIÓN ILÍCITA DE ESTUPEFACIENTES Y SUSTANCIAS PSICOTRÓPICAS

- ANEXo III: INCAUTACIONES DE PRECURSORES DE LOS CUADROS I Y II REALIZADAS EN ESPAÑA DEL AÑO 1993 AL AÑO 2014

- ANEXo IV: Sustancias Catalogadas

- Anexo V: Sustancias no Catalogadas Que SE Utilizan EN la Elaboración DE DROGAS ILÍCITAS 
ACP: $\quad$ Antiguo Código Penal

ADPCP: Anuario de Derecho Penal y Ciencias Penales

APAAN: alfa-fenilacetoacetonitrilo

BGH: Tribunal Supremo Federal alemán

Bger: Tribunal Federal suizo

BMK: 1-fenil-2-propanona o fenilacetona

BOE: Boletín Oficial del Estado

BtMG: Ley de Estupefacientes alemana

BVefG: Tribunal Constitucional Federal alemán

CE: $\quad$ Comunidad Europea

CEE: Comunidad Económica Europea

CGPJ: Consejo General del Poder Judicial

CICAD: Comisión Interamericana para el Control del Abuso de Drogas

CNE: Consejo Nacional de Estupefacientes

CP: $\quad$ Código Penal

CPE: Código penal español

DEA: Administración para el Control de Drogas (USA)

ESDD: Estado social y democrático de Derecho

ETA: Estimulantes de tipo anfetamínico

GBH: gamma-hidroxbutírico

GBL: gamma-butirolactona

Interpol: Organización Internacional de Policía Criminal

JIFE: Junta Internacional de Fiscalización de Estupefacientes

Junta: Junta Internacional de Fiscalización de Estupefacientes

LECrim: Ley de Enjuiciamiento Criminal 
LO: $\quad$ Ley Orgánica

LORC: Ley Orgánica de Represión del Contrabando

l-PAC: l-fenilacetilcarnibiol

LSD: Dietilamina del ácido lisérgico

MDA: Tenamfetamina o píldora del amor

MDE: 3,4-metilendioxietilamfetamina o Eva

MDEA: 3,4-metilendioxietilamfetamina o Eva

MDMA: 3,4-metilendioxi metanfetamina o Éxtasis

MEC: Metiletilcetona o butanona

MEK: Metiletilcetona o butanona

MIBK: Metilisobutilcetona

NC: $\quad$ Nombre común

N-hidroxi-MDA: Hidroxilamina

NSP: $\quad$ Nuevas sustancias psicotrópicas

OEA: Organización de Estados Americanos

OEDT: Observatorio Europeo para las Drogas y las Toxicomanías

OLAF: Oficina Europea de Lucha contra el Fraude

OMS: Organización Mundial de la Salud

ONU: Organización de las Naciones Unidas

ONUDD: Oficina de Naciones Unidas contra la Droga y el Delito

PCP: $\quad$ Fenciclidina

PEN Online: Sistema electrónico de intercambio de notificaciones previas a la exportación

PICS: $\quad$ Sistema de Comunicación de Incidentes relacionados con Precursores

PMK: 3,4-metilendioxifenil-2-propanona

PNUFID: Programa de Naciones Unidas para la Fiscalización Internacional de Drogas

P-1-P: 1-fenil-1-propanona 
P-2-P: 1-fenil-2-propanona o fenilacetona

ROJ: $\quad$ Repertorio Oficial de Jurisprudencia

SAARC: Asociación del Asia Meridional para el Desarrollo

SADC: Comunidad del África Meridional para el Desarrollo

SAN: $\quad$ Sentencia de la Audiencia Nacional

SAP: $\quad$ Sentencia de la Audiencia Provincial

SMG: $\quad$ Ley de Estupefacientes de Austria

STC: $\quad$ Sentencia del Tribunal Constitucional

StGB: Código Penal alemán

StPO: Código Procesal Penal alemán

STS: $\quad$ Sentencia del Tribunal Supremo

TDI: Diisocianato de tolueno

THC: Tetrahidrocannabinol

UE: Unión Europea

UNODC: Oficina de las Naciones Unidas contra la Droga y el Delito

USA: Estados Unidos de América

2C-B: 4-bromo-2,5-dimetoxifeniletilamina

3,4-MDP-2-P: 3,4-metilendioxifenil-2-propanona 



\section{INTRODUCCIÓN}

Quiero iniciar este trabajo diciendo que soy de Nicaragua, un país con muy poca tradición jurídica donde lamentablemente los gobernantes tienen por costumbre retorcer el Derecho a su gusto y antojo, utilizando generalmente el Derecho Penal como un arma para manipular o sacar del juego político a sus adversarios, así como para mantener en muchas ocasiones un estado de cosas injustas e indeseables para el pueblo. Con el ánimo de salir de ese círculo vicioso y de realizar una pequeña aportación para que esto no siguiera ocurriendo - o, mejor dicho, para que al menos sucediera a niveles tolerables-, vine a Salamanca para estudiar Derecho Penal.

Una vez terminado el periodo docente del doctorado, mi Director de tesis, Eduardo Fabián Caparrós, me sugirió que trabajara el delito de tráfico de precursores de drogas, tema que él había tratado en su etapa de doctorando cuando escribió su excelente artículo "Consideraciones de urgencia sobre la Ley Orgánica 8/1992, de 23 de diciembre, de modificación del Código Penal y de la Ley de Enjuiciamiento Criminal en materia de tráfico de drogas" en el año 1993. Quiero expresar que para mí trabajar este acto preparatorio del artículo 368 Código Penal elevado a la categoría de delito autónomo - que, asombrosamente, después de la reforma operada a través de la Ley Orgánica 5/2010 del 22 de junio, es sancionado con la misma pena privativa de libertad del ilícito que le da vida - me pareció desde el principio una excelente idea, pues a pesar de proteger un bien jurídico de suma importancia, como lo es la salud pública, es fuertemente cuestionado por un sector importante de la doctrina española por el notable adelantamiento que supone de la barrera de intervención penal y por no cumplir con la concepción dualista del injusto.

Esta tesis se encuentra dividida en dos partes. La primera de ellas trata del análisis de los aspectos fenomenológicos y de la legislación administrativa de los precursores de drogas, y se desarrolla en los capítulos I, II y III. En ellos tratamos de dimensionar el problema que verdaderamente representa el tráfico de precursores de drogas en la fabricación ilícita de la cocaína, la heroína y los estimulantes de tipo anfetamínico a nivel mundial, regional y nacional. Además, analizamos el nivel de fiscalización que se realiza sobre los precursores de drogas por 
mandato de la Convención de Naciones Unidas celebrada en Viena en el mes de diciembre de 1988, así como las diferentes normas que ha adoptado la Unión Europea para evitar el desvío de precursores y de las medidas nacionales que se han llevado acabo para hacerle frente a este problema destacando en este sentido la Ley 4/2009, de 15 de junio, de control de precursores de drogas. También intentamos establecer en esta parte del trabajo los métodos que utilizan los traficantes de precursores para desviar estas sustancias de los canales lícitos de comercio tanto nacionales como internacionales, así como aquellos que usan para elaborar ellos mismos estas sustancias catalogadas utilizando otras sustancias químicas no sometidas a fiscalización, o bien la sustitución de los precursores por estas últimas, poniendo de relieve la importancia que supone en los últimos años el uso de "sustancias químicas diseñadas por encargo" de los fabricantes de drogas a empresas lícitas para evadir las medidas de fiscalización.

Sobre la primera parte del trabajo queremos subrayar que desde que se inició el enfrentamiento al tráfico de precursores de drogas, hace casi tres décadas, los instrumentos de que disponen los gobiernos son cada vez mejores y lo suficientemente sencillos para que puedan ser utilizados por todas las autoridades nacionales competentes. Sin embargo, nunca se ha logrado su aplicación de forma homogénea, ya que los Estados o territorios más pobres o menos desarrollados -de hecho, regiones enteras- están quedando rezagadas en su utilización, lo que provoca que el alcance de las medidas de fiscalización de estas sustancias catalogadas diste mucho de ser mundial. Esta situación es aprovechada por los traficantes de precursores para desarrollar sus actividades con muy poca dificultad en las regiones donde las medidas de control son prácticamente inexistentes o muy débiles. De hecho, pese a todo el esfuerzo que se realiza a nivel mundial, haciendo uso del ordenamiento penal, del administrativo sancionador y de una parte muy importante de todos los recursos de los cuerpos y fuerzas de seguridad, sólo se logra confiscar anualmente en torno al 15\% de los precursores que se utilizan para la elaboración de la cocaína y la heroína, y el $20 \%$ de los estimulantes de tipo anfetamínico. Nosotros pensamos que la importancia que tienen estas sustancias en la fabricación ilícita de drogas se evidencia en que los traficantes llegan a pagar por ellas, en lugares cercanos a los laboratorios ilícitos, hasta 277 veces su precio en el mercado lícito. Tal es el caso del anhídrido acético, que el litro que cuesta aproximadamente un dólar y medio en USA se ha llegado a pagar en Afganistán hasta por 416 dólares. 
En el caso de España, queremos destacar que los 14 millones de kilogramos de precursores incautados desde la aprobación del delito de tráfico de precursores de drogas en el ordenamiento penal, hace 24 años, podrían haber sido utilizados para la elaboración de drogas tóxicas, estupefacientes y psicotrópicos en cantidades muy importantes, fundamentalmente de cocaína, heroína, anfetamina, metanfetamina, metcatinona, fenciclidina, MDMA (éxtasis) y sustancias análogas como MDA (tenamfetamina o píldora del amor), MDE (Eva), $N$-hidroxi-MDA (Hidroxilamina), así como de otros precursores de drogas tales como el ácido fenilacético, el isosafrol, el piperonal, la P-2-P y la 3,4-MDP-2-P, sustancias que son esenciales en la elaboración de las drogas antes citadas. A tenor de la cantidad de precursores decomisados hasta la fecha - y partiendo de la optimista premisa de que se incauta en torno al $20 \%$ del total de las sustancias catalogadas que se desvían del comercio lícito-, se estima que el tráfico ilícito de precursores mensual en España podría ser de aproximadamente de 265.000 kilogramos, y por ende, el de 3.181.000 kilogramos al año, siendo los precursores que más se desviarían los siguientes: el tolueno, el ácido sulfúrico, la acetona, la metiletilcetona, el éter etílico, el anhídrido acético, el permanganato de potasio, el ácido clorhídrico, la efedrina, el piperonal y el APAAN. De todos estos datos cabe derivar la gran envergadura del problema, tanto para los cuerpos y fuerzas de seguridad, como para el poder judicial y sobre todo para el poder legislativo de cara a poder plantearse la descriminalización de las conductas previstas en el artículo 371 del Código Penal. Añádase a ello España está obligada a sancionar penalmente estas conductas cuando se cometan de forma dolosa con la finalidad de elaborar drogas ilícitas, en la medida en que es Estado Parte del Convenio de Viena de 1988, de obligado cumplimiento.

La segunda parte de la tesis trata los aspectos dogmáticos del tráfico de precursores (capítulos IV, V y VI). En el capítulo IV procuramos determinar si el bien jurídico salud pública, en el caso de este ilícito, tiene la suficiente entidad para su tutela en el ámbito del ordenamiento penal, aunque la posibilidad de lesionar o menoscabar el bien jurídico salud pública resulte más distante que en los delitos relativos al tráfico de drogas -elaboración o fabricación de drogas ilícitas y más aún de su tráfico propiamente dicho- en atención al principio de estricta protección de bienes jurídicos y de su correlato el principio de ofensividad, así como de otros principios y criterios informadores del Derecho Penal o si por el contrario esta protección se puede realizar recurriendo exclusivamente al Derecho Administrativo. Debe recordarse, en cual- 
quier caso, que el tráfico de estas sustancias catalogadas que derive de la imprudencia o del mero incumplimiento de normas de carácter administrativo se encuentra sancionado por la Ley 4/2009, de 15 de junio, de control de precursores de drogas. Posteriormente, en el capítulo $\mathrm{V}$ intentamos establecer la legitimidad de los delitos de peligro abstracto, analizando los distintos grupos de casos que comprende esta técnica de adelantamiento de la barrera punitiva. Particularmente tratamos de determinar si la incorporación de los elementos subjetivos adicionales al artículo 371 Código Penal "a sabiendas de" que van a utilizarse en el cultivo, la producción o la fabricación ilícitas de drogas tóxicas, estupefacientes o sustancias psicotrópicas, o "para estos fines" justifica su protección mediante esta técnica de tutela anticipada. En este sentido, queremos puntualizar que en el caso de la tenencia o fabricación de precursores de drogas que se utilizan para la elaboración de las drogas de diseño, donde no hacen falta sustancias naturales como la hoja de coca o las cápsulas verdes de la adormidera para elaborar cocaína o heroína, tales como la efedrina, seudoefedrina, la P-2-P o la 3,4-MDP-2$\mathrm{P}$, el ácido lisérgico o la piperidina, la posibilidad de menoscabo del bien jurídico salud pública, más aún si está se realiza en emplazamientos cercanos a los laboratorios o en los propios laboratorios donde se fabricara la droga, parece un poco menos distante, pues equivale a tener la materia prima (principal) para elaborar anfetamina, metanfetamina, éxtasis, LSD o fenciclidina, dado que sólo hace falta realizar unos procedimientos bastantes sencillos con equipos muy rudimentarios y otras sustancias químicas para obtener dichas drogas.

Se trata por tanto de determinar si deben castigarse penalmente, o si deben sancionarse en el ámbito del Derecho Administrativo, conductas tales como el desvío de 12.000 kilogramos de permanganato de potasio del comercio internacional (cantidad con la que podrían fabricarse un total de 58.000 kilogramos de clorhidrato de cocaína), realizada por tres sujetos de nacionalidad española que utilizaron para su adquisición una sociedad anónima en trámites de constitución, de la cual dos de los tres sujetos eran sus gestores, efectuando el enmascaramiento de este precursor de drogas en 355 bidones de dióxido de manganeso (sustancia no catalogada) y su posterior envío a Colombia, todo esto a sabiendas de que el permanganato de potasio se utilizaría por un cartel colombiano para la elaboración de clorhidrato de cocaína.

En el capítulo VI abordamos el estudio de parte objetiva y subjetiva del delito de tráfico de drogas, así como el de otras disposiciones del Código Penal relacionados con este ilícito. En éste, procuramos esclarecer 
algunos aspectos muy importantes del delito de tráfico de precursores de drogas tales como si deben subsumirse en el artículo $371 \mathrm{CP}$, en atención al principio de legalidad, las conductas que consistan en fabricar, transportar, distribuir, comerciar o tener en su poder "equipos y materiales" a sabiendas de que van a utilizarse en el cultivo, la producción o la fabricación ilícita de drogas tóxicas, estupefacientes o psicotrópicos o para estos fines o si la redacción del tipo nos remite únicamente a las 24 sustancias catalogadas enumeradas en los Cuadros I y II del Convenio de Viena del 20 de diciembre de 1988, con sus respectivas actualizaciones, así como si en este delito que sólo admite su comisión de forma dolosa puede admitirse esta en la modalidad de dolo eventual.

También intentamos establecer si es legítimo apreciar casos de tentativa en este delito, así como la posibilidad de estimar casos de cooperación no necesaria (complicidad y encubrimiento) en el mismo, al tenor del artículo 29 del Código Penal. Además analizamos la viabilidad de apreciar casos de error tanto de tipo como de prohibición, particularmente cuando el error no se refiera a la calificación especifica de la sustancia, sino a su ilegalidad, es decir cuando se trate de sustancias que no son de conocimiento notorio que sean precursores de drogas, siempre que las circunstancias del hecho y las personales del autor no permitan inferir racionalmente que se actuaba con conciencia de la ilicitud de su conducta, lo cual podría ocurrir posiblemente de forma excepcional, con algunas sustancias recién incorporadas en los Cuadros de la Convención de Viena de 1998 como ha podido suceder en el caso del alfa-fenilacetoacetonitrilo más conocido como APAAN que fue agregado en el Cuadro I en el mes de octubre de 2014, con productos naturales como la efedra de la cual se extrae la efedrina, con el acetite de sasafrás con el cual se elabora el safrol o bien con precursores enmascarados en otras sustancias no catalogadas tal es el caso de la 3,4-MDP-2-P camuflada en 3,4-MDP-2-P glicidato de metilo o bien de la P-2-P enmascarada en bisulfito P-2-P o bisulfito (BMK).

Un aspecto de sumo interés que abordamos en este capítulo es la falta de proporcionalidad de las penas establecidas para este ilícito en relación con la lesividad de las conductas que la generan, pues una cosa es elevar un acto preparatorio del delito de tráfico de drogas a la categoría de delito autónomo, ya sea para darle cumplimiento a un compromiso internacional o bien por razones de política criminal, y otra muy distinta es equiparar este en pena al delito que le da vida. Ante esto realizamos una propuesta de reforma de las penas previstas en el deli- 
to de tráfico de precursores de drogas, así como de la redacción del mismo para que se puedan sancionar a las personas jurídicas, propuesta que en nuestra opinión cumpliría con lo dispuesto en la Decisión Marco 2004/757/JAI del Consejo, de 24 de octubre, tanto en lo relativo a la sanción de estos comportamientos cuando tales conductas se lleven a cabo en el seno de una organización criminal como para poder castigar a las personas jurídicas por su responsabilidad en tales hechos.

Una vez señalados algunos de los aspectos principales que se estudian en esta tesis como corresponde concluyo esta breve introducción dándole las gracias al profesor Eduardo Fabián Caparrós, mi director de tesis quien siempre me ha brindado su apoyo académico y su amistad. Al profesor Ignacio Berdugo Gómez de la Torre por todas sus enseñanzas, sobre todo por enseñarme a dudar, y a todos los profesores del área de Derecho Penal y del programa de Doctorado Estado de Derecho y Buen Gobierno por su magisterio. Finalmente quiero también expresar mi agradecimiento a la Agencia Española de Cooperación Internacional, institución que hizo posible que yo viniera a estudiar a España y a la Universidad de Salamanca quien me concedió una beca de alojamiento en el Colegio Mayor de Oviedo. 


\section{ASPECTOS DE ORDEN}

ADMINISTRATIVO Y FENOMENOLÓGICO

DEL TRÁFICO DE PRECURSORES DE DROGAS TÓXICAS, ESTUPEFACIENTES Y PSICOTRÓPICOS 

CAPÍTULO I

\section{LEGISLACIÓN INTERNACIONAL, SUPRANACIONAL Y NACIONAL DE LOS PRECURSORES DE DROGAS Y FISCALIZACIÓN INTERNACIONAL DE ESTAS SUSTANCIAS}

\section{LEGISLACIÓN INTERNACIONAL}

A) Convenio de Viena de 20 de diciembre de 1988

Como todos sabemos, la obligación de adoptar medidas, tanto de carácter administrativo como penal, con el objetivo de controlar que los denominados precursores de drogas no sean desviados para la fabricación ilegal de drogas viene impuesta de forma internacional por el Convenio de Naciones Unidas contra el tráfico ilícito de estupefacientes y sustancias psicotrópicas, firmado en Viena el 20 de diciembre de 1988 (Convención de Viena) ${ }^{1}$, del que España es parte, al igual que la mayoría de países del mundo (189 países o territorios de 198 existentes), por lo cual en los últimos 28 años el legislador español se ha visto abocado a la tarea de ajustar la legislación interna a las disposiciones

\footnotetext{
Es preciso recordar que antes que la Convención de Viena de 1988 regulara de forma especifica el tráfico de precursores de drogas otros acuerdos ya habían apuntado la necesidad de su desarrollo normativo en el ordenamiento jurídico interno de los países firmantes. El primero de ellos fue la Convención Única de Naciones Unidas de 1961 sobre estupefacientes que en el párrafo número 8 de su artículo número 2 disponía: "las partes harán todo lo posible para aplicar las medidas, que sean factibles a las sustancias no sujetas a las disposiciones de esta Convención, pero que puedan ser utilizadas para la fabricación ilícita de sustancias psicotrópicas". En el mismo sentido el Convenio de Viena de 1971 sobre sustancias psicotrópicas recomendaba en el párrafo número 9 de su artículo número 2 que "las partes harán todo lo posible para aplicar las medidas de supervisión que sean factibles a las sustancias no sujetas a las disposiciones de este Convenio, pero que puedan ser utilizadas para la fabricación ilícita de sustancias psicotrópicas". Para ver el proceso de construcción de un Régimen internacional contra las drogas ilegales. GALÁN PACHÓN, Juan. GUERRERO, Lech Julián. “La legalización de las drogas ilícitas en Colombia: elementos para una discusión" en La batalla perdida contra las drogas: ¿legalizar es la opción?. GALÁN, Juan Manuel. THOUMI, Francisco. RAMÍREZ, William. VARGAS, Ricardo. Ed. Intermedio Editorial Ltda. Bogotá. 2008, pp. 62- 82.
} 
de dicho Convenio, así como al cumplimiento de las Directivas y Reglamentos de la Unión Europea sobre este tema.

La preocupación internacional que existía, y aún perdura, sobre esta cuestión propició que en la Convención de Naciones Unidas anteriormente citada, se impusiera en su artículo 3.1 a los Estados parte la obligación de sancionar penalmente la fabricación, el transporte y la distribución de los denominados precursores (materiales, equipos y sustancias indispensables para el cultivo, producción y fabricación ilícita de estupefacientes o sustancias psicotrópicas) enumerados en el Cuadro I y II de este Convenio siempre que estas conductas se cometieran a sabiendas de que van a utilizarse en el cultivo, la producción o la fabricación ilícitos de estupefacientes o sustancias sicotrópicas o para dichos fines. Debiendo aclararse que en los Cuadros antes citados no aparecen materiales ni equipos, así como que de las 24 sustancias catalogadas como precursores ninguna se utiliza en el cultivo de drogas ilícitas. En su artículo 12 esta Convención establece los mecanismos para ampliar o modificar las listas de sustancias, la cual puede impulsarse a instancia de las partes o bien de la Junta Internacional de Fiscalización de Estupefacientes (JIFE).

Hay que destacar que el artículo 3.1 del Convenio en su inciso c) pide sancionar penalmente, siempre a reserva de los principios constitucionales y de los conceptos fundamentales del ordenamiento jurídico de las partes, la posesión de las sustancias enumeradas en los Cuadros I y II, las conductas consistentes en instigar o inducir públicamente a otros, por cualquier medio, a cometer el delito de tráfico de precursores de drogas, así como la asociación y la confabulación para cometerlos, la tentativa de cometerlos, y la asistencia, la incitación, la facilitación o el asesoramiento en relación con su comisión. Además hay que señalar que en su artículo 3.5 el Convenio establece que las partes dispondrán lo necesario para que sus tribunales y demás autoridades jurisdiccionales competentes puedan tener en cuenta las circunstancias de hecho que den particular gravedad a la comisión de los delitos tipificados de conformidad con el párrafo $\mathrm{l}$, del presente artículo, tales como: a) la participación en el delito de un grupo delictivo organizado del que el delincuente forme parte; b) la participación del delincuente en otras actividades delictivas internacionales organizadas; c) la participación del delincuente en otras actividades ilícitas cuya ejecución se vea facilitada por la comisión del delito; d) el recurso a la violencia o el empleo de armas por parte del delincuente; e) el hecho de que el delincuente ocupe un cargo público y de que el delito guarde relación con 
ese cargo, f) la victimización o utilización de menores de edad, g) el hecho de que el delito se haya cometido en establecimientos penitenciarios, en una institución educativa o en un centro asistencial o en sus inmediaciones o en otros lugares a los que escolares y estudiantes acudan para realizar actividades educativas, deportivas y sociales, y h) una declaración de culpabilidad anterior, en particular por delitos análogos, por tribunales extranjeros o del propio país, en la medida en que el derecho interno de cada una de las "partes" lo permita.

En la legislación europea se aprobó la Decisión Marco 2004/757/JAI del Consejo, de 25 de octubre de 2004, relativa al establecimiento de disposiciones mínimas de los elementos constitutivos de delitos y las penas aplicables en el ámbito del tráfico ilícito de drogas. Esta norma contiene las bases a partir de las cuales debe confeccionarse una legislación nacional que responda con eficacia al problema del tráfico de drogas y de precursores de drogas, sabiendo que corresponde a cada Estado de la Unión Europea la potestad de incrementar, si lo considera necesario, las previsiones contenidas en esta norma comunitaria. Hay que destacar que el concepto de "precursores" que nos proporciona la Decisión Marco es más restringida que la que ofrece la Convención de 1988 y por ende el artículo 371 del Código Penal español, pues sólo se refiere a las 24 sustancias catalagodas en los Cuadros I y II de la Convención, excluyendo los materiales y equipos que deberían estar enumerados en dichos cuadros. Es preciso señalar que el artículo 3.1 de la Decisión Marco impone la obligación a todos los Estados de tipificar como delito la inducción, la complicidad o la tentativa del tráfico de precursores de drogas. En el artículo 4 se dispone que se castigue el delito de tráfico de sustancias catalogadas con pena privativa de libertad de uno a tres años como mínimo y de cinco a diez años, también como mínimo, cuando el delito se haya cometido dentro de una organización delictiva. Sobre las sanciones establecidas por la Decisión Marco a las personas jurídicas, hay que decir que estas no se pueden aplicar en el ordenamiento penal español, debido a un fallo en la redacción del artículo $371^{2}$. cada Estado debe adaptar, hubiera sido deseable discriminar entre los actos de tráfico de drogas y los actos de tráfico de precursores de drogas, fijando para estos últimos un techo penal más bajo en atención a la menor gravedad objetiva de las conductas. FABIÁN CAPARRÓS, Eduardo A. "El tráfico ilícito de drogas en el derecho de la Unión Eu- 
El órgano sobre el cual recae la responsabilidad de decidir sobre la modificación de las listas de precursores es la Comisión de Estupefacientes del Consejo Económico y Social de Naciones Unidas, que después de considerar las recomendaciones que le hagan las partes, así como las recomendaciones de la JIFE, cuyos dictámenes serán determinantes en el ámbito científico, resolverá (con una mayoría de dos tercios de sus miembros) sobre la incorporación de una sustancia al Cuadro I o al Cuadro II, o bien sobre su supresión o el cambio de categoría de alguna sustancia de un Cuadro a otro ${ }^{3}$.

El artículo 12.6 de la Convención de 1988 establece que "toda decisión que tome la Comisión de conformidad al presente artículo será notificada por el Secretario General a todos los Estados y otras entidades que sean partes en la presente Convención o puedan llegar a serlo y a la Junta. Tal decisión surtirá pleno efecto respecto de cada una de las partes a los 180 días de la fecha de notificación". Dentro de este plazo las decisiones adoptadas por la Comisión estarán sujetas a revisión por el Consejo, el cual podrá confirmar o revocar la decisión de la Comisión, notificándose la decisión del Consejo, finalmente, además a los Estados y territorios partes en la Convención o que puedan llegar a serlo, a la Comisión y a la JIFE.

La primera lista de precursores, o lista original, que se estableció en el Convenio de Viena de $1988^{4}$ es la siguiente:

\begin{tabular}{|l|l|}
\hline \multicolumn{1}{|c|}{ CUADRO 1 } & \multicolumn{1}{c|}{ CUADRO 2 } \\
\hline Ácido lisérgico & Acetona \\
\hline Efedrina & Ácido antranílico \\
\hline Ergometrina & Ácido fenílacetico \\
\hline Ergotamina & Anhídrido acético \\
\hline
\end{tabular}

ropea. Comentario a la Decisión Marco 2004/757/JAI del Consejo, de 25 de octubre de 2004, relativa al establecimiento de disposiciones mínimas de los elementos constitutivos de delitos y las penas aplicables en el ámbito del tráfico ilícito de drogas" en $R e$ vista General de Derecho Europeo n.ำ 7, iustel.com. Mayo de 2005, pp. 2-8.

3 Como ejemplo de ello podemos citar el caso de anhídrido acético y el permanganato potásico que fueron trasladados del Cuadro II al Cuadro I de la Convención de 1988 con efectividad del 8 de diciembre de 2008 o a la reciente incorporación del APAAN al Cuadro I en el mes de octubre del año 2014.

4 Convenio de Viena del 20 de diciembre de 1988, pp. 28, 29. 


\begin{tabular}{|l|l|}
\hline 1-Fenil 2-Propanona & Éter etílico \\
\hline Seudoefedrina & Piperidina \\
\hline $\begin{array}{l}\text { Así como las sales de las sustancias enumeradas en ambos cuadros, siempre } \\
\text { que la existencia de dichas sales sea posible. }\end{array}$ \\
\hline
\end{tabular}

La JIFE dándole cumplimiento a su labor de actualización de las sustancias controladas publicó la modificación de productos químicos que conforman los Cuadros I y II del Convenio de Viena de 1988 en el mes enero del año 2015. Decimocuarta edición de la "Lista Roja" 5:

\begin{tabular}{|l|l|}
\hline \multicolumn{1}{|c|}{ CUADRO I } & \multicolumn{1}{c|}{ CUADRO II } \\
\hline Ácido $N$-acetilantranílico & Acetona \\
\hline Ácido lisérgico & Ácido antranílico \\
\hline Anhídrido acético & Ácido clorhídrico \\
\hline Efedrina & Ácido sulfúrico \\
\hline Ergometrina & Éter etílico \\
\hline Ergotamina & Metiletilcetona \\
\hline 1-fenil-2-propanona & Piperidina \\
\hline Isosafrol & Tolueno \\
\hline 3,4-metilendioxifenil-2-propanona & \\
\hline Norefedrina & \\
\hline Permanganato potásico & \\
\hline Piperonal & \\
\hline Safrol & \\
\hline Seudoefedrina & \\
\hline Ácido fenilacético ${ }^{6}$ & \\
\hline Alfa-fenilacetoacetonitrilo & \\
\hline
\end{tabular}

$5 \quad$ Lista de precursores y sustancias químicas utilizadas frecuentemente en la fabricación ilícita de estupefacientes y sustancias sicotrópicas sometidos a fiscalización internacional. Ed. Junta Internacional de Fiscalización. Viena, Austria. 2015.

$6 \quad$ El ácido fenilacético pasó del Cuadro II al Cuadro I de la Convención de 1988 el día 17 de enero del año 2011. Precursores y productos químicos frecuentemente utilizados para la fabricación ilícita de estupefacientes y sustancias sicotrópicas. Informe de la Junta Internacional de Fiscalización de Estupefacientes correspondiente a 2010 sobre la aplicación del artículo 12 de la Convención de Naciones Unidas contra el Tráfico Ilícito de Estupefacientes y Sustancias Sicotrópicas de 1988. JUNTA INTERNACIONAL DE FISCALIZACIÓN DE ESTUPEFACIENTES. Ed. United Nations Publication. New York. 2011, p. 1. 
Así como las sales de las sustancias enumeradas en ambos cuadros, siempre que la existencia de dichas sales sea posible. Las sales del ácido clorhídrico y del ácido sulfúrico quedan específicamente excluidas del Cuadro II.

Como se puede apreciar, la lista original de precursores ha aumentado notablemente en los últimos 28 años, pasando de las 12 sustancias originales hasta 24 que son objeto de control en la actualidad.

Queremos destacar por la importancia de su contenido el artículo 5.7 del Convenio de Viena de 1988, que versa sobre el decomiso de los materiales, equipos y otros instrumentos que estén destinados a ser utilizados en la producción de drogas ilegales y establece que "cada una de las partes considerara la posibilidad de invertir la carga de la prueba respecto del origen ilícito del supuesto producto u otros bienes sujetos a decomiso, en la medida en que ello sea compatible con los principios de su Derecho interno y con la naturaleza de sus procedimientos judiciales y otros procedimientos". Este artículo pone de manifiesto que la internacionalización en la lucha contra el comercio ilícito de narcóticos, como bien afirma Hans-Jorg Albrecht, se ha caracterizado por: un cambio en los supuestos clásicos de la responsabilidad penal que está lejos de ocuparse de la afección de bienes jurídicos, cuya consecuencia inmediata es la proliferación de los delitos de peligro abstracto y la introducción de sanciones que se desvinculan de la responsabilidad a título de culpa y que imponen la inversión de la carga de la prueba, o bien la pura responsabilidad a título de peligro ${ }^{8}$.

Como ya señalamos anteriormente la cantidad de sustancias que integran los Cuadros I y II desde su creación hasta el día de hoy ha experi-

7 La JIFE preocupada por las importantes incautaciones de P-2-P elaboradas a partir de APAAN inició en el mes de marzo del año 2013 los trámites para someter a fiscalización esta sustancia. En su 57ํㅜ período de sesiones, celebrado en el mes de marzo del año 2014, la Comisión de Estupefacientes decidió unánimente seguir las recomendaciones de la Junta e incluir el APAAN y sus isómeros ópticos en el Cuadro I de la Convención de 1988 (decisión 57/1 de la Comisión). Esta desición entro en vigor el día 9 de octubre del año 2014. Precursores y sustancias químicas frecuentemente utilizados..., correspondiente a $2014 \ldots$... pp. 7, 120. Precursores y productos químicos frecuentemente utilizados..., correspondiente a 2011..., pp. 21, 22. Precursores y productos químicos frecuentemente utilizados..., correspondiente a 2013..., p. 2.

8 ALBERT, Hans-Jörg. Criminalidad transnacional, comercio de narcóticos y lavado de dinero. GUERRERO PERALTA, Oscar Julián (Trad.) Ed. Universidad Externado de Colombia. Bogotá. 2001, pp. 68, 69. 
mentado un incremento muy significativo, lo que se materializa en 12 sustancias más (el doble). Hay que señalar que este proceso de actualización de las listas de precursores es determinante en la legislación española, dado que el legislador ha optado por regular el tráfico de precursores de drogas, estupefacientes y psicotrópicos mediante la técnica del tipo penal en blanco, por lo cual esta normativa internacional determina que sustancias se deben de considerar precursores de drogas ilícitas en el ordenamiento jurídico interno. Ello se puede advertir claramente en la redacción del artículo 371 del Código Penal Español que literalmente dice:

\begin{abstract}
"1. El que fabrique, transporte, distribuya, comercie o tenga en su poder equipos, materiales o sustancias enumeradas en el Cuadro I y Cuadro II, de la Convención de Naciones Unidas, hecha en Viena el 20 de diciembre de 1988, sobre el tráfico ilícito de estupefacientes y sustancias psicotrópicas, y cualesquiera otros productos adicionados al mismo Convenio, o que se incluyan en otros futuros Convenios de la misma naturaleza, ratificados por España, a sabiendas que van a utilizarse en el cultivo, la producción o la fabricación ilícita de drogas tóxicas, estupefacientes o sustancias psicotrópicas, o para estos fines, será castigado con la pena de prisión de tres a seis años y multa del tanto al triplo del valor de los géneros y efectos".
\end{abstract}

Como se puede apreciar con la incorporación del artículo 344 bis del Código Penal anterior, que actualmente es el artículo $371^{9}$, se produce un claro adelantamiento del ámbito de protección penal, mediante la sanción de comportamientos que en principio no deberían trascender del orden administrativo, pero que, sin embargo, en atención a los fines perseguidos, transforman estos ilícitos administrativos en ilícitos penales ${ }^{10}$. Sin embargo, es preciso destacar que no todas las transgresiones que se produzcan van a configurar el delito de tráfico de precursores, sino sólo aquellas que objetivamente integren el elemento subjetivo del injusto, lo que permite la exclusión del círculo de relevancia penal de los meros incumplimientos de la normativa reglamentaria sobre la fabricación, transporte, distribución, comercio o posesión de equipos, materiales o sustancias enumeradas en el Cuadro I y en el Cuadro II, tales como la caducidad de licencias o la ausencia de declaración del 
material comercializado, cuando la aludida finalidad no consiga inferirse del conjunto de circunstancias que rodean al hecho' ${ }^{11}$, tema que desarrollaremos en el capitulo VI de este trabajo, específicamente en el apartado que trata el dolo y el elemento subjetivo del injusto.

\section{ESTADO DE LA APLICACIÓN Y EL FUNCIONAMIENTO DE LA LEGISLACIÓN INTERNACIONAL EN MATERIA DE VIGILANCIA Y CONTROL DEL COMERCIO DE PRECURSORES DE DROGAS}

A) MEdidAs adoptadas PARA LA FisCALIZACIÓN DE LOS PRECURSORES DE DROGAS

1. Adhesión a la Convención

Sobre el estado de adhesión a la Convención de Viena de 1988 hay que decir que al día 31 de octubre del año 2000 ya habían ratificado, aprobado o se habían adherido a dicho instrumento 157 Estados o territorios, lo cual representaba el $81.34 \%$ de todos los países y territorios del mundo ${ }^{12}$. Cifra que al día 1 de noviembre del año 2016 era de 189 Estados o territorios, incluida la Unión Europea, lo cual constituye el $95.45 \%$ de todos los Estados o territorios existentes. De hecho de los tres tratados internacionales sobre fiscalización de drogas es el que tiene mayor número de miembros ${ }^{13}$. Como vemos la evolución de la adhesión a la Convención de 1988, es muy positiva, pues del año 2000 al 2016 un total de 32 Estados o territorios ratificaron el Convenio, además hay que decir que entre los 189 Estados partes se encuentran

11 VALLE MUÑIZ, José Manuel y MORALES GARCIA, Oscar. Comentarios a la Parte Especial del Derecho Penal. QUINTERO OLIVARES, Gonzalo (Dir.). MORALES PRATS, Fermín (Coord.). Octava edición. Thomson Reuters. Aranzadi. Navarra. 2009, p. 1447.

12 Precursores y productos químicos frecuentemente utilizados..., correspondiente a 2000..., p. 2.

13 Los índices de adhesión por regiones son los siguientes: África: 51 de 54 países (94.44 \%), América: 35 países (100 \%), Asia: 46 de 47 países (97.87\%), Europa: 45 de 45 países (100\%) y Oceanía: 11 de 16 países (68.75\%). Los siguientes Estados o territorios no son parte de la Convención de 1988: África: Guinea Ecuatorial Somalia y Sudán del Sur. Asia: Estado de Palestina. Oceanía: Islas Salomón, Kiribati, Palau, Papua Nueva Guinea y Tuvalu. Sumando un total de 9 Estados o territorios que aún no son parte de la Convención. Precursores y sustancias químicas frecuentemente utilizados..., correspondiente a 2016 ..., pp. 1, 47-53. 
todos los países fabricantes, así como la inmensa mayoría de los Estados exportadores e importadores de precursores de drogas.

\section{Presentación de Informes a la Junta}

Como todos sabemos la Junta Internacional de Fiscalización de Estupefacientes transmite a todos los gobiernos de los Estados partes y no partes un cuestionario anual sobre las sustancias frecuentemente utilizadas en la fabricación ilícita de estupefacientes y psicotrópicos (denominado formulario D), de conformidad con el párrafo 12 del artículo 12 de la Convención de Naciones Unidas de 1988 celebrada en Viena. Además las partes están obligadas a presentar información anual a la Junta sobre las incautaciones de sustancias de los Cuadros I y II de la Convención. Esta información se utiliza para determinar los patrones regionales y mundiales del tráfico de precursores de drogas. Presentándose siempre el problema de que muchos gobiernos omiten datos sobre los métodos de desviación de las remesas detenidas o sobre la fabricación ilícita de sustancias, lo que afecta la capacidad de la Junta para determinar las tendencias recientes del tráfico de precursores, además hay que señalar que a dia 1 de noviembre del año 2015 un total de 117 Estados y territorios presentaron el formulario D correspondiente al año 2014, la cifra más baja de los últimos 12 años, debiendo destacarse que todos los años se presenta la misma deficiencia que consiste en que aproximadamente un $32.5 \%$ de países no cumple con la obligación de presentar el informe, por lo tanto sobre esos 63 o 64 Estados o territorios la JIFE no dispone de la información requerida. La cual se utiliza para identificar las pautas y tendencias mundiales del tráfico de precursores de drogas y por ende para orientar el enfrentamiento al tráfico de precursores de drogas a nivel mundial, regional y nacional. Sobre este tema hay que añadir que sólo la mitad de los gobiernos presentan sus informes antes del día 30 de junio de cada año, que es el plazo fijado, así como que varios países de ingresos medios y muchos países de bajos ingresos no responden al cuestionario en absoluto o sólo lo hacen parcialmente ${ }^{14}$. 
En el formulario D correspondiente al año 2014, un total de 56 gobiernos informaron de incautaciones de sustancias de los Cuadros I o II de la Convención de 1988. Además 33 gobiernos también reportaron el decomiso de sustancias no incluidas en los dos cuadros antes citados (sustancias no catalogadas). Sin embargo, la mayoría de esos gobiernos no suministraron información detallada sobre los métodos de desviación y fabricación ilícita ni sobre las remesas detenidas. También hay que señalar que en varios casos nunca se facilitó en el formulario D información sobre incautaciones importantes de precursores comunicadas por algunos gobiernos en sus informes nacionales o en ponencias oficiales presentadas en conferencias. Hay que subrayar que esta situación se viene presentando en los últimos diez años. Sobre la cantidad de países que reportan incautaciones hay que decir que se ha producido un incremento significativo pasando de los 45 países en el año 2005 a los 56 paises en el año 2014, lo cual posiblemente se deba al mejor grado de enfrentamiento alcanzado a nivel mundial, así como al hecho de que los traficantes de precursores han ampliado las rutas de desviación de dichas sustancias. Sobre los decomisos de las sustancias no catalogadas es necesario señalar que a partir del año 2009 se empezaron a reportar en el formulario D, pasando de 25 Estados o territorios de este año a 33 del año 201415 .

\section{Presentación de datos sobre el comercio lícito}

Desde el año 1995 la Junta, de conformidad con la resolución 1995/20 del Consejo Económico y Social, ha solicitado que en el "formulario D"

2009 (127), del año 2010 (132), del año 2011 (132), del año 2012 (129) y del año 2013 (136). Hay ciertas discrepancias sobre las cantidades expresadas en los informes de los años 2008 (132-142), 2009 (127-139), 2010 (132-133). Nosotros reflejamos las cantidades que vienen expresadas en el informe y no en las tablas anexas. También es preciso puntualizar que con frecuencia las respuestas al formulario D son incompletas, y algunos gobiernos a veces no los presentan, como ejemplo de ello citamos que seis Estados parte de la Convención de 1988 (Burundi, Gabón, Islas Marshall, Liechtenstein, San Marino y Somalia) nunca han presentado el formulario D a la Junta, mientras que otros 20 Estados no han presentado el formulario D en los últimos 5 años. Precursores y sustancias químicas frecuentemente utilizados..., correspondiente a 2015..., pp. 1, 6064.

15 Precursores y sustancias químicas frecuentemente utilizados..., correspondiente a 2015..., p. 2. 
se le suministren también datos sobre el comercio lícito, utilización y necesidades de los precursores de drogas incluidos en los Cuadros I y II de la Convención de 1988, siendo el suministro de esta información de carácter voluntario. Hay que destacar que esta información es esencial para los esfuerzos de los distintos gobiernos por vigilar los movimientos de estas sustancias catalogadas, en la medida que le permite a la JIFE prestar asistencia a los Estados y territorios partes y no partes del Convenio de 1988 sobre transacciones sospechosas y por ende poder verificar rápidamente la legitimidad de cada envío. En el formulario D correspondiente al año 2014 un total de 108 Estados y territorios habían facilitado información sobre el comercio lícito y 106 habían presentado datos sobre las necesidades y los usos legítimos de una o más de esas sustancias. Gracias a la presentación voluntaria de esos datos, la Junta puede prevenir la desviación de precursores através de la vigilancia de las corrientes del comercio internacional legítimo y la determinación de las pautas de las presuntas actividades ilícitas. Es preciso poner de manifiesto que la evolución de esta actividad no ha sido positiva, dado que de los 107 Estados o territorios que presentaron información sobre el comercio lícito de las sustancias enumeradas en los Cuadros I y II de la Convención de 1988 en el año 2005 se pasó a 108 países en el año 2014. De igual manera ocurrió con los 96 gobiernos que presentaron datos sobre las necesidades legitimas de los precursores de drogas en el año 2005 a los 106 gobiernos que lo hicieron en el año 2014. Hay que destacar que 90 Estados o territorios no han presentado su informe sobre el comercio lícito de precursores de drogas y que 92 gobiernos aún no lo hacen sobre sus necesidades legítimas de estas sustancias catalogadas, lo cual representa una situación muy preocupante, pues esto significa que no tenemos ninguna información sobre el $45,4 \%$ del comercio mundial anual de precursores y que desconocemos el $46.4 \%$ de las necesidades legitimas anuales de estas sus$\operatorname{tancias}^{16}$.

16 Precursores y productos químicos frecuentemente utilizados..., correspondiente a 2015..., pp. 3, 4. Precursores y productos químicos frecuentemente utilizados..., correspondiente a $2006 \ldots$, p. 9. 
B) PREVEnción DE LA DESViación

\section{Notificaciones previas a la exportación}

Es preciso subrayar que el empleo de las notificaciones previas a la exportación de sustancias catalogadas es una de las herramientas más eficaces para prevenir, descubrir y cortar los intentos de desviación de precursores de drogas, posibilitando la supervisión del comercio internacional de estas sustancias y la identificación de remesas sospechosas ${ }^{17}$. Con el objetivo de continuar mejorando el régimen de notificaciones $\mathrm{y}$, en particular, de facilitar al país exportador la información pertinente que se requiere de cada país importador sobre la notificación de exportación de que se trate la JIFE creó, con el apoyo de la Oficina de Naciones Unidas contra la Droga y el Delito (ONUDD), un sistema en línea de Internet para el intercambio de dichas notificaciones, con miras a reemplazar el envío de notificaciones por facsímil. Este sistema se empezó a implementar en el año 2005, no tiene ningún coste y está a disposición de todos los organismos nacionales competentes encargados de enviar y recibir las notificaciones previas a la exportación ${ }^{18}$. Pero fue hasta en el mes de marzo del año 2006 que la Junta puso en marcha de forma oficial el nuevo sistema electrónico de intercambio de notificaciones previas a la exportación denominado PEN Online. Los usuarios inscritos en el Registro pueden acceder a este siste-

17 Para ilustrar la importancia de las notificaciones previas citamos el caso de dos remesas, de 20 y 260 toneladas de permanganato de potasio, destinadas a Australia y la República Islámica de Irán que fueron autorizadas por China, el país exportador, dado que no se había recibido respuesta a la notificación previa a la exportación en el plazo establecido. Las respuestas llegaron a China cuatro meses después, indicando en el caso de Australia que no podían localizar la empresa importadora en ese país, y en el caso de Irán, señalando que la empresa importadora negaba haber realizado ese pedido. Precursores y productos químicos frecuentemente utilizados..., correspondiente a 2002..., pp. IX, X, 10, 11, 23. La JIFE recomendó a los países exportadores la posibilidad de solicitar notificaciones previas a la exportación de las sustancias catalogadas en los Cuadros I y II si se importaban para volverse a exportar nuevamente, dado que los traficantes, al intentar desviar los precursores químicos hacia canales ilícitos, suelen utilizar circuitos que entrañan la importación y reexportación de las sustancias a través de terceros países. Medida fue adoptada por los principales países exportadores y puntos de reexpedición. Precursores y productos químicos frecuentemente utilizados..., correspondiente a $2000 \ldots$, pp. $6-8$.

18 Precursores y productos químicos frecuentemente utilizados..., correspondiente a 2005..., pp. 17, 18. 
ma seguro por el sitio de la JIFE www.incborg/pen. Al día 31 de octubre de 2015 ya se habían inscrito 151 países y territorios, más del doble que en el año 2006. Creemos importante destacar que actualmente cada mes se envían a través de este sistema unas 2.600 notificaciones previas a la exportación, frente a unas 600 notificaciones mensuales que se enviaban cuando empezó a funcionar el sistema. Es necesario precisar que aunque la mayoría de países que tienen un comercio importante de sustancias catalogadas utilizan de forma activa el sistema PEN Online, hay algunos gobiernos registrados en este sistema que no lo usan, de hecho se ha comprobado que sólo 46 países utilizan de forma activa este sistema. Desafortunadamente entre los países que aún no se han inscrito en el sistema PEN Online, muchos se encuentran en regiones utilizadas especialmente por los traficantes como zonas de tránsito o de destino de sustancias catalogadas. En tal situación se encuentran partes importantes de África, zonas de Europa Sudoriental y gran parte de Asia Central. Este sistema como funciona en tiempo real, facilita notablemente el procesamiento de la información por los gobiernos y en particular permite supervisar mejor las notificaciones previas, pues garantiza que éstas lleguen a los usuarios debidos, reduciendo de esta manera las demoras innecesarias en el comercio lícito. Además hay que decir que el sistema PEN Online se está utilizando con éxito en las operaciones internacionales de la JIFE relativas a la desviación de ciertas sustancias químicas usadas en la fabricación ilícita de heroína, cocaína y estimulantes de tipo anfetamínico, convirtiéndose en el mecanismo más eficaz para que los gobiernos supervisen el comercio internacional de las sustancias fiscalizadas. Sin embargo hay que señalar que en algunos casos las notificaciones no se tramitan con suficiente antelación para que puedan ser examinadas por los países importadores o bien se reciben después de haber sido enviada ya la remesa, o peor aún se despachan remesas de precursores sin enviar las correspondientes notificaciones a países que lo han exigido de forma oficial. Un ejemplo de la magnitud del problema es que los Estados Unidos de América siguen exportando precursores de drogas, del Cuadro I y Cuadro II de la Convención de 1988, sin ninguna notificación previa o bien lo hacen solo en raras ocasiones.

Hay que destacar que al día 31 de octubre de 2015 un total de 109 Estados o territorios, habían pedido oficialmente recibir notificaciones previas a la exportación, invocando el párrafo 10 a) del artículo 12 de la Convención de 1988, 64 gobiernos más que en el año 2005 en el que sólo 45 países habían solicitado recibir notificaciones previas de expor- 
tación. Lamentablemente en algunas regiones la mayoría de países no ha invocado todavía su derecho a ser informados, dejando de esta manera amplias zonas vulnerables a la desviación de precursores de drogas. De hecho, actualmente hay un total de 89 Estados o territorios que no lo han hecho (el 72\% de África y el 50\% de América Central y el Caribe, Asia Oriental y Asia Meridional), lo cual no quiere decir que no reciban dichas notificaciones, pero sí que los países exportadores no están obligados a enviárselas ${ }^{19}$. Es preciso puntualizar que todos los usuarios registrados deberían utilizar el sistema PEN Online de forma activa y sistemática para cada transacción de una sustancia del Cuadro I o del Cuadro II de la Convención de 1988, tanto si son remitentes como receptores de notificaciones previas a la exportación para poder descubrir de manera más efectiva los casos de desviación de precursores del comercio internacional.

\section{Sistema de Comunicación de incidentes relacionados con precursores}

En el mes de marzo del año 2012 la JIFE puso en marcha el sistema de comunicación de incidentes relacionados con precursores (PICS), que se elaboro con el fin de mejorar la labor de las autoridades nacionales competentes para dar respuesta a la constante evolución del tráfico de precursores de drogas, a la aparición de sustancias no incluidas en los cuadros que se utilizan para la elaboración de drogas ilícitas, al enmascaramiento de sustancias catalogadas, así como para complementar los mecanismos tradicionales de notificación de las diversas incautaciones de precursores mediante la recopilación de datos en tiempo real. El sistema PICS permite que los usuarios intercambien información, de manera segura y en tiempo real, sobre las desviaciones y tentativas de desviación, así como sobre las incautaciones de precursores. También se puede recurrir a este sistema para iniciar investigaciones nacionales, bilaterales o regionales, a la vez que permite a la Junta identificar de forma rápida los nuevos métodos de desviación. En el mes de noviembre del año 2012 ya se habían registrado un total de 237 usuarios en el PICS, entre ellos 58 gobiernos y 8 organismos internacionales y correspondiente a 2012. Ed. Naciones Unidas. Nueva York. 2010, pp. 32, 33. 
regionales. Este sistema se empleó para comunicar más de 400 incidentes relacionados con 74 países o territorios en sólo ocho meses ${ }^{20}$.

El PICS en muy poco tiempo se consolidó como un instrumento indispensable para los gobiernos, ofreciendo una plataforma de comunicación segura para el intercambio rápido de información (entre los cuerpos y fuerzas de seguridad nacionales y las autoridades de reglamentación) sobre remesas sospechosas, incautaciones, desviaciones y tentativas de desviación, remesas de precursores detenidas, en tránsito e incautaciones de laboratorios y equipos clandestinos. Este sistema facilita el intercambio de inteligencia en tiempo real y permite poner en marcha investigaciones bilaterales y regionales sin demora. En el mes de noviembre del año 2015 ya se habían registrado en este sistema un total de 480 usuarios, 243 más que en el año 2012, que representan a unos 200 organismos de 94 países y territorios, 20 países más que el año que se puso en funcionamiento el sistema, y 10 entidades regionales e internacionales. La cifra de incidentes registrados se elevo hasta los 1.350 incidentes, frente a los 400 del año 2012, relacionados con 84 países y territorios. Es necesario puntualizar que muchos de esos incidentes estuvieron relacionados con sustancias químicas incluidas en la lista de vigilancia internacional especial limitada y con otras sustancias no catalogadas, lo que convierte al PICS en un instrumento fundamental para alertar a las autoridades competentes sobre las nuevas tendencias utilizadas por los traficantes de precursores de drogas ${ }^{21}$.

\section{Actividades en el marco de la fiscalización internacional de precursores}

Es necesario poner de manifiesto que la JIFE ha respaldado de manera decidida varias iniciativas internacionales contra la desviación de precursores de drogas, siendo estas: la Operación Púrpura (1999-2005), la Operación Topacio (2001-2005), el Proyecto Prisma (a partir del año 2002) y el Proyecto Cohesión (a partir del año 2005). Como resultado de estas iniciativas, se ha incrementado considerablemente el número de casos en que se han descubierto y frustrado intentos desviación de

21 Precursores y productos químicos frecuentemente utilizados..., correspondiente a 2014..., p. 17. Precursores y productos químicos frecuentemente utilizados..., correspondiente a 2015..., pp. 11, 12. 
sustancias químicas catalogadas del comercio internacional hacia canales ilícitos. De la Operación Púrpura hay que decir que se inició en el año 1999, siendo un programa intensivo internacional con el fin de prevenir desviaciones de permanganato de potasio, un producto químico esencial en la elaboración de la cocaína. La Operación Topacio que inicio en el año 2001 tuvo por objetivo la vigilancia del anhídrido acético, que es un precursor esencial para la fabricación de la heroína, centrando su atención no solo en la en la vigilancia de las remesas licitas, sino también en las investigaciones de rastreo llevadas a cabo por las autoridades encargadas de hacer cumplir la ley a partir del lugar de incautación o de algún otro punto de interceptación de la sustancia objeto de contrabando. En el año 2006 la Junta realizó una evaluación de los avances realizados en el marco de ambas operaciones internacionales decidiendo los comités directivos de la Operación Púrpura y la Operación Topacio dar inicio a una nueva fase de operaciones conjuntas denominada Proyecto Cohesión ${ }^{22}$ que es una iniciativa mundial que tiene por finalidad prestar asistencia a los países para descubrir y cortar la desviación del anhídrido acético y el permanganato de potasio, proporcionando una plataforma para poner en marcha operaciones regionales con plazos específicos. Este proyecto se centra en actividades regionales con plazos determinados y permite intercambiar información en tiempo real, realizar investigaciones de rastreo y evaluar periódicamente las actividades realizadas. De esta manera es posible coordinar las investigaciones sobre las incautaciones y las remesas detenidas, así como también fiscalizar el comercio lícito, siendo el grupo de tareas del Proyecto Cohesión el encargado de dirigir el proyecto23.

Sobre la Operación Púrpura, desde su inicio en el año 1999 hasta el 1.oㅜ de noviembre del año 2005, se pueden exponer los siguientes resulta-

22 Gracias a las actividades realizadas en la Operación Púrpura y la Operación Topacio se logró establecer información sobre las modalidades, la diversidad y la magnitud del comercio lícito del permanganato de potasio y del anhídrido acético. Además se descubrieron muchos intentos de desviación de esas sustancias hacia canales ilícitos y se pudo localizar y descubrir los eslabones perdidos entre la desviación de los precursores de los canales internacionales y nacionales lícitos y el contrabando de esas sustancias hacia las zonas en que se fabrican drogas ilícitas. Precursores y productos químicos frecuentemente utilizados..., correspondiente a 2003..., pp. 10, 11.

23 Precursores y productos químicos frecuentemente utilizados..., correspondiente a 2005..., p. 11. 
dos: un total de 30 organismos de exportación suministraron 4.380 notificaciones previas a la exportación de remesas que suman más de 136.560 toneladas de permanganato de potasio, estas notificaciones posibilitaron detener o incautar 233 envíos, por un total de 14.316 toneladas de esta sustancia, así como detectar varias desviaciones. La investigación de los envíos antes señalados produjo los siguientes resultados: a) se detuvieron 175 envíos, por un total de 12.685 toneladas de permanganato de potasio, 58 de estos fueron posteriormente liberados sin que suministrara información adicional, b) 21 posibles desviaciones detectadas, relacionadas con 1.528 toneladas de permanganato de potasio y c) 37 informes presentados sobre incautaciones de remesas que ascendían en total a 143 toneladas de esta sustancia catalogada. A manera de conclusión de este periodo se puede decir que la vigilancia del comercio internacional realizada en el ámbito de la Operación Púrpura tuvo resultados satisfactorios, dado que desde el año 1999 se produjo un aumento continuo del número de notificaciones previas a la exportación recibidas por la JIFE y del volumen de permanganato de potasio notificado. Desde el punto de vista de la detección de transacciones sospechosas y de la detención de envíos, si bien se obtuvieron algunos logros, lamentablemente hay que concluir que estos no fueron óptimos y representaron solamente reveses temporales para los traficantes involucrados. Pues los organismos que detectaron y detuvieron los envíos o desviaciones no pusieron en marcha investigaciones de seguimiento, por ello los traficantes afectados simplemente reubicaron sus actividades. Señalando la JIFE que tal situación debía de solventarse mejorando el intercambio de información sobre las incautaciones y los envíos detenidos, a fin de iniciar investigaciones de rastreo para identificar y desarticular las redes involucradas y enjuiciar a los responsables ${ }^{24}$.

Sobre la Operación Topacio que se inicio en el año 2001, evaluando su desarrollo hasta el mes de noviembre del año 2005, se puede decir que en esta operación internacional centrada en el comercio del anhídrido acético, desde sus primeras etapas de planificación se tenía claro que la vigilancia del comercio internacional no sería suficiente por si sola para impedir que los traficantes obtuvieran esta sustancia catalogada, pp. 20, 21. 
puesto que existían rutas y redes de contrabando bien establecidas. Por lo que se requería de la iniciación de investigaciones de rastreo de las interceptaciones e incautaciones de las remesas introducidas de contrabando, a fin de descubrir los métodos y rutas de desviación que se utilizaban. De esta operación hay que señalar que en cuatro años arrojó los siguientes resultados: a) un total de 22 organismos suministraron un total de 7.684 notificaciones previas a la exportación de remesas que sumaban más de 1.350 .000 toneladas de anhídrido acético, b) investigándose 149 casos notificados a la Junta, relacionados con 3.857 toneladas de esta sustancia, de los cuales 4 fueron identificados como desviaciones de remesas que ascendían a un total de 52 toneladas, c) 16 países detuvieron un total de 51 envíos por un total de más 3.186 toneladas de este precursor de drogas, destinados a 23 países o territorios y d) se realizaron 94 incautaciones individuales notificadas, relacionadas con 615 toneladas de anhídrido acético. Como aspecto negativo de esta operación hay que destacar que de 18 países identificados como exportadores de esta sustancia catalogada no se recibieron notificaciones previas a la exportación lo que dificulto mucho la labor de fiscalización. Precisamente, y gracias a los países que sí presentaron dichas notificaciones se pudo determinar las complejas estructuras del comercio de esta sustancia que se reflejan, por ejemplo, en la utilización de parques de depósito en países de reexpedición para almacenar grandes cantidades de la sustancia antes de despachar remesas más pequeñas a los comerciantes o a los usuarios finales 25 .

Un aspecto digno de mención es que, en el marco de estas operaciones, se vienen descubriendo cada vez más vinculaciones entre las redes de contrabando de drogas y del contrabando de sus precursores, lo cual implica la utilización de un modus operandi análogo para ocultar las remesas a fin de evitar que las autoridades aduaneras las descubran. Por lo cual resulta indispensable que los organismos internacionales y regionales competentes como la Interpol, la Organización Mundial de Aduanas, la Europol, la Comisión Interamericana para el Control del Abuso de Drogas (CICAD), la Oficina Europea de Lucha contra el Fraude (OLAF), la Asociación de Asia Meridional para el Desarrollo (SAARC) y la Comunidad de África Meridional para el Desarrollo (SADC) estudien la información de inteligencia que se dispone sobre las redes involu- 
cradas en el tráfico de drogas conjuntamente con la relativa a las del tráfico de precursores con miras a descubrir vínculos comunes y planificar operaciones para frenar esas actividades ${ }^{26}$. Para lograr tal fin es preciso que los Estados partes y no partes del Convenio de 1988 realicen esfuerzos para que los funcionarios de aduanas y los guardias fronterizos adopten cada vez un papel más activo en la interceptación de las sustancias catalogadas, siendo fundamental para lograr este objetivo que se realicen programas de capacitación con ellos, así como que se les faciliten los equipos necesarios para que puedan evaluar adecuadamente los riesgos y adoptar las decisiones procedentes, sobre este tema. Como las interceptaciones o las incautaciones de envíos se realizan muchas veces en puntos donde no se dispone fácilmente de apoyo científico, debe ponerse a disposición de estos funcionarios un equipo adecuado, como el juego de instrumentos de análisis y equipos básicos de seguridad 27 .

Otro elemento a tener en cuenta es que los traficantes no hacen directamente los pedidos en los países donde se realiza la producción ilícita de heroína, sino que lo hacen en otros lugares para introducir luego esas remesas de contrabando en esos países. Lo cual hace inviable vigilar los envíos despachados a una región determinada. También es preciso señalar que el nivel de comercio de esta sustancia es muy elevado sobre todo en los países desarrollados. La Junta en vista de las características señaladas anteriormente asumió que no es posible vigilar físicamente todas las remesas y que la única forma práctica de enfrentar la situación era investigar a las empresas que participan en el comercio, tarea que incluye la identificación del personal directivo y la realización de inspecciones para verificar que todas las remesas destinadas a una empresa concreta han sido de hecho encargadas y recibidas por esa empresa y utilizadas con fines lícitos. Hay que subrayar que por lo general los logros alcanzados en la operación, se registraron principalmente en países desarrollados que cuentan con la infraestructura y los conocimientos técnicos para llevar a cabo investigaciones complejas como es el caso de los países europeos. Sin embargo el éxito obtenip. 18.

27 Precursores y productos químicos frecuentemente utilizados..., correspondiente a 2004..., pp. 15, 16. 
do en los países donde se fabrica la heroína fue mínimo, tanto en las incautaciones realizadas como en la interceptación de remesas de contrabando antes de que entren en su territorio, lo cual se pone de manifiesto en el hecho de que hasta el año 2005 nunca se solicitó la asistencia del grupo de tareas de la Operación Topacio para realizar ni una sola operación en Afganistán o en las Repúblicas de Asia Central ${ }^{28}$.

Las operaciones internacionales Púrpura y Topacio debido al cambio de las estructuras de comercio internacional del permanganato de potasio y del anhídrido acético así como del modus operandi de los traficantes de estos precursores, y como resultado en parte de la experiencia adquirida en ambas operaciones, determinaron la necesidad de analizar profundamente los logros obtenidos y las formas más idóneas para continuar en el futuro, lo cual se hizo en una reunión celebrada en Ciudad de México en octubre de 2005, donde se decidió iniciar conjuntamente una nueva fase de ambas operaciones, denominada "Proyecto Cohesión", que es una iniciativa mundial dirigida a ayudar a los países a hacer frente a la desviación del permanganato de potasio y del anhídrido acético, sirviendo como plataforma que permite realizar operaciones regionales de duración limitada, coordinar las investigaciones sobre las incautaciones y las remesas interceptadas, así como vigilar el comercio lícito. El Proyecto Cohesión lo dirige su respectivo grupo de tareas, el cual esta conformado por autoridades de Alemania, China, Colombia, los Estados Unidos de América, la Federación de Rusia, India, México y Turquía, contando con el apoyo de la JIFE, la Interpol, el Consejo de Cooperación Aduanera (denominado también Organización Mundial de Aduanas) y la Comisión Europea29.

Es importante señalar que en el mes de enero del año 2003 se iniciaron las actividades operacionales del Proyecto Prisma, iniciativa internacional que está enfocada en las cinco principales sustancias catalogadas utilizadas en la fabricación ilícita de estupefacientes de tipo anfetamínico (la efedrina, la seudoefedrina, la 3,4-MDP-2-P, la P-2-P y el safrol). Los miembros del grupo de tareas de este proyecto representan a las principales regiones geográficas y a los organismos internacionales pp. 21, 23, 24. 
competentes. En el marco del Proyecto Prisma las autoridades competentes de los distintos países y territorios se encargan de recopilar y difundir la información sobre la desviación de precursores y de remesas sospechosas tanto en el plano nacional como internacional, y de la coordinación de las actividades que se realicen como parte del proyecto, destacamos, por su importancia, que en el año 2007 el grupo de tareas del proyecto puso en marcha la Operación Crystal Flow que se centró en el comercio lícito de remesas de efedrina, seudoefedrina y efedra con destino a África, América y Asia Occidental ${ }^{30}$. La dirección del Proyecto Prisma está a cargo de un grupo de tareas, cuyos miembros tiene la responsabilidad de determinar problemas concretos que se deberán abordar en sus regiones respectivas y de poner en marcha operaciones o introducir medidas correctivas para hacer frente a problemas concretos ${ }^{31}$.

A manera de resumen sobre el Proyecto Prisma podemos señalar que la Operación Crystal Flow (año 2007) permitió establecer que los traficantes de precursores que operaban en México seguían disponiendo con facilidad de efedrina y seudoefedrina, en gran parte a granel. La Operación Ice Block (año 2008) determinó que los traficantes estaban pasando a utilizar sustancias catalogadas en forma de preparados farmacéuticos con el fin de eludir los controles internacionales. La Operación Pila (años 2009/2010) ratificó la tendencia utilizar preparados farmacéuticos y en la fase posterior al desarrollo de las operaciones indicó que se había vuelto a usar el método P-2-P para fabricar metanfetamina, en particular en México. La Operación PADD (año 2011) centrada en el uso del ácido fenilacético y sus derivados que no están sometidos a fiscalización internacional, posibilitó conocer los volúmenes sin precedentes y los tipos específicos de derivados de este precursor que se utilizaban para fabricar metanfetamina, los países de origen y destino, las rutas de tráfico y el modus operandi que usan en el desvío de dichas sustancias. En definitiva las diferentes operaciones desarrolladas en el marco del Proyecto Prisma han permitido conocer la capa-

$30 \quad$ Precursores y productos químicos frecuentemente utilizados..., correspondiente a 2003..., p. X. Informe de la Junta Internacional de Fiscalización de Estupefacientes sobre el seguimiento del vigésimo periodo extraordinario de sesiones de la Asamblea General. Ed. Naciones Unidas. New York. 2009, pp. 10- 12.

31 Precursores y productos químicos frecuentemente utilizados..., correspondiente a 2005..., p. 19. 
cidad de las organizaciones de traficantes de productos químicos para adaptarse rápidamente a las presiones de los organismos reguladores y policiales, así como de determinar las lagunas de los mecanismos internacionales y nacionales de fiscalización ${ }^{32}$.

4. $\quad$ Necesidades legítimas anuales de importación de precursores de estimulantes de tipo anfetamínico

En su 49. periodo de sesiones, celebrado en el año 2006, la Comisión de Estupefacientes aprobó la resolución 49/3, a través de la cual pidió a los Estados Miembros que proporcionaran a la Junta las previsiones anuales de sus necesidades legítimas de importación de cuatro precursores de estimulantes tipo anfetamínico la 3,4-MDP-2-P, la P-2-P, la efedrina y la seudoefedrina, y en la medida de sus posibilidades de las necesidades de importación de los preparados farmacéuticos que contengan estas sustancias, solicitando además que dieran su opinión sobre la viabilidad de poder suministrar esta información. Señalando que el objetivo principal de este sistema era dar a conocer a las autoridades competentes de los países exportadores al menos, una indicación de las necesidades legítimas de los países importadores. Al día 31 de octubre del año 2006 sólo 15 gobiernos habían contestado a la comunicación de la JIFE: de ellos ocho presentaron una información detallada, y los siete gobiernos restantes informaron que no estaban en condiciones de suministrar la información requerida. Ante tal situación la Junta en el informe, correspondiente al año 2006, señalo que eran comprensibles las dificultades que implicaba una actividad de este tipo, sobre todo cuando se realizaba por primera vez, asumiendo que se necesitarían varios años para logar este objetivo ${ }^{33}$. Es importante destacar que al día 31 de octubre del año 2007 un total de 101 gobiernos informaron sobre sus previsiones de las necesidades legítimas anuales de estas cuatro sustancias, cumpliendo de esta manera con la resolución 49/3 de la Comisión de Estupefacientes. Mientras que en el año 2015 un total de 157 gobiernos habían facilitado previsiones de al menos una de las sustancias mencionadas, lo que representa un incremento de p. 10.

33 Precursores y productos químicos frecuentemente utilizados..., correspondiente a $2006 . . .$, pp. 7, 8. 
$64.33 \%$ con respecto al año 2007. Hay que destacar que el número de autoridades competentes de países exportadores que han consultado a la Junta acerca de las necesidades legítimas anuales de sus interlocutores comerciales también ha aumentado constantemente, lo que indica la utilidad de las previsiones y el mayor conocimiento y uso de este instrumento básico ${ }^{34}$.

Como puede observarse la cantidad de Estados o territorios que envían su informe anual sobre sus necesidades de estos cuatros precursores de estimulantes de tipo anfetamínico (157) es superior a la cantidad de gobiernos que lo hacen a través del formulario D sobre el comercio lícito de precursores (108) o sobre sus necesidades lícitas de precursores (106) lo cual debe valorarse de forma positiva. Sin embargo la experiencia ha revelado las dificultades continuas que se producen: como que algunos países que tienen un importante comercio de estas sustancias, como Suiza, no están en condiciones de prever sus necesidades, o que algunos países reportan previsiones muy elevadas o en rápido aumento en un periodo corto de tiempo, llegando incluso a triplicar sus previsiones, tal es el caso de Bangladesh, Egipto, la República Islámica de Irán, Irak, Pakistán, República Árabe Siria y Jordania. Hay que destacar que está información se puede utilizar para identificar los países y regiones en los que aumenta el riesgo de desviación. Además es motivo de preocupación los 32 Estados y territorios que nunca han presentado ninguna previsión o bien aquellos que no han actualizado sus necesidades legítimas anuales en los últimos cinco años ${ }^{35}$.

Queremos subrayar que en aras de enfrentar el desvío de los precursores de drogas de tipo anfetamínico se han desarrollado muchas actividades; a manera de ejemplo citamos que en el año 2005 las autoridades sudafricanas organizaron, con el apoyo del Gobierno de Francia, un curso de capacitación en Pretoria para nueve de los trece Estados miembros de la Comunidad del África Meridional para el Desarrollo. En el curso se capacitó a los participantes sobre los principios de vigilancia de los precursores y se impartió instrucción sobre la entrega vigila-

$34 \quad$ Precursores y sustancias químicas frecuentemente utilizados..., correspondiente a 2015..., pp. 4, 5. Precursores y productos químicos frecuentemente utilizados..., correspondiente a 2007..., 8, pp. 3, 4. pp. 3, 4 . 
da y el desmantelamiento de laboratorios clandestinos. En vista del aumento de los intentos de desviación de precursores de estimulantes de tipo anfetamínico a través de los países de África, el grupo de tareas del Proyecto Prisma concluyó que es indispensable extender las actividades a toda la región ${ }^{36}$. En el mes de marzo del 2006, la JIFE realizó en Viena una reunión con el grupo de tareas del Proyecto Prisma para evaluar las últimas tendencias relativas a la desviación y el tráfico de precursores de tipo anfetamínico, y de efedra en particular, además en junio de ese mismo año se celebró otra reunión del grupo de tareas, esta vez en Australia, en la que abordaron las tendencias y las actividades operativas mundiales, fundamentalmente sobre las medidas necesarias de seguimiento de la resolución 49/3 de la Comisión de Estupefacientes, denominada "fortalecimiento de los sistemas de fiscalización de precursores de drogas utilizados en la fabricación de drogas sintéticas" y la resolución 49/7, titulada "promoción de un enfoque coherente del tratamiento de aceites ricos en safrol". En el mes de septiembre de este mismo año se volvió a reunir el grupo de tareas en la Haya para tratar de dar respuesta a las últimas tendencias y a los numerosos intentos de desviación que afectaban a África y Asia occidental, donde se abordo también la problemática de los preparados farmacéuticos y la efedra ${ }^{37}$. Queremos concluir este apartado señalando que actividades de esta naturaleza se realizan con bastante frecuencia, sobre todo en las regiones y países más vulnerables, lo cual exponemos ampliamente al abordar las medidas de control adoptadas sobre los distintos precursores de drogas que se utilizan para la elaboración de drogas de tipo anfetamínico.

\section{Medidas legislativas}

En lo que se refiere a las medidas de fiscalización aplicadas por los Estados o territorios miembros del Convenio de 1988 sobre las sustancias catalogadas, hay que señalar que a partir del año 2004 la JIFE en su informe anual sobre precursores de drogas incorporo un apartado sobre las medidas legislativas que adoptaban los países miembros. Desde 
ese año al año 2014 reportaron que un total de 69 países (incluida la Unión Europea) ${ }^{38}$ tomaron algunas de las siguientes medidas: a) crearon por primera vez una ley específica para el control de precursores de drogas, b) reforzaron su legislación sobre sustancias catalogadas, c) aprobaron una nueva reglamentación, d) adoptaron medidas para el control de los preparados farmacéuticos que contienen precursores de drogas, fundamentalmente efedrina y seudoefedrina, o bien de mezclas que contienen precursores e) aprobaron medidas para el control de sustancias no catalogadas que se utilizan en la elaboración ilícita de drogas, f) inclusión de nuevas sustancias de conformidad a los Cuadros I y II de la Convención de 1988 o bien sobre el cambio de categoría de dichas sustancias, $\mathrm{g}$ ) adopción de medidas para el control de los aceites ricos en safrol o sobre la planta efedra (origen natural de la efedrina), h) implementación de medidas para prevenir el desvío de precursores de drogas a través de internet ${ }^{39}$. Siempre sobre este tema es preciso señalar que desde la entrada en vigor de la Convención de 1988, hasta finales del año 2004 los gobiernos de 138 países le habían facilitado información a la JIFE sobre el marco legal y administrativo de la fiscalización de precursores en vigor en su territorio. De este total, 80 países, entre ellos muchos de los principales países fabricantes, exportadores

38 Afganistán, Argentina, Australia, Belice, Bosnia y Herzegovina, Brasil, Bután, Canadá, Chile, China, Colombia, Costa Rica, El Reino Unido de Gran Bretaña e Irlanda del Norte, El Salvador, Federación de Rusia, Filipinas, Ghana, Honduras, India, Jordania, La Unión Europea (28 países miembros), Liberia, los Estados Unidos de América, México, Myanmar, Nicaragua, Nueva Zelanda, Panamá, Paraguay, Perú, República Checa, República de Corea, República Unida de Tanzania, República Yugoslava de Macedonia, Rumania, Samoa, Sudáfrica, Tailandia, Ucrania, Uruguay, Vietnam y Yemen.

39 Precursores y productos químicos frecuentemente utilizados..., correspondiente a 2004..., pp. 6, 7. Precursores y productos químicos frecuentemente utilizados..., correspondiente a $2005 . . .$, pp. 2, 16. Precursores y productos químicos frecuentemente utilizados..., correspondiente a 2006..., p. 6. Precursores y productos químicos frecuentemente utilizados..., correspondiente a $2007 . . .$, p. 3. Precursores y productos químicos frecuentemente utilizados..., correspondiente a 2008..., pp. XI, 3, 4. Precursores y productos químicos frecuentemente utilizados..., correspondiente a 2009..., p. 3. Precursores y productos químicos frecuentemente utilizados..., correspondiente a 2010..., pp. 2, 3. Precursores y productos químicos frecuentemente utilizados..., correspondiente a 2011..., pp. 3, 4. Precursores y sustancias químicas frecuentemente utilizados correspondiente a 2012..., p. 3. Precursores y productos químicos frecuentemente utilizados..., correspondiente a 2013..., pp. 3, 4. Precursores y sustancias químicas frecuentemente utilizados..., correspondiente a 2014..., pp. 9, 10 . 
e importadores, habían adoptado una legislación de fiscalización de conformidad con las disposiciones de la Convención de 1988. Mientras que 58 países y territorios tienen en vigor disposiciones legislativas de fiscalización de algunos productos químicos fiscalizados, principalmente sustancias incluidas en el Cuadro I que tienen usos farmacéuticos ${ }^{40}$. Nosotros no disponemos de información detallada al respecto, pero creemos que actualmente los 189 países que suscribieron el Convenio disponen de normas sobre el control de precursores de drogas.

En esta línea destacamos que en el mes de agosto del año 2004, el Gobierno de Brasil aprobó un decreto con el objetivo de impedir la fabricación ilícita de drogas. Este decreto estableció medidas de control de 146 sustancias químicas que pueden ser utilizadas en la elaboración de drogas. Ordenando que todas las empresas que manejen, importen, exporten, fabriquen o distribuyan cualquiera de esas sustancias, tienen la obligación de registrarse ante la Policía Federal de Brasil, así como remitir a esta autoridad informes mensuales sobre el uso, ventas y existencias de cualquiera de las 146 sustancias sujetas a fiscalización con las que operen. Además toda persona o sociedad que intervenga en la compra, transporte o utilización de una de las sustancias ha de poseer un certificado de aprobación de sus operaciones o una licencia especial extendida por la Policía Federal. Señalando la normativa que las empresas que operen con las 22 sustancias de gran importancia para la fabricación de drogas, estarán también sujetas a la reglamentación del Organismo Nacional de Vigilancia Sanitaria del Ministerio de Salud de Brasili1. La legislación brasileña, es sin lugar a dudas, un claro ejemplo de la dificultad que entraña el control de sustancias no catalogadas. En el presente caso fiscalizan 146 sustancias, de las cuales en ese año 123 sustancias no pertenecen a ninguno de los cuadros del Convenio de

También hay que decir que la mayoría de estos países cumplen el requisito de exigir permiso para importar o exportar algunos precursores químicos, así como que unos 60 países y territorios fiscalizan las exportaciones y exportaciones de las 23 sustancias incluidas en los Cuadros I y II. Además, 49 países y territorios han informado a la JIFE sobre las medidas de fiscalización aplicadas a un total de 155 sustancias no catalogadas en los Cuadros I y II de la convención de 1988. Precursores y productos químicos frecuentemente utilizados..., correspondiente a 2004..., p. 7. p. 6. 
1988, muchas de ellas con un gran nivel de comercio por sus diversos usos lícitos.

Otro ejemplo digno de mención es que en el año 2006 las autoridades de México debido al incremento desmesurado de la actividad del narcotráfico, es el quinto empleador más grande del país (468.000 personas) generando más dinero que el turismo ${ }^{42}$, adoptó una legislación más estricta sobre precursores en particular de efedrina y seudoefedrina. Subrayamos entre las medidas adoptadas la obligación de que las remesas de seudoefedrina se transporten en vehículos blindados previstos de equipos de determinación de la posición y escoltados por la policía para impedir atracos y por ende, su desviación ${ }^{43}$.

En el año 2008 destacamos el caso de Australia que trasladó de Cuadro la efedrina y estableció una pena máxima de 20 años de cárcel para su posesión ilegal, suministro o tráfico, pena bastante superior a la establecida en países de nuestro entorno jurídico. Además, se tipificó como delito el suministro y posesión de ciertas sustancias como la seudoefedrina, de forma ilícita, y la posesión de equipos utilizados para la producción ilícita de drogas, como prensas para hacer pastillas ${ }^{44}$. En esta

42 Vid., para tener una mejor visión: http://www.jornada.unam.mx/2013/03/31/politica/005n1pol, http://www.cnnexpansion.com/expansion/2009/07/17/narco-sa

43 Destacamos que en México los funcionarios de la Comisión Federal para la Protección contra Riesgos Sanitarios (COFEPRIS) empezaron a realizar inspecciones sin previo aviso en los locales de los importadores de precursores de drogas, y adoptaron nuevas Leyes y Reglamentos para restringir las importaciones de precursores, particularmente de efedrina y seudoefedrina para lo cual aplicaron las siguientes medidas: a) prohibir las remesas de importación que pesen más de 500 kilogramos de efedrina y de 3.000 kilogramos de seudoefedrina, b) establecer cupos anuales en el caso de las sustancias antes mencionadas enviadas a cada sociedad (empresa), c) restringir la importación de seudoefedrina limitándolas a las sociedades de productos farmacéuticos exclusivamente, cancelándose todas las licencias de intermediarios, d) exigir que las remesas de seudoefedrina se transporten en vehículos blindados previstos de equipos de determinación de la posición y escoltados por la policía para impedir atracos y por ende sus desviación, e) limitar a farmacias autorizadas la venta de tabletas que contengan seudoefedrina y f) restringir la compra de clientes a tres cajas de tabletas como máximo, siendo necesaria una receta médica para dosis mayores. Precursores y productos químicos frecuentemente utilizados..., correspondiente a 2006..., pp. XI, 5 - 7.

44 Las autoridades de China exigen a partir del año 2008 que todas las expediciones de remesas de precursores destinadas Afganistán, Myanmar y la República Democrática 
misma línea en el mes de octubre del 2009 el Gobierno de Samoa promulgó la Ley de modificación de la legislación sobre estupefacientes del año 2009; en esta modificación el tráfico de precursores de drogas se sanciona con penas privativas de libertad que puede llegar sorprendentemente hasta la cadena perpetua ${ }^{45}$. Siendo evidente que establecer penas de 20 años de prisión, y peor aún de cadena perpetua, para el delito de tráfico de precursores constituye una desproporcionalidad de las penas señaladas en relación con la lesividad de las conductas que la generan. Desafortunadamente de esta tendencia tampoco nos escapamos en España, pues pasamos de la pena máxima agravada a imponer por el delito de tráfico de drogas de 9 años a los 14 años de prisión en virtud de la reforma operada por el artículo 570 bis de la LO 5/2010 cuando los condenados promovieren, constituyeren, organizaren, coordinaren o dirigieren una organización criminal y en el caso de que se cumplan dos de las circunstancias agravantes del artículo 570 bis inciso 2 la pena privativa de libertad podría ser de hasta 18 años $^{46}$.

Queremos poner de relieve que en el año 2015 Australia modifico su legislación penal en materia de tráfico de precursores de drogas, eliminando la exigencia de verificar que una persona que importe o exporte precursores de drogas, lo haga con la intención de elaborar drogas ilícitas o bien a sabiendas de que otra persona las va usar para el fin antes señalado. Suprimiendo de esta manera el elemento subjetivo adicional que contiene el artículo $371 \mathrm{CP}$ en España y que está estipulado en el artículo 3.1 IV de la Convención de Viena de 198847.

En el caso de la Unión Europea hay que decir que ha aprobado una serie de Reglamentos y Directrices para fortalecer la legislación europea sobre el tráfico de precursores de drogas entre ella destacamos las siguientes. En el año 2007 la UE estableció directrices destinadas a las

Popular de Lao tengan licencia de importación antes de abandonar el país. Precursores y productos químicos frecuentemente utilizados..., correspondiente a 2008..., pp. XI, 3, 4.

45 Precursores y productos químicos frecuentemente utilizados..., correspondiente a 2010..., pp. 2, 3.

46 Circular de la Fiscalía General del Estado n. 3/2011 sobre la reforma del Código Penal efectuada por la Ley Orgánica 5/2010, de 22 de junio, en relación con los delitos de tráfico ilegal de drogas y de precursores.

47 Precursores y productos químicos frecuentemente utilizados..., correspondiente a 2015..., pp. 2, 3 . 
empresas que intervienen en el comercio de precursores, con miras a brindar orientación práctica sobre la aplicación de las principales disposiciones de la legislación de la Unión Europea relativa a los precursores de drogas ${ }^{48}$. En el mes de marzo del año 2011 se aprobó el Reglamento número 225/2011, que obliga a todos sus estados miembros a hacer notificaciones previas cuando se exporte anhídrido acético, permanganato de potasio y ácido fenilacético a terceros países. Además modificaron el anexo IV del Reglamento 1277/2005 dado que no figuraban todos los terceros países que han solicitado recibir notificaciones previas a la exportación en relación con determinadas sustancias catalogadas en las categorías 2 y 3 desde la entrada en vigor del Reglamento 297/2009 de la Comisión, siendo dichos países Afganistán, Australia y Ghana. En el año 2013 se adoptaron medidas correctivas para controlar el comercio de anhídrido acético en el que intervengan sus Estados Miembros ${ }^{49}$. En el año 2014 en la Unión Europea se efectuaron reformas en las legislaciones internas de sus estados miembros a través de dos reglamentos el 1258/2013 y 1259/2013 del Parlamento Europeo y del Consejo, fortaleciendo su legislación sobre precursores y superando varias deficiencias que habían sido motivo de preocupación de la JIFE. En virtud de dicho reglamentos los Estados miembros de la Unión Europea están obligados a lo siguiente: a) registrar a los usuarios finales del anhídrido acético ante las autoridades nacionales competentes (con un periodo de transición de 18 meses) y aplicar otras medidas para fortalecer el control del comercio de esa sustancia; b) enviar, con anterioridad a la exportación de preparados farmacéuticos que contengan efedrina o seudoefedrina, una autorización de exportación y una notificación previa a la exportación a las autoridades competentes del país de destino; c) prohibir la entrada de remesas de sustancias no fiscalizadas en el territorio aduanero de la Unión, o su salida de él, cuando existan pruebas suficientes de que esas sustancias están destinadas a la fabricación ilícita de estupefacientes o sustancias sicotrópicas. Además, en virtud de la modificación de los reglamentos, el APAAN pasó a ser una sustancia catalogada de la categoría 1 en la

$48 \quad$ Precursores y productos químicos frecuentemente utilizados..., correspondiente a 2007..., p. 3.

49 Precursores y productos químicos frecuentemente utilizados..., correspondiente a 2013..., pp. 3, 4. Informe Europeo sobre Drogas. Tendencia y novedades. 2015. Ed. Observatorio Europeo de las Drogas y las Toxicomanías. Bruselas. 2015, p. 36. 
Unión Europea, con efecto a partir del día 30 de diciembre del año $2013^{50}$. El 30 de junio de 2015 entraron en vigor el Reglamento Delegado núm. 2015/1011 de la Comisión Europea de 24 de abril de 2015 y el Reglamento de Ejecución núm. 2015/1013 de la Comisión de 25 de junio de 2015, derogando y reemplazando el Reglamento núm. 1277/2005 de la Comisión. Las principales modificaciones guardan relación con la posibilidad de utilizar un procedimiento simplificado de notificación previa a la exportación y de autorización de la exportación de productos medicinales que contienen efedrina o seudoefedrina y con los requisitos de concesión del registro a los operadores. Además, se establecieron procedimientos para otorgar licencias e inscripciones en el registro a los usuarios profesionales. Estipulando que a partir del 1 de julio de 2015, después de un período de transición de 18 meses, los usuarios finales de anhídrido acético tenían que estar registrados con sus autoridades nacionales competentes. La actividad legislativa de la Unión se puede ver con más detalle en apartado correspondiente a la Legislación Europea del capítulo I, al igual que la legislación Española en el apartado correspondiente a la legislación nacional.

6. La colaboración voluntaria con la industria química y la lista limitada de vigilancia especial internacional de las sustancias no incluidas en los cuadros

A fin de enfrentar en mejor medida el desvío de precursores de drogas y otras sustancias no catalogadas que se utilizan como precursores secundarios o sucedáneos de estos precursores o bien que se usan junto a las sustancias catalogadas en la elaboración de drogas ilícitas, así como de equipos y materiales que se emplean con este propósito, la Junta Internacional de Fiscalización de Estupefacientes confeccionó en el año 2009 las directrices para la elaboración de un código de práctica voluntaria destinada a la industria química, instrumento que proporcionaron a las autoridades competentes de todo el mundo. Estas directrices ofrecen orientación a las autoridades nacionales que han adoptado medidas de fiscalización obligatorias pero que desean establecer un sistema más amplio y general para la fiscalización de productos químicos a fin de poder dar respuesta con rapidez y flexibilidad a los cambios de las actividades de fabricación ilícita de drogas en el plano local pp. 9, 10. 
y territorial. La idea es que este código de práctica voluntaria funcione como complemento de la legislación nacional vigente. Con este fin las autoridades designadas presentaran a todas las empresas involucradas además de la lista de sustancias del Cuadro I y II de la Convención de 1988 , todas las sustancias, materiales y equipos incluidos en la lista limitada de vigilancia especial internacional, así como los contemplados en legislaciones o reglamentaciones de ámbito regional. Es preciso recordar que todas las sustancias anteriormente señaladas, así como los materiales y equipos, tienen aplicaciones lícitas lo cual obliga a los gobiernos a asumir la responsabilidad de ejercer una supervisón apropiada que permita garantizar su oferta, sin mayores complicaciones a fin de atender a las necesidades del comercio legítimo y, al mismo tiempo, impedir el acceso a ellos a los productores de drogas ilícitas. Es preciso señalar que el éxito de un código de práctica voluntaria depende del compromiso contraído por el cuerpo directivo de las empresas, así como de la asignación de recursos suficientes, en materia de formación, seguridad, tecnología de la información, transporte e infraestructura ${ }^{51 .}$

Es necesario señalar que en este código se establece el concepto de declaración de usuario final, el cual ha demostrado ser un instrumento sumamente efectivo para descubrir la desviación de productos químicos. Dicha declaración sirve para obtener datos detallados de los clientes y del uso que se proponen hacer de los productos químicos sometidos a vigilancia conforme al código. Se recomienda que no se deban de realizar ventas en efectivo, ni órdenes de compra hechas por teléfono u otro medio de comunicación a distancia por una persona que no sea el representante reconocido de una empresa cliente con una cuenta establecida, independientemente del grado de cumplimiento con la declaración de usuario final. Además es primordial preparar al personal de las empresas para la detección de indicios de desviación de precursores de drogas, sustancias no catalogadas, materiales y equipos tales como: a) el cliente o la entidad empresarial que la persona afirma re-

El código se debe promover como una expresión de una alianza entre las autoridades gubernamentales, la industria química y la industria farmacéutica, siendo necesario que las partes negocien sus responsabilidades sin imponer cargas innecesarias. También es importante que el código no sustituya las obligaciones de las empresas participantes con arreglo a las leyes y reglamentos nacionales vigentes. Directrices para la elaboración de un código de práctica voluntario destinado a la industria química. Ed. JIFE. Nueva York. 2009, pp. 1-8. 
presentar son desconocidos para la empresa, b) el cliente no tiene un historial bien definido de operaciones comerciales con otras empresas de suministros químicos, c) el cliente no está dispuesto a abrir una cuenta ni a someterse a la verificación de su situación crediticia o a otros procedimientos de principios previstos por la empresa en lo relativo a cuentas nuevas, d) el cliente no está en condiciones de presentar documentación de referencia de bancos o instituciones financieras para establecer la legitimidad y antigüedad de la entidad empresarial, e) el cliente desea realizar únicamente operaciones en efectivo, f) la entidad empresarial que el cliente dice representar se ha fundado hace poco tiempo (no está registrada, no figura en la guía de teléfonos ni tiene asociación con una identidad basada en una página web), entre otros indicios 52 .

Como hemos manifestado antes entre las competencias de la JIFE, de conformidad con el artículo 12 de la Convención de Viena de 1988 se encuentran, entre otras, elaborar dictámenes sobre sustancias para su posible incorporación en el Cuadro I y Cuadro II del Convenio antes citado, así como examinar la idoneidad de dichos cuadros. Además de estas funciones el Consejo Económico y Social, en la sección I de su resolución 1996/29 del 24 de junio de 1996, hizo un llamamiento a la Junta

52 Continúa: g) la documentación presentada no es de tipo convincente, h) el cliente no parece tener un conocimiento satisfactorio de la actividad industrial para la que supuestamente se van a adquirir los precursores, i) el cliente afirma actuar como agente o intermediario de un tercero, j) el cliente parece desconocer las prácticas empresariales normales y los plazos propios del suministro de una remesa, k) el cliente se muestra nervioso o se comporta de manera que levata sospechas, l) su forma de entablar contacto no es normal; por ejemplo no anuncia sus visitas, da ocasiones de contacto únicamente por teléfono móvil, y sólo dice su nombre de pila, m) el cliente desea recibir personalmente la remesa, $n$ ) la remesa se debe entregar en un local que no es el de una empresa, una residencia particular o un lugar público, ñ) el cliente ofrece pagar un precio muy superior al precio de venta normal del producto químico, o) el producto químico solicitado no corresponde al carácter de la empresa que el cliente dice representar, p) el producto químico solicitado no concuerda con la finalidad consignada en la declaración de usuario final, q) la lista de los productos químicos pedidos contiene más de uno de los precursores que que figuran en la lista de sustancias sujetas a vigilancia a tenor del código nacional, r) el pedido es para un cliente antiguo, pero las instrucciones de entrega difieren de las pautas establecidas (por ejemplo, la remesa debe enviarse a una persona desconocida para la Empresa), s) se solicita que el pedido se etiquete o embale de manera inhabitual o engañosa, a fin de ocultar la verdadera naturaleza del contenido. Directrices para la elaboración de un código de práctica voluntario destinado a la industria química. Ed. JIFE. Nueva York. 2009, pp. 7, 10, 12, 13. 
para que estableciera una lista limitada para la vigilancia especial internacional de las sustancias no incluidas en los Cuadros y con respecto a las cuales existiera información sustancial de que se utilizaban en elaboración ilegal de drogas. Hay que precisar que la lista de vigilancia especial no es un requisito previo para la inclusión en los Cuadros I y II del Convenio de 1988. La evolución de la lista de vigilancia fue la siguiente: en el año 1997 la Junta tenia seleccionadas un total de 74 sustancias para que el Grupo Asesor de Expertos determinaran un número limitado de sustancias que integrarían la lista limitada de vigilancia especial internacional, así como las medidas que deberían adoptar los Estados y territorios miembros del Convenio de 1988 con esas sustancias $^{53}$. En el año 1998 la Junta seleccionó un total de 27 sustancias para su inclusión en la lista limitada de vigilancia especial internacional, estando la lista estructurada de la siguiente manera:

1. Precursores y reactivos utilizadas en la fabricación ilícita de anfetamina, estimulantes de tipo anfetamínico y otras sustancias sicotropicas: acetonitrilo, ácido fórmico, ácido yodhídrico, alibenceno, amoniaco (incluidas sus soluciones acuosas), benzaldehído, cianuro de bencilo, clorudo de bencilo, etilamina (monoetilamina), formamida, formiato de amonio, hidruro de litio y aluminio, metilamina (monometilamina),

Las sustancias no sometidas a control consideradas importantes para la fabricación ilícita de drogas, para su posible inclusión en una lista de vigilancia especial son las siguientes: acetaldehído, acetato de amoniaco, acetato de butilo, acetato de sodio, acetato etílico, acetonitrilo, ácido acético, ácido benzoico, ácido 2,5-dimetoxibenzoico, ácido fórmico, ácido fosfórico, ácido hidriódico, ácido hidrobrómico, ácido tartárico, ácido 3,4,5-trimetoxibenzoico, alcaloide de cornezuelo, alcohol diacetona, alibenceno, amoniaco (incluido en solución acuosa), anhídrido isatoico, benceno, benzaldehído, bicarbonato de sodio, $n$-butanol, butilamina, carbonato de calcio, carbonato de sodio, carbonato potásico, cianuro de bencilo, cloroformo, cloromercurio, clorometileno, cloruro de acetilo, cloruro de aluminio, cloruro de amoniaco, cloruro de bencilo, cloruro de sodio, cloruro de tionilo, 3,4,5- cloruro de trimetoxibezoil, 2,5-demetoxibenzaldehído, diacetato de etilideno, dietilamina, 2,5-dimetoxitolueno, etilamina, fenilpropanolamina, formamida, formato de amoniaco, $n$-heptano, $n$-hexano, hidróxido de calcio, hidróxido de potasio, hidróxido de sodio, hidroxilamina, hidruro de aluminio y litio, hipoclorito de sodio, isopropanol, litio, metanol, metilisobutilcetona (MIBK), metilamina, $\mathrm{N}$ metilformamida, níquel Raney, nitroetano, norseudoefedrina, oxicloruro de fósforo, óxido de calcio, peróxido de hidrógeno, piridina, sulfato de sodio, tetrahidrofurán, otoluidina, 3,4,5-trimetoxibenzaldehído, trióxido sulfúrico y yodo. Precursores y productos químicos frecuentemente utilizados..., correspondiente a 1997..., pp. 11, 79. 
metilergometrina, $\mathrm{N}$-metilformamida, nitroetano, norefedrina (actualmente precursor de drogas del Cuadro I) y $o$-toluidina.

2. Productos químicos utilizados en la elaboración ilícita de cocaína y heroína: ácido acético glacial, carbonato de potasio, carbonato de sodio, hidróxido de sodio, hipoclorito de sodio y óxido de calcio.

3. Solventes utilizados en la elaboración ilícita de cocaína y heroína: acetato etílico, benceno y metilisobutilcetona ${ }^{54}$.

En el año 2006, la JIFE encargó a su Grupo Asesor de expertos la tarea de evaluar la lista limitada de vigilancia especial internacional de las sustancias no incluidas en los cuadros. Como resultado de dicho examen se concluyó que era necesario revisar esta lista, para lo cual el grupo en mención realizó un estudio sobre las incautaciones correspondientes al quinquenio 2000- 2004. Durante este periodo 44 países notificaron incautaciones de 165 sustancias no fiscalizadas, de las cuales 23 ya estaban incluidas en la lista especial de vigilancia, 35 estaban en la lista de reserva y otras 29 respondían a los criterios establecidos por la Junta para la selección de sustancias con miras a incluirlas en la lista. De las 167 sustancias propuestas finalmente se evaluaron un total de 87 sustancias, con el resultado que se designaron 36 de ellas para su inclusión en la lista limitada de vigilancia especial internacional. El Grupo de Expertos consideró que las medidas recomendadas para esta lista seguían siendo validas, las cuales, como es sabido por todos, deben aplicarse mediante la cooperación voluntaria de la industria química, sin exigencias ni sanciones reglamentarias preceptivas. La JIFE, como siempre lo ha hecho, continuo distribuyendo la lista limitada de vigilancia especial internacional directamente a las autoridades competentes, sin que figure en ningún informe de carácter público ${ }^{55}$. Esta

54 En 1998 cuando la JIFE estableció la lista limitada para la vigilancia especial internacional de las sustancias no incluidas en los cuadros decidió que la misma no se publicara, a fin de salvaguardar su identidad, sino que se distribuyera por separado a las autoridades competentes de todos los gobiernos. Nosotros sólo hemos podido tener acceso a la lista que estaba vigente en el año 2002. Sin embargo estamos covencidos de que la mayoría de sustancias de esta lista (en su versión actualizada) están comprendidas en la relación de sustancias que realizamos en el Anexo V titulado Sustancias no catalogadas que se utilizan en la elaboración de drogas ilícitas. Precursores y productos químicos frecuentemente utilizados..., correspondiente a 1998..., p. 17. 
lista, que ha sido objeto de varias actualizaciones, en la actualidad contiene un total de 52 sustancias y, por extensión genérica, varios derivados. Sin embargo la JIFE tiene conocimiento de que 48 países, además de los 28 Estados miembros de la Unión Europea, han instituido alguna forma de fiscalización respecto de un total de 150 sustancias no incluidas en los Cuadros o de la lista internacional especial limitada de sustancias no incluidas en los cuadros ${ }^{56}$.

Hay que destacar que la información suministrada por algunos gobiernos sugiere que los traficantes, además de estar utilizando una serie de sustancias no catalogadas para sustituir precursores o que se usan en conjunto con estos para elaborar drogas, se están dando a la tarea de fabricar estimulantes de tipo anfetamínico menos frecuentes como 4bromo-2,5-dimetoxifeniletilamina $(2 \mathrm{C}-\mathrm{B})^{57}$ a partir de metoxibenzaldehído (sustancia no catalogada), como han comunicado las autoridades húngaras ${ }^{58}$. Situación similar se presentó con el fentanilo, reportándose en el año 2011 el desmantelamiento de laboratorios clandesti-

cluidas en los cuadros actualizada, se les envío a todos los gobiernos en el mes de julio del 2007. Informe de la Junta Internacional de Fiscalización de Estupefacientes sobre el seguimiento del vigésimo período extraordinario de sesiones de la Asamblea General. Naciones Unidas. New York. 2009, pp. 12, 13.

56 La mayoría de las sustancias de la lista limitada de vigilancia especial internacional de sustancias no incluidas en los cuadros se encuentran contenidas en la lista que nosotros elaboramos con las sustancias químicas no catalogadas que en los últimos 15 años se utilizan frecuentemente en la elaboración de drogas ilícitas y sus precursores, así como sucedáneos de estos últimos. Vid. Anexo V sobre Sustancias no catalogadas que se utilizan en la elaboración de drogas ilícitas. Precursores y productos químicos frecuentemente utilizados..., correspondiente a 2011..., p. 35. La lista de vigilancia internacional especial limitada de siustancias no incluidas en los cudros paso de tener 26 sustancia a 52 sustancias en el año 2012. Precursores y sustancias químicas frecuentemente utilizados..., correspondiente a 2012..., pp. 35, 36. Precursores y sustancias químicas frecuentemente utilizados..., correspondiente a 2014..., p. 5.

57 La 4-bromo-2,5-dimetoxifeniletilamina (2C-B) pertenece a la familia de las fenetilaminas, un derivado de las anfetaminas, psicodélicas. Se le conoce como Nexus o pastillas triposas, en ocasiones se vende como éxtasis o MDMA. Los efectos que produce esta droga son similares a los de los producidos por la LSD y la MDMA, pero no iguales a los que generan la mezcla de esas dos sustancias. Sus efectos psicodélicos no son tan intensos como los de la LSD, y es algo menos estimulante que la MDMA. Los efectos suelen durar entre 2 y 4 horas. http://energycontro.org/infodrogas/2cb.html. p. 13. 
nos que fabricaban esta droga por varios países ${ }^{59}$. Entre ellos los Estados Unidos de América, Canadá y Eslovaquia. Hay que puntualizar que en ninguno de los casos se facilitó información a la JIFE sobre el tipo de precursores, los volúmenes o sobre como los habían obtenido los traficantes. Sin embargo en el mes de agosto de 2010 el gobierno de los Estados Unidos de América decidió fiscalizar el 4-anilino-N-fenetil-4piperidina, precursor inmediato del fentanilo, sometiéndolo a la Ley de sustancias fiscalizadas. Es necesario señalar que cuatro sustancias no catalogadas esenciales para la fabricación ilícita de fentanilo y algunos de sus derivados se encuentran incluidos en la lista de vigilancia internacional especial limitada de sustancias no incluidas en los cuadros ${ }^{60}$. Un dato de sumo interés sobre las sustancias no incluidas en los cuadros de la convención de 1988 que se utilizan en la fabricación de drogas ilícitas lo proporciona el informe de la JIFE sobre precursores del año 2012. En el señalan que a través del formulario D del año 2003 se registraron incautaciones 24 sustancias no catalogadas, mientras que en el informe correspondiente al año 2011 se reportaron incautaciones de 225 sustancias no catalogadas, incremento que demuestra la complejidad del problema al que nos enfrentamos ${ }^{61}$. Situación que se debe, en buena medida, al aumento continuo de las clases y cantidades de las drogas sintéticas, a manera de ejemplo citamos que hasta 2014 se detectaron 388 sustancias distintas, frente a las 348 detectadas hasta el año anterior. Hay que precisar que la mayoría de las sustancias objeto de uso indebido son cannabinoides sintéticos y catinonas sintéticas que imitan los efectos de drogas fiscalizadas como el cannabis y la anfetamina ${ }^{62}$.

59 El fentanilo es un agionista narcótico sintético opioide utilizado en analgesia y anestesia, con una potencia aproximada 100 veces mayor que la morfina. Por vía intravenosa tiene un comienzo de acción de menos de 30 segundos y un efecto máximo de 5 a 15 minutos, con una duracion de acción de 30 a 60 minutos. Por vía epidural o intradural el comienzo de la acción es de 4 a 10 minutos y la duración es de 1 a 2 horas. Es considerado un derivado sintético del opio. http://es.wikipedia.org/wiki/fentanilo.

Precursores y productos químicos frecuentemente utilizados..., correspondiente a 2011..., p. 31. Informe de la Junta Internacional de Fiscalización de Estupefacientes correspondiente a 2012. Ed. Naciones Unidas. Nueva York. 2013, pp. 35, 36. 
Además hay que tener en cuenta que la JIFE señala en el su informe sobre precursores de drogas correspondiente al año 2014 que a partir del año 2010 empezaron a parecer los precursores de diseño a gran escala. A diferencia de las sustancias químicas no incluidas en los Cuadros, suelen elaborarse con un fin específico y pueden convertirse fácilmente en precursores fiscalizados. Esos precursores son suministrados por lo que parecen ser empresas comerciales, que funcionan al límite de la legalidad y producen esas sustancias por encargo con fines a la larga ilícitos, a veces sin conocimiento del productor63.

Finalmente para ilustrar la dificultad que entraña el control del desvío de los precursores de drogas o su producción ilícita por los cuerpos y fuerzas de seguridad, principalmente las que se usan para fabricar drogas de diseño ${ }^{64}$, queremos señalar que es factible su obtención mediante el uso de los denominados precursores secundarios o preprecursores que muchas veces no están sometidos prácticamente a ningún tipo de control o bien la fiscalización que se realiza es muy baja (sustancias químicas no catalogadas), presentándose además algunos casos en que es posible la sustitución del precursor por una sustancia no catalogada para la elaboración de drogas ilícitas ${ }^{65}$. Como ejemplo de ellos citamos los siguientes casos: 1) la 3,4 -metilendixiofenil acético y la sal sódica de 3,4-MDP-2-P ácido glicídico son precursores secundarios del la 3,4-MDP-2-P, 2) el alcohol piperonílico es precursor indirecto del piperonal, 3) el aceite de sasafrás es precursor secundario del safrol e isosafrol, 4) el aceite de Ocotea y el catecol son pre-precursores del safrol, 5) la diacetona alcohol y el alcohol isopropílico son precursores secundarios de la acetona, 6) el ácido acético, es precursor secundario la P-2-P y del anhídrido acético, 7)) el cianuro de bencilo, el cloruro de bencilo y el ácido mandélico se utilizan en la fabricación ilícita del ácido fenilacético y de la P-2-P, 9) el 1-fenil1-propanona, la sal

63 Precursores y sustancias químicas frecuentemente utilizados..., correspondiente a 2014..., p. 5 .

64 Nos referimos a las siguientes sustancias catalogadas: ácido antranílico, ácido Nacetilantranílico, efedrina, seudoefedrina, ergometrina, ergotamina, ácido lisérgico, safrol, isosafrol y piperonal, la 3,4-MDP-2-P y la P-2-P.

65 BERNAL CONTRERAS, Héctor Hernando. Las sustancias químicas...ob.cit, pp. 148, 185. Precursores y productos químicos frecuentemente utilizados..., correspondiente a 2000..., p. 17. 
sódica de P-2-P ácido glicídico y el nitroetano son precursores secundarios de la P-2-P, 9) el benzaldehido es sucedáneo de la P-2-P, 10), el alcohol butílico es precursor secundario de la metiletilcetona 11) el ciclohexano es sucedáneo del tolueno, 12) el cloruro de acetilo es sucedáneo del anhídrido acético, 13) el fenilacetato de etilo es precursor secundario del ácido fenilacético, 14) el peroxido de hidrogeno, el manganato de potasio y el dióxido de manganeso son precursores secundarios del permanganato de potasio, 15) el hipoclorito de sodio y el permanganato de sodio son sucedáneos del permanganato de potasio, 16) el ácido fosfórico y el ácido nítrico son sucedáneos del ácido sulfúrico, 17) el fenilacetilcarnibiol se utiliza en la elaboración de efedrina y seudoefedrina, 18) la ergocritina que es una sustancia no catalogada es un precursor directo del LSD. Además hay que agregar que está comprobado que partiendo de algunas sustancias de origen natural, como el cornezuelo de centeno y la efedra, se pueden obtener precursores secundarios, o directamente sustancias catalogadas. Esta gran cantidad de precursores secundarios, sucedáneos y sustancias naturales que se utilizan como precursores directos de precursores de drogas, no estando señaladas todas, creemos que nos permite ilustrar las dificultades que enfrentan las autoridades competentes para descubrir, prevenir y cortar el tráfico de precursores de drogas y por ende el tráfico de drogas que es el fin último que se persigue.

\section{C.) LEGISLACIÓN SUPRANACIONAL DE LA UNIÓN EUROPEA}

Para empezar este apartado es preciso recordar que el Convenio de Naciones Unidas contra el tráfico ilícito de estupefacientes y sustancias psicotrópicas adoptado en Viena el 20 de diciembre de 1988, fue celebrado por la Unión Europea, en esa fecha Comunidad Económica Europea, mediante la Decisión 90/611/CEE del Consejo el día 24 de noviembre de 1990.

1. El comercio de sustancias catalogadas entre los Estados miembros y terceros países (extracomunitario)

La Unión Europea a través de diversas disposiciones ha mostrado su preocupación por afrontar el problema del tráfico de precursores de drogas, dándole cumplimiento al artículo 12 del Convenio del 20 de diciembre de 1988 de la ONU celebrado en Viena y por ende a la Decisión 90/611/CEE del Consejo anteriormente citada, así el Reglamento del Consejo (CEE) 3677/1990, de 13 de diciembre, conocido como Regla- 
mento base, establecía una serie de medidas con el fin de impedir el desvío de estas sustancias para la producción ilícita de drogas fuera del territorio aduanero de la Unión Europea. Este Reglamento preceptuaba la documentación necesaria para toda operación de importación, exportación o tránsito tales como facturas, declaraciones de carga, documentos aduaneros, documentos de transporte y demás documentos de envío que debían contener la información que permitiera identificar con toda certeza: a) el nombre de la sustancia catalogada como tal y como se indica en el anexo; b) la cantidad y el peso de la sustancia catalogada y, si ésta consiste en una mezcla, la cantidad y el peso de la mezcla, así como la cantidad y peso del porcentaje de la o las sustancias catalogadas que figuran en el anexo que estén contenidas en la mezcla; c) el nombre y la dirección del exportador, del importador, del distribuidor o, siempre que se conozca, del destinatario final; d) se indicaba la obligación a los operadores de etiquetar las sustancias catalogadas en operaciones de importación, exportación o transito.

Por mandato de esta norma se les ordenó a los operadores llevar un registro comercial de las denominadas "sustancias catalogadas" como precursores de drogas tóxicas, estupefacientes y psicotrópicos. Además se establece el deber de notificación, asimismo cada Estado miembro deberá adoptar las medidas pertinentes para que se establezca una efectiva cooperación entre las autoridades competentes y los operadores, para que éstos últimos notifiquen inmediatamente a las autoridades correspondientes cualesquiera circunstancias, tales como pedidos y transacciones inhabituales de sustancias catalogadas, que indiquen que estas pueden ser desviadas para la fabricación ilícita de drogas. También se impone la obligación en el caso de exportación de las sustancias catalogadas del Cuadro I de la presentación previa de un expediente, por lo menos 15 días laborales antes de la presentación de la declaración aduanera, a las autoridades competentes del Estado miembro. En el caso de la existencia de indicios de desviación de dichas sustancias, las autoridades competentes prohibirán su exportación mediante notificación por escrito con acuse de recibo. De las sustancias comprendidas en el Cuadro II se mandaba a realizar la notificación previa únicamente cuando así estuviese acordado con el tercer país.

Con el propósito de fortalecer las medidas de control de este Reglamento se otorgaron poderes a las autoridades competentes, para lo cual cada Estado miembro debía adoptar, con arreglo a su Derecho interno, las medidas pertinentes para que estas autoridades pudieran ob- 
tener información de cualquier pedido u operación relativo a las sustancias catalogadas y tener acceso a los locales profesionales de los operadores con objeto de buscar pruebas de irregularidades. Además se manda a que cada Estado miembro establezca las sanciones aplicables en el caso de infracción de las disposiciones del presente Reglamento. Las cuales deberían ser adecuadas para incitar al cumplimiento de tales disposiciones.

Es preciso puntualizar que el Reglamento del Consejo (CEE) $3677 / 1990$, fue desarrollado, aplicado y modificado por ulteriores reglamentos comunitarios, que a continuación comentamos de forma sucinta, tal es el caso del Reglamento del Consejo 900/1992 del 31 de marzo, que en su artículo 11 bis autorizó a la Comisión establecer tres categorías de sustancias catalogadas, en lugar de las dos que establece el Convenio de Viena de 1988, las categorías al tenor de este instrumento quedaron de la siguiente forma:

Categoría 1: efedrina, ergometrina, ergotamina, ácido lisérgico, 1-fenil-2propanona ${ }^{66}$, seudoefedrina, ácido $\mathrm{N}$-acetilantranilico ${ }^{67}$ y 3,4-metilendioxifenil2-propanona, así como las sales de las sustancias enumeradas en esta categoría siempre que la existencia de dichas sales sea posible.

Categoría 2: anhídrido acético, ácido antranilico, ácido fenilacético, piperidina, isosafrol, piperonal y safrol y las sales de las sustancias enumeradas en esta categoría siempre que la existencia de dichas sales sea posible.

Categoría 3: acetona, éter etílico ${ }^{68}$, metiletilcetona ${ }^{69}$, tolueno, permanganato de potasio, ácido sulfúrico y ácido clorhídrico ${ }^{70}$.

Para cada una de estas tres categorías se estableció un nivel de exigencias diferentes. Siendo mayor el nivel de requerimientos el correspondiente a la categoría 1, y las sustancias comprendidas en la categoría número 3 las que menos obligaciones establecen para su comercialización, quizás por el gran volumen de comercio lícito que se produce de

66 También conocido por el nombre común de fenilacetona o P-2-P.

67 Esta sustancia además es conocida como Ácido 2-Acetamidobenzoico.

68 Nombre común éter dietílico.

69 Esta sustancia catalogada también se conoce como butanona.

70 De igual manera se conoce como cloruro de hidrógeno. 
estos precursores ${ }^{71}$. Otros aspectos a destacar de este Reglamento son; que se eleva a tres años la obligación de conservación de los documentos que certifican las transacciones de sustancias catalogadas por parte de los operadores, la creación de la "licencia de operadores", así como el fortalecimiento de requisitos para otorgar la autorización de las exportaciones de precursores dotando a las autoridades competentes de mayores competencias para desarrollar su labor de averiguación sobre la licitud de las transacciones ${ }^{72}$.

El Reglamento de la Comisión 3769/1992 del 21 de diciembre, estipulaba que los operadores que participaran en la exportación de las sustancias comprendidas en la categoría 3 que no pasaran de un limite estipulado en el periodo de un año estaban dispensados de la obligación de llevar el registro de las transacciones ${ }^{73}$ y traslada de la categoría 2 a

71 La exportación de las sustancias comprendidas en la categoría número 1 del anexo estará sujeta a autorizaciones de exportación individualizadas expedidas para cada operación por las autoridades competentes del Estado miembro en cuya aduana deba presentarse la declaración de exportación con arreglo a la normativa vigente, debiendo describir plenamente la sustancia, su peso y los operadores que intervengan en la transacción, así como información sobre los medios de transporte e itinerario. Siendo necesario presentar la autorización de importación expedida por el país de destino. Es importante señalar que las autoridades tienen un plazo de 15 días laborales para tomar una decisión sobre la exportación una vez que consideren completo el expediente. La exportación de las sustancias de la categoría número 2 del anexo quedará sujeta a autorización expedida por las autoridades competentes, la autorización podrá realizarse de forma global, debiendo describirse de forma detallada el tipo y peso de las sustancias, así como información sobre los distintos operadores que participen en la transacción. También las autoridades competentes tienen el plazo de 15 días laborales para pronunciarse sobre la solicitud e exportación. Hay que aclarar que será necesaria la autorización de exportación individualizada en todos los casos en que parezca que las sustancias están destinadas, directa o indirectamente, a un tercer país del que se tenga conocimiento esta implicado en la fabricación ilícita de estupefacientes o sustancias psicotrópicas. La exportación de sustancias enumeradas en la categoría 3 del anexo podria realizarse de forma global al amparo de una licencia genérica e individual, salvo que existieran indicios de desvío para la fabricación de drogas ilegales o que existiera un acuerdo bilateral con el país de destino que estableciera la necesidad de una autorización de importación. Reglamento (CCE) n.o 900/92 del Consejo del 31 de marzo de 1992, pp. 3, 5 .

Reglamento (CCE) n.o 900/92 del Consejo del 31 de marzo de 1992, pp. 3, 4.

73 Estos umbrales son los siguientes: 1) acetona, no más de 50 kilogramos; 2) éter etílico, no más de 20 kilogramos; 3) metiletilcetona, no más de 50 kilogramos; 4) tolueno, no más de 50 kilogramos; 5) permanganato de potasio, no más de 5 kilogramos; ácido sul- 
la categoría 1 a las siguientes sustancias: isosafrol, piperonal y safrol con lo cual el régimen de transacción de dichas sustancias se endurece notablemente. Además en su artículo 4 establece el modelo de licencia de exportación y en el artículo 5 la licencia genérica individual y además los países (destinos) sensibles para la exportación de anhídrido acético (categoría 2), metiletilcetona, tolueno, permanganato potásico, acido sulfúrico, acetona, éter etílico y acido Clorhídrico (de la categoría 3) ${ }^{74}$. El Reglamento (CEE) de la Comisión 2959/1993 del 27 de octubre, sustituye los anexos II y III del Reglamento anterior, es decir destinos sensibles de las sustancias anteriormente citadas. En tales casos se debe cumplir con las exigencias que establece el artículo 4 del Reglamento base (3677/90), referido a la notificación previa a la exportación. Lo cual implica tratar la operación de comercio de las sustancias de las categorías 2 y 3 con el mismo rigor que se establece para las sustancias comprendidas en la Categoría 1. A su vez el Reglamento (CE) n.o 2093/97 de la Comisión de 24 de octubre de 1997, modifica nuevamente los anexos II y III del Reglamento anterior y el Reglamento (CE) n. $\mathrm{o}$ 1610/2000 de la Comisión de 24 de julio del 2000 vuelve a modificar nuevamente los anexos antes citados que quedan de la siguiente forma:

\section{ANEXO II}

\begin{tabular}{|l|}
\hline Sustancia: anhídirido acético. \\
\hline Destinos: Arabia Saudí, Argentina, Benín, el Estado Plurinacional de Bolivia, \\
Brasil, Chile, Chipre, Colombia, Costa Rica, Ecuador, Emiratos Árabes Unidos, \\
Etiopía, Federación de Rusia, Filipinas, Guatemala, Hong Kong, India, Indo- \\
nesia, Irán, Islas Caimán, Jordania, Líbano, Macao, Malasia, México, Moldavia, \\
Myanmar (Birmania), Nigeria, Paraguay, Perú, República Checa, Singapur, \\
Siria, Sri Lanka, Sudáfrica, Tailandia, Tayikistán, Turquía y la Reública Boli- \\
\hline
\end{tabular}

fúrico no más de 100 kilogramos, y 8) ácido clorhídrico no más de 100 kilogramos. Reglamento (CEE) n. ${ }^{\circ} 3769$ de la Comisión de 21 de diciembre de 1992, pp. 3, 7 .

Anhídrido acético (categoría 2): Colombia, Guatemala, Hong Kong, India, Líbano, Malasia, Myanmar (Birmania), Singapur, Siria, Tailandia y Turquía. Para las sustancias Metiletilcetona, Tolueno, Permanganato de potasio y Ácido sulfúrico (categoría 3): Argentina, El Estado Plurinacional de Bolivia, Brasil, Chile, Colombia, Costa Rica, El Salvador, Ecuador, Guatemala, Honduras, Hong Kong, Panamá, Paraguay, Perú, Siria, Tailandia y Uruguay. Para las sustancias Acetona, Éter etílico y Ácido Clorhídrico (Categoría 3): Argentina, Estado Plurinacional de Bolivia, Brasil, Chile, Colombia, Costa Rica, El Salvador, Ecuador, Guatemala, Honduras, Hong Kong, Irán, Líbano, Myanamar (Birmania), Panamá, Paraguay, Perú, Singapur, Siria, Tailandia, Turquía y Uruguay. 
variana de Venezuela.

Sustancia: ácido antranílico.

Destinos: el Estado Plurinacional de Bolivia, Chile, Colombia, Ecuador, Emiratos Árabes Unidos, India, México, Perú y la República Bolivariana de Venezuela.

Sustancias: ácido fenilacético y piperidina.

Destinos: el Estado Plurinacional de Bolivia, Chile, Colombia, Ecuador, Emiratos Árabes Unidos, los Estados Unidos de América, México, Perú y la República Bolivariana de Venezuela.

\section{ANEXO III}

Sustancias: metiletilcetona, tolueno y ácido sulfúrico.

Destinos: Argentina, el Estado Plurinacional de Bolivia, Brasil, Chile, Colombia, Costa Rica, Ecuador, El Salvador, Emiratos Árabes Unidos, Guatemala, Honduras, Hong Kong, Panamá, Paraguay, Perú, Siria, Tailandia, Uruguay y la República Bolivariana de Venezuela.

Sustancia: permanganato potásico.

Destinos: Arabia Saudí, Argentina, Benín, el Estado Plurinacional de Bolivia, Brasil, Chile, Chipre, Colombia, Costa Rica, Ecuador, El Salvador, Emiratos Árabes Unidos, Etiopía, Federación de Rusia, Filipinas, Guatemala, Honduras, Hong Kong, Islas Caimán, Jordania, Macao, Malasia, Moldavia, Nigeria, Panamá, Paraguay, Perú, República Checa, Siria, Sri Lanka, Sudáfrica, Tailandia, Tayikistán, Turquía, Uruguay y la República Bolivariana de Venezuela.

Sustancias: acetona y éter etílico.

Destinos: Argentina, el Estado Plurinacional de Bolivia, Brasil, Chile, Colombia, Costa Rica, Ecuador, El Salvador, Emiratos Árabes Unidos, Guatemala, Honduras, Hong Kong, Irán, Líbano, México, Myanmar (Birmania), Panamá, Paraguay, Perú, Singapur, Siria, Tailandia, Turquía, Uruguay y la República Bolivariana de Venezuela.

Sustancia: ácido clorhídrico.

Destinos: Argentina, El Estado Plurinacional de Bolivia, Brasil, Chile, Colombia, Costa Rica, Ecuador, Emiratos Árabes Unidos, El Salvador, Guatemala, Honduras, Hong Kong, Irán, Líbano, Myanmar (Birmania), Panamá, Paraguay, Perú, Singapur, Siria, Tailandia, Turquía, Uruguay y la Repúblicas Bolivariana de Venezuela.

El Reglamento (CE) n.o 260/2001 de la Comisión del 8 de febrero de 2001 dándole cumplimiento a la decisión adoptada por la Comisión de estupefacientes de Naciones Unidas en marzo del 2000 de incluir la sustancia norefedrina en el Cuadro I del anexo de Naciones Unidas, modifica el Reglamento (CCE) 3677/90 del Consejo, incorporando di- 
cha sustancia en el Cuadro I, así se pasa de las 22 sustancias que estaban catalogadas hasta entonces a 23 sustancias:

Categoría 1: 1-fenil-2-propanona (P-2-P), ácido $N$-acetilantranílico, Isosafrol, 3,4 metilendioxifenil-2-propanona (3,4-MDP-2-P), piperonal, safrol, efedrina, seudoefedrina, norefedrina, ergometrina, ergotamina y ácido lisérgico. Las sales de las sustancias enumeradas en esta categoría cuando la existencia de dichas sales sea posible y no sean sales de catina.

Categoría 2: anhídrido acético, ácido fenilacético, ácido antranílico y piperidina. Las sales de las sustancias enumeradas en esta categoría cuando la existencia de dichas sales sea posible.

Categoría 3: ácido clorhídrico, ácido sulfúrico, permanganato potásico, tolueno, éter etílico, acetona y metiletilcetona, así como las sales de las sustancias enumeradas en esta categoría cuando la existencia de dichas sales sea posible y no sean sales de ácido clorhídrico y ácido sulfúrico.

Posteriormente, el Reglamento (CE) n.. 1116/2001 del Consejo del 5 de junio del 2001 para resolver problemas en la aplicación de medidas en algunas sustancias, tal es el caso del el aceite de Sasafrás que se interpretaba de manera de divergente en la Unión Europea, dado que este aceite se consideraba como una mezcla que contiene Safrol y, por lo cual, en varios Estados miembros estaba controlado, mientras que en otros Estados miembros estimaban que se trataba de un producto natural al que no se le aplicaban controles. Para solucionar tal situación este Reglamento en su artículo número 1 preceptúa que debe entenderse como "sustancia catalogada: cualquier sustancia contenida en el anexo, incluidas las mezclas y los productos naturales que contengan dichas sustancias. Se excluyen los medicamentos, preparaciones farmacéuticas, mezclas, productos naturales $u$ otras preparaciones que contengan sustancias catalogadas cuya composición sea tal que dichas sustancias no puedan ser utilizadas fácilmente o recuperadas con medios de fácil aplicación o económicamente viables". Además dándole cumplimiento al plan de acción antidroga de la Unión Europea, aprobado por el Consejo Europeo de Santa Maria da Feria de 19 y 20 de junio del 2000 se toman medidas para apoyar la cooperación entre las Administraciones de los Estados miembros y la industria química, en lo que respecta a las sustancias que, aunque no estén contempladas por la normativa como precursores, puedan utilizarse en la fabricación ilícita de estupefacientes y psicotrópicos, para tal fin se toman algunas medidas tales como la creación de una lista, que debe actualizarse de forma periódica, de las sustancias no catalogadas que generalmente se utili- 
zan para la fabricación ilícita de drogas con el objetivo que la industria controle voluntariamente el comercio de tales sustancias.

En este mismo año a través del Reglamento (CE) n.o 1251/2001 de la Comisión del 26 de junio del año 2001, se establecen obligaciones específicas para la exportación de las sustancias catalogadas que figuran en la categoría 2, las que estarán sometidas mutatis mutandi a las disposiciones del artículo 4 del Reglamento base (3677/90) cuando se destinen a un operador establecido en un país que figure en la lista publicada en la serie C del Diario Oficial de las Comunidades Europeas (destinos sensibles), lista que será actualizada de forma regular por la Comisión Europea. También se establecen obligaciones en el mismo sentido para la exportación de las sustancias catalogadas en la categoría 3. El Reglamento (CE) n.o 988/2002 del Consejo del 3 de junio del año 2002 modifica el artículo número 4 del Reglamento base, regulando de mejor manera todo lo concerniente a "la notificación previa de exportación" de las sustancias catalogadas que figuran en la categoría $1^{75}$, así como a "la autorización de exportación”, que figura en el artículo 4 bis que preceptúa que la exportación de las sustancias catalogadas en la categoría 1 estarán sujetas a autorizaciones de exportación expedidas para cada operación por la autoridades competentes del Estado miembro en el que deba presentarse la declaración de exportación según la normativa vigente. Estableciendo este instrumento toda la información requerida, así como los casos en que se precisa de la "autorización de importación del país de destino". Para otorgar la autorización de exportación, también se cuentan con 15 días laborables, una vez completado el expediente, el cual puede ser prorrogado para realizar averiguaciones complementarias. Este Reglamento establece que se podrá denegar la autorización de exportación cuando: a) existan motivos fundados que indiquen que la información facilitada es falsa o incorrecta, b) en los casos contemplados en el apartado 976 cuando se determine que las autoridades competentes del país de destino no han

75 Se concederá al país de destino el plazo de 15 días laborales como máximo, terminado el cual, salvo que se haya recibido información en sentido contrario, se autorizará la exportación por las autoridades competentes del Estado miembro correspondiente.

76 En los casos que exista un acuerdo entre el Estado miembro y el país de destino mediante el cual han estipulado que no se autoricen las exportaciones sin que antes hayan expedido una autorización de importación. 
expedido la correspondiente autorización de importación y c) cuando existan motivos fundados para sospechar que las sustancias de que se trate están destinadas a la fabricación ilícita de estupefacientes o sustancias psicotrópicas. Posteriormente el Reglamento (CE) n.o 1232/2002 de la Comisión del 9 de junio del 2002 modifica los artículos correspondientes a las obligaciones especificas para la exportación de las sustancias catalogadas que figuran en la categoría 2 y 3 . Además para darle cumplimiento a la decisión adoptada en marzo del 2001 por la Comisión de Estupefacientes de Naciones Unidas de integrar el Anhídrido acético y el Permanganato de potasio en el Cuadro I del anexo del Convenio de Naciones Unidas de 1988, quedando establecidas las categorías de sustancias catalogadas de la siguiente manera:

Categoría 1: 1-fenil-2-propanona, ácido $N$-acetilantranílico, isosafrol, 3,4 metilendioxifenil-2-propanona, piperonal, safrol, efedrina, seudoefedrina, norefedrina, ergometrina, ergotamina y ácido lisérgico. Las sales de las sustancias enumeradas en esta categoría cuando la existencia de dichas sales sea posible y no sean sales de catina.

Categoría 2: anhídrido acético, ácido fenilacético, ácido antranílico, piperidina y permanganato de potasio. Las sales de las sustancias enumeradas en esta categoría cuando la existencia de dichas sales sea posible.

Categoría 3: ácido clorhídrico, ácido sulfúrico, tolueno, éter etílico, acetona y metiletilcetona, así como las sales de las sustancias enumeradas en esta categoría cuando la existencia de dichas sales sea posible y no sean sales de ácido clorhídrico y ácido sulfúrico.

El Reglamento (CE) 3677/1990 del 13 de diciembre, conocido como Reglamento base, es derogado finalmente por el artículo 34 del Reglamento (CE) 111/2005 del Consejo del 22 de diciembre del año 200477, pasando este instrumento jurídico a ser el Reglamento base de la

77 Es necesario precisar que si bien este instrumento deroga el Reglamento $3677 / 1990 /$ CEE con efecto a partir del 18 de agosto del 2005, pero no hace lo mismo con los diferentes instrumentos que lo reformaron como el Reglamento del Consejo 900/1992 del 31 de marzo, el Reglamento de la Comisión 3769/1992 del 21 de diciembre, el Reglamento (CEE) de la Comisión 2959/1993 del 27 de octubre, el Reglamento (CE) n.o 2093/97 de la Comisión de 24 de octubre de 1997, El Reglamento (CE) n.o 260/2001 de la Comisión del 8 de febrero de 2001, el Reglamento (CE) n. 1251/2001 de la Comisión del 26 de junio del año 2001 y el Reglamento (CE) n.o 1232/2002 de la Comisión del 9 de junio del 2002. 
Unión Europea en materia de comercio extracomunitario de precursores de drogas. La promulgación de este Reglamento tiene por objetivo mejorar los mecanismos de control destinados a impedir el desvío de precursores de drogas, por ello amplía las normas de vigilancia a los operadores establecidos en la Unión Europea que efectúan transacciones comerciales con terceros países, armonizando a escala comunitaria los procedimientos de concesión de licencias e incrementando los requisitos de control de los medios de suspensión. Este instrumento también pretende adecuarse, en la medida que sea posible, a las medidas adoptadas para el comercio intracomunitario de estas sustancias, en aras de facilitar el cumplimiento por parte de los operadores de los requisitos y disposiciones sobre comercio exterior de precursores. Destacamos de esta norma que desarrolla de mejor forma la sección correspondiente al otorgamiento de licencias y del registro de operadores, así como la referida a la autorización de exportación y las facultades de las autoridades competentes. En su artículo número 4 establece la obligación por parte de los operadores de sustancias catalogadas de conservar toda la documentación sobre las transacciones, de exportación, importación e intermediación, de estas sustancias por un periodo de tres años, que se contabilizará a partir del final del año civil en que haya tenido lugar la operación. En su artículo número 6 ordena que todo los operadores establecidos en la Comunidad que ejerzan actividades de importación, exportación o intermediación con las sustancias catalogadas incluidas en la categoría 1 del anexo, con la salvedad de los agentes de aduanas y los transportistas que actúen únicamente como tales, deberán estar en posesión de una licencia, la cual será expedida por la autoridad competente del Estado miembro, debiendo tener en cuenta la competencia e integridad del solicitante. Dicha licencia se podrá suspender o retirar cuando se hayan dejado de cumplir las condiciones de su concesión o cuando existan motivos fundados para sospechar que existe un riesgo de desvío.

Los operadores establecidos en la Comunidad que realicen las actividades, anteriormente enumeradas, con sustancias catalogadas en la categoría 2 o de exportación de la categoría 3 del anexo, con la salvedad de los agentes de aduanas y de los transportistas que actúen únicamente como tales, deberán registrar de inmediato y actualizar en la medida que sea necesario las direcciones de los locales en los que ejercen tales actividades. Esta obligación se cumplirá ante la autoridad competente del Estado miembro en que esté establecido el operador. En todos los casos, para cualquier sustancia catalogada, los operadores tienen la 
obligación de notificar de forma inmediata a las autoridades competentes sobre pedidos y transacciones inhabituales que indiquen que dichos precursores pueden ser desviados para la fabricación ilícita de drogas, estupefacientes o sustancias psicotrópicas. Para facilitar la cooperación entre las autoridades competentes de los Estados miembros y los operadores establecidos en la Comunidad y la industria química, en particular respecto de "las sustancias no catalogadas", la Comisión, consultando a los Estados miembros elaborará y actualizará unas directrices referidas particularmente a: a) información sobre los medios para identificar y notificar las transacciones sospechosas, b) una lista actualizada periódicamente, de las sustancias no catalogadas, con el fin de que la industria pueda vigilar, de forma voluntaria, el comercio de las mismas. Las exportaciones de sustancias catalogadas de la categoría 1 y las exportaciones de precursores de las categorías 2 y 3 a algunos países de destino (destinos sensibles) irán precedidas de una notificación previa de exportación que las autoridades competentes de la Comunidad enviarán a las autoridades competentes del país de destino de conformidad con el apartado 10 del artículo 12 de la Convención de Naciones Unidas. La lista de los países de destino se determinará de acuerdo con el procedimiento del Comité78.

Por otra parte se establece que las exportaciones de sustancias catalogadas que requieran una declaración en aduana, incluidas las de sustancias catalogadas que salgan del territorio aduanero de la Comunidad tras su almacenamiento en una zona franca del control del tipo I $^{79}$

78 El país de destino podrá contestar en un período de 15 días hábiles, transcurrido este las autoridades competentes del país exportador podrá autorizar la exportación en caso de que las autoridades competentes del país de destino no hayan indicado que la operación puede estar destinada a la fabricación ilícita de estupefacientes o sustancias psicotrópicas. Es necesario señalar que las autoridades competentes podrán aplicar procedimientos simplificados de notificación previa a la exportación cuando tengan certeza de que ello no dará lugar a riesgo de desvío de sustancias catalogadas.

79 El control del tipo I está basado principalmente en la existencia de una cerca. La cerca que delimite la zona franca deberá de ser de características tales que facilite a las autoridades aduaneras la vigilancia del exterior de la zona franca y excluya toda posibilidad de que las mercancías se saquen irregularmente de esta. La zona exterior contigua a la cerca deberá estar acondicionada de tal forma que facilite una vigilancia adecuada por parte de las autoridades aduaneras. El acceso a esta zona estará supeditado al consentimiento de dichas autoridades. 
o en un depósito franco ${ }^{80}$ durante un período de por lo menos 10 días, estarán sujetas a una autorización de exportación. En los casos de que estas sustancias se reexporten dentro de un plazo de 10 días a partir de la fecha de su inclusión en un régimen de suspensión o en una zona franca del control del tipo II ${ }^{81}$ no será necesaria la autorización de exportación. No obstante para la exportación de precursores de la categoría 3 únicamente necesitarán una autorización de exportación en caso de que se requieran notificaciones previas a la exportación o de que las sustancias se exporten a los países de destino que se determinen mediante el procedimiento del Comité con vistas a garantizar un nivel adecuado de control. Las solicitudes de autorización de importación deberán contener los mismos datos o requisitos que la de autorización de exportación ${ }^{82}$.

Las zonas francas o depósitos francos son partes del territorio aduanero de la Comunidad o locales situados en ese territorio, separados, del resto del mismo, en los cuales: a) se considerará que las mercancías no comunitarias, para la aplicación de los derechos de la importación y de las medidas de política comercial de importación, no se encuentran en el territorio aduanero de la Comunidad, siempre que no se despachen a libre práctica, ni se incluyan en otro régimen aduanero, ni se utilicen o consuman en condiciones distintas de las establecidas en la normativa aduanera, b) las mercancías comunitarias, para que una regulación comunitaria específica lo prevea, se beneficiarán, en razón de su inclusión en zona franca o depósito franco, de las medidas relacionadas en principio con la exportación de mercancías.

El control del tipo II están basados principalmente en las formalidades efectuadas conforme al régimen del depósito aduanero. Las disposiciones establecidas para el régimen de depósito aduanero serán aplicables a las zonas francas del control del tipo II.

Expedirán las autorizaciones de exportación las autoridades competentes del Estado miembro en que esté establecido el exportador. En las solicitudes de estas autorizaciones deberán constar como mínimo los siguientes datos: a) nombre y dirección del exportador, del importador en el tercer país, de cualquier otro operador que participe en la operación de exportación o envío y del destinatario final, b) designación de la sustancia catalogada según se indica en el anexo o, en caso de que se trate de una mezcla o producto natural, designación y código NC de ocho cifras y designación de cualquier sustancia catalogada contenida en la mezcla o en el producto natural, c) cantidad y peso de las sustancias catalogadas y, en caso de que se trate de una mezcla o de un producto natural, cantidad y peso y, en su caso, porcentaje de las sustancia catalogadas que contenga, d) información sobre el transporte, tal como la fecha de expedición prevista, el modelo de transporte, la aduana en que se debe presentar la declaración en aduana y, si ya se conocen, la identificación del medio de transporte, el itinerario, el punto previsto de salida del territorio aduanero de la Comunidad y el punto de entrada en el país importador, en todo caso la información sobre el itinerario y el medio de transporte deberá de proporcionarse por el operador en la oficina aduanera de salida, 
Como una novedad legislativa de la Unión Europea el Reglamento (CE) 1277/2005 del la Comisión del 27 de julio del 2005 establece normas, tanto para el Reglamento (CE) 111/2005 del Consejo (extracomunitario) como para el Reglamento (CE) 273/2004 del Parlamento Europeo y del Consejo (comunitario), concernientes a la figura de "la persona responsable", de la concesión de licencias y del registro de operadores, sobre la comunicación de la información, las autorizaciones previas a la exportación y la autorización de exportaciones y exportaciones en el ámbito de los precursores de drogas. Sobre la persona responsable el articulo 3 del Reglamento (CE) 1277/2005 establece que los operadores que intervengan en la exportación, la importación o bien en la intermediación señaladas en el articulo 2 del Reglamento (CE) 111/2005 de sustancias catalogadas de las categorías 1 o 2 deberán nombrar a una "persona responsable" para el comercio de las sustancias catalogadas, debiendo notificar a las autoridades competentes el nombre y los datos de dicha persona. La persona responsable tendrá que asegurarse de que la importación, la exportación o las actividades de intermediación se realicen de conformidad con las disposiciones legales pertinentes y estará facultada para representar al operador. Además se establece que las autoridades competentes deben adoptar una decisión sobre la solicitud de licencias en el plazo de 60 días hábiles a partir de la fecha de la recepción de la solicitud. En el caso de renovación de licencia, la decisión se adoptará en un plazo de 30 días hábiles.

El artículo 14 del Reglamento (CE) 1277/2005 preceptúa que los operadores que intervengan en la exportación de sustancias catalogadas, 0 de sus mezclas, en la categoría 3 estarán exentos, de registrar de inmediato y actualizar en la medida que sea necesario las direcciones de los locales en los que se ejercen tales actividades (artículo 7) del Reglamento (CE), si la suma de las cantidades correspondientes a sus exportaciones en el curso del año natural no supera las cantidades especificadas en el anexo II del presente reglamento ${ }^{83}$. Si las supera el operador deberá de cumplir con el requisito de registro de forma inmediata.

e) cuando se requiera una autorización de importación, será necesaria una copia de esta expedida por el país de destino y f) el número de licencia o registro del operador. 
En los artículos número 20 y 22 del Reglamento (CE) se regula los países de destino de exportaciones de sustancias catalogadas en la categoría 2 y 3 que necesitan una "notificación previa de exportación", así como los países de destino de exportaciones de sustancias catalogadas de la categoría 3 que precisan de la notificación anteriormente señalada, así como de una autorización de exportación al tenor del artículo 11 del Reglamento (CE) 111/2005, ambas listas de países figuran en el Anexo IV del primer reglamento citado ${ }^{84}$ :

\begin{tabular}{|l|}
\hline Sustancia: anhídrido acético y permanganato de potasio. \\
\hline Destinos: Cualquier país. Queremos recordar en este momento que los \\
destinos sensibles para el Anhídrido acético antes eran 40 países y para el \\
Permanganato de potasio 37 países. Igual situación ocurre con el Ácido feni- \\
lacético que anteriormente requería efectuar una notificación previa a la \\
exportación a 34 países, que coincidía con la Piperidina, y por disposición del \\
Reglamento (UE) 225/2011 de la Comisión del 7 de marzo actualmente esta \\
debe realizarse cuando el destino sea cualquier país.
\end{tabular}

\begin{tabular}{|l|}
\hline Sustancia: ácido antranílico. \\
\hline Destinos: Antigua y Barbuda, Benín, el Estado Plurinacional de Bolivia, \\
Brasil, Islas Caimán, Chile, Colombia, Costa Rica, República Dominicana, \\
Ecuador, Etiopía, Haití, La India, Indonesia, Jordania, Kazajistán, Líbano, \\
Madagascar, Malasia, México, Nigeria, Paraguay, Perú, Filipinas, República de \\
Moldova, Federación de Rusia, Arabia Saudí, Sudáfrica, Tayikistán, Turquía, \\
Emiratos Árabes Unidos, Tanzania y la República Bolivariana de Venezuela. \\
El listado se aumenta en 25 países, pasando de 9 a 34 países que necesitan \\
autorización de exportación. De conformidad al Reglamento (CE) 297/2009 \\
de la Comisión hay que agregar a esta lista los siguientes países: Canadá, \\
Maldivas y Omán. Eliminando de esta lista a Rumania. Por mandato del Re- \\
glamento (UE) 225/2011 de la Comisión se incluyen en esta lista los siguien- \\
tes países: Afganistán, Australia y Ghana. Por lo cual pasan a ser 39 países los \\
que precisan autorización de exportación para esta sustancia. \\
\hline
\end{tabular}

Sustancias: piperidina.

Destinos: Antigua y Barbuda, Benín, el Estado Plurinacional de Bolivia, Brasil, Islas Caimán, Chile, Colombia, Costa Rica, República Dominicana, Ecuador, Etiopía, Haití, La India, Indonesia, Jordania, Kazajístan, Líbano, Madagascar, Malasia, México, Nigeria, Paraguay, Perú, Filipinas, República de Moldova, Federación de Rusia, Arabia Saudí, Tayikistán, Turquía, Emiratos Árabes Unidos, República Unida de Tanzania, los Estados Unidos de América y la República Bolivariana de Venezuela. Como se puede apreciar el aumento

84 Los países de destino para exportaciones de las sustancias de la categoría 3 que necesitan tanto una notificación previa de exportación como una autorización de exportación son los mismos. 
de destinos es similar al del Ácido antranílico. Por mandato del Reglamento (CE) 297/2009 de la Comisión hay que agregar a esta lista los siguientes países: Canadá, Maldivas y Omán. Eliminando de esta lista a Rumania. Además se deben agregar: Afganistán, Australia y Ghana en virtud del Reglamento (UE) 225/2011 de la Comisión.

\begin{tabular}{|l|}
\hline Sustancia: metiletilcetona, tolueno, acetona y éter etílico. \\
\hline Destinos: Antigua y Barbuda, Argentina, Benín, el Estado Plurinacional de \\
Bolivia, Brasil, Islas Caimán, Chile, Colombia, Costa Rica, República Domini- \\
cana, Ecuador, Egipto, El Salvador, Etiopía, Guatemala, Haití, Honduras, La \\
India, Jordania, Kazajistán, Líbano, Madagascar, Malasia, México, Nigeria, \\
Pakistán, Paraguay, Perú, Filipinas, República de Moldova, Federación de \\
Rusia, Arabia Saudí, Tayikistán, Turquía, Emiratos Árabes Unidos, República \\
Unida de Tanzania, Uruguay y la República Bolivariana de Venezuela. De \\
conformidad al Reglamento (CE) 297/2009 de la Comisión hay que agregar a \\
esta lista los siguientes países: Canadá, Maldivas, Omán y República de Co- \\
rea. Eliminando de esta lista a Rumania. El Reglamento (UE) 225/2011 de la \\
Comisión adiciona a esta lista los siguientes países: Afganistán, Australia, \\
Ghana y elimina de la misma a Panamá. \\
\hline
\end{tabular}

Sustancia: ácido clorhídrico y el ácido sulfúrico.

Destinos: Estado Plurinacional de Bolivia, Chile, Colombia, Ecuador, Perú, Turquía y la República Bolivariana de Venezuela (disminuyen sensiblemente).

Finalmente es importante puntualizar que el artículo 30 del Reglamento (CE) 1277/2005 deroga el Reglamento 3769/92/CEE con efectos a partir del 18 de agosto del año 2005. Aclarando que las referencias hechas al Reglamento derogado se entenderán hechas al presente Reglamento. A la vez el artículo 31 preceptúa que para el día 31 de diciembre del año 2005 a más tardar, las autoridades competentes revocarán las autorizaciones genéricas de exportación concedidas en virtud del artículo 5, apartado 3, del Reglamento 3677/90/CEE. No obstante tal revocación no afectará a las sustancias catalogadas que hayan sido declaradas para la exportación antes del 1 de enero de 2006.

El Reglamento (UE) n.o 1259/2013 del Parlamento Europeo y del Consejo de 20 de noviembre de 2013, por el que se modifica el Reglamento (CE) n. $\mathrm{o} 111 / 2005$ del Consejo por el que se establecen normas para la vigilancia del comercio de precursores de drogas entre la comunidad y tercero países. Agrega al anexo de este último Reglamento una nueva categoría (categoría 4), en la que se enumeran los medicamentos de uso humano y de uso veterinario que contienen precursores de drogas. En esta categoría se encuentran aquellos medicamentos que contienen efedrina y sus sales y seudoefedrina y sus sales. Estableciendo que todas las exportaciones de las sustancias catalogadas de las categorías 1 
y 4 del anexo, y las exportaciones de precursores incluidos en las categorías 2 y 3 del anexo a algunos países de destino irán precedidas de una notificación previa de exportación que las autoridades competentes de la Unión Europea enviaran a las autoridades competentes del país de destino. Otorgando a la Comisión los poderes para adoptar actos delegados con arreglo al articulo 30 ter del Reglamento 1259/2013, a fin de determinar las listas de los países de destino de las exportaciones de sustancias catalogadas de las categorías 2 y 3 del anexo con vistas a reducir al mínimo el riesgo de desvío de estos precursores de drogas. Además por mandato del artículo 30 bis del presente Reglamento la Comisión estará facultada para adoptar actos delegados conforme lo dispuesto en el artículo 30 ter, antes citado, a fin de adaptar el anexo del mismo a las nuevas tendencias en materia de desvío de precursores de drogas, en particular de aquellas sustancias que pueden transformarse fácilmente en sustancias catalogadas (pre-precursores o precursores secundarios), y de dar seguimiento a cualquier modificación de los Cuadros del anexo del Convenio de 1988. Este Reglamento también incorpora en la categoría 1 del anexo el Alfafenilacetoacetonitrilo (APAAN), precursor de drogas recientemente agregado al Cuadro I de la Convención de 1988, sustancia que se utiliza en los laboratorios clandestinos para elaborar P-2-P, del cual es un precursor inmediato, y por ende anfetamina y metanfetamina.

El Reglamento Delegado (UE) 2015/1011 de la Comisión de 24 de abril de 2015, que completa el Reglamento (CE) n.o 273/2004 del Parlamento Europeo y del Consejo, sobre precursores de drogas, y del Reglamento (CE) n. $-111 / 2005$ del Consejo, por el que se establecen normas para la vigilancia del comercio de precursores de drogas entre la Unión y terceros países y por el que se deroga el Reglamento (CE) n.o 1277/2005 de la Comisión. El Reglamento (UE) 2015/1011 tiene por objeto el establecimiento de las condiciones para la concesión de licencias y registros, determina los casos en que no se requieren las licencias y los registros, establece los criterios para demostrar los fines lícitos de una transacción, determina la información necesaria para vigilar el comercio, fija las condiciones para determinar la lista de los países de destino de exportaciones de sustancias catalogadas de las categorías 2 y 3, establece los criterios para determinar los procedimientos simplificados de notificación previa de exportación y de autorización a la exportación y especifica los requisitos aplicables a la información que se ha de facilitar sobre la aplicación de las medidas de vigilancia en relación con el comercio de drogas. Sobre las condiciones para determi- 
nar las listas de los países de destino de exportaciones de sustancias catalogadas de las categorías 2 y 3 (comercio internacional de precursores). El artículo 10 del presente Reglamento señala que como mínimo incluirán los siguientes países: a) terceros países con que la Unión Europea haya celebrado un acuerdo específico sobre precursores de drogas; b) terceros países que hayan solicitado recibir notificaciones previas a la exportación de conformidad con el artículo 12, apartado 10 del Convenio de 1988; c) terceros países que hayan solicitado recibir notificaciones previas a la exportación de conformidad con el artículo 24 del Convenio de 1988.

Finalmente tenemos el Reglamento de Ejecución (UE) 2015/1013 de la Comisión de 25 de junio de 2015, que establece normas respecto del Reglamento (CE) n.o 273/2004 del Parlamento Europeo y del Consejo,

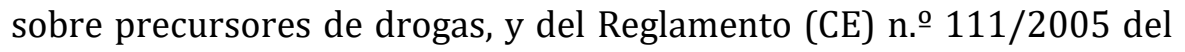
Consejo, por el que se establecen normas para la vigilancia del comercio de precursores de drogas entre la Unión y terceros países. Hay que decir que tiene por objeto el establecimiento de normas uniformes de procedimiento para la aplicación de ambos reglamentos en lo que se refiere a la concesión de licencias y el registro de operadores y usuarios, y su inclusión en la base de datos europea sobre precursores de drogas, a la comunicación por parte de los operadores de la información necesaria para vigilar el comercio y a la autorización de exportaciones e importaciones en el ámbito de los precursores de drogas. Sobre la decisión de la concesión de una licencia es necesario señalar que la autoridad competente debe de resolver si la concede o no en un plazo de 60 días hábiles a partir de la fecha de recepción de una solicitud completa en el caso de una nueva licencia y en el plazo de 30 días hábiles en el caso de una renovación de licencia. Dicha licencia podrá abarcar operaciones tanto del Reglamento (CE) n.o 273/2004 como del Reglamento (CE) n.o 111/2005, la decisión de no conceder una licencia debe ser debidamente motivada. En cuanto al procedimiento de registro hay que señalar que se concederá de conformidad con lo dispuesto en el artículo 3, apartado 6, del Reglamento (CE) n. $273 / 2004$ o en el

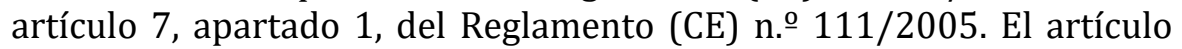
número 11 del Reglamento de Ejecución (UE) 2015/1013 regula de forma pormenorizada todos los procedimientos que se deben cumplir en con las autorizaciones de exportación e importación. 
2. El comercio de sustancias catalogadas entre Estados miembros de la Unión Europea (intracomunitario)

Con el propósito de establecer normas comunes a nivel comunitario, con vistas a la realización del mercado interior, para poder evitar las distorsiones de la competencia en el comercio lícito y garantizar la aplicación uniforme de las normas establecidas se aprobó la Directiva 92/109/CEE del Consejo el 14 de diciembre de 1992 (Directiva base), relativa a la fabricación y puesta en el mercado de determinadas sustancias utilizadas para la fabricación ilícita de estupefacientes y sustancias psicotrópicas. A través de este instrumento se establece la documentación necesaria, incluyendo la declaración del cliente así como el etiquetado de "las sustancias catalogadas" en las categorías 1 y 2, que se corresponden con el Reglamento del Consejo (CEE) 3677/1990, preceptuando que las obligaciones contempladas en esta Directiva no se aplicaran a las sustancias de la categoría número 2 cuando no excedan las cantidades establecidas en el anexo $\mathrm{II}^{85}$. Se instaura la obligación de conservar la documentación de las transacciones por un periodo de tres años. También se dota de facultades a las autoridades competentes de cada Estado miembro para recabar información sobre cualquier pedido de sustancias catalogadas, así como al acceso a los locales profesionales de los operadores con objeto de encontrar pruebas de las irregularidades ${ }^{86}$. Esta Directiva fue modificada por la Directiva 93/46/CEE de la Comisión del 2 de junio de 1993 para hacer efectiva la decisión adoptada por la Comisión de Naciones Unidas sobre estupefacientes de abril de 1992 de incluir las sustancias safrol, piperonal e isosafrol en el Cuadro I del Convenio de Naciones Unidas de 1988, transfiriéndose mediante esta norma dichas sustancias de la Categoría 2 a la categoría 1 de la Directiva comunitaria.

85 Anhídrido acético: 20 litros, ácido antranílico y sus sales: 1 litro, ácido fenilacético y sus sales: 1 kilogramo, piperidina y sus sales: 0,5 kilogramo.

86 En el anexo I de esta Directiva se establecen las tres categorías de sustancias catalogadas. La cuales se corresponden con las establecidas en el Reglamento del Consejo (CEE) $3677 / 1990$ con sus correspondientes reformas. 
A través del Reglamento (CE) n.o 1485/96 de la Comisión del 26 de julio de $1996^{87}$ se establece el modelo de "transacciones únicas" (declaraciones de clientes) para las sustancias comprendidas en la categoría número 1 o 2 del anexo I de la Directiva 92/109/CEE de la Comisión88, también se dispone la creación del modelo correspondiente para la declaración de clientes relativa al uso o usos de una sustancia de la categoría número 2 (transacciones múltiples), el cual se utilizará para toda persona física o jurídica establecida en la Comunidad que proporcione regularmente a un cliente una sustancia catalogada en la categoría número 2 del anexo I de la Directiva antes citada y que tenga obligación de documentar cualquier transacción con arreglo a lo dispuesto en el articulo número 2 de este instrumento podrá aceptar, en lugar de la declaración de transacción única, una sola declaración relativa a varias transacciones realizadas durante un periodo máximo de un año, siempre que el proveedor se asegure que se cumplen los siguientes requisitos: a) que el cliente ha recibido la sustancia del proveedor al menos en tres ocasiones durante los doce meses anteriores, b) que el proveedor no tiene motivos para suponer que la sustancia no se va a utilizar para fines ilícitos y c) que las cantidades encargadas no son inusuales con respecto a ese cliente. Posteriormente el Reglamento (CE) n.o 1533/2000 de la Comisión del 13 de julio del 2000 modifica los modelos de declaración de clientes en aras de establecer un modelo uniforme para todos los operadores que facilite el control de las declaraciones por parte de las autoridades competentes de los Estados miembros.

Mediante la Directiva 2001/8/CE de la Comisión del 8 de febrero de 2001 con vistas de ajustar la Directiva 92/109/CEE del Consejo (comercio de sustancias catalogadas entre estados miembros de la Unión Europea) al Reglamento del Consejo (CEE) 3677/1990 (comercio de sustancias catalogadas entre países miembros de la Unión Europea y terceros países), dándole cumplimiento a la decisión adoptada en marzo del año 2000 por la Comisión de estupefacientes de las Naciones Unidas se incluye la norefedrina como sustancia catalogada en Cuadro

87 Las medidas previstas en este Reglamento se ajustan al dictamen del Comité creado en virtud del artículo 10 del Reglamento (CEE) n.o 3677/90 del Consejo, cuya última modificación la constituye el Reglamento (CEE) n. 3769/92 de la Comisión. 
I, modificando de esta manera la categoría 1 del anexo I de la Directiva base al incorporar esta sustancia. Posteriormente la Directiva 2003/101/CE del 3 de noviembre del año 2003 cumpliendo con la decisión adoptada en marzo del 2001 por la Comisión de estupefacientes de Naciones Unidas de incluir el anhídrido acético y el permanganato de potasio en el anexo I del Convenio de Naciones Unidas de 1988 ubica el permanganato de potasio en la categoría 2 del anexo I, en el caso del anhídrido acético hay que decir que ya se encontraba en esa categoría desde la clasificación realizada por la Directiva 92/109/CEE del Consejo (Directiva base) quedando dicho anexo de la siguiente forma:

Categoría 1: 1-fenil-2-propanona, ácido $N$-acetilantranílico, isosafrol, 3,4 metilendioxifenil-2-propanona, piperonal, safrol, efedrina, seudoefedrina, norefedrina, ergometrina, ergotamina y ácido lisérgico. Las sales de las sustancias enumeradas en esta categoría cuando la existencia de dichas sales sea posible y no sean sales de catina.

Categoría 2: ánhídrido acético, ácido fenilacético, ácido antranílico, Piperidina y permanganato de potasio. Las sales de las sustancias enumeradas en esta categoría cuando la existencia de dichas sales sea posible.

Categoría 3: ácido clorhídrico, ácido sulfúrico, tolueno, éter etílico, acetona y metiletilcetona, así como las sales de las sustancias enumeradas en esta categoría cuando la existencia de dichas sales sea posible y no sean sales de ácido clorhídrico y ácido sulfúrico.

Queremos destacar, por su importancia, la promulgación del Reglamento (CE) 273/2004 del Parlamento Europeo y del Consejo del 11 de febrero del año 2004 sobre precursores de drogas. Instrumento que se considera más adecuado en el contexto de la ampliación de la Unión Europea, que la Directiva 92/109/CEE y de sus anexos (con sus respectivas modificaciones antes señaladas) que deroga ${ }^{89}$, para la aplicación de normas de control uniformes en los 25 Estados miembros. Este nuevo Reglamento en realidad facilita bastante la implementación de medidas para descubrir, prevenir y cortar posibles desviaciones de precursores de drogas en el seno de la Unión Europea, sobre todo a los

89 El artículo 17 del Reglamento 273/2004/CE del Parlamento Europeo y del Consejo deroga la Directiva 92/109/CEE del Consejo, las Directivas 93/46/CEE, 2001/101/CE de La Comisión, y los Reglamentos 1485/96/CE y 1533/2000/CE de la Comisión. Sin embargo es preciso aclarar que cualquier registro, licencia o cualquier declaración de cliente aprobada en virtud de las Directivas o Reglamentos derogados no se verá afectada. 
nuevos Estados miembros de la Unión Europea que inician tal empresa ya con un documento uniforme. El mismo incorpora como novedad el control de las denominadas "sustancias no catalogadas" en apoyo a la industria química, para facilitar la cooperación entre las autoridades competentes de los Estados miembros. Los operadores y la industria química dándole cumplimiento al plan de acción antidrogas de la Unión Europea aprobado por el Consejo Europeo de Santa María da Feria los días 19 y 20 del $2000^{90}$. Otra aportación que hace este instrumento es el establecimiento de la obligación de los operadores que deseen poner en el mercado las sustancias catalogadas de las categorías 1 y 2 del anexo I que deberán designar un agente responsable del comercio, él que cuidará que dicho comercio se lleve a cabo en la observancia del presente Reglamento, este agente esta facultado para representar al operador y adoptar las decisiones necesarias para tal fin. Del Reglamento (CE) 273/2004 en líneas generales se puede decir que representa un avance cualitativo de su antecesor, la Directiva (CE) 92/109, fruto de la experiencia acumulada en 12 años lo cual se puede apreciar en la redacción y contenido del articulado del mismo.

El Reglamento (CE) 1277//2005 de la Comisión establece normas para la aplicación del Reglamento (CE) 273/2004 referidas a la concesión de licencias y del registro de operadores, sobre la comunicación de la información, las notificaciones previas a la exportación y la autorización de exportaciones e importaciones en el ámbito de los precursores de drogas. El instrumento en mención señala de forma detallada todos los requisitos que deben cumplimentar por escrito cualquier operador para solicitar la respectiva licencia91. En lo que lo que se refiere tanto a las disposiciones que regulan los requisitos de concesión de licencias y las obligaciones de notificación de los operadores que efectúan intercambio comerciales intracomunitarios y en intercambios comerciales entre la comunidad y terceros países este instrumento trata de que sean idénticos en la medida de que esto sea posible. Recordamos que

90 En particular las directrices ofrecerán: a) información sobre el modo de reconocer y notificar transacciones sospechosas, b) una lista actualizada de forma periódica de las sustancias no catalogadas a fin de que la industria química y farmacéutica pueda supervisar de forma voluntaria el comercio de las mismas y c) cualquier otra información que se considere útil.

91 Los catorce requisitos que establece el Reglamento 1277/2005/CE para presentar la solicitud son aplicables también al Reglamento 111/2005/CE. 
en su articulo número uno del Reglamento (CE) n.o $1277 / 2005$ de la Comisión establece normas para la aplicación del Reglamento (CE) n.o 273/2004 y del Reglamento (CE) n.o 111/2005.

El Reglamento (UE) n.o 1258/2013 del Parlamento Europeo y del Consejo, de 20 de noviembre de 2013, por el que se modifica el Reglamen-

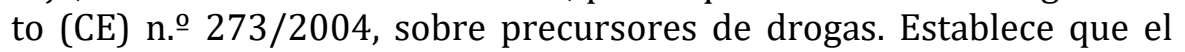
anhídrido acético, catalogado en la categoría 2 del anexo I del Reglamento (CE) n.o 273/2004, debe de incluirse en una nueva subcategoría $2 \mathrm{~A}^{92}$ de dicho anexo I para permitir un mayor control de su comercio, cumpliendo de esta manera con las recomendaciones de La Junta Internacional de Estupefacientes de fortalecer las medidas de control sobre este precursor de drogas en el comercio entre países de la Unión Europea. Preceptuando que desde el día 1 de julio del año 2015, los usuarios deberán obtener un registro de las autoridades competentes del Estado Miembro en el que estén establecidos, antes de poseer sustancias catalogadas de la subcategoría 2. a del anexo I. Señalando que los operadores que posean este registro suministraran las sustancias catalogadas de la categoría $2 \mathrm{~A}$ del anexo I exclusivamente a otros operadores o usuarios que también posean tal registro y además hayan firmado una declaración de cliente del uso o usos de las sustancias, requisito que debe cumplirse con todos los precursores de las categorías 1 o 2 del anexo I, debiendo el operador obtener una declaración distinta para cada sustancia catalogada. En su artículo número 9 el Reglamento 1258/2013 señala una serie de medidas para garantizar el control de las sustancias no catalogadas que pueden utilizarse en la fabricación de drogas ilícitas tales como: que las autoridades competentes tengan acceso a las instalaciones profesionales de los operadores y usuarios para obtener pruebas de irregularidades, así como que se puedan interceptar e incautar los envíos que no cumplan con el presente Reglamento. También hay que destacar que en su artículo 13 bis ordena la creación de una base de datos europea sobre precursores de drogas. En su artículo número 16 este Reglamento incorpora en la categoría 1 del anexo I el Alfa-fenilacetoacetonitrilo (APAAN), precursor de drogas recientemente agregado al Cuadro I de la Convención de 1988, sustancia que se utiliza en los laboratorios clandestinos para 
elaborar P-2-P, del cual es un precursor inmediato, y por ende anfetamina y metanfetamina.

El Reglamento Delegado (UE) 2015/1011 de la Comisión de 24 de abril de 2015, que completa el Reglamento (CE) n.. 273/2004 del Parlamento Europeo y del Consejo, sobre precursores de drogas, y del Reglamento (CE) n. ${ }^{\circ}$ 111/2005 del Consejo, por el que se establecen normas para la vigilancia del comercio de precursores de drogas entre la Unión y terceros países y por el que se deroga el Reglamento (CE) n.o 1277/2005 de la Comisión. El Reglamento (UE) 2015/1011 tiene por objeto el establecimiento de las condiciones para la concesión de licencias y registros, determina los casos en que no se requieren las licencias y los registros, establece los criterios para demostrar los fines lícitos de una transacción, determina la información necesaria para vigilar el comercio, fija las condiciones para determinar la lista de los países de destino de exportaciones de sustancias catalogadas de las categorías 2 y 3 , señalando los criterios necesarios para determinar los procedimientos simplificados de notificación previa de exportación y de su autorización a la exportación, especificando además los requisitos aplicables a la información que se ha de facilitar sobre la aplicación de las medidas de vigilancia en relación con el comercio de drogas.

Sobre el Reglamento de Ejecución (UE) 2015/1013 de la Comisión de 25 de junio de 2015, que establece normas respecto del Reglamento (CE) n. - 273/2004 del Parlamento Europeo y del Consejo, sobre precursores de drogas, y del Reglamento (CE) n. ${ }^{\circ}$ 111/2005 del Consejo, por el que se establecen normas para la vigilancia del comercio de precursores de drogas entre la Unión y terceros países, hay que decir que tiene por objeto el establecimiento de normas uniformes de procedimiento para la aplicación de ambos reglamentos en lo que se refiere a la concesión de licencias y el registro de operadores y usuarios, y su inclusión en la base de datos europea sobre precursores de drogas, así como la comunicación por parte de los operadores de la información necesaria para vigilar el comercio y a la autorización de exportaciones e importaciones en el ámbito de los precursores de drogas. Sobre la decisión de la concesión de una licencia es necesario señalar que la autoridad competente debe de resolver si la concede o no en unplazo de 60 días hábiles a partir de la fecha de recepción de una solicitud completa en el caso de una nueva licencia y en el plazo de 30 días hábiles en el caso de una renovación de licencia. Dicha licencia podrá abarcar operaciones tanto del Reglamento (CE) n.o 273/2004 como del Reglamento (CE) n.o 111/2005. La decisión de no conceder una licencia debe 
ser debidamente motivada. En cuanto al procedimiento de registro hay que señalar que se concederá de conformidad con lo dispuesto en el artículo 3, apartado 6, del Reglamento (CE) n.․ 273/2004 o en el artículo 7, apartado 1, del Reglamento (CE) n.o 111/2005. El artículo número 11 del Reglamento de Ejecución (UE) 2015/1013 regula de forma pormenorizada todos los procedimientos que se deben cumplir con las autorizaciones de exportación e importación. Con el fin de incluir en la base de datos europea sobre precursores de drogas a los operadores y a los usuarios que hayan obtenido una licencia o un registro en virtud del artículo 3, apartado 7, del Reglamento (CE) n.․ 273/2004, cada Estado Miembro designará un solo punto de contacto y comunicara los datos de contacto a la comisión.

3. Estado de la aplicación y el funcionamiento de la legislación comunitaria en materia de vigilancia y control del comercio de precursores de drogas

Como hemos venido exponiendo en los apartados anteriores, desde principios de la década de los noventa la Unión Europea ha venido promulgando una serie de instrumentos jurídicos, fundamentalmente Directivas y Reglamentos, destinados a impedir el desvío de precursores de drogas, mediante el control y vigilancia de su comercio lícito. Creemos pertinente señalar que si bien tradicionalmente la Unión Europea ha sido una gran exportadora de sustancias químicas catalogadas e importadora de drogas ilícitas, paulatinamente se ha ido convirtiendo también en una gran exportadora de drogas sintéticas y por ende en importadora, en alguna medida, de los precursores necesarios para su fabricación ${ }^{93}$. Por consiguiente la legislación comunitaria más reciente, a saber, los Reglamentos 273/2004 (comercio intracomunitario), 111/2005 (comercio extracomunitario) y 1277/2005 (que establece normas de aplicación detalladas para los dos anteriores) reforzaron los controles a la importación de precursores de drogas y ampliaron los requisitos de vigilancia vigentes hasta entonces ${ }^{94}$. Precisamente

93 Hay que aclarar que aunque buena parte de los precursores de drogas sintéticas se producen en Europa, los fabricantes de estas drogas también deben importar estas sustancias de otros países como China, Rusia, la India o México entre otros.

$94 \quad$ La Autoridades Aduaneras de la Unión Europea han incrementado la vigilancia sobre el control del comercio de la efedrina y seudoefedrina a granel o contenida en preparados farmacéuticos o medicamentos, la mayoría de ellos de tránsito a través de territorio comunitario, pero en ocasiones también en exportaciones hacia terceros países en los 
en el artículo 16 del primer Reglamento y en 32 del segundo se establece que, tres años después de la entrada en vigor de dichos instrumentos, se llevaría cabo una evaluación sobre el funcionamiento de dichos Reglamentos y se enviaría un informe al Parlamento y al Consejo, de este informe destacamos, según nuestro criterio, los elementos principales a continuación.

En primer lugar queremos destacar que con el fin de facilitar los acuerdos y la cooperación entre las autoridades competentes y los operadores de las sustancias catalogadas, en el año 2006 se adoptaron las "Directrices de la Unión Europea para operadores sobre el control de precursores de drogas". Estas directrices proporcionan una serie de recomendaciones prácticas, como indicadores de riesgo para transacciones sospechosas entre otras, e incluyen una lista de sustancias catalogadas y no catalogadas ("lista de vigilancia voluntaria de la UE") para ayudar a los operadores económicos a cumplir sus obligaciones en estrecha colaboración con las autoridades competentes. Dado que estas directrices contienen información sensible, son las autoridades competentes de los Estados miembros quienes las difunden directamente, únicamente entre los operadores fiables. También es preciso señalar que los servicios de la Comisión y los Estados miembros han organizado una serie de seminarios destinados a mejorar el conocimiento de la nueva legislación comunitaria sobre precursores de drogas. En definitiva la cooperación entre las autoridades competentes, tanto en lo que respecta al comercio comunitario y extracomunitario funciona satisfactoriamente, aunque en alguna medida se aplica y se utiliza de manera diferente por parte de los Estados miembros, lo cual facilita la notificación

que se lleva a cabo la producción de anfetaminas (incluye también la metanfetamina), lo que ha dado lugar a un importante aumento de las incautaciones, sobre todo en los preparados farmacéuticos que contienen seudoefedrina. Lo cual se evidencia en el hecho de que desde el año 2005 hasta enero del 2010, se han detectado, incautado o interceptado envíos sospechosos de aproximadamente 86 toneladas de efedrina o seudoefedrina a granel o en tabletas, lo que ha evitado la fabricación de hasta 65 toneladas de metanfetamina, cuyo valor en la calle se estima en 9.700 millones de dólares estadounidenses. Informe de la Comisión al Consejo y el Parlamento, de 7 de enero del 2010, sobre la aplicación y funcionamiento de la legislación comunitaria en materia de vigilancia y control del comercio de precursores de drogas, de conformidad con el artículo 16 del Reglamento (CE) 273/2004, y del artículo 32 del Reglamento (CE) 111/2005 del Consejo. Bruselas. 7 de enero del 2010, pp. 2, 8. 
obligatoria o voluntaria de las operaciones sospechosas y evita en buena medida el desvío de las sustancias catalogadas y no catalogadas ${ }^{95}$.

La insistencia de las autoridades competentes en el mejoramiento de los procedimientos y controles aduaneros ha resultado ser muy útil pues se han obtenido avances significativos, pero todavía persisten algunas deficiencias tales como; problemas en la identificación de ciertos envíos sospechosos en relación con los cuales se habían presentado declaraciones aduaneras falsas o el hecho de que algunas administraciones aduaneras no otorgan prioridad a la legislación sobre precursores de drogas o bien que no están suficientemente concienciadas y que carecen de los conocimientos y de los recursos necesarios, ejemplo de ello es la carencia de material para realizar los ensayos. Otro aspecto que hay que resaltar es el de los preparados farmacéuticos y los medicamentos para uso humano que contienen precursores de drogas que se encuentran actualmente fuera del ámbito de aplicación de la legislación sobre precursores de drogas. La fabricación, la importación y la distribución mayorista de medicamentos, incluidos los productos destinados a la exportación, están sujetas al régimen establecido en la legislación comunitaria sobre productos farmacéuticos (Directiva $2001 / 83 / C E)^{96}$. Pero se considera que dichas actividades deberían estar bajo el control sistemático de las autoridades competentes de los Estados miembros en aras de prevenir el desvío de precursores de

Destacamos por su importancia el sistema de notificación previa a la exportación que permite a los terceros países que lo hayan solicitado comprobar la transacción prevista y, de este modo, informar a las autoridades competentes de los Estados miembros sobre si la transacción en principio es licita o no.

96 En este sentido la Comisión de las Comunidades Europeas recomienda que sin duplicar las disposiciones administrativas sobre fabricantes, importadores y distribuidores mayoristas de medicamentos, debería plantearse el refuerzo de las disposiciones de control de los preparados farmacéuticos o de los medicamentos que contengan efedrina o seudoefedrina en tránsito o en transbordo a través de la Unión Europea, auque la legislación sobre productos farmacéuticos ya contiene disposiciones sobre la exportación de medicamentos, debería reflexionarse acerca de si sería conveniente contar con disposiciones prácticas armonizadas específicas sobre la exportación de medicamentos que contengan efedrina o seudoefedrina y su supervisión por parte de las autoridades competentes en materia de medicamentos o si la legislación sobre precursores de drogas debería permitir interceptar las exportaciones de preparados farmacéuticos o medicamentos cuando haya motivos suficientes para sospechar que las sustancias en cuestión se van a utilizar en la fabricación ilícita de drogas. 
drogas. Se realiza la consideración anterior porque estos mismos fabricantes, importadores y distribuidores mayoristas no están sujetos a los requisitos de notificación previa específicos con arreglo a la legislación sobre precursores de drogas cuando exportan medicamentos o preparados farmacéuticos que contienen sustancias catalogadas. Ello ha dado lugar a una situación en la que, en algunos Estados miembros, exportaciones y envíos en tránsito o en transbordo de preparados farmacéuticos o medicamentos que contienen precursores de drogas en particular, efedrina y seudoefedrina no han sido interceptados ni incautados pese a tener información de que era bastante probable que se iban a destinar a la fabricación ilícita de drogas ${ }^{97}$.

Hay que puntualizar que si bien la aplicación y el funcionamiento del sistema común de concesión de licencias introducido en el comercio intracomunitario y en el comercio entre países de la comunidad con terceros países para operadores que manejan precursores de la categoría 1, las sustancias más sensibles, han resultado eficaces en opinión de las autoridades competentes y de los operadores, no ocurre lo mismo con las sustancias catalogadas de la categoría 2 , algo menos sensibles, tanto en el comercio comunitario como extracomunitario, que parece ser insuficiente para permitir un control satisfactorio fundamentalmente en el ámbito intracomunitario. Para ilustrar un poco tal situación se refiere en el informe que los usuarios finales de las sustancias antes señaladas, al no introducir en el mercado estos precursores, no están obligados ni a registrarse ni a informar de las cantidades que compran para su propio uso, por lo que son prácticamente desconocidos para las autoridades competentes. Además es muy complicado para los fabricantes o intermediarios de estas sustancias cumplir con la obligación de comprobar la legitimidad de sus clientes, así como del uso final notificado del precursor, lo que obviamente puede impedir, en gran medida, la notificación a las autoridades competentes de cualquier operación sospechosa. También el control por las autoridades competentes de la así como a la ausencia de procedimientos simplificados de autorización para los envíos repetitivos entre operadores muy conocidos en la Comunidad y en los países de la Asociación Europea de Libre Comercio (Suiza, Noruega, Islandia y Lichtenstein) y la necesidad de seguir simplificando el entorno electrónico aduanero. 
legitimidad de los operadores resulta difícil y más aún cuando los fabricantes o intermediarios y los usuarios finales de las sustancias de la categoría 2 están establecidos en diferentes Estados miembros o cuando el proceso comercial incluye más de dos entidades establecidas en más de un Estado miembro. En este sentido se han detectado problemas en particular con el anhídrido acético, un precursor clave en la fabricación ilícita de heroína ${ }^{98}$. No obstante, de las deficiencias anteriormente señaladas de forma general se puede afirmar que la legislación Comunitaria sobre precursores de drogas funciona de forma satisfactoria, dado que alcanza en buena medida su objetivo de impedir o al menos dificultar el desvío de estas sustancias con fines ilícitos sin crear barreras innecesarias a las actividades comerciales licitas. La política de la Unión en este sentido es centrar el control y la vigilancia en los operadores y no en las transacciones. Resultando la división de las sustancias catalogadas en tres categorías un medio eficaz para la aplicación de un planteamiento modulado, en función de la sensibilidad de las sustancias y las cantidades comercializadas de forma legítima.

La Comunidad hasta el mes de enero del año 2010 realizó 10 acuerdos bilaterales con terceros países para reforzar el control con los principales protagonistas, abordando para ello cuestiones específicas de interés mutuo en el ámbito de control de las sustancias catalogadas. Dichos acuerdos se celebraron con el Estado Plurinacional de Bolivia, Colombia, Ecuador, Perú, la República Bolivariana de Venezuela, Chile, México, los Estados Unidos de América, Turquía y China, además el Consejo controles con todas las sustancias catalogadas de la categoría 2 (en particular con el anhídrido acético, precursor clave en la producción de heroína) a fin de garantizar que los operadores de estos precursores estén sometidos a un control adecuado para disuadir a los traficantes de realizar intentos de desvío. Lo cual se puede lograr, en opinión de la Comisión, con las siguientes medidas: a) modificando el Reglamento $273 / 2004$ (CE) de forma que sea obligatorio el registro de los usuarios finales que posean sustancias de la categoría 2 para uso propio, modificando, por ejemplo, la definición de "operador" o la de "puesta en el mercado" o el apartado 6 del artículo 3, por el que se establece el sistema de registro, b) modificando el Reglamento 1277/2005 (CE) de manera que se introduzcan condiciones y procedimientos comunes de registro y c) modificando el anexo I del Reglamento 273/2004 (CE) y, en consonancia, el anexo del Reglamento 111/2005, de manera que el anhídrido acético pase a estar clasificado como sustancia de la categoría 2 a sustancia de la categoría 1. 
autorizó a la Comisión negociar un acuerdo bilateral con Rusia99. Asimismo se ha creado un grupo de proyectos con expertos en controles operativos de aduanas para mejorar la eficacia operativa en la detección de envíos sospechosos de precursores de drogas que entren en territorio comunitario o salgan de él.

Hay que destacar que en el marco de las Naciones Unidas en el 50. periodo de sesiones de la Comisión de Estupefacientes de la ONU, a partir de una propuesta de la Unión Europea se adopto la Resolución $50 / 10$, sobre la prevención de la desviación de precursores de drogas y otras sustancias utilizadas para la producción ilícita de drogas, estupefacientes y sustancias psicotrópicas, en la que se promueven principios fundamentales del control de los precursores de drogas en la comunidad. Además los servicios de la Comisión y los Estados miembros apoyan las iniciativas operativas específicas dirigidas por las Naciones Unidas para abordar problemas particulares relacionados con el desvío y el tráfico de precursores de drogas y participan activamente en ellas. En concreto, la Unión Europea participa en el proyecto "Prisma" con el fin de enfrentar el desvío de precursores de drogas sintéticas y en el proyecto "Cohesión" para combatir el tráfico de precursores de la heroína y la cocaína, así como en las operaciones específicas conexas.

D.) Reglamento Modelo Para el CONTROL DE SUSTANCIAS QuímiCAS QUE SE UTILIZAN EN LA FABRICACIÓN ILÍCITA DE ESTUPEFACIENTES Y SUSTANCIAS PSICOTRÓPICAS OEA

Nos parece importante realizar una breve reseña al Reglamento Modelo que se utiliza en el continente americano para enfrentar el problema de los precursores de drogas. Este instrumento se publicó por la Secretaria General de la Organización de Estados Americanos en Washington, D.C. en el año 1990 con el objeto de controlar y vigilar la producción, fabricación, preparación, transformación, almacenamiento, importación, exportación, comercialización, transporte y cualquier otro tipo de transacción, tanto nacional como internacional de las sustan- 
cias químicas que se utilizan con frecuencia en la producción, fabricación, preparación o extracción ilícita de estupefacientes, sustancias psicotrópicas u otras de efecto semejante. En el año 1999 y el año 2011 la Comisión Interamericana para el Control del Abuso de Drogas (CICAD) actualizo este Reglamento, esta última versión es la que esta vigente hoy en día. Entre las principales recomendaciones que hace a los Estados miembros queremos destacar las siguientes: a) el establecimiento de una legislación, o adecuación de la ya existente, para el control de sustancias químicas en las transacciones nacionales e internacionales que sea armónica con la de los demás países teniendo en cuenta el presente Reglamento, b) la adopción o actualización de sus normas penales para impedir y controlar el desvío de maquinas destinadas a la presentación final de cápsulas, tabletas o comprimidos, así como los materiales, instrumentos y equipos de uso en los laboratorios desde los canales legítimos hacia la producción ilícita de drogas, c) la incorporación en sus legislaciones internas de medidas de seguridad que debe cumplir el sector privado para el manejo y almacenamiento de las sustancias químicas para prevenir situaciones de emergencia y daño del medio ambiente, así como el establecimiento de una política de "conozca su cliente" por parte de la empresa para prevenir el desvío de precursores de drogas, sustancias no catalogadas, materiales y equipos que se usan en la elaboración de drogas ilícitas, d) el fortalecimiento del control de las sustancias no catalogadas que se utilizan en la fabricación de drogas, que permita el intercambio de información entre los países miembros.

Hay que destacar que este instrumento clasifica los precursores en tres cuadros, los dos primeros deberán, como mínimo, corresponderse con aquellos contenidos en el Cuadro I y Cuadro II del anexo de la Convención de Naciones Unidas contra el tráfico ilícito de estupefacientes y sustancias psicotrópicas de 1988, lo cual ocurre con 15 de las 16 sustancias establecidas en el Cuadro ${ }^{100}$ y las 8 sustancias del Cuadro II, con la particularidad que en este último aparecen 12 sustancias más

100 No aparece el alfa-fenilacetoacetonitrilo (APAAN) que se incorporo como precursor del Cuadro I de la Convención de 1988 en el mes de octubre del año 2014, porque es posterior ala publicación del Reglamento Modelo de la OEA. Las otras 15 sustancias pertenecen al Cuadro I de Naciones Unidas. 
que no se corresponden con la lista de sustancias catalogadas ${ }^{101}$. En el Cuadro III se enumeran una lista de 24 sustancias, no catalogadas en el Convenio de la $\mathrm{ONU}$, que de acuerdo con la experiencia de las autoridades competentes en el continente americano se utilizan frecuentemente en la producción ilícita de drogas, en dicha lista se encuentran sustancias de uso muy común como el yodo, la cal viva o el kerosene ${ }^{102}$. Sobre el sistema de listas establecido en estos tres cuadros hay que decir que tienen un carácter bastante flexible, pues las autoridades de los países miembros podrán incluir, suprimir o cambiar la ubicación de estas sustancias de acuerdo a las necesidades y problemas regionales en los Cuadros de sus ordenamientos internos. La única limitación que tienen es que en los Cuadros I y II, de sus ordenamientos, deben de estar comprendidas las sustancias enumeradas en dichos cuadros en la Convención de Naciones Unidas de 1988.

Entre las medidas de control a los operadores de las sustancias químicas del Cuadro I, se señala que estos se sujetarán a un régimen de control consistente en autorizaciones, licencias u otros similares. En el caso de las sustancia del Cuadro II deberán de inscribirse ante las autoridades competentes a fin de que se conozca la naturaleza y el alcance de las actividades que realizan. En todo caso las licencias, autorizaciones e inscripciones tienen que renovarse de forma periódica por las autoridades competentes de cada Estado miembro. Para el otorgamiento de tales permisos o la revocación de los mismos las autoridades correspondientes podrán considerar diversos antecedentes del solicitante, tales como su capacidad para mantener controles efectivos sobre las sustancias, o la existencia de condenas por infracción a las leyes sobre tráfico ilícito de drogas. Además de los requisitos de Licencia o inscrip-

101 Efectivamente en el Cuadro II están comprendidas las 8 sustancias que enumera el Convenio Internacional en el Cuadro II, más otras 12 sustancias no catalogadas que se utilizan en la fabricación ilícita de drogas, siendo estas: 1) amoniaco anhídrido o en disolución acuosa, 2) hidroxido de Potasio, 3) hidroxido de sodio, 4) sulfato de sodio, 5) carbonato de potasio, 6) carbonato de sodio, 7) hexano, 8) xilenos, 9) cloruro de metileno, 10) benceno, 11) ácido acético y 12) acetato de etilo.

102 1) Cloruro de acetilo, 2) cloruro de amonio, 3) hidróxido de amonio, 4) benzaldehído, 5) cloruro de bencilo, 6) cianuro de bencilo, 7) cianuro de bromobencilo, 8) hidróxido de calcio, 9) óxido de calcio, 10) ciclohexanona, 11) dietilamina, 12) alcohol etílico, 13) formamida, 14) ácido fórmico, sales y sus derivados, 15) ácido yodhídrico, 16) yodo, 17) alcohol isobutílico, 18) acetato isopropílico, 19) alcohol isopropílico, 20) kerosene, 21) alcohol metílico, 22) metilamina, 23) nitroetano y 24) tricloroetileno. 
ción, quienes importen o exporten sustancias del Cuadro I deberán de obtener un permiso de exportación o importación, transito o transbordo, de la autoridad competente. Dicha autoridad podrá someter en los casos de exportación, importación o transito todas o algunas de las sustancias del Cuadro II al mismo régimen anterior, lo cual también lo pueden hacer con algunas o todas las sustancias catalogadas del Cuadro III. El permiso en mención tendrá una validez máxima de 6 meses, será utilizado una sola vez y amparará exclusivamente a una sustancia.

En el artículo 17 de este Reglamento modelo se obliga a los operadores de sustancias químicas controladas a llevar y mantener un registro de todas las operaciones que realicen con dichas sustancias por un período no menor a dos años y en el Titulo VIII del mismo instrumento se regula todo lo concerniente a las notificaciones previas para la importación y exportación de las sustancias del Cuadro I, queremos señalar que las notificaciones previas también pueden hacerse extensivas a las sustancias de los Cuadros II y III si así lo deciden las autoridades competentes de cada Estado miembro. Por último es preciso destacar que de conformidad al artículo 37 de este Reglamento serán considerados delitos la fabricación, preparación, transformación, almacenamiento, importación, exportación, comercialización, transporte, posesión y cualquier otra operación de las 24 sustancias catalogadas en los Cuadros I y II de Naciones Unidas, así como de las otras 36 sustancias no catalogadas que figuran en los cuadros II y III del presente Reglamento o de cualquier otra sustancia química prevista en los ordenamientos internos de los países miembros que se utilice para la elaboración de drogas ilícitas, así como de materiales y equipos que se vayan a utilizar para dichos fines. Queremos destacar que este Reglamento modelo recomienda la sanción de todas las conductas antes señaladas tanto si se han realizado de forma dolosa como imprudente. Además hay que señalar que para la investigación y comprobación de delitos en la medida que los principios y las normas del ordenamiento jurídico interno lo permitan este Reglamento recomienda el uso de las siguientes técnicas de investigación: 1) entregas vigiladas de las sustancias químicas de los Cuadros I, II y III o de otras sustancia químicas que puedan a o vayan a utilizarse en la elaboración ilícita de drogas, 2) intervención, apertura o registro de las comunicaciones y documentos privados y la vigilancia de sospechosos, previas las autorizaciones de las autoridades competentes, 3) el uso de agentes incubiertos e informantes y 4) investigación de transacciones financieras de individuos o entidades sospechosas de estar implicadas en los hechos investigados. Para finalizar este 
apartado es necesario decir que el artículo 45 de este Reglamento Modelo regula la cooperación con la empresa privada ${ }^{103}$.

\section{LEGISLACIÓN NACIONAL}

A) ANTECEDENTES DE LA REGULACIÓN ADMINISTRATIVA DEL TRÁFICO DE PRECURSORES DE DROGAS

Con el fin de adaptar la legislación española a la legislación comunitaria, particularmente al Reglamento CEE 3677/90 del 13 de diciembre (Reglamento base sobre el tráfico de precursores de países de la UE con terceros países) y a la Directiva 92/109/CEE del Consejo el 14 de diciembre de 1992 (Directiva base en todo lo relacionado al tráfico de precursores entre países de la UE) se aprobó la Ley 3/1996, de 10 de enero, sobre medidas de control de sustancias químicas catalogadas susceptibles de desvío para la fabricación ilícita de drogas, así como el Real Decreto 865/1997 del 6 de junio de 1997 por el que se aprueba el Reglamento de desarrollo de la Ley antes citada ${ }^{104}$. Como antecedentes de esta norma en el ordenamiento jurídico español queremos citar por su importancia la Orden del 10 de diciembre de 1991 (RLC 11991/2969), del Ministro de Relaciones con las Cortes y de la Secretaría del Gobierno, la cual se creó con la finalidad de regular algunos aspectos de competencia, como los referidos a la designación de la autoridad competente para el otorgamiento y supervisión de las autorizaciones de exportación de las sustancias catalogadas. Esta Orden posteriormente fue derogada por la Orden del 15 de noviembre de 1994 (RLC 1994/3244), del Ministro de la Presidencia, por la que se regula el control de los precursores de drogas, donde se desarrolla ya de mejor forma los requisitos y tramites para la importación, exportación y

Reglamento Modelo para el control de sustancias químicas que se utilizan en la fabricación ilícita de estupefacientes y sustancias psicotrópicas. Ed. CICAD. Washinton, D.C. 2011. BERNAL CONTRERAS, Héctor Hernando. Las sustancias químicas...op.cit., pp. 149, 150.

104 Véase también la corrección de errores del Real decreto 867/1997 y Real Decreto 559/2001 del 25 de mayo, por el que se modifica el anexo I de la Ley 3/1996 del 10 de enero, sobre medidas de control de sustancias químicas catalogadas susceptibles de desvío para la fabricación ilícita de drogas, así como la Ley 30/1992, de 26 de noviembre de Régimen Jurídico de las Administraciones Públicas y el procedimiento Administrativo Común. 
transito de los precursores de drogas ${ }^{105}$. Creemos necesario recordar en este sentido también la Ley orgánica 1/1992 del 21 de febrero referida a la protección de la seguridad ciudadana, que dentro de la sección 4. a del capitulo II y bajo el epígrafe de "actividades relevantes para la seguridad ciudadana", en su artículo 12.3 recoge disposiciones en materia de precursores, atribuyendo al poder ejecutivo la potestad de acordar la necesidad de registro para la fabricación, almacenamiento y comercio de productos químicos susceptibles de ser utilizados en la elaboración o transformación de drogas tóxicas, estupefacientes y psicotrópicos y otras sustancias nocivas para la salud.

B.) LEY 3/1996, DE 10 ENERO, SOBRE MEDIDAS DE CONTROL DE SUSTANCIAS QUÍMICAS CATALOGADAS, SUSCEPTIBLES DE DESVÍO PARA LA FABRICACIÓN ILÍCITA DE DROGAS

La ley 3/1996, de 10 de enero, como ya señalamos en el párrafo anterior, tuvo por objetivo ajustar la legislación española a las obligaciones que imponen las normas supranacionales (Naciones Unidas y Unión Europea) con el fin de evitar el desvío de las sustancias catalogadas como "precursores" para la fabricación ilícita de drogas toxicas, estupefacientes y sustancias psicotrópicas. En su artículo 2 establece las personas físicas y jurídicas que se encuentran obligadas por esta norma, indicando también la forma en que los operadores deben de realizar las diversas actividades con las sustancias anteriormente señaladas, así como el deber de todos los sujetos obligados, que se dediquen a la fabricación, transformación, procesamiento, almacenamiento, distribución, corretaje, transporte, comercialización, importación, exportación, o cualquier otra actividad con estas sustancias químicas catalogadas, a inscribirse en el registro de operadores ${ }^{106}$ y a realizar los tramites co-

Esta Orden fue derogada por el Real Decreto 865/1997 de 6 de junio, por el que se aprueba el Reglamento de desarrollo de la Ley 3/1996, de 10 de enero, sobre medidas de control de sustancias químicas catalogadas susceptibles de desvío para la fabricación ilícita de drogas. Hay que aclarar que se mantiene el régimen establecido para las operaciones de exportación, importación y transito de las sustancias químicas catalogadas establecido en la Orden derogada, pero al incorporar su contenido en el Reglamento se procede a la derogación de esta Orden Ministerial.

106 Para tal efecto se crea en la Delegación de Gobierno para el Plan Nacional sobre Drogas, adscrita al Ministerio del Interior, "el Registro General Central de Operadores de Sustancias Químicas Catalogadas". En la sede de la Delegación de Gobierno en cada Comunidad Autónoma y en las Delegaciones de Gobierno de Ceuta y Melilla se crean Registros Delegados del Registro General Central, dejando abierta la posibilidad de crear 
rrespondientes para la obtención de licencia de actividad cuando esta corresponda ${ }^{107}$, de la licencia individual de exportación ${ }^{108}$ o bien de la licencia genérica ${ }^{109}$. Es necesario precisar que se exige estar en pose-

también Registros Delegados en algunas Provincias si las circunstancias así lo requieren. En el Registro General Central deben de inscribirse todos los sujetos obligados, que realizan sus actividades en dos Comunidades Autónomas o más antes de realizar cualquier actividad con las sustancias químicas catalogadas, salvo aquellos sujetos que realicen actividades de importación, exportación o tránsito con sustancias de la categoría 1 y 2 del anexo I de la ley 3/1996, o de la categoría 3 del mismo anexo siempre que se destinen a la exportación y que se superen dentro del año natural anterior las cantidades señaladas en el anexo II, que deberán de inscribirse en el "Registro Especial de Operadores" adscrito al Departamento de Aduanas e Impuestos Especiales de la Agencia Estatal de Administración Tributaria. En el Registro Delegado deberán inscribirse los operadores que pretendan desarrollar en dicha Comunidad Autónoma una o más de las actividades sujetas, a excepción de aquellas que deben inscribirse en el Registro Especial de Operadores.

107 Para realizar las actividades que enumeramos anteriormente con las sustancias químicas catalogadas en la categoría 1, o mezclas que la contengan, del anexo I de la presente Ley, los sujetos obligados deberán estar en posesión de la "licencia de actividad" concedida por la autoridad competente (Delegado del Gobierno para el Plan nacional sobre Drogas, Delegado del Gobierno en la Comunidad Autónoma, Delegados del Gobierno en Ceuta y Melilla, Delegado del Gobierno en la Provincia cuando se haya creado en la misma un Registro Delegado o por el Director del departamento de Aduanas e Impuestos Especiales de la Agencia Estatal de la Administración Tributaria cuando se trate de actividades de exportación, importación y transito de las sustancias catalogadas). Para solicitar esta licencia es requisito indispensable que el sujeto obligado este inscrito, o haya solicitado la inscripción, en el correspondiente Registro General o Especial de Operadores de Sustancias Químicas Catalogadas.

108 Para la exportación de sustancias químicas catalogadas en la categoría 1 es necesario la obtención previa de una Licencia individual de exportación para cada operación, al igual cuando se trate de sustancias de la categoría 2 siempre que estas estén dirigidas a un Estado sensible (anexo IV de la Ley 3/1996) o bien de sustancias catalogadas de la categoría 3 (anexo V de la Ley 3/1996) cuando la Unión Europea así lo haya acordado con ese país. Es competente para otorgar esta Licencia el Departamento de Aduanas e Impuestos Especiales de la Agencia Estatal de Administración Tributaria.

109 Está licencia será otorgada por el Departamento de Aduana e Impuestos Especiales de la Agencia Estatal de Administración Tributaria cuando las sustancias químicas catalogadas de las categorías 2 y 3 del anexo I de la Ley 3/1996 no vayan a ser exportadas a ninguno de los Estados sensibles (anexo IV y V de la Ley 3/1996), y cuando por el destino de las mismas, el volumen de las corrientes de intercambio que se produzcan (anexo II y III) u otras circunstancias no generen sospechas de desvío de esas sustancias para la producción de drogas ilegales. Los umbrales establecidos en el anexo II (categoría 3 del anexo I) son de: 50 kilogramos para la acetona, 20 kilogramos para el éter etílico, 50 kilogramos para la metiletilcetona, 50 kilogramos para el Tolueno, 5 kilo- 
sión de una licencia individual de exportación cuando se trate de una sustancia catalogada en la categoría 2 y esté dirigida directa o indirectamente a un Estado que figure en el anexo IV (destinos sensibles) ${ }^{110} \mathrm{y}$ en el caso de sustancias catalogadas de la categoría 3 a un Estado que figure en el anexo V (destinos sensibles) ${ }^{111}$. Hay que destacar que en los casos que así se haya acordado, entre los Estados de destino y la Comisión Europea, la exportación de sustancias químicas catalogadas exigirá una autorización previa o notificación previa de tales autoridades ${ }^{112}$. Además esta normativa regula los requisitos del etiquetado de las distintas sustancias, las obligaciones de identificación de los pre-

gramos para el permanganato de potasio (modificado por el Real Decreto 293/2004, del 20 de febrero, esta sustancia pasa de la categoría 3 a la categoría 2 del anexo I, sin embargo su umbral se aumenta a 100 kilogramos en el anexo III), 100 kilogramos para el ácido sulfúrico y 100 kilogramos para el ácido clorhídrico. Los umbrales establecidos en el anexo III (categoría 2 del anexo I) son de: 20 litros para el anhídrido acético (modificado por el Real Decreto 293/2004, del 20 de febrero, en vez de restringirse se incrementa su umbral a 100 litros), 1 kilogramo para el ácido antranílico y sus sales, 1 kilogramo para el ácido fenilacético y sus sales y 0.5 kilogramos para la piperidina y sus sales. La vigencia de esta licencia es de cuatro años.

110 Para el anhídrido acético: Colombia, Guatemala, Hong Kong, India, Irán, Líbano, Malasia, Myanmar (Birmania), Singapur, Siria, Tailandia y Turquía.

111 Para la metiletilcetona, tolueno, permanganato potásico (esta sustancia paso formar parte de la categoría II por mandato del Real Decreto 293/2004) y ácido sulfúrico: Argentina, El Estado Plurinacional de Bolivia, Brasil, Chile, Colombia, Costa Rica, El Salvador, Ecuador, Guatemala, Honduras, Hong Kong, Panamá, Paraguay, Perú, Siria, Tailandia y Uruguay. Para la acetona, éter etílico y ácido clorhídrico: Argentina, El Estado Plurinacional de Bolivia, Brasil, Chile, Colombia, Costa Rica, El salvador, Ecuador, Guatemala, Honduras, Hong Kong, Irán, Líbano, Myanmar (Birmania), Panamá, Paraguay, Perú, Singapur, Siria, Tailandia, Turquía y Uruguay.

112 El artículo 47 del Real decreto 865/1997, de 6 de junio, por el que se aprueba el Reglamento de desarrollo de la Ley 3/1996 dispone que en los casos que así lo hayan comunicado los Estados de destino a la Comisión Europea o lo tuvieran con ello convenido, la exportación de las sustancias químicas catalogadas exigirá una notificación previa a las autoridades competentes del tercer Estado de destino, por lo cual el Departamento de Aduanas e impuestos especiales de la Agencia Estatal de Administración Tributaria no expedirá la correspondiente licencia de exportación, en tanto no haya realizado previamente dicha notificación. El artículo 48 de este Reglamento establece que en los casos que así lo hayan comunicado los Estados de destino a la Comisión Europea o lo tuvieran con ella convenido, no se expedirá la licencia de exportación de sustancias químicas catalogadas, en tanto no se haya presentado al Departamento de Aduanas e Impuestos Especiales copia de la autorización de importación en aquél, de la que se podrá solicitar confirmación. 
cursores en la documentación mercantil y administrativa, así como obligaciones específicas para las operaciones de exportación, importación y tránsito113. Como todos sabemos esta Ley y su respectivo Reglamento de desarrollo ${ }^{114}$, divide las sustancias catalogadas en tres categorías ${ }^{115}$ que obviamente se corresponden con las listas de sustancias establecidas en las normativas comunitarias.

113 Otra obligación que se establece es la declaración de uso por clientes, en todas las operaciones de comercialización de los precursores de las categorías 1 y 2 , siempre y cuando en las de la última categoría citada las cantidades superen durante el año natural anterior la cantidad señalada en el anexo III de la Ley 3/1996, de 10 de enero, respecto a cada sustancia, se acompañará además, una declaración del cliente en la que se especificarán los usos a los que se destinarán las sustancias, o las mezclan que las contengan, realizando a tal efecto una declaración separada para cada sustancia química catalogada (declaración de transacción única). La declaración incluirá la información que figura en el modelo recogido en el anexo VII del Reglamento de la Ley 3/1996. Sin embargo los sujetos obligados que proporcionen regularmente a un cliente una sustancia catalogada en la categoría 2 podrán aceptar en lugar de una declaración de transacción única, una sola declaración relativa a varias transacciones realizadas durante un periodo máximo de un año (transacciones múltiples), siempre que el proveedor se asegure que no hay indicios de desvío de de tales sustancias para la fabricación ilícita de drogas para lo cual se establecen una serie de requisitos. Real Decreto 865/ 1997, de 6 de junio, por el que se aprueba el Reglamento de desarrollo de la Ley 3/1996, p. 24.

114 A través de la Orden del Ministerio del Interior del 12 de julio de 2001 se modifican los modelos normalizados contenidos en los anexos III, V, VII y VIII del Reglamento de la Ley 3/1996, aprobado por el Real Decreto 865/1997 de 6 de junio con el fin de ajustar dichos modelos a la normativa comunitaria.

115 La clasificación que realiza esta Ley en el anexo I es la siguiente: categoría 1: 1-fenil-2propanona (NC fenilcetona), ácido $N$-acetilantranílico (NC ácido 2 acetamidobenzoico), Isosafrol, 3,4 metilendioxifenil-2-propanona (NC 1-(1,3-benzodioxol-5-il) propan-2ona), piperonal, safrol, efedrina, seudoefedrina, norefedrina, ergometrina, ergotamina y ácido lisérgico. Las sales de las sustancias enumeradas en esta categoría cuando la existencia de dichas sales sea posible y no sean sales de catina. Categoría 2: anhídrido acético, ácido fenilacético, ácido antranílico, piperidina y permanganato potásico (modificado por el Real Decreto 293/2004, del 20 de febrero, antes pertenecía a la categoría 3). Las sales de las sustancias enumeradas en esta categoría cuando la existencia de dichas sales sea posible. Categoría 3: ácido clorhídrico (NC cloruro de hidrógeno), ácido sulfúrico, tolueno, éter etílico (NC éter dietílico), acetona y metiletilcetona (NC butanona), así como las sales de las sustancias enumeradas en esta categoría cuando la existencia de dichas sales sea posible y no sean sales de Ácido clorhídrico y Ácido sulfúrico. Señalamos que la clasificación realizada por esta Ley se corresponde con el Anexo del formulario D ("Lista Roja”). Undécima edición. JIFE. Enero del 2007, las 14 sustancias del Cuadro I de esta Lista están comprendidas en la categoría 1, a excepción del anhídrido acético y el permanganato de potasio que se encuentran clasificados en 
En el artículo 7 del Reglamento de desarrollo de la Ley 3/1996 se establece que todos los sujetos obligados tienen el deber de notificar de forma inmediata a la Delegación del Gobierno para el Plan Nacional sobre Drogas, a la Delegación del Gobierno en su Comunidad Autónoma, al Departamento de Aduanas e Impuestos Especiales de la Agencia Estatal de Administración Tributaria, si se trata de operaciones de importación, exportación o tránsito, a los Cuerpos y Fuerzas de Seguridad del Estado, o bien a la Fiscalía Especial para la prevención y represión del tráfico ilícito de drogas, cualquier operación sobre la que tengan certeza o indicios de que alguna de las sustancias químicas catalogadas puedan ser desviadas para la fabricación ilícita de drogas tóxicas, estupefacientes o psicotrópicos. Debiendo los operadores de abstenerse de ejecutar cualquier operación en tales casos, salvo cuando la abstención no sea posible o bien pueda dificultar la persecución de los beneficiarios de una operación ilícita, en estos supuestos los sujetos obligados podrán llevarla a cabo, efectuando la comunicación a las autoridades competentes inmediatamente después de la ejecución de la operación ${ }^{116}$.

Para facilitar la detección del desvío de precursores de drogas los operadores deben permitir a los funcionarios de los Cuerpos y Fuerzas de Seguridad del Estado, de los servicios de Aduanas, debidamente acreditados, el acceso a sus locales profesionales, aun sin previo aviso y en

la categoría 2 y las 9 sustancias del Cuadro II se encuentran clasificadas en las categorías 2 y 3 de esta lista.

En todo caso las operaciones siempre deberán de ser notificadas en los siguientes supuestos: a) cuando el suministro se haya efectuado por transporte aéreo, b) cuando el suministro solicitado se deba de realizar de forma inmediata a cambio de un sobreprecio, que exceda en más de un $10 \%$ el valor normal de la mercancía, c) cuando el pago se realice en efectivo en la compra de grandes cantidades, d) en caso de adquisición de grandes cantidades, cuando el transporte de la mercancía se realice con vehículo propio o cuando en la entrega de las mismas esté físicamente presente el ordenante ante el suministrador, e) cuando exista una petición de carga de las sustancias dentro de contenedores, f) cuando exista petición de entrega o envío de una cantidad inusual, g) cuando la orden de compra se efectúe por personas físicas o jurídicas que no puedan ser identificadas, h) cuando la entrega se haya de efectuar a través de rutas de tránsito inusuales, i) cuando el cliente desconozca el motivo o finalidad del negocio, o muestre reticencia o rechazo para darlo a conocer, j) cuando el cliente muestre reticencia o rechazo para facilitar su identidad y/o su dirección, k) cuando concurran otras circunstancias que se deriven de la operación o del adquirente distintas de las anteriores, que permitan sospechar fundamentadamente que las sustancias químicas catalogadas serán objeto de desvío a fines ilícitos. 
cualquier momento. Es preciso recalcar que los sujetos obligados deben permitir el acceso de las autoridades competentes no únicamente en aquellos locales donde se llevan a cabo las actividades de administración, dirección y control, sino también en aquellos otros donde se realicen las operaciones materiales de fabricación, transformación, procesamiento, almacenamiento, distribución, corretaje, transporte, comercialización, importación, exportación o tránsito, o cualquier otra actividad relacionada con las anteriores, que tengan por objeto las sustancias químicas catalogadas, o mezclas que la contengan, así como a los lugares donde se hagan las declaraciones aduaneras, incluyendo las realizadas desde zonas francas, depósitos francos o depósitos aduaneros. Los operadores igualmente tienen la obligación de presentar los documentos y registros 117 que de conformidad a la Ley 3/1996 y el Reglamento desarrollo de esta norma están obligados a llevar, así como a facilitar copia de estos y a permitirle a las autoridades competentes llevar a cabo recuentos de existencias de las sustancias químicas catalogadas.

La Ley 3/1996 clasifica las infracciones de las normas relativas a las obligaciones en ellas impuestas, en leves ${ }^{118}$, graves ${ }^{119}$ y muy graves ${ }^{120}$

117 Los sujetos obligados deberán conservar durante cinco años la documentación mercantil y administrativa de todas las operaciones que realicen con las sustancias químicas catalogadas. En el caso de la inscripción en el Registro General Central de Operadores o del Registro Especial de Operadores, así como en el caso de las Licencias de actividad, de más esta decir que deben conservarse de forma permanente mientras el operador tenga tal condición.

118 Las infracciones leves se establecen en el artículo número 16 de forma negativa: "los incumplimientos de cualquiera otra de las obligaciones previstas en esta Ley que no tengan la consideración de muy graves o graves".

119 Son infracciones graves: a) no notificar de forma inmediata a las autoridades competentes de cualquier operación sobre la que tengan certeza o sospecha de que las sustancias catalogadas van a ser desviadas para la fabricación de drogas ilegales, b) no expresar de forma clara en el etiquetado de las sustancias catalogadas en las categorías 1 y 2 la información que establece el artículo 5 de la Ley 3/1996, c) no cumplir con las obligaciones de identificación de las sustancias químicas catalogadas en la documentación mercantil y administrativa en la categoría 1 y en la categoría 2, siempre que estas últimas cantidades superen durante el año natural las cantidades establecidas en el anexo III de la Ley en mención, d) el incumplimiento de las obligaciones de conservación de los documentos mercantiles y administrativos por cinco años y e) en el caso de operaciones con sustancias catalogadas en la categoría 1, no recoger en la documentación el número de Licencia de actividad de la persona o entidad con la que se establece la relación, aclaramos que en el caso de las sustancias de la categoría 1 ambas partes deben estar en posesión de la licencia de actividad. 
(artículos 13 y siguientes), estableciendo para dichas infracciones las sanciones correspondientes (artículos 18 y siguientes). En el caso de las infracciones leves las multas establecidas, no existiendo otro tipo de sanción, puede llegar hasta los 6.010,12 euros. Para las infracciones graves se establece la suspensión de la licencia de actividad o de la licencia genérica de exportación de sustancias químicas catalogadas por un periodo máximo de hasta cinco años y multa de 6.010,13 hasta $90.151,82$ euros, finalmente para las infracciones muy graves se contempla la retirada de la licencia de actividad o de la licencia genérica de exportación de sustancias químicas catalogadas o la suspensión de las mismas por un periodo de entre cinco y diez años, y multa de $90.151,83$ hasta $601.012,10$ euros. Sin perjuicio de la multa que corresponda imponer, las infracciones serán sancionadas con el comiso de las sustancias químicas catalogadas y del beneficio ilícito obtenido como consecuencia de la transgresión. Queremos señalar que la parte correspondiente al procedimiento sancionador (capitulo V de esta ley) reconoce de forma expresa el principio non bis in idem cuando dispone en su artículo 24 que "no podrán sancionarse con arreglo a esta Ley, las conductas que lo hubieren sido penal o administrativamente, cuando se aprecie identidad de sujeto, hecho y fundamento. También se establece que cuando los hechos que motivan el expediente pudieran ser constitutivos de delitos, se ordenará, si se hubiese incoado, la suspensión del procedimiento sancionador, dándose traslado de los mismos al Ministerio Fiscal. Una vez concluido el procedimiento penal se reanu-

120 Se estipulan como infracciones muy graves las siguientes: a) la negativa o resistencia a brindar información a las autoridades competentes, mediante requerimiento escrito o bien proporcionar información inexacta, b) la negativa o resistencia a permitir que las autoridades competentes accedan a sus locales profesionales y analicen los documentos y registros que tienen la obligación de llevar o conservar, c) la realización de cualquier actividad sin estar en posesión de la Licencia de Actividad o sin haberse dado de alta en el Registro de Operadores cuando así venga exigido en el artículo 4 de esta Ley, d) la exportación de sustancias químicas catalogadas sin la correspondiente Licencia de Exportación, e) la realización de operaciones de sustancias químicas catalogadas de la categoría 1 con sujetos no expresamente autorizados para ello (ambas partes deben de estar en posesión de la Licencia de Actividad), f) la realización de operaciones de exportación o importación y transito sin llevar el registro establecido, o que se produzcan en dichos registros falsedades o inexactitudes y g) las tipificadas como graves cuando durante los cinco años anteriores el sujeto infractor hubiese sido condenado en sentencia firme por un delito de tráfico de drogas (artículos 368 a 371 del Código Penal español). 
dará la tramitación del expediente sancionador contra los sujetos obligados que no hubieren sido condenados en la vía penal. Es preciso aclarar que la resolución que se dicte deberá respetar en todo caso la declaración de hechos probados en dicho procedimiento penal.

El Real Decreto 559/2001, de 25 de mayo, modifica el Anexo I de la ley 3/1996, de 10 de enero, de Medidas de control de sustancias químicas catalogadas para la fabricación ilícita de drogas, incluyendo en la Categoría 1 la sustancia denominada norefedrina. Posteriormente a través del Real Decreto 293/2004, del 20 de febrero se modifican los anexos I y III de la Ley 3/1996, dándole cumplimiento a la decisión adoptada en marzo del 2001 por la Comisión de Estupefacientes de Naciones Unidas de incluir el anhídrido acético y el permanganato de potasio en el Cuadro I de la Convención de Naciones Unidas y de la Directiva 2003/101/ CE de la Comisión, del 3 de noviembre del 2003 sobre el mismo tema. En virtud de estas normas se suprime el permanganato de potasio de la categoría 3 y se incorpora en la categoría $2^{121}$, además se modifica su umbral en el anexo III ampliándolo de 5 kilogramos a 100 kilogramos. En el caso del anhídrido acético se aumenta su umbral en el anexo III de 20 litros a 100 litros $^{122}$, lo cual responde a la voluntad de la Ley 3/1996 de no interferir de una forma gravosa en el normal desarrollo de la actividad química y farmacéutica. Es necesario precisar que esta Ley estuvo vigente hasta el día 17 de junio del año 2009.

\section{C.) LEY 4/2009, DE 15 DE JUNIO, DE CONTROL DE PRECURSORES DE DROGAS}

El día 16 de junio del año 2009 se publicó en el BOE la Ley 4/2009, de 15 de junio, de control de precursores de drogas, que derogó la Ley $3 / 1996$ de la que nos ocupamos en el apartado anterior ${ }^{123}$. La Ley

121 El permanganato de potasio ya se encuentraba ubicado en la categoría 2 en el apartado correspondiente a la clasificación de las sustancias de la Ley 3/1996 que realizamos mas arriba, lo mismo ocurre con el anhídrido acético.

122 Los umbrales para la categoría 2 en el anexo III quedan de la siguiente forma: Anhídrido acético: 100 litros, Permanganato de potasio: 100 kilogramos, Ácido antranílico y sus sales: 1 kilogramo, Ácido fenilacético y sus sales: 1 kilogramo, Piperidina y sus sales: 0,5 kilogramos.

123 La Ley 3/1996, de 10 de enero, sobre medidas de control de sustancias químicas catalogadas susceptibles de desvío para la fabricación ilícita de drogas queda derogada de forma expresa, así como cualquier disposición de igual o inferior rango se opongan a la 
4/2009 tiene la particularidad de ser el primer instrumento en el que se usa de forma oficial el término "precursores de drogas". Esta norma se aprueba para darle cumplimiento a las siguientes normativas comunitarias: Reglamento (CE) 273/2004 del Parlamento Europeo y del Consejo del 11 de febrero del año 2004 (operaciones intracomunitarias de precursores de drogas), Reglamento (CE) 111/2005 del Consejo del 22 de diciembre del año 2004 (operaciones extracomunitarias de precursores de drogas) y el Reglamento 1277//2005 de la Comisión del 27 de julio del 2005 (establece las normas para la aplicación de los dos Reglamentos anteriores) ${ }^{124}$.

La clasificación de las sustancias catalogadas que realiza la Ley 4/2009 es la siguiente:

Categoría 1: 1) 1-fenil-2-propanona ( $\mathrm{NC}^{125}$ fenilcetona), 2) ácido $\mathrm{N}$ acetilantranílico (NC ácido 2 acetamidobenzoico), 3) isosafrol, 4) 3,4 metilendioxifenil-2-propanona (NC 1-(1,3-benzodioxol-5-il)propan-2-ona), 5) piperonal, 6) Safrol, 7) efedrina, 8) seudoefedrina, 9) norefedrina, 10) ergometrina, 11) ergotamina y 12) ácido lisérgico. Las sales de las sustancias enumeradas en esta categoría cuando la existencia de dichas sales sea posible y no sean sales de catina.

Categoría 2: 13) anhídrido acético, 14) ácido fenilacético, 15) ácido antranílico, 16) piperidina y 17) permanganato potásico (modificado por el Real Decreto 293/2004, del 20 de febrero, antes pertenecía a la categoría 3). Las sales de las sustancias enumeradas en esta categoría cuando la existencia de dichas sales sea posible.

Categoría 3: 18) ácido clorhídrico (NC Cloruro de hidrógeno), 19) ácido sulfúrico, 20) tolueno, 21) éter etílico (NC Éter dietílico), 22) acetona y 23) metiletilcetona (NC butanona), así como las sales de las sustancias enumeradas en esta categoría cuando la existencia de dichas sales sea posible y no

Ley 4/2009 por mandato de la Disposición derogatoria única de esta norma. Vid., el contenido de la Ley en el Anexo I.

Ver el Real Decreto 129/2017, de 24 de febrero, por el que se aprueba el Reglamento de control de precursores de drogas (BOE Núm. 57 de 8 de marzo de 2017).

Las siglas NC cuando aparece entre paréntesis se refieren a la nomenclatura combinada, se presenta únicamente cuando su nombre es diferente al de la sustancia catalogada. NC es la nomenclatura común de las mercancías del sistema aduanero de la Unión Europea. Fue adoptada el día 23 de julio de 1987 por medio del Reglamento (CE) 2658/87 del Consejo relativo a la nomenclatura arancelaria y estadística y al arancel aduanero común. Modificada en su anexo I por el Reglamento (CE) 1549/2006 de la Comisión. 
sean sales de ácido clorhídrico y ácido sulfúrico. La clasificación realizada por esta Ley se corresponde con el Anexo del formulario D ("Lista Roja"). Undécima edición. JIFE. Enero del 2007126, las 14 sustancias del Cuadro I de esta Lista están comprendidas en la categoría 1, a excepción del anhídrido acético y el permanganato de potasio que se encuentran clasificados en la categoría 2 y las nueve sustancias del Cuadro II se encuentran clasificadas, respectivamente, en las categorías 2 y 3 de esta lista.

La primera novedad que establece esta norma es la eliminación de todos los Registros Delegados que existían al tenor de la Ley 3/1996, los cuales en el plazo de tres meses después de la publicación de la Ley 4/2009 deberán transferir todos los datos de que dispongan al Registro General de Operadores de Sustancias Químicas Catalogadas. Precisamente el artículo 3.1 establece la existencia de este Registro en el Ministerio del Interior donde se inscribirán las personas físicas y jurídicas que realicen operaciones intracomunitarias con las sustancias catalogadas en todo el territorio nacional ${ }^{127}$. A la vez se preceptúa que en el Ministerio de Economía y Hacienda funcionara el Registro de Operadores de Comercio Exterior de Sustancias químicas Catalogadas (antes Registro Especial de Operadores) en el que se inscribirán todas las personas físicas y jurídicas que realicen operaciones extracomunitarias con dichas sustancias. Ambos Registros, como ya señalamos anteriormente, serán únicos para todo el territorio nacional. Es necesario puntualizar que el Real Decreto 129/2017, de 24 de febrero, por el que se aprueba el Reglamento de control de precursores de drogas establece que las competencias atribuidas en la Ley 4/2009, de 15 de junio, al Ministerio del Interior serán desarrolladas por el Centro de Inteligencia contra el Terrorismo y el Crimen Organizado integrado en la Secretaria de Estado de Seguridad y las atribuidas al Ministerio de Hacienda

126 La clasificación de las tres categorías de sustancias que realiza la Ley 4/2009 es la misma que establecía la Ley 3/1996 que estuvo vigente hasta el día 16 de junio del 2009.

127 También deberán de inscribirse en el Registro General de Operadores de Sustancias Químicas Catalogadas las farmacias, los dispensarios de productos veterinarios, los laboratorios de las Fuerzas Armadas y de los Cuerpos y Fuerzas de Seguridad, y cualesquiera otros tipos de autoridades o instituciones que reglamentariamente se determine, para el uso de las sustancias catalogadas de las categorías 1 y 2 del anexo I del Reglamento 273/2004, del parlamento Europeo y del Consejo, de 11 de febrero, en el ámbito de sus actividades profesionales u oficiales. 
serán desarrolladas por el departamento de Aduanas e Impuestos Especiales de la Agencia Estatal de Administración Tributaria.

Los operadores establecidos en la Comunidad que realicen actividades de exportación, importación o intermediación (comercio extracomunitario) con precursores de la categoría número 1, con la salvedad de los agentes de aduanas y transportistas que actúen únicamente como tales, deberán de estar en posesión de una licencia, la cual será expedida por la autoridad competente del Estado miembro en que este establecido el operador. Creemos necesario señalar que esta licencia de actividad por mandato de el Reglamento (CE) 1277/2005 de la Comisión podrá abarcar las actividades mencionadas en el Reglamento (CE) 273/2004 (comercio interno) y en el Reglamento (CE) 111/2005 (comercio externo) ${ }^{128}$. Así mismo se establece la obligación a los operadores que realizan las actividades antes descritas con sustancias catalogadas en la categoría 2 o de exportación de precursores de la categoría $3^{129}$, exceptuando agentes de aduanas y transportistas que actúen solamente como tales, de registrar de inmediato y actualizar en la medida que sea necesario las direcciones de los locales en los que ejercen tales actividades ante las autoridades competentes de cada Estado miembro ${ }^{130}$.

128 Las autoridades competentes podrán conceder una licencia en una de las siguientes formas: a) una licencia que cubra todas las sustancias catalogadas y todas las actividades efectuadas por establecimiento comercial o b) una licencia que cubra todas las sustancia catalogadas y todas las actividades por Estado miembro.

129 Por mandato del Reglamento (CE) 1277/2005 de la Comisión quedan eximidos de la obligación de registro de sus locales los operadores que intervengan en la exportación de sustancias de la categoría 3 o de sus mezclas, si las cantidades correspondientes a sus exportaciones en el curso del año natural no supera los siguientes umbrales: $50 \mathrm{ki}-$ logramos para la acetona, 20 kilogramos para el éter etílico, 50 kilogramos, para la metiletilcetona (MEK), 50 kilogramos para el tolueno, 100 kilogramos para el ácido sulfúrico y 100 kilogramos para el ácido clorhídrico. Lo cual vale también para las sales de las cuatro primeras sustancias, siempre que la existencia de tales sales sea posible.

130 El artículo 3.2 del Reglamento de control de precursores de drogas preceptua quelas licencias de actividad se concederán atendiendo a la actividad a desarrollar por el sujeto obligado, mediante resolución del Secretario de Estado de Seguridad o del titular del Deoartamento de Aduanas e Impuestos Especiales de la Agencia Estatal de Administración Tributaria, en el ámbito de sus respectivas competencias, que se adoptarán y notificarán en el plazo de sesenta días hábiles a contar desde su presentación completa, conforme a lo previsto en el artículo 3 del Reglamento Delegado (UE) 2015/1011 de la Comisión, de 24 de abril de 2015, y el artículo 3 del Reglamento de Ejecución (UE) 
En el caso del comercio intracomunitario, el Reglamento (CE) 273/2004 del Parlamento Europeo y del Consejo dispone que los operadores que deseen poner en el mercado las sustancias catalogadas de las categorías 1 y 2 del anexo I deberán designar un agente responsable del comercio de dichas precursores, la misma obligación tienen los operadores que realicen operaciones con estas sustancias en el comercio extracomunitario. Este agente cuidara de que el comercio de las sustancias catalogadas que efectúe el operador se lleve a cabo en observancia de lo dispuesto en el presente Reglamento. Debiendo los operadores que realicen actividades comerciales con precursores de la categoría 1 estar en posesión de una licencia ${ }^{131}$ expedida por la autoridad competente, antes de poseer o poner en el mercado las sustancias antes señaladas, las cuales solo podrán suministrarse a personas físicas o jurídicas que posean tal licencia y hayan firmado una declaración de cliente. Las autoridades competentes podrán conceder licencias especiales a farmacias, dispensarios de productos veterinarios, determinados tipos de autoridades y fuerzas armadas. Esas licencias especiales serán válidas únicamente para el uso de los precursores en el ámbito de los servicios oficiales. Los operadores que pongan el mercado sustancias de la Categoría 2 deberán declarar sin demora a las autoridades competentes la dirección de los locales en que fabriquen o comercialicen dichas sustancias, así como cualquier cambio antes de ponerlas en el mercado. Como ya adelantamos antes, en los casos de las sustancias catalogadas en la categoría 1, los operadores también deberán obtener una declaración de cliente, donde se especificara el uso o usos específicos de las sustancias, debiendo realizarse una declaración distinta para cada sustancia catalogada, salvo algunas excepciones en que se permite realizar una declaración múltiple ${ }^{132}$, lo cual es valido también para el

2015/1013 de la Comisión, de 25 de junio de 2015, pudiendo entenderse desestimada la solicitud en caso contrario.

131 Para conceder una licencia la autoridad competente debe tener en cuenta la competencia e integridad del solicitante, la duración de la misma no debe exceder los tres años de validez. La licencia se denegará cuando existan motivos fundados para dudar de la adecuación y la fiabilidad del solicitante o del agente encargado del comercio de las sustancias catalogadas.

132 Un operador que suministre habitualmente a un cliente una sustancia catalogada en la categoría 2 podrá aceptar una única declaración para las diversas transacciones realizadas con dicha sustancia durante el periodo máximo de un año, siempre que se cumplan los siguientes requisitos: a) el cliente a recibido la sustancia del operador al me- 
comercio extracomunitario, y además se impone la obligación de designar un agente responsable ${ }^{133}$.

Otro elemento a destacar de esta Ley es el referido a las infracciones. Se establece en el artículo 5 de esta norma que constituyen infracciones administrativas en materia de precursores de drogas las acciones y omisiones, incluso a título de simple negligencia, que sean contrarias a las obligaciones y deberes establecidos en el Reglamento 273/2004, del Parlamento Europeo y del Consejo, en el Reglamento 111/2005, del Consejo y el Reglamento 1277/2005, de la Comisión. Por mandato de dichos instrumentos las infracciones leves, al igual que en la Ley 3/1996, se definen de forma negativa, señalando que serán los incumplimientos de las obligaciones recogidas en las tres normativas comunitarias citadas anteriormente que no constituyan infracciones graves o muy graves. Destacamos en el apartado de las infracciones graves las siguientes: a) la no designación de un agente responsable de comercio de sustancias catalogadas cuando dicha designación sea preceptiva, b) no obtener de los clientes la declaración de uso o usos específicos de las sustancias catalogadas suministradas y c) carecer de las medidas de protección o de los protocolos de actuación para la realización de actividades con sustancias catalogadas, en la forma que se determine reglamentariamente, sin que dichas carencias hubiesen dado lugar a la sustracción o retirada no autorizada de precursores ${ }^{134}$.

nos en tres ocasiones durante los 12 meses anteriores, b) el operador no tiene motivos para sospechar que la sustancia se va a utilizar con fines ilícitos, c) las cantidades solicitadas son congruentes con respecto al consumo habitual del cliente.

133 De la obligación de designar un agente responsable y de la obligación de obtener una declaración de cliente están exentos los operadores de las sustancia catalogadas en la categoría 2 siempre que no se superen en el periodo de un año los siguiente umbrales: 100 litros para el anhídrido acético, 100 kilogramos para el permanganato de potasio, 1 kilogramo para el ácido antranílico y sus sales, 1 kilogramo para el ácido fenilacético y sus sales y 0.5 kilogramo para la piperidina y sus sales.

134 Constituyen además infracciones graves los siguientes comportamientos: d) no comunicar en la forma que se establezca reglamentariamente, las modificaciones de los datos que deben constar en el Registro General de Operadores o en el Registro de Operadores de Comercio Exterior, e) suministrar sustancias catalogadas de la categoría 1 del anexo I del Reglamento 273/20004 o del Reglamento 111/2005, sin comprobar de modo diligente que la persona física o jurídica destinataria de las mismas posee la licencia de actividad para operar con tales sustancias, f) incumplir las obligaciones relativas a la documentación que debe acompañar a las operaciones con sustancias catalo- 
Son infracciones muy graves: a) realizar actividades con sustancias catalogadas sin haber obtenido la inscripción en el Registro General o en el Registro de Operadores de Comercio Exterior de Sustancias Químicas Catalogadas requerida para tales actividades; b) realizar actividades con sustancias catalogadas sin haber obtenido la licencia de actividad requerida; c) aportar datos o documentos, falsos o manifiestamente inexactos, para obtener la inscripción en el Registro general o en el Registro de Operadores de Comercio Exterior o para obtener una Licencia de actividad; d) la resistencia, obstrucción, o negativa a las actuaciones de los órganos de la Administración que resulten competentes en cada caso y, en particular: no facilitar el examen de documentos, informes, antecedentes, libros, registros, ficheros, facturas, justificantes y asientos de contabilidad principal o auxiliar, programas y archivos informáticos, sistemas operativos y de control, y cualquier otro dato con trascendencia para el control, así como negar o impedir indebidamente la entrada o permanencia en fincas o locales a los funcionarios autorizados de la Administración o el reconocimiento de locales, maquinas, instalaciones y explotaciones que se utilicen para el desempeño de actividades en relación con las sustancias catalogadas, así como no atender al requerimiento debidamente notificado; e) realizar operaciones con sustancias catalogadas sobre las que se tenga certeza o sospecha razonable de que dichas sustancias "pueden desviarse" hacia la fabricación ilícita de estupefacientes o de sustancias psicotrópicas, sin haber notificado tal certeza o sospecha a las autoridades competentes, o antes de que estas hayan respondido a la notificación previa del operador; f) carecer de las medidas de protección o de los protocolos de actuación para la realización de actividades con sustancias catalogadas, en la forma que se determine reglamentariamente, siempre que dichas carencias hubiesen dado lugar a la sustracción o retirada no autorizada de precursores; g) realizar actividades con sustancias catalogadas sin la autorización de exportación cuando fueran preceptivas o si hubiese expirado el periodo de validez de las mismas; h) realizar acciones tipifi-

gadas, así como lo referido a su etiquetado, g) no informar inmediatamente a las autoridades competentes acerca de los pedidos y transacciones de sustancias catalogadas, sobre los que se tenga certeza o sospecha razonable de que dicha sustancias pueden desviarse hacia la fabricación ilícita de drogas. Hacemos la aclaración de que el orden de las infracciones no se corresponde con el establecido en el articulo número 7 de la Ley $4 / 2009$. 
cadas como graves cuando durante los cinco años anteriores el sujeto infractor hubiera sido condenado en sentencia firme por un delito de tráfico de drogas, tipificado en el Código Penal, o sancionada en firme al menos por dos infracciones administrativas graves de las establecidas en la presente Ley. En este supuesto, en ningún caso se podrá tener en cuenta la reincidencia como criterio para graduar la sanción a imponer.

Se puede decir que todas las infracciones muy graves que establecía la Ley 3/1996 están contenidas en esta nueva ley, mejorando en alguna medida la redacción de las conductas sancionables, presentando como novedad los incisos c), e) y f). Nosotros queremos llamar la atención sobre el inciso e), porque en nuestra opinión la conducta consistente en realizar operaciones con sustancias químicas catalogadas teniendo la certeza de que dichas sustancias "pueden desviarse hacia la fabricación ilícita de drogas" quizás, ya que la frontera entre una y otra norma es muy tenue, podría llegar a subsumirse en el artículo 371.1 del Código Penal que sanciona la fabricación, transporte, distribución, comercialización o tenencia de dichas sustancias "a sabiendas de que van a utilizarse en el cultivo, la producción o la fabricación ilícita de drogas". Este tema lo analizaremos detalladamente en el capitulo VI de este trabajo, específicamente en el apartado sobre el dolo y el elemento subjetivo del injusto.

En cuanto a la prescripción de las infracciones esta nueva norma establece cuatro años para las infracciones muy graves (antes eran cinco años), dos años para las infracciones graves (al igual que en la Ley $3 / 1996)$ y un año para las infracciones leves (antes eran seis meses). Sobre las sanciones que establece la Ley 4/2009 tenemos que decir que bajan sustancialmente todas, en relación a las establecidas en la norma anterior, así las infracciones leves serán sancionadas con multas desde 300 euros a 600 euros (antes hasta 6.000,12 euros). Las sanciones por infracciones graves serán sancionadas, de forma conjunta o alternativa con: a) multas desde 601 euros hasta 6.000 euros (antes de 6.010,13 euros a 90.151,82 euros); b) suspensión de la licencia o de las licencias de actividad por un periodo de hasta seis meses (antes por un periodo de hasta cinco años). Las infracciones muy graves serán sancionadas de forma conjunta o alternativa con: a) multas de 6.000 hasta 60.000 euros (antes de 90.151 .83 euros hasta 601.012,10 euros) y b) retirada de la licencia o licencias de actividad o la suspensión de las mismas por un periodo de hasta cinco años (antes la suspensión era 
por un periodo de hasta diez años) ${ }^{135}$. Además en este instrumento se incluyen varios preceptos en relación con el procedimiento sancionador, como la posibilidad de adoptar medidas provisionales, la competencia de imponer las sanciones o su publicidad. También se establecen aquellos supuestos en los que la sanción que se imponga por la comisión de alguna de las infracciones tipificadas en la Ley, conlleva el comiso de determinados bienes, efectos o instrumentos, e incluso la posible enajenación de los mismos, tanto por la autoridad administrativa, ya sean los Ministros o los Secretarios de Estado a los que la Ley reconoce esa competencia, como por la autoridad judicial.

En lo que se refiere a la notificación previa a la exportación el Reglamento (CE) 1277/2005 de la Comisión en su artículo número 20 establece las listas mencionadas en el artículo 11, apartado 1, del Reglamento (CE) 111/2005 (comercio extracomunitario) del Consejo, que preceptúa la obligación de que todas las exportaciones de sustancias catalogadas en la categoría 1 y las exportaciones de sustancias catalogadas de las categorías 2 y 3 a algunos países de destino ${ }^{136}$ irán prece-

135 Competencia para la imposición de sanciones: 1) Para la imposición de sanciones por la comisión de infracciones muy graves serán competentes los Ministros del Interior y Ministro de Economía y Hacienda en el ámbito de sus respectivas competencias, 2) para la imposición de sanciones por la comisión de infracciones graves y leves serán competentes el Secretario de Estado de Seguridad y el Secretario de Estado de hacienda y Presupuestos, en el ámbito de sus respectivas competencias y 3) Las resoluciones sancionadoras pondrán fin a la vía administrativa, siendo recurribles ante el orden jurisdiccional contencioso-administrativo.

136 Lista de los países a los que se refiere el artículo 20: Categoría 2: anhídrido acético y permanganato de potasio: Cualquier tercer país (antes al tenor de la Ley 3/1996 existía una lista de países determinados). Ácido antranílico: Antigua y Barbuda, Benin, Estado Plurinacional de Bolivia, Brasil, Islas Caimán, Chile, Colombia, Costa Rica, República Dominicana, Ecuador, Etiopía, Haití, La India, Indonesia, Jordania, Kazajistán, Líbano, Madagascar, Malasia, México, Nigeria, Paraguay, Perú, Filipinas, República de Moldova, Rumanía, Federación de Rusia, Arabia Saudí, Sudáfrica, Tayikistán, Turquía, Emiratos Árabes Unidos, Tanzania y la República Bolivariana de Venezuela. Ácido fenilacético y piperidina: Antigua y Barbuda, Benin, Estado Plurinacional de Bolivia, Brasil, Islas Caimán, Chile, Colombia, Costa Rica, República Dominicana, Ecuador, Etiopía, Haití, La India, Indonesia, Jordania, Kazajistán, Líbano, Madagascar, Malasia, México, Nigeria, Paraguay, Perú, Filipinas, República de Moldova, Rumanía, Federación de Rusia, Arabia Saudí, Tayikistán, Turquía, Emiratos Árabes Unidos, Tanzania, los Estados Unidos de América y la República Bolivariana de Venezuela. Categoría 3: metileteilcetona (MEK), tolueno, acetona y éter etílico: Antigua y Barbuda, Argentina, Benin, Estado Plurinacional de Bolivia, Brasil, Islas Caimán, Chile, Colombia, Costa Rica, República Dominicana, 
didas de una notificación previa de exportación que las autoridades competentes de la Unión Europea enviarán alas autoridades competentes del país destino de conformidad con el apartado 10 del artículo 12 de la Convención de Naciones Unidas celebrada en Viena en 1988. Debiendo el país de destino contestar en un plazo de 15 días al Estado miembro exportador sobre la licitud de la transacción comercial, transcurrido este plazo el país exportador podrá autorizar la exportación. Por mandato del Reglamento (CE) 111/2005 del Consejo las exportaciones de sustancias catalogadas que requieran una declaración en aduana, incluidas la de las sustancias catalogadas que salgan del territorio aduanero de la Comunidad tras su almacenamiento en una zona franca del Tipo I o en un depósito franco durante un periodo de por lo menos 10 días, estarán sujetas a una autorización de exportación ${ }^{137}$. No obstante, las exportaciones de precursores de la Categoría 3 solamente estarán sujetas a una autorización de exportación en caso de que se requieran notificaciones previas a la exportación o que las sustancias se exporten a los países de destino que se determinen mediante el procedimiento del Comité con vistas a garantizar un nivel adecuado de control138. En todos los casos expedirán las autorizaciones de exportación las autoridades competentes del Estado miembro en que esté estable-

Ecuador, El Salvador, Egipto, Etiopía, Guatemala, Haití, Honduras, La India, Jordania, Panamá, Kazajistán, Líbano, Madagascar, Malasia, México, Nigeria, Pakistán, Paraguay, Perú, Filipinas, República de Moldova, Rumania, Federación de Rusia, Arabia Saudí, Tayikistán, Turquía, Emiratos Árabes Unidos, Tanzania, Uruguay y la República Bolivariana de Venezuela. Ácido clorhídrico y Ácido sulfúrico: Estado Plurinacional de Bolivia, Chile, Colombia, Ecuador, Perú, Turquía y la República Bolivariana de Venezuela.

137 En los casos en que las sustancias catalogadas se reexporten dentro de un plazo inferior a 10 días a partir de la fecha de su inclusión en un régimen de suspensión o en una zona franca del control del tipo II, no será necesaria la autorización de exportación.

138 Categoría 3: metileteilcetona (MEK), tolueno, acetona, éter etílico: Antigua y Barbuda, Argentina, Benin, Estado Plurinacional de Bolivia, Brasil, Islas Caimán, Chile, Colombia, Costa Rica, República Dominicana, Ecuador, El Salvador, Egipto, Etiopía, Guatemala, Haití, Honduras, La India, Jordania, Panamá, Kazajistán, Líbano, Madagascar, Malasia, México, Nigeria, Pakistán, Paraguay, Perú, Filipinas, República de Moldova, Rumanía, Federación de Rusia, Arabia Saudí, Tayikistán, Turquía, Emiratos Árabes Unidos, Tanzania, Uruguay y República Bolivariana de Venezuela. Ácido clorhídrico y ácido sulfúrico: Estado Plurinacional de Bolivia, Chile, Colombia, Ecuador, Perú, Turquía y la República Bolivariana de Venezuela. 
cido el exportador. Debiendo la autorización acompañar el envío hasta el tercer país ${ }^{139}$.

Hay que señalar que del artículo 20 al artículo 25 de este Reglamento están reguladas las autorizaciones de importación, lo cual es valido para las importaciones, valga la redundancia, de sustancias catalogadas de la Categoría 1 dentro del territorio comunitario. Estas autorizaciones únicamente se podrán conceder a los operadores establecidos en la Comunidad Europea. Expedirán las autorizaciones de importación las autoridades competentes de los Estados miembros. No obstante en el caso de que las sustancias antes citadas se descarguen o transborden, se encuentren almacenadas temporalmente, almacenadas en una zona franca de control Tipo I o en un depósito franco o estén sometidas al procedimiento de tránsito comunitario, no se exigirá dicha autorización de importación. Este permiso deberá acompañar las sustancias catalogadas desde el punto de entrada del territorio aduanero de la Comunidad hasta los locales del importador o del destinatario final.

Para terminar este apartado queremos destacar que la Ley 4/2009 en su disposición adicional segunda preceptúa que el Gobierno promoverá convenios de colaboración voluntaria entre la industria química y farmacéutica y los Departamentos ministeriales correspondientes, especialmente en lo concerniente a las "sustancias químicas no catalogadas", entendiéndose por tales cualquier sustancia que haya sido identificada en la fabricación de drogas ilegales, hay que recordar que con este propósito se suscribió el día 5 de julio de 1999 el Convenio de Colaboración voluntaria, frente al desvío de sustancias químicas no catalogadas, susceptibles de ser utilizadas en la fabricación ilícita de estupefacientes y sustancias psicotrópicas, dándole de esta manera cumplimiento al plan de acción antidroga de la Unión Europea aprobado por el Consejo Europeo de Santa Maria da Feria los días 19 y 20 de junio del 2000.

139 A petición del operador interesado, las autoridades competentes podrán conceder una autorización de exportación por procedimiento simplificado, tal como se indica en el artículo 19 del Reglamento (CE) 111/2005, en casos de exportaciones frecuentes de una sustancia catalogada específica de la Categoría 3 en los que intervenga el mismo exportador establecido en la Comunidad y el mismo importador del mismo tercer país de destino y para un periodo de tiempo específico de 6 a 12 meses. 
En este sentido el Reglamento de control de precursores de drogas ${ }^{140}$ en su artículo 6 estipula que se inscribirán de oficio en el registro correspondiente los datos relativos a las operaciones con productos químicos no sometidos preceptivamente a control administrativo, conocidos o nuevos, y que puedan utilizarse para elaborar cualquiera de las 24 sustancias catalogadas o bien las propias drogas ilícitas, cuya información se obtenga de la colaboración voluntaria a que se refiere la disposición adicional antes citada de la Ley 4/2009 de control de precursores de drogas. Preceptuando además esta norma que la autoridad competente podrá adoptar cualquiera de las medidas previstas en el artículo 10.1 del Reglamento (CE) 273/2004 del Parlamento Europeo y del Consejo, de 11 de febrero, o en el artículo 26.3 del Reglamento (CE) 111/2005, del Consejo, de 22 de diciembre de 2004, así como recabar la información sobre transacciones comerciales, recibir la notificación de las sustracciones y las transacciones sospechosas de dichas sustancias ${ }^{141}$. control de precursores de drogas.

141 Se trata de la adopción de las siguientes medidas: a) recabar información sobre cualquier pedido de sustancias no catalogadas o de cualquier actividad comercial de estas sustancias, b) tener acceso a las instalaciones profesionales de los operadores y usuarios para obtener pruebas de irregularidades, c) interceptar e incautar los envíos de sustancias no catalogadas que no cumplan con lo dispuesto en el presente Reglamento, d) verificar que ha tenido lugar un desvío o el intento de desvío de un sustancia no catalogada. 

CAPITULO II

\section{LOS PRECURSORES DE DROGAS ILÍCITASY LAS MEDIDAS DE CONTROL ADOPTADAS SOBRE LAS SUSTANCIAS CATALOGADAS QUE SE UTILIZAN EN LA ELABORACIÓN DE LA COCAÍNA Y LA HEROÍNA}

\section{PRECURSORES QUE SE UTILIZAN EN LA ELABORACIÓN DE DROGAS ILÍCITAS Y SU PROCESO DE FABRICACIÓN}

A.) SUSTANCIAS QUÍMICAS QUE SE USAN EN LA FABRICACIÓN DE DROGAS ILÍCITAS

Iniciamos este capítulo señalando que si tradicionalmente venía achacándose a los países productores de opio y cocaína los problemas derivados de la oferta de drogas en los mercados internacionales, no debe olvidarse que son necesarios, prácticamente imprescindibles, para la producción de drogas tóxicas, sustancias estupefacientes y psicotrópicos, diversos productos químicos, conocidos como precursores o sustancias químicas catalogadas, cuya fabricación y producción se realiza fundamentalmente en los países desarrollados del mundo ${ }^{1}$. Sin embargo hay decir que en la última década los países desarrollados de forma progresiva se han ido convirtiendo también en grandes exportadores de drogas sintéticas y por consiguiente en importadores, en cierta medida, de los precursores necesarios para su fabricación. No obstante es preciso tener en cuenta que todas estas sustancias químicas se desti-

Por ello se afirma que los cultivos de coca y amapola por sí solos no son suficientes para generar la oferta de drogas, razón por la cual, la prevención del desvío y el control de los precursores constituye un elemento importante para impedir la cadena de producción de las drogas ilícitas. Como ejemplo de ello se señala que la producción de cocaína y heroína en los países Andinos se fundamenta en dos variables interdependientes: cultivos ilícitos y sustancias químicas indispensables para su procesamiento. En estos países como no se tiene la infraestructura industrial necesaria para suplir de las sustancias químicas utilizadas en la producción de alcaloides, irónicamente estas sustancias tienen como lugar de origen los mismos países a los que se destina finalmente la mayor cantidad de drogas. Lo cual evidencia que el problema de las drogas debe regirse, más que ningún otro, por el principio de responsabilidad compartida. BERNAL CONTRERAS, Héctor Hernando. Las sustancias químicas...op.cit., p. 15. 
nan fundamentalmente a la fabricación industrial de diferentes derivados de gran importancia como la síntesis de plásticos, productos farmacéuticos, cosméticos, detergentes, procesamiento de alimentos o aromatizante de bebidas entre otros productos lícitos, por lo cual su control debe dirigirse únicamente a evitar su posible desvío para la fabricación ilícita de drogas, sin interferir de forma gravosa en el normal desarrollo de la industria química y farmacéutica ${ }^{2}$. Se trata por lo tanto de sustancias necesarias para la vida de las cuales no podemos prescindir, para ilustrar un poco tal situación a continuación señalamos sus utilidades en las distintas ramas de la industria, así como su uso en la producción ilícita de drogas 3 .

1. La acetona o propanona se usa en la fabricación de plásticos, fibras, cosméticos, removedores de esmalte para las uñas, medicamentos y otros productos químicos, como solvente en procesos que involucran resinas, lacas, grasas, ceras, adhesivos, tintas de impresión, en la manufactura de barnices, removedores de barniz, en la manufactura de caucho sintético y productos químicos de fotografía, así como disolven-

2 Es necesario citar por su importancia en la producción y exportación de los denominados precursores de drogas los siguientes países: los Estados Unidos de América, Canadá, Alemania, Australia, el Reino Unido de Gran Bretaña e Irlanda del Norte, Japón, Bélgica, Holanda, Francia, Italia, España, Suiza, Dinamarca, la República Checa, Sudáfrica, la India, Eslovenia, Brasil, México y China (que en los últimos años ha cobrado un gran auge). Precursores y productos químicos frecuentemente utilizados..., correspondiente a $2000 \ldots$, p. 6. Sobre el incremento de la producción de drogas de síntesis en países desarrollados, como los pertenecientes a la Unión Europea. Vid., el Informe de la Comisión al Consejo y al Parlamento, de 7 de enero del 2010, sobre la aplicación y funcionamiento de la legislación comunitaria en materia de vigilancia y control del comercio de precursores de drogas, de conformidad con el artículo 16 del Reglamento (CE) no 273/2004 del Parlamento Europeo y del Consejo, de 11 de febrero de 2004, y del artículo 32 del Reglamento (CE) 111/2005 del Consejo. Bruselas. 2010, p. 2.

3 BERNAL CONTRERAS, Héctor Hernando. Las sustancias químicas...op.cit, pp. 55- 148. Química orgánica. ALLINGER, Norman, CAVA, Michael, DE JONGH, Don, JOHNSON, Carl, LEBEL, Norman, STEVENS, Calvin. Segunda edición. Editorial Reverte S.A. Barcelona, Bogotá, Buenos aires, Caracas, México, Rio de Janeiro. 1978, pp. 314, 343, 854, 1086, 1363, 1364, 1370. Química Orgánica. WADE, L.G. Jr. (Trad. MONTAÑA PEDRERO, Ángel Manuel. BATALLA GARCIA, Consuelo). Quinta edición. Pearson Prentice Hall. Madrid. 2004, pp. 18, 21, 59, 71, 232, 459, 707, 777, 847, 978, 979, 1079. www.quiminet.com.mx/art/ar_\%25B7\%25C7\%25F7X\%25D6\%25A6\%253F\%252B.php. Precursores y productos químicos frecuentemente utilizados..., correspondiente a 2000..., pp. 78-80. Vid., en el Anexo IV las características y usos lícitos e ilícitos de las sustancias catalogadas como precursores de drogas. 
te de uso generalizado en la industria química y farmacéutica. También es utilizado como intermediario en la fabricación de cloroformo y en la fabricación de aceites lubricantes. Sobre su uso ilícito hay que decir que es un precursor que se necesita para elaborar cocaína y heroína, de hecho es el solvente más utilizado en la elaboración de la cocaína y tiene gran importancia en la producción de heroína ${ }^{4}$, además se usa en la elaboración de metanfetamina. Esta sustancia catalogada se fabrica en los laboratorios clandestinos de cocaína a partir del alcohol isopropílico, y se conocen casos de su sustitución como solvente en la elaboración de cocaína por sustancias no catalogadas como el acetato de etilo y el acetato de butilo ${ }^{5}$.

2. El alfa-fenilacetoacetonitrilo, más conocido como APAAN es un compuesto orgánico químico que prácticamente no tiene usos lícitos

4 BERNAL CONTRERAS, Héctor Hernando. Las sustancias químicas...op.cit., pp. 55-58, 156. Entre las mayores incautaciones de precursores de drogas registradas en el periodo de 1995 al año 2000 en América del Sur ocupa un lugar muy importante la acetona, de hecho ocupa el primer lugar. Precursores y productos químicos frecuentemente utilizados..., correspondiente a 2000..., pp. 19-21. Precursores y productos químicos frecuentemente utilizados..., correspondiente a 2004..., p. 22.

5 Como ejemplo de sustitución de un precursor en la elaboración de un producto lícito, valga citar el caso del quitaesmalte o removedor de esmalte de uñas conocido comúnmente por su composición como acetona, no sin antes aclarar que no sabemos si tal sustitución se produjo para evadir los controles que existen sobre la acetona o por razones puramente comerciales. El caso en cuestión es que hace aproximadamente unos seis años se empezó a comercializar el quitaesmalte sin acetona, sustituyendo esta sustancia por acetato de etilo o acetato de butilo, estos dos solventes son sustancias no catalogadas que se utilizan en la elaboración ilícita de cocaína como sustituto de la acetona en América del Sur. Las casas comerciales venden este producto señalando que es más conveniente porque es menos agresivo para las uñas que los productos que contienen acetona. En todo caso, hay quienes dicen que los tres productos tienen una toxicidad parecida, y como la acetona es un solvente más fuerte, se tiene que usar menos cantidad en la elaboración del quitaesmalte que cuando se usa cualquiera de las dos sustancias antes mencionadas, que también están fiscalizadas en países como Costa Rica o Colombia, pero obviamente con menos exigencias y control que la acetona. En todo caso es preciso decir que en Centroamérica y Suramérica, viene muy bien la comercialización del removedor de uñas sin acetona, pues el que contiene acetona esta prohibido en casi todos los países de la región, dado que se utilizaba para la fabricación de cocaína. Sin embargo, en países como España se siguen comercializando ambas versiones del quitaesmalte. Informe Diagnostico Situacional sobre los cuatro insumos químicos controlados de mayor uso en la fabricación de drogas en Perú. UNODC. Lima. 2011, p. 9. 
conocidos (no hay aplicaciones industriales conocidas en que se utilice APAAN), pues no existe comercio lícito documentado de esta sustancia salvo, en pequeñas cantidades que se destinan a actividades de investigación y desarrollo y en análisis de laboratorio. De forma ilícita se utiliza en la elaboración, de otro precursor de drogas, la fenilcetona, más conocida como P-2-P en los laboratorios clandestinos, del cual es un precursor inmediato, que se usa para elaborar anfetamina y metanfetamina ${ }^{6}$.

3. El ácido $\mathrm{N}$-acetilantranílico se utiliza de forma lícita como materia prima para la síntesis de analgésicos y antipiréticos del tipo de ácido mefenámico y ácido flufenámico que forman parte de algunos medicamentos para el tratamiento del dolor y la fiebre, así como en la manufactura de plásticos y productos químicos refinados. Esta sustancia se usa de manera ilícita para la elaboración de metacualona y meclocualona. Es necesario señalar que el ácido $N$-acetilantranilico se prepara a menudo a partir del ácido antranílico (otra sustancia catalogada) ${ }^{7}$.

4. El ácido antranílico se emplea de forma legal como materia prima para la síntesis de analgésicos y antipiréticos del tipo de ácido mefenámico ${ }^{8} \mathrm{y}$ ácido flufenámico ${ }^{9}$ que forman parte de algunos medicamentos para el tratamiento del dolor y la fiebre, también se usa en la fabricación de tintes y perfumes, así como en la preparación de repelentes

6 La JIFE preocupada por las importantes incautaciones de P-2-P a partir de APAAN inicio en el mes de marzo del año 2013 los tramites para someter a fiscalización esta sustancia. En su 57o período de sesiones, celebrado en el mes de marzo del año 2014, la Comisión de Estupefacientes decidió unánimemente seguir las recomendaciones de la Junta e incluir el APAAN y sus isómeros ópticos en el Cuadro I de la Convención de 1988 (decisión 57/1 de la Comisión). Esta desición entro en vigor el día 9 de octubre del año 2014. Precursores y sustancias químicas frecuentemente utilizados.., correspondiente a 2014..., pp. 7, 120. Precursores y productos químicos frecuentemente utilizados..., correspondiente a 2011..., pp. 21, 22. Precursores y productos químicos frecuentemente utilizados..., correspondiente a 2013..., p. 2.

7 Precursores y productos químicos frecuentemente utilizados..., correspondiente a 2005..., p. 14.

$8 \quad$ El ácido mefenámico es un agente antiinflamatorio no esteroídico que se utiliza como analgésico y para aliviar la dismenorrea primaria. También se utiliza en el tratamiento de la artritis reumatoide y osteoartritis, además posee actividad antipirética.

9 El ácido flufenámico es un medicamento antiinflamatorio no esteroideo derivado del ácido fenámico o fenamato, indicado como analgésico, antiinflamatorio y antipirético. 
de pájaros e insectos. Este precursor se utiliza ilegalmente para la síntesis del ácido $N$-acetilantranílico, que luego se emplea para la elaboración de metacualona ${ }^{10}$ y meclocualona ${ }^{11}$.

5. El ácido clorhídrico también llamado ácido muriático por su extracción de la sal marina en América. Se emplea para limpiar, tratar y galvanizar metales, curtir cueros, procesamiento de alimentos, activación de pozos de petróleo y en la refinación y manufactura de una amplia variedad de productos, también se utiliza como un agente de limpieza en una solución al $18 \%$, en la fabricación de cloruros y clorhidratos, para la neutralización de sistemas básicos. Como catalizador y disolvente en síntesis

La metacualona tiene mecanismos de acción farmacológica que consisten en la disminución de la función del sistema nervioso con efectos hipnóticos, sedantes, anticonvulsivantes, antiespasmódicos y antihistamínicos. Fue sintetizada en la India en 1955 para luchar contra la Malaria, es un derivado de la quinazolina. Produce efectos que se asemejan a los de los barbitúricos de acción rápida. Se puede presentar bajo la forma de un polvo cristalino de color crema o blanco, amarga e inodora, o bajo forma de píldoras o pastillas. Se consume por vía oral o por inyección intravenosa sola o asociada a otros productos (heroína, alcohol, etc.). Sus efectos inmediatos son la disminución del nivel de conciencia precedida de mareo y estupor con coma que persiste de 2 a 4 días, sensación de descanso, relajación muscular, euforia, desinhibición afectiva. Pueden presentarse delirios y alucinaciones cuando es asociado al alcohol. Los efectos a corto plazo son falta de coordinación motora, alteración de las percepciones subjetivas, estado depresivo o al contrario, un estado de nerviosismo extremo. Los efectos a largo plazoson temblores, episodios amnésicos, una degradación intelectual, trastornos del humor, del carácter y del comportamiento. La metacualona provoca una dependencia física y psíquica. Precursores y productos químicos frecuentemente utilizados..., correspondiente a 2005, p. 14.

11 La 3-(0-clorofenil-2-metil-4(3H)quinazolina, cuya denominación común es meclocualona, se administra por vía oral, se biotransforma en el organismo. Esta sustancia se comporta como los barbitúricos de acción intermedia. Es un farmaco hipnótico, antihistaminico, espasmolítico, antitusígeno, relajante de la musculatura estriada por inhibir reflejos polisinápticos, anticonvulsionante y potenciador de los analgésicos. Inhibe el consumo de oxigeno cerebral incrementando el consumo de glucosa. Entre los efectos tóxicos de la meclocualona destacan: coma, parestesias, hipotensión, depresión cardiaca, vertigo, sequedad en la boca, anorexia, náuseas, hemorragias y trastornos cutáneos, como todos los hipnóticos produce farmacodependencia. Esta sustancia se emplea como inductor del sueño, sedante, potenciador de analgésicos y como relajante de la musculatura esqueletica. VELASCO MARTÍN, Alfonso. ALVAREZ GONZALEZ, Francisco Javier. Compendio de psiconeurofarmacia. Ediciones Díaz de Santos. S.A. Madrid. 1988, p. 112. Por Orden del 11 de febrero de 1981 se incluye la meclocualona en la lista II del anexo I del Real decreto del 6 de octubre de 1977, sobre sustancias y preparados psicotrópicos. 
orgánicas. Este precursor se usa de forma ilícita en la producción de heroína, cocaína, metanfetamina, MDMA y fenciclidina ${ }^{12}$.

6. El ácido fenilacético es la materia prima para la preparación de analgésicos y antipiréticos del tipo ibuprofeno (hay muchos medicamentos que contienen este compuesto y se utilizan para el tratamiento del dolor y la fiebre), para síntesis de penicilinas, además se usa como aromatizante de bebidas, alimentos, para la fabricación de perfumes y en soluciones de limpieza. Este precursor se utiliza de forma ilegal para producir anfetaminas, metanfetaminas y otro precursor de drogas la P-2-P13.

7. El ácido lisérgico se emplea en síntesis orgánicas y de ergonovina, medicamento que usualmente se suministra a las mujeres para detener el sangrado fuerte que se produce después del parto, así como en investigaciones medicas. Se puede usar como materia prima para la elaboración de drogas relacionadas con el LSD.

8. El ácido sulfúrico es el compuesto químico que más se produce en el mundo, por eso se utiliza como uno de los medidores de la capacidad industrial de los países. Una gran parte de la producción de este precursor se emplea en la obtención de fertilizantes, además se utiliza para fabricar productos orgánicos, pinturas, pigmentos, explosivos, alcoholes, tintas, detergentes sintéticos, caucho sintético y natural, pulpa, papel, celulosa rayón y fibras textiles. También se usa para la síntesis de otros ácidos y sulfatos y en la industria petroquímica para refinar petróleo, así como para procesar y limpiar metales. Es utilizado además en la manufactura de fosfato y sulfato de amonio. El ácido sulfúrico

Precursores y sustancias químicas frecuentemente utilizados..., correspondiente a 2012..., p. 14. El ácido clorhídrico para evitar que puedan ocurrir reacciones violentas, debido a su incompatibilidad química no debe almacenarse de manera inadecuada junto a las siguientes sustancias: alcohol bencílico, hidruro de litio y aluminio, nitrito de níquel, tri-iso-butil-aluminio, amoníaco, cloratos, percloratos y permanganatos. Los cuatro insumos químicos que más se utilizan en la producción de cocaína en Perú son el ácido sulfúrico, el ácido clorhídrico, la acetona y el carbonato de sodio. Informe Diagnostico Situacional sobre los cuatro insumos químicos controlados de mayor uso en la fabricación de drogas en Perú. UNODC. Lima. 2011, p. 9.

13 Una tendencia que viene observándose en América del Norte es la utilización del ácido fenilacético como sustitutivo de la efedrina o la seudoefedrina en la fabricación de metanfetamina para eludir el férreo control que hay en esa región de esas dos sustancias. Precursores y productos químicos frecuentemente utilizados..., correspondiente a 2006..., pp. 13, 16. 
tiene una gran importancia en la producción ilícita de cocaína, heroína y metanfetamina ${ }^{14}$.

9. El anhídrido acético, sobre sus usos lícitos hay que decir que la mayor parte de la producción de este precursor va a parar a la fabricación de acetato de celulosa (plásticos y fibras textiles), también tiene otras aplicaciones como la síntesis de la tetraacetiletilenodiamina en la industria de detergentes, y la síntesis de fármacos tales como el ácido acetil salicílico (aspirina) o el paracetamol. También encuentra aplicación en la producción de polimetilacrilimida (espuma dura), plastificantes acetilados, explosivos, ciertos fluidos para frenos hidráulicos, fluidos de perforación, tintes, herbicidas, aromas, fragancias y para la limpieza de metales. El anhídrido acético es una sustancia indispensable para la fabricación de la heroína y de de drogas de tipo anfetaminico (metanfetamina, anfetamina y la metacualona) ${ }^{15}$. El anhídrido acético también se puede utilizar para obtener otros precursores de drogas tales como la P-2-P ${ }^{16}$ y el ácido fenilacético ${ }^{17}$.

10. La efedrina es un compuesto que forma parte de muchos medicamentos para el tratamiento del asma y otros procesos respiratorios como el catarro, así como alergias. Forma parte igualmente de gotas

Precursores y sustancias químicas frecuentemente utilizados..., correspondiente a 2012..., p 14. El ácido sulfúrico para evitar que puedan ocurrir reacciones violentas debido a su incompatibilidad química no debe almacenarse de manera inadecuada junto a las siguientes sustancias: clorato de potasio, perclorato de potasio y permanganato de potasio. Precursores y productos químicos frecuentemente utilizados..., correspondiente a $2009 . . .$, p. 79. Los cuatro insumos químicos que más se utilizan en la producción de cocaína en Perú son el ácido súlfurico, el ácido clorhídrico, la acetona y el carbonato de sodio. Informe Diagnostico Situacional sobre los cuatro insumos químicos controlados de mayor uso en la fabricación de drogas en Perú. UNODC. Lima. 2011, p. 9. Precursores y productos químicos frecuentemente utilizados..., correspondiente a 2008..., p. 14.

Precursores y productos químicos frecuentemente utilizados..., correspondiente a 2005..., p. 14. El anhídrido acético también es una sustancia controlada por el programa Global Shield, que es una iniciativa multinacional de la Oficina de Naciones Unidas contra la Droga y el Delito, La Organización Internacional de Policía Criminal y la Organización Mundial de Aduanas centrada en los precursores de alto Riesgo utlizados para fabricar artefactos explosivos improvisados. Precursores y productos químicos frecuentemente utilizados..., correspondiente a 2011..., p. 10.

$16 \quad$ Idem.

$17 \quad$ Ibidem, pp. 20, 21. 
nasales para descongestionar la nariz, y además, se ha promovido como la sustancia natural perfecta para bajar de peso porque acelera el metabolismo, aumenta la energía física y quita el hambre, por ello muchos atletas y fisicoculturistas toman efedrina. Esta sustancia puede usarse de forma ilegal como materia prima para la elaboración de drogas de diseño como anfetaminas y metanfetaminas. Hay que destacar que los preparados farmacéuticos que contienen efedrina suelen ser utilizados por los narcotraficantes como precursores para la fabricación ilícita de metanfetamina. Por ello muchos de los gobiernos interesados, entre ellos los de Australia, los Estados Unidos de América, la Federación de Rusia, México, República Checa y Tailandia, han tomado medidas para fiscalizar el comercio internacional y la distribución interna de estos productos ${ }^{18}$. Esta sustancia también se usa para la elaboración ilícta de metcatinona ${ }^{19}$.

11. La ergometrina también conocida como ergonovina se utiliza para la prevención y tratamiento de la hemorragia posparto o del aborto debido a atonía uterina, es además un poderoso estimulante uterino (oxitócico) empleado en la obstetricia, también se utiliza como vasoconstrictor, especialmente en el tratamiento de la migraña. Este precursor como es un derivado del ácido lisérgico, se usa de manera ilegal como materia prima en la obtención de drogas relacionadas con el LSD.

12. La ergotamina es un compuesto que forma parte de algunos medicamentos utilizados para el tratamiento del dolor de cabeza de tipo migraña y como oxitóxico en obstetricia. Por su estructura (es un derivado del ácido lisérgico) puede usarse de forma ilegal para la elaboración de drogas de tipo LSD (dietilamina del ácido lisérgico).

13. El éter etílico o éter dietílico es un buen disolvente de las grasas, azufre, fósforo, se utiliza como extractante de aceites, ceras y resinas, en la fabricación de plásticos y perfumes, en medicina se emplea como anestésico general. Además tiene aplicaciones industriales como disolvente de usos generalizado en laboratorios químicos y en industria química y farmacéutica, así como en las fábricas de explosivos y munip. 8.

19 Precursores y productos químicos frecuentemente utilizados..., correspondiente a 2003..., p. 32. 
ciones. Esta sustancia se usa de forma ilícita en la fabricación de cocaína y heroína ${ }^{20}$.

14. El isosafrol se usa comúnmente en la preparación de perfumes, fragancias y sabores de bebidas gaseosas, jabones perfumados, pesticidas, en pequeñas cantidades junto con saliciliato de metilo en aromatizantes de cerveza de raíces y zarzaparrilla, en diversas síntesis orgánicas, y de forma ilícita en la manufactura de otras sustancias catalogadas como el piperonal y la 3,4-MDP-2-P, por ende el isosafrol se usa para fabricar MDA y sustancias análogas como el MDMA21.

15. La metiletilcetona o butanona es un disolvente que se utiliza de forma legal en algunas reacciones químicas. Es un producto industrial, usado como base disolvente en diversas aplicaciones, solvente para pinturas, barnices y lacas de nitrocelulosa, como intermediario de síntesis del peróxido de metiletilcetona, empleado en la catálisis de algunas reacciones de polimerización, producción de disolventes para revestimientos, adhesivos, cintas magnéticas, separación de la cera de aceites lubricantes, cuero sintético, papel transparente, papel de aluminio, quita grasas, extracción de grasas, aceites, ceras, resinas sintéticas y naturales y pólvora sin humo. Este precursor se utiliza de forma ilícita para la fabricación de heroína y cocaína.

16. La norefedrina o fenilpropanolamina es comúnmente utilizada como descongestionante nasal y como inhibidor del apetito, en veterinaria se emplea para controlar la incontinencia urinaria de los perros. De forma ilegal se usa para producir anfetaminas, metanfetaminas y del 4metil-aminorex ${ }^{22}$. La norefedrina se añadió al Cuadro I de la Conven-

Para evidenciar la importancia que tiene este precursor en la producción de drogas ilícitas citamos que en el primer estudio realizado en 1982, por el Instituto Colombiano de Comercio Exterior, con apoyo de la Policía Nacional y de la Embajada de los Estados Unidos de América, se concluyó que solo el $2 \%$ del éter etílico que importaba el país estaba siendo utilizado por la industria colombiana legalmente constituida, mientras que el 98\%, muy probablemente, estaba siendo desviado hacia canales ilícitos. Las sustancias químicas y el tráfico de estupefacientes. BERNAL CONTRERAS, Héctor Hernando. Ed. Ministerio de Justicia y del Derecho. Bogotá. 2003, pp. 17, 18, 156. Precursores y productos químicos frecuentemente utilizados..., correspondiente a 2009..., p. 81.

Esta droga es similar a la metanfetamina ya que ambas producen una euforia extrema, con la salvedad de que el 4-metil-aminorex tiene mayor duración su efecto, pudiendo 
ción de 1988 en el mes de de noviembre del año 2000 en cumplimiento de una recomendación de la JIFE23.

17. El permanganato potásico o permanganato de potasio es un compuesto inorgánico con propiedades oxidantes, útil en diferentes procesos de oxidación de compuestos orgánicos, reactivo en química analítica, desinfectante, ingrediente para tintura, agente en el tratamiento médico de algunos venenos, también se usa para remover de una solución hierro y manganeso, blanqueo de resinas, ceras, grasas, aceite, paja, algodón, seda y diversas fibras, colorante pardo de maderas, estampado de telas, fabricación de aguas minerales, fotografía, fabricación de insecticidas, curtido de cueros, purificación del agua, desinfectantes, en medicina se usa como bactericida y fungicida, para el tratamiento de eccema y de las alergias a la planta rhus radicans y similares, para el tratamiento oral de barbitúricos, hidrato cloral y muchos alcaloides. Se utiliza de forma ilícita en la producción de cocaína ${ }^{24}$. Especificamente se emplea para extraer la cinamoilcocaína y otros alcaloides oxidables de la cocaína, de hecho es la sustancia más empleada con este fin, puesto que su color violeta en la solución sirve como indicador. En Colombia por las dificultades que tienen los productores de drogas para conseguir esta sustancia, debido a los severos controles a los que está sometido su tráfico, se realiza un proceso rústico para la producción de permanganato de potasio en laboratorios clandestinos utilizando como precursor secundario el dióxido de manganeso ${ }^{25} \mathrm{y}$ el manganato de potasio ${ }^{26}$. El permanganato de potasio también se emplea de manera ile-

llegar a las 12 horas. Esta droga en las calles es conocida como euphoria. Es muy fácil de sintetizar incluso en una cocina normal con pocos utensilios y fenilpropanolamina.

Precursores y productos químicos frecuentemente utilizados..., correspondiente a 2000..., p. 8.

24 BERNAL CONTRERAS, Héctor Hernando. Las sustancias químicas...op.cit., p. 158.

25 Las autoridades colombianas encontraron este permanganato rústico a partir del año 2000 en el desmantelamiento de 24 laboratorios clandestinos, en todos ellos utilizaban como precursor secundario para obtener el permanganato de potasio el dióxido de manganeso. Las sustancias químicas y el tráfico de estupefacientes. Ibidem, p. 159.

26 El problema de Drogas en las Americas. Estudios. Producción y oferta de drogas, fármacos y precursores químicos. Ed. Organización de Estados Americanos. ISBN 978-0-82706002-9. 
gal en la elaboración de metcatinona (efedrona) y otras drogas de tipo anfetaminico ${ }^{27}$.

18. La piperidina se usa de forma lícita como disolvente y reactivo de uso generalizado en laboratorios químicos y en la industria química y farmacéutica, puede formar parte de compuestos con propiedades antihistamínicas y neurolépticas, así como en la preparación de anestésicos locales, analgésicos y otros fármacos, humectantes y germicidas, también se usa como intermedio en la aceleración de la vulcanización del caucho, en el curado de resinas expoxídicas, como solvente, catalizador en reacciones de condensación, se emplea también en la producción de plásticos. Esta sustancia se utiliza de forma ilícita en la fabricación de fenciclidina ${ }^{28}$.

19. El piperonal se utiliza en la producción de perfumes, así como en la confección de aromas de cereza y vainilla, en síntesis orgánica y como componente para los repelentes de mosquitos. Además es un compuesto que de forma ilícita se utiliza en la elaboración de las drogas de diseño como el éxtasis y el polvo de ángel y el MDA entre otras, siendo el precursor de MDMA más comercializado ${ }^{29}$, el piperonal es también materia prima, o precursor secundario, para la elaboración de otra sustancia catalogada 3,4-MDP-2-P30.

27 La JIFE señala que las incautaciones de permanganato de potasio realizadas fuera de América Latina son demasiadas pequeñas para ser aprovechadas en la fabricación ilícita de cocaína. por consiguiente, se relaciona más con la producción ilícita de metcatinona (efedrona) mediante la oxidación de la efedrina o seudoefedrina. Precursores y productos químicos frecuentemente utilizados..., correspondiente a 2004..., p. 21. Precursores y productos químicos frecuentemente utilizados..., correspondiente a 2006..., pp. 18, 19.

28 La fenciclidina (contracción del nombre químico fenilciclohexilpiperidina), conocida por su abreviatura del inglés PCP, es una droga disociativa usada como agente anestésico que posee efectos alucinógenos y neurotóxicos. Se le conoce comúnmente como "polvo de ángel", "hierba mala" o "píldora de la paz". La fenciclidina se desarrolló comercialmente en los años 1950 por la compañía farmacéutica Parke-Davis. Precursores y productos químicos frecuentemente utilizados..., correspondiente a 2003..., pp. 32, 34.

29 Precursores y productos químicos frecuentemente utilizados..., correspondiente a 2001..., p. 27.

$30 \quad$ Precursores y productos químicos frecuentemente utilizados..., correspondiente a 2005..., p. 6. Precursores y productos químicos frecuentemente utilizados..., correspondiente a 2008..., p. 10. 
20. El safrol se usa de forma lícita en la producción de perfumes, aromas, insecticidas y jabones. Este precursor presenta la característica de servir en la síntesis de otras sustancias catalogadas como el piperonal, el isosafrol y la 3,4- metilendioxifenil-2-propanona que se utilizan de forma ilícita para producir MDA (tenamfetamina o píldora del amor). MDE (Eva), MDMA (Éxtasis) y N-hidroxi-MDA (Hidroxilamina) ${ }^{31}$.

21. La seudoefedrina es un agente farmacológico con acción agonista adrenérgico, utilizado en medicina por sus propiedades como descongestivo sistémico; frecuentemente indicado para tratar la congestión nasal, de senos y de la trompa de Eustaquio. De manera ilegal se usa para la elaboración de metanfetaminas y anfetaminas. Es preciso señalar que los preparados farmacéuticos que contienen seudoefedrina suelen ser utilizados por los narcotraficantes como precursores para la fabricación ilícita de metanfetamina. Por ellos muchos de los gobiernos interesados, entre ellos los de Australia, los Estados Unidos de America, la Federación de Rusia, México, República Checa y Tailandia, han tomado medidas para fiscalizar el comercio internacional y la distribución interna de estos productos ${ }^{32}$.

22. El tolueno o metilbenceno es la materia prima a partir de la cual se obtienen derivados del benceno, el ácido benzoico, el fenol, la caprolactama, la sacarina, el TDI (diisocianato de tolueno) materia prima para la elaboración de poliuretano, medicamentos, colorantes, perfumes, explosivos, pinturas, lacas, resinas, limpiadores, pegamentos, detergentes y como aditivo de la gasolina. Hay que señalar que también se utiliza de forma ilegal en la elaboración de cocaína, heroína, metacualona y metanfetamina ${ }^{33}$.

23. La 1-fenil-2-propanona, también conocida como $P$-2-P, se utiliza en la producción de propilhexedrina que se usa para tratamiento de la

Precursores y productos químicos frecuentemente utilizados..., correspondiente a 2006..., p. 17. Precursores y productos químicos frecuentemente utilizados..., correspondiente a $2008 \ldots$, p. 10

32 Precursores y productos químicos frecuentemente utilizados..., correspondiente a 2000 ..., p. 8.

33 El tolueno se ha encontrado en muchos laboratorios de metanfetamina desmantelados en la República Checa. Precursores y sustancias químicas frecuentemente utilizados..., correspondiente a $2012 \ldots$, p. 14. Precursores y productos químicos frecuentemente utilizados..., correspondiente a 2005..., p. 14. 
obesidad, también en síntesis orgánicas y en la fabricación de productos de limpieza y desinfección ${ }^{34}$. Además se usa de manera ilegal en la fabricación de anfetaminas y metanfetaminas. Por lo general esos laboratorios sintetizan ellos mismos este precursor o bien utilizan como sucedáneo de este el benzaldehído que es una sustancia química no catalogada 35 .

24. La 3,4-metilendioxifenil-2-propanona, conocida también como 3,4$M D P-2-P$, se usa de forma lícita en la producción de fragancias y como reactivo en síntesis orgánica, y se utiliza de forma ilegal para producir MDA, MDMA, MDE y (N-hidroxi-MDA). Es preciso señalar que este precursor es el reactivo principal en la síntesis de estas drogas ilícitas ${ }^{36}$.

Es necesario terminar este apartado poniendo de manifiesto de que existen una cantidad importante de sustancias químicas no catalogadas como precursores, nosotros hemos logrado determinar un total de 90 sustancias, que se usan en la elaboración de drogas tóxicas, estupefacientes y psicotrópicos de forma frecuente a nivel mundial ${ }^{37}$, o bien como precursores secundarios de drogas, es decir sustancias que sirven para elaborar los precursores propiamente dichos, o incluso que se utilizan como sucedáneos de las sustancias químicas catalogadas en la elaboración de las drogas ilícitas. Estas sustancias se almacenan o elaboran en emplazamientos cercanos a los laboratorios ilícitos o en los propios laboratorios. Situación que dificulta de forma considerable el enfrentamiento de esta parcela de la narcoactividad por los cuerpos y

Precursores y productos químicos frecuentemente utilizados..., correspondiente a 2008..., pp. 9, 10.

35 Precursores y productos químicos frecuentemente utilizados..., correspondiente a 2000..., pp. 29, 30. www.basc-costarica.com/documentos/Precursores.pdf. Sobre la elaboración de P-2-P en los propios laboratorios clandestinos. Precursores y productos químicos frecuentemente utilizados..., correspondiente a 2003..., p. 23. Precursores y sustancias químicas frecuentemente utilizados..., correspondiente a 2012..., p. 16. Global SMART Update, volumen 7, marzo 2012. Informe global de monitoreo de drogas sintéticas 2012. Ed. UNODC. 2012, p. 5.

$36 \quad$ Precursores y productos químicos frecuentemente utilizados..., correspondiente a 2008..., p. 10. Vid., en el Anexo IV de forma amplia las características, usos lícitos e ilícitos de los precursores de drogas.

37 Vid., en el Anexo V todas estas sustancias no catalogadas, así como sus usos lícitos e ilícitos. 
fuerzas de seguridad, diferentes funcionarios implicados, así como por los organos del poder judicial. Sobre este tema es necesario señalar que sustancias como el permanganato de potasio y el anhídrido acético, principales precursores en la elaboración de la cocaína y la heroína, y las principales sustancias químicas catalogadas que se utilizan en la elaboración ilícita de los estimulantes de tipo anfetamínico como la efedrina, la seudoefedrina, la P-2-P, la 3,4-MDP-2 y el ácido fenilacético (todas del Cuadro I del Convenio de 1988) se fabrican ilícitamente. Llegando incluso los químicos o cocineros a elaborar solventes del Cuadro II tales como la acetona, la metiletilcetona y el ácido sulfúrico.

\section{B.) EL PROCESO DE ELABORACIÓN DE LAS DROGAS ILÍCITAS}

Iniciamos este apartado señalando que las 24 sustancias químicas catalogadas, señaladas anteriormente, no se utilizan en el procesamiento de los productos ilegales que se obtienen de las variedades de cannabis índico y cannabis sativa. Por lo cual sólo realizaremos una breve referencia de estos, por encontrarse al margen del objetivo de nuestra investigación que son los precursores de drogas. El primero de ellos es la marihuana, que como todos sabemos solo consiste en el proceso de secado de las hojas y pequeños tallos de la planta por medios naturales o artificiales. La resina de marihuana (hachís) que no es más que la agrupación por medio de presión y/o calor de los tricomas desprendidos por la planta seca, 100 gramos de cannabis pueden producir cinco gramos de resina por lo tanto son necesarios casi 100 kilogramos de planta para poder producir un kilo de hachís de primera calidad ${ }^{38}$ y por último nos encontramos con el aceite de marihuana, que es el producto con mayor concentración de tetrahidrocannabinol (THC), este se puede obtener básicamente por dos métodos: a) por destilación de la hierba o del hachís, y b) por el flujo de gas butano a través de la hierba, quere-

38 El hachís es una sustancia con propiedades alucinógenas que se prepara a partir de la resina de cannabis. Posee diferentes presentaciones como polvo fino o comprimido formateado en pastillas o tabletas de color pardo oscuro, estas últimas se parecen a barras de chocolatinas que pueden tener pesos entre 100 gramos y 1 kilogramo. La concentración de tetrahidrocannabinol (THC) puede variar entre el $4 \%$ y el $10 \%$ dependiendo de su origen y su forma de producción. En América prácticamente no se produce hachís, estando su producción limitada a países asiáticos. BERNAL CONTRERAS, Héctor Hernando. Las sustancias químicas...op.cit., p. 166. 
mos señalar que este método se utiliza poco debido a la peligrosidad que reviste la utilización de gas ${ }^{39}$.

\section{El proceso de elaboración de la cocaína}

Como es de conocimiento general la cocaína es un alcaloide natural que se obtiene de la hoja de coca, planta del género Erythroxylon, por extracción de las hojas y un proceso de purificación. La coca que se utiliza para la producción ilícita de cocaína se cultiva principalmente en Bolivia, Perú y Colombia. En los dos primeros países se registran hasta dos cosechas al año, mientras que en Colombia entre cuatro y cinco cosechas anuales. Es importante señalar que el arbusto de coca puede llegar a producir entre 30 y 40 años. Normalmente las hojas de coca de América del Sur contienen entre el 0,5 y el 1,5\% de alcaloide, entre los cuales la cocaína es el principal de ellos ${ }^{40}$. La producción del clorhidrato de cocaína a partir de las hojas de coca se suele llevar a cabo en tres etapas: 1) extracción de la cocaína y demás alcaloides de las hojas de coca, lo que da la pasta de coca, 2) purificación de la pasta de coca en cocaína base y 3) conversión de la cocaína base en clorhidrato de cocaína. Estas etapas se pueden realizar en dos o tres laboratorios diferentes o bien en uno solo. En cada una de las etapas se precisan productos químicos que poseen determinadas propiedades. A qué etapas se dedica cada laboratorio se averigua por las sustancias que se encuentran en él. Para cada etapa hacen falta las siguientes sustancias: 1) producción de pasta de coca: kerosene, gasolina u otros solventes orgánicos parecidos: álcalis, por ejemplo, carbonatos de sodio, potasio o calcio, hidróxido de sodio u óxido de calcio; ácidos tales como el sulfúrico. 2) Producción de cocaína base: oxidantes, por ejemplo, permanganato de potasio o peróxido de hidrogeno; ácido sulfúrico y solución

39 Este subproducto del cannabis en algunos países se conoce como hachís liquido. Desde el punto de vista técnico se trata de la fracción oleosa de la planta, la cual generalmente tiene un $65 \%$ de THC, pudiendo llegar a tener más del $80 \%$ del principio activo, THC, dependiendo de la concentración a que se lleve. Antiguamente se comercializaba en las farmacias como "tintura o extracto de cáñamo indiano", que se utilizaba en medicina. El aceite de marihuana tiene una apariencia similar al aceite de cocina o bien tiene una consistencia casi sólida parecida al asfalto, de olor penetrante y con altas concentraciones de principio activo entre el 80 y 95\%. BERNAL CONTRERAS, Héctor Hernando. Las sustancias químicas...op.cit., p. 167. 
acuosa de amoníaco (agua amoniacal). 3) Producción de clorhidrato de cocaína: solventes orgánicos tales como, éter etílico, acetona, metiletilcetona o tolueno y ácido clorhídrico. Queremos poner de manifiesto que en los laboratorios ilícitos que se han encontrado en España se realiza la última etapa, es decir la conversión de cocaína base a clorhidrato de cocaína.

Es importante observar que para estas operaciones se requiere un instrumental sencillo y un número relativamente pequeño de sustancias químicas. De estas sustancias, las más críticas son las que se emplean en las etapas finales de la producción del clorhidrato de cocaína; el oxidante (permanganato de potasio) y los solventes orgánicos (éter etílico, acetona, metiletilcetona o tolueno), todos ellos sustancias catalogadas en la legislación de la Unión Europea. A continuación describimos los procedimientos que se emplean en la producción ilícita de cocaína:

Primera etapa: producción de pasta de coca. Las hojas secas de coca se humedecen con una solución alcalina para convertir la cocaína en una forma insoluble en agua. Para esta extracción inicial se han usado los carbonatos de sodio, potasio y calcio; el hidróxido de sodio (sosa cáustica), el óxido de calcio (cal viva) o el hidróxido de amonio (agua amoniacal). Luego las hojas de coca humedecidas se maceran en kerosene (o en algún otro solvente orgánico apropiado) el cual disuelve la cocaína y la extrae. La gasolina también se ha utilizado en lugar del kerosene pero no resulta conveniente por su inflamabilidad y volatilidad. Es preciso decir en este momento que el kerosene extrae otros alcaloides de la coca además de la cocaína. La solución de kerosene se mezcla con el ácido sulfúrico diluido; de esta forma la cocaína y los otros alcaloides se convierten en sulfatos, los cuales son solubles en la solución ácida acuosa la cual se retiene. En esta extracción se separan de la cocaína y los otros alcaloides, las ceras y grasas de las hojas de coca. En lugar del ácido sulfúrico se puede emplear en este paso el ácido clorhídrico, el ácido nítrico, o el ácido fosfórico. Lo más común es que se emplee el ácido sulfúrico, por ser muy común y por sus propiedades físicas. Es un ácido fuerte y de baja volatilidad por lo que resulta más seguro, fácil de usar y más eficaz que los otros. A la solución de ácido sulfúrico que contiene el sulfato de cocaína se le añade agua amoniacal, lo que convierte el sulfato de cocaína en cocaína base, la cual es insoluble en agua. La cocaína y los otros alcaloides entonces se separan del líquido por filtración. El sólido resultante es la "pasta de coca" (también se llama a veces sulfato), la cual contiene aproximadamente un $50 \%$ de cocaína. Los productos que se usan en este primer paso se encuentran con relativa facilidad en 
todo el mundo, a veces inclusive en los países en que se produce la cocaína, y existen sustitutivos prácticos para cada uno de ellos.

Segunda etapa: a fin de transformar la cocaína en un producto vendible, o sea soluble en agua e inyectable, la pasta de coca se purifica y la cocaína restante se convierte en cocaína base. Para ello, la pasta de coca se disuelve en ácido sulfúrico diluido, lo que convierte la cocaína y los otros alcaloides en sulfatos solubles en agua. A esa solución ácida se le agrega la solución diluida de un oxidante, que suele ser el permanganato de potasio. En su lugar también se emplea, y a veces se ha encontrado en los laboratorios clandestinos, el peróxido de hidrógeno (agua oxigenada). Estos oxidantes tienen el propósito de oxidar la cinamilcocaína y otros alcaloides indeseables y convertirlos en formas insolubles en agua, que entonces se separan por la filtración de la solución donde esta la cocaína. La separación de estas impurezas ayuda a la cristalización del clorhidrato de cocaína en la etapa final y facilita la obtención de un producto final blanco que es lo que desean los distribuidores y consumidores de cocaína. Creemos oportuno aclarar que el oxidante preferido, y el más empleado en los laboratorios clandestinos, es el permanganato de potasio, que le da un color violeta azulado a la solución, el cual sirve como indicador de la oxidación completa de los alcaloides indeseables. Es precisamente por la gran importancia que tiene el permanganato de potasio en la producción de clorhidrato de cocaína que se encuentra en el cuadro I de la lista de los precursores de drogas del Convenio de 1988 de Naciones Unidas celebrado en Viena, y en la categoría 2 de la legislación comunitaria (UE). Las impurezas se filtran de la solución de ácido sulfúrico; entonces estas se alcalinizan con agua amoniacal o con otras de las sustancias alcalinas mencionados previamente. Esta reacción convierte la sal de cocaína en cocaína, que es insoluble en agua y precipita. Se separa por filtración y la cocaína resultante se seca.

Tercera etapa: las sustancias que se emplean en la conversión de la cocaína base en clorhidrato de cocaína cristalino son los solventes orgánicos capaces de disolver la cocaína y el ácido clorhídrico; de éste último provienen los iones de cloro que convierten la cocaína en su clorhidrato. Los solventes más comunes para este fin son el éter etílico, la acetona, la metiletilcetona y el tolueno, todos ellos sustancias catalogadas.

En esta etapa, la cocaína seca se disuelve en la cantidad mínima de un solvente orgánico, por ejemplo el éter etílico o la acetona, y se filtra para separar cualquier sustancia insoluble (las impurezas). Al líquido se 
le añade una solución de ácido clorhídrico en un solvente orgánico soluble en agua como la acetona. Esto transforma la cocaína en clorhidrato de cocaína, el cual es insoluble en el solvente orgánico y precipita. La solución entonces se filtra, y el clorhidrato de cocaína cristalino se retiene y se seca. La pureza del producto resultante suele oscilar entre el $90 \%$ y el 98\%, expresada en términos de clorhidrato de cocaína ${ }^{41}$.

Hay que destacar que, aunque hay muchos solventes orgánicos, hay varios factores que limitan considerablemente la selección de los que son prácticos para esta etapa. El solvente orgánico tiene que cumplir con los siguientes requisitos: 1) disolver la cocaína; 2) no disolver, o disolver muy poco, el clorhidrato de cocaína; 3 ) mezclarse con el agua y con el otro solvente orgánico utilizado; 4) ser volátil, y 5) hallarse con facilidad. Sobre este tema hay que decir que son muchos lo solventes orgánicos corrientes que, de sustituirse por las sustancias catalogadas no cumplirían algunas de estas condiciones; entre ellos se encuentran el benceno, el acetato de etilo, el hexano, el cloruro de metileno, el cloroformo, el alcohol isopropílico y la metilisobutilcetona. Por ejemplo, la cocaína es soluble en cloruro de metileno y cloroformo, pero estos también disuelven el clorhidrato de cocaína. Por ello en los análisis de las muestras de de polvo de clorhidrato de cocaína que vienen realizando desde el año 1986 en los laboratorios de la Administración para la ejecución de las Leyes sobre Estupefacientes (DEA), demuestran que los solventes más utilizados son la acetona, el éter etílico, la metiletilcetona y el tolueno. Lo cual es corroborado por las incautaciones de sustancias químicas practicados en los laboratorios clandestinos sudamericanos. Como ya señalamos antes se pueden encontrar sustitutos para estos solventes (precursores de drogas) pero estos muchas veces no resultan prácticos por las limitaciones que presentan.

Es preciso decir que como en el caso de la marihuana, de la cocaína se pueden obtener diferentes subproductos que tienen en su composición la molécula metil-benzoilecgonina y los diferentes contaminantes o sustancias químicas adicionadas para modificar su efecto, tipo de consumo o hacer rendir la producción. El primero de los subproductos de la cocaína es la base de cocaína que se obtiene mediante el tratamiento del sulfato de cocaína, pasta de cocaína, con acetona o éter etílico (sus- 
tancias catalogadas). Posteriormente la solución formada se deja reposar y se filtra para adicionar luego una base. En muchos casos, durante esta etapa, se agrega una solución del agente oxidante, en el medio ácido, con el objeto de destruir residuos orgánicos. Este subproducto se conoce con el nombre de basuco, su consumo se realiza a través de cigarrillo, que esta cobrando mucho auge en países de Sudamérica, principalmente en Colombia ${ }^{42}$.

Luego tenemos la base libre y el crack, que son derivados de la cocaína de uso común en los países desarrollados donde no llega el basuco. Estas dos drogas son sustancias elaboradas a partir del clorhidrato de cocaína. Lo que buscan los traficantes con estas sustancias es un producto que pueda ser fumado, mediante la reversión del proceso de refinamiento que fue realizado en los laboratorios clandestinos de los países productores de la hoja de coca. La base libre se elabora mediante la reacción de la cocaína con una solución de amonio y éter etílico (sustancia catalogada), mientras que el crack, que toma su nombre debido al sonido que emite cuando se ésta consumiendo, se obtiene haciendo reaccionar la cocaína con una solución de soda, omitiendo la reacción con el éter. En ambos casos se lleva a cabo un proceso de recristalización. Debido a que la obtención del crack es menos peligrosa que la obtención de la base libre, es común encontrarlo en mercados de los países consumidores de Norteamérica y Europa.

\section{El proceso de elaboración de la heroína}

La heroína es un analgésico narcótico semisintético ${ }^{43}$ que se prepara por la acción de un compuesto acetilizante, ejemplo de ello, el anhídri-

43 Como señalamos arriba, la heroína es semisintética pues se obtiene a través de la morfina, lo cual significa que no se encuentra en la naturaleza. Esta semisíntesis fue desarrollada por el alemán Dreser en el año 1806. En los años posteriores a su aparición tuvo bastante éxito en el tratamiento de la tuberculosis, pero lamentablemente se descubrió que la heroína generaba altos procesos adictivos en los consumidores. Hay que destacar que esta sustancia es entre dos y tres veces más potente que la morfina, aunque algunos autores sostienen que la forma del clorhidrato puede ser hasta diez veces más potente que la morfina. La dosis mínima letal estimada para un adulto es de 200 miligramos, pero al igual que ocurre con la morfina, un adicto puede llegar a soportar una dosis hasta diez veces mayor. Sin embargo se han reportado dosis letales a partir de 10 miligramos. Ibidem., p. 181. 
do acético, sobre la morfina, que es también analgésica y narcótica, que es uno de los alcaloides que se obtienen del opio. Para entrar en materia es preciso decir que del fruto verde de la adormidera (papaver somniferum $L$.) se extrae un látex o zumo espeso, este una vez seco constituye el opio. Un $20 \%$ del peso de opio aproximadamente consiste en alcaloides de los que la morfina (del 10\% al 16\%) es el más importante y abundante; entre los demás alcaloides del opio están la codeína, la tebaína, la narcotina y la paverina. Como sabemos la adormidera se cultiva de forma comercial a gran escala, de hecho España es el segundo productor a nivel mundial, como fuente de alcaloides de uso medicinal, de aceite y de alimentos. Pero como todos sabemos también se cultiva de manera ilícita para la producción de heroína en diferentes países. Las principales regiones productoras de opio con el fin de producir esta droga son Asia Sudoriental, Asia Sudoccidental, América del Norte (México) y América del Sur (Colombia).

La elaboración clandestina de heroína a partir del opio consiste en tres etapas: 1) extracción y purificación de la morfina del opio; 2) síntesis de la heroína a partir de la morfina, y 3) conversión de la heroína en clorhidrato de heroína. Estas tres etapas o pasos se suelen llevar a cabo en el mismo laboratorio. Hacemos la salvedad que los procedimientos pueden variar un poco dependiendo del país, especialmente en cuanto al grado de purificación de la morfina. Además es necesario puntualizar que todos los procedimientos los pueden llevar a cabo una persona un poco o nada calificada en química, ya que sólo se necesitan unas pocas sustancias y un instrumental muy sencillo para elaborar esta droga. Las sustancias más comunes que se utilizan en la elaboración del clorhidrato de heroína a partir de la morfina y del opio son las siguientes: 1) alcalisis: óxido de calcio (cal viva), hidróxido de calcio (cal apagada), hidróxido de amonio (solución acuosa de amoníaco o agua amoniacal), carbonato de sodio, bicarbonato de sodio o carbonato de calcio (piedra caliza); 2) ácidos: el tartárico, y el clorhídrico (precursor de drogas), y sus sales, como el cloruro de amonio; 3) agentes acetilizantes: anhídrido acético (precursor de drogas) o cloruro de acetileno; 4) solventes: acetona (precursor de drogas), éter etílico (precursor de drogas), etanol o metiletilcetona (precursor de drogas); agentes absorbentes: el carbón activado que sirve para filtrar y decolorar.

La más crítica de estas sustancias es el anhídrido acético, cuya reacción con la morfina produce la heroína. También revisten gran importancia los siguientes solventes: acetona, éter etílico o la metiletilcetona, que se usan principalmente en la conversión de la heroína en clorhidrato de 
heroína o sea, en el producto final que se vende en las calles. Todas estas sustancias están catalogadas como precursores de drogas en la legislación europea, así como en el Convenio de Naciones Unidas celebrado en Viena en el mes de diciembre de 1988 del cual son firmantes 189 países o territorios del mundo (95.45 \% del total). Las demás sustancias que referimos anteriormente, entre ellas, las alcalinas y las ácidas son muy comunes y se encuentran con mucha facilidad en los países donde se elabora la heroína. A continuación describimos los procedimientos o etapas mediante los cuales la morfina se extrae del opio y se convierte en clorhidrato de heroína:

Primera etapa: extracción y purificación de la morfina del opio: 1) extracción: el opio se dispersa en agua, y la mezcla se calienta y se alcaliniza con óxido o hidróxido de calcio. Esto forma la sal de calcio de la morfina, la cual es soluble en la solución acuosa; los demás alcaloides del opio precipitan. Después la solución acuosa se filtra para separar los alcaloides precipitados, y se le añade cloruro de amonio. Esto convierte la sal de calcio de la morfina en morfina. La solución se deja en reposo por varias horas hasta que la morfina precipita; entonces se filtra y se seca la morfina impura. El precipitado seco es pardo oscuro y suele contener entre el 50\% y el 70\% de morfina; 2) purificación: la morfina impura precipitada se lava primero con pequeñas cantidades de acetona para limpiarla de los otros alcaloides, y entonces se disuelve en una solución de ácido tartárico (calentada a 80 y 90 grados centígrados), lo que la convierte en bitartrato de morfina. Esta solución se trata con carbón activado y se filtra. El carbón activado es un descolorante que elimina el color pardo. La solución acuosa y ácida resultante se alcaliniza con amoníaco, lo que transforma de nuevo el bitartrato de morfina en morfina. La morfina precipita, se recupera por filtración y se seca. La pureza de la morfina resultante de esta etapa es de $85 \%$ a $95 \%$.

Segunda etapa: síntesis de la heroína a partir de la morfina: en esta etapa la morfina se hace reaccionar con un compuesto acetilizante para que forme la heroína (la diacetilmorfina). La morfina sólida y seca obtenida de la primera etapa se mezcla con un exceso de anhídrido acético y se calienta hasta que se disuelve completamente. La solución se sigue calentando casi hasta el punto de ebullición, y se mantiene a esta temperatura durante 30 minutos, aproximadamente, mientras se produce la síntesis de la heroína por reacción entre la morfina y el anhídrido acético. El anhídrido acético es el reactivo preferido para la conversión de la morfina en heroína. También se puede usar para este 
fin otro reactivo fácil de encontrar, el cloruro de acetilo. Este sin embargo, tiene los inconvenientes de ser sumamente corrosivo, más volátil y de más difícil manipulación que el anhídrido acético. Por estas razones, no se usa de forma corriente en la producción de heroína. Posteriormente se deja enfriar la solución de heroína y se le añade agua para eliminar el anhídrido acético que siempre sobra de la reacción de acetilización. Al añadirse agua, la heroína se convierte en acetato de heroína, que es soluble en el medio acuoso. La solución se filtra y luego se alcaliniza con carbonato de sodio, o en su lugar con hidróxido de sodio, bicarbonato de sodio o hidróxido de amonio. El acetato de heroína en solución se convierte en heroína, la cual es insoluble en agua; por lo tanto, precipita, se separa del líquido por filtración y se seca. La pureza de la heroína resultante depende de la pureza de la morfina original y del grado de acetilización conseguido.

Tercera etapa: conversión de la heroína en clorhidrato de heroína: la heroína conseguida en la segunda etapa se disuelve en acetona caliente y se le agrega carbón activado que la descolora. La solución se agita y filtra, y se retiene la parte líquida donde está la heroína. A esta solución de la heroína en acetona se le añade ácido clorhídrico concentrado; se mezcla bien y se deja reposar. Esta operación convierte la heroína en clorhidrato de heroína. La solución se filtra y el clorhidrato de heroína se retiene y se seca. La pureza de este producto oscila entre el $80 \%$ y el $95 \%$. Las impurezas principales que contiene suelen ser la monoacetilmorfina y la acetilcodeina. La pureza del clorhidrato de heroína depende del grado anterior al que se haya llevado la purificación previa de la morfina. En la elaboración del clorhidrato de heroína se han utilizado como solventes la acetona, el éter etílico y la metietilcetona, que tienen en común la propiedad importante de disolver la heroína pero no el clorhidrato de heroína ${ }^{44}$. 


\section{El proceso de elaboración de la anfetamina y la metanfetamina}

La anfetamina ${ }^{45}$ es una amina simpaticomimética de gran consumo indebido por sus efectos estimulantes sobre el sistema nervioso central. Lo mismo puede decirse de la metanfetamina ${ }^{46}$. Hoy en día, hay cierta

45 La anfetamina, cuya fórmula química es $\mathrm{C}_{9} \mathrm{H}_{13} \mathrm{~N}$, es un agente adrenérgico sintético, potente estimulante del sistema nervioso central. Los estimulantes de tipo anfetamínico (ATS) son la familia farmacológica integrada por compuestos con estructura química análoga o derivada de la molécula de anfetamina, con propiedades clínicas similares y con grado de actividad farmacológica (potencia) comparable. Sobre su acción terapéutica podemos decir que la anfetamina estimula el sistema nervioso central mejorando el estado de vigilia y aumentando los niveles de alerta y la capacidad de concentración. Favorece las funciones cognitivas superiores, como la atención y la memoria. A nivel conductual, refuerza los sistemas implicados en la regulación de las respuestas a emociones específicas; reduce los niveles de impulsividad (autocontrol). En el caso particular de la obesidad, se le ha utilizado debido a su acción sobre los centros hipotalámicos que regulan el apetito. Además es un agente activante del sistema nervioso simpático, con efectos adrenérgicos periféricos, que se traducen en un aumento en el nivel de la actividad motriz. Como droga recreativa, la anfetamina, más conocida como speed o anfeta, es utilizada para pasar largas noches sin dormir, apareciendo en forma de polvo que es inhalado. Los efectos van desde euforia, vista borrosa y energía no habitual a sudoración, vómitos y ataques de ansiedad. Los consumidores pueden pasar varios días consecutivos sin dormir, con el consecuente cansancio psíquico que lleva a veces a crisis de paranoia y ansiedad. La anfetamina produce un síndrome denominado psicosis anfetamínica, parecido a la psicosis cocaínica o a la esquizofrenia paranoide. http://es.wikipedia.org/wiki/Anfetamina.

46 La metanfetamina también conocida como desoxiefedrina tiene por fórmula química $\mathrm{C}_{10} \mathrm{H}_{15} \mathrm{~N}$, es un potente psicoestimulante. Es un agente agonista adrenérgico sintético, estructuralmente relacionado con el alcaloide efedrina y con la hormona adrenalina. El compuesto en su forma pura, es un polvo blanco, cristalino, inodoro, de sabor amargo, muy soluble en agua o etanol. Fue sintetizada en Japón en el año 1919 tomando como modelo la molécula de anfetamina, sin embargo sólo comenzó a comercializarse en el año 1938 con el nombre de Methedrina. Originalmente se utilizaba en descongestivos nasales e inhaladores bronquiales. También se ha usado como droga estimuladora para el sexo. Durante la segunda guerra mundial fue usada tanto por las tropas aliadas como por las del Eje para estimular a sus tropas. En el año 1971 la Convención Internacional de Psicotrópicos sometió a control la metanfetamina, ubicándola en la Lista II, por lo que su circulación se vio drásticamente reducida, pero continuo siendo legal. Aunque la estructura química de la metanfetamina es similar a la anfetamina, sus efectos sobre el sistema nervioso central son más pronunciados. La metanfetamina está indicada en el tratamiento de la narcolepsia, del desorden caracterizado por déficit de atención y también en el control de la obesidad. En todo caso hay que señalar que estos tratamientos son reconocidos como terapia de segunda línea. Como droga ilícita se fabrica generalmente en laboratorios clandestinos utilizando procedimientos sencillos y reactivos relativamente baratos. El producto vendido en la calle se conoce como anfetas, 
producción lícita de éstas drogas para su uso médico en el tratamiento de la obesidad, los desordenes de la atención y la narcolepsia. Si bien ocurre que algunos de estos productos farmacéuticos se desvían al tráfico ilícito, la mayor parte de la anfetamina y metanfetamina encontrada en el tráfico ilícito se produce en los laboratorios clandestinos. Hay que destacar que a diferencia de la cocaína y la heroína, la anfetamina y metanfetamina se producen únicamente por medio de síntesis. Hay una gran variedad y número de síntesis que sirven para la elaboración de anfetamina y metanfetamina. Sin embargo en los laboratorios clandestinos sólo utilizan unas pocas. Al parecer, para la síntesis de anfetamina suelen emplear la 1-fenil-2-propanona (P-2-P) como materia prima principal, y la efedrina o seudoefedrina o la P-2-P son las materias primas esenciales en la síntesis de la metanfetamina. La P-2-P si bien se puede adquirir comercialmente, con frecuencia se elabora en los laboratorios clandestinos a partir del ácido fenilacético (otro precursor), el cianuro de benzilo o aldehido benzoico, también conocido como benzaldehído, y el nitroetano (sustancias no catalogadas).

Esas síntesis son relativamente sencillas y no requieren de un equipo muy complicado, ni de productos químicos exóticos. Cada procedimiento se efectúa en unos pocos pasos, los cuales se llevan a cabo como máximo en un par de días y obtienen rendimientos relativamente abundantes. Estas síntesis proceden a través de una o más reacciones para producir anfetamina y metanfetamina básica, que son líquidos oleosos. Esas bases se purifican y luego se convierten en sales usualmente el clorhidrato para las metanfetaminas y el sulfato para las anfetaminas, que son sustancias cristalinas. La purificación y conversión requieren solamente de disolventes orgánicos, por ejemplo éter etílico, acetona, metiletilcetona y tolueno (todas sustancias catalogadas) entre otras, sustancias alcalinas, como el hidróxido sódico, carbonato sódico (sustancias no catalogadas), etcétera, y el ácido correspondiente, por ejemplo ácido clorhídrico (precursor) o cloruro de hidrogeno gaseoso

meta y tiza. Los efectos de esta droga puede durar entre 6 y 8 horas. Los adictos a esta sustancia pueden permanecer despiertos varios días. Una vez que la droga abandona el organismo, estos sujetos pueden experimentar estados de gran agitación psicomotriz, a veces asociados con comportamientos violentos y delirios persecutorios, llegando a cuadros de disociación psíquica apenas distinguibles de los que caracterizan a una esquizofrenia de tipo paranoide. https://es.wikipedia.org/wiki/Metanfetamina. 
(sustancia no catalogada) para el clorhidrato o el ácido sulfúrico para el sulfato ${ }^{47}$.

Existen dos isómeros ópticos y una muestra racémica (mezcla a partes iguales de los dos isómeros ópticos) de la anfetamina y la metanfetamina. Los isómeros dextrógiros (d) son estimulantes más potentes del sistema nervioso central que los levógiros (l) o que las mezclas rácemicas $(d, l)$. En la mayoría de los casos, la materia prima inicial determina la forma isomérica del producto final. Las síntesis que comienzan con la 1-fenil-2-propanona resultan en una mezcla racémica de dextrógiros y levógiros. Las síntesis que comienzan con la efedrina o la seudoefedrina (los isómeros que se encuentran comúnmente) producen la metanfetamina.

La reducción de la efedrina para sintetizar la metanfetamina es una reacción sencilla de un solo paso que produce aceite de metanfetamina (base) que se purifica y se convierte en clorhidrato. El rendimiento normal de este procedimiento es del $50 \%$ al $75 \%$. Se puede usar la seudoefedrina en lugar de la efedrina con resultados similares. Se usa la efedrina a granel o en tabletas (con o sin extracción). La efedrina o seudoefedrina se calienta con reflujo en ácido yodhídrico y fósforo rojo (sustancias no catalogadas) durante 16 horas o más. Al parecer, incluso si no se calienta se pueden producir pequeñas cantidades de metanfetamina. Aunque se pueden usar otros agentes reductores, raras veces se han encontrado en los laboratorios clandestinos. Hay que señalar que algunos laboratorios producen su propio ácido yodhídrico a partir del yodo, el fósforo rojo y un ácido fuerte.

La reacción de Leuckart se usa para producir anfetamina o metanfetamina a partir de la 1-fenil-2-propanona por un procedimiento algo más complicado. La P-2-P se calienta con reflujo en formiato amonico o formamida (para la anfetamina) o N-metilformamida (metanfetamina) durante varias horas. Entonces se añade el ácido clorhídrico a la mezpara obtener la cocaína, o el latéx de la amapola para obtener la morfina y de esta la heroína. Para fabricar las drogas sintéticas o drogas de diseño se puede partir de muchas sustancias diferentes, inclusive si no se cuenta con los precursores, estos pueden a su vez ser fabricados de forma clandestina a partir de sustancias no controladas. BERNAL CONTRERAS, Héctor Hernando. Las sustancias químicas...op.cit., p. 184. 
cla (que contiene un derivado del formilo) y se calienta con reflujo durante varias horas más para producir anfetamina o metanfetamina básica. Luego se purifica y se convierte en sulfato de anfetamina o clorhidrato de metanfetamina. La afinación reductora P-2-P es otro método relativamente sencillo que se usa en los laboratorios clandestinos para producir anfetaminas y metanfetaminas. La 1-fenil-2-propanona se hace reaccionar con el amoníaco (para dar anfetamina) o con la metilamina (para dar metanfetamina) durante unas pocas horas, en presencia de cloruro mercúrico y de papel de aluminio. Luego sigue la purificación de la forma básica y su conversión a sulfato de anfetamina o clorhidrato de metanfetamina.

Queremos destacar que un método común de sintetizar la 1-fenil-2propanona es utilizar el ácido fenilacético, el anhídrido acético (precursores de drogas) y el acetato como materias primas. Esos tres ingredientes se calientan juntos con reflujo durante 18 horas, se enfrían y se alcalinizan. La 1-fenil-2-propanona resultante se purifica por destilación o extracción. La destilación del ácido fenilacético y del acetato de plomo también produce 1-fenil-2-propanona. Es necesario señalar que algunas veces, el ácido fenilacético se sintetiza en los laboratorios clandestinos a partir del clorhídrico benzoico y del cianuro de sodio o cianuro de bencilo ${ }^{48}$.

\section{El proceso de elaboración del MDMA y otras sustancias análogas}

Si se introducen ciertas modificaciones a las síntesis antes señaladas, en el apartado anterior, se obtienen una gran variedad de sustancias estimulantes o alucinógenas análogas de la anfetamina y de la metanfetamina. Por ejemplo la sustitución de la metilamina por la etilamina en la animación reductora de la 1-fenil-2-propanona produce etanfetamida (etilanfetamida), un estimulante del sistema nervioso central. Sin en lugar de 1-fenil-2-propanona se usa la 3,4 metilendioxifenil2.propanona en esta síntesis, se obtiene: el MDA ${ }^{49}$ conocido como "dro-

49 La MDA 3,4-metilendioxianfetamina o tenamfetamina conocida también como: dulce droga de América, píldora del amor, droga del abrazo o anfetamina para amantes se sintetiza a partir de la aminización de los aceites ricos en safrol o del piperonal. Las píldoras de MDA se administran de manera oral acompañadas con líquidos. Esta droga empieza a actuar entre 30 y 60 minutos después de la ingestión, alcanzando un máxi- 
ga del amor" (3,4-metilendioxianfetamina). Se considera que esta droga posee efectos más estimulantes que el $\mathrm{MDMA}^{50}$ y que tiene efectos despersonalizadores similares al LSD pero menos pronunciados; el MDMA conocido como éxtasis cuya fórmula es 3,4-metilen-dioxi-Nmetil-anfetamina es un tipo de droga psicoactiva conocido en el mundo con distintos nombres: MDMA, cristal, E, Adam, X, XTC y Empathy. El proceso de producción para elaborar MDMA varía según el método de síntesis. En la literatura científica se describen más de 20 recetas de las cuales sólo siete son subjetivas, siendo la más sencilla la que parte de la 3.4-MDP-2-P mediante un proceso de conversión. Tambien se puede sintetizar esta droga a partir del piperonal, el isosafrol o el safrol. El MDMA se puede conseguir en forma de cristales o de polvo de cristal, de ahí que se le llame también cristal. Además se comercializa en pastillas que suelen llevar compactantes y aglutinantes. Finalmente tenemos el MDEA o "Eva" que tiene un proceso similar al éxtasis sólo que usando como precursor el safrol. Queremos señalar que estas son las drogas sintéticas más comunes, pero por supuesto no son las únicas que existen 51 .

Un elemento digno de mención es que la JIFE ha recibido información sobre accidentes ocurridos en laboratorios clandestinos de drogas en

mo a los 90 minutos y presentando una duración entre 8 y 12 horas. Al llegar al cerebro la MDA se fija en los receptores adrenérgicos estimulando el sistema nerviosos central, con ello aumenta el nivel de vigilia, provoca una sensación de bienestar físico e intensifica las percepciones sensoriales y emocionales. La MDA pertenece a la familia de las anfetaminas, por tanto es un estimulante. Su efecto alucinógeno es mayor que la del éxtasis. Hay que decir que los supuestos efectos afrodisíacos no están comprobados científicamente. La N-hidroxi-MDA (N-OH-MDA) es un homologo de la MDA. https://es.wikipedia.org/wiki/Teanfetamina.

50 La 3,4-metilendioximetanfetamina, cuya fórmula es $\mathrm{C}_{11} \mathrm{H}_{15} \mathrm{NO}_{2}$, también conocida como MDMA, M o éxtasis es una sustancia psicoactiva con propiedades estimulantes y empatógenas de sabor amargo. Está estructuralmente relacionada con la MDA y otras feniletilaminas de anillo sustituido. Es frecuente confundir la MDMA con el llamado éxtasis líquido o ácido gamma-hidroxibutírico, con el que no tiene relación estructural. El MDMA se particulariza por sus efectos entactógenos, relativos a una sensación subjetiva de apertura emocional e identificación afectiva con el otro. Estas propiedades definitivas pueden estar medidas por un incremento en los niveles de serotonina y otros neurotransmisores (principalmente la noradrenalina y, en menor medida, la dopamina) en la sinapsis neuronales. Se ha visto que la actividad de la serotonina está relacionada funcionalmente con los estados de ánimo. https://es.wikipedia.org/wiki//MDMA. 
América del Norte y Europa donde se fabrica MDMA en que los encargados resultaron muertos o lesionados. Estos accidentes ocurren porque hace algunos años las personas que manipulaban las sustancias químicas para elaborar los estimulantes de tipo anfetamínico en esos laboratorios por lo general poseían conocimientos rudimentarios de química, pero desde que las recetas, los productos químicos y los equipos necesarios se pueden encontrar a través de Internet, personas que carecen de conocimiento alguno sobre química intentan fabricar este tipo de drogas ilícitas y ponen en peligro de esa forma, tanto a la comunidad en general como a sí mismos ${ }^{52}$.

5. Dosis callejeras de drogas fabricadas ilícitamente utilizando sustancias catalogadas (precursores)

A continuación detallamos la cantidad de precursores de drogas tóxicas, estupefacientes y psicotrópicos que normalmente se utilizan para la elaboración de las dosis callejeras de las principales drogas ilícitas:

1. Anfetamina. La dosis callejera es de $10 \mathrm{mg}$ a $250 \mathrm{mg}$ : con un kilogramo de ácido fenilacético se pueden fabricar de 1.000 a 25.000 dosis, con un litro de 1-fenil-2-propanona se pueden fabricar de 2.000 a 50.000 dosis, con un kilogramo de norefedrina se pueden elaborar de 2.500 a 70.000 dosis.

2. Cocaína. La dosis callejera es de 100 mg a 200 mg: con un kilogramo de permanganato de potasio se pueden fabricar de 25.000 a 50.000 dosis, con un litro de acetona, éter etílico, metiletilcetona o tolueno se pueden elaborar de 250 a 500 dosis.

3. Heroína. La dosis callejera es de $100 \mathrm{mg}$ a $500 \mathrm{mg}$ : con un litro de anhídrido acético se pueden fabricar de 800 a 4.000 dosis, con un litro de acetona, éter etílico, metiletilcetona o tolueno se pueden elaborar de 100 a 500 dosis.

4. $L S D$. La dosis callejera es de $50 \mathrm{mg}$ a $80 \mathrm{mg}$ : con un kilogramo de ergometrina o ergotamina se pueden fabricar 2.500 .000 a 4.000 .000 de dosis, con un kilogramo de ácido lisérgico se pueden elaborar de 8.500 .000 a 13.000 .000 de dosis. 
5. Metanfetamina. La dosis callejera es de $30 \mathrm{mg}$ a $250 \mathrm{mg}$ : con un kilogramo de efedrina o seudoefedrina se pueden fabricar 2.500 a 21.000 dosis.

6. Metacualona. La dosis callejera es de $250 \mathrm{mg}$ : con un kilogramo de ácido antranílico se pueden elaborar 4.000 dosis, con un kilogramo de ácido N- acetilantranílico se pueden elaborar 3.200 dosis.

7. MDA y sustancias análogas. La dosis callejera es de $100 \mathrm{mg}$ : con un kilogramo de safrol se pueden fabricar 1.000 dosis, con un kilogramo de isosafrol se pueden elaborar 2.000 dosis, con un kilogramo de piperonal se pueden fabricar 2.000 dosis y con un litro de 3,4metiledioxifenil-2-propanona se pueden elaborar 4.000 dosis. Es preciso aclarar que para el MDMA o MDEA se pueden fabricar el doble de dosis con las cantidades de los precursores anteriormente citados.

8. Fenciclidina. La dosis callejera es de $1 \mathrm{mg}$ a $10 \mathrm{mg}$ : con un kilogramo de piperidina se pueden elaborar de 100.000 a 1.000 .000 de dosis ${ }^{53}$.

\section{PRECURSORES QUE SE EMPLEAN EN LA FABRICACIÓN ILÍCITA DE LA COCAÍNA Y LA HEROÍNA}

\section{A.) PRECURSORES UTILIZAdoS EN LA FABRICACIÓN ILÍCITA DE COCAÍNA}

Como ya señalamos antes, en el apartado correspondiente al proceso de elaboración de la cocaína, en la fabricación del clorhidrato de cocaína a partir de la hoja de coca se suelen utilizar un total de siete precursores de drogas, contenidos en los Cuadros de la Convención de Naciones Unidas de 1988, siendo estos: la acetona, el ácido clorhídrico, el ácido sulfúrico, el éter etílico, la metiletilcetona, el permanganato de potasio y el tolueno, además de una serie de sustancias no catalogadas $^{54}$. De los precursores antes señalados el más indispensable en los p. 77.

$54 \quad$ Las sustancias no catalogadas que más se usan son la siguientes: a) conversión de la hoja de coca en pasta de coca: carbonato de sodio, carbonato de potasio, carbonato de calcio, hidróxido de sodio, oxido de calcio, hidróxido de amonio, oxido de calcio, hidróxido de amonio, kerosene, ácido nítrico, ácido fosfórico, b) conversión de la pasta base en cocaína: peróxido de hidrogeno, c) conversión de la cocaína en clorhidrato de 
laboratorios clandestinos es el permanganato de potasio, por ello es el único que se encuentra en el Cuadro I del Convenio de Viena, sustancia en la cual se centran los principales esfuerzos de los organismos nacionales e internacionales para tratar de evitar o al menos dificultar la producción ilícita de cocaína.

Resulta anecdótico el ingenio que han desarrollado los narcotraficantes en las selvas colombianas para evadir las medidas de control que ha establecido el Gobierno sobre los precursores de drogas ilegales (que por el gran poder de corrupción que tiene el narcotráfico siguen ingresando en el país), y otras sustancias controladas por el Estado. Cuando empezó la persecución del mercado negro de insumos químicos traídos desde Estados Unidos de América y Europa, los narcotraficantes suplieron algunas de estas sustancias por cemento y gasolina roja, tan es así, que en la selva se vendían tantas bolsas de cemento como las necesarias para poder pavimentar dos veces Bogotá y Medellín (las ciudades más importantes de Colombia), y la gasolina que se comercializaba afirman era suficiente para llenar los depósitos de todo el parque automotor del país. Una vez que las autoridades incrementaron el control sobre el cemento y la gasolina. Para procesar la coca los mafiosos se dieron a la tarea de comprarle a los campesinos orines de cerdo (sustituto de la gasolina) y cenizas de árbol (sustituto del cemento), llegando a pagar hasta 15.000 pesos colombianos por cada litro de orines de cerdo. Además hay que poner de relieve que utilizan para el cultivo y procesamiento de hoja de coca y la amapola grandes cantidades de herbicidas, fertilizantes y plaguicidas ${ }^{55}$.

cocaína: benceno, acetato de etilo, el hexano, el cloruro de metileno, el cloroformo, el alcohol isopropílico y la metilisobutilcetona. Vid., en el Anexo V las sustancias químicas no catalogadas que se usan en la elaboración de drogas ilícitas.

BUSTOS VALENCIA, Alirio. La Ley del Monte. Ed. Intermedio. Santa fe de Bogotá. Colombia. 1999, pp. 67- 76. En esta carrera contra el narcotráfico destacamos la Resolución número 07037 del 5 de julio de 1983 del Ministerio de Salud, como miembro del Consejo Nacional de Estupefacientes, que obligó a las personas naturales o jurídicas que importen, fabriquen o vendan sustancias como el cloroformo a inscribirse ante la División de Vigilancia y control de dicho Ministerio o el Decreto 1041 del 1 de mayo de 1984 que consideró como contravención sancionable con arresto, las conductas de comerciar, portar o almacenar sin justificación, gasolina, solventes , disolventes, carbonato liviano y otros similares. Queremos mencionar también la Ley 30 de 1986 que estableció el control del amoniaco, así como la Resolución 009 del 18 de febrero de 1987 del Consejo Nacional de Estupefacientes que ya regula en todo el territorio nacional, la 
Destacamos por la importancia que tuvo en el enfrentamiento al tráfico de cocaína la Operación Púrpura, programa voluntario de seguimiento internacional iniciado en el año 1999 que tenía por objeto descubrir envíos sospechosos de permanganato de potasio e impedir su desviación del comercio lícito internacional, en el que participaron un total de 27 países, la Organización Internacional de la Policía Criminal (Interpol), la Oficina de Naciones Unidas contra la Droga y el Delito y el Consejo de Cooperación Aduanera (conocido también como Organización Mundial de Aduanas). En el marco de esta operación se aplicaron medidas rigurosas de vigilancia y seguimiento a todas las remesas de más de 100 kilogramos del precursor antes citado desde el país de fabricación, pasando por todos los puntos de reexpedición, hasta llegar al usuario final. También se investigaba a todos los operadores que realizaban las transacciones y se informaba acerca de las transacciones sospechosas o los envíos detenidos a las partes pertinentes, otro objetivo de esta operación fue determinar las necesidades reales de esas empresas. A nivel nacional, las autoridades de reglamentación y represión de los países y territorios interesados participaron plenamente en el programa de seguimiento. Hay que decir que todos los países fabricantes tomaron parte en la operación, así como los principales importadores y algunos países donde se realizaba la reexpedición de este precursor indispensable para elaborar de forma ilícita cocaína. A nivel internacional la JIFE, en el ejercicio de sus funciones se ocupó activamente de la iniciativa de la operación. Así la Junta coadyuvó a las investigaciones de los gobiernos en relación con los envíos detenidos o cancelados que fiscalizaba la operación a fin de aclarar si entrañaban intentos de desviación, con el fin de identificar a los traficantes implica-

importación, fabricación, distribución, transporte y uso de 18 sustancias entre las cuales se encuentran precursores que se establecerían posteriormente en el Convenio de Viena de 1988 como: Acetona, ácido clorhídrico, éter etílico, ácido sulfúrico, permanganato de potasio, metiletilcetona y otras sustancias no catalogadas como: cloroformo, amoniaco, carbonato de sodio, disolvente alifático $\mathrm{n}-1$, thinner, acetato de etilo, alcohol metílico, acetato de butilo, diacetona, alcohol, hexano y alcohol butilico. El CNE en la misma dirección emitió la Resolución 001 del 13 de mayo para controlar el cemento gris y la gasolina, la Resolución 0004 del 10 de septiembre de 1996 adiciona a la lista el control especial de la urea amoniacal, el ACPM (gasóleo o diesel) y el kerosene, en noviembre del 2002 el CNE emitió las Resoluciones 001 al 011 que establece controles al cemento gris, kerosene, gasolina, ACPM y urea. BERNAL CONTRERAS, Héctor Hernando. Las sustancias químicas ...op.cit., pp. 18- 22. 
dos y de comunicar los resultados de las investigaciones a los otros gobiernos con miras a prevenirles de los nuevos métodos utilizados para desviar las sustancias catalogadas. Queremos destacar que en el ámbito de la operación púrpura las autoridades colombianas lograron determinar los países en que se realizaron las desviaciones de este precursor en los años 2000 y 2001, siendo estos: la República de Corea, España, México, los Países Bajos y los Estados Unidos de América (en el tercer trimestre del año 2001 todos los desvío procedían de México), también se logró establecer los métodos y rutas empleados por los narcotraficantes ${ }^{56}$.

Con respecto a las incautaciones realizadas fuera de América Latina destacamos el caso de España y Ucrania, países donde se fabrica permanganato de potasio de forma lícita por varias empresas, que reportaron en el año 2001 más de 100 kilogramos decomisados de esta sustancia. Es preciso decir que estas incautaciones se han ido incrementando en los últimos años, lo cual está directamente relacionado con el creciente número de laboratorios de cocaína desmantelados en España. La JIFE informo que esto quizás se deba a que los traficantes al tener cada vez más dificultades para abastecerse de precursores en la región de América del Sur y dada la relativa facilidad con que se pueden obtener en Europa han optado por instalar sus laboratorios clandestinos para la elaboración de cocaína en estos países, claro ejemplo de ello, como ya señalamos antes, puede ser España donde las autoridades

Esta operación inicialmente solo iba a durar un año, pero se prorrogo por un plazo indeterminado con una forma distinta. La segunda etapa de la operación, donde la JIFE actúo como centro internacional de coordinación comenzó en enero del año 2000. Precursores y productos químicos frecuentemente utilizados..., correspondiente a 2000, pp. 8, 9, 17, 19. Precursores y productos químicos frecuentemente utilizados..., correspondiente a $2001 \ldots$ pp. 10, 16, 17. Precursores y productos químicos frecuentemente utilizados..., correspondiente a 2002..., pp. X, 12- 15, 22. Precursores y productos químicos frecuentemente utilizados..., correspondiente a 2003..., p. 12. Participaron en la Operación Púrpura las autoridades competentes de los siguientes Estados y territorios: Alemania, Argentina, Austria, Bélgica, el Estado Plurinacional de Bolivia, Brasil, Bulgaria, China, Colombia, Ecuador, Eslovaquia, Eslovenia, España, los Estados Unidos de América, Grecia, Hong Kong (RAE de China), India, Italia, México, los Países Bajos, Perú, el Reino Unido de Gran Bretaña e Irlanda del Norte, la República Checa, Sudáfrica, Ucrania, Uruguay y la República Bolivariana de Venezuela, además formaron parte de la operación la Oficina de Naciones Unidas contra la Droga y el Delito, la Interpol y la Organización Mundial de Aduanas. Precursores y productos químicos frecuentemente utilizados..., correspondiente a $2004 \ldots$, p. 29. 
competentes han logrado éxitos notables en la detección y desmantelamiento de laboratorios de esa índole ${ }^{57}$. Hay que destacar que en el año 2001 se observó un creciente volumen de exportaciones de permanganato de potasio a países no participantes en la Operación Púrpura, sobre todo países de Asia, lográndose detener 17 envíos de esta sustancia catalogada con más de 1.100 toneladas de permanganato de potasio destinado a canales ilícitos. Si se hubiera desviado, esa cantidad habría bastado para fabricar más de 5.500 toneladas de cocaína ${ }^{58}$.

A partir del año 2002 los narcotraficantes colombianos continuaron en su empeño de fabricar ellos mismos permanganato de potasio a partir de mineral de manganeso extraído en Colombia. En este plazo de tiempo fueron desmantelados siete laboratorios de este tipo, el mayor de ellos permitió el decomiso de casi una tonelada de este precursor de drogas. Es necesario puntualizar que aunque sea posible que la fabricación ilícita interna de permanganato de potasio permita la obtención de una pequeña parte del volumen que realmente necesitan los traficantes, el aumento en las incautaciones de esta sustancia indican que los traficantes están en condiciones una vez más de obtener grandes cantidades de esta sustancia catalogada, posiblemente desviándola de los canales internos de distribución, ya sea en Colombia o en otros países de la región, para después pasarla de contrabando a las zonas donde se fabrica la cocaína. Además hay que aclarar que los resultados de los análisis de las muestras de cocaína revelaron que es posible que los traficantes estén utilizando un producto químico sustitutivo del permanganato de potasio, aparentemente se trata de hipoclorito sódico,

Precursores y productos químicos frecuentemente utilizados..., correspondiente a 2002..., p. 21.

$58 \quad$ El volumen de exportación como el porcentaje de comercio total destinado a países no participantes, en la Operación Púrpura, de Asia fue aumentando desde la primera etapa, esto también ocurrió con países no participantes de África y Oceanía. En cambio, el porcentaje total de exportaciones a países participantes de Asia ha ido descendiendo durante el mismo periodo, lo que demuestra la efectividad de las medidas adoptadas en el marco de esta operación, pues se estaba obligando a los narcotraficantes a buscar otros países para desviar este precursor de drogas. Precursores y productos químicos frecuentemente utilizados..., correspondiente a 2001..., pp. X, 9, 10. Hay que decir que Canadá uno de los principales países importadores de permanganato de potasio hasta el año 2004 presento su primer informe sobre sus necesidades lícitas y el comercio lícito de esta sustancia. Precursores y productos químicos frecuentemente utilizados..., correspondiente a 2004..., p. 4 . 
conocido en la región como lejía, sustancia de la cual se registraron incautaciones sin precedentes en Colombia y Perú (60 toneladas en el año 2002 y 9 toneladas en el año 2003). También es preciso señalar que en el año 2003 en el contexto de la Operación Púrpura los gobiernos de Colombia, Panamá y Perú incautaron por lo menos 42 toneladas de permanganato de potasio ${ }^{59}$.

Siempre en el marco de la Operación Púrpura, ya en su cuarto año de ejecución, mediante la aplicación de los mecanismos de trabajo y los procedimientos operativos uniformes en el año 2003 se lograron impedir 19 desvíos de permanganato de potasio, aproximadamente 900 toneladas, del comercio internacional hacia la fabricación ilícita de drogas, esa cantidad de permanganato si se hubiera desviado por los traficantes habría sido suficiente para elaborar 4.500 toneladas de cocaína. Hay que señalar que en el programa de seguimiento se vigilaron un total de 778 envíos, que contenían casi 23.000 toneladas de esta sustancia, siendo el mayor volumen comercial del que se haya informado en un año desde 1999, de estas remesas el mayor número de envíos se realizo a países no participantes en la operación y un tercio de los envíos fue cursado a través de intermediarios de países por cuyo territorio no habían pasado los envíos. Como resultado de la labor de vigilancia internacional se identificaron posibles rutas de desviación, en particular por países de Asia (República Islámica del Irán, Tailandia y Vietnam) región en la que no se realiza la producción ilícita de cocaína pero a la que es posible que se dirijan los narcotraficantes en sus intentos por obtener este precursor ${ }^{60}$. Un año después la JIFE, valorando toda la información que tenía, señaló que las incautaciones de permanganato de potasio realizadas fuera de América Latina eran demasiado trasbordo de la región, informaron en el año 2003 de una incautación de 350 kilogramos de permanganato de potasio. Lo cual es importante por que desde este país se pueden pasar precursores de contrabando a países de la subregión andina. Precursores y productos químicos frecuentemente utilizados..., correspondiente a 2003..., pp. 26, 27. Precursores y productos químicos frecuentemente utilizados..., correspondiente a 2004..., pp. 21, 22.

60 La República Islámica del Irán logró descubrir y frustrar un intento de desviar 500 toneladas de permanganato de potasio, al establecerse que la empresa que supuestamente había cursado el pedido no existía. Precursores y productos químicos frecuentemente utilizados..., correspondiente a 2003..., pp. X, 12, 13, 14. 
pequeñas para poder ser aprovechadas en la producción ilícita de cocaína y, por consiguiente, se relacionan más probablemente con la fabricación ilícita de metcatinona (efedrona) mediante la oxidación de la efedrina o de la seudoefedrina ${ }^{61 .}$

En el año 2004 se vigilaron un total de 780 envíos que contenían casi 20.000 toneladas de permanganato de potasio, cifras similares en el número de envíos y en el volumen comercializado el año anterior, de estos se paralizaron 17 envíos comerciales internacionales, que contenían más de 620 toneladas de esta sustancia catalogada, dado que habían motivos para sospechar que iban a ser desviadas del comercio lícito hacia el tráfico ilícito. Hay que destacar que a cinco años de ponerse en marcha la Operación Púrpura los países participantes en esta operación desarrollaron mecanismos adecuados para utilizar procedimientos operacionales uniformes que permitían enfrentar de mejor manera el tráfico ilícito de este precursor, lo cual no ocurre con los países no participantes en la operación que presentan a menudo puntos débiles en la implementación de los mecanismos antes señalados. Para enfrentar esta situación la JIFE se dio a la tarea de vigilar el comercio de permanganato de potasio en estos países con el fin de ayudarles a identificar y prevenir desviaciones. A manera de ejemplo citamos que 9.675 toneladas de permanganato, que representaba el $47 \%$ del total de las operaciones mundiales comunicadas, tenían por destino países no participantes de Asia. Además, de los más de 200 envíos que fueron objeto de seguimiento por la Junta a estos países no participantes de la región, se lograron descubrir 8 envíos sospechosos que posteriormente fueron interceptados. Estas remesas se dirigían hacia Bangladesh, Indonesia, Malasia, República Islámica del Irán y Taiwán ${ }^{62}$.

Debido a la utilización adecuada de los mecanismos de trabajo de la Operación Púrpura los países de Centroamérica y América del Sur lograron evaluar sus necesidades internas lícitas de permanganato de potasio, lo cual se tradujo en una reducción significativa del volumen de importación de esta sustancia en la región hasta el año 2001, sin embargo desde este año hasta a finales del año 2004 se detectó un aup. 21. pp. 10, 11, 22. 
mento de las remesas de esta sustancia catalogada. Precisamente para evitar posibles desviaciones de permanganato de potasio la Interpol inició la segunda fase de la Operación Andes, iniciativa para la vigilancia de precursores de drogas durante un periodo de tiempo limitado en el que participaron todos los gobiernos de la región. El objetivo de esta operación fue detectar remesas de esta sustancia de contrabando o mal etiquetadas que pasaban a través de los países participantes o tenían en ellos su punto de destino ${ }^{63}$. En este año las autoridades competentes del Estado Plurinacional de Bolivia, Colombia, Ecuador, Jamaica y Perú notificaron importantes incautaciones de permanganato de potasio, destacando las autoridades colombianas que decomisaron más de 170 toneladas de esta sustancia ${ }^{64}$.

Siempre en el año 2004, la JIFE reportó que además de los intentos de desvío de permanganato de potasio, se descubrieron también intentos de desviar acetona y metiletilcetona (MEC), sustancias incluidas en el cuadro II de la Convención de 1988 que se utilizan el la elaboración de la cocaína. En este período se detuvieron dos envíos entre Sudáfrica y Costa Rica relacionados con 250 toneladas de acetona y MEC cuando se advirtió que la empresa radicada en Costa Rica no estaba autorizada a importar ninguna de esas sustancias. Se detuvieron asimismo dos envíos, de 350 toneladas de acetona y 150 toneladas de MEC, entre Sudáfrica y Grecia en vista de que el supuesto importador de Grecia negó haber realizado esos pedidos ${ }^{65}$.

Es preciso recordar que hasta el año 2005 la mayor parte de la información sobre el permanganato de potasio provenía de la Operación Púrpura, así como que uno de los objetivos principales de esta operación era prevenir las desviaciones de esta sustancia catalogada del comercio lícito para su utilización en la fabricación ilícita de cocaína en América del Sur. Sobre el cumplimiento de este objetivo hay que decir que desde que se inicio la Operación, seis años, se produjo una disminución tanto del número de envíos como del volumen de permanganap. 11. p. 10. 
to de potasio importado a este continente, sin embargo paulatinamente fue aumentado en países que no participan en la Operación, debiendo puntualizarse que la participación de intermediarios hace difícil el rastreo físico de la sustancia, dado que ésta rara vez se despacha directamente del país fabricante al país consumidor. Como todos sabemos uno de los pilares de la vigilancia del comercio internacional de este precursor de drogas es, sin duda alguna, el sistema de notificaciones previas a la exportación. Para hacernos una idea de como ha evolucionado el comercio de esta sustancia tomaremos como referencia los informes de la JIFE sobre los precursores de drogas del año 2005 al año 2014 (diez años). Para empezar hay que señalar que en el año 2005 (del día 1 de noviembre del año 2004 al día 31 de octubre del año 2005) un total de 20 países exportadores proporcionaron 824 notificaciones previas a la exportación de envíos de esta sustancia a 87 países o territorios importadores por un monto total de 27.200 toneladas. Mientras que en el año 2014 ya contábamos con un total de 31 países exportadores, un $35.5 \%$ más, que enviaron un total de 1.630 notificaciones previas de exportación, el doble de remesas, a un total de 123 países, un 29.5\% más, por un monto de 27.500 toneladas, similar al año 2005. Por tanto lo que se ha incrementado es el número de países exportadores y la cantidad de notificaciones previas de exportación, posiblemente por las facilidades que proporciona el sistema PEN Online, y el número de países o territorios importadores. Manteniéndose prácticamente igual la cantidad de permanganato de potasio comercializado a nivel mundial, siendo el año 2009 el que registro el menor nivel de comercio (14.571 toneladas) y el año 2007 el de mayor nivel (28.888 toneladas), mientras que la cantidad tanto de países exportadores como de países o territorios exportadores ha mantenido una tendencia al alza que puede calificarse de moderada ${ }^{66}$, lo cual posiblemente responda

Precursores y productos químicos frecuentemente utilizados..., correspondiente a 2005..., pp. 8- 12. Precursores y productos químicos frecuentemente utilizados..., correspondiente a 2006..., pp., 17, 18. Precursores y productos químicos frecuentemente utilizados..., correspondiente a $2007 \ldots$, pp. 13, 14. Precursores y productos químicos frecuentemente utilizados..., correspondiente a 2008..., p. 11. Precursores y productos químicos frecuentemente utilizados..., correspondiente a 2009..., p. 16. Precursores y productos químicos frecuentemente utilizados..., correspondiente a 2011..., pp. 23, 24, 26. Precursores y sustancias químicas frecuentemente utilizados..., correspondiente a 2012..., p. 21. Precursores y sustancias químicas frecuentemente utilizados..., correspondiente a 2013..., p. 22. Precursores y sustancias químicas frecuentemente utilizados..., correspondiente a 2014..., p. 33. 
en alguna medida a los cambios de rutas de desviación de este precursor de drogas, propiciada por el aumento de los niveles de fiscalización de esta sustancia sobre todo en los países participantes en las Operaciones Púrpura y Cohesión. En todo caso, no debemos olvidar que la mayor cantidad de desvíos de permanganato de potasio se producen en el comercio nacional o interno, así como de que existe un nivel muy importante de producción de este precursor de drogas en los laboratorios ilícitos en varios países y que hay evidencia de que en algunos laboratorios ilícitos de cocaína, de los principales países productores, se han utilizado sustancias no catalogadas como sustitutos de este precursor de drogas tales como el hipoclorito sódico y el permanganato sódico.

En este sentido nos parece importante señalar que en el periodo 20042005 la producción mundial de cocaína disminuyó. Decimos esto porque como todos sabemos la idea de frenar el tráfico de precursores de drogas responde a reducir la oferta de las drogas en el mercado ilegal, y de esta manera reducir la demanda, y por ende el consumo de drogas. Sin embargo, es preciso puntualizar que tal situación no incidió significativamente en los niveles de consumo en los Estados Unidos de América y Europa en este periodo. Otro elemento a tener en cuenta es que tampoco se incremento el precio de la cocaína, y se podría decir que hasta bajo considerablemente. Observándose que la afectación temporal, producida en las regiones por las políticas de control, no tienen impactos duraderos y aunque los mercados se reducen temporalmente, luego se reacomodan y no tienen repercusiones importantes en los precios internacionales de la cocaína, y además, para colmo de males, el nivel de pureza de la droga se mantiene. Tan es así que el Observatorio Europeo registro un descenso de los precios de la cocaína de casi el $45 \%$ en el periodo 2000- 2005, mientras que en Colombia el precio de la pasta básica y de la base de cocaína se mantuvieron estables. Queremos puntualizar que tampoco se aprecio ninguna repercusión significativa de este descenso de producción mundial de cocaína en el comercio internacional del permanganato de potasio ${ }^{67}$, pero sí en las in-

GALÁN PACHÓN, Juan. "La legalización de las drogas... op.cit, pp. 99- 104, 119. En el periodo 2004-2005 se comercializaron a nivel mundial un total de 27.200 toneladas de permanganato de potasio, mientras que en el periodo 2005-2006 se redujo a 19.151 toneladas, pero en el periodo 2006-2007 se produjo un importante incremento llegándose a comercializar un monto total de 28.888 toneladas (un poco por encima de las 24.677 toneladas que es la media anual de los últimos 10 años). Precursores y productos químicos frecuentemente utilizados.., correspondiente a 2005..., pp. 8- 12. Precursores 
cautaciones de este precursor ${ }^{68}$, así como en los intentos de desviación desde el comercio internacional. Sin embargo no estamos seguros de que se pueda atribuir dicho descenso de las incautaciones a la disminución de la producción mundial de cocaína o a que los traficantes hubiesen mejorado sus métodos y canales de desviación, utilizando los canales de distribución internos de terceros países no relacionados con la fabricación de cocaína. Como posiblemente ocurre en países de África, donde los principales países importadores de la región, también son países donde operan organizaciones dedicadas al tráfico de esta droga, la JIFE señala en ese sentido que se ha constatado en otras regiones que los países por donde discurre el tráfico de drogas suelen ser utilizados por los traficantes, aprovechando sus contactos, como fuente de suministro o lugares de reexpedición de las sustancias catalogadas o demás productos químicos necesarios para la elaboración de la droga. Creemos que el descenso de las incautaciones puede responder a la creciente fabricación del permanganato de potasio en los laboratorios clandestinos, así como al uso de sustancias no catalogadas para su sustitución. De hecho los Estados Unidos de América, que como ya hemos referido antes es un importante exportador de permanganato de potasio, en el año 2006 sometió a valoración la fiscalización nacional del permanganato sódico que es un sustitutivo directo del precursor antes mencionado tanto con fines lícitos como ilícitos ${ }^{69}$.

y productos químicos frecuentemente utilizados..., correspondiente a 2006..., pp., 17, 18. Precursores y productos químicos frecuentemente utilizados..., correspondiente a 2007..., pp. 13, 14.

68 En el año 2004 se incautaron 171.962 kilogramos de permanganato de potasio, en el año 2005 se incautaron 182.682 kilogramos, en el año 2006 se incautaron 100.973 kilogramos, pero luego en el año 2007 se incautaron 153.281 kilogramos, para luego caer a 47.356 kilogramos del año 2008, tendencia que se produjo hasta el año 2011 para luego experimentar un notable incremento en el año 2012 que se incautaron 92.702 kilogramos y luego descender en el año 2013 hasta los 57.566 kilogramos. Precursores y sustancias químicas frecuentemente utilizados..., correspondiente a 2014..., pp. 71-90. Precursores y sustancias químicas frecuentemente utilizados..., correspondiente a 2013..., pp. 67-84. Precursores y sustancias químicas frecuentemente utilizados..., correspondiente a $2009 . . .$, pp. 37-50, 51-62.

69 La Junta observa con satisfacción que este año Polonia que es un importante exportador de permanganato de potasio empezó a solicitar notificaciones previas a la exportación, lo que proporciona a la JIFE valiosa información sobre las pautas del comercio internacional. Precursores y productos químicos frecuentemente utilizados..., correspondiente a $2006 \ldots$, p. 18. 
Es importante señalar que en el mes de octubre del año 2005 en México se celebró la reunión conjunta de los comités directivos de la Operación Púrpura y la Operación Topacio, donde se decidió iniciar una nueva fase de esas dos operaciones, combinándolas bajo el nombre de Proyecto Cohesión. Se tomo esta decisión tomando en cuenta el cambio que se había producido en la dinámica del comercio internacional del permanganato de potasio y del anhídrido acético, así como en el modus operandi de los traficantes de estos precursores de drogas. Se determinó que este proyecto se centraría en operaciones regionales de duración definida y en él se prevén el intercambio de información en tiempo real, investigaciones de rastreo y la evaluación de las actividades de forma periódica. Este enfoque se tomó del Proyecto Prisma, que como es bien sabido ha dado resultados satisfactorios ${ }^{70}$.

En el año 2006 la JIFE continúo vigilando las remesas de permanganato de potasio dirigidas a países de Centroamérica y América del Sur, señalando en su informe que sólo 15 países de la región importaron este precursor de drogas, y de esos países, cinco (Argentina, Brasil, Chile, Ecuador y Perú) importaron más de 20 toneladas de permanganato de potasio, y sin embargo no se reportó ninguna exportación de esta sustancia a Colombia, país donde se realizan las mayores incautaciones de esta sustancia catalogada. Por esta razón la Junta recomendó a todos los países de la región prestar especial atención a los canales de distribución nacionales para cerciorarse de que los traficantes no utilizaban estos canales como fuente de abastecimiento de esta sustancia ${ }^{71}$. No hay que olvidar que Perú es uno de los tres principales países productores de cocaína en el mundo, así como que en Ecuador existe una producción considerable de esta droga, y que uno de los métodos de los productores de drogas es desviar los precursores de los canales nacio-

Precursores y productos químicos frecuentemente utilizados..., correspondiente a 2005..., pp. III, XII, 22- 24. Precursores y productos químicos frecuentemente utilizados..., correspondiente a 2006 ..., p. 11. pp., 17, 18. En el año 2007Argentina, Brasil y Chile fueron los principales importadores de esta sustancia, correspondiéndole a cada país más de 100 toneladas por año. Hay que decir que la mayor parte de las remesas provenían de fuera de la región, siendo muy limitado el comercio de permanganato de potasio dentro de América del Sur. Precursores y productos químicos frecuentemente utilizados..., correspondiente a 2007..., pp. 13, 14. 
nales para luego pasarlos de contrabando a las regiones donde tienen sus laboratorios ilícitos.

Un dato interesante es que en el año 2006 la Federación de Rusia notificó la incautación de más de una tonelada de permanganato de potasio. En Bulgaria y Rumania informaron que habían incautado más de 100 kilogramos de este precursor, y en Australia como de costumbre notificaron pequeñas incautaciones de esta sustancia, pero en todos estos casos la JIFE aprecia que el desvío no se realiza para fabricar cocaína sino para la elaboración de drogas de tipo anfetamínico. En este año el mayor volumen de incautaciones de permanganato de potasio en el mundo correspondió una vez más a Colombia por un total de 99 toneladas. Además es importante señalar que en este país se destruyeron 15 laboratorios ilícitos que producían esta sustancia catalogada. También se decomisaron 1,3 toneladas de esta sustancia en el Perú y 0,3 toneladas en el Ecuador. La JIFE ha señalado que las incautaciones realizadas en el Ecuador pueden estar relacionadas con la producción de cocaína en el propio país, como lo demuestra la destrucción de un laboratorio ilícito con una capacidad de fabricación estimada de 2 o 3 toneladas de cocaína al mes. Mientras que en Brasil, que es uno de los principales importadores de permanganato de potasio en la región, la cantidad total de la sustancia incautada desde el año 2003 es baja y no sobrepasó los 100 kilogramos por año. Hay que destacar que en el continente africano en el periodo comprendido entre el año 2001 y 2006 no se reportaron incautaciones de permanganato de potasio. Pero en el año 2007 la República Democrática del Congo comunico un intento de desviación de 500 kilogramos. Sobre esta situación la Junta manifestó sus sospechas de que los traficantes pudieran estar dirigiendo sus esfuerzos a África, por su bajo nivel de fiscalización de las sustancias catalogadas, con el fin de obtener permanganato de potasio para la producción de cocaína en América del Sur ${ }^{72}$.

En el año 2007 un total de 15 países reportaron incautaciones de esta sustancia, por un monto de 153,3 toneladas. Brasil, Colombia, la Federación de Rusia, Perú, los Países Bajos y Ucrania incautaron cada uno más de 100 kilogramos de permanganato de potasio. Destacamos que

72 Precursores y productos químicos frecuentemente utilizados..., correspondiente a 2006..., pp. 18, 19. Precursores y productos químicos frecuentemente utilizados..., correspondiente a $2007 \ldots$, pp. $14,15$. 
Colombia decomisó por si sola en el año 2008, en más de 300 intervenciones, 144,4 toneladas de este precursor, cantidad que triplicó con creces el de las importaciones lícitas de esta sustancia catalogada a Colombia (es preciso subrayar que el monto incautado bastaría para abastecer la fabricación ilícita del país por un año) ${ }^{73}$. La JIFE manifestó su preocupación por la falta de conocimientos disponibles sobre los orígenes y métodos de desviación de los precursores de drogas, en particular por el permanganato de potasio, que se usa para la elaboración ilícita de cocaína en América del Sur, pues aunque continúe disminuyendo el número de tentativas de desviación del permanganato de potasio del comercio internacional lícito, no hay escasez de este producto químico en los laboratorios ilícitos. Sobre este tema hay que decir de que existen fuertes indicios de que los traficantes han encontrado la forma de de eludir los controles del comercio internacional, posiblemente mediante la desviación del comercio interno y el contrabando dentro de la región. Además hay que destacar que una de las fuentes de obtención de este precursor es la fabricación ilícita del mismo dentro del propio país, como ejemplo de ello señalamos que las autoridades colombianas en el año 2006 destruyeron 15 laboratorios ilícitos, y en el año 2007 otros cuatro laboratorios, que fabricaban permanganato de potasio a partir de dióxido de manganeso, un mineral común de manganeso, que transforman en manganato de potasio (sustancias no catalogadas) que después transforman en permanganato de potasio. Es importante señalar que la JIFE estima que la producción ilícita de permanganato de potasio en Colombia oscila entre un $60 \%$ y $80 \%$ del total que se utiliza en la fabricación de cocaína de la región ${ }^{74}$.

Un total de 16 países reportaron en el año 2010 decomisos de este precursor de drogas, cuyo total fue de 32,1 toneladas, aunque esta cifra fue un poco superior a la reportada en el periodo anterior $(25,2$ toneladas), fue la segunda mas baja comunicada en el último decenio. Es preciso recordar que desde el año 2005 empezaron a disminuir las incautaciones. La JIFE sostiene que la disminución del número de decomisos de esta sustancia catalogada puede deberse al aumento de la fap. 11.

74 Precursores y productos químicos frecuentemente utilizados..., correspondiente a 2008 , pp. XII, 11, 12. 
bricación ilícita de la misma, así como a la utilización de otras sustancias químicas no catalogadas en su lugar, o bien a la posibilidad de que una parte del procesamiento de cocaína se esté desplazando de América del Sur hacia otras zonas más vulnerables como América Central. La Oficina de Naciones Unidas contra la Droga y el delito (UNODC) aplicando dos factores de conversión estima que las incautaciones que se comunican anualmente se corresponden entre el $26 \%$ y el $30 \%$ del volumen de permanganato de potasio disponible para su utilización ilícita en la región. Precisamente en el año 2010 las autoridades de Colombia incautaron una cantidad sin precedentes de 605 toneladas de manganato de potasio que, como hemos señalado antes, se utiliza en la fabricación ilícita de permanganato de potasio. Además es necesario decir que la mayoría de las incautaciones de ácidos y solventes del Cuadro II se realizan en tres países de la región andina, que son los mayores productores de coca; Colombia, Perú y el Estado Plurinacional de Bolivia, además estos países reportaron la mitad de las incautaciones mundiales de éter etílico, ácido clorhídrico, metiletilcetona y ácido sulfúrico. Así como el $90 \%$ de las incautaciones de acetona y el $66 \%$ de las de tolueno ${ }^{75}$. Dos incidentes comunicados a la Organización mundial de Aduanas, en que las autoridades de Costa de Marfil detuvieron dos remesas de 1.200 litros de acetona y 2.600 litros de metiletilcetona con destino a Benín y Guinea, respectivamente, y que supuestamente iban a ser dedicadas a refinar cocaína, sirven de recordatorio de que las actividades ilícitas relacionadas con la fabricación de cocaína pueden realizarse en cualquier lugar a lo largo de las rutas de tráfico de la cocaína ${ }^{76}$.

Los factores que se aplican para calcular esta cantidad son dos: el primero es que se parte del supuesto de que se usa este precursor en toda la fabricación ilícita de cocaína, y el segundo es que toda la fabricación ilícita de clorhidrato de cocaína se realiza en los países productores de coca y de que el volumen necesario para procesar la cocaína base a fin de obtener clorhidrato de cocaína es un quinto del volumen final de clorhidrato de cocaína obtenido. Precursores y productos químicos frecuentemente utilizados..., correspondiente a 2011..., pp. 23, 24, 26. En el año 2010 se desmantelaron en Colombia 2.623 laboratorios de cocaína (ONUDD, 2012) y se incautaron un total de 26 toneladas de permanganato de potasio (el $81 \%$ de las incautaciones mundiales). El problema de la drogodependencia en Europa. Informe anual 2012. Ed. Observatorio Europeo de las Drogas y las Toxicomanías. Luxemburgo. 2012, pp. 65, 66. Vid., las incautaciones realizadas en España en el Anexo III. 
Un elemento a destacar es que el permanganato de potasio, que sigue siendo el principal oxidante en la fabricación de clohidrato de cocaína, según sugieren varios indicadores su utilización para la fabricación ilícita de cocaína ha descendido en los principales países productores de América del Sur, lo cual puede responder a la fabricación ilícita de este precursor, la reducción del cultivo de arbustos de coca en la región, la aparición de laboratorios de cocaína en otros países de la región, y por último lo que más nos llama la atención, a los cambios recientes en los métodos utilizados para transformar la hoja de coca en cocaína. Particularmente las autoridades del Perú han informado que se está empleando un proceso diferente para fabricar cocaína, en el cual, se prescinde de la fase de oxidación, para la que se necesita el permanganato de potasio 77 .

Sobre el posible desplazamiento de parte del procesamiento de cocaína fuera de la región andina de América del Sur, señalamos que las autoridades competentes de Honduras comunicaron por primera vez el desmantelamiento de un laboratorio clandestino de cocaína cerca de la frontera con Guatemala en el mes de marzo del año 2011. Este gran laboratorio se dedicaba a convertir cocaína base en clorhidrato de cocaína. Entre las sustancias que se incautaron había 50 kilogramos de permanganato de potasio, 2.500 litros de ácido clorhídrico, 208 litros de ácido sulfúrico y cantidades importantes de otras sustancias no catalogadas. También hay que destacar que en el mes de enero del mismo año se produjo el desmantelamiento de un laboratorio de procesamiento de cocaína en España. Este laboratorio es el mayor y más avanzado descubierto hasta la fecha en Europa. El mismo le pertenecía a Ana María Cameno conocida como "la reina de la coca o la tetas" y estaba ubicado en una granja en las proximidades de Madrid. El operativo policial se denominó Operación Colapso. En dicho laboratorio se decomisaron 33 toneladas de sustancias químicas esenciales, entre ellas 11.345 litros de tolueno, 8.060 litros de metiletilcetona, 6.400 litros de acetona, 350 litros de ácido sulfúrico, 300 litros de ácido clorhídrico y 
otras sustancias no catalogadas que se utilizan en la elaboración de la cocaína ${ }^{78}$.

Queremos señalar que en el año 2012, como de costumbre, China fue el mayor exportador de permanganato de potasio, pues realizó más de tres de las cuartas partes de las notificaciones, seguido por los Estados Unidos de América, la India y Hong Kong (R.A.E. de China), mientras que, como ocurriera en años anteriores, la República Islámica del Irán continuó siendo el mayor importador de esa sustancia, seguida por Tailandia, Bélgica, Brasil y la República de Corea. Como nota anecdótica señalamos que los principales países productores de coca de América del Sur (Estado Plurinacional de Bolivia, Colombia y el Perú) siguen desempeñando un papel insignificante en el comercio general de permanganato de potasio notificado mediante el sistema PEN Online, al representar menos del $10 \%$ de las importaciones mundiales de esta sustancia catalogada. Lo que seguramente se debe, como ya hemos señalado antes, a la fabricación de este precursor en los laboratorios ilícitos, al uso de permanganato de potasio de contrabando (desviado de los canales nacionales) y al uso de sustancias químicas no catalogadas para sustituir al permanganato de potasio ${ }^{79}$.

Un total de 15 gobiernos informaron sobre incautaciones de permanganato de potasio en el año 2011, por un monto total de 37 toneladas, como en años anteriores Colombia reportó la mayor cantidad de decomisos (65\% del total), seguida por el Estado Plurinacional de Bolivia con el $27 \%$ (la mayor de su historia). Del volumen total de incautaciones de esta sustancia catalogada en este año, los países de América del Sur (casi exclusivamente los principales países productores de coca) representaban el 99\% de las incautaciones. De hecho se estima que en estos se decomisa aproximadamente entre el $12 \%$ y el $25 \%$ del permanganato de potasio disponible anualmente para uso lícito ${ }^{80}$. Un dato a tener en cuenta es que se ha reportado a la JIFE en Colombia la existencia de laboratorios clandestinos dedicados a la elaboración de co-

78 Precursores y productos químicos frecuentemente utilizados..., correspondiente a 2011..., p. 26.

79 Precursores y sustancias químicas frecuentemente utilizados..., correspondiente a 2012..., p. 21.

$80 \quad$ Ibidem, pp. 21, 22. 
caína en los 32 departamentos del país, pero solo se ha informado de la existencia de laboratorios dedicados a la elaboración ilícita de permanganato de potasio en la capital y en 13 departamentos, siendo los departamentos con mayor número de laboratorios de procesamiento de cocaína base y pasta de cocaína desmantelados, donde se han encontrado el mayor número de laboratorios clandestinos de permanganato de potasio ${ }^{81}$.

Es preciso destacar también que la mayoría de las incautaciones de todo el mundo de ácidos y disolventes incluidos en el Cuadro II del Convenio de Naciones Unidas de 1988 que se utilizan en la elaboración de la cocaína se realizan en principales países productores de coca de la región subandina. Entre el año 2007 y el año 2011, el Estado Plurinacional de Bolivia, Colombia y el Perú efectuaron por termino medio entre uno y dos tercios de las incautaciones mundiales de éter etílico, ácido clorhídrico, metiletilcetona y ácido sulfúrico, y casi el $90 \%$ de las incautaciones mundiales de acetona. La JIFE ha obtenido información de que estas sustancias los traficantes las obtienen a través del contrabando y de su fabricación ilícita. Otro elemento a destacar es que cada vez se obtiene más información de la existencia de laboratorios clandestinos de fabricación de cocaína, especialmente de cristalización de cocaína, en otros países, tal es el caso de España, Honduras y la República Bolivariana de Venezuela. También se ha recibido información sobre una nueva sustancia no catalogada que se utiliza en la fabricación ilícita de cocaína denominada metabisulfito sódico, el Estado Plurinacional de Bolivia, Ecuador y la República Bolivariana de Venezuela reportaron en el formulario D correspondiente al año 2011 la incautación de 6,5 toneladas de esta sustancia y Honduras en el mes de abril del año 2012 decomisó 24,5 toneladas de esta sustancia química no catalogada ${ }^{82}$.

Un dato de sumo interés es que en Colombia los traficantes se han dado a la tarea de reciclar los precursores de drogas líquidos con el propósito de evitar, en lo posible, que se descubra la fabricación ilícita de cocaína y también con el objetivo de reducir al mínimo los costos de fabricación. Muy probablemente debido a esto, las incautaciones de ácidos y disolventes están disminuyendo en ese país los dos años anterio- 
res. Además hay que añadir que las autoridades competentes de Colombia informaron haber descubierto casos de fabricación clandestina de ácido sulfúrico a partir de azufre que puede encontrarse en las minas de las zonas volcánicas del país ${ }^{83}$. También se tiene información de la fabricación ilícita de ácido clorhídrico y amoníaco (sustancia no catalogada) en laboratorios clandestinos de Colombia, como parte del proceso de optimización de la producción ilícita de cocaína ${ }^{84}$.

En el año 2012 un total de 15 gobiernos informaron de incautaciones de permanganato potásico, por un total de 92,7 toneladas, que representa el doble del promedio anual comunicado desde el año 2008. Hay que hacer la salvedad de que dicho incremento se debió en gran medida a importantes incautaciones de esta sustancia que se realizaron en China (30 toneladas), la mayor cantidad notificada hasta la fecha fuera del continente americano. Como siempre, Colombia reportó la mayor cantidad de permanganato de potasio decomisado (56 toneladas), que representó el $60 \%$ del total a nivel mundial, y el doble de la cantidad que se había incautado el año anterior en el país. Mediante el sistema PICS se informó sobre otra sustancia no catalogada el permanganato sódico, que se empieza a utilizar como sucedáneo del permanganato de potasio en los países andinos. La Junta muestra su preocupación por la creciente amenaza de que la producción ilícita de cocaína se extienda a los países de Centroamérica y a otras subregiones fuera de América del Sur que no están en condiciones de enfrentar este problema ${ }^{85}$.

En el formulario D correspondiente al año 2013 un total de 17 países y territorios informaron de incautaciones de permanganato de potasio por un monto de 58 toneladas, un $37.5 \%$ menos que el año anterior. Realizándose las mayores incautaciones en: Colombia (22 toneladas), Brasil (15 toneladas), España (5,9 toneladas), Paraguay $(3,7$ toneladas), China (3,5 toneladas), Estado Plurinacional de Bolivia $(3,1$ toneladas), Perú (2,8 toneladas) y Qatar (1,6 toneladas). Una vez más del $80 \%$ del decomiso mundial de permanganato de potasio se realizó en

83 Informe de la Junta Internacional de Fiscalización de Estupefacientes correspondiente a 2012. Ed. Naciones Unidas. Nueva York. 2013, p. 82. 2013. Ed. Naciones Unidas. Nueva York. 2014, p. 68. pp. 22-25. 
países de América del Sur, incluidos los tres principales países productores de coca (Estado Plurinacional de Bolivia, Colombia y Perú) ${ }^{86}$.

Hay que destacar el descubrimiento de una pequeña plantación de arbustos de coca en Panamá en el año 2013 y de otra en el sudoeste de México, cerca de la frontera con Guatemala en el año 2014, pues son los primeros casos de este tipo ocurridos fuera de la región de América del Sur. Por otra parte es necesario señalar que la mayoría de las incautaciones de los ácidos y disolventes del Cuadro II de la Convención de 1988 comunicadas por los países productores de cocaína han variado considerablemente en los últimos años, aunque en el último decenio predominó la tendencia a la baja. La JIFE sostiene que esto se debe en parte a que los disolventes se reciclan cada vez más y se reutilizan varias veces, pero también a los cambios que se han producido en las prácticas de fabricación ilícitas. En particular, al aumentar la utilización directa de ácido clorhídrico alcohólico, sin disolventes adicionales, lo que ha producido una disminución del uso de disolventes de manera importante. Lo cual se corrobora con los análisis forenses de la cocaína procedente de Colombia decomisada en el año 2013 que indican que cada vez más los laboratorios ilícitos de clorhidrato de cocaína utilizan cantidades menores de los disolventes necesarios, como se deduce del hecho de que una mayoría de las muestras (52\%) fueron procesadas sin mezclar el ácido clorhídrico con disolventes antes de agregarlo a la mezcla de disolventes y cocaína base ${ }^{87}$.

Las autoridades colombianas informaron en el año 2013 el decomiso de diversas sustancias químicas utilizadas en la fabricación ilícita de cocaína que estaban sujetas a fiscalización nacional, pero no internacional. Entre las sustancias incautadas figuraban disolventes empleados tanto para la extracción de cocaína base a partir de las hojas de coca como para la transformación de la cocaína base en clorhidrato de cocaína, y casi 7.000 litros de disolventes a base de acetato (acetato de

Precursores y sustancias químicas frecuentemente utilizados..., correspondiente a 2014..., p. 33. España incauto desde el año 1993 al año 2014 un total de 6.195 kilogramos de permanganato de potasio, siendo el decomiso más importante el efectuado en el año 2013 por un monto de 5.929 kilogramos de esta sustancia. Vid., el anexo III sobre las incautaciones de precursores de drogas. pp. 34-36. 
etilo y acetato isopropílico). En este mismo año se decomisaron en Colombia más de 2 toneladas de dióxido de manganeso, sustancia utilizada para la fabricación ilícita de permanganato de potasio, en 10 incidentes, así como casi 62 toneladas de cloruro de calcio, agente desecante que se utiliza en el reciclaje de disolventes. Por último Colombia también reporto la incautación de más de 50 toneladas de metabisulfito sódico, agente reductor empleado en la fase de reoxidación de la cocaína base para homogenizar el nivel de oxidación de la cocaína base extraída de distintas fuentes antes de oxidarla con permanganato de potasio. Las autoridades de Ecuador informaron el decomiso de $25 \mathrm{ki}$ logramos de metabisulfito sódico. En el año 2014 siguieron produciéndose incidentes relacionados con esta sustancia no catalogada y se comunicaron por medio del sistema PICS tres incidentes: dos en el Estado Plurinacional de Bolivia y uno en Honduras. Las autoridades competentes de Perú también comunicaron incautaciones de sustancias no catalogadas que se utilizan en la fabricación ilícita de cocaína, entre ellas: 10 toneladas de amoníaco, 43 toneladas de urea, 620 toneladas de hidróxido de calcio y 370 toneladas de oxido de calcio ${ }^{88}$.

En el período 2014-2015, las autoridades competentes de 31 países exportadores notificaron a sus homólogos de 125 países o territorios (el 63\% del total) planes para exportar 1.357 remesas de permanganato de potasio por un monto de 25.500 toneladas, cifra similar a la de los dos años anteriores, la participación de los tres principales países productores de coca, como siempre, represento menos del 1\% de todas las importaciones de este precursor de drogas de las que se enviaron notificaciones a través del sistema PEN Online. En el formulario D correspondiente al año 2014 las autoridades colombianas reportaron la incautación de un total de 166 toneladas de permanganato de potasio, la mayor cantidad reportada en los últimos seis años. En este periodo 11 países reportaron decomisos de este precursor de drogas por un monto de 7,5 toneladas, siendo los países que realizaron incautaciones de más de una tonelada los siguientes: Perú $(2,7$ toneladas $)$, China $(2,1$ to- 
neladas), Estado Plurinacional de Bolivia (1,5 toneladas) y la República Bolivariana de Venezuela $(1,12 \text { toneladas })^{89}$

Es importante señalar que del año 2004 al año 2013 se reportó a través del formulario D el decomiso de 904.360 kilogramos de permanganato de potasio (cantidad con la que se podrían elaborar un total de 4.521.800 kilogramos de clorhidrato de cocaína) ${ }^{90}$, el tercer precursor del Cuadro I en nivel de incautaciones, desglosado de la siguiente manera: 171.962 kilogramos en el año 2004, 182.682 kilogramos en el año 2005, 100.973 kilogramos en el año 2006, 153.281 kilogramos en el año 2007, 47.356 kilogramos en el año 2008, 27.325 kilogramos en el año 2009, 32.107 kilogramos en el año 2010, 38.406 kilogramos en el año 2011, 92.702 kilogramos en el año 2012 y 57.566 kilogramos en el año 2013. Los decomisos se produjeron en un total de 37 países pertenecientes a cuatro continentes, exceptuando a África. Los países o territorios que incautaron más de 1.000 kilogramos en este periodo fueron: México (40.045 kilogramos), el Estado Plurinacional de Bolivia (17.599 kilogramos), Brasil (16.376 kilogramos), Colombia (746.759 kilogramos), Ecuador (2.377 kilogramos), Paraguay (3.755 kilogramos), Perú (13.090 kilogramos), la República Bolivariana de Venezuela (2.547 kilogramos), Kazajistán (3.290 kilogramos), Pakistán (1.250 kilogramos), Qatar (1.600 kilogramos), China (33.448 kilogramos), Ucrania (3.611 kilogramos), España (5.960 kilogramos) y los Países Bajos (7.149 kilogramos). Los tres países donde se realizaron las mayores incautaciones de permanganato de potasio fueron: Colombia, China y el Estado Plurinacional de Bolivia. Cabe destacar que en Colombia se realizaron el $82,5 \%$ de las incautaciones mundiales, así como que en los tres principales países productores de cocaína (Colombia, Perú y Bolivia) se llevaron a cabo el $85,9 \%$ de las incautaciones realizadas a nivel mundial en este periodo. Es probable que el nivel de incautaciones se redujera a partir del año del año 2008 porque los narcotraficantes fapp. 24, 25. 
brican, en gran medida, el permanganato de potasio en sus laboratorios clandestinos ${ }^{91}$.

Siempre sobre el mismo tema, hay que señalar que la mayoría de las incautaciones notificadas de varios de los ácidos y disolventes incluidos en el Cuadro II de la Convención de 1988, que son necesarios en las distintas fases de casi todas las operaciones ilícitas de drogas, se realizan en los principales países productores de cocaína (el Estado Plurinacional de Bolivia, Colombia y el Perú) donde se efectuaron entre el $27 \%$ y $54 \%$ de las incautaciones mundiales de éter etílico, ácido clorhídrico, metiletilcetona, tolueno y ácido sulfúrico, así como el 90\% de las incautaciones mundiales de acetona. Sin embargo hay que señalar que los decomisos de estos ácidos y disolventes, en estos países, han experimentado cierta disminución, lo cual responde en gran medida a que los disolventes se reciclan cada vez más y se reutilizan varias veces. Además, en la fabricación de cocaína cada vez se usan con mayor frecuencia disolventes no fiscalizados, como el acetato de etilo y el acetato de $n$-propilo, el cloruro de metileno y el alcohol isopropílico, en lugar de los incluidos en el Cuadro II, especialmente en la última fase de elaboración, en el que la cocaína base se transforma en clorhidrato de cocaína. Prueba de ello son los análisis de muestras de cocaína incautadas en el año 2013 que confirmaron la utilización de disolventes a base de acetato en casi el $75 \%$ de las muestras analizadas. También, la utilización y las cantidades de metiletilcetona, parecen disminuir y, aparentemente, aumenta el uso de ácido clorhídrico alcohólico en comparación con el ácido clorhídrico concentrado. Otra sustancia no catalogada que está en auge en la fabricación de cocaína es el metabisulfito sódico, una sustancia química antioxidante, de la cual el Estado Plurinacional de Bolivia, Ecuador, Honduras, Nueva Zelanda y la República Bolivariana de Venezuela informaron en el formulario D correspondiente al año 2012 incautaciones de 8,4 toneladas ${ }^{92}$.

$91 \quad$ Precursores y sustancias químicas frecuentemente utilizados..., correspondiente a 2014., pp. 71-90. Precursores y sustancias químicas frecuentemente utilizados..., correspondiente a 2013..., pp. 67-84. Precursores y sustancias químicas frecuentemente utilizados..., correspondiente a $2009 . .$. , pp. 37-50, 51-62. Vid., las incautaciones realizadas en España desde 1993 hasta el 2014 en el Anexo VI.

92 En el formulario D correspondiente al año 2012 a nivel mundial se reporto la incautación de: 88 toneladas de acetona, 53 toneladas de éter etílico, 34 toneladas de ácido clorhídrico, 19 toneladas de metietilcetona, 52 toneladas de ácido sulfúrico y 32 tone- 
Para terminar este apartado queremos destacar que las incautaciones de permanganato de potasio a nivel mundial representan menos del $1 \%$ del comercio internacional reportado por los gobiernos ${ }^{93}$, lo cual responde muy probablemente a que los productores de cocaína elaboran ellos mismos entre el $60 \%$ y el $80 \%$ de este precursor de drogas en sus laboratorios clandestinos, además hay que tener en cuenta que la mayor parte de las desviaciones del comercio lícito se hacen de los canales nacionales de distribución para luego pasarlos de contrabando a los países y regiones donde realizan la fabricación ilícita de la droga. Otro elemento que puede influir notablemente en el enfrentamiento a la elaboración de cocaína es el uso de sustancias no catalogadas para sustituir al permanganato de potasio. No hay que olvidar que también se elaboran en los laboratorios clandestinos otros precursores del cuadro II de la Convención de 1988, que se utilizan en la elaboración de la cocaína, tales como el ácido sulfúrico, el ácido clorhídrico, la metiletilcetona, el éter etílico e incluso sustancias no catalogadas como el amoniaco. Todos estos elemento han propiciado que el comercio ilícito de cocaína, pese a lo grandes esfuerzos realizados en la lucha contra el narcotráfico, siga gozando de buena salud, ya que el nivel de pureza de la cocaína ha aumentado en los últimos años, mientras que el precio ha permanecido relativamente estable. Por último queremos decir que nosotros pensamos que la reducción que experimento la producción mundial de cocaína se debió fundamentalmente al ascenso que experimentaron las drogas de diseño en el mundo, hay que recordar que después del cannabis los estimulantes de tipo anfetamínico son las drogas más consumidas en el mundo, superando el consumo de cocaína y de heroína ${ }^{94}$.

ladas de tolueno. Precursores y sustancias químicas frecuentemente utilizados..., correspondiente a 2013..., pp. 24, 25. Vid., las incautaciones realizadas en España de los precursores del Cuadro II del año 1993 a 2014 en el Anexo III. p. 10.

94 Global Smart Update, volumen 7, marzo de 2012. Informe global de monitoreo de drogas sintéticas 2012. UNODC. 2012, pp. 2, 3. Informe Europeo sobre Drogas. Tendencia y novedades 2015. Ed. Observatorio Europeo de las Drogas y las Tóxicomanias. Bruselas. 2015, p. 26. Resumen Ejecutivo. Informe Mundial sobre las Drogas 2014. Ed. UNODC. 2015, p. 3. 


\section{B.) PRECURSORES UTILIZAdoS EN LA FABRICACIÓN ILÍCITA DE HERoÍNA}

Siempre en la misma línea, de la Operación Púrpura, en el año 2000 con el fin de iniciar un programa intensivo y dinámico de fiscalización del anhídrido acético, precursor indispensable en la fabricación ilícita de heroína, la JIFE convocó una reunión internacional sobre esa sustancia la cual se celebró en Antalya (Turquía). Asistieron a la misma, autoridades competentes de los principales países fabricantes de esta sustancia catalogada, de los países donde se había incautado este precursor y de los países en los que se fabrica heroína. En la reunión se acordó iniciar una operación internacional voluntaria de fiscalización del anhídrido acético denominada Operación Topacio, que comprendía: a) un programa intensivo encaminado a seguir el rastro de envíos del anhídrido acético desde los países fabricantes hasta su destino final con objetivo de impedir la desviación de esa sustancia del comercio internacional lícito y b) actividades de los organismos de represión encaminadas a interceptar sustancias introducidas de contrabando, investigar remesas incautadas y la fabricación ilícita de heroína, así como determinar los países en que se desvía anhídrido acético con el propósito de reelaborar los mecanismos adecuados para impedir la desviación de los canales de distribución interna ${ }^{95}$.

La Operación Topacio se inicia oficialmente el día 1 de abril del año 2001, aunque como señalamos antes se empieza a gestar en el año 2000, en ella participaron un total de 46 países y territorios (al 1o de noviembre del 2004) ${ }^{96}$, esta operación en sus primeros seis meses impidió la desviación de 10 envíos por un total de 170 toneladas de anhídrido acético, a esto hay que agregar que varios estados lograron in-

Precursores y productos químicos frecuentemente utilizados..., correspondiente a 2000..., p. 10.

96 Los Estados o territorios participantes en la Operación Topacio son: Afganistán, Alemania, Argentina, Austria, Bélgica, Brasil, Bulgaria, China, Colombia, Dinamarca, Emiratos Árabes Unidos, Eslovaquia, Eslovenia, España, los Estados Unidos de América, ex República Yugoslava de Macedonia, la Federación de Rusia, Finlandia, Francia, Grecia, India, República Islámica del Irán, Irlanda, Israel, Italia, Kazajistán, Kirguistán, México, Myanmar, Noruega, los Países Bajos, Pakistán, RAE de Hong Kong de China, el Reino Unido de Gran Bretaña e Irlanda del Norte, la República Checa, Rumania, Serbia y Montenegro, Singapur, Sudáfrica, Suecia, Suiza, Tailandia, Tayikistán, Turkmenistán, Turquía y Uzbekistán. Precursores y productos químicos frecuentemente utilizados... correspondiente a $2004 \ldots$... p. 29. 
cautar otras 51 toneladas de esta sustancia. Estas 221 toneladas decomisadas de anhídrido acético habrían servido para elaborar entre 55 y 230 toneladas de heroína. Es preciso señalar que en esta operación al igual que en la Operación Púrpura la JIFE, a través de su secretaria, funcionaba como centro de coordinación internacional para intercambiar información. Siendo la clave en esta operación, sin lugar a dudas, el intercambio de información en tiempo real. Transcurridos los ocho primeros meses de la Operación Topacio, los resultados preliminares indicaron que las pautas mundiales del comercio del anhídrido acético son muy diferentes a las del permanganato de potasio, dado que en el caso del anhídrido acético, tanto el número de transacciones como las cantidades enviadas son mucho mayores, además las rutas comerciales son más complejas y casi el $85 \%$ de las remesas vigiladas pasan por puntos de reexpedición y no van directamente de los países fabricantes a los países consumidores ${ }^{97}$. Hay que destacar que en el año 2002 el 92\% de todas las transacciones de anhídrido acético se realizaron entre países de la Unión Europea no detectándose desvíos ni intentos de desvío de este precursor de drogas en dichas transacciones, lo cual posiblemente se deba al gran volumen de comercio que se lleva a cabo diariamente en todo el mundo, lo que hace inviable vigilar cada una de las transacciones ${ }^{98}$.

En el año 2001, ya en el marco de la Operación Topacio se realizaron dos grandes incautaciones, una de 70 toneladas en el Reino Unido de Gran Bretaña e Irlanda del Norte destinada a Yugoslavia y otra en Turquía de 50 toneladas proveniente de Yugoslavia. Un elemento a desta-

Precursores y productos químicos frecuentemente utilizados..., correspondiente a 2001..., pp. X, 10-14. La Operación Topacio tiene dos componentes principales: a) un programa internacional intensivo de seguimiento que se concentra en los envíos internacionales lícitos de anhídrido acético y b) investigaciones con fines de represión para rastrear el producto químico incautado o interceptado hasta su fuente original. La JIFE presta asistencia a la operación y sirve, por conducto de su secretaria, de centro internacional de coordinación del intercambio de la información necesaria. Precursores y productos químicos frecuentemente utilizados..., correspondiente a 2002..., pp. 16- 19.

Por el gran volumen de comercio de anhídrido acético que se lleva a cabo parece que resulta más recomendable centrarse en las actividades de represión como detectar el contrabando de los canales de distribución nacionales de este precursor, y la realización de incautaciones en depósitos o laboratorios clandestinos de heroína a fin de localizar las fuentes de las que se desviaron las sustancias. Ibidem, pp. 17-18. Precursores y productos químicos frecuentemente utilizados..., correspondiente a 2003..., p. 34. 
car es que en zonas donde tradicionalmente no se producía heroína, tal es el caso de América Latina varios gobiernos reportaron también incautaciones ${ }^{99}$. La Federación de Rusia con las autoridades del gobierno de Turquía en octubre del año 2002 realizaron una entrega vigilada de tres toneladas y media de anhídrido acético, descubriendo que en una expedición de madera, se había vaciado el centro de los troncos para ocultar los recipientes que contenían esta sustancia catalogada, método que ya se había utilizado en algunos envíos de contrabando desde Serbia y Montenegro100.

A través de la Operación Topacio en el año 2003 se logró recabar información detallada sobre el comercio internacional del anhídrido acético, lo cual permitió que la JIFE lograra una comprensión adecuada del comercio y previniera desviaciones de esa fuente. Obteniendo éxitos destacados en la identificación de redes de traficantes y empresas ficticias a través de las cuales se realizan las desviaciones de esta sustancia catalogada del comercio lícito hacia el tráfico ilícito en Europa. Además Afganistán, Kazajistán, Kirguistán y Tayikistán se unieron a la operación. Precisamente por la aplicación en estos países de los mecanismos de trabajo y los procedimientos operativos uniformes de la operación se pudieron realizar incautaciones por un monto total de 25 toneladas de esta sustancia en Afganistán durante el año 2003, lo cual fue muy importante de cara a prevenir desviaciones o contrabando a la región y, a este país que como todos sabemos es el mayor productor de heroína del

99 En América Latina, varios gobiernos informaron por primera vez de incautaciones de anhídrido acético, que se suman a las comunicadas por Colombia. La República Bolivariana de Venezuela decomiso casi una tonelada de esta sustancia y en operaciones conjuntas de los gobiernos de Brasil, Chile, Colombia, el Ecuador, México, Panamá, el Perú y la República Bolivariana de Venezuela se produjo el decomiso de casi tres toneladas. Además, en el ámbito de la Operación Topacio, las autoridades colombianas decomisaron otras seis toneladas de esta sustancia. Precursores y productos químicos frecuentemente utilizados..., correspondiente a 2001..., p. 22. En relación a la fabricación ilícita de heroína en el Afganistán hay que decir que hasta el año 2002 no se habían producido avances significativos en la detección de tráfico de precursores, tan es así que ningún país fronterizo reporto ninguna incautación en el periodo 2001-2002, aunque en años anteriores se había detectado contrabando de anhídrido acético en los países limítrofes con el Afganistán. Precursores y productos químicos frecuentemente utilizados..., correspondiente a $2002 . . .$, pp. 24- 26.

100 Precursores y productos químicos frecuentemente utilizados..., correspondiente a 2003..., p. 29. 
mundo. Durante el año 2004, las autoridades afganas llevaron a cabo el desmantelamiento de algunos laboratorios ilegales de fabricación de heroína, además incautaron 375 litros de anhídrido acético, junto con 675 kilogramos cloruro de amoniaco (sustancia no catalogada) y 75 kilogramos de bicarbonato de sodio (sustancia no catalogada), desafortunadamente el anhídrido acético no se encontró en los contenedores originales, ni se encontraron documentos relacionados con la sustancia, lo que impidió realizar el rastreo hasta la fuente de esta sustancia ${ }^{101}$.

Es importante destacar que desde que se inició la Operación Topacio en el año 2000, la estructura del comercio internacional lícito experimento variaciones, al inicio, los Estados Unidos de América y los Países Bajos eran los ejes principales, sin embargo, en el año 2002 Bélgica comenzó a adquirir importancia por haberse trasladado de los Países Bajos a su territorio el centro de operaciones de una gran empresa productora de esta sustancia y, en el año 2003, sus autoridades vigilaron más de 2.000 envíos, que representaron más del $75 \%$ del volumen de todas las remesas notificadas en el marco de operación. Aunque hay que puntualizar que este país, como ya señalamos antes, era el eje más importante del comercio internacional por la cantidad de remesas, en el año 2003 México pasó a ser el principal exportador de anhídrido acético al haber vendido más de 110.000 toneladas, equivalentes a casi

101 En el año 2003, como novedad significativa, informaron de varias incautaciones de anhídrido acético en Afganistán; 11 toneladas en una granja abandonada de la provincia de Nangarhar, otras 3 toneladas en la misma provincia y otras 11 toneladas en una operación militar. Precursores y productos químicos frecuentemente utilizados..., correspondiente a $2003 \ldots$.. pp. X, XI, 30,31. Como era evidente que se necesitaba más información concreta sobre los métodos de desviación de anhídrido acético que se utilizan para la fabricación ilícita de heroína en Afganistán. Se realizaron directamente sobre el terreno pruebas de los productos químicos incautados utilizando los juegos de los instrumentos de análisis desarrollados por la sección de laboratorio y asuntos científicos de la Oficina de las Naciones Unidas contra la Droga y el Delito para identificar los productos químicos fiscalizados y no fiscalizados que se emplean en la fabricación de la heroína, lo cual reviste mucha importancia en zonas remotas o en zonas donde el acceso a los laboratorios es limitado. En este sentido la JIFE exhortó a los gobiernos a que suministren a los funcionarios de Aduanas juegos de análisis de productos químicos. Precursores y productos químicos frecuentemente utilizados..., correspondiente a 2004..., pp. 2, 24. Llama la atención que Afganistán además de ser el mayor productor de heroína del mundo, según un estudio de la UNODC probablemente produce más resina de cannabis (hachís) que ningún otro país del mundo. Informe de la Junta Internacional de Fiscalización de Estupefacientes correspondiente a 2011. Ed. Naciones Unidas. JIFE. New York, 2012, p. 92. 
el $40 \%$ del volumen total que se notifico en el ámbito de la Operación. Salvo los cambios señalados en Bélgica y México, la estructura general del comercio internacional que la Junta observo en el año 2003 se asemeja a la del año 2002, de tal manera que el mayor número de envíos sigue registrándose entre Estados miembros de la Unión Europea ${ }^{102}$.

En el año 2004 se suman a la Operación Topacio dos nuevos países, Serbia y Montenegro y Turkmenistán. Su participación en la operación se consideró muy importante. En el caso de Serbia y Montenegro porque los traficantes eligieron este país para la desviación del anhídrido acético del comercio lícito, sustancia que después se pasaba de contrabando a zonas donde se fabricaba ilícitamente heroína. En el caso de Turkmenistán hay que decir que los traficantes desde hace algunos años han utilizado este país para pasar de contrabando el precursor de drogas que nos ocupa a Afganistán, además era el único país sensible de la región que no participaba en la operación. En este año 17 países notificaron alrededor de 750 envíos de anhídrido acético con un volumen total de aproximadamente 210.000 toneladas, volumen considerablemente inferior al que se reportó en años anteriores, lo cual se debe posiblemente a que Bélgica, un punto importante de transbordo de esta sustancia, no facilitó datos sobre el comercio de esta sustancia en el año 2004 por que su "autoridad nacional central" se encontraba en proceso de reestructuración. Sin embargo se puede decir que las pautas del comercio de este precursor se ha mantenido estable en gran medida en los últimos años, manteniéndose los Estados Unidos de América como el principal exportador de esta sustancia seguido por México. Alemania y China, por este orden aparecen como los mayores importadores ${ }^{103}$.

Siempre en el año 2004 las autoridades de Bosnia y Herzegovina incautaron más de 42 toneladas de anhídrido acético importado al país en dos remesas provenientes de los Países Bajos. Atendiendo a una solici-

Precursores y productos químicos frecuentemente utilizados..., correspondiente a 2003..., pp. 15- 17. Canadá es uno de los principales países importadores de anhídrido acético, país que hasta el año 2004 brindó su primer informe sobre las necesidades legítimas y el comercio lícito de esta sustancia. Igual situación presenta China un importante productor de esta sustancia también este año mando su primer informe a la JIFE. Precursores y productos químicos frecuentemente utilizados..., correspondiente a 2004..., p. 4. 
tud de la JIFE las autoridades competentes de este país pusieron en marcha nuevas investigaciones para verificar la legitimidad de los envíos y en ellas se descubrió que en los pedidos hechos en los Países Bajos se habían presentado autorizaciones de importación falsas por lo que se procedió a presentar cargos contras los responsables de la desviación. En Serbia y Montenegro se decomisaron 6,5 toneladas de anhídrido acético y en Bulgaria se incautaron cuatro envíos separados de esta sustancia, que ascienden a más de 1.700 litros, que se estaban enviando de contrabando a Turquía. También se reportaron grandes incautaciones de este precursor en China (15 toneladas) y Turquía (9,7 toneladas), la Federación de Rusia (53 toneladas), así como incautaciones de más de 250 kilogramos en Belarús, la ex República Yugoslava de Macedonia, Rumania y Ucrania. Entre estas reviste particular interés la incautación de 370 litros de anhídrido acético que notificaron las autoridades de la ex República Yugoslava de Macedonia, dado que la sustancia se estaba introduciendo de contrabando al país procedente de Albania con destino a Grecia, desde donde iba a ser transportada a Turquía para intercambiarla por heroína, siendo este el primer caso que se conoció de trueque de anhídrido acético por heroína. A esta fecha era motivo de preocupación que Afganistán y los países vecinos no hubieran notificado incautaciones importantes de esta sustancia. Debiendo señalarse que Afganistán, que es el principal productor de heroína en el mundo, no tiene ninguna necesidad legitima de esta sustancia y por lo tanto no realiza importaciones de la misma ${ }^{104}$.

Para hacernos una idea del nivel de comercio mundial del anhídrido acético tomaremos como referencia las notificaciones previas de exportación realizadas desde el periodo 2004-2005 al periodo 20132014. En estos diez años se notificó la comercialización de 2.477 millones de litros de esta sustancia catalogada entre empresas de más de la mitad de Estados o territorios del mundo, debiendo tenerse en cuenta que los envíos no se hacen de un país a otro casi nunca, produciéndose en la mayoría de los casos múltiples reexpediciones. Por lo cual un mis-

104 Otro caso que es necesario reseñar es la detención de un envío de 500 toneladas de anhídrido acético por el Gobierno de Alemania destinado a Serbia y Montenegro a solicitud de la autoridades de este país en vista de que el pedido se había realizado en circunstancias poco usuales y de que se había dado al Ministerio de Sanidad el nombre de un usuario final inusual de esta sustancia. Ibidem, pp. 23- 26. Precursores y productos químicos frecuentemente utilizados..., correspondiente a 2005..., pp. 12-14, 23. 
mo país puede ser país exportador, importador y de reexpedición de remesas de esta sustancia. Hay que señalar que en el periodo 20042005 un total de 14 países exportadores realizaron un total de 1.300 notificaciones a 48 países importadores por un monto total de 306.506.000 de litros de anhídrido acético. Mientras que en el periodo 2013-2014 un total de 28 países exportadores (el doble), realizaron un total de 1.523 notificaciones de exportación (223 más), a 86 países importadores (38 más) por un monto total de 364.000.000 de litros de este precursor de drogas (57.494.000 litros más). Siendo el periodo 2007-2008 en el que se reporto el menor nivel de comercio (115.750.000 litros) y el periodo 2013-2014 el de mayor nivel (364.000.000 litros). En todo caso hay que puntualizar que estas cifras son orientativas, pues sabemos que una cantidad considerable de envíos se realiza sin que se realicen las notificaciones previas de exportación, y además las cantidades informadas por esta vía casi nunca cuadran con las informadas a través del formulario $\mathrm{D}$ por los países exportadores e importadores. No obstante gracias a la información suministrada en las notificaciones antes mencionadas, la Junta pudo establecer, en alguna medida, las modalidades del complejo comercio internacional de este precursor de drogas, logrando identificar países de reexpedición que juegan un papel importante en el comercio lícito de esta sustancia catalogada, como Bélgica, los Países Bajos y Singapur. Hay que puntualizar, una vez más, que la participación de intermediarios dificulta mucho el rastreo físico de la sustancia dado que ésta rara vez se despacha directamente del país fabricante al país consumidor ${ }^{105}$.

Cada periodo evaluado va del día 1 noviembre de un año al día 31 de octubre del año siguiente. Precursores y productos químicos frecuentemente utilizados..., correspondiente a 2005..., pp. 10, 12. En el perido 2005-2006 un total de 20 países exportadores realizaron un total de 1.129 notificaciones previas a la exportación a un total de 74 países por un monto total de 188.181 .000 litros de anhídrido acético. Precursores y productos químicos frecuentemente utilizados..., correspondiente a 2006..., p. 19. En el periodo 2006-2007 un total de 21 países exportadores realizaron 938 notificaciones previas a la exportación a 80 países importadores por un monto total de 199.310 .000 litros de anhídrido acético. Precursores y productos químicos frecuentemente utilizados..., correspondiente a $2007 . . .$, p. 16. En el periodo 2007-2008 un total de 27 países exportadores realizaron un total de 800 notificaciones previas a la exportación a 81 países importadores por un monto total de 115.750 .000 litros. Precursores y productos químicos frecuentemente utilizados..., correspondiente a 2008..., pp. 12, 13. En el periodo 2008-2009 un total de 29 países exportadores realizaron 960 notificaciones previas a la exportación a 81 países importadores por un monto total de 125.010 .000 litros de anhídrido 
Como ya se señaló, en el apartado anterior, a partir del mes de octubre del año 2005 la Operación Topacio se fusionó con la Operación Púrpura y pasó a denominarse Proyecto Cohesión. Este nuevo proyecto es una iniciativa mundial cuyo objetivo es enfrentar la desviación de los canales lícitos del anhídrido acético y el permanganato de potasio, que sirve de plataforma para realizar operaciones de duración limitada, coordinar las investigaciones sobre las incautaciones y las remesas interceptadas, y vigilar el comercio licito de estos precursores. En el marco del Proyecto Cohesión en el año 2006 se realizó la Operación Reexpedición que consistió en una acción contra el tráfico de anhídrido acético en Asia central, para detectar e incautar las remesas de esta sustancia llevadas de contrabando a Afganistán a través de Asia central, esta operación se centró principalmente en el transporte por carretera, pero también prestó atención a los puertos del Mar Caspio y a las vía ferroviarias que cruzan fronteras desde China hasta la Federación de Rusia. En la operación participaron los cinco países de Asia central (Kazajistán, Kirguistán, Tayikistán, Turkmenistán y Uzbekistán). Además los Gobiernos de Alemania, los Estados Unidos de América, la Federación de Rusia, Francia, el Reino Unido de Gran Bretaña e Irlanda del Norte y Turquía, estos países prestaron asistencia para las actividades realizadas en los cruces de frontera estratégicos de la región. Las actividades operativas se desarrollaron a lo largo de diez días y dieron como resultado incautaciones de ácido sulfúrico, así como de opio, hachís y heroína en Kazajistán, Kirguistán y Tayikistán. Aunque

acético. Precursores y productos químicos frecuentemente utilizados..., correspondiente a 2009, pp. 16, 17. En el periodo 2009-2010 un total de 27 países exportadores realizaron 1.230 notificaciones previas a la exportación a 86 países importadores por un monto total de 215.000 .000 litros. Precursores y productos químicos frecuentemente utilizados..., correspondiente a 2010, pp. 14, 15. En el periodo 2010-2011 un total de 27 países exportadores realizaron 1.550 notificaciones previas a la exportación a 93 países exportadores por un monto total de 362 millones de litros de anhídrido acético. Precursores y productos químicos frecuentemente utilizados..., correspondiente a 2011, pp. 27, 28. En el periodo 2011-2012 un total de 25 países exportadores realizaron 1.500 notificaciones previas a la exportación a 94 países por un monto total de $336 \mathrm{mi}-$ llones de litros de anhídrido acético. Precursores y sustancias químicas frecuentemente utilizados..., correspondiente a 2012..., pp. 24, 25. En el periodo 2012-2013 un total de 24 países exportadores realizaron 1.440 notificaciones previas a la exportación a 86 países por un monto total de 266 millones de litros. Precursores y sustancias químicas frecuentemente utilizados..., correspondiente a 2013..., p. 26. Precursores y sustancias químicas frecuentemente utilizados..., correspondiente a 2014..., pp. 37-39, 71-90. 
no se realizó ninguna incautación de anhídrido acético, la JIFE señalo que la experiencia obtenida en la operación sería de gran utilidad para actividades futuras ${ }^{106}$.

En el año 2005 un total de 15 países reportaron incautaciones de anhídrido acético por un monto de 22 toneladas. Cabe destacar que Afganistán, la India y Turquía comunicaron distintas incautaciones de conformidad con los procedimientos operativos estándar del Proyecto Cohesión. Sin embargo la Junta mostraba su preocupación porque a pesar de las grandes incautaciones realizadas, se facilitaba muy poca información sobre las fuentes y los métodos o rutas seguidos para desviar las remesas del comercio lícito a los canales ilícitos. Por lo cual recomendó que los gobiernos intensificaran sus esfuerzos por descubrir los grupos delictivos involucrados y el modo de operar empleado en el tráfico de este precursor de drogas. Señalamos por su importancia la incautación notificada por las autoridades de Afganistán que tuvo lugar en el mes de mayo del 2006, en el curso de una operación conjunta del Servicio de Aduanas y la Policía de Lucha contra la Droga de Afganistán en la provincia de Paktia, En total fueron decomisados 1.250 litros de anhídrido acético y otros productos químicos utilizados para transformar el opio en clorhidrato de heroína. Siempre en este año en la provincia de Nangarhar incautaron 2,4 toneladas de cloruro de amonio, producto químico no fiscalizado que se utiliza para la fabricación ilícita de heroína. Como las dos provincias donde se realizaron las incautaciones limitan con Pakistán, la Junta le solicitó a ese gobierno que incrementara sus esfuerzos para interceptar el tráfico de precursores a lo largo de la frontera ${ }^{107 .}$

Las autoridades competentes de Turquía informaron sobre dos incautaciones de anhídrido acético en el año 2006. La primera de ellas fue de 1.650 litros de esta sustancia, se realizó en Estambul, donde se incautaron también 2.680 kilogramos de carbonato sódico, sustancia no fiscalizada que se utiliza en la fabricación de heroína. Como sucede con frecuencia en los decomisos de anhídrido acético, los contenedores no tenían señales de identificación por lo que fue imposible emprender ac-

106 Precursores y productos químicos frecuentemente utilizados..., correspondiente a 2006..., pp. 11, 12.

107 Ibidem, pp. 19, 20. 
ciones de rastreo hasta la fuente. El segundo caso se trató de una incautación de 125 litros este precursor de drogas realizada en Hakkari, en el sudeste de Turquía, las investigaciones realizadas indican que esta remesa se iba a llevar de contrabando a Irak, país sobre el que la JIFE sospecha que puede estar siendo utilizado como país fuente o país de reexpedición de anhídrido acético, pues en el transcurso del año 2006 se exportaron al mismo grandes remesas de esta sustancia. Aunque la Junta verificó la legitimidad de cada envío con las autoridades, es posible que los traficantes utilicen Irak para establecer sociedades de fachada con el fin de desviar anhídrido acético y otros productos del comercio lícito ${ }^{108}$.

En el año 2006 un total de 19 Estados reportaron incautaciones de esta sustancia catalogada por un monto de 24,5 toneladas. A China, Colombia, la Federación de Rusia, Myanmar (el segundo productor mundial de opio) y Turquía les correspondió en conjunto el 98\% de la cantidad de este precursor incautado en el mundo. En el caso de Europa únicamente tres países (Bulgaria, la Federación de Rusia y Rumania) comunicaron decomisos de anhídrido acético. De estas la más importante fue la notificada por la Federación de Rusia de 4.300 litros, pues Bulgaria reportó el decomiso de 10 litros y Rumania de 43 litros. Esta disminución constante de las incautaciones notificadas por los países situados a lo largo de los Balcanes, así como las realizadas en Turquía desde el año 2002, es indicio de que los traficantes encontraron posiblemente otras fuentes y rutas de desviación de esta sustancia catalogada a las zonas donde se realiza la fabricación de la heroína. En cuanto a la situación de Oceanía hay que decir que Australia y Nueva Zelanda han reportado pequeñas incautaciones de anhídrido acético, pero estas, casi seguramente, tienen que ver con la fabricación ilícita de drogas de tipo anfetamínico y no de heroína. En todo caso hay que señalar que los decomisos realizados del año 2000 hasta el año 2007 han ido disminuyendo paulatinamente. Además el bajo número de remesas sospechosas detectadas en el comercio internacional es indicio de que los traficantes han encontrado la forma de desviar el anhídrido acético a nivel 
nacional, principalmente de los canales de fabricación y distribución internos ${ }^{109}$.

En Afganistán la producción potencial de opio se incrementó de 6.100 toneladas en el año 2006 a 8.200 toneladas en el año 2007, proyectándose que la demanda ilícita de anhídrido acético aumentaría de forma proporcional. En el año anteriormente citado se informó por primera vez a la JIFE de un pedido de 80 toneladas de esta sustancia catalogada con destino a Afganistán. La Junta agradeció a China su oportuna intervención para detener la remesa, puesto que este país no tiene necesidades legítimas de anhídrido acético. En Asia se reportaron otras incautaciones de esta sustancia catalogada en el año 2006, Myanmar reporto 1.401 litros, la India 120 litros, Turquía 3.772 litros y Kazajistán 4 litros. La Junta valoró que las incautaciones realizadas de anhídrido acético en los países limítrofes con el Afganistán fueron insignificantes, por lo que insto a los gobiernos de los países de Asia a que reforzarán los controles del movimiento de la sustancia dentro de sus territorios y prestaran asistencia a Afganistán en la interceptación de remesas de este precursor de drogas que se introduce de contrabando en su territorio. En Europa es destacable la operación realizada entre los gobiernos de Eslovenia y Turquía que propicio el decomiso de 13 toneladas de anhídrido acético sacadas de contrabando de Eslovenia en el año 2007. Sobre Oceanía una situación que llama la atención es que se encontraron pequeñas cantidades de anhídrido acético en laboratorios ilícitos de Australia que producían en pequeña escala heroína "de fabricación casera" a partir de tabletas de morfina ${ }^{110}$.

En el periodo que va del 1 de noviembre del año 2007 al 31 de octubre del año 2008, las autoridades competentes de 27 países exportadores enviaron más de 800 notificaciones previas a la exportación de remesas de anhídrido acético, las cuales sumaban en total 125.000 toneladas, y tenían por destino 81 países y territorios importadores. Los Estados Unidos de América continuaron siendo los principales productores y exportadores de este precursor en todo el mundo. En todo caso la

109 Ibidem, p. 21. Precursores y productos químicos frecuentemente utilizados..., correspondiente a 2007..., p. 16. Informe de la Junta Internacional de Fiscalización de Estupefacientes correspondiente a 2011. Ed. Naciones Unidas. JIFE. New York, 2012, p. 80. pp. 16, 17. 
Junta considera que el volumen de comercio internacional real es superior al reportado a través del sistema de notificaciones previas, ejemplo de ello es que el volumen total de anhídrido acético exportado en el año 2007, según los datos facilitados a la Junta mediante el formulario D fue de 260.000 toneladas, lo que demuestra la disparidad existente. Sobre las incautaciones de esta sustancia cabe señalar que estas a partir del año 2001 han venido disminuyendo de forma paulatina, llegando en el año 2006 a cifrarse en 26,4 toneladas. Es a partir de finales del año 2007 y durante el año 2008 que se empieza a corregir el problema gracias al esfuerzo desarrollado por algunos gobiernos y a medidas operacionales desarrolladas, así en el año 2007 un total de 13 países reportaron incautaciones de anhídrido acético por un monto de 56,3 toneladas. Siendo los países que comunicaron las incautaciones más importantes la Federación de Rusia, Turquía, Eslovenia, China, Colombia y Rumania (al menos una tonelada en cada país). Mientras que en el año 2008 en el marco del Proyecto Cohesión, se decomisaron 121 toneladas en Europa (Eslovenia, Hungría y Turquía) y otras 33 toneladas en Asia (Afganistán, la India, el Pakistán, la República de Corea y la República Islámica del Irán). En el continente americano las autoridades colombianas, que informan de forma periódica importantes incautaciones de anhídrido acético, reportaron que en el año 2007 fueron decomisadas 4,7 toneladas, sin que se suministrara mayor información al respecto ${ }^{111}$.

Un aspecto muy importante a destacar es que la JIFE manifestaba su preocupación porque que según la legislación de la Unión Europea, las sustancias catalogadas que se comercializan entre sus 27 Estados miembros se consideran objeto de comercio interno y por lo tanto no estaban sometidos al sistema establecido de notificaciones previas a la exportación, lo cual puede facilitar el desvío de precursores en esta región. Sobre este tema la Junta señala que en el año 2007, seis países europeos iniciaron investigaciones conjuntas de rastreo de una remesa de 13 toneladas de anhídrido acético decomisada en Turquía. En el año 2008 estas investigaciones dieron lugar a una serie de incautaciones de

111 En el año 2008 las autoridades pakistaníes incautaron 14 toneladas de anhídrido acético. Las investigaciones de rastreo en Asia Occidental condujeron a nuevas incautaciones de 5 toneladas en la República Islámica del Irán y de 12 toneladas en la República de Corea. Precursores y productos químicos frecuentemente utilizados..., correspondiente a 2008..., pp. 12, 13. 
esta sustancia, que sumaron 112 toneladas en Eslovenia. Las autoridades a cargo de la investigación lograron establecer que las expediciones decomisadas habían sido desviadas del comercio intracomunitario, dentro de la Unión Europea, continuando los intentos de los traficantes a lo largo del año 2008 de obtener anhídrido acético en el mercado interno de la Unión Europea. Además hay que señalar que las autoridades húngaras, en cooperación con las autoridades checas y eslovacas incautaron una remesa de más de 20 toneladas de este precursor, siendo el modus operandi utilizado por los traficantes, similar al que usaron los traficantes de Eslovenia. En vista de estos hechos la JIFE le hizo un llamado a los estados miembros de la Unión Europea para que adoptaran las medidas adecuadas para impedir la desviación de anhídrido acético en su mercado interno ${ }^{112}$. En el año 2009 la Junta señalo en su informe anual que las medidas de fiscalización del anhídrido acético en la Unión Europea les seguían pareciendo insuficientes ${ }^{113}$.

En Afganistán la situación continuó siendo sumamente complicada, aunque haya mejorado un poco la estabilidad, el control de precursores de drogas siguió exigiendo urgente atención. Desde finales del año 2007 y durante el año 2008 la cooperación más intensa en esta materia posibilitó la incautación, e impidió la desviación de grandes cantidades de productos químicos que se habrían usado en este país para producir heroína. Precisamente debido a estas incautaciones, el precio de estas sustancias catalogadas y no catalogadas que sirven para elaborar heroína subió notablemente, tanto en este país como en aquellos situados a lo largo de las rutas del tráfico hacia el Afganistán, en lo que sin lugar a dudas han tenido que ver la medidas adoptadas en el ámbito de la Operación Dice. A pesar de ello, lamentablemente no existen pruebas de que la heroína escaseara en las calles de todo el mundo. La Junta señalo que era evidente que el Gobierno de Afganistán no tenía la suficiente capacidad para enfrentar el problema por sí solo y necesitaba asistencia para establecer estructuras y elaborar políticas que le permitan fiscalizar el mercado lícito y el ilícito de las sustancias catalogadas, fundamentalmente de anhídrido acético, que los traficantes utili-

112 Ibidem, pp. 12, 14.

113 Precursores y productos químicos frecuentemente utilizados..., correspondiente a 2009..., p. XII. 
zan para elaborar heroína114. Para hacernos una idea de la magnitud del problema es preciso señalar que la República Islámica del Afganistán es un país extremadamente pobre y tiene una superficie de $647.500 \mathrm{~km}^{2}$, prácticamente la misma extensión que Francia, el país es montañoso (el 75\%), no tiene mar y tiene un total de 5.529 kilómetros de fronteras, el doble que Francia, con Pakistán $(2.640 \mathrm{~km})$, con China (76 km), con Tayikistán $(1.206 \mathrm{~km})$, con Uzbekistán $(137 \mathrm{~km})$, con Turkmenistán $(744 \mathrm{~km})$ y con Irán $(939 \mathrm{~km})$. Teniendo solamente $31 \mathrm{mi}-$ llones de habitantes, la mitad que Francia, de los cuales el $90 \%$ se dedica a la agricultura y sólo el $36 \%$ esta alfabetizado. Además hay que decir que el Gobierno controla en alguna medida la capital y poco más, encontrándose el sector público entre los tres países más corruptos del mundo según el informe que publicó en el año 2014 la organización para la transparencia internacional, siendo también muy importante el nivel de corrupción existente en todos los países vecinos, todo lo cual propicia que los contrabandistas de precursores de drogas y los traficantes de drogas campen a sus anchas en todo el territorio nacional, pudiendo entrar y salir de él prácticamente sin ninguna dificultad 115 .

Como ya se ha señalado anteriormente a la JIFE no se le ha informado de ningún uso legítimo de anhídrido acético en Afganistán. Sin embargo desde el año 2006 se señalan a la atención de la Junta pedidos de esta sustancia con destino a este país. Precisamente en el año 2007 las autoridades competentes de la Federación de Rusia iniciaron investigaciones sobre un pedido importante hecho por unos traficantes a una empresa legítima. La remesa en cuestión que era de diez toneladas fue decomisada. Afortunadamente el Gobierno de Afganistán en el 2009 tomó la decisión de no autorizar la importación de anhídrido acético en su territorio. En el periodo 2007-2008 las autoridades alemanas detectaron pedidos sospechosos de más de 50 toneladas de esta sustancia catalogada con destino al Afganistán, Pakistán y la República Islámica del Irán, lográndose impedir en todos los casos la entrega de las remesas contratadas. En este mismo periodo se identificaron remesas sospechosas de anhídrido acético con destino a países del Asia Occidental, como Irak, y la República Árabe de Siria. La mayor de estas remesas

114 Precursores y productos químicos frecuentemente utilizados..., correspondiente a 2008..., pp. III, 12, 13, 16.

115 http://www.datosmacro.com/estado/indice-percepcion-corrupcion 
(340 toneladas) fue detenida por las autoridades de los Emiratos Árabes Unidos y su legitimidad no se pudo confirmar en Irak. Además una expedición de 20 toneladas de anhídrido acético fue detenida en los Países Bajos porque la empresa importadora de la República Árabe Siria, país que se había declarado como destino de la remesa, no pudo ser localizada ${ }^{116 .}$.

El grupo de tareas del Proyecto Cohesión se reunió en Viena en el mes de marzo del año 2008 para evaluar las reducidas tasas de decomiso de anhídrido acético llevadas a cabo en el periodo anterior, así como para corregir tal situación, por lo que decidieron iniciar la Operación Dice, iniciativa relacionada con la información y centrada en el intercambio de datos sobre incautaciones, tentativas descubiertas de desviaciones y remesas sospechosas de anhídrido acético y otros productos químicos que se utilizan o se sospecha que se pueden usar para la fabricación ilícita de heroína. Esta operación se desarrollo del 1.ํ de abril al 30 de septiembre del año 2008, produciendo importantes resultados. En esta operación, la Junta examinó 388 remesas internacionales de anhídrido acético y declaró cinco de estas sospechosas. En total se comunicaron a la Junta 20 casos de decomisos de precursores y de sospecha de desviación de precursores de heroína, lo que incluye incautaciones de anhídrido acético y cloruro de acetilo (sustancia no catalogada) ${ }^{117}$.

A través de la Operación Dice y de la iniciativa de comunicación, especialización y capacitaciones regionales para la lucha contra determinados tipos de tráfico regional, que cuenta con el apoyo de la Oficina de Naciones Unidas contra la Droga y el Delito, informaron que además del tráfico de anhídrido acético, se producía el tráfico de otras sustancias catalogadas como el ácido sulfúrico y sustancias no catalogadas como el ácido acético glacial. Muestra de ello es que las autoridades de

116 Precursores y productos químicos frecuentemente utilizados..., correspondiente a 2008..., pp. 13,14 . Precursores y productos químicos frecuentemente utilizados..., correspondiente a $2009 \ldots$, p. 3.

117 Precursores y productos químicos frecuentemente utilizados..., correspondiente a 2008..., p. 7. El grupo de tareas del Proyecto Cohesión se reunió nuevamente en el mes de junio del año 2009 en Alemania para evaluar las tendencias del tráfico de anhídrido acético, observando un aumento de pedidos sospechosos de este precursor en Asia Occidental, por lo que se decidió proseguir con actividades que se basarán en los logros obtenidos de la Operación Dice. Precursores y productos químicos frecuentemente utilizados..., correspondiente a $2009 \ldots$, p. 7. 
Kirguistán comunicaron diversas incautaciones de ácido sulfúrico por un total de 6,8 toneladas. En este mismo año las autoridades de Afganistán decomisaron más de tres toneladas de sustancias no catalogadas, entre ellas cloruro amónico y carbonato sódico, pasadas de contrabando a través de su frontera con Pakistán. Siempre en el año 2008, las autoridades iraníes incautaron 15,9 toneladas de cloruro de acetilo, sustancia que puede utilizarse para la fabricación de anhídrido acético. También este año las autoridades de Uzbekistán decomisaron 1,6 toneladas de ácido acético destinadas al Afganistán, Pakistán y la Federación de Rusia, las autoridades de estos países advirtieron a la Junta de la sospecha de que se estaba fabricando anhídrido acético a partir de ácido acético glacial, que no es más que ácido acético concentrado al $99.5 \%$, se le llama glacial por que al congelarse forma cristales. La JIFE realizó una visita a Pakistán en el mes de abril del año 2008, donde recibió pruebas técnica fiables sobre la fabricación ilícita de anhídrido acético a partir de ácido acético glacial ${ }^{118}$.

En el periodo comprendido entre el día 1 de octubre del año 2008 y el día 31 de octubre del año 2009 los principales exportadores del mundo de anhídrido acético fueron China y los Estados Unidos de América. En el formulario D correspondiente al año 2008 un total de 20 países declararon el decomiso de 199.300 litros de esta sustancia. Esta incautación representa 142.000 litros más que el total reportado en el año 2007, y fue la segunda mayor incautación anual comunicada a la Junta desde el año 1998. Los siguientes países incautaron más de 5.000 litros de este precursor de drogas: Eslovenia (86.100 litros), Hungría (63.600 litros), Pakistán (15.239 litros), la República de Corea (14.800 litros), Turquía (10.553 litros) y China (5.186 litros). Según las informaciones que tiene la JIFE la mayor parte del anhídrido acético incautado en el año 2008 había sido desviado de los circuitos nacionales de distribución ${ }^{119}$.

En el año 2009 la Junta informó que el continente africano se ha convertido en el nuevo objetivo para los traficantes que tratan de obtener anhídrido acético. Además se registro un aumento del número de intentos de desvío en países de Asia Occidental, en particular en Irak. pp. 16, 17. 
Mientras que en la Unión Europea, varios países reportaron desvíos de esta sustancia catalogada del mercado intracomunitario. En todos los principales países exportadores, sobre todos los que pertenecen a la Unión Europea y los países de Asia Oriental y Sudoriental, sigue siendo elevado el riesgo de desvío de anhídrido acético de los circuitos nacionales de distribución. En este periodo los traficantes recurrieron cada vez mas a empresas nuevas en el mercado de las sustancias catalogadas. En Europa, pequeñas empresas que anteriormente se dedicaban a actividades con los productos químicos, por ejemplo empresas de restauración y hostelería realizaron encargos de anhídrido acético. En Asia, algunas empresas que encargaban este precursor no pudieron dar explicaciones satisfactorias sobre la naturaleza de tales pedidos, aduciendo fines difícilmente justificables desde el punto de vista económico o práctico, como por ejemplo la fabricación de vinagre. Por ello la Junta pidió a todos los países exportadores que incrementaran sus esfuerzos para verificar la legitimidad del uso final del anhídrido acético en sus países ${ }^{120}$.

En 2008 y 2009 las autoridades de España, en cooperación con los proveedores lícitos de esta sustancia en su país, suspendieron unas remesas sospechosas de este precursor destinadas a la República Islámica de Irán, Irak y la República Árabe de Siria. En este periodo las autoridades alemanas también impidieron la entrega de remesas sospechosas de anhídrido acético por un total de 70 toneladas a países de Asia Occidental, entre ellos Afganistán, Armenia, la República Islámica de Irán, Irak, Pakistán, los Emiratos árabes Unidos y Uzbekistán. Debiendo destacarse que empresas radicadas en Irak incrementaron de forma considerable los pedidos de este precursor de drogas a Alemania, la India, España, el Reino Unido de Gran Bretaña e Irlanda y los Estados Unidos de América. La mayoría de los pedidos fueron realizados por empresas que eran nuevas en el mercado de precursores, que no necesitaban lícitamente esta sustancia o no estaban autorizadas para importarlas. Por ellos las au-

En el año 2008 los siguientes países europeos reportaron la incautación de más de 100 litros de anhídrido acético: Eslovenia, Hungría, los Países Bajos, Ucrania y Polonia. Las investigaciones para determinar el origen de las incautaciones realizadas en Eslovenia y Turquía en el año 2007 concluyeron que habían tenido lugar dentro de la Unión Europea. En los años 2008 y 2009, varios países de la UE, incluidos la República Checa, Hungría, Eslovaquia y Eslovenia descubrieron intentos de los traficantes de obtener esta sustancia. Ibidem, p. 17. 
toridades competentes de estos países impidieron la entrega de un total de 95 toneladas de esta sustancia catalogada ${ }^{121}$.

En el ámbito del Proyecto Cohesión en el mes de julio del año 2009 se inició la Operación DICE-2, la cual estuvo centrada en compartir información sobre las incautaciones, intentos de desviación y remesas sospechosas de anhídrido acético, así como en la comprobación de la legitimidad del uso final de remesas anteriores de anhídrido acético. En el curso de esta operación, que duro nueve meses y contó con el apoyo de 60 países y territorios, la JIFE examinó 860 remesas internacionales del precursor antes citado y envió diez notificaciones de transacciones sospechosas en las que intervenía la sustancia. Las incautaciones realizadas en el curso de la operación sumaron más de 26 toneladas, interviniendo en ella varios países de América, Europa y Asia. La Operación permitió el intercambio de información sobre las tendencias del tráfico y de la desviación de precursores, destacando la importancia de una red de intercambio multilateral de inteligencia y otros datos. Al igual que en el caso de la Operación Pila (del Proyecto Prisma), la Operación DICE-2 permitió identificar debilidades de los mecanismos de fiscalización y la necesidad de que los gobiernos revisaran las medidas de fiscalización ${ }^{122}$.

Las incautaciones reportadas en el año 2009 en todo el mundo ascendieron a 21.000 litros. Los países que incautaron esta sustancia catalogada en cantidades superiores a 1.000 litros fueron: Japón (8.424 litros), Pakistán (4.532 litros), los Emiratos Árabes Unidos (4.000 litros) y la India (1.038 litros). Un elemento positivo que destaco en su informe la JIFE fue la creciente conciencia de los Estados miembros de la Unión Europea de la necesidad de abordar la cuestión de la desviación interna del anhídrido acético dentro del mercado intracomunitario. En este sentido la Junta tomo nota de un informe sobre la aplicación y el funcionamiento de la legislación sobre precursores aprobado por la comisión Europea en el mes de enero del año 2010, en el que se seña-

121 En este periodo también se reportaron incautaciones de anhídrido acético en Alemania destinadas a Armenia (10 toneladas), en los Países Bajos destinadas a la República Árabe de Siria (20 toneladas), En España destinada a la República Árabe de Siria (media tonelada) y en Pakistán se incautaron 5 toneladas que se iban a pasar de contrabando a Afganistán. Ibidem, p. 18. pp. 5, 6 . 
lan algunas insuficiencias de las medidas de fiscalización del anhídrido acético y se recomiendan varias medidas correctivas opcionales, entre ellas la modificación de la legislación vigente sobre precursores ${ }^{123}$.

Un aspecto positivo a destacar fue que las autoridades de Pakistán informaron del decomiso de 4.600 litros de anhídrido acético en el mes de julio del año 2009 que se pretendían pasar de contrabando a Afganistán. Posteriormente, en el mes de marzo del año 2010, las autoridades pakistaníes incautaron otros 14.600 litros de este precursor, en ruta desde China, vía la India y los Emiratos Árabes Unidos, siempre con destino a Afganistán. Como parte de la cooperación, comunicación, competencia técnica y capacitaciones regionales específicas para la lucha contra el tráfico de drogas en el marco de la Operación TARCET II, la Oficina de las Naciones Unidas contra la Droga y el Delito (UNODC) registro unos 400 litros de anhídrido acético incautados en el Afganistán por autoridades de ese país y de 1.000 litros decomisados por fuerzas extranjeras en Afganistán. En general, se puede decir que el Gobierno de este país esta haciendo esfuerzos por enfrentar el contrabando de sustancias para la fabricación de heroína, pero aun le queda mucho que mejorar en la información que facilita a la Junta al respecto, razón por la cual es imposible saber la cantidad de precursores que se decomisan en el país. Por otra parte hay que señalar que también se siguen presentando serios problemas en Irak que continua estando en el punto de mira de los traficantes para realizar compras de anhídrido acético utilizando empresas fantasmas, la Junta le recomendó a las autoridades de este país que centre sus esfuerzos en las investigaciones de seguimiento para identificar a los responsables de las órdenes de compra sospechosas dentro del país ${ }^{124}$.

Sobre las sustancias no catalogadas que se utilizan en la fabricación de heroína en este período tenemos que señalar que en el mes de mayo del año 2010 se informó a la Junta de una expedición de 17.600 litros de cloruro de acetilo cuya importación no había sido autorizada por las autoridades de Irán. El Gobierno de Colombia informó en el año 2009 el decomiso de 1.500 litros de ácido acético presuntamente destinado a la fabricación ilícita de heroína. Como parte de la Operación TARCET II,

\footnotetext{
123 Ibidem, pp. 14, 15.

124 Ibidem, pp. 15, 16.
} 
la UNODC registró en el año 2009 incautaciones de sustancias químicas no fiscalizadas, incluidas cinco toneladas de cloruro de acetilo en el Pakistán, dos toneladas de cloruro amónico, 23,5 toneladas de cafeína y 2,2 toneladas de carbonato de sodio en Afganistán; y 1.500 litros de ácido acético en China. Todas estas sustancias no catalogadas pueden ser utilizadas en varias etapas de la fabricación ilícita de heroína, incluida su adulteración, o se sospecha que pueden ser usadas como precursores o sustitutivos del anhídrido acético ${ }^{125}$.

En el período que va del 1 de noviembre del año 2010 al 31 de octubre del año 2011 los cinco países que realizaron las mayores exportaciones en el mundo de anhídrido acético (el 87\%) fueron los Estados Unidos de América, México, China, Suiza y Bélgica. Mientras que los mayores importadores (el 62\% de las importaciones mundiales) fueron Alemania, los Países Bajos, China, Bélgica y México. Hay que aclarar que algunos países son a la vez grandes exportadores e importadores y también reexportadores. En el año 2010 un total de 14 gobiernos reportaron un total de 128 incautaciones de anhídrido acético que sumaban casi 60.000 litros. De estos seis países comunicaron decomisos de volúmenes superiores a 1.000 litros; Bulgaria (21.111 litros), China (16.346 litros), Pakistán (16.178 litros), México (4.821 litros) y Colombia (1.007 litros). La JIFE señaló que el número de desviaciones descubiertas de este precursor del comercio internacional había disminuido en los últimos años, ya que actualmente en la mayoría de los casos reportados se trata de incautaciones de la sustancia de los canales internos de distribución, antes de su paso de contrabando a otros países, con frecuencia a Afganistán, que es el mayor productor de heroína del mundo. En dicho país de forma periódica se producen incautaciones de anhídrido acético pero lamentablemente hasta la fecha nunca las han comunicado en el formulario $\mathrm{D}^{126}$. Hay que destacar que los decomisos de este precursor de drogas ocuparon el primer puesto a nivel mundial, del Cuadro I de la Convención de 1988, pues del año 1995 al año 2010 se incautaron un total de 1.584.876 litros equivalentes a 1.711 .532 kilo-

\section{Ibidem, p. 16.}

El anhídrido acético con destino a Afganistán sigue siendo desviado de los canales internos de distribución, principalmente de países ajenos a la región, y posteriormente pasados de contrabando al país. De modo que los países vecinos de Afganistán fueron utilizados como países de transito del contrabando de esta sustancia. Precursores y productos químicos frecuentemente utilizados..., correspondiente a 2011..., pp. 27, 28. 
gramos. En el año 2008 se realizaron los mayores decomisos de esta sustancia por un monto de 201.363 litros, en los años siguientes los niveles fueron disminuyendo, hasta llegar a 59.667 litros en el año 2010. En todo caso hay que señalar que a pesar de los avances que se han producido para evitar el desvío de esta sustancia catalogada, en el marco del Proyecto Cohesión, los mercados ilegales de la droga jamás han estado desabastecidos de heroína ${ }^{127}$.

Queremos subrayar una incautación de 6.500 litros de anhídrido acético realizado en Hungría en el año 2011, pues por este decomiso y otros anteriores varios países europeos desarrollaron una serie de investigaciones que permitieron descubrir algunas deficiencias en el mecanismo de fiscalización precursores de drogas de la Unión Europea, cuando se trata de comercio intracomunitario, sobre las que se estaban tomando medidas para su erradicación. También es necesario señalar el incremento de pedidos de este precursor realizado por empresas de Irak, que anteriormente no eran conocidas por la Junta, realizados principalmente a exportadores europeos, informando las autoridades de Irak que muchas de esas empresas no tenían necesidades legítimas de la sustancia ni la debida autorización para importarla. El último intento de desviación registrado se produjo en el mes de diciembre del año 2010, se trato de 100.000 litros (108 toneladas) de esta sustancia catalogada, remesa que fue detenida por las autoridades de Irán ${ }^{128}$. México también reportó la incautación de 8 remesas de anhídrido acético por un monto de 56.000 litros, pero estas posiblemente estuvieran relacionadas con la fabricación de metanfetamina, aunque en este país también se fabrica heroína. Según estudios realizados por la UNODC se estima que la disponibilidad potencial anual de anhídrido acético para la fabricación ilícita de heroína sería de 699.000 a 2.602 .000 litros, por lo que el nivel de incautaciones, partiendo del año 2005 al año 2010, oscilaria entre el $2 \%$ y el $9 \%$ del volumen de este precursor disponible para la fabricación de heroína. En todo caso hay que tener en cuenta que algunos países, entre ellos Afganistán no comunican los decomisos rea-

127 Precursores y productos químicos frecuentemente utilizados..., correspondiente a 2010..., pp. 16- 41. Precursores y productos químicos frecuentemente utilizados..., correspondiente a 2011..., pp. 66-100. Vid., las incautaciones de anhídrido acético realizadas en España en el Anexo III. 
lizados a la JIFE, por lo que el porcentaje de incautaciones podría ser un poco mayor ${ }^{129}$.

En el formulario D correspondiente al año 2011 un total de 17 gobiernos reportaron incautaciones por un monto de 198.000 litros de anhídrido acético. Seis países reportaron decomisos superiores a 1.000 litros, siendo estos: México (76.625 litros), Afganistán (68.245 litros), los Estados Unidos de América (24.700 litros), China (16.946 litros), Eslovaquia (6.020 litros) y Turquía (3.706 litros). Es preciso destacar que la mayoría de incautaciones de esta sustancia que se informaron a la Junta, en países distintos a Afganistán, y fueron desviadas presuntamente de canales de distribución interna. En este periodo se han observado mejoras en la cooperación y la presentación de informes de la autoridades afganas, que en el año 2011 reportaron a través del formulario D la incautación de 68.245 litros de este precursor de drogas, casi el triple que el año anterior, además las autoridades competentes de este país se inscribieron en el PICS y actualmente están comunicando activamente incidentes por medio de este sistema. Debiendo destacarse que la mayor incautación entre los meses de enero y octubre del año 2012 se reportó a través de este sistema. Se trató del decomiso de 10.000 litros de anhídrido acético que había sido ocultado en un contenedor proveniente de la República Islámica del Irán. Como todos sabemos, la evolución de los precios de los precursores en el mercado negro puede ser una valiosa información sobre el mercado ilícito. En un estudio realizado por el Ministerio de lucha contra los estupefacientes de Afganistán, junto con la UNODC se logró establecer que entre el mes de mayo del año 2010 y el mes de mayo del año 2012 los precios disminuyeron de unos 416 dólares USA (277 veces más que el precio de mercado) el litro de anhídrido acético a entre 165 y 232 dólares USA (el margen estimado en función de la calidad percibida de la sustancia). Mientras que, el anhídrido acético obtenido de fuentes mayoristas legitimas cuesta aproximadamente 1,5 dólares USA el litro. El continuo descenso de este precursor en el mercado negro de este país indica que ha aumentado la disponibilidad del mismo en relación con la demanda ilícita ${ }^{130}$.

130 Precursores y sustancias químicas frecuentemente utilizados..., correspondiente a 2012..., pp. 25, 26. Informe de la Junta Internacional de Fiscalización de Estupefacientes correspondiente a 2013. Ed. Naciones Unidas. Nueva York. 2014, p. 86. 
En el mes de septiembre del año 2013 se realizó en Adelboden (Suiza) una reunión de los grupos de tareas sobre precursores de la JIFE del Proyecto Prisma y Proyecto Cohesión, en el que los participantes analizaron la situación relativa al tráfico de anhídrido acético destinado a Afganistán y evaluaron información sobre investigaciones llevadas a cabo recientemente. Además el grupo de tareas sobre precursores puso en marcha en este año una operación internacional denominada "Ojo de Águila" que se centró en la comprobación de la legitimidad del comercio interno y el uso del anhídrido acético. Uno de los objetivos de la operación consistió en controlar las medidas de fiscalización para detectar el comercio transfronterizo de este precursor de drogas ${ }^{131}$. Por otra parte hay que decir que los traficantes de anhídrido acético siguen empeñados en utilizar Irak para realizar desvíos de esta sustancia del comercio internacional, aunque el gobierno de este país no ha informado de ninguna incautación hasta la fecha. Pero desde el mes de enero del año 2012 empresas supuestamente ubicadas en Irak han realizado pedidos de anhídrido acético por un monto de 35.000 litros a empresas chinas. Afortunadamente como las empresas importadoras no pudieron justificar su legítima necesidad, el país exportador suspendió todos los envíos ${ }^{132}$.

En el formulario D correspondiente al año 2012 un total de 17 gobiernos comunicaron incautaciones de anhídrido acético por un monto de 88.530 litros, menos de la mitad de las incautaciones comunicadas en el año 2011, siendo las de mayor importancia, por su cantidad, las reportadas por: Afganistán (31.451 litros), Brasil (1.878 litros), China (17.131 litros), México (35.040 litros) y Polonia (1.755 litros). Además a través del sistema PICS se reportaron un total de 25 incidentes confirmados relacionados con este precursor de drogas, por un total de 33 toneladas y 15.000 litros. Estos incidentes se produjeron en Afganistán, la India, la República Islámica de Irán, México y Pakistán. Es importante destacar que los precios del anhídrido acético en el mercado negro de Afganistán continuaron bajando hasta situarse entre los 114 y 224 dólares USA el litro. Mientras que el precio de este precursor de drogas obtenido de fuentes mayoristas se mantiene en 1,5 dólares el litro. La

131 Precursores y productos químicos frecuentemente utilizados..., correspondiente a 2013..., pp. 7, 8.

$132 \quad$ Ibidem, p. 26. 
JIFE afirmo que la disminución del precio del anhídrido acético es indicio de que pueden haber aumentado los suministros o el acceso a la sustancia en el Afganistán, lo que ha generado también una disminución del precio de la heroína en ese país. Otra información relevante es que las incautaciones de anhídrido acético aumentaron de forma considerable en México, siendo incluso mayores que las de Afganistán, pasando de los 4 litros en el año 2008 a los 35.000 litros en el año 2012, lo cual puede responder a las 12.000 hectáreas donde se cultiva ilícitamente adormidera en ese país, así como a la elaboración ilícita de P2-P para fabricar metanfetamina ${ }^{133}$.

Otro dato de sumo interés es que está aumentando el nivel de incautaciones del cloruro de amonio en los países que se produce heroína, sustancia no catalogada que se usa habitualmente en el proceso de extracción de la morfina del opio. Del año 2008 al año 2012 se decomisaron casi 94 toneladas de esta sustancia, habiéndose realizado las mayores incautaciones en Afganistán y, en los últimos años, en México. En el año 2012 el gobierno de Afganistán comunico siete incidentes relacionados con el cloruro de amonio y se incautaron casi 1,8 toneladas. El mayor de estos decomisos se efectúo en la provincia de Badakhshan consistiendo en 1.057 kilogramos de esta sustancia, proviniendo la misma de Pakistán ${ }^{134}$.

En el periodo que va del día 1 de noviembre del año 2013 al día 31 de octubre del año 2014 las autoridades de 28 países y territorios exportadores utilizaron el sistema PEN Online para transmitir más de 1.523 notificaciones previas a la exportación de anhídrido acético. Los envíos estaban destinados a 86 países y territorios importadores y sumaban un volumen total de 364 millones de litros de este precursor de drogas (27.8\% más que el periodo anterior). En el formulario D correspondiente al año 2013 un total de 19 países o territorios reportaron incautaciones de anhídrido acético por un monto de 175.779 litros. Los países que realizaron las mayores incautaciones fueron: China (94.948 litros), Pakistán (15.840 litros), Turquía (14.672 litros) y Afganistán (14.212 litros). Hay que destacar que en España se incautaron 9.497 litros, y que también este año se desmanteló un laboratorio de fabricación 
de clorhidrato de heroína, además de dos locales donde se almacenaban equipos y sustancias químicas para la fabricación de esta droga ${ }^{135}$.

Es necesario señalar que el anhídrido acético sigue utilizándose de manera generalizada para la fabricación de heroína en Afganistán. En función de la percepción de la calidad del producto, el precio medio del litro de anhídrido acético en este país los primeros 10 meses del año 2014 osciló entre los 106 (70 veces el precio de mercado) y 258 (172 veces el precio de mercado) dólares norteamericanos, considerablemente inferior al alcanzado en el periodo 2008-2010, un poco menos de la mitad, y un poco menor que en los años 2012 y 2013. Esos precios hacen pensar que en la actualidad la accesibilidad de este precursor con fines ilícitos es mayor que en años anteriores. No obstante, el precio más alto del anhídrido acético en Afganistán, comparado con el del mercado internacional lícito, confirma que la demanda ilícita de esta sustancia en Afganistán sigue siendo alta. No hay que olvidar que las incautaciones de anhídrido acético también están relacionadas con la fabricación de metanfetamina, en este sentido mencionamos el decomiso de 7.597 litros en México en el año 2013 y de 27.064 reportada a través del sistema PICS en el mes de mayo del 2014 por Guatemala136. En el caso de la Unión Europea, como todos sabemos, la mayor parte de la heroína proviene de Afganistán y en menor medida de Irán y Pakistán, teniéndose información de que las últimas fases de la fabricación de la heroína, en no pocos casos, pueden estar llevándose a cabo en Europa, como lo indicó el descubrimiento de dos laboratorios que convertían morfina en heroína en España (2013-2014)137.

En lo que respecta a las sustancias no catalogadas que se utilizan en la elaboración de heroína hay que decir que el ácido acético glacial no está sometido a fiscalización internacional, pero está incluido en la lista de vigilancia internacional especial limitada de sustancias no incluidas en los Cuadros de la Convención de 1988, debido a su posible utilización directa en los laboratorios de heroína y como tapadera para ocul-

135 Precursores y sustancias químicas frecuentemente utilizados..., correspondiente a 2014..., pp. 36-39, 71-90.

$136 \quad$ Ibidem, p. 38.

137 Informe Europeo sobre Drogas. Tendencia y novedades 2015. Ed. Observatorio Europeo de las Drogas y las Toxicomanías. Bruselas. 2015, p. 24. 
tar anhídrido acético de contrabando. En el marco de la operación Ojo de Águila, las autoridades competentes de Afganistán confirmaron que el ácido acético se utilizaba en los laboratorios de heroína del país, mezclando diversas proporciones de anhídrido acético. En el mes de diciembre de 2013 el gobierno de este país sometió a fiscalización nacional el ácido acético, así como el cloruro de acetilo, el cloruro de amonio y el carbonato de calcio, por ser sustancias que se utilizan en la elaboración de la heroína. El cloruro de amonio suele utilizarse para extraer morfina del opio, por lo cual en los últimos años cada vez son más frecuentes las incautaciones de esta sustancia no catalogada: Afganistán (5,8 toneladas) y México (520 kilogramos) ${ }^{138}$.

En el periodo 2014-2015 las autoridades competentes de 25 países y territorios exportadores de anhídrido acético reportaron a través del sistema PEN Online un total de 1.493 notificaciones previas de exportación de este precursor de drogas. Las remesas estaban destinadas a un total de 86 paíes por un monto de 352 millones de litros de anhídrido acético (4,3\% menos que el año anterior). En el formulario correspondiente al año 2014 se reporto la incautación de un total de 44.971 litros de anhídrido acético, la cantidad más baja de los últimos cinco años (el 25,5\% que el año anterior), de los 13 países y territorios que comunicaron decomisos de esta sustancia catalogada únicamente Afganistán (7.750 litros), China (22.600 litros) y México (13.500 litros) reportaron el decomiso de más de 1.000 litros de este precursor de drogas 139 .

Creemos que es muy importante poner de manifiesto que del año 2004 al año 2013 se reportó a través del formulario $\mathrm{D}$ el decomiso de un total de 1.088 .590 litros de anhídrido acético a nivel mundial, equivalentes a 1.175.583 kilogramos (cantidad con la que se pueden fabricar entre 293.896 y 1.175 .583 kilogramos de clorhidrato de heroína) ${ }^{140}$, siendo el segundo precursor en nivel de incautación del Cuadro I en este periodo, desglosado de la siguiente manera: 79.469 litros en el año p. 39. pp. 27-30. 
2004, 22.379 litros en el año 2005, 26.430 litros en el año 2006, 57.308 litros en el año 2007, 213.637 litros en el año 2008, 70.501 litros en el año 2009, 155.656 litros en el año 2010, 197.744 litros en el año 2011, 89.657 litros en el año 2012 y 175.739 litros en el año 2013. Las incautaciones se llevaron a cabo en un total de 40 países pertenecientes a cuatro continentes, exceptuando África. Los países que realizaron los mayores decomisos de anhídrido acético fueron: los Estados Unidos de América (87.433 litros), México (124.547 litros), la India (7.785 litros), Afganistán (186.061 litros), la República Islámica de Irán (16.501 litros), Pakistán (51.426 litros), Turquía (75.787 litros), China (183.120 litros), Japón (8.424 litros), Myanmar (5.880 litros), República de Corea (14.813 litros), la Federación de Rusia (93.237 litros) Bulgaria (28.255 litros), Eslovaquia (8.820 litros), España (9.513 litros), Hungría (63.649 litros) y Eslovenia (92.590 litros). Como era de esperarse el mayor nivel de incautación de anhídrido acético se realizó en Afganistán que es el mayor productor de heroína del mundo. Otra información relevante es el elevado nivel de incautaciones de anhídrido acético de México, lo cual puede responder al incremento de fabricación de heroína en este país, ya que las 12.000 hectáreas donde se cultiva ilícitamente adormidera lo convierten en el tercer principal cultivador de esta planta, también debe tenerse en cuenta que los carteles mexicanos utilizan este precursor para la elaboración ilícita de P-2-P (precursor de drogas) que usan para fabricar metanfetamina. En el caso de China creemos que el elevado nivel de incautaciones se debe a que es uno de los principales productores de anhídrido acético del mundo, a que es un país que tiene fronteras con Afganistán, y además al notable incremento del cultivo de la adormidera en la región (62.000 hectáreas) principalmente en Myanmar (segundo lugar en cuanto a la superficie dedicada al cultivo de la adormidera y segundo productor de opio a nivel mundial), la República Democrática de Laos y Tailandia ${ }^{141}$.

141 Precursores y sustancias químicas frecuentemente utilizados..., correspondiente a 2014..., pp. 25, 26, 71-90. Precursores y sustancias químicas frecuentemente utilizados..., correspondiente a 2013..., pp. 67-84. Precursores y sustancias químicas frecuentemente utilizados..., correspondiente a 2009..., pp. 37-50, 51-62. Informe de la Junta Internacional de Fiscalización correspondiente al año 2013. Ed. Naciones Unidas. Nueva York. 2014 p. 71. Informe de la Junta Internacional de Fiscalización de Estupefacientes correspondiente al año 2014..., pp. 76, 78. Vid., en el Anexo III las incautaciones de anhídrido acético realizadas en España desde el año 1993 al año 2014. 
Para recapitular un poco sobre el estado de la cuestión hay que decir que el anhídrido acético es utilizado principalmente en la fabricación de heroína pero últimamente también se usa en la elaboración ilícita de otro precursor de drogas la P-2-P que se utiliza para la elaboración de metanfetamina, fundamentalmente en México y los Estados Unidos de América. La información disponible indica que la desviación del anhídrido acético de los canales de comercio internacional es poco frecuente. Afganistán que es el mayor productor de heroína del mundo, no tiene comercio lícito de esta sustancia, ni se tiene constancia de su elaboración ilícita en el país, pero sí en su país vecino Pakistán y posiblemente en Colombia, donde al igual que México se fabrica heroína. Lo que ocurre en el caso de Afganistán es que todos los años se desvían cientos de miles de litros de este precursor de los canales de comercio interno de otros países y se introducen de contrabando por la extensa frontera de Afganistán. Algo similar ocurre con los otros dos grandes productores de heroína: México y Myanmar, que se abastecen desviaciones de sus canales internos o bien de las de otros países. Hay que señalar que en el periodo 2010-2015 las cifras correspondientes al comercio lícito indican que entre 25 y 27 países exportadores utilizaron el sistema PEN Online para informar de un promedio 1.500 remesas de anhídrido acético por una media de 336 millones de litros anuales destinados a unas 340 empresas pertenecientes a unos 90 países importadores. Cifra que como ya hemos expresado antes no es muy fiable ya que las cantidades comunicadas por los gobiernos de los países importadores y exportadores a través del formulario D y de notificaciones previas a la exportación sugieren, por sus incongruencias, que parecen exportarse cada año cantidades importantes de anhídrido acético a los países importadores sin previa notificación a través del sistema PEN Online. En este sentido hay que decir que el sector privado estima que la fabricación mundial de anhídrido acético ronda los $2.130 \mathrm{mi}-$ llones de litros anuales, y que aproximadamente dos tercios son utilizados por las propias empresas que fabrican esta sustancia catalogada, estando el resto, unos 710 millones de litros, disponible para el comercio internacional, cantidad que duplica la comercialización de cualquiera de los diez últimos años reportado a través del sistema PEN Online.

En todo caso hay que puntualizar que, como es costumbre, el número de tentativas de desviación detectadas en el comercio internacional sigue siendo reducido. Dicho esto a continuación nos permitimos destacar algunos elementos que evidencian las dificultades que existen en el enfrentamiento de la desviación de este precursor de drogas actual- 
mente: 1) en función de la cantidad anual estimada de anhídrido acético para la fabricación ilícita de heroína (entre 600.000 y 1.500 .000 litros), se requeriría menos del 1\% del comercio legitimo para abastecer la fabricación de esa droga en el mundo, lo que entraña serias dificultades; 2) como en años anteriores, solo seis países informaron oficialmente de la fabricación lícita de este precursor, por parte de 44 empresas: mientras que otras fuentes de información indican que el número de países y empresas es considerablemente mayor. Por ejemplo en una encuesta sobre el anhídrido acético realizada recientemente por el gobierno de los Estados Unidos de América se constató que más de 90 empresas fabricaban esta sustancia catalogada de forma lícita en 17 países; 3) se desconoce prácticamente la capacidad de cada país y de cada empresa para fabricar anhídrido acético; 4) en los últimos cinco años, los gobiernos de alrededor de 60 países informaron a la Junta de sus necesidades legítimas de anhídrido acético, que ascendían en total a una media de 330 millones de litros anuales, a pesar de que desde el año 2009 se reporta anualmente a través del sistema PEN Online la existencia de no menos de 86 países importadores de esta sustancia; 6) la JIFE ha estimando que el nivel de incautación anual a nivel mundial es menos del $17 \%$ del anhídrido acético que se utiliza para la fabricación ilícita de heroína (entre el 6\% y el 15\%); 7) el nivel de enfrentamiento en el mundo al desvío de esta sustancia catalogada, al igual que otras que se usan en el proceso de elaboración de la heroína, es desigual dado que los países más pobres o menos desarrollados, y de hecho regiones enteras, se están quedando rezagadas ${ }^{142}$; 8) que el precio del anhídrido acético en el mercado ilícito ha experimentado una notable reducción en los últimos años, y 9) lamentablemente el nivel de pureza y disponibilidad de la heroína en Europa ha aumentado, lo cual es extrapolable a otras regiones del mundo, lo que se evidencia en el hecho constatado de que la producción de opio y por ende de heroí-

142 También se fabrica heroína en los países de la zona llamada triangulo de oro de Asia Sudoriental, sin embargo todos los países de la zona, excepto China, comunican pocas incautaciones de anhídrido acético, por no decir ninguna. Por otra parte hay que señalar que en México y sus alrededores el incremento de los decomisos de anhídrido acético parece estar más relacionado con la utilización de P-2-P en la fabricación de metanfetamina y no con el aumento importante de fabricación de heroína en la región. Precursores y sustancias químicas frecuentemente utilizados..., correspondiente a 2012..., pp. 24,25 . Precursores y sustancias químicas frecuentemente utilizados... correspondiente a 2013..., p. 26. 
na en Afganistán ha sufrido un notable incremento ${ }^{143}$. Por todo lo expuesto desafortunadamente se puede concluir que el nivel de enfrentamiento al tráfico de anhídrido acético y otras sustancias catalogadas y no catalogadas que se utilizan para la fabricación de la heroína, a pesar de todos los esfuerzos realizados por la comunidad internacional, continua siendo insuficiente.

Queremos terminar este apartado señalando que en España se decomisaron del año 1993 al año 2014 un total de 9.678 litros de anhídrido acético ${ }^{144}$. Si asumimos de forma muy optimista que esta cantidad representa el $20 \%$ del total que se desvía del comercio lícito, o bien se produce ilícitamente, para la fabricación ilícita de heroína podríamos estimar que se habrían desviado aproximadamente en este periodo de 21 años un total 48.390 litros y por ende un total de 2.304 litros anuales. Lo cual representa una cantidad bastante importante que podría utilizarse para la elaboración de heroína en Afganistán, Myanmar o inclusive en España, ya que no hay que olvidar que somos el segundo mayor productor legal de opio del mundo con un total de 13.000 hectáreas, cantidad similar a la cultivada en México que es el segundo productor mundial ilícito de de opio del mundo, cultivadas en Andalucía, Castilla y León, Castilla la Mancha y el País Vasco.

\section{C.) OTROS ÁCIDOS Y disOlvENTES INCLUIDOS EN EL CUADRo II DE LA CONVENCIÓN} DE 1988

A continuación analizaremos las estadísticas de las incautaciones de algunas de la sustancias del Cuadro II de la Convención de 1988, ácidos y disolventes, que son precursores que también se utilizan en la elaboración de drogas ilícitas como: la cocaína, la heroína, la anfetamina, la metanfetamina, el MDMA y sustancias análogas, la metacualona, la fenciclidina y el LSD. Estos precursores son importantes para la elaboración de todas estas drogas, pero no tienen el papel principal en la fabricación de las mismas. Es preciso señalar que el comercio internacional de estas sustancias no catalogadas es muy elevado y las medidas de fis-

Informe Europeo sobre Drogas. Tendencia y novedades 2015. Ed. Observatorio Europeo de las Drogas y las Tóxicomanias. Bruselas. 2015, pp. 25, 26. Resumen Ejecutivo. Informe Mundial sobre las Drogas 2014. Ed. UNODC. 2015, p. 2.

144 Vid., las incautaciones de precursores realizadas en España en el Anexo III. 
calización son menos rigurosas que las establecidas para las sustancias del Cuadro I, por lo cual los traficantes, en principio, tienen menos dificultades para realizar el desvío de estas sustancias tanto de comercio internacional, como del nacional. Sin embargo también se produce la sustitución de unos precursores por otros, y en muchas ocasiones, de estas por otras sustancias no catalogadas cuando la situación lo requiere o inclusive se ha constado su fabricación de forma ilícita en laboratorios clandestinos. Queremos señalar que como estas sustancias catalogadas tienen un nivel de fiscalización menor se dispone de muy poca información sobre sus niveles de comercio internacional, tendencias de desvío y de fabricación ilícita.

\section{La acetona}

Es necesario señalar que la acetona se utiliza en la fabricación ilícita de la cocaína, la heroína y la metanfetamina. En el año 2008 se decomisaron a nivel mundial un total de 1.610 .608 litros de acetona. Las incautaciones de acetona más importantes en el mundo fueron: América del Norte: Canadá (1.235 litros), los Estados Unidos de América (5.301 litros) y México (8.674 litros); América del Sur: Argentina (719 litros), Estado Plurinacional de Bolivia (5.472 litros), Colombia (1.468.212 litros), Perú (29.864 litros); Asia Oriental y Sudoriental: China (82.232 litros) y Filipinas (902 litros); Europa: Federación de Rusia (5.214 litros), Bélgica (1.510 litros), España (862 litros) y los Países Bajos (6.631 litros). En el resto del mundo se decomisaron 662 litros de este precursor de drogas. Colombia realizó la mayor cantidad de incautaciones de acetona en el mundo. El segundo y tercer lugar lo ocuparon China y Perú respectivamente. El 92.95\% de las incautaciones de acetona se efectuaron en los tres principales países productores de cocaína (Colombia, Perú y Bolivia). Aunque la acetona también se usa en la fabricación ilícita de heroína Afganistán, principal productor del mundo, no reporto ninguna incautación de esta sustancia ${ }^{145}$

En el año 2009 se incautaron en el mundo un total de 1.626 .060 litros de acetona, un 0,53\% más que el año anterior. Los decomisos más importantes se realizaron en: América del Norte: Canadá (1.023 litros), 
los Estados Unidos de América (7.060 litros) y México (13.242 litros); América del Sur: Estado Plurinacional de Bolivia (67.199 litros), Brasil (84.520 litros), Colombia (1.381.411 litros), Ecuador (2.285 litros), Perú (18.580 litros); Asia Oriental y Sudoriental: China (31.522 litros), Myanmar (8.227 litros); Europa: Federación de Rusia (1.252 litros), Ucrania (574 litros), Bélgica (1.165 litros), España (3.705 litros) y los Países Bajos (720 litros); Oceanía: Australia (2.027 litros). En el resto del mundo se decomisaron un total de 77.616 litros. Como ocurrió el año anterior la mayor incautación la reportó Colombia, seguido por Brasil y Bolivia. El 90.2\% de las incautaciones de acetona se realizaron en los tres principales países productores de cocaína (Colombia, Bolivia y Perú). Es destacable que Myanmar, importante productor de heroína, reportó un nivel de decomiso de acetona muy importante. Sin embargo Afganistán, el mayor productor del mundo de heroína, un año más no comunicó ninguna incautación ${ }^{146}$.

En el año 2010 se incautaron a nivel mundial un total de 846.973 litros de acetona, un 47,9\% menos que el año anterior. Destacamos las siguientes incautaciones: América del Norte: Los Estados Unidos de América (55.390 litros) y México (7.776 litros); América del Sur: Brasil (956 litros), Chile (1.600 litros), Colombia (688.224 litros), Ecuador (4.320 litros), Paraguay (4.500 litros), Perú (31.139 litros), Asia Occidental: Kazajistán (245 litros), Asia Oriental y Sudoriental: China (31.966 litros), Myanmar (1.202 litros); Europa: Ucrania (20.726 litros), España (442 litros) y los Países Bajos (1.434 litros). En este año, una vez más, el mayor nivel de decomisos se realizó en Colombia, seguido de los Estados Unidos de América y China. Llama la atención que el Estado Plurinacional de Bolivia no reportara ninguna incautación. A pesar de ello el $84.9 \%$ de las incautaciones mundiales se realizaron en dos de los tres principales países productores de cocaína (Colombia y Perú). En este año Myanmar de nuevo reportó una incautación significativa de acetona ${ }^{147}$.

En el año 2011 se decomisaron en el mundo un total de 696.666 litros de acetona, un 17,75\% menos que el año anterior. Los decomisos más importantes se realizaron en África: Nigeria (400 litros); América del

\footnotetext{
146 Idem.

147 Idem.
} 
Norte: los Estados Unidos de América (7.142 litros) y México (32.262 litros); América del Sur: Estado Plurinacional de Bolivia (51.663 litros), Brasil (954 litros), Colombia (463.883 litros), Paraguay (4.500 litros), Perú (32.456 litros) y la República Bolivariana de Venezuela (15.858 litros); Asia Occidental: Uzbekistán (274 litros); Asia Oriental y Sudoriental: China (21.474 litros); Europa; Ucrania (1.821 litros), Bélgica (602 litros) y los Países Bajos (6.485 litros). En el resto del mundo se decomisaron un total de 56.890 litros. Como de costumbre la mayor incautación la efectúo Colombia, y el 78,6\% de las incautaciones del mundo la realizaron los principales países productores de cocaína (Colombia, Perú y Bolivia). Aunque la acetona también se usa en la fabricación ilícita de heroína Afganistán, principal productor del mundo, una vez más no reportó ninguna incautación de esta sustancia ${ }^{148}$.

En el año 2012 se incautaron a nivel mundial un total de 986.216 litros de acetona, un 29\% más que el año anterior. Destacamos las incautaciones realizadas en América del Norte: Canadá (2.786 litros), los Estados Unidos de América (10.594 litros) y México (10.669 litros); En América del Sur: Estado Plurinacional de Bolivia (59.711 litros), Brasil (1.606 litros), Colombia (739.247 litros), Perú (70.024 litros) y la República Bolivariana de Venezuela (39.331 litros); En Asia Oriental y Sudoriental: China (31.953 litros) y Filipinas (6.436 litros); En Europa: Ucrania (10.324 litros), España (425 litros) y los Países Bajos (1.245 litros). En el resto del mundo únicamente se decomisaron 1.865 litros. Como puede apreciarse la mayor incautación la realizo Colombia, y el $88 \%$ de las incautaciones del mundo la realizaron los principales países productores de cocaína (Colombia, Perú y Bolivia), aunque esta sustancia también se utiliza en la fabricación ilícita de heroína Afganistán, que es el principal productor de heroína del mundo, no informó, una vez más, de ningún decomiso de acetona este año. En este sentido hay que destacar que México y Colombia donde también se elabora heroína realizaron decomisos muy importantes de este precursor ${ }^{149}$.

En el año 2013 se incautaron en el mundo un total de 1.038 .127 litros de acetona, un $5.1 \%$ más que el año anterior. Destacamos las siguientes incautaciones: América del Norte: Canadá (569 litros), los Estados Uni-

\footnotetext{
148 Idem.

149 Idem.
} 
dos de América (2.457 litros) y México (6.901 litros); América del Sur: Argentina (2.768 litros), Estado Plurinacional de Bolivia (99.315 litros), Brasil (2.491 litros), Colombia (482.063 litros) y Perú (86.313 litros); Asia Occidental: el Afganistán (174 litros) y Qatar (565 litros); Asia Oriental y Sudoriental: China (351.870 litros); Europa: Ucrania (1.163 litros) y España (1.190 litros). En este año una vez más el mayor nivel de decomiso lo realizaron en Colombia, seguido por China y el Estado Plurinacional de Bolivia. En los tres principales países productores de cocaína se efectuaron el $64.3 \%$ de las incautaciones mundiales de este precursor de drogas ${ }^{150}$.

Del año 2004 al año 2013 se reporto a través del formulario D la incautación de 14.521.507 litros de acetona a nivel mundial (cantidad que podría utilizarse para fabricar 968.100 kilogramos de cocaína o heroína), desglosadas de la siguiente forma: 3.260 .582 litros en el año 2004, 1.378.693 litros en el año 2005, 1.663 .487 litros en el año 2006, 1.414.635 litros en el año 2007, 1.610 .608 litros en el año 2008, 1.626.060 en el año 2009, 846.973 litros en el año 2010, 696.666 litros en el año 2011, 986.216 litros en el año 2012, 1.038 .127 litros en el año 2013. Dichos decomisos se llevaron a cabo en un total de 56 países pertenecientes a los cinco continentes. Las mayores incautaciones se realizaron en los siguientes países: Canadá (6.426 litros), los Estados Unidos de América (2.164.591 litros), México (72.554 litros), Argentina (8.781 litros), Estado Plurinacional de Bolivia (283.858 litros), Brasil (92.367 litros), Colombia (10.388.266 litros), Ecuador (6.625 litros), Paraguay (5.332 litros), Perú (394.854 litros), República Bolivariana de Venezuela (55.189 litros), China (716.577 litros), Filipinas (20.124 litros), Myanmar (11.092 litros), Belarús (35.282 litros), Federación de Rusia (145.617 litros), Ucrania (45.751 litros), España (8.849 litros) y los Países Bajos (63.999 litros). Hay que destacar que en Colombia se realizaron el 71,5\% de las incautaciones del mundo en estos diez años, así como que los tres principales países productores de cocaína (Colombia, Perú y Bolivia) decomisaron el 76,2\% de acetona a nivel mundial ${ }^{151}$. Queremos subrayar que entre los principales países exportado-

150 Precursores y sustancias químicas frecuentemente utilizados..., correspondiente a 2014..., pp. 93-107.

151 Precursores y sustancias químicas frecuentemente utilizados..., correspondiente a 2009..., pp. 37-50, 51-62. Precursores y sustancias químicas frecuentemente utilizados..., corres- 
res de este precursor de drogas se encuentran: España, los Estados Unidos de América y Bélgica, mientras que los principales países importadores son: China, los Países Bajos, Alemania, el Reino Unido de Gran Bretaña e Irlanda del Norte y Bélgica ${ }^{152}$. Es importante también poner en relieve que es bastante probable que los fabricantes de cocaína elaboren ellos mismo la acetona en los laboratorios clandestinos o la sustituyan por otras sustancias catalogadas o no catalogadas que elaboren ellos mismos o les sea muy fácil desviar de los canales nacionales de distribución.

Consideramos oportuno citar como ejemplo de sustitución de un precursor en la elaboración de un producto lícito, el caso del quitaesmalte o removedor de esmalte de uñas conocido comúnmente por su composición como acetona, no sin antes aclarar que no sabemos si tal sustitución se produjo para evitar los controles que existen sobre la acetona o por razones puramente comerciales. El caso en cuestión es que hace aproximadamente unos seis años se empezó a comercializar el quitaesmalte sin acetona, sustituyendo esta sustancia por acetato de etilo o acetato de butilo, siendo preciso aclarar que estos dos solventes son sustancias no catalogadas que también se utilizan en la elaboración ilícita de cocaína como sustituto de la acetona en América del Sur. Entre la marcas comerciales que venden este producto podemos nombrar a Deliplus, Cutex, Les Cometiques, Sante, Pino Glaux, Ufaes, Yves Rocher, Mussital, Cien, Nail Desing, entre otras muchas. Estas casas comerciales promocionan este producto afirmando que es más conveniente porque agrede menos las uñas que los productos que contienen acetona. En todo caso hay quienes dicen que las tres sustancias tienen una toxicidad similar, y como la acetona es un solvente mas fuerte, se tiene que usar menos cantidad en la elaboración del quitaesmalte, que cuando se usa cualquiera de las otras dos sustancias, que también están fiscalizadas en países como Costa Rica o Colombia, pero obviamente con menos exigencias y control que la acetona que es un precursor de drogas incluido en Cuadro II de la Convención de Viena de 1988. Es necesario decir que en Centro América y América de Sur, viene muy bien la comercialización de el removedor de uñas sin acetona, pues el que con-

pondiente a 2014..., pp. 93-107. Vid., en el Anexo III las incautaciones de acetona realizadas en España del año 1993 al año 2014.

152 http://www.smartexport.com/es/Acetona.291411.html 
tiene acetona esta prohibido casi en todos los países de la región pues se utilizaba por los traficantes para la fabricación de cocaína; puntualizamos que en España se siguen comercializando ambas versiones del quitaesmalte.

\section{El ácido clorhídrico}

Antes de nada queremos recordar que el ácido clorhídrico se utiliza en la fabricación ilícita de la cocaína, la heroína, la metanfetamina, el MDMA y la fenciclidina. En el año 2008 se incautaron en el mundo un total de 835.227 litros de ácido clorhídrico. Destacamos las incautaciones efectuadas en: África: Sudáfrica (1.038 litros); América del Norte: los Estados Unidos de América (9.110 litros) y México (14.102 litros); América del Sur: Estado Plurinacional de Bolivia (1.533 litros), Brasil (1.357 litros), Colombia (313.312 litros) y Perú (75.963 litros); Asia Occidental: Afganistán (718 litros); Asia Oriental y Sudoriental: China (405.671 litros); Europa: Federación de Rusia (5.214 litros), Bélgica (1.850 litros) y los Países Bajos (3.971 litros). En el resto del mundo solamente se decomisaron 1.388 litros. Destacamos que las mayores incautaciones se realizaron en China, Colombia y Perú, en ese orden, así como que el $46,7 \%$ de las incautaciones se llevaron a cabo en los principales países productores de cocaína (Colombia, Perú y Bolivia), además que Afganistán reportó el decomiso de una cantidad significativa de este precursor de drogas ${ }^{153}$.

En el año 2009 a nivel mundial se decomisaron un total de 486.664 litros de ácido clorhídrico, un 41,7\% menos que el año anterior. Los decomisos más importantes de esta sustancia catalogada se realizaron en: América del Norte: los Estados Unidos de América (8.152 litros) y México (7.681 litros); América del Sur: Estado Plurinacional de Bolivia (11.008 litros), Brasil (17.797 litros), Colombia (191.926 litros), Ecuador (3.984 litros), Perú (72.601 litros); Asia Occidental: Afganistán (6.150 litros) y Pakistán (8.220 litros); Asia Oriental y Sudoriental: China (151.298 litros) y Myanmar (2.378 litros); Europa: Federación de Rusia (1.088 litros), Ucrania (2.113 litros). En el resto de mundo únicamente se decomisaron 2.268 litros. Las mayores incautaciones se 
efectuaron en Colombia, China y Perú, respectivamente, además hay que subrayar que el $56,6 \%$ de las incautaciones se realizaron en los principales países productores de cocaína (Colombia, Perú y Bolivia). Por otra parte hay que señalar que el Afganistán, Myanmar y Pakistán, grandes productores de heroína, reportaron incautaciones importantes de este precursor de drogas ${ }^{154}$.

En el año 2010 se incautaron en el mundo un total de 793.226 litros de ácido clorhídrico, un 38,6\% más que el año anterior. Destacamos los decomisos realizados en: América del Norte: los Estados Unidos de América (69.940 litros) y México (10.244 litros); América del Sur: Brasil (22.381 litros), Colombia (187.914 litros), Ecuador (2.286 litros), Perú (172.807 litros); Asia Occidental: Afganistán (5.286 litros), Kazajistán (51.794 litros) y Pakistán (7.110 litros); Asia Oriental y Sudoriental: China (141.918 litros) y Myanmar (2.378 litros); Europa: Ucrania (111.221 litros), Bélgica (1.016 litros) y los Países Bajos (6.178 litros). En el resto del mundo únicamente se incautaron 753 litros. En este año los principales países productores de cocaína, a pesar de que Bolivia no reportó ninguna incautación, incautaron el $45.4 \%$ de este precursor de drogas. Es preciso destacar que las mayores incautaciones a nivel mundial se realizaron en Colombia, Perú y China, así como que los dos, de los tres, mayores productores del mundo de heroína (Afganistán y Myanmar) efectuaron decomisos importantes de ácido clorhídrico ${ }^{155}$.

En el año 2011 se incautaron a nivel mundial un total de 679.785 litros, un 14,4\% menos que el año anterior. Los decomisos más significativos de este precursor de drogas se produjeron en: América Central y el Caribe: Guatemala (8.707 litros); América del Norte: los Estados Unidos de América (109.602 litros) y México (78.125 litros); América del Sur: Estado Plurinacional de Bolivia (9.307 litros), Brasil (7.211 litros), Colombia (96.660 litros), Perú (145.850 litros) y la República Bolivariana de Venezuela (25.781 litros); Asia Occidental: Kazajistán (10.707 litros), Pakistán (7.110 litros); Asia Oriental y Sudoriental: China (150.165 litros); Europa: Ucrania (24.608 litros) y los Países Bajos (8.429 litros). Las mayores incautaciones correspondieron a China, Pe-

\footnotetext{
$154 \quad$ Idem.

155 Idem.
} 
rú y los Estados Unidos de América. Destacamos que el 37\% del ácido clorhídrico confiscado correspondió a los principales países productores de cocaína. Además que el Afganistán sólo decomiso 120 litros de ácido clorhídrico y Myanmar no reportó ninguna incautación (principales productores de heroína) ${ }^{156}$.

En el año 2012 se decomiso en el mundo un total de 504.165 litros de ácido clorhídrico, un 25,9\% menos que el mes anterior. Las principales incautaciones a nivel mundial se produjeron en: América del Norte: México (29.310 litros); América del Sur: Estado Plurinacional de Bolivia (5.873 litros), Brasil (91.697 litros), Colombia (76.290 litros), Perú (87.695 litros) y la República Bolivariana de Venezuela (28.605 litros); Asia Occidental: Kazajistán (1.600 litros); Asia Oriental y Sudoriental: China (166.825 litros) y Filipinas (1.646 litros); Europa: Ucrania (2.211 litros), España (990 litros) y los Países Bajos (4.567 litros). En el resto del mundo se decomisaron 6.856 litros de ácido clorhídrico. Los principales países productores de cocaína (Colombia, Perú y Bolivia) incautaron el 33.6\% de esta sustancia. En este año cabe destacar que Afganistán y Myanmar no reportaron ninguna incautación ${ }^{157}$. En este periodo la JIFE informó que los narcotraficantes en Colombia han comenzado a fabricar ácido clorhídrico en laboratorios clandestinos, seguramente para su utilización en la elaboración ilícita de cocaína, heroína, metanfetamina y MDMA ${ }^{158}$.

En el año 2013 las incautaciones de ácido clorhídrico ascendieron a 2.332.545 litros, la mayor cantidad registrada desde el año 2008. Los mayores decomisos se produjeron en: América del Norte: los Estados Unidos de América (1.681 litros) y México (14.207 litros); América del Sur: Estado Plurinacional de Bolivia (24.839 litros), Brasil (2.491 litros), Colombia (144.686 litros), Paraguay (2.019 litros) y Perú (73.200 litros); Asia Occidental: Afganistán (4.705 litros), Pakistán (925 litros) y Qatar (407.363 litros); Asia Oriental y Sudoriental: China (1.627.816 litros), y Tailandia (450 litros); Europa: Belarús (10.751 litros), Ucrania (3.053 litros), Bélgica (735 litros), España (490 litros) y los Países

\footnotetext{
156 Idem.

157 Idem.

158 Informe de la Junta Internacional de Fiscalización de Estupefacientes correspondiente a 2013. Ed. Naciones Unidas. Nueva York. 2014, p. 68.
} 
Bajos (19.988 litros). Los mayores decomisos se realizaron en: China, que realizó el mayor nivel de incautaciones desde el año 2008 hasta la fecha, Qatar y Colombia ${ }^{159}$.

Del año 2004 al año 2013 a través del formulario D se reporto la incautación de 65.296.517 litros de ácido clorhídrico en todo el mundo (cantidad con la que se podría fabricar un total de 215.478.506 kilogramos de cocaína o de heroína), desglosado de la siguiente manera: 56.621 .642 litros en el año 2004, 579.789 litros en el año 2005, 1.462.662 litros en el año 2006, 1.000 .812 litros en el año 2007, 835.227 litros en el año 2008, 486.664 litros en el año 2009, 793.226 litros en el año 2010, 679.785 litros en el año 2011, 504.165 litros en el año 2012 y 2.332 .545 litros en el año 2013. Estos decomisos se llevaron a cabo en 59 países pertenecientes a los cinco continentes del mundo. Los países que realizaron las mayores incautaciones fueron: El Salvador (412.500 litros), los Estados Unidos de América (56.406.856 litros), México (154.468 litros), Argentina (108.025 litros), el Estado Plurinacional de Bolivia (94.174 litros), Brasil (157.505 litros), Colombia (2.213.384 litros), Perú (759.457 litros), China (3.208.805 litros), Kazajistán (64.345 litros), Afganistán (16.261 litros), Qatar (407.363 litros), Belarús (40.003 litros), la Federación de Rusia (752.882 litros), Bélgica (14.521 litros) y los Países Bajos (58.499 litros). Hay que destacar que en estos diez años los Estados Unidos de América realizaron el $86,3 \%$ del total de las incautaciones del mundo ${ }^{160}$. No sabemos la cantidad de ácido clorhídrico que se comercializa mundialmente en un año, pero si que los principales países exportadores son: Alemania, Canadá y los Países Bajos y que los principales países importadores son: los Estados Unidos de América, Francia, Bélgica, Italia y Austria ${ }^{161}$. Es necesario señalar que desde el año 2012 la JIFE tiene información contrastada de que los traficantes de drogas elaboran ilícitamente ácido clor-

159 Precursores y sustancias químicas frecuentemente utilizados..., correspondiente a 2014..., pp. 93-107.

160 Precursores y sustancias químicas frecuentemente utilizados..., correspondiente a 2009..., pp. 37-50, 51-62. Precursores y sustancias químicas frecuentemente utilizados..., , pp. 93107. Vid., en el Anexo VI las incautaciones de ácido clorhídrico realizadas en España del año 1993 al año 2014.

http://www.smartexport.com/es/Cloruro_de_hidrogeno_acido_clorhidrico.280610.html 
hídrico en Colombia, desconociéndose la cantidad total o en que porcentaje suplen las necesidades de la producción de cocaína en ese país.

\section{El ácido sulfúrico}

Iniciamos este apartado recordando que este precursor se usa en la fabricación ilícita de cocaína y de anfetamina. Queremos señalar en este momento que esta sustancia es el compuesto químico que más se produce en el mundo, por eso se utiliza como uno de los tantos medidores de la capacidad industrial de los países. La producción mundial lícita de este precursor de drogas se estima en unas 150 millones de toneladas anuales ${ }^{162}$. En el año 2008 a nivel mundial se decomisaron un total de 626.214 litros de ácido sulfúrico, realizándose las principales incautaciones en: América del Norte: los Estados Unidos de América (2.720 litros) y México (6.004 litros); América del Sur: Estado Plurinacional de Bolivia (23.621 litros), Chile (1.593 litros), Colombia (305.755 litros) y Perú (30.776 litros); Asia Meridional: las Maldivas (10.860 litros); Asia Occidental: Kirguistán (2.983 litros); Asia Oriental y Sudoriental: China (238.215 litros); Europa: Federación de Rusia (1.598 litros) y los Países Bajos (770 litros). En el resto del mundo únicamente se incautaron 1.249 litros. Los principales países productores de cocaína (Colombia, Perú y Bolivia) incautaron el 57.5\% de este precursor de drogas. Siendo los países donde se reportaron los mayores decomisos Colombia, China y Perú163.

En el año 2009 se incautaron en todo el mundo un total de 505.172 litros de ácido sulfúrico, un 19,4\% menos que el año anterior. Las principales incautaciones se llevaron a cabo en: América del Norte: los Estados Unidos de América (7.087 litros) y México (2.230 litros); América del Sur: Estado Plurinacional de Bolivia (62.276 litros), Brasil (1.947 litros), Chile (1.185 litros), Colombia (249.441 litros), Ecuador (1.378 litros), Paraguay (5.160 litros) y Perú (77.257 litros); Asia Occidental: Kazajistán (1.530 litros); Asia Oriental y Sudoriental: China (89.448 litros); Europa: Ucrania (4.700 litros). Los principales países productores de cocaína realizaron el $67.1 \%$ de las incautaciones de este año.

\footnotetext{
162 http://genesis.uag.mx/edmedia/material/quimicaII/pdf/acidosulfurico.pdf

163 Precursores y sustancias químicas frecuentemente utilizados..., correspondiente a 2013..., pp. 86-99.
} 
Siendo los países donde se realizaron los mayores decomisos de este precursor de drogas por segundo año consecutivo Colombia, China y Perú164.

En el año 2010 las incautaciones a nivel mundial de ácido sulfúrico ascendieron a un total de 1.042.622 litros, un poco más que el doble que el año anterior. Los decomisos más importantes se realizaron en: América del Norte: los Estados Unidos de América (28.387 litros) y México (2.927 litros); América del Sur: Brasil (1.834 litros), Chile (2.223 litros), Colombia (631.247 litros), Ecuador (1.473 litros) y Perú (31.367 litros); Asia Meridional: las Maldivas (7.331 litros); Asia Oriental y Sudoriental: China (219.388 litros), Myanmar (2.000 litros); Europa: Ucrania: (112.410 litros). En el resto de países del mundo únicamente decomisaron 2.035 litros de ácido sulfúrico. Los principales países productores de cocaína, aunque Bolivia no reporto ninguna incautación, realizaron el $63,7 \%$ de los decomisos. Ejecutando las mayores incautaciones a nivel mundial Colombia, China y Ucrania ${ }^{165}$.

En el año 2011 se decomisaron en todo el mundo un total de 2.040.787 litros de ácido sulfúrico, prácticamente el doble que el año anterior. La principales incautaciones se realizaron en: América del Norte: los Estados Unidos de América (1.231.111 litros) y México (1.652 litros); América del Sur: el Estado Plurinacional de Bolivia (201.621 litros), Brasil (4.747 litros), Colombia (201.812 litros), Ecuador (3.954 litros), Paraguay (5.229 litros), Perú (28.505 litros) y la República Bolivariana de Venezuela (30.284 litros); Asia Occidental: Tayikistán (6.803 litros) y Ubekistán (2.540 litros); Asia Oriental y Sudoriental: China (23.024 litros); Europa: Ucrania (281.755 litros), Bélgica (3.733 litros) y los Países Bajos (12.404 litros). En el resto del mundo sólo se decomisaron 1.613 litros. En este año hay que destacar el espectacular nivel de incautación realizado en los Estados Unidos de América, que fue superior al nivel de incautaciones mundial de todo el año anterior ${ }^{166}$.

En el año 2012 el nivel de incautación mundial de ácido sulfúrico fue de 512.447 litros, que representa tan solo el 25,1\% de las incautaciones que se llevaron a cabo el año anterior. Los decomisos más impor-

164 Idem.

165 Idem.

166 Idem. 
tantes se realizaron en: América del Norte: México (3.171 litros); América del Sur: Estado Plurinacional de Bolivia (72.034 litros), Brasil (28.271 litros), Colombia (163.242 litros), Paraguay (5.229 litros), Perú (29.777 litros) y la República Bolivariana de Venezuela (87.470 litros); Asia Occidental: Afganistán (3.764 litros), Kirguistán (3.703 litros), Uzbekistán (2.540 litros); Asia Oriental y Sudoriental: China (18.479 litros) y Filipinas (3.080 litros); Europa: Federación de Rusia (91.433 litros), Ucrania (3.302 litros) y los Países Bajos (2.020 litros). Hay que señalar que las incautaciones realizadas por los principales países productores de cocaína represento el 51,7\% del total mundial ${ }^{167}$. En este año las autoridades competentes de Colombia informaron haber descubierto casos de fabricación clandestina de ácido sulfúrico a partir de azufre que puede encontrarse en las minas de las zonas volcánicas del país ${ }^{168}$.

En el año 2013 las incautaciones de ácido sulfúrico en el mundo fueron de 4.146.274 litros, la mayor realizada desde el año 2008 hasta la fecha. Los principales decomisos se realizaron en: América del Norte: los Estados Unidos de América (1.930 litros) y México (439 litros); América del Sur: Estado Plurinacional de Bolivia (67.929 litros), Brasil (698 litros), Chile (63.610 litros), Colombia (1.060.578 litros), Ecuador (1.625 litros), Paraguay (6.960 litros) y Perú (87.675 litros); Asia Occidental: Kazajistán (913 litros), Kirguistán (4.386 litros) y Qatar (443.814 litros); Asia Oriental y Sudoriental: China (1.297.043 litros) y Myanmar (924 litros); Europa: Belarús (10.751 litros), Ucrania (631 litros), España (1.086.979 litros), los Países Bajos (8.165 litros) y Polonia (1.436 litros). Las mayores incautaciones, por ese orden se realizaron en: China, España y Colombia, siendo esta la mayor cantidad decomisada en los tres países desde 2008 hasta la fecha. Destacamos el caso de España que no había registrado un nivel de incautación que llegara tan siquiera a los 100 litros de este precursor de drogas ${ }^{169}$.

167 Idem.

168 Informe de la Junta Internacional de Fiscalización de Estupefacientes correspondiente a 2012. Ed. Naciones Unidas. Nueva York. 2013, p. 82.

169 Precursores y sustancias químicas frecuentemente utilizados..., correspondiente a 2014..., pp. 93-107. Vid., en el Anexo III las incautaciones de ácido sulfúrico realizadas en España del año 1993 al año 2014. 
Del año 2004 al año 2013 se reportaron a través del formulario D la incautación de 17.845.435 litros de ácido sulfúrico a nivel mundial (cantidad con la que podría elaborase entre 4.461 .359 y 17.845 .435 kilogramos de cocaína), desglosado de la siguiente manera: 1.084 .609 litros en el año 2004, 1.870 .325 en el año 2005, 5.131.145 litros en el año 2006, 907.910 litros en el año 2007, 601.144 litros en el año 2008, 505.172 litros en el año 2009, 1.042 .622 litros en el año 2010, 2.040.787 litros en el año 2011, 512.447 litros en el año 2012 y 4.149.274 litros en el año 2013. Estas incautaciones se realizaron en un total de 55 países pertenecientes a los cinco continentes. Los principales decomisos de este precursor de drogas se realizaron en: los Estados Unidos de América (5.311.820 litros), México (16.450 litros), Argentina (109.547 litros), el Estado Plurinacional de Bolivia (508.178 litros), Brasil (315.687 litros), Chile (83.856 litros), Colombia (5.247.127 litros), Ecuador (13.699 litros), Paraguay (17.349 litros), Perú (373.808 litros), la República Bolivariana de Venezuela (117.754 litros), China (2.310.607 litros), las Maldivas (18.196 litros), Qatar (443.814 litros), Kirguistán (11.743 litros), Belarús (96.061 litros), Rusia (1.150.251 litros), Ucrania (539.869 litros), España (1.087,511 litros) y los Países Bajos (25.485 litros). Hay que subrayar que en estos diez años los Estados Unidos de América y Colombia incautaron más de cinco millones de litros, cada país, de ácido sulfúrico ${ }^{170}$. No hay que olvidar que desde el año 2012 los traficantes de drogas en Colombia elaboran de forma ilícita ácido sulfúrico, desconocemos que porcentaje de la producción ilícita de drogas satisfacen con esta actividad. En todo caso hay que decir que las posibilidades de desviar ácido sulfúrico del comercio lícito son bastante altas si se tiene en cuenta que anualmente se producen un total de 150 millones de toneladas, siendo además el ácido más barato que existe. Los principales países exportadores de esta sustancia son: Canadá, Japón y la India, y los principales países importadores son: los Estados Unidos de América, China, Filipinas, Namibia y Brasil ${ }^{171}$.

$170 \quad$ Precursores y sustancias químicas frecuentemente utilizados..., correspondiente a 2009..., pp. 37-50, 51-62. Precursores y sustancias químicas frecuentemente utilizados..., correspondiente a 2014..., pp. 93-107. Vid., en el Anexo III las incautaciones de ácido sulfúrico realizadas en España del año 1993 al año 2014.

171 http://www.smartexport.com/es/Acido_sulfurico_oleum.280700.html 


\section{El éter etílico}

Este precursor de drogas se utiliza en la fabricación ilícita de la cocaína y la heroína. En el año 2008 se confiscó a nivel mundial un total de 82.057 litros de éter etílico. Las principales incautaciones se realizaron en: América del Norte: los Estados Unidos de América (206 litros) y México (447 litros); América del Sur: Argentina (290 litros), Colombia (68.228 litros) y Perú (150 litros); Asia Oriental y Sudoriental: China (11.687 litros), Myanmar (352 litros); Europa: Federación de Rusia (477 litros) y España (104 litros). En el resto del mundo únicamente se incautaron 116 litros. Los principales países productores de cocaína, aunque Bolivia no reportó ningún decomiso, realizaron el $83.3 \%$ del total de las incautaciones, y los mayores decomisos se registraron en Colombia, China y la Federación de Rusia ${ }^{172}$.

En el año 2009 se decomisaron en todo el mundo un total de 33.920 litros de éter etílico, un 58,6\% menos que el año anterior. Las incautaciones más importantes se llevaron a cabo en: América del Norte: los Estados Unidos de América (205 litros); América del Sur: Argentina (271 litros), Brasil (1.336 litros), Colombia (5.034 litros); Asia Oriental y Sudoriental: China (25.147 litros) y Myanmar (1.707 litros); Europa: Federación de Rusia (109 litros). En el resto del mundo solo se incautaron 111 litros. En este año es necesario destacar el nivel de incautación de China, el mayor desde el año 2008 hasta la fecha, así como los 1.707 kilogramos confiscados en Myanmar que es uno de los mayores productores de heroína en el mundo ${ }^{173}$.

En el año 2010 la incautación a nivel mundial fue de 48.683 litros de éter etílico, un $30.3 \%$ más que el año anterior. Los principales decomisos se llevaron a cabo en: América: los Estados Unidos de América (25.258 litros); América del Sur: Argentina (237 litros) y Colombia (6.455 litros); Asia Oriental y Sudoriental: China (16.512 litros). En este año hay que destacar que los Estados Unidos de América realizaron el nivel de incautación más alto en ese país desde el año 2008 hasta la fecha ${ }^{174}$.

\footnotetext{
172 Precursores y sustancias químicas frecuentemente utilizados... correspondiente a 2013..., pp. 86-99.

173 Idem.

174 Idem.
} 
En el año 2011 se decomisaron en todo el mundo un total de 20.970 litros de éter etílico, un 57\% menos que el año anterior. Las principales incautaciones se realizaron en: América del Norte: los Estados Unidos de América (115 litros) y México (219 litros); América del Sur: Argentina (182 litros), Brasil (128 litros) y Colombia (1.541 litros); Asia Oriental y Sudoriental: China (17.980 litros); Europa: Ucrania (555 litros). Hay que destacar que como todos los años China es un país donde se realizan importantes decomisos de esta sustancia ${ }^{175}$.

En el año 2012 se incautaron a nivel mundial un total de 60.854 de éter etílico, casi tres veces más que el año anterior. Los decomisos más importantes se llevaron a cabo en: América del Sur: Argentina (131 litros), Bolivia (7.120 litros), Brasil (466 litros), Colombia (25.295 litros); Asia Occidental: Líbano (2.358 litros); Asia Oriental y Sudoriental: China (15.770 litros); Europa: Ucrania (9.216 litros), España (287 litros) y Alemania (97 litros). De este año hay que subrayar que no se realizó ninguna incautación importante en América del Norte, así como que por primera vez en cinco años Líbano reporta incautación de precursores ${ }^{176}$.

En el año 2013 se decomisaron en todo el mundo un total de 43.708 litros de éter etílico, un $28.2 \%$ menos que el año anterior. Las principales incautaciones se realizaron en: América del Norte: México (28.001 litros); América del Sur: Argentina (104 litros), Colombia (2.286 litros) y Perú (128 litros); Asia Oriental y Sudoriental: China (12.204 litros) y Myanmar (600 litros); Europa: España (297 litros). Las mayores incautaciones este año le correspondieron a México y China ${ }^{177 .}$

Del año $2004 \mathrm{al}$ año 2013 se reportaron a través del formulario D la incautación de 883.169 litros de éter etílico a nivel mundial (cantidad con la que se podría fabricar 58.878 kilogramos de cocaína o de heroína), desglosado de la siguiente forma: 320.743 litros en el eño 2004, 77.765 litros en el año 2005, 46.787 litros en el año 2006, 145.377 li-

175 Idem.

176 El Líbano en el año 2012 además del decomiso de los 2.358 litros de éter etílico informo de la incautación de 13 litros de acetona, 6 kilogramos de efedrina a granel y 20 kilogramos de preparados farmacéuticos que contienen efedrina. Idem. . pp. 93-107. 
tros en el año 2007, 84.362 litros en el año 2008, 33.920 litros en el año 2009, 48.683 litros en el año 2010, 20.970 litros en el año 2011, 60.854 litros en el año 2012 y 43.708 litros en el año 2013. Estos decomisos fueron realizados en un total de 39 países pertenecientes a los cinco continentes. Los países o territorios donde se realizaron las mayores incautaciones fueron: los Estados Unidos de América (230.286 litros), México (29.998 litros), el Estado Plurinacional de Bolivia (7.207 litros), Colombia (325.141 litros), Perú (12.973 litros), China (233.211 litros), Myanmar (11.698 litros), la Federación de Rusia (9.274 litros) y Ucrania (9.903 litros) ${ }^{178}$. Los principales países exportadores de este precursor de drogas son: Bélgica, Alemania y la India, y los principales países importadores son: los Países Bajos, los Estados Unidos de América, Francia, Malasia e Italia ${ }^{179}$. Es necesario recordar que se conoce que los traficantes de drogas fabrican de forma ilícita éter etílico, desconociéndose el impacto que tiene dicha producción en la fabricación ilícita de drogas a nivel regional y mundial.

\section{La metiletilcetona}

La metiletilcetona se utiliza de forma ilícita en la elaboración de la cocaína y la heroína. En el año 2008 se reportaron a través del formulario D la incautación de un total de 32.344 litros de esta sustancia en todo el mundo. Los principales decomisos se realizaron en: Norte América: México (1.002 litros); América del Sur: Estado Plurinacional de Bolivia (684 litros), Brasil (225 litros), Colombia (21.359 litros) y Ecuador (6.927 litros); Europa: España (2.083 litros). En el resto del mundo únicamente se incautaron 116 litros de este precursor de drogas. En los principales países productores de cocaína se realizaron el $68,1 \%$ del total de las incautaciones. Nos llama la atención que en Afganistán y Myanmar, los mayores productores de heroína del mundo, no se reporte ninguna incautación de esta sustancia ${ }^{180}$.

178 Precursores y sustancias químicas frecuentemente utilizados..., correspondiente a 2009..., pp. 37-50, 51-62. Precursores y sustancias químicas frecuentemente utilizados..., correspondiente a 2014 ..., pp. 93-107. Vid., en el Anexo III las incautaciones de éter etílico realizadas en España del año 1993 al año 2014.

179 http://www.smartexport.com/es/Eter_dietilico_oxido_de_dietilo.290911.html

180 Precursores y sustancias químicas frecuentemente utilizados..., correspondiente a 2013..., pp. 86-99. 
En el año 2009 las incautaciones mundiales de metiletilcetona fueron de 74.203 litros, un $56,5 \%$ más que el año anterior. Los principales decomisos se llevaron a cabo en: América del Sur: Estado Plurinacional de Bolivia (221 litros), Colombia (38.849 litros) y Ecuador (6.927 litros); Asia Meridional: Bangladesh (17.624 litros); Asia Oriental y Sudoriental: China (871 litros); Europa: Ucrania (996 litros) y España (256 litros). En el resto del mundo solo se decomisaron 8.429 litros. Queremos destacar que en dos de los principales países productores de cocaína se llevaron a cabo el 52,6\% del total de las incautaciones, así como la enorme cantidad de metiletilcetona decomisada en Bangladesh, país en el que no se había reportado ninguna incautación importante de este ni de ningún otro precursor de drogas. Este año Afganistán Myanmar y México, principales productores de heroína del mundo, no reportaron ninguna incautación de metiletilcetona ${ }^{181}$.

En el año 2010 se decomisaron en todo el mundo un total de 86.894 litros de metiletilcetona, la mayor desde el año 2008 hasta la fecha. Los principales decomisos se realizaron en: América del Norte: México (370 litros); América del Sur: Brasil (6.714 litros), Colombia (44.160 litros) y Ecuador (10.774 litros); Asia Meridional: Bangladesh (22.767 litros); Asia Oriental y Sudoriental: China (1.403 litros); Europa: Ucrania (131 litros) y los Países Bajos (375 litros). En el resto del mundo solo se incautaron 200 litros de metiletilcetona. Colombia, como suele suceder, realizo la mayor incautación, seguido por Bangladesh que por segundo año consecutivo realiza un nivel de decomiso muy elevado. En Afganistán y Myanmar no se reportó ninguna incautación de esta sustancia ${ }^{182}$.

En el año 2011 las incautaciones mundiales de metiletilcetona fueron de 7.343 litros, las más bajas desde el año 2008 hasta la fecha. Las incautaciones más importantes se realizaron en: América del Sur: el Estado Plurinacional de Bolivia (176 litros), Brasil (96 litros), Ecuador (2.400 litros), Perú (310 litros) y la República Bolivariana de Venezuela (1.140 litros); Asia Oriental y Sudoriental: China (1.391 litros); Europa: Ucrania (1.706 litros). Este año sorprendentemente Colombia no reporto ninguna incautación de este precursor de drogas. Correspondiéndole a Ucrania el mayor nivel de incautación de esta sustancia en el mundo. Además

\footnotetext{
181 Idem.

182 Idem.
} 
hay que destacar que en este periodo Afganistán, Myanmar y México tampoco reportaron ninguna incautación de metiletilcetona ${ }^{183}$.

En el año 2012 el nivel de incautaciones de metiletilcetona en el mundo también fue bajo, reportándose un total de 11.069 litros. Los principales decomisos se realizaron en: América del Sur: Estado Plurinacional de Bolivia (680 litros), Brasil (3.308 litros) y Colombia (1.419 litros); Asia Oriental y Sudoriental: China (1.217 litros); Europa: Ucrania (720 litros), España (123 litros), Francia (3.019 litros) y el Reino Unido de Gran Bretaña e Irlanda del Norte (385 litros). En este periodo Colombia y Francia reportaron las mayores incautaciones. Destacamos que Afganistán y Myanmar, una vez más, no reportaron ninguna incautación de esta sustancia y que México sólo incautó 64 litros ${ }^{184}$.

En el año 2013 las incautaciones a nivel mundial de metiletilcetona fueron de 9.264 litros, un $16.4 \%$ menos que el año anterior. Los decomisos más importantes se realizaron en: América del Norte: México (94 litros); América del Sur: Colombia (3.406 litros), Ecuador (1.420 litros) y Perú (157 litros); Asia Oriental y Sudoriental: China (1.906 litros); Europa: España (2.197 litros). En este año como de costumbre Colombia realizó el mayor nivel de decomiso del mundo. Una vez más el Afganistán y Myanmar no reportaron ninguna incautación de este precursor de drogas ${ }^{185}$.

Del año 2004 al año 2013 se reportaron a través del formulario D la incautación de 516.261 litros de metiletilcetona a nivel mundial (cantidad con la que podrían elaborarse 34.417 kilogramos de cocaína o de heroína), desglosados de la siguiente manera: 28.696 litros en el año 2004, 31.542 litros en el año 2005, 94.196 litros en el año 2006, 141.358 litros en el año 2007, 31.696 litros en el año 2008, 74.203 litros en el año 2009, 86.894 litros en el año 2010, 7.343 litros en el año 2011, 11.069 litros en el año 2012 y 9.264 litros en el año 2013. Estos decomisos se realizaron en un total de 37 países pertenecientes a cuatro continentes, exceptuando a África. Las mayores incautaciones se realizaron en los siguientes países: los Estados Unidos de América:

\footnotetext{
183 Idem.

184 Idem.

Precursores y sustancias químicas frecuentemente utilizados..., correspondiente a 2014..., pp. 93-107.
} 
(2.991 litros), Argentina (35.872 litros), Brasil (14.672 litros), Colombia (299.791 litros), Ecuador (91.956 litros), Bangladesh (40.391 litros), China (6.788 litros), Ucrania (8.119 litros), Francia (3.019 litros) y España (5.913 litros). Destacamos que Colombia realizó en estos diez años el 58\% de las incautaciones mundiales de este precursor de drogas ${ }^{186}$. Es preciso recordar que la JIFE tiene información contrastada de la fabricación ilícita de este precursor de drogas, no pudiendo determinarse el porcentaje que suplen con dicha producción en la fabricación ilícita de drogas.

\section{El tolueno}

El tolueno se utiliza en la fabricación de la cocaína, la metanfetamina, y también se han registrado casos de su uso en la elaboración de la heroína y la metacualona. En el año 2008 las incautaciones a nivel mundial fueron de 36.862 litros de tolueno. Los principales decomisos se reportaron en: América del Norte: Canadá (906 litros), los Estados Unidos de América (6.455 litros) y México (425 litros); América del Sur: el Estado Plurinacional de Bolivia (1.105 litros), Ecuador (449 litros) y Perú (3.318 litros); Asia Oriental y Sudoriental: China (11.781 litros), Indonesia (105 litros); Europa: Federación de Rusia (725 litros), Ucrania (10.314 litros) y los Países Bajos (400 litros); Oceanía: Nueva Zelanda (643 litros). Los países donde se realizaron los mayores decomisos fueron: China, Ucrania y los Estados Unidos de América. Hay que destacar que en este año Colombia sólo incauto 27 litros de este precursor de drogas ${ }^{187}$.

En el año 2009 en todo el mundo se decomisaron un total de 53.379 litros de tolueno, un 31\% más que el año anterior. Las principales incautaciones se realizaron en: América del Norte: Canadá (1.024 litros), los Estados Unidos de América (6.432 litros) y México (13.502 litros); América del Sur: Estado Plurinacional de Bolivia (349 litros), Brasil (185 litros) y Colombia (2.914 litros); Asia Oriental y Sudoriental: Chi-

186 Precursores y sustancias químicas frecuentemente utilizados..., correspondiente a 2009..., pp. 37-50, 51-62. Precursores y sustancias químicas frecuentemente utilizados..., correspondiente a 2014, pp. 93-107. Vid., en el Anexo III las incautaciones de metiletilcetona realizadas en España del año 1993 al año 2014. pp. 86-99. 
na (18.099 litros); Europa: Federación de Rusia (239 litros), Ucrania (5.227 litros), Alemania (322 litros) y Francia (4.656 litros); Oceanía: Nueva Zelanda (321 litros). Las principales incautaciones se reportaron en: China, México y los Estados Unidos de América. Siendo China el país donde se realizaron los mayores decomisos, por segundo año consecutivo, y América del Norte la región donde se producen mayores incautaciones ${ }^{188}$.

En el año 2010 las incautaciones a nivel mundial fueron de 125.873 litros de tolueno, un $57.6 \%$ más que el año anterior. Los decomisos más importantes se realizaron en: América del Norte: Canadá (423 litros), los Estados Unidos de América (1.305 litros) y México (21.451 litros); América del Sur: Brasil (6.748 litros) y Colombia (66.060 litros); Asia Oriental y Sudoriental: Filipinas (300 litros), Malasia (725 litros); Europa: Federación de Rusia (118 litros), Ucrania (26.235 litros) y los Países Bajos (942 litros); Oceanía: Nueva Zelanda (1.434 litros). En este año las mayores incautaciones se realizaron en Colombia (el 52\% del total de las incautaciones), Ucrania y México189.

En el año 2011 se decomisaron en todo el mundo un total de 142.873 litros de tolueno, un $11.9 \%$ más que el año anterior. Las principales incautaciones se realizaron en: África: Nigeria (200 litros); América del Norte: Canadá (1.825 litros), los Estados Unidos de América (262 litros) y México (49.410 litros); América del Sur: Estado Plurinacional de Bolivia (5.590 litros), Colombia (42.044 litros), Ecuador (449 litros), Paraguay (2.650 litros), Perú (1.919 litros) y la República Bolivariana de Venezuela (1.200 litros); Asia Oriental y Sudoriental: Filipinas (31.313 litros) y Malasia (950 litros); Europa: Ucrania (4.245 litros) y Polonia (103 litros); Oceanía: Nueva Zelanda (476 litros). Las mayores incautaciones a nivel mundial se registraron en México, Colombia, grandes productores de cocaína, heroína y metanfetamina, y Filipinas que al igual que México reporto en este año su mayor nivel de incautaciones desde el año 2008 hasta la fecha ${ }^{190}$.

En el año 2012 se incautaron a nivel mundial un total de 126.932 litros de tolueno, un $11,2 \%$ menos que el año anterior. Los decomisos más

$\begin{array}{cc}188 & \text { Idem. } \\ 189 & \text { Idem. } \\ 190 & \text { Idem. }\end{array}$


importantes se llevaron a cabo en: América del Norte: Canadá (1.178 litros) y México (26.243 litros); América del Sur: el Estado Plurinacional de Bolivia (6.349 litros), Brasil (3.742 litros), Colombia (33.792 litros), Perú (100 litros) y la República Bolivariana de Venezuela (427 litros); Asia Oriental y Sudoriental: China (13.900 litros), Filipinas (17.941 litros) y Malasia (150 litros); Europa: Ucrania (20.089 litros) y Alemania (1.164 litros); Oceanía: Nueva Zelanda (682 litros). Este año Colombia y México continúan liderando el nivel de incautaciones a nivel mundial, seguidos por Ucrania que ya había realizado importantes incautaciones en los años 2008 y $2010^{191}$.

En el año 2013 se incautó a nivel mundial un total de 11.749 .436 litros de tolueno, la mayor cifra incautada desde el año 2008 hasta la fecha con mucha diferencia. Las principales incautaciones se realizaron en: América del Norte; Canadá (981 litros), los Estados Unidos de América (102 litros) y México (12.333 litros); América del Sur: el Estado Plurinacional de Bolivia (140 litros) y Colombia (765 litros); Asia Occidental: Qatar (597 litros); Asia Oriental y Sudoriental: China (221.026 litros); Europa: Ucrania (602 litros) y España (11.511.987 litros); Oceanía: Nueva Zelanda (35 litros). Destacamos el nivel de tolueno decomisado en España, el mayor realizado hasta la fecha, debiendo puntualizarse que en este año también se realizaron en este país grandes incautaciones de acetona, ácido sulfúrico y metiletilcetona ${ }^{192}$.

Del año 2004 al año 2013 se reportó a través del formulario D la incautación de 12.878.705 litros de tolueno (cantidad con la que podrían elaborarse un total de 858.580 kilogramos de cocaína o de heroína), desglosada de la siguiente manera: 258.938 litros en el año 2004, 82.110 litros en el año 2005, 170.914 litros en el año 2006, 133.375 litros en el año 2007, 35.441 litros en el año 2008, 53.379 litros en el año 2009, 125.873 litros en el año 2010, 142.307 litros en el año 2011, 126.932 litros en el año 2012 y 11.749 .436 litros en el año 2013. Estos decomisos se realizaron en un total de 45 países pertenecientes a los cinco continentes. Los países que llevaron a cabo las mayores incautaciones fueron: Canadá (7.513 litros), los Estados Unidos de América

\section{Idem.}

192 Precursores y sustancias químicas frecuentemente utilizados..., correspondiente a 2014..., pp. 93-107. Vid., en el Anexo III las incautaciones de tolueno realizadas en España del año 1993 al año 2014. 
(48.696 litros), México (126.424 litros), Argentina (54.973 litros), el Estado Plurinacional de Bolivia (15.556 litros), Brasil (18.027 litros), Colombia (297.459 litros), Perú: 11.301 litros), China (422.704 litros), Filipinas (59.157 litros), la Federación de Rusia (90.312 litros), Ucrania (184.493 litros) y España (11.512.077 litros). Sin lugar a dudas hay que destacar que España incauto en un solo año, 11.511.987 litros en 2013, más de ocho veces el total de las incautaciones de tolueno realizadas en todo el mundo en diez años, cuando nunca había superado tan siquiera los cincuenta litros anuales ${ }^{193}$. Es preciso señalar que los principales países exportadores de tolueno son: Corea del Sur, los Países Bajos y Alemania. Mientras que entre los principales países importadores se encuentran: los Estados Unidos de América, Alemania, China, los Países Bajos y la India ${ }^{194 .}$

Para concluir queremos señalar que la mayoría de las incautaciones notificadas de varios de los ácidos y disolventes, antes citados, que son necesarios en las distintas fases de casi todas las operaciones ilícitas de drogas (cocaína, heroína y estimulantes de tipo anfetamínico), se realizan en los principales países productores de cocaína (el Estado Plurinacional de Bolivia, Colombia y el Perú) donde se efectuaron entre el $27 \%$ y $54 \%$ de las incautaciones mundiales de éter etílico, ácido clorhídrico, metiletilcetona, tolueno y ácido sulfúrico, así como el $90 \%$ de las incautaciones mundiales de acetona. Sin embargo hay que señalar que los decomisos de estos ácidos y disolventes, en estos países, han experimentado cierta disminución, lo cual responde en gran medida a que los disolventes se reciclan cada vez más y se reutilizan varias veces. Además, en la fabricación de cocaína cada vez se usan con mayor frecuencia disolventes no fiscalizados, como el acetato de etilo y el acetato de $n$-propilo, el cloruro de metileno y el alcohol isopropílico, en lugar de los incluidos en el Cuadro II, especialmente en la última fase de elaboración, en el que la cocaína base se transforma en clorhidrato de cocaína. Prueba de ello son los análisis de muestras de cocaína incautadas en el año 2013 que confirmaron la utilización de disolventes a

193 Precursores y sustancias químicas frecuentemente utilizados..., correspondiente a 2009..., pp. 37-50, 51-62. Precursores y sustancias químicas frecuentemente utilizados..., correspondiente a 2014..., pp. 93-107. Vid., en el Anexo III las incautaciones de tolueno realizadas en España del año 1993 al año 2014.

194 http://www.smartexport.com/es/Tolueno.290230.html 
base de acetato en casi el 75\% de las muestras analizadas. En el caso de la utilización de estas sustancias catalogadas del Cuadro II (solventes y disolventes) en la elaboración de heroína y los estimulantes de tipo anfetamínico, tenemos que admitir que no se tiene la suficiente información disponible para poder realizar una valoración sobre su evolución. 

CAPITULO III

\section{FISCALIZACIÓN INTERNACIONAL DE PRECURSORES} DE ESTIMULANTES DE TIPO ANFETAMÍNICO

\section{PRECURSORES UTILIZADOS EN LA FABRICACIÓN ILÍCITA DE ES- TIMULANTES DE TIPO ANFETAMÍNICO (ETA)}

En el mes de junio del año 2002 se celebró una reunión internacional organizada por la JIFE en Washington, D.C., a la cual asistieron representantes de las autoridades reguladoras y de represión de todos los principales países fabricantes y exportadores, países de tránsito e importadores de los precursores de los estimulantes de tipo anfetamínico, así como de aquellos en los que se producen los desvíos o la fabricación ilícita de esas sustancias. En total estuvieron presentes en la reunión 38 Estados y un territorio, así como la Comisión Europea, la Oficina Europea de Policía (Europol), la Organización Internacional de Policía Criminal (Interpol), la Comisión Interamericana para el control de abusos de drogas (CICAD) de la OEA y el Programa de Naciones Unidas para la Fiscalización Internacional (PNUFID). En este evento se decidió iniciar un proyecto internacional voluntario denominado Proyecto Prisma cuya finalidad es la prevención de la desviación de las diferentes sustancias químicas catalogadas que se utilizan en la fabricación ilícita de estimulantes de tipo anfetamínico. Teniendo la misión este proyecto de prestar asistencia a los gobiernos en los siguientes aspectos: a) el desarrollo y la aplicación de mecanismos de trabajo y de procedimientos operacionales uniformes para fiscalizar y vigilar más eficazmente tanto el comercio internacional como la distribución nacional de este tipo de precursores, a fin de prevenir desviaciones de esas fuentes, y b) el desarrollo y la aplicación de mecanismos eficaces para facilitar la realización por parte de las autoridades de represión de investigaciones internacionales de seguimientos de las incautaciones, las desviaciones y el contrabando de los precursores de los estimulantes de tipo anfetamínico con miras a localizar la fuente de esos envíos ${ }^{1}$. 
En el mes de enero del año 2003 se iniciaron las actividades operacionales del Proyecto Prisma, iniciativa internacional destinada a hacer frente a las desviaciones de los cinco principales precursores utilizados en la fabricación ilícita de estimulantes de tipo anfetamínico, a saber, la efedrina, la seudoefedrina, la 1-2-fenil-2-propanona (P-2-P), la 3,4metilendioxifenil-2-propanona (3,4-MDP-2-P) y el safrol, así como los equipos utilizados en la fabricación ilícita de de estas drogas ${ }^{2}$. Este proyecto está dirigido por un grupo de tareas, el cual está compuesto por miembros que representan a las principales regiones geográficas: China, los Estados Unidos de América, los Países Bajos y Sudáfrica, así como la Comisión Europea, la Interpol y la Organización Mundial de Aduanas. Este grupo de tareas a su vez está apoyado por dos grupos de trabajo: a) el grupo de trabajo sobre precursores químicos, que está integrado por: Alemania, Australia, Bélgica, Brasil, Canadá, los Estados Unidos de América, Francia, India, México, los Países Bajos, Hong Kong (RAE de China), la República Checa y Sudáfrica. También participan en este grupo de trabajo representantes de los siguientes organismos intergubernamentales y regionales: Oficina de las Naciones Unidas contra la Droga y el Delito (UNODC), la JIFE (a través de su secretaría), Comisión Europea e Interpol, b) el grupo de trabajo sobre equipos en el cual participan representantes de los siguientes estados: Alemania, China, Eslovaquia, los Estados Unidos de América, India, los Países Bajos, el Reino Unido de Gran Bretaña e Irlanda del Norte, Sudáfrica y Tailandia. También participan representantes de la Oficina de las Naciones Unidas contra la Droga y el Delito, la JIFE (a través de su secretaria), la Comisión Europea, Europol y la Interpol ${ }^{3}$.

2 Destacamos entre las actividades operacionales de las autoridades competentes las siguientes: a) realización de investigaciones policiales de rastreo hasta la fuente de la maquinaria incautada para elaborar tabletas y b) realización de las actividades apropiadas de los casos en que se haya utilizado internet para desviar o intentar desviar precursores de estimulantes de tipo anfetamínico. Precursores y productos químicos frecuentemente utilizados..., correspondiente a 2003..., p. X, 10- 12.

3 La JIFE les envió una circular a todos los países participantes en la que les solicitaba que designaran una autoridad nacional central con el fin de garantizar un canal que posibilite el intercambio de información operacional urgente, al día 1. de noviembre del año 2004 ya lo habían hecho 88 gobiernos. Precursores y productos químicos frecuentemente utilizados..., correspondiente a 2004..., pp. 8, 28. 
La necesidad de establecer prioridades y de focalizar el uso de los recursos limitados de que se dispone en el Proyecto Prisma obliga a abordar el uso indebido de internet caso por caso. La información que se obtenga en este sentido se debe utilizar en el curso de las operaciones de rastreo hasta la fuente. Además al margen de este proyecto, la JIFE seguirá examinando la desviación de estupefacientes y sustancias psicotrópicas a través de las farmacias de Internet ${ }^{4}$. Hay que destacar que en los años 2004, 2005, 2006 en sus informes anuales, la Junta señaló que se necesitaba más información concreta sobre todas las sustancias que se utilizan para la fabricación ilícita de, una de las drogas de síntesis más importante, la metilenedioximetanfetamina (MDMA, conocida generalmente como éxtasis) y sus análogos. Por lo que recomendó no basarse sólo en los informes de las investigaciones y las incautaciones, sino, en particular, sobre el análisis químico de las muestras decomisadas de la droga final y de los precursores utilizados, lo cual cada vez tiene más importancia dado que los traficantes, especialmente los que elaboran MDMA, utilizan cada vez más precursores obtenidos de fuentes ilícitas, lo que puede permitir definir perfiles para identificar un producto químico concreto o una ruta 5 .

Es preciso destacar un análisis realizado por un grupo de expertos de la ONU que señalaron que existe la tendencia de que en los próximos años los cultivos de coca y de amapola ubicados en los países andinos y en el sudeste asiático se reduzcan paulatinamente en beneficio de las drogas sintéticas. Las razones de la expansión de los estimulantes de tipo anfetamínico son: a) su extendida aceptación entre la población joven; b) que las drogas de síntesis son más rentables que las de origen natural; c) los laboratorios de fabricación están mucho más cerca de los centros de consumo y los costes de producción son menores, y d) los precursores para elaborar este tipo de drogas se consiguen con mayor facilidad, ya sea en el mercado lícito o ilícito, que los necesarios para procesar las drogas de origen natural6. Para ilustrar la expansión de este tipo de dro-

Ibidem, p. 10.

$5 \quad$ Ibidem, pp. 2, 15. Precursores y productos químicos frecuentemente utilizados..., correspondiente a $2006 \ldots$, p. 17.

6 BERNAL CONTRERAS, Héctor Hernando. URRUTIA BERMÚDEZ, Isaac. Las Sustancias Químicas y el Tráfico de Estupefacientes. Tercera Edición. Ministerio del Interior y de Justicia. Dirección Nacional de Estupefacientes. Bogotá. 2006, pp. 157, 158. 
gas queremos señalar que el Observatorio Europeo de las Drogas y Toxicomanías afirma que en muchos países europeos, las anfetaminas (término genérico que incluye la anfetamina y la metanfetamina) o el éxtasis constituyen la segunda sustancia ilegal más consumida después del cannabis ${ }^{7}$, situación que es similar en el resto del mundo ${ }^{8}$.

Como ya señalamos antes en el mes de marzo del año 2006 la Junta puso en marcha de forma oficial el sistema de notificaciones previas a la exportación PEN Online. Desde el año 2006 al año 2014 un total de 45 países exportadores haciendo uso de este sistema realizaron un promedio de 4.537 notificaciones previas a la exportación anuales sobre remesas de sustancias utilizadas para la fabricación de estimulantes de tipo anfetamínico, verificándose la legitimidad de, al menos, 300 remesas por año, en diferentes países, con apoyo de la JIFE, lo que propicio la suspensión o incautación de una media 45 remesas anuales. Es necesario puntualizar que se ha producido un notable incremento del uso de este valioso instrumento para la prevención de la desviación de precursores, en este caso de estimulantes de tipo anfetamínico, pasándose de 3.143 notificaciones (2006-2007) a las 6.400 (2013-2014) lo que constituye un incremento de un poco más del doble de notificaciones enviadas, labor que sin lugar a dudas dificulta en alguna medida la actividad ilícita de los traficantes de precursores de drogas. No obstante, de más está decir que hay que potenciar el uso del sistema de notificaciones (PEN Online) en los países desarrollados, ya que algunos han

$7 \quad$ La producción mundial de anfetamina sigue concentrada en Europa, las mayores incautaciones de esta droga, por orden de importancia, en este continente se realizan en los Países Bajos, Bélgica, Polonia, Bulgaria, Turquía y Estonia. El problema de la drogodependencia en Europa. Informe anual 2012. Ed. Observatorio Europeo de las Drogas y las Toxicomanías. Luxemburgo. 2012, pp. 54, 55. En Europa los laboratorios de ETA son cada vez más complejos y emplean para la elaboración de estas drogas maquinaria industrial diseñada a medida, por lo que cuentan con una mayor capacidad de producción. Global SMART Update, volumen 7, marzo 2012. Informe global de monitoreo de drogas sintéticas 2012. Ed. UNODC. 2012, p. 3.

8 Después del cannabis los estimulantes de tipo anfetamínico (ETA) son las drogas más consumidas en todo el planeta, superando el consumo de cocaína y heroína. Desde el año 1990 más de 65 países han reportado la fabricación ilícita de ETA, y la cifra continua aumentando. Es importante destacar que la tercera parte de los ETA y la mitad de la metanfetamina incautada en todo el mundo en el año 2010 procedían de Asia Oriental y Sudoriental. Global SMART Update, volumen 7, marzo 2012. Informe global de monitoreo de drogas sintéticas 2012. Ed. UNODC. 2012, pp. 2, 3. 
importado cantidades significativas de precursores sin enviar las respectivas notificaciones, y en el caso de los países menos desarrollados deben prácticamente empezar a implementar el uso de este sistema, lo cual se evidencia en que las autoridades de varios países exportadores han comunicado la falta de respuesta de los países importadores, pues de esta debilidad se aprovechan los narcotraficantes ${ }^{9}$.

Queremos destacar que en el mes de diciembre del año 2011 se presentó un informe conjunto de Europol y el Observatorio Europeo de las Drogas y las Toxicomanías que señalaba que la escala y la complejidad de la fabricación de las drogas ilícitas en Europa se están incrementando. Así puede observarse en países de noroeste de Europa como los Países Bajos y Bélgica, en que se utiliza maquinaria industrial hecha a medida para fabricar anfetamina. Este equipo más moderno aumenta la capacidad de fabricación y por ende el rendimiento, elevándolo de cinco a ocho kilogramos de anfetamina por ciclo de fabricación a una cifra situada entre 30 y 40 kilogramos por ciclo. En la región del noreste, especialmente en Polonia, se informa de que la fabricación está aumentando, y que la capacidad de las instalaciones clandestinas de fabricación se ha incrementado de unos tres kilogramos por ciclo a una cifra entre cuatro y ocho kilogramos por ciclo ${ }^{10}$.

No queremos terminar este apartado sin subrayar en el marco del Proyecto Prisma el papel que jugaron la Operación Crystal Flow (de enero a junio 2007), la Operación Ice Block (de enero a septiembre del 2008) de las cuales haremos referencia mas adelante, y la Operación Pila (julio del 2009 a marzo del 2010), la cual estuvo centrada en el comercio mundial de efedrina, seudoefedrina, con especial atención a los preparados farmacéuticos, y sobre el comercio de P-2-P y del ácido fenilacético, generando importante información de inteligencia sobre los métodos del tráfico y las organizaciones. Información que vino a complementar considerablemente los conocimientos adquiridos gracias a las operaciones anteriormente citadas, además hay que destacar que se logró detectar la facilidad con la que algunos países importadores au-

$9 \quad$ Precursores y productos químicos frecuentemente utilizados..., correspondiente a 2007..., p. 8. Precursores y productos químicos frecuentemente utilizados..., correspondiente a 2014..., p. 19.

10 Global SMART Update, volumen 7, marzo 2012. Informe global de monitoreo de drogas sintéticas 2012. Ed. UNODC. 2012, p. 12. 
torizaban remesas incluso cuando el país exportador y la Junta hubieran manifestado sospechas sobre la licitud de las mismas. Como muestra del éxito de la Operación Pila cabe citar la información obtenida que permitió avanzar en algunas operaciones policiales. En total se detectaron un total de 40 remesas sospechosas; se suspendieron, detuvieron o decomisaron expediciones por el monto de más 12,8 toneladas y 199 millones de tabletas de efedrina y seudoefedrina, impidiéndose así la elaboración de hasta 11,5 toneladas de metanfetamina. Asimismo, se descubrieron remesas sospechosas de P-2-P, la gran mayoría de estas destinadas a Guatemala, lo que confirma que los países de Centroamérica se han convertido en destinos y puntos de tránsito importantes para los precursores que finalmente se convertirán en metanfetamina. Otra revelación de esta operación es el hecho de que los traficantes están utilizando sustancias no fiscalizadas, como los ésteres del ácido fenilacético para la elaboración de las anfetaminas ${ }^{11}$. A continuación pasamos a analizar las diferentes sustancias catalogadas que se utilizan en la fabricación ilícita de los estimulantes de tipo anfetamínico.

A.) PRECURSORES QUE SE EMPLEAN EN LA ELABORACIÓN DE ANFETAMINA Y METANFETAMINA (ANFETAMINAS)

\section{Efedrina y seudoefedrina}

Iniciamos este apartado recordando que la efedrina y la seudoefedrina se utilizan en la elaboración ilícita de la anfetamina, la metanfetamina y la metcatinona. Sobre las acciones desarrolladas para evitar el desvío o la fabricación ilícita de estos precursores de drogas hay que decir que en el año 1999 se decomisaron más de 18 toneladas de efedrina a nivel mundial, realizándose las mayores incautaciones en Asia Meridional y Sudoriental, regiones en donde se fabricaba la mayor parte de esta sustancia catalogada y donde la metanfetamina tradicionalmente ha sido objeto de uso indebido. Nos referimos particularmente a China, la India y Myanmar donde se realizaron la mayor parte de los decomisos de esta sustancia, situación que se mantuvo en el año 2000 (en este periodo las incautaciones siguieron consistiendo en muchas remesas pequeñas de efedrina desviadas de los canales de distribución interna e introdu- 
cida de contrabando en las zonas donde se fabrica metanfetamina de forma ilícita). Es preciso señalar que tanto China, uno de los principales países exportadores de estas sustancias, como la India desarrollaron grandes esfuerzos durante los años 1999 y 2000 para prevenir esas desviaciones. El Gobierno de China formuló directrices nacionales para el control de la fabricación, venta, utilización y exportación de la efedrina, y en la India, la fabricación y distribución de esta sustancia está regulada por la Ley sobre estupefacientes y sustancias psicotrópicas, que preceptúa penas de hasta 10 años de prisión para sus infractores. Por otra parte los Estados Unidos de América comunicaron la incautación de un millón de unidades de efedrina en el año 1999, lo que representa 17 kilogramos de la sustancia; esto fue un indicio de que los traficantes no podían obtener este precursor, o al menos tenían dificultades para su obtención, y por ello empezaron a recurrir a preparados farmacéuticos que contienen efedrina y seudoefedrina, además las autoridades de este país decomisaron 425 kilogramos de efedrina y tres toneladas de seudoefedrina ${ }^{12}$.

Hay que destacar que en el año 2001 se incautaron 50 millones de tabletas de seudoefedrina en la frontera de los Estados Unidos de América con Canadá. Siendo necesario precisar que en América del Norte esta sustancia seguía siendo el producto químico preferido para su utilización en la elaboración ilícita de metanfetamina, también se conoció de la introducción de pequeñas cantidades de seudoefedrina a los Estados Unidos de América desde México ${ }^{13}$. La influencia de los controles

12 Precursores y productos químicos frecuentemente utilizados.., correspondiente a 2000..., pp. 25-28. Precursores y productos químicos frecuentemente utilizados..., correspondiente a 2001., pp. 22, 23. Precursores y productos químicos frecuentemente utilizados..., correspondiente a 2004..., p. 4. Vid., en el Anexo V grafico sobre la utilización de la efedrina y la seudoefedrina en la elaboración de anfetamina y metanfetamina.

13 Precursores y productos químicos frecuentemente utilizados..., correspondiente a 2001..., p. 23. Precursores y productos químicos frecuentemente utilizados..., correspondiente a $2002 \ldots$, p. 28. A raíz de las importantes desviaciones de Canadá a los Estados Unidos de América de tabletas que contenían seudoefedrina que se produjeron en los años 2001 y 2002. El Gobierno de Canadá promulgó en el mes de enero del año 2003 una Ley destinada a impedir la desviación de precursores de drogas. Inmediatamente antes de que esa legislación entrará en vigor, los traficantes canadienses realizaron una serie de intentos de desviación de efedrina hacia el Canadá, cursando pedidos en China, Alemania, la India, los Países Bajos y el Reino Unido de Gran Bretaña e Irlanda del Norte. En todos estos casos se presentó con el pedido una carta falsa, procedente supuestamente del Ministerio de Sanidad de Canadá, en la que se indicaba que no había objeciones para 
internacionales en la disponibilidad de partidas ilícitas de la efedrina y la seudoefedrina resulta más clara cuando se estudian los procedimientos que los narcotraficantes se ven obligados a utilizar para obtener incluso pequeñas cantidades de precursores para elaborar las denominadas drogas de diseño. En los Estados Unidos de América los fabricantes de metanfetamina empleaban empresas postales privadas ubicadas en el exterior donde se pueden recoger las remesas para introducirlas posteriormente en los Estados Unidos, también usaban intermediarios que compraban las tabletas en un país vecino para introducirlas de contrabando por la frontera, además se informo sobre robos de seudoefedrina realizados por empleados corruptos en empresas de productos químicos, así como de robos a mano armada en esas empresas ${ }^{14}$.

En el año 2002 reportaron incautaciones de efedrina en la India y Myanmar, proveniente de desviaciones de esta sustancia de los canales de distribución interno de China. También se comunicaron varios decomisos en Australia, debiendo destacarse un envío de 550 kilogramos que se interceptó cuando los traficantes trataban de introducirlo de contrabando en el país procedente de Yugoslavia, país que no fabrica efedrina. Las investigaciones de las autoridades aduaneras de Australia revelaron que los traficantes involucrados formaban parte de un grupo muy bien organizado, que sobornaba a empleados de empresas legítimas a fin de que colaboraran en las operaciones de contrabando, siendo este el primer caso de contrabando de efedrina de Europa a Oceanía del cual se tuvo noticia. Además hay que decir que este año aumentaron en Europa las incautaciones de preparados farmacéuticos que con-

que se realizara la transacción. Los seis pedidos sumaban más de seis toneladas de la sustancia. Sin embargo gracias a los mecanismos operativos que se pusieron en marcha para verificar la legitimidad de las expediciones de efedrina en el comercio internacional, todos los envíos fueron detenidos con excepción de 300 kilogramos exportados desde los Países Bajos. Precursores y productos químicos frecuentemente utilizados.., correspondiente a $2003 \ldots$, pp. 21, 22.

14 Precursores y productos químicos frecuentemente utilizados..., correspondiente a 2000 ..., p. 28. Canadá es uno de los principales países importadores de seudoefedrina, que hasta el año 2004 envío su primer informe a la JIFE sobre sus necesidades legitimas y el comercio lícito de esta sustancia, situación similar presentaba Pakistán otro gran importador de este precursor. Precursores y productos químicos frecuentemente utilizados.., correspondiente a 2004... p. 4. 
tienen efedrina ${ }^{15}$. Por otra parte las autoridades competentes de México reportaron, en este mismo año, la incautación de tres toneladas de seudoefedrina, la mayor registrada hasta la fecha. Posteriormente decomisaron 4,2 millones de tabletas que contenían seudoefedrina (equivalente a más de 250 kilogramos de esta sustancia) cuando se hizo el intento de presentar una falsa declaración de la expedición desde Hong Kong (RAE de China). Este decomiso notificado por México se hizo al mismo tiempo que otras incautaciones realizadas en los meses de marzo y abril de 2003, cuando se produjo en los Estados Unidos de América el decomiso de dos remesas, cada una de ellas de 8 millones de tabletas de seudoefedrina (equivalente a más 500 kilogramos de esta sustancia), y una incautación en Panamá de una remesa de 4,8 millones de tabletas (equivalente casi a 300 kilogramos de seudoefedrina). Es necesario destacar que en todos los casos, la expedición se había declarado como "medicinas" y se había hecho con un nombre comercial. Las remesas habían sido expedidas desde Hong Kong (RAE de China) y circulaban en tránsito por los Estados Unidos de América en ruta hacia México, también se informo en este periodo de incautaciones de tabletas que contenían efedrina o seudoefedrina por países europeos, tal es el caso de Bulgaria, Finlandia y Noruega ${ }^{16}$.

En el año 2003 hay que poner de relieve el caso de Filipinas donde incautaron más de 4 toneladas de efedrina, cuando las autoridades de este país localizaron tres lugares que se utilizaban para almacenar ilegalmente esta sustancia y desmantelaron posteriormente cuatro laboratorios clandestinos que fabricaban metanfetamina. La efedrina incautada había sido en todos los casos reenvasada en bolsas de 25 kilos, que habían sido también etiquetadas nuevamente. Este año las autoridades de la India también desmantelaron una importante red responsable de la desviación de al menos 2,6 toneladas de esta sustancia catalogada ${ }^{17}$. Este año la JIFE recomendó a los gobiernos de Asia Meridio-

Precursores y productos químicos frecuentemente utilizados..., correspondiente a 2000..., pp. 30, 31. También informaron sobre incautaciones de efedrina en el periodo 20012002 los siguientes países: Eslovaquia, Estonia, Finlandia, Letonia, Lituania, el Reino Unido de Gran Bretaña e Irlanda del Norte, la República Checa, Suecia y Ucrania. Precursores y productos químicos frecuentemente utilizados.., correspondiente a 2002..., p. 27.

16 Precursores y productos químicos frecuentemente utilizados..., correspondiente a 2003..., pp. 20, 21. 
nal y Sudoccidental que incrementaran la vigilancia sobre el ácido fenilacético, dado que los traficantes en vistas de las fuertes medidas de control desarrolladas sobre la efedrina y la seudoefedrina estaban tratando de desviar otras sustancias catalogadas para la fabricación de drogas de tipo anfetamínico (tal es el caso de la P-2-P y el ácido fenilacético). Al llamado de atención de la JIFE respondieron satisfactoriamente los países de la región obteniendo buenos resultados ${ }^{18}$. Siempre en el año 2003 en Sudáfrica fueron desmantelados 16 laboratorios dedicados a la fabricación ilícita de metcatinona. Las investigaciones realizadas en estos laboratorios revelaron que se utilizaba efedrina como precursor y como agente oxidante dicromato sódico (sustancia no catalogada) en vez de permanganato de potasio. Es preciso señalar que los laboratorios tenían un tamaño reducido y lo más curioso es que la efedrina se obtenía desviándola a partir de preparados farmacéuticos comprados en farmacias de venta al público ${ }^{19}$.

En el año 2004 Canadá reportó la incautación de ocho toneladas de seudoefedrina que constituyó el decomiso más grande notificado por cualquier gobierno este año, lo cual se puede atribuir a la promulgación en ese país de la legislación necesaria para tal efecto, lo que permitió a los organismos represivos tomar medidas contra los traficantes identificados, gracias a investigaciones de seguimiento y rastreo, que habían importado grandes cantidades de esta sustancia a Canadá para introducirla de contrabando a los Estados Unidos de América antes de que se promulgara esa legislación. Además en Canadá, se descubrió un caso de intento de desvío de una tonelada de seudoefedrina a Italia y tres remesas de preparados farmacéuticos (600.000 tabletas equivalentes 100 kilogramos) que contenían seudoefedrina a Panamá. Hay que señalar que Australia también notificó sus mayores incautaciones de seudoefedrina este año y que realizaron una operación conjunta en la que participaron autoridades australianas, filipinas y chinas que dio por resultado la incautación de una tonelada y media de seudoefedrina dos intentos de desviación de dos y cuatro toneladas de P-2-P de China a Vietnam a través de la Región Administrativa Especial de Hong Kong de China. Precursores y productos químicos frecuentemente utilizados..., correspondiente a 2004, p. 20. 
en Filipinas. Esta remesa había sido importada desde China a Filipinas para introducirla de contrabando a Australia en partidas de 500 kilogramos utilizando aeronaves ligeras ${ }^{20}$.

Un dato muy llamativo fue reportado por la autoridades de Australia, las cuales detectaron un nuevo método para pasar efedrina de contrabando, este se descubrió en el aeropuerto de Perth, y consistió en impregnar con efedrina cuatro remesas de 20 toallas de baño. El hecho de que los traficantes de precursores estén utilizando métodos que normalmente se asocian con el contrabando de drogas, enmascaramiento de sustancias en objetos comunes en el equipaje de viajeros o de comercio cotidiano, indica hasta que punto las medidas de fiscalización de estas sustancias en el comercio internacional se están mostrando eficaces en la prevención de tales desviaciones. En este mismo país se reportó un importante decomiso de efedrina que había sido pasada de contrabando desde Yugoslavia en una partida de baldosas ${ }^{21}$, así mismo, fue desmantelada un red que trataba de introducir 750 kilogramos de seudoefedrina de Tailandia a Australia cuando las autoridades de este país descubrieron la sustancia oculta en placas decorativas para paredes ${ }^{22}$.

En el año 2004 las autoridades competentes de Sudáfrica desmantelaron 28 laboratorios ilícitos que elaboraban metanfetamina o metcatinona. El número de esos laboratorios continuó aumentando en el año 2005. Otro motivo de preocupación que surgió este año fueron los intentos de desviación de efedrina y seudoefedrina que se descubrieron en toda África, en particular en Angola, Kenia, Mozambique y la República Democrática del Congo. Las autoridades españolas prestaron asistencia a la JIFE para interceptar un desvío de 26 toneladas de seudoe-

$20 \quad$ Precursores y productos químicos frecuentemente utilizados..., correspondiente a 2004..., p. 16. El gobierno de Canadá por recomendaciones de la JIFE promulgo en el año 2003 un amplio marco regulatorio para la fiscalización de precursores, que incluía los productos farmacéuticos que contenían esas sustancias, como resultado, el volumen de seudoefedrina importado al Canadá volvio a los niveles necesarios para atender finalidades legítimas. Precursores y productos químicos frecuentemente utilizados..., correspondiente a 2005..., p. 2.

21 Precursores y productos químicos frecuentemente utilizados..., correspondiente a 2003..., p. 21.

22 Precursores y productos químicos frecuentemente utilizados..., correspondiente a 2004..., p. 17. 
fedrina de un pedido realizado en España, supuestamente por una empresa de la República Democrática del Congo ${ }^{23}$. En este mismo año las autoridades de Filipinas desarticularon una red de traficantes que operaba en todo el país y, además de incautar 1.700 kilogramos de seudoefedrina durante la operación, lograron decomisar 4.000 kilogramos de efedrina en operaciones dirigidas contra laboratorios ilícitos. En Europa aunque aumentaron las incautaciones de efedrina y seudoefedrina, estas no suelen ser de cantidades muy grandes. Cabe destacar que en Grecia se decomisaron 1.100 kilogramos de efedrina que estaban siendo introducidos de contrabando ocultos en un cargamento de arroz proveniente de Pakistán. ${ }^{24}$.

Como es sabido la fabricación ilícita de metanfetamina es motivo de gran preocupación en los Estados Unidos de América y el Canadá, donde con frecuencia se desmantelan varios de los denominados "súper laboratorios" (con capacidad de fabricar más de cinco kilogramos de droga en 24 horas), además de un gran número de pequeños laboratorios domésticos. Ha quedado demostrado que muchos de esos laboratorios ilegales se abastecen de tabletas y combinaciones de productos que contienen seudoefedrina. Se cree que por las medidas de control implementadas en los Estados Unidos de América algunos traficantes han trasladado sus operaciones a México, país donde se destruyeron más de 30 laboratorios de metanfetamina en el año 2004. Como suele ocurrir cuando se introducen medidas adecuadas de control en un país, tal es el caso de México, los traficantes de inmediato reaccionaron centrando sus esfuerzos en países de otras regiones donde los controles eran menos eficientes; así se detectaron pedidos de preparados farmacéuticos que contenían seudoefedrina a países de Asia Sudoriental, y se descubrieron intentos de desviar 3.000 kilogramos de efedrina y 3.000 kilogramos de seudoefedrina a través de Belice y 350.000 tabletas de seudoefedrina a través de Nicaragua, los cuales seguramente los traficantes pretendían pasar de contrabando a México. Al mismo tiempo en este país los intermediarios estaban haciendo también en Europa pedidos de seudoefedrina a granel. De estos se detuvieron tres remesas provenientes de Suiza (siete toneladas de seudoefedrina), cuatro envíos

23 Precursores y productos químicos frecuentemente utilizados..., correspondiente a 2005..., p. 4.

$24 \quad$ Ibidem., p. 5. 
provenientes de Alemania y la India (20 toneladas de seudoefedrina), más otras 23 toneladas de esta sustancia provenientes de otros países ${ }^{25}$.

En el mes de marzo del año 2005 el grupo de trabajo del Proyecto Prisma realizó una serie de medidas contra la desviación de las sustancias catalogadas antes mencionadas a América del Norte. Entre ellas se destacan el envío de notificaciones previas a la exportación por las autoridades competentes de algunos de los principales países exportadores de preparados farmacéuticos que contienen seudoefedrina destinados a América del Norte, así como la elaboración de un marco para realizar una evaluación subregional de las necesidades legitimas del precursor antes mencionado por parte de Canadá, los Estados Unidos de América y México. También hay que señalar que se fortalecieron las medidas de control por las autoridades competentes de los Estados Unidos de América y Canadá sobre los envíos de efedrina. Todas las medidas adoptadas posiblemente influyeron en que las importaciones tanto de efedrina como seudoefedrina en América del Norte y México disminuyeran, y como consecuencia de esto se registraron aumentos de las exportaciones de estos precursores a países de otras regiones cercanas, tal es el caso de Centroamérica y América del Sur, y en menor medida a países de África y Asia ${ }^{26}$.

En lo que se refiere al tráfico ilegal de las efedrinas (efedrina y seudoefedrina), hay que decir que en el año 2005 se incautaron más de cuarenta toneladas de ambos precursores en 26 países y territorios de todas las regiones, a saber: Alemania, Australia, Bulgaria, Canadá, China, la RAE de Hong Kong (China), Eslovaquia, Finlandia, Francia, Grecia, Hungría, Indonesia, Islandia, la Federación de Rusia, la República Checa, Letonia, los Estados Unidos de América, México, Myanmar, Noruega, Nueva Zelanda, Rumania, Sudáfrica, Tailandia, Ucrania y Zambia, lo que pone de manifiesto la complejidad del enfrentamiento a la fabricación ilícita de metanfetamina. La actividad operacional realizada en el Proyecto Prisma permitió conocer las nuevas tendencias del trafico ilícito de estas sustancias, las cuales se pueden resumir en: la desviación y el contrabando de materias primas de Asia Meridional a África, América

$25 \quad$ Ibidem., pp. 4, 5.

Precursores y productos químicos frecuentemente utilizados..., correspondiente a 2006..., pp. 12, 13. 
Central y Asia Occidental, el contrabando de remesas de efedra de Asia Oriental al Canadá y países de Europa, así como el contrabando de preparados farmacéuticos con destino a América Central, América del Sur, África y Asia Occidental. Otra tendencia que se viene observando en América del Norte es la utilización de ácido fenilacético como sustitutivo de la efedrina o la seudoefedrina en la elaboración de metanfetamina, lo cual es la repuesta de los traficantes al férreo control que hay en esa región de estas dos sustancias ${ }^{27}$.

Sobre África es conveniente señalar que desde el año 2005 se informaron incautaciones de efedrina y seudoefedrina en Sudáfrica y Zambia. Las incautaciones de efedrina en Sudáfrica disminuyeron en este año, pero continuó aumentando la fabricación clandestina de metcatinona y metanfetamina, en reemplazo de la decreciente fabricación de metacualona. Mientras que en el año 2006 se descubrieron tentativas de desviación de grandes cantidades de efedrina a través de Kenia, con pedidos de diez toneladas hechos en Canadá y la India, también se interceptaron varios cargamentos destinados a Angola, Ghana, la República Democrática del Congo y Zimbabwe lo que evidencia que los países africanos se utilizan como lugares de reexpedición de las remesas de efedrina y seudoefedrina organizadas por redes internacionales de traficantes y destinadas a Norteamérica. Esta información se verifico con pruebas como la incautación de 300 kilogramos de seudoefedrina en Bélgica en el año 2006. La sustancia incautada provenía de la República Democrática del Congo y se introdujo de contrabando por vía aérea en Bélgica, estando destinada a México ${ }^{28}$.

En el caso de América hay que decir que las incautaciones de efedrina y seudoefedrina disminuyeron notablemente en los Estados Unidos de América pasando de 175 toneladas en el año 2004 a 1,5 toneladas en el año 2005, siendo esta la menor cantidad anual que se ha notificado desde el año 1992. En México también disminuyeron las incautaciones en gran medida, mientras en el año 2006 continuaron los intentos de desviación de estos precursores en Centroamérica y América del Sur. A manera de ejemplo citamos que las autoridades de la India interceptaron una remesa de cinco toneladas de efedrina y otra de 2,5 toneladas 
de seudoefedrina, destinadas ambas a Belice. Siempre en este mismo año se detecto un caso de tentativa de desviación desde la India de media tonelada de efedrina destinada a Santa Lucia (isla del caribe), descubriéndose también un caso de intento de desviación de efedrina a Paraguay. Así mismo los gobiernos de Colombia, Costa Rica y El Salvador detectaron intentos de desviación de estas sustancias catalogadas en forma de preparados farmacéuticos. Mientras que en Asia la mayor parte de la efedrina incautada correspondió a China, Indonesia y Myanmar. Por otra parte hay que señalar que en el año 2006 sociedades de Asia Occidental realizaron pedidos sospechosos de efedrina y seudoefedrina, así como preparados de estas sustancias, que sumaban una cantidad considerable de toneladas, muestra de ello fue un envío de 50 toneladas de efedrina de la India a Irak, envío que fue interceptado tras descubrirse que se utilizaba una sociedad fachada y un permiso de importación falsificado ${ }^{29}$.

Las incautaciones de efedrina en Europa aumentaron en el periodo 2005- 2006 en relación con el año anterior. Realizándose decomisos de este precursor en 14 países, los más destacados se realizaron en Alemania, Bulgaria, la Federación de Rusia, Grecia y Rumania. Investigaciones realizadas sobre las incautaciones de efedrina en la República Checa y de tabletas de efedrina en Eslovaquia indicaron que en los dos casos las remesas se utilizaban en la elaboración ilícita de drogas de tipo anfetamínico. También en este periodo se incrementaron los decomisos de efedrina y seudoefedrina en Oceanía, de los volúmenes incautados la mayor parte correspondió a la efedrina, introducida de contrabando en Australia desde Sudáfrica y Vietnam, y a la seudoefedrina incautada en Nueva Zelanda. En ambos países los preparados farmacéuticos fueron la principal fuente de la seudoefedrina incautada en la frontera y en laboratorios clandestinos. El contrabando y el uso de correo fueron los métodos utilizados por los traficantes para introducir los preparados de este precursor de drogas ${ }^{30}$. A lo largo del año 2006 las autoridades australianas continuaron reforzando las medidas de control de abastecimiento a minoristas de medicamentos que contuvieran seudoefedrina, utilizando para tal propósito el Proyecto Stop, que es un sistema de inteligencia que permite vigilar en tiempo real las ventas de 
medicamentos que contienen seudoefedrina en las farmacias minoristas. El sistema ayuda a los farmacéuticos a determinar, sobre la base de las compras recientes, si los clientes tienen una necesidad médica legítima de los medicamentos que desean comprar, y proporciona también a la policía información de inteligencia sobre actividades ilícitas. Este proyecto se comenzó a implementar a nivel nacional en el año 200731.

Como respuesta al aumento observado en el año 2006 del envío de remesas sospechosas de efedrina y seudoefedrina hacia países de África, América Central, América del Sur y Asia Occidental, el grupo de tareas del Proyecto Prisma inicio el día 1. de enero del año 2007 una operación de seis meses de duración con objetivos delimitados denominada operación Crystal Flow, en esta operación se utilizó en la comprobación de las notificaciones previas a la exportación a través del sistema PEN Online en relación con la efedrina y la seudoefedrina, la efedra y preparados farmacéuticos afines. En el curso de la operación los países participantes verificaban la legitimidad de los importadores y de los usuarios finales, lográndose detectar transacciones sospechosas, la información sobre estas fue comunicada a los miembros del grupo de tareas de la región respectiva, con el fin de iniciar labores de rastreo de las incautaciones y las remesas detenidas. Siempre que fue posible se realizaron entregas vigiladas. La secretaria de la JIFE actuó como centro coordinador. En la operación participaron un total de 65 estados de África, América, Asia Occidental y todos los principales países exportadores y de transito de los precursores antes señalados. Durante la misma los organismos competentes de 22 países y territorios suministraron información sobre 1.399 remesas despachadas en el comercio internacional. Las remesas estaban destinadas a 119 países o territorios y su volumen total ascendía 153,43 toneladas de efedrina y 652 toneladas de seudoefedrina. La Junta inicio indagaciones sobre la legitimidad de 187 de esas remesas con gobiernos de 54 estados, lo que permitió detectar 35 transacciones sospechosas. Se logró determinar que el destino real o probable de la mitad de estas transacciones era México. Como resultado se detuvieron o incautaron remesas por un volumen total de 53 toneladas de efedrina y seudoefedrina, cantidad que habría sido suficiente para fabricar aproximadamente 48 toneladas de 
metanfetamina. En el marco de esta operación también se pudo establecer que el incremento de vigilancia sobre la efedrina y la sudoefedrina ha llevado a los traficantes a obtener sustancias que no están incluidas en los cuadros, por lo cual la JIFE hizo un llamado a las autoridades competentes de todos los países y territorios para que establecieran mecanismos adecuados para detectar transacciones sospechosas de estas sustancias no catalogadas ${ }^{32}$.

Precisamente sobre este tema en el año 2007 la Junta informó a los participantes en el Proyecto Prisma, mediante alertas especiales, de las sustancias no incluidas en los cuadros que se utilizaban en los laboratorios de metanfetamina clandestinos. Ejemplo de ello es que en México las autoridades competentes decomisaron casi 20 toneladas de un derivado de la efedrina no sujeto a fiscalización, el acetato de $N$-acetil pseudoefedrina. Las autoridades de Sudáfrica también informaron a la Junta de intentos de producción de efedrina a partir de N-metil-DLalanina. En el mes de abril del año antes señalado las autoridades competentes de Camboya desmantelaron un gran laboratorio de fabricación ilícita de metanfetamina que venia utilizando cloruro de tionilo como reactivo. Para enfrentar tal situación la JIFE recomendó la atención de todos los gobiernos a "la lista limitada actualizada de vigilancia especial internacional de las sustancias no incluidas en los Cuadros", que fue publicada en junio del año 2007 para su utilización por parte de los organismos reguladores y de represión, con el fin de que los gobiernos aseguren los mecanismos adecuados para verificar la legitimidad de las transacciones en que se comercializan dichas sustancias ${ }^{33}$. Como ya hemos venido señalando a lo largo de este capítulo probablemente por el fortalecimiento de las medidas de control en muchas regiones, particularmente en América del Norte, Asia Oriental y Oceanía, los fabricantes de drogas se han visto obligados a buscar precursores alternativos para producir metanfetamina. La Junta ha recibido información que confirma que elementos de la delincuencia organizada han fijado su atención en el l-fenilacetilcarnibiol, sustancia que se utiliza como producto intermedio

$32 \quad$ Ibidem., pp. 6, 7.

33 Precursores y productos químicos frecuentemente utilizados.., correspondiente a 2007..., p. 13. 
para la fabricación industrial de efedrina, y están tratando de adquirir la sustancia en los países productores de la misma ${ }^{34}$.

Los países importadores y exportadores que participaron en la operación Cristal Flow reportaron a la Junta remesas por más de 120 toneladas $(17,8$ toneladas de efedrina y 103,6 toneladas de seudoefedrina) de las que se tenía sospecha de que iban a ser utilizadas para la fabricación ilícita de metanfetamina. Es preciso señalar que durante el desarrollo de la operación únicamente se descubrió un caso relacionado con la efedra (sustancia natural con la que se puede elaborar efedrina o seudoefedrina). La mayoría de las remesas sospechosas detectadas durante la operación se estaban enviando a países de África y Asia Occidental o pasando de contrabando a través de esos países, y una cantidad relativamente limitada de estas remesas se estaba enviando directamente a América. Es preciso subrayar que se detectaron muchos casos de intentos de desviación de efedrina y seudoefedrina en los siguientes países: Burundi, Egipto, Emiratos Árabes Unidos, Etiopía, Ghana, Guayana, República Islámica del Irán, Irak, Kenia, México, Nigeria, República Árabe Siria, República Democrática del Congo, República Unida de Tanzania, Somalia, Sudáfrica y Sudán, por lo que la Junta recomendó a los países productores y de transito de estas sustancias que no autoricen los envíos de remesas a África, América y el Asia Occidental hasta que no se haya comprobado debidamente su legitimidad. Otro elemento a destacar es que como las medidas de control en América del Norte son cada vez son más eficientes, los traficantes han buscado nuevas formas para abastecer de materias primas los laboratorios de la región, para lo cual utilizan el contrabando y la desviación de esas sustancias de las redes de distribución interna, siendo este uno de los métodos más utilizados. En vista de que prácticamente en todos los países del mundo las autoridades competentes están sometiendo los pedidos de precursores a un creciente escrutinio, los productores de drogas han optado por hacer pedidos de preparados farmacéuticos que contienen efedrina o seudoefedrina a empresas legítimas, supuestamente para enviarlos a países en vías de desarrollo. Esto porque en muchos de estos países los controles sobre estos preparados son menos estrictos o simplemente no existen, lo cual hace más fácil a los traficantes in- 
troducir posteriormente las remesas de contrabando en América del Norte y otras regiones ${ }^{35}$.

En el caso del continente africano la JIFE se mostró preocupada por que esta se ha convertido en una importante zona de desviación de precursores de estimulantes de tipo anfetamínico. Durante el periodo 2006-2007 los participantes en el Proyecto Prisma y la operación Crystal Flow detectaron muchas remesas sospechosas destinadas a África, desde donde debían de ser desviadas a América del Norte u Oceanía. En total se impidió la desviación de más de 75 toneladas de efedrina y seudoefedrina. Sólo en la República Democrática del Congo en el año 2007 se interceptaron siete remesas, cuyo volumen total era de 23 toneladas. Uno de los métodos más utilizados en la región fue la falsificación de permisos de importación, ejemplo de ello se presento en la República Islámica del Irán, donde se suspendió el envío de seis toneladas de seudoefedrina que se iban despachar a Somalia. El permiso de importación presentado autorizaba supuestamente la importación de 15 toneladas de efedrina y 15 toneladas de seudoefedrina. Sin embargo de acuerdo a los datos recibidos de los países importadores las necesidades legítimas de este país son de 100 kilogramos por año. Hay que recordar que Somalia al igual que varios estados africanos no están en condiciones de responder oportunamente a las notificaciones previas de exportación ni a las indagaciones sobre remesas sospechosas de precursores de drogas. También hay que decir que en África el número de incautaciones fue muy bajo en el periodo que va del año $2000 \mathrm{al}$ año 2006. Las incautaciones de seudoefedrina realizadas en la región ascendieron a 242 kilogramos, correspondiendo la mayoría de las mismas a Sudáfrica. País que fue el único que reporto en el año 2006 la incautación de 10 kilogramos de efedrina. Sin embargo, como ya señalamos antes, en la operación Crystal Flow, que sólo tuvo una duración de seis meses, se incautaron varias toneladas de seudoefedrina en el República Democrática del Congo, gracias a una eficaz entrega vigilada y a la cooperación de varios gobiernos participantes en el Proyecto Prisma ${ }^{36}$.

35 Precursores y productos químicos frecuentemente utilizados.., correspondiente a 2007..., pp. 9, 18.

$36 \quad$ Ibidem., p. 10. 
En reconocimiento de los resultados alcanzados y de la respuesta positiva de muchos gobiernos sobre la eficacia de la operación Cristal Flow, que se extendió del 1. de enero al 30 de junio del 2007, el grupo de tareas del Proyecto Prisma decidió proseguir y ampliar estas actividades con la finalidad de continuar con el intercambio de información sobre transacciones sospechosas e investigaciones de rastreo. La nueva iniciativa, denominada Operación Ice Block, se desarrolló del 2 de enero al 30 de septiembre del 2008. Esta operación se centró en el comercio de efedrina y seudoefedrina, incluidos los preparados farmacéuticos que contienen estas sustancias y en la efedra, así como el comercio de P-2-P y de ácido fenilacético en el que intervienen países de África, América, Asia Occidental y Oceanía. Como en ocasiones anteriores, el instrumento primario para identificar transacciones sospechosas fue el sistema PEN Online ${ }^{37}$. Esta operación por decisión del grupo de tareas del Proyecto Prisma se amplió hasta el año 2009 con los mismos objetivos ${ }^{38}$.

Durante el desarrollo de la operación la Junta examinó información sobre 2.057 expediciones de las sustancias sometidas a vigilancia. Estas remesas sumaban 201 toneladas de efedrina y más de 1.056 toneladas de seudoefedrina. Como resultado de este examen, la JIFE inició 219 indagaciones sobre la legitimidad de las transacciones. Lo que permitió identificar 49 transacciones sospechosas. Como consecuencia directa de la operación se logró incautar 49 toneladas de efedrina y seudoefedrina, cantidad que habría permitido fabricar entre 37 y 44 toneladas de metanfetamina. Además se pudo establecer que muchas remesas de precursores que tenían por destino América del Norte fueron desviadas en países de África, América Central y Asia Occidental, o por medio de ellos, mientras que Europa se utilizaba como zona de reexpedición, y que Oceanía se utilizaba también como punto de destino. Otro asunto que se logro determinar es que el tráfico de los preparados farmacéuticos que contienen efedrina y seudoefedrina continuaba siendo un problema de suma importancia ${ }^{39}$.

Precursores y productos químicos frecuentemente utilizados..., correspondiente a 2008..., p. 6. Precursores y productos químicos frecuentemente utilizados..., correspondiente a 2009..., p. 7.

39 En el desarrollo de la Operación Ice Block se identificaron 46 remesas sospechosas de efedrina o seudoefedrina. Estas remesas sumaban 12,9 toneladas de efedrina y 40 to- 
La Operación Crystal Flow vino a confirmar que los traficantes habían hecho pedidos de preparados farmacéuticos que contienen efedrina o seudoefedrina a empresas farmacéuticas legitimas del Asia Occidental, supuestamente para despacharlos a países en vías de desarrollo. Esto se produce por que las medidas de fiscalización de dichos preparados a menudo no existen o son poco estrictas. En el año 2007 una empresa farmacéutica registrada de los Emiratos Árabes Unidos importo 15 toneladas de seudoefedrina a granel para la fabricación de un preparado farmacéutico que supuestamente se iba a despachar a Kenia, sin embargo se logró constatar que dicha cantidad superaba con creces las necesidades legítimas anuales de este país. En otro caso una empresa legítima de la República Árabe de Siria había importado grandes cantidades de seudoefedrina en bruto. El preparado farmacéutico elaborado a partir de esta sustancia iba a ser exportado a México, los Emiratos Árabes Unidos y España. No obstante, ninguno de esos estados tenía conocimiento de las remesas ni las había autorizado, de hecho, el preparado farmacéutico ni siquiera estaba registrado en ninguno de esos países. Aunque no se sabe si las remesas llegaron realmente a su destino, se sospecha que fueron desviadas hacia canales ilícitos. En este periodo se incautaron 1,2 toneladas de efedrina a granel en la India, 1,3 toneladas en Myanmar y cantidades de menos de 100 kilogramos en Filipinas, Kazajistán y la República de Corea ${ }^{40}$.

En el año 2007 un total de 23 países reportaron incautaciones de efedrina que sumaron 21,8 toneladas, siendo Panamá el que informó sobre el mayor volumen de incautaciones (10 toneladas), seguido por China (5,8 toneladas) y México (3,7 toneladas). En contraste con la información recabada a través del Proyecto Prisma, que indicaban una desviación a gran escala de preparados farmacéuticos que contienen efedrina, únicamente nueve países comunicaron pequeños decomisos

neladas de seudoefedrina. El destino de casi la mitad de estas remesas era México. Las discrepancias que eixten en estos datos con los indicados arriba son propias del informe de la JIFE. Además la autoridades aduaneras de Alemania decomisaron una remesa de 535 kilogramos de polvo marrón de efedra, en transito desde la India cuyo destino final era también México. Precursores y productos químicos frecuentemente utilizados..., correspondiente a 2008..., , p. 6, 8.

$40 \quad$ Precursores y productos químicos frecuentemente utilizados..., correspondiente a 2007..., pp. 11,18 . Precursores y productos químicos frecuentemente utilizados..., correspondiente a 2008..., pp. XII, 8. 
de estos preparados, que en total sumaron 19 kilogramos. En este mismo año 15 países informaron sobre incautaciones de seudoefedrina, que sumaron 23,3 toneladas, encabezados por México (12,2 toneladas) y Francia (7 toneladas), y sólo siete países comunicaron incautaciones de preparados farmacéuticos que contienen seudoefedrina por un total de 395 kilogramos $^{41}$. Mientras que en el año 2008 un total de 23 países notificaron a la JIFE incautaciones de efedrina o seudoefedrina. El peso total comunicado de la efedrina bruta incautada fue de $12.637,47$ kilogramos y las mayores proporciones correspondieron a China (6.700 kilogramos) y a México (3.293 kilogramos). El resto de los decomisos de efedrina se realizaron en Australia (1.103 kilogramos), Myanmar (750 kilogramos), Filipinas (204 kilogramos), los Países Bajos (135 kilogramos), el Canadá (105 kilogramos) y los Estados Unidos de América (104 kilogramos). A diferencia del año anterior, en este mismo periodo, 17 países notificaron incautaciones de preparados farmacéuticos que contenían efedrina por un total de 861,1 kilogramos; Bélgica decomiso 810 kilogramos, Australia incauto 27,8 kilogramos y Nueva Zelanda 23,3 kilogramos. Los gobiernos también informaron en el formulario D de la incautación de 5.130 kilogramos de seudoefedrina bruta. México reporto la mayor cantidad decomisada (2.873 kilogramos), seguido de China (1.100 kilogramos), los Estados Unidos de América (602 kilogramos) y Francia (502 kilogramos). Un total de 17 países presentaron datos sobre incautaciones de preparados farmacéuticos que contenían seudoefedrina. Las autoridades mexicanas notificaron siete incautaciones, la mayor de ellas de 3.768 kilogramos de comprimidos provenientes de China. En Australia se incautaron dos envíos encubiertos de comprimidos, 850 kilogramos y 662 kilogramos respectivamente, provenientes de Tailandia, y en Nueva Zelanda se incautaron un total de 622 kilogramos, la seudoefedrina decomisada se encontraba en forma de gránulos, fabricados en principio para comercializarse en cápsulas, la mayoría de estas remesas provenían de China. Hay que destacar que aunque las cantidades incautadas de efedrina y seudoefedrina bruta que se notificaron son considerables, en opinión de la JIFE estos datos únicamente ofrecen una visión parcial de la importancia que tienen estas sustancias catalogadas en la fabricación ilícita de metanfetamina. A esto hay que agregar que la información que se recibe sobre los decomisos de estas sustancias mezcladas en forma 
de preparados farmacéuticos es bastante limitada, lo cual no permite valorar la importancia cada vez mayor en la fabricación de estimulantes de tipo anfetamínico ${ }^{42}$.

Se ha constatado que el continente africano continúa siendo una importante zona de desviación de precursores de estimulantes de tipo anfetamínico, a pesar de ello el número de incautaciones realizadas por los gobiernos de la región es sumamente bajo. En el año 2008 los participantes en el Proyecto Prisma y en la Operación Ice Block detectaron numerosas remesas destinadas a África pero que sospechaban tenían como destino final México. En total se impidió que se desviaran hacia África o a través de este continente más de 30 toneladas de efedrina y seudoefedrina. Se sabe que los traficantes utilizan compañías ficticias, licencias de importación y documentos empresariales falsificados para sus operaciones ilícitas. Ejemplo de ello ocurrió en Etiopía donde los traficantes intentaban expedir dos remesas de seudoefedrina y una remesa de efedrina, que sumaban un total de 12,5 toneladas. Dichas remesas iban acompañadas de unas licencias de importación falsificadas, afortunadamente fueron detenidas a petición de las autoridades de Etiopía. La República Unida de Tanzania de la misma manera fue víctima de la falsificación de permisos de importación, también hay que señalar que algunos países de África importan volúmenes de estas sustancias considerablemente superiores a los indicados en los informes como sus necesidades anuales ${ }^{43}$.

Otro elemento a destacar es que después que México prohibiera la importación de efedrina y seudoefedrina, las importaciones de varios países de América Central y América del Sur comenzaron a incrementarse de forma considerable. Guatemala, Honduras y Nicaragua fueron utilizadas por grupos criminales organizados para adquirir las sustancias y posteriormente pasarlas de contrabando desde los mercados internos hacia América del Norte, evitando de esta manera los controles establecidos y asegurando así el suministro necesario para las operaciones de fabricación ilícita de drogas. En el caso de América del Sur, la Junta advirtió a las autoridades argentinas del volumen cada vez más excesipp. 8, 9.

43 Precursores y productos químicos frecuentemente utilizados..., correspondiente a 2008..., pp. 8, 9 . 
vo de las importaciones de las sustancias catalogadas antes señaladas en los últimos años. En el año 2008 en este país se decomisaron 1.222 kilogramos de efedrina. En un caso se descubrió una remesa de 600 kilogramos de efedrina ocultos en un cargamento de azúcar que se iban a exportar a México. Además hay que decir que los informes señalan un incremento de las incautaciones de efedrina y seudoefedrina en América del Sur, habiéndose incautado en Perú grandes cantidades de tabletas de seudoefedrina. Una información que reviste gran interés es que en el mes de julio de este año se desmanteló el primer laboratorio de metanfetamina en la Argentina, lo cual constituye un claro indicio del creciente interés de las organizaciones de traficantes por obtener precursores de estimulantes de tipo anfetamínico en esta región ${ }^{44}$.

En el continente asiático también se han comunicado muchas incautaciones de efedrina y seudoefedrina, tanto en bruto como en preparado farmacéuticos. Ejemplo de ello es que en Myanmar en el año 2007 se decomiso media tonelada de efedrina en transito de Camboya a Australia. En la India se desmanteló en Mumbai un laboratorio clandestino que había participado en la extracción de tabletas de seudoefedrina con destino a Australia. Asimismo es preciso señalar que en los últimos cinco años se han destruido en Asia numerosos laboratorios clandestinos que se dedicaban a la fabricación ilícita de metanfetamina a escala industrial. Sobre las incautaciones de las sustancias catalogadas antes señaladas en Australia y Nueva Zelanda se puede afirmar que se mantiene la misma tendencia que en otras regiones, es decir, los traficantes se interesan cada vez más por lo preparados farmacéuticos para burlar las medidas de control establecidas para estas sustancias cuando se presentan bajo la forma de productos brutos. Un intento de desviación en Nauru (país no miembro del Convenio de 1998) demuestra la necesidad de que países y territorios de Oceanía aumenten la capacidad de los organismos gubernamentales de vigilar de forma adecuada el comercio de precursores de drogas dentro de la región ${ }^{45}$.

Entre enero y septiembre del 2008 en el marco de la Operación Ice Block la Junta logró detectar un total de 49 transacciones sospechosas relacionadas con el comercio internacional de efedrina y seudoefedrina 
bruta, la mayoría de estas remesas correspondían a materia prima y sólo 11 de ellas a preparados farmacéuticos. Después de este periodo se produjo un descenso considerable del desvío de estas sustancias en bruto del comercio internacional, así, el $70 \%$ de los casos de envíos sospechosos detectados se referirían a preparados farmacéuticos en forma de comprimidos. En muchos de casos las pastillas se habían envasado de forma tosca o parcialmente, o se habían enviado a granel por lo que no cabía duda de que su destino no era la venta en los canales comerciales farmacéuticos legítimos, lo cual demuestra que los narcotraficantes están explotando las reglamentaciones internacionales existentes respecto de esos precursores en esa forma. También se tiene información de que estos han realizado un importante cambio de las rutas de desviación de efedrina y seudoefedrina bruta desde la Operación Ice Block mediante la cual se estableció que África era la región en la que se produjo el mayor número desviaciones o intentos de desviación. Por el contrario en el año 2009 únicamente se detectaron dos casos de desviación en este continente, uno de 1.250 kilogramos de efedrina a la República Centroafricana y otro de 1.000 kilogramos de seudoefedrina a Kenia. Sin embargo en el mismo periodo se produjeron numerosos casos de envíos sospechosos a América Central, en casi todos ellos se trataba de efedrina o seudoefedrina en forma de preparados farmacéuticos ${ }^{46}$.

En muchos casos se enviaron los preparados en forma de comprimidos a destinos de Centroamérica a través de países de la Unión Europea. En el mes de octubre del año 2008 las autoridades francesas realizaron tres incautaciones de preparados de seudoefedrina. En la mayor de ellas se descubrieron 11 millones de comprimidos en tránsito desde la República Árabe Siria a Honduras. Los otros dos envíos estaban destinados a Guatemala, uno de ellos desde la India y el otro desde Vietnam. En el mes de noviembre del año 2008 las autoridades competentes del Reino Unido de Gran Bretaña e Irlanda del Norte decomisaron 1.650.000 comprimidos de efedrina en tránsito desde la India a México. Bélgica decomisó 1,5 millones de comprimidos de efedrina provenientes de la República China de Taiwán con destino a México. En el mes de mayo del año 2009 en los Países Bajos detuvieron un envío de 11 millones de comprimidos de seudoefedrina provenientes de Vietnam, 
después que las autoridades del país de destino, Guatemala, informaran que el envío no estaba autorizado. En este mismo año las autoridades mexicanas decomisaron 1,7 toneladas de seudoefedrina en forma de comprimidos, esta remesa se cree que provenía de la India y había pasado a través de Alemania ${ }^{47}$.

Para ilustrar más la complejidad del problema señalamos que siempre en el año 2009 las Autoridades de los Estados Unidos de América incautaron cinco millones de comprimidos de seudoefedrina procedentes de la India en ruta hacia Haití, cuyo destino era México. Mientras que en Honduras se descubrieron dos remesas de seudoefedrina de tres y dos millones de comprimidos respectivamente, las dos provenientes de Bangladesh y con destino a México. También las autoridades mexicanas decomisaron 198.000 comprimidos de esta sustancia que provenían de Bangladesh. En América del Sur las autoridades de Chile notificaron varias incautaciones del precursor antes mencionado, la mayor de 1.000 kilogramos, que iban a ser enviadas a México. Argentina también realizo importantes incautaciones de efedrina, la más importante de 4,5 toneladas, con el mismo destino. Siempre en este año en México se decomisaron un total de ocho millones de comprimidos de seudoefedrina que llegaron en transito a través de la República de Corea pero que provenían de la India. En fin podríamos afirmar que cuando de efedrina o seudoefedrina se trata todos los caminos conducen a México. Por ello el Gobierno de este país ha realizado grandes esfuerzos para enfrentar las poderosas redes delictivas que operan en su territorio, cuyo poder radica en la enorme riqueza que genera la fabricación y distribución ilícita de drogas, en particular de la metanfetamina, a manera de ejemplo citamos que en el mes de agosto del 2009, las autoridades competentes descubrieron un complejo de fabricación ilícita de metanfetamina en Durango, consistente en 22 instalaciones dispersadas en 240 hectáreas, donde recuperaron un total de 32.800 litros de sustancias químicas que se utilizan en la elaboración de metanfetamina, incautando además un total de 49.640 litros de una solución que contenía seudoefedrina y dextrometorfano, un antitusivo frecuentemente utilizado en muchos preparados farmacéuticos que contienen

47 La efedrina y la seudoefedrina en bruto que llega a través del contrabando a Centro América se está enviando no sólo a través de países europeos, sino también a través de países de América del Norte, como de América del Sur, pero el destino final siempre es México. Ibidem., p. 10. 
seudoefedrina. En el laboratorio se extraía de este preparado la seudoefedrina, para convertirla, una vez aislada en metanfetamina. En el lugar además se encontraron grandes cantidades de precursores de drogas secundarios como 3.250 kilogramos de yodo, 1.850 litros de ácido hipofosforoso y 3.250 kilogramos de hidróxido de sodio ${ }^{48}$.

Hay que destacar que año 2010 la totalidad de intentos de desviación y de las incautaciones de preparados farmacéuticos que contenían seudoefedrina con destino a Guatemala, como en ocasiones anteriores, provenían de Bangladesh. Las incautaciones individuales pesaban entre 6 kilogramos y 1,2 toneladas, y las tabletas tenían un contenido relativamente elevado de seudoefedrina (240 miligramos). Las autoridades hondureñas también realizaron decomisos de preparados que contenían seudoefedrina. Una de las incautaciones, de casi 30 millones de tabletas, tenía su origen en la Provincia China de Taiwán, y una segunda incautación, por un total superior a 152 millones de tabletas (más de 9 toneladas), provenía de la República Árabe Siria. Además, las autoridades de la India informaron a través del formulario D la detención de un envío de 120 kilogramos a petición de las autoridades de Honduras, aplicando así la prohibición de importar hidrocloruro de seudoefedrina a ese país. También fueron identificados Belice, Jamaica y República Dominicana como destino de remesas sospechosas de efedrina o seudoefedrina. En América del Sur informaron de la detención de 55 kilogramos de hidrocloruro seudoefedrina en Brasil, así como de la incautación de 47 kilogramos de materia prima de seudoefedrina en este país y de 220 kilogramos en Colombia ${ }^{49}$.

En México, durante este periodo, continuaron las incautaciones de efedrina, tanto como materia prima como bajo la forma de preparados farmacéuticos. Estas incautaciones se realizaron, en su mayoría, en el puerto marítimo de Manzanillo (Colima) donde se decomisaron ocho toneladas en cinco remesas. En el mes de abril del año 2010 las autoridades de este país comunicaron una incautación de 3,7 toneladas de seudoefedrina, la cual se realizo en el puerto de Veracruz en un buque procedente de la India. Las autoridades de Paraguay, Chile, Alemania y 
los Países Bajos también reportaron incautaciones de efedrina, la mayoría de estas remesas estaban destinadas a México y tenían su origen en la India (uno de los principales fabricantes mundiales de efedrina y seudoefedrina) ${ }^{50}$. Además China reportó en el año 2009 la incautación de 2.500 kilogramos de cloruro de tionilo, sustancia que se utiliza de manera frecuente en la reducción de efedrina bruta y seudoefedrina para fabricar metanfetamina ${ }^{51}$.

Como se informó en años anteriores, Europa sigue siendo utilizada como punto de reexpedición, habiéndose vinculado Alemania, España, los Países Bajos y el Reino Unido de Gran Bretaña e Irlanda del Norte con remesas de Asia Meridional y Sudoriental con destino a Belice, Guatemala y, como no podía ser de otra forma, México, aunque hayan disminuido las cantidades reexpedidas. También se ha informado de los Emiratos Árabes Unidos, México y Panamá como países de tránsito ${ }^{52}$.

Frente al fortalecimiento de las medidas de control aplicadas sobre la efedrina y la seudoefedrina en América del Norte y América Central, las organizaciones criminales dedicadas al narcotráfico tanto en México como en el Canadá recurrieron a una sustancia denominada $l$ fenilacetilcarnibiol ( $I$-PAC), precursor intermedio utilizado en la fabricación industrial de efedrina bruta y seudoefedrina para convertirla en efedrina que después se procesa para fabricar metanfetamina. Las autoridades competentes de Canadá informaron a la JIFE que habían comprobado que esta sustancia no catalogada se desviaba de la India y luego se expedía de manera ilegal al Canadá. Como el l-PAC no está sujeto a controles internacionales la Junta recomendó a todos los países la posibilidad de someter esta sustancia a controles nacionales. Australia también señalo haber descubierto una fuente inusual de efedrina, se trata de la planta Sida cordifolia que contiene varios alcaloides, entre

Ibidem., p. 7. En la India se ha informado de la fabricación ilícita de efedrina. Informe de la Junta Internacional de Fiscalización de Estupefacientes correspondiente a 2011. Ed. Naciones Unidas. JIFE. New York, 2012, p. 90. p. 15. pp. 7, 8. Se tiene información de que la mayoría de laboratorios ilícitos de ETA en Africa están ubicados en Sudáfrica. Global SMART Update, volumen 7, marzo 2012. Informe global de monitoreo de drogas sintéticas 2012. Ed. UNODC. 2012, p. 3. 
ellos la efedrina. Este hallazgo se produjo cuando las autoridades australianas incautaron un total de 128 kilogramos de extracto en polvo de la planta antes mencionada, antes ya habían encontrado esta sustancia en un pequeño laboratorio clandestino que se dedicaba a la fabricación de metcatinona ${ }^{53}$. Hay que señalar que en los años 2009, 2010 y 2011 se han realizado incautaciones de la planta antes mencionada también en laboratorios clandestinos de metanfetamina en Nueva Zelanda ${ }^{54}$.

Es preciso señalar que existe una tendencia a la disminución de las incautaciones de efedrina y seudoefedrina a nivel mundial, lo que posiblemente se deba en parte al incremento del uso del sistema PEN Online por la mayoría de los países lo cual propicia que se detengan una mayor cantidad de envíos antes de ser exportados y por ende no se produzcan los decomisos. La otra razón de tal disminución es que los traficantes, sobre todo en México están utilizando cada vez más el método P-2-P, empleando para sun elaboración ácido fenilacético, para fabricar metanfetamina para lo cual recurren a sustancias no fiscalizadas como los ésteres del ácido fenilacético. No obstante la desviación de preparados farmacéuticos que contienen efedrina o seudoefedrina obtenidos en farmacias continúa siendo la fuente primaria de los precursores que se usan en un elevado número de laboratorios de pequeña escala, sobre todo en los Estados Unidos de América, lo cual también ocurre en laboratorios de mediana escala y gran escala en otros países, ejemplo de ello es que en Australia y Nueva Zelanda se han incrementado los decomisos de ContacNT, una fórmula farmacéutica granular

53 La sida cordifolia se utiliza para la preparación de varios medicamentos a base de hierbas, en particular en la India donde se cultiva comercialmente. Precursores y productos químicos frecuentemente utilizados..., correspondiente a 2009..., p. 15.

54 Precursores y productos químicos frecuentemente utilizados..., correspondiente a 2011..., p. 16. Como todos sabemos los Estados Unidos de América es un un mercado importante de ETA. Muchos de los laboratorios que se desmantelan en ese país tienen vínculos con las organizaciones mexicanas de narcotraficantes. En México se reportan de forma constante grandes incautaciones de metanfetamina, así como el descubrimiento de laboratorios a gran escala que fabrican estas drogas, donde decomisan gran cantidad de sustancias no catalogadas. Por otra parte hay que decir que en Canadá se continúa obteniendo informaciones sobre la elaboración de éxtasis. Global SMART Update, volumen 7, marzo 2012. Informe global de monitoreo de drogas sintéticas 2012. Ed. UNODC. 2012, p. 3. 
que contiene seudoefedrina 55 . A pesar de lo dicho hasta aquí hay que aclarar que las incautaciones de seudoefedrina y efedrina a granel son considerables, tan es así que ocupan el tercer y quinto lugar en niveles de incautaciones a nivel mundial 56 .

Con el objetivo de lograr resolver importantes lagunas de información sobre el tráfico de efedrina y seudoefedrina en África se puso en marcha el día 1 de junio del 2012 la Operación EPIG, actividad realizada en el marco del Proyecto Prisma, la cual finalizó el 31 de agosto del mismo año. En la misma participaron un total de 51 países, de los 54 que hay en el continente. La operación tenía por objeto reunir información estratégica sobre el comercio lícito, y el uso ilícito de la efedrina y la seudoefedrina, incluidos los preparados farmacéuticos que contienen esas sustancias. Sin embargo, las limitaciones de capacidad en materia de represión y reglamentación en muchos de los países de la región dificultaron en gran medida la posibilidad de reunir información valiosa ${ }^{57}$. En este periodo se detuvieron varias remesas de estos dos precursores de drogas. Se suspendió una remesa de 500 kilogramos de sulfato de seudoefedrina a granel de Bélgica a Egipto porque la remesa no tenía autorización de importación. En la República Islámica de Iran se detuvo un envío de 300 kilogramos de preparados que contenían seudoefedrina que tenía como destino Austria. Se suspendió una remesa de 1.800 kilogramos de preparados que contenían seudoefedrina procedentes de la República Popular de Lao con destino a Guatemala, luego que las autoridades guatemaltecas le notificaran al país de origen que la importación de esa sustancia estaba prohibida en el país de destino.

55 Precursores y productos químicos frecuentemente utilizados..., correspondiente a 2011..., pp. 12-15. En Filipinas en el mes de enero del año 2012 al desmantelar un laboratorio ilícito dedicado a la fabricación ilícita de metanfetamina encontraron muchas cajas vacías de un producto farmacéutico denominado Novahis-D que contiene efedrina. Global SMART Update, volumen 7, marzo 2012. Informe global de monitoreo de drogas sintéticas 2012. Ed. UNODC. 2012, p. 7.

56 Ibidem., pp. 66-100. Precursores y productos químicos frecuentemente utilizados..., correspondiente a 2010..., pp. 16-41. Precursores y productos químicos frecuentemente utilizados..., correspondiente a 2006..., pp. 38-60. Precursores y productos químicos frecuentemente utilizados..., correspondiente a 2004..., pp. 45-66. Precursores y productos químicos frecuentemente utilizados..., correspondiente a 2000..., pp. 47-61.

57 Precursores y sustancias químicas frecuentemente utilizados..., correspondiente a 2012..., pp. 7, 8 . 
Se detuvo un envío de 60 kilogramos de efedrina procedente de la India de tránsito por el Reino Unido de Gran Bretaña e Irlanda del Norte con destino a Panamá, cuando las autoridades de ese país le informaron a la Junta que la compañía receptora era desconocida ${ }^{58}$.

Un total de 38 países reportaron en el formulario D correspondiente al año 2011 que se habían incautado un monto de 75,9 toneladas de efedrina y seudoefedrina a granel y en preparados farmacéuticos que contenían esas sustancias, de las cuales 29,2 toneladas correspondían a efedrina a granel, 33,8 toneladas a preparados farmacéuticos que contenían efedrina. 6,4 toneladas de seudoefedrina a granel y 2,3 toneladas a preparados farmacéuticos que contenían seudoefedrina. Además también se comunico el decomiso de 15,1 millones de comprimidos de preparados que contenían seudoefedrina y 447.078 de comprimidos que contenían efedrina. En el año 2011, Australia, China (donde existen más de 160.000 operadores que fabrican sustancias catalogadas), los Estados Unidos de América, la India, Malasia, México, la República Islámica del Irán comunicaron incautaciones de varias toneladas de efedrinas. Debe subrayarse que continuaron reportándose de cuantiosas incautaciones de preparados farmacéuticos que contienen efedrina y seudoefedrina en toda Asia Oriental y Sudoriental destinados principalmente a la fabricación ilícita de metanfetamina en Myanmar y, cada vez más, en Camboya. Ya en el año 2012 se notificaron importantes decomisos sobre todo en forma de preparados farmacéuticos que contenían seudoefedrina en Hong Kong (RAE de China), República Democrática de Laos, Tailandia, Singapur y Ghana. Mientras que Nigeria y Sudáfrica reportaron incautaciones de efedrina a granel 59 .

Como ejemplo de la corrupción que propicia el tráfico de precursores de drogas queremos citar que las autoridades de Tailandia detectaron la desaparición de grandes cantidades de preparados farmacéuticos

58 Las autoridades Chinas reportaron en el año 2011 la incautación de 5,4 toneladas de efedrina y seudoefedrina, cifra similar al año anterior. En este año realizaron un examen de la industria de los precursores de drogas donde se determinó que habían más de 160.000 operadores que fabricaban estas sustancias. Este examen posibilitó la inspección de empresas que fabrican preparados que contienen efedrina y seudoefedrina, a raíz de ello se desmantelaron varias operaciones ilegales. Ibidem., p. 12. 
que contenían efedrina en varios hospitales tanto públicos como privados de las zonas del centro, el noreste y el norte del país, y supuestas irregularidades en relación a pedidos de esta sustancia para uso lícito, lo que dio lugar a encontrar discrepancias notables entre la cantidad de comprimidos solicitados a la autoridad nacional competente y las existencias de los hospitales. Existiendo fuertes indicios de que posteriormente los comprimidos se pasaron de contrabando a países vecinos para su utilización en la fabricación ilícita de metanfetamina, lográndose comprobar que varios funcionarios sanitarios y miembros del personal de los hospitales estaban implicados en actividades que se llevaron a cabo durante tres años ${ }^{60}$.

En México, al igual que en América Central, siguen disminuyendo las incautaciones de efedrina y seudoefedrina. Lo cual se debe a la utilización en la región de forma predominante del método P-2-P para fabricar metanfetamina. Tan es así que en el año 2011 las autoridades de México sólo reportaron el decomiso de 315 kilogramos de efedrina y seudoefedrina, cifra mucho menor que las 9 toneladas reportadas el año anterior. Guatemala también notificó que las incautaciones de efedrina y seudoefedrina estaban disminuyendo. Mientras que en Oceanía la fabricación ilícita de metanfetamina sigue dependiendo en gran medida de la efedrina y la seudoefedrina, tanto a granel como en forma de preparados farmacéuticos. En el mes de diciembre del año 2011 las autoridades de Australia decomisaron 650 kilogramos de ContacNT, una forma farmacéutica granular de tipo bien definido que contiene seudoefedrina. Australia desmantelo un total de 703 laboratorios clandestinos dedicados a la fabricación de metanfetamina donde se incauto efedrina y seudoefedrina. En Nueva Zelanda donde desmantelaron 109 laboratorios de la droga antes citada, también se encontró Contac NT, así como efedrina y seudoefedrina ${ }^{61}$.

En el año 2013 la Junta continuó mostrando su preocupación por lo elevadas que son las necesidades legítimas de importación de efedrina y seudoefedrina, y por el consiguiente riesgo de desviación de estos precursores a canales del comercio ilícito en muchos países de Asia occidental. Claro ejemplo de ello es Pakistán que según sus reglamentos

$60 \quad$ Ibidem., $\mathrm{p} 13$.

$61 \quad$ Ibidem., p. 121. 
nacionales asignan a cada empresa farmacéutica un contingente máximo de 500 kilogramos de efedrina al año para la fabricación de preparados farmacéuticos que contienen esa sustancia. Sin embargo, en los expedientes judiciales se alega que a algunas empresas les asignaron contingentes muy por encima de esa cantidad y que no pudieron explicar qué había sucedido con esas asignaciones de precursores. Por lo cual las autoridades competentes de ese país han continuado sus investigaciones para determinar si ha existido desviación de efedrina en dichas empresas. Además el incremento en el número de laboratorios clandestinos de metanfetamina desmantelados en África sugiere que es fácil obtener estos precursores en toda la región ${ }^{62}$.

En periodo 2012-2013 un total de 37 gobiernos reportaron en el formulario D que se había incautado un total de 36 toneladas de efedrina y seudoefedrina a granel y en forma de preparados farmacéuticos. La disminución de las incautaciones, en relación al año anterior, posiblemente se debe a los cambios sobrevenidos en los procesos de fabricación de metanfetamina a base de los ésteres del ácido fenilacético y la P-2-P. Un ejemplo de tal situación es que en México no se realizó prácticamente ninguna incautación de efedrina o seudoefedrina en el año 2012, ya que el proceso de fabricación de metanfetamina a base de P-2-P ha pasado a ser el método dominante que utilizan los cárteles mexicanos ${ }^{63}$.

Sin embargo en China en el año 2012 se desmantelaron un total de 228 laboratorios de metanfetamina, incautándose 6,5 toneladas de efedrina, informando las autoridades competentes de este país que aproximadamente el $55 \%$ de los precursores utilizados para la fabricación de metanfetamina se obtuvieron a partir de preparados farmacéuticos. Lo mismo ocurre en Estados unidos de América, Canadá, Australia y Nueva Zelanda donde para la elaboración de esta droga en los laboratorios ilícitos emplean preparados farmacéuticos o productos dietéticos que contienen efedrina o seudoefedrina. En el mismo año un total de 18 países europeos incautaron 2,3 toneladas de efedrinas. Produciéndose el mayor decomiso en España, una remesa de 1.500 kilogramos de efedrina originaria de China y que estaba de camino hacia Marruecos. Hay

62 Precursores y productos químicos frecuentemente utilizados..., correspondiente a 2013..., pp. $4,5,10,11$.

63 Ibidem., pp. 10-14. 
que destacar que en el año 2013 en Kenia las autoridades comunicaron el desmantelamiento de un laboratorio clandestino de efedrina ${ }^{64}$. La JIFE informa que en Timor-Leste es fácil adquirir preparados farmacéuticos que contienen efedrina y seudo efedrina en numerosas farmacias del país que no están sometidas a un control reglamentario adecuado, situación que es especialmente preocupante dado que este país es utilizado por los traficantes de drogas como zona de transito para el contrabando a Australia e Indonesia de metanfetamina, éxtasis, cannabis, cocaína y heroína ${ }^{65}$.

La Junta señala que el aumento del tráfico de precursores en África, especialmente de efedrina, donde se han reportado incautaciones de esa sustancia en Benin, Botswana, Costa de Marfil, Guinea, Namibia, Nigeria, la República Democrática del Congo y Zimbabwe, puede indicar que se están estableciendo laboratorios para la fabricación ilícita de estimulantes de tipo anfetamínico en el continente. Aprovechando de esta manera la vulnerabilidad del mismo, ya que pocos gobiernos utilizan los instrumentos de que se dispone para vigilar la corriente internacional de precursores. También informó la JIFE que los traficantes de

64 Sobre el decomiso de los 1.500 kilogramos de efedrina que se produjo en España, las autoridades que investigaban irregularidades y discrepancias en los documentos descubrieron una sociedad ficticia en Marruecos que se dedicaba a importar cantidades considerables de efedrina para luego enviarlas de contrabando a Marruecos. España informó sobre el incidente a través del sistema PICS y, tras recibir la alerta, las autoridades de Canadá entablaron contacto con las autoridades españolas mediante este sistema para intercambiar información relativa a un caso parecido de efedrina en el que parecía estar involucrado Canadá. Ibidem., pp. 13-15. Informe de la Junta Internacional de Fiscalización de Estupefacientes correspondiente a 2013. Ed. Naciones Unidas. Nueva York. 2014, p. 102. Se absuelve por no poder establecer con certeza el elemento subjetivo a los cuatro procesados del delito de tráfico de precursores de drogas (dos británicos y dos españoles), por haber introducido en España 1.495 kilogramos de efedrina siendo su posterior destino una empresa radicada en Marruecos, utilizando para ello su empresa "Alborán Farma" sin tener las preceptivas autorizaciones. Hay que decir que aunque se absuelve a los procesados, los 1.495 kilogramos de efedrina se decomisaron y se destruyeron, señalando el Tribunal que al ser "la efedrina una sustancia sometida a control en su distribución, independientemente del pronunciamiento absolutorio, pero al no constar las preceptivas autorizaciones, ni su utilización a fines legítimos, procede acordar el comiso y destrucción". SAN (ROJ: 3347/2013) de 3 de julio de 2013. Ponente: Fernando Grande-Marlaska Gómez. Vid., en el Anexo III las incautaciones de efedrina realizadas en España desde el año 1993 al año 2014. 
drogas en Asia Meridional extraen efedrina y seudoefedrina de preparados farmacéuticos y además fabrican efedrina a partir de una sustancia no catalogada la 1-fenil-1-propanona (P-1-P) ${ }^{66}$.

Del 1 de noviembre del 2013 al 31 de octubre del 2014 los países exportadores enviaron mediante el sistema PEN Online más de 5.000 notificaciones previas a la exportación de efedrina y seudoefedrina en bruto y en forma de preparados farmacéuticos. Las remesas notificadas sumaban un total de más de 1.030 toneladas de seudoefedrina y 130 toneladas de efedrina. Las remesas de efedrina y seudoefedrina provenían de 41 países y territorios exportadores y estaban destinadas a 161 países y territorios importadores (el $81 \%$ del total de países del mundo). Gracias al uso del sistema PEN Online se impidieron los envios de muchas de estas remesas, fundamentalmente por que las empresas importadoras no estaban autorizadas para realizar tales operaciones o bien porque no habían solicitado dichas remesas. Entre las que destacamos las siguientes: 30 kilogramos de seudoefedrina de la India para Honduras, 75 kilogramos de la India para Zimbabwe, 100 kilogramos de efedrina de la India para la República Democrática del Congo, 311 kilogramos de preparados farmacéuticos que contenían seudoefedrina de Egipto para a Irak, 84 kilogramos de preparados farmacéuticos de Bélgica con destino Kuwait, 125 kilogramos de efedrina de Suiza hacia Paraguay y 500 kilogramos de seudoefedrina de Singapur para Vietnam ${ }^{67}$.

La JIFE informó que la mayoría de las incautaciones de efedrina y seudoefedrina se realizan en América del Norte y Asia Oriental y Sudoriental, y que a partir del año 2009 los decomisos de estas sustancias se han desplazado ligeramente de América del Norte a las regiones vecinas de Centroamérica y el Caribe y América del Sur. En el año 2013 a través del formulario $\mathrm{D}$ un total de 33 países y territorios reportaron incautaciones de efedrina, de los cuales 21 comunicaron decomisos de efedrina en bruto y 17 de preparados farmacéuticos que contenían efedrina. Un total de 25 países y territorios informaron de incautaciones de seudoefedrina, 15 de ellos reportaron decomisos de efedrina en bruto y 14 de preparados farmacéuticos que contenían este precursor

$66 \quad$ Ibidem., pp. 44, 49, 50, 78.

67 Precursores y productos químicos frecuentemente utilizados..., correspondiente a 2014..., pp. 19, 20. 
de drogas. A nivel mundial la incautación de efedrina y seudoefedrina ascendió a un total de 43 toneladas. Hay que destacar que siete países informaron que habían decomisado más de una tonelada de estas sustancias siendo estos: Australia, China, los Estados Unidos de América, la India, México, el Reino Unido de Gran Bretaña e Irlanda del Norte y Ucrania. Además hay que subrayar que en China se incautaron más de 280 kilogramos de 2-bromopropiofenona, producto intermedio conocido en la fabricación de efedrina y seudoefedrina y precursor fiscalizado de categoría 1 en ese país 68.

Como todos sabemos en Europa se fabrica de forma ilícita tanto anfetamina como metanfetamina, pero la anfetamina siempre ha tenido mayor demanda y por ende ha sido mayor su producción, sin embargo hay que destacar que la producción de metanfetamina a partir del año 2002 hasta el año 2014 mantiene una tendencia al alza. La anfetamina se elabora principalmente en Bélgica, los Países Bajos, Polonia, los Estados Bálticos y, en menor medida en Alemania, mientras que la metanfetamina se fabrica en los Estados Bálticos y en Europa Central. Hay que enfatizar que la producción de metanfetamina parece estar cambiando, en parte debido a la disponibilidad de precursores de drogas, así la producción de esta droga a partir de P-2-P, al igual que América del Norte, como precursor principal se centra en Lituania, mientras que la producción de metanfetamina basada en la efedrina y la seudoefedrina se realiza fundamentalmente en la República Checa, Eslovaquia y Alemania ${ }^{69}$.

En el periodo que va del 1 de noviembre del año 2014 al 31 de octubre del año 2015 se reportaron a través del sistema PEN Online un total de 5.260 notificaciones previas de exportación de remesas de efedrina y seudoefedrina por un monto de 2.300 toneladas de seudoefedrina y de 114 toneladas de efedrina. Dichos envíos los realizaron 35 países exportadores a un total de 154 países exportadores. En el formulario D correspondiente al año 2014 un total de 27 países realizaron incautaciones de efedrina, en bruto o en forma de preparados farmacéuticos, que sumaban más de 33 toneladas. Los decomisos en bruto más importantes se realizaron en China (31,5 toneladas), Filipinas (510 kilogra- 
mos) y Australia (460 kilogramos). Los mayores decomisos de efedrina en forma de preparados farmacéuticos se llevaron a cabo en China $(3,2$ toneladas) y en todos los demás países en conjunto se incautaron un total de 40 kilogramos. En el caso de la seudoefedrina en este periodo un total de 16 países informaron de la incautación de 350 kilogramos en bruto de esta sustancia y de 1,3 toneladas de seudoefedrina en forma de preparados farmacéuticos. Los decomisos más importantes en forma de preparados se realizaron en Bulgaria (840 kilogramos), Malasia (112 kilogramos) y la República Checa (150 kilogramos) ${ }^{70}$.

Para tener una mejor perspectiva de la situación es necesario señalar que del año 2004 al año 2013 se reportó a través del formulario D la incautación de 307.390 kilogramos de seudoefedrina a nivel mundial (cantidad con la que podría fabricarse un total de 204.927 kilogramos de anfetamina o metanfetamina) ${ }^{71}$, desglosada de la siguiente forma: 176.347 kilogramos en el año 2004, 839 kilogramos el año 2005, 739 kilogramos el año 2006, 24.956 kilogramos el año 2007, 7.578 kilogramos en el año 2008, 26.581 kilogramos en el año 2009, 17.900 kilogramos en el año 2010, 6.398 kilogramos en el año 2011, 30.481 kilogramos en el año 2012 y 15.571 kilogramos en el año 2013. Los decomisos de este precursor se llevaron a cabo en 34 países del mundo pertenecientes a los cinco continentes. Los países que realizaron incautaciones de más de 1.000 kilogramos en este periodo fueron: los Estados Unidos de América (203.160 kilogramos), México (17.039 kilogramos), Guatemala (14.030 kilogramos), Honduras (22.566 kilogramos), la India (11.446 kilogramos), China (4.824 kilogramos), Filipinas (18.012 kilogramos), Myanmar (3.272 kilogramos) y Australia (3.461 kilogramos) ${ }^{72}$.

Del año 2004 al año 2013 se reportaron a través del formulario D el decomiso de un total de 249.955 kilogramos de efedrina en todo el

Precursores y productos químicos frecuentemente utilizados..., correspondiente a 2015..., pp, 13, 14.

71 Precursores y productos químicos frecuentemente utilizados..., correspondiente a $2004 \ldots$, p. 80.

72 Precursores y sustancias químicas frecuentemente utilizados..., correspondiente a 2014..., pp. 71-90. Precursores y sustancias químicas frecuentemente utilizados..., correspondiente a 2013..., pp. 67-84. Precursores y sustancias químicas frecuentemente utilizados..., correspondiente a 2009..., pp. 37-50, 51-62. Vid., en el Anexo III las incautaciones de seudoefedrina realizadas en España del año 1993 al año 2014. 
mundo (cantidad con la podría fabricarse un total de 166.636 kilogramos de anfetamina o metanfetamina) ${ }^{73}$, desglosados de la siguiente manera: 13.940 kilogramos en el año 2004, 41.996 kilogramos en el año 2005, 10.275 kilogramos en el año 2006, 22.666 kilogramos en el año 2007, 23.302 kilogramos en el año 2008, 61.308 kilogramos en el año 2009, 22.262 kilogramos en el año 2010, 33.326 kilogramos en el año 2011, 7.624 kilogramos en el año 2012 y 13.256 kilogramos en el año 2013. Dichas incautaciones se realizaron en un total de 49 países o territorios de los cinco continentes. Los países que realizaron un nivel de decomisos superior a 1.000 kilogramos de efedrina fueron: Nigeria (4.717 kilogramos), Panamá (10.000 kilogramos) Canadá (5.122 kilogramos), los Estados Unidos de América (37.574 kilogramos), México (13.214 kilogramos), Argentina (15.148 kilogramos), Chile (1.187 kilogramos), la India (13.068 kilogramos), República Islámica del Irán (6.547 litros), China (110.953 kilogramos), Filipinas (6.537 kilogramos), Myanmar (7.402 kilogramos), España (1.500 kilogramos), Grecia (1.088 kilogramos) y Australia (3.220 kilogramos) ${ }^{74}$.

Queremos concluir este apartado afirmando que a través del Proyecto Prisma se le ha prestado una atención esmerada al problema de la desviación de la efedrina y seudoefedrina, obteniendo importantes resultados tanto en la prevención de la desviación como en el enfrentamiento al trafico ilícito de estas sustancias que juegan un papel muy importante en la fabricación de la anfetamina, la metanfetamina y la metcatinona a nivel mundial. Sin embargo hay que señalar que el nivel de comercio internacional de estas sustancias es muy elevado y complejo pues circulan por casi la totalidad de países o territorios del mundo, siendo muchos países exportadores a la vez importadores y de reexpedición de estos precursores, en cuanto a las rutas utilizadas hay que decir que prácticamente nunca las sustancias viajan de un país a otro directamente. Hemos pasado de los 21 países exportadores de estos precursores de drogas en el año 2004 a los 41 países exportadores del

73 Precursores y productos químicos frecuentemente utilizados..., correspondiente a 2004..., p. 80.

$74 \quad$ Precursores y sustancias químicas frecuentemente utilizados..., correspondiente a 2014..., pp. 71-90. Precursores y sustancias químicas frecuentemente utilizados..., correspondiente a 2013..., pp. 67-84. Precursores y sustancias químicas frecuentemente utilizados correspondiente a 2009, pp. 37-50, 51-62. Vid., en el Anexo III las incautaciones de efedrina realizadas en España del año 1993 al año 2014. 
año 2014 (20,7\% de países o territorios del mundo), casi el doble, y de las 1.893 notificaciones previas a la exportación anuales que enviaban estos países inicialmente hasta las 5.000 notificaciones sobre remesas que enviaron en el año 2014, mucho más del doble, así como de los 100 estados o territorios importadores de estas sustancias a los 161 países importadores que hay actualmente $(81 \%$ de países o territorios del mundo). Manteniéndose en estos diez años estable el nivel de comercio de seudoefedrina, un poco más de 1.000 toneladas anuales, aunque del año 2005 al año 2009 llego a más de 2.500 toneladas. En cambio en el caso de la efedrina la tendencia del comercio ha sido negativa, pasando de las 526 toneladas registradas en el año 2004 a las 130 toneladas que se reportaron en el año 2014. Sobre este tema hay que aclarar que el nivel de comercio real, como ocurre con todas las sustancias catalogadas, siempre es superior al nivel reportado a través del sistema PEN Online. Además hay que tener en cuenta que existe evidencia de la fabricación de ambas sustancia en distintas regiones del mundo, utilizando para ello una serie de sustancias no catalogadas $(N$ acetilseudoefedrina, $N$-metil-DL-alanina, 1-fenilacetilcarbinol, metilamina, cloruro de tionilo, P-1-P, 2-bromopropiofenona entre otras sustancias) y sustancias naturales como la efedra o la sida cordifolia, sin que pueda determinarse que porcentaje representa en la producción ilícita de las anfetaminas. Otro elemento a tener en cuenta es que se utilizan otras sustancias catalogadas como la norefedrina, la 1-fenil-2propanona (P-2-P) o el ácido fenilacético (que se usa para elaborar P2-P) y sus ésteres para sustituir a estos precursores de drogas en la fabricación de anfetamina y metanfetamina. También hay que recordar el papel que juegan el uso de los preparados farmacéuticos de la efedrina y la seudoefedrina, mucho más difíciles de controlar, en la producción ilícita de drogas. Todo lo cual propicia que las incautaciones de efedrina sean actualmente un poco menores que hace 10 años, y estén muy por debajo del promedio anual de decomisos, y que las incautaciones de seudoefedrina hayan experimentado un descenso espectacular, constituyendo en la actualidad el $9 \%$ de las realizadas en el año 2004. Manteniéndose completamente abastecido el mercado ilícito mundial de anfetamina y metanfetamina, aumentando en ambos casos su nivel de pureza en relación a años anteriores, siendo más notable el incremento del nivel de pureza en la metanfetamina ${ }^{75}$. 


\section{Especial referencia al caso de la efedra}

Queremos empezar este apartado señalando que es posible que los traficantes estén centrando su atención en la efedra, planta de la que se extraen la efedrina y la seudoefedrina, que no se encontraba sometida a la fiscalización internacional, lo cual se evidencia en una serie de intentos de desviación de este producto natural realizados en el año 2005. En total se trató de 15 envíos que ascendían a un total de 933 toneladas. Todas las remesas provenían de China y estaban destinadas a Alemania, México, los Países Bajos y Suecia. Hay que destacar que en todos los casos las autoridades chinas habían proporcionado a los países importadores notificaciones previas a la exportación lo que posibilitó detener los envíos a tiempo. En tres casos, las investigaciones efectuadas por los organismos competentes revelaron que las remesas tenían como destino final México, país que prohíbe las importaciones de efedra. Sin embargo hay que decir que, en los casos restantes, no se logró establecer si los traficantes trataban de desviar la efedra para extraer los precursores señalados anteriormente o bien para elaborar metcatinona. Al respecto hay que recordar que en el año 2004 las autoridades sudafricanas desmantelaron un laboratorio que elaboraba esta droga usando como materia prima para su síntesis efedra. Consideramos muy importante señalar que en España existen abundantes variedades de efedra entre ellas, en la zona mediterránea y de Aragón, se encuentra la variedad E. major que contiene el doble de efedrina que la efedra china ${ }^{76}$. En el año 2006, la Junta convocó a su grupo asesor de expertos para encontrar posibles líneas de acción para hacer frente a

peo de las Drogas y las Toxicomanías. Bruselas. 2015, pp. 27-29. Resumen Ejecutivo. Informe Mundial sobre las Drogas 2014. Ed. UNODC. 2015, p. 5.

76 Precursores y productos químicos frecuentemente utilizados..., correspondiente a 2005..., p. 4. Las efedráceas (Ephedraceae) son una familia de arbustos muy ramificados, similares a la retama, habitualmente discos, los que se distribuyen en zonas templadas y calidas del mediterráneo y las regiones áridas de Asia y América. Comprende un único género la ephedra, con unas 35 especies. La efedra es una anfetamina natural, usada con fines médicos y rituales desde hace miles de años. El compuesto que se extrae de esta planta es la efedrina. http://es.wikipedia.org/wiki/Ephedraceae. En España existen abundantes variedades de efedra. Entre ellas en la zona mediterránea y de Aragón se encuentra la variedad E. major que contiene el doble de efedrina que la efedra china. http://aliados.tripod.com/efedra.htm. 
los intentos de desviación de esta planta de los canales del comercio lícito para su uso en la fabricación ilícita de drogas ${ }^{77}$.

El tema del contrabando de efedra se trato por el grupo de tareas del Proyecto Prisma en dos reuniones la primera realizada en marzo del 2006 en Viena y otra realizada en septiembre de este mismo año en la Haya, pues era a esta fecha una nueva tendencia de los traficantes el contrabando de esta sustancia a países de América del Norte, México y Europa. Esta situación se produjo probablemente debido a la intensificación de las medidas de fiscalización de la efedrina y la seudoefedrina en estos países, fundamentalmente en México. Desde que la Junta puso a todas las autoridades nacionales centrales en conocimiento de la prohibición de importación de efedra en México, solicitándoles que informaran sobre los pedidos de esta planta, se notifico la incautación de una serie de envíos por parte de Alemania, la RAE de Hong Kong (China), Dinamarca, los Estados Unidos América, México, los Países Bajos y Suecia donde se decomisaron dos toneladas de efedra declaradas falsamente como un producto natural distinto. Además desde inicio del año 2005, se comunicaron a la JIFE más de 30 casos sospechosos que suponían más de 2.100 toneladas de efedra. En la mayoría de los casos se había comprobado que el destino final era México ${ }^{78}$. Debido al aumento registrado en el 2006 de los intentos de desviación de la efedra de los canales lícitos de sus estados miembros, la Unión Europea decidió en el año 2007 tratar esta sustancia como un producto natural que contiene efedrina que puede ser utilizada y extraída por medios de fácil aplicación y económicamente viable, por lo cual la efedra vino a quedar dentro del campo de aplicación del artículo 12 de la Convención de Viena de 1988, y por ende de la Ley 4/2009, de 15 de junio, de control de precursores de drogas. Siempre sobre este tema hay que decir que China es el único exportador de esta sustancia, que envía con regulari-

Precursores y productos químicos frecuentemente utilizados..., correspondiente a 2005..., p. 2.

78 Precursores y productos químicos frecuentemente utilizados... correspondiente a 2006..., pp. 10, 13, 15. Los Países Bajos informaron en el año 2006 una incautación de 94 toneladas de efedra (que contenía más del $20 \%$ de efedrina). Alemania este mismo año comunico un intento de desviación de 800 toneladas de extracto de efedra y en Luxemburgo incautaron dos toneladas de esta sustancia que había sido etiquetada como citrus auriantium (naranja amarga), estas remesas estaban destinadas a México. Precursores y productos químicos frecuentemente utilizados..., correspondiente a 2007..., pp. 9, 10. 
dad las notificaciones previas a la exportación de remesas de extractos de efedra, produciéndose una disminución de sus exportaciones en el periodo 2005-200779. En el año 2008 las autoridades aduaneras de Alemania reportaron la incautación de una remesa de 535 kilogramos de polvo marrón de efedra, en transito de la India con destino a México ${ }^{80}$.

Las autoridades de Camboya informaron sobre una operación realizada en el mes de marzo del año 2009 en la cual se decomiso un total de 1.725 kilogramos de extracto de efedra, proveniente del norte de China, además Rumania mediante el formulario D informo el decomiso de 4,9 kilogramos de esta sustancia ${ }^{81}$. En el período que va del 1 de noviembre del 2009 al día 31 de octubre del 2010 parece que se produjo un cambio de tendencia en el tráfico de la efedra, dado que únicamente Alemania y Australia reportaron incautaciones de esta sustancia, procediendo de los Estados Unidos de América la mayoría de los pequeños envíos a esos dos países. En el caso de Oceanía sólo una remesa de Nueva Zelanda a Australia llegó a sumar casi 25 kilogramos. Lo cual difiere mucho en relación con los años anteriores, cuando varios países comunicaban incautaciones o intentos de desvío de muchas toneladas de efedra. La Junta tomó nota de esta evolución de los acontecimientos que se produjo después de la aprobación en varios países de medidas legislativas y de fiscalización que prohíben la importación de efedra o establecen medidas de fiscalización correctas ${ }^{82}$.

En Australia, las autoridades competentes reportaron en el formulario D correspondiente al año 2010 un total de 34 casos de incautación de efedra, que sumaron un total de tres kilogramos. La mayoría de las remesas decomisadas se enviaron desde los Estados Unidos de América

Las autoridades competentes de China informaron que en el año 2005 se hicieron pedidos de más de 30 remesas (1.150 toneladas en total) de efedra, en el año 2006 el número de remesas de esta sustancia disminuyo a 15 (por un total de 970 toneladas) y en el año 2007 este país no notifico a la JIFE ninguna remesa de efedra. Ibidem., pp. XI, $9,10,18$. Precursores y productos químicos frecuentemente utilizados..., correspondiente a 2008..., p. 8. Precursores y productos químicos frecuentemente utilizados..., correspondiente a 2009..., p. 12. p. 9. 
por correo en forma de suplementos dietéticos o para perder peso, por lo que no se puede afirmar que las mismas estuvieran destinadas a la fabricación ilícita de efedrina para elaborar metanfetamina. Siempre en este año se informo a la JIFE de dos incautaciones importantes de plantas cortadas de efedra procedentes de Kirguistán, la primera incautación de 14 toneladas la realizaron en la Federación de Rusia en el puerto marítimo de Vostochniy proveniente de Kirguistán, mientras que la segunda incautación de 28 toneladas se produjo en una granja del país anteriormente citado. En ambos casos, las autoridades competentes informaron que la efedra pasada de contrabando tenía como destino la República de Corea. Hay que destacar que además en el año 2011 en Nueva Zelanda se produjo el decomiso de una remesa de Sida cordifolia, planta de la cual también se extrae efedrina y que se ha encontrado en laboratorios clandestinos donde se fabrica metanfetamina ${ }^{83}$.

Para hacernos una idea de la facilidad con la que los traficantes de drogas pueden abastecerse de efedra, citamos el caso de Kirguistán un país pobre, con una tasa de desempleo muy alta y un nivel de corrupción importante, donde los narcotraficantes ya operan utilizando su territorio como ruta de transito para transportar remesas ilícitas de drogas, fundamentalmente de heroína y opio, del Afganistán a los países de la Comunidad de estados independientes y a Europa, es decir ya tienen una infraestructura creada en Kirguistán, país donde las plantas de efedra, utilizadas en la fabricación ilícita de metanfetamina, crece de forma silvestre en una superficie aproximada de 55.000 hectáreas, pudiendo los traficantes disponer de este recurso cuando así lo deseen si mayores complicaciones ${ }^{84}$.

En todo caso hay que aclarar que las incautaciones de efedra que se han realizado en laboratorios clandestinos de metanfetamina son poco habituales y representan una pequeña porción de las sustancias que normalmente se ocupan en los mismos. Las autoridades competentes de Australia, Kirguistán y Nueva Zelanda informaron en formulario D

83 En Nueva Zelanda entre el año 2005 hubo tres casos confirmados de utilización de Efedra y Sida cordifolia en laboratorios ilícitos donde se fabricaba metanfetamina, manteniéndose dicha tendencia en los años 2010 y 2011. Precursores y productos químicos frecuentemente utilizados..., correspondiente a 2011..., pp. 15, 16. 
correspondiente al año 2011 decomisos de esta planta por un monto de 28 toneladas. Kirguistán reportó de la incautación de 27,8 toneladas. En Australia se identificaron 84 remesas de la planta efedra por un total de 14,5 kilogramos. La mayoría de estas habían sido enviadas a través del servicio postal, principalmente desde los Estados Unidos de América, Nueva Zelanda y la Provincia China de Taiwán, muchas veces en forma de suplementos dietéticos o adelgazantes. Sin embargo no se logró determinar si estaban destinadas a la fabricación ilícita de drogas. Hay que poner de relieve que en el mes de mayo del año 2012 en China las autoridades desmantelaron un laboratorio clandestino de extracción de efedrina, donde se incautaron 14 toneladas de material extraído de la planta efedra y 47 kilogramos de efedrina elaborada. Las autoridades de este país no pudieron establecer si la efedrina estaba destinada al mercado interno o al internacional. También es preciso señalar que en este periodo se han encontrado plantas de Sida cordifolia, y sus extractos que contienen efedrina, en laboratorios de metanfetamina de diverso países, entre ellos; los Estados Unidos de América (14 toneladas), Nueva Zelanda y Australia ${ }^{85}$.

Es necesario poner de relieve que en los años 2012 y 2013 no se reportó ningún decomiso de efedra, así como que tampoco hubo comunicaciones relativas a incautaciones a través del sistema PICS durante este periodo86. Lo cual también ocurrió en el año 2014, sin embargo se tiene información que en China se siguieron realizando incautaciones de esta sustancia, específicamente en el año 2014 de cantidades importantes de esta planta, manifestando las autoridades de este país, en su informe anual sobre fiscalización de drogas, que la disminución, en relación a años anteriores, se debe a la aplicación de controles más estrictos en las zonas de producción de la efedra de la Región Autónoma de Mongolia Interior, la Región Autónoma de Xianjiang Uighur, la Provincia de Gansu y la Región autónoma de Ningxia ${ }^{87}$. Nosotros creemos que la popp. 15, 16. Informe de la Junta Internacional de Fiscalización de Estupefacientes correspondiente a 2012. Ed. Naciones Unidas. Nueva York. 2013, p. 121.

86 Precursores y productos químicos frecuentemente utilizados..., correspondiente a 2013..., p. 15. Precursores y productos químicos frecuentemente utilizados..., correspondiente a $2014 \ldots$, pp. $24,25$.

87 Precursores y productos químicos frecuentemente utilizados..., correspondiente a 2015..., pp. 17, 18. 
sibilidad de utilización de esta planta natural, pese al descenso de sus incautaciones, sigue latente pues es un recurso que los traficantes siguen teniendo a su disposición del que harán uso cuando así lo requieran.

\section{Norefedrina}

Es preciso señalar que la norefedrina se utiliza para la elaboración de anfetamina, metanfetamina y 4-metil-aminorex (euphoria), así como que este precursor de drogas se añadió al Cuadro I de la Convención de 1988 en el mes de de noviembre del 2000 en cumplimiento de una recomendación de la JIFE88. Sin embargo hay que decir que las incautaciones de este precursor de drogas entre el año 2001 y el año 2006 fueron muy bajas, siempre de menos de 20 kilogramos anuales a nivel mundial. Como se ha ido exponiendo a lo largo de este trabajo los fabricantes de drogas ilícitas siempre buscan la manera de diversificar los precursores que pueden desviar para elaborar estimulantes de tipo anfetamínico. En respuesta a las rigurosas medidas de control de las efedrinas adoptadas por la mayoría de países del mundo, al parecer, como posible alternativa, las redes de traficantes de sustancias catalogadas manifestaron nuevamente su interés por la norefedrina a partir del año 2007 en diferentes regiones del mundo, específicamente en este año en los Estados Unidos de América se incautaron un total de 1.132 kilogramos de esta sustancia catalogada, asimismo las autoridades de los Países Bajos en el año 2008 incautaron un envío de 165 kilogramos de norefedrina (en bruto) en transito hacia México, y en el mes de octubre del mismo año las autoridades competentes de Canadá decomisaron un total de 230 kilogramos de este precursor de drogas. Mientras que en el año 2009 en Australia se interceptaron 22,8 kilogramos de norefedrina, procedentes de Sudáfrica, los cuales se encontraban ocultos dentro de maquinaria ${ }^{89}$.

En lo que respecta al comercio internacional de norefedrina reportado a través del sistema PEN Online 2009-2010 al 2014-2015 hay que señalar que este consistió en envíos de remesas realizadas por 12 países p. 8. Vid., en el Anexo IV las características de la norefedrina. 
exportadores de un promedio de 43 toneladas anuales a un total 33 países importadores, siendo el periodo 2014-2015 el más bajo (20,5 toneladas) y el periodo 2012-2013 el más alto (64 toneladas). Como se puede apreciar el nivel de comercio de esta sustancia es bastante reducido si se compara con el de la efedrina o la seudoefedrina. Sin embargo como resultado del incremento de las restricciones a la disponibilidad de estos dos precursores de drogas que se usan en la elaboración de anfetamina y metanfetamina, la Junta instó a todos los gobiernos para que se sometiera a vigilancia la norefedrina, ya que puede ser utilizada para la elaboración de estas drogas con una pequeña modificación en su proceso de elaboración ${ }^{90}$.

En cuanto a las incautaciones hay que señalar que del año 2004 al año 2014 se informó a través del formulario D el decomiso de 1.964 kilogramos de norefedrina (cantidad con la que podrían fabricarse un total de 1.309 kilogramos de anfetamina o metanfetamina), siendo el tercer precursor del Cuadro I que tiene el menor nivel de incautación, desglosado de la siguiente manera: 7 kilogramos en el año 2004, 2 kilogramos en el año 2005, 6 kilogramos en el año 2006, 1.150 kilogramos en el año 2007, 230 kilogramos en el año 2008, 196 kilogramos en el año 2009, 62 kilogramos en el año 2010, 2 kilogramos en el año 2011, 286 kilogramos en el año 2012, 23 kilogramos en el año 2013 y en el año 2014 en Australia, China y Filipinas se reportaron decomisos en cantidades inferiores a 100 gramos. Las incautaciones se realizaron en un total de 15 países de cuatro continentes, exceptuando África. Los mayores decomisos se efectuaron en: Filipinas (273 kilogramos), Canadá (230 kilogramos), los Países Bajos (165 kilogramos) y los Estados Unidos de América (1.158 kilogramos) ${ }^{91}$. Como ha podido observarse tan-

Precursores y productos químicos frecuentemente utilizados..., correspondiente a 2010..., pp. 9, 16-41. Precursores y productos químicos frecuentemente utilizados..., correspondiente a 2011..., pp. 66-100. Precursores y sustancias químicas frecuentemente utilizados..., correspondiente a 2012..., p. 15. Precursores y productos químicos frecuentemente utilizados..., correspondiente a 2013..., p. 15. Precursores y productos químicos frecuentemente utilizados..., correspondiente a 2014..., pp. 24, 25. Precursores y productos químicos frecuentemente utilizados..., correspondiente a 2015, p. 17.

91 Precursores y sustancias químicas frecuentemente utilizados..., correspondiente a 2014... pp. 71-90. Precursores y sustancias químicas frecuentemente utilizados..., correspondiente a 2013..., pp. 67-84. Precursores y sustancias químicas frecuentemente utilizados..., correspondiente a 2009..., pp. 37-50, 51-62. Precursores y productos químicos frecuentemente utilizados..., correspondiente a 2015..., p. 17. 
to el nivel de comercio mundial de la norefedrina como el nivel de incautaciones es bastante bajo. Además no conocemos el nivel de utilización de este precursor de drogas en la producción de anfetamina y metanfetamina, ni disponemos de información de que esta sustancia se elabore de forma ilícita en los laboratorios clandestinos, lo que nos hace concluir que el uso de esta sustancia en la fabricación de las anfetaminas es de carácter residual u ocasional, dado que los productores de las drogas antes mencionadas, recurren al uso de esta sustancia catalogada cuando tienen alguna dificultad para obtener efedrina, seudoefedrina, P-2-P, ácido fenilacético o sus ésteres ${ }^{92}$.

\section{1-fenil-2-propanona}

Sobre el 1-fenil-2-propanona (P-2-P) es preciso decir que se puede sintetizar a partir del ácido fenilacético y utilizar en la fabricación ilícita de anfetamina o metanfetamina ${ }^{93}$. En el año 2000 las incautaciones en todo el mundo fueron bastante limitadas. Pero es importante recordar que la P-2-P era la sustancia catalogada que procuraban obtener los narcotraficantes de Europa para utilizarla en la fabricación ilícita de anfetamina. Sin embargo, posiblemente, debido a los controles y la fiscalización más estricta que se fue imponiendo sobre este precursor, los traficantes empezaron a usar sucedáneos no fiscalizados como el benzaldehído. Es a partir de la segunda mitad de los años noventa que los decomisos de la P-2-P empezaron a aumentar ligeramente, tanto en Europa como en los Estados Unidos de América, lo cual probablemente respondió al hecho de que los traficantes encontraron nuevas fuentes para abastecerse de esta sustancia en el Asia Meridional y Sudoriental, como se puso de manifiesto cuando el gobierno de la India descubrió una serie de desviaciones hacia Europa a finales de los años 90 y también cuando se conoció un intento de desviación desde China en el año 199994.

92 En España desde el año 1993 hasta el año 2014 no se ha realizado ninguna incautación de norefedrina. Vid., el anexo III.

93 Vid. las características de la P-2-P en el Anexo IV.

94 Del año 1990 a 1995 las incautaciones de P-2-P fueron bastante escasas. Sin embargo Alemania reportó en 1999 el desmantelamiento de un laboratorio que utilizaba P-2-P para la fabricación de metanfetamina a gran escala. En este operativo participaron autoridades de Alemania, Austria, Hungría, la India y la República Checa, el cual se inicio cuando las autoridades de la India descubrieron órdenes sospechosas de compra de P- 
En el año 2001 se reportaron decomisos de 1-fenil-2-propanona en los siguientes países europeos: Bélgica, Grecia, Polonia, Bulgaria, Hungría y los Países Bajos ${ }^{95}$. En este año se incautaron 23 toneladas de P-2-P, la mayoría de estas se llevaron a cabo en los Países Bajos (18,2 toneladas). Estas incautaciones se realizaron al interceptarse en el puerto de Rotterdam envíos de contrabando procedentes de China, país que controla de forma estricta las exportaciones de este precursor, el cual tiene un comercio internacional muy limitado, lo que hizo pensar a la JIFE que los traficantes o estaban desviando esta sustancia catalogada del comercio nacional lícito o bien han recurrido a empresas no autorizadas para fabricar ilegalmente esta precursor de drogas con el fin de introducirlo posteriormente de contrabando en los países en que se produce la fabricación ilícita de anfetamina, metanfetamina ${ }^{96}$.

En el año 2003 los decomisos de P-2-P fueron limitados. Los Países Bajos reportaron una incautación de 500 litros y otra de 5.500 litros, reportando las autoridades competentes de este país que los precios en el mercado negro de esta sustancia se mantuvieron estables, lo que demuestra que los traficantes todavía podían obtener este precursor y que posiblemente estuviesen utilizando rutas alternativas para introducir de contrabando esta sustancia a Europa. Es preciso decir que el modus operandi de los traficantes estaba muy desarrollado, en muchos casos esta sustancia catalogada ocupaba el lugar de aceites vegetales o minerales o era ocultado dentro de radiadores o lámparas de lava. Una

2-P enviadas por empresas europeas. Además China en los años 1999 y 2000 logro desmantelar varios laboratorios clandestinos que fabricaban anfetaminas donde incautaron varias toneladas de P-2-P. También informaron sobre decomisos de esta sustancia las autoridades de Hungría. Precursores y productos químicos frecuentemente utilizados..., correspondiente a $2000 . . .$, pp. 29, 30. Precursores y sustancias químicas frecuentemente utilizados..., correspondiente a 2012..., p. 16. Hay que señalar que el benzaldehído sustancia que sustituye la P-2-P en la producción de anfetamina y metanfetamina es una sustancia fiscalizada por el gobierno de Costa Rica. www.basccostarica.com/documentos/Precursores.pdf.

Precursores y productos químicos frecuentemente utilizados..., correspondiente a 2001..., pp. 24, 25.

96 Se han desmantelado laboratorios de fabricación ilícita en China, Indonesia, los Estados Unidos de América, Sudáfrica y en Holanda donde en el año 2001 se desmantelaron 35 laboratorios que se dedicaban a esta actividad. Precursores y productos químicos frecuentemente utilizados..., correspondiente a 2002..., pp. 30, 31. Precursores y productos químicos frecuentemente utilizados..., correspondiente a 2004, pp. 18,19, 54. 
información sumamente relevante fue reportada por Turquía, país en el que jamás se había conocido sobre la elaboración de estimulantes de tipo anfetamínico, hasta que las autoridades competentes desmantelaron un gran laboratorio que se dedicaba a la fabricación ilícita de anfetaminas, en este caso los traficantes supuestamente estaban manufacturando tabletas de "Captagon" para los mercados lícitos de Asia occidental, sin embargo los análisis de medicina legal establecieron que el ingrediente activo de estas tabletas era anfetamina, y no fenetilina, que era el ingrediente activo del "Captagon" cuando se fabricaba lícitamente. Lo más relevante a los efectos que aquí nos interesa, es que en dicho laboratorio los traficantes utilizaban la P-2-P que ellos mismos elaboran a partir de sustancias no catalogadas ${ }^{97}$.

En el año 2003 la JIFE recomendó a todos los Estados y territorios parte y no parte de la Convención de 1988 que cuando se cursara un pedido de precursores de estimulantes de tipo anfetamínico, como la P-2-P y la 3,4-MPD-2-P, que tienen usos lícitos especializados, el gobierno del país desde el que se hace el pedido debería de realizar un examen a fondo para establecer el uso final que se piensa dar a la sustancia y los volúmenes necesarios a esos efectos, incluso llevando a cabo inspecciones oculares en la empresa importadora y de los consignatarios para asegurarse de que el uso final es compatible con las actividades declaradas de la empresa de que se trate ${ }^{98}$.

Las autoridades competentes de Polonia informaron en el año 2004 de la incautación de un envío de 4.680 litros de P-2-P provenientes de China que habían sido introducidas de contrabando a Polonia. Las autoridades de ambos países en el contexto del Proyecto Prisma realizaron investigaciones de rastreo que concluyeron con la detención de los traficantes. También se logró impedir dos intentos de desvío de dos y

97 El Captagon era un medicamento de uso geriátrico y pediátrico que fue prohibido en 1986 porque generaba adicción, pero que se sigue produciendo de forma clandestina por la gran demanda que existe en los países árabes. Actualmente se produce de forma ilegal agregándole más cafeína y menos fenetilina. Precursores y productos químicos frecuentemente utilizados..., correspondiente a 2003..., pp. 22, 23. Las autoridades de Irlanda informaron de una incautación de 4.500 litros de P-2-P que habían sido introducidos al país desde China a través de los Países Bajos. Precursores y productos químicos frecuentemente utilizados..., correspondiente a 2004 ..., p. 19.

$98 \quad$ Precursores y productos químicos frecuentemente utilizados..., correspondiente a 2003..., p. 18. 
cuatro toneladas de esta sustancia catalogada de China a Vietnam a través de la RAE Hong Kong de China. Además hay que señalar la interceptación de 50 litros de P-2-P cuando se estaba tratando de introducir de contrabando el envío en transbordador de Lituania a Alemania, siendo la P-2-P de muy baja calidad, datos que apuntan hacia la posibilidad de que se esté fabricando ilícitamente P-2-P en Europa, fundamentalmente en Ucrania, la Federación de Rusia y probablemente en Lituania99.

En el año 2006 disminuyeron las incautaciones de P-2-P en todas las regiones, excepto en Europa. A nueve países de esta región les correspondió la mayor parte de los 2.607 litros decomisados de este precursor. Se incautaron cantidades superiores a los 100 litros en Dinamarca, la Federación de Rusia, los Países Bajos, Polonia y Turquía, en tanto que Canadá y los Estados Unidos de América comunicaron incautaciones más pequeñas. Las autoridades de Polonia señalaron como causa del aumento de las incautaciones de P-2-P (1.085 litros) el éxito de las operaciones conjuntas llevadas a cabo en la región europea. Hay que destacar que la mayor parte de las remesas decomisadas en Polonia habían sido introducidas al país desde Lituania y estaban en camino hacia Bélgica y los Países Bajos, además en Polonia se incautaron también cantidades más pequeñas de esta sustancia catalogada en laboratorios de anfetamina clandestinos. Situación que se produjo igualmente en Bulgaria, donde se decomisaron pequeñas cantidades de P-2-P en un laboratorio de anfetamina clandestino ${ }^{100}$.

En el periodo que va del 1 de noviembre del año 2007 al día 31 de octubre del año 2008 la JIFE fue informada del envío de 18 remesas de P2 -P, por un monto de 25 toneladas, y aunque esta cifra represente una disminución con respeto al año anterior, la Junta observó con preocupación que más del $75 \%$ del comercio mundial de esta sustancia tenía por destino dos países de Asia Occidental, en los que el supuesto uso final era la fabricación de productos de limpieza y desinfección. La Junta recomendó a los países de Asia Occidental que presten mucha atención a los productos industriales cuyas fórmulas contengan P-2-P para pp. 19, 20. 
asegurarse de que la sustancia no se puede extraer con facilidad para fabricar de manera ilícita anfetaminas. También recomienda la JIFE que se vigilen esos productos industriales de la misma forma que los preparados farmacéuticos que contienen efedrina y seudoefedrina, además de considerar la posibilidad de identificar sustancias alternativas a la P-2-P para utilizarlas en productos industriales y domésticos no regulados 101 .

Creemos necesario destacar, por la importancia que tuvo, la Operación Ice Block, la cual se desarrolló del 2 de enero al 30 de septiembre del año 2008. Esta operación se centró fundamentalmente en el comercio de efedrina y seudoefedrina, incluidos los preparados farmacéuticos que contienen estas sustancias, la efedra y, en la medida que resultara posible en identificar expediciones de este tipo, así como el comercio de P-2-P, que es el tema que nos ocupa en este apartado, y del ácido fenilacético en el que intervienen países de África, América, Asia Occidental y Oceanía. Como en ocasiones anteriores, el instrumento primario para identificar transacciones sospechosas fue el sistema PEN Onli$n e$, lográndose determinar la forma en que estas sustancias catalogadas llegaban a los laboratorios clandestinos y definir los vínculos entre las organizaciones de traficantes que intervenían en estas actividades ${ }^{102}$. Esta operación por decisión del grupo de tareas del Proyecto Prisma se amplió hasta el año 2009 con los mismos objetivos ${ }^{103}$.

Según las notificaciones efectuadas mediante el sistema PEN Online entre el día 1 de noviembre del año 2008 y el día 31 de octubre del año 2009 se registraron dos expediciones de P-2-P por un volumen total de 20.800 litros, del cual más del $95 \%$ estaba destinado a un solo país de Asia occidental donde, según lo informado por las autoridades, la sustancia se empleaba para la fabricación de productos de limpieza y desinfección, hay que señalar que al mismo tiempo, las autoridades de

101 Precursores y productos químicos frecuentemente utilizados..., correspondiente a 2008..., pp. 9, 10. En el año 2009 le continuó preocupando a la Junta la supuesta utilización de P-2-P para elaborar productos de limpieza y desinfección en el Asia Occidental. Precursores y productos químicos frecuentemente utilizados..., correspondiente a 2009..., p. XII.

102 Precursores y productos químicos frecuentemente utilizados..., correspondiente a 2008..., p. 6.

103 Precursores y productos químicos frecuentemente utilizados..., correspondiente a 2009..., p. 7. 
muchos países de Asia Occidental comunicaron ingentes incautaciones de un estimulante de tipo anfetamínico en forma de pastillas que suele contener anfetamina (denominado localmente "captagon"). La Junta recomendó una vez más para evitar los riesgos de desvío de este precursor que reemplacen la utilización del mismo por alguno de los diversos productos químicos disponibles para la formulación de productos de limpieza y desinfección ${ }^{104}$. Queremos señalar que en el mes de agosto del año 2008 las autoridades chinas realizaron el desmantelamiento, en la provincia de Guangdong, de un gran laboratorio perfeccionado de metanfetamina. Los operadores de este complejo utilizaban fenilacetonitrilo y acetato de etilo para la fabricación de un precursor intermedio o secundario el alfa-fenilacetoacetonitrilo (APAAN), que se convierte luego en P-2-P. Este proceso, si bien está documentado en la literatura científica, nunca se había encontrado en el contexto de la fabricación ilícita de drogas. En dicho laboratorio también se halló formiato de sodio y ácido tartárico ${ }^{105}$.

Una información de suma importancia fue reportada a la Junta por las autoridades de los Países Bajos: en el mes de octubre del 2008 descubrieron una cantidad de P-2-P que había sido químicamente modificada para que dejara de presentar las características físicas de un líquido aceitoso, casi incoloro, a fin de eludir las medidas de control. La sustancia identificada era un aditivo de bisulfito P-2-P o bisulfito BMK, que tiene el aspecto físico de un cristaloide sólido blanco húmedo. Este aditivo puede reconvertirse fácilmente para liberar P-2-P mediante la aplicación de productos químicos muy asequibles, sin que este procedimiento requiera conocimientos químicos especiales. Hay que se destacar que la aplicación de esta técnica se puede también aplicar al 3,4MDP-2-P que presenta semejanzas estructurales con la P-2-P, por lo que podría disimularse mediante la formación de un aditivo de bisulfito. La modificación química o disimulación química de precursores usados para la fabricación de estimulantes de tipo anfetamínico ofrece ventajas potenciales a los traficantes que desean expedir sustancias catalogadas a diferentes países. Además de la modificación radical de las p. 12. 
características físicas de la sustancia, el precursor modificado puede eludir las medidas nacionales de control, dado que el bisulfito de P-2-P no se corresponde a las definiciones de las sustancias objeto de control en el Convenio de 1988. Razón por la cual la Junta recomendó a los gobiernos tomar medidas para enfrentar la disimulación química de los precursores incluidos en los cuadros para fines ilícitos ${ }^{106}$.

En el año 2009 en la India se detuvo una remesa de 4.000 litros de P-2P, tras recibir de la República Árabe Siria información de que esta sustancia destinada a su país no había sido encargada por la empresa mencionada. Es necesario señalar que en este periodo un total de ocho países brindaron información sobre incautaciones de esta sustancia catalogada. La Federación de Rusia informo a la JIFE que se habían confiscado 2.127 litros de P-2-P, y China notificó la incautación de 2.857 litros. Las autoridades de Lituania señalaron que habían interceptado un camión con 553,5 litros de este precursor ocultos en una cisterna de combustible. Polonia y Estonia informaron del decomiso de 39 y 22 litros de esta sustancia respectivamente y los demás países que realizaron incautaciones lo hicieron de cantidades muy pequeñas. La Junta manifestó que como no se reporto ningún decomiso de P-2-P en la región de Asia Occidental, donde se interceptaron cantidades importantes de productos que contienen anfetamina en forma de pastillas, debe de considerarse la posibilidad de que los traficantes disponen de una cantidad ilimitada de productos industriales y domésticos que contienen P-2-P, de los cuales se abastecen mediante su desviación. Por otra parte hay que puntualizar que en México se obtuvo información contrastada de la utilización de ácido fenilacético para su conversión en P2-P y posteriormente en metanfetamina en los laboratorios clandestinos, donde también se han encontrado grandes cantidades de productos químicos esenciales, en particular de acetato de sodio, el acetato de plomo y de anhídrido acético ${ }^{107}$. Mientras que las autoridades de Bélgica realizaron la incautación de más de una tonelada de alfa- fenilacetoacetonitrilo (APAAN), precursor mediato de la P-2-P, en ruta de Asia

106 Precursores y productos químicos frecuentemente utilizados..., correspondiente a 2009..., p. 16. Global SMART Update, volumen 7, marzo 2012. Informe global de monitoreo de drogas sintéticas 2012. Ed. UNODC. 2012, p. 5. pp. 12-14. 
Sudoriental a los Países Bajos en el mes de agosto del año 2010. En este mismo año la JIFE alerto al las autoridades competentes de todo el mundo sobre la utilización del benzaldehído, precursor secundario de la P-2-P, para la fabricación de anfetaminas y metanfetaminas ${ }^{108}$.

Entre el día 1 de noviembre del año 2009 y el día 31 de octubre del año 2010 a través del sistema PEN Online se reportaron a la Junta 35 remesas de P-2-P, 8 países exportaron un volumen total de 14.690 litros a 16 países importadores, cantidad que incluye una expedición individual de 8.865 litros a Jordania, por este envío el país generó por segundo año consecutivo, la mayor parte del comercio internacional de esta sustancia catalogada comunicado a la JIFE. Jordania y la vecina República Árabe Siria fueron también los países de destino de una remesa de 9.800 litros y de otra de 3.900 litros, respectivamente, que las autoridades competentes detuvieron en el año 2009. Es preciso recordar que desde un año antes, la Junta había alertado a las autoridades jordanas y demás gobiernos que tuvieran mucho cuidado al autorizar expediciones de P-2-P para supuestos usos finales como la elaboración de productos de limpieza y desinfección, recomendándoles la JIFE que usaran en lugar de este precursor cualquiera de las sustancias químicas no fiscalizadas que se pueden utilizar para elaborar esos productos. Las dudas sobre la legitimidad de las expediciones a Jordania y su destino final que era Irak, se vieron refrendadas por los resultados que se comunicaron a la Junta de los análisis de laboratorio de los supuestos productos de limpieza que no mostraban trazas de P-2-P. Hay que señalar que a pesar de estos resultados, las autoridades jordanas informaron a la JIFE de su intención de autorizar la importación de 9 toneladas de P-2-P para fabricar el mismo producto de limpieza y desinfección. Por otra parte hay que destacar que informaron mediante el formulario D sobre incautaciones de esta sustancia en este período un total de 13 países, los decomisos más importantes los realizaron: China con casi 2.300 litros, y la Federación de Rusia con más de 1.700 litros. En países de Europa Oriental, o con vínculos con ellos, se efectuaron otras incautaciones de P-2-P, de cantidades inferiores a 120 litros, en Alemania, Bulgaria, Lituania y Polonia. En el mes de agosto del año 2010 en Bélgica se realizó una incautación de 5.000 litros de este precursor, un 
volumen que se equipara con el total de incautaciones mundiales del año 2009109. Un elemento positivo a destacar es que en el año 2012 por fin el gobierno de Jordania prohibió las importaciones de P-2-P para su presunta utilización en la fabricación de productos de limpieza ${ }^{110}$.

Las autoridades de Bélgica, Lituania y Hong Kong (RAE de China), en este mismo período comunicaron a través del formulario $\mathrm{D}$ el desmantelamiento de laboratorios clandestinos dedicados a la fabricación de P-2-P. En los laboratorios detectados en Lituania y Hong Kong, el objetivo que presuntamente perseguían los traficantes era la elaboración de metanfetamina, fundamentando así la sospecha de un retorno a los métodos basados en el P-2-P para fabricar esta droga, esta situación ya se había planteado anteriormente en México, pero parece que se está extendiendo a otras partes del mundo111. En el año 2011 continuaron presentándose casos de contrabando de este precursor en América del Norte y Europa, así como de obtener P-2-P a través del ácido fenilacético y sus ésteres. En el período que abarca el informe de este año úni-

Precursores y productos químicos frecuentemente utilizados..., correspondiente a 2010 ..., pp. 10, 11. Es importante puntualizar que en el periodo que va del año 1995 al año 2010 se decomisaron en todo el mundo un total de 450.787 litros (equivalentes a 457.652 kilogramos) de P-2-P, ocupando el cuarto lugar en el orden de incautaciones realizadas de la lista de los precursores del Cuadro I de la Convención de Naciones Unidas de 1988. Con esta sustancia se paso de los 1.015 litros decomisados en el año 1995 a los 26.294 litros incautados en el año 2010, debiendo destacarse que en el año 2004 se decomisaron un total de 349.344 litros (cifra record). Sin embargo hay que decir que estas cantidades son sumamente limitadas si se tiene en cuenta el nivel de la producción mundial de anfetamina y metanfetamina en estos 15 años, situación que se presenta fundamentalmente por el hecho de que la mayor parte de esta sustancia catalogada se fabrica directamente en laboratorios clandestinos partiendo de sustancias no catalogadas como el ácido fenilacético y sus ésteres, la P-1-P y el APAAN, así como el uso del enmascaramiento químico de la P-2-P para su contrabando o bien el uso de sucedáneos de esta sustancia como el benzaldeído, lo cual dificulta enormemente la labor de las autoridades competentes para evitar el tráfico de este precursor de drogas y por ende la fabricación ilícita de anfetaminas y metanfetaminas en prácticamente todas las regiones del mundo. Precursores y productos químicos frecuentemente utilizados..., correspondiente a 2011..., pp. 66-100. Precursores y productos químicos frecuentemente utilizados..., correspondiente a 2010..., pp. 16-41.

110 Precursores y sustancias químicas frecuentemente utilizados..., correspondiente a 2012..., p. 16.

111 Precursores y productos químicos frecuentemente utilizados..., correspondiente a 2010..., p. 13. 
camente se reportó mediante el sistema PEN Online un total de 26 remesas de esta sustancia catalogada, que sumaban 17.700 litros. Un total de 11 gobiernos informaron a través del formulario D sobre incautaciones de P-2-P por un monto total de 26.924 litros, el volumen de incautaciones más importante reportado desde el año 2005, la mayoría de estos decomisos (el 95\%) fueron realizados por México (14.203 litros), el Canadá (5.924 litros) y Bélgica (5.050 litros). Informaron sobre incautaciones menores en Hong Kong RAE de China (660 litros) y los Países Bajos (330 litros). Tanto las autoridades competentes de Bélgica como las de Canadá lograron establecer que la mayor parte de este precursor provenía de Vietnam, país en el que la Junta no conoce ningún fabricante ni comercio legítimo, ni medidas internas de fiscalización de dicha sustancia112. Mientras que el Gobierno de Canadá reportó en este mismo período la incautación de 640 litros de 1-fenil-1propanona (P-1-P) y en Polonia se decomisaron 220 kilogramos de al$f a$-fenilacetoacetonitrilo (APAAN) ambos precursores inmediatos de la P-2-P. Las autoridades de los Países Bajos informaron a la Junta del desmantelamiento de dos grandes laboratorios para la conversión de APAAN en P-2-P a principios del año 2011 y de la incautación de una remesa que contenía 1.000 kilogramos de esta sustancia no catalogada en el puerto de Rotterdam. La información procedente de este país indica que, basándose en los precios del mercado ilícito, la P-2-P fabricada ilícitamente a partir de APAAN es considerablemente más barata que la que se encuentra en el mercado ilícito ${ }^{113}$. No obstante la JIFE señaló que se sigue sintetizando P-2-P a partir del ácido fenilacético y sus

112 Las autoridades búlgaras informaron en enero del 2011 del desmantelamiento de un laboratorio clandestino en Sofía, donde se encontraron 2,5 litros de P-2-P, además de varios litros de ácido sulfúrico, ácido clorhídrico y ácido fórmico. Precursores y productos químicos frecuentemente utilizados..., correspondiente a 2011..., pp. 16, 17. Señala la JIFE que las incautaciones mundiales de P-2-P se multiplicaron por cinco pasando de los 4.900 litros en el año 2009 a 26.300 litros en el año 2010. El problema de la drogodependencia en Europa. Informe anual 2012. Ed. Obsevatorio Europeo de las Drogas y las Toxicomanías. Luxemburgo. 2012, p. 54.

113 Precursores y productos químicos frecuentemente utilizados..., correspondiente a 2011..., pp. 21, 22. Global SMART Update, volumen 7, marzo 2012. Informe global de monitoreo de drogas sintéticas 2012. Ed. UNODC. 2012, p. 5. 
ésteres, y que el uso de P-2-P para la fabricación de metanfetamina continúa siendo el más utilizado ${ }^{114}$.

En el periodo que va del 1 de noviembre del 2011 al 31 de octubre del 2012 a través del sistema PEN Online se enviaron sólo 36 notificaciones de remesas de P-2-P, por un total de 22.900 litros. Además hay que decir que únicamente 27 gobiernos comunicaron necesidades legítimas de esta sustancia, y solo siete de ellos informaron que tenían una necesidad legítima anual superior a un kilogramo de esta sustancia catalogada. Durante este periodo se cancelaron dos envíos de P-2-P, el primero de 400 kilogramos de la India a Azerbayán por irregularidades en el permiso de importación, y el segundo por dos toneladas de la India a Mozambique porque el certificado de importación había sido falsificado. Mediante el formulario D correspondiente al año 2011 un total de 12 gobiernos notificaron a la JIFE que habían incautado 5.312 litros de P-2-P, los decomisos más importantes fueron reportados por: México (2.182 litros), la Federación de Rusia (1.060 litros), Lituania (600 litros), Bulgaria (545 litros). Es importante señalar que un examen forense del perfil de la metanfetamina incautada en los Estados Unidos de América indicó que prácticamente toda la metanfetamina decomisada se ha fabricado utilizando métodos a base de P-2-P115.

Como ya hemos señalado anteriormente el APAAN, es una sustancia no catalogada que puede ser transformada fácilmente en P-2-P a una relación aproximadamente de 1,4 a 1, sigue siendo la sustancia preferida de los laboratorios ilícitos de anfetamina a base de P-2-P en Europa, y existen indicios que su utilización se está extendiendo. En el año 2011 tres países europeos comunicaron incautaciones de remesas de APAAN por un monto de 3,5 toneladas, aparentemente todos estos envíos estaban destinados a los Países Bajos. Siempre en este año las autoridades de ese país decomisaron ocho remesas de APAAN por un total de 2.810 kilogramos y siguieron realizando incautaciones de esta sustancia en el año 2012. En este año autoridades de Bélgica, Bulgaria, los Países Bajos y Rumania comunicaron por medio del sistema PICS 17 incidentes relativos a 13,6 toneladas de esta sustancia no catalogada,

114 Precursores y sustancias químicas frecuentemente utilizados..., correspondiente a 2012..., p. 16.

115 Precursores y sustancias químicas frecuentemente utilizados..., correspondiente a 2012..., pp. 16, 17. 
en todos los casos la sustancia provenía de China. Siempre en el año 2012 las autoridades de Canadá reportaron por medio del sistema PICS la incautación de dos remesas de APAAN provenientes de China por un monto de 6,7 toneladas, siendo este el primer caso de incautación de esta sustancia en el continente americano. La JIFE señala que el incremento del tráfico de esta sustancia puede obedecer a su bajo costo en comparación con el de la P-2-P fabricado a partir del ácido fenilacético y sus ésteres ${ }^{116 .}$

Los gobiernos de seis países europeos informaron por medio del formulario D correspondiente al año 2012 sobre el decomiso de remesas de APAAN por un monto de 17,5 toneladas. Las principales incautaciones se produjeron en Bélgica ( 7 toneladas), los Países Bajos (6,8 toneladas) y Hungría (3 toneladas). Desde que se puso en marcha el sistema PICS, marzo de 2012, se han transmitido un total de 57 comunicaciones relacionadas con remesas de alfa-fenilacetoacetonitrilo, que han totalizado 79,4 toneladas. Hay que decir que aunque los incidentes los han comunicado principalmente países europeos, Canadá también ha reportado varias incautaciones importantes de esta sustancia. La Junta ha determinado que las remesas de APAAN suelen tener su origen en China y pasan de tránsito por varios países europeos siendo el destino previsto los Países Bajos ${ }^{117}$.

Es importante destacar que aunque se siguieron comunicando decomisos de APAAN a través del sistema PICS, la frecuencia y las cantidades totales han experimentado una leve disminución a partir del primer trimestre del año 2013. Del mes de noviembre del año 2012 al mes de octubre del año 2013 se comunicaron, mediante el sistema PICS, un total de 29 incidentes relacionados con esta sustancia por las autoridades competentes de: Alemania, Austria, Bélgica, Estonia, Francia, Letonia, Luxemburgo y los Países Bajos. Lográndose determinar que la declaración fraudulenta y el etiquetado engañoso de las remesas son el método principal que utilizan los traficantes del APAAN. La JIFE ha tenido conocimiento que se han registrado otros incidentes que no se comunicaron por medio del sistema PICS relacionados con remesas de esta sustancia, que luego fueron despachadas porque no existía legislación

116 Ibidem., p. 19.

117 Precursores y productos químicos frecuentemente utilizados..., correspondiente a 2013..., p. 19. 
nacional que permitiera su incautación. Además se señala que aunque el alfa-fenilacetoacetonitrilo suele presentarse en forma de polvo cristalino blanco, blancuzco o amarillo claro, últimamente las autoridades han detectado la sustancia en forma líquida o como mezcla bifásica consistente en cristales sin disolver de APAAN en etanol o en una mezcla de etanol y agua. Lo cual puede propiciar que los organismos de reglamentación y los cuerpos y fuerzas de seguridad no puedan detectar el APAAN líquido con el equipo portátil de ensayo in situ más habitual118.

En el periodo que va del 1 de noviembre del 2012 al 31 de octubre del 2013 el sistema PEN Online fue utilizado para enviar notificaciones de sólo 25 remesas de P-2-P por un total de 18.700 litros, comunicando el $75 \%$ de los Estados o territorios que no tenían necesidades legítimas de esta sustancia o bien que habían prohibido su importación. En esta etapa a través del formulario $\mathrm{D}$ un total de 13 gobiernos informaron de la incautación de 6.818 litros de este precursor. Los gobiernos de nueve países europeos comunicaron el decomiso de 836 kilogramos (lo que representa tan solo el $12 \%$ de las incautaciones a nivel mundial), lo que posiblemente se deba a que las sustancias sustitutivas de la P-2-P se utilizan cada vez más como materia prima. Hay que señalar que el año 2012 fue el tercer año consecutivo en el que México comunicó las mayores incautaciones de este precursor en el mundo, por un monto de 4.669 litros. Sin embargo la JIFE señala que esa cifra no refleja la magnitud de la fabricación ilícita de metanfetamina en ese país con el método P-2-P, porque las materias primas utilizadas en ese proceso consisten principalmente en pre-precursores de la P-2-P, como los ésteres o derivados del ácido fenilacético o el APAAN. Para ilustrar un poco la relevancia de la P-2-P en la fabricación de metanfetamina por los carteles mexicanos hay que decir que el $90 \%$ de la metanfetamina que se incautó en Estados Unidos de América proviene de México y se había elaborado utilizando P-2-P119.

Las autoridades del Reino Unido de Gran Bretaña e Irlanda del Norte informaron en el año 2012 sobre el desmantelamiento de un laboratorio que se había dedicado a fabricar ilegalmente P-2-P, utilizando para ello un "pre-precursor de drogas", desconocido hasta ese momento, "la

\footnotetext{
118 Ibidem., p. 20.

119 Ibidem., pp. 15-17.
} 
sal sódica de P-2-P ácido glicídico", que puede transformarse en P-2-P en una relación práctica de 2 a 1 aproximadamente. Durante el registro del laboratorio, se encontraron 100 kilogramos de la sustancia, que había sido importada desde China. En el operativo fueron detenidas cinco personas, dos de ellas eran químicos de nacionalidad China. La Junta informo a todas las autoridades nacionales acerca del hecho de que el análisis químico de esta sustancia no catalogada podría plantear problemas en cuanto a su identificación, ya que puede darse el caso que la P-2-P se detecte incorrectamente como componente principal 120. La JIFE además comunico que el uso del APAAN está cobrando cada vez más protagonismo en Europa para la fabricación ilícita de P-2-P, señalando que generalmente está sustancia no catalogada la mayoría de las veces proviene de China ${ }^{121}$.

Como ya habíamos señalado antes el benzaldehído y el cianuro de bencilo son otros dos pre-precursores de la P-2-P, en el formulario D correspondiente al año 2012 un total de 5 gobiernos reportaron incautaciones de benzaldehído: Alemania (94 kilogramos), Estonia (15 kilogramos), la Federación de Rusia (6 kilogramos), Hungría (5 kilogramos) y Polonia (15 litros). Las autoridades de Filipinas comunicaron la incautación de 2.400 litros de cianuro de bencilo, además las autoridades del Líbano comunicaron a través del sistema PICS un incidente relacionado con la introducción de contrabando en el país de 520 litros de esta sustancia no catalogada. En este mismo periodo le informaron a la JIFE cuatro gobiernos de la realización de incautaciones de metilamina, sustancia que junto con la P-2-P se usa en la fabricación de metanfetamina; los Estados Unidos de América (6.929 litros), Honduras (51.000 litros), México (197 toneladas y 150.000 litros) y Polonia (403 litros). También se reportaron otros incidentes con esta sustancia no catalogada por medio del sistema PICS, entre ellos el decomiso de 800 litros de metilamina, junto con otras sustancias químicas y equipo de laboratorio en un camión en México ${ }^{122}$.

\footnotetext{
$120 \quad$ Ibidem., pp. 20, 21.

121 Informe de la Junta Internacional de Fiscalización de Estupefacientes correspondiente a 2013. Ed. Naciones Unidas. Nueva York. 2014, p. 95. 
Debido a la importancia que tiene el APAAN en la fabricación de P-2-P y por ende en la fabricación de anfetamina y metanfetamina, la Junta cursó una comunicación al Secretario General para iniciar de forma oficial los trámites de clasificación en los cuadros del alfafenilacetoacetonitrilo en el mes de marzo del año 2013. El Secretario General invitó a los gobiernos, mediante un cuestionario que la Comisión de Estupefacientes distribuyó, para que expresaran su opinión al respecto. Un total de 42 gobiernos respondieron al cuestionario, faciltando información sobre la fabricación, la utilización y el comercio lícito del APAAN en sus territorios, así como sobre su uso para la fabricación ilícita de drogas y sobre las consecuencias que la clasificación de la sustancia podría tener en la industria y el comercio legitimo. En función de las respuestas recibidas, la Junta presentó a la Comisión de estupefacientes la recomendación de incluir esta sustancia en el Cuadro I de la Convención de 1988123. En su 57. periodo de sesiones, celebrado en el mes de marzo del 2014, la Comisión de estupefacientes decidió unánimemente seguir la recomendación de la Junta e incluir el APAAN y sus isómeros ópticos en el Cuadro número I de la Convención de 1988 (decisión 57/1 de la Comisión), esta decisión entro en vigor el 9 de octubre del 2014124 .

En el periodo que va del 1 de noviembre del 2013 al día 31 de octubre del 2014, un total de siete países exportadores enviaron por medio del sistema PEN Online 24 notificaciones previas de exportación a 12 países importadores por un monto de 34.000 litros de P-2-P, lo cual representa un incremento de un $45 \%$ de las exportaciones de esta sustancia con relación al periodo anterior. El envío de 9.850 litros de P-2-P de la India a la República Árabe Siria fue detenido por las autoridades de la India a petición del país importador. Es preciso señalar que en algunas partes del mundo, el empleo de métodos basados en P-2-P ha sustituido prácticamente el uso de las efedrinas como materias primas principales para la fabricación ilícita de metanfetamina. Además, es necesario precisar que, desde hace mucho tiempo este precursor de drogas se utiliza en Europa para la fabricación de anfetamina. Cabe recordar que la P-2-P se viene sintetizando cada vez más a partir del ácido

123 Ibidem., p. 2.

124 Precursores y sustancias químicas frecuentemente utilizados..., correspondiente a 2014..., p. 7. 
fenilacético y de diversas sustancias no catalogadas como los ésteres del ácido fenilacético y el APAAN ${ }^{125}$.

En el año 2013 a través del formulario D correspondiente a este año un total de 10 países o territorios reportaron incautaciones de P-2-P. China reportó el decomiso de 5.500 litros de P-2-P y México de 2.800 litros de esta sustancia. Ningún otro país informó de incautaciones superiores a 50 litros de este precursor de drogas. Hay que resaltar que en el año 2014 el 95\% de la metanfetamina incautada en los Estados Unidos de América, en su mayoría proveniente de México, se elaboro usando los métodos basados en P-2-P, situación que se está empezando a producir en Australia. Además se tiene información de la utilización de estos métodos para la elaboración de anfetamina en América del Norte, América Central y Europa ${ }^{126 .}$

Las incautaciones de APAAN se siguieron produciendo en Europa en el periodo 2013-2014; en Bélgica (5,12 toneladas que provenían de China), Bulgaria (una tonelada), en Estonia (más de una tonelada), Lituania (180 kilogramos), los Países Bajos (36 toneladas), Rumania (600 kilogramos provenientes de China y destinados a los Países Bajos) y Alemania $(5,4$ toneladas provenientes de China y con destino a los Países Bajos). Como se puede apreciar estos 49.300 kilogramos de APAAN (equivalentes a 50.050 litros) decomisados es seis veces la cantidad de P-2-P incautada este mismo año, lo que nos da una idea de la importancia de este nuevo precursor en la fabricación ilícita de P-2-P y por ende de anfetamina y metanfetamina. A finales del año 2014, cuando esta sustancia ya estaba incorporada al Cuadro I del Convenio de 1988 se decomisaron cinco toneladas en un contenedor en el puerto de Hamburgo (Alemania). Las autoridades competentes de Polonia informaron del desmantelamiento de un laboratorio clandestino que transformaba APAAN en P-2-P, en el que se recuperaron 1.400 litros de P-2P. Mientras que las autoridades Chinas, en cooperación con los países importadores, informaron que en el año 2013 habían impedido la exportación de 13,5 toneladas de APAAN 127.

125 Ibidem., p. 25.

126 Ibidem., pp. 27, 28.

127 Ibidem., p. 30. En el año 2013 se incautaron 48.000 kilogramos de APAAN en Europa, cantidad con la que se podría haber producido más de 22 toneladas de anfetamina o 
Los Países Bajos informaron de la incautación de cantidades pequeñas, menos de 500 gramos, de 1-fenil-2-nitropropeno, producto intermedio en la fabricación de anfetamina y, a partir de P-2-P, también de metanfetamina, de modo similar se incauto en este país un total de 75 kilogramos de 3-oxo-2-fenilbutanamida otro producto intermedio en la fabricación de P-2-P lo que indica que se sigue empleando el método de aminación reductiva para la fabricación de anfetamina. Las autoridades de Polonia también comunicaron incautaciones de estas mismas sustancias ${ }^{128}$.

En el año 2014 se comunico la realización de incautaciones de este precursor de drogas por un total de 16.575 litros, el doble que el año anterior. Los decomisos más importantes se llevaron a cabo en: México (5.982 litros), Myanmar (4.800 litros), China (3.241 litros), Polonia (1.472 litros), Lituania (690 litros) y los Países Bajos (480 litros). Queremos destacar que la mayor parte de las incautaciones realizadas se llevaron a cabo en laboratorios ilícitos, habiéndose fabricado la P-2-P a partir de otros precursores de drogas como el APAAN o los ésteres del ácido fenilacético ${ }^{129}$. Queremos poner de manifiesto que el comercio internacional de P-2-P

Para tener una visión de conjunto queremos señalar que el comercio internacional de P-2-P es bastante reducido. Del año 2004 al año 2013 se comercializó un total de 202.815 litros (cantidad con la que podrían fabricarse 101.408 kilogramos de anfetamina o metanfetamina) ${ }^{130}$, lo que arroja un promedio de unos 22.000 litros anuales entre menos del $10 \%$ de países del mundo (a lo sumo 7 países exportadores y 12 países importadores). Hay que decir a través del formulario $D$ en este periodo se reportó la incautación de 96.433 litros de P-2-P a nivel mundial, desglosados de la siguiente forma: 32.684 litros en el año 2004, 2.940 litros en el año 2005, 2.607 litros en el año 2006, 834 litros en el año

metanfetamina. Informe Europeo sobre Drogas. Tendencia y novedades. 2015. Ed. Observatorio Europeo de las Drogas y las Toxicomanías. Bruselas. 2015, p. 36.

$128 \quad$ Ibidem., p. 31.

Precursores y sustancias químicas frecuentemente utilizados..., correspondiente a 2015..., pp. 18, 19, 68-87. p. 80. 
2007, 5.620 litros el año 2008, 4.923 litros el año 2009, 26.403 litros el año 2010, 5.312 litros el año 2011, 6.818 litros el año 2012 y finalmente 8.292 litros en el año 2013. En estos diez años los decomisos se realizaron en 24 países o territorios del mundo, perteneciendo los mismos a cuatro continentes, en África no se realizó ninguna incautación, siendo los países donde se realizaron los mayores decomisos en este periodo los siguientes: México (24.001 litros), China (35.323 litros), Canadá (6.510 litros), Rusia (5.546 litros), Alemania (1.716 litros), Bélgica (5.688 litros), Lituania (1.313 litros), los Países Bajos (5.509 litros) y Polonia (7.040 litros). Probablemente la P-2-P incautada en América se iba a utilizar para la elaboración ilícita de metanfetamina, mientras que la decomisada en Europa se usaría para la fabricación ilícita de anfetamina131. De estos datos llama mucho la atención que en los años 2004 y 2010 los niveles de incautación fueron muy superiores a los niveles de comercio a nivel mundial en esos años, así como que en los últimos diez años se incautó el 47.5\% del total de P-2-P que se comercializó a nivel mundial en este periodo ${ }^{132}$.

Debe destacarse que en el mes de diciembre del año 2015 agentes de la Policía Nacional desmantelaron en una casa rural ubicada en Altea (Alicante) un laboratorio de elaboración de drogas sintéticas, donde incautaron un total de 122 kilogramos de APAAN, precursor que se utilizaba en la elaboración de anfetamina, lo cual constituyó el mayor decomiso de esta sustancia en Europa desde su inclusión desde su inclusión en el Cuadro I del Convenio de Viena de 1988. En el operativo se detuvieron cuatro personas (tres británicos y un holandés). La investigación estuvo a cargo del Juzgado de Instrucción número tres de Denia y se realizaron en coordinación con la National Crime Agency (NCA) británica133.

A manera de conclusión se puede afirmar que aunque los traficantes de precursores de drogas siguen realizando esfuerzos por desviar P-2-P

131 Precursores y sustancias químicas frecuentemente utilizados..., correspondiente a 2014..., pp. 71-90. Precursores y sustancias químicas frecuentemente utilizados..., correspondiente a 2013..., pp. 67-84. Precursores y sustancias químicas frecuentemente utilizados..., correspondiente a $2009 . . .$, pp. 37-50, 51-62.

132 En España desde el año 1993 hasta el año 2014 no se realizó ninguna incautación de P2-P. Vid., el Anexo III.

133 http://www.abc.es/espana/comunidad-valenciana/alicante/abci-incautan-alicantemayor-alijo-droga-sintetica-apaan-europa-201602061309_noticia.html 
del comercio internacional y nacional (cuyo nivel de comercio es bastante reducido), gran parte, no pudiéndose determinar el porcentaje, de la P-2-P que se utiliza en la fabricación de anfetamina y metanfetamina a nivel mundial es producido en laboratorios clandestinos, usando para ello precursores de drogas como el APAAN y el ácido fenilacético y sus ésteres. Lo cual se fundamenta en que en el año 2013 se incautó seis veces más APAAN que P-2-P, y en lo últimos diez años se decomisó 14 veces más ácido fenilcético que P-2-P. También hay que señalar que existe evidencia que se elabora P-2-P a partir de otras sustancias no catalogadas tales como: el benzaldehído, el cianuro de bencilo, la P-1-P, la sal sódica de P-2-P ácido glicídico, la 3-oxo-2fenilbutanamida y el fenilacetonitrilo. Además hay que recordar que los fabricantes de anfetaminas (anfetamina y metanfetamina) si tienen problemas para obtener P-2-P siempre pueden recurrir a la efedrina, la seudoefedrina y la norefedrina. Lo que les permite mantener completamente abastecido el mercado ilícito mundial de anfetamina y metanfetamina, aumentando en ambos casos su nivel de pureza en relación a años anteriores, siendo más notable el incremento del nivel de calidad en la metanfetamina ${ }^{134}$.

\section{5. Ácido fenilacético}

Del ácido fenilacético hay que decir que se utiliza en los laboratorios ilícitos para elaborar P-2-P y por ende anfetamina y metanfetamina. Del año 2000 al año 2003 las incautaciones de ácido fenilacético fueron limitadas, solo Bulgaria, Australia y los Estados Unidos de América informaron sobre decomisos. Mientras que las autoridades del Reino Unido de Gran Bretaña e Irlanda del Norte y Sudáfrica realizaron con éxito una entrega vigilada de esta sustancia que permitió el desmantelamiento de un laboratorio clandestino dedicado a la fabricación de metanfetamina. Por otra parte, en Asia se evitó la desviación de 50 toneladas de esta sustancia y 100 toneladas de anhídrido acético, ambos precursores inmediatos de la P-2-P, gracias a que el gobierno de la República Democrática de Corea informó al país exportador que la em- 
presa, que supuestamente había cursado el pedido, no era conocida por las autoridades competentes del país ${ }^{135}$.

Siempre en Asia las autoridades de China en el año 2004 identificaron un intento de desviación de 20 toneladas de ácido fenilacético de China a la India ${ }^{136}$. En este mismo año las autoridades de Serbia y Montenegro pusieron en marcha una exitosa investigación de rastreo tras la incautación de más de tres toneladas de ácido fenilacético, a pesar de que no se realizaron detenciones en el momento de la incautación el embalaje fue utilizado para identificar al fabricante en China, y las autoridades de este país utilizaron los números de serie para identificar al destinatario del desvío original. Además en los Países Bajos informaron del decomiso de 48 kilogramos de esta sustancia catalogada proveniente de Ghana que estaba siendo introducido de contrabando a los Países Bajos con destino a Ucrania. Al mismo tiempo las autoridades de este país notificaron el desmantelamiento de un laboratorio ilícito que dedicaba a la fabricación de precursores y drogas, aunque en el lugar no se encontró ácido fenilacético, la lista completa de los productos incautados indica que se podía haber fabricado P-2-P y posiblemente metanfetamina, hay que añadir que también se ha detectado fabricación ilícita de P-2$\mathrm{P}, \mathrm{y}$ muy probablemente se está usando para ello ácido fenilacético, en la Federación de Rusia y posiblemente también en Lituania ${ }^{137}$.

En el año 2005 las autoridades competentes de los Estados Unidos de América y de México reportaron grandes incautaciones de ácido fenilacético, 925 kilogramos y 15.000 kilogramos respectivamente, y las autoridades mexicanas también detectaron e interceptaron una remesa sospechosa de dicha sustancia en el ámbito del comercio internacional en el año 2006. Como los traficantes de drogas tenían serias dificultades para poder abastecerse de efedrina o seudoefedrina debido al fépp. 24, 25. Precursores y productos químicos frecuentemente utilizados correspondiente a $2003 \ldots$, p. 25.

136 Precursores y productos químicos frecuentemente utilizados..., correspondiente a 2004 ..., p. 20.

137 Ibidem., pp. 19, 20. 
rreo control que se estableció sobre estas sustancias en la región, optaron por usar como sustituto el ácido fenilacético para estos fines ${ }^{138}$.

Del 1 de noviembre del 2007 al 31 de octubre del 2008, se comunicaron a la JIFE mediante el sistema PEN Online 118 remesas de ácido fenilacético, por un monto total de 1.426 toneladas. La Junta señaló que mientras se siguieran reforzando las medidas de fiscalización de la efedrina y la seudoefedrina, el ácido fenilacético continuaría incrementando su importancia como sustancia objeto de desviaciones para la fabricación ilícita de estimulantes de tipo anfetamínico. Por esta razón la JIFE insto a los países exportadores de esta sustancia que todavía no emitían notificaciones previas a la exportación de esta sustancia catalogada a través del sistema PEN Online a que lo hicieran con el fin de ayudar a los países importadores a enfrentar mejor los intentos de desviación de este precursor de drogas ${ }^{139}$. Como ya hemos señalado antes por el fortalecimiento de las medidas de control en muchas regiones, particularmente en América del Norte, Asia Oriental y Oceanía, los fabricantes de drogas se vieron obligados a buscar precursores alternativos para producir metanfetamina. En el mes de julio del 2008 las autoridades mexicanas informaron de una incautación importante de sustancias no catalogadas, entre ellos fenilacetato de metilo, acetato de feniletilo, acetato de fenilamilo y fenilacetato de isobutilo. Todas estas sustancias son ésteres del ácido fenilacético, y como tales pueden transformarse fácilmente en ácido fenilacético, precursor que estaba incluido en el Cuadro II de la Convención de 1988. Hay que recordar que esta sustancia catalogada ha sido durante muchos años el punto de partida más común para la producción ilícita de un precursor fundamental de la anfetamina y la metanfetamina, la P-2-P. El decomiso realizado en México constituye un claro indicio de que los fabricantes de drogas ilícitas, respondiendo a la prohibición total del comercio de la efedrina y la seudoefedrina en todas sus formas que aprobó el Gobierno de este país en junio del 2008, reaccionaron con rapidez para eludir pp. 16, 51, 52 . 
esas medidas y centraron sus esfuerzos en obtener nuevas sustancias químicas no fiscalizadas para la fabricación de metanfetamina ${ }^{140}$.

Como respuesta a la preocupación de la JIFE sobre las medidas de fiscalización del ácido fenilacético se convocó en el año 2006 una reunión de su grupo asesor de expertos para examinar los movimientos internacionales de dicha sustancia. En el año 2007 sobre la base de la recomendación realizada por este grupo, la Junta envió una recomendación al Secretario General de Naciones Unidas para iniciar de forma oficial el procedimiento de traslado de esta sustancia catalogada del Cuadro II al Cuadro I del Convenio de Naciones Unidas de 1988. El Secretario General procedió a invitar a todos los gobiernos a que expresaran su opinión sobre la reclasificación propuesta. En el año 2008 el grupo asesor de expertos se reunió nuevamente para evaluar las respuestas de los gobiernos y determinar el grado de apoyo a nivel mundial sobre el cambio del Cuadro II al Cuadro I de este precursor. El grupo llegó a la conclusión de que la información disponible respaldaba la continuación del procedimiento de reclasificación del ácido fenilacético. En el año 2009 la JIFE solicitó a los gobiernos que presentaran información actualizada, sobre el uso de esta sustancia en la fabricación ilícita de estimulantes de tipo anfetamínico, con inclusión de las incautaciones de este precursor, la detección del mismo en laboratorios clandestinos y los análisis forenses en que se hubiera detectado la sustancia en la síntesis de estimulantes de tipo anfetamínico. Sobre la base de estas respuestas, se confirmaron las sospechas iniciales de la Junta respecto a la importancia y la magnitud de la utilización del ácido fenilacético en la fabricación de este tipo de drogas, por lo cual La JIFE presentó a la Comisión de Estupefacientes la recomendación de trasladar esta sustancia catalogada del Cuadro II al Cuadro I de la Convención de 1988141. Finalmente en el mes de marzo del 2010 la Comisión decidió por unanimidad, en su 33. período de sesiones, trasladar el ácido fenilacético pp. 10, 11. 
del Cuadro II al Cuadro I de la Convención. Esta decisión entró en vigor el 17 de enero del $2011^{142}$.

Para demostrar las dificultades que se presentan para establecer el nivel de comercio del ácido fenilacético queremos señalar que en el periodo 2008-2009 un total de cinco países informaron a través del formulario D exportaciones de ácido fenilacético con destino a 34 países, por un total de 77.437 kilogramos. Así mismo 14 países declararon usando este formulario la importación de 2.693 .793 kilogramos de esta sustancia (véase la disparidad de cifras). Pero para complicar un poco más el asunto, durante este mismo periodo a través del sistema PEN Online un total de 8 gobiernos reportaron 86 expediciones por un total de 142,8 toneladas de este precursor. Hay que destacar que México fue el principal país importador de ácido fenilacético, habiendo importado 2.242.821 kilogramos procedentes de cinco países. De las incautaciones de esta sustancia reportadas en el formulario D se puede afirmar que las cantidades son similares a la de años anteriores: 160 kilogramos a nivel mundial, de los cuales 153 kilogramos correspondieron a Bulgaria. Sin embargo se sabe que en México esta sustancia tiene una contribución importante en la fabricación ilícita de estimulantes de tipo anfetamínico, particularmente de metanfetamina, prueba de ello es que las autoridades mexicanas reportaron que en mayo del 2009 ya habían incautado casi 18.000 kilogramos de ácido fenilacético. Se cree que las fuentes de abastecimientos de esta sustancia son el desvío de esta sustancia del comercio nacional y el contrabando de la misma desde los Estados Unidos de América143.

En el periodo que va del 1 de noviembre del 2009 al 31 de octubre del 2010, se notificaron a la Junta un total de 315 remesas del ácido fenilacético, por un monto de 2.989 toneladas, procedentes de 12 países exportadores y con destino a 41 países importadores. Si se excluye una remesa individual de 2.688 toneladas de los Estados Unidos de América a los Países Bajos, el comercio internacional registrado ascendió a unas 310 toneladas. México sigue siendo uno de los principales importadores de la sustancia, con 132 toneladas. La JIFE señaló que con el

\footnotetext{
142 Precursores y productos químicos frecuentemente utilizados..., correspondiente a 2010..., p. 1.

143 Precursores y productos químicos frecuentemente utilizados..., correspondiente a 2009..., pp. 13, 14.
} 
traslado de este precursor al Cuadro I de la Convención de 1988 en enero del año 2011, aumentaría el comercio internacional reportado a través del sistema PEN Online. Hay que señalar que la información suministrada sobre incautaciones de esta sustancia por los gobiernos a través del formulario D correspondiente al año 2009 consistió en el decomiso de un total de 41,7 toneladas, frente a menos de 160 kilogramos reportados en el año 2008, correspondiendo las más importantes a México (30,6 toneladas), China (8,5 toneladas) y Serbia (1,9 toneladas), debiendo puntualizarse que muchas de estas incautaciones fueron realizadas en laboratorios ilícitos de drogas. La JIFE manifestó que el incremento de las incautaciones probablemente se debió al fortalecimiento de las medidas de fiscalización sobre esta sustancia ${ }^{144}$.

En México, desde la aprobación de una norma que fortalece las medidas de control sobre el ácido fenilacético, sus sales y derivados en el año 2009, se han producido una serie de decomisos importantes de esta sustancia que sumaron una cifra récord de 450 toneladas en el 2010. La mayoría de estas expediciones tenían su origen en Shangai (China) pero, a la fecha de cierre del informe de la Junta, no se había logrado determinar que estuvieran destinadas a la fabricación ilícita de P-2-P y posteriormente de metanfetamina. Es preciso puntualizar que algunos derivados del ácido fenilacético, en particular sus ésteres, se pueden reconvertir de nuevo en ácido fenilacético utilizando medios relativamente fáciles. También hay que señalar que en el mes de abril del 2010, en Belice, las autoridades aduaneras detuvieron también a petición de México, el país de destino, dos remesas de más de 45 toneladas de fenilacetato de etilo también conocido como etil fenil acetato, un derivado del ácido fenilacético fiscalizado en la legislación mexicana. Presentándose el caso de que en Belice no existe una norma que regule las incautaciones de sustancias no incluidas en los Cuadros de la Convención de 1988, por lo cual optaron por devolver la sustancia al país exportador para que adoptaran las medidas pertinentes ${ }^{145}$.

Del día 1 de noviembre del 2010 al día 31 de octubre del 2011 se reportaron a través del sistema PEN Online 380 remesas de ácido fenilapp. 10, 11. 
cético que sumaban 210 toneladas. Sin lugar a dudas este precursor y sus ésteres desempeñan hoy un papel mucho más importante que antes en la fabricación de metanfetamina, en particular en México. En el formulario D correspondiente al año 2010 cuatro gobiernos reportaron el decomiso de 183,5 toneladas de ácido fenilacético, que si se hubieran desviado hacia la fabricación ilícita habrían permitido obtener 46 toneladas de anfetamina pura. Esta cantidad es cuatro veces superior a la cifra récord registrada en el año 2005. Los gobiernos que reportaron los decomisos más importantes en el año 2010 fueron China (4,7 toneladas), México (56,1 toneladas, más otros 907 litros) y los Estados Unidos de América (122,7 toneladas). Hay que destacar que en América del Norte y América Central se producen cada vez más incautaciones de derivados del ácido fenilacético, en particular de sus ésteres, tal es el caso del etil fenil acetato (fenil acetato de etilo) del que México decomisó 178.000 litros y los Estados Unidos de América 145.000 litros $^{146}$.

En el mes de marzo del 2011 y bajo la dirección del grupo del Proyecto Prisma se inició la Operación PAAD con el fin de recopilar información estratégica sobre el comercio, el tráfico y el uso del ácido fenilacético y sus derivados. Esta operación de seis meses de duración, que tuvo un buen resultado, fue la primera realizada en el marco del Proyecto Prisma que se centró sistemáticamente en las sustancias no fiscalizadas de uso incipiente, la misma contó con la participación de 63 países.

Precursores y productos químicos frecuentemente utilizados..., correspondiente a 2011..., pp. 16-18. Para hacernos una idea de la importancia que tiene el ácido fenilacético en la elaboración ilícita de anfetaminas y metanfetaminas queremos manifestar que del año 1995 al año 2010 se han incautado en el mundo un total de 277.529 kilogramos de esta sustancia, siendo la sexta sustancia en nivel de incautaciones del Cuadro I de la Convención de 1988, teniendo este precursor una tendencia ascendente en sus incautaciones. Tan es así, que en el año 1995 se decomisaron 984 kilogramos de esta sustancia y en el año 2010 un total de 183.466 kilogramos, sin contar con las incautaciones de sus ésteres que cada vez son mayores en América del Norte y América Central. De la prevención de la desviación de este precursor nos permitimos señalar, que pese a los avances obtenidos hasta la fecha, todavía queda mucho por hacer para enfrentar en mejor medida el problema, sobre todo cuando se trata de derivados de este precursor. Ibidem. pp. 66-100. Precursores y productos químicos frecuentemente utilizados... correspondiente a 2010..., pp. 16-41. Precursores y productos químicos frecuentemente utilizados..., correspondiente a 2006..., pp. 38-60. Precursores y productos químicos frecuentemente utilizados..., correspondiente a 2004..., pp. 45-66. Precursores y productos químicos frecuentemente utilizados..., correspondiente a 2000..., pp. 47-61. 
En la operación, además del sistema PEN Online, se utilizaron notificaciones no transmitidas a través de Internet para hacer el seguimiento de remesas de derivados no fiscalizados del ácido fenilacético. Aunque esta sustancia catalogada tiene numerosos derivados y ésteres, el éster identificado con mayor frecuencia durante la operación fue el fenilacetato de etilo, también conocido como éster etílico del ácido fenilacético o etil fenil acetato. La JIFE recomendó a todos los gobiernos que den a los ésteres del ácido fenilacético el mismo tratamiento que al ácido fenilacético. Durante el desarrollo de la operación se incautaron un total de 25 remesas, de las cuales 11 estaban destinadas a México (284 toneladas), 8 a Guatemala (196 toneladas), una a Belice (15 toneladas) y una a Nicaragua (17 toneladas). Además las autoridades mexicanas reportaron el decomiso de 20 remesas de derivados del ácido fenilacético que sumaban 421 toneladas, siendo el origen de la mayor parte de estas remesas China y la India. Produciéndose además otros decomisos en Guatemala, Nicaragua y El Salvador también provenientes de China. Destacamos por su importancia el desmantelamiento de un laboratorio ilícito de escala industrial en el sur de México en el mes de mayo del año 2011 donde se ocuparon 11.000 litros de fenilacetato de etilo, entre los 140.000 litros de productos químicos decomisados. Además las autoridades de este país informaron del desmantelamiento de un almacén ilícito en el que había casi 800 toneladas de fenilacetamida otro derivado del ácido fenilacético ${ }^{147}$.

Queremos señalar, por la importancia que tiene, que en el mes de enero del 2012 en Michoacán, México en una operación conjunta del Servi-

El fenilacetato de etilo se transforma en ácido fenilacético con un rendimiento próximo al 75\%, por lo cual se necesitan 135 kilogramos de esta sustancia no catalogada para producir 100 kilogramos de ácido fenilacético. Otra sustancia que se necesita para realizar esta conversión es el anhídrido acético. Dependiendo del procedimiento de síntesis utilizado y de la eficiencia de la conversión práctica, se necesitan aproximadamente 150 kilogramos de esta sustancia para obtener 100 kilogramos de ácido fenilacético. Sin embargo, el anhídrido acético puede ser sustituido por sustancias químicas no fiscalizadas como el acetato de plomo, que se ha encontrado en algunos laboratorios ilícitos de México. También los Países Bajos en el mes de diciembre del año 2011 en el aeropuerto de Schiphol incautaron 1.000 kilogramos de feniacetato de etilo que presuntamente estaban destinados a fabricar ácido fenilacético, P-2-P y posteriormente metanfetamina. Precursores y productos químicos frecuentemente utilizados..., correspondiente a $2011 \ldots$, p. 20. Global SMART Update, volumen 7, marzo 2012. Informe global de monitoreo de drogas sintéticas 2012. Ed. UNODC. 2012, pp. 11, 14. 
cio de Administración fiscal, el Secretario de la Marina de México y la Oficina del Ministerio Público se incautaron 12 contenedores que contenían metilamina una sustancia química que se utiliza para elaborar metanfetamina, con un peso aproximado de 195 toneladas métricas. Los contenedores llegaron al puerto Lázaro Cárdenas procedentes de China. Diez de ellos iban destinados a Puerto Quetzal en Guatemala, y los otros dos se dirigían al puerto de Corinto en Nicaragua. Se trata de la primera vez en que se utiliza a México para intentar traficar sustancias no catalogadas a Nicaragua y la segunda vez que se trata de realizar el tráfico a Guatemala. Esta incautación pone de manifiesto un aumento de la fabricación de metanfetamina en Centroamérica y la creciente influencia de los carteles mexicanos en el mercado de drogas sintéticas en la región ${ }^{148}$. Se puede afirmar que a partir del año 2011 en México la proporción de precursores incautados basados en efedrinas descendió drásticamente. Esta disminución obedece al incremento del método P-2-P para la elaboración de metanfetamina, lo cual se refleja en el incremento del número de decomisos de sustancias no catalogadas tales como la fenilacetamida, el cloruro de bencilo, el 2-feniletanol, así como otros derivados del ácido fenilacético ${ }^{149}$.

En el periodo 2011-2012, a través del sistema PEN Online, se reportaron el envío de un total de 411 remesas de ácido fenilacético por un monto de 307 toneladas, lo que representó un incremento respecto de los años anteriores, lo cual posiblemente obedezca al traslado de esta sustancia al Cuadro I de la Convención de 1988 en el año 2011. En el periodo evaluado las autoridades de Polonia solicitaron la detención de una remesa de 18 toneladas de ácido fenilacético, que se había encargado a un proveedor en China, por que la empresa no estaba autoriza-

En diciembre del año 2011 se realizó la primera incautación de metilamina (741 toneladas métricas) en México que tenía por destino Guatemala. Global SMART Update, volumen 7, marzo 2012. Informe global de monitoreo de drogas sintéticas 2012. Ed. UNODC. 2012, p. 14. En el año 2011 cuatro gobiernos reportaron incautaciones de metilamina por un total 665 toneladas y 478.000 litros. México registro el $56 \%$ de los decomisos de esta sustancia (597 toneladas y 70.600 litros), seguido por los Estados Unidos de América, con el 38\% de incautaciones. Entre los meses de enero y octubre del año 2012, la JIFE fue informada de seis decomisos de metilamina en cuatro países de América Central y América del Norte, por un total de 130.000 litros; el 90\% de esta sustancia procedía de China. Precursores y sustancias químicas frecuentemente utilizados..., correspondiente a $2012 \ldots$, p. 20. 
da a importar la sustancia. Asimismo la Comisión Europea informó del resultado de una investigación llevada a cabo por las autoridades de Alemania y los Países Bajos en relación con la importación de ácido fenilacético de la India a Alemania. Un total de 11 toneladas de este precursor estaban destinadas a una empresa alemana. La investigación sobre esta operación permitió la incautación de seis toneladas de ácido fenilacético y de 2,5 toneladas de otras sustancias químicas en Alemania. Además, también se decomisaron cinco toneladas de ácido fenilacético en Rotterdam (Países Bajos). En la investigación se determinó que todos estos precursores que habían sido desviados, estaban destinados a utilizarce en la fabricación ilícita de anfetamina en Polonia150. En este periodo las autoridades de México informaron que el estireno, una materia prima industrial que se utiliza en la fabricación de plásticos se puede utilizar en la síntesis del ácido fenilacético, en el mes de julio del año 2012 al desmantelar un laboratorio de metanfetamina incautaron 5.600 litros de estireno ${ }^{151}$.

En el periodo que va del 1 de noviembre del 2012 al 31 de octubre del 2013, se presentaron por conducto del sistema PEN Online 518 notificaciones de remesas de ácido fenilacético, por un monto de 395 toneladas. En el informe correspondiente al año 2012 siete estados reportaron a través del formulario D la incautación de 1.700 kilogramos de este precursor de drogas, siendo esta la cifra más baja que se comunica desde el año 2010, lo que refleja el importante descenso de las cifras notificadas por China, los Estados Unidos de América y México en el año 2011. Queremos destacar que en este año Nicaragua comunicó por primera vez incautaciones de ácido fenilacético, así como que se decomisaron en Guatemala 16.000 kilogramos de fenilacetato de etilo, un éster del ácido fenilacético no incluido en los cuadros de la Convención de 1988. Dicha sustancia provenía de China. Informando las autoridades de Guatemala a la JIFE que no disponían de los recursos necesarios para manipular, almacenar y destruir esta sustancia no catalogada. A lo largo de año 2011 se siguieron realizando decomisos de ésteres del ácido feniacético en México, las autoridades de ese país, en el que dichas sustancias han estado sometidas a fiscalización desde el mes de noviembre del año 2009, informaron en el formulario correspondiente

\footnotetext{
$150 \quad$ Ibidem., pp. 16, 17.

151 Ibidem., p. 20.
} 
al año 2012 de la incautación de 72,8 toneladas y 46.000 litros de fenilacetato de etilo ${ }^{152}$.

En el periodo que va del 1 de noviembre del 2013 al 31 de octubre del 2014 un total de 12 países exportadores reportaron a través del sistema PEN Online 480 notificaciones previas a la exportación de remesas de ácido fenilacético por un monto de 1.000 toneladas, más del doble que el año anterior, a 43 países importadores. En lo que respecta al volumen de la totalidad de incautaciones de este periodo, hay que señalar que el 99\% de los decomisos se realizaron en tres países: los Estados Unidos de América, México y China, en este orden. En el formulario D correspondiente al año 2013 un total de cinco países informaron de la incautación de ácido fenilacético; China reporto la incautación de 6,5 toneladas, México de 3.320 kilogramos, Bulgaria de 97 kilogramos y Myanmar de 95 kilogramos. Ningún otro país informó de incautaciones superiores a 50 kilogramos. Siendo necesario destacar que sin embargo se siguen decomisando ésteres del ácido fenilacético. Belice comunicó la incautación en el año 2013 de una remesa de más de 800 litros de fenilacetato de etilo y de anhídrido acético (necesario para transformar los ésteres en P-2-P). México en este mismo año reporto el decomiso de 520 kilogramos y 12.000 litros de fenilactetato de etilo, así como de casi ocho toneladas de 2-fenilacetamida (precursor del ácido fenilacético), y en el año 2014 este país reporto a través del sistema PICS la incautación de 10 toneladas y 20.000 litros de fenilacetato de etilo ${ }^{153}$.

En el periodo 2014-2015 un total de 13 países exportadores enviaron notificaciones previas a 50 países importadores sobre 458 remesas por un monto de 254 toneladas de ácido fenilacético, la cuarta parte que el año anterior. Mientras que en el formulario D correspondiente al año 2014 se reporto la incautación de un total de 51.066 kilogramos, cinco veces más que el periodo anterior. Los decomisos más importantes se realizaron en China (50 toneladas) y México (1,3 toneladas). En este mismo año las incautaciones de APAAN, el otro precursor de drogas que frecuentemente se utiliza para la elaboración ilícita de P-2-P, ascendieron a más de 11 toneladas y fueron comunicadas en su totalidad pp. 15, 16, 21. 
por países europeos. Esta cifra representa una importante disminución con respecto al año anterior (43,5 toneladas) ${ }^{154}$.

Para hacernos una idea de la trascendencia de este precursor de drogas en la fabricación ilícita de anfetamina y metanfetamina queremos subrayar que del año 2004 al año 2013 a través del formulario D se comunico la incautación de un total 1.358 .802 kilogramos de ácido fenilacético a nivel mundial (cantidad con la que podrían fabricarse 339.700 kilogramos de anfetamina o metanfetamina) ${ }^{155}$, ocupando el primer lugar en nivel de incautaciones de sustancias del Cuadro I en este periodo, desglosado de la siguiente forma: 232 kilogramos en el año 2004, 47.732 kilogramos en el año 2005, 521 kilogramos en el año 2006, 159 kilogramos en el año 2007, 155 kilogramos en el año 2008, 41.655 kilogramos en el año 2009, 234.329 kilogramos en el año 2010, 1.022.231 kilogramos en el año 2011, 1.700 kilogramos en el año 2012 y 10.068 kilogramos en el año 2013. Estos decomisos se realizaron en un total de 20 países de 4 continentes, exceptuando África. Se efectuaron incautaciones de más de 1.000 kilogramos en cinco países: los Estados Unidos de América (1.172.155 kilogramos), México (120.616 kilogramos), China (55.875 kilogramos), Serbia (1.900 kilogramos) y Alemania (6.028 kilogramos) ${ }^{156}$. Como ya señalamos en el apartado correspondiente a la P-2-P, tanto el nivel de comercio internacional, como el nivel de incautaciones del ácido fenilacético es muy superior al de la P-2-P, además no hay que olvidar que existe evidencia de la fabricación ilícita de ácido fenilacético, así como de que hay mucha dificultad en establecer controles efectivos sobre los derivados de este precursor de drogas. Por lo cual hay que concluir que pese a los esfuerzos realizados por las autoridades competentes en todo el mundo para en-

154 En Alemania incautaron 5 toneladas de APAAN, proveniente de China, que estaba destinada a Polonia. Precursores y sustancias químicas frecuentemente utilizados..., correspondiente a $2015 \ldots$, pp. 18, 19, 68-87.

155 Precursores y productos químicos frecuentemente utilizados..., correspondiente a 2004..., p. 80.

156 Precursores y sustancias químicas frecuentemente utilizados..., correspondiente a 2014..., pp. 71-90. Precursores y sustancias químicas frecuentemente utilizados..., correspondiente a 2013..., pp. 67-84. Precursores y sustancias químicas frecuentemente utilizados..., correspondiente a 2009..., pp. 37-50, 51-62. En España del año 1993 hasta el año 2014 se incautaron sólo 96 kilogramos de ácido fenilacético. Vid., el Anexo III. 
frentar el desvío y la fabricación ilícita de esta sustancia aún no se han logrado los resultados deseados.

B.) PRECURSORES QUE SE UTILIZAN PARA ELABORAR MDMA (ÉXTASIS), MDA (TENAMFETAMINA O PÍLDORA DEL AMOR), MDE (EVA) Y N-HIDROXI-MDA (HIDROXILAMINA)

\section{3,4-metilendioxifenil-2-propanona}

Para iniciar este apartado queremos recordar que la 3,4-MDP-2-P se utiliza en la fabricación ilícita del éxtasis (MDMA) y otras drogas análogas como MDA (tenamfetamina o píldora del amor), MDEA (Eva) y Nhidroxi-MDA (es un homologo de la MDA), sin embargo es necesario precisar que este precursor de drogas se usa de forma mayoritaria para elaborar éxtasis ${ }^{157}$. Para entrar en materia sobre las incautaciones de MDMA hay que decir que en el año 1999 alcanzaron niveles sin precedentes, sin embargo no ocurrio lo mismo con los precursores que se utilizan para elaborar esta droga (3,4-metilendioxifenil-2-propanona, piperonal, isosafrol y safrol) ya que el nivel de decomiso de estas sustancias fue muy reducido. De estos precursores el que más buscan los narcotraficantes para la fabricación de MDMA es la 3,4metilendioxifenil-2-propanona (3,4-MDP-2-P), realizándose este año incautaciones por un monto de 6.324 litros a nivel mundial, siendo la más importante la que se llevo a cabo en Eslovaquia (5.864 litros), presentándose la particularidad de que en la mayoría de casos esta sustancia provenía de China ${ }^{158}$. Se puede afirmar que la 3,4-MDP-2-P es la sustancia catalogada más utilizada en la producción de MDMA, teniendo en la mayoría de países pocos usos lícitos, entre los que podemos citar pequeñas cantidades utilizadas por las compañías de perfumería. Lo cual es totalmente distinto en China donde se fabricaba 3,4-MDP-2$\mathrm{P}$ a gran escala para usarlo en la elaboración de un producto farmacéu-

Vid., en el Anexo II el grafico del proceso de elaboración de la MDMA.

158 La JIFE había advertido en años anteriores que la fabricación ilícita de MDMA podía extenderse desde Europa a otras regiones. En 1999 se informo de que en Colombia se había desmantelado un laboratorio en que se fabricaba MDMA y se habían incautado 300.00 tabletas y en los Estados Unidos de América también desmantelaron 19 laboratorios, lo que supone el doble de los desmantelados en 1997 y 1998. Precursores y productos químicos frecuentemente utilizados..., correspondiente a 2000..., pp. 30, 31. 
tico. En ese país los traficantes suelen evitar las estrictas medidas de control impuestas por las autoridades, y en lugar de tratar de desviar la sustancia por el comercio internacional, optaban por sacarla de contrabando del país después de adquirirla a través de los canales internos de distribución. En este contexto se logro establecer que un gran número de empresas provinciales de China estaban en condiciones de fabricar este precursor, por lo que se determino que era esencial que las autoridades de los países, especialmente los de Europa, que han realizado incautaciones de esta sustancia compartieran oportunamente con las autoridades chinas todos los resultados de las investigaciones que fueran necesarios para rastrear, esta sustancia catalogada hasta las fuentes de desviación para poder adoptar medidas al respecto ${ }^{159}$. En el año 2000 se produjo un incremento importante en el decomiso de este precursor de drogas, fundamentalmente en Europa: Bélgica (11,5 toneladas), los Países Bajos (2,5 toneladas) y Alemania (media tonelada) ${ }^{160}$.

En el año 2001 se produjeron importantes incautaciones de 3,4-MPD$2-\mathrm{P}$, de hecho, fueron las segundas en importancia comunicadas hasta esa fecha (11 toneladas). Es preciso puntualizar que la mayoría de los decomisos se llevaron a cabo en los Países Bajos, y se realizaron al interceptarse en el puerto de Rotterdam envíos de contrabando procedentes de China, país que controla de forma estricta las exportaciones de esta sustancia, la cual, como ya hemos señalado antes, tiene un comercio internacional muy limitado, lo que hizo pensar a la JIFE que los traficantes o estaban desviando esta sustancia catalogada del comercio nacional lícito o bien han recurrido a empresas no autorizadas para fabricar ilegalmente este precursor con el fin de introducirlo posteriormente de contrabando en los países en que se produce la fabricación ilícita de anfetamina, metanfetamina y MDMA ${ }^{161 .}$

En el año 2003 los decomisos de 3,4-MDP-2-P experimentaron un descenso considerable. Los Países Bajos reportaron una incautación de siete toneladas de esta sustancia, señalando las autoridades competenpp. 14, 15.

161 Precursores y productos químicos frecuentemente utilizados..., correspondiente a 2002..., pp. 30, 31. Precursores y productos químicos frecuentemente utilizados..., correspondiente a $2004 \ldots$, pp. $18,19,54$. 
tes de este país que los precios en el mercado negro de este precursor se mantuvieron estables, lo que demuestra que los traficantes todavía podían obtener esta sustancia sin mayores dificultades y que posiblemente estuvieran utilizando rutas alternativas para introducirla de contrabando a Europa. Destacamos que el modus operandi de los traficantes en estos casos estaba muy desarrollado en el enmascaramiento, como ejemplo de ello citamos que muchas veces esta sustancia catalogada ocupaba el lugar de aceites vegetales o minerales o era ocultado dentro de radiadores o lámparas de lava u otro tipo de objetos de uso cotidiano $^{162}$. Estonia también informó sobre decomisos de esta sustancia catalogada en el año 2003. Cabe señalar que la incautación de 3,4MPD-2-P se realizó en un laboratorio de MDMA (Éxtasis) y, que aparte del precursor, se incautaron también 26.000 tabletas de MDMA y 60 litros de MDMA líquido. Las autoridades de este país, en cooperación con las autoridades rusas pusieron en marcha investigaciones de rastreo para determinar la fuente de la 3,4-MDP-2-P incautada. Esa investigación condujo a la identificación y desmantelamiento de un laboratorio de fabricación ilícita de esta sustancia en la Federación de Rusia y la incautación de otros 430 litros más de este precursor a principios del año 2004. Es necesario especificar que la fabricación de este sustancia catalogada en dicho laboratorio se hacía a partir de safrol en forma de aceite de sasafrás, que había sido introducido de contrabando a la Federación de Rusia desde Vietnam a través de China. Lamentablemente, todas las marcas habían sido borradas de los propios contenedores y no se encontró documentación justificativa, por lo que no se emprendieron las investigaciones de rastreo complementarias. Para concluir hay que decir que en este año las autoridades chinas también lograron impedir la desviación de cinco toneladas de 3,4-MDP-2-P destinadas a Guinea ${ }^{163}$.

En el año 2003 la JIFE recomendó a todos los Estados y territorios parte y no parte de la Convención de 1988 que cuando se cursara un pedi-

Precursores y productos químicos frecuentemente utilizados..., correspondiente a 2003..., pp. 22, 23.

163 El caso citado indica que en Europa los traficantes pueden estar fabricando 3,4-MDP-2P, las autoridades de Irlanda informaron de la incautación de 4.500 litros de esta sustancia que había sido introducida a este país de contrabando desde China a través de los Países Bajos. Precursores y productos químicos frecuentemente utilizados..., correspondiente a $2004 \ldots$, pp. 19, 20. 
do de precursores de estimulantes de tipo anfetamínico, como la 3,4MPD-2-P y la P-2-P, que tienen usos lícitos muy especializados, el gobierno del país desde el que se hace el pedido debería de realizar un examen a fondo para establecer el uso final que se piensa dar a la sustancia y los volúmenes necesarios a esos efectos, incluso llevando a cabo inspecciones oculares en la empresa importadora y de los consignatarios para asegurarse de que el uso final es compatible con las actividades declaradas de la empresa de que se trate ${ }^{164}$.

El gobierno de Canadá en el año 2004 reportó la incautación de 1.500 litros de 3,4-MDP-2-P y China de cinco toneladas de esta sustancia, en el mes de septiembre del año 2005 las autoridades competentes de este país e Indonesia iniciaron una investigación conjunta que dio por resultado la interceptación de una remesa de tres toneladas de este precursor que se estaba introduciendo de contrabando a Indonesia, donde se sabe que existen laboratorios ilícitos que fabrican MDMA desde el año 2002. Aunque Europa sigue siendo el fabricante principal de gran parte de esta droga de diseño, son muy pocos los decomisos reportados en esta región. Por otra parte las autoridades de Australia, que descubren de forma frecuente pequeños laboratorios que fabrican MDMA, lograron desarticular una red de traficantes que venía introduciendo en el país de contrabando remesas de precursores de varias toneladas. En la operación en cuestión las autoridades incautaron una mezcla de 3,4-MDP-2-P y piperonal, de el análisis forense no se logró determinar si el piperonal se había utilizado como material base para obtener 3,4-MDP-2-P o si ambas sustancias se obtuvieron durante el intento de fabricar una u otra a partir de safrol. Investigaciones complementarias dieron por resultado el decomiso de otras dos toneladas de esa mezcla ${ }^{165}$.

En el año 2006 las incautaciones de 3,4-MDP-2-P continuaron aumentando en Canadá, lo cual respondía posiblemente al incremento de la demanda de MDMA en la región. Mientras que en Asia se desmantelo una organización de traficantes que operaba en China, Hong Kong (RAE de China) e Indonesia, realizándose la incautación de tres toneladas de p. 18. pp. 6, 7. 
este precursor de drogas. En Europa se realizaron el $40 \%$ de las incautaciones mundiales de 3,4-MDP-2-P, cantidad inferior a la del año anterior lo cual responde probablemente a que la fabricación de MDMA se extendió a otras regiones. En Australia los decomisos de esta sustancia catalogada también disminuyeron en este periodo, pero en este caso no se debe a la reducción de la elaboración ilícita de MDMA, que por el contrario está en aumento en este país, sino a la utilización de piperonal como sustitutivo del 3,4-MDP-2-P para la elaboración de esta droga ${ }^{166}$.

Es importante señalar que el comercio internacional de 3,4-MDP-2-P fue bastante limitado durante el periodo que va del 1 de noviembre del 2004 al 31 de octubre del 2005, prueba de ello es que únicamente se recibió una notificación relacionada con esta sustancia y en el periodo 2005-2006 no se notificó a la Junta ningún envío de esta sustancia. Como este precursor no suele desviarse del comercio internacional, las investigaciones de rastreo hasta la fuente puede ser una de las maneras más eficaces de enfrentar el desvío. También hay que decir que aunque este precursor sigue siendo el insumo químico preferido para la fabricación de MDMA y se hayan reportado importantes incautaciones en este periodo, estas siguen resultando pequeñas en relación con la cantidad de MDMA disponible en el mercado. Sobre este tema la JIFE señaló que del piperonal, precursor que tiene aplicaciones lícitas más amplias, durante el mismo periodo se notificaron 150 envíos por un total de 3.800 toneladas, siendo por lo tanto el precursor de MDMA más comercializado en el mundo, habiéndose notificado incautaciones de esta sustancia en China en el año 2004 de 13 toneladas, en Hong Kong en el año 2005 de cuatro toneladas y en, Rumania en el año 2004 de 2.5 toneladas, lo cual hace pensar que los traficantes pueden estar recurriendo a esta sustancia para la fabricación de MDMA, MDA (conocida como dulce droga de América o píldora del amor) o bien para la fabricación ilícita de 3,4-MDP-2-P para elaborar estas drogas ${ }^{167}$.

Precursores y productos químicos frecuentemente utilizados..., correspondiente a 2006..., pp. 16, 17.

167 Precursores y productos químicos frecuentemente utilizados..., correspondiente a 2005..., p. 6. La JIFE observa con preocupación que si bien se ha logrado reducir el contrabando de 3,4-MDP-2-P a Europa Occidental, poco se sabe sobre los nuevos métodos y rutas que emplean los traficantes para desviar esta sustancia. Precursores y productos químicos frecuentemente utilizados..., correspondiente a 2006..., p. 15. 
En el periodo que va del 1 de noviembre del 2006 al 31 de octubre del 2007 ningún país o territorio reportó el envío de ninguna remesa lícita de esta sustancia. Sólo Alemania, Australia, Hungría, Malta y Suecia comunicaron necesidades legítimas de 3,4-MDP-2-P, pero en todos los casos se trataba de cantidades muy pequeñas ${ }^{168}$. De igual manera tampoco se reportaron remesas lícitas de este precursor de drogas entre el 1 de noviembre del 2007 y el 31 de octubre del 2008. Es más, hay que destacar que únicamente cinco países informaron a la Junta de sus previsiones de utilización lícita de esta sustancia para este periodo, y en todos los casos se trataba de cantidades ínfimas ${ }^{169}$.

Después de un periodo de seis años en el que realizaron importantes incautaciones de 3,4-MDP-2-P destinadas a la fabricación ilegal de MDMA (éxtasis), en el año 2006 disminuyeron a nivel mundial tanto el número como el volumen de las incautaciones, únicamente reportaron decomisos Canadá (7.378 litros) y los Países Bajos (105 litros). En el año 2007 se desmanteló en el país antes citado un gran laboratorio dedicado a la fabricación de MDMA, además las autoridades competentes de Croacia informaron del decomiso de 1.132 litros de 3,4-MDP-2-P, realizada en colaboración con las autoridades italianas. La sustancia había sido introducida a Croacia en un contenedor marítimo proveniente de China ${ }^{170}$. Hay que señalar que en el año 2007 se mantuvo la tendencia, señalada en el año 2006, sobre la disminución de las incautaciones reportadas de 3,4-MDP-2-P tanto en número como en volumen. Durante el periodo evaluado, únicamente cuatro países comunicaron haber realizado importaciones de esta sustancia, siendo estos: Hungría, Nueva Zelanda, el Reino Unido de Gran Bretaña e Irlanda del Norte y la República de Corea. Las autoridades competentes de Canadá informaron en este año del decomiso de 369 litros del precursor antes mencionado. Posteriormente, este mismo país comunicó de otra incautación de 3,7 toneladas de 3,4-MDP-2-P que se intentaba introducir de contrabando oculta en una remesa de hidróxido sódico en el año 2008, pp. 11, 12. p. 9. 
siendo el volumen de las incautaciones de esta sustancia catalogada extremadamente bajo en comparación con las incautaciones de MDMA comunicadas en todo el mundo. La JIFE señaló que esta disparidad se debe a la producción de forma ilegal de este precursor y su salida de contrabando directamente desde los países donde se fabrica. Por consiguiente, la Junta instó a todos los países, en particular a los que cuentan con industrias apreciables de producción química, a que vigilen estrechamente su ámbito interno para identificar compras sospechosas de precursores. Manifestando que también debe de vigilarse muy de cerca el comercio del safrol y del piperonal que son precursores secundarios de la 3,4-MDP-2-P171. Un elemento que reviste gran importancia sobre este tema es que en el año 2008 las autoridades competentes de China, hasta entonces el mayor productor legal del mundo, informaron de manera oficial a la Junta que ya no se fabricaba lícitamente 3,4metilendioxifenil-2-propanona (3,4-MDP-2-P) en el país ${ }^{172}$.

Entre el día 1 de noviembre del 2008 y el día 31 de octubre del 2009, según las notificaciones realizadas a través del sistema PEN Online, sólo dos países exportaron 3,4-MDP-2-P a dos países importadores por un volumen total de menos de cinco litros. De conformidad con la información suministrada a la JIFE en el formulario D en el año 2008 hubo dos operaciones de exportación de la sustancia por un total inferior a un litro, además hay que decir que, una vez más, sólo cinco países notificaron a la JIFE sus evaluaciones sobre el uso lícito de este precursor y, en todos los casos se trataba de cantidades muy pequeñas. Sobre las incautaciones es importante enfatizar que ningún país comunicó en el formulario antes citado ninguna incautación. Sin embargo las autoridades canadienses informaron por otras vías el decomiso en el año 2008 de 2,8 toneladas de 3,4-MDP-2-P, comunicaron además de la utilización de esta sustancia para la fabricación de MDMA mediante un procedimiento conocido como "método frío", muy frecuente en la provincia de la Columbia Británica. El hecho de que no se haya realizado en el mundo ninguna otra incautación de este precursor, cuando aumentan el numero y la frecuencia de incautaciones de MDMA, responde posiblemente a que los narcotraficantes están realizando la fabricación

171 Precursores y productos químicos frecuentemente utilizados..., correspondiente a 2008..., p. 10.

172 Ibidem., p. 4. 
ilícita de 3,4-MDP-2-P a gran escala, utilizando fundamentalmente piperonal, safrol y aceites ricos en safrol, y usan el contrabando para su distribución por lo cual la Junta recomendó a todos los países fortalecer las medidas de control sobre dichas sustancias ${ }^{173}$.

En el período que va del día 1 de noviembre del 2009 al día 31 de octubre del 2010 el comercio internacional de 3,4-MDP-2-P, también fue muy bajo, a través del sistema PEN Online se informó de cinco remesas que sumaban un total de cuatro litros. La discrepancia observada en los últimos años entre el volumen y la frecuencia de incautaciones de MDMA y 3,4-MDP-2-P se mantuvo en este período, pues únicamente las autoridades competentes de Australia y los Países Bajos reportaron a través del formulario D incautaciones de este precursor, de un volumen muy limitado. Un dato sumamente curioso es que las autoridades de Alemania informaron del único intento de desviación comunicado desde el año 2005, en que una persona trato de comprar 300 litros de esta sustancia catalogada ${ }^{174}$. Un dato digno de mención es que en el mes de abril del año 2010 en los Países Bajos al desmantelar un laboratorio ilícito de MDMA descubrieron una sustancia denominada 3,4MDP-2-P glicidato de metilo. Esta sustancia tiene la particularidad de que enmascara o disimula el 3,4-MDP-2-P, y se puede reconvertir en este con facilidad. Hay que señalar que se trató del primer incidente con esta sustancia no catalogada en este país, y que al mismo le siguieron varias incautaciones en Eslovaquia y nuevamente en los Países Bajos, queremos precisar que la 3,4-MDP-2-P glicidato de metilo cada vez se utiliza más en la fabricación de MDMA principalmente en países de Europa Occidental y Central. Es necesario recordar que el 3,4-MDP-2-P glicidato de metilo se detectó y se describió por primera vez en el año 2004 en Australia175.

Precursores y productos químicos frecuentemente utilizados..., correspondiente a 2009..., pp. 12, 13. La JIFE alerto a las autoridades competentes de todo el mundo en el año 2010 sobre el uso de safrol para fabricar MDMA. Precursores y productos químicos frecuentemente utilizados..., correspondiente a 2010...,p. 13.

174 Precursores y productos químicos frecuentemente utilizados..., correspondiente a 2010 ..., p. 10.

175 Precursores y productos químicos frecuentemente utilizados..., correspondiente a 2010..., p. 12. Global SMART Update, volumen 7, marzo 2012. Informe global de monitoreo de drogas sintéticas 2012. Ed. UNODC. 2012, p. 5. 
Del día 1 de noviembre del 2010 al día 31 de octubre del 2011 solo se comunicaron mediante el sistema PEN Online cinco remesas de 3,4MDP-2-P, que sumaban un total de dos litros, sin embargo este dato no es muy fiable, dado que con frecuencia se presentan discrepancias con los datos reportados a través del formulario D. Esto posiblemente se deba, en opinión de la JIFE, a que cuando los países de la Unión Europea comercializan esta sustancia entre sus países miembros no se realizan las notificaciones previas a la exportación. Sobre las incautaciones de esta sustancia catalogada hay que decir que únicamente dos países reportaron decomisos de este precursor por un total de 2,1 litros. Lo cual es una cantidad irrisoria si se compara con en nivel de MDMA que se comercializó de forma ilícita en este período en las distintas regiones del mundo 176 .

Como señalamos antes el comercio de 3,4-MDP-2-P sigue siendo muy bajo, no siendo así el de otra sustancia catalogada el piperonal que también se utiliza para fabricar MDMA, de hecho muy pocos gobiernos tienen una necesidad legítima de importar 3,4-MDP-2-P, y los que la tienen informan de cantidades mínimas. Durante el periodo 2011-2012 mediante el sistema PEN Online sólo se reportó sólo una remesa de esta sustancia catalogada, frente a más de 500 de piperonal. Un total de 14 gobiernos (el 7\% de países o territorios del mundo) informaron a la Junta de una necesidad legítima de 3,4-MDP-2-P por un total de 133 kilogramos, mientras que 87 países informaron que no tenían ninguna necesidad legítima de este precursor de drogas. A través del formulario D co-

176 Precursores y productos químicos frecuentemente utilizados..., correspondiente a 2011..., p. 18. Para hacernos una idea del estado de la cuestión queremos señalar que del año 1995 al año 2010 se incautaron en el mundo un total de 83. 284 litros (equivalentes a 99.981 kilogramos) de 3,4-MDP-2-P, siendo esta la octava sustancia en niveles de incautaciones de las listas del Cuadro I de la Convención de Naciones Unidas de 1988. Hay que señalar que estas cifras son totalmente insignificantes si se comparan con el nivel de producción de MDMA que se realiza en las diferentes regiones del planeta, y lo que es peor aún es que los niveles de decomisos de esta sustancia presentan una tendencia descendente, así se paso de incautar 1.514 litros en el año 2005 a incautar únicamente dos litros en el año 2010. Ibidem., pp. 66-100. Precursores y productos químicos frecuentemente utilizados..., correspondiente a 2010..., pp. 16-41. Precursores y productos químicos frecuentemente utilizados..., correspondiente a 2006..., pp. 38-60. Precursores y productos químicos frecuentemente utilizados..., correspondiente a 2004, pp. 45-66. Precursores y productos químicos frecuentemente utilizados... correspondiente a 2000, pp. 47-61. 
rrespondiente al año 2011 tres países reportaron incautaciones de esta sustancia: Australia, Canadá y Lituania por un monto de 124 litros ${ }^{177}$.

Durante el periodo que va del 1 de noviembre de 2012 al 31 de octubre del 2013 únicamente se comunicó por medio del sistema PEN Online la comercialización de 0,5 litros de 3,4-MDP-2-P. Sin embargo, tras un prolongado paréntesis en las incautaciones de este precursor a nivel mundial en el periodo 2009-2011, en el que solamente se decomisaron 166 litros, en el año 2012 las autoridades de Irlanda, Filipinas y Nicaragua, comunicaron en el formulario D incautaciones de 3,4-MDP-2-P por un monto total de 229 litros. La Junta manifestó que era posible que estuvieran utilizando la India como nueva fuente de suministro de este precursor, según se desprende de una serie de incidentes notificados en los años 2012 y 2013. Además, la India comunicó por conducto del sistema PICS dos incautaciones de este precursor de drogas por un monto de 137 kilogramos entre abril y mayo de 2013. En este mismo año, siempre a través del sistema PICS, se informo del decomiso de 1.000 litros de 3,4-MDP-2-P procedente de China y destinada a los Países Bajos mientras pasaba en transito por Eslovenia. La sustancia se introdujo clandestinamente en un contenedor mezclado con piperonal y fue aprehendida en el puerto esloveno de Koper. También informaron mediante este sistema las autoridades de los Países Bajos la incautación de 100 litros de 3,4-MDP-2-P en un laboratorio clandestino, determinándose que se había utilizado para su elaboración la sustancia química catalogada denominada piperonal y/o 3,4-MDP-2-P glicidato de metilo (sustancia no catalogada) ${ }^{178}$.

Las autoridades de Luxemburgo reportaron a través del sistema PICS decomisos de un nuevo "pre-precursor" de la MDMA, "la sal sódica de 3,4-MDP-2-P ácido glicídico", que puede transformarse en 3,4-MDP-2-P en una relación práctica de 2 a 1 aproximadamente. Una partida de 420 kilogramos de la sustancia, originaria de China, había llegado a Luxem-

Precursores y sustancias químicas frecuentemente utilizados..., correspondiente a 2012..., pp. 17, 18.

178 Se siguen realizando en Europa pequeñas incautaciones de la sustancia 3,4-MDP-2-P glicidato de metilo. Sustancia no catalogada que se utiliza para elaborar 3,4-MDP-2-P y por ende MDMA. Las autoridades de Luxemburgo reportaron a través del sistema PICS decomisos de un nuevo "pre-precursor" de la MDMA. Precursores y productos químicos frecuentemente utilizados..., correspondiente a 2013..., pp. 17, 18, 21. 
burgo por vía aérea desde Hong Kong (RAE de China) e iba destinada a los Países Bajos. El contenido de la remesa había sido declarado fraudulentamente como un "preparado tensoactivo orgánico". Las autoridades competentes de Luxemburgo informaron posteriormente de que se habían producido más incidentes relacionados con la sustancia no catalogada; también se reportó que habían producido otros incidentes relacionado con este "pre-precursor" en Estonia y Rumania. La Junta alertó a todas las autoridades nacionales acerca del hecho de que el análisis de la sal sódica de 3,4-MDP-2-P ácido glicídico puede plantear problemas en cuanto a su identificación, ya que puede darse el caso que la 3,4-MDP-2-P se detecte incorrectamente como componente principal ${ }^{179}$.

En el año 2012 informaron a la JIFE cuatro gobiernos de la realización de incautaciones de metilamina, sustancia que junto con la 3,4-MDP-2-P se usa en la fabricación de MDMA; los Estados Unidos de América (6.929 litros), Honduras (51.000 litros), México (197 toneladas y 150.000 litros) y Polonia (403 litros). También se reportaron otros incidentes con esta sustancia no catalogada por medio del sistema PICS, entre ellos el decomiso de 800 litros de metilamina, junto con otras sustancias químicas y equipo de laboratorio en un camión en México ${ }^{180}$.

Como ya se ha señalado antes, el nivel de comercio lícito de 3,4-MDP-2$\mathrm{P}$ es muy reducido, de hecho sólo cuatro gobiernos comunicaron tener necesidades legítimas de importación de más de un kilogramo al año de este precursor de drogas. En el periodo que va del día 1 de noviembre del 2013 al 31 de octubre del 2014 no se envió ninguna notificación previa de exportación de remesas de 3,4-MDP-2-P por medio del sistema PEN Online. En el formulario D correspondiente al año 2013 un total de cinco países (Austria, Bélgica, China, Eslovenia y los Países Bajos) reportaron incautaciones de esta sustancia por un monto de 3.930 litros. Destacamos que Bélgica realizo tres incautaciones, dos de ellas procedían de China, que ascendían a 2.781 litros, y Eslovenia decomisó 
900 litros de 3,4-MDP-2-P, que también tenía por origen China y estaba destinada a los Países Bajos ${ }^{181}$.

En el año 2013 se continuaron decomisando en Europa derivados del ácido 3,4-MDP-2-P metilglicídico, entre ellos el éster metílico y la sal sódica de la sustancia. Generalmente las remesas iban destinadas a los Países Bajos y solían pasar por varios países europeos. Alemania, Eslovaquia, los Países Bajos y Rumania comunicaron en el formulario D correspondiente al año 2013 incautaciones de uno o más de esos derivados; algunas de las incautaciones se efectuaron en operaciones de entrega vigilada en las que a menudo participaban organismos de represión del narcotráfico de varios países. Por ejemplo, en Eslovaquia se decomisaron 1,2 toneladas en una operación de entrega vigilada de una remesa enviada desde Rumania que había pasado por Hungría. Al registrarse posteriormente un almacén se encontraron indicios de que la cantidad total podría haber sido superior a las ocho toneladas; la remesa supuestamente procedía de China y su destino final era los Países Bajos. Otro hecho que hay que destacar es que en el mes de octubre del año 2013 las autoridades de China detuvieron una remesa de 1,5 toneladas de 3,4-MDP-2-P glicidato de metilo que iba destinada a una empresa española después de que supuestamente se hubieran entregado dos remesas anteriores que sumaban un total de 3.000 kilogramos. En las investigaciones internacionales posteriores participaron siete países: Bulgaria, China, España, Letonia, los Países Bajos, Suiza y Ucrania. Se sospecha que la misma empresa española también estaba relacionada con la importación de APAAN para su exportación a distintos países europeos. Los dos propietarios de la empresa eran de Bélgica y los Países Bajos ${ }^{182}$.

En el periodo 2014-2015 sólo se notifico el envío una remesa de tres litros de 3,4-MDP-2-P a través del sistema PEN Online, y únicamente cuatro gobiernos informaron que tienen una necesidad legítima anual para la importación de más de un litro de este precursor de drogas. En el formulario D correspondiente al año 2014 se reporto la incautación de 58 litros de 3,4-MDP-2-P a nivel mundial, correspondiendo las mismas a tres países Australia (20 litros), Bélgica (5 litros) y China (33 li-

181 Precursores y sustancias químicas frecuentemente utilizados..., correspondiente a 2014.., pp. 28, 29.

$182 \quad$ Ibidem., p. 32. 
tros). Queremos poner de manifiesto que la cantidad decomisada en este periodo es una de las tres más bajas en los últimos 20 años. No obstante hay que señalar que a través del sistema PICS se informo a la Junta de una incautación de 60 kilogramos de esta sustancia catalogada en Australia en el mes de mayo del año 2015, asimismo se notifico el decomiso de 1.500 kilogramos por la autoridades de Hong Kong (RAE China). En ambos casos la procedencia de la sustancia era China ${ }^{183}$.

Para tener una visión de conjunto del nivel de enfrentamiento al desvío o fabricación ilícita de la 3,4-MDP-2-P a nivel mundial queremos señalar que del año 2004 al año 2013 a través del formulario D se reportó la incautación de 47.514 litros de este precursor de drogas, equivalentes a 57.039 kilogramos (cantidad con la que podría fabricarse un total de 38.011 kilogramos de MDMA) ${ }^{184}$, distribuidos de la siguiente manera: 16.333 litros en el año 2004, 12.924 litros en el año 2005, 8.816 litros en el año 2006, 2.297 litros en el año 2007, 2.823 litros (2008), 40 litros (2009), 2 litros (2010), 124 litros (2011), 228 litros (2012) y 3.927 litros (2013). Los decomisos se realizaron en 17 países de cuatro continentes, exceptuando África. Las mayores incautaciones se llevaron a cabo en: Canadá (15.994 litros), China (5.351 litros), Hong Kong (3.357 litros), Croacia (1.333 litros), Bélgica (6.005 litros), los Países Bajos (7.619 litros) Eslovenia (912 litros) ${ }^{185}$. Como puede apreciarse del año 2006 al año 2012 se produjo una disminución muy importante en los niveles de incautación de esta sustancia, repuntando un poco en el año 2013, pero sin alcanzar los niveles del año 2006. Debiendo señalarse que con la 3,4-MDP-2-P existe la particularidad de que los niveles de incautación de cualquier año superan descomunalmente los niveles de comercio internacional. Por ello en el caso de este precursor de drogas más que evitar el desvío, pues se comercializa de forma lícita entre uno y cinco litros de esta sustancia al año a nivel mundial, se trata de

183 Precursores y sustancias químicas frecuentemente utilizados..., correspondiente a 2015..., pp. 19, 20.

184 Precursores y productos químicos frecuentemente utilizados..., correspondiente a 2004..., p. 81.

185 Precursores y sustancias químicas frecuentemente utilizados..., correspondiente a 2014..., pp. 71-90. Precursores y sustancias químicas frecuentemente utilizados..., correspondiente a 2013..., pp. 67-84. En España desde el año 1993 hasta el año 2014 sólo se incauto un litro de 3,4-MDP-2-P. Vid., el Anexo III. 
impedir la producción ilícita en prácticamente todas las regiones del mundo a partir de otras sustancias catalogadas como el piperonal, el isosafrol, el safrol o los aceites ricos en safrol como el aceite de sasafrás a través de diversos métodos, $\mathrm{u}$ otras sustancias no catalogadas, para llevar la 3,4-MDP-2-P a los lugares donde se encuentran los laboratorios ilícitos de MDMA, cuando no se fabrica en los propios laboratorios. En la labor de impedir la producción de este precursor lamentablemente hay que decir que no se han conseguido resultados satisfactorios si se toma en cuenta el nivel de producción mundial de MDMA y MDA, que ha aumentado a pesar de los esfuerzos realizados por los organismos competentes de prácticamente todo el mundo ${ }^{186}$.

\section{Safrol (sus derivados) y el isosafrol}

Sobre el safrol hay que decir que se reportan de forma frecuente incautaciones, pero en cantidades no muy significativas, lo que incluye decomisos de este precursor bajo la forma de aceite de sasafrás, en laboratorios ilícitos donde se usa para la fabricación de 3,4-MDP-2-P y por ende de MDMA y otras drogas análogas, los países que reportaron incautaciones de esta sustancia catalogada en el año 2001 fueron Australia, Dinamarca y Alemania. Un elemento a destacar es que el aceite de sasafrás puede utilizarse para elaborar las cuatro sustancias catalogadas, safrol, isosafrol, piperonal y 3,4-metilendioxifenil-2-propanona, que se usan para fabricar MDMA. Lo cual se ha puesto de manifiesto en una operación combinada que se realizó entre las autoridades de Alemania, la República Checa y China. En la misma se logró establecer que los narcotraficantes intentaron conseguir 3,4-MDP-2-P en China y al no lograrlo, debido a los controles existentes sobre esta sustancia, obtuvieron aceite de sasafrás en ese país, con vistas a enviarlo a Alemania donde estaba previsto convertirlo en 3,4-metilendioxifenil-2yor parte de las pastillas vendidas como éxtasis en Europa contenían dosis muy bajas de MDMA, así como una reducción en la producción de esta droga, la situación parece estar cambiando, dado que nuevos datos indican un incremento en los últimos cinco años en la disponibilidad de pastillas con alto contenido de MDMA, lo cual también ocurre con el éxtasis en polvo y en forma cristalina. Informe Europeo sobre Drogas. Tendencia y novedades. 2015. Ed. Observatorio Europeo de las Drogas y las Toxicomanías. Bruselas. 2015, p. 30. Resumen Ejecutivo. Informe Mundial sobre las Drogas 2014. Ed. UNODC. 2015, p. 5. 
propanona y llevarlo posteriormente a los Países Bajos para la producción ilícita de MDMA ${ }^{187}$. Además los gobiernos de Francia y Sudáfrica realizaron dos operaciones de entregas vigiladas de safrol, la primera en el año 2001 y luego otra en el año 2003. Esta última investigación trataba de 40 kilos de safrol en forma de aceite de sasafrás. La entrega vigilada permitió la identificación de una red que desviaba pequeñas cantidades de este precursor desde hace mucho tiempo en Sudáfrica para su utilización en la fabricación ilícita de MDMA. En este caso tiene que subrayarse que los traficantes estuvieran exportando legalmente el safrol, de Francia a Sudáfrica, utilizando el código de un aceite esencial (3302.90) y no el código especifico del safrol (2932.94). También hay que mencionar que las autoridades belgas y alemanas realizaron una entrega vigilada de 150 kilos de safrol en forma de aceite de sasafrás que permitió la incautación de 150 litros de P-2-P y de equipo de laboratorio, además del safrol. En este caso hay que destacar que el pedido original se realizó a través de Internet, método que los traficantes de precursores utilizan cada vez más ${ }^{188}$.

Durante el año 2002 las autoridades de Rumania informaron a la JIFE de la incautación de casi dos toneladas de safrol, lo que representó casi la totalidad de los decomisos de esta sustancia realizadas en este año. Al llevar a cabo las investigaciones policiales de rastreo hasta la fuente para determinar el origen de la sustancia, descubrieron que todo el safrol incautado formaba parte de un envío importado legalmente por Rumanía de los Países Bajos en 1998. Supuestamente el safrol debería de haber sido utilizado para la manufactura legal de otra sustancia controlada 3,4-MDP-2-P, para su exportación a la República de Moldova, lo cual resultaba inverosímil por que en ese país no existe ninguna empresa que tenga una necesidad lícita de 650 kilogramos de 3,4-MDP-2$\mathrm{P}$, que sería la cantidad que se podría obtener a partir del safrol decomisado ${ }^{189}$. En el año 2003 también se reportó en Rumania un decomiso importante de safrol, alrededor de 1,9 toneladas. Esta incautación se

187 Precursores y productos químicos frecuentemente utilizados..., correspondiente a 2001..., p. 28. Precursores y productos químicos frecuentemente utilizados..., correspondiente a $2004 \ldots$, p. 21.

188 Precursores y productos químicos frecuentemente utilizados..., correspondiente a 2003..., pp. 25, 26.

$189 \quad$ Idem., pp. 25, 26. 
llevó a cabo gracias a informaciones de inteligencia que habían sido iniciadas a partir de la incautación realizada en el año 2002. El safrol había sido importado de los Países Bajos, presentando un pedido con documentación falsa para garantizar la exportación. Esta remesa los traficantes la iban a utilizar en Rumania para la fabricación ilícita de isosafrol y 3,4-MDP-2-P190.

Las autoridades competentes de Australia informaron, en el año 2003 de su mayor incautación de este precursor. En la misma los traficantes trataron de introducir de contrabando en el país más de 400 litros de safrol declarándolos como "aceite blanco", un aceite industrial utilizado en la fabricación de cosméticos. Junto con el safrol, las autoridades encontraron metilamina, sustancia no sometida a control que se usa en la fabricación de MDMA y de metanfetamina. Destacamos que como resultado de las investigaciones realizadas en este caso se logro desmantelar un laboratorio clandestino de MDMA. Los Estados Unidos de América también desmantelaron seis laboratorios ilícitos que se dedicaban a la fabricación de MDMA este año, donde se decomisaron más de 100 litros de safrol. La JIFE afirmó que esta sustancia es la preferida por los traficantes para elaborar, directamente, MDMA en América del Norte, mientras que en Europa es la 3,4-MDP-2-P. Además, es preciso decir que gracias a los procedimientos operativos regulares del Proyecto Prisma, las autoridades competentes de China empezaron a enviar notificaciones previas a la exportación de safrol en forma de aceite de sasafrás, lo que permitió en el año 2004 suspender un envío de 1,5 toneladas de aceite de sasafrás a Canadá, aunque la exportación fue autorizada posteriormente tras el cumplimiento de los requisitos legales ${ }^{191}$.

Durante el periodo comprendido entre el día 1 de noviembre del 2004 y el día 31 de octubre del 2005, se informó a la Junta del envío de 33 remesas de safrol, incluido el safrol en forma de aceite de sasafrás, que

190 Precursores y productos químicos frecuentemente utilizados..., correspondiente a 2004..., p. 20.

191 Ibidem., pp. 20, 21. La UNODC señala que el safrol además de utilizarse para la elaboración de 3,4.MDP-2-P se puede utilizar directamente para elaborar MDMA. Global SMART Update, volumen 7, marzo 2012. Informe global de monitoreo de drogas sintéticas 2012. Ed. UNODC. 2012, p. 4. La descripción de la metilamina y demás especificaciones sobre esta sustancia se encuentra en el apartado correspondiente del capitulo I sobre sustancias no catalogadas que se utilizan en la elaboración de drogas. 
ascendían a 6,2 toneladas de este precursor. Hay que destacar que normalmente existe disparidad entre las cifras del comercio internacional comunicadas por los países exportadores y las reportadas por los países importadores, además de ser la información poco detallada. Precisamente la falta de información sobre esta sustancia fue una de las cuestiones fundamentales abordadas en el ámbito del Proyecto Prisma, por lo cual en el año 2005 la JIFE, con la asistencia de la Oficina Regional para Asia y el Pacífico de Naciones Unidas contra la Droga y el Delito (ONUDD), llevó a cabo un análisis del comercio de aceites ricos en safrol exportados desde países de Asia Sudoriental, descubriendo que las remesas no se detectaban mediante los mecanismos de fiscalización internacional debido a que se declaraban como "aceites esenciales". Sobre las incautaciones de safrol hay que decir que se recibieron notificaciones de todas las regiones del mundo, pero casi todas fueron de cantidades pequeñas (de menos de 100 kilogramos), salvo China que notificó incautaciones por un monto de aproximadamente 5,5 toneladas de esta sustancia' ${ }^{192}$.

En el mes de junio del 2005 la Junta convocó una reunión en Viena del grupo de tareas del Proyecto Prisma para evaluar los avances del proyecto durante el año. La Organización Mundial de Aduanas en la reunión presentó un informe sobre un programa de rastreo de tres meses relacionado con el safrol y el isosafrol, y si bien no se detecto ningún intento de desviación de estas sustancias, esta investigación proporcionó un valioso panorama del comercio internacional de estas sustancias y permitió identificar países importadores no conocidos hasta ahora como tales. En la reunión también se realizó un examen preliminar de los aceites ricos en safrol provenientes de Asia Sudoriental. La Junta en vista a que los aceites ricos en safrol se canjean en remesas de varias toneladas sin pasar por ningún control, y el hecho de que se han

192 Ibidem., p. 9. Para realizar el análisis se recopiló información sobre 23 casos de exportación de aceites ricos en safrol desde, Camboya, China y la República Democrática Popular de Lao a través de intermediarios en Vietnam. Los 23 envíos ascendían a 745 toneladas de aceites ricos en safrol y estaban destinados a ocho países: Alemania, Brasil, China, los Estados Unidos de América, Israel, Italia, Singapur y Suiza. Se solicitó a las autoridades competentes de los países importadores que comprobaran la legitimidad de cada envío, lo cual permitió detectar cuatro posibles desviaciones de remesas con un volumen total de 192 toneladas de aceites ricos en safrol. Precursores y productos químicos frecuentemente utilizados..., correspondiente a 2005 ..., pp. 7, 8. 
descubierto estos aceites en laboratorios dedicados a la fabricación ilícita de MDMA, recomendó que el aceite de sasafrás, por su elevado contenido de safrol sea considerado como el propio safrol, bajo la denominación de "safrol en forma de aceite de sasafrás", debiéndose aplicar a esta sustancia el mismo régimen de fiscalización que al safrol ${ }^{193}$. Precisamente en el año 2006 la Junta encargó a su grupo asesor de expertos examinar el estado actual de la fiscalización del safrol y los aceites ricos en safrol, para formular, de ser necesario, una definición de de esta sustancia a efectos de su fiscalización con arreglo al Convenio de Viena de $1988^{194}$. También sobre el tema de los aceites ricos en safrol trato el grupo de tareas del proyecto prisma en junio del año 2006 en una reunión celebrada en Australia, y a petición del grupo de tareas el Centro Regional para Asia Oriental y el Pacífico de Naciones Unidas contra la Droga y el Delito (ONUDD) realizó un estudio regional sobre la producción, usos y comercio ilícito de aceites ricos en safrol. Realizándose además en el mes de septiembre de este mismo año una reunión en Kuala Lumpur de los países participantes y el grupo de tareas para examinar los resultados de los estudios nacionales ${ }^{195}$. Ya en su informe del año 2007 la JIFE, atendiendo a una solicitud de la Comisión de Estupefacientes define los aceites ricos en safrol de la siguiente manera: "se entiende por aceites ricos en safrol cualquier tipo de mezcla o de producto natural que contenga safrol de manera tal que pueda utilizarse o extraerse por medios de fácil aplicación" ${ }^{\prime 196 . ~}$

En el periodo que va del 1 de noviembre del 2005 al 31 de octubre del 2006 únicamente se recibieron seis notificaciones previas a la exportación, cuatro de ellas se referían al envío de 9 litros de safrol, y dos a envíos de aceite de sasafrás por un total de 1.900 kilogramos. La JIFE mostraba su preocupación por la escasa información que suministran sobre las remesas particulares de safrol, incluido el safrol en forma de aceite de sasafrás, e isosafrol en el marco del comercio internacional. Además este desfase se evidenciaba en que según los datos del comer-

\footnotetext{
$193 \quad$ Ibidem., pp. 19, 23.

194 Ibidem., p. 2.

195 Precursores y productos químicos frecuentemente utilizados..., correspondiente a 2006..., pp. 10, 11.

196 Precursores y productos químicos frecuentemente utilizados..., correspondiente a 2007..., pp. XI, 2.
} 
cio lícito suministrado por los gobiernos en el formulario D correspondiente al año 2005, con respecto al safrol e isosafrol, hubo 13 países exportadores y 10 importadores, y el comercio anual notificado para ambas sustancias sumó 126 toneladas. En todo caso, dado que el safrol y los aceites ricos en safrol se usan ampliamente con fines lícitos, como la fabricación de piperonal (otra sustancia catalogada), artículos de perfumería e insecticidas, el volumen del comercio internacional de estas sustancias debería ser mucho mayor del que comunican los gobiernos y territorios. Además hay que señalar que únicamente tres gobiernos notificaron en el año 2005 haber realizado decomisos de estas sustancias que ascendieron a 46,5 litros, que es la cantidad más baja notificada a la Junta desde el año 1992 hasta la fecha. En atención a la prevalencia del abuso de MDMA en todo el mundo y de que el safrol es un precursor clave en la fabricación de esta droga, la ausencia de incautaciones indica la necesidad de que la respuesta de los gobiernos al tráfico de precursores de la MDMA sea más contundente ${ }^{197}$.

En el periodo comprendido entre el día 1 de noviembre del 2006 y el día 31 de octubre del 2007 se comunicaron a la Junta el envío de 24 remesas de safrol. No obstante, los datos sobre incautaciones probablemente no reflejen correctamente el verdadero alcance del uso indebido de la sustancia para la fabricación ilícita de MDMA. Australia, los Estados Unidos de América y Francia informaron en el año 2006 incautaciones de este precursor por un total de 62 litros. De esa cantidad sólo Australia decomisó 50 litros provenientes de los Estados Unidos, Sudáfrica y Tailandia. Además, las autoridades australianas desmantelaron un laboratorio que elaboraba ilícitamente anfetamina y MDMA a gran escala, dicho laboratorio había sido equipado con grandes reactores de acero inoxidable hechos especialmente para la fabricación de esas drogas. La capacidad de los recipientes de reacción, de 50 a 150 litros, da una idea de la cantidad de precursores que habría sido necesario desviar para una sola instalación de fabricación ${ }^{198}$. En el siguiente periodo, es decir entre el día 1 de noviembre del 2007 y el día 31 de octubre del 2008 se reportaron a la Junta el envío de 15 remesas de sa-

197 Precursores y productos químicos frecuentemente utilizados..., correspondiente a 2006 ..., p. 17.

198 Precursores y productos químicos frecuentemente utilizados..., correspondiente a 2007..., pp. 12, 13. 
frol, por un monto de 185 litros. Cifra que no tiene parangón con el volumen de la sustancia que se utiliza para fabricar MDMA. A manera de ejemplo señalamos que las autoridades de Tailandia comunicaron una incautación de safrol cuyo volumen se elevaba a 45.970 litros ${ }^{199}$.

En el año 2007 el Centro Regional para Asia Oriental y el Pacífico de la Oficina de las Naciones Unidas contra la Droga y el Delito (ONUDD) realizó un estudio regional a gran escala, a petición del grupo de tareas del Proyecto Prisma, sobre los aceites ricos en safrol. Como resultado se determino que Camboya, China, Indonesia, Myanmar y la República Democrática Popular de Lao eran los principales productores de aceites ricos en safrol, con una producción estimada de 1.500 toneladas anuales, estableciéndose que de esta producción la mayor parte se consumía en el Asia Sudoriental. Además en este estudio se logró determinar que las remesas de safrol en forma de aceites ricos en safrol se declaraban a menudo simplemente como "aceites esenciales", lo que dificultaba notablemente a las autoridades competentes la identificación de las distintas remesas de safrol 200 .

Para evidenciar las serias discrepancias existentes sobre la información que se suministra sobre el comercio internacional de safrol, citamos como ejemplo que en el año 2008 cuatro gobiernos comunicaron en el formulario D la exportación de 159.641 litros de safrol, casi todo en forma de aceites ricos en safrol. En el mismo periodo, a través del sistema PEN Online se declararon 19 exportaciones de un total de 265 litros de safrol. Hay que aclarar que la inmensa mayoría del comercio de safrol se realiza en forma de aceite de sasafrás, del cual 86.710 kilogramos se exportaron en siete remesas. El Canadá fue el único país que declaró haber detenido expediciones de safrol. Se trataba de siete expediciones de menos de un litro. Un total de cuatro países informaron sobre incautaciones de esta sustancia catalogada en este año por un monto total de 1.904 litros, de los cuales 1.841 litros se confiscaron en Estonia. En el mes de junio del año 2009, las autoridades de Camboya señalaron que habían descubierto 5,2 toneladas de aceite de sasafrás en el parque natural de Phonm Sankos. Hay que destacar que en los úlp. 10. 
timos años en Camboya se desmantelaron más de 50 instalaciones ilegales de extracción de aceite de sasafrás. Sobre este tema la JIFE afirmó que el safrol extraído de fuentes naturales es la principal fuente de obtención de 3,4-MDP-2-P, ya sea mediante el desvío directo y la conversión ilícita en ese precursor clave de MDMA, o indirectamente a través del desvío de piperonal, una sustancia, que también es un precursor de drogas, fabricada a partir del safrol, muy utilizado en las actividades industriales de muchos países del mundo 201 .

Entre el día 1 de noviembre del 2009 y el día 31 de octubre del 2010, se le reportaron a la JIFE el envío de 39 remesas de safrol, gran parte en forma de aceites ricos en safrol, por un monto de 101.840 litros. Debiendo destacarse que una sola remesa, de España a Brasil, ascendía a más de 14.500 litros. Así como, que dos tercios del comercio de safrol se efectúa bajo la forma de aceites ricos en safrol. La cantidad de expediciones sospechosas y de incautaciones de esta sustancia catalogada asi como de los aceites ricos en safrol que se han comunicado a la Junta continúan siendo insignificantes en comparación con los niveles estimados de fabricación ilícita de MDMA. Durante este período se identificaron como sospechosas dos transacciones de 180 litros de esta sustancia, con origen en los Estados Unidos de América y con destino a México, comunicadas a través del sistema PEN Online. Mientras que ningún país comunicó detenciones de remesas de este precursor en el formulario D. Sin embargo las autoridades competentes de cinco países informaron a la JIFE de incautaciones de este precursor en el año 2009 que sumaron 1.050 litros, de los cuales 929 fueron decomisados en Lituania. Las autoridades de Australia, Canadá, los Países Bajos y el Reino Unido de Gran Bretaña e Irlanda del Norte notificaron incautaciones de menor volumen (entre 5 y 80 litros) de safrol e isosafrol. Mientras que el gobierno de Camboya, con asistencia de la Policía Federal Australiana, destruyó 13.600 litros de aceites ricos en safrol en el mes de febrero del año 2010. Cabe señalar que esta cantidad representaba todas las

También en Guinea informaron que en varias localidades de Conakry habían realizado varias incautaciones de productos químicos, entre ellos aceite de sasafrás, y materiales para elaborar drogas, lo que demuestra que en África Occidental se están fabricando drogas de tipo anfetamínico. Aprovechando las organizaciones delictivas que en esas regiones las autoridades cuentan con muy poco desarrollo y al mismo tiempo hacen frente a una pobreza generalizada. Precursores y productos químicos frecuentemente utilizados..., correspondiente a 2009..., pp. 14, 15. 
existencias conocidas de aceites ricos en safrol de Camboya y fue la segunda más importante destruida desde que las autoridades de este país ilegalizaron estos aceites en el año 2007202.

En el período que va del 1 de noviembre del 2010 al 31 de octubre del 2011 se reportaron a la Junta un total de 45 remesas de safrol, incluida la sustancia en forma de aceites ricos en safrol, que sumaron un volumen total de 256.000 litros. Es preciso puntualizar que el 99\% del volumen de comercio de esta sustancia se hizo en forma de aceites ricos en safrol. En cuanto a las incautaciones un total de cinco países (los Países Bajos, Australia, Nueva Zelanda, los Estados Unidos de América y Alemania) reportaron decomisos en el formulario D correspondiente al año 2010, por un monto de 168 litros. Fuera de la fecha de cierre de este informe, pero siempre en el año 2010, las autoridades competentes de Camboya informaron el decomiso de siete toneladas de safrol, sin que se hubiera demostrado que las mismas se fueran a utilizar para la producción ilícita de MDMA. Otra incautación a gran escala fue reportada por México en el mes de agosto del año 2011, se trato de 2.500 litros de safrol que se intervinieron en el puerto de Manzanillo. La sustancia tenía su origen en la República de Corea y había sido declarada falsamente como producto químico de limpieza ${ }^{203}$. p. 11.

Precursores y productos químicos frecuentemente utilizados..., correspondiente a 2011..., p. 19. Para tener una mejor perspectiva sobre los niveles de incautación del safrol y el isosafrol citamos que en el periodo que va del año 1995 al año 2010 se incautaron a nivel mundial 99.172 litros (equivalentes a 108.741 kilogramos) de safrol siendo la séptima sustancia del Cuadro I de la Convención de 1988 en nivel de incautación. Existiendo una tendencia descendente en los montos decomisados de esta sustancia, ilustramos tal situación indicando que en el año 1995 se incautaron un total de 2.892 litros de esta sustancia y en el año 2010 únicamente 168 litros. Destacando que fue en el año 2007 cuando se produjeron las mayores incautaciones de safrol a nivel mundial por un monto total de 45.986 litros. Del isosafrol se decomisaron en estos 16 años un total de 23.878 litros (equivalentes a 26.769 kilogramos) lo cual representa solo el $24.6 \%$ de la cantidad decomisada en este periodo de safrol. Ibidem., 66-100. Precursores y productos químicos frecuentemente utilizados..., correspondiente a 2010, pp. 16-41. Precursores y productos químicos frecuentemente utilizados..., correspondiente a 2006..., pp. 38-60. Precursores y productos químicos frecuentemente utilizados..., correspondiente a 2004..., pp. 45-66. Precursores y productos químicos frecuentemente utilizados..., correspondiente a $2000 \ldots$, pp. $47-61$. 
Durante el periodo 2011-2012 se le informó a la JIFE que se comercializaron 56 remesas de safrol, incluso en forma de aceites ricos en safrol, que sumaron un total de 176.200 litros. Alrededor del $80 \%$ del comercio del safrol consistió en aceites ricos en safrol, únicamente se comunicaron a través del sistema PEN Online dos remesas de isosafrol (de un litro cada una). De esta última sustancia no se informó sobre la suspensión de ningún envío, lo que refleja el limitado comercio de este precursor de drogas. Las incautaciones de safrol y de aceites ricos en safrol, tras disminuir durante varios años, se incrementaron en el año 2011, nueve países utilizaron el formulario D para reportar decomisos de estas sustancias por un monto de 17.122 litros siendo estos: Australia, Bélgica, Canadá, Camboya, los Estados Unidos de América, Hungría, Malasia, México y los Países Bajos 204.

En el periodo que va del día 1 de noviembre del año 2012 al día 31 de octubre del año 2013 a través del sistema PEN Online se reportaron un total de 50 remesas de safrol, incluso en forma de aceites ricos en safrol, que sumaron un total de 5.767 litros. En este periodo se informó sobre la detención de una remesa de 210 kilogramos de safrol en forma de aceite de sasafrás, que procedía de los Estados Unidos de América e iba destinada a Malasia. Sólo se comunicó mediante este sistema el envío de una remesa de un litro de isosafrol, y tampoco se informó de la suspensión de envíos de isosafrol, lo que refleja el limitado comercio internacional que existe de esta sustancia. A través del formulario D correspondiente al año 2012 cuatro gobiernos reportaron la incautación de safrol, incluso en forma de aceites ricos en safrol, por un monto de 2.028 litros. Se destaca que las autoridades chinas en cooperación con las australianas incautaron 3,35 toneladas de safrol en el mes de abril del año 2012. En este mismo periodo a través del sistema PICS se informó de 13 incidentes relacionados con incautaciones de safrol por un total de 15.970 litros y 217 kilogramos, los países involucrados en estos decomisos fueron: Australia, Canadá, Indonesia, los Países Bajos, los Estados Unidos de América y Camboya ${ }^{205}$. pp. 18, 19. 
Del 1 de noviembre del 2013 al 31 de octubre del 2014 mediante el sistema PEN Online un total de seis países exportadores enviaron notificaciones previas de exportación de 29 remesas de safrol por un monto de 4.500 litros, también en forma de aceites ricos en safrol, a 12 países importadores. El nivel de comercio de isosafrol como todos sabemos es mucho más limitado, en este periodo sólo se notificó através del sistema PEN Online el envío de una remesa de un litro de esta sustancia catalogada. La JIFE sostiene que a pesar del evidente aumento de la disponibilidad de 3,4-MDP-2-P, es posible que no haya disminuido la utilidad del safrol en la producción ilícita de MDMA. En el formulario D correspondiente al año 2013 un total de cinco países (Australia, los Estados Unidos de América, Indonesia, Lituania y los Países Bajos reportaron incautaciones de safrol o de aceites ricos en safrol de más de 14.000 litros, 12.000 litros más que el año anterior. Destacamos la incautación realizada en los Países Bajos por un total de 13.800 litros, siendo a la vez el único país que informó de decomisos de isosafrol por un monto de 10 litros $^{206}$.

En el periodo 2014-2015 un total de 8 países exportadores enviaron a través del sistema PEN Online 37 notificaciones previas a la exportación de remesas de safrol y aceites ricos en safrol por un monto de 4.000 litros a un total de 15 países importadores, cantidad similar a los tres últimos años, debiéndose puntualizar que a diferencia de otros años sólo una pequeña parte del safrol comercializado consistió en aceites ricos en safrol. En el caso del isosafrol hay que decir que en este periodo no se envío ninguna notificación previa a la exportación. Sin embargo en lo que se refiere a la incautaciones sorprendentemente se invirtieron los papeles ya que únicamente se informó en el formulario D correspondiente al año 2014 de una incautación realizada en Australia de 184 litros de safrol, y otra de isosafrol en Namibia pero por un monto de 2.100 litros, la mayor registrada en los últimos 11 años, superando en más de 1.800 litros el total incautado en lo últimos 10 años ${ }^{207}$.

Para hacernos una idea del papel que desempeña el isosafrol en la elaboración de la 3,4-MDP-2-P y por ende de la MDMA queremos señalar que del año 2004 al año 2013 se informó a través del formulario D la

206 Precursores y sustancias químicas frecuentemente utilizados..., correspondiente a 2014.., pp. 29, 30 .

207 Ibidem., pp. 20, 21, 67-87. 
incautación de 283 litros de isosafrol a nivel mundial, cantidad con la que podrían haberse fabricado 149 kilogramos de éxtasis ${ }^{208}$, siendo el segundo precursor del Cuadro I que tiene el menor nivel de decomisos en el mundo, sólo es menor el ácido $N$-acetilantranilico. Lo cual posiblemente responde a que los narcotraficantes recurren más al safrol, incluyendo los aceites ricos en safrol para elaborar de forma ilícita 3,4MDP-2-P y MDMA. Los 283 litros de este precursor fueron incautados en tres países: Australia (262 litros), los Países Bajos (20 litros) y los Estados Unidos de América (1 litro) ${ }^{209}$.

Una situación diferente se presenta con el safrol dado que del año 2004 al año 2013 se reportó a través del formulario D la incautación de 88.218 litros, equivalentes a 96.750 kilogramos (cantidad con la que podrían elaborarse 23.215 kilogramos de MDMA) ${ }^{210}$, desglosados de la siguiente manera: 5.707 litros en el año 2004, 39 litros en el año 2005, 62 litros en el año 2006, 45.986 litros en el año 2007, 1.922 litros en el año 2008, 1.068 litros en el año 2009, 169 litros en el año 2010, 17.122 litros en el año 2011, 2.028 litros en el año 2012 y 14.115 litros en el año 2013. Estos decomisos se realizaron en un total de 18 países ubicados en cuatro continentes, exceptuando África, los países que llevaron a cabo incautaciones mayores de 1.000 litros fueron los siguientes: los Países Bajos (14.095 litros), Malasia (7.675 litros), Australia (2.698 litros), México (2.371 litros), los Estados Unidos de América (2.348 litros), Canadá (2.236 litros), Camboya (2.058 litros), China (5.519 litros), Tailandia (45.965 litros) y Estonia (1.841 litros) ${ }^{211}$. Hay que concluir que a pesar de todos los esfuerzos realizados en todos estos años, tanto por la JIFE como por las autoridades competentes de los estados

$208 \quad$ Ibidem., p. 81.

209 Ibidem., pp. 71-90. Precursores y sustancias químicas frecuentemente utilizados..., correspondiente a 2013..., pp. 67-84. Precursores y sustancias químicas frecuentemente utilizados..., correspondiente a 2009..., pp. 37-50, 51-62. En España desde el año 1993 hasta el año 2014 sólo se incautaron cinco litros de safrol, la misma se realizó en el año 1999. Vid., el Anexo III.

210 Precursores y productos químicos frecuentemente utilizados..., correspondiente a 2004..., p. 81.

211 Precursores y sustancias químicas frecuentemente utilizados..., correspondiente a 2014..., pp. 71-90. Precursores y sustancias químicas frecuentemente utilizados..., correspondiente a 2013..., pp. 67-84. Precursores y sustancias químicas frecuentemente utilizados..., correspondiente a 2009..., pp. 37-50, 51-62. 
miembros del Convenio de 1988, aún existen serios problemas para determinar correctamente el nivel de comercio mundial de safrol, incluyendo los aceites ricos en safrol, y peor aún con el nivel de producción mundial de estas sustancias que juegan un papel sumamente importante en la producción ilícita de la 3,4-MDP-2-P y de la MDMA. Es necesario precisar que en muchos años, en la mayoría de ellos, los niveles de incautación mundial superan los niveles de comercio internacional notificado, lo cual posiblemente se debe, a que el nivel de comercio es bastante superior al que reportan los países y territorios, así como a que debe existir un nivel importante de producción ilícita de este precursor de drogas, sobre todo en forma de aceites ricos en safrol que es aprovechado por los productores de éxtasis.

\section{Piperonal}

Ante las dificultades que implica el desvío de 3,4-MDP-2-P del comercio lícito, dadas sus pocas aplicaciones legales, los narcotraficantes han optado por desviar piperonal, precursor que tiene aplicaciones lícitas más amplias y por ende puede ser más fácil su obtención por los traficantes que se dedican a la elaboración de éxtasis. Para tener una perspectiva del nivel del comercio internacional queremos señalar que durante el periodo 2004-2015 un total de 17 países exportadores reportan a través del sistema PEN Online envíos anuales por un promedio de 2.500 toneladas de piperonal a 51 países, siendo el precursor de MDMA más comercializado en el mundo, debiendo indicarse que el periodo de menor nivel de comercio fue el 2011-2012 (1.800 toneladas) y el periodo de mayor nivel de comercio el 2007-2008 (4.600 toneladas). Habiéndose notificado incautaciones de esta sustancia en China en el año 2004 de 13 toneladas, en Hong Kong (RAE de China) en el año 2005 de 4 toneladas y en Rumania en el año 2004 de 2.5 toneladas, lo cual demostró que los traficantes recurren a la utilización de esta sustancia para la fabricación de MDMA o MDA ${ }^{212}$.

Precursores y productos químicos frecuentemente utilizados..., correspondiente a 2005..., pp. 6, 7. Precursores y productos químicos frecuentemente utilizados..., correspondiente a $2007 . . .$, p. 12. Precursores y productos químicos frecuentemente utilizados..., correspondiente a 2008..., p. 10. Precursores y productos químicos frecuentemente utilizados correspondiente a 2010..., pp. 10, 11. Precursores y productos químicos frecuentemente utilizados..., correspondiente a 2011, p. 18. Precursores y sustancias químicas frecuentemente utilizados..., correspondiente a 2014..., pp. 71-90. Precursores y sustancias quími- 
Las incautaciones mundiales de piperonal durante el año 2006 (un kilogramo) fueron insignificantes en comparación con las comunicadas en los cinco años anteriores (de 6 a 17 toneladas por año). Es preciso decir que no se ha encontrado una explicación inmediata de ese hecho, teniendo en cuenta que el piperonal es utilizado por los fabricantes de drogas ilícitas como alternativa del safrol para elaborar el precursor fundamental de la MDMA, la 3,4-MDP-2-P213. En el año 2007 las autoridades de México fueron las únicas que comunicaron una incautación de esta sustancia (dos toneladas). Recomendando la Junta a todos los gobiernos que realizaran una vigilancia activa del comercio de esta sustancia dado que el volumen de su comercio mundial es alto y por que es probable que aumente la demanda ilícita de piperonal a medida que se refuerce la fiscalización del safrol ${ }^{214}$. No hay que olvidar que el piperonal también se utiliza de forma ilegal para producir también MDA, MDEA y (N-hidroxi-MDA)215.

Hay que subrayar que las autoridades de España informaron a la Junta a través del formulario D correspondiente al año 2009 de la detención de dos remesas de piperonal, de una tonelada con destino a México y de 500 kilogramos con destino a Turquía. Además las autoridades de varios países europeos, entre ellos Bulgaria, Hungría, Italia y Portugal, notificaron incautaciones de piperonal bajo la forma de tabletas parecidas a las de éxtasis. No se logró determinar si se trataba de una nueva tendencia

cas frecuentemente utilizados..., correspondiente a 2013..., pp. 67-84. Precursores y sustancias químicas frecuentemente utilizados..., correspondiente a 2015, p. 20.

Precursores y productos químicos frecuentemente utilizados..., correspondiente a 2007..., p. 12.

214 Precursores y productos químicos frecuentemente utilizados..., correspondiente a 2008..., p. 10.

215 La MDA (3,4-metilendioxianfetamina) conocida también como dulce droga de América, píldora del amor, droga del abrazo o anfetamina para amantes se sintetiza a partir de la aminización de los acetes ricos en safrol o del piperonal. Las píldoras de MDA se administran de manera oral acompañadas con líquidos. Esta droga empieza a actuar entre los 30 y los 60 minutos después de la ingestión, alcanzando un máximo a los 90 minutos y presentando una duración entre 8 y 12 horas. Al llegar al cerebro la MDA se fija en los receptores adrenérgicos estimulando el sistema nerviosos central, con ello aumenta el nivel de vigilia, provoca una sensación de bienestar físico e intensifica las percepciones sensoriales y emocionales. La N-hidroxi-MDA (N-OH-MDA) es un homólogo de la MDA. 
para ocultar la identidad de la sustancia como precursor o si esto responde a un deseo de engañar a los consumidores potenciales en otra faceta del mercado ilícito de drogas de síntesis ${ }^{216}$. En el formulario D correspondiente al año 2010 sólo un país informó de la incautación de cantidades ínfimas de piperonal representa una gran discrepancia entre el volumen y frecuencia de de las incautaciones de MDMA. Asimismo, únicamente hubo una remesa detenida de 1.000 kilogramos de esta sustancia catalogada procedente de China y con destino a Vietnam, porque las autoridades de este país informaron que la empresa importadora nunca había solicitado una licencia para importar esa sustancia ${ }^{217}$.

En el periodo 2011-2012 sólo se informó por medio del sistema PICS sobre una incautación de piperonal. En el mes de enero del año 2012 las autoridades competentes de Filipinas decomisaron un kilogramo de piperonal tras realizar de forma satisfactoria una operación de entrega vigilada relacionada con el tráfico por correo postal internacional. La remesa de piperonal incautada formaba parte de una serie de remesas que habían llegado de China etiquetadas de forma indebida como wolframato de sodio. Lamentablemente, a esta fecha, no se conocían las necesidades legítimas de este precursor de drogas en el mundo, dado que no se les solicitaba aún a los gobiernos que informaran sobre sus necesidades lícitas de piperonal218. En el año 2012 un total de seis gobiernos reportaron a través del formulario $\mathrm{D}$ la realización de decomisos de esta sustancia por un monto de 336 kilogramos, dos de ellos, Filipinas y Serbia, notificaron incautaciones de piperonal por primera vez ${ }^{219}$.

En el formulario D correspondiente al año 2013 cuatro países (Autralia, España, Hungría y Rumania) informaron de incautaciones de piperonal por un monto de 1.405 kilogramos. Destacamos que España reporto el mayor nivel de decomisos de esta sustancia (1.400 kilogra-

216 Precursores y productos químicos frecuentemente utilizados..., correspondiente a 2010..., pp. 10, 11.

217 Precursores y productos químicos frecuentemente utilizados..., correspondiente a 2011..., p. 18. Precursores y sustancias químicas frecuentemente utilizados..., correspondiente a 2012..., pp. 17, 18. pp. 17, 18. 
mos) ${ }^{220}$, cantidad con la que se podían haber elaborado un total de 280 kilogramos de éxtasis, lo que representa un total de 280.000.000 de dosis callejeras. Mientras que en el año 2014 los Países Bajos reportaron tres incautaciones de piperonal, en almacenes donde guardaban precursores de varias drogas, a través del sistema PICS. Sin embargo, en el formulario D correspondiente a este año no se informo ningún decomiso de este precursor de drogas ${ }^{221}$.

Para que tengamos una idea del nivel de enfrentamiento al desvío de piperonal queremos indicar que del año 2004 al año 2013 se reportó a través del formulario D la incautación de 33.340 kilogramos de piperonal (cantidad con la que podrían fabricarse un total de 15.876 kilogramos de MDMA), desglosado de la siguiente forma: 16.864 kilogramos en el año 2004, 6.196 kilogramos en el año 2005, 107 gramos en el año 2006, 2.000 kilogramos en el año 2007, 2.299 kilogramos en el año 2008, 4.299 kilogramos en el año 2009, 0 kilogramos en el año 2010, 10 kilogramos en el año 2011, 336 kilogramos en el año 2012 y 1.405 kilogramos en el año 2013. Los decomisos se llevaron a cabo en un total de 12 países de tres continentes (América, Asia y Europa), y las mayores incautaciones se realizaron en México (10.292 kilogramos), China (13.278 kilogramos), España (1.400 kilogramos), Lituania (332 kilogramos), Rumania (2.418 kilogramos) y Australia (3.050 kilogramos $)^{222}$. Como ya señalamos antes los niveles de incautación de esta sustancia son prácticamente insignificantes $(0.15 \%$ anual del comercio internacional reportado) si se tiene en cuenta su nivel de comercio mundial y la importancia que tiene este precursor de drogas para la fabricación ilícita de MDMA. Queremos subrayar que no tenemos conocimiento de que este precursor de drogas se fabrique ilícitamente en laboratorios clandestinos, por tanto debemos considerar que todo el

Precursores y sustancias químicas frecuentemente utilizados..., correspondiente a 2014..., pp. 28, 29.

221 Precursores y sustancias químicas frecuentemente utilizados..., correspondiente a 2015..., p. 20.

222 Precursores y sustancias químicas frecuentemente utilizados..., correspondiente a 2014..., pp. 71-90. Precursores y sustancias químicas frecuentemente utilizados..., correspondiente a 2013..., pp. 67-84. Precursores y sustancias químicas frecuentemente utilizados correspondiente a 2009, pp. 37-50, 51-62. Vid., en el Anexo III las incautaciones de piperonal realizadas en España del año 1993 al año 2014. 
piperonal que se utiliza en la elaboración del éxtasis se desvía del comercio internacional o bien de los canales de distribución interno.

\section{C.) PRECURSORES DE LA METACUALONA, LA METCATINONA, LA FENCICLIDINA Y EL LSD}

\section{Precursores de la metacualona y la metcatinona}

Posterior al desmantelamiento en el año 2002 de unas grandes instalaciones de fabricación ilícita de metacualona ${ }^{223}$ en la India y Sudáfrica, los traficantes se dieron a la tarea de iniciar la fabricación ilícita de esta droga en otras regiones, así en el año 2003 las autoridades de Bulgaria realizaron la incautación de cinco toneladas de ácido antranílico y cinco toneladas de ortotoluidina (sustancia no catalogada que se usa para la elaboración ilícita de metacualona). Las investigaciones generales de rastreo hasta la fuente, demostraron que el envío en cuestión había sido exportado de la India a Turquía y posteriormente a Bulgaria, donde había sido reetiquetado y enviado nuevamente a Turquía. La incautación se produjo antes de que se llevara a cabo la reexportación, sin lograr establecer cual era la ruta que iban a seguir estas sustancias ${ }^{224}$. En el año 2004 disminuyó en Sudáfrica la detección de laboratorios de metacualona, pero aumentaron los descubrimientos de laboratorios de metanfetamina y metcatinona ${ }^{225}$, sin embargo en este año se desmantela-

La metacualona es un medicamento sedante-hipnótico similar en sus efectos a un barbitúrico, un depresivo general del sistema nerviso central. Su uso extensivo se produjo a partir de 1960 como un hipnótico, para el tratamiento del insomnio, como sedante y relajante muscular. Esta sustancia también ha sido utilizada como droga recreativa, conocida además como: Quaaludes, Soprs, Ludes o Mandrax. Desde su introducción en el año 2001, esta siendo usada masivamente en Sudáfrica, donde le llaman smarties. La metacualona producida de forma ilegal sigue siendo incautada por agencias gubernamentales y de policía en varias regiones del mundo.

224 Precursores y productos químicos frecuentemente utilizados..., correspondiente a 2003..., pp. 31, 32.

225 La metcatinona es un derivado metilado de la catinona que produce efectos estimulantes del sistema nervioso central similares a las anfetaminas y está sujeto a abuso. La metcatinona posee efectos similares menores a los de la catinona y se ha sintetizado en laboratorios clandestinos de los Estados Unidos de América, su consumo no es muy amplio y se conoce también con el nombre de efedrona. Hay que señalar que la metcatinona a pesar de los muchos inconvenientes que presenta, algunos consumidores de drogas han encontrado atractivo varios aspectos del compuesto. Estos usuarios experimentan euforia acompañado de sentimientos fuertes y prolongados de placer sexual, 
ron siete laboratorios ilícitos de metacualona donde se incautaron 20 kilogramos de ácido antranílico. También en la India se decomisaron en este año tres toneladas de ácido antranílico, tres toneladas de anhídrido acético y dos toneladas de tolueno que iban a ser utilizadas en la fabricación ilícita de metacualona, además hay que destacar que las autoridades de China decomisaron diez toneladas de ácido $N$-acetilantranílico que también es un precursor de la droga antes mencionada ${ }^{226 .}$

Siempre sobre la fabricación ilícita de metacualona hay que señalar, que las autoridades de Sudáfrica incautaron en el año 2003 un total de 7.200 litros de anhídrido acético y 450 kilogramos de ácido antranílico. Mientras que en el año 2004 fueron decomisados otros 550 kilogramos de ácido antranílico, los laboratorios, donde se encontraron los precursores, descubiertos funcionaban a escala más pequeña que los que se habían encontrado anteriormente, teniendo información la JIFE que la fabricación de metacualona a gran escala se realizaba en China. Ejemplo de ello es que cuatro toneladas de polvo de metacualona y $100 \mathrm{mi}-$ llones de tabletas de esta droga incautadas en Sudáfrica habían sido fabricadas ilícitamente en China. No obstante hay que señalar que aparentemente la red de fabricación de esta droga en este país asiático había sido desarticulada 227.

En el año 2006 se mantuvo la tendencia de los años anteriores, dado que la detección en Sudáfrica de los laboratorios que fabricaban ilícitamente drogas de tipo anfetamínico aumento, mientras que disminuía el descubrimiento de los laboratorios que producían ilícitamente metacualona. Sin embargo es preciso decir que en África se sigue abusando de esta droga. En este año las autoridades de Kenia desmantelaron un laboratorio ilícito de metacualona y se incautaron más de 400 kilogramos de esta droga, así como productos químicos y equipos utilizados en la fabricación de la misma. Este desplazamiento de la fabricación ilícita a raíz de las actuaciones fructíferas de represión antidrogas en un

junto a la capacidad de ingerir más alcohol de lo normal. Tales características pueden transformar una sustancia, que de otra manera es desagradable, en una droga para fiestas. p. 14. 
país ya se había observado antes en África, por lo que la Junta instó a todos los países a permanecer vigilantes para que estas actividades no se implanten en otros países de la zona ${ }^{228}$. En el año 2007 las autoridades competentes de la India detuvieron una remesa de cinco toneladas de ácido antranílico que iban a ser enviadas a Kenia, dado que este país no tiene ninguna necesidad legítima de esta sustancia. Las autoridades de los Estados Unidos de América, la India y Rumania informaron de incautaciones de ácido antranílico y de ácido $N$-acetilantranílico en este mismo periodo. Habida cuenta del uso indebido de drogas existente en África y de la situación de tráfico en ese continente, la JIFE hizo un llamamiento a los países de la región para que mantuvieran la vigilancia de todas las remesas de los precursores de drogas antes señalados ${ }^{229}$.

La fabricación ilícita de metacualona en Sudáfrica se mantuvo sin cambios en el año 2007, con respecto al año 2006, dado que no se informó de ningún caso de fabricación ilícita de metacualona. No obstante, durante este periodo las autoridades sudafricanas desmantelaron 30 laboratorios que habían producido metanfetamina o metcatinona, cuya existencia es un reflejo directo del incremento de estimulantes de tipo anfetaminico en la región. Hay que señalar que las incautaciones reportadas de sustancias catalogadas que se utilizan para elaborar metacualona en todo el mundo se reducen a un solo caso, en Ucrania, relacionado con el ácido antranílico ${ }^{230}$.

Las autoridades de Sudáfrica informaron de incrementos en el desmantelamiento de laboratorios dedicados a producir metacualona a partir del año 2008, en el año 2010 comunicaron haber desmantelado cinco laboratorios. En el mes de abril del año 2011 se descubrió en Ciudad del Cabo un laboratorio de metacualona de escala industrial en el que se encontraron 800 kilogramos de esa droga sintetizada en polvo. Las sustancias químicas encontradas indicaban que el proceso se iniciaba con anhídrido isatóico, una sustancia no fiscalizada. También fueron incautadas otras sustancias químicas, pero no se reportaron a la JIFE

228 Precursores y productos químicos frecuentemente utilizados..., correspondiente a 2006..., p. 21. Precursores y productos químicos frecuentemente utilizados..., correspondiente a 2007..., p. 17. 
sobre el tipo, los volúmenes ni el origen de la desviación de las mismas. Tomando en cuenta la información disponible, se estimó que dicho laboratorio había producido anteriormente más de 2,8 toneladas de clorhidrato de metacualona ${ }^{231}$. Para tener una mejor perspectiva de la situación de estos precursores de drogas nos permitimos citar que en el periodo de que va de 1995 al año 2010 se incautaron en el mundo un total de 17.058 gramos (equivalentes a 17 kilogramos con 58 gramos) de ácido $N$-acetilantranílico, siendo una de las sustancias del Cuadro I del Convenio de 1988 sobre las que se han efectuado menores decomisos (por debajo sólo de la ergotamina y el ácido lisérgico), para que nos hagamos una idea basta señalar que en 8 de los 16 años evaluados no se realizó ninguna incautación de esta sustancia. Del ácido antranílico en este mismo periodo (1995-2010) se decomisaron a nivel mundial un total ded 34.844 kilogramos, por lo que fue una de las sustancias del Cuadro II del Convenio de 1988 sobre las que se realizaron menores incautaciones. De esta sustancia los decomisos son muy bajos, tan es así que en cinco años no se realizó ninguna incautación. No obstante hay que destacar que en el año 2002 se incautaron un total de 25.626 kilogramos, mientras que en el año 2008 sólo las autoridades competentes de la India reportaron la incautación de 188 kilogramos de ácido antranílico ${ }^{232}$.

Durante el periodo 2011-2012 se reporto el envío de ocho remesas de ácido $\mathrm{N}$-acetilantranílico, por un total de 2,4 kilogramos; tres países exportaron la sustancia a cinco países importadores. Mientras que del ácido antranílico se registraron un total de 263 envíos por un total de 1.030 toneladas. Como ya se ha puesto de manifiesto en el desarrollo de este apartado no es habitual que se reporten incautaciones de ácido $\mathrm{N}$-acetilantranílico o de ácido antranílico. De hecho desde al año 2006 hasta la fecha solo siete gobiernos han informado sobre incautaciones

231 Precursores y productos químicos frecuentemente utilizados..., correspondiente a 2011..., p. 31.

232 Precursores y sustancias químicas frecuentemente utilizados..., correspondiente a 2013..., pp. 86-99. Precursores y productos químicos frecuentemente utilizados..., correspondiente a 2011..., pp. 66-100. Precursores y productos químicos frecuentemente utilizados..., correspondiente a 2010..., pp. 16-41. Precursores y productos químicos frecuentemente utilizados..., correspondiente a 2006..., pp. 38-60. Precursores y productos químicos frecuentemente utilizados..., correspondiente a 2004..., pp. 45-66. Precursores y productos químicos frecuentemente utilizados..., correspondiente a 2000..., pp. 47-61. 
mediante el formulario D. En el formulario correspondiente al año 2011 las autoridades de Suecia informaron del desmantelamiento de un laboratorio ilícito de metacualona, en el que se incautaron pequeñas cantidades de ácido antranílico cuya procedencia no se determino ${ }^{233}$.

Del periodo que va del 1 de noviembre del 2012 al 31 de octubre del 2013 se informo el envío de dos remesas de ácido $\mathrm{N}$-acetilantranílico, por un total de algo más de un kilogramo, dos países exportaron la sustancia a dos países importadores. Además se registro el envío de 277 remesas de ácido antranílico por un monto total de 1.120 toneladas. A través del formulario D correspondiente al año 2012 el Reino Unido de Gran Bretaña e Irlanda del Norte reporto la incautación de un kilogramo de ácido $N$-acetilantranílico ${ }^{234}$.

Del día 1 de noviembre del año 2013 al día 31 de octubre del año 2014, dos países exportadores enviaron notificaciones previas de exportación de dos remesas de ácido $N$-acetilantranílico, que sumaban un poco más de un kilogramo, a dos países importadores. Además durante este periodo se enviaron 277 envíos de ácido antranílico que sumaban un total de 1.120 toneladas. En el mes de junio del año 2014 se desmantelo un laboratorio que presuntamente fabricaba metacualona a gran escala en Sudáfrica. La Junta asume que se encontró ácido antranílico, posiblemente desviado de fuentes de abastecimiento locales, pero no se reportó más información al respecto ${ }^{235}$.

Para formarnos una idea sobre los resultados obtenidos en los últimos diez años ponemos de manifiesto que del año 2004 al año 2013 se informó a través del formulario D de la incautación de 10.149 kilogramos de ácido $N$-acetilantranílico en todo el mundo (cantidad con la podrían fabricarse 8.119 kilogramos de metacualona) ${ }^{236}$, siendo los seis países en que se produjeron: los Estados Unidos de América (133 kilogra-

233 Precursores y sustancias químicas frecuentemente utilizados..., correspondiente a 2012..., pp. 28, 29.

234 Precursores y sustancias químicas frecuentemente utilizados..., correspondiente a 2013..., p. 29

235 Precursores y sustancias químicas frecuentemente utilizados..., correspondiente a 2014..., pp. 39, 40.

236 Precursores y productos químicos frecuentemente utilizados..., correspondiente a 2004 ..., p. 82. 
mos), la India un kilogramo en el año 2008, China 10.000 kilogramos (2004), Malasia 13 kilogramos en el año 2010, el Reino Unido de Gran Bretaña e Irlanda del Norte un kilogramo y Polonia un kilogramo en el año 2013. En este mismo periodo se reporto el decomiso de 493.888 kilogramos de ácido antranílico (cantidad con la que se podrían producir 493.888 kilogramos de metacualona). Las incautaciones fueron realizadas por siete países: la India 3.538 kilogramos, China 490.316 kilogramos, Sudáfrica 20 kilogramos, Argentina un kilogramo, Ucrania seis kilogramos y Rumania siete kilogramos. Como se puede observar los decomisos de estas dos sustancias se realizan en regiones muy limitadas (diez países del mundo), probablemente se deba a que las drogas que se fabrican con ellas la metacualona y metcatinona, son de un consumo bastante limitado por lo que pueden considerarse drogas residuales ${ }^{237}$. Dicho esto, queremos manifestar que no comprendemos los criterios seguidos en la Convención de Viena de 1988 para establecer que el ácido $\mathrm{N}$-acetilantranílico se encuentre en el Cuadro I y el ácido antranílico en el Cuadro II, cuando este último precursor se comercializa mucho más, las incautaciones son considerablemente mayores y su rendimiento para fabricar metacualona también es superior.

\section{Precursores de la fenciclidina}

En el año 2003 el gobierno de Ucrania informó del desmantelamiento de un laboratorio ilícito que fabricaba fenciclidina ${ }^{238}$, siendo este el primer laboratorio descubierto fuera de los Estados Unidos de Améri-

237 También reportan la incautación de 6,5 litros de ácido $N$-acetilantranilico realizada en Qatar en el año 2013 que no aparece en las tablas. Precursores y sustancias químicas frecuentemente utilizados..., correspondiente a 2014..., pp. 39, 40, 71-90, 93-107. Precursores y sustancias químicas frecuentemente utilizados..., correspondiente a 2013..., pp. 67-84, 91-107. Precursores y sustancias químicas frecuentemente utilizados..., correspondiente a 2009..., pp. 37-50, 51-62. En España desde el año 1993 hasta el año 2014 no se ha realizado ninguna incautación de estas dos sustancias. Vid., el Anexo III.

238 La fenciclidina o PCP es una droga disociativa usada como agente anestésico que posee efectos alucinógenos y neurotóxicos. Se le conce comúnmente como "polvo de ángel", "hierba mala" o "píldora de la paz". Esta droga esta en la lista II de los Estados Unidos de América a tenor de la Convención sobre sustancias sicotrópicas de 1971. Química y farmacológicamente es un miembro de la familia de los anestésicos, dentro de los cuales se incluye la ketamina, tiletiamina y altas dosis de dextrometorfano. Hay que puntualizar que aunque los efectos psicoactivos primarios de la droga duran sólo horas, la eliminación total del cuerpo tarda mucho más tiempo, usualmente varias semanas. 
ca. En este local se incauto un kilogramo de piperidina. La JIFE mostró su preocupación por el hecho de que estos narcotraficantes utilizaban un proceso de síntesis muy complejo cuyo resultado era la formación de fosgeno y de cianuro de hidrogeno como subproductos, ambos incluidos en la lista 3 de la Convención sobre la prohibición del desarrollo, la producción, el almacenamiento y empleo de armas químicas. La presencia de estas sustancias tóxicas en un laboratorio ilícito de fabricación de drogas constituye un recordatorio de que el desmantelamiento de estos locales es peligroso ya que muchos de los productos químicos que se encuentran son tóxicos o cáusticos 239 . Hay que precisar que como la fenciclidina es una droga de consumo residual, su precursor la piperidina presenta unos niveles de incautaciones muy bajos, siendo la sustancia catalogada del Cuadro II de la Convención de 1988 sobre la que se han realizado menores decomisos. La mayor incautación se llevo a cabo en el año 2012 en los Estados Unidos de América por un monto de 189 litros. Debiendo destacarse que en este país se registran los mayores decomisos de esta sustancia ${ }^{240}$.

Con el fin de hacer un balance de los niveles de incautación de los últimos 10 años señalamos que del año 2004 al año 2013 se reportó a través de formulario $\mathrm{D}$ la incautación de 774 kilogramos de piperidina a nivel mundial (cantidad con la que se podrían fabricar 774 kilogramos de fenciclidina) ${ }^{241}$, desglosadas de la siguiente manera: 20 kilogramos en el año 2004, 16 kilogramos en el año 2005, 59 kilogramos en el año 2006, 2 kilogramos en el año 2007, 216 kilogramos en el año 2008, 43

239 Naciones Unidas, Treaty Series, vol. 1974, N. -33757 . Precursores y productos químicos frecuentemente utilizados..., correspondiente a 2003..., pp. 32, 34.

240 De 1995 al año 2013 sólo se habían decomisado en todo el mundo un total de 1.090 kilogramos (cantidad con la que podrían fabricarse 10.900 kilogramos de fenciclidina). Precursores y sustancias químicas frecuentemente utilizados..., correspondiente a 2014..., pp. 93-107. Precursores y sustancias químicas frecuentemente utilizados..., correspondiente a 2013..., pp. 86-99. Precursores y productos químicos frecuentemente utilizados..., correspondiente a 2011..., pp. 66-100. Precursores y productos químicos frecuentemente utilizados..., correspondiente a 2010..., pp. 16-41. Precursores y productos químicos frecuentemente utilizados..., correspondiente a 2006..., pp. 38-60. Precursores y productos químicos frecuentemente utilizados..., correspondiente a 2004..., pp. 45-66. Precursores y productos químicos frecuentemente utilizados..., correspondiente a 2000, pp. 47-61.

241 Precursores y productos químicos frecuentemente utilizados..., correspondiente a 2004..., p. 81. 
kilogramos en el año 2009, 90 kilogramos en el año 2010, 12 kilogramos en el año 2011, 257 kilogramos en el año 2012 y 59 kilogramos en el año 2013. Dichas incautaciones se realizaron únicamente en ocho países, de estos decomisaron más de 10 kilogramos en: Canadá (18 kilogramos), España (57 kilogramos), Rumania (61 kilogramos) y los Estados Unidos de América (610 kilogramos), lo cual representa el 78.8\% del total de los decomisos ejecutados en el mundo. Brasil, China, la Federación de Rusia y Luxemburgo realizaron incautaciones inferiores a 10 kilogramos ${ }^{242}$. El bajo nivel de decomisos de este precursor de drogas del Cuadro II del Convenio de 1988, que se reduce a ocho países, probablemente se debe al carácter residual que tiene el consumo de la feciclidina a nivel mundial.

\section{Precursores del LSD (ergotamina, ergometrina y ácido lisérgico)}

En este apartado realizaremos una valoración de las tres sustancias catalogadas que se utilizan para fabricar de forma ilegal la dietilamida de ácido lisérgico (LSD). Empezamos refiriéndonos a una incautación de ergotamina que se produjo en el año 2003 en Eslovaquia, donde decomisaron seis kilogramos de esta sustancia que iba a ser desviada para su utilización en la fabricación de LSD. Aparentemente la ergotamina había sido ordenada por una empresa de España, las investigaciones de seguimiento permitieron determinar que diez kilogramos habían sido inicialmente importados legalmente de la República Checa, de estos, seis kilos fueron desviados por un ciudadano de los Países Bajos e introducidos de contrabando a Eslovaquia. Por otra parte las autoridades de los Países Bajos identificaron una red que intentaba desviar cinco kilogramos de ergotamina proveniente de Eslovenia con destino a Suriname, a través de los Países Bajos. Vale la pena destacar que el envío había sido declarado como "productos farmacéuticos". También las autoridades de la Federación de Rusia notificaron la incautación de más de 12 kilogramos de esta sustancia. Hay que aclarar que los intentos de desviación de precursores de la LSD y el desmantelamiento de laboratorios clandestinos que se dediquen a la fabricación de esta droga son poco

242 Precursores y sustancias químicas frecuentemente utilizados..., correspondiente a 2014..., pp. 93-107. Precursores y sustancias químicas frecuentemente utilizados..., correspondiente a 2013..., pp. 86-99. Precursores y sustancias químicas frecuentemente utilizados..., correspondiente a 2009..., pp. 37-50, 51-62. 
comunes, sin embargo en el año 2004 en los Estados Unidos de América desmantelaron uno, cuando la persona encargada de establecerlo fue detenida al intentar comprar ergotamina proveniente de Vietnam ${ }^{243}$.

A raíz de la detección del desvío de ergotamina en el año 2003 en Eslovaquia, las autoridades checas empezaron a preocuparse también por los pedidos de ergocristina, sustancia no catalogada que también se utiliza en la elaboración del LSD, por lo cual solicitaron la asistencia de la JIFE para comprobar la legitimidad de determinados envíos de esa sustancia. Producto de las investigaciones realizadas, al respecto, las autoridades panameñas incautaron un kilogramo de esa sustancia a inicios del año 2005, tras este decomiso, se recibió un nuevo pedido proveniente de las Antillas Neerlandesas. Se realizo el seguimiento de esta remesa y se descubrió un laboratorio clandestino. A partir de esta experiencia la Junta invitó a los gobiernos a que vigilaran los envíos de alcaloides del cornezuelo, incluidos los sucedáneos no sometidos a fiscalización internacional244. En el año 2006 los países de América del Sur y América Central se vieron afectados por intentos de desviación de precursores de la dietilamina del ácido lisérgico (LSD) ${ }^{245}$.

En el año 2007 sólo se comunicó un caso de elaboración de dietilamina del ácido lisérgico (LSD), mientras que en el año 2008 no se informó a la JIFE de ninguna prueba de que hubiera una fabricación ilícita de esta droga. Es preciso decir que aunque América central y América del Sur

Precursores y productos químicos frecuentemente utilizados..., correspondiente a 2004..., p. 27.

244 Precursores y productos químicos frecuentemente utilizados..., correspondiente a $2005 . .$. p. 14. El cornezuelo de centeno o ergot (claviceps purpúrea) es un hongo del grupo de los acomicetos parásito del centeno, pero también de otros cereales. El género claviceps contiene más de 50 especies, todas ellas parasitas de cereales. Se le conoce como el rey de los alucinógenos naturales, pues es la base del LSD y además posee una inusitada complejidad química. El ergot puede llegar a contener hasta 300 alcaloides distintos. Los principales alcaloides con propiedades psicoactivas son: el ácido lisérgico, la ergotamina, la ergometrina (sustancias catalogadas), la ergocristina y la ergocriptina (sustancias no catalogadas), cada una de estas sustancias tiene unas acciones farmacológicas bien diferenciadas, pero todas sirven para elaborar LSD. El cornezuelo de centeno o ergot contiene alcaloides muy tóxicos, así como otros con propiedades medicinales como la ergonovina que tiene utilidad como uterotónica y hemostática. precursores quimicossitdi.blogspot.com/2009/10/blog-post.html. 
ocupaban un lugar importante en anteriores intentos de desviación de precursores de este alucinógeno, en el año 2008 Oceanía fue el centro de la limitada actividad que se registró, habiendo incautado las autoridades australianas 32 gramos de ergotamina ${ }^{246}$.

Entre el día 1 de noviembre del año 2009 y el 31 de octubre del año 2010 se comunicaron 330 remesas de alcaloides del cornezuelo (ergotamina, ergometrina y sus sales), que ascendían a un total de $2.763 \mathrm{ki}-$ logramos y 107 litros, que 12 países exportaron a 49 países importadores. Además durante el período considerado hubo nueve remesas de ácido lisérgico, por un total de 8,5 kilogramos. Sobre los decomisos de estas sustancias hay que decir que las autoridades de Australia, la Federación de Rusia e Irlanda informaron mediante el formulario D incautaciones de ácido lisérgico por un total de 322 gramos, de los que 300 gramos fueron incautados en Irlanda. Además las autoridades de Australia y Ucrania comunicaron pequeños decomisos de ergotamina y ergometrina, respectivamente ${ }^{247}$.

Durante el período que va del 1 de noviembre del 2010 al día 31 de octubre del 2011 se reportaron 399 remesas del ergot (ergotamina y ergometrina y sus sales), que sumaron 1.794 kilogramos que 19 países exportaron a 54 países. Además durante el período considerado hubo 10 remesas de ácido lisérgico, por un total de 9,2 kilogramos. Es importante señalar que del año 2005 al año 2010 los principales países exportadores de ergot han sido la República Checa, Suiza e Italia que comercializaron el $98 \%$ del volumen total. Mientras que los principales países importadores fueron Turquía, Suiza, Argentina, la India y Chile que sumaron el 59\% de las importaciones. En el caso del ácido lisérgico el comercio internacional, comunicado mediante el sistema PEN Online, fue muy reducido habiéndose comercializado un total de 31.5 kilogramos entre el año 2005 y el año 2010 procedentes de dos países y con destino solo a tres países. Los decomisos del ergot y del ácido lisérgico, como ya hemos señalado anteriormente, son bastantes escasos, y cuando se producen son de cantidades muy pequeñas, que no parecen haber sido desviadas del comercio internacional. De hecho en el formup. 15. pp. 16, 17.
} 
lario D correspondiente al año 2010 únicamente dos gobiernos reportaron incautaciones de alcaloides del ergot, siendo estos Australia (99,7 gramos) y México (2.000 gramos). Mientras que dos gobiernos facilitaron información sobre incautaciones de ácido lisérgico; la Federación de Rusia (102,1 gramos) y Australia (4,3 gramos) ${ }^{248}$.

Un dato de sumo interés se reportó en el mes de diciembre del año 2011 en los Países Bajos (Amersfoort) donde se incautaron tres gramos elimoclavina y dos gramos de agroclavina (sustancias no catalogadas), lo cual podría ser un indicio de que los traficantes de drogas están utilizando un método diferente para sintetizar dietilamida del ácido lisérgico (LSD). Dado que la agroclavina es otro alcaloide del cornezuelo de centeno que puede transformarse en elimoclavina mediante oxidación y utilizarse para sitetizar drogas a base de cornezuelo. Hay que destacar que estos productos provenían de la India y nunca habían sido decomisados en los Países Bajos ${ }^{249}$.

Durante el periodo 2011-2012 se comunicaron un total de 384 remesas de alcaloides del ergot (ergometrina y ergotamina) por un total de 1.620 kilogramos que 17 países exportaron a 50 países, queremos recordar que estas sustancias se utilizan en el tratamiento de la migraña y como oxitócico en obstetricia. Además durante este periodo se regis-

Precursores y productos químicos frecuentemente utilizados..., correspondiente a 2011..., p. 31. Para comprender un poco el nivel de incautaciones de los precursores del LSD nos permitimos señalar que en el periodo 1995-2010 se decomisaron 291 kilogramos con 702 gramos de ergotamina, en seis años no se reporto ninguna incautación y en el resto de años las cantidades incautadas han sido insignificantes. En el caso de la ergometrina los decomisos fueron aún menores 3 kilogramos con 138 gramos en 16 años. Del ácido lisérgico sólo se incautaron 2 kilogramos con 138 gramos en el mismo periodo. De hecho de estas tres sustancias, del Cuadro I del Convenio de 1998, fueron de las que se reportaron las menores incautaciones. Lo cual posiblemente se deba a que la LSD es prácticamente una droga de consumo residual. El problema de la drogodependencia en Europa. Informe anual 2012. Ed. Observatorio Europeo de las Drogas y las Toxicomanías. Luxemburgo. 2012, p. 54. Ibidem., pp. 66-100. Precursores y productos químicos frecuentemente utilizados..., correspondiente a 2010..., pp. 16-41. Precursores y productos químicos frecuentemente utilizados..., correspondiente a 2006..., pp. 38-60. Precursores y productos químicos frecuentemente utilizados..., correspondiente a 2004..., pp. 45-66. Precursores y productos químicos frecuentemente utilizados..., correspondiente a 2000..., pp. 47-61.

249 Global SMART Update, volumen 7, marzo 2012. Informe global de monitoreo de drogas sintéticas 2012. Ed. UNODC. 2012, p. 11. 
traron 6 remesas de ácido lisérgico por un total de 17 kilogramos. Una remesa de 95 kilogramos de ergotamina, cantidad importante tratándose de este tipo de sustancia, enviada de Chile a Honduras. El envío fue detenido porque las autoridades de Honduras le informaron a la Junta que la autorización de exportación se había expedido solo por 133 gramos. Para que nos hagamos una idea queremos señalar que el peso promedio de las remesas en este año fue de un kilogramo. En el año 2011 únicamente las autoridades de Australia informaron a través del formulario D de la incautación de 4 gramos de alcaloides del ergot. Mientras que tres gobiernos comunicaron decomisos de ácido lisérgico: la India (62,4 gramos), Irlanda (44,9 gramos) y los Estados Unidos de América (2,5 gramos) ${ }^{250}$.

En el periodo que va del 1 de noviembre del año 2012 al 31 de octubre del año 2013 se reportaron 337 remesas de los alcaloides del ergot (ergometrina y ergotamina y sus sales) por un monto total de 145 kilogramos; 17 países exportaron alcaloides del ergot a 53 países. Además se registraron tres remesas de ácido lisérgico por un total de 0,5 kilogramos. Los gobiernos de Australia, el Canadá, los Estados Unidos de América, México y Ucrania utilizaron el formulario D correspondiente al año 2012 para comunicar incautaciones del ergot, las mayores fueron: México (1,6 kilogramos de ergotamina) y Australia (0.69 kilogramos de ácido lisérgico) ${ }^{251}$. En el formulario D correspondiente al año 2013 tres países registraron incautaciones de los alcaloides del cornezuelo de centeno: Australia, China y España. Además Australia decomiso una cantidad muy pequeña de ergometrina y fue el único país que informó de incautaciones de esta sustancia en este año. En todos los casos, las cantidades decomisadas eran inferiores a un kilogramo.

Como ya señalamos antes, las incautaciones de ácido lisérgico suelen ser muy reducidas, para ilustrar un poco esta situación señalamos que del año 2004 al año 2013 se incautaron en todo el mundo un total de 2 kilogramos con 849 gramos, prácticamente 3 kilogramos (cantidad con pp. 27, 28. 
la que se podrían elaborar 2 kilogramos de LSD ${ }^{252}$, distribuidos de la siguiente manera: 2005 (226 gramos), 2007 (165 gramos), 2008 (120 gramos), 2009 (411 gramos), 2010 (106 gramos), 2011 (521 gramos), 2012 (694 gramos) y 2013 (606 gramos). Dichos decomisos se realizaron en seis países, siendo estos; Australia (1.446 gramos), Canadá (116 gramos), los Estados Unidos de América (116 gramos), la India (62 gramos en el año 2011), Irlanda (749 gramos), la Federación de Rusia (240 gramos), siendo por tanto el país que mayores decomisos ha realizado de esta sustancia Australia (1.446 gramos en 10 años) ${ }^{253}$.

El nivel de incautaciones de ergometrina también es muy bajo, prueba de de ello es que en 10 años (2004-2013) únicamente se decomisaron en todo el mundo 2 kilogramos con 59 gramos de este precursor de drogas, con esta cantidad se podrían fabricar 800 gramos de LSD. Las incautaciones se realizaron en dos países: Australia que incautaron 59 gramos en el año 2008 y México que incauto 2 kilogramos en el año $2010^{254}$.

Las incautaciones de ergotamina a nivel mundial del año 2004 al año 2013 fueron de 373 kilogramos con 670 gramos (cantidad con la que se podrían fabricar 74,7 kilogramos de LSD) ${ }^{255}$, distribuidas de la siguiente manera: en el año 2005 (276.105 gramos), en el año 2006 (5.022 gramos), en el año 2007 (10.032 gramos) en el año 2008 (300 gramos), en el año 2010 (79.0 80 gramos), en el año 2011 (824 gramos), en el año 2012 (1.650 gramos) y en el año 2013 (657 gramos). Los decomisos se realizaron en ocho países siendo estos: Panamá (5.000 gramos), Venezuela (78.360 gramos), México (1.630 gramos), los Estados Unidos de América (11.449 gramos), China (276.449 gra-

252 Precursores y productos químicos frecuentemente utilizados..., correspondiente a 2004 ..., p. 81.

253 Precursores y sustancias químicas frecuentemente utilizados..., correspondiente a 2013..., pp. 67-84. Precursores y sustancias químicas frecuentemente utilizados..., correspondiente a 2014..., pp. 71-90. Precursores y sustancias químicas frecuentemente utilizados..., correspondiente a 2009..., pp. 37-50, 51-62.

254 Precursores y sustancias químicas frecuentemente utilizados..., correspondiente a 2013..., pp. 67-84. Precursores y sustancias químicas frecuentemente utilizados..., correspondiente a 2014..., pp. 71-90. Precursores y productos químicos frecuentemente utilizados..., correspondiente a $2004 \ldots$, p. 82.

255 Ibidem., p. 81. 
mos), Australia (356 gramos), Canadá (425 gramos) y España (1 gramo), siendo el país que decomiso más ergotamina en estos diez años China (276.449 gramos) ${ }^{256}$. Para comprender un poco el nivel de incautaciones de los precursores del LSD nos permitimos señalar que en este periodo estas tres sustancias (ergotamina, ácido lisérgico y y ergometrina), del Cuadro I del Covenio de 1998, fueron de las que se reportaron las menores incautaciones a nivel mundial, lo cual posiblemente se deba a que la LSD es prácticamente una droga de consumo residual 257 , sin embargo tenemos que manifestar que no conocemos la cantidad de producción de esta droga, ni un estimado de la misma que nos permita hacernos una idea clara del nivel de desviación o producción ilícita de estas sustancias catalogadas.

\section{INCAUTACIONES DE PRECURSORES DE DROGAS REALIZADAS EN ESPAÑA}

Una vez finalizado el estudio del tráfico de precursores a nivel mundial queremos señalar que las incautaciones de precursores de drogas realizadas en España desde el año 1993 hasta el año 2014, veintidós años que comprenden desde la incorporación del delito de tráfico de precursores de drogas al ordenamiento penal español hasta el último informe disponible, han sido de un monto de 13.958.348 kilogramos con 130 gramos, desglosadas de la siguiente forma:

1) Tolueno (Cuadro II): 13.296 .904 kilogramos.

2) Ácido sulfúrico (Cuadro II): 590.723 kilogramos con 18 gramos.

3) Acetona (Cuadro II): 21.901 kilogramos con 67 gramos.

4) Metiletilcetona (Cuadro II): 15.775 kilogramos con 88 gramos.

256 Precursores y sustancias químicas frecuentemente utilizados..., correspondiente a 2013..., pp. 67-84. Precursores y sustancias químicas frecuentemente utilizados..., correspondiente a 2014..., pp. 71-90. Precursores y sustancias químicas frecuentemente utilizados..., correspondiente a 2009..., pp. 37-50, 51-62. Vid., en el Anexo III la incautación de ergotamina realizada en España.

257 En términos generales, los niveles de consumo de drogas alucinógenas como el LSD y los hongos alucinógenos en los países europeos por lo general son bajos y se han mantenido estables en los últimos años. El problema de la drogodependencia en Europa. Informe anual 2012. Ed. Observatorio Europeo de las Drogas y las Toxicomanías. Luxemburgo. 2012, p. 54. 
5) Éter etílico (Cuadro II): 12.427 kilogramos.

6) Anhídrido acético (Cuadro I): 8.961 kilogramos con 82 gramos.

7) Permanganato de potasio (Cuadro I): 6.195 kilogramos.

8) Ácido clorhídrico (Cuadro II): 2.325 kilogramos.

9) Efedrina (Cuadro I): 1.517 kilogramos.

10) Piperonal (Cuadro I): 1.449 kilogramos.

11) APAAN (Cuadro I): 122 kilogramos.

Se decomisaron menos de 100 kilogramos de:

12) Ácido fenilacético (Cuadro I): 96 kilogramos.

13) Piperidina (Cuadro II): 70 kilogramos con 76 gramos.

14) Safrol (Cuadro I): 4 kilogramos con 56 gramos.

15) 3,4-MDP-2-P (Cuadro I): 833 gramos.

16) Ergotamina (Cuadro I): 1 gramo.

No se realizó ninguna incautación de:

17) Ácido $N$-acetilantranílico (Cuadro I).

18) Ácido lisérgico (Cuadro I).

19) Ergometrina (Cuadro I).

20) P-2-P (Cuadro I).

21) Isosafrol (Cuadro I).

22) Norefedrina (Cuadro I).

23) Seudoefedrina (Cuadro I).

24) Ácido antranílico (Cuadro II).

25) APAAN (Cuadro I) ${ }^{258}$.

Hay que destacar que los casi catorce millones de kilogramos de precursores incautados durante el transcurso de veintidós años en España

258 Para realizar la conversión de litros a kilogramos de las cantidades expresadas en las tablas de incautaciones de anhídrido acético, 3,4-MDP-2-P, safrol, acetona, ácido clorhídrico, ácido sulfúrico, éter etílico, metiletilcetona, piperidina, y tolueno utilizamos los parámetros establecidos por la JIFE. Precursores y productos químicos frecuentemente utilizados..., correspondiente a 1998..., pp. 42-57. Precursores y productos químicos frecuentemente utilizados..., correspondiente a 2004..., pp. 45-66. Precursores y productos químicos frecuentemente utilizados..., correspondiente a 2009..., pp. 37-62. Precursores y productos químicos frecuentemente utilizados..., correspondiente a 2014..., pp. 69-107. Precursores y productos químicos frecuentemente utilizados..., correspondiente a 2015, pp. 67-102. Vid., detalles de todas las incautaciones en el Anexo III. 
podrían haber sido utilizados para la elaboración de drogas ilícitas tales como: 886.460 kilogramos de clorhidrato de cocaína o de heroína, 1.515 kilogramos de anfetamina o metanfetamina y 1.449 kilogramos de éxtasis, así como de otros precursores de drogas tales como: ácido fenilacético, isosafrol, piperonal, P-2-P y 3,4-MDP-2-P, sustancias que también se utilizan en la elaboración de las drogas antes citadas y otras como la fenciclidina. Queremos aclarar que los precursores decomisados podrían haber sido usados para la elaboración de drogas ilícitas en España ${ }^{259}$ o en cualquier otro país del mundo, muestra de ello son dos importantes incautaciones: 1) de 1.500 kilogramos de efedrina que tenían por destino Marruecos 260,2 ) de una operación de entrega vigilada de 12.000 kilogramos de permanganato de potasio la cual se adquirió en Bélgica, se enmascaró como dióxido de manganeso en España y fue incautada en Colombia 261.

Para poder hacernos una idea del nivel de producción ilícita de precursores de drogas, así como del desvío de los mismos del comercio lícito tomamos como referencia que la Oficina de las Naciones Unidas contra la Droga y el Delito en su informe correspondiente al año 2014 estimó que se logra incautar a nivel mundial aproximadamente el $15 \%$ del permanganato de potasio, principal precursor destinado a la fabricación ilícita de cocaína, el 15\% del anhídrido acético, principal precursor utilizado para la elaboración ilícita de heroína y el 20\% de los precursores de drogas destinados a la fabricación ilícita de las anfetaminas $^{262}$. Nosotros tomando como referencia el mayor porcentaje de in-

STS (ROJ: 2484/1999) de 14 de abril de 1999. Ponente: Eduardo Moner Muñoz. STS (ROJ: 583/2004) de 3 de febrero de 2004. Ponente: Enrique Bacigalupo Zapater. STS (ROJ: 232/2013) de 18 de enero de 2013. Ponente: Alberto Gumersindo Jorge Barreiro. SAN (ROJ: 6508/2006) de 21 de julio de 2006. Ponente: Juan Francisco Martel Rivera. SAP de Madrid (ROJ: 2827/2009) de 16 de marzo de 2009. Ponente: Jesús Ángel Guijarro López. SAP de Madrid (ROJ: 1011/2014) de 28 de enero de 2014. Ponente: Adoración María Riera Ocariz.

Sobre el decomiso de los 1.500 kilogramos de efedrina que se produjo en España. Las autoridades que investigaban irregularidades y discrepancias en los documentos descubrieron una sociedad ficticia en Marruecos que se dedicaba a importar cantidades considerables de efedrina para luego enviarlas de contrabando a Marruecos. SAN (ROJ: 3347/2013) de 3 de julio de 2013. Ponente: Fernando Grande-Marlaska Gómez. STS (ROJ: 89/2003) de 16 de enero de 2003. Ponente: Luis Román Puerta Luis. Resumen Ejecutivo. Informe Mundial sobre las Drogas 2014. Ed. UNODC. 2015, p. 7. 
cautación, el más optimista, asumiremos que se decomisan el $20 \%$ de todos los precursores de drogas que se desvían del comercio lícito, o se fabrican ilícitamente, en España. Lo que nos permite suponer que es probable, tomando como referencia los 14.000 .000 de kilogramos de precursores de drogas incautados en los veintidós años evaluados, que el tráfico ilícito de precursores anual podría ser de aproximadamente de 5.000.000 kilogramos, y por ende el mensual de 424.000 kilogramos. Siendo los precursores que más se desviarían los siguientes: tolueno, ácido sulfúrico, acetona, metiletilcetona, éter etílico, anhídrido acético, permanganato de potasio, ácido clorhídrico, efedrina, piperonal y APAAN.

III. MÉTODOS UTILIZADOS POR LOS NARCOTRAFICANTES PARA EL DESVÍO DE PRECURSORES DE DROGAS TÓXICAS, ESTUPEFACIENTES Y PSICOTRÓPICOS

Sobre la base de la información que ha recabado la JIFE en los últimos 16 años proveniente de todos los gobiernos de los países y territorios partes y no partes de la Convención de 1988, podemos señalar que los métodos más usados por los narcotraficantes para abastecerse de precursores de drogas son los siguientes:

a) El contrabando es el método preferido por los traficantes para trasladar precursores de drogas, o preparados farmacéuticos que contienen estos, a través de las fronteras internacionales a las zonas de fabricación ilícita de drogas después de haber desviado las sustancias de los canales internos de distribución ${ }^{263}$.

b) Los narcotraficantes están introduciendo mecanismos más elaborados para obtener los precursores que necesitan. En algunos casos han formado empresas ficticias para llevar a cabo negocios en cierta medida lícitos con las sustancias enumeradas en los Cuadros I y II de la Convención de 1988, así las cantidades de productos químicos fiscalizados que sobrepasan las necesidades lícitas de la empresa posterior-

263 "El tráfico transfronterizo se ha convertido en el método más común para obtener productos químicos con los que abastecer los laboratorios ilícitos". Precursores y productos químicos frecuentemente utilizados..., correspondiente a 2008..., pp. XI, 16. Precursores y sustancias químicas frecuentemente utilizados..., correspondiente a 2012..., p. 37. 
mente se desvían hacia la fabricación ilícita de drogas ${ }^{264}$, también la experiencia a demostrado que los traficantes de precursores utilizan empresas legítimas para efectuar transacciones ilegítimas ${ }^{265}$.

c) Introducción de las sustancias catalogadas de contrabando en puertos, aeropuertos o fronteras terrestres utilizando métodos que normalmente se asocian con el contrabando de drogas, tal es el caso de impregnar toallas de baño con efedrina o el ocultamiento de esta misma sustancia dentro de una partida de baldosas o bien envasar P-2-P o 3,4-MDP-2-P en botellas de aceite vegetal o mineral o camuflando estas sustancias dentro de radiadores o lámparas de lava, vaciar el centro de troncos de una partida de madera para introducir en ese lugar recipientes con anhídrido acético, introducir anhídrido acético en botellas de vodka o bien ocultar efedrina en el interior de los forros de cajas que contenían pasas rojas entre otra medidas de enmascaramiento ${ }^{266}$.

d) Los informes ponen de manifiesto que las sustancias catalogadas se continúan desviando de los canales nacionales de distribución, de muchas formas, entre ellas; robos de pequeñas cantidades realizadas por empleados corruptos de las empresas de productos químicos, o bien por los transportistas de las sustancias, así como por robos a mano armada realizados por los narcotraficantes a estas empresas, sustracción de medicamentos que contienen precursores en hospitales, etc. Cuando la desviación se realiza en los canales de distribución interna en un país diferente al país en que se realiza la fabricación ilícita de drogas posteriormente se pasa de contrabando a dicho país ${ }^{267}$.

Precursores y productos químicos frecuentemente utilizados..., correspondiente a 2000..., pp. 19, 21, 22, 28. Precursores y productos químicos frecuentemente utilizados..., correspondiente a $2001 \ldots$, p. 17.

265 Precursores y sustancias químicas frecuentemente utilizados..., correspondiente a $2012 \ldots$, p 7.

266 Precursores y productos químicos frecuentemente utilizados..., correspondiente a 2003..., pp. 21- 23, 29, 30. Global SMART Update, volumen 7, marzo 2012. Informe global de monitoreo de drogas sintéticas 2012. Ed. UNODC. 2012, p. 7.

267 Esos empleados corruptos sacan pequeñas cantidades de los productos químicos cada vez para no despertar sospechas y las pérdidas, si es que son detectadas, se imputan a mermas aceptables durante el transporte y la fabricación o bien a derrames. Precursores y productos químicos frecuentemente utilizados..., correspondiente a 2000..., pp. 19, $21,22,28$. Colombia ha comunicado una incautación de 20 toneladas de ácido clorhídrico y ha informado a la JIFE que el método de desviación utilizado por los trafican- 
e) La utilización de los servicios postales para realizar el contrabando de sustancias catalogadas, fundamentalmente de aquellos precursores empleados para la fabricación ilícita de estimulantes de tipo anfetamínico 268 .

f) Los narcotraficantes vigilan los mercados de sustancias catalogadas e identifican empresas con necesidades lícitas de estas sustancias, luego utilizan los nombres de esas empresas en los intentos de desviación, elaborando contratos de venta o certificados de importación falsos, con la perspectiva de que las autoridades reconozcan los nombres de esas empresas establecidas y despachen los envíos sin realizar las comprobaciones debidas ${ }^{269}$.

g) Los traficantes siguen formulando pedidos de precursores de drogas a través de intermediarios situados en países distintos de aquellos

tes. En el caso en cuestión consiste en que los conductores de los camiones que se encargaban de entregar los paquetes entre empresas que tenían una necesidad lícita de la sustancia se quedaban con pequeñas cantidades de ácido clorhídrico cada vez que realizaban una entrega. Las cantidades así obtenidas eran acumuladas para entregarlas a los narcotraficantes en fechas posteriores. Este mismo método es descubierto por las autoridades de la India para la desviación de anhídrido acético. Precursores y productos químicos frecuentemente utilizados..., correspondiente a 2001, pp. 16, 19, 21. Precursores y productos químicos frecuentemente utilizados..., correspondiente a 2007..., p. 18. Precursores y productos químicos frecuentemente utilizados..., correspondiente a 2009..., pp. XII, 17. Precursores y sustancias químicas frecuentemente utilizados..., correspondiente a 2012..., p. 37. Informe de la Junta Internacional de Fiscalización de Estupefacientes correspondiente a 2012. Ed. Naciones Unidas. Nueva York. 2013, pp. 33, 34, 52, 125.

268 Se han reportado incautaciones de 3,4-metilendioxifenil-2-propanona en los Países Bajos de remesas que se habían enviado por correo desde Hong Kong. Precursores y productos químicos frecuentemente utilizados..., correspondiente a 2000..., pp. 17, 28, 30.

Es preocupación de la JIFE el creciente número de intentos de desviación descubiertos en Asia sudoriental, como ejemplo citamos que los traficantes lograron desviar 100 toneladas de permanganato de potasio utilizando el nombre de una empresa ubicada en Vietnam, debido a que las autoridades competentes no pudieron responder a tiempo a la notificación previa a la exportación enviada por el país exportador. Situación similar ocurrió con una partida de piperonal en Brasil. Precursores y productos químicos frecuentemente utilizados..., correspondiente a 2001..., p. 16- 18, 27. Se descubrieron cuatro intentos de desvío de permanganato de potasio en el año 2002 usando contratos falsos de venta de empresas verdaderas en Alemania, Austria e Irlanda. Precursores y productos químicos frecuentemente utilizados..., correspondiente a 2002..., pp. 15, 16, 20, 23. Precursores y productos químicos frecuentemente utilizados..., correspondiente a $2004 \ldots$ p. 22. 
por los que el envío está destinado a transitar, las sustancias suelen utilizar circuitos que entrañan la importación y reexportación de las mismas a través de terceros países, aprovechando que en muchos países no existe una legislación, o bien no cuentan con los recursos adecuados, que permita vigilar y fiscalizar esas actividades de los intermediarios, tal es el caso del continente africano, particularmente África oriental y occidental o de América Central y el Caribe. En definitiva las rutas de desviación cada vez son más complejas. Hay que destacar que estos países especialmente vulnerables cada vez más se utilizan por los narcotraficantes para la elaboración de drogas ilícitas ${ }^{270}$.

h) La elaboración del propio precursor de drogas en laboratorios clandestinos, tanto en lugares cercanos, como en zonas alejadas a los laboratorios donde se produce la droga o inclusive en países distintos donde se encuentran estos, tal es el caso del permanganato de potasio, del ácido clorhídrico, del ácido sulfúrico, de éter etílico y metiletilcetona en Colombia ${ }^{271}$, del anhídrido acético en el Pakistán 272 o de la efedrina $^{273}$, la seudoefedrina274 la 3,4-MDP-2-P275, la P-2-P276, del safrol277 y

$270 \quad$ Precursores y productos químicos frecuentemente utilizados..., correspondiente a 2000..., pp. 6- 8. Precursores y productos químicos frecuentemente utilizados correspondiente a 2001..., p. 16. Precursores y productos químicos frecuentemente utilizados..., correspondiente a 2011..., p. 32. Informe de la Junta Internacional de Fiscalización de Estupefacientes correspondiente a 2011. Naciones Unidas. Ed. JIFE. New York. 2012, pp. 55, 58, 61, 121. Informe de la Junta Internacional de Fiscalización de Estupefacientes correspondiente a 2012. Ed. Naciones Unidas. Nueva York. 2013, pp. 58, 61, 66. Precursores y productos químicos frecuentemente utilizados..., correspondiente a 2013..., p. 19.

271 Precursores y productos químicos frecuentemente utilizados.., correspondiente a 2001..., p. 17. En el año 2006 se desmantelaron en Colombia 15 laboratorios ilícitos que producían permanganato de potasio. Precursores y productos químicos frecuentemente utilizados..., correspondiente a 2007..., p. 18. Informe de la Junta Internacional de Fiscalización de Estupefacientes correspondiente a 2012. Ed. Naciones Unidas. Nueva York. 2013, p. 82. El problema de Drogas en las Américas. Estudios. Producción y oferta de drogas, fármacos y precursores químicos. Ed. Organización de Estados Americanos. ISBN 978-08270-6002-9, p. 41.

272 A invitación del Gobierno de el Pakistán, la Junta visito este país en el mes de abril del año 2008, donde recibió pruebas técnicas fiables sobre la fabricación ilícita de anhídrido acético a partir de ácido acético glacial. Precursores y productos químicos frecuentemente utilizados..., correspondiente a 2008..., p. 14.

273 Ibidem., pp. 10, 11. En la India sus autoridades han informado sobre la fabricación ilícita de efedrina en su territorio. Informe de la Junta Internacional de Fiscalización de Estupefacientes correspondiente a 2011. Ed. Naciones Unidas. JIFE. New York, 2012, p. 90. 
del ácido fenilacético ${ }^{278}$ en diferentes partes del mundo, por lo cual podemos afirmar que las ocho sustancias catalogadas más importantes, todas del Cuadro I del Convenio de 1988, en las que centran todos sus esfuerzos el Proyecto Prima y el Proyecto Cohesión se fabrican ilícitamente, así como, por lo menos, cuatro sustancias del Cuadro II y una cantidad considerable de sustancias no catalogadas que se utilizan en la elaboración de drogas ${ }^{279}$.

i) Realizar la transferencia de la sustancia catalogada debidamente etiquetada en sus envases originales a envases sin etiquetar o con etiquetas falsas, tal como se ha descubierto en remesas de anhídrido acético, el 3,4-metilendioxifenil-2-propanona (3,4-MDP-2-P), el permanganato de potasio o de otros precursores de drogas ${ }^{280}$.

274 Precursores y productos químicos frecuentemente utilizados..., correspondiente a 2008..., p. 9.

275 Ibidem., p. 10. Las autoridades de Luxemburgo reportaron a través del sistema PICS decomisos de un nuevo "pre-precursor" de la MDMA, "la sal sódica de 3,4-MDP-2-P ácido glicídico", que puede transformarse en 3,4-MDP-2-P en una relación práctica de 2 a 1 aproximadamente. Una partida de 420 kilogramos de la sustancia, originaria de China, había llegado a Luxemburgo por vía aérea desde Hong Kong, China, e iba destinada a los Países Bajos. Precursores y productos químicos frecuentemente utilizados..., correspondiente a $2013 \ldots$, p. 21.

276 Precursores y productos químicos frecuentemente utilizados..., correspondiente a 2011..., pp. 21, 22. Desmantelan en el Reino Unido de Gran Bretaña e Irlanda del Norte u n laboratorio clandestino de P-2-P utilizando un nuevo "pre-precursor de drogas", la sal sódica de P-2-P ácido glicídico. Precursores y productos químicos frecuentemente utilizados..., correspondiente a 2013..., pp. 20, 21.

277 Precursores y productos químicos frecuentemente utilizados..., correspondiente a 2009..., pp. 14, 15.

278 Precursores y productos químicos frecuentemente utilizados..., correspondiente a 2008..., pp. 10, 11.

279 Global SMART Update, volumen 7, marzo 2012. Informe global de monitoreo de drogas sintéticas 2012. Ed. UNODC. 2012, p. 5. Informe de la Junta Internacional de Fiscalización de Estupefacientes correspondiente a 2012. Ed. Naciones Unidas. Nueva York. 2013, p. 34.

280 Precursores y productos químicos frecuentemente utilizados..., correspondiente a 2001..., pp. 20, 26. Se ha determinado que la declaración fraudulenta y el etiquetado engañoso de las remesas son los modus operandi principales que utilizan los traficantes de APAAN. Precursores y productos químicos frecuentemente utilizados..., correspondiente a $2013 \ldots$, p. 20. Gaspar y José Ignacio importaron un cargamento de unos 12.000 kilo- 
j) Almacenar los precursores de drogas durante un largo periodo de tiempo, como ha ocurrido con el anhídrido acético, ya que los traficantes saben que las autoridades tienen unos recursos limitados y no pueden mantener indefinidamente un envío bajo observación ${ }^{281}$.

k) Procurar la obtención de precursores de drogas y otros productos químicos necesarios para la elaboración de drogas ilegales, así como de equipos y materiales para este fin a través de Internet 282 .

l) La corrupción es un factor importante a tener en cuenta para tratar de prevenir desviaciones o interceptar envíos de contrabando de

gramos de permanganato de potasio (envasados en bidones de 50 kilogramos), con el fin de exportarlo a Colombia. Esta remesa les fue suministrada por la empresa "Innochem" que tiene su sede en la localidad belga de Meerhort. Gaspar y José Ignacio antes de exportar el permanganato de potasio a Colombia decidieron camuflar la mercancía y para este propósito adquirieron 6.000 kilogramos de dióxido de manganeso (sustancia no catalogada, pero que también se utiliza en la elaboración ilícita de permanganato de potasio en países de América del Sur), dicha remesa se las proporcionó la empresa R. Orts Simo S.A. de Aldaya (Valencia), ajena a estos hechos, así como 365 etiquetas y 144 bidones de plástico opaco con sus correspondientes precintos comprados a la empresa Reyde S.A, de Sant Boi de Llobregat (Barcelona) también ajena a estos hechos, para realizar el camuflaje encargaron a Miguel, hijo de José Ignacio, trasvasar 40 kilos de permanganato de potasio en bolsas de basura, a cada uno de los nuevos bidones (355) recibidos, completando el peso de 50 kilos por unidad con 10 kilos de dióxido de manganeso, y tras precintar cada bidón ponerle una nueva etiqueta referida a esta última sustancia, destruyendo las etiquetas originales del permanganato de potasio. STS (ROJ: 89/2003) del 16 de enero de 2003. D. Ponente: Luis Román Puerta Luis.

281 Precursores y productos químicos frecuentemente utilizados para la fabricación ilícita de estupefacientes y sustancias sicotrópicas. Informe de la Junta Internacional de Fiscalización de Estupefacientes correspondiente a 2001 sobre la aplicación del artículo 12 de la Convención de Naciones Unidas contra el Tráfico Ilícito de Estupefacientes y Sustancias Sicotrópicas de 1988. JUNTA INTERNACIONAL DE FISCALIZACIÓN DE ESTUPEFACIENTES. Ed. United Nations Publication. New York. 2002, p. 20.

282 Precursores y productos químicos frecuentemente utilizados..., correspondiente a 2002..., p. 19. Precursores y productos químicos frecuentemente utilizados..., correspondiente a 2003..., p. 26. Precursores y productos químicos frecuentemente utilizados..., correspondiente a $2011 \ldots$... pp. 31, 32. Para enfrentar el tráfico por internet de precursores de drogas y otros productos químicos que se utilizan en la elaboración de drogas ilícitas la Junta Internacional de Fiscalización de Estupefacientes elaboró en el año 2009 unas directrices, que deben adoptar las autoridades competentes nacionales, para prevenir la venta ilegal de estas sustancias por internet. Directrices dirigidas a los gobiernos para prevenir la venta ilegal por internet de sustancias sometidas a fiscalización internacional. Ed. Junta Internacional de Fiscalización de Estupefacientes. Nueva York. 2009, pp. 1-14. 
precursores químicos, ya que los narcotraficantes se dan a la tarea de infiltrar empleados de las empresas navieras, de transporte ${ }^{283}$, de la industria química o farmacéutica, así como funcionarios de aduanas, migración, patrullas fronterizas, agentes de policía y militares para asegurarse que las remesas de precursores circulen por los puertos internacionales, aeropuertos, aduanas y fronteras terrestres sin ningún percance. Además esta labor de infiltración les permite a los traficantes obtener información previa sobre actividades de los servicios de represión con respecto a determinadas remesas. Como ejemplo de ello citamos que en México, América Central y la mayoría de países de América del Sur los narcotraficantes han corrompido algunas instituciones públicas, que se han visto desbordadas por los recursos desplegados por estas organizaciones criminales 284 .

283 Precursores y productos químicos frecuentemente utilizados..., correspondiente a 2002..., p. 20. A través de una investigación realizada por The New York Times se supo que en Estados Unidos de América se esta llevando a cabo una limpia entre los funcionarios estadounidenses que vigilan los más de 3.000 kilómetros de frontera entre Estados Unidos y México. Según este medio de difusión masiva en los últimos tres años, cerca de 130 agentes de Migración y Aduanas, así como de la patrulla fronteriza han sido arrestados y acusados de vínculos con cárteles de la droga, de ellos 23 agentes de los cuerpos antes citados en los tres últimos meses del año 2011. http://www.elmundo.es/america/2011/10/ 25/mexico/1319571851.html. En América Central, en las zonas expuestas a la intensa actividad del narcotráfico se registran índices más elevado de homicidios. Además el narcotráfico ha corrompido a alguna de las instituciones públicas, desbordadas en varios casos ante los recursos desplegados por las organizaciones de traficantes. Informe de la Junta Internacional de Fiscalización de Estupefacientes correspondiente a 2012. Ed. Naciones Unidas. Nueva York. 2013, p. 61.

284 Informe de la Junta Internacional de Fiscalización de Estupefacientes correspondiente a 2012. Ed. Naciones Unidas. Nueva York. 2013, p. 61. "En todos los países del mundo los narcotraficantes corrompen a los funcionarios de las fuerzas del orden y del gobierno a todos los niveles para poder realizar sus actividades sin trabas". Informe de la Junta Internacional de Fiscalización de Estupefacientes correspondiente a 2013. Ed. Naciones Unidas. Nueva York. 2014, p. 4. En México era evidente, y buena medida lo sigue siendo, que utilizar a la policía como fuerza de choque contra el crimen organizado era imposible, pues no se trata de que este organismo estuviera infiltrado sino que una parte importante de esta institución trabajaba como fuerza de choque del crimen organizado. Avalando esta afirmación el propio presidente de México Felipe calderón Hinojosa declaró, tras una evaluación de la fiabilidad de los cuerpos de seguridad, que la mitad de los policías mexicanos eran "no recomendables". Además hay que recordar el elevado número de policías, fiscales, jueces o altos cargos del ejército que han sido destituidos en este país por su implicación con el narcotráfico. ALVAREZ GARCÍA, Francisco Javier. 
m) Los traficantes están utilizando cada vez más los preparados farmacéuticos para obtener los precursores que necesitan, no sólo de efedrina y seudoefedrina, necesarias para fabricar la anfetamina y la metanfetamina, sino también ergometrina, ergotamina y ácido lisérgico, para elaborar alucinógenos como la dietilamina del ácido lisérgico (LSD), para lo cual elaboran falsas declaraciones de expedición, declarando el contenido como "medicinas" utilizando nombres de marcas comerciales reconocidas 285 .

n) Los traficantes procuran cada vez más obtener otras formas de efedrina y seudoefedrina, en particular a través de productos naturales como la efedra o la sida cordifolia, así como también tratan de obtener ergotamina a través del cornezuelo de centeno ${ }^{286}$.

ñ) En vista de que en todo el mundo las autoridades competentes están sometiendo los pedidos de precursores a un creciente escrutinio, los traficantes han optado por hacer pedidos de preparados farmacéuticos que contienen efedrina o seudoefedrina a empresas legítimas, supuestamente para enviarlos a países en vías de desarrollo. Esto porque en muchos de estos países o territorios los controles sobre los preparados farmacéuticos son menos estrictos o simplemente no existen, lo

"La necesidad de un cambio de paradigmas en el tráfico de drogas: la urgencia de su legalización" en Cuadernos de Política Criminal. Año 2011. Número 105, pp. 215-220.

285 Precursores y productos químicos frecuentemente utilizados..., correspondiente a 2003..., p. 18, 20. Precursores y productos químicos frecuentemente utilizados..., correspondiente a 2007..., p. 18. Actualmente un porcentaje bastante considerable de los casos detectados de envíos sospechosos o desviaciones de efedrina o seudoefedrina corresponde a preparados farmacéuticos que contienen dichas sustancias. Hay que destacar que las rutas de desviación de esos precursores ha cambiado, y han aparecido numeroso países que intermedios que importan estas sustancias, las convierten en preparados para luego enviarlas a diversos lugares del continente americano. Precursores y productos químicos frecuentemente utilizados..., correspondiente a 2009..., p. XII. Informe de la Junta Internacional de Fiscalización de Estupefacientes correspondiente a 2012. Ed. Naciones Unidas. Nueva York. 2013, p. 87, 93, 94. Precursores y productos químicos frecuentemente utilizados..., correspondiente a 2013..., p. 19.

286 Precursores y productos químicos frecuentemente utilizados..., correspondiente a 2006..., p. 22. Precursores y productos químicos frecuentemente utilizados..., correspondiente a 2007..., p. 18. Precursores y productos químicos frecuentemente utilizados... correspondiente a $2009 \ldots$, p. 15. 
cual hace mas fácil a los traficantes introducir posteriormente las remesa de contrabando en América del Norte y otras regiones ${ }^{287}$.

o) Debido a la vigilancia cada vez más estricta de las sustancias catalogadas en los Cuadros I y II del Convenio de naciones Unidas de 1988, las organizaciones de narcotraficantes procuran, para la elaboración de drogas ilegales, obtener sustancias que no figuren en los cuadros, sustancias no catalogadas, incluso derivados elaborados especialmente en industrias químicas y farmacéuticas para sustraerse de los controles existentes ${ }^{288}$.

p) El uso de la modificación química o disimulación química para enmascarar las remesas de precursores. Las autoridades de los Países Bajos, en el mes de octubre del año 2008 descubrieron una cantidad de P-2-P que había sido químicamente modificada para que dejara de presentar las características físicas de un líquido aceitoso, casi incoloro, a fin de eludir las medidas de control. La sustancia identificada era un aditivo de bisulfito P-2-P o bisulfito BMK, que tiene el aspecto físico de un cristaloide sólido blanco húmedo. Este aditivo puede reconvertirse fácilmente para liberar P-2-P mediante la aplicación de productos químicos muy asequibles, sin que este procedimiento requiera conocimientos químicos especiales. Hay que se señalar que la aplicación de esta técnica también se ha aplicado al 3,4MDP-2-P que presenta semejanzas estructurales con el P-2-P. La modificación química o disimulación química de precursores usados para la fabricación de estimulantes de tipo anfetamínico ofrece ventajas potenciales a los traficantes que desean expedir sustancias catalogadas a diferentes países. Dado que además de la modificación radical de las características físicas de la sustancia, el precursor modificado puede eludir las medidas nacionales

Precursores y productos químicos frecuentemente utilizados..., correspondiente a 2007..., pp. 9, 18.

288 Ibidem., p. 18. Precursores y productos químicos frecuentemente utilizados..., correspondiente a 2009..., p. XI. Precursores y productos químicos frecuentemente utilizados..., correspondiente a $2011 \ldots$, pp. 32, 35. Global SMART Update, volumen 7, marzo 2012. Informe global de monitoreo de drogas sintéticas 2012. Ed. UNODC. 2012, pp. 4, 5. Informe de la Junta Internacional de Fiscalización de Estupefacientes correspondiente a 2012. Ed. Naciones Unidas. Nueva York. 2013, 75. Ibidem., p. 113. Informe de la Junta Internacional de Fiscalización de Estupefacientes correspondiente a 2013. Ed. Naciones Unidas. Nueva York. 2014, p. 107. Precursores y sustancias químicas frecuentemente utilizados..., correspondiente a $2014 \ldots$, p. 5. 
de control, dado que el bisulfito de P-2-P no se corresponde a las definiciones de las sustancias objeto de control en el Convenio de 1988, lo cual también ocurre con el 3,4-MDP-2-P glicidato de metilo ${ }^{289}$.

q) Reciclar los precursores de drogas y sustancias no catalogadas líquidas con el objetivo de evitar, en la medida de lo posible, la fabricación ilícita de precursores de drogas, asi como su desviación de los canales nacionales e internacionales, y también con la finalidad de reducir al mínimo los costes de producción de la producción ilícita de drogas 290.

289 Precursores y productos químicos frecuentemente utilizados..., correspondiente a 2009..., p. 16. Precursores y productos químicos frecuentemente utilizados..., correspondiente a $2010 \ldots$, p. 12. Global SMART Update, volumen 7, marzo 2012. Informe global de monitoreo de drogas sintéticas 2012. Ed. UNODC. 2012, pp. 2, 6.

290 Informe de la Junta Internacional de Fiscalización de Estupefacientes correspondiente a 2012. Ed. Naciones Unidas. Nueva York. 2013, p. 82. 

PENALIZACIÓN DEL DELITO

DE TRÁFICO DE PRECURSORES DE DROGAS 

CAPÍTULO IV

\section{BIEN JURÍDICO, DELITOS COLECTIVOS Y} TRÁFICO DE PRECURSORES

\section{FUNCIÓN DE EXCLUSIVA DE PROTECCIÓN DE BIENES JURÍDICOS}

\section{A.) INTRODUCCIÓN}

Para iniciar nuestro estudio sobre el tratamiento que entendemos se le debe dispensar en el ordenamiento jurídico penal español al tráfico de precursores de drogas tóxicas, estupefacientes y sustancias psicotrópicas (artículo 371 del Código Penal), asumimos que resulta verdaderamente imprescindible en primer lugar establecer qué es lo que protege este tipo penal, es decir, qué bien o bienes jurídicos se están tutelando. Esto en atención a que, como es aceptado por la doctrina mayoritaria, la ausencia de un bien jurídico protegido despoja a la norma penal de todo contenido material y por ende de toda legitimidad (nullum crimen sine iniuria) ${ }^{1}$, razón por la cual nos abocamos a continuación al estudio de esta importante categoría que en nuestra opinión, a pesar de sus inconcreciones, continua siendo un fundamento necesario para delimitar la intervención del Derecho Penal en la regulación de la convivencia humana.

Retrocediendo en el tiempo, queremos recordar que la determinación de los límites de intervención penal al legislador desde sus orígenes ha resultado un tema bastante complejo, situación que obviamente ha estado condicionada por los diferentes modelos de Estados que han exis-

DEMETRIO CRESPO, Eduardo, RODRÍGUEZ YAGÜE, Cristina. Curso de Derecho Penal. Parte General. Ediciones Experiencia, S. L. Barcelona. 2016, pp, 8-11. BUSTOS RAMÍREZ, Juan. Control Social y Sistema Penal. Ed. PPU. Barcelona. 1987, p. 196. FABIÁN CAPARRÓS, Eduardo Ángel. El Delito de Blanqueo de Capitales. Ed. Colex. Madrid. 1998, p. 165. "El bien jurídico sólo tiene sentido como concepto material; de otro modo se convierte en un mero instrumento interpretativo teleológico -que en definitiva carece de importancia propia- y queda imposibilitado a ser fundamento del ilícito penal". ROXIN, Claus. Derecho Penal. Parte General. Tomo I. Fundamentos. La Estructura de la Teoría del Delito. (Traducción de la segunda edición alemana por LUZÓN PEÑA, Diego Manuel y otros autores). Ed. Civitas. Madrid. 1997, pp. 51, 52. 
tido a lo largo de la historia (formaciones económicas sociales que ha experimentado la humanidad). Muchos años tuvieron que transcurrir para que se iniciara el necesario proceso de separación entre lo que debía considerarse inmoral y lo que debía entenderse delictivo, en definitiva, la correcta delimitación de lo que debe ser objeto de tutela a través del medio de intervención más grave de que dispone el Estado; el Derecho Penal que como todos sabemos es un medio imprescindible para posibilitar la vida en comunidad.

En este sentido es innegable en nuestra opinión la trascendencia que ha tenido, y tiene en la actualidad el bien jurídico, la cual se materializa en las diversas funciones que cumple, destacamos entre estas la función crítica (punto de convergencia entre la dogmática jurídico penal y la política criminal) como limite al ius puniendi del Estado, importancia que en los últimos años ha sido cuestionada por algunos penalistas defensores del funcionalismo sistémico, también conocido como funcionalismo radical, cuyo más relevante exponente en la actualidad es, sin lugar a dudas, el profesor Günther Jakobs².

Queremos señalar que este concepto tan ampliamente difundido (bien jurídico) que ha servido de columna vertebral del sistema penal, pre-

2 JAKOBS, Günther. Derecho Penal. Parte General. Fundamentos y Teoría de la Imputación. (Trad. CUELLO CONTRERAS, Joaquín. SERRANO GONZÁLEZ DE MURILLO, José Luis). Segunda edición. Marcial Pons. Madrid 1997, p. 45. Además de Jakobs en la doctrina alemana toman distancia de la teoría del bien jurídico; Michael Köhler, Amelung, Sratenwerth, Androulakis (el punto de partida reside en la pena y no en el concepto del bien jurídico) y Hirsch, quien afirma: "que la legitimación de la pena presupone el principio de proporcionalidad y, como partes de él, a los principios de subsidiaridad y ultima ratio". HIRSCH, Hans Joachim. "Acerca del estado actual de la discusión sobre el concepto de bien jurídico". (Trad. PASTOR, Daniel R.). Modernas tendencias en la ciencia del Derecho Penal y la Criminología. Ed. UNED. Madrid. 2001, pp, 371, 372, 376379. Hassemer en sentido opuesto señala: "que la teoría del bien jurídico se sitúa en una tradición de la formación teórica de las ciencias penales interesada en la legalidad del Derecho Penal, que persigue como objetivo la proporcionalidad de la pena", añadiendo que está tradición "relaciona la dogmática penal con la política criminal, y con el Derecho Penal Constitucional, y alcanza tanto al Derecho Penal material como al Derecho Penal formal". HASSEMER, Winfried. "Bienes jurídicos en el Derecho Penal" (Trad. ZIFFER, Patricia S.). BAIGÚN, David (et.al.). Estudios sobre Justicia Penal. Homenaje al Profesor Julio B. J. Maier. Ed. Editores del Puerto. Buenos Aires. 2005, p. 63. Planteando serias objeciones a Jakobs. ZAFFARONI, Raúl Eugenio. "El funcionalismo sistémico y sus perspectivas jurídico-penales". Estudios Penales en memoria del profesor Agustín Fernández Albor. Ed. Universidad Santiago de Compostela. 1989, pp. 760- 762. 
senta serios problemas de concreción, constituyendo uno de los problemas de la dogmática jurídico penal sobre el que más se ha escrito y menos claridad se ha logrado; por ello, es prioritario seguir trabajando en la concreción del contenido material del bien jurídico, necesidad que se ve reflejada claramente en la expansión penal que se ha producido en los últimos tiempos, lo cual se materializa en el constante incremento de tipos penales de dudosa legitimidad (tal es el caso de muchos delitos de peligro abstracto). Situación a la cual lamentablemente no ha escapado prácticamente ningún ordenamiento jurídico de nuestro entorno, lo que ha propiciado la creación en alguna medida, pues hay ocasiones en que está sobradamente justificado, del denominado Derecho Penal simbólico. Esta situación en nuestra opinión pone de relieve la importancia de acudir al principio de exclusiva protección de bienes jurídicos, así como a las exigencias que establecen los criterios de necesidad e idoneidad de pena ${ }^{3}$.

Es preciso decir que la falta del necesario establecimiento de límites a la actividad punitiva del Estado se remonta mucho tiempo atrás, cuando imperaba la ideología teológica del absolutismo que consideraba el delito como una ofensa a Dios, que se materializaba como una agresión al soberano (legítimo representante de Dios en la tierra), asimilándose el delito con el pecado, propiciando tal situación que se cometieran tremendas atrocidades al amparo de la ley (cacería de herejes, brujas, endemoniados y similares), como resultado de la confusión Estado- Religión. Hommel ${ }^{4}$, sobre este tema, manifestó que los delitos religiosos no tenían cabida en el sistema penal, afirmando que: "pecados, delitos y acciones irrespetuosas deben separarse unos de otros", advirtiendo de esta manera que los pecados que no le ocasionaran daños a la sociedad, no debían tener cabida en el Derecho Penal.

En España una rigurosa concordancia de la inmoralidad, o inconveniencia política con el delito, se puede observar en el Código de 1944, que en su exposición de motivos señalaba: "el Código de delitos y penas

3 ZODER, Isabel. La protección personal del nasciturus. Tesis Doctoral. Universidad de Salamanca. 1997, pp. 1, 2.

4 RUDOLPHI, Hans Joachim. "Los diferentes aspectos del concepto de bien jurídico". (Trad. BACIGALUPO ZAPATER, Enrique), en Nuevo Pensamiento Penal, año 4. Buenos Aires. 1975, pp. 333, 334. 
y la Ley de prisiones significan el amparo de la autoridad para el vivir pacifico de los españoles y la eficaz sanción de la ley para los que se aparten de las reglas de moralidad y rectitud, que son norma de toda sociedad iluminada en su marcha a través de los caminos de la historia por los reparadores principios del cristianismo y el sentido católico de la vida". Hay que señalar que la secularización y democratización del ordenamiento penal español se produjo a partir de $1977^{5}$. Una situación similar ocurre en Alemania, donde la plasmación de la concepción liberal del Derecho Penal tiene lugar con la reforma de 19696.

Es sin lugar a dudas con el influjo liberal, que se empiezan a asegurar condiciones mínimas para posibilitar el libre desarrollo de los ciudadanos frente al todopoderoso Estado. El delito ya no se concibe como una ofensa al orden divino, sino como una ofensa al orden social, de este modo la pena ya no constituirá la expiación del pecado realizado. A partir de la ideología de libertad del iluminismo, se realizaron grandes esfuerzos en aras de establecer el adecuado campo de intervención del Derecho Penal. Sin embargo resulta innegable que todavía hoy podemos encontrar residuos inequívocamente morales y religiosos a todas luces carentes de la requerida relevancia social en la mayoría de los ordenamientos jurídico penales del mundo, tal es el caso de la regulación de la cooperación al suicidio, la cooperación ejecutiva al suicidio y la eutanasia, preceptuadas en los apartados 2, 3 y 4 del artículo 143 del Código Penal Español vigente ${ }^{7}$ e el artículo 173 del Código Penal alemán que regula el incesto entre parientes 8 .

5 Afirmaba Marino Barbero que el Código de 1944 no acogió "in totum ninguna concepción científica". BARBERO SANTOS, Marino. "La reforma penal de la Monarquía constitucional española" en VVAA. Reforma política y Derecho. Ed. Centro de publicaciones del Ministerio de Justicia Madrid. 1985, p. 288.

6 ROXIN, Claus. ARZT, Günther. TIEDEMANN, Klaus. Introducción al Derecho Penal y al Derecho Procesal. (Trad. ARROYO ZAPATERO, Luis. GOMEZ COLOMER, Juan-Luis). Ed. Ariel. Barcelona. 1989, pp. 21, 22.

$7 \quad$ González Rus sostiene que la penalización de la eutanasia impone el respeto a la vida aún en "el caso de que su mantenimiento puramente temporal suponga una auténtica tortura", lo cual "va más allá del plausible propósito de proteger la vida", afirmando que semejante proceder sólo puede explicarse desde posiciones morales que a su juicio resultan contrarias a la Constitución. GONZALEZ RUS, Juan José. "Formas de homicidio II". COBO DEL ROSAL, Manuel (Dir.). Curso de Derecho Penal español. Parte especial I. Ed. Marcial Pons, Ediciones jurídicas y sociales. S.A. Madrid. 1996, pp. 99, 100. En opinión de Valle Muñiz la Constitución española no permite una interpretación del dere- 
Como todos sabemos la justicia perfecta nunca ha existido sobre la faz de la tierra. Así la humanidad ha llegado a sufrir sistemas tan brutales como el que se gestó en Alemania con el nacional socialismo al amparo de la tristemente célebre escuela de Kiel encabezada por Dahm y Schaffstein ${ }^{9}$. Ilustrando este acontecimiento histórico Fabián Caparrós afirma que: "El bien jurídico también desfiló triunfante en 1945 por las

cho a la vida incompatible con la dignidad humana, lo cual produce serias dudas sobre la existencia de un deber constitucional de proteger la vida contra la voluntad de su titular, y por ende de sancionar penalmente los comportamientos de ayuda (participación) "en un suicidio libremente deseado de forma expresa e inequívoca". Por lo que concluye, que la determinación político criminal de dotar de relevancia penal a las conductas de cooperación en el suicidio citadas anteriormente, no encuentra explicación en "la configuración constitucional del derecho de autodeterminación", por lo cual sostiene que el fundamento de tal punición tendrá que buscarse en otras fuentes más cercanas a la ética o a la religión. VALLE MUÑIZ, José Manuel. "Libro II: Titulo I". QUINTERO OLIVARES, Gonzalo (Dir.). MORALES PRATS, Fermín (Coord.). Comentarios a la Parte Especial del Derecho Penal. Ed. Aranzadi. Navarra. 2002, pp. 76- 93.

8 EIRANOVA ENCINAS, Emilio (Coord.). Código Penal Alemán StGB. Código Procesal Penal Alemán StPO. Ed. Marcial Pons. Madrid. 2000, p. 112. Para ilustrar el problema que se presenta citamos como ejemplo el caso de unos hermanos de parte de madre (Patrick S. De 28 años y Susan K. De 21 años), que tienen siete años de cohabitar y han procreado cuatro hijos, de los cuales dos presentan algún tipo de trastorno. Patrick fue condenado en el año 2001 a un año de prisión por tal situación, y en el año 2005 a dos años y medio de prisión por reincidir en sus relaciones incestuosas. A pesar de ello la pareja de hermanos sigue conviviendo en el mismo domicilio, y reivindicando su derecho a hacerlo. Este caso esta siendo analizado por el Tribunal Superior de Kalsruhe, siendo un tema de gran trascendencia tanto en el ámbito jurídico como social en toda Alemania. Ver resolución del 26 de febrero de 2008 del Tribunal Constitucional Federal alemán (BVefG) sobre la constitucionalidad del artículo 173.2 del Código Penal alemán, relativo al incesto entre hermanos.

$9 \quad$ Estos ilustres representantes de la Escuela de Kiel rechazaron en un primer momento la teoría del bien jurídico, pero a mediados de 1937 y 1938 lo aceptaron, después de que el neokantiano Schwinge y el nacional socialista Klee defendiesen la compatibilidad del bien jurídico con el nacional socialismo. MIR PUIG, Santiago. Introducción a las bases del Derecho Penal. Ed. Bosch. Barcelona. 1976, p. 131. POLAINO NAVARRETE, Miguel. El bien jurídico en el Derecho Penal. Ed. Publicaciones de la Universidad de Sevilla. 1974, pp. 164- 174. QUINTERO OLIVARES, Gonzalo. Parte General del Derecho Penal. Cuarta edición. Aranzadi/Thomson Rehuters. Navarra. 2010, pp. 72, 73. MIR PUIG, Santiago. Derecho Penal. Parte general. 9a edición. REPPERTOR. Barcelona. 2011, p. 120. 
calles de Berlín. Tras casi seis años a lo largo de los cuales la humanidad fue brutalmente agredida" 10 .

Nos parece muy importante señalar que no es correcto afirmar que existan delitos que se hallan castigado en todo tiempo y lugar por más grotescos que puedan resultar a la racionalidad actual o al sentido común que se estima debe poseer el frecuentemente citado hombre medio, pues como bien expresó Beccaria11: "cualquiera que leyere con mirada filosófica los códices de las naciones y sus anales, encontrará casi siempre cambiarse los nombres de vicio y de virtud, de buen ciudadano o de reo, con las revoluciones de los siglos". Además, debemos tener en cuenta que es evidente que no sólo el paso del tiempo incide directamente en la selección de los bienes o valores que deben ser objeto de protección penal, pues bastante demostrado está, que también influye de forma decisiva el factor cultural. Claro ejemplo de ello se manifiesta en el distinto tratamiento que se le daba al aborto hasta hace muy poco en países muy próximos geográficamente como sucede en el caso de España y Portugal ${ }^{12}$. Muñoz Conde al respecto, sostiene acertadamente que: "los valores que en cada época determinada el legislador somete a tutela penal, dependen no solamente de las necesidades sociales concretas, sino también, y quizás en primera línea, de las concepciones morales dominantes en la sociedad"13.

10 FABIÁN CAPARRÓS, Eduardo Ángel. El Delito de Blanqueo..., op. cit., , p. 168. González Rus también sostiene que el bien jurídico fue uno de los vencedores de la contienda bélica. GONZALEZ RUS, Juan José. Bien jurídico y Constitución. Ed. Fundación Juan March. Madrid. 1983, p. 20.

11 BECCARIA, Cesare. De los Delitos y las Penas, cit. por FERRAJOLI, Luigi. Derecho y razón. Teoría del garantismo penal (Trad. ANDRÉS IBAÑEZ, Perfecto y otros). Segunda edición. Trotta. Madrid. 1997, p. 462.

12 En Portugal a inicios del mes de febrero del año 2007 se realizó un referéndum sobre la despenalización del aborto (interrupción voluntaria del embarazo por decisión de la mujer durante las diez primeras semanas). El resultado del mismo fue del 56,4\% a favor del derecho de las mujeres a interrumpir el embarazo. Siguiendo el procedimiento establecido, el Parlamento portugués aprobó la Ley № 16/2007 de 17 de abril sobre la Exclusión de la ilicitud de los casos de interrupción voluntaria del embarazo. Se calcula que anualmente se realizaban unos veinte mil abortos ilegales en Portugal, y que una cantidad similar de portuguesas abortaron en España entre 1996 y 2007. http://www.elmundo.es/elmundo/elmundosalud/2007/02/09/mujer/1171047920.html. edición. Tirant lo Blanch. Valencia. 2015, pp. 63- 65. PORTILLA CONTRERAS, Guiller- 
Afortunadamente, en la actualidad podemos afirmar que la doctrina mayoritaria comparte los planteamientos que asumen que la misión del Derecho Penal es la protección de bienes jurídicos ${ }^{14}$ (principio de

mo. "La supuesta crisis de la teoría del bien jurídico: la tensión entre el iuspositivismo y positivismo, entre la necesidad de referencias externas y la inmanencia del Derecho. Especial atención a la legitimidad de ciertos bienes colectivos". OCTAVIO DE TOLEDO Y UBIETO, Emilio. GURDIEL SIERRA, Manuel. CORTÉS BECHIARELLI, Emilio (Coords.). Estudios penales en recuerdo del profesor Ruiz Antón. Ed. Tirant lo Blanch. Valencia. 2004, pp. 895, 896.

14 ABANTO VÁSQUEZ, Manuel A. "Acerca de la teoría de bienes jurídicos", en Revista Penal. Julio de 2006. № 18. La Ley, pp. 39- 41. BERDUGO GÓMEZ DE LA TORRE, Ignacio y otros. Curso de Derecho Penal Parte General. Ed. Experiencia. Barcelona. 2004, pp. 7-9. BUSTOS RAMÍREZ, Juan. Control Social..., op. cit., pp, 164- 167. CEREZO MIR, José. Curso de Derecho Penal español. Parte General. I. Introducción. Quinta edición. Tecnos. Zaragoza. 1996, p. 13- 15. DÍEZ RIPOLLÉS, José Luis. Derecho Penal español. Parte General. 4⿳亠口冖 edición. Tirant lo Blanch. Valencia. 2016, pp. 24-27. FABIÁN CAPARRÓS, Eduardo Ángel. El Delito de Blanqueo..., op. cit., , pp, 83, 84. GARCÍA-PABLOS DE MOLINA, Antonio. Introducción al Derecho Penal. Editorial Universitaria Ramón Areces. Madrid. 2005, pp. 176, 177. HASSEMER, Winfried. "Bienes jurídicos en el Derecho Penal" (Trad. ZIFFER, Patricia S.). BAIGÚN, David (Et.al.). Estudios sobre Justicia Penal. Homenaje al Profesor Julio B. J. Maier. Ed. Editores del Puerto. Buenos Aires. 2005, p. 67. JESCHECK, Hans-Heinrich. Tratado de Derecho Penal. Parte General. (Trad. MANZANARES SAMANIEGO, José Luis). Cuarta edición. Comares. Granada. 1993, pp. 1, 6, 42, 231. KARGL, Walter. "Protección de bienes jurídicos mediante protección del Derecho". (Trad. RAGUÉS i VALLÉS, Ramón). ROMEO CASABONA, Carlos María (Dir). La insostenible situación del Derecho Penal. Ed. Comares. Granada. 2000, p. 62. LUZÓN PEÑA, Diego Manuel. Curso de Derecho Penal. Parte General I. Editorial Universitas. S.A. Madrid. 1996, p. 82. MIR PUIG, Santiago. Derecho Penal P.G..., op. cit., pp. 119, 120. MUÑOZ CONDE, Francisco. Derecho Penal. Parte General..., op. cit., pp. 63-75, 88-93. NESTLER, Cornelius. "El principio de protección de bienes jurídicos y la punibilidad de la posesión de armas de fuego y de sustancias estupefacientes". (Trad. BENLLOCH PETIT, Guillermo). ROMEO CASABONA, Carlos María (Dir.). La insostenible situación del Derecho Penal. Ed. Comares. Granada. 2000, p. 63. QUINTERO OLIVARES, Gonzalo. Parte General..., op. cit., p. 6870. GRACIA MARTÍN, Luis. "Contribución al esclarecimiento de los fundamentos de legitimidad de la protección penal de los bienes jurídicos colectivos por el Estado Social y Democrático de Derecho" en HORMAZÁBAL MALARÉE (Coord.). Estudios de Derecho Penal en memoria del Profesor Juan José Bustos Ramírez. Ed. Ubijus. México DF. 2011, p. 142. ROXIN, Claus. Derecho Penal. P.G..., op. cit., p. 51. ROXIN, Claus. ARZT, Günther. SCHÜNEMANN, Bernd. "Sobre la dogmática y la política criminal del Derecho Penal del medio ambiente", en Temas actuales y permanentes del Derecho Penal después del milenio. Ed. Tecnos. Madrid. 2002, p. 204. TIEDEMANN, Klaus. Introducción al Derecho Penal y al Derecho Procesal. (Trad. ARROYO ZAPATERO, Luis. GOMEZ COLOMER, JuanLuis). Ed. Ariel. Barcelona. 1989, pp. 23, 24. VON HIRSCH, Andrew. "El concepto de bien jurídico y el principio del daño". (Trad. ALCÁCER GUIRAO, Rafael) en HEFENDEHL, Roland (Ed.). La teoría del bien jurídico. ¿Fundamento de legitimación del Derecho Penal o 
estricta protección de bienes jurídicos o protección subsidiaria de bienes jurídicos), en este sentido resultó muy significativo en su momento, que el proyecto alternativo alemán estableciera en su párrafo $2^{2}$ : "Las penas y las medidas sirven para la protección de bienes jurídicos", a pesar de que no fue incorporado lamentablemente a la legislación positiva de ese país. Sin embargo, legislaciones de reciente cuño, como la salvadoreña ${ }^{15}$ en su artículo $3^{\circ}$ regula: "no podrá imponerse pena o medida de seguridad alguna, si la acción u omisión no lesiona o pone en peligro efectivo un bien jurídico protegido por la ley penal". El Código Penal para el Distrito Federal de México en su artículo 4ํㅜ incluye también el principio de exclusiva protección de bienes jurídicos ${ }^{16}$. Similar redacción presenta el Código Penal de Nicaragua que en su artículo 7 preceptúa el principio de ofensividad, regulando que: "solo podrá ser sancionada la conducta que dañe o ponga en peligro de manera significativa un bien jurídico tutelado por la Ley penal"17. En igual dirección el Tribunal Supremo Español de forma reiterada (sentencias del 8 de febrero y 2 de marzo de 1983 entre otras), a puesto de manifiesto que: "el concepto de bien jurídico, es indispensable y consustancial para la noción del delito, en tanto en cuanto, sin la lesión o puesta en peligro de un bien jurídico, el juicio de antijuricidad carece totalmente de sentido"18, en el mismo sentido se ha pronunciado el Tribunal Constitucional Español${ }^{19}$.

juego de abalorios dogmático?. Ed. Marcial Pons, ediciones jurídicas y sociales, S.A. Madrid. Barcelona. 2007, p. 37. Estableciendo algunas similitudes entre la teoría del bien jurídico y el "harm principle" anglosajón. Idem. pp. 38- 52. DEMETRIO CRESPO, Eduardo. "Crítica al funcionalismo normativista" en Revista de Derecho Penal y Criminología. 3a Época, no 3 (2010), p. 18. GIL Y GIL, Alicia y otros autores. Curso de Derecho Penal. Parte General. Ed. Dykinson. Madrid. 2011, pp. 8, 9.

15 ASAMBLEA LEGISLATIVA. Código Penal y Ley Penitenciaria 1997. Ed. Asamblea Legislativa. San Salvador. 1997.

16 HORMAZÁBAL MALARÉE, Hernán. “Consecuencias político criminales y dogmáticas del principio de exclusiva protección de bienes jurídicos”. PÉREZ ALVAREZ, Fernando. Serta in memoriam Alexandri Baratta. Ed. Universidad de Salamanca. 2004, p. 1083.

17 Código Penal de Nicaragua aprobado en mayo del 2008.

18 STS (ROJ: 1516/1983) de 8 de febrero de 1983. Ponente: D. Juan Latour Brotons. STS (ROJ: 1154/1983) de 2 de Marzo de 1983. Ponente: D. Juan Latour Brotons. En España, el artículo 3.1 del borrador del Anteproyecto del Código Penal establecía: "La pena presupone la lesión o la puesta en peligro de bienes jurídicos". Sin embargo, no se incluyo en los proyectos posteriores, ni forma parte del Código Penal vigente. Señala además Mora- 
En otra dirección se ha pronunciado el Tribunal Constitucional Federal alemán (BVerfG) en una resolución publicada el día 26 de febrero de 2008 sobre la constitucionalidad del artículo 173.2, relativo al incesto entre hermanos, este tribunal ha establecido, tras el análisis de proporcionalidad que: "las normas penales, conforme a la Constitución, en relación a los fines perseguidos con ellas, no están sujetas a ningún requisito más estricto que vaya más allá de la propia Constitución. En particular, dichas normas no pueden derivarse de la teoría jurídicopenal del bien jurídico. Ni siquiera existe unidad ya sobre el propio concepto de bien jurídico. Si por bien jurídico se entiende, en el sentido de un concepto normativo de bien jurídico, lo que el legislador, tal y como se muestra en el derecho vigente, contempla como digno de protección jurídica, el concepto se reduce a expresar la ratio legis de la correspondiente norma penal; en este caso no se puede asumir una función rectora o de guía para el legislador. Por el contrario, si se quiere reconocer mediante una teoría naturalista del bien jurídico, como bienes jurídicos legítimos únicamente determinadas circunstancias previamente dadas de la vida social o, de otra manera, partir de un concepto suprapositivo del bien jurídico, este concepto entendido y aplicado como elemento del parámetro constitucional de revisión o supervisión-entra en contradicción con el hecho de que conforme al ordenamiento constitucional es competencia del legislador legitimado democráticamente, de la misma manera que fijar la pena, establecer también los bienes jurídicos a proteger con los medios del Derecho Penal y adaptar las normas penales a la evolución de la sociedad. Esta potestad no puede ser restringida apelando a bienes jurídicos supuestamente preexistentes o reconocidos por instancias diferentes al legislador, sino que su límite se halla en el ámbito del Derecho Penal, y en cualquier otro únicamente en la propia Constitución, siempre y cuando ésta excluya de antemano la persecución de un fin determinado. No se trata aquí de juzgar la contribución que el concepto de protección de bienes

les Valdés que en Italia hay quienes entienden que el principio de ofensividad esta regulado en los artículos 40 y 43 de su Código Penal, otro sector de la doctrina opina que este se encuentra en el artículo 49 de dicho texto. MORALES VALDES, Hugo. Bien jurídico, principio de ofensividad e idoneidad lesiva. Análisis crítico del concepto strict liability en el Derecho Ingles. Tesis Doctoral. Universidad de Salamanca. 2004, pp. 599- 606.

19 Vid., STC (105/1988) de 8 de junio de 1988. Ponente: D. Luis Díez-Picazo y Ponce de León, y STC (136/1999) de 20 de julio de 1999. Ponente: D. Carles Viver Pi-Sunyer. 
jurídicos pudiera aportar para la política jurídica y para la dogmática del Derecho Penal; en todo caso, dicho concepto no proporciona ningún criterio de contenido, que debiera obligatoriamente asumirse en el derecho Constitucional, cuya tarea consiste en fijar los límites máximos al poder de regulación del legislador". Es preciso señalar que Hassemer (ex vicepresidente del Tribunal Constitucional), adjuntó a la opinión mayoritaria de la Sala Segunda del Tribunal Constitucional un voto particular disidente ${ }^{20}$.

Sin embargo como ya señalamos anteriormente, que la exclusiva protección de bienes jurídicos sea la misión del Derecho Penal se ha cuestionado en los últimos años; en España a partir de los años setenta y ochenta y en Alemania resurgió la polémica en este sentido entre los años sesenta y setenta, siendo en la actualidad, el más relevante exponente de las críticas a la teoría del bien jurídico, el profesor de la escuela de Bonn Günther Jakobs. Sobre la posición de este profesor y quienes comparten sus planteamientos en torno al papel que debe desempeñar

20 Hassemer afirmó que el artículo 173.2, inciso 2 protege sólo concepciones morales existentes o supuestas, pero que para ese fin habría otros y mejores medios que el Derecho Penal, siendo la decisión sobre esta sentencia incompatible con el principio de proporcionalidad. Añadiendo que "dejar pasar una tipificación penal tan desafortunada bendice graves errores y omisiones del legislador y extiende excesivamente el campo de juego legislativo en el Derecho Penal a costa de la competencia de control del Tribunal Constitucional". Tal argumento responde a que para Hassemer sólo el principio de protección de bienes jurídicos en su formulación negativa se adaptaría fácilmente a la tradición constitucional de la prohibición del exceso. BOTTKE, Wifried. “¿Roma locuta causa finita? ¿Adiós a la exigencia de protección de los bienes jurídicos" en LUZÓN PEÑA, Diego Manuel (Dir.). Derecho Penal del Estados Social y Democrático de Derecho. Libro homenaje a Santiago Mir Puig. Ed. La Ley. Madrid. 2010 pp. 116- 118. Afirma Bottke que el Derecho penal no es el último recurso para el Tribunal Federal Alemán. No es subsidiario respecto a otros medios estatales, por tanto representa un mecanismo de protección que coexiste con otros. Únicamente depende del juicio y la apreciación del legislador penal sobre si es necesaria la aplicación del Derecho Penal. Lo que permanece es el juicio de proporcionalidad, los criterios inherentes al juicio de proporcionalidad, es decir, la idoneidad del medio para lograr el objetivo pretendido, de modo que la necesidad y la adecuación se interpretan con una generosidad tal, que el criterio del legislador penal apenas experimenta restricción alguna. La jurisprudencia constitucional se caracteriza, teniendo en cuenta la prohibición del exceso, por el mayor retraimiento o contención. Para ello es preciso que: a) la norma penal debe perseguir un fin admisible constitucionalmente, b) la norma penal tiene que ser adecuada para alcanzar el fin y c) la norma penal debe ser el medio menos gravoso. Si se dispone de otro medio igual de eficaz, pero menos restrictivo del bien jurídico, no será necesaria la norma penal. Ibidem, pp. 102- 105. 
el bien jurídico en la teoría del delito, más adelante realizaremos las observaciones que consideramos pertinentes ${ }^{21}$.

Queremos destacar en este momento que lamentablemente en la actualidad en el marco de lo que se conoce como Moderno Derecho Penal, se observa la tendencia de utilizar el principio de protección de bienes jurídicos como criterio positivo para justificar decisiones criminalizadoras, perdiendo por tanto el criterio negativo que tuvo originalmente. Así lo que clásicamente se formulo como "un concepto crítico para que el legislador se limitara a la protección de bienes jurídicos, se ha convertido ahora en una exigencia para que penalice determinadas conductas" 22 .

Sobre el establecimiento de qué bienes jurídicos merecen y necesitan de la intervención penal para su tutela, realizaremos algunas observaciones que estimamos fundamentales para el desarrollo de la presente investigación, ya que sería impensable analizar cualquier norma penal sin preguntarnos: ¿que son bienes jurídicos?, ¿como deben seleccionarse? y ¿que función cumplen estos en el sistema penal?. Advertimos que aunque este no es el objeto central de nuestra investigación, lo

21 Álvarez García advierte que la afirmación de que el principio de estricta protección de bienes jurídicos constituye un límite al ius puniendi puede llegar a convertirse en mera literatura, si no somos capaces de construir un concepto material del bien jurídico. ÁLVAREZ GARCÍA, Francisco Javier. "Bien jurídico y Constitución”, en Cuadernos de Política Criminal no 43. Ed. Edersa. Madrid. 1991, p. 5. Alfonso Cadavid, señala que la protección de bienes jurídicos es generalmente admitida por todos, desde que Von Liszt acogió y difundió ese concepto. CADAVID QUINTERO, Alfonso. Introducción a la Teoría del Delito. Ed. Biblioteca Jurídica Dike. Medellín. 1998, p. 110. "Sucederá también, que existirán delitos sin bien jurídico, incluso en el caso de que la norma de valoración se refiera inequívocamente a un objeto como referencia descriptiva de las conductas no deseadas. Quedará así desmentida la generalizada opinión de que todo delito supone la lesión o la puesta en peligro de un bien jurídico. Como puede apreciarse la definición material de bien jurídico genera un embrollo lingüístico nada desdeñable e incita a la confusión acerca de la condición jurídica de un objeto del que la misma se desea". LASCURAÍN SÁNCHEZ, Juan Antonio. "Bien jurídico y objeto protegible" en Anuario de Derecho Penal y Ciencias Penales, vol. LX. 2007, pp. 123, 124.

22 HASSEMER, Winfried. Persona, mundo, responsabilidad. Bases para una teoría de la imputación en el Derecho Penal. (Trad. MUÑOZ CONDE, Francisco. DIAZ PITA, María del Mar). Ed. Tirant lo Blanch. Valencia. 1999, pp. 47, 48. El principio de protección de bienes jurídicos actualmente se utiliza "como criterio para exigir la intervención del Derecho Penal o la anticipación y agravación de la misma". MENDOZA BUERGO, Blanca. El Derecho Penal..., op. ct. en la sociedad de riesgo. Ed. Civitas. Madrid. 2001, pp. 76, 77. 
consideramos indispensable para el desarrollo de la misma, por lo cual desde nuestras modestas posibilidades, procuraremos establecer el contenido material del bien jurídico penal. Desde este momento adelantamos que creemos condenado al fracaso aventurarse a obtener un catálogo de bienes que deban ser tutelados penalmente, labor que está de más decir, resultaría contraproducente, por lo cual somos partidarios de la idea de trabajar en el establecimiento de una serie de criterios que nos permitan determinar que condiciones y circunstancias de la vida deben constituir bienes jurídicos penales.

\section{Las funciones del bien jurídico penal}

Acerca de las funciones que desempeñan o mejor dicho deben desempeñar los bienes jurídicos penales, se puede afirmar que hay un consenso generalizado en la doctrina respecto a la función sistemática e interpretativa que deben cumplir dichos bienes. En cuanto a la función político criminal también conocida como función critica, podemos decir que su aceptación es respaldada por la doctrina mayoritaria. Existiendo como ya señalamos anteriormente, un sector (funcionalismo radical) que quiere negar dicha función, la cual es considerada por muchos autores como un punto intermedio entre la dogmática penal y la política criminal.

Con relación a la función sistemática que debe desplegar el bien jurídico penal se puede constatar fácilmente que tanto los Códigos Penales como las Leyes penales especiales casi siempre se encuentran organizados en atención a los bienes jurídicos que se tutelan, así se puede observar en la parte especial de los Códigos Penales grupos de delitos contra: la libertad, la vida, la salud pública o contra el medio ambiente entre otros; cuando la sistematización legal no es correcta o bien no es la más adecuada, se debe tomar como criterio sistematizador al bien jurídico $^{23}$. Es necesario aclarar, que aunque el bien jurídico cumple una función esencial en este sentido, no es el único criterio necesario para fundamentar la sistemática de los códigos penales, ya que deben tomarse en cuenta otros elementos como: la forma de ataque al objeto 
protegido, la estructura singular de los tipos penales o la gravedad de la infracción en otros ${ }^{24}$.

Otra importante función que desempeña el bien jurídico es la función interpretativa, la cual versa sobre la interpretación teleológica y valorativa. En esta dirección, el bien jurídico nos ayuda a establecer el sentido y la finalidad protectora de los diferentes tipos penales de forma tal que posibilita excluir la tipicidad de conductas que parecen adecuarse a la redacción literal del tipo pero que sin embargo no lesionan ni ponen en peligro el bien jurídico tutelado. Tómese como ejemplo de ello la interpretación jurisprudencial sobre el artículo 368 del Código Penal vigente, que determina que el bien jurídico protegido en este tipo penal es la salud pública. Así, aunque la donación de droga en principio es una forma de tráfico, a través de una interpretación restrictiva se puede considerar atípica aquella donación ocasional y para consumo personal de una pequeña cantidad de droga a una persona que de todos modos puede procurársela por otra vía. Además, esta categoría dogmática sirve como criterio de medición de la pena atendiendo al nivel de afectación al bien jurídico ${ }^{25}$.

Sobre la función crítica o de política criminal, sabemos que esta se produce antes de la labor dogmática de interpretación y sistematización del tipo del injusto, y que desempeña una importante función política criminal de límite y orientación del ius puniendi, reclamando la supresión de aquellos tipos penales que no tutelen verdaderos bienes jurídicos (delitos de mera desobediencia), y exigiendo la creación de nuevos tipos cuando existan bienes jurídicos que necesiten protección penal. Queremos señalar que sobre esta función se ha generado una importante discusión entre los principales exponentes de la dogmática jurídica penal en el transcurso de varias décadas, la cual algunos estudiosos del Derecho han tildado de infructuosa; no obstante en nuestra modesta opinión, entendemos que esta discusión ha retomado una importancia trascendental en la determinación del futuro del Derecho Penal, compartiendo en este sentido el criterio expresado por el profe-

GUERRERO AGRIPINO, Luis Felipe. La Delincuencia Organizada. Repercusiones en la Autoría y Participación. Problemas de Tipificación. Regulación en el Sistema Penal Mexicano. Tesis Doctoral. Universidad de Salamanca. 2000, p. 308. 
sor Muñoz Conde ${ }^{26}$, quien afirma "que con la pérdida de la teoría del bien jurídico podría perder la dogmática jurídico penal el último apoyo que le queda para la crítica del Derecho Penal positivo".

\section{La evolución histórica del bien jurídico en la teoría del delito}

A continuación procedemos a realizar un breve recorrido histórico de la evolución del bien jurídico, el cual estará desde luego, enfocado hacia aquellos aspectos que estimamos más relevantes, ya que no es el propósito de este trabajo extendernos en este sentido, sobre el cual existen excelentes obras de sobra conocidas por todos.

Iniciamos este apartado señalando que el concepto de bien jurídico aparece a inicios del siglo XIX bajo la influencia de la teoría del contrato social. Así, Von Feuerbach, tratando de dotar de un referente material a la norma penal, vincula al Derecho Penal con la tutela de los derechos subjetivos de los ciudadanos (teoría de los derechos subjetivos) ${ }^{27}$. Posteriormente Birnbaum (iusnaturalismo) cuestionó "la escasa consistencia de esta relación si el derecho subjetivo no se concretaba en algo material, un bien" (teoría del bien jurídico) incorporando la noción de

MUÑOZ CONDE, Francisco. Derecho Penal y Control Social. Ed. Fundación Universitaria. Jerez de la Frontera. 1985, p. 28. BUSTOS RAMÍREZ, Juan. HORMAZÁBAL MALARÉE, Hernán. Lecciones de Derecho Penal. P.G..., p. 75. Silva Sánchez en este sentido señala que no cabe asignarle a la idea del bien jurídico una trascendencia que no alcanza, pues es imposible controlar ninguna ley penal desde la perspectiva de una hipotética vulneración del principio de estricta protección de bienes jurídicos, lo cual sólo se puede lograr desde el principio de proporcionalidad. SILVA SÁNCHEZ, Jesús María. La expansión del Derecho Penal. Aspectos de la política criminal en las sociedades postindustriales. Segunda edición. Civitas. Madrid. 2001, pp. 114- 117.

FERNÁNDEZ, Gonzalo D. Bien jurídico..., op. cit., pp, 12- 14. Feuerbach al entender el delito como la lesión de derechos subjetivos, se vio obligado por ello, a probar en cada precepto penal la concurrencia de un derecho subjetivo del particular o del Estado como objeto de protección. JESCHECK, Hans-Heinrich: Tratado de Derecho Penal Parte General. (Trad. MAnZANARES SAMANIEGO, José Luis). Cuarta edición. Comares. Granada. 1993, pp. 231, 232. Para Feuerbach el objeto del Derecho Penal consistía en proteger los derechos del Estado y de sus súbditos, afirmando que la renuncia o bien la indisponibilidad del derecho subjetivo excluía el delito. Esta teoría (el derecho subjetivo como objeto de protección) fue dominante hasta inicios del siglo XX. MORALES VALDÉS, Hugo. Bien jurídico, principio de ofensividad e idoneidad lesiva. Análisis crítico del concepto de strict liability en Derecho Inglés. Tesis Doctoral. Salamanca 2005, pp, 7- 12. MIR PUIG, Santiago. Derecho Penal. PG..., op. cit., p. 120. 
bien jurídico dentro de las categorías fundamentales del Derecho Penal en el año $1834^{28}$, quien continuó expresándose en un sentido axiológico de "cualquier bien que debe de ser tutelado por el Estado, siempre que esa tutela general no pudiera ser realizada más que mediante la amenaza de una pena determinada" 29 . Este autor tuvo el mérito de ser el creador de la entonces nueva teoría del bien jurídico, entendiendo al bien jurídico no como un derecho, sino como un bien natural garantizado por el poder del Estado, asumiendo que de estos bienes podía ser portador tanto el individuo como la comunidad, y que estos son vulnerables en sentido naturalístico ${ }^{30}$.

De la noción de bien jurídico sostenida por Birnbaum se deriva su particular concepción del delito como "toda lesión o puesta en peligro de bienes atribuibles al querer humano....", señalando que dichos bienes "deben de ser garantizados de forma equivalente a todos por el poder estatal, en tanto que una garantía general no puede ser conseguida de otra forma que no sea por la conminación de una determinada pena y por la ejecución de la amenaza legal a todo infractor"31. De este autor se dice que verdaderamente estaba interesado en criminalizar los delitos contra la moral y la religión que Feuerbach había eliminado del Código Penal de Baviera de 1813, por ello algunos autores afirman que Birn-

28 BIRNBAUM. Über das Erfordernis einer Rechtsverletzung zum Begriff des Verbrechens usw., Neues Archiv des Criminalrechts 15, 1834, p, 149 y ss, cit por JESCHECK, HansHeinrich: Tratado de Derecho Penal Parte General. (Trad. MANZANARES SAMANIEGO, José Luis). Cuarta edición. Comares. Granada. 1993, p. 229. VELÁZQUEZ VELÁZQUEZ, Fernando. Derecho Penal. Parte General. Ed. Temis. Bogotá. 1997, pp. 43, 44

29 FERRAJOLI, Luigi. Derecho y razón..., op. cit., p. 468. MIR PUIG, Santiago. Derecho Penal. P.G..., op. cit., p. 120.

30 BIRNBAUM, "Neues Archiv des criminalrechts",15 (1834), p. 179, cit. por JESCHECK, Hans: Tratado de Derecho Penal Parte General. (Trad. MANZANARES SAMANIEGO, José Luis). Cuarta edición. Comares. Granada. 1993, p. 232. La idea de bien jurídico que formulo Birnbaum carece de capacidad para expresar lo realmente protegido por el Derecho Penal. HORMAZÁBAL MALARÉE, Hernán. Bien Jurídico...,op. cit, p. 9.

31 BIRNBAUM, “Neues Archiv des criminalrechts”,15 (1834), pp. 179 y ss, cit por HORMAZÁBAL MALARÉE, Hernán. Bien Jurídico y Estado Social y Democrático de Derecho (el objeto protegido por la norma penal). Ed. PPU. Barcelona. 1991, p. 28. 
baum con su teoría sobre los bienes jurídicos no intentaba reducir, sino ampliar la punibilidad 32 .

La elaboración teórica realizada por Birnbaum sobre el bien jurídico dio origen a dos corrientes fundamentales, antagónicas entre sí. La primera de ellas es la teoría formal de Binding y la segunda la teoría material de Von Liszt.

Desde una óptica positivista Karl Binding afirmó que el bien jurídico no viene a ser algo natural que vaya más allá del Derecho, sino que es sin más una creación del legislador. Desde su perspectiva, el bien jurídico carece de sentido fuera de la norma, por lo cual se le puede catalogar dentro de las corrientes inmanentes al sistema. Para este ilustre penalista alemán, lo fundamental en el delito era la infracción del deber de obediencia de los individuos frente al Estado; pero sin embargo mantuvo que lo que se lesiona con el delito no es la norma ni el derecho subjetivo público (obediencia al Estado), sino el bien jurídico, afirmando que toda norma contiene un bien jurídico y por lo tanto la desobediencia a cualquier norma comporta la lesión de ese bien jurídico. Como se puede apreciar, este autor representa en cierta manera la culminación del racionalismo heredado de la ilustración llevando el derecho positivo al límite, ya que lo determinante para él lo constituían los juicios de valor del legislador, los cuales garantizaban asegurar sin más la sana vida en común ${ }^{33}$. Definiendo los bienes jurídicos como: "todo lo que a los ojos de la ley, en tanto que condición de la vida sana de la comunidad jurídica es valioso para esta" 34 .

Es importante destacar que Binding atribuía al Derecho Penal una naturaleza básicamente sancionadora de normas preexistentes a la ley

FERNÁNDEZ, Gonzalo D. Bien jurídico..., op. cit., p. 81. HORMAZÁBAL MALARÉE, Hernán. Bien Jurídico..., op. cit., pp, 32, 33.

33 Binding afirmó que el Estado podía decidir a su arbitrio que quería sancionar y como quería hacerlo. HIRSCH, Hans Joachim. "Acerca del estado actual..., op. cit., p. 374. El derecho subjetivo al que se refiere Binding no es el mismo al que se refería Feuerbach, sino al que de acuerdo a la teoría política le asiste al Estado "de mandar y exigir obediencia". BINDING, Karl. Handbuch des Strafrechts, I, 1885, cit por HORMAZÁBAL MALARÉE, Hernán. Bien Jurídico..., op. cit., pp. 42, 43.

34 JAKOBS, Günther. Derecho Penal. P.G..., op. cit. , p. 50. POLAINO NAVARRETE, Miguel. "Protección de bienes jurídicos y confirmación de la vigencia de la norma: ¿dos funciones excluyentes?" en Cuadernos de Política Criminal. Año 2007. Núm. 93, p. 23. 
penal, por lo tanto la protección de bienes jurídicos resultaba equivalente a limitar al ordenamiento penal a sancionar los ataques a bienes reconocidos en otras ramas del ordenamiento jurídico, hecho que es tan discutible como la llana naturaleza sancionadora que le asignó al Derecho Penal 35 . Por lo tanto para él el bien jurídico carece de todo potencial limitador, desplegando únicamente algún efecto restrictivo en la medida en que, a través del pensamiento de protección de bienes, se configure el Derecho Penal desde una ética del resultado. Sosteniendo que de esta forma se podría eludir el riesgo de que el Derecho Penal, como moral codificada, venga a asegurar la vigencia de la norma ${ }^{36}$.

Resulta evidente que el papel que le corresponde al individuo en el sistema de Binding, estaba limitado a obedecer o pagar su desobediencia con una pena. En nuestra opinión posturas como estas pecan de una excesiva confianza en la bondad y sapiencia de los órganos de poder, siendo evidente que posiciones como las mantenidas por el autor en mención o próximas a las mismas pueden propiciar sin duda alguna el fortalecimiento ciego del poder político, independientemente de cual sea su naturaleza, ya que todo gira alrededor del Estado o del sistema, lo cual en nuestra opinión obliga a renunciar totalmente a la función crítica que a nuestro entender debe necesariamente desempeñar el bien jurídico penal ${ }^{37}$.

Frente a la posición anteriormente esbozada a todas luces conservadora y positivista de Binding, Von Liszt impregnado por el pensamiento liberal con el fin de limitar al omnipotente Estado, se dio a la tarea de establecer una determinación general del delito a través de la teoría del bien jurídico. Tomando como argumento central que el Derecho existe como resultado de la voluntad humana, aseguró que los fines del Derecho no podrían ser otros que la tutela de los intereses vitales de las personas, los cuales entendía como bienes jurídicos. De ello Afirmó

35 MIR PUIG, Santiago. "Bien jurídico y Bien jurídico-penal como límites del ius puniendi" en Estudios Penales y Criminológicos XIV. Santiago de Compostela. 1991, p. 206.

36 BUNZEL, Michael. SCHMIDT, Juana. STOLLE, Peer. "Primera sesión. Teoría del bien jurídico y harm principle". (Trad. ALCÁCER GUIRAO, Rafael). HEFENDEHL, Roland (Ed.). La teoría del bien jurídico. ¿Fundamento de legitimación del Derecho Penal o juego de abalorios dogmático? Ed. Marcial Pons, ediciones jurídicas y sociales, S.A. Madrid. Barcelona. 2007, 417, 418. 
que, cuando dichos bienes son reconocidos jurídicamente, no son creados por el legislador, sino que son el resultado de la vida y por lo tanto están previamente dados a él ${ }^{38}$. De esta manera, este gran penalista desarrolló la idea de que el sistema penal encuentra su legitimidad en los fines que persigue, que son la protección de los intereses esenciales para la vida en común, esto es, de los bienes jurídicos.

Compartimos plenamente con el profesor Luzón Peña la opinión de que con Von Liszt se inicia el desarrollo de una posición crítica y reformista que hoy goza de cómoda postura en la doctrina, basada en la afirmación de que los bienes jurídicos son preexistentes al reconocimiento jurídico que les concede el legislador, y que dichos bienes consisten en intereses o valores de gran importancia para los individuos o la sociedad que permiten su desarrollo, siendo esta importancia la que los hace merecedores de tutela penal. Sostiene además Luzón, que esta perspectiva permite fijar un límite al legislador posibilitando que la creación de los tipos penales se produzca sólo cuando se lesionen o se pongan en peligro bienes jurídicos concretos, bien sean estos personales o sociales ${ }^{39}$.

Continuando con este breve estudio del desarrollo histórico del bien jurídico, nos encontramos con los neokantianos ${ }^{40}$, que constituyeron la doctrina dominante a partir de los años veinte. Ellos abandonaron los postulados inmanentes al sistema, continuando de cierta forma el planteamiento de Von Liszt al remitir a una realidad externa al Derecho positivo; pero en lugar de recurrir al terreno social basaron su posición entorno al bien jurídico en el mundo espiritual subjetivo de los valores

38 Expresa Rudolphi que la posición de Von Liszt se aparta de la mantenida hasta entonces por los iluministas, en que su concepción obtiene el contenido material del delito de las circunstancias sociales concretas de la comunidad Estatal, y no de teoremas filosóficos jurídicos. RUDOLPHI, Hans Joachim. "Los diferentes aspectos del concepto de bien jurídico" en Nuevo Pensamiento Penal, año 4. Buenos Aires. 1975, p. 334.

39 LUZÓN PEÑA, Diego Manuel. Curso de Derecho Penal..., op. cit., p. 326. POLAINO NAVARRETE, Miguel. “Protección de bienes jurídicos..., op. cit., p. 23.

40 GIMBERNAT ORDEIG, Enrique. Concepto y método de la ciencia del Derecho Penal. Ed. Tecnos. Madrid. 1999, pp. 41- 43. Fue la corriente neokantiana de Escuela Sudoccidental Alemana la que se expresó específicamente en el campo del Derecho Penal. Entre los juristas que se sitúan en esta línea podemos mencionar a: Erich Scwinge, Gustav Radbruch, Max Ernst Mayer, Wilhelm Sauer y Edmund Mezger. HORMAZÁBAL MALARÉE, Hernán. Bien Jurídico..., op. cit. , p. 62. 
culturales $^{41}$, postura que obviamente resultó incapaz de servir de límite al legislador penal. Los neokantianos han sido objeto de fuertes críticas, pues para algunos autores éstos despojaron al bien jurídico de todo contenido real y concreto, lo cual entienden que abonó el camino para su perversión por los ideólogos del nacionalsocialismo ${ }^{42}$.

Como ya hemos referido anteriormente, la Escuela de Kiel encabezada por Dahm y Schaffstein, rechazaron en un primer momento al bien jurídico, pues lo juzgaban como un obstáculo para la realización de sus intereses. Pero posteriormente (1937 y 1938) lo aceptaron, después de que el neokantiano Schwinge y el nacional socialista Klee defendiesen la compatibilidad del bien jurídico con el nacional socialismo ${ }^{43}$ desnaturalizando totalmente su contenido. Así la lesión o puesta en peligro de bienes jurídicos se materializaba en la infidelidad y desobediencia de los individuos al Estado, y peor aún, frente a su jefe, despreciando de esta forma la importancia del comportamiento externo que mantuviera el individuo, pues bastaba su simple actitud. Se trataba en definitiva, de la infracción de un deber frente al pueblo, su Estado y su líder.

Otra experiencia de perversión del bien jurídico, se produjo con el tecnicismo formalista de derivación positivista que sirvió de base a la codificación fascista italiana en 1930, mediante la marginación del bien jurídico de la teoría del injusto a través de la implementación reduccionista en clave meramente interpretativa ${ }^{44}$.

Fue Hans Welzel quien se encargaría de revisar de forma crítica los aportes realizados por los neokantianos, llegando a concluir que la protec-

"Los neokantianos admiten (al menos por una rendija), que el fin de la norma no hace sino consagrar valores arraigados en el mundo social". FERNANDEZ, Gonzalo D. Bien jurídico..., op. cit., p. 28. MIR PUIG, Santiago. Introducción a las Bases..., op. cit., p. 130.

42 CARO CORIA, Dino Carlos. La Estabilidad del Ecosistema como Bien Jurídico Penal y su Protección mediante la Técnica de los Delitos de Peligro. Tesis Doctoral. Universidad de Salamanca. 1997, p. 170.

43 MIR PUIG, Santiago: Introducción a las Bases..., op. cit., p. 131. MIR PUIG, Santiago. Derecho Penal. P.G.., op. cit., p. 120. QUINTERO OLIVARES, Gonzalo. Parte General..., op. cit., pp. 72, 73.

44 MOCCIA, Sergio. "De la Tutela de Bienes a la tutela de Funciones: Entre ilusiones postmodernas y reflujos liberales”. (Trad. RAGUÉS VALLÉS, Ramón), en SILVA SÁNCHEZ, Jesús María (Ed.). Política Criminal y nuevo Derecho Penal. Libro homenaje a Claus Roxin. Ed. J. M. Bosch Editor. Barcelona. 1997, p. 117. 
ción de los bienes jurídicos se debía realizar mediante la punición de los desvalores de actos, asumiendo que al proteger los valores elementales de conciencia de carácter ético-social se protegen los bienes jurídicos, sosteniendo de esta manera que la misión primordial del Derecho Penal no lo constituía la protección de bienes jurídicos, sino la protección de los valores de actos éticos socialmente relevantes. Así, para él, la protección de los bienes jurídicos por el Derecho Penal esta mediatizada, manteniendo inclusive la idea de que no todas las normas penales protegen o deben proteger bienes jurídicos. Este profesor expresando sus reservas sobre el tema manifestó, la célebre afirmación, que "el bien jurídico se ha convertido en un auténtico Proteo, que en las propias manos que creen sujetarlo se transforma enseguida en algo distinto" 45 .

En nuestra opinión resulta innegable la aportación de Welzel en la revitalización de la discusión en torno al bien jurídico, siendo preciso destacar que cuestiona las posiciones espiritualizadoras del bien jurídico y vuelve a ubicarlo en el plano de la relación social ${ }^{46}$. Además, y aunque es cierto que afirmaba que el bien jurídico está determinado por la norma, también lo es, que sostenía que este encuentra su origen en la sociedad, es decir, que su conformación se realiza en una etapa pre jurídica, y aunque a Welzel se le reproche comúnmente la exclusión del bien jurídico como objeto de protección por el Derecho penal, es preci-

45 WELZEL. Studien zum System des Strafrechts, ZStW, 58, pp. 491- 509, cit. por JAKOBS, Günther. Derecho Penal. Parte General. Fundamentos y Teoría de la Imputación. (Trad. CUELLO CONTRERAS, Joaquín. SERRANO GONZÁLEZ DE MURILLO, José Luis). Segunda edición. Marcial Pons. Madrid 1997, pp. 47, 48. Cobo del Rosal y Vives Antón afirmaron que "el énfasis en torno a la función garantizadora de este concepto no debe exagerarse. Pues, en efecto, el muy distinto modo de entenderse el bien jurídico desde mediados del siglo XIX convierte la llamada función protectora en un postulado absolutamente equivoco y ambiguo. GARCIA- PABLOS DE MOLINA, Antonio. Introducción al estudio..., op. cit., pp. 568, 569. "Sin embargo Welzel considera incluida la protección de los bienes jurídicos concretos dentro de la prioritaria protección de los valores elementales de la actitud interna". ROXIN, Claus. Derecho Penal. P.G..., op. cit., p. 68. La idea de Welzel es que Derecho Penal promociona una ética colectiva. QUINTERO OLIVARES, Gonzalo. Parte General del Derecho Penal. Cuarta edición. Aranzadi/Thomson Rehuters. Navarra. 2010, p. 68. 
samente por él que se reaviva la discusión sobre la antijuricidad material como fundamento del desvalor de resultado 47 .

Posteriormente se han desarrollado dos corrientes sobre el fundamento que debe tener el bien jurídico. En la primera de estas ubicamos a los autores que suscriben las teorías del bien jurídico con fundamento sociológico o funcionalistas, entre estos destacamos por su importancia a Amelung, Hassemer, Callies, Jakobs y Mir Puig. En la segunda corriente encontramos a los autores que abogan por dotar de un fundamento constitucional al bien jurídico entre ellos, encontramos a Bricola, Sax, Musco, Pulitano, Fiandiaca, Angioni y González Rus. Además, es importante señalar que hay penalistas muy relevantes que por las posiciones que sostienen se pueden clasificar en ambas corrientes; como ejemplo de ello citamos a Roxin y Rudolphi en la doctrina alemana ${ }^{48}$.

Concluimos este apartado afirmando que a pesar de que los contornos del bien jurídico no están aún bien determinados, esta categoría "se ha asegurado desde hace tiempo un puesto firme en el arsenal conceptual del Derecho Penal" afirmación que tuvo plena validez hasta inicios de los años setenta (prácticamente existia unanimidad sobre el tema), ya que posteriormente, la teoría del bien jurídico se ha cuestionado por algunos representantes de la teoría del funcionalismo sistémico (de Amelung a Jakobs) quienes sostienen que la misión del Derecho Penal es el aseguramiento de la vigencia de la norma, sin otra referencia material legitimadora que la defensa del sistema social ${ }^{49}$. Afortunadamente estas posturas no gozan de gran aceptación en la doctrina penal, prevaleciendo en la actualidad la opinión mayoritaria de asumir que la misión del Derecho Penal es la protección de bienes jurídicos (acep-

Hormazábal, afirma que son válidas las críticas que se le realizan a Welzel en lo que se refiere a la mediatización del bien jurídico por la protección de valores de acto y de hecho, entendiendo que su definición de bien jurídico, no deja de ser una definición formal, que no expresa lo que es el bien jurídico en sentido material. Ibidem., pp. 87, 88.

48 Rudolphi desde una posición sociológica funcionalista afirma que una norma penal únicamente estará justificada cuando "sea necesaria para la protección y seguridad de las condiciones de vida de una sociedad, estructurada sobre la base de la libertad de la persona y, al mismo tiempo, entendida por todos como razonable". FERNÁNDEZ, Gonzalo D. Bien jurídico..., op. cit., p. 63. HORMAZÁBAL MALARÉE, Hernán. Bien Jurídico..., op. cit. , pp, 93- 138.

49 HORMAZÁBAL MALARÉE, Hernán. Bien Jurídico..., op. cit, p. 7. 
tando la función crítica) en el entendido de estos bienes como las condiciones esenciales que las personas consideradas tanto individual, como colectivamente necesitan para su autorrealización y el desarrollo de su personalidad en la vida social, los cuales para que sean considerados bienes jurídico penales deben cumplir con los criterios de merecimiento, necesidad e idoneidad de pena.

\section{B.) ANÁLISIS DEL FUNCIONALISMO SISTÉMICO}

Como es sabido hasta la primera mitad del siglo XX el poder Estatal, y por ende el Derecho Penal sustentaban su legitimidad a través de filosofía o de la teoría política europea. Sin embargo una vez finalizada la Segunda Guerra Mundial, y posiblemente como consecuencia de la supremacía de los Estados Unidos de América en el mundo, la sociología empieza a tomar este lugar, concretamente dentro de esta ciencia, la corriente denominada "funcionalismo", que aunque tiene su origen en el positivismo, la antropología y el economismo europeo, "con carta de ciudadanía norteamericana pasa a constituirse en la teoría social predominante en la sociología occidental" ${ }^{20}$.

La teoría funcionalista encuentra su origen en Durkheim (La división del trabajo social, 1893), en el desarrollo de la misma sus más destacados representantes son Parson y Merton. De la versión alemana del funcionalismo hay que destacar sin lugar a dudas a Luhmann ${ }^{51}$, que con los autores anteriormente citados son los referentes para su recepción

Ibidem., p. 95.

51 La teoría de los sistemas de Luhmann no es, ni procura serlo, una concepción normativista de la sociedad, de la que pueda extraerse un criterio legitimador del orden social. El funcionalismo se presenta como un método de análisis sociológico, que describe de forma objetiva el ser de la sociedad moderna, sin brindar pautas valorativas con potencial crítico y promotoras de un cambio de la realidad social, por lo cual "su concepción del Derecho se limita a identificar la función social del sistema jurídico y su modo de operar", por lo cual se puede concluir que el funcionalismo no sirve como criterio de legitimación del Derecho. SOTO NAVARRO, Susana. La protección penal de los bienes jurídicos colectivos en la sociedad moderna. Ed. Comares. Granada. 2003, pp. 22, 23. SOTO NAVARRO, Susana. "Concreción y lesión de los bienes jurídicos colectivos. El ejemplo de los delitos ambientales y urbanísticos" en Anuario de Derecho Penal y Ciencias Penales. Vol. LVII. 2005, pp. 891, 892. Luhmann entiende que la sociedad se compone de comunicaciones y no de sujetos. DEMETRIO CRESPO, Eduardo. "Crítica al funcionalismo..., op. cit., pp. 16, 17. 
por el Derecho alemán. De Durkheim hasta Luhmann el funcionalismo o teoría sistémica entienden la sociedad como un sistema total donde cada uno de sus aspectos no puede ser comprendido si no es en referencia al sistema total, "el sistema consiste en una pluralidad de actores individuales que interactúan en una determinada situación motivados por recíprocas expectativas. Lo fundamental en el sistema es la interdependencia de los diversos factores, de tal forma que no puede afirmarse que uno de ellos determine la producción de un fenómeno", siendo el factor de cohesión "la presencia de un código moral y un sistema de valores compartidos por los actores sociales" 52 .

\section{El funcionalismo sistémico de Amelung a Jakobs}

Para ilustrar un poco la posición mantenida por los defensores del denominado funcionalismo sistémico, funcionalismo normativista ${ }^{53}$ o radical (también conocido como funcionalismo extremo) en torno al bien jurídico, nos permitimos exponer de forma muy breve la posición desarrollada por Amelung, que es quien introduce el análisis sistémico en el Derecho Penal en un intento de "hacer accesible el examen empírico y con ello posibilitar el contacto entre las ciencias sociales empíricas y dogmáticas". Este célebre penalista alemán sobre el tema en cuestión afirmo que: "el contenido del bien jurídico está condicionado por lo que es socialmente dañoso"..., señalando que entran dentro de tal categoría "los acontecimientos disfuncionales, los fenómenos sociales que impiden o dificultan al sistema social la superación de los problemas que obstaculizan su progreso"..., así "el delito es sólo un caso especial del

52 La concepción funcionalista de la sociedad, considera al hombre, aun cuando valora la acción humana para la consecución de ciertos fines, como un ser completamente social, que únicamente la sociedad llena de contenido. Por lo cual los objetivos del hombre son los objetivos de la sociedad, quedando el individuo mediatizado y postergado por el sistema que pasa a ser lo fundamental. HORMAZÁBAL MALARÉE, Hernán. Bien Jurídico..., op. cit., pp. 97, 98.

53 Por funcionalismo cabe entender orientaciones de la dogmática jurídico-penal que pretenden construir las categorías del sistema a partir de los fines del Derecho Penal. Es preciso distinguir dos tipos de funcionalismo: a) el funcionalismo de carácter sistémico de Jakobs y b) el funcionalismo puramente político-criminal de Roxin, que busca "la acomodación de Derecho Penal a ciertos fines y principios político-criminalmente asentados en la Constitución propia del Estado de Derecho". DEMETRIO CRESPO, Eduardo. “Crítica al funcionalismo..., op. cit., pp. 14, 15. 
fenómeno disfuncional"..., "a un sistema de acciones e interacciones que se mantiene por sí mismo, que sobrevive al periodo de vida de un individuo y que se completa por la reproducción biológica y donde se asume la socialización de las eventuales nuevas generaciones". Este autor en aras de armonizar el principio liberal de protección de las personas con el mantenimiento del sistema, llega a afirmar: "que la lesión de una persona es dañina socialmente, pues ningún sistema de interacciones puede existir sin personas", aseverando en consecuencia, que los bienes jurídicos son las condiciones de existencia de la vida social ${ }^{54}$.

El profesor Berdugo, en nuestra opinión acertadamente, sostiene que pretender determinar desde una perspectiva funcionalista el campo de intervención del Derecho Penal, tomando como criterio la disfuncionalidad de las conductas frente al sistema, deja sin resolver un problema clave, común a toda la sociología funcionalista que sólo puede ser resuelto mediante la introducción de elementos externos al mismo, pues al afirmar la funcionalidad o disfuncionalidad de un comportamiento con relación a un sistema, no se está efectuando ninguna valoración sobre la naturaleza de este último, lo cual representa la renuncia al eje liberal de la teoría del bien jurídico y su procedencia del individuo ${ }^{55}$,

54 HORMAZÁBAL MALARÉE, Hernán. Bien Jurídico..., op. cit, pp. 110, 111. Amelung reconocía que aunque el análisis sistémico permite fijar un contenido objetivable del concepto de dañosidad social, no puede decirse nada concluyente sobre las normas concretas que deben institucionalizarse. Señalando que la dañosidad social es un concepto relativo, pues el análisis funcionalista puede ayudar a racionalizar las decisiones políticas, pero no ofrece criterios de legitimación. SOTO NAVARRO, Susana. La protección penal..., op. cit., p. 70.

55 BERDUGO GÓMEZ DE LA TORRE, Ignacio. Reflexiones sobre la problemática..., op. cit., p. 6. En el mismo sentido. HORMAZÁBAL MALARÉE, Hernán. “Consecuencias político criminales y dogmáticas del principio de exclusiva protección de bienes jurídicos". PÉREZ ÁLVAREZ, Fernando (Editor). Serta in memoriam Alexandri Baratta. Ed. Universidad de Salamanca. 2004, pp. 1083-1086. NEUMANN, Ulfrid. "Alternativas: Ninguna. Sobre la crítica más reciente a la teoría personal del bien jurídico" en Cuadernos de Política Criminal. Año 2007. Núm. 93, pp. 9, 10. Jakobs ha ido destruyendo el edificio sistemático de la teoría del delito en sus bases mismas mediante el formalismo de las categorías y la utilización de conceptos vagos e imprecisos que carecen de capacidad de subsunción. Lo cual se aprecia en la distinción entre injusto y culpabilidad, pues siendo lo decisivo el quebrantamiento y vigencia de la norma, la culpabilidad termina convirtiéndose en presupuesto de la acción, además de no considerar el hecho real de la lesión de un bien jurídico, sino solo su relevancia comunicativa para la vigencia del Derecho en la sociedad. DEMETRIO CRESPO, Eduardo. "Crítica al funcionalismo...", op. cit., pp. 15-18. 
idea que no es viable si se suscribe, como lo hacen en nuestros países la doctrina mayoritaria, un sistema social personalista de orientación por tanto, hacia el individuo ${ }^{56}$.

Nosotros compartimos plenamente la idea de que asumir una perspectiva exclusivamente funcionalista como la propuesta por Amelung y posteriormente secundada con algunas matizaciones por Jakobs entre otros autores, anula de hecho la eficacia limitadora del concepto de bien jurídico, ya que inclusive la protección de valores estrictamente morales (como estrategia política), puede resultar funcional en una determinada sociedad, o si de forma contraria, determinadas conductas inmorales resultaran disfuncionales al sistema, desde esta concepción, habría que dar por sentado que su criminalización estaría legitimada sin más, por lo que entendemos que la opción propuesta por Amelung no resulta viable ni aún en los sistemas democráticos más consolidados. Sostenemos esta posición por la posibilidad real de perversión de los mismos y de más está decir, que en las democracias formales o en vía de desarrollo, donde la desigualdad material entre los individuos es verdaderamente desmesurada y por ende no existe un consenso ni siquiera aceptable de los ciudadanos en la necesidad de mantener el sistema existente, resulta totalmente incoherente defender este tipo de planteamientos ${ }^{57}$.

Kindhäuser, quien sostiene una posición "moderada" frente al desarrollo actual del sistema penal, señala que la teoría de la prevención general positiva que defiende la estabilización de las normas mediante el

56 MIR PUIG, Santiago. "Límites del normativismo en el Derecho Penal". MIR PUIG, Santiago (Dir.). Derecho Penal del siglo XXI. Ed. Consejo General del Poder Judicial. Madrid. 2008, pp. 57, 58, 63, 64. MUÑOZ CONDE, Francisco. Derecho Penal. P. G..., op. cit., p. 61.

57 Bustos, objeta a Jakobs que desde su perspectiva funcionalista sistémica entiende que el bien jurídico es la validez y eficacia de la norma, y por ende lo que se lesiona o se pone en peligro es la vigencia de la norma, lo cual debe entenderse como un retorno al positivismo jurídico de Binding, que niega totalmente la teoría del bien jurídico. BUSTOS RAMÍREZ, Juan. Manual de Derecho Penal. Parte General. Ed. Ariel. Barcelona. 1989, p. 47. BUSTOS RAMÍREZ, Juan. HORMAZÁBAL MALARÉE, Hernan. Lecciones de Derecho Penal. P.G.., op. cit., pp. 75- 77. SILVA SÁNCHEZ, Jesús María. Aproximación al Derecho Penal Contemporáneo. Ed. J. M. Bosch Editor. Barcelona. 1992, p. 269. QUINTERO OLIVARES, Gonzalo. Parte General..., op. cit., p. 277. Ambos conceptos, norma y bien jurídico, no tienen por qué ser incompatibles, sino todo lo contrario: ambos se exigen mutuamente, de manera que la norma es la forma y el bien jurídico su contenido. POLAINO NAVARRETE, Miguel. “Protección de bienes jurídicos..., op. cit., pp. 26-36. 
ejercicio de la fidelidad al derecho "se ajusta como anillo al dedo al Derecho Penal de la seguridad. Añadiendo que en este último, se ha originado, entre otras transformaciones, un claro distanciamiento de los fines de la pena ${ }^{58}$. En opinión de Schünemann, Jakobs en su empeño por ofrecer una construcción dogmática libre de toda reminiscencia ontologista, incurre "en una versión normativista intransigente, radical y contradictoria" 59 .

En todo caso opinamos que la alusión exclusiva a la disfuncionalidad social como criterio para determinar la incriminación de una conducta, "encierra el peligro, de raíz totalitaria, de atender a las necesidades del conjunto social olvidando al individuo", así como de propiciar una concepción estática del concepto de bien jurídico ${ }^{60}$. De ahí que con sobrada razón se reivindique que la teoría del bien jurídico en el marco del Estado Social y Democrático de Derecho, somete a un análisis crítico el objeto protegido por la norma penal, que además de identificar lo que protege dicha norma, verifica la necesidad de protección de dicho objeto constituyendo este carácter dinámico del bien jurídico "la fuente del permanente proceso de incriminación y desincriminación a que está expuesto el Derecho Penal"61. Atendiendo lo expresado hasta aquí consideramos que no resulta adecuado tomar como referencia directa de la antijuricidad material a la dañosidad social, ya que la primera crítica que puede y debe formularse a quienes asumen esta postura, es precisamente que el bien jurídico es perfectamente apto para incorporar la referencia social, por lo cual no tiene sentido prescindir de él.

Consideramos importante destacar que el funcionalismo o teoría sistémica, ha suministrado el marco teórico para una nueva fundamentación del Derecho Penal; la teoría de la prevención positiva. La expre-

MENDOZA BUERGO, Blanca. El Derecho Penal..., op. cit., p. 53.

60 Silva señala que la idea de dañosidad social está marcada por su finalidad coyuntural, pues los conceptos sociológicos de bien jurídico tienen como leit motiv la separación de la moral y el Derecho, pero no específicamente jurídico penal, por lo cual no se preocupan en resolver qué grado de dañosidad social se precisa para que la lesión o puesta en peligro de un bien jurídico tenga relevancia penal. SILVA SÁNCHEZ, Jesús María. Aproximación al Derecho..., op. cit., p. 269.

61 BUSTOS RAMÍREZ, Juan, HORMAZÁBAL MALARÉE, Hernán. Lecciones de Derecho Penal Vol. II. Ed. Trotta. Madrid. 1999, p. 27. 
sión más completa de esta teoría se encuentra en la obra del profesor Jakobs, para quien, el Derecho Penal se legitima formalmente mediante la aprobación conforme a la Constitución de las leyes penales, y encuentra su legitimación material en su necesidad para el mantenimiento de la forma de la sociedad y el Estado, afirmando además que el sistema penal no posee en sus normas ningún contenido genuino, pues dichos contenidos se rigen por el contexto de regulación ${ }^{62}$. Desde esta perspectiva, el papel del Derecho Penal consiste únicamente en asegurar el cumplimiento de las normas garantizando que las expectativas imprescindibles para el buen funcionamiento de la vida social en la forma establecida legalmente no se pierdan en caso de que resulten defraudadas, por lo que este profesor propone que: "se debe definir como bien a proteger la firmeza de las expectativas normativas esenciales, frente a la decepción, firmeza"..., "que tiene el mismo ámbito que la vigencia de la norma puesta en práctica", ha dicho bien, lo denomina bien jurídico penal63.

Como vemos, este autor no propone eliminar del lenguaje jurídico la expresión bien jurídico penal, sino que rechaza la concepción que la doctrina mayoritaria mantiene del mismo, afirmando que es incorrecto considerar que el núcleo de todos los delitos sea la lesión de un bien jurídico, ya que el núcleo de todos los delitos en su opinión lo constituye el incumplimiento de un deber64. Esta posición nos parece bastante

SOTO NAVARO, Susana. La protección penal..., op. cit., p. 23.

63 Jakobs entiende que al contexto de regulación pertenecen, tanto las realidades de la vida social, como las normas entre éstas principalmente las constitucionales. JAKOBS, Günther. Derecho Penal..., op. cit., pp. 44, 45. PARMA. Carlos. El pensamiento de Günther Jakobs. El Derecho Penal del siglo XXI. Ed. Cuyo. Segunda reimpresión. Mendoza. 2004, pp. $145-152$.

64 Jakobs asume que el delito es una comunicación defectuosa, así el Derecho Penal restablece en el plano de la comunicación la norma perturbada, y con ello piensa que se representa la identidad de la norma no modificada de la sociedad. JAKOBS, Günther. Derecho Penal...., op. cit., p. 53. Señala que el adelantamiento de la barrera punitiva es favorecido por el principio de protección de bienes jurídicos. JAKOBS, Günther. Bases para una teoría funcional del Derecho Penal. (Trad. CANCIO MELIA, Manuel. FEIJOO SANCHEZ, Bernardo. PEÑARANDA RAMOS, Enrique. SANCINETTI, Marcelo. SUAREZ GOZALEZ, Carlos). Ed. Palestra Editores. Lima. 2000, pp. 211, 212. En la misma dirección se pronuncia Müssig (discípulo de Jakobs). MENDOZA BUERGO, Blanca. El Derecho Penal..., op. cit., pp. 138- 140. "La denominación de bien jurídico debe de reservarse así para referirse a lo protegido por una norma”. LASCURAÍN SÁNCHEZ, Juan Antonio. 
desafortunada, dado que considerar estrictamente el delito, como la infracción de la norma prescindiendo del bien jurídico, conduce inequívocamente a fundamentar el injusto exclusivamente en el desvalor de acto, así la norma impone deberes a todos y cada uno de los miembros de la sociedad y al infringir éstas, se realiza un acto de desobediencia que lesiona "un discutible derecho del Estado de exigir obediencia a las personas"65. Avanzando un poco más en sus objeciones a la teoría de bien jurídico Jakobs afirma que esta favorece las anticipaciones de la punibilidad, dado que este principio induce a creer en la legitimación de todo aquello que puede ser puesto en una relación positiva con el concepto de bien jurídico, así sostiene que "tomar como exclusivo punto de partida el bien jurídico conduce sin duda al desbordamiento, por que ello cae por completo fuera de la perspectiva del autor" 66.

En la misma línea de ideas el profesor Jakobs ${ }^{67}$, expone que la finalidad de las penas no es la reparación de bienes, sino la confirmación normativa de la sociedad, por lo que el Derecho Penal no debe reaccionar frente a un hecho en cuanto lesión o puesta en peligro de un bien jurídico, "sino sólo frente a un hecho en cuanto quebrantamiento de una

"Bien jurídico y objeto protegible" en Anuario de Derecho Penal y Ciencias Penales, vol. LX. 2007, pp. 123, 124, 126, 127, 132.

65 Por tal razón, la realización típica debe constituir un desvalor determinado por el bien jurídico protegido por la norma, debiendo considerar también la antijuridicidad, ya que el contenido material de esta última categoría viene también dado por el bien jurídico, el cual vincula a la realización típica con el resto del ordenamiento jurídico y además permite su valoración por éste. BUSTOS RAMÍREZ, Juan, HORMAZÁBAL MALARÉE, Hernán. Lecciones de Derecho Penal Vol. II. Ed. Trotta. Madrid. 1999, p. 36. ESER, ALBIN. "Consideraciones finales". ESER, Albin. HASSEMER, Winfried. BURKHARDT, Björn. (Coordinadores de la versión alemana). HEFENDEHL, Roland. "El bien jurídico: imperfecto, pero sin alternativa”. (Trad. MARTÍN LORENZO, María), en GARCÍA VALDÉS, Carlos, MARTÍNEZ ESCAMILLA, Margarita, ALCÁCER GUIRAO, Rafael, VALLE MARISCAL DE GANTE, Margarita (Coord.). Estudios Penales en homenaje a Enrique Gimbernat. Tomo I. EDISOFER. Madrid. 2008, pp. 393, 394. MUÑOZ CONDE, Francisco. GARCÍA ARÁN, Mercedes. Derecho Penal. Parte General. 9a edición. Tirant lo Blanch. Valencia. 2015, p. 65.

66 JAKOBS, Günther. Estudios de Derecho Penal. (Trad. PEÑARANDA RAMOS, Enrique). Ed. Civitas. Madrid. 1997, pp. 294, 295.

67 JAKOBS, Günther. Sociedad, norma y persona en una teoría de un Derecho penal Funcional. (Trad. CANCIO MELIÁ, Manuel. FEIJóo SÁNCHEZ, Bernardo). Ed. Civitas. Madrid. 1996, pp. 11, 12. 
norma", quebrantamiento "que no es un suceso natural entre seres humanos, sino un proceso de comunicación, de expresión de sentido entre personas", entendiendo para realizar tal afirmación a la sociedad como un sistema de comunicación normativa. Como se puede apreciar este profesor se encuentra distante a toda noción material, pues parte de una concepción radicalmente funcionalista del Derecho Penal que lo conduce a adoptar una perspectiva semejante a la del positivismo jurídico propuesto por Binding 68 .

Roxin sostiene que Jakobs en sus presupuestos sistemáticos y teóricos no contempla ningún contenido ni orientación político criminal, pues lo decisivo para él es "la fuerza de la autoconservación del sistema", señalando el profesor de München que esto no le parece acertado, pues en su opinión debe procurarse convertir las premisas de un Estado Liberal y Social de Derecho en categorías dogmáticas y en soluciones de problemas jurídicos, dado que "quien sólo sabe que una sociedad está organizada funcionalmente, no sabe nada sobre su concreta configuración". Por esta razón, la teoría sistémica como fundamento del sistema penal, resulta árida en cuanto al contenido; Sin embargo Roxin entiende que esto no debe de expresarse de "la dogmática real" de Jakobs, pues él no pretende explicar el Derecho Penal sobre las premisas de cualquier sistema sino "de la mano de los objetivos de la legislación alemana de nuestro tiempo"69. Sobre este tema Silva Sánchez afirma que los procesos de criminalización son de competencia exclusiva de "la política jurídica", por lo cual no puede calificarse la idea del bien jurídico defendida por Jakobs de reaccionaria ni conservadora ${ }^{70}$.

Nosotros somos de la opinión de que un Derecho Penal neutral, capaz de servir a cualquier modelo de sociedad, fundamentado en la "comunicación personal" presenta serios inconvenientes, pues son presu-

CARO CORIA, Dino Carlos. Derecho Penal del Ambiente..., op. cit., pp. 17, 18.

69 A pesar de los señalamientos que se le hacen al profesor Jakobs, Roxin considera incorrecto señalar como estériles las aportaciones que este realiza en su tratado de Derecho Penal, que contiene "gran número de propuestas originales, inteligentes y fructíferas". ROXIN, Claus. La evolución de la política Criminal, el Derecho penal y el proceso penal. (Trad. GÓMEZ RIVERO, Carmen. GARCÍA CANTIZANO, María del Carmen). Ed. Tirant lo Blanch alternativa. Valencia 2000, pp. 53, 54, 67.

70 SILVA SÁNCHEZ, Jesús María. La expansión del Derecho..., op. cit., pp. 114- 123. NEUMANN, Ulfrid. “Alternativas: Ninguna..., op. cit, pp. 9, 10. 
puestos axiológicos para el establecimiento de la comunicación "la igualdad y la libertad", presupuestos que el modelo funcional es aparentemente incapaz de cumplir, ya que "la simple funcionalidad cuando no persigue la igualdad y la libertad, no puede garantizar una sociedad en donde la comunicación personal sea una aspiración seria". Como vemos, Jakobs plantea una propuesta que no puede proporcionarse los medios necesarios para la consecución de los fines que persigue, ya que un sistema penal neutro imposibilita la comunicación entre los individuos, siendo necesario además destacar que la pura estabilización de la norma le es tan útil a una sociedad de individuos libres como a una carente de libertad ${ }^{71}$. Así el entendimiento del bien jurídico como la vigencia de la norma, y el delito como la defraudación de las expectativas sociales contenidas en la norma, sólo posibilita establecer un límite formal al legislador, el cual consideramos insuficiente para determinar el marco de protección penal, pues paradójicamente en este caso la materia a controlar crearía el medio de control $^{72}$, lo que obviamente deja vacío de contenido tanto al bien jurídico como a la norma penal, transformándolos, si se nos permite la metáfora en un cheque en blanco al portador, que puede ser utilizado por ideologías o políticas de cualquier signo ${ }^{73}$.

Acertadamente señala Muñoz Conde ${ }^{74}$ que con la aceptación de la posición del funcionalismo sistémico de entender que la misión del Derecho Penal es asegurar sobre todas las cosas, la vigencia de la norma sin otra referencia material legitimadora que la defensa del sistema social, significaría la negación de la teoría del bien jurídico con lo cual perdería "la ciencia del Derecho Penal el último apoyo que le queda para la crítica del Derecho Penal positivo". En la misma dirección Octavio de

71 CARO CORIA, Dino Carlos. La Estabilidad del Ecosistema..., op. cit., pp. 188- 190.

72 CADAVID QUINTERO, Alfonso. Introducción a la Teoría..., op. cit., pp. 116, 117.

73 CARO CORIA, Dino Carlos. La Estabilidad del Ecosistema como Bien Jurídico Penal y su Protección mediante la Técnica de los Delitos de Peligro. Tesis Doctoral. Universidad de Salamanca. 1997, p. 191.

74 Se le critica al funcionalismo sistémico que lleva al positivismo jurídico hasta el extremo, donde el Derecho es un dato que no puede ser cuestionado. MUÑOZ CONDE, Francisco. Derecho Penal y Control Social. Ed. Fundación Universitaria de Jerez. 1985, pp. 27, 28. BUSTOS RAMÍREZ, Juan. HORMAZÁBAL MALARÉE, Hernán. Lecciones de Derecho Penal. P.G...,op. cit., pp. 75- 77. HEFENDEHL, Roland. “El bien jurídico..., op. cit, pp. 393, 394. 
Toledo y Ubieto 75 objeta a los partidarios del funcionalismo sistémico, que el Estado y los grupos que detentan el poder con mucho gusto castigarían aquellos comportamientos que resulten disfuncionales "para el sistema de producción y distribución que les permita seguir manteniendo aquella posición hegemónica". De igual manera se resistirían a sancionar aquellas conductas que les resultan funcionales, lo que evidentemente no constituye un verdadero límite al ius puniendi estatal, pudiendo, además, propiciar un peligroso y antidemocrático inmovilismo social76. Por esto consideramos, que no se debe olvidar nunca que el sistema social es un sistema de relaciones entre personas, y por lo tanto, las normas de conducta son una consecuencia especifica de dichas relaciones y no algo ajeno a ellas, resultando por tal razón inaceptable la postura sostenida por los partidarios del funcionalismo sistémico de subordinar a las personas en aras del buen funcionamiento y supervivencia del sistema ${ }^{77}$.

Parece que el profesor Jakobs se basa para fundamentar su posición en torno al bien jurídico, en una sociedad ideal donde la igualdad material es una realidad y por ende, todos los ciudadanos aceptan de forma unánime su rol, lo cual nos resulta un tanto utópico y peligroso por el exceso de confianza que deposita en la bondad del Estado. Con esto, no queremos afirmar que Jakobs quiera con sus posiciones posibilitar o favorecer el mantenimiento de regímenes de corte totalitario y antidemocrático, pero estimamos que la aplicación de este tipo de posturas, posibilita el sometimiento del individuo en aras de la conservación de tan majestuoso sistema. Pero como lamentablemente no se trata del Derecho Penal de una sociedad deseable, sino de aquel ordenamiento penal que es producto del sistema jurídico, nosotros no somos partidarios de un modelo penal coherente y sistemático, pero con la tendencia a divorciar la dogmática de la política criminal, ya que pensamos que

75 OCTAVIO DE TOLEDO Y UBIETO, Emilio. “Función y límites..., op. cit., pp. 9, 21.

76 CADAVID QUINTERO, Alfonso. Introducción a la Teoría.., op. cit., p. 117. En el mismo sentido GARCÍA-PABLOS DE MOLINA, Antonio. Introducción al Derecho..., op. cit., pp. 718, 719. ZAFFARONI, Raúl Eugenio. "El funcionalismo sistémico y sus respectivas jurídico- penales”. Estudios penales en memoria del profesor Agustín Fernández- Albor. Ed. Universidad de Santiago de Compostela. 1989, p. 756.

77 HORMAZÁBAL MALARÉE, Hernán. Bien Jurídico..., op. cit, p. 145. ZAFFARONI, Raúl Eugenio. "El funcionalismo sistémico..., op. cit., p.759- 762. 
en algunas ocasiones esta última recomienda el distanciamiento de los puros resultados dogmáticos para permitir resultados materialmente justos aunque asistemáticos, por lo que abogamos por un Derecho Penal que reivindique la indispensable vinculación entre la dogmática y el mundo axiológico ${ }^{78}$.

Continuando con la crítica a la teoría del bien jurídico, Jakobs ${ }^{79}$ afirma que los bienes reconocidos por el Derecho Penal no gozan de protección absoluta, pues inclusive a veces se sacrifican bienes para posibilitar el contacto social sosteniendo que los bienes jurídicos adquieren relevancia en la medida en que desempeñan una función. También recoge en su crítica que los bienes señalados pueden resultar menoscabados mediante sucesos naturales, así, como por actividades que aunque intervengan personas, los mismos no sean evitables, afirmando que el Derecho Penal no debe proteger dichos bienes en todo caso. Nosotros obviamente, asumimos que estos señalamientos son acertados, pero no introducen ningún elemento que contradiga la teoría del bien jurídico que compartimos, ya que al realizar la afirmación de que la protección de bienes jurídicos es la misión del Derecho Penal (doctrina mayoritaria), no se afirma que dicha protección sea absoluta, pues es comúnmente entendido que la tutela de bienes o intereses está condicionada por la aplicación de los principios de fragmentariedad y de subsidiaridad, de tal forma que sólo serán dignos de protección aque-

CARO CORIA, Dino Carlos. La Estabilidad del Ecosistema..., op. cit., pp. 187, 188. La profesora Corcoy BIDÁSOLO, en defensa de Jakobs señala que si se trata de un Estado democrático, las normas se aprueban por los representantes libremente elegidos por el pueblo, por lo que en todo caso los cuestionamientos deberían dirigirse al Estado. Preguntado además, que si aceptamos las reglas de un Estado democrático, si se pueden calificar de injustas las normas dictadas por los representantes libremente electos. CORCOY BIDÁSOLO, Mirentxu. Delitos de Peligro y Protección de Bienes jurídico-penales supra-individuales. Nuevas Formas de Delincuencia y reinterpretación de Tipos penales clásicos. Ed. Tirant lo Blanch. Valencia. 1999, pp. 178, 179.

79 JAKOBS, Günther. Derecho Penal. P.G...,op. cit., pp. 45, 56. Nos parece preciso puntualizar en este momento, que desde hace mucho tiempo la doctrina mayoritaria ha propugnado la exigencia de un comportamiento humano para legitimar la intervención del ordenamiento jurídico penal, el cual al tenor de la legislación penal española, debe ser necesariamente doloso o imprudente (artículo 5 del Código Penal español), ya que como es por todos conocido, ni la dogmática jurídico-penal, ni la teoría del bien jurídico pretende de ninguna manera tutelar a través de la legislación penal bienes de desastres naturales o del simple deterioro que puedan sufrir con el paso del tiempo, pues evidentemente, no tendría ningún sentido. 
llos bienes esenciales que posibiliten el desarrollo del individuo en la sociedad, pero además únicamente serán objeto de tutela las modalidades de ataque más graves a dichos bienes.

Nosotros pensamos que la dogmática penal además de dotar de un instrumento útil al legislador para el desempeño de sus funciones, debe establecer límites al mismo, pues es una realidad prácticamente innegable que en algunas ocasiones priman intereses partidarios o inclusive personales en la formulación de las normas jurídicas, por lo que debe ser tarea cotidiana del penalista tratar de evitar desde sus modestas posibilidades que se pervierta tan importante labor, como es la de diseñar las reglas indispensables para garantizar las posibilidades de participación del individuo en la sociedad, por lo que no podemos renunciar desde ningún punto de vista al principio de estricta protección de bienes jurídicos.

Para concluir este apartado queremos manifestar que estimamos fundamentada la posibilidad de desempeño de la función crítica o de política criminal del bien jurídico por la existencia de puntos de coincidencia muy importantes sobre aquellas realidades que no deben considerarse bienes jurídico penales, por lo que pensamos que el grado de indeterminación alrededor del concepto de bien jurídico no constituye una barrera insalvable para no otorgarle al mismo un papel fundamental en la estructura del hecho punible; lo que es posible por el mínimo de condiciones positivas que le son reconocidas por la doctrina ${ }^{80}$. Queremos recordar que tanto Hasssemer como Ferrajoli han puesto de relieve en este sentido que la capacidad de rendimiento del concepto de bien jurídico radica más bien en su carácter negativo que nos posibilita determinar que no debe asumirse como un bien jurídico y por ende, no debe ser objeto de tutela penal81. Por todo lo expuesto hasta aquí, conBLOS DE MOLINA, Antonio. Introducción al estudio..., op. cit., p. 573.

81 "En realidad no puede nunca alcanzarse una definición exclusiva y exhaustiva de la noción de bien jurídico. Lo que significa que una teoría del bien jurídico no puede casi nunca decirnos positivamente- y además no serviría de nada que nos lo dijera- que una determinada proposición penal es justa en cuanto protege un determinado bien jurídico. Puede ofrecernos únicamente una serie de criterios negativos de deslegitimación"..., "Pero, por otra parte, esto es todo lo que se pide a la categoría del bien jurídico, cuya función de límite o garantía consiste precisamente en el hecho de que la lesión de un bien debe ser condición necesaria, aunque nunca suficiente, para justificar su prohibi- 
sideramos que pese a los problemas de concreción que padece el bien jurídico, puede y debe cumplir su función de límite al ius puniendi Estatal, asumiendo que esta no es una respuesta completa, pues señala solamente condiciones necesarias, pero no suficientes para la criminalización de una conducta ${ }^{82}$.

\section{Algunas reflexiones sobre la dañosidad social}

Iniciamos este apartado recordando que la idea de la dañosidad social surge con la finalidad de responder esencialmente a la elaboración de un concepto de bien jurídico que sirviera de base teórica al movimiento despenalizador que se estaba produciendo a partir de los años sesenta en Alemania, y de los años setenta en España, originándose así los conceptos sociológicos funcionalistas de bien jurídico que consideran necesario entender los bienes jurídicos en su dimensión social como las condiciones necesarias para la conservación de un orden social. Por ello, la característica común de los hechos lesivos de bienes jurídicos debía ser la dañosidad social. Es preciso señalar que se les reconoce a estas corrientes la recuperación de la noción de bien jurídico del mundo abstracto y su incorporación en la esfera de la realidad social ${ }^{83}$. Sin embargo se les cuestiona que adoptan una perspectiva meramente funcionalista que imposibilita la función limitadora que se pretende, ya que la tutela de valores estrictamente morales o de intereses eminentemente políticos pueden estimarse funcionales en una sociedad determinada, dado que la exclusiva referencia a la disfuncionalidad social entraña el peligro de atender a las necesidades del conjunto social en detrimento del individuo. Otra objeción que se realiza a quienes sostienen estas posturas es que expresan una concepción estática del bien jurídico ${ }^{84}$, porque pueden ser tildadas como tesis conservadoras, así,

ción y punición como delito". FERRAJOLI, Luigi. Derecho y razón..., op. cit., p. 471. La "protección de bienes jurídicos es, desde sus inicios, un principio negativo". HASSEMER, Winfried. "Bienes jurídicos..., op. cit., p. 69- 71. 
Terradillos señala que si la regla político criminal es "suprimir lo disfuncional y potenciar lo funcional, lo que se hace es consolidar sin límite la situación presente" 85 .

También es necesario destacar, como se afirmó anteriormente, que la noción de dañosidad social se encuentra marcada por su finalidad coyuntural, que consistía precisamente en excluir del ámbito penal, lo estrictamente inmoral, dado que los conceptos sociológicos de bien jurídico "tienen como let motiv la separación de Moral y Derecho (en general); así, construyen ciertamente una teoría de las condiciones positivamente valoradas que merecen protección jurídica (a partir del criterio de dañosidad social) pero no específicamente jurídico penal", por lo que no resolvieron el nivel de dañosidad social requerido para que la lesión o puesta en peligro de un bien jurídico alcanzara relevancia penal ${ }^{86}$.

El profesor Gómez Benítez cuestiona las teorías que él denomina espiritualistas sobre la sistemática del bien jurídico penal, pues entiende que en cada época histórica, en cada ámbito cultural, se estaría reflejando una criminalización selectiva de lo anticultural, de tal forma que el hecho penal, es desde esa perspectiva, una realidad normativa condicionada por la cultura, lo cual considera erróneo, ya que desde su punto de vista debería buscarse la materialidad del delito en su asocialidad (la cual debe deducirse directamente de la puesta en relación del hecho con el funcionamiento del sistema social). De esta manera, para él la lesión o puesta en peligro de los bienes jurídico-penales es la lesión o la posibilidad de afectar un bien social, sin que medien valoraciones ajenas al significado exclusivamente social del Derecho Penal. Asumiendo por lo tanto que el Estado únicamente estará legitimado para prohibir conductas socialmente dañosas, constituyendo esta la única vía para establecer un límite al ius puniendi; ya que el marco de actuación

85 TERRADILLOS BASOCO, Juan. "La satisfacción de necesidades como criterio de determinación del objeto de tutela jurídico penal", en Revista de la Facultad de Derecho de la Universidad Complutense de Madrid. 1981, p. 135.

SILVA SÁNCHEZ, Jesús María. Aproximación al Derecho..., op. cit., pp. 269, 270. Amelung dado que la dañosidad social en concreto, para cada sociedad, es un concepto relativo, recurre a dos premisas normativas (que no pertenecen al funcionalismo); 1) una norma penal únicamente "es legítima si contribuye al mantenimiento del sistema social concreto (en su caso, la República Federal alemana)" y 2) "la estructura de este sistema social debe estar legitimada por la Constitución". SOTO NAVARRO, Susana. La protección penal..., op. cit., p. 70. 
del Estado se limitará a intervenir sólo cuando exista un perjuicio social y no cuando dicho perjuicio sea moral, cultural o ético. Analizando los criterios para el establecimiento de lo que es perjudicial socialmente (dañosidad social), establece que el primer criterio a tomar en cuenta debe ser el principio de irrelevancia o insignificancia de la acción desde el punto de vista de su perjuicio social; el segundo criterio a su entender, está dado en las normas generales de la solución social de conflictos que son las causas de justificación (ausencia de las causas de justificación en el supuesto de hecho), otro elemento importante para determinar el perjuicio social es la inclusión de los componentes subjetivos del desvalor de la acción en el tipo. Este penalista define el perjuicio social de la siguiente forma: "perjudicial socialmente es aquello que es preciso prevenir de cara al colectivo social mediante el instrumento penal, como condición del funcionamiento del sistema social; y sólo es necesario prevenir cuando se pueda motivar al colectivo social. La prohibición va dirigida pues a la colectividad", concluyendo de esta forma que la dañosidad social es la disfuncionalidad del sistema ${ }^{87}$.

Esta posición, nosotros la compartimos parcialmente, en cuanto consideramos que conductas carentes de relevancia social, no deben estar dentro del campo de acción del Derecho Penal, así como que no pueden tener cabida dentro del ordenamiento penal los valores morales imperantes en una sociedad, por más extendidos que estén, sino revisten dañosidad social. Sin embargo, discrepamos de estos planteamientos de Gómez Benítez en cuanto a la protección predominante que entiende debe otorgar el Derecho Penal al sistema social, pues mediatiza la

87 Gómez Benítez considera que la cuestión central será buscar el acomodo del concepto de bien jurídico en tal teoría sobre la disfuncionalidad social. Piénsese, en efecto, que la pretensión que estamos analizando se centra en la definición e investigación del bien jurídico como concepto de contenido social. No pretende, pues, renunciar a la definición de la función del Derecho Penal como protección de bienes jurídicos, sino complementar tal función como protección del funcionamiento de los sistemas sociales; protección frente a perjuicios sociales y no frente a desvalores morales, espirituales o culturales. En este contexto, los concretos bienes jurídicos han de ser la concreción de los elementos de funcionalidad aludidos; así podrá decirse que la protección de esa funcionalidad se realiza a través de la protección de bienes jurídicos". GÓMEZ BENÍTEZ, José Manuel. “Sobre la Teoría del Bien Jurídico (aproximación al ilícito penal)” en Revista de la Facultad de Derecho de la Universidad Complutense de Madrid № 69. Madrid. 1983, pp. 105, 106. Idem. Estudios Penales. Ed. Colex. Madrid. 2001, pp. 16- 31. 
tutela que entendemos se le debe dispensar al individuo ${ }^{88}$, por lo que nos adherimos plenamente a la idea que sostiene que un ordenamiento penal que no protege víctimas, sino funciones, convierte el injusto penal en un ilícito de simple transgresión, lo cual no varía aunque se sustituya el concepto de función por el sustancialmente equivalente de bien social ${ }^{89}$.

Moccia, reflexionando acerca de la dañosidad social, estima la misma como condición indispensable para que la sociedad apruebe la incriminación de una conducta por parte del Estado, sosteniendo que obviar la dañosidad social, es decir, tener como correcta la incriminación de conductas muy lejanas a la lesión o puesta en peligro de bienes jurídicos, nos llevaría a castigar de forma simple la infracción de normas organizativas y no la realización de conductas socialmente dañosas, lo que no es más que sacrificar garantías fundamentales en aras de garantizar la funcionalidad de los mecanismos de intervención del Estado, de lo cual deben esperarse consecuencias negativas que nos pueden conducir a transformar el injusto penal en un ilícito de mera transgresión que en realidad, no cambia tampoco si el concepto de función se sustituye por el sustancialmente equivalente de bien social. Afirma además este profesor italiano que para la adaptación del Derecho Penal a fenómenos nuevos impregnados de dañosidad social, no debe optarse por una adecuación de los principios a las exigencias de control, sino al revés, por lo que reivindica la función de garantía del bien jurídico ${ }^{90}$.

Sobre este tema se pronuncia Álvarez García, señalando que existen imprecisiones muy importantes para poder definir lo que es socialmente dañoso, lo cual opina no consigue Gómez Benítez, quien se remite a peticiones de principios como la insignificancia de la acción desde el ángulo del perjuicio social con lo que incluye lo definido en la defini-

Cadavid, expresa que para Gómez Benítez la funcionalidad social no se corresponde con la protección de intereses individuales, pues para él la protección de bienes jurídicos es en todo caso, la protección del sistema social. CADAVID QUINTERO, Alfonso. Introducción a la Teoría..., op. cit., p. 124.

El profesor Moccia, sostiene que puede constatarse una mayor sensibilidad de los nuevos fenómenos criminales por parte de los ciudadanos, en problemas tales como; medio ambiente, la gestión global de los sistemas productivos, el sistema fiscal (productiva utilización del fruto de los tributos) entre otros. Ibidem., pp. 114- 119. 
ción o recurre a puntos de vista que no aclaran ningún límite de lo que debe ser protegido penalmente. También señala que este jurista recurre a conceptos generales como la inclusión de la carencia de causas de justificación en la materia prohibida o la incorporación de componentes subjetivos del desvalor de acción en el tipo, obteniendo como resultado una definición que no resuelve los problemas de falta de concreción que pretende resolver ${ }^{91}$. Reforzando esta idea el profesor Octavio de Toledo y Ubieto considera evanescentes los criterios de dañosidad social de cara a la determinación de los bienes jurídicos penales ${ }^{92}$.

Silva Sánchez señala que las dificultades que presenta la dañosidad social pueden propiciar que el Derecho Penal proteja tanto valores morales como intereses estrictamente políticos, por lo que cree imprescindible la inclusión en el concepto de bien jurídico de una referencia central al individuo (autorrealización del individuo) de tal manera que hechos disfuncionales que no afecten a la anteriormente referida autorrealización del individuo, no deberán ser punibles siendo evidente la peligrosa ambigüedad del concepto de dañosidad social entendido por separado de toda otra consideración. Para ilustrar tal afirmación señala problemas como el de la definición de lo socialmente dañoso en una sociedad dividida cuyos diferentes estratos responden a intereses contrapuestos que no son fácilmente resolubles, de ahí que estime más adecuado integrar en una sola idea los aspectos de referencia individual y de dañosidad social; afirmando que el objeto de protección jurídico penal necesariamente debe expresar las condiciones que hacen posible un libre desarrollo del individuo a través de su participación en la vida social. Además, sostiene que fusionar la idea de dañosidad social y de referencia individual posibilita que sea tutelada penalmente la posibilidad de cada ciudadano de desarrollarse de forma autónoma sin perder la orientación de que el desarrollo individual debe producirse necesariamente en la sociedad ${ }^{93}$.

Este autor entiende que para poder establecer límites al ius puniendi debe recurrirse al ordenamiento constitucional, y no a posiciones como la mantenida por Gómez Benítez que propone como límite "el perjuicio social". ÁLVAREZ GARCÍA, Francisco Javier. "Bien jurídico..., op. cit, p. 18.

92 OCTAVIO DE TOLEDO Y UBIETO, Emilio. “Función y límites..., op. cit., p. 8.

93 Silva entiende que la combinación de los aspectos de afectación a individuos y dañosidad social posibilita la exclusión de conductas netamente morales o intereses políticos, 
El profesor Jakobs sobre la dañosidad social afirma que es imprescindible introducirla en la lesión del bien desde fuera, pues sólo así puede dársele el calificativo de lesión de bien jurídico porque desde su perspectiva, que las unidades de funcionamiento puedan elevarse como bienes jurídicos por su significación social, no lo puede determinar la teoría del bien jurídico. Concluyendo que no debe prescindirse del filtro constituido por la dañosidad social, pues las normas que pasan este tamiz son protectoras de bienes jurídicos, y además, creadoras de los mismos para garantizar la preservación de la paz jurídica. Pero muy a pesar de todas las objeciones que realiza a la teoría del bien jurídico, afirma que no es conveniente rechazarla tajantemente y realizar la determinación del delito a través de la dañosidad social sin intermediación de un bien jurídico ${ }^{94}$.

Sobre el papel de la dañosidad social para la determinación de los bienes jurídicos penales, Roxin manifiesta que pretender basar el concepto material del delito en una teoría del daño social resulta poco acertado, pues esa atención a la funcionalidad para el sistema de una conducta conduce a que se proteja a la persona no por sí misma, sino sólo en interés de la sociedad de forma tal, que se podría sacrificar al individuo para que el sistema permanezca inalterado, lo cual ésta en contraposi-

pero opina que aunque estos dos elementos revisten gran importancia no son suficientes para determinar el objeto de protección jurídico penal, por lo que cree necesario seguir trabajando en la concreción de las ideas rectoras para tal fin. SILVA SÁNCHEZ, Jesús María. Aproximación al Derecho..., op. cit., pp. 270, 271. En el mismo sentido CARO CORIA, Dino Carlos. La Estabilidad del Ecosistema..., op. cit., pp. 174, 175. HIRSCH, Hans Joachim. "Acerca del estado actual..., op. cit., p. 378.

Jakobs sostiene que sólo el interés público en la conservación de un bien, lo convierte en bien jurídico y señala que el interés público no siempre está referido a la tutela de bienes. JAKOBS, Günther. Derecho Penal. P.G..., op. cit., p. 56. JAKOBS, Günther. “¿Dañosidad social?. Anotaciones sobre un problema teórico fundamental en el Derecho Penal". (Trad. Miguel Polaino- Orts) en Cuadernos de Política Criminal. Año 2010. Núm. 100 , pp. 39-45. Soto Navarro afirma que la dañosidad social aunque trata de ofrecer un criterio eficaz para la concreción de los contenidos dignos de tutela penal, no consigue superar las deficiencias de la doctrina del bien jurídico. Señalando que el criterio de dañosidad social no integra el principio de ultima ratio. SOTO NAVARRO, Susana. La protección penal..., op. cit., pp. 71, 72. Recordemos que este autor no se propone eliminar del vocabulario jurídico la expresión bien jurídico, sino que mantiene una concepción del mismo bastante diferente a la que nosotros nos adherimos, sobre la cual ya nos hemos detenido anteriormente (validez fáctica de la norma = bien jurídico penal). JAKOBS, Günther. Derecho Penal. P.G..., op. cit., pp. 57, 58. 
ción directa a la dirección liberal de la idea de bien jurídico, ya que el Estado existe para el individuo, que ha de ser protegido por sí mismo y no como parte de todo el sistema social ${ }^{95}$.

Por todo lo expuesto anteriormente, se infiere que para poder determinar qué realidades deben por su importancia constituir bienes jurídico penales, es imprescindible tomar en cuenta la dañosidad social de los comportamientos de tal manera que no se criminalice un valor moral que no produzca una repercusión socialmente dañosa ${ }^{96}$, ya que si bien es cierto que la dañosidad social constituye un criterio suficiente para la determinación de los bienes jurídicos en sentido general, no lo es para delimitar el bien jurídico penal que exige necesariamente la referencia al individuo, y además de otros requisitos derivados de las ideas de proporcionalidad, subsidiaridad y necesidad, de manera que un resultado socialmente dañoso que no lesione o ponga en peligro las posibilidades de participación del individuo en sociedad no deberá ser objeto de tutela penal (bien jurídico penal). Por lo tanto "la síntesis de afectación a los individuos, junto a la anteriormente referida dañosidad social, sin lugar a dudas constituye un primer paso que posibilita aislar las conductas netamente inmorales, y además refuerza la protección de los bienes jurídicos colectivos"97.

\section{C.) SOBRE LA FUENTE DEL BIEN JURÍDICO}

El problema que nos ocupa en este apartado, está referido a determinar si los bienes jurídico penales (sobre los que existe un importante consenso, de que no son creados por el legislador sino reconocidos por éste), deben necesariamente extraerse de la Constitución, o si por el contrario tienen que encontrar una procedencia diferente. Como todos sabemos existen básicamente dos teorías que se han ocupado de resolver este dilema; las teorías constitucionalistas, que se subdividen en estrictas y amplias, y las teorías sociológicas.

De forma general podemos decir que las teorías constitucionales pretenden extraer de la Constitución los bienes que deben ser tutelados

\footnotetext{
95 ROXIN, Claus. Derecho Penal. P.G..., op. cit., p. 68.

96 CADAVID QUINTERO, Alfonso. Introducción a la Teoría..., op. cit., p. 131.

97 SILVA SÁNCHEZ, Jesús María. Aproximación al Derecho..., op. cit., p. 276.
} 
penalmente, de tal manera que la constatación de la relevancia penal de un bien radicaría en su inclusión dentro del texto constitucional como fuente suprema de todo el ordenamiento jurídico. Mientras que las teorías sociológicas tratan de determinar los bienes que deben protegerse mediante el Derecho Penal a través de la realidad social, más específicamente mediante la dañosidad social, como criterio determinante para el establecimiento de los objetos a tutelar penalmente. Iniciamos el presente estudio analizando las tesis constitucionalistas.

\section{Tesis constitucionalistas}

Las teorías Constitucionalistas en general, con el propósito de encontrar una fuente más segura para realizar la selección de los bienes jurídico-penales que limiten al legislador ordinario en la creación de ilícitos penales, recurren a la Ley fundamental como norma suprema del ordenamiento jurídico así, los criterios de fragmentariedad y subsidiaridad servirían para delimitar dentro del catálogo de bienes comprendidos en la Carta Magna, cuales de ellos son dignos de protección penal; por lo tanto desde esta perspectiva la coincidencia de los valores consagrados en las leyes penales con los valores contenidos en la Constitución es obligada.

Tiedemann manifiesta que en Alemania el vínculo entre el Derecho Penal y el Derecho Constitucional es limitado por dos razones fundamentales: la primera de ellas se materializa en el hecho de que el ordenamiento constitucional de valores y la legislación penal son creaciones relativamente independientes. Estas parten de objetivos distintos del comportamiento humano y por ello muestran diferentes ámbitos de regulación. La segunda razón consiste en que el espacio de juego del legislador penal ordinario es relativamente amplio para cumplimentar el marco constitucional, tanto en lo atinente a los principios teóricos vinculantes, que son el fundamento de una construcción escalonada por la unidad del ordenamiento jurídico, como en el mismo uso del lenguaje, en el que el Derecho Penal se asume como un Derecho de ejecución de la Carta Magna ${ }^{98}$. El Tribunal Constitucional alemán, en reiteradas ocasio- 
nes, establece que el merecimiento de protección en sede penal "debe de determinarse desde la perspectiva de la comunidad, de modo que sólo se incriminen conductas socialmente dañosas e insoportables para una vida en común ordenada", así la legitimación de las normas penales reside en la tutela de los bienes fundamentales para la sociedad ${ }^{99}$.

A favor de las tesis constitucionalistas se pronuncia Díez Ripollés afirmando que en las recientes Constituciones, a diferencia de las elaboradas hace muchos años, se especifican además de los procedimientos formales para el desempeño de los órganos de poder, los objetivos que se persiguen, lo que en su opinión ha dotado a las referidas normas fundamentales de un pequeño grupo de principios o valores superiores, que deben de inspirar en todo momento la actuación de los poderes públicos; los cuales suelen ir referidos a un extenso catálogo de derechos fundamentales, libertades públicas o garantías individuales que superan con creces la tradicionalmente breve enumeración de las Constituciones anteriores ${ }^{100}$.

En lo que se refiere a la Unión Europea (y por ende a España), es preciso señalar que esta organización por su naturaleza establece un espacio geográfico criminal. Dicha criminalidad se realiza mediante la utilización de instrumentos e instituciones europeas, por tanto los daños que se producen afectan a organismos de la UE específicos, lo cual da lugar a la aparición de un conjunto de bienes jurídicos europeos. Estos bienes los podemos clasificar en dos grupos; el primero de ellos está integrado por bienes jurídicos europeos institucionales, tal es el caso de la actividad funcional de la misma por medio de sus funcionarios o de los recursos financieros de la UE. El segundo grupo está formado por bienes europeos que aparecen como resultado de la actividad

SEMER, Winfried. "Bienes jurídicos..., op. cit., p. 66. En Alemania entre los primeros defensores de la concepción constitucional del bien jurídico figuran Walter Sax y Ernst Rudolphi. ABANTO VÁSQUEZ, Manuel A. “Acerca de la teoría..., op. cit., p. 8.

99 Soto Navarro afirma que en algunos casos la limitación al legislador por parte del BverG, consiste en constatar de que la norma penal no sea contraria a los valores constitucionales. Ver sentencias BverG 88, 203 (258) y 27, 18. SOTO NAVARRO, Susana. La protección penal..., op. cit., pp, 59, 60.

100 DÍEZ RIPOLLÉS, José Luis. "El Bien jurídico protegido en un Derecho Penal Garantista”, en Nuevo Foro Penal no 60. Revista del Centro de Estudios Penales de la Universidad de Antioquía. Ed. Temis. Bogotá. 1999, p. 116. 
normativa, y de esta con relación a los diferentes sectores de actividad: ejemplo de ello es la libre competencia o las condiciones de funcionamiento del mercado agrario entre otros. Estos bienes jurídicos europeos tienen que ser necesariamente protegidos mediante los sistemas de sanciones penales y administrativos de los estados miembros 101 . Tómese como muestra, de ello el artículo 309 del Código Penal español que sancionaba la obtención indebida de fondos de los presupuestos generales de la unión europea, artículo que fue derogado el día 27 de diciembre del año 2012102, o la Decisión Marco 2004/757/JAI del Consejo de 25 de octubre de 2004, "relativa al establecimiento de disposiciones mínimas de los elementos constitutivos de delitos y las penas aplicables en el ámbito del tráfico ilícito de drogas"103. Otro ejemplo

101 GRACIA MARTÍN, Luis. “Qué es modernización del Derecho Penal?”. DIEZ RIPOLLES, José Luis. ROMEO CASABONA, Carlos María. GRACIA MARTÍN, Luis. HIGUERA GUIMERÁ, Juan Felipe (Editores). Ed. Tecnos. Madrid. 2002, pp. 374- 379. Tiedemann afirma que al menos en un sentido mediato la Unión Europea es fuente de Derecho Penal. GRACIA MARTIN, Luis. Prolegómenos para la lucha por la modernización y expansión del Derecho Penal y para la crítica del discurso de resistencia. Ed. Tirant lo Blanch. Valencia. 2003, pp. 98- 105. En el mismo sentido Arroyo Zapatero señala: "la legitimidad de protección de un bien jurídico puede provenir tanto de su referencia constitucional interna, como de su referencia en el marco de su ordenamiento supranacional". ARROYO ZAPATERO, Luis. “Derecho Penal económico y Constitución” en Revista Penal. №1. Enero. 1998, p. 2.

102 El artículo 309 del CPE establecía: "el que obtenga indebidamente fondos de los presupuestos generales de la Comunidad Europea u otros administrados por ésta, en cuantía superior a 50.000 euros, falseando las condiciones requeridas para su concesión u ocultando las que hubieran impedido, será castigado con la pena de prisión de uno a cuatro años y multa del tanto al séxtuplo de la citada cuantía". Este artículo fue derogado por la disposición derogatoria única de la Ley Orgánica 7/2012, de 27 de diciembre. Heine afirma que a los países firmantes del Estatuto de Roma, por el que se instituye el Tribunal Penal Internacional, les viene impuesto el deber de ampliar sus leyes penales nacionales mediante la incorporación de los delitos contra la Administración Pública, entre los que se encuentra el delito de corrupción. HEINE, Günter. "La Ciencia del Derecho Penal ante las tareas de futuro". ESER, Albin. HASSEMER, Winfried. BURKHARDT, Björn. (Coordinadores de la versión alemana). MUÑOZ CONDE, Francisco. (Coordinador de la versión española). La Ciencia del Derecho Penal ante el nuevo milenio. Ed. Tirant lo Blanch. Valencia. 2004, pp, 430, 431.

103 Esta norma contiene las bases a partir de las cuales debe construirse una legislación nacional que responda de forma eficaz al tráfico de drogas y de precursores químicos, en el entendido de que cada Estado tiene la facultad de endurecer, si le parece conveniente, las previsiones contenidas en la Decisión Marco. Teniendo la obligación los Estados miembros de comunicar a la Comisión y a la Secretaría General del Consejo, las 
más reciente es que todas las reformas promovidas por la Ley Orgánica 5/2010, de 22 de junio, responden a decisiones marco del Consejo Europeo, con lo que se sigue abundando en la unificación de las legislaciones penales de los países miembros de la Unión Europea. También hay que valorar que el Derecho Europeo puede actuar sobre estos Estados en algunos casos en un sentido negativo, es decir deber de no penalizar conductas que son conformes con el Derecho Europeo ${ }^{104}$.

Las tesis constitucionalistas como señalamos anteriormente, se subdividen en dos corrientes que se diferencian entre sí por el grado de vinculación entre el bien jurídico penal y los valores constitucionales; estas dos tendencias son las teorías Constitucionalistas estrictas y las amplias, que a continuación abordamos.

\section{El constitucionalismo estricto}

Estas teorías sostienen que la Constitución contiene las decisiones valorativas fundamentales para la elaboración de un concepto de bien jurídico, exigiendo una vinculación directa entre el bien jurídico y el precepto constitucional, así todo bien tutelado penalmente está condicionado por la voluntad del constituyente, dado que si la norma constitucional no valora de forma positiva una realidad, tampoco podrá hacerlo el legislador penal ordinario, lo cual implica que la Constitución agota los bienes susceptibles de protección penal.

Entre los más destacados representantes del constitucionalismo estricto se encuentra, sin lugar a dudas el profesor Bricola quien sostiene que es preciso que el bien a tutelar penalmente se encuentre contenido de forma explícita o implícita en la Constitución, así bienes susceptibles de protección penal serían: "los derechos reconocidos a los ciudadanos en el texto constitucional, los garantizados en convenios internaciona-

disposiciones mediante las cuales incorporen a su ordenamiento interno las obligaciones derivadas. FABIÁN CAPARRÓS, Eduardo A. "El tráfico ilícito de drogas en el Derecho de la Unión Europea. Comentario a la Decisión Marco 2004/757/JAI del Consejo de 25 de octubre de 2004, relativa al establecimiento de disposiciones mínimas de los elementos constitutivos de delitos y las penas aplicables en el ámbito del tráfico ilícito de drogas", en iustel.com, $R G D E$, nํㅜ 7, mayo 2005, pp. 2, 3, 14.

104 CUELLO CONTRERAS, Joaquín. MAPELLI CAFFARENA, Borja. Curso de Derecho Penal. Parte General. Ed. Tecnos. Madrid. 2011, p. 24. GRACIA MARTIN, Luis. Prolegómenos para la lucha..., op. cit., pp. 106- 108. 
les y reconducibles a la fórmula de derechos inviolables"..., "los valores objetivamente tutelables en sí mismos, aún sin ir referidos a una persona concreta"105, y "aquellos otros que sin ser propiamente constitucionales están ligados a uno de ellos por una relación que los convierte en presupuesto necesario para la lesión de aquéllos"106. Algunos autores se refieren a estos bienes como integrables, homologables o asimilables a los propiamente constitucionales ${ }^{107}$. Como se puede observar, para este jurista italiano, no basta, la simple "no incompatibilidad" entre la carta Magna y el bien jurídico a tutelar ${ }^{108}$.

En la doctrina española, González Rus se adhiere al constitucionalismo estricto, expresando que es la mejor opción para delimitar en buena forma el área del ilícito penal, ya que en su opinión la búsqueda del concepto de bien jurídico penal debe partir del reconocimiento que el legislador (tanto ordinario, como el constituyente), otorga la categoría de bien jurídico a lo que ya existía en la realidad social como valor, de lo que se deduce que hay que reconocerle al concepto sustancial de bien jurídico un soporte real, una naturaleza empírica sobre la cual se produce la valoración del legislador; debiendo cumplir el bien tutelado con los criterios de merecimiento, necesidad e idoneidad de protección. Además, afirma que pueden integrar el concepto de bien jurídico penal, tanto bienes como valores de naturaleza individual o social. Es necesario señalar que este profesor posteriormente matizó su posición señalando la necesidad armonizar las teorías constitucionales estrictas con las amplias ${ }^{109}$.

105 Por bienes tutelables en sí mismos, deben entenderse aquellos bienes sin referencia personal, tal es el caso de la salud pública o el patrimonio histórico, etc.

GONZÁLEZ RUS, Juan José. Bien jurídico y Constitución..., op. cit., pp. 26, 27.

Ibidem., p. 41.

CARO CORIA, Dino Carlos. El Derecho Penal del Ambiente..., op. cit., pp, 36, 37. En contra de la posturas sostenidas por el Constitucionalismo estricto, sosteniendo "que puede surgir un bien jurídico que tenga como base referencial un derecho todavía no reconocido en la Constitución y que, sin embargo, ya aparece como constitutivo de una relación social concreta y, por tanto, como fundamental desde una perspectiva de profundización democrática del sistema". BUSTOS RAMÍREZ, Juan. Control social..., op. cit., p. 193. 
Álvarez García ${ }^{110}$, siguiendo al profesor Bricola111, toma como punto de partida el valor que la Constitución Española otorga a la libertad personal, por lo que sostiene que únicamente ante la lesión o puesta en peligro de "otro bien que tenga sino igual, semejante relevancia en el ámbito normativo, resulta lícita la privación de libertad", lo cual cobra sentido si se parte de que la privación de libertad sigue siendo la principal consecuencia jurídica del ordenamiento penal, lo que hace aconsejable seleccionar sólo bienes constitucionales también relevantes que sean coherentes con los principios de proporcionalidad, de intervención mínima y estricta protección de bienes jurídicos; por tanto, la norma penal, debe caracterizarse por reducirse a los márgenes de estricta necesidad y de congruencia, entre el bien protegido penalmente y la Constitución ${ }^{112}$. Esta ponderación propuesta entre las libertades restringidas y libertades que se crean o se protegen nos parece muy ra-

110 ÁLVAREZ GARCÍA, Francisco Javier. “Bien jurídico..., op. cit., pp. 21, 30, 31. En la misma línea Angioni señala que el principio de proporcionalidad exige que el bien afectado por el delito sea de valor proporcionado al lesionado por la pena. ANGIONI, Francesco. Contenuto e funzioni del concetto di bene giuridico. Milán. 1983, p. 166, cit por MORALES VALDÉS, Hugo. Bien jurídico, principio de ofensividad e idoneidad lesiva. Análisis crítico del concepto strict liability en Derecho Inglés. Tesis Doctoral. Universidad de Salamanca. 2005, p. 239.

111 Señala Bricola que "la sanción penal puede ser adoptada solamente en presencia de la violación de un bien, él cual si no puede ser de igual grado de valor sacrificado (libertad personal), esté al menos dotado de relevancia constitucional". HORMAZÁBAL MALARÉE, Hernán. Bien Jurídico y Estado Social y Democrático de Derecho (el objeto protegido por la norma penal). Ed. PPU. Barcelona. 1991, p. 127.

112 GONZÁLEZ RUS, Juan José. Bien jurídico y Constitución..., op. cit., pp. 37, 40. CARBONELL MATEU, Juan Carlos. "Reflexiones sobre el abuso del Derecho Penal y la banalización de la legalidad". ARROYO ZAPATERO, Luis A. BERDUGO GÓMEZ DE LA TORRE, Ignacio (Dir).NIETO MARTÍN, Adán. (coord.). Libro homenaje al Dr. Marino Barbero Santos in memorian. Vol. I. Ed. Universidad de Castilla La Mancha. Universidad de Salamanca. Cuenca. 2001, pp. 130, 131. Ver en este sentido "la prohibición del exceso" planteada por Isensee. HASSEMER, Winfried. "Bienes jurídicos..., op. cit., pp. 69-72. HASSEMER, Winfried. “¿Puede Haber delitos que no afecten a un bien jurídico penal?”. (Trad. SPÍNOLA TÁRTALO, Beatriz). HEFENDEHL, Roland (Ed.). La teoría del bien jurídico. ¿Fundamento de legitimación del Derecho Penal o juego de abalorios dogmático?. Ed. Marcial Pons, ediciones jurídicas y sociales, S.A. Madrid. Barcelona. 2007, pp. 98- 101. Las tesis constitucionalistas puras se fundamentan en la pena, lo cual presupone la posibilidad de establecer una jerarquía entre los valores acogidos por la Constitución. SOTO NAVARO, Susana. La protección penal..., op. cit., p. 53. 
zonable y necesaria, pues asumimos que el Estado jamás debe restringir bienes jurídicos más importantes que los que pretende proteger.

A quienes defienden los planteamientos del constitucionalismo estricto se les critica, que en la mayoría de los casos siempre es posible encontrar un punto de apoyo en la Constitución, y además, se les cuestiona que pueden limitar la incriminación de nuevos comportamientos resultantes del desarrollo histórico social que afecten realidades no comprendidas en la Carta Magna, y aún más, se les señala que al incluir como objetos tutelables penalmente valores implícitos, homologables o asimilables, para superar los problemas de rigidez de la Constitución, lo que hacen es generar incertidumbre y arbitrariedad por el nivel de imprecisión que se produce con la introducción conceptos tan ambiguos ${ }^{113}$.

Queremos señalar que en la actualidad el constitucionalismo estricto no goza de gran aceptación en la doctrina española, prevaleciendo la opinión de que el valor de la Constitución debe extraerse de los principios materiales que ella contiene ${ }^{114}$. El profesor Bustos Ramírez al respecto señala que es innegable que las Constituciones son el marco de referencia fundamental del sistema, pero sin embargo no deben cerrar el sistema, y por ende, la Carta Suprema no debe cortar el desarrollo y evolución del bien jurídico, lo cual en nuestra opinión debe tenerse en

113 Fortaleciendo las críticas anteriormente señaladas, se objeta que en la actualidad la sociedad presenta como rasgo característico la velocidad en el desarrollo de los recursos y de los medios técnicos, lo que aumenta sin lugar a dudas la potencialidad lesiva de los derechos ciudadanos, lo cual parece indicar la necesidad de adoptar una teoría sobre el bien jurídico que posibilite superar el estrecho marco propuesto por la teoría constitucional estricta, ya que las constituciones no son elaboradas como un catálogo de bienes susceptibles de agresión por parte de los particulares o de los poderes del Estado, que agotara el ámbito de lo que debiera de ser punible en sede penal. CADAVID QUINTERO, Alfonso. Introducción..., op cit., p.139. En el mismo sentido. SOTO NAVARRO, Susana. La protección penal..., op. cit., p. 51.

114 CARO CORIA, Dino Carlos. El Derecho Penal del ambiente..., op. cit., pp. 37, 38. Soto Navarro señala que el Tribunal Constitucional español confirma la extracción de los bienes jurídicos del modelo de convivencia establecido, es decir, de la realidad social, sin más limite constitucional que la exigencia de legitimidad de estos bienes, en cuanto no sean contrarios a los valores de un Estado Social y Democrático de Derecho, por lo que entiende que el legislador sólo encuentra en la Constitución un limite de carácter negativo. Ver STC (111/1993) de 25 de marzo de 1993. Ponente: D. Alvaro Rodríguez Bereijo y STC (105/1988) de 8 de junio de 1988. Ponente: D. Luis Diez-Picazo y Ponce de León. SOTO NAVARRO, Susana. La protección penal..., op. cit., pp. 59, 64. 
consideración por el vertiginoso desarrollo científico y tecnológico en que nos vemos inmersos, desarrollo que aumenta en gran medida la potencialidad de lesión (o puesta en peligro) de bienes imprescindibles para el desarrollo y auto realización de las personas en la vida social, por ello, nos parece necesario adoptar una teoría del bien jurídico que sea capaz de superar el estrecho marco propuesto por las tesis constitucionalistas de corte estricto ${ }^{115}$.

\section{El constitucionalismo amplio}

Los autores que se adhieren a las teorías constitucionalistas amplias tienen como denominador común que toman como punto de partida el modelo de Estado Social y Democrático de Derecho ${ }^{116}$ constitucionalmente establecido, sosteniendo estos que la determinación de los bienes jurídicos a tutelar penalmente no debe ser potestad exclusiva del legislador, dado que resulta imprescindible en esta labor una participación activa de la sociedad ${ }^{117}$.

115 BUSTOS RAMÍREZ, Juan. Control Social..., op. cit., p. 192.

116 La constitución española en su artículo 1.1 establece: "España se constituye en un Estado Social y Democrático de Derecho". Es necesario precisar que la primera Carta Magna en la que se plasma la expresión "Estado Social de Derecho", fue la Ley fundamental de Bonn de 1949, así como, que dicho concepto fue acuñado por Hermann Heller en su obra Rechtsstaat oder Diktatur? publicada en 1930. Carmona Cuenca afirma que el cometido esencial del ESDD consiste en articular los causes de participación que posibiliten la extensión de la democracia a todos los sectores de la sociedad (principalmente en la toma de decisiones económicas) y no únicamente a la toma de decisiones políticas. Como todos sabemos en la actualidad existe una enorme concentración de poder económico en manos de unos cuantos particulares, cuyas decisiones afectan todos los ámbitos de la vida social, incluido el ámbito político, por lo cual es necesario garantizar la democracia empresarial para controlar la denominada exclusión social y así asegurar efectivamente la democracia política. CARMONA CUENCA, Encarnación. El Estado Social de Derecho en la Constitución. Ed. Consejo Económico y Social. Madrid. 2002, pp. 57, 58, 191,192, 197.

117 García Arán sostiene que el legislador ordinario cuenta con un considerable margen de decisión que le permite tutelar bienes jurídicos no establecidos expresamente en la Constitución, sin embargo, el sistema constitucional de valores no puede ser ignorado por el legislador ordinario al decidir cuál es la intervención penal proporcionada, sobre este tema es pertinente recordar la STC 65/1986, de 22 de mayo. Ponente: D. Ángel Latorre Segura, en la que se admite que la decisión sobre la proporcionalidad de la intervención penal es competencia del legislador en el ámbito de su política criminal, siempre que con ello no vulnere el valor de la justicia ni la dignidad humana de la persona. 
Las tesis constitucionalistas amplias se pueden a su vez subdividir en dos grupos: el primero de estos asume la Constitución como un marco de referencia en el cual los autores sociales establecen las condiciones esenciales para el desarrollo del sistema social, siendo necesario por tanto que en la determinación de los bienes jurídicos penales tenga una activa participación la base social, la cual hará llegar su sentir a las instancias políticas correspondientes, de tal forma que se ejercite verdaderamente la democracia118. El segundo grupo aboga por una "vinculación programática entre el bien jurídico y el sistema socio-personalista al que la Constitución desea servir de marco", atribuyéndole una función promocional al Derecho Penal en "relación con la vigencia y respeto de los nuevos intereses necesarios para alcanzar las metas constitucionales"119. Este carácter promocional, como un caso de superación de los limites utilitarios que fundamentan la pena, del sistema penal es rechazado de forma contundente por un sector doctrinal que sostiene que las transformaciones sociales no deben atribuirse al sistema jurídico, y mucho menos al Derecho Penal ${ }^{120}$, ya que es evidente que este último no

GARCIA ARAN, Mercedes. "Constitución y Derecho Penal veinte años después". ARROYO ZAPATERO, Luis. BERDUGO GOMEZ DE LA TORRE, Ignacio (Dir). NIETO MARTÍN, Adán (coord.). Libro homenaje al DR. Marino Barbero Santos in memoriam. Volumen I. Ed. Universidad de Castilla la Mancha- Universidad de Salamanca. Cuenca. 2001, p. 288. HORMAZÁBAL MALARÉE, Hernán. Bien Jurídico..., op. cit. , pp. 142, 143. ROXIN, Claus. Derecho Penal. P.G..., op. cit., pp. 56-58.

118 Idem.

119 CARO CORIA, Dino Carlos. Derecho Penal del Ambiente...., op. cit., pp. 38, 39. Fabián Caparrós advierte, que en algunas ocasiones no resulta fácil establecer la frontera que separa las teorías estrictas de las amplias, señalando que no es muy raro que la posición doctrinal de un autor "se vincule simultáneamente a ambas posturas, dependiendo de cual sea la fuente consultada". El Delito de Blanqueo de Capitales. Ed. Colex. Madrid. 1998, p. 170. A favor del carácter promocional del Derecho Penal se pronuncia Octavio de Toledo. HORMAZÁBAL MALARÉE, Hernán. Bien Jurídico..., op. cit., pp. 134, 135. Zúñiga Rodríguez señala, que las teorías constitucionalistas amplias consideran a la Constitución como norma programática, y por lo tanto como modelo a seguir (metas a alcanzar), siendo de la opinión que estas teorías tampoco logran concretar el contenido material del bien jurídico, y que al referirse al carácter material de la Constitución se confunden con las teorías sociológicas, con lo cual se regresa a las caracterizaciones negativas. ZÚÑIGA RODRÍGUEZ, Laura. Libertad Personal y Seguridad Ciudadana: estudio del tipo penal de injusto del delito de detenciones ilegales practicadas por funcionarios públicos. Ed. PPU. 1993, pp. 50, 51.

Caro Coria manifiesta al respecto que: "el no cambio y el posible conformismo social, no son atribuibles directamente al sistema jurídico". CARO CORIA, Dino Carlos. Derecho 
puede convertirse en la base de las transformaciones sociales, lo cual no niega que su instrumento esencial, la pena, contribuya mediante la defensa de los valores básicos a la estabilidad del propio sistema ${ }^{121}$.

En Italia la doctrina mayoritaria 122 al referirse a las relaciones entre bienes jurídicos penales y Constitución, hace referencia a la "no incompatibilidad" con la norma suprema, así para Mantovani la Constitución no vendría a decidir la tutela de determinados bienes jurídicos, sino a servir de punto de relación conforme al sistema penal que se ha de construir, de tal manera que en dicho sistema no se protejan bienes contrarios a la Constitución, así esta jugaría un papel negativo de exclusión de determinados valores, rechazando por tanto la posibilidad de otorgar un carácter positivo vinculante a la Carta Magna en la de-

Penal del Ambiente..., op. cit., p. 40. "El Derecho Penal no es motor de cambio social".., "lo que corresponde al Derecho Penal es una función instrumental, protectora de bienes jurídicos" por lo que deben rechazarse los cometidos simbólicos y promociónales. GARCÍA-PABLOS, Antonio. "Tendencias actuales del Derecho Penal" en Modernas tendencias en la Ciencia del Derecho Penal y la Criminología. Ed. UNED. Madrid. 2001, pp. 41, 42. Silva afirma que no es competencia (ni tiene posibilidades) del Derecho Penal la transformación de los principios de organización de la sociedad, más bien, ocurre que el Derecho Penal refleja el orden social, por ello se debe rechazar el carácter promocional de este. SILVA SÁNCHEZ, Jesús María. La expansión del Derecho Penal. Aspectos de la política criminal en las sociedades postindustriales. Segunda edición. Civitas. Madrid. 2001, p. 116. SOTO NAVARRO, Susana. La protección penal...,op. cit.., p. 174, 186- 190. TERRADILLOS BASOCO, Juan. “La satisfacción de necesidades..., op. cit., pp, 125- 127.

121 CARBONELL MATEU, Juan Carlos. “Reflexiones sobre el abuso..., op. cit, pp. 134, 135. PORTILLA CONTRERAS, Guillermo. "La supuesta crisis..., op. cit., p. 922.

122 En contra de la idea de "no incompatibilidad" con la Constitución política. GONZÁLEZ RUS, Juan José. Bien jurídico y Constitución..., op. cit., pp. 26, 27, 31, 40- 42. Pulitano y Fiandaca también se adscriben al constitucionalismo amplio, Fiandaca expresa que el planteamiento constitucional acertado es el que asume la Constitución como fuente que ha de proporcionar directivas programáticas de protección, y no parámetros vinculantes para el legislador. HORMAZÁBAL MALARÉE, Hernán. Bien Jurídico... op . cit., pp. 129- 131. Méndez Rodríguez afirma que las teorías constitucionalistas amplias no exigen que la correspondencia entre bienes jurídicos y valores constitucionales sea plena, pero sí reclaman una adaptación genérica que no se sabe con exactitud si consiste en "una congruencia de los bienes jurídicos con los principios constitucionales básicos del Estado o con valores y derechos fundamentales que la Constitución consagra". MÉNDEZ RODRÍGUEZ, Cristina. Los Delitos de Peligro y sus Técnicas de Tipificación. Ed. Universidad Complutense. Madrid. 1993, p. 18. Soto Navarro se pronuncia a favor de la "no incompatibilidad" constitucional en la determinación de los bienes jurídicos penales. SOTO NAVARRO, Susana. La protección penal..., op. cit., pp. 66, 67. 
terminación de los bienes jurídico penales. El dilema que se plantea con la anteriormente señalada "no incompatibilidad" estriba en la posibilidad de la creación de normas penales que protejan bienes o intereses no consagrados expresa, ni tácitamente en la Constitución, lo cual parece plenamente admisible desde la posición planteada por Mantovani, librándose por ello al menos de forma aparente de las críticas realizadas al constitucionalismo estricto, ya que no se le puede acusar de cerrar el sistema ni de cortar la necesaria evolución del bien jurídico penal.

Muñoz Conde sostiene que afirmar que el Derecho Penal tutela derechos fundamentales es una obviedad, pues cualquiera de los bienes jurídicos protegidos en los distintos tipos penales contenidos en el Código Penal de cualquier país, son reconducibles directa o indirectamente a algunos de los derechos reconocidos en cualquier carta fundamental constitucional. Sin embargo afirma que no todos los bienes jurídicos que protege el Derecho Penal tienen directamente el carácter de derechos fundamentales, lo cual evidencia que el Derecho Penal no es un simple apéndice del Derecho Constitucional, si así fuera, su misión consistiría únicamente en tutelar a través de la sanción penal los derechos previamente reconocidos en la Constitución ${ }^{123}$. En este sentido resulta muy interesante la posición sostenida por Bustos Ramírez al afirmar que: los bienes jurídicos considerados materialmente, son relaciones sociales concretas que surgen como síntesis normativa de los procesos interactivos de discusión y confrontación que tiene lugar dentro de una sociedad democrática, los cuales son dinámicos pues están en perma-

123 MUÑOZ CONDE, Francisco. "Protección de bienes jurídicos como limite constitucional del Derecho Penal”. QUINTERO OLIVARES, Gonzalo, MORALES PRATS, Fermín (Coord.). El nuevo Derecho Penal español. Estudios penales en memoria del profesor José Manuel Valle Muñiz. Ed. Aranzadi. 2001, p. 562. García Arán sostiene que el legislador ordinario dispone de un margen considerable de decisión que le permite proteger bienes jurídicos que no están establecidos de forma expresa en la Carta magna, lo cual no significa que el sistema de valores constitucional deba ser ignorado por el legislador para determinar cuál es la intervención proporcionada. Sobre este tema ver la Sentencia del Tribunal Constitucional 65/1986 del 22 de mayo de 1986. Ponente: D. Ángel Latorre Segura, en la que se admite que "la decisión sobre la proporcionalidad de la intervención penal es competencia del legislador en el ámbito de su política criminal, siempre que no vulnere el valor de la justicia ni la dignidad de la persona humana". GARCÍA ARÁN, Mercedes. "Constitución y Derecho Penal, veinte años después" en ARROYO ZAPATERO, Luis. BERDUGO GÓMEZ DE LA TORRE, Ignacio (Dir.). NIETO MARTÍN, Adán (coord..). Homenaje al Dr Marino Barbero Santos: in memoriam. Volumen I. Ed. Universidad de Castilla- La Mancha. Universidad de Salamanca. Cuenca. 2003, p. 288. 
nente discusión y revisión"124, lo que lo lleva a admitir el surgimiento de bienes jurídicos que tengan como base un derecho aún no reconocido en la Carta Magna, si este "aparece como constitutivo de una relación social concreta y, por tanto, como fundamental desde una perspectiva de profundización democrática del sistema"125.

Hassemer afirma que si se quiere encajar la definición penal y la concepción del bien jurídico en la discusión constitucional sobre el Derecho Penal y sus límites, deben de retomarse dos conceptos del Derecho Constitucional y de la ciencia del Derecho Constitucional: "la prohibición del exceso" (Übermaßverbot) en que se pone de relieve la tradición clásica de los derechos fundamentales como derecho de defensa frente a las intromisiones estatales que sobrepasan la medida legitima, y "la prohibición de defecto" (Untermaßverbot) que establece un deber de protección. Sostiene este profesor y jurista alemán que ambos principios están en condiciones de reconstruir desde el punto de vista del Derecho Constitucional las tradiciones de Derecho Penal, en cuyo núcleo se encuentra el bien jurídico, ya que determinan los dos polos que determinan el derecho de intervención estatal conforme a la Constitución ${ }^{126}$.

Es preciso señalar que el Derecho Penal en virtud del principio de intervención mínima y de la elaboración doctrinal del concepto de bien jurídico, presenta una serie de particularidades que lo convierten en un mecanismo de tutela jurídica autónomo y hasta cierto punto independiente de las demás áreas del ordenamiento jurídico, incluido el Derecho Constitucional el cual, sólo representa un marco dentro del cual el Derecho Penal se mueve con más o menos libertad a la hora de decidir qué derechos fundamentales en forma de bienes jurídicos debe proteger, y cómo debe hacerlo. Por tanto se puede afirmar que el legislador no está obligado a sancionar penalmente toda conducta que lesione un bien jurídico, ni es el Derecho Penal el único medio protector de los mismos, independientemente de que sean estos o no derechos fundamentales. Estimamos necesario recordar que los bienes jurídicos como

BUSTOS RAMÍREZ, Juan. HORMAZÁBAL MALARÉE, Hernán. Lecciones de Derecho Penal..., op. cit., p. 73.

125 BUSTOS RAMÍREZ, Juan. Control social..., op. cit., p. 193. 
señala Roxin: "no sólo deben ser protegidos por el Derecho Penal, sino también ante el Derecho Penal"127.

Nosotros consideramos justificado, en alguna medida, que existan algunas reservas sobre las teorías constitucionalistas en general, ya que resulta difícil negar que en la práctica, en la determinación de los bienes jurídicos penales los legisladores en no pocas ocasiones guardan silencio acerca de sus intenciones, las encubren y en algunos casos, ni siquiera a ellos les resultan excesivamente claras las leyes que formulan, sobre todo en los casos de compromiso, es decir, las negociaciones cotidianas que se dan en cualquier cuerpo legislativo para la búsqueda del necesario consenso para realizar la aprobación de las normas, lo cual puede propiciar la creación del denominado Derecho Penal simbólico ${ }^{128}$. También hay que tener en cuenta en este sentido el papel que juegan los medios de comunicación masiva, Weaver sostiene que "los datos acumulados permiten apoyar la afirmación de que el énfasis de los medios en ciertos temas a lo largo del tiempo influye en el número de personas que se ocupa o presta atención a dichos asuntos.., así mismo afirma que la machacona insistencia de los medios en los mismos asuntos.., a lo largo de prolongados periodos de tiempo puede desembocar en la aceptación acrítica por la audiencia de la (supuesta) importancia de esas cuestiones". Lo que implica que los medios de difusión masiva juegan un rol activo y no son un mero reflejo de la opinión pública. Sobre este tema el profesor Killias afirma que los medios de comunicación ofrecen una visón deformada de la realidad criminológica, dado que centran la atención en delitos violentos o dramáticos que generan con cierta periodicidad oleadas de temor o de indignación, lo que

127 Muñoz Conde afirma que "tan importante o más que el concepto de bien jurídico o de derecho fundamental que subyace en todo tipo delictivo, es el proceso mismo social y político a través del que se constituye. En esta tarea el Derecho Penal goza de una autonomía casi absoluta, pero esto no quiere decir que los bienes jurídicos puedan ser protegidos de cualquier modo o de forma arbitraria" puesto que la protección de bienes jurídicos no significa necesariamente protección mediante el Derecho Penal. MUÑOZ CONDE, Francisco. “Protección de bienes..., op. cit., pp. 563, 567, 568.

128 HASSEMER, Winfried. "Derecho Penal Simbólico y Protección de Bienes jurídicos" en Nuevo foro penal, numero 51. 1991, p. 23- 27. 
provoca en no pocas ocasiones un actuar irracional del aparato legislativo para demostrar que responde de forma rápida y efectiva ${ }^{129}$.

Por todo lo expuesto anteriormente con relación a las teorías constitucionalistas (estrictas y amplias), podemos afirmar que es innegable la necesidad de tomar como punto de referencia la Constitución para la determinación de los bienes jurídicos penales. Si bien es cierto que ambas posturas tienen la intención de dotar de garantías al Derecho penal, así como la de permitir la eficacia limitadora (función crítica o de política criminal) del bien jurídico, también es cierto que continúan siendo insuficientes para determinar los bienes que deben ser tutelados penalmente, pues la exigencia de una consagración constitucional, ya bien sea esta directa o indirecta, parece un marco demasiado amplio y flexible. Y aunque resulta innegable que el reconocimiento constitucional es un criterio relevante para determinar la protección jurídica de un bien, también lo es, que no todas aquellas realidades contempladas en la Constitución adquieren en virtud de ello la cualidad de penalmente tutelable, pues la Constitución no establece cual ha de ser el mecanismo protector de las realidades que valora positivamente ${ }^{130}$.

\section{Tesis sociológicas}

En el contexto del Estado Social y Democrático de Derecho se produjo un resurgimiento de la política criminal, y con este, aparece la necesi-

SOTO NAVARRO, Susana. La protección penal..., op. cit., pp. 97, 98, 150, 160. Argumentando consideraciones similares. JAREBORG, Nils. "Derecho Penal e ideología" en ESER, Albin. HASSEMER, Winfried. BURKHARDT, Björn. (Coordinadores de la versión alemana). MUÑOZ CONDE, Francisco. (Coordinador de la versión española). La Ciencia del Derecho Penal ante el nuevo milenio. Ed. Tirant lo Blanch. Valencia. 2004, p. 444.

Hormazábal afirma que las denominadas Teorías Constitucionales, de incuestionable valor orientativo para la determinación del merecimiento de protección, no constituyen verdaderas teorías del bien jurídico, pues no expresan lo que este es, sino que se limitan a buscar en la Constitución política el referente que da fundamento a una política penal coherente con los lineamientos del modelo de Estado que da la propia Constitución. HORMAZÁBAL MALARÉE, Hernán. Bien Jurídico..., op. cit., pp. 139, 140. SILVA SÁNCHEZ, Jesús María. Aproximación al Derecho..., op. cit., pp. 274, 275. Soto Navarro opina que aunque el reconocimiento constitucional es un criterio relevante para determinar la tutela penal de un bien, también pueden protegerse penalmente bienes carentes de plasmación constitucional, tomando como base un notable grado de consenso social en su protección. Lo cual es valido tanto para bienes jurídicos individuales como colectivos. SOTO NAVARRO, Susana. La protección penal..., op. cit., pp. 66, 67. 
dad de encontrar un nuevo fundamento racionalizador del Derecho Penal y de su monopolización por parte del Estado. La búsqueda de dicho fundamento se realizaría en la sociología y particularmente dentro de ésta, en corrientes que se encuentran englobadas bajo el funcionalismo y el interaccionismo ${ }^{131}$. Del funcionalismo sistémico (funcionalismo radical o normativismo radical), ya nos hemos ocupado anteriormente con cierta amplitud, por lo cual en este momento, nos limitamos a ratificar las críticas extrasistemáticas que señalamos antes al analizar los planteamientos del profesor Jakobs. Entre estas, destacamos que el entendimiento del bien jurídico como la vigencia de la norma y el delito como la defraudación de las expectativas sociales contenidas en la norma, sólo posibilita establecer un límite formal al legislador, el cual, consideramos insuficiente para determinar el marco de protección penal, pues paradójicamente en este caso la materia a controlar crearía el medio de control ${ }^{132}$.

Otra crítica que nos parece conveniente rescatar en este momento, es que pretender determinar desde una perspectiva funcionalista el campo de intervención del Derecho Penal tomando como criterio la disfuncionalidad de las conductas frente al sistema, "deja sin resolver un problema clave, común a toda la sociología funcionalista, que sólo puede ser resuelto mediante la introducción de elementos externos al mismo; pues, al afirmar la funcionalidad o disfuncionalidad de un comportamiento con relación a un sistema no se está efectuando ninguna valoración sobre la naturaleza de este último"133. Marsal ya en el año 1977 se pronunció al respecto, manifestando en la misma línea que: "el funcionalismo sirve para legitimar cualquier modelo social industrial avanzado" 134 .

131 HORMAZÁBAL MALARÉE, Hernán. Bien Jurídico..., op. cit., p. 93.

132 CADAVID QUINTERO, Alfonso. Introducción a la Teoría..., op. cit., pp. 116, 117. En este sentido García Cotarelo afirma: "que la idea principal de la teoría de los sistemas es unir el cambio con un mecanismo autorregulado; esto es, la teoría acepta el cambio en la medida en que contribuye a determinar la identidad social. Lo que implica que el cambio se utiliza como medio para preservar el inmovilismo". SOTO NAVARO, Susana. La protección penal..., ob. cit., pp. 20, 21.

BERDUGO GÓMEZ DE LA TORRE, Ignacio. Reflexiones sobre..., op. cit., p. 6.

134 HORMAZÁBAL MALARÉE, Hernán. Bien Jurídico..., op. cit., p. 95. 
Esta corriente sociológica tiene entre sus máximos exponentes a: Durkheim $^{135}$, Parsons ${ }^{136}$, Merton ${ }^{137}$, Luhmann ${ }^{138}$, Amelung139 y en estos últimos años a Jakobs. Como todos sabemos estos autores tomando como punto de partida que el hombre es un ser social, mediatizan su protección en aras del mantenimiento del sistema ${ }^{140}$. González Rus afirma

135 DURKHEIM, E. La división del trabajo social. París. 1893, cit. por HORMAZÁBAL MALARÉE, Hernán. Bien Jurídico y Estado Social y Democrático de Derecho (el objeto protegido por la norma penal). Ed. PPU. Barcelona. 1991, pp. 96- 102.

PARSONS, Talcott. La estructura de la acción social I y II. Madrid. Ediciones Guadarrama. 1968, cit por CARO CORIA, Dino Carlos. El Derecho Penal..., op. cit., p. 21. HORMAZÁBAL MALARÉE, Hernán. Bien Jurídico..., pp. 96- 102. Parsons cae directamente en el idealismo centrando sus estudios en el mismo sistema, sin el cual no podrían comprenderse ninguno de sus elementos, que siempre debían referirse al todo. Para este autor el sistema es algo autónomo, cerrado en sí mismo, que convive con otros sistemas. ZAFFARONI, Raúl Eugenio. "El funcionalismo sistémico..., op. cit., pp. 748- 753.

137 MERTON, Robert. Teoría y estructuras sociales. Fondo de Cultura Económico. México. 1984, cit por CARO CORIA, Dino Carlos. El Derecho Penal del Ambiente..., , p. 21. HORMAZÁBAL MALARÉE, Hernán. Bien Jurídico y Estado Social y Democrático de Derecho (el objeto protegido por la norma penal). Ed. PPU. Barcelona. 1991, pp. 96- 102. Zaffaroni afirma que Merton a pesar de ser uno de los más destacados funcionalistas, su interés sistémico fue algo lateral, debido a su concepto abierto de "sistema social". ZAFFARONI, Raúl Eugenio. "El funcionalismo sistémico..., op. cit., p. 747, 748.

138 Luhmann entiende que en las sociedades actuales donde no se puede afirmar la confianza personal en el cumplimiento de las expectativas, producto de la complejidad de las relaciones y las formas diferenciadas de Derecho, éste esta llamado a institucionalizar esta confianza, de modo que se sustituye la confianza personal por la confianza institucional, llevando el positivismo jurídico hasta sus últimas consecuencias. HORMAZÁBAL MALARÉE, Hernán. Bien Jurídico..., op. cit., pp. 102, 103. Para Luhmann el sistema no esta cerrado en sí mismo, no se agota en lo intrasistémico, sino que se halla abierto en permanente relación con el medioambiente. De esta manera el sistema ya no es algo estático, sino dinámico que se encuentra en permanente relación con el medio ambiente, que es extra-sistémico y, por ende, no controlable por el sistema, pero frente al cual el sistema reacciona, para mantener su propio equilibrio, apelando a estrategias de selección y reducción”. ZAFFARONI, Raúl Eugenio. “El funcionalismo sistémico..., op. cit., pp. 753- 756.

139 BERDUGO GÓMEZ DE LA TORRE, Ignacio. Reflexiones sobre la problemática..., op. cit., p. 6. HORMAZÁBAL MALARÉE, Hernán. Bien Jurídico..., op. cit. , pp. 110, 111. POLAINO NAVARRETE, Miguel. Recensión de a AMELUNG, Knut. "Rechtsgüterschutz und Schutz der Gesellschaft". Frankfurt am Main. 1972 en Anuario de Derecho Penal y Ciencias Penales. № 26. 1973.

140 El factor de cohesión del funcionalismo radica en la presencia de un código moral y un sistema de valores compartido por todos los actores sociales. Así la estabilidad del sis- 
que los autores anteriormente citados, entendieron o entienden la sociedad como un conjunto de interacciones en la que el criterio fundamental para enjuiciar cualquier comportamiento estaría constituido por la "funcionalidad", de lo cual se deduce que las conductas disfuncionales serían delictivas por excelencia, dado que contradicen las normas que rigen el funcionamiento de la sociedad, lo que propicia, que el legislador perfectamente pueda considerar como delito lo que no debería serlo ${ }^{141}$.

Otra manifestación de las teorías sociológicas funcionalistas es la que comúnmente conocemos como "funcionalismo moderado", corriente que está representada fundamentalmente por el profesor Claus Roxin y sus discípulos. Asumimos que la diferenciación más relevante de esta tendencia con el funcionalismo radical versa sobre la concepción que mantienen acerca de la misión que está llamado a cumplir el Derecho Penal, así como por la asunción de principios y valores políticocriminales ${ }^{142}$, lo cual obliga a una amplia normativización de los conceptos, pero proporciona la flexibilidad necesaria para hacer posible las variaciones de contenido en los conceptos en función de los cambios valorativos o del equilibrio de los fines, lo que puede propiciar en nuestra opinión el progreso hacia la construcción de un sistema abierto de orientación teleológica143.

La segunda corriente sociológica es el interaccionismo simbólico, que surge como una alternativa sociológica no radical. Para esta corriente

tema está dada en las mutuas expectativas que generan el consenso en el mismo código moral. HORMAZÁBAL MALARÉE, Hernán. Bien Jurídico..., op. cit, pp. 97, 98.

141 GONZÁLEZ RUS, Juan José. Bien jurídico..., op. cit., pp. 22, 23.

142 Silva señala que con diversos matices, el método dogmático teleológico se ha extendido en España. En este sentido menciona entre otros a Gimbernat, Mir Puig, Bustos Ramírez, Gómez Benítez y Muñoz Conde, destacando que es necesario aclarar que existen diferencias significativas en cuanto al grado de funcionalización del sistema de la teoría del delito, el punto de partida (premisa) de la funcionalización, y la forma concreta de llevarlo a término. SILVA SÁNCHEZ, Jesús María. Aproximación al Derecho..., op. cit., pp. 70- 72 .

143 CARO CORIA, Dino Carlos. Derecho Penal del Ambiente..., op. cit., p. 17. García-Pablos sostiene, que la pretensión de Roxin es vencer las barreras existentes entre el Derecho Penal y la política criminal, haciendo "del sistema un instrumento válido para la solución satisfactoria de los problemas reales de la sociedad". GARCÍA-PABLOS DE MOLINA, Antonio. Introducción al Derecho..., op. cit., pp. 711-713. 
tanto el individuo como la sociedad constituyen unidades inseparables que se encuentran en "mutua interrelación" asumiendo que "como consecuencia del proceso de interacción el individuo internaliza los símbolos transmitidos así como su significación". Esta corriente sociológica se reconoce como una dirección de la psicología social y de la sociolingüística, que ha dado lugar conjuntamente con la etnometodología inspirada en la sociología fenomenológica, a una teoría criminológica conocida como "labeling approach" (teorías del etiquetamiento y de la reacción social), la cual se inscribe dentro de las corrientes criminológicas denominadas de reacción social, siendo el centro de sus investigaciones la respuesta social que produce el comportamiento desviado y la forma que asume el control de dichos comportamientos ${ }^{144}$. Esta nueva escuela les objetaba a sus antecesoras, que centradas en la búsqueda de los factores de la criminalidad, hubieran pasado por alto que no se puede dar criminalidad sin criminalización, por lo tanto la criminalidad como un resultado de procesos de definición social y estatal, sería no una realidad dada en forma previa sino construida por el hombre y sus instituciones ${ }^{145}$.

\section{Toma de postura sobre la fuente del bien jurídico}

Como hemos señalado antes tanto a las teorías constitucionalistas como a las sociológicas se les pueden realizar una serie de objeciones, entre ellas queremos destacar que las tesis sociológicas se caracterizan básicamente en invertir la base de los planteamientos liberales (subordinación de lo social a lo individual), abogando por el sometimiento del individuo a la sociedad, tomando como base el perjuicio social que no permite hacer una correcta selección los intereses que deben ser objeto de tutela penal, además se les señala que con su carácter neutral el funcionalismo contribuye al desarrollo de un proceso conservador de legitimación del sistema. En el caso de las tesis de corte liberal o constitucionalistas se les critica que estas ofrecen nociones tan amplias que

\footnotetext{
144 HORMAZÁBAL MALARÉE, Hernán. Bien Jurídico..., op. cit, pp. 106, 107.

145 HASSEMER, Winfried. Crítica al Derecho Penal de hoy. (Trad. ZIFFER, Patricia S.). Ed. Universidad del Externado de Colombia. Bogotá. 1997, pp. 51, 52. Esta teoría otorga relevancia a los mecanismos de control social como configuradores de la criminalidad. GARCÍA-PABLOS DE MOLINA, Antonio. Tratado de Criminología. Ed. Tirant lo Blanch. Valencia. 1999, pp. 175- 178.
} 
no posibilitan la supresión de los valores de carácter ético, así como que en cierta medida puede frenar el necesario desarrollo y evolución del bien jurídico. Por lo que se puede concluir que ambas tesis, por separado, han demostrado su ineficacia para proporcionar un concepto de bien jurídico capaz de cumplir con la función crítica o político criminal ${ }^{146 .}$

Nosotros compartimos la opinión de que la distinción realizada sobre las tesis constitucionalistas estrictas y amplias versa fundamentalmente en el diferente grado de sujeción al articulado de la norma normarum, por lo que la frontera entre unas tesis y otras en ocasiones resulta muy débil, y a veces, es imperceptible. Además, hay que señalar que las teorías constitucionalistas (estrictas y amplias), así como también las sociológicas, coinciden en que el objeto de protección penal (bien jurídico penal) no es una creación del legislador, sino que requiere de un sustento de la realidad social que se pretende sea regulada por el Derecho ${ }^{147}$. Por lo cual es conveniente que el bien jurídico sea analizado con un concepto de raíz sociológica o social ubicado en el sistema social y confrontado dinámicamente con el mismo, pero, a su vez, la teoría del bien jurídico no debe obviar la escala de valores que ha sido recogida en la Constitución porque la norma fundamental constituye una premisa político criminal de gran trascendencia para la modulación del sistema penal. La Constitución, aparece así, como un instrumento teórico al servicio de los objetivos de la reforma penal y en consecuencia, de la política criminal ${ }^{148}$.

PORTILLA CONTRERAS, Guillermo. “Principio de intervención mínima y Bienes jurídicos colectivos”, en Cuadernos de Política Criminal № 39. Madrid, 1989, pp. 731, 735.

147 FABIÁN CAPARRÓS, Eduardo Ángel. El Delito de blanqueo... op. cit., pp. 170, 171. CADAVID QUINTERO, Alfonso. Introducción a la Teoría..., op. cit., p. 137. GARCIA- PABLOS DE MOLINA, Antonio. Introducción al estudio..., op. cit., p. 572. El concepto de bien jurídico, como todos los conceptos normativos, es una creación artificial, el producto de un consenso o de un proceso constitutivo en el que necesariamente es reelaborado $\mathrm{y}$, a veces manipulado y pervertido de sus elementos esenciales. De tal manera que poco se gana con decir que el Derecho Penal protege bienes jurídicos, si no hay acuerdo en lo que debe entenderse por tales. MUÑOZ CONDE, Francisco. Derecho Penal. P.G..., op. cit., p. 88. 
Una vez sentadas estas puntualizaciones optamos por un concepto de bien jurídico de corte sociológico y constitucionalmente orientado ${ }^{149}$, pues entendemos que "la concurrencia entre las posiciones sociológicas y constitucionales no es sólo posible, sino absolutamente necesaria", lo que nos conduce a concluir que la Constitución es un marco de referencia (compatibilidad) imprescindible pero insuficiente para la determinación de los bienes jurídico penales dada la complejidad y dinamismo de las relaciones sociales que existe en la actualidad, las cuales, bajo ningún concepto pueden ser ignoradas (dañosidad social). Otro criterio que no podemos dejar de observar es la necesaria orientación personal en el entendido de que el Derecho existe por y para los individuos considerados tanto individual como colectivamente ${ }^{150}$, siendo necesario además recurrir a los criterios de merecimiento, necesidad e idoneidad de pena para poder determinar qué realidades deben de ser objeto de tutela jurídico penal.

\section{LOS BIENES JURÍDICOS COLECTIVOS}

El tema de los bienes jurídicos colectivos en los últimos años ha generado una profunda discusión doctrinal, tan es así que se ha llegado a afirmar que la irrupción de estos bienes está estremeciendo los cimientos garantistas que han distinguido al Derecho Penal ${ }^{151}$. Sobre este tema algunos autores han llegado a la conclusión de que el Derecho Penal clásico es incapaz de proporcionar los medios necesarios "para enfrentar los nuevos modos de amenaza originados por la civilización técni-

149 FABIÁN CAPARRÓS, Eduardo Ángel. El Delito de blanqueo..., op. cit., p. 171. ROXIN, Claus. Derecho Penal. P.G..., op. cit., pp. 56- 58. CUELLO CONTRERAS, Joaquín. MAPELLI CAFFARENA, Borja. Curso de Derecho Penal. Parte General. Ed. Tecnos. Madrid. 2011, p. 32.

150 Como señala Hassemer el ciudadano no debe quedar funcionalizado en aras del Estado, sino que es el Estado el que debe funcionalizarse en aras del ciudadano. HASSEMER, Winfried. Persona, mundo, responsabilidad..., op. cit., p. 44. MUÑOZ CONDE, Francisco. Derecho Penal. P.G..., op. cit., pp. 60, 61. BUSTOS RAMÍREZ, Juan. HORMAZÁBAL MALARÉE, Hernan. Lecciones de Derecho Penal..., op. cit., p. 179.

151 HIRSCH, Hans Joachim. “Acerca del estado actual..., op. cit, p. 381- 385. SANTANA VEGA. Dulce María. La protección penal..., op. cit., p. 25. SOTO NAVARRO, Susana. La protección penal..., op. cit., pp. 213, 214. 
ca"152. Precisamente en atención a la revitalización de la discusión que se ha generado sobre este asunto, sobre su contenido, la necesidad de su tutela, su vinculación o relación material con los bienes jurídicos individuales, así como a las técnicas para la formulación de los tipos de peligro encargados de su protección, estimamos pertinente detenernos a analizar con mayor profundidad los denominados bienes jurídicos conocidos como bienes supraindividuales ${ }^{153}$, intereses difusos ${ }^{154}$ o bienes jurídicos colectivos.

En nuestra opinión resulta poco acertado denominar a estos bienes jurídicos supraindividuales, pues ellos no constituyen una categoría que esté por encima del individuo, ya que dichos bienes se encuentran en función de todos y cada uno de los miembros que componen la sociedad155. Sin embargo hay que decir que llamar a estos bienes jurídicos "supraindividuales" es una práctica bastante extendida tanto en la doctrina alemana como en la española. En el caso de los denominados "bienes jurídicos difusos" o "intereses difusos", hay que decir que se cuestiona, tanto su capacidad de proporcionar una base sólida que posibilite sustentar la protección penal de los intereses fundamentales de la sociedad siendo coherentes con el principio de intervención mínima, como la incapacidad epistemológica de su concepto, razones que nos hacen reflexionar sobre la conveniencia de su utilización en la dogmática jurídico penal ${ }^{156}$.

152 CARO CORIA, Dino Carlos. "Sociedades de riesgo y bienes jurídico colectivos", en Themis Revista de Derecho. Segunda época /1998/37. Lima, p. 197.

153 BUSTOS RAMÍREZ, Juan. Control Social..., op. cit., p. 196.

154 Bustos, traduce el término anteriormente aludido como "intereses difundidos". BUSTOS RAMÍREZ, Juan. . Control Social y Sistema Penal. Ed. PPU. Barcelona. 1987, p. 202. Fabián Caparrós, afirma que la noción de interessi diffusi (traducido incorrectamente al español como intereses difusos) fue introducida por Sgubbi en su conocido articulo tutela penali di interessi difussi. FABIÁN CAPARRÓS, Eduardo Ángel. El delito de blanqueo..., op cit., p. 181.

155 BUSTOS RAMÍREZ, Juan. Control Social..., op. cit., p. 196.

156 CARO CORIA, Dino Carlos. “Sociedades de riesgo..., op. cit., p. 208. Sgubbi muestra desconfianza hacia la categoría bien jurídico, expresando que la misma es fruto del Derecho subjetivo, sosteniendo que representa una visión burguesa que ha sido utilizada para tutelar derechos subjetivos o para proteger valores funcionales de los derechos subjetivos privados. Agregando que el Derecho Penal burgués "no ha utilizado jamás al 
Continuando con nuestro análisis sobre estos bienes jurídicos, nos encontramos que estos presentan como particularidad esencial su carácter masivo y universal, así, su lesión o puesta en peligro está referida a la colectividad en general o al menos a una parte de ésta, por lo que nos parece más apropiado referirnos a ellos como bienes jurídicos colectivos, lo cual es coherente con la postura mantenida por un sector muy importante de la doctrina que clasifica los bienes jurídicos en dos grupos fundamentales (independientemente de si estos tienen un sustrato material o inmaterial); los bienes jurídicos individuales que constituyen las bases mínimas para la existencia del sistema, referidos directamente a la persona como núcleo fundamental, a partir del cual se articula la sociedad, y un segundo grupo compuesto por los bienes jurídicos colectivos los cuales "son necesarios para el funcionamiento de la sociedad, aseguran las bases y las condiciones anteriores, y también sirven por lo tanto, aunque de una forma mediata, a los fines individuales"157. Queremos hacer énfasis en que los nuevos bienes jurídicos colectivos se caracterizan por que las fuentes de peligro para los mismos provienen de actividades lícitas y socialmente necesarias, que no pueden ser suprimidas, sino tan sólo sometidas a control.

\section{A.) LA TUTELA DE LOS BIENES JURÍDICOS COLECTIVOS}

Para empezar este apartado importante destacar que la tutela penal de los bienes jurídicos colectivos, surge, como respuesta a la necesidad de resolver nuevos conflictos que se plantean en la sociedad moderna (nuevas formas de ataque) ante la imposibilidad de su protección con las estructuras normativas típicas tradicionales de los bienes jurídicos individuales; por lo que se recurrió paulatinamente a fórmulas de naturaleza colectiva con referencia individual.

Doval Pais sin desestimar la utilidad la clasificación de bienes jurídicos individuales y bienes jurídicos colectivos dentro de la dogmática penal, propone una nueva clasificación que también consta de dos grupos: el primero de ellos compuesto por "los bienes jurídicos tradicionales", el

bien jurídico para dar protección a derechos antagónicos". SANTANA VEGA. Dulce María. La protección penal..., op. cit., p. 38. 
cual subdivide en: a) públicos (del Estado como institución en sus diversas manifestaciones y funciones), b) individuales (referidos a la persona) y c) los colectivos con referencia a los bienes jurídicos individuales (que aseguran la existencia de los bienes individuales: tal es el caso de la seguridad de tráfico, la salud pública o la seguridad en el trabajo). Afirmando que esta clasificación responde tanto a la configuración de estos bienes como a la relación que guardan con los bienes jurídicos individuales clásicos ${ }^{158}$.

El segundo grupo corresponde a los bienes jurídicos que él denomina "modernos o de nueva generación", los cuales constituyen una nueva especie que está integrada por una naturaleza propiamente difusa (como por ejemplo el orden económico, la ordenación del territorio o el medio ambiente). Estos objetos en su opinión, se presentan desligados de los bienes jurídicos individuales, por lo que entiende que constituyen bienes jurídicos colectivos autónomos fundamentándose su tutela unas veces casi exclusivamente en la obligación constitucional de protegerlos y en otras, se llega al extremo de apelar tautológicamente a su propio carácter de intereses difusos, lo cual no sucede con los bienes jurídicos colectivos que denomina tradicionales o clásicos que precisamente encuentran su base en la misma necesidad de protección de bienes esenciales para el desarrollo de la persona ${ }^{159}$. Con relación a los citados bienes jurídicos colectivos de nueva generación un parte de la doctrina opina que es bastante discutible que se trate de una plasmación de nuevas necesidades sociales, así Sgubbi señala que: "el Derecho Penal ha creado bienes jurídicos artificiales que son equiparables al ejercicio del monopolio del Estado sobre determinados intereses, a la exclusividad de la disciplina de dirección estatal en determinados sectores..., que no protege como objetos en sí..., sino como objetos en cuanto son un vehículo para la realización de fines políticos"160.

Como podemos apreciar, este profesor sostiene que existen dos clases o especies de bienes jurídicos colectivos; los tradicionales y los de nueva generación, los que entiende presentan diferencias relevantes por lo que precisan de un tratamiento dogmático atento a su diversidad, ya que no todos los bienes jurídicos colectivos tienen un origen común ni una estructura idéntica, como tampoco responden a las mismas necesidades de tutela. DOVAL PAIS, Antonio. "Estructura de las conductas... op cit, pp. 27, 28. 
Una clasificación similar, pero con algunas matizaciones es la que sostiene Cerezo Mir, que entiende que los delitos de peligro abstracto protegen dos tipos de bienes jurídicos colectivos, el primer grupo para él esta conformado por los bienes jurídicos colectivos (bienes jurídicos intermedios), en los cuales esta en primera línea un bien jurídico colectivo que es afectado o lesionado por la conducta descrita en el tipo y en un segundo orden esta un bien jurídico individual (mediatamente protegido), como ejemplo de estos cita los delitos contra la seguridad del tráfico viario o contra la salud pública. El segundo grupo está integrado por los que él denomina "bienes jurídicos supraindividuales" que tienen un carácter autónomo, tal es el caso de los delitos contra la Administración Pública o contra la Administración de Justicia161.

Como todos sabemos la doctrina en general asume la complementariedad de los bienes jurídicos colectivos con relación a los bienes jurídicos individuales, para Mata y Martín el carácter complementario se observa con mayor nitidez en los denominados "bienes jurídicos intermedios" o "de referente individual" en los que se vincula de forma simultanea la protección de bienes jurídicos individuales y bienes jurídicos colectivos de naturaleza homogénea o situados en una misma línea de ataque. Se produce en estos casos una relación medial, en el sentido que, "conforme a los requisitos establecidos por el legislador para la particular figura del delito, la de lesión o puesta en peligro de un bien jurídico colectivo (intermedio) es medio o paso previo necesario para la lesión o puesta en peligro del bien individual" 162 .

161 CEREZO MIR, José. "Los delitos de peligro abstracto" en Revista de Derecho Penal. Buenos Aires. 2001-1, pp. 730, 731, 745, 746. SOTO NAVARRO, Susana. "Concreción y lesión de los bienes jurídicos colectivos. El ejemplo de los delitos ambientales y urbanísticos” en Anuario de Derecho Penal y Ciencias Penales. Vol. LVII. 2005, p. 888. Los bienes jurídicos supra individuales se dividen en dos grupos: a) los bienes jurídicos intermedios, que se configuran como contextos previos de lesión de bienes jurídicos individuales y b) los bienes jurídicos institucionales, los cuales comprenden realidades sociales que no se perfilan como meros sectores de riesgo para intereses individuales, sino que son auténticos bienes públicos, instituciones esenciales para el desarrollo social basadas en la participación de sus integrantes, y que por ello, su lesión es autónoma. RODRÍGUEZ MONTAÑ́́S, Teresa. Delitos de peligro..., op. cit., pp. 299-304. GIL Y GIL, Alicia y otros autores. Curso de Derecho Penal. Parte General. Ed. Dykinson. Madrid. 2011, pp. 10-12.

162 Mata y Martín de acuerdo a la clasificación que él propone señala que en el Código Penal español son bienes jurídicos colectivos intermedios: el abandono de menores o incapaces (art. 231.2), el delito ecológico (art. 325), la protección del medio ambiente 
El profesor Bustos Ramírez asume que existen bienes jurídicos que están referidos a las bases y condiciones de subsistencia del sistema (la persona y su dignidad) que tienen un carácter micro-social, existiendo otros bienes relacionados al funcionamiento del sistema de carácter macro-social que aseguran materialmente las relaciones microsociales. Este segundo grupo de bienes jurídicos tiene tres subdivisiones; 1- Los bienes jurídicos institucionales referidos a instituciones básicas para el funcionamiento del sistema (delitos contra la correcta administración de justicia etc.). 2- Los bienes jurídicos colectivos que entiende están en referencia a la satisfacción de necesidades de carácter social y económico. 3- Finalmente tenemos a los bienes jurídicos de control que tienen que ver con la organización del aparato estatal para asegurar el cumplimento de sus funciones (delitos contra la autoridad, contra la seguridad interior y exterior del Estado, entre otros) ${ }^{163}$.

Este profesor opina que las mayores restricciones de la actividad punitiva deben producirse necesariamente en los bienes jurídicos referidos al funcionamiento del sistema, ya que una amplia intervención en este

en relación a depósitos y vertederos (art. 326), los delitos relativos a la energía nuclear y a las radiaciones ionizantes (arts. 341-343), los supuestos de fabricación, manipulación, transporte, tenencia o comercialización de sustancias peligrosas (art. 348) o de organismos (art. 349), la infracción de las normas de seguridad en las obras (art. 350), el tipo básico de incendio (art. 351), los incendios forestales (párrafo segundo del art. 352), el despacho de medicamentos deteriorados o caducados que incumplan las exigencias técnicas (art. 361), la alteración de la composición de medicamentos ( núm. 1 del art. 362.1), la imitación o simulación de medicamentos o sustancias beneficiosas para la salud (núm. 2 del precepto anterior), el deposito, anuncio, publicidad, ofrecimiento, exhibición, venta, facilitación o utilización de los medicamentos anteriores (362 bis), los fraudes alimentarios nocivos (art. 363), la adulteración de sustancias o bebidas destinadas al comercio alimentario (art. 364.1), la administración de sustancias no permitidas a animales destinados al consumo humano (art. 364.2), la conducción temeraria (art. 381), los desórdenes públicos (art. 557). Supuestos dudosos, ante la novedad que representan, serían los delitos relativos a la manipulación genética (arts. 159 y ss.) y los delitos societarios (art. 290 y ss.). MATA Y MARTÍN, Ricardo M. Bienes jurídicos intermedios y Delitos de peligro. Aproximación a los presupuestos de la técnica de peligro para los delitos que protegen bienes jurídicos intermedios (-tutela penal del medio ambiente, delitos económicos, seguridad del tráfico). Ed. Comares. Granada. 1997 , pp. 8, 9, 31, 32, 56, 57, 71, 72. En contra de la formulación propuesta por Mata y Martín por entender que difiere de la formulación planteada originalmente sobre esta categoría de bienes jurídicos elaborada por Schünemann. SOTO NAVARRO, Susana. La protección penal..., op. cit., pp 179- 186. 
sentido podría propiciar el cierre del sistema o provocar problemas en su funcionamiento como resultado de una desmesurada protección de los bienes jurídicos institucionales, manifestando que también es recomendable actuar de forma mesurada en el caso de los bienes jurídicos colectivos recomendando que tanto la protección de los bienes jurídicos colectivos como los de control, sin menoscabar su importancia, nunca deben ir más allá de lo fundamental para la atención de las necesidades de todos los miembros de la sociedad o de colectivos determinados, pues lo contrario, "sólo es expresión de la tendencia autoritaria de un régimen" 164 .

Creemos importante destacar que a los bienes jurídicos colectivos se les cuestiona de cierta manera su capacidad para ofrecer una base material precisa al ilícito penal, esto ocurre fundamentalmente en atención a su carácter masivo y universal. Pero verdaderamente de lo que se trata, es de tutelar materialmente las necesidades esenciales de los individuos, así la protección de su vida, su libertad y su salud adquieren un sentido material, siendo por lo tanto, los bienes jurídicos colectivos complementarios de los individuales en un sentido material ${ }^{165}$, de tal forma que los bienes jurídicos colectivos deben definirse partiendo de una relación social, que precisamente está basada en la satisfacción de las necesidades de todos y cada uno de los individuos que integran

164 Bustos, hace énfasis en la necesidad de restringir aún más cuando se trata de bienes jurídicos de control, dado que el aparato de control cuenta con poder suficiente, por lo que la criminalización de hechos en su contra debe realizarse de forma muy puntual, pues lo contrario podría conducir a la creación de Estados policiales. BUSTOS RAMÍREZ, Juan. Control social..., op. cit., pp. 200, 201. En el mismo sentido. HEFENDEHL, Roland. "El bien jurídico..., op. cit., pp. 402, 403.

Bustos, afirma que muchas de las críticas que se hacen a los bienes jurídicos colectivos están debidamente fundamentadas, ya que su formulación, en no pocas ocasiones, se realiza de forma muy imprecisa, citando como ejemplo de tal afirmación, que se habla de ataques a los créditos del Estado o al ordenado comercio, etc. BUSTOS RAMÍREZ, Juan. Control Social..., op. cit., pp. 195- 197. En este sentido en el ordenamiento jurídico penal alemán ha sido muy criticado el artículo 324 StGB, de este se dice que pretende proteger una situación que no puede conceptuarse como bien jurídico (la limpieza del agua), así como actos de contaminación, independientemente de que produzcan no ya algún efecto en la salud de las personas, sino incluso aunque no tengan ningún efecto sobre el agua. MENDOZA BUERGO, Blanca. El Derecho Penal..., op. cit., pp. 70- 72. 
la sociedad o de un colectivo en concordancia con el funcionamiento del sistema social ${ }^{166}$.

1. Sobre la expansión del Derecho Penal mediante la protección de nuevos bienes jurídicos colectivos

Sobre la expansión del Derecho Penal, Hassemer manifestó que "quien acepte los bienes jurídicos colectivos de forma amplia, corre el peligro de aceptar el Derecho Penal, no como última sino como la prima o la sola ratio de la protección de los bienes jurídicos"167. Constituyendo una preocupación muy extendida en, un sector importante de la doctrina, que mediante la tutela de intereses colectivos de forma desmesurada se hipertrofie el ordenamiento penal, por lo que le parece razonable a este profesor alemán que en la selección de los bienes jurídicopenales (incluidos los colectivos) se exija que aquélla, se realice sólo sobre aquellos intereses o valores cuya lesión o puesta en peligro pueda ser reconducible directa o indirectamente al individuo en aras de propiciar una mayor concreción en los delitos de peligro abstracto y por ende, su transformación en delitos de peligro concreto ${ }^{168}$. En esta

BAIGÚN, David (et. al.). "El bien jurídico orden económico". Estudios sobre Justicia Penal. Homenaje al Profesor Julio B. J. Maier. Ed. Editores del Puerto. Buenos Aires. 2005, pp, 25, 26. BUSTOS RAMÍREZ, Juan. Control Social..., op. cit., p. 197.

167 HASSEMER, Winfried. Persona, mundo, responsabilidad..., op. cit. Bases para una teoría de la imputación en el Derecho Penal. (Trad. MUÑOZ CONDE, Francisco. DIAZ PITA, Maria del Mar). Ed. Tirant lo Blanch. Valencia. 1999, pp. 68, 69. HASSEMER, Winfried. “¿Puede Haber delitos..., op. cit., pp. 95, 96. FERRAJOLI, Luigi. Derecho y razón..., op. cit., pp. 478, 479. HERZOG. Felix. "Límites al control penal..., op cit., pp. 317-321. MÉNDEZ RODRÍGUEZ, Cristina. Los Delitos de Peligro..., op. cit., p. 31. En el mismo sentido, respaldando una concepción personalista del bien jurídico sostiene; "que los bienes jurídicos colectivos o universales sólo son legítimos en tanto sirvan al desarrollo personal del individuo". MUÑOZ CONDE, Francisco. Derecho Penal. P.G..., op. cit., p. 61. POLAINO NAVARRETE, Miguel. “La controvertida legitimación..., op. cit., pp. 718, 747.

168 HASSEMER, Winfried. Persona, mundo, responsabilidad..., op. cit., p. 69. A favor de la orientación personalista de los bienes jurídicos colectivos. KARGL, Walter. "Protección de bienes jurídicos mediante protección del Derecho". (Trad. RAGUES i VALLES, Ramón) en ROMEO CASABONA, Carlos María (Dir). La insostenible situación del Derecho Penal. Ed. Comares. Granada. 2000, p. 57. NEUMANN, Ulfrid. "Alternativas: Ninguna..., op. cit., pp. 6, 10, 11, 14-16. "La referencia a la persona es la única garantía que posibilita limitar la finalidad preventiva del Derecho Penal y su función de protección de bienes jurídicos", pues los bienes jurídicos deben apreciarse en función de su repercusión en las personas, enfoque que entiende propio de un Estado democrático. CORCOY BI- 
dirección Roxin reivindica un concepto de bien jurídico liberal, personal y critico con la legislación ${ }^{169}$.

Queremos recalcar en este momento que una de las principales críticas que se le formulan al denominado "moderno Derecho Penal" es la perversión del principio de estricta protección de bienes jurídicos, lo cual supone una amenaza para él mismo, puesto que se está abandonado la misión hasta ahora encomendada a éste, de asegurar un mínimo ético, para convertirse en un instrumento de control de los grandes problemas sociales, pasando por ello de sancionar puntuales lesiones concretas a bienes jurídicos a la prevención a gran escala de situaciones problemáticas. Así, el sistema penal ya no protegería víctimas potenciales, sino meramente funciones ${ }^{170}$.

DÁSOLO, Mirentxu. Delitos de Peligro y Protección..., op. cit., p. 140. García-Pablos manifiesta que no esta de acuerdo con "el monismo ultraindividualista" propuesto por Hassemer, dado que no comparte las consecuencias político criminales que se desprenden del mismo, al negar la legítima y necesaria intervención del sistema penal en ámbitos preocupantes de la criminalidad organizada de nuestro tiempo. GARCÍA-PABLOS DE MOLINA, Antonio. Introducción al Derecho..., op. cit., pp. 179, 180, 722- 724. MENDOZA BUERGO, Blanca. Límites dogmáticos y político-criminales de los delitos de peligro abstracto. Ed. Comares. S. L. Granada. 2001, pp. 368, 369. MIR PUIG, Santiago. "Límites del normativismo en el Derecho Penal". MIR PUIG, Santiago (Dir.). Derecho Penal del siglo XXI. Ed. Consejo General del Poder Judicial. Madrid. 2008, pp. 58- 64. PORTILLA CONTRERAS, Guillermo. "Principio de intervención mínima y Bienes jurídicos colectivos", en Cuadernos de Política Criminal № 39. Madrid, 1989, p. 745. SÁNCHEZ GARCÍA DE PAZ, María Isabel. El moderno Derecho Penal y la anticipación de la tutela penal. Ed. Universidad de Valladolid. 1999, pp. 69, 74-76. MU. "La criminalización en el ámbito previo como tendencia política-criminal contemporánea" en QUINTERO OLIVARES, Gonzalo. MORALES PRATS, Fermín (Coordinadores). El nuevo Derecho Penal español. Estudios penales en memoria del profesor José Manuel Valle Muñiz. Ed. Aranzadi. Navarra. 2001, pp. 702- 709. En contra de la teoría personalista de bien jurídico. CARO CORIA, Dino Carlos. Derecho Penal del Ambiente..., op. cit., p. 510. GIL Y GIL, Alicia y otros autores. Curso de Derecho Penal. Parte General. Ed. Dykinson. Madrid. 2011, pp. 12, 13.

169 ROXIN, Claus. “¿Es la protección de bienes jurídicos una finalidad del Derecho penal?”. (Trad. ORTIZ DE URBINA GIMENO, Iñigo) en HEFENDEHL, Roland (Ed.). La teoría del bien jurídico. ¿Fundamento de legitimación del Derecho Penal o juego de abalorios dogmático?. Ed. Marcial Pons, ediciones jurídicas y sociales, S.A. Madrid. Barcelona. 2007, pp. 445- 449.

170 HASSEMER, Winfried. "Bienes jurídicos..., op. cit., p. 64. MENDOZA BUERGO, Blanca. El Derecho Penal..., op. cit, pp, 50, 51. NESTLER, Cornelius. "El principio de protección..., op. cit., p. 64. En contra, Jakobs afirma que el principio de protección de bienes jurídi- 
Como todos sabemos, una buena parte de los denominados tipos delictivos modernos se encuentran orientados a la protección de bienes jurídicos colectivos que fundamentalmente se corresponden a los ámbitos socio-económico y del medio ambiente, los cuales se formulan lamentablemente sin la precisión deseada, propiciando que se hable de la disolución del concepto del bien jurídico o de la desmaterialización del mismo, dado que estos no estarían constituidos por ninguna realidad empírica que sea perceptible y susceptible de ser referida a intereses específicos de las personas, sino por "las condiciones ideales, normativa y abstractamente definidas de la capacidad de funcionamiento adecuado conforme a su fin de determinados subsistemas o instituciones sociales o económicas". Tal es el caso del fraude de subvenciones (artículo $264 \mathrm{StGB}$ ), o el abuso de seguros (artículo $265 \mathrm{StGB}$ ). De estos tipos penales u otros de la misma naturaleza se dice que no protegen verdaderos bienes jurídicos, sino funciones u objetivos políticos, económicos o sociales que son utilizados como excusa para realizar una ampliación de la incriminación de conductas. Por ello algunos autores sostienen que el concepto de bien jurídico en el denominado Derecho Penal moderno únicamente poseería un carácter nominal ${ }^{171}$.

Silva Sánchez, sobre este tema, sostiene que nos encontramos, en un modelo de sociedad dirigido a "una restricción progresiva de las esferas de actuación arriesgada". Lo cual puede verse reflejado en algunos casos de desarrollo doctrinal y jurisprudencial, y más aún, esto se manifiesta también en la sociedad en una resistencia psicológica frente a la aceptación del caso fortuito, lo cual se materializa en una creciente tendencia hacia la transformación del accidente fortuito en injusto penal provocando el incremento de infracciones de deberes de cuidado,

cos propicia el adelantamiento de la barrera punitiva. JAKOBS, Günther. Bases para una teoría..., op. cit., pp. 211, 212.

171 El profesor Gonzalo Fernández señala; "la parábola involutiva” recorrida por el bien jurídico, la cual en sus orígenes tiene supuestamente una clara vocación limitadora de la actividad legislativa de criminalización primaria. Sin embargo afirma que la realidad ha demostrado una utilización del concepto del bien jurídico completamente distinta, tendiente a legitimar científicamente cualquier nuevo tipo penal. FERNANDEZ, Gonzalo D. Bien jurídico..., op. cit., pp, 5, 6. En la misma línea. MENDOZA BUERGO, Blanca. El Derecho Penal..., op. cit., pp. 68- 78. "Hasta los delitos de peligro menos graves y los delitos de peligro presunto podrían aferrarse a un bien jurídico de especial trascendencia para adquirir legitimación". LASCURAÍN SÁNCHEZ, Juan Antonio. “Bien jurídico..., op. cit., p. 135. 
así como de la tipificación de delitos de peligro, lo que nos lleva a un aumento significativo del ámbito de intervención del Derecho Penal ${ }^{172}$.

Es importante señalar que el Código Penal Español de 1995, ha extendido su campo de aplicación, con respecto al Código Penal anterior, a conductas que ya estaban tipificadas como infracciones administrativas de urbanismo, relaciones laborales, medio ambiente o consumo. De este modo se ha incrementado el elenco de comportamientos tipificados simultáneamente como infracciones administrativas y delitos, dando lugar a importantes problemas de delimitación tanto prácticos como teóricos. Cecilia Suay afirma, en este sentido, que el actual Código Penal ha invertido la tendencia despenalizadora observada desde finales de los años setenta, que transformó en infracciones administrativas varios delitos o faltas. Esta expansión penal se debe fundamentalmente a dos elementos: el primero responde a las propias deficiencias del régimen administrativo sancionador. El segundo elemento esta vinculado a la función simbólica que está cumpliendo el Derecho Penal, en una sociedad sometida a la influencia de los medios de comunicación. Así la penalización de no pocas conductas se realiza, no porque así se vayan a resolver realmente algún problema social, sino porque se aparenta que se va a resolver ${ }^{173}$.

172 SILVA SÁNCHEZ, Jesús María. La expansión del Derecho..., op. cit., pp. 42- 52. El modelo italiano en este sentido resulta paradigmático. Su Código Penal describe aproximadamente unos quinientos delitos, mientras que la legislación penal especial italiana contempla cerca de cinco mil delitos. La mayor parte de estos versa sobre delitos económicos, teniendo un destacado protagonismo en la misma las contravenciones, fiel modelo de la administrativización del Derecho Penal que constituye el $90 \%$ del total de la legislación penal especial. GARCÍA-PABLOS DE MOLINA, Antonio. Introducción..., op. cit, p. 224.

173 SUAY HERNÁNDEZ, Cecilia. "Los delitos contra la salubridad y seguridad del consumo en el marco de las relaciones entre el Derecho Penal y el Derecho Administrativo sancionador" en PICó LORENZO, Celsa. Las fronteras del Código Penal y el Derecho Administrativo sancionador. Ed. Consejo General del Poder Judicial. Madrid. 1997, pp. 126129. Sobre los paradigmas de unificación y diferenciación entre el Derecho Penal y el Derecho Administrativo Sancionador, así como sobre las bases para una delimitación entre ambos ordenamientos. Idem. pp. 129- 138. HERZOG. Felix. "Límites al control..., op. cit., pp. 323- 326. CUELLO CONTRERAS, Joaquín. MAPELLI CAFFARENA, Borja. Curso de Derecho Penal. Parte General. Ed. Tecnos. Madrid. 2011, pp. 32, 33. PÉREZ CEPEDA, Ana Isabel. "De la sociedad neoliberal del riesgo a la expansión de Derecho Penal" en MUÑOZ CONDE, Francisco José. Problemas actuales del Derecho Penal y de la Criminología. Estudios Penales en memoria de la Profesora. Dra. María del Mar Díaz Pita. Ed. Tirant lo Blanch. Valencia. 2008, pp. 165, 166, 183,-187. 
Stratenwerth en su ponencia inaugural de las Jornadas de profesores de Derecho Penal celebradas en Basilea en 1993, manifestó su rechazo a lo que él asume como una "retirada del Derecho Penal del terreno del aseguramiento de futuro" propuesta por la escuela de Frankfurt ${ }^{174}$ recomendando, que para enfrentar los riesgos que amenazan el futuro, el Derecho Penal debe ir más allá de la protección de bienes jurídicos anclados en el pensamiento antropocéntrico proponiendo la tutela jurídico-penal de normas de conductas referidas al futuro, sin necesidad de que exista retro-referencia a intereses individuales. Queremos señalar que esta posición la mantiene actualmente este profesor, expresando la necesidad de discutir estos temas "sin el gravamen del dogma del bien jurídico"175. De manera similar el profesor Bernd Schünemann sin re-

174 Algunos representantes de la escuela de Frankfurt como Hassemer, Naucke y Albretch se muestran contrarios a combatir los problemas de la sociedad moderna (aseguramiento de futuro), mediante el Derecho Penal por el temor de que en el afán de lograr una intervención efectiva en estos campos se sacrifiquen garantías esenciales del Estado de Derecho. Por ello Hassemer propone "una reducción del Derecho Penal a un Derecho Penal nuclear" y propugna resolver los nuevos o modernos problemas mediante un Derecho de la intervención, que esté situado entre; el Derecho Penal y el Derecho Contravencional, entre el Derecho Civil y el Derecho Público. Albrecht aboga por una retirada del Derecho Penal de la pretensión de control preventivo abarcándolo todo, y por un giro simultáneo hacia formas adecuadas de control que ya están disponibles en; el Derecho Civil, el Derecho Público y en el Derecho Social". ROXIN, Claus. Derecho Penal. P.G..., op. cit., pp. 61, 62. Muy crítica con el "Derecho Penal nuclear" propuesto por la escuela de Frankfurt se muestra Corcoy BIDÁSOLO, señalando que esta posición obedece a la voluntad de "proteger de la intervención penal a determinados sectores de la sociedad". CORCOY BIDÁSOLO, Mirentxu. Delitos de Peligro..., op. cit., pp. 184- 187.

175 STRATENWERTH, Günter. "La criminalización en los delitos contra bienes jurídicos colectivos". (Trad. ORTIZ DE URBINA GIMENO, Iñigo. VALLE MARISCAL DE GANTE, Margarita. HEFENDEHL, Roland (Ed.). La teoría del bien jurídico. ¿Fundamento de legitimación del Derecho Penal o juego de abalorios dogmático?. Ed. Marcial Pons, ediciones jurídicas y sociales, S.A. Madrid. Barcelona. 2007, pp. 371, 372. Critico con la posición de Stratenwerth. HEFENDEHL, Roland. "El bien jurídico..., op. cit. 8, p. 396. Stratenwerth, asumiendo que vivimos en una sociedad de riesgos, es partidario de que en delitos tales como los referidos al medio ambiente o tecnología genética, se deben proteger contextos de la vida sin necesidad de que estos se puedan reconducir a cualquiera de los participantes. ROXIN, Claus. Derecho Penal. P.G.., op. cit.., p. 62. En sentido similar Heine sostiene que El Derecho Penal debería reducir los peligros para la futura vida en común. HEINE, Günter. "La Ciencia del Derecho..., op. cit., pp, 433- 437. Mendoza Buergo señala que Stratenwerth, en los terrenos de lo que él denomina "aseguramiento del futuro" renuncia al concepto de bien jurídico, proponiendo que la dogmática jurídicopenal se refiera a normas de comportamiento generales, es decir, que se oriente al desvalor de la conducta. MENDOZA BUERGO, Blanca. El Derecho Penal..., op. cit., p. 74 
nunciar al concepto de bien jurídico, pero en franca oposición a la orientación personal de este, asevera que esta; "tiene en mayor consideración a la más absurda apetencia del individuo egoísta que a las condiciones de vida futuras"176. A favor de una plena funcionalización del Derecho Penal y sus categorías fundamentales, y en aras de propiciar la adaptación de las nuevas expectativas y tareas, especialmente las que surgen en relaciones de interacción en el ámbito colectivo se encuentran los profesores Jakobs y Müssig177.

En Alemania un importante sector doctrinal se muestra crítico en relación a la posibilidad de considerar suficientemente idóneo el efecto preventivo general de la pena, y más aún, de la eficacia preventiva de los tipos de peligro (abstracto) para la tutela de bienes jurídico colectivos poco delimitados. Prittwitz señala que el balance de la eficacia del Derecho Penal en las áreas donde se producen las presiones de criminalización es poco alentador. Más bien, refiere que el éxito es tan escaso, que incluso los partidarios más entusiastas de la intervención penal en estos ámbitos (medio ambiente, drogas, economía, criminalidad organizada) aceptan que hay una evidente crisis de efectividad en estos sectores. Afirma además este autor que si a esta crisis de efectividad le sumamos otra de legitimidad, el resultado del Derecho Penal de control

176 SCHÜNEMANN, Bernd. Consideraciones críticas sobre la situación espiritual de la Ciencia Jurídico- Penal Alemana. (Trad. CANCIO MELIÁ, Manuel). Ed. Universidad Externado de Colombia. Centro de Investigaciones de Derecho Penal y Filosofía del Derecho. Santafé de Bogotá. 1996, p. 22.

177 JAKOBS, Günther. “¿Dañosidad social?. Anotaciones sobre un problema teórico fundamental en el Derecho Penal". (Trad. Miguel Polaino- Orts) en Cuadernos de Política Criminal. Año 2010. Núm. 100, pp. 35-45. MÜSSIG, Bernd. “Desmaterialización del bien jurídico y de la Política Criminal. Sobre las perspectivas y los fundamentos de una teoría del bien jurídico crítica hacia el sistema". (Trad. Manuel Cancio Meliá y Enrique Peñaranda Ramos) en Revista de Derecho Penal y Criminología. 2a Época. Núm. 9 (2002), pp. 193-208. Kindhäuser acepta el discurso de la sociedad de riesgo, pero se muestra más preocupado por los problemas de legitimidad que acechan a la consecución de está seguridad a través del Derecho Penal. MENDOZA BUERGO, Blanca. El Derecho Penal..., op. cit., pp. 126, 127. FEIJOO SÁNCHEZ, Bernardo. "Sobre la administrativización del Derecho Penal en la sociedad del riesgo" en DIAZ- MAROTO Y VILLAREJO, Julio. (Dir.). Derecho y justicia penal. En homenaje al profesor Antonio González- Cuellar García. Ed. Colex. Madrid. 2006, pp. 151- 154. 
global resultaría evidente ${ }^{178}$. Hassemer con la intención de dar una respuesta a este problema propone la creación de un "Derecho de intervención", sin las exigencias de atribución de responsabilidad propias del Derecho Penal, aunque también sin las sanciones propias del mismo ${ }^{179}$. Silva Sánchez en similar dirección afirma que el problema radica no tanto en la expansión del Derecho Penal en general, sino en la expansión del Derecho Penal de la pena privativa de libertad, planteando la alternativa del denominado "Derecho Penal de dos velocidades"180. Estas propuestas que sin lugar a dudas persiguen un fin loable, salvaguardar las garantías penales para todos aquellos ilícitos que se sancionen con penas privativas de libertad, creemos que pueden ser resueltas, en buena medida, por el Derecho Administrativo sancionador o en su caso por las sanciones y medidas del Derecho Privado (civiles y mercantiles). Sin embargo queremos expresar que tal afirmación no desdice la necesidad de profundizar en el estudio de ambas propuestas con el fin de fortalecer el Derecho Administrativo sancionador, tarea, que de más esta decirlo, supera con creces el propósito de esta investigación.

178 En el sector doctrinal que mantiene esta posición podemos citar a: Prittwitz, Hassemer, Lüderssen, Albrecht, y Herzog. MENDOZA BUERGO, Blanca. El Derecho Penal..., op. cit., pp. 53- 55.

179 HASSEMER, Winfried. MUÑOZ CONDE, Francisco. La responsabilidad por el producto en el Derecho Penal. Ed. Tirant lo Blanch. Valencia. 1995, pp. 43 y ss. Ese Derecho de intervención que se propone como una vía intermedia entre el Derecho Penal y el Derecho Administrativo, y entre el Derecho Civil y el Derecho Público, no parece imprescindible como rama autónoma con entidad propia MENDOZA BUERGO, Blanca. El Derecho Penal..., op. cit., p. 183.

180 Silva plantea como solución que en aquellos delitos que lesionen o pongan en peligro verdaderos bienes jurídicos individuales o colectivos deben ser sancionados con pena privativa de libertad, debiendo de mantenerse en estos casos todos los criterios básicos de imputación y principios de garantías. Para los casos de los delitos de acumulación o de peligro presunto, que en su opinión deben de admitirse de forma resignada, propone que no tienen cabida las pena privativa de libertad, sobre estos ilícitos sostiene que pueden flexibilizarse los criterios de imputación. SILVA SÁNCHEZ, Jesús María. La expansión del Derecho..., op. cit, pp. 159- 162. En contra de esta propuesta. CEREZO MIR, José. "Los delitos de peligro..., op. cit, p. 733. En contra del Derecho Penal de dos velocidades se pronuncia también. MENDOZA BUERGO, Blanca. El Derecho Penal..., op. cit., pp. 184, 185. En total desacuerdo con el Derecho Penal de dos velocidades. CORCOY BIDÁSOLO, Mirentxu. "Protección de bienes jurídico-penales supraindividuales y Derecho Penal mínimo". MIR PUIG, Santiago (Dir.). Derecho Penal del siglo XXI. Ed. Consejo del Poder Judicial. Madrid. 2008, pp. 401, 402. 
Mirentxu Corcoy sostiene que se debe abogar por una concepción "del bien jurídico menos centrada en el daño y en el conflicto personal entre autor y víctima" siendo de la opinión de que debe atenderse más a la tutela de los intereses que la sociedad actual considera prevalentes, y no limitarse a la protección de los intereses individuales básicos (Derecho Penal nuclear) afirmando, que frente a la modernización que se produce en la sociedad el sistema penal está llamado a realizar esfuerzos para enfrentar los nuevos problemas sociales (informática, genética, industrialización etcétera) ${ }^{181}$.

En la misma línea Caro Coria señala que como consecuencia del desarrollo tecnológico que se está gestando en nuestras sociedades, nos encontramos con una serie de nuevos riesgos, citando como ejemplo de ello casos ampliamente conocidos tales como Cotergan ${ }^{182}$, Lederspray $^{183}$, Holzchutzmittel ${ }^{184}$ en Alemania y el aceite de Colza ${ }^{185}$ en Espa-

181 CORCOY BIDÁSOLO, Mirentxu. Delitos de Peligro..., op. cit., pp. 187- 189. GRACIA MARTÍN, Luis. "Contribución al esclarecimiento..., op. cit., pp. 142-168. GRACIA MARTIN, Luis. Prolegómenos para la lucha..., op. cit., pp. 130- 133.

Caso Contergan; este también es conocido como caso de la talidomida. Se trata de un tranquilizante cuyo componente principal es la talidomida, el cual estaba recomendado para mujeres embarazadas. A finales de los años 50 e inicios de los años 60 en la entonces República Federal Alemana como consecuencia de su consumo, se produjeron más de 10.000 casos de aborto, y graves daños en los sistemas óseos de los recién nacidos, los cuales morían al poco tiempo de nacer o sobrevivían con graves malformaciones, focomelias o extremidades en forma de foca, y lesiones irreversibles. CARO CORIA, Dino Carlos. "Sociedades de riesgo..., op. cit., p. 195. Ver la sentencia del Landgericht Aachen (Tribunal de los Länder alemanes) del 18 de diciembre de 1970. MENDOZA BUERGO, Blanca. El Derecho Penal..., op. cit., p. 98.

183 Este también es conocido como el caso Erdal, y consiste en la comercialización durante más de 20 años de un producto (spray o lederspray) recomendado para la protección de zapatos de cuero y prendas de vestir de este material. Como consecuencia de su uso la empresa productora recibió muchas reclamaciones de personas que usaron el producto en la forma indicada, y sufrieron dificultades respiratorias, náuseas, escalofríos o fiebre, detectándose en la mayoría de casos un edema pulmonar, produciéndose hasta el año 1986 casos similares. CARO CORIA, Dino Carlos. "Sociedades de riesgo..., op. cit., pp. 195, 196. Ver sentencia del Bundesgerichtshof (Tribunal Supremo Alemán) del 6 de julio de 1990. MENDOZA BUERGO, Blanca. El Derecho Penal..., op. cit., p. 98.

184 Se trata de una sustancia protectora de maderas, la cual fue producida desde los años 50 por la empresa D. Chemie GmbH, que logró eludir dos denuncias por presuntas lesiones interpuestas en 1956 y 1963. En los años 70 se popularizó en Alemania el consumo de estos productos, "razón por la cual la citada empresa comercializó el protector Xyladecor 200 que, entre sus principales componentes, contenía las sustancias PCP y 
ña, así como la utilización de energía nuclear o el uso del ambiente natural, lo cual en su opinión propicia que bienes jurídicos individuales tales como la vida, la salud o el patrimonio estén constantemente amenazados, lo que opina evidencia la imposibilidad de hacer frente a dichos riegos (sociedad de riesgo) en el marco del Derecho Penal clásico que se centra en la relación autor-víctima, de tal forma que los tradicionales instrumentos de que dispone el Derecho Penal resultan ineficaces, por lo que estima necesario crear nuevas técnicas de imputación que permitan la determinación de la responsabilidad de quienes realizan comportamientos no permitidos ex ante riesgosos que se realizan en la lesión o el peligro de los bienes tutelados. En tal línea de esfuerzos, se inscribe según el criterio de este autor "la protección generalizada de los bienes jurídicos colectivos, la reevaluación de los delitos imprudentes y omisivos, la técnica de los delitos de peligro y de la ley penal en blanco, la responsabilidad de las personas jurídicas y sus órganos de dirección, el distanciamiento del dogma causal y el reconoci-

Lindano, estableciendo hasta 1979 la indicación de apropiado para usos interiores, pese a que ningún estudio avalaba su inocuidad en tales circunstancias". Este producto fue el causante de la muerte de una persona en 1977, y de las lesiones padecidas por un gran numero de consumidores, consistentes en daños en la piel y mucosidades. CARO CORIA, Dino Carlos. "Sociedades de riesgo..., op. cit., p. 196. Ver sentencia del Oberlandesgericht (Tribunal Superior de los Länder alemanes) de Frankfurt del 19 de diciembre de 1991. MENDOZA BUERGO, Blanca. El Derecho Penal..., op. cit., p. 98.

185 En el mes de mayo de 1981 se produjo una epidemia localizada en Madrid y Torrejón de Ardoz, que posteriormente se extendió a otras zonas de España. Las lesiones correspondieron a una neumonía intersticial. Se estudiaron varias hipótesis sobre su causa, cobrando fuerza su atribución al aceite de colza desnaturalizado con anilina al $2 \%$, este producto se importó principalmente de Francia para actividades estrictamente industriales de modo, que para asegurarse el no desvío para el consumo humano, las autoridades administrativas ordenaban desnaturalizar los caracteres organolépticos del aceite mediante anilina al $2 \%$ entre otros productos. Sin embargo, mediante una serie de intervenciones individuales y de empresas, como RAPSA y RAELCA, dicho aceite desnaturalizado fue refinado y comercializado, fundamentalmente a través de vendedores ambulantes, en muchas regiones de España, lo cual tuvo como consecuencia al menos de 330 muertes y 15.000 afectados. CARO CORIA, Dino Carlos. "Sociedades de riesgo..., op. cit., p. 196. Ver las STS (ROJ: 20999/1992) de 23 de abril de 1992. Ponente: Dr. Enrique Bacigalupo y STS (ROJ: 5661) de 26 de septiembre de 1997. Ponente: D. Gregorio García Ancos. 
miento del valor del método de la imputación objetiva del resultado, entre otras construcciones dogmáticas" 186.

Queremos señalar para terminar este apartado que Roxin califica de "atrevidas" las críticas realizadas por algunos autores a la escuela de Frankfurt, basándose para ello en que la "nueva dogmática" que propugnan quienes comparten estas ideas, no es reconocible aún ni en sus perfiles, afirmando además que en todo caso esta "nueva dogmática" no tendrá la misión de sustituir a la actual dogmática, sino que estará llamada a complementarla, recordándonos, que aunque si bien es cierto que el futuro de nuestro planeta en la realidad actual se pone en peligro menos por personas individualmente consideradas que por colectividades (grandes empresas). Esta realidad lo que pone de manifiesto es la necesidad de desarrollar nuevos criterios de imputación, como también, es cierto que el aporte que puede realizar el Derecho Penal en este sentido es limitado. Piénsese por ejemplo en el papel que deben jugar en el aseguramiento del futuro los Tratados y Convenios internacionales, así como toda la labor de concienciación necesaria para cambiar las mentalidades (medios de control no formalizados), además del aporte que debe realizar todo el ordenamiento jurídico en este sentido, lo cual nos hace concluir que aunque tuviéramos que ir más allá de la tutela de bienes jurídicos por el Derecho Penal, protegiendo contextos de la vida como tales, sin duda alguna seguiría siendo válido el principio de subsidiaridad así como el carácter fragmentario ${ }^{187}$.

Para este autor somos testigos de una verdadera crisis del Derecho Penal liberal, siendo imperante la necesidad de desarrollar un modelo dogmático capaz de solventar los requerimientos político- criminales actuales. CARO CORIA, Dino Carlos. "Sociedades de riesgo..., op. cit., pp. 195- 198.

187 ROXIN, Claus. Derecho Penal. P.G..., op. cit., p. 62. Heine señala que el intento de desarrollar una dogmática general del riesgo se encuentra aún en pañales. HEINE, Günter. "La Ciencia del Derecho..., op. cit., pp, 434, 435. Realiza crítica a Stratenwerth y Schünemann sobre el papel que le conceden al Derecho Penal en el aseguramiento del futuro. PRITTWITZ, Cornelius. "Sociedad de riesgo y Derecho Penal" en ARROYO ZAPATERO, Luis. NEUMANN, Ulfrid. NIETO MARTÍN, Adán (Coord.). Crítica y justificación del Derecho Penal en el cambio de siglo. Ediciones de la Universidad de Castilla- La Macha. Cuenca. 2003, pp. 268- 273. SILVA SÁNCHEZ, Jesús María. “¿Protección penal del medio ambiente? Texto y contexto del artículo I y II” en La Ley. 1997-3, p. 1717. PÉREZ CEPEDA, Ana Isabel. “De la sociedad neoliberal..., op. cit., pp. 171-174. 


\section{Valoración sobre la legitimidad de los bienes jurídicos colectivos}

Compartimos con Mir Puig la idea de que existen dos enfoques posibles para la valoración de los intereses colectivos. El primero de estos exige su valoración tomando como base su importancia para el sistema social, lo cual sería propio de un Estado autoritario, que se caracterizaría por subordinar al individuo al todo social y por ende, al sistema. El segundo enfoque, que es el que nosotros secundamos, es propio de un Estado Social y Democrático de Derecho que propone la aceptación de los intereses colectivos en cuanto condicionen la vida de las personas; así el sistema social estará al servicio del individuo y no el individuo al servicio del sistema ${ }^{188}$, pues esta última orientación de más esta decir, resulta un riesgo que no debemos asumir en ningún sistema social por muy democrático que este sea, situación que es aún más inadmisible en democracias no consolidadas (democracias formales), tal es el caso de no pocos países del denominado tercer mundo donde el mantenimiento del sistema no consideramos sea lo más deseable para la inmensa mayoría de personas que viven en los mismos, por lo que asumimos plenamente que la determinación de los bienes jurídicos colectivos debe exigir necesariamente la constatación como mínimo de una determinada gravedad en la repercusión del interés colectivo en los individuos individualmente considerados. Así en la tensión que se produce entre lo individual y lo colectivo no consideramos suficiente comprobar la importancia abstracta del bien, sino que estimamos necesario constatar una importancia del concreto grado de menoscabo de dicho bien ${ }^{189}$.

188 Opina este profesor que el razonamiento realizado es fundamental para evitar la tendencia que a su entender tiene todo Estado social a hipertrofiar el Derecho Penal mediante una administrativización de su contenido de tutela. MIR PUIG, Santiago. El Derecho Penal en el Estado Social y Democrático de Derecho. Ed. Ariel. Barcelona. 1994, pp. 164, 165. MÉNDEZ RODRÍGUEZ, Cristina. Los Delitos de Peligro..., op. cit., pp. 32- 35.

189 MIR PUIG, Santiago. El Derecho Penal en el Estado..., op. cit., pp. 165, 166. La doctrina mayoritaria sostiene que el objeto del peligro común es la colectividad, pero esto no significa que deba de ponerse en peligro a una pluralidad de sujetos, sino que esa colectividad puede venir representada por una sola persona, indeterminada ex ante, como parte de esa colectividad. RODRÍGUEZ MONTAÑÉS, Teresa. Delitos de peligro..., op. cit., pp, 16, 17 . 
En la misma línea Muñoz Conde, siguiendo a Hassemer ${ }^{190}$, afirma que los bienes jurídicos colectivos sólo estarán legitimados en la medida en que sirvan al desarrollo personal del individuo ${ }^{191}$, pues de lo que se trata es de atender materialmente sus necesidades ${ }^{192}$, y como es sabido por todos, al ser las personas seres sociales, únicamente pueden asegurar sus intereses dentro del marco social y por ende de sus instituciones, lo que justifica en algunos casos la protección penal de dichas instituciones tales como la Administración de Justicia o la Administración publica. Sin embargo, es "preciso concebir tales bienes en un sentido instrumental respecto a la persona humana"193.

Cristina Méndez ${ }^{194}$ analizando el problema de la autonomía de los bienes jurídicos colectivos respecto a los individuales, sostiene que aunque es conocido que la protección de las relaciones y conflictos sociales encuentra su razón de ser en la relación social básica que es individual, por lo que en este sentido se puede hablar de bienes complementarios, no es correcto afirmar que los únicos bienes existentes son los individuales, y que por tanto los colectivos sólo sean formas de protección de éstos en atención a la evolución de las formas de ataque, afirmando que na es la única garantía que posibilita limitar la finalidad preventiva del Derecho Penal y su función de protección de bienes jurídicos". CORCOY BIDÁSOLO, Mirentxu. Delitos de Peligro..., op. cit., p. 140. Respalda también esta posición Fabián Caparrós afirmando que los bienes jurídicos independientemente de que su titularidad sea individual o colectiva son siempre personales, aseverando que siempre el sistema debe estar en función del individuo. FABIÁN CAPARRÓS, Eduardo Ángel. El Delito de Blanqueo..., op. cit., p. 182. En contra se pronuncia Tiedemann, quien contrapone los bienes jurídicos colectivos con los individuales como categorías independientes y desconectadas. Así para este autor la protección de bienes jurídicos colectivos como la economía o los intereses de la sociedad constituyen fines en sí mismos. SANTANA VEGA, Dulce María. La protección penal..., op. cit., pp. 84, 85.

192 Así tendrán que definirse los bienes jurídicos colectivos a partir de las relaciones sociales, las cuales se basan en la satisfacción de necesidades de cada uno de los miembros de la sociedad o de un colectivo y en conformidad con el sistema social. BUSTOS RAMÍREZ, Juan. Control Social..., op. cit., pp. 196, 197.

SILVA SÁNCHEZ, Jesús María. Aproximación al Derecho...op. cit., pp. 291, 292.

MÉNDEZ RODRÍGUEZ, Cristina. Los Delitos de Peligro..., op. cit., pp. 32- 35, 159. TERRADILLOS BASOCO, Juan Maria. "Peligro abstracto y garantías penales" en QUINTERO OLIVARES, Gonzalo.. El nuevo Derecho Penal..., op. cit., pp. 805, 806. 
los bienes jurídicos colectivos poseen sustantividad propia cuyo origen es la relación básica individual, pero cobra un significado que va más allá de ésta. Por esta razón asume que la estructuración de los delitos de peligro con relación a los bienes jurídicos colectivos "no tiene por que basarse ni tomar como objetivo a los bienes jurídicos individuales" 195 .

La respuesta a la interrogante $i$ son los bienes jurídicos colectivos entidades susceptibles de ser lesionadas? Es en nuestra opinión que depende del nivel de concreción alcanzado en la definición del bien jurídico, de tal manera, que la posibilidad de su lesión estará condicionada por el contenido de su definición. Así tratándose bienes jurídicos concebidos con un carácter muy amplio y por tanto vago, resulta difícil pensar en la posibilidad de su lesión, sin embargo resulta imaginable si se define el bien jurídico colectivo de forma más concreta, lo cual es coherente con el principio de lesividad, con el cual se cumple únicamente si el bien jurídico puede ser verdaderamente afectado. Con relación a los tipos de peligro consideramos que un bien sólo podrá ser puesto en peligro si es posible su lesión, lo cual puede expresarse de la siguiente manera "existen estados peligrosos porque estos pueden desembocar en lesión". Como ejemplo de lesión de bienes jurídicos colectivos nos remitimos a los delitos conocidos como "fraudes alimentarios" donde la salud pública como bien jurídico tutelado ha resultado lesionada cuando en la conducta concurren determinadas cualidades que la hacen ya potencialmente peligrosa para la salud de las personas, así la salud pública, en cuanto conjunto de condiciones que positiva y negativamente garantizan y fomentan la salud de los ciudadanos, debe entenderse previamente lesionada si el alimento nocivo circula ya por la cadena alimentaria. También puede citarse como ejemplo en este sentido la conducción temeraria regulada en el artículo 381 del Código Penal español ${ }^{196}$.

Corcoy Bidásolo también es partidaria de la autonomía de los bienes jurídicos colectivos. CORCOY BIDÁSOLO, Mirentxu. Delitos de Peligro..., op. cit., pp. 20, 44, 184. En la misma línea. CARO CORIA, Dino Carlos. Derecho Penal del Ambiente. Delitos y técnicas de tipificación. Ed. Gráfica Horizonte S. A. Lima. 1999, p. 510. "La relación que cabe establecer entre los bienes jurídicos individuales y los colectivos es más bien de dependencia reciproca". SOTO NAVARRO, Susana. La protección penal..., op. cit., pp. 179, 180, $231-233$. 
Bustos en este sentido afirma que, en los ilícitos que tutelan bienes jurídicos colectivos el injusto se fundamenta en la afección del bien de que se trate. Lo que implica que no es necesario que se ponga en peligro el bien jurídico individual, basta con la lesión del bien jurídico colectivo que se encuentra en una relación teleológica con los bienes jurídicos individuales, cuya protección, en último termino, es la que se pretende. En atención a lo sostenido hasta aquí, este autor, afirma que la protección de un bien jurídico colectivo puede adoptar, lo mismo que un individual, la forma de delito de lesión o de peligro. Pues no toda vez que hay un precepto que proteja un bien jurídico colectivo, necesariamente ha de haber un delito de peligro. Aclarando Corcoy Bidasolo que la lesión de un bien jurídico colectivo no debe de entenderse como la destrucción de este, sino como su afectación ${ }^{197 .}$

Otro aspecto a resolver en este apartado es la disponibilidad de los bienes jurídicos por sus titulares. En nuestra opinión al ser la titularidad de estos bienes compartida por todas las personas o por una colectividad de personas, con independencia de que la tutela de dichos bienes sea útil a cada uno de estos para alcanzar su desarrollo, nadie de forma individual tiene capacidad para disponer de dichos bienes, incluyendo en este sentido a las instituciones públicas (el Estado o la Administración). Por lo tanto la indisponibilidad de dichos bienes es trasladable al "conjunto de la masa que la ostentaría, de suyo, imposible de determinar a estos efectos"198. Un rasgo característico de los bienes jurídicos colectivos muy ligado a la indisponibilidad de estos, es

TA Y MARTÍN, Ricardo Bienes jurídicos intermedios..., op. cit., pp. 56- 61. "Para dar cumplimiento al principio de ofensividad puede sólo considerarse bien jurídico aquél que puede ser afectado" MÉNDEZ RODRÍGUEZ, Cristina. Los Delitos de Peligro..., op. cit., pp. 43, 160. SOTO NAVARRO, Susana. La protección penal..., op. cit., pp. 185, 186, 278. La lesión de los bienes jurídicos colectivos es un efecto que puede verificarse en el propio sistema social, si se adopta una perspectiva sociológica -normativa. Idem. p. 322. SOTO NAVARRO, Susana. “Concreción y lesión..., op. cit., pp. 903-910. GRACIA MARTÍN, Luis. “Contribución al esclarecimiento..., op. cit., pp. 163-165. op. cit., p. 252. CORCOY BIDÁSOLO, Mirentxu. Delitos de Peligro..., op. cit., pp. 233, 234.

198 Corcoy Bidásolo afirma, que aunque se tratara de la lesión o puesta en peligro de la correcta Administración de Justicia o de la Administración Pública, el Estado no tiene la disponibilidad de dichos bienes jurídicos. CORCOY BIDÁSOLO, Mirentxu. Delitos de Peligro..., op. cit., pp. 121, 204. DOVAL PAIS, Antonio. "Estructura de las Conductas..., op. cit., pp. 50, 68. SOTO NAVARRO, Susana. La protección penal..., op. cit., 195, 196. 
la indivisibilidad (que sólo poseen los bienes jurídicos colectivos), en este sentido Hefendehl apunta, que un bien jurídico será colectivo "cuando sea conceptual, fáctica o jurídicamente imposible dividir tal bien en partes y atribuirlas de forma individual en porciones"199.

Todo lo dicho hasta ahora sobre los bienes jurídicos penales colectivos nos lleva a afirmar que la legitimación de estos, independientemente de que puedan tener un carácter autónomo con relación a los bienes jurídicos individuales 200 y que necesiten un tratamiento acorde con su diversidad $^{201}$, estará condicionada a su utilidad para el desarrollo personal del individuo dentro del marco social, así como a las exigencias derivadas de los principios de merecimiento, necesidad e idoneidad de pena, lo cual nos lleva a concluir en este sentido que el Derecho Penal deberá seguir tutelando los bienes jurídicos más importantes (las con-

199 HEFENDEHL, Roland. "El bien jurídico como eje material de la norma penal". (Trad. MARTÍN LORENZO, María) en HEFENDEHL, Roland (Ed.). La teoría del bien jurídico. ¿Fundamento de legitimación del Derecho Penal o juego de abalorios dogmático?. Ed. Marcial Pons, ediciones jurídicas y sociales, S.A. Madrid. Barcelona. 2007, 188, 189. Opina lo mismo. SOTO NAVARRO, Susana. La protección penal de los bienes jurídicos colectivos en la sociedad moderna. Ed. Comares. Granada. 2003, pp. 213, 228. PAREDES CASTAÑón, José Manuel. El riesgo permitido en el Derecho Penal (Régimen jurídicopenal de las actividades peligrosas). Ed. Ministerio de Justicia e Interior. Secretaria General Técnica. Centro de publicaciones. Madrid. 1995, pp. 79, 80. SOTO NAVARRO, Susana. “Concreción y lesión..., op. cit., p. 887.

200 La autonomía de los bienes jurídicos colectivos es reivindicada por diversos autores entre ellos Caro Coria, quien aclara que al defender la autonomía de dichos bienes, no se refiere a un divorcio de estos con los bienes jurídicos individuales, pues entiende que los bienes colectivos tienen su incidencia en el funcionamiento del sistema, por lo que se encuentran al servicio de bienes micro- sociales, como la vida o la salud, por lo cual son de jerarquía inferior a los individuales y por lo tanto precisan de una tutela penal menos intensa pero autónoma de "cara a la eficacia penal sostenida en los fines preventivos y de protección de bienes jurídicos". Este autor muestra serias reservas al carácter personalista del bien jurídico penal que nosotros compartimos, entendiendo que está opción "conduce a resultados político criminales que están reñidos con las necesidades de protección penal de los propios bienes jurídicos individuales". CARO CORIA, Dino Carlos. "Sociedades de riesgo..., op. cit., pp. 198, 201, 202. Corcoy BIDÁSOLO también reconoce la autonomía de los bienes jurídicos colectivos. CORCOY BIDÁSOLO, Mirentxu. Delitos de Peligro..., op. cit., p. 207. En el mismo sentido Doval Pais asevera que a los bienes jurídicos colectivos se les debe procurar un tratamiento atento a su diversidad. Expresando que "es difícil negar que se constituyan en bienes jurídicos colectivos autónomos". DOVAL PAIS, Antonio. “Estructura de las Conductas..., op. cit., p. 28. 
diciones esenciales que todas las personas consideradas tanto individual como colectivamente necesitan para su autorrealización y el desarrollo de su personalidad en la vida social), de sus modalidades de ataque más graves, cuando estos, no puedan protegerse por otro medio menos lesivo que el Derecho Penal, dándole cumplimiento a los principios de subsidiaridad, fragmentariedad y ultima ratio.

\section{TOMA DE POSTURA SOBRE LOS BIENES JURÍDICOS}

Una vez realizado estas consideraciones sobre la teoría del bien jurídico, nos permitimos realizar las conclusiones que estimamos fundamentales sobre el tema para reivindicar la función crítica o de política criminal que necesariamente debe desplegar el bien jurídico penal, la cual se ha querido negar en los últimos tiempos por los representantes del funcionalismo sistémico, también conocido como "funcionalismo radical", "funcionalismo extremo" o "normativismo radical". Con el fin de centrar el asunto que nos ocupa, nos aventuramos a realizar una aproximación al concepto de bien jurídico, el cual formulamos tomando como referencia el concepto ofrecido por el profesor Muñoz Conde, así llegamos a la conclusión de que bienes jurídicos serán las condiciones esenciales que todas las personas consideradas tanto individual como colectivamente necesitan para su autorrealización y el desarrollo de su personalidad en la vida social ${ }^{202}$. En este concepto se advierte la orientación personal del bien jurídico, lo cual de ninguna manera niega la protección de bienes jurídicos colectivos, siempre que la lesión o puesta en peligro de estos, afecte la realización personal de los individuos que integran la sociedad, siendo imprescindible para ello, sin duda alguna, el reconocimiento de la dignidad humana y por consiguiente, el libre desarrollo de la personalidad. Queremos hacer la aclaración de que las condiciones esenciales a las que nos referimos pueden consistir tanto en objetos materiales como inmateriales, relaciones, intereses o derechos que necesariamente deben ser socialmente valiosos. Las condiciones antes aludidas requieren tener además un titular concreto (las personas consideradas tanto individual como colectivamente) 203.

202 MUÑOZ CONDE, Francisco. Derecho Penal. P.G...., op. cit., p. 59.

203 LUZÓN PEÑA, Diego Manuel. Curso de Derecho..., op. cit., p. 327. MUÑOZ CONDE, Francisco. Derecho Penal. P.G., p. 61. Silva Sánchez afirma que al ser las personas seres emi- 
Como ya sostuvimos en un apartado anterior de este trabajo, nosotros partimos de la idea comúnmente aceptada por la doctrina de que el legislador no crea los bienes jurídicos, sino que estos surgen del desarrollo social y al Derecho lo que le compete es reconocerlos, otorgarles tal categoría. Así, Roxin afirma que el concepto material de delito es previo al Código Penal y que éste, dota al legislador de un criterio políticocriminal para determinar las conductas o comportamientos que deben criminalizarse ${ }^{204}$. Asumida esta idea nos pronunciamos a favor de un concepto de bien jurídico trascendente al sistema, en los términos antes señalados, rechazando de forma tajante aquellas concepciones inmanentes que dejan relegado al bien jurídico a un simple problema interpretativo, lo cual nos obligaría a buscar el contenido de este en la misma norma, situación que consideramos nos conduciría a un círculo vicioso, pues bastaría con la simple desobediencia a la norma para justificar la protección penal. De esta manera la desobediencia al Estado 205 justificaría sobradamente la incriminación de cualquier conducta, de lo cual se infiere que un presupuesto que reviste vital importancia en la búsqueda del concepto material del bien jurídico-penal, es precisamente que este no debe perder la vinculación con la realidad social en la cual debe operar. De esto, se deduce que para que pueda cumplir con la función crítica limitando al legislador y a los jueces en los procesos de criminalización primaria y secundaria, tiene que ser coherente y funcional a un sistema de valores que están relacionados de forma directa con la realidad histórica que se vive y la que se pretende alcanzar206. El Tribunal Supremo Español sobre este tema afirma que "desde

nentemente sociales, sólo se puede preservar y asegurar sus intereses dentro de la sociedad y de las instituciones de la misma, lo que legitima la protección en ciertos casos de la Administración Pública o la Administración de Justicia, siendo necesario concebir tales bienes en un sentido instrumental respecto a la persona humana. SILVA SÁNCHEZ, Jesús María. Aproximación al Derecho..., op. cit., pp. 291, 292. MIR PUIG, Santiago. Derecho Penal. P.G..., op. cit., p. 122.

204 Al referirse al concepto material de delito el profesor Roxin nos advierte que el concepto abstracto de bien jurídico tutelado despliega toda su virtualidad, y se acredita al concretarse en cada figura delictiva, ya que en su opinión un concepto formal de bien jurídico carece de significado desde el punto de vista político-criminal. ROXIN, Claus. Derecho Penal. P.G..., op. cit., p. 51. En el mismo sentido. DOVAL PAIS. Antonio. Delitos de Fraude..., op. cit., p. 165.

BUSTOS RAMÍREZ, Juan. Control Social..., op. cit., pp. 137, 138.

206 BERDUGO GOMÉZ DE LA TORRE, Ignacio. Reflexiones sobre la problemática..., op. cit., p. 9. 
el punto de vista de la antijuricidad material lo que se requiere es que el hecho no solo infrinja una norma sino que además produzca la lesión de un bien jurídico"207.

Continuando con el desarrollo de nuestras conclusiones, queremos afirmar que asumimos plenamente que el principio de exclusiva protección de bienes jurídicos adquiere pleno significado con la acción del Estado Social y Democrático de Derecho (ESDD) ${ }^{208}$ en el campo penal, pues sólo de la acción de un Estado Democrático es posible esperar que se realice apropiadamente el proceso de selección de los intereses sociales transformables en bienes jurídico-penales, y que en esta transformación, no se reelaboren de forma errónea o no se perviertan en sus elementos esenciales tales intereses. Es preciso aclarar que lo afirmado anteriormente no quiere decir que no exista riesgo de que no ocurra así, ni de que dicho riesgo no se materialice en algunas ocasiones, pues lo que queremos evidenciar es que el modelo de ESDD es ne-

207 STS (ROJ: 4335/2003) de 21 de junio de 2003. Ponente: D. Enrique Bacigalupo Zapater. "Tratándose de un delito de peligro, aun cuando sea abstracto dicho peligro como riesgo de futura lesión del bien jurídico, debe contenerse en la acción, quedando excluidos aquellas totalmente inadecuadas para lesionar o poner en peligro, aun potencialmente, la salud pública"..., "lo que sanciona es la puesta en peligro del bien jurídico, razón por la cual deben de quedar excluidas de la punición por este delito aquellas conductas en las que, aun cuando aparentemente se realice la conducta típica, por las especiales o excepcionales circunstancias que concurren en el caso concreto, puede excluirse totalmente la generación de riesgo alguno para el bien jurídico protegido". STS (ROJ: 4708/2003) de 4 de julio de 2003. Ponente: D. Cándido Conde-Pumpido Touron. "Esta Sala viene declarando, incluso en casos de tráfico efectivo, que cuando la cantidad de droga transmitida es tan insignificante que resulta incapaz de producir efecto nocivo alguno a la salud, carece de antijuridicidad material por falta de un verdadero riesgo para el bien jurídico protegido en el tipo". STS (ROJ: 5898/2001) de 29 de julio de 2001. Ponente: D. Adolfo Prego de Oliver Tolivar. En el mismo sentido. STS (ROJ: 9063/2000) de 11 de diciembre de 2000. Ponente: D. Adolfo Prego de Oliver Tolivar. STS (ROJ: 4708/2003) de 4 de julio de 2003. Ponente Cándido Conde-Pumpido Tourón.

208 Cascajo Castro entiende el ESDD como un principio constitutivo de la democracia constitucional española, por lo cual suscribe la tesis que sostiene "la compatibilidad de los principios del Estado Social de Derecho con las clásicas garantías jurídico formales propias del Estado Liberal Democrático". Tesis que se materializa en el artículo 1 de la Constitución española. CASCAJO CASTRO, José Luis. "La voz Estado Social y Democrático de Derecho: Materiales para un léxico constitucional español", en Revista del Centro de estudios Constitucionales. Num. 12 Mayo- Agosto 1992, pp. 11,12, 23. 
cesario como punto de referencia imprescindible para la construcción de un concepto material de bien jurídico penal209.

Siguiendo con esta línea de ideas queremos destacar que, como es mayoritariamente aceptado, es función del Estado la protección de bienes jurídicos, para lo cual este dispone de diferentes medios de control (formalizados y no formalizados). Entre éstos, cuenta con las diferentes ramas del ordenamiento jurídico del cual es parte integrante el Derecho Penal, al que siendo consecuentes con los principios de fragmentariedad, subsidiaridad, y última ratio no le corresponde la tutela de todos los bienes jurídicos, sino sólo de aquellos esenciales para posibilitar la participación de las personas individualmente consideradas en el sistema social de tal forma que si la tutela de determinados bienes jurídicos puede dispensarse por cualquier otra rama del ordenamiento jurídico u otro medio de control social no formalizado, debe preferirse éste ${ }^{210}$, pues, el Derecho Penal está llamado a proteger los bienes más importantes para el desarrollo de las personas en el marco social, frente a las modalidades de ataque más graves, lo que pone de manifiesto que el concepto de bien jurídico es mucho más amplio que el de bien

209 OCTAVIO DE TOLEDO Y UBIETO, Emilio. “Función y límites..., op. cit., p. 15. Para el profesor Pérez Royo la fórmula ESDD es compleja por que los dos elementos de la misma están muy desigualmente delimitados. Sostiene que actualmente los problemas los plantea fundamentalmente el término "social", dado que los demás están bastante claros. Por lo que estima necesario descomponer la fórmula y analizar de forma separada los dos elementos de la misma, análisis que debe realizarse en el orden opuesto al que han sido empleados por el constituyente, ya que tanto desde un punto de vista lógico como histórico el estudio del Estado Democrático de Derecho tiene que preceder al estudio del Estado Social de Derecho. Sobre la primera fórmula cabe decir que Estado de Derecho y Estado Democrático son términos idénticos. "Un Estado que no sea democrático es, por definición un Estado que no es de Derecho". En lo referido al Estado Social de Derecho, el Estado sigue siendo un Estado de Derecho, se trata de un "Estado garantista del individuo frente al poder y el intercambio con los demás ciudadanos, pero es también un Estado social, esto es, un Estado comprometido con la promoción del bienestar de la sociedad y de manera muy especial con la de aquellos sectores más desfavorecidos de la misma". Por tanto el Estado Social es una consecuencia del proceso de democratización del Estado. Este profesor afirma que todos los Estados democráticos europeos del siglo XX han sido Estados sociales, y sin embargo, sólo algunos los son por imperativo constitucional. Expresando que en la comparación entre unos y otros no se pueden detectar diferencias esenciales. PEREZ ROYO, Javier. Curso de Derecho Constitucional. Décima edición. Marcial Pons. Madrid. 2005, pp. 191- 194.

210 DEMETRIO CRESPO, Eduardo. Curso de Derecho Penal..., op. cit., pp. 8-11. QUINTERO OLIVARES, Gonzalo. Parte General..., op. cit. pp. 75, 76. 
jurídico penal211. De lo sostenido en este párrafo se deduce que nos oponemos a las leyes penales de carácter simbólico que no sirven para la protección de bienes jurídicos, sino que persiguen fines extrapenales, como la tranquilidad del electorado o la de procurarle una buena imagen al Estado 212 .

Para poder proseguir con nuestro estudio sobre la búsqueda del concepto material del bien jurídico penal estimamos conveniente realizar las siguientes puntualizaciones; la primera de ellas consiste en que no debemos identificar el bien jurídico-penal con el objeto jurídico de la acción o del delito, pues el bien jurídico aunque puede poseer un sustrato tanto material como inmaterial, este sustrato no constituye un bien hasta que se le agrega la consideración valorativa de estimarle esencial para el desarrollo del individuo en la sociedad, mientras que el objeto material es aquel sobre el que en algunos delitos recae la acción ${ }^{213}$. Tampoco debemos incurrir en el error de confundir los bienes jurídico-penales con los derechos fundamentales. Aunque existan realidades que puedan poseer ambas condiciones en muchas ocasiones, sin embargo no todos los derechos fundamentales adquieren la categoría de bien jurídico-penal, pues como todos sabemos se exige algo más que la consagración constitucional para que un determinado bien sea tutelado penalmente. Análoga situación ocurre con los derechos humanos. Creemos necesario también afirmar en este apartado que el bien jurídico-penal no tiene porqué coincidir con un bien que deba ser per-

211 MIR PUIG, Santiago. Derecho Penal P.G..., op. cit., pp. 125- 130.

212 ROXIN, Claus. “¿Es la protección de bienes jurídicos una finalidad del Derecho penal?”. (Trad. ORTIZ DE URBINA GIMENO, Iñigo) en HEFENDEHL, Roland (Ed.). La teoría del bien jurídico. ¿Fundamento de legitimación del Derecho Penal o juego de abalorios dogmático?. Ed. Marcial Pons, ediciones jurídicas y sociales, S.A. Madrid. Barcelona. 2007, p. 451.

213 Para diferenciar bien jurídico del objeto de la acción, podemos tomar como ejemplo que en el homicidio, el objeto material lo constituiría la parte del cuerpo humano que recibe el impacto de un proyectil, mientras que el bien jurídico lo constituye la vida como algo individual y socialmente dañoso. LUZÓN PEÑA, Diego Manuel. Curso de Derecho Penal..., op. cit., p. 328. "El concepto de bien jurídico, como todos los conceptos normativos, es una creación artificial, el producto de un consenso o de un proceso constitutivo, en el que necesariamente es reelaborado y, a veces, manipulado y pervertido en sus elementos esenciales. De tal modo que poco se gana con decir que el Derecho Penal protege bienes jurídicos, si antes no nos ponemos de acuerdo sobre lo que entendemos por tales". MUÑOZ CONDE, Francisco. Derecho Penal. P. G...,op. cit., p. 78. 
ceptible sensorialmente, pues como afirmamos anteriormente su sustrato puede ser tanto material como inmaterial.

Siempre con el fin de establecer un concepto de bien jurídico-penal, podemos afirmar que gozan de cómoda postura en la doctrina las posiciones que mantienen que las conductas inmorales, siempre que no sean lesivas para los derechos de los demás, deben estar excluidas del Derecho Penal214. Como ejemplo de ello podemos citar la homosexualidad entre adultos, cuando exista el debido consentimiento o acuerdo entre los intervinientes y, no se perturbe a otras personas. En situaciones de tal naturaleza tendremos que coincidir en que se puede estar lesionando conceptos generales como "la moral", pero en ningún caso se estarán lesionando bienes jurídicos penales que puedan ser determinables. Tampoco son admisibles bienes jurídicos que protejan finalidades meramente ideológicas, como por ejemplo la necesaria conservación de la pureza de la raza, o aquellos que quieran proteger intereses religiosos por más extendidos que estos estén en la sociedad. De esta forma, la protección de normas morales, ideológicas o religiosas cuya lesión o puesta en peligro no posea relevancia social, no deben ser objeto de tutela del Derecho Penal por muy extendida que sea su aceptación, pues es deber del Estado Social y Democrático de Derecho en todo caso proteger las posiciones discrepantes que mantengan las minorí$a^{215}$. Aclaramos que al afirmar que no deben tutelarse penalmente intereses estrictamente morales, no negamos que coincidan en gran medida los bienes jurídicos penales con los bienes morales más importantes, pero se exigen que tengan algo más que los haga merecedores de protección penal216, consistente en la relevancia o dañosidad social que deben comportar, dañosidad que debe ser entendida en sus justas dimensiones. En consecuencia, sólo deberán considerarse bienes jurídicos aquellas realidades con trascendencia social constatable ${ }^{217}$.

214 Cadavid Quintero sostiene que la posibilidad de dispensar tutela penal a valores morales, debe de estimarse en "sus justas dimensiones", ya que entiende que a veces su protección resulta lógica e inevitable. CADAVID QUINTERO, Alfonso Introducción..., op. cit., p. 131.

215 ROXIN, Claus. Derecho Penal. P.G..., op. cit., pp. 52, 56, 62.

216 MIR PUIG, Santiago. Derecho Penal P.G..., op. cit., pp. 128, 129.

217 CADAVID QUINTERO, Alfonso. Introducción..., op. cit., pp. 110- 113, 116. 
Lo dicho hasta aquí nos permite afirmar que la dañosidad social que reviste la lesión o puesta en peligro de bienes, es criterio suficiente para legitimar la protección de bienes jurídicos. Sin embargo, esta resulta necesaria, pero es insuficiente para legitimar la protección penal de dichos bienes jurídicos, ya que la tutela penal demanda la necesaria referencia de afectación individual en las posibilidades de participación en la sociedad, así como la atención a diferentes criterios derivados del principio de proporcionalidad ${ }^{218}$. Como podemos observar, el objeto de tutela penal deberá estar referido a las posibilidades de participación de las personas en el sistema social, de tal forma, que cuando no se limite esta posibilidad o no se afecte en alguna medida dicha posibilidad, no estaremos ante ningún hecho delictivo, pues no se habrá lesionado o puesto en peligro ningún bien jurídico penal219.

Para seguir avanzando en la concreción del concepto material del bien jurídico penal, nos resulta de gran utilidad la orientación constitucional entendida no en un sentido estricto, sino vinculada con el dinamismo del desarrollo social y las exigencias que de él se derivan siendo innegable, que la teoría del bien jurídico no debe obviar la escala de valores que ha sido recogida en la Constitución, ya que la norma fundamental constituye una premisa político-criminal de gran trascendencia para la modulación del sistema penal. La Constitución aparece así como un instrumento teórico al servicio de los objetivos de la reforma penal y en consecuencia, de la política criminal 220.

Resulta además necesario de conformidad con el principio de proporcionalidad realizar una ponderación de intereses entre las libertades creadas o protegidas por el Estado y las que se restringen con la impo-

218 Silva Sánchez afirma que la combinación de los aspectos de afectación de los individuos y la dañosidad social nos permite la exclusión de los comportamientos estrictamente inmorales, así como la protección penal de otros valores o estrategias meramente políticas. SILVA SÁNCHEZ, Jesús María. Aproximación al Derecho..., op. cit., pp. 272, 276.

219 CADAVID QUINTERO, Alfonso. Introducción..., op. cit, p. 132.

220 QUINTERO OLIVARES, Gonzalo. MORALES PRATS, Fermín. Parte General..., op. cit., pp. 273, 274. Mir Puig manifiesta que no debemos olvidar que la función principal de la Constitución no es la de regular el comportamiento de las personas entre sí, sino la de establecer las claves fundamentales del ejercicio del poder político. MIR PUIG, Santiago. “Bien jurídico..., op. cit., p. 210. 
sición de las penas y medidas de seguridad ${ }^{221}$. Como todos sabemos el Estado irremediablemente para poder crear seguridad se ve en la obligación de restringir libertad, por lo cual se propone la exigencia de que entre la seguridad creada y la libertad restringida se produzca un saldo positivo. Además el Estado, está obligado a elegir siempre la medida menos ofensiva, de forma tal que se obtenga la máxima protección al mínimo coste que supone a su vez, el máximo de libertad, por lo que el bien lesionado o puesto en peligro, debe ser más importante o al menos semejante al bien restringido ${ }^{222}$. Lo que expresado en forma coloquial podría explicarse de la siguiente manera; no puede de ninguna manera resultar más grave para las personas el medicamento que la propia enfermedad.

Otro límite frente a la determinación de los bienes jurídico-penales, como ya señalamos antes, lo encontramos en el respeto que debe existir hacia la dignidad humana (principio de humanidad), pues no es correcto que el Estado para reprimir hechos punibles, formule normas de comportamiento jurídico-penales a costa de una infracción de la dignidad humana, pues con ello la protección de los bienes jurídicos perdería su legitimidad, dado que la principal tarea del Derecho Penal, y en consecuencia, de todo el sistema penal, consiste en "proporcionar una concordancia práctica y en armonizar - bajo la garantía de dignidad humana- la protección de los bienes jurídicos de la víctima del hecho, incluida la comunidad, y la protección de los derechos fundamentales del autor" conforme a lo establecido a tal efecto en la Ley Fundamental, así como al principio de proporcionalidad ${ }^{223}$.

221 Nos resulta verdaderamente razonable en este sentido, que los bienes lesionados o puestos en peligro deben ser más importantes o al menos semejantes, que los bienes que se restringen mediante la imposición de las penas y/o medidas de seguridad. Ibidem., p. 211.

222 ABANTO VÁSQUEZ, Manuel A. "Acerca de la teoría..., op. cit., p. 13. ALVAREZ GARCÍA, Francisco Javier. "Bien jurídico..., op. cit., p. 31.

223 WOLTER, Jürgen. "Derechos humanos y protección de bienes jurídicos en un sistema Europeo del Derecho Penal". (Trad. BALDÓ LAVILLA, Francisco) en SCHÜNEMANN, B., FIGUEREIDO DIAS (Coord.). SILVA SÁNCHEZ, Jesús María (Ed.). Fundamentos de un sistema Europeo del Derecho Penal. Ed. J.M. Bosch Editor, S.A. Barcelona, 1995, pp. 40, 41, 51. "El principio de proporcionalidad es así la clave para la conformación de un Derecho Penal reducido a lo estrictamente necesario y ventajoso en la protección de la libertad, de la autonomía personal de los ciudadanos". LASCURAÍN SÁNCHEZ, Juan An- 
Una vez establecida la necesidad de la exigencia de dañosidad social, la obligada referencia individual (entendida como posibilidad de participación social) y la indispensable orientación constitucional, entendemos que se cumple en buena medida con los criterios de merecimiento de pena, lo cual nos permite establecer qué comportamientos humanos merecen tutela penal. Pero aunque se cumplan las exigencias anteriormente relacionadas, aún no logramos determinar que comportamientos deben incriminarse atendiendo a lo oportuna que debe resultar la intervención penal, o dicho de otra forma, a la efectividad o utilidad de dicha intervención ${ }^{224}$, para lo cual es imprescindible recurrir a criterios de necesidad de pena los cuales responden a juicios de utilidad o eficiencia, lo que obliga a proteger bienes jurídicos al menor coste social posible. Así, deberán de preferirse medios menos lesivos, como el Derecho Administrativo, el Derecho Civil, así como otros medios extrapenales y sólo cuando no sea posible dispensar la protección por estos medios, debe recurrirse al Derecho Penal, exigiéndose también que la pena sea útil para motivar la inhibición de tales conductas 225 , lo cual está vinculado al principio de efectividad, también denominado de eficacia o idoneidad que exige que el Derecho Penal sólo estará llamado a intervenir cuando resulte al menos mínimamente eficaz para la prevención del delito, por lo que se debe renunciar a su intervención cuando resulte político criminalmente inoperante o peor aún contraproducente, lo que obligará a buscar otro medio de control social más eficaz ${ }^{226}$.

tonio. “Bien jurídico..., op. cit., pp. 146, 147. MIR PUIG, Santiago. Derecho Penal. P.G..., op. cit., p. 122.

224 Silva Sánchez acertadamente realiza la salvedad de que el bien jurídico penal aunque en muchos casos constituye una realidad permanente, está sujeto obviamente al cambio histórico, así como también está condicionado por las estructuras socioculturales, de lo cual se infiere que no es posible obtener un catálogo de bienes a proteger penalmente, sino una serie de características que posibiliten en buena medida esta tarea. SILVA SÁNCHEZ, Jesús María. Aproximación al Derecho..., op. cit., p. 288.

225 CARO CORIA, Dino Carlos. La Estabilidad del Ecosistema..., op. cit., p. 210. Luzón Peña manifiesta que la eficacia de la pena no es correcto medirla sobre la base de los que ya han delinquido, sino por quienes se han inhibido de hacerlo por la amenaza de la pena. LUZÓN PEÑA, Diego Manuel. Curso de Derecho Penal..., op. cit., p. 85.

226 Ibidem.. Curso de Derecho Penal. Parte General I. Editorial Universitas. S.A. Madrid. 1996, p. 84. 
Nos parece importante recordar en este momento que en la práctica se producen tensiones entre los criterios de merecimiento y necesidad de pena que no son de fácil solución. En este sentido compartimos plenamente que el criterio necesidad de pena sin merecimiento de pena, no puede fundamentar la incriminación, del mismo modo que tampoco el merecimiento de pena sin necesidad de pena puede hacerlo. En cuanto a la despenalización entendemos que puede fundamentarse en cuanto falte el merecimiento o la necesidad de pena ${ }^{227}$. En todo caso, no omitimos afirmar que resulta evidente que hace falta seguir trabajando en la concreción del concepto de bien jurídico-penal, pero no obstante, consideramos que existe un consenso importante en la doctrina sobre los criterios que deben reunir las realidades que deben tutelarse penalmente, lo que permite que el bien jurídico penal cumpla con su función crítica o de política criminal, hecho este que no desdice la imperiosa necesidad de seguir avanzando en su concreción para responder a la necesaria actualización de su contenido, así como a las necesidades que resultan de la dinámica social.

Es preciso hacer énfasis en que todo lo dicho hasta aquí, como no puede ser de otro modo, es válido para los bienes jurídicos colectivos, más aún cuando su protección se realiza generalmente mediante la tipificación de delitos de peligro abstracto, que es la técnica de tutela penal más anticipada, por lo que opinamos debe recurrirse en estos casos a su protección mediante el Derecho Penal como último recurso, valga la redundancia con un plus de ultima ratio, de tal manera qué las conductas seleccionadas representen ataques realmente graves a bienes jurídicos de la mayor importancia para que esta extrema tutela esté justificada, lo que de ninguna manera, significa dar la espalda a la realidad social, pues entendemos que las transformaciones económicas y tecnológicas que han hecho surgir nuevas entidades (bienes colectivos) que cumplen con los criterios anteriormente señalados deben ser objeto de protección del Derecho Penal.

Una vez que hemos llegado a este punto nos permitimos manifestar que la ausencia de un bien jurídico que tutelar despoja a la norma penal de su contenido material y por tanto de su legitimidad, y aún más, posibilita la realización de abusos por parte del Estado sobre las per- 
sonas y la comunidad en general, por lo cual en nuestra opinión resulta acertado afirmar que el concepto de bien jurídico racionaliza al Derecho Penal ${ }^{228}$. No obstante, estimamos necesario destacar en este momento que el principio de estricta protección de bienes jurídicos no constituye el único límite que nos ofrece la dogmática jurídico-penal frente al ius puniendi estatal ${ }^{229}$. Este, ha de complementarse con el principio de intervención mínima y en atención al mismo con los criterios de merecimiento de pena, necesidad de pena, y de proporcionalidad, sin olvidar el principio de intervención legalizada, así como otros criterios señalados anteriormente en este apartado ${ }^{230}$.

\section{EL BIEN JURÍDICO PROTEGIDO EN EL DELITO DE TRÁFICO DE DROGAS TÓXICAS, ESTUPEFACIENTES Y PSICOTRÓPICOS}

Una vez que hemos analizado la importancia que reviste el bien jurídico dentro de la teoría del delito así como la imperiosa necesidad de la búsqueda de su concepto material, nos abocamos a la tarea de determinar qué bien jurídico o bienes jurídicos se protegen en los delitos relativos al tráfico de las denominadas drogas tóxicas, estupefacientes y psicotrópicos ${ }^{231}$. Advertimos que sobre la solución de este dilema no existe unanimidad en la doctrina. Sin embargo es preciso señalar que la

BUSTOS RAMÍREZ, Juan. HORMAZÁBAL MALARÉE, Hernan. Lecciones de Derecho Penal..., op. cit., p. 180. HEFENDEHL, Roland. "El bien jurídico..., op. cit, pp. 389- 404. DONNA, Edgardo Alberto. "La sociedad de riesgos y los delitos de peligro abstracto", en GARCÍA VALDÉS, Carlos, MARTÍNEZ ESCAMILLA, Margarita, ALCÁCER GUIRAO, Rafael, VALLE MARISCAL DE GANTE, Margarita (Coord.). Estudios Penales en homenaje a Enrique Gimbernat. Tomo I. EDISOFER. Madrid. 2008, pp. 877, 878. Kindhäuser sostiene que el concepto de bien jurídico racionaliza al Derecho Penal, ya que pregunta por el daño o menoscabo que puede ser evitado mediante el cumplimiento de la norma. MENDOZA BUERGO, Blanca. El Derecho Penal..., op. cit., p. 169.

El bien jurídico es un fundamento necesario, pero no suficiente para limitar el poder punitivo del Estado. MUÑOZ CONDE, Francisco. Derecho Penal. P.G..., op. cit., p. 80. ABANTO VÁSQUEZ, Manuel A. "Acerca de la teoría..., op. cit., p. 11. FABIÁN CAPARRÓS, Eduardo Ángel. El Delito de Blanqueo..., op. cit., pp. 165, 167. El bien jurídico por si solo no puede conformar una teoría adecuada de la criminalización. VON HIRSCH, Andrew. "El concepto de bien jurídico..., op. cit., p. 52.

230 MUÑOZ CONDE, Francisco. Derecho Penal. P.G..., op. cit., pp. 88-93.

231 Es en el Código Penal de 1928 donde se encuentra la primera referencia al tráfico de drogas tóxicas o estupefacientes. DOVAL PAIS, Antonio. Delitos de fraude..., op. cit., p. 175. 
doctrina mayoritaria se decanta por asumir que el bien jurídico tutelado en estos delitos es la salud pública; no obstante, algunos autores mantienen opiniones diferentes en torno al problema en cuestión, así, hay quienes entienden que se trata de delitos pluriofensivos, hasta quienes asumen que se protegen bienes jurídicos tales como la libertad, los intereses fiscales, la moral, la seguridad colectiva e inclusive intereses económicos entre otros.

\section{A.) LA SALUD PÚBLICA}

Como señalamos anteriormente, la doctrina mayoritaria en España sostiene que es la salud pública o colectiva el bien jurídico protegido en los delitos relativos al tráfico de drogas ilegales ${ }^{232}$, lo cual ocurre tam-

232 Arroyo Zapatero manifiesta que resulta pacífica la afirmación de que es la salud pública el bien jurídico tutelado en los delitos relativos al tráfico de drogas. ARROYO ZAPATERO, Luis. "Aspectos Penales del Trafico de Drogas", en Revista de la Facultad de Derecho de la Universidad Complutense de Madrid № 6 (Monográfico). Madrid. 1985, p. 32. ARROYO ZAPATERO, Luis. BERDUGO GÓMEZ DE LA TORRE, Ignacio. FERRÉ OLIVÉ, Juan Carlos. GARCÍA RIVAS, Nicolás. SERRANO PIEDECASAS, José Ramón. TERRADILLOS BASOCO, Juan María (Directores). Comentarios al Código Penal. Ed. Iustel. Madrid. 2007, p. 812. "Como se desprende de forma inequívoca del texto legal es la salud pública" el bien jurídico tutelado en los delitos relativos a las drogas. BACIGALUPO, Enrique. Estudios sobre la Parte Especial del Derecho Penal. Segunda edición. Akal/iure. Madrid 1994, p. 158. BOIX REIG, Javier. "Delitos contra la Seguridad Colectiva (II)". VIVES ANTÓN, Tomás y otros autores. Derecho Penal. Parte Especial. Segunda edición. Tirant lo Blanch. Valencia. 1996, pp. 630, 631. CARBONELL MATEU, Juan Carlos. "Consideraciones técnico-jurídicas en torno al delito de tráfico de drogas" en FERNÁNDEZ ALBOR y otros autores. La problemática de la droga en España (Análisis y propuestas político criminales). Edición conjunta de los Institutos Universitarios de Criminología de las Universidades de Santiago de Compostela y Complutense de Madrid. Ed. Edersa. Madrid. 1986, pp. 3337-341. CARMONA SALGADO, Concepción. "Delitos contra la salud pública II" en COBO DEL ROSAL, Manuel. Curso de Derecho Penal español. Parte Especial II. Ed. Marcial Pons. Madrid. 1997, p. 155. CONDE PUMPIDO-FERREIRO, Cándido (Dir.). Código Penal comentado. Tomo II. 3a Ed. Bosch. Barcelona. 2012, p. 1331. CORCOY BIDÁSOLO, Mirentxu. MIR PUIG, Santiago (Dir.). Comentarios al Código Penal. Reforma L.O. 5/2010. Ed. Tirant lo Blanch. Valencia 2011, p. 782, 800. CÓRDOBA RODA, Juan. GARCÍA ARAN, Mercedes (Dir.). Comentarios al Código Penal. Parte Especial. Tomo II. Ed. Marcial Pons. Madrid. 2004, pp. 1554- 1556. FABIÁN CAPARRÓS, Eduardo A. "Consideraciones de urgencia. sobre la Ley Orgánica 8/1992, de 23 de diciembre, de modificación del Código Penal y la Ley de Enjuiciamiento Criminal en materia de tráfico de drogas", en Anuario de Derecho Penal y Ciencias Penales. 1993, p. 611. GARBERÍ LLOBREGAT, J. (Dir.). Práctica jurisprudencial del Código Penal. Tomo III. Ed. BOSHC. Barcelona, pp. 2235- 2237. GARCÍA-PABLOS DE MOLINA, Antonio. "Bases para una política criminal de la droga”. La problemática de la droga en España (Análisis y propuestas polí- 
bién en Italia ${ }^{233}$, y en alguna medida en Suiza ${ }^{234}$ y Alemania ${ }^{235}$. Quere-

tico- criminales). Editoriales de Derecho Reunidas S.A. Madrid. 1986, pp. 371 y ss. GARCÍA RAMÍREZ, Efraín. Drogas. Análisis jurídico del delito contra la salud. Ed. ISTA. México D.F. 1997, p 241. JOSHI JUBERT, Ujala. Los delitos de tráfico de drogas I. Un estudio analítico del art. 368 CP. Ed. J.M. Bosch Editor. Barcelona. 1999, p. 40. LAMARCA PÉREZ, Carmen (Dir.). Derecho Penal. Parte Especial. 3a edición. Colex. 2005, p. 502. LUZÓN PEÑA, Diego Manuel. Problemas del tráfico de drogas en la jurisprudencia. Simposio sobre la droga. Aspectos jurídicos. Ejemplar mecanografiado. Madrid 2-6 de febrero de 1981, p. 13. MAGRO SERVET, Vicente. Guía práctica de la casuística existente en los delitos contra la salud pública. Ed. La Ley. Madrid. 2004, p. 26. MARCHENA GÓMEZ, Manuel. Código Penal de 1995. Un año de vigencia en la doctrina del Tribunal Supremo, Audiencias Provinciales y Fiscalía General del Estado. Ed. Comares. Granada. 1997, p. 407. MATA y MARTÍN, Ricardo M. Bienes jurídicos intermedios..., op. cit., p. 25. MORA ALARCÓN, José Antonio. Suma de Derecho Penal. Parte General y Parte Especial. Ed. Edisofer. S.L. Madrid. 1996, p. 526. MORILLAS CUEVAS, Lorenzo (Coord.). Sistema de Derecho Penal español. Parte Especial. Ed. Dikinson, S. L. Madrid, 2011, pp. 803, 804. MUÑOZ CONDE, Francisco. Derecho Penal. Parte Especial. 18 edición, revisada y puesta al día. Tirant lo Blanch. Valencia. 2010, pp. 647, 672- 674. QUINTERO OLIVARES, Gonzalo (Director). Comentarios a la Parte Especial del Penal. Ed. Aranzadi-Thomson Reuters. Navarra. 2011, pp. 1488- 1489. REY HUIDOBRO, Luis Fernando. El delito de tráfico de estupefacientes. Su inserción en el ordenamiento penal español. Primera edición. Bosch, Casa Editorial. Barcelona. 1987, pp, 137, 138. SÁNCHEZ TOMÁS, José Miguel. Derecho de las drogas y de las drogodependencias. Ed. FAD. Madrid. 2002, p. 116. SEQUEROS SAZATORNIL, Fernando. El tráfico de drogas..., op. cit., pp. 51- 68. ESPINOZA V. Manuel. Delito de narcotráfico. Segunda edición. Rodhas. Lima. 1998, pp. 137, 138. SERRANO GÓMEZ, Alfonso. Derecho Penal parte especial. 5a edición. Dykinson. Madrid. 2000, p. 744. CARDONA TORRES, Juan. Derecho Penal. Parte Especial. Editorial Bosch. S.A. Barcelona. 2010, pp. 426, 437. MOLINA MANSILLA, María del Carmen. El Delito de Narcotráfico. Ed. Bosh, S. A. Barcelona. 2008, pp. 25, 29, 30. MOLINA MANSILLA, María del Carmen. "El delito de tráfico de drogas: el tipo básico y los subtipos agravados" en Anuario de derecho Penal y Ciencias Penales. Volumen LIX, 2006, pp. 277, 298. ÁLVAREZ GARCIA, F. Javier (Dir.). El Delito de Tráfico de Drogas. Ed. Tirant lo Blanch. Valencia. 2009, pp. 21-25.

233 El bien jurídico "salud pública" ha encontrado pleno reconocimiento en la doctrina italiana. CRUZ BLANCA, María José. "Las sustancias estupefacientes en la legislación penal italiana" en MORILLAS CUEVA, Lorenzo (Coord.). Estudios jurídico-penales y político-criminales sobre tráfico de drogas y figuras afines. Ed. Dykinson. Madrid. 2003, pp. 484, 485. En Francia el legislador ha optado por establecer los delitos de tráfico de drogas en el Titulo II del Código Penal, dedicado a "los delitos contra las personas", en un Capitulo que lleva por rúbrica "de los delitos contra la integridad física o psíquica de las personas". Como vemos, no proclaman como objeto de protección "la salud pública", sino "la salud individual". Sin embargo el Código Penal se remite al Código de la Salud Pública para delimitar el concepto de estupefacientes, y este, a su vez, se remite a la normativa administrativa. Así, el legislador francés utiliza la técnica de la Ley penal en blanco, de tal manera que una sustancia no puede ser considerada como objeto material del delito de tráfico de drogas, hasta que no haya sido calificado como tal por Or- 
mos recalcar que constantemente se hace énfasis en que es la salud pública y no la individual el bien tutelado por el riesgo que representan sus formas comisivas para la colectividad ${ }^{236}$. Bacigalupo en concordan-

den del Ministro de Sanidad, previa propuesta del Director General de la Agencia de Seguridad de los productos sanitarios. ARÁNGUEZ SÁNCHEZ, Carlos. ALARCÓN NAVÍO, Esperanza. "Principales características de la regulación francesa sobre los delitos relativos al tráfico de drogas" en MORILLAS CUEVA, Lorenzo (Coord.). Estudios jurídicopenales y político-criminales sobre tráfico de drogas y figuras afines. Ed. Dykinson. Madrid. 2003, p. 523, 524.

234 El Tribunal Federal Suizo señala: "el objetivo de la legislación en materia de estupefacientes consiste en proteger a la sociedad de perjuicios para la salud como consecuencia del abuso de drogas y de los efectos para terceros vinculados a él. Todo manejo de estupefacientes dirigido a la venta constituye el comienzo de una puesta en peligro de la salud del consumidor potencial y, en definitiva, de la salud pública". Bger del 3 de junio de 1991. Cit. por VON HIRSCH, Andrew. WHOLLERS, Wolfgang. "Teoría del bien jurídico..., op. cit., p. 286.

235 El Tribunal Supremo Alemán (BGH) sostiene que: “Los bienes jurídicos protegidos en las normas penales sobre estupefacientes no son sólo y en primer lugar la vida y la salud de los particulares, como en los parágrafos 211, 212,222, 223 y ss. StGB (delitos contra la vida y la integridad física), sino que se pretenden prevenir los daños para la comunidad resultantes de un consumo extendido de drogas, sobre todo de drogas duras, y los perjuicios para la salud de los particulares derivados de él (bien jurídico protegido salud pública..,)”. Cit por VON HIRSCH, Andrew. WHOLLERS, Wolfgang. "Teoría del bien jurídico..., op. cit., p. 286. "Ha sido precisamente la llamada salud pública, el supuesto bien jurídico de la Ley de sustancias estupefacientes, la que ha reavivado la discusión sobre el bien jurídico". BUNZEL, Michael. SCHMIDT, Juana. STOLLE, Peer. "Primera sesión. Teoría del bien jurídico y harm principle". (Trad. ÁLCACER GUIRAO, Rafael) en HEFENDEHL, Roland (Ed.). La teoría del bien jurídico. ¿Fundamento de legitimación del Derecho Penal o juego de abalorios dogmático?. Ed. Marcial Pons, ediciones jurídicas y sociales, S.A. Madrid. Barcelona. 2007, pp. 420, 421. SCHROEDER, FriedrichChristian. "La posesión como hecho punible" (Trad. Polaino-Orts, Miguel) en Revista de Derecho Penal y Criminología, 2o Época, número 14, p. 159.

236 Mora Alarcón afirma que en los delitos relativos al tráfico de drogas no se penaliza el hecho en función del daño concreto causado a una persona determinada, en cuyo supuesto tendría que acreditarse la relación causal entre el consumo de drogas y el daño, sino que lo que se tiene en cuenta es el peligro abstracto, pues estos delitos sólo admiten formas consumadas al estar configurados como delitos de mera actividad, por lo que no se requiere de un resultado concreto. Esta postura ha sido sostenida por el Tribunal Supremo de forma reiterada en los delitos referidos a la salud pública, entendiéndolos como delitos de peligro por lo que se fundamenta su punición en la situación de peligro que se genera por las conductas comprendidas en el tipo penal, de tal forma que la ejecución de un acto exterior correspondiente a cualquiera de las acciones típicas previstas determinaría la consumación del delito. MORA ALARCóN, José Antonio. Suma de Derecho..., op. cit., pp. 526, 530. 
cia con lo expuesto hasta aquí, manifiesta que estos tipos delictivos son considerados en general como delitos contra la salud pública, lo cual es y ha sido plenamente compartido, tanto por la jurisprudencia como por la doctrina mayoritaria sin que haya sido afectada esta postura por los diferentes textos que se han aplicado, destacando que en todos los casos "la realización del tipo no ha requerido la producción de un resultado concreto lesivo del bien jurídico"237.

Antes de empezar a analizar las diferentes posturas que existen sobre la definición de salud pública como bien jurídico tutelado en los delitos concernientes al tráfico de drogas, nos parece necesario señalar que la Organización Mundial de la Salud (OMS) define como droga o fármaco: "toda sustancia que introducida en el organismo vivo puede modificar una o varias funciones de éste". Para concretar este concepto de droga a todas luces bastante amplio, en la actualidad existe un consenso importante alrededor de definir como droga "toda sustancia que, con independencia de su utilidad terapéutica, actúa sobre el sistema nervioso central modificando la conducta del individuo, y que tras un uso continuado puede crear en él, el fenómeno conocido como fármaco dependencia" 238 .

Con el objetivo de realizar una primera aproximación al concepto de salud pública recurrimos a la carta constitucional de la OMS de 1946 que define como salud: "el estado de completo bienestar físico, mental y social, y no solamente la ausencia de enfermedades y dolencias". En el campo jurídico-penal varios autores se adscriben a está definición. Así. Boix Reig afirma que debe entenderse por salud pública "el nivel de bienestar físico y psíquico que afecta a la colectividad, a la generalidad de ciudadanos" 239 .

237 BACIGALUPO, Enrique. Estudios sobre la Parte Especial..., op. cit., p. 157. BACIGALUPO, Enrique. "Problemas dogmáticos del delito de tráfico ilegal de drogas" en FERNÁNDEZ ALBOR y otros autores. La problemática de la droga en España (análisis y propuestas político- criminales). Ed. Edersa. Madrid. 1986, pp. 95, 96.

238 LEGANÉS GÓMEZ, Santiago, ORTOLÁ BOTELLA, María Ester. Criminología. Parte Especial. Ed. Tirant lo Blanch. Valencia. 1999, p. 159.

239 BOIX REIG, Javier. "Delitos contra la Seguridad Colectiva (II)”. VIVES ANTÓN, Tomás y otros autores. Derecho Penal. Parte Especial. Segunda edición. Tirant lo Blanch. Valencia. 1996, pp. 630, 631. Sobre esta definición se destaca que presenta "la ventaja de tratar de fijar el significado de salud en términos positivos y de ser más amplia y acorde con su sentido actual que la tradicional"..., "la ausencia de enfermedades e invalide- 
Joshi Jubert manteniendo la misma línea argumental sostiene que el bien jurídico que se asegura en estos preceptos penales es la salud pública, pero hace énfasis en que se refiere a está en un sentido jurídico penal, proponiendo para la elaboración del concepto jurídico penal de salud pública la necesidad de recurrir a consideraciones tanto médicas como sociales y jurídicas; así las consideraciones médicas que constituyen el punto de partida, deben delimitar el modo en que las sustancias puedan afectar la salud pública; las consideraciones sociales deben versar sobre el nivel de salud que la sociedad estima tanto óptima como insoportable, y finalmente, las consideraciones jurídicas opina que deben formularse desde dos perspectivas; la primera constitucional y la segunda penal. Esta última perspectiva debe respetar "los principios de fragmentariedad, insignificancia, adecuación social, proporcionalidad y última ratio entre otros", Jubert afirma además, que la conducta que afecte la salud pública "no tiene porqué lesionar ni inmediata ni directamente, aunque sí de forma mediata e indirecta la salud individual"; concluyendo que la peligrosidad y gravedad de las conductas deben materializarse en el hecho de perjudicar a un número indeterminado de individuos, lo que puede poner en grave peligro la realización de los principios básicos de organización de los individuos y de convivencia de la sociedad, De esta manera el carácter penal del bien jurídico no permitiría incluir en el tipo aquellos comportamientos que , a pesar de ser subsumibles en él, no sean creadores de un riesgo penalmente relevante. Afirmando esta profesora que el concepto de salud pública no puede llegar a buen puerto sin una correcta articulación de sus diversas acepciones y sus conexiones con otras áreas, sobre las cuales también se proyecta 240 .

ces"..., "pero, por otro lado, se le imputan los siguientes inconvenientes: la exigencia del inalcanzable concepto de bienestar, la equiparación de bienestar y salud, el carácter estático del que se dota a la salud y la omisión del aspecto objetivo de la misma (como capacidad de funcionamiento)". Realmente nos parece poco recomendable la introducción de la expresión "bienestar", dado que esta posee unos límites inclusive más imprecisos que "salud pública". Suscriben está definición también Orts Berenguer, Carbonell Mateu y González Cussac. DOVAL PAIS, Antonio. Delitos de fraude alimentario..., op. cit., pp. 192, 193, 195.

JOSHI HUBERT, Ujala. Los Delitos de tráfico de drogas..., op. cit., pp. 39- 42. En contra de realizar un concepto específico de la salud pública jurídico-penal por su imposibilidad real, argumentando que "en realidad no hay más salud que la individual. Por lo tanto, las expresiones "salud pública" hacen referencia a la difusión que pueden alcanzar las 
Calderón Cerezo y Choclán Montalvo, desde otra perspectiva, sostienen que la salud pública es una "parcela determinada de la seguridad colectiva", afirmando que la salud pública como bien jurídico tutelado en el tráfico de drogas no es sino una faceta de la seguridad colectiva, en el entendido de que como bien jurídico colectivo, trata de dimensionar la protección de la seguridad particular, lo que se plasma mediante una preocupación por sancionar conductas que amenazan los bienes jurídicos individuales que se entienden comprendidos dentro de la idea genérica de seguridad. En este caso, para garantizar seguridad para la vida o la integridad corporal de cada persona frente al conjunto de riesgos sociales que propicia el tráfico de drogas, afirman que el margen de seguridad a tutelar se establece como un bien jurídico colectivo ya que su titularidad es universal, es decir, que la salud pública en su opinión es el mismo bien jurídico que la seguridad colectiva pero aplicada al consumo público (entiéndase tráfico de drogas, mercado alimentario y medicamentos entre otros) ${ }^{241}$.

Sobre este planteamiento nosotros compartimos la posición que entiende la referencia que se hace sobre la seguridad colectiva como una fórmula deliberadamente amplia para dar cabida a los diferentes bienes que pueden ser afectados por las conductas típicas, de tal forma

prácticas del consumo de drogas o la pluralidad de sujetos que pueden verse afectados por los otros delitos previstos en el capítulo III del Título XVII CP". STS (ROJ: 931/2004) de 13 de febrero de 2004. Ponente: D. Enrique Bacigalupo Zapater. CóRDOBA RODA, Juan. Comentarios al Código Penal..., op. cit., pp, 1554, 1555. En el mismo sentido. MOLINA MANSILLA, María del Carmen. El Delito de Narcotráfico..., op. cit., pp. 29, 30. Sequeros Sazatornil afirma que la salud pública "además de constituir un concepto jurídico penal, rebasa generosamente tan angosto espacio para anclar sus reales extramuros del derecho punitivo". Así la configuración de la salud pública debe valerse dada su configuración de norma penal en blanco de otras fuentes como el Derecho Administrativo. SEQUEROS SAZATORNIL, Fernando. El Tráfico de Drogas..., op. cit., pp. $51,52$.

241 Estos Magistrados sostienen que el bien jurídico que se protege en los delitos relativos al tráfico de drogas es "el valor social difuso que se conoce como salud pública", que en su opinión es una parte determinada de la seguridad colectiva, que es el bien genéricamente protegido en el Título XVII del Código Penal español. CALDERÓN CEREZO, Ángel, CHOCLÁN MONTALVO. Derecho Penal Tomo II. Parte Especial. Ed. Bosch. Barcelona. 1999, p. 977. También el profesor Espinoza en la misma línea afirma que la salud pública se encuentra enlazada con otro bien protegido de mayor dimensión en el tráfico de drogas que es la seguridad pública, "en cuyo marco jurídico se ampara la salud pública. ESPINOZA V. Manuel. Delito de Narcotráfico..., op. cit., p. 133. 
que no se trata de una referencia inmediata a bienes jurídicos protegidos singulares de esta sección sistemática del Código Penal, por lo que debemos asumir que los delitos contra la seguridad colectiva constituyen una categoría de delitos que complementan a los delitos de lesión que precisamente surgen por la incapacidad que poseen las estructuras clásicas de lesión para cubrir las diferentes modalidades de ataque de los que se trata de amparar a ciertos bienes individuales tales como la vida o la salud entre otros ${ }^{242}$. Pero en este sentido consideramos acertados los planteamientos que sostienen que si bien en todo delito de peligro podría hablarse de la seguridad como bien jurídico tutelado, sería con cierta impropiedad, dado que la seguridad por sí misma no es nada, pues sólo adquiere sentido cuando se predica de algo ${ }^{243}$.

Consideramos importante señalar que la aparición de la rúbrica "salud pública" en el ordenamiento jurídico español, se produjo por primera vez en el Código Penal de 1822, pero es en el Código Penal de 1870 que su contenido quedó establecido de forma definitiva hasta la actualidad $^{244}$. En nuestros días la legitimación de la protección de la salud pública mediante el Derecho Penal, así como por otras ramas del ordenamiento jurídico, y de la Administración Pública en general se consagra en el artículo 43.2 de la Constitución española que literalmente establece que: "compete a los poderes públicos organizar y tutelar la salud pública a través de medidas preventivas y de las prestaciones y servicios necesarios. La ley establecerá los derechos y deberes de todos al respecto".

Avalando la postura que sostiene que el bien jurídico tutelado en los delitos relativos al tráfico de drogas, es la salud pública, el Código Penal Español en atención a la función sistemática del bien jurídico ubica estos tipos penales en el Libro II Título XVII relativo a los delitos contra la seguridad colectiva y específicamente en el Capítulo III (artículos 368 al 378) que precisamente comprende los delitos contra la salud pública. Una situación similar se presenta en algunas legislaciones penales

DOVAL PAIS, Antonio. Delitos de fraude alimentario..., op. cit., p. 141.

DOVAL PAIS, Antonio. Delitos de fraude alimentario..., op. cit., p. 212.

Cuando en 1822 se introdujo por primera vez en el Código Penal español el término salud pública solamente se hacía referencia al incumplimiento de requisitos de carácter formal; licencias, autorizaciones y títulos en el ejercicio de profesiones sanitarias y de comercio. DOVAL PAIS, Antonio. “Estructura de las Conductas..., op. cit., pp. 29, 30. 
de Hispanoamérica entre estas: la mexicana ${ }^{245}$, panameña ${ }^{246}$, salvadoreña ${ }^{247}$ o la peruana ${ }^{248}$ y de cierta manera en la legislación de los Estados Unidos de América ${ }^{249}$, hacemos la salvedad de que en la mayoría de ordenamientos del continente americano la regulación del narcotráfico está plasmada en leyes especiales de reciente cuño que hacen alusión a la salud pública como bien tutelado. Fortaleciendo aún más esta posición el Tribunal Supremo Español en reiteradas ocasiones se ha pronunciado sobre el tema; afirmando que el bien jurídico protegido en el tráfico ilegal de drogas tóxicas estupefacientes y psicotrópicos es la salud pública, lo cual puede constatarse en diversas sentencias tales como: de 21 de junio de 2003, de 10 de mayo de 2004, de 5 de octubre de 2004, de 3 de junio de 2004, de 7 de noviembre de 2005, de 17 de junio de 2005 , de 7 de febrero de 2005, de 18 de febrero de 2005 y de 20 de abril de 2010 entre otras ${ }^{250}$.

Código Penal Federal de México, de 18 de mayo de 1999, que en el Libro segundo en su Título séptimo regula los delitos contra la salud, en el Capítulo I relativo a la producción, tenencia, tráfico, proselitismo y otros actos en materia de narcóticos. En su artículo 193 párrafo segundo expresa "que constituye un grave problema para la salud pública". Actualizado a julio del 2000.

246 Código Penal de Panamá que en su Capitulo V. De los Delitos contra la salud pública regula los delitos relativos al tráfico de drogas. Noviembre de 1994.

247 Ver la Ley reguladora de las actividades relativas a las Drogas. Decreto № 728 del 5 de marzo de 1991.

248 Ver la Ley de represión del tráfico ilícito de drogas del 2 de marzo de 1978 y la Ley sobre el tráfico de drogas del 15 de junio de 1981. en Anexos, normas complementarias del Código Penal de Perú.

249 El tráfico de drogas esta regulado en el Código de Estados Unidos (donde se desarrolla la práctica totalidad de normas, leyes y disposiciones emitidas por el Estado). Su regulación expresa se encuentra recogida en el Capitulo 13 Titulo 21, "de la comida y las drogas", donde se realiza una minuciosa descripción de todos los comportamientos punibles. En el Capitulo 13 el legislador estadounidense tipifica todas las conductas que afectan la "salud pública" como consecuencia de la alteración o manipulación incorrecta de determinados productos alimenticios, drogas o cosméticos. MORILLAS FERNÁNDEZ, David L. "Legislación estadounidense en materia de drogas" en MORILLAS CUEVA, Lorenzo (Coord.). Estudios Jurídico-Penales y Político-Criminales sobre el tráfico de drogas y figuras afines. Ed. Dikynson. Madrid. 2003, pp, 531, 536.

250 STS (ROJ: 4335/2003) de 21 de junio de 2003. Ponente: D. Enrique Bacigalupo Zapater, STS (ROJ: 3127/2004) de 10 de mayo de 2004. Ponente: D. Carlos Granados Pérez, STS (Roj: 6197/2004) de 5 de octubre de 2004: Ponente: D. Diego Antonio Ramos Gancedo, STS (Roj: 3843/2004) de 3 de junio del 2004: D. Ponente: Miguel Colmenero Gómez de 
Queremos advertir que sobre la salud pública se produjo cierta polémica en cuanto a si esta debía referirse solamente a la salud física de las personas o si tenía que abarcar también la salud psíquica o mental de las mismas, discusión que a nuestro entender se encuentra superada, pues en la actualidad, existe un consenso muy importante en asumir que la salud publica comprende tanto la salud física como psíquica de los individuos. Así, Carmona Salgado se refiere a la salud pública como: "situación de bienestar físico y psíquico concerniente a la colectividad", es decir, a todos y cada uno de los miembros de una sociedad determinada 251 . Boix Reig en el mismo sentido la define como: "aquel nivel del bienestar físico y psíquico que afecta a la colectividad, a la generalidad de ciudadanos" 252 .

Entrando en materia sobre el concepto de salud pública, nos encontramos con diferentes puntos de vista. A continuación destacamos los tres más importantes; en el primer grupo enmarcamos a aquellos que señalan que se trata de la "salud de todos en general"253, el segundo grupo aglutina a autores que sostienen que la salud pública se independiza relativamente como valor instrumental de la protección directa de la salud individual a la cual propende para configurarse como tutela "en primera línea del conjunto de condiciones positivas y negativas que garantizan y fomentan la salud"254, y un tercer grupo, que apun-

Luarca, STS (ROJ: 6801/2005) de 7 de noviembre del 2005. Ponente: D. Juan Ramón Berdugo Gómez de la Torre, STS (ROJ: 3967/2005) de 17 de junio de 2005. Ponente: D. Diego Antonio Ramos Gancedo, STS (ROJ: 6272/2005) de 7 de febrero de 2005. Ponente: D. Andrés Martínez Arrieta, STS (ROJ: 999/2005) de 18 de febrero de 2005. Ponente: D. Juan Ramón Berdugo Gómez de la Torre. STS (ROJ: 2061/2010) de 20 de abril de 2010. Ponente: D. Joaquín Jiménez García. (Bien jurídico protegido en los delitos relativos al tráfico de drogas).

251 COBO DEL ROSAL, Manuel (Dir.). Curso de Derecho..., op. cit., p. 127.

252 MUÑOZ CONDE, Francisco. Derecho Penal. P.E.., op. cit.., p. 547.

253 En este sentido Ferrer Sama y Sainz Cantero entre otros. Estas definiciones al igual que "la suma de saludes individuales" parten de la vinculación de la salud pública con la salud individual. DOVAL PAIS, Antonio. Delitos de fraude alimentario..., op. cit., pp. 188, 190.

254 CóRdobA RodA, Juan. Comentarios al Código Penal..., op. cit, pp. 1554- 1556. CARO CORIA, Dino Carlos. Derecho Penal del Ambiente. Delitos y técnicas de tipificación. Ed. Gráfica Horizonte S. A. Lima. 1999, p. 517. DOVAL PAIS, Antonio. "Los Delitos de fraude alimentario..., op. cit., pp. 140, 141. GARCIA ALVERO, Ramón. "Libro II: Titulo XVII" en QUINTERO OLIVARES, Gonzalo (Dir.). Comentarios a la Parte Especial del derecho Penal Ed. Aranzadi-Thomson Reuters. Navarra. 2011, pp. 1429- 1431. PEREZ ALVAREZ, Fer- 
tando en una dirección diferente tal vez por entender que la definición anterior no era coherente con la naturaleza de los tipos delictivos comprendidos como delitos de riesgo, define la salud pública como "la suma de las saludes individuales" de una colectividad de ciudadanos que se pone en peligro cuando más o menos aproximadamente, se agudice la posibilidad de que alguno o algunos de los individuos de tal colectividad resulten atacados en su salud personal ${ }^{255}$. Queremos destacar que la segunda y tercera definición son las que más seguidores agrupan en la doctrina actual, la tercera (suma de saludes individuales), parte de la vinculación de la salud pública con la salud individual y la segunda (conjunto de condiciones...), pretende configurar un bien jurídico relativamente desvinculado de la salud individual, con manifiestas pretensiones de autonomía o al menos, no tan dependiente de la salud individual.

Sobre la primera de las definiciones propuesta "la salud de todos en general", "la salud de la colectividad" o bien "la salud de la generalidad de ciudadanos", pensamos que esclarece muy poco sobre su contenido y más aún, sobre las relaciones existentes entre la salud pública y la salud individual en estos tipos delictivos limitándose este tipo de defini-

nando. "La regulación del delito alimentario nocivo en el proyecto del Código Penal de 1992", en Anuario de Derecho Penal y Ciencias Penales T. XLVI, 1993, p. 1072. PEREZ ALVAREZ, Fernando. "Alimentos transgénicos y Derecho Penal. Apuntes para una reflexión" en ARROYO ZAPATERO, Luis, BERDUGO GÓMEZ DE LA TORRE, Ignacio (Dir.) NIETO MARTIN, Adán (Coord.). Homenaje al Profesor Marino Barbero Santos. Volumen II. Ed. Universidad Castilla la Mancha. Universidad de Salamanca. Cuenca. 2001, p. 463. RODRÍGUEZ RAMOS, Luis. Compendio de Derecho Penal. Parte Especial. Primera edición. Trivium. Madrid 1985, p. 90. VIVES ANTÓN, Tomas y VVAA. Derecho Penal Parte Especial. Segunda edición. Tirant lo Blanch. Valencia. 1996, p. 610. MUÑOZ CONDE, Francisco. Derecho Penal. P.E.., op. cit., pp. 646, 647. BLANCO LOZANO, Carlos. Tratado de Derecho Penal español. Tomo II. El Sistema de la Parte Especial. Volumen 2. Delitos contra los bienes jurídicos colectivos. J.M. Bosch. Editor. Barcelona. 2005, pp. 365, 366. CARDONA TORRES, Juan. Derecho Penal. Parte Especial. Editorial Bosch. S.A. Barcelona. 2010, p. 426.

255 CALDERÓn CEREZO, Ángel. CHOCLÁn MONTALVO, José Antonio. Derecho Penal. Tomo II. Parte Especial. Ed. Bosch. Barcelona, 1999, p. 977. LORENZO SALGADO, José M. “Titulo XIV: Delitos contra la seguridad colectiva. Capitulo III. De los delitos contra la salud pública" en Documentación jurídica. Núm. 37/40. Monográfico dedicado a la propuesta de anteproyecto del nuevo Código Penal. Volumen. Ed. Ministerio de Justicia. Madrid, 1983, p. 964. REY HUIDOBRO, Luis Fernando. El delito de tráfico..., op. cit., p. 130. 
ciones a establecer una característica de la colectividad que pone de relieve una peculiaridad que identifica su estructura típica ${ }^{256}$.

Es preciso señalar que la idea de entender la salud pública como "el conjunto de condiciones objetivas que defienden de unas posibles enfermedades a una pluralidad de personas", se le objeta que aunque es evidente que la salud pública depende de que existan ciertas condiciones, no es lo más adecuado erigir estas como bien jurídico protegido dado que hacerlo "es tanto como pretender garantizar sólo el medio por el cual se asegura la salud", lo cual puede conducir a formalizar excesivamente el bien jurídico tutelado en el entendido de que no es correcto definir la salud pública a través de los medios que garantizan la salud, ya que su definición debe establecer su significado y no los medios necesarios para su aseguramiento. Esto es así porque la necesidad de garantizar las "condiciones" anteriormente señaladas responde al interés en la protección de la salud ${ }^{257}$.

Hay que señalar que a la definición de salud pública como "la suma de las saludes individuales" se le cuestiona que la salud del colectivo social es algo más que la suma de las saludes individuales ${ }^{258}$, que posee

de proteger la salud, siendo esta idea la única esas "condiciones" responde al interés rente material. DOVAL PAIS, Antonio. Delitos de fraude alimentario..., op. cit., pp. 204, 205. CARBONELL MATEU, Juan Carlos. “Consideraciones técnico- jurídicas..., op. cit, pp. 337,340 .

258 GARCÍA ALBERO, Ramón. "LibroII: Título XVII” en QUINTERO OLIVARES, Gonzalo (Dir). MORALES PRATS, Fermín (Coord.). Comentarios al nuevo Código Penal. Ed. Aranzadi. Navarra. 2005, pp. 1854, 1855. Dado que la salud ontológicamente valorada, se halla protegida por el Derecho Penal en una doble dimensión, individual y colectiva, las diferencias "sobre la entidad de dicha protección no pueden establecerse desde una observación cuantitativa del bien tutelado en razón de que la salud del colectivo venga determinada por la suma de la de cada uno de los miembros que la integran. Tampoco puede decirse que sean más las notas que separan dichos conceptos que las que los unen", pues de lo que se trata es de que son supuestos diversos cuya punición obedece a impulsos distintos y en las que el bien afectado se escenifica de forma diferente, ya que con la inclusión de los delitos contra la salud pública no se pretende proteger la salud concreta individual de las personas que ya es objeto de tutela en otros capítulos del Código Penal. De lo que se trata es de evitar la creación de riesgos añadidos que puedan afectar al nivel de salud de un país. SEQUEROS SAZATORNIL, Fernando. El Tráfico de Drogas..., op. cit., pp. 54, 65. STS (R0J: 6801/2005) de 7 de noviembre de 2005. Ponente: D. Juan Ramón Berdugo Gómez de la Torre, STS (ROJ: 3967/2005) de 17 de ju- 
una naturaleza diferenciada de la mera suma de saludes individuales, por el propio componente social y no individual de la misma, lo cual se evidencia en que en los delitos contra la salud pública el ataque está dirigido contra la colectividad en atención a la imposibilidad de poder individualizar tal ataque en una persona concreta, por lo que se afirma que hay que entender que la referida suma de las saludes individuales de la colectividad de ciudadanos se pone en peligro cuando se agudice la posibilidad de que alguno o algunos individuos que conforman tal colectividad resulten afectados en su salud personal 259 .

Como podemos apreciar, ninguna de las fórmulas propuestas anteriormente sobre salud pública se encuentra libre de objeciones. Sin embargo hay que adjudicarles a cada una de ellas sus méritos; así cuando se refiere a esta como una característica de la colectividad se pone de relieve una peculiaridad que identifica su estructura típica. Cuando se describe como "la suma de saludes individuales" se destaca la base material de la salud pública (la salud individual); de este modo, las diferentes infracciones que se examinen deben referir el peligro a la salud individual, pues se entiende que la probabilidad de lesión ha de proyectarse sobre el bien jurídico complementado (la salud individual) y no sobre el bien jurídico complementario (la salud pública). Y finalmente cuando se define esta como "un conjunto de condiciones que posibilitan la salud" se distinguen los medios cuya lesión es necesaria para poner en peligro la salud, además de destacar el adelantamiento de la barrera de protección penal que se produce en estos delitos ${ }^{260}$.

Después de haber realizado este breve estudio sobre los principales conceptos de salud pública que se defienden en la doctrina penal española, sostenemos que la definición de salud pública como "conjunto de condiciones positivas y negativas que garantizan y fomentan la salud" en nuestra opinión resulta más conveniente, por su mayor amplitud, para incluir todos los tipos delictivos contra la salud pública sin tener que dejar fuera los delitos relativos al tráfico de drogas, estupefacientes y psicotrópicos y por ende, el tema que nos ocupa en este trabajo,

nio de 2005. Ponente: D. Diego Antonio Ramos Gancedo y STS (ROJ: 672/2005) de 7 de febrero de 2005. Ponente: Andrés Martínez Arrieta. 
"el tráfico de precursores" de dichas sustancias, que no participan de la característica de exigir la infracción de la normativa sanitaria, denominador común de los demás delitos contra la salud pública ${ }^{261}$.

En resumen debemos afirmar que en la expresión "salud pública" el carácter público de la salud no debe comprenderse como una referencia a la peculiaridad del bien jurídico tutelado, sino como un rasgo característico de los ataques que suponen estos delitos, es decir, la afección plural que representan (que afectan a una pluralidad indeterminada de personas) como delitos de peligro. Por esto, inferimos que la salud pública tiene los rasgos propios de un bien jurídico colectivo de referente individual. Este modo de entender los delitos contra la salud pública consideramos que proporciona un referente material más firme para la intervención penal en esta materia así como para la interpretación ilícitos penales y sus relaciones entre sí y con otras figuras del ordenamiento penal ${ }^{262}$.

Tomando como base lo afirmado hasta aquí se puede decir que es innegable que la salud pública constituye una condición básica de posibilidad para garantizar una vida humana digna, por lo que se asume comúnmente que la tutela jurídica de "las condiciones de sanidad del medio integra, junto a la tutela de la vida y la salud individual, un substrato básico a partir del cual cobra sentido pensar en la posibilidad del ejercicio de derechos y libertades de la persona". Sin embargo, es necesario destacar el hecho de que si la salud pública, es un presupuesto básico para la realización personal, "lo es en la medida en que establece ciertas condiciones que pueden posibilitar la salud individual" 263 .

261 Ibidem., p. 215. DOVAL PAIS, Antonio. "Los Delitos de fraude alimentario..., op. cit., pp. 140, 141. MUÑOZ CONDE, Francisco. Derecho Penal. P.E..., op. cit., pp. 647, 672- 674. CORCoY BIDÁSOlO, Mirentxu. Comentarios al Código Penal..., op. cit., p. 782, 800. QUINTERO OLIVARES, Gonzalo (Dir.). Comentarios a la Parte Especial..., op. cit., pp. 1429- 1431. VIVES ANTÓN, Tomas S. y otros autores. Derecho Penal. Parte Especial. Ed. Tirant lo Blanch. Valencia. 2010, p. 604. MORILLAS CUEVAS, Lorenzo (Coord.). Sistema de Derecho..., op. cit, p. 804.

262 DOVAL PAIS, Antonio. "Los Delitos de fraude alimentario..., op. cit., p. 141. VIVES ANTÓN, Tomás S. Derecho P.E..., op. cit., p. 604.

263 Afirma Doval que la salud pública aparece como un presupuesto básico, pero aún mediato, de estos fines últimos perseguidos por el Derecho es decir, que la salud individual dota de contenido a la salud pública, y aunque las modalidades de conducta de unos y otros delitos son exclusivas en sus elementos constitutivos, sería incorrecto 
Es preciso señalar que existe unanimidad en el Tribunal Supremo en asumir que el bien jurídico protegido en los delitos relativos al tráfico de drogas es la salud pública, pronunciándose sobre este tema en diferentes sentencias ${ }^{264}$. En éstas, lamentablemente más que clarificar la definición de salud pública, lo que se ha hecho es proponer expresiones sinónimas a la misma como; "sanidad colectiva"265, "salud colectiva social"266, "salud colectiva de los seres humanos en general" o "de la humanidad"267 y con "el bienestar colectivo" o "bienestar colectivo de la sociedad"268, entre otras. Como se puede apreciar, estas definiciones

afirmar que los objetos de protección sean completamente escindibles. DOVAL PAIS, Antonio. Delitos de fraude alimentario..., op. cit., pp. 166, 167, 185. García Alvero sostiene que la salud pública no es únicamente una fórmula para designar la naturaleza del peligro común o general que sobre la salud individual proyectan determinadas conductas, sino un bien jurídico suficientemente decantado históricamente que, por mucho que complemente la salud individual, asume perfiles propios. QUINTERO OLIVARES, Gonzalo (Dir.). MORALES PRATS, Fermín (Coord.). Comentarios al nuevo Código Penal. 4⿳亠丷厂 edición. Aranzadi. Navarra. 2005 p. 1855. En el mismo sentido se pronuncia REY HUIDOBRO, Luís Fernando. El Delito de tráfico..., op. cit., p. 130.

264 STS (ROJ: 4335/2003) de 21 de junio de 2003. Ponente: D. Enrique Bacigalupo Zapater, STS (ROJ: 3127/2004) de 10 de mayo de 2004. Ponente: D. Carlos Granados Pérez, STS (ROJ: 6197/2004) de 5 de octubre de 2004. Ponente: D. Diego Antonio Ramos Gancedo, STS (ROJ: 3843/2004) de 3 de junio del 2004. Ponente: Miguel Colmenero Gómez de Luarca, STS (ROJ: 6801/2005) de 7 de noviembre del 2005. Ponente: D. Juan Ramón Berdugo Gómez de la Torre, STS (ROJ: 3967/2005) de 17 de junio del 2005. Ponente: D. Diego Antonio Ramos Gancedo, STS (ROJ: 6272/2005) de 7 de febrero de 2005. Ponente: D. Andrés Martínez Arrieta, y STS (ROJ: 999/2005) de 18 de febrero de 2005. Ponente: D. Juan Ramón Berdugo Gómez de la Torre. (Bien jurídico protegido en los delitos relativos al tráfico de drogas es la salud pública).

265 STS (ROJ: 1494/1966) de 23 de diciembre de 1966. Ponente: D. Enrique Cid y Ruiz Zorrilla, STS (ROJ: 2750/1970) de 11 de marzo de 1970. Ponente: D. Fidel de Oro Pulido y STS (ROJ: 3310/1972) de 27 de junio de 1972. Ponente: D. José Espinosa Herrera. (Sobre la definición de la salud pública).

266 STS (ROJ: 1680/1969) de 28 de octubre de 1969. Ponente: D. Ángel Escudero Coral y STS (ROJ: 1507/1982) de 24 de febrero de 1982. Ponente: D. Martín Jesús Rodríguez López. (Sobre la definición de la salud pública).

267 STS (ROJ: 1910/1971) de 9 de marzo de 1971. Ponente: D. Ángel Escudero del Coral y STS (ROJ: 1131/1985) de 25 de octubre de 1985. Ponente: D. José Hijas palacios. (Sobre la definición de la salud pública).

268 STS (ROJ: 4399/1978) de 6 de noviembre de 1978. Ponente: D. Luis Vivas Marzal y STS (ROJ: 1161/1985) de 29 de junio de 1985. Ponente: D. José augusto de Vega Ruiz. (Sobre la definición de la salud pública). 
contribuyen muy poco a esclarecer que entiende el Tribunal Supremo Español por salud pública. En definitiva podemos afirmar que en la inmensa cantidad de resoluciones sobre delitos contra la salud pública no han podido establecer en buena medida las relaciones existentes entre salud individual y salud pública, lo cual se debe tal vez a su empeño por diferenciar los delitos contra la salud pública de los delitos contra la salud de las personas ${ }^{269}$.

El Tribunal Constitucional también se ha pronunciado sobre este tema en la sentencia 62/1983, de 11 de julio declarando que "el bien jurídico protegido en los delitos de riesgo general contra la salud pública es el bien común que la misma consiste, que se refleja en definitiva en la salud personal de los ciudadanos, por lo que estamos en un supuesto en el que la defensa de este interés se hace sosteniendo el interés común"270. Esta resolución evidencia que el TC entiende el bien jurídico salud pública como un instrumento de protección indirecta de la salud individual, así la referencia al interés común se considera "un medio necesario al que acudir en determinados supuestos para la defensa de la salud individual (el interés personal)", lo cual pone de manifiesto la relación de complementariedad del bien jurídico salud pública con el bien jurídico salud individual. En esta misma sentencia afirman que "la única forma de defender el interés personal es sostener el interés común". En nuestra opinión el principal mérito de esta sentencia radica en lograr expresar una coordinación armónica entre los bienes jurídicos individuales y colectivos (bien jurídico salud pública y bien jurídico salud individual) ${ }^{271}$.

Por todo lo expuesto anteriormente pensamos que lo que caracteriza a la salud pública con respecto a la salud individual no radica en poseer diferente sustrato material (ya anteriormente indicamos que poseen la misma naturaleza), sino por la diferente estrategia que se emplea para la protección del mismo objeto que obviamente lo constituye la salud individual, por lo que la configuración del concepto de salud pública ha de entenderse como una fórmula legislativa adoptada para sancionar

DOVAL PAIS, Antonio. Delitos de fraude alimentario..., op. cit., pp. 234 - 237.

Fundamento jurídico número 2, B. Fue Magistrado ponente Don Rafael Gómez-Ferrer Morant.

DOVAL PAIS, Antonio. Delitos de fraude alimentario..., op. cit., pp. 237, 238. 
una serie de conductas graves que de otro modo no podrían castigarse ofreciendo por ello una protección adelantada a la salud individual; así podemos concluir que la salud pública es complementaria de la individual en el entendido de que en este caso "el bien jurídico colectivo ofrece un complemento para la integración del bien jurídico de carácter individual". Este bien se encuentra protegido no únicamente de su lesión, sino también de su puesta en peligro con lo cual se logra una tutela integral de la salud individual, protección que evidentemente debe respetar los límites que imponen los principios de subsidiaridad y fragmentariedad. Lo sostenido hasta este momento nos permite afirmar que el concepto de salud pública se puede entender como un expediente de técnica legislativa empleado para la punición de ciertas conductas graves que, de otro modo, habrían de quedar impunes, lo que supone una excepción a la regla general de impunidad de las formas de imperfecta ejecución en la imprudencia o "la tipificación de una actuación peligrosa con dolo eventual en la fase de tentativa" 272 .

Como ya hemos señalado antes, consideramos que el bien jurídico es imprescindible para la noción de delito, puesto que sin la producción de lesión o puesta en peligro de un bien jurídico el juicio de antijuridicidad es imposible o en todo caso carente de base jurídica ${ }^{273}$. En atención a esta afirmación pensamos que en los delitos relativos al tráfico de drogas, es coherente exigir que las sustancias consideradas como tales puedan producir una significativa perturbación de la salud ${ }^{274}$. En la práctica como todos sabemos, el Tribunal Supremo Español considera que "la inclusión de una sustancia en las listas anexas a los convenios o leyes nacionales- es suficiente- sin que sea necesario indagar sobre su

272 Ibidem., pp. 237- 253.

273 PRIETO RODRÍGUEZ, Javier Ignacio. El Delito de Tráfico Tráfico y el Consumo de Drogas en el Ordenamiento jurídico penal español. Ed. Aranzadi. Segunda edición. Pamplona. 1993, p. 209.

274 CARBOnEll MATEU, Juan Carlos. "Consideraciones técnico- jurídicas..., op. cit., p. 1074. CONDE PUMPIDO-FERREIRO, Cándido. Código Penal comentado..., op. cit., pp. 1289, 1290. CóRDOBA RODA, Juan. Comentarios al Código Penal..., op. cit., p. 1557. LORENZO SALGADO, José M. "Reforma de 1983 y tráfico de drogas". FERNÁNDEZ ALBOR y otros autores. La problemática de la droga en España (análisis y propuestas políticocriminales). Ed. Edersa. Madrid. 1986, pp, 33- 39. MUÑOZ CONDE, Francisco. Derecho Penal. P.E..., op. cit., pp, 672- 673. PRIETO RODRÍGUEZ, Javier Ignacio. El Delito de Tráfico..., op. cit., p. 216. 
nocividad", lo cual pone de manifiesto que el criterio de este Tribunal obedece a la idea de acatar lo dispuesto en los Convenios Internacionales integrados en el Derecho interno (de conformidad a lo dispuesto en el artículo 96.1 de la Constitución Española) ${ }^{275}$. Sobre este tema en particular la Decisión Marco 2004/757/JAI del Consejo, de 25 de octubre de 2004, opta por un concepto normativo de drogas excluyendo así la posibilidad de que tales sustancias vengan dadas por criterios médicos o sanitarios ${ }^{276}$. En contra de esta postura se argumenta que las listas

275 Son drogas ilícitas las establecidas en los Convenios internacionales: STS (ROJ: 4252/1981) de 22 de junio de 1981. Ponente: D. Juan Latours Brotons. STS (ROJ: 4704/1981) de 8 de junio de 1981. Ponente: D. Manuel García Miguel. STS (ROJ: 1383/1984) de 22 de marzo de 1984. Ponente: D. José Hijas Palacios, STS (ROJ: 1344/1987) de 26 de febrero de 1987. Ponente: D: José Jiménez Villarejo. Circular 1/1984 de la Fiscalía General del Estado. BOIX REIG, Javier. "Delitos contra la seguridad colectiva II" en VIVES ANTÓN, T.S. VVAA. Derecho Penal. Parte Especial. Ed. Tirant lo Blanch. Valencia. 1996, p. 631. Sin embargo el Tribunal puede incluir en el tipo como droga tóxica, estupefaciente o psicotrópico, cualquier otra sustancia no contenida en las listas citadas. CONDE- PUMPIDO FERREIRO, Cándido. "El tratamiento penal del tráfico de drogas: las nuevas cuestiones" en FERNÁNDEZ ALBOR y otros autores. La problemática de la droga en España (análisis y propuestas político- criminales). Ed. Edersa. Madrid. 1986, p. 121, 129- 131. El objeto material del tipo debe de determinarse en función de criterios penales como el bien jurídico tutelado, actuando la normativa administrativa como un límite y no como fundamento de la punición. En consecuencia el artículo 368 no constituye una norma penal en blanco cuyo contenido punitivo se complemente por su remisión a una normativa extrapenal, sino que el concepto de droga depende básicamente a su definición médica. Sin embargo la normativa extrapenal constituye un límite mínimo de intervención, dado que nunca deberá sancionarse penalmente una conducta que afecte a sustancias no incluidas como prohibidas en la legislación internacional sobre estupefacientes. CONDE-PUMPIDO FERREIRO, Cándido. Código Penal Comentado..., op. cit., pp. 1289, 1290. La jurisprudencia mayoritaria y un sector doctrinal han aceptado el carácter de le Ley penal en blanco del precepto, admitiendo la sumisión a la legislación penal internacional y nacional a efectos de la determinación del objeto material del delito. Sin embargo no ocurre lo mismo con la normativa Estatal de naturaleza administrativa, que serviría de mera pauta interpretativa debiendo el juez valorar el potencial lesivo de las sustancias. CÓRDOBA RODA, Juan.. Comentarios al Código Penal..., op. cit., pp. 1562, 1563. RODRÍGUEZ RAMOS, Luis (Coord.). Código Penal comentado y con jurisprudencia. Segunda edición. La Ley. Madrid. 2007, pp. 838, 839. Son estupefacientes las sustancias incluidas en las listas I, II y IV del Convenio de 1961 y las que adquieran tal condición en el ámbito internacional, más las que se declaren expresamente como tales dentro de España al tenor del artículo 3 del Convenio y del artículo 2 de la Ley de 8 de abril de 1967. MOLINA MANSILLA, María del Carmen. "El delito de tráfico de drogas..., op, cit., pp. 279, 280, 298.

Esta norma señala que debe entenderse por "droga" únicamente aquello que esté definido como tal, independientemente de las repercusiones que puedan provocar en el 
del Convenio de 1961 no tienen carácter ejecutivo, sino meramente indicativo, así como que el artículo 368 del Código Penal y demás dedicados a la regulación del tema no están estructurados como una norma penal en blanco, lo que si ocurre con el artículo 371 que regula el tráfico de precursores, cuyo contenido prohibitivo se determina por la remisión a un ámbito extrapenal, sino como delitos autónomos cuyo supuesto de hecho debe determinarse por criterios meramente penales como el bien jurídico protegido y el de su ubicación sistemática entre los delitos contra la salud pública. Por ello se afirma, con razón, que únicamente las sustancias nocivas para la salud pública deben de estar incluidas en su ámbito de protección. No obstante hay que señalar que la remisión normativa extrapenal puede plantear lagunas de punibilidad en relación con el descubrimiento de nuevas drogas que no figuren en los convenios normativos ratificados por España ${ }^{277}$, a manera de

organismo humano. Por tanto se consideran drogas las establecidas en; la Convención Única de Naciones Unidas sobre estupefacientes de 1961, enmendada en su Protocolo de 1972, en el Convenio de Viena de sustancias psicotrópicas de 1971 y en la Acción Común 97/396/JAI, de 16 de junio, relativa al intercambio de información, la evaluación del riesgo y el control de las nuevas drogas sintéticas. FABIÁN CAPARRÓS, Eduardo A. "El tráfico ilícito de drogas..., op. cit., p. 4. Morales García afirma que la consideración del artículo 368 como norma penal en blanco no cuestiona de manera alguna su constitucionalidad, dado que su supuesto de hecho y su consecuencia jurídica se encuentran perfectamente delimitadas en el tipo, además señala que no es necesaria la elaboración de un catálogo de sustancias lesivas a modo de numerus clausus propuesto por un sector doctrinal, pues la constante dinamización del mercado obligaría una constante actualización del mismo, cuyo efecto en su opinión sería similar al provocado por los Tratados Internacionales y sus anexos de actualización. QUINTERO OLIVARES, Gonzalo (Dir.). Comentarios a la Parte Especial..., op. cit., p. 1491.

MUÑOZ CONDE, Francisco. Derecho Penal. P.E..., op. cit., pp. 672- 674. Como ejemplo queremos citar el caso de la inclusión de la Ketamina entre las sustancias sometidas a fiscalización, sustancia que la Comisión de estupefacientes de Naciones Unidas, en su 53 período de sesiones celebrado en marzo de 2010, aprobó la resolución E/CN.7/2010/L.9 titulada «Cooperación internacional para combatir la administración subrepticia de sustancias psicoactivas relacionadas con la agresión sexual y otros actos delictivos» mediante la cual, entre otras recomendaciones, insta a los Estados Miembros a que consideren la posibilidad de que en su legislación nacional o sus directrices pertinentes se prevean circunstancias agravantes en los casos en que se administren subrepticiamente sustancias psicoactivas para cometer una agresión sexual, tal es el caso de la Ketamina. El Estado español en respuesta a tal resolución aprobó la Orden SAS/2712/2010, de 13 de octubre mediante la cual incorporan la sustancia antes señalada a la lista de sustancias psicotrópicas, pasando por ende a formar parte de las tres categorías que enumera el artículo 368 CP: drogas tóxicas, estupefacientes o sustancias psicotrópicas. CONDE-PUMPIDo FERREIRO, Cándido. Código Penal Comentado..., op. 
ejemplo señalamos el aumento continuo de las clases y cantidades de las drogas sintéticas, hasta 2014 se detectaron 388 sustancias distintas, frente a las 348 detectadas que habían sido detectadas el año anterior. La mayoría de las sustancias objeto de uso indebido son cannabinoides sintéticos, catinonas sintéticas y opioides sintéticos que imitan los efectos de drogas fiscalizadas como el cannabis, las anfetaminas y la heroína ${ }^{278}$. La opinión de Sequeros Sazatornil sobre este tema es que se deben considerarse drogas ilícitas todas las sustancias que adquieran tal condición en el ámbito internacional (Convenios) y las que se declaren expresamente en España ${ }^{279}$.

Una situación diferente, que en nuestra opinión es más acertada, se produce en la Ley de estupefacientes Alemana (BtMG), que en su artículo 1 preceptúa que: "el Gobierno Federal está facultado para modificar por decreto con asentimiento del Consejo Federal los anexos I al III (lista de estupefacientes) luego de oír el dictamen de técnicos, cuando esto sea necesario: 1) según el conocimiento científico, debido al modo de funcionamiento de una sustancia, respecto de la provocación de una dependencia, 2) debido a la posibilidad de producir estupefacientes con una sustancia o con empleo de una sustancia, o 3) Para la seguridad o para los controles del tráfico de estupefacientes o de otras sus-

cit., pp. 1292, 1293. La determinación del objeto material del delito de tráfico de drogas del artículo 344 del Código Penal no ha dejado de plantear problemas, desde la perspectiva del principio de legalidad, la doctrina sentada por esta sala ha venido sancionando las conductas tipificadas en el artículo antes citado relativas tanto a las sustancias incluidas directamente en las listas anexas de los correspondientes Tratados Internacionales, como las posteriormente incorporadas a ellas en el ámbito interno en virtud de las pertinentes órdenes ministeriales. Idem. 1303.

278 https://www.incb.org/documents/Publications/AnnualReports/AR2014/Spanish/Press_ Kit_2014_S.pdf, p. 8. En los últimos años se han detectado en Europa un total de 130 canabinoides sintéticos. Se sospecha que la mayor parte de estas sustancias se han fabricado en China. Tras enviarse en polvo a Europa, los productos químicos se suelen añadir a la materia vegetal y se envasan para su venta como "productos euforizantes legales. Además se han detectado 14 opioides sintéticos nuevos desde el año 2005 hasta la fecha, entre los que se encuentran varios fentanilos sin control muy potentes. Informe Europeo sobre Drogas. Tendencia y novedades 2015. Ed. Observatorio Europeo de las Drogas y las Toxicomanías. Bruselas. 2015, pp. 21, 24, 32.

279 SEQUEROS SAZATORNIL, Fernando. El Tráfico de drogas..., op. cit., pp. 285, 286. 
tancias o de preparados debido a la medida abusiva de su empleo y debido al peligro mediato o inmediato para la salud" 280 .

En todo caso, no puede negarse, que asumir que la salud publica es el bien jurídico tutelado en los delitos concernientes al tráfico de drogas presenta ciertas contradicciones prácticas, pues aunque se entiende justificada la intervención penal en el caso de las denominadas drogas duras por la nocividad que comportan para la salud, no es así en el caso de las drogas blandas que son escasamente perjudiciales, lo cual resulta contradictorio si tenemos en cuenta que hay otras sustancias como el alcohol o el tabaco que presentan similar o mayor nivel de menoscabo para la salud y su comercio, así como su consumo se encuentran permitidos. Pensemos por ejemplo, en el masivo consumo de tabaco que se produce en la mayoría de países del mundo así como en el impacto que produce en la salud pública tal vez, superior a la generada por todas las drogas ilegales juntas ${ }^{281}$. Sobre este tema un estudio científico realizado a nivel mundial sobre la carga que representan las enfermedades asociadas al consumo de drogas, señala en sus conclusiones que, de un total de 43 factores de riesgo para la salud, el consumo

280 Es más, está Ley establece que en casos urgentes para la seguridad o para los controles del tráfico de estupefacientes, El Ministro Federal de Salud está facultado para incorporar sustancias a los anexos I al III, pudiendo hacerlo por Decreto sin asentimiento del Consejo Federal. Un decreto aprobado en base a este precepto pierde su vigencia luego del transcurso de un año. También puede modificar, por Decreto sin aprobación del Consejo Federal los anexos I al III o los Decretos dictados en base a esta Ley cuando ello sea necesario debido a las modificaciones de las listas de la Convención Única de 1961 sobre estupefacientes en la versión de la publicación del 4 de febrero de 1977 y del Tratado de 1971 sobre sustancias psicotrópicas en su versión vinculante para la República Federal Alemana. BROND, Leonardo G. "Ley de estupefacientes alemana (BtMG)", en Revista de Derecho Penal Argentina. 2004/1, pp. 499, 500.

281 El consumo de tabaco produce más problemas que cualquier otra droga legal o ilegal. GALÁN PACHÓN, Juan. GUERRERO, Lech Julián. "La legalización de las drogas ilícitas en Colombia: elementos para una discusión” en GALÁN, Juan Manuel. THOUMI, Francisco. RAMÍREZ, William. VARGAS, Ricardo. La batalla perdida contra las drogas: ¿legalizar es la opción?. Ed. Intermedio Editorial Ltda. Bogotá. 2008, p. 130. MUÑOZ CONDE, Francisco. Derecho Penal. P:E..., op. cit., p. 673. La Agencia Sanitaria de Naciones Unidas afirma que el consumo de tabaco es la principal causa de mortalidad evitable en el mundo, estimando que alrededor de unos seis millones de personas mueren anualmente por esta causa. Señalando que más de cinco millones mueren por consumir el producto y aproximadamente 600.000 personas son no fumadores expuestos al humo del tabaco. http://www.who.int/entity/mediacentre/factsheets/fs339/es/index.html 
de drogas ilícitas ocupa el puesto número 19 en la clasificación de las principales causas de fallecimiento en todo el mundo, mientras que el consumo de tabaco ocupa el segundo puesto y el consumo de alcohol el tercero. Además se ha logrado comprobar que los ingresos que obtienen los gobiernos de la venta legal del tabaco y el alcohol son inferiores a los costos económicos y de salud derivados del abuso de esas sustancias ${ }^{282}$.

Es preciso decir que en atención a la escasa nocividad que representan las drogas blandas (marihuana, hachís y aceite de cannabis) nos parece aconsejable su despenalización en aras de proteger la constantemente aludida salud pública ${ }^{283}$. Afirmamos esto en el sentido de prevenir la adición de sustancias verdaderamente perjudiciales como cemento, cal entre otras por los traficantes para aumentar la cantidad de la droga en el caso del hachís. Lo cual creemos además permitiría limitar en alguna medida la posibilidad de acceder a este tipo de drogas a menores de edad o disminuidos mentales, ya que como todos sabemos, en muchas ocasiones les es más fácil acceder a las denominadas drogas ilegales que al alcohol o el tabaco. Creemos que para regular el consumo de las denominadas drogas blandas, podrían adoptarse medidas de carácter

282 Informe de la Junta Internacional de Fiscalización de Estupefacientes correspondiente a 2013. Ed. Naciones Unidas. Nueva York. 2014, pp. 2, 5.

283 Nos parece necesario señalar que el cultivo ilícito de marihuana es el más extendido a nivel mundial, superando ampliamente los cultivos de amapola y coca. Los datos suministrados por el programa de Naciones Unidas para la fiscalización internacional de drogas indican que la superficie total del cultivo de cannabis puede variar entre 670.000 y 1.800 .000 hectáreas, lo cual representa tres o seis veces la superficie del cultivo de la adormidera y la coca respectivamente. Las sustancias químicas y el tráfico de estupefacientes. BERNAL CONTRERAS, Héctor Hernando. Las sustancias químicas...op. cit., pp. 167, 168. El cannabis es también la droga más extendida en Europa, donde se importa o se produce internamente. El problema de la drogodependencia en Europa. Informe anual 2012. Ed. Observatorio Europeo de las Drogas y las Toxicomanías. Luxemburgo. 2012, p. 43. A favor de terminar con la política prohibicionista en materia de tráfico de drogas tóxicas, estupefacientes y psicotrópicos. ALVAREZ GARCÍA, Francisco Javier. "La necesidad de un cambio de paradigmas en el tráfico de drogas: la urgencia de su legalización" en Cuadernos de Política Criminal. Año 2011. Número 105, pp. 202, 206, 208, 228, 229, 243-246. En contra de la legalización de las denominadas drogas blandas y duras. MANTOVANI, Ferrando. "Droga: oscuro mal de la vida y de la libertad". (Trad. BENÍTEZ ORTÚZAR, Francisco) en Cuadernos de Política Criminal. Año 2010. Número 100, pp. 47-60. 
administrativo, para lo cual puede resultar muy interesante analizar las medidas adoptadas recientemente con el tabaco ${ }^{284} \mathrm{y}$ el alcohol 285 .

Continuando con la idea de lo perjudicial que resulta para la salud de los consumidores la prohibición de las drogas, queremos señalar que drogas como la cocaína o subproductos de esta como el basuco ${ }^{286}$, la base libre y el crack $^{287}$ contienen además de varios componentes de la

Durante la extracción de la base de cocaína se generan subproductos que contienen cantidades variables de alcaloides, residuos vegetales y sustancias químicas utilizadas en el procesamiento. El basuco es conocido con varios nombres, entre los que se destacan, pitillo (Bolivia), baserolo (Ecuador) y basuco, suki o suzuki (Colombia), entre otros. El basuco es insoluble en agua, tiene un punto de fusión (paso de sólido a líquido con el calor) más alto que la cocaína, razón que posibilita su consumo a través de cigarrillo. Es de más rápida absorción en el cuerpo. Los efectos del basuco se manifiestan casi de inmediato después de la primera inhalación del cigarrillo produciendo una sensación de euforia que dura entre cuatro y cinco minutos para posteriormente dar paso a una sensación de tristeza y malestar que obliga a consumir nuevamente. El poder adictivo de esta droga es bastante elevado los fumadores compulsivos llegan a fumar hasta cien cigarrillos en una sesión que puede durar menos de una noche. BERNAL CONTRERAS, Héctor Hernando. Las sustancias químicas y el tráfico de estupefacientes. Ed. Ministerio de Justicia y del Derecho. Bogotá. 2003, pp. 173,174.

287 La base libre y el crack son derivados de la cocaína de uso común en los países industrializados donde no llega el basuco. Ambas drogas son formas básicas químicamente parecidas, que se diferencian exclusivamente por el mecanismo de obtención. A diferencia del basuco, la base libre y el crack son sustancias elaborados a partir del clorhidrato de cocaína. Lo que buscan el traficante y el consumidor es obtener un producto que pueda ser fumado, característica que le dan las formas básicas de la cocaína. La base libre se elabora mediante la reacción de la cocaína con una solución de amonio (sustancia no catalogada) y éter etílico (precursor de drogas), mientras que el crack, que toma su nombre debido al sonido que emite cuando se esta consumiendo, se obtiene haciendo reaccionar la cocaína con una solución de soda, omitiendo la reacción con el éter etílico. En ambos casos se lleva a cabo un proceso de recristalización. Teniendo en cuenta que estas drogas son menos contaminadas químicamente, los efectos son menos nocivos que los del basuco, pero más potentes que la cocaína. Tanto la base libre como el crack producen una sensación de euforia y de bienestar y, en muchos consumidores, con excitación sexual. Sin embargo, estos efectos positivos para los consumidores desaparecen rápidamente y son reemplazados por una fuerte depresión, irritabi- 
hoja de coca, diversas proporciones de sustancias químicas y mezclas que se usan para su elaboración como residuos de solventes (acetatos, cetonas, hidrocarburos), bases fuertes (hidróxido de sodio, residuos de amonio), sales básicas (carbonato de sodio, bicarbonato de sodio), combustibles (gasolina, kerosene, petróleo), productos terminados (cemento, yeso), sales oxidantes (generalmente permanganato de potasio), así como otras sustancias que agregan los expendedores callejeros entre las que se encuentran el polvo de ladrillo, harinas, talcos desodorantes, anestésicos locales y estimulantes farmacéuticos (lidocaína, procaína, aminopirina, fenacitina) de venta libre, estimulantes lícitos (cafeína), carbohidratos (almidones, lactosa) entre otras sustancias que sin lugar a dudas perjudican seriamente la salud de los consumidores de estas drogas 288 . Queremos destacar por su elevado nivel de nocividad para la salud de sus consumidores la droga denominada como desomorfina, dihidrodesoximorfina, "Permonid", también conocida como "cocodrilo", que los drogadictos utilizan como sustituto de la heroína. La desomorfina es un análogo de opiáceo inventado en 1932 en la Unión Soviética. Es un derivado de la morfina, en el cual se ha eliminado el grupo 6-hidroxilo y se ha reducido el doble enlace 7,8.2 posee efectos sedantes y analgésicos, siendo entre 8 a 10 veces más potente que la morfina. Esta droga ha ganado una terrible popularidad al ser responsable de la producción de gravísimos daños en los tejidos (flebitis y gangrena), que requiere muchas veces la amputación del o los miembros infectados, produciendo además infecciones en los huesos, osteomielitis en los huesos de la mandíbula y la cara, llagas y úlceras en la frente y cráneo, así como necrosis en orejas, nariz y labios, generando también problemas en el hígado y los riñones. Hay que señalar que el daño en los tejidos blandos ocurre principalmente alrededor de las zonas inyectadas y es causado por la acumulación de la droga. La mezcla también parece acumularse en las venas, ya que no logra disolverse completamente en la sangre. Estas acumulaciones necrosan los tejidos y se abren camino hacia lugares distantes del cuerpo ampliando el daño causado. Además el efecto de esta droga es bastante efímero, mientras que el efecto de la heroína dura varias horas, el cocodrilo

lidad, angustia, insomnio y disminución del apetito. BERNAL CONTRERAS, Héctor Hernando. Las sustancias químicas..., op. cit., pp. 174, 175. 
dura entre 90 minutos y 2 horas lo que induce a sus usuarios a inyectarse varias veces por día, aumentando aún más el daño causado. Es necesario señalar que esta terrible droga se elabora utilizando cloruro de tionilo, codeína (tabletas), yodo, fosforo rojo, thinner y gasolina (todas son sustancias no catalogadas de fácil acceso), usando sólo un precursor de drogas el ácido clorhídrico. La desomorfina se consume en la Federación de Rusia y otros países del este de Europa, reportándose casos de consumo también en México y los Estados Unidos de América ${ }^{289}$.

Una vez asumido que en la prohibición de las drogas ilegales, estupefacientes y psicotrópicos está presente la preocupación por la salud pública, en el entendido que prácticamente cualquier droga afecta la salud (en mayor o menor medida) de quienes las consumen, no es menos cierto, que a las personas no se les debe imponer normas represivas con relación a lo que pueden o no consumir, partiendo de la idea que nosotros compartimos de que la salud es un bien que debe ser disponible por su titular, si este es mayor de edad y goza de plena capacidad mental. Así el consumo de drogas realizado por personas adultas con facultades mentales normales no debe ser objeto de prohibición penal en atención al principio de libertad individual290, situación que se aplica sin problema alguno al extendido consumo de drogas, que perjudican la salud pública, como el alcohol y el tabaco.

Para concluir este breve estudio sobre el concepto de salud pública, queremos insistir en que entendemos que el carácter público que se atribuye al bien jurídico protegido está referido más un rasgo que define la modalidad de ataque al que dan lugar las conductas (que afecta a una cantidad indeterminada de personas) que al objeto tutelado (que se puede asimilar a la salud individual). Pensamos que esta perspectiva aporta un referente material más sólido para delimitar la intervención penal en esta materia (perspectiva político criminal) así como para la

289 https://es.wikipedia.org/wiki/Desomorfina.

290 Frente a los menores o discapacitados mentales "no puede afirmarse el principio de libertad individual que fundamenta la impunidad del consumo". ARROYO ZAPATERO, Luis. "Aspectos Penales..., op. cit., p. 29. BUSTOS RAMÍREZ, Juan. Manual de Derecho Penal P.E..., op. cit., pp. 277, 278. NESTLER, Cornelius. “El principio de protección..., op. cit, p. 75. 
interpretación de los tipos delictivos y sus relaciones entre sí y con otras figuras del Código Penal (perspectiva dogmática) ${ }^{291}$.

\section{B.) OTRAS POSTURAS SOBRE EL BIEN JURÍDICO PROTEGIDO EN EL DELITO DE TRÁFICO} DE DROGAS

Siempre en la línea de asumir como bien jurídico tutelado la salud pública en estos tipos penales pero afirmando que se protegen además otros bienes jurídicos, se pronuncian algunos autores entre ellos, De la Cuesta Arzamendi quien afirma que la referencia a la salud pública no agota los bienes jurídicos afectados por las conductas comprendidas en estos tipos, sosteniendo que también se tutelan otros bienes tales como; la salud individual, la juventud, la seguridad colectiva o el orden público, enfatizando que interesa aún más la seguridad en las calles (en su opinión auténtico bien jurídico protegido) que la propia salud pública ${ }^{292}$. Martínez Burgos y Prieto Rodríguez también son de la idea de que nos encontramos frente a un delito pluriofensivo 293.

En sentido similar Romeral Moraleda y García Blázquez, sostienen que además de la salud pública como bien jurídico protegido por la norma existen otros intereses tutelados, que ellos denominan de segundo

291 Doval entiende que los bienes jurídicos colectivos y en consecuencia "la salud pública", son "creaciones dogmáticas que encuentran su razón de ser en la protección de valores o intereses individuales y, por consiguiente, tienen un carácter meramente instrumental o medial en el sistema diseñado por el legislador para la protección de bienes jurídicos individuales". Siendo precisamente por ese carácter, que se afirma que los bienes jurídicos colectivos son complementarios de los individuales. Complementariedad que no debe comprenderse como una relación de complementariedad entre un bien jurídico y otro, "sino en el sentido de que el bien jurídico colectivo ofrece un complemento para la integración del sistema de protección de bienes jurídicos de carácter individual que el Código Penal contiene. DOVAL PAIS, Antonio. Delitos de fraude alimentario. Análisis de sus elementos esenciales. Ed. Aranzadi. Pamplona. 1996, pp. 251, 252. DOVAL PAIS, Antonio. "Los Delitos de fraude alimentario..., op. cit., p. 141.

292 DE LA CUESTA ARZAMENDI, José L. "Legislación Penal Europea Occidental- Comunitaria y comparada sobre Drogas" en Doctrina Penal Teoría y práctica de las Ciencias penales año 14. 1991b. Buenos Aires. 1991, pp. 434, 454.

293 Martínez Burgos afirma que los bienes jurídicos protegidos en este tipo penal son; la salud individual, la salud colectiva y la seguridad social. Prieto Rodríguez parece entender que se tutelan; la salud pública, la libertad del consumidor, la moral, la seguridad colectiva e inclusive intereses económicos. PRIETO RODRÍGUEZ, Javier Ignacio. El Delito de Tráfico..., op. cit., p. 228. 
grado los cuales, asumen se reflejan de forma muy clara en algunos convenios internacionales tales como; la Convención Única de 1961 sobre estupefacientes en la que se manifiesta que la "toxicomanía constituye un mal grave para el individuo y entraña un peligro social y económico para la humanidad"; posteriormente el Convenio del 21 de febrero de 1971 relativo al uso de sustancias psicotrópicas advierte sobre "los problemas sanitarios que origina el uso indebido de ciertas sustancias"; y finalmente el Convenio de 20 de diciembre de 1988 contra el tráfico ilícito de estupefacientes y sustancias psicotrópicas refiere que las partes "profundamente preocupadas por la magnitud y la tendencia creciente de la producción, la demanda y el tráfico ilícito de estupefacientes y sustancias psicotrópicas, que representan una grave amenaza para la salud y el bienestar de los seres humanos y menoscaban las bases económicas, culturales y políticas de la sociedad" 294.

En nuestra opinión el problema que conlleva afirmar que nos encontramos ante delitos pluriofensivos es precisamente la identificación del bien jurídico protegido, ya que para afirmar dicho carácter deberá de confirmarse en la figura delictiva la lesión o puesta en peligro de una diversidad de bienes jurídicos. Como todos sabemos en la mayoría de delitos podemos identificar diferentes bienes afectados en alguna medida por la conducta típica, pero la importancia de la individualización del bien jurídico sólo adquiere sentido "en la medida que ponga de relieve una particularidad de determinados delitos que está ausente en otros", por lo que de muy poco nos sirve advertir en estos delitos la presencia de intereses que le son comunes a la mayoría de figuras preceptuadas en el Código Penal; sirva como ejemplo la seguridad en general, el orden público o la tutela de las nuevas generaciones, lo que no quiere decir que para afirmar que determinado precepto penal no tenga un carácter pluriofensivo baste con acudir a lo que las rúbricas del ordenamiento penal establezca, es decir, que la selección no debe estar integrada por todos aquellos bienes que puedan ser afectados inclusive de forma ocasional a la par del bien jurídico protegido, ni por aquellos que necesariamente lo hayan de ser de todas maneras, "sino únicamente por los que pertenecen al ámbito específico de la norma" 295 , siendo

294 ROMERAL MORALEDA, Antonio. GARCÍA BLÁZQUEZ, Manuel. Tráfico y Consumo de Drogas. Aspectos penales y médico-forenses. Ed. Comares. Granada. 1993, p. 4.

295 Doval afirma que la solución de este complejo problema radica en diferenciar "el objeto de lesión del objeto de protección". Además sostiene acertadamente a nuestro enten- 
conscientes por nuestra parte de que la determinación de dichos ámbitos no constituye una tarea sencilla. En este sentido Cobo del Rosal expresa de forma magistral que "las diversas causas que impulsan al legislador a la incriminación de estas conductas son múltiples, además se anidan tras el bien jurídico e incluso le confieren sus últimas motivaciones, pero no deben confundirse con él so pena de renunciar a su certeza, concreción y mínima utilidad" 296.

Un sector de la doctrina española argumenta que el bien jurídico protegido en los delitos relativos al tráfico de drogas no es precisamente la salud pública, sino la libertad personal, ya que en su opinión el problema de las drogas no es su fabricación, distribución o trafico, sino la existencia de estructuras organizadas destinadas a imponer de cualquier forma su consumo especialmente entre menores o personas especialmente vulnerables. Afirmando que "la esencia del lazo que liga al hombre con la droga es la dependencia", ya que infiere un ataque a la libertad del consumidor en cuanto disminuye su voluntad para decidir libremente, y tras el continuo consumo de estas sustancias, queda atrapado en las redes de la dependencia luchando por conseguir su dosis diaria"297.

der, que para determinar la naturaleza pluriofensiva de un delito, se requiere en primer lugar decidir la cuestión acerca de la entidad de los bienes o intereses afectados (debe tratarse de bienes que merezcan la consideración de bienes jurídico penales). Luego, se debe establecer si su afección es necesaria en todos los casos (y no sólo de forma eventual); y finalmente es indispensable averiguar si el tipo penal del que se trate ofrece una protección especifica a dichos bienes, es decir, que la lesión del bien sea esencial a la ofensa. Como asevera Durigato esto se tendrá que decidir partiendo al tenor del dato textual normativo, así cuando este respalde la hipótesis de que no se trata de sólo un interés, sino de una pluralidad de intereses, el objeto jurídico del delito, habrá que reconocer que estamos frente a un delito pluriofensivo. DOVAL PAIS, Antonio. Delitos de fraude alimentario. .., op. cit., pp. 219, 220.

296 COBO DEL ROSAL, Manuel. "Consideraciones generales sobre el denominado tráfico ilegal de drogas tóxicas o estupefacientes” en Delitos contra la salud pública. Tráfico ilegal de drogas toxicas o estupefacientes. Ed. Universidad de Valencia. 1977, pp. 161 y ss.

297 BUSTOS RAMÍREZ, Juan. Manual de Derecho Penal P.E..., op. cit., pp. 277, 278. DE LA CUESTA ARZAMENDI, José L. "Legislación Penal..., op. cit., p. 435. PRIETO RODRÍGUEZ, Javier Ignacio. El Delito de Tráfico..., op. cit., p. 216. Se dispone de pruebas convincentes de un síndrome de dependencia de las anfetaminas tras el consumo intensivo regular. Entre los síntomas asociados a la abstinencia pueden encontrarse el deseo compulsivo de consumir y la depresión con aumento del riesgo de suicidio. Por otra parte la de- 
Nosotros no compartimos la idea de asumir que el bien jurídico protegido en estos delitos sea la libertad personal, dado que todos los delitos contra la voluntad lo son concretamente contra la voluntad del sujeto pasivo, y en los casos que nos ocupan, es por todos conocido que el traficante en muchas ocasiones trata con toxicómanos que carecen de voluntad, tienen la misma bastante disminuida o asumen plenamente la decisión de consumir la sustancia estupefaciente de forma voluntaria. También es necesario tener en consideración que la "libertad" de una forma mediata es prácticamente afectada en la mayoría de delitos, pero para que constituya el bien jurídico protegido, es necesario que tal requisito se de como elemento principal e inmediato del delito lo cual entendemos no se produce en los delitos relativos al tráfico de drogas ${ }^{298}$.

Por otra parte, hay quienes sostienen sin mucho acierto en nuestra opinión, que el bien jurídico defendido en los delitos que nos ocupan son los intereses fiscales, afirmación que no nos convence dado que entendemos que los intereses fiscales del Estado en el tráfico de drogas están protegidos por las normas relativas al contrabando, así como otras que regulan las diferentes actividades comerciales. También hay quienes afirman que el bien protegido es la moral. Esto en atención a lo establecido en ciertos instrumentos legales, tal es el caso del Convenio Único de 1961 donde se hace alusión, no sólo a la salud pública, sino además a "la salud moral de la humanidad". Además, se habla de la protección de intereses económicos ocultos por encima de la protección de la salud pública en el Convenio de Viena de 1988: "la demanda y el tráfico ilícito menoscaban las bases económicas de la sociedad"..., "el tráfico ilícito genera considerables rendimientos financieros y grandes for-

pendencia del gamma-hidroxibutirato (GBH) es un trastorno clínico reconocido, con un síndrome de abstinencia potencialmente intenso cuando se interrumpe bruscamente su administración después de un consumo regular o crónico. Existen datos que demuestran la posibilidad de que aparezca dependencia física entre los consumidores recreativos. En el caso de los consumidores de heroína se producen síntomas físicos de abstinencia. El problema de la drogodependencia en Europa. Informe anual 2012. Ed. Observatorio Europeo de las Drogas y las Toxicomanías. Luxemburgo. 2012, 61-63, 81, 82.

$298 \mathrm{Ni}$ en el caso de los menores o disminuidos mentales el bien jurídico tutelado sería la libertad personal, pues como es sabido siempre es necesario que el sujeto pasivo ostente la libertad que se protege. Además únicamente cuando el traficante obligara al receptor a adquirir la droga forzando su voluntad, deberíamos afirmar que se está vulnerando la voluntad de este, pero en todo caso estaríamos frente a un delito de coacciones. REY HUIDOBRO, Luis Fernando. El Delito de tráfico de estupefacientes..., op. cit., p. 121. 
tunas que permiten a las organizaciones delictivas transnacionales invadir, contaminar y corromper"... "las actividades comerciales lícitas"299. Sobre estos señalamientos como ya afirmamos anteriormente, consideramos que no deben asumirse como bienes jurídicos tutelados en los delitos relativos al tráfico de drogas, pues aunque no dudamos que son sopesados por el legislador a la hora de criminalizar estas conductas no constituyen el elemento principal del delito.

\section{C.) ALGUNAS REFLEXIONES SOBRE LA LUCHA CONTRA EL TRÁFICO DE DROGAS}

Para hacernos una idea del coste económico que representa el tráfico de drogas nos remitimos a la región de América del Norte, que es el principal mercado de drogas ilícitas del mundo. Según estimaciones recientes cada año fallecen en esta región alrededor de 45.000 personas por causas relacionadas con las drogas, la tasa más elevada del mundo. En un informe publicado en el año 2011 por el National Drug Intelligence Center del Departamento de Justicia de los Estados Unidos de América se estimó que en el año 2007 el impacto económico en ese país fue de 193.000 millones de dólares. En esa cifra se tiene en cuenta el gasto relacionado con la justicia penal, los costos de las atenciones de salud, la pérdida de competitividad económica, la capacidad de acción militar, los resultados en enseñanza y la productividad de la fuerza de trabajo. En Canadá se calculó que los costes del uso indebido de drogas ilegales superan los 9.000 millones de dólares al año. Mientras que en México, como país importante en el tráfico y origen del tráfico de drogas como la cocaína, la heroína, cannabis, metanfetamina y el fentanilo, en el ejercicio económico del año 2012 se presupuestó en gastos relacionados con el enfrentamiento a la actividad de narcotráfico 10.700 millones de dólares ${ }^{300}$.

Prieto Rodríguez manifiesta que resulta verdaderamente difícil diferenciar el interés del Estado del interés individual o colectivo directamente afectado en estos tipos penales. Sin embargo afirma que es bastante evidente la actitud extremadamente intervencionista desplegada por el Estado en el control de dichas drogas ilegales, frente a la permi-

299 PRIETO RODRÍGUEZ, Javier Ignacio. El Delito de Tráfico..., op. cit., pp. 220- 224. 
sibilidad que se mantiene con otras drogas que se consideran legales como el tabaco o las bebidas alcohólicas, sobre las cuales hoy en día ya nadie discute su nocividad para la salud, tanto individual como pública o colectiva, realidad que obliga a entender que la aprobación por parte del Estado del consumo y comercio de ciertas sustancias nocivas como las anteriormente citadas, responde fundamentalmente a intereses económicos así como a la aceptación social que existe sobre el consumo de determinadas sustancias como el alcohol y actualmente en menor medida del tabaco, y en todo caso, por la imposibilidad real de su erradicación. Situación que en nuestra opinión, es trasladable a algunas drogas ilegales sobre todo si se piensa en las denominadas drogas blandas, no se debe olvidar que los derivados del cannabis son las drogas ilícitas más consumidas en el mundo, de las cuales múltiples estudios han arrojado que al menos no son más nocivas que las drogas legales de amplio consumo antes citadas ${ }^{301}$.

Al hijo de lo expresado anteriormente nos parece conveniente recordar la tristemente célebre historia de la implementación de la denominada "Ley Seca" o "Volstead" que en los Estados Unidos de América en el año 1919 criminalizó el tráfico de bebidas alcohólicas, Ley que no hizo más que propiciar que aumentara vertiginosamente el consumo de dichas sustancias, además de posibilitar el desarrollo y fortalecimiento de la criminalidad organizada en ese país alrededor del tráfico de las bebidas alcohólicas en sus 13 años de vigencia y, para colmo de males, aún con toda la política represiva que se desplegó para acabar con el trafico y consumo de las sustancias anteriormente aludidas no tuvieron más alternativa, ante el rotundo fracaso, que abolir esta prohibición sin sentido que provocó 30.000 muertes y 100.000 víctimas con diversas lesiones por consumo de alcohol metílico ${ }^{302}$. Acertadamente, Betham alcohólicas. Inicialmente se establecieron zonas de prohibición en las proximidades de bases militares, posteriormente se produjo la Prohibition party. Hasta que en 1919 entra en vigor la Enmienda XVIII que reformando la Constitución permite la entrada en vigor de la Ley seca que preceptúa el cierre de los establecimientos donde se descubriera el consumo de alcohol, estableciendo penas de hasta cinco años de prisión para los reincidentes en la fabricación o comercio del mismo. Es importante recordar que la aplicación de esta Ley género más de 45.000 condenas de prisión, y más del triple fueron objeto de sanciones administrativas. Como todos sabemos la Enmienda señalada 
mucho tiempo atrás señaló que no tenía ningún sentido legislar con el propósito de erradicar males tales como el alcoholismo o la fornicación $^{303}$. Creemos que un ejemplo contundente de la imposibilidad real de la erradicación del tráfico y consumo de las denominadas drogas ilegales lo constituye el hecho irrefutable de que ni en las cárceles, donde se produce el más férreo control sobre las personas, se ha podido erradicar el tráfico y consumo de estas sustancias ilícitas.

Nos llama la atención que el Gobierno colombiano, apoyado firmemente por la Administración de los Estados Unidos de América en la lucha contra el narcotráfico, para erradicar los cultivos de coca y amapola, se ha dado a la ardua tarea de fumigar con medios aéreos (aviones fumigadores Turbo Trush) las zonas donde se encuentran estos cultivos ilícitos con glifosato. Es anecdótico que como respuesta los cultivadores de amapola "cubren con preservativos (condones) los botones de la flor maldita para impedir que el glifosato las destruya". Mientras que para la protección del tallo y las hojas recurren a la misma técnica que los cultivadores de coca en las selvas del Guaviare, Caquetá y Putomayo, de lavar las plantas con agua mezclada con azúcar o panela de azúcar. Desafortunadamente, aunque los condones (con un uso no descartable) logran proteger las plantaciones ilegales, el glifosato afecta seriamente a la flora y fauna (que nadie se molesta en proteger) de estos lugares. Encontrándose seriamente afectado el parque natural fronterizo ubicado entre el Valle y Tolima que abarca 125.000 hectáreas donde nacen alrededor de treinta ríos y quebradas que conforman un

anteriormente fue derogada 13 años después por la enmienda XXI. HOMS SANZ DE LA GARZA, Joaquín. Trastorno mental transitorio y drogas que inciden en la imputabilidad. Ed. Bosch Editor, S.L. Barcelona. 1996, pp. 435- 437. NEUMAN, Elías. La legalización de las drogas. Segunda edición. Depalma. Buenos Aires. 1997, pp. 259- 261.

303 Bentham, sobre las posibilidades de erradicar conductas no deseables como el alcoholismo manifestaba que "ni siquiera todas las torturas que el ingenio puede inventar serían suficientes; y antes que haya hecho algún progreso que merezca ese nombre, el castigo habrá producido una tal cantidad de daño, que excederá más de mil veces el peor agravio producido por la ofensa". BUSTOS RAMÍREZ, Juan. Manual de Derecho Penal Parte Especial. Ed. Ariel. Barcelona. 1986, p. 275. Afirma García-Pablos que en España para enfrentar el problema de las drogas se optó por "terminar con los problemas sociales a golpe de prohibiciones", convirtiendo "el problema social de la droga en un problema criminal, y se encomendó al Derecho Penal (es decir, a la cirugía penal) la misión de velar por la salud pública de todos". GARCÍA-PABLOS, Antonio. "Bases para una política..., op. cit., pp. 357- 367. 
sistema hídrico de vital importancia para los cultivos de los dos departamentos. De esta manera por querer erradicar la flor maldita o las plantaciones de coca se está acabando con los páramos y con especies animales como los osos, las dantas y los venados, que antes se topaban a la vera del camino ${ }^{304}$.

Sobre la lucha contra las drogas ilícitas resulta muy interesante la opinión de Alessandro Baratta, que sostenía que nos encontramos ante una crisis general de las ideologías positivas, así como de los proyectos políticos en general donde la guerra contra las drogas ilegales se ha convertido en un eje de redefinición de la propia identidad que abarca a todos los actores, guerra que se justifica en la aparente defensa de la salud pública, del bien y de la civilización en detrimento de una estigmatización y represión de una minoría de consumidores de dichas drogas que son objeto de un drástico proceso de inserción en roles criminales de lo que se ha denominado el "círculo de la droga"; siendo esta guerra contra determinadas drogas (ilegales) tal vez el mejor instrumento de que disponen los Estados Unidos de América para legitimar su hegemonía en el orden internacional, sustituyendo la lucha contra el extinto comunismo. De ahí que sea "el país que más ha presionado la internacionalización de la política represiva contra ciertas drogas", internacionalización en que la mayoría de Estados han optado producto de la presión internacional (Convenios Internacionales) por enfrentar el problema casi de forma exclusiva a través del Derecho Penal, situación que además de ser totalmente lamentable parece estar condenada al fracaso si tomamos en cuenta los 55 años transcurridos de lucha infructuosa, o al menos no exitosa, contra las drogas ilegales $^{305}$. Para ver un amplio desarrollo sobre la influencia religiosa y moral en el prohibicionismo sobre las drogas en los Estados Unidos de

304 BUSTOS VALENCIA, Alirio. La Ley del Monte..., op. cit., pp. 43, 44. Sobre el desastre ecológico y humanitario en Colombia, y otros países productores de cocaína, por las fumigaciones con glifosato. ALVAREZ GARCÍA, Francisco Javier. "La necesidad de un cambio.., op. cit., pp. 204-212.

BARATTA, Alessandro. "Fundamentos Ideológicos de la Actual Política Criminal sobre Drogas". DÍEZ RIPOLLÉS, José Luis. LAURENZO COPELLO, Patricia (coord.). La Actual Política Criminal sobre Drogas. Una perspectiva comparada. Ed. Tirant lo blanch. Valencia 1993, pp. 27, 33. 
América se puede consultar "la batalla perdida contra las drogas"306. En todo caso para ilustrar un poco la magnitud del problema en términos reales el profesor Ethan Nadelmann de la Universidad de Pricenton, afirma que El Gobierno de los Estados Unidos ha gastado cada año en la aplicación de su política antidrogas casi veinte mil millones de dólares y que aproximadamente un tercio de la población penitenciaria de ese país se encuentra en la cárcel por problemas relacionados con el tráfico de drogas ${ }^{307}$.

En todo caso, nosotros entendemos que no se debe "seguir manteniendo la idea de que la guerra contra los estupefacientes legitima la adopción y puesta en práctica de cualquier tipo de medidas represivas, y lo que es más, no puede afirmarse que el Estado pueda imponer a los ciudadanos sus propios cánones de salud pública, forzándolos a un abandono involuntario del consumo de estas drogas"308. Señalamos como ejemplo de la irracionalidad de la lucha contra las drogas ilegales en el mundo, la legislación antidrogas vigente en Irán, que sanciona la producción, exportación, entrega, venta, ofrecimiento de venta, o compra de opio y sus derivados cuando exceda de 5 kilos con pena de muerte, constando en los registros judiciales de ese país que se han ejecutado del año 1980 al 2000 más de 4.000 personas por este delito, ejecuciones que lamentablemente continúan en la actualidad ${ }^{309}$, también la legislación cubana es bastante dura con este tipo de delitos preceptuan-

306 GALÁN PACHÓN, Juan. GUERRERO, Lech Julián. “La legalización de las drogas..., op. cit., pp. 38- 61, 114- 115.

307 GALÁN PACHÓN, Juan. GUERRERO, Lech Julián. “La legalización de las drogas..., op. cit., $107,108$.

308 El profesor Cristie destaca la importancia del necesario cambio de mentalidad en la lucha contra las drogas, aseverando que la adopción de medidas no represivas no supone desentenderse del problema de las drogas, añadiendo que el planteamiento debe estar encaminado al control administrativo del tráfico y consumo de drogas, ya que no debe perderse de vista la importancia de las implicaciones morales con relación al consumo de drogas. CHRISTIE, Nils: "The impossibility of total control". LAURENZO COPELLO, Patricia (Coord.). La Actual Política Criminal sobre Drogas. Una perspectiva comparada. Ed. Tirant lo Blanch. Valencia 1993, p. 515. GARCÍA-PABLOS, Antonio. "Bases para una política..., op. cit., pp. 382- 385.

SHAMS NATERI, Mohammad Ebrahim. "Política criminal de Irán en materia de narcóticos, drogas y sustancias psicotrópicas” en Revista Penal. № 7, Ed. La Ley. 2001, pp. 90-98. 
do la pena de muerte para varios supuestos ${ }^{310}$, igual ocurre con China, Singapur, Arabia Saudita, Tailandia, Indonesia, Malasia, Taiwán, Bangladesh, Irak, Kuwait, Laos, Omán y Vietnam. Afortunadamente la Junta Internacional de Fiscalización en su informe correspondiente al año 2014 recomendó a los Estados que siguen aplicando la pena de muerte por la comisión de delitos relacionados con el tráfico de drogas que consideren la posibilidad de abolir dicha pena para estos delitos. Por nuestra parte, no nos queda otra cosa más, que esperar que dicha recomendación surta algún efecto en dichos países ${ }^{311 .}$

Nosotros tenemos el convencimiento de que una política criminal coherente con los principios que inspiran a un Estado Social y Democrático de Derecho debe en principio excluir a los consumidores que precisamente son los portadores del bien jurídico tutelado, de toda intervención de tipo represivo y optar por las medidas de carácter preventivo y rehabilitador, así como por estudiar los diversos factores que inciden en los sujetos que realizan el tráfico, como su adicción a las drogas o su condición social para poder desarrollar una actuación digna de un Estado Democrático ${ }^{312}$, ya que no debemos olvidar en ningún momento que la mejor política penal es sin lugar a dudas una adecuada política social.

Queremos destacar por su contenido el artículo 5.7 del Convenio de Viena de 1988 relativo al decomiso de los materiales, equipos y otros instrumentos destinados a ser utilizados en la fabricación de drogas ilícitas que dispone que "cada una de las partes considerara la posibili-

En su artículo 190.3 el Código Penal establece la imposición de pena privativa de libertad de quince a treinta años o muerte: a) si los hechos a los que se refiere el apartado 1 se cometen por funcionarios públicos, autoridades o sus agentes o auxiliares, o estos facilitan su ejecución, aprovechándose de esa condición o utilizando medios o recursos del Estado; b) si el inculpado en la transportación o tráfico ilícito internacional de drogas, estupefacientes, sustancias sicotrópicas u otras de efectos similares, penetra en territorio nacional por cualquier circunstancia, utilizando nave o aeronave u otro medio de transportación; c) si el inculpado participa de cualquier forma en actos relacionados con el tráfico ilícito internacional de drogas o estupefacientes, sustancias sicotrópicas u otras de efectos similares; d) si en la comisión de los hechos previstos en los apartados anteriores se utiliza persona menor de 16 años.

311 Informe de la Junta Internacional de Fiscalización de Estupefacientes correspondiente a 2014. Ed. Naciones Unidas. Nueva York. 2015, p. III.

312 REY HUIDOBRO, Luis Fernando. El Delito de tráfico..., op. cit., p. 141. 
dad de invertir la carga de la prueba respecto del origen ilícito del supuesto producto u otros bienes sujetos a decomiso, en la medida que sea compatible con los principios de su derecho interno y con la naturaleza de sus procedimientos judiciales y otros procedimientos". La recomendación de adoptar este tipo de medidas pone de manifiesto que en los últimos años la internacionalización en la lucha contra el comercio de narcóticos se ha caracterizado por; a) un cambio en los supuestos clásicos de la responsabilidad penal que está lejos de ocuparse de la efectiva lesión o puesta en peligro de bienes jurídicos, cuya consecuencia inmediata es el establecimiento de los delitos de peligro abstracto y b) la introducción de sanciones que se desvinculan de la responsabilidad a título de culpa, y que imponen la inversión de la carga de la prueba, o la pura responsabilidad a titulo de peligro ${ }^{313}$.

En resumen como ya hemos manifestado a lo largo de este apartado, nos inclinamos por asumir que la salud pública constituye el núcleo fundamental de los delitos relativos al tráfico de drogas, y es por lo tanto el bien jurídico protegido en los delitos relativos al tráfico de drogas estupefacientes y psicotrópicos en el ordenamiento penal español ${ }^{314}$. Para concluir esta parte del trabajo creemos preciso señalar que la legislación vigente en España sobre el tráfico de drogas responde fundamentalmente a una política criminal represiva, situación que es simi-

ALBRECHT, Hans-Jörg. Criminalidad transnacional, comercio de narcóticos y lavado de dinero. (Trad. GUERRERO PERALTA, Óscar Julián). Ed. Universidad Externado de Colombia. Bogotá. 2001, pp 68, 69.

314 Rey Huidobro sostiene que cuando el delito es cometido por autoridad, funcionario público facultativo o un trabajador social (artículo 369 inciso 8을 del CPE) le parece razonable afirmar la pluriofensividad del delito, pues opina que se estaría afectando otro bien jurídico distinto de la salud pública que se materializa en el abuso por parte del sujeto activo de sus facultades o de la violación de los deberes inherentes al desenvolvimiento de una función pública, por lo que nos encontramos al lado de la salud pública como bien jurídico esencial y jerárquicamente superior, con otro interés que está constituido por "la integridad de la función y del servicio que implican las referidas profesiones". Sosteniendo que el interés de la Administración, en el desempeño de que los cargos relacionados se realicen de forma correcta es sin lugar a dudas un bien que aún revistiendo una importancia menor que la salud pública, es asumido por la ley como razón fundamental de la incriminación, reflejándose ello en la pena aplicable al sujeto activo en estos casos. Nosotros consideramos que resulta indudable la preponderancia que tiene la salud pública sobre el interés anteriormente citado, en el entendido de que su puesta en peligro es inherente a la propia esencia del injusto típico. REY HUIDOBRO, Luis Fernando. El Delito de tráfico..., op. cit., p. 138. 
lar en todos los países del denominado "mundo civilizado", lo cual ha decidido no sólo la necesidad de su ilegalización, sino también la criminalización de comportamientos dirigidos a incrementar o fomentar dicho consumo, sancionando la realización de dichas conductas con penas privativas de libertad muy duras, que en muchos casos no resultan justificadas ni eficaces. Pensamos que en atención a esta Política Criminal, y no por razones dogmáticas, las distintas figuras penales para enfrentar este problema se construyen en principio como tipos de peligro abstracto ${ }^{315}$.

\section{EL BIEN JURÍDICO PROTEGIDO EN EL DELITO TRÁFICO DE PRE- CURSORES DE DROGAS TÓXICAS ESTUPEFACIENTES Y SUSTAN- CIAS PSICOTRÓPICAS}

Como ya hemos señalado antes, al igual que en otros países de nuestro entorno jurídico, la política sobre drogas en España se ha caracterizado fundamentalmente en ajustar la legislación penal interna a los Convenios Internacionales, nos referimos especialmente a los diferentes Convenios que la Organización de Naciones Unidas (ONU) ha realizado sobre esta materia, Convenios que han propiciado que las legislaciones penales de los diferentes Estados intervengan no sólo sobre las drogas ilegales propiamente dichas, sino también sobre los productos químicos necesarios para la producción de estas sustancias. Destacamos en este sentido el Convenio del 20 de diciembre de 1988 celebrado en Viena316, que en su articulo 3, 1 a) IV) impone a los Estados Parte la

315 CÓRDOBA RODA, Juan. Comentarios al Código Penal..., op. cit., pp 1552, 1553. GARBERÍ Llobregat, J. (Dir.). Práctica jurisprudencial del Código Penal. Tomo III. Ed. BOSHC. Barcelona, pp. 2234, 2235. CARDONA TORRES, Juan. Derecho Penal. P.E..., op. cit, pp. $435,436$.

316 Antes de que la Convención de Viena regulara de forma específica el tráfico de precursores de drogas, otros dos convenios habían señalado la necesidad de su desarrollo normativo en los ordenamientos jurídicos de los países firmantes. El primero de ellos fue La Convención Única de Naciones Unidas de 1961 sobre estupefacientes que en el párrafo 8 del artículo 2 disponía: "las partes harán todo lo posible para aplicar las medidas de fiscalización, que sean factibles a las sustancias no sujetas a las disposiciones de esta Convención, pero que puedan ser utilizadas para la fabricación ilícita de sustancias psicotrópicas". En el mismo sentido el Convenio de sustancias psicotrópicas celebrado en Viena en 1971, recomendaba en el párrafo 9 de su artículo 2 que: "las partes harán todo lo posible para aplicar las medidas de supervisión que sean factibles a las sustancias no sujetas a las disposiciones de este Convenio, pero que puedan ser utiliza- 
obligación de sancionar penalmente la fabricación, el transporte o la distribución de los precursores (equipos, materiales, sustancias indispensables para el cultivo y producción de drogas tóxicas, estupefacientes y psicotrópicos). Nos parece necesario señalar, una vez más, que se trata de sustancias lícitas (precursores) que son utilizadas para la producción de sustancias ilícitas (drogas ilegales) ${ }^{317}$, lo cual conlleva un claro adelantamiento del ámbito de tutela penal, partiendo de que es el bien jurídico salud pública el que legitima la punición de los delitos relativos al tráfico de drogas (artículo 368 y siguientes), y por ende el del tráfico de precursores de dichas drogas (dado que el artículo 371 tiene una dependencia directa del artículo 368) ${ }^{318}$, donde la posibilidad de

das para la fabricación ilícita de sustancias psicotrópicas”. El Convenio de Viena de del 20 de diciembre de 1988 fue ratificado en España por instrumento de 30 de julio de 1990 y publicado en el B.O.E. № 270 de 10 de noviembre de 1990.

317 Si usualmente venía atribuyéndose a los países productores de opio y cocaína los problemas derivados de la oferta de estos productos en los mercados internacionales, no debe olvidarse que son necesarios para la producción de las drogas tóxicas, sustancias estupefacientes y psicotrópicos, diversos productos químicos, conocidos como precursores, cuya fabricación y producción se realiza fundamentalmente en países desarrollados (los Estados Unidos de América, Canadá, China, Alemania, Inglaterra, Bélgica, Holanda, Francia y España entre otros). Sin embargo no debe perderse la perspectiva de que estos productos químicos se destinan fundamentalmente a la fabricación industrial de diversos derivados de gran importancia y que, por lo tanto, su control debe dirigirse exclusivamente a evitar su posible desvío para la elaboración ilegal de drogas, procurando no interferir de forma gravosa en el desarrollo normal de la industria química y farmacéutica. Exposición de motivos de la Ley 3/1996, de 10 de enero, sobre medidas de control de sustancias químicas catalogadas susceptibles de desvío para la fabricación ilícita de drogas (España).

318 Sobre tráfico de precursores ver las sentencias de: STS (ROJ: 2484/1999) de 14 de abril de 1999. Ponente: D. Eduardo Moner Muñoz. STS (ROJ: 2497/2001) de 26 de marzo de 2001. Ponente: D. José Jiménez Villarejo. STS (ROJ: 89/2003) de 16 de enero de 2003. Ponente: D. Luis Román Puerta Luis. STS (ROJ: 583/2004) de 3 de febrero de 2004. Ponente: D. Enrique Bacigalupo Zapater. STS (ROJ: 1748/2009) de 18 de marzo de 2009. Ponente: D. Carlos Granados Pérez. STS (ROJ: 232/2013) de 18 de enero de 2013. Ponente: Alberto Gumersindo Jorge Barreiro. STS (ROJ: 5672/2016) de 23 de diciembre de 2016. Ponente: D. Andrés Palomo del Arco. SAN (ROJ: 4326/2002) de 9 de julio de 2002. Ponente: Dña. Raimunda de Peñafort Lorente Martínez. SAN (ROJ: 6508/2006) de 21 de julio de 2006. Ponente: D. Juan Francisco Martel Rivera. SAN (ROJ: 3347/2013) de 3 de julio de 2013. Ponente: D. Fernando Grande- Marlaska Gómez. SAP de Madrid (ROJ: 1659/2003) de 10 de febrero de 2003. Ponente: D. Adrián Varillas Gómez. Absuelven porque no se demuestra el elemento subjetivo. SAP de Guadalajara (ROJ: 71/2007) de 7 de marzo de 2007. Ponente: Dña. María Ángeles Martínez Domínguez. Absuelven porque no se puede demostrar el elemento subjetivo. SAP de 
lesionar o afectar el bien jurídico salud pública es bastante más distante, sancionando como delitos autónomos estos actos preparatorios con el fin de evitar en un estadio previo el tráfico de drogas ilegales ${ }^{319}$.

En aras de adaptar la legislación penal española al Convenio anteriormente mencionado se introduce el delito de tráfico de precursores en el artículo 344 bis g) del anterior Código Penal (Ley orgánica 8/1992) ${ }^{320}$, que en el Código Penal vigente (Ley orgánica 10/1995) se encuentra regulado en el artículo 371, el cual dispone: "El que fabrique, transporte, distribuya, comercie o tenga en su poder equipos, materiales o sustancias enumeradas en el Cuadro I y Cuadro II de la convención de Naciones Unidas, hecha en Viena el 20 de diciembre de 1988, sobre el tráfico ilícito de estupefacientes y sustancias psicotrópicas, y cualesquiera otros productos adicionados al mismo Convenio o que se incluyan en otros futuros Convenios de la misma naturaleza, ratificados por España, a sabiendas que van a utilizarse en el cultivo, la producción o la fabricación ilícitas de drogas tóxicas, estupefacientes o sustancias psicotrópicas, o para estos fines, será castigado con pena de prisión de tres a seis años y multa del tanto al triplo del valor de los géneros o efectos". En su artículo 12 esta Convención establece los me-

Madrid (ROJ: 15967/2005) de 17 de noviembre de 2005. Ponente: D. Juan Francisco Martel Rivero. SAP de Madrid (ROJ: 2827/2009) de 16 de marzo de 2009. Ponente: D. Jesús Ángel Guijarro López. SAP de Madrid (ROJ: 1011/2014) de 28 de enero de 2014. Ponente: Dña. Adoración María Riera Ocariz. SAP de Murcia (ROJ: 2858/2011) de 16 de diciembre de 2011. Ponente: D. José Manuel Nicolás Manzanares. SAP de Salamanca (ROJ: 348/2004) de 3 de junio de 2004. Ponente: D. Ildefonso García del Pozo.

319 El tráfico de precursores de drogas regulado en el artículo 371 no encuentra legitimado, dado que si la punición de la tentativa de peligro abstracto (tráfico de drogas) no está legitimada, mucho menos pueden estarlo los actos preparatorios, en relación con estos mismos delitos. CORCOY BIDÁSOLO, Mirentxu. Delitos de Peligro..., op. cit., pp. 284-286. SÁNCHEZ GARCÍA DE PAZ, Isabel. "La criminalización en el ámbito previo como tendencia política-criminal contemporánea" en QUINTERO OLIVARES, Gonzalo. MORALES PRATS, Fermín (Coordinadores). El nuevo Derecho Penal español. Estudios penales en memoria del profesor José Manuel Valle Muñiz. Ed. Aranzadi. Navarra. 2001, pp. 702- 706.

320 La Ley orgánica 8/1992, no es simplemente el cumplimiento de una obligación contraída por España ante los demás Estados parte de La Convención de Viena de 1998, sino que, "de manera coordinada con lo que se está haciendo en todos los países de nuestra órbita cultural, también supone su aportación un sugestivo proyecto de integración del Derecho Penal a escala mundial, difícil de concebir hasta hace bien poco". FABIÁN CAPARRÓS, Eduardo A. “Consideraciones de urgencia..., op. cit., p. 587. 
canismos para ampliar o modificar las listas de sustancias, la cual puede impulsarse a instancia de las partes o bien de la Junta Internacional de Fiscalización de Estupefacientes (JIFE), siendo el órgano encargado de decidir sobre la modificación de las listas la Comisión de Estupefacientes del Consejo Económico y Social de Naciones Unidas ${ }^{321 .}$

La jurisprudencia sobre el tema sostiene que el delito de tráfico de precursores es "un tipo en el que la respuesta penal se adelanta al momento de realización de actos meramente preparatorios, inspirados por una determinada finalidad de su autor, que quedarían impunes de no ser por la previsión legal. La ratio del precepto no puede ser más clara: el legislador a tipificado en este caso actos preparatorios, en relación con el cultivo y la fabricación de productos tóxicos o estupefacientes o sustancias psicotrópicas, porque ha querido concertar con la comunidad internacional los instrumentos jurídicos orientados a la represión de determinadas actividades definidas como singularmente amenazadoras y perjudiciales para el bienestar de los pueblos. El adelantamiento de la protección penal ha supuesto en este caso, considerar como objeto del delito no sólo las drogas ya elaboradas sino los productos que se denominan sus precursores" 322 .

Queremos señalar que como en este ilícito penal la posibilidad de lesionar o menoscabar el bien jurídico salud pública resulta bastante distante, más que en los delitos relativos al tráfico de drogas, la doctrina mayoritaria cuestiona su legitimidad por estar reñido con el principio de lesividad, de fragmentariedad, subsidiaridad y de ultima ratio y por consiguiente constituir un delito de peligro presunto que encuentra su legitimidad en un acto de mera desobediencia, que no debería trascen-

321 En el mes de enero del año 2015 (Decimocuarta edición) la JIFE actualizo la lista de precursores, siendo las sustancias comprendidas como tales las siguientes: Cuadro I: ácido $N$-acetilantranílico, ácido lisérgico, alfa-fenilacetoacetonitrilo (APAAN), anhídrido acético, efedrina, ergometrina, ergotamina, 1-fenil2-propanona (P-2-P), isosafrol, 3metilenedioxifenil-propanona (3,4-MDP-2-P), norefedrina, permanganato potásico, piperonal, safrol, y seudoefedrina. Cuadro II: acetona, ácido antranílico, ácido clorhídrico, ácido fenilacético, ácido sulfúrico, éter etílico, metiletilcetona, piperidina y tolueno. Esta lista es conocida como "Lista Roja".

STS (ROJ: 2497/2001) de 26 de marzo de 2001. Ponente: D. José Jiménez Villarejo. SAP de Guadalajara (ROJ: 71/2007) de 7 de marzo de 2007. Ponente: Dña. María Ángeles Martínez Domínguez. SAP de Madrid (ROJ: 1011/2014) de 28 de enero de 2014. Ponente: Dña. Adoración María Riera Ocariz. 
der del orden administrativo ${ }^{323}$. Constituyendo su inclusión en el ordenamiento jurídico penal un claro ejemplo del afán de control total preventivo del legislador, pues tipifica conductas donde el bien jurídico protegido resulta impreciso, por lo cual no es patente que sea merecedor de tutela penal producto del incierto contenido lesivo que comportan las distintas conductas que sanciona este tipo penal. Así, esta pretensión de crear preceptos omnímodos provoca una redacción tortuosa de los tipos, con remisiones entre ellos, conceptos indeterminados, reenvíos tremendamente generales a normas extrapenales, incluso hacia el futuro que entran en contradicción con principios sumamente asentados en el Derecho Penal ${ }^{324}$. Sin embargo queremos puntualizar que en el caso de la tenencia o fabricación de precursores de drogas

323 ARANA, Xavier. "Delitos contra la salud pública y nuevo Código Penal: fondeados en la misma dársena" en ARANA, Xavier, MARKEZ, Iñaki (Coords.). Los agentes sociales ante las drogas. Ed Dykinson. 1998, p. 260. DÍEZ RIPOLLÉS, José Luis. "Alternativa a la actual legislación sobre drogas" en Nuevo Foro Penal. № 54. 1991, p. 470. FABIÁN CAPARRÓS, Eduardo A. "Consideraciones de urgencia..., op. cit., pp, 622, 623. MUÑOZ CONDE, Francisco. Derecho Penal. P.E..., op. cit., p. 674. El tráfico de precursores se enmarca en los delitos que la doctrina describe como "ilícitos administrativos elevados a la condición de delitos". QUINTERO OLIVARES, Gonzalo. MORALES PRATS, Fermín. Parte General..., op. cit., p 270. VALLE MUÑIZ, José Manuel, MORALES GARCÍA, Oscar. Libro II: Titulo XVII en QUINTERO OLIVARES, Gonzalo (Dir). Comentarios al nuevo Código Penal 4 a edición. Aranzadi. Navarra. 2005, p. 1928. QUINTERO OLIVARES, Gonzalo (Dir). MORALES PRATS, Fermín (Coord.). Comentarios al Código Penal español. Tomo II. 6a a edición. Aranzadi/Thomson Reuters. Navarra. 2011, pp. 968, 969. REY HUIDOBRO, Luis Fernando. El Delito de tráfico..., op. cit, p. 270. Este adelantamiento del ámbito de protección penal, formaliza aún mas la estructura del tipo, de tal manera que la proximidad con el bien jurídico salud pública "se torna aquí insostenible". SUÁREZ LÓPEZ, José María. "El tráfico de precursores. Propuestas de lege ferenda" en MORILLAS CUEVA, Lorenzo (Coord.). Estudios jurídico-penales y político-criminales sobre tráfico de drogas y figuras afines. Ed. Dykinson. Madrid. 2003, pp. 72, 77. El tráfico de precursores de drogas regulado en el artículo 371 no está legitimado, dado que si la punición de la tentativa de peligro abstracto (tráfico de drogas) no está legitimada, mucho menos pueden estarlo los actos preparatorios, en relación con estos mismos delitos. CORCOY BIDÁSOLO, Mirentxu. Delitos de Peligro..., op. cit., pp. 284- 286. SÁNCHEZ GARCÍA DE PAZ, Isabel. "La criminalización en el ámbito...”, op. cit. , pp. 702- 706.

324 Uno de los rasgos que mejor caracteriza al moderno Derecho Penal es la creciente utilización de los delitos de peligro abstracto, así como los delitos de "emprendimiento" o de consumación anticipada y la punición específica de actos preparatorios. Pretendiendo con este adelantamiento de la barrera de protección penal obtener una mejoría de la seguridad y de la propia sensación de seguridad. MENDOZA BUERGO, Blanca. El Derecho Penal..., op. cit., pp. 95- 97. SUÁREZ LÓPEZ, José María. "El tráfico de precursores..., op. cit. , pp. 76, 77. 
que se utilizan para la elaboración de las drogas de diseño, donde no hace falta ni la hoja de coca ni las capsulas verdes de la adormidera para elaborar cocaína o heroína, tales como la efedrina, seudoefedrina, la P-2-P o la 3,4-MDP-2-P, la posibilidad de menoscabo del bien jurídico salud pública, si se nos permite la expresión, parece un poco menos distante, pues equivale casi a tener anfetamina, metanfetamina o éxtasis $^{325}$. También queremos matizar que si bien la introducción de la comprobación de los elementos subjetivos, en el artículo $371 \mathrm{CP}$, "a sabiendas de" o "para estos fines" (elaboración de drogas ilícitas) no permite solventar en buena medida la utilización de la técnica de los delitos de peligro abstracto para su tutela, si propicia que no se pueda afirmar con total propiedad que se trate de un delito presunto que castiga un acto de mera desobediencia ${ }^{326}$.

Es importante destacar que como el delito de tráfico de precursores de drogas, en principio, no tiene la suficiente entidad para su protección de forma autónoma en el Derecho Penal, a pesar de proteger un bien jurídico de suma importancia como la salud pública, es viable pensar que suprimir el artículo $371 \mathrm{CP}$, por ser una figura de poca eficacia, no reduciría de manera significativa la protección del bien jurídico tutelado por este tipo penal, puesto que en los supuestos más graves de tráfico de precursores de drogas se podría recurrir al delito de tráfico de drogas mediante el empleo, para sancionar dichas conductas, de las reglas previstas para la autoría y participación, así como las de las formas de imperfecta ejecución, de hecho ya se hacía antes de la aprobación de este tipo penal ${ }^{327}$ o bien por la Ley de Represión del Contrabando correcto criticar la legitimidad de los delitos de peligro abstracto desde la consideración de que en ellos se pena la mera desobediencia o un desvalor de conciencia pues actualmente se acepta con carácter general la formulación del profesor Torío López en el sentido de negar la tipicidad cuando en el caso concreto se comprueba que el peligro para el bien jurídico quedó excluido de antemano. CARO CORIA, Dino Carlos. Derecho penal del ambiente..., op. cit., p. 501.

327 Refiriéndose a la aprobación de 344 bis g) Rodríguez Devesa manifiesta que se adapta de esta manera el Código Penal a lo dispuesto en el artículo 3 c), ii) del Convenio de Viena de 1988. Afirmando que en "realidad estas figuras se encontraban ya tipificadas en el artículo 344 del Código Penal, pues podían perseguirse como tentativa de los tipos que ahí se recogen". RODRÍGUEZ DEVESA, José María. SERRANO GÓMEZ, Alfonso. Derecho Penal..., op. cit., pp. 1086, 1087. En el m ismo sentido. REY HUIDOBRO, Luis 
cuando se trate de la exportación, expedición, importación o introducción de las sustancias catalogadas ${ }^{328}$, y en los casos de menor relevan-

Fernando. El delito de tráfico de drogas. Aspectos penales y procesales. Ed. Tirant lo Blanch. Valencia. 1999, p. 273. Es preciso decir que antes de la aprobación en la legislación española del delito de tráfico de precursores de drogas en el Código Penal, artículos 344 bis g) y 344 j), a partir de la Ley Orgánica 8/1992 de 23 de diciembre, podía sancionarse por el delito de tráfico de drogas la tenencia de precursores sin que se encontraran ni siquiera residuos de alguna droga ilícita, ni materia prima básica para su fabricación, tal es el caso de la Sentencia del Tribunal Supremo del día 13 de mayo de 1996 que condena como autor de un delito de elaboración de drogas, de las que causan grave daño a la salud, a la pena de 2 años, 4 meses y 1 día de prisión menor, y al pago de la parte proporcional de las costas que le correspondan a un sujeto que en el mes de noviembre del año 1989 le ocuparon en un registro en su vivienda en Villagarcía de Arosa "tres hojas tamaño folio escritas a mano, en las que se describían procedimientos relativos a la transformación de diversos productos, en cocaína, mediante el uso de sustancias químicas. Encontrando después en un alpendre, una botella de ácido clorhídrico, otra de ácido sulfúrico, otra de éter etílico, un frasco de permanganato potásico (precursores de drogas), un frasco de agua fuerte y otra de amoniaco (sustancias no catalogadas). STS (ROJ: 2847/1996) de 13 de mayo de 1996. Ponente: D. José Augusto de Vega Ruiz. También el tráfico de precursores se castigaba algunas veces como un delito de tráfico de drogas en grado de conspiración. Así lo ratifico el Tribunal Supremo en su Sentencia de 30 de junio de 1995 en el caso de cinco personas que en el mes de noviembre de 1990 en Murcia tomaron la decisión de fabricar y comercializar algún o algunos de los derivados de la cocaína como el "basuco" e inclusive clorhidrato de cocaína a partir de pasta base de esta sustancia. Para lo cual se dieron a la tarea de adquirir pequeñas cantidades de algunos precursores en la zona, los que posteriormente les decomisaron, siendo estos ácido sulfúrico, acetona y ácido clorhídrico y de otras sustancias no catalogadas como el etanol, así como dos ollas express y un manuscrito donde aparecían un listado de sustancias y equipos necesarios que podrían servir para elaborar la droga. El laboratorio clandestino, rudimentario, lo pensaban montar en un remolque en las afueras de la ciudad, ahí estaban reunidos sin empezar a fabricar "basuco" o cocaína y sin tener la necesaria pasta base (materia prima), cuando fueron detenidos por dos oficiales de la Guardia Civil. Los cinco acusados fueron condenados por el Tribunal de Instancia como autores responsables de un delito contra la salud pública del artículo 344 del Código Penal, en grado de conspiración, sin la concurrencia de circunstancias modificativas de la responsabilidad criminal a la pena de cuatro meses y un día de arresto mayor y accesorias de suspensión de todo cargo público y derecho de sufragio durante el tiempo de sus condenas y con multa de 500.000 pesetas a cada uno. STS (ROJ: 3860/1995) de 30 de junio de 1995. Ponente: D. Joaquín Martín Canivell.

328 Morales García señala, en relación a la ejecución de los actos de elaboración ilegal de drogas preceptuado en el artículo $368 \mathrm{CP}$, que el legislador no se conforma con la tipificación del objeto material sino que adelanta la barrera punitiva hasta cualquier acto de la cadena de producción, de esta manera bastará con la realización de cualquiera de los pasos tendentes a la obtención de la droga, siendo completamente equivalente cualquier aportación a la cadena de elaboración. QUINTERO OLIVARES, Gonzalo. Comenta- 
cia podrían sancionarse, como ya se hace, con las infracciones previstas en la Ley 4/2009 de control de precursores de drogas ${ }^{329}$ (Derecho Administrativo) donde sí se encuentra plenamente justificada la protección de este bien jurídico. Sin embargo somos conscientes de que existen muy pocas posibilidades de un cambio de orientación en la política criminal desarrollada a corto o mediano plazo sobre este ilícito (que en el mes de diciembre de este año cumplirá 24 años de vigencia), pues España está obligada a sancionar penalmente este tipo de comportamiento por el Convenio de Viena de 1988 y otras normativas comuni$\operatorname{tarias}^{330}$. Para hacernos una idea de la dificultad que presenta la despenalización del tráfico de precursores queremos señalar que de conformidad al Convenio de Viena de 1988 un total 189 estados o territorios, que representan el 95,45\% del mundo, tienen tipificado como delito en sus ordenamientos jurídicos el tráfico de precursores de drogas, así como que el enfrentamiento a este sector de la narcoactividad se controla de forma permanente por la Junta Internacional de Fiscalización de Estupefacientes de Naciones Unidas y otras organizaciones internacionales ${ }^{331}$, además es necesario puntualizar que quienes mayoritariamente realizan las conductas de desvío, transporte y fabricación ilícita de las 24 sustancias catalogadas son auténticas mafias que operan a nivel internacional, con mucho éxito debido a su gran capacidad económica y de innovación, utilizando los mismos métodos y medios

rios al Código Penal español..., op. cit., p. 935. Ley orgánica 6/2011 de 30 de junio, por la que se modifica la Ley Orgánica 12/1995, del 12 de diciembre, de Represión del Contrabando.

Ley 4/2009, de 15 de junio, de control de precursores de drogas.

330 La Decisión Marco 2004/757/JAI del Consejo, de 24 de octubre que señala de forma expresa la necesidad de que los Estados miembros sancionen con penas máximas de 5 a 10 años los delitos de tráfico de precursores de drogas cuando se cometan en el seno de una organización criminal.

331 Los índices de adhesión por regiones son los siguientes: África: 51 de 54 países lo que representa el 94.44 \%, América: 35 países lo que representa el 100 \%, Asia: 46 de 47 países lo que representa el $97.87 \%$, Europa: 45 de 45 países lo que representa el 100 \% y Oceanía: 11 de 16 países lo que representa el 68.75 \%. Los siguientes Estados o territorios no son parte de la Convención de 1988: África: Guinea Ecuatorial Somalia y Sudán del Sur. Asia: Estado de Palestina. Oceanía: Islas Salomón, Kiribati, Palau, Papua Nueva Guinea y Tuvalu. Sumando un total de 9 Estados o territorios que aún no son parte de la Convención. Precursores y sustancias químicas frecuentemente utilizados..., correspondiente a 2015..., pp. 1, 41-46. 
que usan para el tráfico de drogas, lo cual dificulta aún más un cambio de orientación de la política criminal en el plano internacional, donde están convencidos que no podría enfrentarse esta área de la narcoactividad en buena medida sin la intervención del Derecho Penal, y de su tutela adelantada mediante un delito de peligro abstracto, sumamente cuestionado por la doctrina, como el preceptuado en el artículo 371 del Código Penal español. Sobre la complejidad que entraña el tráfico de precursores a nivel mundial puede consultarse los capítulos I, II y III de este trabajo. En todo caso nosotros ante la imposibilidad real de derogación del delito antes mencionado nos proponemos trabajar en aras de ofrecer unas pautas de interpretación lo más seguras posibles y respetuosas tanto de los principios básicos de Derecho Penal, así como del Estado Social y Democrático de Derecho ${ }^{332}$.

Sobre el artículo 373 que sanciona los actos preparatorios punibles en los delitos previstos en los artículos 368 al 372, hay que decir que en el caso del artículo 371 la situación es verdaderamente insostenible pues se sanciona la provocación, la conspiración y la proposición de fabricar, transportar, comerciar o simplemente la tenencia de las sustancias clasificadas como precursores de drogas, criminalizando de esta manera el peligro del peligro del tráfico de drogas. Por lo cual la probabilidad de afectación del bien jurídico "salud pública" es excesivamente remota, por lo que resulta ineludible proponer la eliminación del tráfico de

332 Somos conscientes de que es muy difícil de que este tipo penal sea suprimido, no por su evolución en la práctica jurídica, que es bastante escasa, sino más bien porque este se introdujo en el ordenamiento penal español hace 23 años para darle cumplimiento al Convenio de Viena de 1988 y demás normas comunitarias sobre el tráfico de precursores. Para que nos hagamos una idea del alcance de la aplicación de este Convenio internacional hay que decir que un total de 189 Estados o territorios del mundo sancionan estas conductas en sus ordenamientos penales internos (lo que representa el 95.45\% del total de países o territorios). Precursores y sustancias químicas frecuentemente utilizados..., correspondiente a 2015..., p. 1. Sobre la legitimidad de los delitos de peligro abstracto Roxin señala que donde "una conducta peligrosa prohibida está claramente descrita y si es claramente visible su referencia al bien jurídico y tampoco se vulnera el principio de culpabilidad, entonces son inobjetables incluso los delitos de peligro abstracto", citando como ejemplo de ello el artículo 316 del Código Penal alemán que sanciona la conducción de vehículos a motor bajo la influencia de bebidas alcohólicas. ROXIN, Claus. Derecho Penal. P.G..., op. cit., p. 60. Cerezo Mir sostiene que el tráfico de precursores de drogas es un delito de "peligro abstracto de aptitud" o de "peligro abstracto concreto" por lo cual está legitimada su criminalización. CEREZO MIR, José. “Los delitos de peligro..., op. cit., pp. 745, 746. 
precursores del artículo 373, dado que es un auténtico despropósito jurídico ${ }^{333}$. Lamentablemente creemos que esto no va a ocurrir, pues la tendencia apunta en dirección contraria.

Queremos poner de manifiesto que las consecuencias prácticas de la configuración jurisprudencial de la salud pública como bien jurídico tutelado en el delito de tráfico de precursores de drogas son las siguientes: 1) la salud pública es un bien jurídico que merece protección penal, la cual se encuentra justificada en la mayoría de supuestos establecidos en los delitos relativos al de tráfico de drogas, pero no se puede decir lo mismo en el caso de las conductas contempladas en el delito de tráfico de precursores de drogas, dado que la posibilidad de afectación de este bien jurídico es mucho más lejana, recordemos que se tratan de actos preparatorios del delito de tráfico de drogas (elaboración de drogas tóxicas, estupefacientes o sustancias psicotrópicas) que por decisión del legislador se elevan a la categoría de delito autónomo, de hecho estos comportamientos no son simples infracciones formales porque tienen incorporado el elemento subjetivo adicional "a sabiendas de" o "para estos fines", de no ser así el artículo 371 CP tendría que ser declarado inconstitucional en los mismos términos que lo fue el artículo 509 del anterior Código Penal ${ }^{334}$. 2) En todo caso resulta evidente que

333 La Ley no legitima la incriminación de los actos preparatorios de los delitos de peligro. CORCOY BIDÁSOLO, Mirentxu. "Protección de bienes..., op. cit., pp. 396-3 98, 401.

334 Sobre el artículo 509 CP "se han enfrentado dos posible variantes de la interpretación del precepto sobre las que nuestro análisis deberá versar, sin excluir la posibilidad de otras diferentes, que no es posible enjuiciar, porque no han sido objeto de debate: a) ..., la sola tenencia de instrumentos idóneos para ejecutar un delito de robo hace presumir el especial destino a tal ejecución, a menos que el acusado facilite mediante el correspondiente descargo la prueba en contrario, b) ..., la posesión de los instrumentos, como la idoneidad de estos para un delito de fuerza en las cosas, y la especial destinación o destino por su poseedor a la ejecución de delitos de tal tipo, corresponde siempre probarlas, como cualquier otro elemento inculpatorio, a la parte acusadora, sin que por exigencia de la Ley tenga el acusado que realizar prueba alguna. En esta interpretación, la idea de descargo suficiente posee un sentido distinto. No es una actividad necesaria del acusado, sino una actividad libre de este, que alguna de las tesis mantenidas en el presente recurso considera como una especial causa de justificación, aun cuando probablemente sea más exacto calificarla de libertad del acusado para alegar y probar una destinación diferente. Tras lo dicho, resulta, como necesaria conclusión del análisis que se realiza, que la primera de las interpretaciones cuestionadas, es decir la que antes ha sido expuesta bajo la letra a), es contraria a los dictados del art. 24.2 de la Constitución y al derecho fundamental de la presunción de inocencia, lo que no ocurre en cambio, con la segunda de las interpretaciones. La primera de ellas, es como decíamos, contraria al art. 24.2 Contiene una presun- 
la situación se vuelve aún más insostenible con la incorporación del artículo 373 del Código Penal que sanciona la provocación, la conspiración y la proposición para cometer el tráfico de precursores de drogas. Castigando de esta forma "los actos preparatorios de los actos preparatorios del tráfico de drogas, es decir la preparación de la preparación" dado que además de criminalizar el tráfico de precursores, también se sanciona los actos preparatorios de este ${ }^{335}$. 3) La salud pública al no

ción en contra del reo que es la presunción del mal uso o la presunción de la tendencia o finalidad, que se considera además como iuris tantum, produciendo una traslación o inversión de la carga de la prueba, de suerte que la destrucción o desvirtuación de tal presunción corresponde al acusado a través del descargo. Llegados a este punto parece obligado concluir que la disposición de la Ley enjuiciada no es en sí misma inconstitucional, pero que si lo es alguna de las interpretaciones de que ha sido y puede ser todavía objeto. Ello impone la conveniencia de llegar a una sentencia constitucional de carácter interpretativo, que tome, sobre todo, en consideración el principio de conservación de las disposiciones legales, en cuanto a las mismas pueden ser interpretadas y aplicadas de conformidad con la Constitución. En virtud de todo lo expuesto, el Tribunal Constitucional, por la autoridad que le confiere la Constitución española, ha decidido declarar inconstitucional el art. 509 del Código Penal en cuanto se interprete que la posesión de instrumentos idóneos para ejecutar el delito de robo presume que la finalidad y el destino que les da su poseedor es la ejecución de tal delito". STC 105/1988, de 8 de junio de 1988. Ponente: Luis Díez-Picazo y Ponce de León. Valle Muñiz y Morales García afirman que este problema no se resuelve con el recurso a la exigencia de específicos elementos subjetivos para la conformación del injusto, como son en esta los fines de cultivo, producción o fabricación de sustancias tóxicas, puesto que si la apertura de las conductas contenidas en el artículo 368 merecen ya un juicio negativo de valoración sobre su desmesurado alcance, con mayor motivo lo suscita la retracción del reproche penal hasta conductas que en sí mismas ni siquiera son capaces de promover o facilitar el consumo ilegal (como la fabricación de equipos o materiales), supuestos en los que se hace aún más difícil predicar su vinculación con el bien jurídico tutelado. VALLE MUÑIZ, José Manuel y MORALES GARCIA, Oscar. "Libro II: Titulo XVII" en QUINTERO OLIVARES, Gonzalo (Dir.). MORALES PRATS, Fermín (Coord.). Comentarios al nuevo Código Penal. Ed. Aranzadi. Navarra. 2005, p. 1928. QUINTERO OLIVARES, Gonzalo. Comentarios al Código Penal español..., op. cit., pp. 968, 969. ARANA, Xavier. "Delitos contra la salud pública..., op. cit., p. 260. La inclusión del elemento subjetivo "a sabiendas de que tales objetos van a utilizarse...", cumple una necesaria misión limitadora del ámbito de punición de la norma. FABIÁN CAPARRÓS, Eduardo A. “Consideraciones de urgencia..., op. cit., pp, 595, 596.

335 Así la posible puesta en peligro del bien jurídico salud pública no sólo se desvanece sino que desaparece de la punición de todas las conductas relacionadas con la expansión, mantenimiento o difusión del consumo de drogas tóxicas, estupefacientes o psicotrópicos. CóRDOBA RODA, Juan. Comentarios al Código Penal..., op. cit., p. 1664. JOSHI JUBERT, Ujala. Los delitos de tráfico..., op. cit., p. 230. REY HUIDOBRO, Luis Fernando. El delito de tráfico de drogas..., op. cit, p. 274. SUÁREZ LÓPEZ, José María. "El tráfico de precursores..., op. cit. , p. 76. 
ser esencialmente diferente a la suma de las saludes individuales estará afectada únicamente en el caso de que verdaderamente concurra el peligro, aunque este sea muy lejano, para terceras personas. 4) Como se trata de un delito de peligro abstracto, no hace falta identificar las terceras personas afectadas. 5) Es totalmente irrelevante que el daño que pueda causarse en concreto a una persona determinada sea o no grave, a efectos de la aplicación de este precepto penal. 6) La salud pública se pondrá en peligro, cuando se realice cualquiera de las conductas previstas en el tipo, siendo indiferente que ello se haga a título lucrativo, dado que en estos casos el desvalor de la acción no tiene nada que ver con el ánimo de lucro del autor. 7) Se produce una extensión desmesurada del tipo, más aun que en el tráfico de drogas, ya que en la práctica, y ante el caso concreto, no se examina la afectación al bien jurídico protegido, aunque si la comprobación del elemento subjetivo adicional, antes señalado, el cual se realiza generalmente mediante un juicio de inferencia por parte del Tribunal competente ${ }^{336}$.

Para terminar este apartado estimamos pertinente recordar, una vez más, que las diferentes sustancias que denominamos precursores de drogas tóxicas, estupefacientes y psicotrópicos son utilizadas cotidianamente para la elaboración de una gran cantidad de productos necesarios para la sociedad, muchos de ellos imprescindibles como las medicinas (precursores que se emplean como materia prima de analgésicos, antipiréticos que son necesarios para la elaboración de medicamentos para el tratamiento del dolor y la fiebre, así como otras medicinas que sirven para tratar diversas enfermedades), o la fabricación de disolventes que se utilizan en diversas reacciones químicas (elaboración de cosméticos, pinturas entre otros productos), por lo que el control de estas sustancias debe estar dirigido a prevenir su desvío para la fabricación de drogas ilegales, sin perjudicar el necesario desarrollo de las actividades industriales que, sin lugar a dudas requieren de las mismas ${ }^{337}$.

336 JOSHI JUBERT, Ujala. Los delitos de tráfico..., op. cit., p. 30.

337 REY HUIDOBRO, Luis Fernando. El Delito de tráfico..., op. cit., p. 280. SUÁREZ LÓPEZ, José María. “El tráfico de precursores..., op. cit., p. 75. 

CAPÍTULO V

\section{LOS DELITOS DE PELIGRO Y LA VIRTUALIDAD DE SU CONCEPTO EN EL MARCO DEL TRÁFICO DE PRECURSORES}

\section{INTRODUCCIÓN}

\section{A.) APROXIMACIÓN A LOS DELITOS DE PELIGRO}

Iniciamos este apartado destacando que los delitos de peligro no son fruto del legislador ni de la dogmática actual, lo cual puede constatarse a través de los estudios realizados por Binding sobre este tema, quien afirmó en 1919 que el primer delito de peligro que existió fue el "incendio peligroso", cuya aparición sitúa en el siglo XVIII ${ }^{1}$. Schroeder refiriéndose a los delitos que conminan con una pena la posesión de objetos señala que sancionar este tipo de conductas no es una novedad, como ejemplo de ello cita la Lex Cornelia de Sicariis et Veneficis contra sicarios y envenenadores del año 81 antes de Cristo que castigaba con la pena de muerte la tenencia de veneno, advirtiendo que es no está

1 RODRÍGUEZ MONTAÑÉS, Teresa. Delitos de peligro..., op. cit., p. 5. Peris Riera señala que la expansión del Derecho Penal no es una cuestión nueva, dado que en el año 1883 Rotering ya afirmaba que las infracciones de peligro suponían un incremento de la criminalidad "impuesta por el progreso técnico y la creciente peligrosidad de la vida social". PERIS RIERA, Jaime M. "Delitos de peligro y sociedad de riesgo: una constante discusión en la dogmática penal de la última década" en CARBONELL MATEU, Juan Carlos. DEL ROSAL BLASCO, Bernardo. MORILLAS CUEVA, Lorenzo. ORTS BERENGUER, Enrique. QUINTANAR DIEZ, Manuel (Coord.). Estudios penales en homenaje al profesor Cobo del Rosal. Ed. Dykinson. Madrid. 2005, pp. 687, 688. Quintero Olivares afirma que la incorporación al ordenamiento penal de los delitos de peligro partió, históricamente, de la imposibilidad de imputar como tentativa actos en que lo único apreciable era su carga de peligro objetivo para un bien jurídico, dado que el deseo o aceptación de un resultado lesivo no estaba comprendido subjetivamente en la conducta del autor. Por lo tanto la declaración de la tipicidad de ciertas conductas es un anticipo de lo que, en situación normal de producción de resultado "hubiera sido siempre un delito imprudente y no uno doloso". QUINTERO OLIVARES, Gonzalo. "Los delitos de riesgo en la política criminal de nuestro tiempo" en ARROYO ZAPATERO, Luis. NEUMANN, Ulfrid. NIETO MARTÍN, Adán (Coord.). Crítica y justificación del Derecho Penal en el cambio de siglo. Ediciones de La Universidad Castilla-La Mancha. Cuenca. 2003, p. 246. 
claro si debía de probarse la existencia de la intención homicida². Sin embargo, se puede afirmar que es a partir de los años sesenta cuando se produce la expansión de estos tipos penales en la mayoría de los ordenamientos jurídicos de nuestro entorno, lo cual posiblemente se deba en gran parte, a la necesidad de enfrentar la creciente peligrosidad que entraña lo que comúnmente denominamos como "sociedad de riesgo"3. Estimamos preciso dar por sentando desde ahora, que vivimos en un mundo que ha asumido el peligro como un medio natural en el que se desarrolla nuestra vida cotidiana, realidad que está refrendada por el capitalismo e incrementado aún más por la corriente neoliberal que impera en nuestro tiempo, corriente que limita cada vez más al Estado Social y Democrático de Derecho y que encuentra su fundamento en "la búsqueda irrestricta del progreso". Precisamente para paliar los efectos negativos de tal empresa los legisladores de prácticamente la mayoría de países del mundo, se han dado a la tarea de "fortalecer" la protección penal de los bienes jurídicos incrementando la pena de los bienes ya protegidos y ampliando el universo de bienes tutelados por el Derecho Penal, como claro ejemplo de ello nos permitimos señalar: los delitos contra la salud pública, el medio ambiente, la seguridad en el trabajo, el tráfico automotor y los delitos socio-económicos entre otros.

Los delitos de peligro que, es el tema que nos ocupa, constituyen un claro adelantamiento de la barrera de intervención penal frente a la exigencia del menoscabo efectivo para los bienes jurídicos tutelados. Estos tipos delictivos hacen intervenir al poder punitivo del Estado en momentos previos a la afectación efectiva del bien jurídico. Como todos sabemos el legislador para dar cumplimiento a su misión de protección de bienes jurídicos, puede sancionar conductas a través de la técnica de los delitos de lesión, o bien mediante la prohibición de puesta en peligro de un bien, para lo cual no hace falta que el comportamiento llegue a menoscabar el contenido propio del objeto jurídico tutelado. Sin embargo como es aceptado por la doctrina mayoritaria,

2 SCHROEDER, Friedrich-Christian. "La posesión como hecho punible" (Trad. PolainoOrts, Miguel) en Revista de Derecho Penal y Criminología, 2o Época, número 14, pp. 155, 156.

3 RODRÍGUEZ MONTAÑÉS, Teresa. Delitos de peligro..., op. cit., p. 6. SILVA SÁNCHEZ, Jesús María. La expansión del Derecho Penal. Aspectos de la política criminal en las sociedades postindustriales. Segunda edición. Civitas. Madrid. 2001, p. 25- 42. 
toda conducta punible debe afectar un bien jurídico que por sus características tenga suficiente relevancia penal, pero el modo de dañar o perjudicar puede ser diverso según estemos frente a delitos de lesión o delitos de peligro. Los delitos de lesión suponen, valga la redundancia, la efectiva lesión o menoscabo del bien jurídico, mientras en los delitos de peligro lo que se produce es la creación de una situación de riesgo para la incolumidad del bien protegido.

Rodríguez Montañés sostiene que estos tipos delictivos no poseen un contenido de injusto propio, sino que responden a un adelantamiento de la barrera punitiva, lo que destaca la continuidad existente entre los delitos de lesión y los delitos de peligro, afirmando que estos últimos tratan de evitar, al igual que los delitos de lesión, el menoscabo de bienes jurídicos, afirmando que este adelantamiento del ámbito de protección penal no se establece con los tipos dolosos de lesión, sino con los imprudentes, lo cual ha llevado al legislador a su punición de forma expresa, sin esperar la producción de un resultado lesivo, surgiendo así los delitos de peligro que son en su opinión tentativas, o bien formas de imperfecta ejecución, de delitos imprudentes ${ }^{4}$. En tal

4 RODRÍGUEZ MONTAÑÉS, Teresa. Delitos de peligro..., op. cit., pp. 134, 135. Sobre la punición de delitos de peligro abstracto imprudentes; Rudolphi con la idea de la asunción del riesgo sostiene que el ámbito de limitación de estos delitos a través de una reducción teológica, dotándolos de un contenido de desvalor de acción, “debe de hacerse mediante la exigencia de al menos imprudencia en relación con el hecho desvalorado. Horn afirma "se trata de modalidades de delitos imprudentes". Brehm dice que son tentativas imprudentes de lesión, con idéntico contenido de injusto y culpabilidad que los delitos imprudentes de lesión, diferenciándose tan sólo en los presupuestos de responsabilidad. Schünemann recurre a la figura de la "tentativa imprudente". Wolter se pronuncia a favor de realizar "una reducción teológica de estos delitos, exigiendo la creación dolosa o imprudente de un riesgo adecuado de puesta en peligro de la vida". Graul manifiesta que en los delitos de peligro abstracto "no puede hablarse siempre de un desvalor de acción material en el sentido de afección concreta inmediata al bien jurídico. La mera infracción dolosa o imprudente de la norma (por ejemplo, de la que ordena no incendiar viviendas) es suficiente en los delitos de peligro abstracto para fundamentar el injusto y la culpabilidad". Idem, pp. 280-293. Corcoy sobre la incriminación de conductas imprudentes señala que desde una perspectiva garantista esta debería negarse, no obstante afirma que desde una perspectiva políticacriminal que atienda a la eficacia y utilidad, así como a las finalidades preventivas y de protección de bienes jurídicos "podría ser conveniente incriminar también las imprudentes, aun cuando se limiten a los supuestos de imprudencia grave". CORCOY BIDÁSOLO, Mirentxu. "Protección de bienes..., op. cit., pp. 389, 390. Quintero Olivares afirma que constituye una opinión muy extendida en la doctrina que los delitos de peligro son delitos dolosos que se caracterizan en lo subjetivo por estar integrados por 
dirección apunta un sector importante de la doctrina española afirmando que los delitos de peligro se crean con la finalidad de sancionar la ejecución de conductas peligrosas imprudentes respecto del eventual resultado lesivo (sin que sea necesario esperar su consumación), por lo que este adelantamiento de la barrera de protección penal en el ámbito del delito imprudente consiste en la criminalización de forma excepcional de la tentativa imprudente "ante la importancia del bien puesto en peligro y la especial relevancia lesiva de la forma de ataque al mismo, en ciertos ámbitos en los que la naturaleza de la actividad y la experiencia acumulada han permitido tipificar la norma de cuidado con la suficiente precisión, haciendo posible la punición de esa conducta peligrosa sin resultado, sin menoscabo de la seguridad jurídica"5. Lo que la Ley no legitima es la incriminación de la tentativa de los delitos de peligro, bien sea este real o potencial ${ }^{6}$, ni la de actos

el llamado dolo de peligro, el cual es un concepto fronterizo entre el dolo y la culpa que ha nacido forzado por necesidades político- criminales de adelantamiento del ámbito de protección penal. QUINTERO OLIVARES, Gonzalo. Parte General del Derecho Penal. Ed. Thomson-Aranzadi. Navarra. 2005, pp. 355- 357.

5 Luzón Peña afirma que los delitos de peligro se consuman sin que sea preciso la lesión del bien jurídico, bastando con "la inseguridad y la probabilidad de lesión del bien jurídico", lo cual representa un adelantamiento de la barrera punitiva a una fase precedente de la lesión, que normalmente procede de la expresa criminalización de una conducta imprudente, lo que supone una excepción a la regla general de impunidad de las formas imperfectas de ejecución en la imprudencia o la tipificación de una actuación peligrosa con dolo eventual en la fase de tentativa. LUZÓN PEÑA, Diego Manuel. Curso de Derecho..., op. cit., pp. 313, 314. Al no poderse sancionar la tentativa de delitos imprudentes el legislador ha introducido su punición expresa a través de los delitos de peligro en aquellos ámbitos de la vida en los cuales la experiencia ha demostrado que determinado comportamientos conllevan un gran riesgo para determinados bienes jurídicos. Cuando no sea así, el legislador no estará legitimado para incriminar tales delitos de peligro. OCTAVIO DE TOLEDO Y UBIETO, Emilio. "Algunas cuestiones sobre autoría, participación, tentativa, peligro e imprudencia, a propósito de la responsabilidad penal por el producto" en OCTAVIO DE TOLEDO Y UBIETO, Emilio. GURDIEL SIERRA, Manuel. CORTÉS BECHIARELLI, Emilio (Coordinadores). Estudios penales en recuerdo del profesor Ruiz Antón. Ed. Tirant lo Blanch. Valencia. 2004, pp. 840- 843. Algunos autores en la misma línea sostienen que los delitos de peligro presentan características estructurales que los aproximan a los delitos imprudentes por lo menos hasta un cierto grado de desarrollo. QUINTERO OLIVARES, Gonzalo. Parte General..., op. cit., p. 355. RODRÍGUEZ MONTAÑÉS, Teresa. Delitos de peligro..., op. cit. , p. 7.

6 OCTAVIO DE TOLEDO Y UBIETO, Emilio. "Algunas cuestiones..., op. cit., pp. 837- 840. CORCOY BIDÁSOLO, Mirentxu. “Protección de bienes..., op. cit., pp. 393- 396, 401. 
preparatorios de delitos de peligro ${ }^{7}$. Sirva como ejemplo de los excesos legislativos en este sentido el artículo 373 del CPE que sanciona: la provocación, la conspiración y la proposición del tráfico de precursores de drogas tóxicas, estupefacientes y psicotrópicos, produciéndose de esta manera un adelantamiento de la barrera punitiva a todas luces insostenible con los principios que informan el Derecho Penal en un Estado Social y Democrático de Derecho.

De la tensión que se produce entre seguridad y riesgo, es decir de esta ponderación de bienes o intereses, queremos destacar la experiencia general derivada de múltiples hechos lesivos de bienes jurídicos fundamentales, como efectivamente lo fueron casos muy conocidos por su relevancia como; Contergan ${ }^{8}$, Holtzschutzmittel $^{9}$ y Lederspray ${ }^{10}$ en la

Ibidem., pp. 396-3 98, 401.

8 Caso Contergan, este también es conocido como caso de la talidomida. Se trata de un tranquilizante cuyo componente principal es la talidomida, este producto estaba recomendado para mujeres embarazadas. El caso en mención sucedió a finales de los años 50 e inicios de los años 60 en la entonces República Federal Alemana, como consecuencia del consumo del tranquilizante antes señalado, se produjeron más de 10.000 casos de abortos y graves daños en los sistemas óseos de los recién nacidos, los cuales morían al poco tiempo de nacer o sobrevivían con graves malformaciones, focomelias o extremidades en forma de aletas de foca, así como lesiones irreversibles. CARO CORIA, Dino Carlos. "Sociedades de riesgo..., op. cit., p. 195. Vid. Sentencia del Landgericht Aachen (Tribunal de los Länder alemanes) del 18 de diciembre de 1970. MENDOZA BUERGO, Blanca. El Derecho Penal..., op. cit., p. 98.

9 Se trata de una sustancia destinada a la protección de maderas, la cual fue producida desde los años 50 por la empresa $D$. Chemie $G m b H$, que logro eludir dos denuncias por presuntas lesiones interpuestas en 1956 y 1963. En los años 70 se popularizo en Alemania el consumo de estos productos, "razón por la cual la citada empresa comercializo el protector Xyladecor 200 que, entre sus principales componentes, contenía la sustancia PCP y Lindano, estableciendo hasta 1979 la indicación de apropiado para usos interiores, pese a que ningún estudio avalaba su inocuidad en tales circunstancias". Este producto fue el causante de la muerte de una persona en 1977, y de las lesiones padecidas por un gran numero de consumidores, consistentes en daños en la piel y mucosidades. CARO CORIA, Dino Carlos. "Sociedades de riesgo..., op. cit., p. 196. Vid. Sentencia del Oberlandesgericht (Tribunal Superior de los Länder alemanes) de Frankfurt del 19 de diciembre de 1991. MENDOZA BUERGO, Blanca. El Derecho Penal..., op. cit., p. 98.

Este también es conocido como el caso Erdal, y consistió en la comercialización por mas de 20 años de un producto (spray o lederspray) recomendado para la protección de zapatos de cuero y prendas de vestir de este material, como consecuencia de su uso la empresa productora recibió muchas reclamaciones de personas que usaron el 
jurisprudencia alemana o bien el caso Colza ${ }^{11}$ en España. Creemos oportuno señalar en este momento que la revitalización de la polémica en torno a los delitos de peligro, se debe fundamentalmente al debate que se ha producido alrededor de los delitos de peligro abstracto, dado que a estos tipos se les cuestiona su probable incompatibilidad con los principios fundamentales que constituyen la base de los actuales sistemas penales de nuestro entorno jurídico ${ }^{12}$.

\section{B.) Los delitos de Peligro en el Derecho Penal moderno}

Hassemer señalo que actualmente en el Derecho Penal, tanto en la teoría como en la práctica, se está pasando de la formalización y la vinculación a principios valorativos a una tecnología social, que gradualmente se va convirtiendo en un instrumento político, situación que se produce fundamentalmente en ámbitos como el económico, medio ambiente, salud pública y seguridad del Estado; ejemplo de ello es la protección primordial de bienes jurídicos colectivos como la salud pública y el empleo de los delitos de peligro abstracto que prescinden

producto en la forma indicada y sufrieron dificultades respiratorias, náuseas, escalofríos o fiebre, detectándose en la mayoría de casos un edema pulmonar, produciéndose hasta el año 1986 casos similares. CARO CORIA, Dino Carlos. "Sociedades de riesgo..., op. cit. , pp. 195, 196. Vid. Sentencia del Bundesgerichtshof (Tribunal Supremo Alemán) del 6 de julio de 1990. MENDOZA BUERGO, Blanca. El Derecho Penal..., op. cit., p. 98.

11 En el mes de mayo de 1981 se produjo una epidemia localizada en Madrid y Torrejón de Ardoz, que posteriormente se extendió a otras zonas de España. Las lesiones correspondieron a una neumonía intersticial, se estudiaron varias hipótesis sobre su causa, cobrando fuerza su atribución al aceite de colza desnaturalizado con anilina al 2\%. Este producto se importo principalmente de Francia para actividades estrictamente industriales de modo, que para asegurarse el no desvió para el consumo de boca, las autoridades administrativas ordenaban desnaturalizar los caracteres organolépticos del aceite mediante anilina al $2 \%$ entre otros productos. Sin embargo, mediante una serie de intervenciones individuales y de empresas, como RAPSA y RAELCA, dicho aceite desnaturalizado fue refinado, y posteriormente comercializado (para el consumo humano) fundamentalmente a través de vendedores ambulantes, en muchas regiones de España, lo que propicio no menos de 330 muertes y 15.000 afectados por dicha sustancia. CARO CORIA, Dino Carlos. "Sociedades de riesgo..., op. cit. , pp. 195, 196. Vid. STS (Roj: 20999/1992) de 23 de abril de 1992. Ponente: Enrique Bacigalupo Zapater. STS (Roj: 5661/1997) de 26 de septiembre de 1997. Ponente: Gregorio García Ancos.

12 MÉNDEZ RODRÍGUEZ, Cristina. Los Delitos de Peligro..., op. cit., p. 130. 
de presupuestos de la pena, tales como el resultado o la causalidad y posibilitan la imposición de una sanción basándose únicamente en la realización de una conducta peligrosa, así como en la supresión de los diferentes grados de la imputación jurídico-penal (tentativa, consumación, complicidad- autoría) ${ }^{13}$. Desafortunadamente, la consecuencia de este proceso, como claramente puede apreciarse en la prác-

13 Manifiesta además este profesor alemán que se ha producido un aumento considerable de las penas con finalidades preventivo-generales intimidatorias. Mientras que en el campo del Derecho Procesal las reformas se han caracterizado por acortar, abaratar y desformalizar el proceso, así como por la eliminación de todos los obstáculos que puedan perturbarlo. HASSEMER, Winfried. Persona, mundo, responsabilidad..., op. cit., pp. 30, 31. FERRAJOLI, Luigi. Derecho y Razón..., op. cit., pp. 468, 469. Manteniendo Una posición critica sobre la expansión desmesurada del Derecho Penal. GARCÍA ARÁN, Mercedes. "Constitución y Derecho Penal, veinte años después" en ARROYO ZAPATERO, Luis. BERDUGO GÓMEZ DE LA TORRE, Ignacio (Dir.). NIETO MARTÍN, Adán (Coord.). Libro homenaje al Dr. Marino Barbero Santos in memoriam. Volumen I. Ed. Universidad de Castilla-La Mancha. Universidad de Salamanca. Cuenca. 2003, pp. 290- 297. GARCIA-PABLOS DE MOLINA, Antonio. Introducción al estudio..., op. cit., pp. 565, 566. HIRSCH, Hans Joachim. "Problemas actuales de la legislación penal propia de un Estado de Derecho". (Trad. GUZMÁN DALBORA, José Luis) en FIGUEREIDO DIAS, Jorge. SERRANO GÓMEZ, Alfonso. POLITOFF LIFSCHITZ, Sergio. ZAFARONI, Raúl Eugenio (Dir.). GUZMÁN DALBORA, José Luis (Coord.). Homenaje a Manuel de Rivacoba y Rivacoba. El penalista liberal. Controversias nacionales e internacionales en Derecho Penal, Procesal Penal y Criminología. Ed. Hammurabi. Buenos Aires. 2004, pp. 130- 134. KARGL, Walter. "Protección de bienes jurídicos mediante protección del Derecho". (Trad. RAGUÉS i VALLÉS, Ramón) en ROMEO CASABONA, Carlos María (Dir.). La insostenible situación del Derecho penal. Ed. Comares. Granada. 2000, pp. 61- 62. MENDOZA BUERGO, Blanca. El Derecho Penal..., op. cit., pp. 78- 81, 111- 113, 186. En el mismo sentido. MOCCIA, Sergio. "De la tutela de bienes..., op. cit., pp. 136- 138. NAVARRO CARDOSO, Fernando. "El Derecho Penal del riesgo y la idea de seguridad. Una quiebra del sistema sancionador" en PEREZ ALVAREZ, Fernando (Ed.). SERTA in memoriam Alexandri Baratta. Ed. Universidad de Salamanca, pp. 1324, 1325. POLAINO NAVARRETE, Miguel. "La controvertida legitimación del Derecho Penal en las sociedades modernas. ¿Más Derecho Penal” en CARBONELL MATEU. Juan Carlos. DEL ROSAL BLASCO, Bernardo. MORILLAS CUEVA, Lorenzo. ORTS BERENGUER, Enrique. QUINTANAR DIEZ, Manuel (Coordinadores). Estudios en homenaje al profesor Cobo del Rosal. Ed. Dykinson. Madrid. 2005, pp. 718, 747. En contra se posiciona Schünemann ilustrando su crítica en los delitos medioambientales. SCHÜNEMANN, Bernd. Consideraciones críticas..., op. cit., pp. 19- 25. SCHÜNEMANN, Bernd. "Sobre la dogmática y la Política Criminal del medio ambiente". (Trad. SACHER, Marina) en SCHÜNEMANN, Bernd. Temas actuales y permanentes del Derecho Penal después del milenio. Ed. Tecnos. Madrid. 2002, pp. 222, 223. Realizando una critica extensa al denominado Derecho Penal Nuclear. CORCOY BIDÁSOLO, Mirentxu. "Protección de bienes..., op. cit., pp. 365- 377. 
tica, no es que el sistema penal este en función de cumplir estas nuevas funciones, sino más bien que en estos ámbitos se produce un déficit considerable de ejecución lo que provoca, en muchos casos, efectos meramente simbólicos, pero con ello "el legislador al menos obtiene el rédito político de haber respondido con celeridad a los miedos y grandes perturbaciones sociales con los severos medios del Derecho Penal"14. Esta modificación del ordenamiento penal que se ha desarrollado a inicios de los años setenta se conoce como "Derecho Penal moderno" o "Derecho Penal del riesgo", el cual se manifiesta fundamentalmente en la parte especial de los Códigos Penales o en Leyes especiales mediante un incremento notable de nuevos tipos penales o bien en la agravación de las consecuencias jurídicas de algunos tipos tradicionales ${ }^{15}$.

HASSEMER, Winfried. Crítica al Derecho..., op. cit., pp. 54- 56. DONNA, Edgardo Alberto. "La sociedad de riesgos y los delitos de peligro abstracto" en GARCÍA VALDÉS, Carlos, MATINEZ ESCAMILLA, Margarita, ALCÁCER GUIRAO, Rafael, VALLE MARISCAL DE GANTE, Margarita (Coord.). Estudios Penales en homenaje a Enrique Gimbernat. Tomo I. EDISOFER. Madrid. 2008, pp. 877, 878. HERZOG, Felix. "Sociedad de riesgo, Derecho Penal del riesgo, regulación del riesgo". (Trad. DEMETRIO CRESPO, Eduardo) en ARROYO ZAPATERO, Luis. NEUMANN, Ulfrid. NIETO MARTÍN, Adán (Coord.). Crítica y justificación del Derecho Penal en el cambio de siglo. Ediciones de La Universidad Castilla-La Mancha. Cuenca. 2003, pp. 249- 258. SANTANA VEGA, Dulce María. La protección penal..., op. cit., pp. 171-176.

En la moderna ciencia del Derecho Penal alemana ha tenido una repercusión importante la concepción del sociólogo Beck, quien afirma que la sociedad industrial está siendo sustituida por otro modelo, la sociedad del riesgo. Esta evolución tendría consecuencia en el ámbito del Derecho Penal, en que se apreciaría un menoscabo de los principios básicos del Derecho Penal liberal, en aras de la función preventiva frente a los nuevos riesgos (manipulación genética, uso de la energía nuclear, actividades industriales que afectan el medio ambiente o la salud pública). CEREZO MIR, José. "Los delitos de peligro abstracto" en Revista de Derecho Penal. 2001-1. Buenos Aires, pp. 727- 733. GRACIA MARTÍN, Luis. Prolegómenos para la lucha por la modernización y expansión del Derecho Penal y para la crítica del discurso de resistencia. Ed. Tirant lo Blanch. Valencia. 2003, pp. 57, 58. Frente al "moderno Derecho Penal" existen dos posiciones que se ocupan de su evolución, tanto desde un punto de vista dogmático como político criminal: 1) "la teoría del aseguramiento del futuro con los medios del Derecho Penal" que se muestra partidaria de la evolución de esta rama del Derecho, participando activamente en su construcción y desarrollo. 2) "La teoría crítica del moderno desarrollo del Derecho Penal" que se muestra contraria a la actual tendencia expansiva del Derecho Penal. NAVARRO CARDOSO, Fernando. "El Derecho Penal..., op. cit., pp. 1321, 1322. PRITTWITZ, Cornelius. "Sociedad de riesgo y Derecho Penal". (Trad. NIETO MARTÍN, Adán. DEMETRIO CRESPO, Eduardo) en ARROYO ZAPATERO, 
Jakobs sostiene que uno de los motivos que propician la anticipación de la intervención del Derecho Penal es precisamente "el principio de protección de bienes jurídicos". Dado que este principio, en su opinión, induce a entender que todo aquello que pueda ponerse en una relación positiva con el concepto de bien jurídico está legitimado por ello a ser sancionado penalmente, así todo ataque peligroso a un bien jurídico tiene que considerarse socialmente nocivo. Desde su perspectiva tomar como punto exclusivo de partida el bien jurídico conduce, sin lugar a dudas, a un desbordamiento del Derecho Penal, pues el autor viene definido únicamente por el hecho de que puede constituir un peligro para el bien jurídico, con el añadido de que cabe anticipar, potencialmente sin límite alguno, el comienzo de tal peligro ${ }^{16}$. Sobre las discrepancias que mantenemos con este autor, con relación al papel que desempeña el principio de protección de bienes jurídicos en la teoría del delito, nos remitimos a lo sostenido anteriormente en el capítulo número cuatro de este trabajo.

Nos parece importante destacar que la protección penal de los nuevos bienes jurídicos colectivos se puede realizar, en algunos casos, incluso de forma más eficaz, por otros sectores del ordenamiento jurídico como el Derecho Civil, el Derecho Mercantil y especialmente por el Derecho Administrativo sancionador. No hay que olvidar que en este último en España se aplican ya algunos principios básicos del Derecho Penal como el principio de legalidad, el de la irretroactividad de las leyes desfavorables, el de la retroactividad de las leyes favorables $\mathrm{y}$, de

Luis. NEUMANN, Ulfrid. NIETO MARTíN, Adán (Coord.). Crítica y justificación del Derecho Penal en el cambio de siglo. Ediciones de la Universidad de Castilla-La Macha. Cuenca. 2003, pp 61- 64. MATA y MARTÍN, Ricardo M. Bienes jurídicos intermedios..., op. cit., pp. 1-7. SÁNCHEZ GARCÍA DE PAZ, Isabel. "La criminalización en el ámbito..., op. cit., pp. 685- 688 .

16 “Cuanto más intensamente se optimice la protección de bienes jurídicos, tanto más se define al autor como enemigo, sin un ámbito externo". JAKOBS, Günther. Bases para una teoría funcional del Derecho Penal. (Trad. CANCIO MELIA, Manuel. FEIJOO SÁNCHEZ, Bernardo. PEÑARANDA RAMOS, Enrique. SANCINETTI, Marcelo. SUAREZ GONZALEZ, Carlos). Ed. Palestra Editores. Lima. 2000, pp. 211- 215, 247. JAKOBS, Günther. Estudios de Derecho Penal. (Trad. PEÑARANDA RAMOS, Enrique). Ed. Civitas. Madrid. 1997, pp. 294, 295. "Hasta los delitos de peligro menos graves y los delitos de peligro presunto podrían aferrarse a un bien jurídico de especial trascendencia para adquirir legitimación". LASCURAÍN SÁNCHEZ, Juan Antonio. "Bien jurídico y objeto protegible” en Anuario de Derecho Penal y Ciencias Penales, vol. LX. 2007, p. 135. 
forma parcial el principio de culpabilidad, lo cual es lógico dado que entre el ilícito penal y el ilícito administrativo en muchos casos existen únicamente diferencias cuantitativas ${ }^{17}$. También puede contribuir como un filtro en estos ilícitos (medio ambientales, socioeconómicos, de tráfico viario o contra la salud pública) la determinación del nivel máximo de riesgo permitido, lo cual en nuestra opinión puede resultar de gran utilidad tanto para el legislador como para los operadores del Derecho. Sobre este tema se puede consultar el excelente trabajo realizado por el profesor Paredes Castañón ${ }^{18}$.

Corcoy Bidásolo sostiene que un factor que influye decisivamente en la aparición de un "nuevo Derecho Penal" procede de una concepción utilitarista de esta rama del Derecho, dado que la mayoría de Estados en su opinión han llegado a la conclusión de que prevenir no sólo es más eficaz sino también más barato que sancionar resultados lesivos, lo cual entiende, resulta además menos dañoso tanto para los autores (por la menor gravedad de las penas), como para las víctimas (que son protegidas sin necesidad de que sus derechos fundamentales sean lesionados). Otro factor sustancial que sustenta la transformación del Derecho Penal, desde su perspectiva, radica en la aparición de los nuevos riesgos propios de la sociedad tecnológica, así como el complejo sistema económico social que demanda la intervención del ordenamiento jurídico-penal, lo cual ha llevado al legislador "a proteger nuevos bienes jurídicos, a la doctrina y jurisprudencia a reinterpretar el sentido de algunos bienes jurídico-penales tradicionales y, por último, al sistema judicial a perseguir efectivamente y a condenar por la comisión de delitos de peligro sin esperar a que se sobre la distinción de ilícitos". QUINTERO OLIVARES, Gonzalo. MORALES PRATS, Fermín (Coord.). El nuevo Derecho Penal Español. Estudios penales en memoria del profesor José Manuel Valle Muñiz. Ed. Aranzadi. Navarra. 2001, pp. 343- 354. Para ver las diversas teorías sobre el tema. Idem. pp. 326- 376. MATA y MARTÍN, Ricardo M. Bienes jurídicos intermedios..., op. cit., pp. 77, 78.

18 PAREDES CASTAÑóN, José Manuel. El riesgo permitido en el Derecho Penal (Régimen jurídico-penal de las actividades peligrosas). Ed. Ministerio de Justicia e Interior. Secretaria General Técnica. Centro de publicaciones. Madrid. 1995, pp. 483- 510. MENDOZA BUERGO, Blanca. Límites dogmáticos..., op. cit., pp. 465- 470. 
haya producido un resultado lesivo"19. En Alemania un sector doctrinal asume que el moderno Derecho Penal cumple su función de conformidad a la realidad social sobre la que se proyecta, en el entendido de que si las sociedades modernas son sociedades de riesgo, el Derecho Penal se encuentra funcionalmente legitimado para actuar en defensa de la seguridad y de la prevención frente a los peligros, en este sentido se pronuncian; Schünemann, Kuhlen, Kindhäuser, Kratsch, Jakobs, Müsig o Seelmann, sin embargo es necesario precisar que sus posiciones distan mucho de ser homogéneas ${ }^{20}$.

Hay que decir que se le critica al Derecho Penal moderno, de una forma bastante extendida en la doctrina, la sustitución progresiva del modelo tradicional de la lesión o puesta en peligro concreto de bienes jurídicos individuales, por otro en que tendría preponderancia el peligro abs-

Esta profesora hace énfasis en la necesidad de que en este nuevo Derecho Penal debe atenderse al principio de proporcionalidad en la determinación de la clase y de la medida de la pena, además justifica su postura en la necesidad de controlar los riesgos tecnológicos y socio-económicos actuales frente a los cuales el ciudadano se encuentra indefenso. Esta situación en su opinión ha conducido al legislador a tutelar penalmente nuevos bienes jurídicos. CORCOY BIDÁSOLO, Mirentxu. Delitos de Peligro..., op. cit., pp, 24, 25. CORCOY BIDÁSOLO, Mirentxu. "Protección de bienes..., op. cit., pp. 399, 400. Argumentando la necesidad de la modernización del Derecho Penal. GRACIA MARTÍN, Luis. “¿Qué es modernización del Derecho Penal?” en DIEZ RIPOLLES, José Luis. ROMEO CASABONA, Carlos María. GRACIA MARTíN, Luis. HIGUERA GUIMERÁ, Juan Felipe (Editores). La ciencia del Derecho Penal ante el nuevo siglo. Libro homenaje al Profesor. Doctor. Don José Cerezo Mir. Ed. Tecnos. Madrid. 2002, pp. 350, 351. 387- 393. GRACIA MARTÍN, Luis. Prolegómenos para la lucha por la modernización y expansión del Derecho Penal y para la crítica del discurso de resistencia. Ed. Tirant lo Blanch. Valencia. 2003, pp. 189- 216. "En cualquier caso, el legislador resulta absolutamente impermeable a cualquier crítica: la producción de Derecho Penal y de cualquier otro derecho coercitivo, entendida como prueba de presencia y activismo político, es buscada con decisión". MAZZACUVA, Nicola. "El futuro del Derecho Penal" en ARROYO ZAPATERO, Luis. NEUMANN, Ulfrid. NIETO MARTÍN, Adán (Coord.). Crítica y justificación del Derecho Penal en el cambio de siglo. Ediciones de la Universidad de Castilla-La Mancha. Cuenca. 2003, p. 232. A favor de la protección de los nuevos bienes jurídicos colectivos pero sin modificar o renunciar las garantías que proporciona la teoría del delito. PORTILLA CONTRERAS, Guillermo. "La supuesta crisis..., op. cit., pp. 907-913. SOTO NAVARRO, Susana. La protección penal de los bienes jurídicos colectivos en la sociedad moderna. Ed. Comares. Granada. 2003, p. 192.

20 SUÁREZ GONZÁLEZ, Carlos J. "Derecho Penal y riesgos tecnológicos” en ARROYO ZAPATERO, Luis. NEUMANN, Ulfrid. NIETO MARTÍN, Adán (Coord.). Crítica y justificación del Derecho Penal en el cambio de siglo. Ediciones de la Universidad Castilla-La Mancha. Cuenca. 2003, pp. 295- 297. 
tracto o presunto, como contenido material de los tipos penales, pues un modelo de esta naturaleza resultaría contrario al principio de lesividad y al de protección subsidiaria de bienes jurídicos, lo cual obviamente también afectaría a otras garantías penales en mayor o menor medida, tal es el caso de los principios de proporcionalidad y culpabilidad. En definitiva se afirma: que utilizar el peligro abstracto como respuesta política a la sociedad de riesgo puede llegar a transformar el caso fortuito en injusto penal ${ }^{21}$. En esta línea muchos juristas se muestran críticos con relación a la posibilidad de considerar suficientemente idóneo el efecto preventivo general de la pena, y más aún de la eficacia preventiva de los tipos de peligro abstracto para la tutela de bienes jurídicos colectivos poco delimitados. Es necesario destacar además que el balance de la eficacia del Derecho Penal en las áreas donde se producen las presiones de criminalización es poco alentador, dado que el éxito es tan escaso, que incluso los partidarios más entusiastas de la intervención penal en estos ámbitos (medio ambiente, drogas ilícitas, economía, criminalidad organizada) aceptan que hay una evidente crisis de efectividad en estos sectores. Prittwitz afirma que si a esta crisis de efectividad le sumamos otra de legitimidad, el resultado del fracaso Derecho Penal de control global resultaría evidente ${ }^{22}$.

La resistencia a una desmesurada expansión del Derecho Penal creemos que no debe de entenderse como "la retirada del Derecho Penal a los cuarteles de invierno", sino como un llamado a la reflexión sobre la evolución de esta rama del Derecho, pues todos los problemas de la sociedad de riesgo no pueden ni deben ser solucionados mediante el Derecho Penal. En nuestra opinión no debemos asumir sin mayor

GRACIA MARTÍN, Luis. Prolegómenos para la lucha por la modernización y expansión del Derecho Penal y para la crítica del discurso de resistencia. Ed. Tirant lo Blanch. Valencia. 2003, pp. 134- 136. MAZZACUVA, Nicola. "El futuro del Derecho Penal". (Trad. RODRÍGUEZ ARIAS, Miguel Ángel) en ARROYO ZAPATERO, Luis. NEUMANN, Ulfrid. NIETO MARTÍN, Adán (Coord.). Crítica y justificación del Derecho Penal en el cambio de siglo. Ediciones de la Universidad de Castilla-La Mancha. Cuenca. 2003, pp. 232- 237.

22 Las pretendidas mejoras que se realizan en el Derecho Penal socavan paulatinamente su perfil constitucional. PRITTWITZ, Cornelius. "Sociedad de riesgo..., op. cit., pp. 261264, 278- 283. En el sector doctrinal que mantiene esta posición podemos citar a: Prittwitz, Hassemer, Lüderssen, Albrecht, y Herzog. MENDOZA BUERGO, Blanca. El Derecho Penal..., op. cit., pp. 53- 55. El Derecho Penal del riesgo es legislación simbólica. NAVARRO CARDOSO, Fernando. “El Derecho Penal..., op. cit., pp.1329, 1330. 
reparo que "cuanto más importante es un problema más legítima aparece la utilización del Derecho Penal"23, pues como bien decía Sófocles "para quien tiene miedo todos son ruidos"24. En este sentido Albrecht apunta la necesidad de recurrir a eficaces políticas estructurales propias del Derecho Administrativo 25 o de otras ramas del Derecho como el civil o el mercantil, esto es así, en nuestra opinión, pues como sostiene la doctrina mayoritaria a la existencia de un bien jurídico debe añadirse la idoneidad de los instrumentos del Derecho Penal para su protección.

Una opinión diferente a la planteada anteriormente, al menos en parte, es defendida por Schünemann, quien afirma que los delitos de peligro abstracto están dotados de una alta definición tanto en las circunstancias del hecho como en la acción típica misma, lo cual los hace más conformes con el mandato de determinación del tipo en cuanto exigencia material del principio de legalidad, de lo que puedan serlo los tradicionales tipos imprudentes de resultado ${ }^{26}$. Tiedemann siguiendo la misma línea argumental sostiene que la legitimidad de los delitos de peligro abstracto, no se encuentra reñida con los principios de proporcionalidad y de última ratio ${ }^{27}$. Para Gracia Martín la modernización del Derecho Penal es "la lucha por integrar en el discurso penal a la criminalidad material de las clases sociales poderosas que estas mismas han podido excluir hasta ahora de aquel gracias a su posición de poder de disposición absoluto sobre el

$23 \quad$ PRITTWITZ, Cornelius. “Sociedad de riesgo..., op. cit., p. 279.

24 GÓMEZ RUFO, Antonio. "El futuro ya está aquí" en El Mundo. Madrid. 17 de mayo de 2008 , p. 4. Nuestra sociedad puede definirse como "la sociedad de la inseguridad sentida" o como "la sociedad del miedo". SILVA SÁNCHEZ, Jesús María. La expansión del Derecho..., op. cit., p. 32.

25 GARCÍA-PABLOS de Molina, Antonio. "Tendencias actuales del Derecho Penal" en CEREZO MIR, José (Dir.). Modernas tendencias en la Ciencia del Derecho Penal y la Criminología. Ed. UNED. Madrid. 2001, pp. 57- 59. NAVARRO CARDOSO, Fernando. “El Derecho Penal..., op. cit., p. 1340- 1345.

26 SCHÜNEMANN, Bernd. Consideraciones críticas..., op. cit., pp. 29- 34. En el mismo sentido se pronuncia en la doctrina española. CORCOY BIDÁSOLO, Mirentxu. "Protección de bienes..., op. cit., pp. 384- 386.

27 GRACIA MARTÍN, Luis. Prolegómenos para la lucha por la modernización y expansión del Derecho Penal y para la crítica del discurso de resistencia. Ed. Tirant lo Blanch. Valencia. 2003, pp. 158, 159. 
principio de legalidad penal desde su invención por el ideario político ilustrado liberal de la burguesía capitalista" ${ }^{28}$. Entendiendo desde esta perspectiva por Derecho Penal moderno en sentido material al sistema de regulaciones jurídico penales que tienen por objeto "la criminalización formal de conformidad con el sistema de garantías políticas del Estado Social y Democrático de Derecho, del sistema de acción ético socialmente reprobable de las clases sociales poderosas"29.

En todo caso, estimamos preciso afirmar que aunque en los delitos de peligro no es necesario que la conducta llegue a menoscabar de forma efectiva un bien jurídico penalmente tutelado, estos tipos delictivos requieren, sin lugar a dudas, de la creación de una situación de riesgo para la incolumidad de dicho bien jurídico, lo cual no entra en contradicción con la función protectora de bienes jurídicos que debe cumplir el Derecho Penal, ya que como todos sabemos el modo de afectación a los bienes jurídicos puede ser diverso según se trate de delitos de lesión o delitos de peligro ${ }^{30}$. Resultando en estos últimos, imprescindible la existencia de al menos la afección potencial efectiva del bien, pues como es generalmente aceptado por la doctrina mayoritaria el Derecho Penal no debe intervenir cuando no exista referencia alguna a la protección de bienes jurídicos, pues la intervención del ordenamiento penal sin la debida constatación de que la probabilidad de menoscabo del bien jurídico verdaderamente se ha producido (delitos de peligro abstracto sin ofensividad) vulnera el principio de intervención mínima ${ }^{31}$.

Frente a la idea de una expansión penal desmedida, que se pudiera producir mediante un Derecho Penal del peligro, se ha señalado que esta comporta un doble riesgo; en primer lugar la relativización de los presupuestos políticos criminales que fundamentan la penalización del comportamiento humano, en especial el principio de ofensividad y, por

$28 \quad$ Ibidem., pp, 166, 167.

29 Ibidem., pp, 190, 191.

30 Mata y Martín señala que los delitos de peligro se consuman en un momento anterior al menoscabo efectivo (lesión) del bien jurídico penal, cuando sólo existe realmente un riesgo para él mismo, por lo cual se produce un adelantamiento de la barrera punitiva. MATA Y MARTÍN, Ricardo M. Bienes jurídicos intermedios...., op. cit., pp. 48, 49. 
ende, de antijuricidad material, y en segundo lugar la desconfianza que existe de que el uso de estas técnicas de tipificación no permiten obtener, en el ámbito de la criminalización secundaria la deseada protección de bienes jurídicos, sino la mera instrumentalización de la reacción penal con fines simbólicos ${ }^{32}$. En este sentido señala Herzog que "el Derecho Penal del peligro supone una respuesta muy limitada, y sobre todo a limitar para las situaciones de peligro de la vida moderna"33, pues como es sabido por todos se carece de un exhaustivo desarrollo dogmático de esta técnica, lo cual pensamos ha propiciado su desordenada expansión en el Derecho Penal, así como su asistemática interpretación jurisprudencial, lo cual en nuestra opinión no niega de forma alguna la necesidad de tutelar bienes jurídicos mediante las técnicas de peligro, siempre que se respeten los principios político criminales que sustentan el Estado Social y Democrático de Derecho.

Mendoza Buergo destaca que hay un grupo de autores que adoptan sobre este tema una posición intermedia, se pueden agrupar aquí quienes plantean vías que no defienden el "Derecho Penal de la seguridad" ni de adaptación funcional a cualquier demanda de protección, sino que aceptan, con ciertas limitaciones, la asunción por el Derecho Penal de los ámbitos de regulación constituidos por los nuevos riesgos, pero exigiendo que esta tutela se realice con total respeto a los principios básicos de garantía del Derecho Penal del Estado de Derecho y a las estructuras clásicas de la imputación de la

32 CARO CORIA, Dino Carlos. Derecho Penal del Ambiente..., op. cit., p. 405. Un precepto penal que solo tenga un valor simbólico ha de rechazarse. CORCOY BIDÁSOLO, Mirentxu. "Protección de bienes..., op. cit., p. 400. Destacados juristas como Seelmann, Block o Hassemer advierten que el efecto simbólico una vez descubierto, conduce a la ineficacia. MENDOZA BUERGO, Blanca. El Derecho Penal..., op. cit. , pp, 46, 47. NAVARRO CARDOSO, Fernando. “El Derecho Penal..., op. cit., p. 1331, 1332.

33 En el mismo sentido se pronuncian Hassemer, Albrecht y Lüderssen. HERZOG, Felix. "Sociedad del riesgo, Derecho Penal del riesgo, regulación del riesgo-perspectivas más allá del Derecho Penal" (Trad. CRESPO, Eduardo Demetrio) en ARROYO ZAPATERO, Luis. NEUMANN, Ulfrid, NIETO MARTÍN, Adán. (Coord.). Crítica y justificación del Derecho Penal en el cambio de siglo. Ediciones de la Universidad de Castilla-La Mancha. Cuenca. 2003, pp, 249- 251, 254- 257. HERZOG, Felix. "Límites al control penal de los riesgos sociales. Una perspectiva crítica ante el Derecho Penal en peligro" (Trad. Larrauri, Elena. PEREZ ALVAREZ, Fernando) en Anuario de Derecho Penal y Ciencias Penales. 1993, pp. 317- 319. 
responsabilidad penal. En su opinión así podrían clasificarse las posturas de profesores como Roxin, Hirsch, Frisch, Köhler y Prittwitz en la doctrina alemana. En la doctrina española con importantes diferencias y matices entre ellos señala a Silva Sánchez, Paredes Castañón, Rodríguez Montañés y Corcoy Bidásolo ${ }^{34}$.

Para cerrar este apartado del denominado Derecho Penal del riesgo o Derecho Penal moderno se puede decir que estaría constituido por un grupo de tipos delictivos con un contenido de lo injusto relativamente homogéneo, dado que en todos ellos se trataría de la realización de comportamientos que representarían, sólo como máximo, un simple peligro abstracto para bienes jurídicos principalmente individuales. Un sector de la doctrina considera que este ámbito del moderno Derecho Penal sería consecuencia del modo político en que el Estado decide afrontar los conflictos sociales de la dinámica sociedad moderna, el cual consiste básicamente en que el legislador recurre al tipo penal de peligro abstracto como "instrumento técnico adecuado por excelencia", por todas las ventajas que ofrece ${ }^{35}$.

\section{C.) LOS DELITOS CONTRA LA SEGURIDAD COLECTIVA COMO DELITOS DE RIESGO GENERAL}

Nos motiva a analizar el contenido de la categoría denominada "peligro general" que el tráfico de precursores de drogas, objeto de nuestro

34 MENDOZA BUERGO, Blanca. El Derecho Penal..., op. cit., pp. 120, 121. Siguiendo la tesis de Silva Sánchez Mendoza Buergo afirma que debe de procurarse una óptima síntesis entre los objetivos preventivos y de eficacia y el mantenimiento del garantismo. Idem. p. 189.

35 Producto del desarrollo científico y tecnológico, industrial y económico actual se realizan una cantidad de actividades que originan nuevos riesgos, generalmente como consecuencias no deseadas. Como característica de estos nuevos riesgos se puede señalar sus grandes dimensiones y la indeterminación del número de personas a las que potencialmente amenazan. GRACIA MARTÍN, Luis. Prolegómenos para la lucha por la modernización y expansión del Derecho Penal y para la crítica del discurso de resistencia. Ed. Tirant lo Blanch. Valencia. 2003, pp. 60- 65. MENDOZA BUERGO, Blanca. "Gestión del riesgo y política criminal de seguridad en la sociedad del riesgo" en DIAZMAROTO Y VILLAREJO, Julio. (Dir.). Derecho y justicia penal. En homenaje al profesor Antonio González- Cuellar García. Ed. Colex. Madrid. 2006, pp. 351- 356. Navarro Cardoso señala que en relación al principio de estricta protección de bienes jurídicos, "el Derecho Penal del riesgo" contribuye de forma decidida a la consolidación de este principio en factor de criminalización. NAVARRO CARDOSO, Fernando. "El Derecho Penal..., op. cit pp. 1328, 1329. 
estudio, en el Código Penal anterior ${ }^{36}$ estaba regulado en el Título $\mathrm{V}$ Capítulo II que comprendía "los delitos de riesgo en general"37, que a partir de la publicación del Código Penal de 1995 se refiere a "los delitos contra la seguridad colectiva"; a esta categoría al igual que a su antecesora no se le atribuye en general otra función que la sistemática. Sin embargo en opinión de Doval Pais es un concepto fecundo en consecuencias si se proyecta, materialmente, sobre las estructuras típicas de los delitos de peligro que comprende, pues la generalidad del peligro exige una colectividad expuesta al peligro, de lo cual se desprenden consecuencias prácticas como la imposibilidad de poder apreciar en determinados casos un concurso de delitos cuando exista un peligro para una pluralidad de individuos, señalando además que únicamente los bienes jurídicos vida, integridad física o salud pública, pueden dada su importancia integrar los denominados delitos de riesgo general, afirmando también que si la indeterminación de personas es una característica de los delitos de riesgo general (delitos contra la seguridad colectiva), lo es también "la indeterminación numérica de los bienes jurídicos afectados por el peligro" 38 .

Como todos sabemos, el Título XVII contiene muchos delitos de diferente naturaleza entre estos podemos citar: los delitos de riesgo catastrófico, los relativos a la energía nuclear y a las radiaciones ionizantes, los delitos de estragos, de incendios, así como los delitos contra la salud pública y contra la seguridad del tráfico. Estos tipos

Decreto 3.096/1973, de 14 de septiembre por el que se publica el Código Penal, texto refundido conforme a la Ley 44/1971, de 15 de noviembre (BOE no 297 a 300, de 12 a 15 de diciembre de 1973).

37 La rúbrica de "los delitos de riesgo en general" se incorpora en el ordenamiento penal español a partir del Código de 1967, manteniéndose la misma hasta la publicación del Código Penal de 1995, la rúbrica en mención tiene su origen en la elaboración dogmática del Derecho Penal alemán de la categoría del "peligro común" como aglutinador de un grupo autónomo de delitos. Esta categoría es un producto del pensamiento jurídico penal alemán de la ilustración que se materializo por primera vez en la Ordenanza territorial prusiana de 1794. DOVAL PAIS. Antonio. Delitos de Fraude Alimentario..., op. cit., pp. 284, 285.

38 Este autor afirma que los delitos de riesgo o peligro general comportarán obligatoriamente una amenaza para una pluralidad de bienes jurídicos (iguales $u$ homogéneos) en número indeterminado, lo que estima no se debe a que el bien jurídico protegido tenga carácter colectivo. DOVAL PAIS. Antonio. Delitos de Fraude Alimentario..., op. cit., pp. 288, 289, 327. 
penales tienen por denominador común que afectan la "seguridad colectiva". En estos delitos de lo que se trata es de adelantar la barrera punitiva para poder sancionar penalmente conductas peligrosas que, cuando se producen en estos ámbitos, deben sancionarse por la trascendencia de los daños que pueden ocasionar a bienes jurídicos individuales (vida, integridad física, salud o patrimonio) o a bienes jurídicos colectivos (medio ambiente, salud pública), de ahí que se haga referencia a "delitos de peligro general", "delitos contra la seguridad colectiva" o bien de "peligro común". En definitiva, se puede afirmar que estos ilícitos se caracterizan por estar referidos directamente a bienes jurídicos colectivos e indirectamente a bienes jurídicos individuales ${ }^{39}$, para la protección de estos bienes el legislador utiliza generalmente las figuras de delitos de peligro concreto y abstracto, sin embargo el Tribunal Supremo parece que sólo concibe como delitos de peligro general a los delitos de peligro abstracto, lo cual posiblemente se deba a que en estos en el momento de consumación no se encuentran concretados o determinados los sujetos portadores del bien jurídico ${ }^{40}$.

A manera de conclusión podemos afirmar que el peligro general se caracteriza en primer lugar, porque una pluralidad de personas se encuentra amenazada por un peligro $\mathrm{y}$, en segundo lugar, porque los sujetos expuestos al peligro han de ser indeterminados, lo cual no debe conducirnos a pensar, que toda puesta en peligro de una pluralidad personas indeterminadas constituya un peligro general, ya que este no es únicamente un peligro, sino un peligro común, compartido que afecta a todos y al mismo tiempo a ninguno en especial, otro elemento

39 La doble naturaleza de estos delitos plantea complejos problemas interpretativos en el momento de resolver el concurso entre el delito de peligro como tal y la posible lesión de bienes jurídicos individuales que no pueden ser resueltos a priori sin referencia al tipo concreto en cuestión. La distinción de delito de peligro concreto y delito de peligro abstracto, que tradicionalmente se usa para solucionar estos problemas, no es del todo traspasable a la regulación que se contiene en los delitos contra la seguridad colectiva, donde también hay bastantes delitos de peligro hipotético. MUÑOZ CONDE, Francisco. Derecho Penal. Parte Especial. Decimoquinta edición. Tirant lo Blanch. Valencia. 2004, pp. 601, 603.

$40 \quad$ DOVAL PAIS. Antonio. Delitos de Fraude Alimentario..., op. cit., pp. 338, 339. STS (ROJ: 3499/1993) de 29 de mayo de 1993. D. Cándido Conde-Pumpido Ferreiro. 
a tener en cuenta será el ánimo del autor ${ }^{41}$. Para ilustrar un poco tal afirmación podemos pensar en un sujeto que sube a la azotea de un edifico con un fusil automático, y empieza a disparar indiscriminadamente contra las personas que se encuentran en una plaza muy concurrida, en este ejemplo se puede apreciar a pesar de ser los sujetos pasivos indeterminados: tentativa del delito de lesiones, homicidio o bien asesinato de varias personas, así como de delitos de peligro tipificados fuera de los delitos de peligro del Título XVII (Delitos contra la seguridad colectiva) del Código Penal, que deben resolverse por la vía concursal. Otro ejemplo a tener en cuenta podría ser el abandono simultáneo de varios niños tipificado en el artículo 229 del CPE, lo cual evidencia que no sólo los delitos de peligro general representan un riesgo para una pluralidad de sujetos ${ }^{42}$.

De lo expuesto hasta aquí se infiere que los casos de peligro general estarán constituidos por:

a) Los de peligro general colectivo, en los que existe peligro para una pluralidad indeterminada de personas, de los que varios, o todos ellos, indeterminados, son objetivamente susceptibles de lesión.

b) Los de peligro general individual, cuando existe peligro para una pluralidad indeterminada de individuos, de los que sólo uno de ellos es objetivamente susceptible de lesión ${ }^{43}$.

Nos parece importante precisar que actualmente goza de cómoda postura en la doctrina la opinión que sostiene que el objeto del peligro

41 De cara a la afirmación del peligro general se requiere por lo tanto que el colectivo expuesto al peligro se halle indeterminado, lo cual sucederá, cuando el autor de la conducta del peligro no haya elegido especialmente a los sujetos a exponer al riesgo, ya bien sea de forma dolosa o imprudente, y, por lo tanto, no limite los posibles efectos de su comportamiento. DOVAL PAIS. Antonio. Delitos de Fraude Alimentario..., op. cit., pp. 315- 319 .

42 DOVAL PAIS. Antonio. Delitos de Fraude Alimentario..., op. cit., pp. 306- 308.

$43 \quad$ Ibidem., pp. 306, 319, 320. Los denominados "bienes jurídicos intermedios no siempre estarán incluidos en esta categoría sistemática, pues el legislador puede optar por otorgar autonomía sistemática a determinadas conductas que se dirijan contra un bien singularizado (de carácter intermedio) que posea suficiente relevancia como sucede en los delitos contra el medio ambiente. MATA y MARTíN, Ricardo M. Bienes jurídicos intermedios..., op. cit., pp. 33, 34. 
común es la colectividad, lo que sin embargo no significa de forma alguna que deba ponerse en peligro a una pluralidad de individuos, ya que la pluralidad a la que se alude puede estar representada perfectamente por una sola persona, indeterminada ex ante como parte de esa colectividad, así como por todas ellas o algunos miembros de la pluralidad aludida. Como se puede observar, en esta afirmación, basta con que cualquiera de los miembros de un colectivo se encuentre acosado por el peligro, para que todos y cada uno de ellos sean amenazados por la eventualidad del daño ${ }^{44}$. También creemos que es necesario aclarar que aunque puede parecer que el Tribunal Supremo español considera sólo delitos de peligro general a los delitos de peligro abstracto (STS del 29 de mayo de 1993 RJ 1993 4282) esto no es así, dado que se puede afirmar que en los delitos de peligro concreto se produce la puesta en peligro de una pluralidad indeterminada de personas. Por lo tanto se puede concluir que en los delitos de peligro general están comprendidos tanto los delitos de peligro concreto como de peligro abstracto, dentro de estos últimos los denominados delitos de peligro hipotético o delitos de peligro abstracto-concreto 45 .

\section{EL CONCEPTO DE PELIGRO}

El establecimiento del concepto de peligro constituye actualmente un problema mayúsculo para la doctrina jurídico penal, sobre el cual aún no se ha logrado el consenso deseado, lo cual responde quizás a la propia naturaleza fugaz del peligro, el cual puede producir la lesión de un bien jurídico o por el contrario la salida de dicho bien del ámbito del peligro. Sobre este intrincado tema existe una cantidad considerable de obras, lo cual se debe en gran medida a que este asunto no atañe

44 Doval Pais afirma que en el concepto de peligro en general "puede entenderse tanto en el sentido de que hayan de ser varios los sujetos expuestos al riesgo (un colectivo o una pluralidad), siendo solamente uno de ellos susceptible de lesión, como el de que hayan de ser varios los expuestos al riesgo, pudiendo ser todos ellos (o varios) lesionados. De modo que, si bien riesgo colectivo, plural o general, significa que el peligro ha de implicar a un conjunto de personas, ello no supone, sin embargo, que hayan de ser todas ellas quienes pudieran sufrir el daño que podría derivar de la conducta peligrosa". DOVAL PAIS. Antonio. Delitos de Fraude Alimentario..., op. cit., p. 304. RODRÍGUEZ MONTAÑÉS, Teresa. Delitos de peligro..., op. cit., p. 16, 17. 
únicamente a los delitos de peligro, sino que es un concepto toral de diversas instituciones de la teoría del delito, tal es el caso de la imputación objetiva, la tentativa, el riesgo permitido, los delitos imprudentes o las causas de justificación ${ }^{46}$. Queremos destacar en este momento la importancia que reviste el estudio de la configuración del concepto de peligro (estructura y requisitos), pues precisamente del contenido de este depende la amplitud o restricción de la protección concedida a los diferentes bienes jurídicos, y del éxito en el establecimiento de los requisitos requeridos para comprobar la subsistencia o no del peligro, dependerá la efectividad de esta técnica de tutela ${ }^{47}$.

Como sabemos, en el ordenamiento jurídico penal español no se especifica el contenido del peligro de los denominados delitos de peligro. La ausencia de una definición legal, siendo más explícitos jurídico penal, parece afectar la seguridad jurídica. Sin embargo este silencio legislativo es valorado por algunos autores positivamente, dado que asumen que dicho silencio evita el estancamiento del concepto de peligro, lo cual posibilita su desarrollo a través de la dogmática y la jurisprudencia ${ }^{48}$. Estimamos preciso aclarar que no pretendemos en este trabajo construir un concepto universal de peligro ajustable a todos los ámbitos en que este opera, sino intentar el establecimiento de un concepto de peligro que resulte válido para determinar la existencia de un riesgo típico y penalmente relevante, pues de más está decir que pretender obtener un concepto de peligro que sea válido para todas las instituciones del Derecho Penal excede con creces el marco de este trabajo ${ }^{49}$, para lograr este objetivo

46 RODRÍGUEZ MONTAÑÉS, Teresa. Delitos de peligro..., op. cit., p. 21. Hirsch señala que en la discusión sobre el concepto de peligro se produce una incorrecta distinción entre el "peligro" en que se encuentra el bien jurídico y la concreta "peligrosidad" de una conducta. Sosteniendo que el "peligro" se produce una vez que "un objeto entra en el radio de acción de un hecho". Mientras que la "peligrosidad se da cuando "un acto entraña la posibilidad concreta de lesión de un objeto". HIRSCH, Hans Joachim. "Peligro y peligrosidad" (Trad. SOLA RECHE, Esteban). Derecho Penal. Obras completas. Tomo I. Ed. Rubinzal- Culzoni Editores. Buenos Aires. 1999, pp. 69- 73.

47 MÉNDEZ RODRÍGUEZ, Cristina. Los Delitos de Peligro..., op. cit., p. 51.

48 CARO CORIA, Dino Carlos. Derecho Penal del Ambiente..., op. cit., p. 460.

49 Sobre la necesidad de alcanzar un concepto valido de peligro en todos los ordenamientos jurídicos. HIRSCH, Hans Joachim. "Peligro y peligrosidad”...,op. cit., pp. 
consideramos necesario estudiar el desarrollo que ha tenido el concepto de peligro en la doctrina penal, y por supuesto las principales tendencias que existen en la actualidad sobre este tema.

Sobre el asunto en cuestión en la doctrina alemana a finales del siglo XIX se desarrollaron dos posiciones en apariencia contradictorias: por una parte los defensores de la teoría subjetiva del peligro y, por el otro los seguidores de la teoría objetiva del peligro. A continuación realizaremos un breve repaso sobre ellas. Sin embargo queremos señalar, desde este momento, que a ambas tendencias se les cuestiona que tienen como denominador común confundir "el peligro como situación con el peligro como juicio"50.

\section{A.) TEORÍAS SUBJETIVAS: CONCEPCIÓN DEL PELIGRO COMO JUICIO}

Iniciamos este apartado abordando la teoría subjetiva del peligro, la cual asumía el entendimiento del peligro como un producto de la mente, entre sus partidarios podemos ubicar a los positivistas más radicales y a los neoidealistas. A grosso modo podemos decir que los primeros únicamente aceptaban como realidad al mundo físico fenoménico y las leyes que lo regulaban, basándose especialmente en el principio de causalidad, por lo que el peligro para ellos "sólo podía concebirse como una mera impresión psicológica (entendida bien como juicio de orden subjetivo, o como impresión subjetiva por parte del sujeto pasivo del hecho delictivo)". Mientras que los neoidealistas afirmaban que la realidad era obra del conocimiento operado por el sujeto, de tal manera que el peligro era una creación de la mente humana. Entre los neokantianos destacamos el pensamiento de Radbruch, quien sostuvo que "las premisas filosóficas de la ciencia del Derecho, se basan en el reconocimiento de un orden axiológico

80, 81. Sosteniendo que el concepto de peligro debe de ser siempre el mismo en todo el Derecho Penal. CEREZO MIR, José. “Los delitos...,op. cit., pp. 726, 727.

50 CORCOY BIDÁSOLO, Mirentxu. Delitos de Peligro..., op., p. 31. En todo caso la dirección actual se ocupa más que en el análisis del concepto ontológico del peligro, en la búsqueda de presupuestos básicos sobre la valoración del juicio de peligro y la prueba del mismo. MÉNDEZ RODRÍGUEZ, Cristina. Los Delitos de Peligro..., op. cit., p. 52. 
superior al ontológico y capaz de expresar, a través de la mediación del pensamiento, el sentido" 51 .

Queremos recalcar que los positivistas como buenos "fenomenólogos" únicamente aceptaban como realidad al mundo físico y a las leyes que lo regulaban. Por ello Von Liszt asumía que la realidad supone la confirmación del principio de necesidad que regula los acontecimientos que se producen en el mundo. Esta afirmación del principio de necesidad condiciona su manera de concebir el peligro, dado que de acuerdo con este principio, cualquier resultado que se produzca, se producirá, porque así tenía que suceder, lo que implica que si dicho resultado no acontece, es porque precisamente no podía producirse de ninguna forma. Como se puede apreciar esta posición no deja lugar para la posibilidad o bien a la probabilidad de la lesión de un bien jurídico, pues desde esta perspectiva el peligro tiene que ser necesariamente un juicio originado por una impresión de orden subjetivo ${ }^{52}$.

Nos parece importante señalar, que un sector de los subjetivistas percibían el juicio de peligro como una impresión subjetiva por parte del sujeto pasivo del hecho delictivo, es decir como un estado de temor, de esta manera los partidarios de estas tesis atribuyen al peligro un desvalor autónomo. No obstante en detrimento de la objetividad de dicho desvalor, Horn manifestó su oposición a este planteamiento argumentando a nuestro parecer, acertadamente, que el resultado típico subsiste al margen de la consideración de la víctima porque está dotado de un contenido objetivo ${ }^{53}$. En opinión de este autor se produciría un resultado de peligro "cuando las circunstancias concurrentes tendrían que haber dado lugar a la producción del

$52 \quad$ Al afirmar el principio de necesidad el concepto de posibilidad se reduce al "reflejo del mundo real en los ojos de quienes lo contemplan", por lo cual el peligro tiene que ser obligatoriamente un juicio originado por una impresión de orden subjetivo. Ibidem., pp. $53,54$.

53 En el mismo sentido Angioni contradice tajantemente esta postura subjetivista, dado que en su opinión semejante planteamiento conduciría a negar el peligro, siempre que la víctima no sea consciente del mismo. Ibidem., pp. 55, 56. 
resultado delictivo, de acuerdo con las leyes causales conocidas", es decir, cuando el resultado no haya acontecido de modo inexplicable ${ }^{54}$.

Uno de los máximos exponentes del positivismo y de la de la defensa de la ley de causalidad fue Finger, quien desde una posición subjetivista parte de que los hombres no conocen verdaderamente el mundo, pues asume que lo que se percibe de esté es una imagen subjetiva, así el conocimiento que se posee será siempre inexacto e imparcial, conocimiento que se adquiere a través de la abstracción y la generalización. Partiendo de estas premisas este autor entiende, que el peligro es "un juicio sobre hechos trascendentes basado en una cierta situación del mundo típicamente reconocida conforme a la experiencia que nos enseña que en ciertas situaciones resulta fácil la producción de lesiones a bienes jurídicos. Y cada juicio ligado a situaciones similares es una conclusión generalizadora por analogía. Pero, puesto que ese juicio se funda en un conocimiento parcial"... "constituye algo subjetivo, un acto emocional, dependiente de la medida del saber ontológico y nomológico aunque con pretensiones de validez general y con una fuerte influencia del juzgador"55. Se le cuestiona a esta postura al igual que las restantes teorías subjetivistas que no proponen un concepto de peligro, sino más bien una definición del juicio de peligro, por lo que este juicio posee una función no sólo declarativa del peligro sino también, constitutiva del juicio de peligro 56 . Como vemos, para Finger el peligro no es algo que pueda definirse mediante relaciones objetivas, producto de las limitaciones que el hombre tiene sobre el conocimiento del mundo, por lo tanto para él sólo existe "la causalidad y la no causalidad".

También en el plano de las teorías subjetivas sobre la noción del peligro, Hertz desde una perspectiva mucho más escéptica, calificó al

Para Cerezo el intento de Horn de determinar el concepto de resultado de peligro desde un punto de vista ex post y con base en la concepción de causalidad como condición conforme a una ley no tiene sentido, señalando que de esta forma se restringiría demasiado el concepto de resultado de peligro, lo cual desde en su opinión resulta insatisfactorio desde el punto de vista político-criminal, añadiendo que "es muy raro que ex post algo no se pueda explicar racional o científicamente. CEREZO MIR, José. "Los delitos de peligro...,op. cit., p. 723. RODRÍGUEZ MONTAÑ́́S, Teresa. Delitos de peligro..., op. cit. , pp. 23, 24. 
peligro como "un hijo de nuestra ignorancia" negando de forma tajante la posibilidad de establecer un concepto de peligro mediante las relaciones objetivas ${ }^{57}$.

Queremos terminar este apartado recordando que se señala comúnmente en la doctrina que la principal contradicción de en entender el peligro como juicio, consiste en la vulneración del principio de certeza jurídica, ya que de esta manera el peligro se agotaría en el juicio subjetivo de quien le corresponda valorar la existencia del peligro, lo cual no se puede superar recurriendo a parámetros de carácter objetivo o a la valoración del hombre medio, situación que es totalmente evidente en el caso de quienes asumen el peligro como un juicio del sujeto pasivo, pues se enfrentan con la dificultad de no poder explicar que sucede cuando la víctima no es consciente del peligro, ya que desde esta perspectiva tendríamos que negar el peligro, lo cual resulta claramente insostenible ${ }^{58}$.

\section{B.) TEORÍAS OBJETIVAS}

Las teorías objetivas, referente a los delitos de peligro, comparten el mismo punto de partida de las teorías subjetivas, que es el principio de necesidad causal. Kries digno exponente de las teorías objetivas, define el peligro como "la posibilidad objetiva de un resultado lesivo, que presupone el conocimiento de las conexiones causales generales", afirmando "que sólo es posible hablar de peligro en relación a ciertas condiciones determinadas de forma general, que abarcan una pluralidad de formas de conducta", por lo cual "podría denominarse

57 Carlos Caro expresa que en el seno de las teorías subjetivas del peligro se pueden apreciar dos tendencias: la primera de ellas "el subjetivismo moderado" que tiene como unos de sus principales exponentes a Finger que manifiesta que los conocimientos empíricos relativos al mundo fáctico pueden propiciar la realización de una "prognosis futura" mediante un espectador objetivo, de manera que el juicio sobre la peligrosidad de una acción es un juicio medio que es realizado ex ante, así un comportamiento puede valorarse de peligroso si no pudiera establecerse los motivos por los que ex post el resultado lesivo no se produce. La segunda tendencia la denomina "subjetivismo extremo o radical" la cual esta representada por Hertz y Janka, se caracteriza por negar de forma total la existencia de una base objetiva útil para la determinación de un juicio de peligro. CARO CORIA, Dino Carlos. Derecho penal del Ambiente..., op. cit., p. 433, 434.

58 MÉNDEZ RODRÍGUEZ, Cristina. Los Delitos de Peligro..., op. cit., p. 55. 
peligroso un estado de cosas concebido en general, que representa una elevada probabilidad de producción de un resultado lesivo" ${ }^{59}$. Esta postura admite que el peligro se materializa en la posibilidad real de producción de afectar a bienes jurídicos. Sin embargo se les cuestiona a los defensores de estas teorías que tampoco logran un concepto satisfactorio de peligro, ya que la básica referencia probabilística ex ante fundamentada en las leyes causales queda sin lugar, ante la necesaria consideración ex post del efectivo desenvolvimiento del curso causal, además de cuestionársele el no aportar una escala eficiente para la valoración del nivel de peligro necesario para determinar la relevancia penal ${ }^{60}$. Además se les critica al igual que a las teorías subjetivas que no ofrecen un concepto de peligro, sino más bien una definición de juicio de peligro ${ }^{61}$.

En opinión de algunos autores la diferencia esencial entre las teorías anteriormente señaladas consiste en el carácter que se le concede al juicio de peligro: así la teoría subjetiva como niega la existencia real del peligro, el juicio de peligro posee un carácter constitutivo. Mientras para los defensores de la teoría objetiva, el peligro tiene una entidad propia en el mundo externo, con independencia de la persona que emite el juicio, por lo que este tiene un carácter meramente declarativo o de reconocimiento del peligro. Al margen de los aciertos que se les reconoce y de las críticas de que son objeto ambas posiciones, varios autores que han tratado el tema afirman que ninguna de estas teorías ofrece un concepto valido de peligro ${ }^{62}$. No obstante queremos señalar

Destacamos que la concepción objetiva del peligro es respaldada por la doctrina mayoritaria. RODRÍGUEZ MONTAÑÉS, Teresa. Delitos de peligro..., op. cit., p. 27.

60 CARO CORIA, Dino Carlos. Derecho penal del Ambiente..., op. cit., pp. 436, 437. La teoría de la adecuación que formula Kries, se encuentra cimentada en la utilización del juicio de posibilidad a la relación de causalidad, ante la imposibilidad del conocimiento de todas las circunstancias y las leyes de la naturaleza del caso concreto, no es correcto emitir juicios de necesidad, lo cual hace necesario investigar que posibilidad representa una acción para la producción de un resultado, así la acción que fundamentada en general y sobre la base de la experiencia sea adecuada para la producción de un resultado, será la causa de este. MÉNDEZ RODRÍGUEZ, Cristina. Los Delitos de Peligro..., op. cit., pp, 60- 62. 
que en la actualidad goza de mayor aceptación en la doctrina el concepto objetivo de peligro pero con algunas matizaciones ${ }^{63}$. Al respecto Méndez Rodríguez opina que aunque resulta innegable que se debe adoptar un concepto objetivo de peligro, que no dependa de la impresión subjetiva del juzgador, también es evidente que el peligro no posee autonomía por sí mismo sino que depende de la entidad que adjetiva $^{64}$.

\section{C.) El CONCEPTO NORMATIVO DEL PELIGRO}

Precisamente con el propósito de superar las limitaciones que presentaban las diferentes posiciones adscritas a las teorías objetivas, Hippel introdujo la idea de un concepto normativo de peligro, el que posteriormente fue desarrollado por Demuth y Schünemann entre otros autores que a continuación expondremos ${ }^{65}$. Pero antes queremos señalar que la idea de optar por un concepto normativo de peligro goza de cómoda postura en la doctrina. En España autores que se han ocupado particularmente del tema como Méndez Rodríguez, Rodríguez Montañés, García Rivas, Corcoy Bidásolo y Doval Pais entre otros se decantan también por desarrollar un concepto normativo de peligro que toma como fundamento "la falta de dominio sobre la posible realización del riesgo en el resultado lesivo"66.

material de peligro". CARO CORIA, Dino Carlos. Derecho Penal del Ambiente..., op. cit., p. 438. CORCOY BIDÁSOLO, Mirentxu. Delitos de Peligro..., op. cit., p. 33.

63 La doctrina dominante en Alemania, niega que se pueda hablar de peligro en sentido puramente objetivo, entendiendo que el peligro es algo valorativo. Lo cual no contradice que para realizar esa valoración previamente debe existir el peligro. CORCOY BIDÁSOLO, Mirentxu. Delitos de Peligro..., op. cit., pp. 36, 37.

64 Esta autora afirma que debe de rechazarse la concepción subjetiva del peligro. Debiendo optarse por un concepto objetivo de peligro cuya existencia no esté supeditada a la impresión subjetiva del juzgador. MÉNDEZ RODRÍGUEZ, Cristina. Los Delitos de Peligro..., op. cit., p. 60.

65 RODRÍGUEZ MONTAÑÉS, Teresa. Delitos de peligro..., op. cit., p. 34. Cerezo se muestra crítico con el concepto de resultado de peligro sostenido por los autores que respaldan la denominada teoría normativa de peligro, pues opina que se da una restricción excesiva desde el punto de vista político-criminal al ámbito de los comportamientos punibles. CEREZO MIR, José. "Los delitos de peligro...,op. cit., pp. 723, 724. 
Corcoy Bidásolo señala que "para las teorías normativas del peligro la relevancia penal de la conducta del sujeto depende de la infracción del cuidado debido en el sentido de los delitos imprudentes", planteamiento que ella considera acertado por cuanto, desde "la perspectiva del injusto típico, el tipo objetivo supone, en todo caso, la creación de un riesgo grave para un bien jurídico penal (o el no control de un riesgo equiparable a su creación)". Por lo tanto, la comprobación de la presencia de un peligro adecuado, ex ante para lesionar un bien jurídico será el presupuesto común de todos los delitos ya sean estos de lesión, de peligro, dolosos o imprudentes ${ }^{67}$. Esta profesora hace una distinción entre peligro y riesgo, que no ha encontrado suficiente eco en la doctrina ya que se siguen usando los dos términos de forma indistinta, señalando que desde una perspectiva científica "el peligro se concibe como la capacidad intrínseca de una circunstancia, sustancia o agente para provocar efectos adversos, mientras que el riesgo es la probabilidad de que ese efecto adverso ocurra", de esta manera el riesgo entendido como probabilidad de lesión, en su opinión, puede ser evaluado si se conocen las circunstancias concurrentes y su verificación, así cuando se trata de un riesgo jurídico-penalmente relevante legitima la intervención penal ${ }^{68}$.

Se puede afirmar que la teoría normativa del peligro lo que pretende es poner en relación el peligro objetivo real con el objetivo aparente ex ante, relevante desde la perspectiva penal, así el concepto normativo de peligro se debe definir como "la probabilidad de lesión de un bien jurídico penal". Por consiguiente, "la calificación de una conducta como peligrosa se deberá de plantear como un problema de probabilidad de lesión en el caso concreto, atendiendo a los bienes jurídico penales potencialmente puestos en peligro y al ámbito de actividad donde se desarrolla esa situación", debiendo suponer la probabilidad de lesión

peligroso en sentido jurídico cuando se crea una situación, subsumible en la ley de frecuencia en abstracto, en el tipo penal del peligro cuyo desarrollo escapa al control del agente. En palabras de Ostendorf se trata de la "imposibilidad de dominar el curso del peligro". MÉNDEZ RODRÍGUEZ, Cristina. Los Delitos de Peligro..., op. cit., pp. 117119, 112, 123. MENDOZA BUERGO, Blanca. Límites dogmáticos..., op. cit., pp. 28-31. MUÑ̃Z CONDE, Francisco. GARCÍA ARÁN, Mercedes. Derecho Penal. Parte General. 6 ${ }^{\mathrm{a}}$ edición. Tirant lo Blanch. Valencia. 2004, pp. 302, 303.

CORCOY BIDÁSOLO, Mirentxu. Delitos de Peligro..., op. cit., pp. 40, 41. 
una entidad cercana a la seguridad de lesión para que se encuentre legitimada la consideración de típica de esa conducta69. Por tanto calificar el concepto de peligro como un concepto normativo, responde a la necesidad de dejar claro que para el Derecho Penal, ni siquiera como indicio, es válido un peligro objetivo estadístico analizado en abstracto respecto de una determinada clase de conducta. "La determinación del peligro exige una valoración, y esta valoración, aun cuando tenga como base leyes estadísticas de probabilidad, no puede ser ontológica sino normativa, puesto que la norma penal sólo pretende prohibir peligros que pudieran ser conocidos por el autor en el momento concreto", esto si entendemos que la posibilidad de motivación es el eje fundamental de legitimación de la intervención penal. Otro factor que se debe tomar en cuenta, es la calidad del riesgo, dado que, como es comúnmente aceptado por la doctrina dominante, el riesgo permitido restringe el riesgo penalmente relevante ${ }^{70}$.

69 Entiende Corcoy que el grado de peligrosidad exigible es el que determina, en un primer momento, la idoneidad de ese peligro para lesionar un bien jurídico. Pero determinar el grado de peligrosidad en abstracto es utópico por diferentes razones, siendo la principal de ellas que el peligro no posee una existencia independiente de un comportamiento situado en un momento concreto, el cual surge por diversas circunstancias. Por esta razón no es correcto decantarse por una teoría objetiva o subjetiva de peligro, dado que el peligro que nos importa "es el peligro como adjetivo calificativo de un comportamiento que puede ser objeto de prohibición penal". CORCOY BIDÁSOLO, Mirentxu. Delitos de Peligro..., op.cit., pp. 45- 47, 51, 52. Con una postura menos restrictiva sobre el peligro Cerezo Mir señala que "si la producción del resultado aparece como no absolutamente improbable la acción era peligrosa". CEREZO MIR, José. “Los delitos de peligro...,op. cit., pp. 721, 722.

70 Por ello, el peligro objetivo que llega a ser conocido, con posterioridad a los hechos no debe tener ninguna relevancia como substrato del juicio de peligro, aun cuando ontológicamente ya existiera en ese momento. "Tampoco pueden formar parte del grado de peligro, inherente a la situación sobre la que recae el juicio de peligro, aquellas circunstancias que, aun conociéndose el peligro objetivo que entrañaban en el momento en que se realizó el hecho eran permitidas". CORCOY BIDÁSOLO, Mirentxu. Delitos de Peligro..., op. cit., pp. 53- 55. 
Es Schünemann ${ }^{71}$, a partir del principio de confianza, quien plantea las bases de un concepto normativo de peligro, señalando que el nivel de probabilidad no puede determinarse en abstracto, ya que este se encuentra supeditado a la clase de bien jurídico de que se trate, así como al entorno del peligro y otros factores que establecen el nivel de riesgo permitido, de tal forma que el propio tipo ofrece criterios para establecer el grado de peligro exigible. Además sostiene que aquellas causas salvadoras que impiden la producción del resultado que no respondan al desarrollo normal del curso causal, deben ser valoradas como inadecuadas para eximir de responsabilidad penal al indiciado, por lo que en consecuencia únicamente aquellos medios salvadores dominables por el autor excluyen la responsabilidad de la acción, y de ninguna forma la mera casualidad o el azar ${ }^{72}$. En esta misma dirección basada en la falta de dominabilidad por parte del autor de la producción del resultado se pronuncian Cramer $^{73}$ y Roxin ${ }^{74}$.

71 Como ejemplo de esa mera casualidad a la que hace alusión este autor, señala un adelantamiento peligroso en una curva, donde la colisión con el otro vehículo no se produzca por la especial capacidad del otro conductor o bien ya sea por un golpe de viento repentino. Son circunstancias con las que no se debe contar, y por lo tanto no excluyen el peligro. RODRÍGUEZ MONTAÑÉS, Teresa. Delitos de peligro..., op. cit., p. 35. Frisch sostiene que en los delitos de peligro abstracto posee mayor relevancia "el contenido del presupuesto de imputación entendido como idoneidad ex ante", por lo que asume que estos tipos delictivos son delitos de aptitud, que valga la redundancia, acentúan la aptitud ex ante de la conducta para provocar los resultados que hay que evitar. CORCOY BIDÁSOLO, Mirentxu. Delitos de Peligro..., op. cit., p. 41.

72 Schünemann se aparta en alguna medida de la exigencia de la concurrencia de una infracción del deber objetivo de cuidado, al declarar que lo relevante es "la infracción del deber subjetivo de cuidado, así, los delitos de peligro aparecen como supuestos de tentativas imprudentes sin que sea preciso que el peligro objetivo sea idóneo para producir un resultado lesivo. CORCOY BIDÁSOLO, Mirentxu. Delitos de Peligro..., op. cit., p. 41. "La idea fundamental de peligro deriva de si el agente podía confiar en la eficacia de una determinada causa salvadora o en la no realización del evento lesivo a consecuencia de la casualidad". CARO CORIA, Dino Carlos. Derecho Penal del Ambiente..., op. cit., p. 442.

73 Cramer sostiene que lo distintivo del peligro es la falta de dominabilidad de los efectos de la conducta, en función de los conocimientos y habilidades de quien los realiza, por lo que la producción del resultado lesivo queda al arbitrio de la casualidad. Ibidem., p. 443.

74 Roxin quien también suscribe la Teoría normativa de resultado de peligro afirma que las circunstancias excepcionales que no dependen del autor no le eximen de responsabilidad por la producción del delito de peligro, citando como ejemplo de ello el caso del conductor temerario que realiza un adelantamiento en una curva cerrada 
Demuth elabora su concepto de peligro tomando como punto de partida las funciones que desempeña el resultado de peligro y el aspecto valorativo del peligro, asumiendo que el peligro como resultado típico cumple además de "la función interpretativa y de filtro o selección de las acciones especialmente aptas para lesionar, de entre todas las acciones peligrosas", con la "función de prevención general de conductas y, de adelantamiento de la barrera de protección de bienes jurídicos", funciones que solamente podrán ser cumplidas, si la producción de dicho peligro genera una impresión de desvalor semejante a la de lesión tanto para la sociedad como para el propio autor. Este sentimiento o impresión de desvalor se produce cuando el peligro representa una realidad social en forma de una "aguda crisis para el bien jurídico de sensación de amenaza", es decir, cuando ya no es posible confiar en la posibilidad de evitar el menoscabo de un bien jurídico a través de los medios normales de defensa ${ }^{75}$.

Es necesario también exponer aunque sea de forma breve el concepto práctico de peligro desarrollado por Kindhäuser, que es también un concepto normativo de peligro, para este profesor el concepto de

invadiendo el carril contrario, resultando que no se produce la colisión con el coche que circula en dirección contraria producto de una repentina ráfaga de viento o de la especial destreza del otro conductor. Señala que en este caso no se le debe de eximir de responsabilidad al autor de esta conducta pues se trata de circunstancias en las que nadie debe confiar. ROXIN, Claus. Derecho Penal. P. G..., op. cit., pp. 405, 406. Muñoz Conde en la misma línea sostiene que el peligro es un concepto normativo por cuanto se basa en un juicio de probabilidad de que un bien jurídico determinado pueda ser afectado por un comportamiento, aunque dicha lesión después no se produzca. Señala además que quien realiza el juicio de peligro (juzgador) debe conocer la situación de hecho en que se produjo la acción, así como las leyes de la naturaleza y de la experiencia a través de las cuales se puede concluir que la acción analizada realizada en esa forma determinada y bajo las mismas circunstancias pueda generalmente producir la afectación de un bien jurídico. MUÑOZ CONDE, Francisco GARCÍA ARÁN, Mercedes. Derecho Penal. Parte General. 6a edición. Tirant lo Blanch. Valencia. 2004, p. 302.

75 Rodríguez Montañés comparte el concepto normativo de peligro expuesto por Demuth, asumiendo que el elemento fundamental del peligro estriba en que "el bien jurídico se encuentra en una situación en la que su lesión no puede ser evitada con seguridad a través de los medios normales". RODRÍGUEZ MONTAÑÉS, Teresa. Delitos de peligro..., op. cit., pp. 36, 37. En el mismo sentido se pronuncia Caro Coria, quien señala que Demuth aporto la definición sobre el contenido de peligro mejor lograda hasta el día de hoy en la doctrina jurídico penal. CARO CORIA, Dino Carlos. Derecho Penal del Ambiente..., op. cit., p. 473. 
peligro no puede definirse como causa hipotética de daño a un bien, puesto que su naturaleza no es empírico-teórica, sino teleológicapráctica, afirmando que un comportamiento comporta peligro cuando el sujeto activo ya no puede excluir con certeza la entrada de circunstancias relevantes para la lesión, así lo que determina el peligro es la incapacidad de prevención o de evitación ${ }^{76}$.

Cristina Méndez sostiene que aunque es innegable que el concepto de peligro posee una naturaleza normativa (dado que su objeto de referencia lo constituye el bien jurídico), también es cierto que el fundamento del peligro no es únicamente de naturaleza normativa, ya que toma como base una regla de experiencia que es sintetizada en un tipo penal. Por ello asume que se trata de "una regla de frecuencia abstracta basada en un principio de probabilidad", que cobra sentido en la configuración del tipo penal pero no en el análisis del caso concreto, ya que no es correcto aplicar sin más la teoría matemática de la probabilidad a las conductas humanas ${ }^{77}$.

Entrando ya en materia, en cuanto a la tarea de conceptualizar se refiere, Doval Pais define el peligro como "aquel estado de cosas en el que es previsible la posibilidad de que un bien jurídico protegido sufra una lesión", señalando que con el término "estado de cosas" se refiere a un conjunto de hechos o circunstancias objetivas y externas, pertenecientes a la realidad física ${ }^{78}$. No se trata por lo tanto de que un individuo determinado se sienta en una situación de peligro, sino de identificar que verdaderamente se producen ciertas circunstancias específicas, asumiendo que el concepto de peligro más que describir el

76 RODRÍGUEZ MONTAÑÉS, Teresa. Delitos de peligro..., op. cit., pp. 36, 37.

77 Afirma que "El tipo penal de peligro no hace otra cosa que recoger una regla de experiencia: se penalizan ciertas acciones que provocan resultados de peligro porque, precisamente en estos casos, se ha demostrado que la lesión es frecuente". MÉNDEZ RODRÍGUEZ, Cristina. Los Delitos de Peligro..., op. cit., pp. 117- 119. BUSTOS RAMÍREZ, Juan. Control social..., op. cit., p. 323. TERRADILLOS BASOCO, Juan Maria. "Peligro abstracto y garantías penales" en QUINTERO OLIVARES, Gonzalo. MORALES PRATS, Fermín (Coord.). El nuevo Derecho Penal Español. Estudios en memoria del Profesor José Manuel Valle Muñiz. Ed. Aranzadi. Navarra. 2001, pp. 789, 790.

Sobre "la previsibilidad de la posibilidad de lesión", señala que se trata de un requisito que limita de forma considerable el concepto de peligro haciéndolo más funcional y operativo a efectos jurídico penales. DOVAL PAIS. Antonio. Delitos de Fraude Alimentario..., op. cit., p. 275- 279. 
peligro, lo que hace es valorar una situación de hecho determinada, valoración que debe formularse de acuerdo con ciertas reglas que suministran los procesos inductivos a partir de la experiencia ${ }^{79}$.

Como se ha podido apreciar en el desarrollo de este apartado existen diversas definiciones de peligro. Destacamos entre estas la expuesta por Demuth, quien asume que el peligro es "una situación que representa una amenaza exteriorizada para un bien jurídico ya no controlable con los medios normales, y que crea un sentimiento de inseguridad, porque la no producción de la lesión no puede ser controlada con las medidas normales de evitación de daños" 80 . También resulta digno de mención el concepto práctico de Kindhäuser, quien afirma que "una conducta es peligrosa cuando el autor no está ya en situación de excluir con certeza la entrada de circunstancias relevantes para la lesión..." de tal manera que "lo relevante para el peligro es la incapacidad de prevención o evitación" por parte del autor de la lesión de un bien jurídico ${ }^{81}$. Como puede observarse, estos dos autores suscriben conceptos normativos de peligro que presentan como común denominador dos elementos; la ausencia de dominio de la situación por parte del autor, y la causalidad como factor decisivo.

Es importante señalar que a pesar de que existen importantes diferencias doctrinales sobre el concepto de peligro, podemos afirmar que actualmente existe un significativo consenso sobre determinados presupuestos indispensables para la formulación del mismo que a continuación detallamos:

a) No parece acertado pretender formular un concepto de peligro válido para todo el ordenamiento jurídico, por lo que se estima aconsejable trabajar en la delimitación de una definición que atienda a los principios limitadores del ius puniendi, y más aún, como la noción de peligro, sin lugar a dudas, ejerce un notable influjo en la dogmática de la imprudencia, la tentativa, la imputación objetiva, el riesgo

Doval afirma que de la observación de cómo se suceden los fenómenos en la realidad pueden extraerse algunas regularidades causales que permitirán en adelante realizar juicios de pronóstico acerca de las consecuencias de hechos que presenten determinadas características ya observadas. Ibidem., p. 280. 
permitido y las infracciones de peligro, resulta recomendable articular un concepto de peligro que responda a la necesidad de tutelar anticipadamente los bienes jurídico penales que nos permita contar con una noción de peligro ajustada a los delitos de peligro $^{82}$.

b) Es necesario que en la formulación de la noción de peligro adquieran una notable trascendencia los criterios de imputación objetiva ${ }^{83}$. Para poder entender el peligro como criterio normativo desde una doble consideración, es decir, como atributo de la acción y del resultado, posición que actualmente goza de gran aceptación en la doctrina de cara a distinguir los delitos de peligro abstracto (de peligrosidad) de los delitos de peligro concreto (de resultado de peligro) ${ }^{84}$.

c) Una vez aceptada la necesidad de contar con una noción de peligro que permita determinar la legitimidad de los delitos de peligro, y la trascendencia de la imputación objetiva en tal realización, no únicamente en el ámbito de la imprudencia, sino también en los delitos dolosos y de mera actividad, es factible abandonar "la concepción ontológica o causal naturalista del injusto sustentada en la afirmación de las leyes de certeza, y avanzar hacia su entendimiento normativo desde una perspectiva teleológica, es decir, acorde con las leyes

82 GARCÍA RIVAS, Nicolás. Contribución al estudio del tipo de peligro y aplicación a los delitos contra la salud pública y el medio ambiente. Inédito. Albacete 1995, pp. 43, 44. Cit. por CARO CORIA, Dino Carlos. Derecho Penal del Ambiente..., op. cit., pp. 461, 462. "Hay que destacar que parte de la doctrina contemporánea se decanta más bien por un análisis particularizado, especialmente de los conceptos de peligro concreto y abstracto". MÉNDEZ RODRÍGUEZ, Cristina. Los Delitos de Peligro..., op. cit., pp. 51, 52.

83 Se trata de la imputación objetiva desde dos niveles. El primero de ellos le da contenido al desvalor de la acción y se materializa a través de la creación de un riesgo típicamente relevante (perspectiva ex ante), lo que supone la superación del limite del riesgo penalmente permitido por la conducta del sujeto activo, la cual es capaz de poner en peligro o lesionar un bien jurídico. El segundo nivel de imputación dota de contenido al desvalor de resultado, constituyendo de esta manera una consecuencia o producto de la acción peligrosa, por lo cual el resultado únicamente será imputable si, desde una perspectiva ex post, puede apreciarse como la realización del riesgo creado. CARO CORIA, Dino Carlos. Derecho penal del Ambiente..., op. cit., p. 462.

84 Ibidem., p. 463. Sobre la necesidad de aplicar el primer nivel de los criterios de imputación objetiva a los delitos de peligro abstracto. MENDOZA BUERGO, Blanca. Límites dogmáticos..., op. cit., pp. 439- 454. 
probabilísticas y en función del criterio de la previsibilidad como condición para la imputación típica" 85.

d) Hay que reconocer que no se pueden establecer reglas para determinar de forma unitaria el riesgo mínimo requerido para apreciar la relevancia penal, ya que este se encuentra condicionado a un concreto tipo de injusto; así "el peligro típico debe graduarse en función del riesgo permitido que varía dependiendo de la clase de bien jurídico o de la intensidad del riesgo requerido según la naturaleza del área vital en juego", para lo cual es preciso reconocer la realidad del peligro y por ende la posibilidad de explicar el mundo en virtud de leyes de probabilidad 86 .

f) Otro elemento a tener en cuenta, es que el peligro no posee un carácter autónomo, ya que el legislador no sanciona la puesta en peligro como un fin en sí mismo, dado que la relevancia penal del riesgo creado radica en la posibilidad de afectar a un bien jurídico penal, o sea que el merecimiento y necesidad de pena para criminalización de estos sucesos peligrosos consiste, en que estos producen una situación en la que no puede asegurarse que no se lesionará el bien jurídico ${ }^{87}$.

\section{EL DOLO DE PELIGRO}

Quintero Olivares señala que existe una posición bastante extendida en la doctrina de entender que los delitos de peligro son delitos dolosos, los cuales se caracterizan en lo subjetivo por estar integrados por el denominado dolo de peligro, el cual "compone un concepto fronterizo entre el dolo y la culpa" que ha surgido forzado por necesidades político-criminales de adelantar la barrera de protección penal. Afirma este profesor que sólo violentando el sentido de las palabras se ha superado la diferencia de dolo entre delitos de resultado y de resultado

85 ROXIN, Claus. La problemática de la imputación objetiva. (Trad. CASAS BARRERO, Enrique) en Cuadernos de Política Criminal № 39 1989, pp. 749- 769. CARO CORIA, Dino Carlos. Derecho penal del Ambiente..., op. cit., p. 462.

86 GARCÍA RIVAS, Nicolás. Contribución..., op. cit., p. 45. Cit por CARO CORIA, Dino Carlos. Derecho Penal del Ambiente..., op. cit., p. 465.

$87 \quad$ Ibidem., p. $465,466$. 
de peligro, ya que la similitud entre una puesta en peligro y una efectiva lesión de un bien jurídico sin lugar a dudas, "puede declararlo el jurista pero no la realidad", agregando, en este sentido, que aunque la sensación de peligro es perceptible por los sentidos no es comparable a la lesión. Concluye Quintero señalando que la razón de incorporar a las leyes penales los delitos de peligro, responde a la imposibilidad de imputar como tentativa actos que revisten peligro para un bien jurídico, ya que por razones dogmáticas no se admite la apreciación de la tentativa en los delitos imprudentes, por lo cual en su opinión no parece conveniente referirse al dolo de peligro, cuando a lo sumo se estará ante una culpa con o sin previsión, "caracterizada porque atañe a bienes muy importantes y viola normas de especial rigor en sus medidas preventivas" 88 .

Rodríguez Montañés también se inclina por asumir que el dolo de peligro no constituye de manera alguna una clase especial de dolo, sino el concepto común referido a una determinada clase de delitos, dolo que por lo tanto está integrado por el elemento intelectivo y el volitivo de la realización de los elementos objetivos del tipo (principalmente la acción peligrosa y el resultado) ${ }^{89}$. El conocimiento o elemento

Cuando nos referimos a delitos de peligro nos encontramos ante conductas peligrosas, cuyos autores ya bien sea con culpa consciente o inconsciente, o ya bien sea con dolo eventual realizan acciones que el legislador a decidido criminalizar sin esperar a que se produzca la lesión del bien jurídico, esta decisión responde a criterios de prevención general. QUINTERO OLIVARES, Gonzalo. Parte General..., op. cit., pp. 336, 356, 357. QUINTERO OLIVARES, Gonzalo. “Los delitos de riesgo..., op. cit., pp. 246, 247.

Las exigencias mínimas de la representación que se alude son las siguientes: "1Conocimiento fáctico de la posibilidad de una concreta lesión, lo que supone en primer lugar, la percepción del objeto susceptible de ser lesionado y de su entrada en el ámbito de eficacia de la acción peligrosa. El concreto peligro exige un concreto objeto de ataque, que el autor debe representarse como cierto (dolo directo de $2^{\circ}$ grado) o como posible (dolo eventual). El grado de concreción en la representación de dicho objeto viene determinado por la redacción del tipo. En segundo lugar, la percepción de las circunstancias que convierten la acción en peligrosa. Y, en tercer lugar, cierta proximidad física e inmediatez temporal de la posible lesión". 2- El juicio de peligro. Es necesario aclarar que al afirmar el dolo de peligro por el hecho de que el autor se represente el peligro concreto y aún así continúe actuando, no significa que se prescinda del elemento volitivo, "sino tan sólo que su mínimo exigible viene implícito en la actuación pese a la representación”. RODRÍGUEZ MONTAÑÉS, Teresa. Delitos de peligro..., op. cit., pp. 141, 142, 164-168, 183. La distinción entre dolo de peligro no tiene sentido, en ambos casos el sujeto activo a de querer y conocer los elementos del tipo. "el problema especial en los delitos de peligro se presenta si el sujeto no quiere la 
intelectivo al que nos hemos referido precisa del conocimiento fáctico de la posibilidad de una concreta lesión, así como del juicio de peligro que el autor debe formularse es decir: su falta de capacidad para evitar de forma segura la lesión, siendo coherente con las leyes de la experiencia, incluyendo el juicio de peligro el conocimiento nomológico. Mientras que el elemento volitivo en el dolo de peligro se caracteriza por que este viene dado desde que el sujeto activo se representa el peligro, y a pesar de representárselo continúa actuando, lo cual basta para afirmar el dolo de peligro. Esta autora es partidaria de entender que el dolo de lesionar lleva implícito, necesariamente, el dolo de poner en peligro ${ }^{90}$.

Méndez Rodríguez en la misma línea afirma que la estructura del dolo en estos delitos es básicamente la misma que en los delitos de lesión, dado que aunque el autor de un delito de peligro puede que no sea consciente o no se represente la posibilidad de la lesión de un bien jurídico, si es conocedor de que con su actuación genera una situación de peligro que puede menoscabar la integridad de diversos bienes jurídicos; piénsese por ejemplo en el vertido de sustancias contaminantes a un río, o en la violación de medidas de seguridad durante la construcción de un edificio de varias plantas en una zona muy transitada ${ }^{91}$.

Una vez expuestas las ideas de estos docentes españoles sobre el dolo de peligro queremos recordar que la doctrina mayoritaria tanto en Alemania como en España sostiene que el dolo en los delitos de lesión y en los delitos de peligro no puede tener un contenido distinto ${ }^{92}$. Sobre

lesión, sino sólo la puesta en peligro del bien jurídico, con lo que se pone en primer plano el elemento cognoscitivo del dolo. BUSTOS RAMÍREZ, Juan. HORMAZÁBAL MALARÉE, Hernán. Lecciones de Derecho Penal..., op. cit., p. 249. La doctrina mayoritaria en Alemania defiende la identidad entre el dolo de peligro y el dolo de lesión. CORCOY BIDÁSOLO, Mirentxu. Delitos de Peligro..., op. cit., pp. 227.

RODRÍGUEZ MONTAÑÉS, Teresa. Delitos de peligro..., op. cit., pp. 49, 50.

MÉNDEZ RODRÍGUEZ, Cristina. Los Delitos de Peligro..., op. cit., pp. 228, 229.

CORCOY BIDÁSOLO, Mirentxu. Delitos de Peligro..., op. cit., p. 114. Existe una identidad entre el dolo de peligro y el dolo de lesión. CORCOY BIDÁSOLO, Mirentxu. "Protección de bienes..., op. cit., pp. 387, 388. Muchos autores concuerdan en afirmar que "lo peculiar del denominado dolo de peligro es la referencia objetiva del mismo" o "en el tipo legal al que hace referencia, que no exige la lesión del bien jurídico, sino tan sólo 
este tema Corcoy Bidásolo afirma que para que concurra un delito de peligro doloso es preciso demostrar que el sujeto conocía el peligro objetivo idóneo presente. Así el dolo en los delitos de peligro no puede tener un contenido distinto del que se predique sobre los delitos de lesión, aunque señala que existe una polémica muy fuerte sobre el elemento volitivo en el dolo, justamente en relación con el "querer el resultado". Al respecto como sabemos, se han desarrollado diferentes teorías, siendo preciso decir que sobre este tema se están imponiendo aquellas que ponen el acento en el elemento cognitivo del dolo, concebido como conocimiento de la situación de peligro típica. Esta autora piensa que si se debe diferenciar el dolo de los delitos de peligro, "en cuanto delitos en los que se protegen bienes jurídicos supraindividuales, y el dolo de peligro propiamente dicho, puesto que este último sólo tiene sentido en relación con los delitos de peligro concreto". Por lo tanto para Corcoy la identidad del dolo en los delitos de peligro y en los delitos de lesión no obedece, solamente, al concepto de dolo sino también del objeto del dolo, que en un caso es un resultado de peligro y en el otro un resultado de lesión ${ }^{93}$.

El acercamiento de posiciones hacia un concepto de dolo objetivado no excluye las divergencias respecto de cuál es el objeto de conocimiento del propio dolo; si se considera que la producción del resultado no pertenece al injusto, el resultado no será objeto del dolo $\mathrm{y}$, si se entiende que el resultado forma parte del injusto, naturalmente el dolo deberá abarcar la producción del resultado, afectando la distinta comprensión de la ubicación del resultado a las diferencias entre dolo de peligro y dolo de lesión, en la concepción tradicional. Sí el resultado forma parte del injusto, y por lo tanto es objeto del dolo, "el dolo de lesión será sustancialmente distinto del dolo de peligro porque comprenderá el conocimiento y la producción del resultado". Si en

su puesta en peligro". RODRÍGUEZ MONTAÑÉS, Teresa. Delitos de peligro..., op. cit., p. 45- 50.

93 CORCOY BIDÁSOLO, Mirentxu. Delitos de Peligro..., op. cit., pp. 114- 117. Sobre el dolo de peligro frente al dolo de lesión, se trataría en el caso del primero de prescindir del elemento volitivo del dolo, bastando para configurar este último el elemento intelectual referido al riesgo típico. SÁNCHEZ GARCÍA DE PAZ, María Isabel. El moderno Derecho Penal y la anticipación de la tutela penal. Ed. Universidad de Valladolid. 1999, pp. 44- 47. SÁNCHEZ GARCÍA DE PAZ, Isabel. "La criminalización en el ámbito..., op. cit., p. 713. 
sentido opuesto, se sostiene que el resultado no pertenece al injusto, sino de la punibilidad, para que exista dolo de lesión basta con que el sujeto conozca el exacto peligro típico creado con su conducta (lo cual implica que conoce su eficacia para producir el resultado). En dicho caso tendría el mismo contenido que en un delito de peligro, "por consiguiente, el fundamento de la identidad conceptual entre dolo de peligro y dolo de lesión no depende de que se defienda una teoría volitiva o una cognitiva sino, básicamente, de que la producción del resultado sea o no objeto del dolo"94. No queremos concluir este apartado sin hacer énfasis en que compartimos la opinión de la doctrina mayoritaria sobre la coincidencia del dolo de peligro y el dolo de lesión.

\section{EL DESVALOR DE ACCIÓN Y EL DESVALOR DE RESULTADO EN LOS DELITOS DE PELIGRO}

Para introducir este apartado queremos recordar que existen fundamentalmente dos clases de delitos de peligro: 1) los delitos de peligro concreto, que exigen la concreta puesta en peligro del bien jurídico de tal forma que el peligro concreto es un resultado típico (la realización del tipo presupone que el objeto de la acción se haya encontrado realmente en peligro en el caso individual), por tanto son delitos de resultado, con la particularidad de que el resultado que exigen es un resultado de peligro, cuya conexión con la acción debe ser comprobada con los criterios de causalidad e imputación objetiva y 2) los delitos de peligro abstracto, que sancionan una acción típicamente peligrosa sin exigir que en el caso concreto se haya puesto efectivamente en peligro un bien jurídico, en estos delitos el legislador describe una conducta que, según la experiencia, suele ser peligrosa para un bien jurídico. Por ello el peligro no es un elemento del tipo, sino la razón de la incriminación de ese comportamiento. Es importante señalar que es aceptado de forma muy extendida en la doctrina penal que un criterio válido para diferenciar los delitos de peligro abstracto de los de peligro concreto consiste en determinar si es suficiente establecer el desvalor de acción (acción desaprobada por el ordenamiento jurídico), o si es preciso determinar además un 
desvalor de resultado (lesión o puesta en peligro de un bien jurídico) ${ }^{95}$, problema del que nos ocuparemos a continuación.

Nosotros compartimos el razonamiento que sostiene que para la estructuración de los delitos de peligro resulta esencial el desvalor del resultado, como consecuencia de la realización de una conducta prohibida, de lo cual se deriva que estimamos correcto que no deban criminalizarse aquellas conductas carentes de significación lesiva o de riesgo para bienes jurídicos, aunque sea este en último caso, al menos de carácter potencial, ya que como es reconocido de forma mayoritaria por la doctrina, el injusto típico está integrado tanto por el desvalor de acción como por el desvalor de resultado, por lo que pensamos deben rechazarse aquellas posturas subjetivistas que abogan por fundamentar la antijuricidad en el desvalor de la acción, y adjudican el desvalor del resultado al azar o la casualidad. Por ello consideramos que siendo consecuentes con los fines del Derecho Penal debe entenderse que tanto el desvalor de acción como el desvalor de resultado son igualmente importantes en la determinación de la antijuricidad, dado que resulta impensable su consideración por separado. Así, se entiende que sólo aceptando la vinculación del injusto al desvalor del resultado se solventa con utilidad el principio de estricta protección de bienes jurídicos, el de proporcionalidad y de última ratio, y que de no ser así ya no constituiría materia de prohibición la realización de aquellas conductas ex ante peligrosas, pero que ex post no han significado una puesta en riesgo o la lesión de algún interés penalmente tutelado, de lo cual se infiere que el autor del ilícito no deberá responder penalmente por el acaecimiento de consecuencias azarosas, sino únicamente de aquellas que pudo prever y dominar mediante su acción u omisión, hecho este que nos conduce a pensar que una configuración dual del injusto es más consecuente con un Derecho Penal excluyente de la responsabilidad objetiva96. Digno de

MUÑOZ CONDE, Francisco. Derecho Penal. Parte General..., op. cit., , pp. 323-327. DÍEZ RIPOLLÉS, José Luis. Derecho Penal Español. Parte General. 4o edición. Tirant lo Blanch. Valencia. 2016, pp. 172-175. CARO CORIA, Dino Carlos. Derecho Penal del Ambiente..., op. cit., pp. 113, 130.

96 DEMETRIO CRESPO, Eduardo. Curso de Derecho Penal..., op. cit., 198- 200. CARO CORIA, Dino Carlos. Derecho Penal del Ambiente..., op. cit., pp. 197, 406- 415, 480. BUSTOS RAMÍREZ, Juan. HORMAZÁBAL MALARÉE, Hernán. Lecciones de Derecho Penal..., op. cit., pp. 181, 182, 186, 187, 244, 245. CORCOY BIDÁSOLO, Mirentxu. "Protección de bienes..., op. cit. , pp. 392, 393. HUERTA TOCILDO, Susana. Sobre el contenido de la 
mención es que el profesor Hirsch introduce un tercer elemento: "el desvalor sobre el estado de las cosas", que entiende, es más amplio que el desvalor de resultado, dado que el primero comprende todas las circunstancias objetivas del hecho de lo injusto típico, esto es, junto al resultado, también circunstancias acompañantes o medios empleados, señalando que el desvalor de resultado se refiere, en cualquier caso, en una utilización precisa del término, al resultado típico en el sentido de los delitos de resultado, el cual no tiene por qué ser idéntico a la lesión del bien jurídico ${ }^{97}$. En todo caso queremos aclarar que esta última clasificación propuesta por Hirsch no está consolidada en la doctrina, la cual se sigue inclinando por la clasificación tradicional que todos conocemos de desvalor de acción y desvalor de resultado, asumiendo que "el desvalor sobre el estado de las cosas" está comprendido en este último.

Es necesario destacar que precisamente se les cuestiona a los delitos de peligro abstracto su legitimidad por no exigir la puesta en peligro efectivo del bien jurídico tutelado (desvalor de resultado) y por ende infringir el principio de lesividad, habiendo por ellos varios autores propuesto su eliminación del ordenamiento penal. No obstante es

antijuricidad. Ed. Tecnos. Madrid. 1984, pp. 67- 73. LAURENZO COPELLO, Patricia. El resultado..., op. cit., pp. 51-60. MÉNDEZ RODRÍGUEZ, Cristina. Los Delitos de Peligro y sus Técnicas de Tipificación. Ed. Universidad Complutense. Madrid. 1993, pp. 89- 94. MUÑ OZ CONDE, Francisco. Derecho Penal. Parte General..., op. cit., pp. 327-329. PAZ Y PAZ BAILEY, Claudia. Tesis Doctoral. La protección penal de los pueblos. Especial consideración del delito de genocidio. Salamanca. 2005, pp. 296- 298. RODRÍGUEZ MONTAÑÉS, Teresa. Delitos de peligro..., op. cit., pp. 129, 130. ROXIN, Claus. Derecho Penal. P. G..., op. cit., pp. 319- 326.

97 Hirsch afirma que el concepto de desvalor de acción no puede determinarse desvinculado del contenido y el alcance de la acción, dado que una acción consumada consiste en la realización voluntaria de las circunstancias objetivas perseguidas, de modo que el alcance del correspondiente desvalor de acción depende de cuáles sean los elementos objetivos del tipo que deban de ser comprendidos por la voluntad. Por consiguiente, el desvalor de acción se prolonga en los delitos puramente dolosos hasta la consumación del tipo: en los delitos dolosos de resultado, hasta el resultado; en otros delitos dolosos, hasta el correspondiente criterio de consumación requerido. HIRSCH, Hans Joachim. "Los conceptos de desvalor de acción y desvalor de resultado o sobre el estado de las cosas". (Trad. DEMETRIO CRESPO, Eduardo) en DIEZ RIPOLLES, José Luis. ROMEO CASABONA, Carlos María. GRACIA MARTÍN, Luis. HIGUERA GUIMERÁ, Juan Felipe (Editores). La ciencia del Derecho Penal ante el nuevo siglo. Libro homenaje al Profesor. Dr. D. José Cerezo Mir. Ed. Tecnos. Madrid. 2002, pp. 772, 779. 
preciso advertir que hay que hacer una diferenciación en los delitos de peligro abstracto. De hecho el profesor Muñoz Conde en la última edición de su manual de parte general lo hace distinguiendo en los delitos de peligro tres grupos: los delitos de peligro concreto, los delitos de peligro abstracto y los delitos de peligro hipotético o de peligro abstracto-concreto. En los delitos de peligro abstracto estarán comprendidos aquellos delitos en que la punibilidad no depende de una puesta en peligro real del bien jurídico tutelado, sino que es suficiente que el comportamiento sea peligroso en general para el bien jurídico aunque en el caso concreto no llegue a ponerlo en peligro de lesión, se trata en definitiva de delitos de peligro abstracto puros. Mientras que en los delitos de peligro hipotético "la acción típica, en general peligrosa, tiene que ser idónea en el caso concreto para crear una situación de riesgo"98. Sobre estos delitos el profesor Torio López sostiene que el tipo reclama una acción idónea para producir un peligro sobre el bien jurídico "como elemento material integrante del tipo de delito", tratándose por tanto de delitos de peligro posible, por ello "son atípicas, las acciones que, desde la perspectiva del juicio de peligrosidad, aparecen como accidentales o irrelevantes, pese a hallarse formalmente comprendidas en la descripción típica". Concluyendo que en los delitos de peligro hipotético es necesario "acreditar la peligrosidad de la acción (desvalor real de la acción) y la posibilidad del resultado peligroso (desvalor potencial de resultado). Por ello, los delitos de peligro abstracto, en la medida en que se correspondan con la tipología propuesta de los delitos de peligro hipotético o peligro abstracto-concreto (cabe recordar que en estos ilícitos no se produce un resultado material), cumplirían, al menos en cierta medida, (con la perspectiva dualista) que se reivindica para todo ilícito penal (principio de ofensividad). Cuando esto no ocurra se estará penalizando un acto de mera desobediencia (delito de peligro abstracto puro) ajeno a los límites del Derecho Penal que debe prevalecer en un Estado Democrático ${ }^{99}$. 
En una dirección diferente se pronuncian autores como Armin Kaufmann, Zielinski o Sancinetti, quienes afirman que para calificar un hecho como injusto "bastaría con apreciar en él un desvalor de acción (que se identifica de manera predominante con la voluntad antinormativa del autor), quedando relegado el desvalor de resultado a un papel secundario, fuera del injusto", como una simple condición objetiva de punibilidad. El resultado desde esta perspectiva queda supeditado en gran medida a la casualidad o el azar. Este modo de explicar el ilícito penal se denomina "doctrina monista subjetiva" la cual es seriamente cuestionada por la doctrina mayoritaria porque entraña, en el fondo, una orientación autoritaria que es más compatible con un Derecho Penal de autor que con un Derecho Penal del hecho, al dejar en un segundo plano la necesaria valoración sobre la afectación o perturbación del bien jurídico ${ }^{100}$.

exige un efecto separable de la acción y atribuible a ésta a través de la causalidad. Desvalor de resultado y el resultado estructural se convierten así en dos conceptos con contenido propio y funciones diversas". Desde esta perspectiva en los delitos de peligro hipotético "el contenido del injusto, aunque no sería idéntico al de los tipos de lesión y de peligro concreto, tampoco escaparía a la perspectiva dualista de lo ilícito penal". Estos delitos exigen que sea posible la identificación del objeto de protección en los que verdaderamente s epoda hablar de las barreras de intervención penal respecto a un bien jurídico determinado. LAURENZO COPELLO, Patricia. El resultado..., op. cit., pp. 57, 59, 60, 179-183. SEQUEROS SAZATORNIL, Fernando. El tráfico de drogas..., op. cit., p. 291. En la misma línea en sentencia del Tribunal Supremo se declara que "tratándose de un delito de peligro, aun cuando sea abstracto, dicho peligro, como riesgo de futura lesión del bien jurídico, debe contenerse en la acción, quedando excluidas aquellas totalmente inadecuadas para lesionar o poner en peligro, aun potencialmente, la salud pública. STS (Roj: 4708/2003) de 4 de julio de 2003. Ponente: Cándido Conde- Pumpido Ferreiro. En los delitos de peligro abstracto-concreto o de peligro hipotético la acción típica generalmente es peligrosa, es idónea en el caso concreto para crear una situación de riesgo, cuya existencia efectiva no tiene que ser comprobada. MUÑOZ CONDE, Francisco. Derecho Penal. Parte General..., op. cit., pp. 326, 327. GUISASOLA LERMA, Cristina. "Principio de legalidad y estructura de los delitos de peligro abstracto. A propósito de la STC 42/1999" en Revista de Derecho Penal. Año 2002, Núm. 7, pp. 52-55.

DEMETRIO CRESPO, Eduardo. Curso de Derecho Penal..., op. cit., pp, 198,-200. Zielinski, afirma que "el ilícito consiste exclusivamente en la acción", de tal manera que el resultado desde su perspectiva esta supeditado en gran medida a la casualidad. En la misma dirección toma postura Sancinetti. Lo cual en opinión de Caro Coria no es más que atribuirle a la casualidad mayor trascendencia que la que en realidad tiene en la puesta en peligro o lesión de un bien jurídico, ya que la práctica ha demostrado sobradamente que es incorrecto afirmar que todo resultado es obra del azar, téngase 
Como ya se señaló en el inicio de este apartado es necesario destacar la importancia del desvalor del resultado en el injusto penal, dado que el fin último de la teoría de la imputación, tanto objetiva como subjetiva, consiste precisamente en rechazar todos aquellos resultados que no pertenecen a la acción del autor, sino que son producto del azar. En definitiva, consideramos que entender el resultado estrictamente como obra de la casualidad o en el peor de los casos del destino está reñido tanto con la experiencia general como con la capacidad humana de prever y controlar las consecuencias de su comportamiento, y además se encuentra en clara contradicción con el principio de culpabilidad, es por ello que se afirma que debe entenderse por azar aquello que resulta verdaderamente imprevisible tanto desde una perspectiva ex ante, como ex post. En atención a lo dicho hasta aquí creemos adecuado afirmar que "la exclusión del resultado del núcleo del injusto se opone al significado mismo del principio del bien jurídico", lo cual se reafirma si entendemos que el respeto al principio de proporcionalidad, así como al principio de última ratio únicamente se confirman si se asume como esencial el resultado, ya sea de lesión o de peligro101, lo cual pensamos no niega de ninguna manera el acento que tienen en los delitos de peligro el desvalor de acción ni la exigencia de un

como ejemplo de ello un disparo con arma de fuego realizado a quemarropa en la sien de un sujeto. Dino Carlos. Derecho Penal del Ambiente. Delitos y técnicas de tipificación. Ed. Gráfica Horizonte S. A. Lima. 1999, pp. 420- 424. SÁNCHEZ GARCÍA DE PAZ, María Isabel. El moderno Derecho..., op. cit., pp. 20, 21, 44- 47. SÁNCHEZ GARCÍA DE PAZ, Isabel. "La criminalización en el ámbito previo..., op. cit., p. 713. LAURENZO COPELLO, Patricia. El resultado..., op. cit., pp. 35-37. En los delitos de peligro abstracto-concreto o de peligro hipotético la acción típica generalmente es peligrosa, es idónea en el caso concreto para crear una situación de riesgo, cuya existencia efectiva no tiene que ser comprobada. MUÑOZ CONDE, Francisco. Derecho Penal. Parte General..., op. cit., pp. 327-329.

101 MÉNDEZ RODRÍGUEZ, Cristina. Los Delitos de Peligro..., op. cit., pp. 91, 92. RODRÍGUEZ MONTAÑÉS, Teresa. Delitos de peligro..., op. cit., p. 132. Desarrollando ampliamente el desvalor de acción y desvalor de resultado. SANTANA VEGA, Dulce María. "La fundamentación del injusto a la luz de sus teorías y de los principios informadores del Derecho Penal" en LUZON PEÑA, Diego Manuel. Derecho Penal del Estado Social y Democrático de Derecho. Libro homenaje a Santiago Mir Puig. Ed. La Ley. Madrid. 2010, pp. 298-326. 
desvalor de resultado, al menos de carácter potencial o intermedio, al que se ha hecho alusión anteriormente en este trabajo ${ }^{102}$.

\section{LOS DELITOS DE PELIGRO CONCRETO}

Los delitos de peligro concreto se distinguen por que en ellos el legislador manifiesta la posibilidad de que determinadas acciones sean peligrosas para el bien jurídico tutelado, dejando en manos del intérprete la apreciación de sí, en el caso específico, el bien ingreso en el radio de acción del peligro (apreciación del peligro ex post facto, valorando todas las circunstancias del hecho) ${ }^{103}$, lo que implica que los delitos de peligro concreto exigen que en el caso puntual se haya generado un peligro real para el objeto tutelado por el tipo respectivo, debiendo crearse por lo tanto "un peligro de resultado" en el sentido de un riesgo adecuado de lesión que no esté permitido. Para la

102 Los delitos de peligro abstracto deben constituir una categoría específica cuya particularidad reside en que, si bien no exigen un resultado estructural, si presuponen una cierta vinculación con el bien jurídico protegido, de donde se puede deducir que contienen un desvalor potencial de resultado. LAURENZO COPELLO, Patricia. El resultado..., op. cit., p. 181. QUINTERO OLIVARES, Gonzalo. Parte General..., op. cit., pp 280 - 282. Sobre la aceptación, por la doctrina dominante, de un resultado intermedio en la tentativa como presupuesto del injusto. ROXIN, Claus. Derecho Penal. P. G..., op. cit., pp. 325, 326. ACALE Sánchez señala que el resultado jurídico no puede faltar jamás en un tipo penal, agregando que el desvalor de resultado, consistente en la lesión o puesta en peligro de bienes jurídicos, se da tanto en los delitos de resultado material como en los de mera actividad, mientras que el resultado material, modificación del mundo exterior causada por la acción material, se produce solo en los delitos de lesión. ACALE SÁNCHEZ, María. El tipo de injusto en los delitos de mera actividad. Ed. Comares. Granada. 2000, pp. 155, 156.

103 DEMETRIO CRESPO, Eduardo. Curso de Derecho Penal..., op. cit., pp, 213, 214. Los delitos de peligro concreto desde el punto de vista dogmático son delitos de resultado. CEREZO MIR, José. "Los delitos de peligro...,op. cit., p. 720. DOVAL PAIS, Antonio. Delitos de Fraude Alimentario...,op. cit., p. 337. GOERNER, Gustavo. "Los delitos de peligro abstracto y las garantías constitucionales" en Revista de Derecho Penal. 2002-2, pp. 565,566 . En la clasificación que propone Hirsch los delitos de peligro concreto se corresponden con los delitos de "peligro". Los delitos de peligro abstracto son delitos de peligrosidad. HIRSCH, Hans Joachim. "Peligro y peligrosidad"...,op. cit., pp. 67- 69. Ver diferenciación entre delitos de peligro concreto y abstracto propuesta por Mirentxu Corcoy. CORCOY BIDÁSOLO, Mirentxu. Delitos de Peligro..., op. cit., p. 373. MIR PUIG, Santiago. Derecho Penal. Parte general. 9a edición. REPPERTOR. Barcelona. 2011, p. 239. 
comprobación de este peligro en concordancia con los criterios de imputación se exige "una prognosis objetivo- posterior"104. A pesar de que existe poca claridad en determinar como debe de estar configurado $\mathrm{y}$, como debe comprobarse ese resultado de peligro concreto, es posible afirmar que existen dos presupuestos de los delitos de peligro concreto que son generalmente reconocidos por la doctrina mayoritaria: el primero de ellos consiste en la necesidad de que exista un objeto de la acción y que este haya entrado en el ámbito operativo de quien lo pone en peligro; el segundo presupuesto exige que la acción que se incrimina tiene que haber creado un peligro próximo a la lesión de ese objeto de la acción ${ }^{105}$. Un claro ejemplo de delito de peligro concreto es la conducción temeraria o la fabricación y expedición de medicamentos defectuosos preceptuados en los artículos 381, 361 y 362 del CPE106.

104 Como sabemos la teoría de la adecuación se ha ido perfeccionando a lo largo de los años. Así actualmente se afirma que una condición es adecuada (o sea adaptada al resultado) si la misma ha aumentado la posibilidad de producción del resultado de modo relevante, de no ser así resulta verdaderamente inadmisible que la conducta de lugar a dicho resultado. En el desarrollo de esta teoría se produjo una larga polémica sobre el punto de vista (¿ex post o ex ante?, ¿desde el punto de vista de el autor o un tercero?, ¿sobre que base científica?) que debía adoptarse para realizar el juicio de adecuación. Discusión que condujo a elegir el "pronóstico (prognosis) objetivo posterior", el cual establece que "el juez debe colocarse posteriormente (o sea en el proceso) en el punto de vista de un observador objetivo que juzgue antes del hecho y disponga de los conocimientos de un hombre inteligente del correspondiente sector del tráfico y además del saber especial del autor". ROXIN, Claus. Derecho Penal P. G..., op. cit., p. 360. Los delitos de peligro concreto son delitos de resultado, porque la puesta en peligro concreta del bien jurídico constituye el resultado típico exigido por el delito. MATA Y MARTÍN, Ricardo M. Bienes jurídicos intermedios..., op. cit., pp. 52, 53.

DOVAL PAIS, Antonio. Delitos de Fraude Alimentario...,op. cit., pp. 337, 338. En el mismo sentido se pronuncia Mata y Martín, quien opina que en estos casos la acción del sujeto activo debe producir una situación de peligro, lo que lo hace concluir que los delitos de peligro concreto son delitos de resultado, así la puesta en peligro concreta del bien jurídico constituye el resultado típico exigido por el delito. MATA Y MARTÍN, Ricardo M. Bienes jurídicos intermedios..., op. cit., p. 53. MÉNDEZ RODRÍGUEZ, Cristina. Los Delitos de Peligro..., op. cit., pp. 211- 216. Muy interesante resulta la relación que se establece Mir Puig entre tentativa idónea que se corresponde a los delitos de peligro concreto y la tentativa inidónea con los delitos de peligro abstracto en el marco de la tentativa. MIR PUIG, Santiago. Derecho Penal. Parte General. 7ạ edición. Reppertor. S. L. Barcelona. 2005, pp. 233- 235. ROXIN, Claus. Derecho Penal. P. G..., op. cit., pp. 404- 406.

106 ARROYO ZAPATERO, Luis. Comentarios al Código Penal...,op. cit pp. 791-800, 835-837. 
De lo afirmado anteriormente se desprende que estaremos frente a un peligro concreto "desde el momento en que el bien jurídico protegido entra en el ámbito de eficacia de la acción peligrosa, y deja de ser segura la evitación de la lesión"107, constituyendo las dos notas primordiales para la concepción del peligro concreto la previsibilidad y la pérdida de dominio de las consecuencias de la conducta peligrosa ${ }^{108}$. Queremos precisar en este momento, que aunque pueda parecer que el Tribunal Supremo únicamente concibe como delitos de peligro general a los delitos de peligro abstracto (STS 29 de mayo de 1993), creemos que esta idea resulta poco afortunada, pues resulta totalmente viable entender que en los delitos de peligro concreto, se produce la puesta en peligro de una pluralidad indeterminada de sujetos, por lo cual entendemos injustificada la exclusión de los delitos de peligro concreto del ámbito de los delitos de peligro general ${ }^{109}$.

Como se ha puesto de manifiesto ya en este apartado, los delitos de peligro concreto se configuran de forma dual, dado que abarcan tanto el desvalor de acción como el de resultado, por lo cual no prohíben la simple conducta peligrosa, ni la mera realización de resultados, se precisa por tanto que el riesgo se realice en un resultado de peligro que representa un nivel de ataque al bien jurídico menor que el resultado lesivo, aunque mayor al del peligro abstracto, lo que supone que la categoría de delitos de peligro concreto, como ya señalamos antes, es una categoría de delitos de resultado ${ }^{110}$, dado que únicamente cuando

RODRÍGUEZ MONTAÑÉS, Teresa. Delitos de peligro..., op. cit., p. 37.

CARO CORIA, Dino Carlos. Derecho Penal del Ambiente..., op. cit., p. 475.

DOVAL PAIS, Antonio. Delitos de Fraude Alimentario...,op. cit., pp. 338, 339. STS (Roj: 3499/1993) de 29 de mayo de 1993. Ponente: Cándido Conde-Pumpido Ferreiro.

LAURENZO COPELLO, Patricia. El resultado..., op. cit., pp. 27, 28. Méndez Rodríguez es de la opinión que lo importante no es "el hecho de que el peligro aparezca o no entre los elementos del tipo a la hora de configurar un delito de peligro concreto; la nota realmente relevante es que se trate de un resultado de puesta en peligro". MÉNDEZ RODRÍGUEZ, Cristina. Los Delitos de Peligro..., op. cit., pp. 227, 228. DOVAL PAIS. Antonio. Delitos de Fraude Alimentario..., op. cit., pp. 337, 338. MATA Y MARTÍN, Ricardo M. Bienes jurídicos intermedios..., op. cit., p. 53. ACALE Sánchez sostiene que el paso de un delito de peligro abstracto a un delito de peligro concreto (Proyecto de 1980 y Anteproyecto de 1983 donde se decide que un delito de peligro concreto deja de ser de mera actividad) no determina que deje de ser de mera actividad y se convierta en un delito de resultado, pues como admite la doctrina mayoritaria hay delitos de mera actividad y de peligro, de mera actividad y de lesión, de resultado y de 
sea preciso individualizar un verdadero resultado de peligro para un bien jurídico determinado puede calificarse como un delito de peligro concreto.

Es preciso señalar que en los postulados de la imputación objetiva, se acepta de forma unánime que la constatación del desvalor de acción en los delitos de peligro concreto "se concreta en un análisis ex ante anclado precisamente en el momento de la acción", así para determinar si se ha creado un riesgo penalmente relevante únicamente importan las circunstancias cognoscibles por el autor, se trata por lo tanto de las conocidas por este y las que estaba obligado a conocer (según el ámbito específico de la actividad que realiza) en el momento de la acción. Esto en atención a la función motivadora de la norma, ya que para poder acatar el mandato de la norma es presupuesto indispensable que el sujeto se encuentre en capacidad de prever las consecuencias que pueden generar tanto sus acciones como omisiones, por ello el grado de previsibilidad exigible estará en función de lo que el autor efectivamente conozca en el caso concreto al momento de ejecutar la acción típica, pero también con aquello que esté obligado a conocer, jurídicamente, según el ámbito específico de la actividad que realiza ${ }^{111}$. Sin embargo, la imputación objetiva del resultado de peligro debe realizarse desde una perspectiva diferente, pues no se trata ya de investigar si la conducta ha superado el nivel de riesgo permitido, sino de establecer si a consecuencia de esa conducta se ha puesto en crisis el bien jurídico, lo cual implica comprobar si en el caso concreto el desarrollo del riesgo no podría dominarse mediante los medios normales de prevención, por lo que la verificación de este segundo nivel de imputación objetiva no deberá realizarse a través de la perspectiva ex ante, situada en el momento que se realiza la acción peligrosa, sino ex post, que nos permite determinar si el riesgo se ha realizado en un resultado peligroso, lo cual no significa que el juicio ex

peligro y, finalmente de resultado y lesión. ACALE SÁNCHEZ, María. El tipo de injusto..., op. cit., pp. 152- 158.

111 Entendiéndose de que no tendrán por ende trascendencia alguna aquellos datos, hechos o circunstancias que, desde una perspectiva ex ante no fueron cognoscibles por el autor, lo que incluye tanto los conocidos en el momento del resultado peligroso, tras la lesión del bien jurídico o durante el proceso penal, aunque estos guarden relación con el propio autor, las posibles víctimas o el juez. CARO CORIA, Dino Carlos. Derecho Penal del Ambiente..., op. cit., pp. 480- 482. 
post deba extenderse hasta la producción o no de la lesión del bien jurídico, ya que como sabemos, goza de cómoda postura en la doctrina entender que el resultado lesivo no pertenece al núcleo del injusto del resultado de peligro. Por lo tanto en este estudio lo fundamental es establecer si el riesgo creado se materializa en un resultado peligroso, es decir, si el bien jurídico entra en el radio de acción peligrosa, si ello no sucede, entonces quedará negado el peligro. Aun así es necesario recordar que "el peligro para el bien jurídico no se elimina por la no concurrencia del daño"112. Dado que el bien jurídico en los delitos de peligro, tanto cualitativa como cuantitativamente, se encuentra en el mismo estado antes y después del hecho' ${ }^{113}$.

Fiandaca afirma que el mayor defecto de los delitos de peligro concreto radica en "la dificultad de formular una definición del peligro que resulte, al mismo tiempo, científicamente fundamentada y fácilmente utilizable en la praxis aplicativa". Otra de las principales objeciones que efectúa a esta modalidad de tipos delictivos, es la imposibilidad de su utilización para la protección de bienes jurídicos colectivos, proponiendo que estos se refieran exclusivamente a bienes jurídicos individuales, pues en su opinión son los únicos que permiten la individualización material de la lesión y los únicos que pueden ser

112 CARO CORIA, Dino Carlos. Derecho Penal del Ambiente..., op. cit., pp. 482- 484. García Rivas en este sentido asevera que cualquier interrupción del normal discurrir de los acontecimientos impedirá referirse a un resultado de peligro. Sin embargo "la catalogación de la situación como peligrosa exigirá un análisis de los factores que se hallan en ese momento en presencia y que ex ante se puedan considerar impeditivos de la lesión; si dichos factores no se encuentran ex ante y aparecen posteriormente de manera casual, carecerán de relevancia para negar la existencia del peligro", de manera que el peligro para el bien jurídico no se elimina por la "no concurrencia" de la lesión efectiva. GARCÍA RIVAS, Nicolás. Contribución al estudio..., op. cit., p. 45. Cit por CARO CORIA, Dino Carlos. Derecho penal del Ambiente..., op. cit., p. 484.

113 Doval asume que entender el peligro como la amenaza de un daño efectivo posee un sentido claro, situación que no sucede tanto al referirse al peligro como la amenaza de un perturbación del bien jurídico (una perturbación no concretable en la destrucción del bien jurídico en términos puramente materiales), dado que la amenaza de perturbación puede verse ya como una perturbación actual que sufre el bien jurídico tutelado y, por lo tanto, como una lesión del mismo. Si es así, el peligro puede llegar a igualarse conceptualmente con la lesión allí donde el bien jurídico protegido sea inmaterial y por lo tanto no permita ser lesionado en el sentido de materialmente destruido. DOVAL PAIS. Antonio. Delitos de Fraude Alimentario..., op. cit., pp. 261, 262. 
afectados por la acción peligrosa del sujeto. En el mismo sentido se pronuncia también Pedrazzi114.

Como respuesta a la idea anterior es importante destacar que la posibilidad de verificar el peligro depende en gran medida del nivel de concreción del bien jurídico, pues cuanto más delimitado se encuentre este, mayor será la posibilidad de establecer la efectiva puesta en peligro y menores inconvenientes planteará el recurso a los delitos de peligro concreto. Así la respuesta a la interrogante ¿son los bienes jurídicos colectivos entidades susceptibles de ser lesionadas?, en nuestra opinión debe responderse que depende precisamente del nivel de concreción alcanzado en la definición del bien jurídico, de tal manera que la posibilidad de su lesión estará condicionada por el contenido de su definición, por lo tanto cuando se trate de bienes jurídicos concebidos con un carácter muy amplio y por tanto vago, resulta difícil pensar en la posibilidad de su lesión, sin embargo, esta resulta imaginable si se define el bien jurídico colectivo de forma más concreta, lo cual es coherente con el principio de lesividad, con el cual se cumple únicamente si el bien jurídico puede ser afectado verdaderamente. En todo caso queremos manifestar que consideramos que un bien sólo podrá ser puesto en peligro si es posible su lesión, es decir, si "existen estados peligrosos es porque estos pueden desembocar en lesión"115.

Otro aspecto que es necesario abordar, antes de culminar este apartado, es que en los delitos de peligro el contenido del injusto

114 Méndez Rodríguez es de la opinión que emplear la dificultad de individualización de la ofensa para argumentar la incapacidad del peligro concreto, no es correcto, pues el mismo problema se presenta en los delitos de resultado lesivo, dado que la indeterminación del bien jurídico colectivo posiblemente se deba a la dimensión de este o bien o la legitimidad del bien jurídico. MÉNDEZ RODRÍGUEZ, Cristina. Los Delitos de Peligro..., op. cit., pp. 216- 221. En contra del planteamiento realizado por Fiandaca. Vid también MATA Y MARTÍN, Ricardo M. Bienes jurídicos intermedios..., op. cit., pp. 81- 84.

115 MÉNDEZ RODRÍGUEZ, Cristina. Los Delitos de Peligro..., op. cit., p. 236. MATA Y MARTÍN, Ricardo M. Bienes jurídicos intermedios..., op. cit., pp. 81, 82. Al analizar la lesividad propia de los delitos contra bienes jurídicos colectivos, "advertíamos que la lesión no puede confundirse con destrucción, sino que equivale a afectación". CORCOY BIDÁSOLO, Mirentxu. Delitos de Peligro..., op. cit., pp 233- 235. El legislador debe esforzarse en crear tipos suficientemente concretos, sin caer en la técnica legislativa casuística, pudiendo recurrir a la técnica de la Ley penal en blanco. CORCOY BIDÁSOLO, Mirentxu. "Protección de bienes..., op. cit., p. 401. 
expresado en sus dos componentes desvalor de acción y desvalor de resultado, presenta como característica que en ellos se intensifica el desvalor de acción frente al papel del desvalor de resultado en el conjunto del injusto ya que la materia de prohibición de los delitos de peligro se nutre de los momentos precedentes a la lesión del bien jurídico, situación que se acentúa aún más en los delitos de peligro abstracto que estudiaremos a continuación.

\section{LOS DELITOS DE PELIGRO ABSTRACTO}

\section{A.) NOCIÓN SOBRE LOS DELITOS DE PELIGRO ABSTRACTO}

Iniciamos este apartado recordando que en la teoría de las normas propuesta por Binding existen tres tipos de normas: a) las que penalizan una lesión, b) las que criminalizan un peligro que produce una modificación en el mundo jurídico y c) las que prohíben la realización de acciones que podrían causar resultados no deseables, aunque en el caso concreto no las causen. Las conductas comprendidas en este último grupo de normas son punibles desde su perspectiva porque "suponen una amenaza una desobediencia por sí mismas dentro de la cual se esconde la lesión al bien jurídico". Como podemos observar este profesor alemán pese a advertir la posibilidad de que las conductas sancionadas no ocasionaran un peligro efectivo, consideraba, sin embargo, preciso la punición de dichos comportamientos por el principio del mal menor, ya que lo que se castiga es la desobediencia a la autoridad sin exigir ningún otro requisito ${ }^{116}$. Esta tercera categoría de delitos se asocia comúnmente con los denominados delitos de peligro abstracto.

Torío, sin embargo, entiende que Binding niega la existencia de los delitos de peligro abstracto entendidos en el sentido anteriormente señalado, puesto que en su exposición ofrecida en "las normas"117 exige como momento conceptual propio de los delitos de peligro, "la posibilidad de un contacto entre la acción peligrosa y el objeto de

116 MÉNDEZ RODRÍGUEZ, Cristina. Los Delitos de Peligro..., op. cit., pp. 150, 151.

117 BINDING, Karl. Die Normen und ihre Übertretung. I: Norm und Strafgesetzse. Segunda Edición. Leipzig. 1914. Die Normen und ihre Übertretung. II. Segunda edición. Leipzig 1916. 
protección" lo que refleja la necesidad de "la producción del peligro para el bien jurídico protegido", dado que para Binding los delitos de peligro abstracto son delitos de peligro posible, por lo que afirmaba que ante la imposibilidad de contacto entre la acción peligrosa y el objeto protegido la tipicidad queda excluida, lo que también ocurre cuando el sujeto activo ha procedido de forma diligente adoptando medidas que excluyen de antemano la posibilidad del peligro concreto. A diferencia de lo que ocurre con los delitos de desobediencia, ya que en ellos el peligro es a lo sumo el motivo del legislador para incriminar una conducta, por lo que no los entiende conectados a los delitos de peligro $^{118}$.

Una vez realizadas estas breves puntualizaciones sobre la idea del peligro abstracto de Binding, procedemos a señalar que generalmente se dice que por delitos de peligro abstracto debemos entender aquellos en los que el legislador decide su sanción tomando como base la experiencia, la peligrosidad general de determinadas conductas (teoría de la peligrosidad general) para el bien jurídico tutelado, de tal manera que basta con la realización del comportamiento típico para cometer el

118 Como ya señalamos antes el profesor Torío López piensa que la noción de peligro propuesta por Binding ha sido mal entendida, dado que él considera que está es una de las contribuciones más brillantes de la teoría del delito. Puesto que Binding niega la existencia de los delitos de peligro abstracto. Entendiendo por peligro la acción que, según un juicio de probabilidad, en caso de producirse un contacto entre ambos, es idónea para producir una lesión en el bien jurídico protegido" por tanto "la misma acción peligrosa es caracterizable como peligro". Torío opina que aunque esta construcción ha sido criticada por la doctrina, hay que reconocerle que "aunque comprenda en una unidad genérica superior el desvalor de acción- la acción peligrosay el desvalor de resultado- la consecuencia peligrosa- contribuye a una delimitación de la responsabilidad digna de consideración". TORÍO LÓPEZ, Ángel. "Los delitos de peligro hipotético..., op. cit., pp. 828- 842. Para Rodríguez Montañés el esfuerzo de Binding por reconducir todos los delitos de peligro al peligro concreto no resulta satisfactorio, pues al exigir siempre el dolo de poner en peligro quedarían impunes múltiples casos en que, pese a cometerse dolosamente el comportamiento no hay dolo de peligro, lo cual también ocurriría en todos los supuestos de comisión imprudente. RODRÍGUEZ MONTAÑÉS, Teresa. Delitos de peligro..., op. cit., pp. 263, 264. Sobre "los delitos que la doctrina llama de peligro hipotético o posible; en ellos es necesaria, aunque también suficiente la ejecución de una acción peligrosa, idónea para producir un peligro para el bien jurídico protegido y la imposibilidad de la producción del peligro excluye la tipicidad". STS (ROJ: 1046/1985) de 12 de noviembre de 1985. Ponente: MARTÍN Jesús Rodríguez López. MORILLAS CUEVA, Lorenzo (Coord.). Sistema de Derecho Penal Español. Parte Especial. Ed. Dikinson, S. L. Madrid, 2011, 804, 805. 
delito de forma consumada, así el autor, será castigado aun cuando en el caso concreto la acción "no hubiera dado lugar a un auténtico peligro, razón por la cual se afirma que en estos delitos el peligro no constituye un elemento del tipo de injusto, por lo cual se parte de un juicio de probabilidad estadística, en el que no se pronostica un daño concreto, sino una relación estadística entre un cierto tipo de comportamientos y un resultado lesivo ${ }^{119}$. Otra forma de fundamentar los delitos de peligro abstracto es "la teoría de la peligrosidad abstracta". Esta asume que el legislador define en el tipo formas de comportamiento consideradas peligrosas porque poseen las condiciones mínimas suficientes para causar un daño. La relevancia lesiva de estas conductas no se basa en un proceso deductivo sobre la base de la frecuencia con que las mismas producen resultados lesivos, sino inductivos: es decir a partir de unas condiciones mínimas que pueden

119 DEMETRIO CRESPO, Eduardo. Curso de Derecho Penal..., op. cit., pp, 213, 214. CEREZO MIR, José. "Los delitos de peligro...,op. cit., p. 719. DOVAL PAIS. Antonio. Delitos de Fraude Alimentario..., op. cit., pp. 330- 332. GOERNER, Gustavo. "Los delitos de peligro...,op. cit., pp. 560, 564, 565. Como no se exige que realmente se ponga en peligro el bien jurídico, lo que sucede es la introducción de una presunción de peligrosidad (iuris et de iure) que se basa en una consideración estadística. MATA Y MARTíN, Ricardo M. Bienes jurídicos intermedios..., op. cit., p. 53. En Italia el debate sobre la posible inconstitucionalidad de los delitos de peligro abstracto está íntimamente ligado a la consagración legislativa del principio de ofensividad. Así el artículo 49.2 del Código Penal italiano dice: La punibilidad se excluye también cuando, por la falta de idoneidad de la acción o por la inexistencia del objeto de ésta, sea imposible el resultado dañoso o peligroso, este artículo se pone en relación con los artículos 27.3 y 25 de la Constitución de ese país, sin embargo a partir de los años 70 la doctrina empieza a interpretar el principio de ofensividad de forma más elástica, llegando a justificar la doctrina mayoritaria la técnica de los delitos de peligro abstracto, aduciendo que "el requisito realmente necesario para la configuración de un tipo penal es la existencia de un bien jurídico constitucionalmente relevante, pero que de esta necesaria vinculación legislativa no se deriva ninguna indicación precisa sobre la modalidad y los limites de tutela. MÉNDEZ RODRÍGUEZ, Cristina. Los Delitos de Peligro..., pp. 138- 141, 156. NAVARRO CARDOSO, Fernando. "El Derecho Penal..., op. cit., pp. 1334, 1335. Se trata de un juicio de probabilidad estadística, en el que no se pronostica un daño concreto, sino una relación estadística entre determinadas clases de acciones y un resultado lesivo. Esta es la doctrina mayoritaria en Alemania. En tre sus defensores se encuentran: von Wanjek, Rotering, von Buri, A. Merkel, Beling, A. Kohler, von Hippel, R. Schmidt, H. Mayer, Engisch, Welzel, Gallas, Schmidhäuser, Stratenwerth, Schroeder, Blei, Weber, Benfer, Bohnert, Keller Bockelmann/Volk, Platzgummer, Jescheck, Dimitratos, Janiszewski,Dereher/Tröndle, Lackner y Otto. En la doctrina española sin embargo es minoritaria: Cerezo, Bacigalupo y Rodríguez Devesa. RODRÍGUEZ MONTAÑÉS, Teresa. Delitos de peligro..., op. cit. , pp. 238- 240. 
señalarse como causa de eventuales resultados lesivos, se establece que toda conducta que reúna esas condiciones es peligrosa en abstracto. En definitiva se sostiene que todo comportamiento típico posee la relevancia típica, aun en el caso de absoluta ausencia de peligrosidad en concreto, creándose una presunción del peligro iuris et de iure ${ }^{120}$. Por ello, la prevención de peligros concretos y de lesiones a bienes jurídicos constituye únicamente el motivo del legislador, dado que ambas teorías prescinden de toda referencia al peligro en el caso concreto para la creación de estos tipos penales sin que su concurrencia sea requisito del tipo. Se trata como puede apreciarse de delitos de mera actividad ${ }^{121}$, pero sin embargo hay que aclarar que

120 En Alemania es una tesis minoritaria, la siguen; Finger, Frank, Bermer, Miricka, Mezger, Henkel, Bassenge y Maurach entre otros, mientras que en España e Italia ha tenido mayor acogida, en España: Jiménez de Asua, Lorca García, Quintano, Beristain, Rodríguez Morullo, del Rosal, Rodríguez Ramos, Morillas Cueva, Sainz Cantero. RODRÍGUEZ MONTAÑÉS, Teresa. Delitos de peligro..., op. cit., pp. 241- 245. GIL Y GIL, Alicia y otros autores. Curso de Derecho Penal. Parte General. Ed. Dykinson. Madrid. 2011, pp. 188-190.

121 Bockelmann sostiene que los delitos de peligro abstracto son delitos de mera actividad, en los que el dolo requiere sólo la conciencia de que se realiza la actividad que la Ley penal establece, en el mismo sentido Weber afirma que como la producción del peligro no es elemento del tipo, ni el dolo ni la imprudencia tienen que referirse a él. RODRÍGUEZ MONTAÑÉS, Teresa. Delitos de peligro..., op. cit., pp. 246, 247. Sin embargo no debe llegarse a la conclusión contraria, es decir, que todo delito de mera actividad sea un delito de peligro, ejemplo de ello es el allanamiento de morada donde existe un resultado de lesión del bien jurídico. BUSTOS RAMÍREZ, Juan. HORMAZÁBAL MALARÉE, Hernán. Lecciones de Derecho Penal..., op. cit., pp. 246, 247. A partir de los años 70 sé a impuesto en la doctrina europea la equiparación entre delitos de mera actividad y delitos de peligro abstracto. GARCÍA RIVAS, Nicolás. Delito ecológico. Estructura y aplicación judicial. Ed. Praxis: Wolters Kluwer. Barcelona. 1998, p. 53. ACALE Sánchez afirma que los delitos de mera actividad no siempre son de peligro abstracto, citando como ejemplo de ello el artículo 202 del CPE que regula el allanamiento de morada, que es un delito de mera actividad y de resultado. En segundo lugar afirma que los delitos de mera actividad no son delitos formales pues precisan de un bien jurídico que tutelar, en caso contrario lo que cabe es simplemente la despenalización de la conducta para darle cumplimiento al principio de ofensividad. Lo que sí podría afirmarse es que los delitos de mera actividad suelen ser delitos de peligro abstracto o viceversa. ACALE SÁNCHEZ, María. El tipo de injusto..., op. cit., pp. 3$5,16,17,22,23,29-34,215,227$. Stratenwerth señala: "habría delitos de mera peligrosidad y de peligro, de mera actividad y lesión, de resultado y de peligro y, finalmente de resultado y lesión. STRATENWERTH, Günter. Derecho Penal. Parte General. I. El hecho punible. (Traducción de la segunda edición alemana de 1976. 
estos tipos de ilícitos también tienen un resultado122 en los que el peligro es declarado ex ante, teniéndose por conductas peligrosas las descritas en el ilícito respectivo. Se cita comúnmente como ejemplo de estos tipos delictivos el artículo 379 del Código Penal que sanciona la conducción de un vehículo a motor o un ciclomotor bajo la influencia de drogas tóxicas, estupefacientes, sustancias psicotrópicas o de bebidas alcohólicas ${ }^{123}$. También es un delito de peligro abstracto el tráfico de precursores de drogas objeto de este trabajo que está regulado en el artículo 371 del Código Penal, que prohíbe la fabricación, transporte, distribución, comercio o tenencia de equipos, materiales o sustancias enumeradas en el cuadro I y cuadro II de la Convención de Naciones Unidas, realizada en Viena el día 20 de diciembre de 1988, cuando dichas sustancias vayan a destinarse a la elaboración de drogas ilícitas ${ }^{124}$.

ROMERO, Gladis). Ed. EDERSA D.L. Madrid. 1982, p. 79. TERRADILLOS BASOCO, Juan Maria. “Peligro..., op. cit., pp. 796, 797.

123 En este tipo penal es irrelevante que el sujeto activo haya tenido la fortuna de no encontrarse con nadie en el camino de vuelta a casa, y por tanto, no lesionara ni pusiera en peligro a ninguna persona. Aquí lo relevante es que en el momento de la acción no quedara excluida la potencialidad lesiva de su comportamiento, es decir, que el autor no este en situación de conducir con el mínimo de seguridad exigible debido a la ingestión de alcohol o drogas. En el plano subjetivo el dolo y la imprudencia no han de referirse al peligro concreto como resultado de la acción típica, lo que significa que el dolo respecto del peligro abstracto no implica dolo de peligro concreto. RODRÍGUEZ MONTAÑÉS, Teresa. Delitos de peligro..., op. cit., pp. 298, 299. El artículo 379 de Código Penal español es un delito de "peligro de mera actividad", "sin que sea necesaria la producción de un resultado separado en el tiempo". GOMÉZ PAVÓN, Pilar. El delito de conducción bajo la influencia de bebidas alcohólicas, drogas toxicas y estupefacientes. Ed. Bosch. Barcelona. 1998, p. 173. También son delitos de peligro abstracto todos los relativos al tráfico de drogas vid STS (ROJ: 6801/2005), de 7 de noviembre de 2005. Ponente: D. Juan Ramón Berdugo Gómez de la Torre. STS (ROJ: 3967/2005) de 17 de junio de 2005. Ponente: D. Diego Antonio Ramos Gancedo, STS (ROJ: 676/2005) de 7 de febrero de 2005. Ponente: D. Miguel Colmenero Menéndez de Luarca, STS (ROJ: 3843/2004) de 3 de junio de 2004. Ponente: D. Miguel Colmenero Menéndez de Luarca, STS (ROJ: 5254/2003) de 21 de julio de 2003. Ponente: D. Julián Artemio Sánchez Melgar y STS (ROJ: 6197/2004) de 5 de octubre de 2004. Ponente: D. Diego Antonio Ramos Gancedo.

124 En opinión de Cerezo Mir, el delito de tráfico de precursores de drogas es un claro ejemplo de los delitos de peligro abstracto- concreto al igual que los demás tipos delictivos relacionados al tráfico de drogas. Manifestando que el problema de 
Nos parece importante recordar en este momento que el Código Penal Español de 1995 amplió su campo de aplicación, con respecto al Código Penal anterior, a conductas que ya estaban tipificadas como infracciones administrativas de urbanismo, relaciones laborales, medioambiente o consumo. De este modo se incrementó el catálogo de conductas tipificadas simultáneamente como infracciones administrativas y delitos, dando lugar a importantes problemas de delimitación, tanto prácticos como teóricos, por ello se afirma con razón, en este sentido, que el actual Código Penal ha invertido la tendencia despenalizadora observada desde finales de los años setenta, que transformó en infracciones administrativas varios delitos o faltas. Esta expansión penal se debe fundamentalmente a dos elementos: el primero de ellos responde a las propias deficiencias del régimen administrativo sancionador; el segundo elemento está vinculado a la función simbólica que está cumpliendo el Derecho Penal en una sociedad sometida a la influencia de los medios de comunicación, lo cual conlleva a que la penalización de no pocas conductas se realiza, no porque así se vaya a resolver realmente algún problema social, sino porque se aparenta que se va a resolver ${ }^{125}$.

legitimidad de los delitos de peligro abstracto, sólo puede ser resuelto por el legislador, transformando los delitos de peligro abstracto puros en delitos de aptitud para la producción de un daño o de peligro abstracto concreto. Afirmando además que el legislador en el Código Penal de 1995 a seguido esta pauta, transformando los delitos de peligro abstracto contra la salud pública en delitos de aptitud para la producción de un daño o de peligro abstracto-concreto (arts. 359, 360, 363, 364, 365, 369, 370 y 371) e incluso sustituyéndolos, en ocasiones, por delitos de peligro concreto. CEREZO MIR, José. "Los delitos de peligro...,op. cit., pp. 720, 721, 745, 746. Una opinión diferente es la expuesta por Corcoy, quien afirma que el tráfico de precursores de drogas regulado en el artículo 371 no esta legitimado, dado que si la punición de la tentativa de los delitos de peligro abstracto (tráfico de drogas) no esta legitimada, mucho menos pueden estarlo los actos preparatorios, en relación con estos mismos delitos. Por lo cual sostiene que debe de exigirse la comprobación del destino inmediato de las sustancias catalogadas para la elaboración de drogas ilícitas. CORCOY BIDÁSOLO, Mirentxu. Delitos de Peligro..., op. cit., pp 283-286. En el mismo sentido. MENDOZA BUERGO, Blanca. El Derecho Penal..., op. cit., pp. 95- 97.

125 CARBOnEll MATEU, Juan Carlos. "Reflexiones sobre el abuso del Derecho Penal y la banalización de la legalidad” en ARROYO ZAPATERO, Luis A. BERDUGO GÓMEZ DE LA TORRE, Ignacio (Dir). NIETO MARTÍN, Adán. (Coord.). Libro homenaje al Dr. Marino Barbero Santos in memorian. Vol. I. Ed. Universidad de Castilla La Mancha. Universidad de Salamanca. Cuenca. 2001, pp. 137, 138. De igual opinión. JAREBORG, Nils. "Derecho Penal e ideología” en ESER, Albin. HASSEMER, Winfried. BURKHARDT, Björn. 
Jakobs afirma que los delitos de peligro abstracto están formulados como delitos de desobediencia, lo que supone la exigencia al autor de la obediencia de la norma aun cuando esté descartada la puesta en peligro concreto, lo cual en su opinión ocurre en la mayoría de los casos en determinados ámbitos del tráfico rodado. Como ejemplo de ello señala al conductor que conduce un vehículo de noche, con una proporción de alcohol en la sangre del 1,3 por 1.000 centímetros cúbicos en sangre, unos cuantos metros en una carretera secundaria muy apartada, que evidentemente se halla vacía del todo. En este caso pese a la indiscutible falta de peligrosidad, el simple hecho de ejecutar la desobediencia tiene un sentido, pues hay que ejercitar la observancia de la regla ${ }^{126}$. Sin embargo, en sentido contrario, un importante sector de la jurisprudencia en España se decanta por exigir, por lo menos hasta hace poco tiempo, que la ingestión de alcohol o las drogas influya de forma efectiva en la conducción ${ }^{127}$. En la misma

(Coordinadores de la versión alemana). MUÑOZ CONDE, Francisco. (Coordinador de la versión española). La Ciencia del Derecho Penal ante el nuevo milenio. Ed. Tirant lo Blanch. Valencia. 2004, p. 444. QUINTERO OLIVARES, Gonzalo. Parte General..., op. cit. del Derecho Penal. Ed. Thomson-Aranzadi. Navarra. 2005, p. 270. SUAY HERNÁNDEZ, Cecilia. "Los delitos contra la salubridad y seguridad del consumo en el marco de las relaciones entre el Derecho Penal y el Derecho Administrativo sancionador" en PICÓ LOREnZO, Celsa. (Coord.). Las fronteras del Código Penal y el Derecho Administrativo sancionador. Ed. Consejo General del Poder Judicial. Madrid. 1997, pp. 126- 138. TERRADILLOS BASOCO, Juan Maria. “Peligro abstracto..., op. cit., pp. 794-796.

126 JAKOBS, Günther. Derecho Penal. Parte General. Fundamentos y Teoría de la Imputación. (Trad. CUELLO CONTRERAS, Joaquín. SERRANO GONZÁLEZ DE MURILLO, José Luis). Segunda edición. Marcial Pons. Madrid 1997, pp. 210- 214. JAKOBS, Günther. Estudios de Derecho..., op. cit., pp. 308, 309.

127 En este sentido citamos entre otras: STS (ROJ: 6617/1987) de 22 de octubre de 1987. Ponente: D. Fernando Díaz Palos y STS (ROJ: 7902/1987) de 9 de diciembre de 1987. Ponente: D. José Hermenegildo Moyna Menguez: "El elemento nuclear del delito no consiste en la presencia de un determinado grado de impregnación alcohólica en la sangre, sino en la conducción de un vehículo a motor bajo la influencia de bebidas alcohólicas, sin que la prueba quede restringida a determinados medios". STS (ROJ: 8150/1989) del 19 de mayo de 1989. Ponente: D. José Hermenegildo Moyna Mengues y STS: (ROJ: 4052/1989) de 7 de julio de 1989. Ponente: D. Luis Román Puerta Luis: "no basta comprobar el grado de impregnación alcohólica del conductor, sino que es preciso comprobar también su influencia en la conducción". STS (ROJ: 1437/1992) de 24 de febrero de 1992. Ponente: D. Fernando Díaz Palos: exige la efectiva influencia del alcohol y prueba de la misma. STS (ROJ: 2632/2002) de 15 de abril de 2002. Ponente: D. Julián Artemio Sánchez Melgar: "dos son los elementos que caracterizan el tipo delictivo regulado en el art. 379 del Código Penal: uno, objetivo, consistente en el grado 
dirección se pronuncia el Tribunal Constitucional ${ }^{128}$ y la doctrina mayoritaria ${ }^{129}$.

de impregnación alcohólica que padece el sujeto activo, y otro subjetivo que se refiere a la influencia que tal grado de impregnación alcohólica determina en la conducción. Ahora bien, tal influencia no tiene por que exteriorizarse en una flagrante infracción de las normas de tráfico visible e inmediata (delito de peligro concreto), apreciada por el agente actuante, o en la producción de un resultado lesivo, sino basta el delito de peligro \{in abstracto\}, practicándose la correspondiente prueba de detección alcohólica, y apreciándose por lo agentes los signos externos de donde puede deducirse después (mediante prueba indirecta) ese grado de influencia en la conducción". STS (ROJ: 5324/2006) de 15 de septiembre de 2006. Ponente: D. Andrés Martínez Arrieta: "Es un criterio jurisprudencial y forense consolidado, que la diferencia entre el ilícito administrativo y el penal, cuando se trata de conducción bajo ingesta alcohólica, radicaba entre otros aspectos, en el carácter meramente formal de la norma administrativa de superar una determinada ingesta alcohólica mediante las oportunas periciales, en tanto que el ilícito penal supera esa trasgresión formal para exigir la acreditación de un peligro real para la seguridad del tráfico, esto es, la influencia en las facultades psicofísicas necesarias para la conducción poniendo en peligro los bienes jurídicos protegidos en la norma".

128 Vid., STC (145/1985) del 28 de octubre de 1985. Ponente: Dña. Gloria Begué Cantón: "Este delito no consiste en un determinado grado de impregnación alcohólica, sino en la conducción de un vehículo de motor bajo influencia de bebidas alcohólicas". STC (148/1985) de 30 de octubre de 1985. Ponente: Dña. Gloria Begué Cantón: "la influencia de bebidas alcohólicas constituye un elemento normativo del tipo penal que, consecuentemente, requiere una valoración del juez en la que éste deberá comprobar si en el caso concreto de que se trata el conductor se encontraba afectado por el alcohol. STC (22/1988) de 18 de febrero de 1988. D. Fernando García- Mon y González: "requiere no sólo la presencia de determinada concentración alcohólica, como entiende la sentencia recurrida, sino que, además, esa circunstancia influya o se proyecte en la conducción". STC (188/2002) de 14 de octubre de 2002. Dña. María Emilia Casas Baamonde: "el delito no consiste en un determinado grado de impregnación alcohólica, sino en la conducción de un vehículo de motor bajo la influencia de bebidas alcohólicas". STC (200/2004) del 15 de noviembre de 2004. Ponente: D. Eugeni Gay Montalvo: "no basta con comprobar a través de la pertinente prueba de alcoholemia que el conductor a ingerido alcohol o alguna otra de las sustancias mencionadas en el mismo, sino que es necesario que se acredite que dicha ingestión ha afectado a la capacidad psicofísica del conductor y, como consecuencia de ello, a la seguridad del tráfico, que es el bien protegido por dicho delito".

129 BARBERO SANTOS, Marino. "Contribución al estudio..., op. cit., p. 493. CORDOBA RODA, Juan. "Les delits de mis en danger" en Informe nacional presentado al coloquio preparatorio del X congreso internacional de Derecho Penal, RDIP, 1969, p. 374. MÉNDEZ RODRÍGUEZ, Cristina. Los Delitos de Peligro..., op. cit., pp. 136, 137. MUÑOZ CONDE, Francisco y GARCÍA ARÁN, Mercedes. Derecho Penal. Parte General. 6a edición. Tirant lo Blanch. Valencia. 2004, pp. 304, 305. OCTAVIO DE TOLEDO Y UBIETO, Emilio. 
Mata y Martín sobre los delitos de peligro abstracto afirma que en "la mayoría de los casos comprendidos en la descripción típica existe el peligro (pero con la consecuencia de que en el caso concreto puede no estar presente la peligrosidad), sin que quepa revocar la presunción de peligrosidad"130, por lo que comúnmente se afirma, como ya señalamos anteriormente, que la estructura de los delitos de peligro abstracto se corresponde a la de los delitos de mera actividad carentes de un resultado estructural, ya que el tipo se entiende realizado cuando el autor realiza una conducta ex ante peligrosa, sin que sea necesario verificar que esta conducta ha dado lugar a un resultado penalmente relevante. Claro ejemplo de ello es el delito tipificado en el artículo 379 CP (conducción bajo los efectos del alcohol u otras drogas) el cual se considera de mera actividad por lo cual no precisa de un resultado concreto para su consumación ${ }^{131}$. Sin embargo, hay autores que sostie-

HUERTA TOCILDO, Susana. Derecho Penal. Parte General. Segunda edición. Madrid. 1986, p. 165. PÉREZ ALVAREZ, Fernando. Protección penal del Consumidor. Salud Pública y alimentación. Ed. Praxis. Barcelona. 1991, p. 60. QUINTERO OLIVARES, Gonzalo. MORALES PRATS, Fermín. Parte General del Derecho Penal. Ed. ThomsonAranzadi. Navarra. 2005, pp. 272, 273. RODRÍGUEZ MONTAÑÉS, Teresa. Delitos de peligro..., op. cit., pp. 323- 337. TERRADILLOS BASOCO, Juan. Delitos de peligro y criminalidad económica. Ejemplar dactilografiado, p. 40- 43. Cit por MÉNDEZ RODRÍGUEZ, Cristina. Los Delitos de Peligro..., op. cit., pp. 152, 153.

130 MATA Y MARTÍN, Ricardo M. Bienes jurídicos intermedios..., op. cit., p. 53. CEREZO MIR, José. “Los delitos de peligro...,op. cit., pp. 736, 737. La necesidad de los tipos de peligro abstracto para la protección de los bienes jurídicos individuales de mayor valor en los ámbitos específicos de riesgo característicos de la sociedad moderna tendría que estar fuera de toda duda. GRACIA MARTÍN, Luis. "Contribución al esclarecimiento de los fundamentos de legitimidad de la protección penal de los bienes jurídicos colectivos por el Estado Social y Democrático de Derecho" en HORMAZÁBAL MALARÉE (Coord.). Estudios de Derecho Penal en memoria del Profesor Juan José Bustos Ramírez. Ed. Ubijus. México DF. 2011, pp. 166, 167.

131 MATA Y MARTÍN, Ricardo M. Bienes jurídicos intermedios..., op. cit., pp. 54, 55. BARBERO SANTOS, Marino. "Contribución al estudio..., op. cit., p. 489. Se cita a manera de ejemplo el delito de conducción en estado de ebriedad o bajo los efectos de otras drogas (artículo 379 del código penal español), señalando que la simple interpretación de la norma nos conduciría a entender que la mera conducción de un coche bajo la influencia de drogas es suficiente para establecer la tipicidad, sin embargo si tomamos en consideración los criterios de imputación objetiva, concluiremos que aunque no es preciso la existencia de un resultado lesivo o de peligro, tampoco basta con la simple infracción formal del tipo. De modo que es necesario establecer la peligrosidad de la acción, así quedarán fuera de la esfera de acción penal todas aquellas conductas que ex ante resulten inidoneas para poner en peligro algún bien jurídico, tal es el caso de la 
nen que las objeciones que se pueden formular en la actualidad a los delitos de peligro abstracto ya no deberían consistir en señalar la ausencia de peligrosidad de la acción, en el entendido de la creación de un riesgo penalmente relevante, sino en la falta de un resultado peligroso que revele la lesividad de la conducta prohibida.

Sobre la naturaleza del peligro de los delitos relativos al tráfico de drogas Conde-Pumpido Ferreiro señala que el peligro abstracto, al que se hace referencia en estos tipos de delito, no debe de confundirse con el peligro presunto, de forma que cualquier acción que cumpla objetivamente la hipótesis legal se entienda ya, per se, sin admisión de prueba o estimación en contrario, integradora del delito pues tal tipo de presunción vulneraría el derecho constitucional a la presunción de inocencia. En su opinión peligro abstracto sólo quiere decir que en el momento de la consumación anticipada, con que el legislador ha configurado el tipo, no están concretados o determinados los sujetos portadores del bien jurídico protegido, cuya salud va a ser puesta en peligro o afectada por el agotamiento de la acción. Pero lo que sí es preciso es que tal peligro, como riesgo de futura lesión de aquel bien jurídico, se encuentre realmente presente en la acción para que ésta incluya en sí el contenido de la antijuricidad material y la adecuación al tipo necesarios para su ilicitud penal (STS del 29 de mayo de 1993) ${ }^{132}$.

conducción bajo influencia de drogas en un lugar completamente deshabitado. CARO CORIA, Dino Carlos. Derecho Penal del Ambiente..., op. cit., p. 469, 492. Ostendorf sostiene que los delitos de peligro abstracto "son delitos puros de mera actividad, que se distinguen por la peligrosidad general para un tipo de bien jurídico, que es causada a través de acciones. MÉNDEZ RODRÍGUEZ, Cristina. Los Delitos de Peligro..., op. cit., pp. $65,133,134$. Realiza un análisis sobre la necesidad o no de seguir manteniendo la categoría de los delitos de mera actividad. ACALE SÁNCHEZ, María. El tipo de injusto..., op. cit., pp. 319-321. No debe de confundirse la clasificación que distingue entre delitos de lesión y de peligro con aquella otra que distingue entre delitos de lesión y de mera actividad. ORTS BERENGUER, Enrique. GONZALEZ CUSSAC, José L. Compendio de Derecho Penal. (Parte General y Parte Especial). Ed. Tirant lo Blanch. Valencia. 2004, p. 159. Plantea serios reparos a aceptar sin más los delitos con bien jurídico intermedio espiritualizado. MENDOZA BUERGO, Blanca. Límites dogmáticos..., op. cit., pp. 52- 55.

132 CONDE-PUMPIDO FERREIRO, Cándido. Código Penal Comentado. 3a Ed. Bosch. Barcelona. 2012, p. 1300. STS (Roj: 3499/1993) de 29 de mayo de 1993. Ponente: Cándido Conde-Pumpido Ferreiro. (Tráfico de drogas y naturaleza de los delitos de peligro abstracto). Sobre el tráfico de precursores de drogas como delito de peligro abstracto ver: STS (Roj: 1748/2009) de 18 de marzo de 2009. Ponente: Carlos Granados Pérez. SAN (Roj: 4326/2002) de 9 de julio de 2002. Ponente: Raimunda de 
Cerezo sobre este tema afirma que los delitos de peligro abstracto no plantean ningún problema desde el punto de vista del principio de legalidad, pues en este sentido resultan más satisfactorios que los delitos imprudentes de resultado ${ }^{133}$. No obstante son varios los reparos desde la perspectiva del Derecho Penal clásico que se le plantean a esta categoría: entre ellas podemos señalar que la exclusión del resultado del núcleo del injusto se encuentra en contradicción con el principio de protección del bien jurídico o de lesividad, proporcionalidad y ultima ratio, principios que sólo se garantizan si se concibe como necesario un resultado de peligro; también se le objeta ciertas contradicciones con el principio de culpabilidad ${ }^{134}$. Pérez Álvarez afirma que los delitos de peligro abstracto al contener una presunción ipso iure relativa a la producción del peligro, presunción que no admite prueba en contrario, vulnera la presunción de inocencia consagrada en el artículo 24 párrafo segundo de la Constitución Española135.

Tal vez el ejemplo más característico de delito de peligro abstracto puro puede observarse en el artículo 384 del CPE que íntegra y literalmente dice: "El que condujere un vehículo a motor o ciclomotor en los casos de pérdida de vigencia del permiso o licencia por pérdida

Peñafort Lorente Martínez. SAP de Madrid (Roj: 1659/2003) de 10 de febrero de 2003. Ponente: Adrián Varillas Gómez.

133 CEREZO MIR, José. “Los delitos de peligro...,op. cit., pp. 720, 721, 745, 746. Caro Coria asume que atendiendo las tendencias actuales ya no es correcto cuestionar la legitimidad de los delitos de peligro abstracto desde la consideración de que en ellos se criminaliza la mera desobediencia o únicamente un desvalor de conciencia, para tal afirmación se basa en la formulación propuesta por el profesor Torío López de "negar la tipicidad cuando en el caso concreto se comprueba que, dada una conducta, el peligro para el bien jurídico quedo excluido de antemano". Así este autor deja sentado que se distancia de las "criticas radicales" que en la doctrina alemana realizan los seguidores de la escuela de Frankfurt contra estos tipos delictivos. CARO CORIA, Dino Carlos. Derecho Penal del Ambiente..., op. cit., , pp. 501- 503.

134 MÉNDEZ RODRÍGUEZ, Cristina. Los Delitos de Peligro y sus Técnicas de Tipificación. Ed. Universidad Complutense. Madrid. 1993, pp. 89- 94. CARO CORIA, Dino Carlos. Derecho Penal del Ambiente..., op. cit., pp. 469, 470. MENDOZA BUERGO, Blanca. Límites dogmáticos..., op. cit., pp. 340- 361. MUÑOZ CONDE, Francisco y GARCÍA ARÁN, Mercedes. Derecho Penal. Parte General. 6a edición. Tirant lo Blanch. Valencia. 2004, pp. 304, 305. SÁNCHEZ GARCÍA DE PAZ, María Isabel. El moderno Derecho..., op. cit., pp. 39- 42. 
total de los puntos asignados legalmente, será castigado con la pena de prisión de tres a seis meses o con la de multa de doce a veinticuatro meses y trabajos en beneficio de la comunidad de treinta y uno a noventa días. Las mismas penas se impondrán al que realizare la conducción tras haber sido privado cautelar o definitivamente del permiso o licencia por decisión judicial, y al que condujere un vehículo de motor o ciclomotor sin haber obtenido nunca permiso o licencia de conducción"136. Como vemos en este caso, se trata de un delito de peligro abstracto basado en la ausencia o infracción de una autorización o control administrativo, que en nuestra opinión debería cumplir con la exigencia que plantea que el núcleo de la acción punible consista en algo más que una infracción de normas administrativas, pues de no ser así se diluye notablemente el instituto de la pena ${ }^{137 .}$

Siempre sobre el tema de los delitos de peligro abstracto Schröder señala que resulta impensable la construcción del Derecho de circulación exclusivamente mediante la técnica de los delitos de peligro concreto, pues tal intento estaría abocado al fracaso porque las dificultades de prueba pondrían en duda su practicabilidad138. Roxin también refrenda esta idea al expresar que donde "una conducta peligrosa prohibida está claramente descrita y si es claramente visible su referencia al bien jurídico y tampoco se vulnera el principio de culpabilidad, entonces son inobjetables incluso los delitos de peligro abstracto", citando como ejemplo de ello el artículo 316 del Código Penal alemán que sanciona la conducción de vehículos a motor bajo influencia de bebidas alcohólicas ${ }^{139}$.

136 BOE núm. 288. Sábado 1 de diciembre de 2007. Ley orgánica 15/ 2007, de 30 de noviembre, por la que se modifica la Ley orgánica 10/1995, de 23 de noviembre, del Código Penal en materia de seguridad vial.

137 MENDOZA BUERGO, Blanca. Límites dogmáticos..., op. cit., pp. 340- 361. MUÑOZ CONDE, Francisco y GARCÍA ARÁN, Mercedes. Derecho Penal. Parte General. 6ª edición. Tirant lo Blanch. Valencia. 2004, pp. 58-61, 487- 490.

"No se puede dudar que el legislador esté legitimado para imponer una pena a aquellas acciones que supongan un peligro típico para intereses protegidos jurídicamente". SCHRÖDER. Die Gefährdungsdelikte im Srafrecht. ZStW. 1969, p 16, en igual sentido se pronuncia Horn. Konkrete Gefährdungsdelikte, Köln, 1973, p. 93, cit por MÉNDEZ RODRÍGUEZ, Cristina. Los Delitos de Peligro..., op. cit., pp. 141, 155, 156. 
En lo que respecta a la jurisprudencia española, sobre los delitos de peligro abstracto hay que decir que tradicionalmente se han considerado como ilícitos meramente formales ${ }^{140}$, aunque poco a poco se ha venido imponiendo con mejor criterio, el requerimiento de una cierta aptitud de los comportamientos para dar lugar a la lesión del bien jurídico tutelado ${ }^{141}$ así se afirma que en los delitos de peligro

tráfico viario e inclusive propone que algunos tipos penales, seguridad e higiene en el trabajo, que están regulados en el Código Penal español como delito de peligro concreto se configuren como delitos de peligro abstracto. CORCOY BIDÁSOLO, Mirentxu. Delitos de Peligro..., op. cit., pp. 226- 228. En contra de la automatización y el estricto cumplimiento de las normas en materia de tráfico. RODRÍGUEZ MONTAÑÉS, Teresa. Delitos de peligro..., op. cit., pp. 323- 337. En la misma dirección. ACALE SÁNCHEZ, María. El tipo de injusto..., op. cit., pp. 207- 210. En el mismo sentido CARO CORIA, Dino Carlos. Derecho Penal del Ambiente..., op. cit., p. 469.

140 "El delito contra la salud pública del artículo 344 del Código Penal, en cuanto a su naturaleza, es un delito de peligro, de carácter formal, en el que la conducta y su resultado se identifican porque éste se integra por el simple riesgo de que ocurra el mal por la realización de la actividad, lo que implica la imposibilidad de toda ejecución imperfecta". STS (ROJ: 4296/1980) de 19 de diciembre de 1980. Ponente: D. Mariano Gómez de Liaño Cobaleda. En el mismo sentido STS (ROJ: 5086/1981) de 2 de octubre de 1981. Ponente D. Mariano Gómez de Liaño Cobaleda, STS (ROJ: 1615/1983) de 20 de enero de 1983. Ponente: D. Mariano Gómez de Liaño Cobaleda, STS (ROJ: 1007/1984) de 24 de mayo de 1984. Ponente: D. Mariano Gómez de Liaño Cobaleda, STS (ROJ: 1111/1985) de 18 de marzo de 1985. Ponente: D. Benjamín Gil Sáez. La antijuricidad formal no es más que la oposición entre un hecho y el ordenamiento jurídico positivo, juicio que se constata en el modo expuesto. QUINTERO OLIVARES, Gonzalo. Parte General del Derecho Penal. Cuarta edición. Aranzadi/Thomson Rehuters. Navarra. 2010, pp. 282, 283.

141 En función del bien jurídico protegido ha de catalogarse como de peligro abstracto, lo que presupone tanto una coincidencia formal entre la acción y la descripción típica, lo que conlleva la exigencia de comprobación de que la conducta era potencialmente idónea para la creación de un riesgo para el bien jurídico protegido, que en el supuesto típico no es otro que la salud pública, y cuya aprehensión supone un análisis meticuloso en cada caso concreto, poniendo en función las connotaciones de la conducta, la clase de droga y demás circunstancias concomitantes que puedan poner en evidencia la realidad de que la conducta es capaz de provocar el peligro potencial o abstracto a la salud pública, con la obligada consecuencia de que sí la acción no era idónea la punibilidad quedaba excluida. STS (ROJ: 278/1985) del 20 de febrero de 1985. Ponente: D. Juan Latour Brotons. STS (ROJ: 6801/2005) de 7 de noviembre de 2005. Ponente: Juan Ramón Berdugo Gómez de la Torre. STS (ROJ: 6197/2004) de 5 de octubre de 2004. Ponente: Diego Antonio Ramos Gancedo. En estos delitos de peligro abstracto se requiere que el bien objeto de protección haya corrido un peligro real. STS (ROJ: 1985/1993) de 25 de marzo de 1993. Ponente D. Cándido Conde-Pumpido Ferreiro. "El peligro abstracto no debe de ser confundido con el peligro presunto...", lo 
abstracto, dicho peligro, como riesgo de futura lesión al bien jurídico, debe contenerse en la acción, quedando excluidos aquellos comportamientos totalmente inadecuados para lesionar o poner en peligro, aún de forma potencial, que en el caso de los delitos relativos al tráfico de drogas es la salud pública. Como lo que se sanciona es la puesta en peligro de un bien jurídico, deben quedar excluidas de la punición aquellas conductas en las que, aun cuando aparentemente se realice la conducta típica, por las especiales o excepcionales circunstancias que concurren en el caso concreto, puede excluirse totalmente la generación de riesgo alguno para el bien jurídico tutelado ${ }^{142}$. Sobre esta cuestión la doctrina mayoritaria exige la presencia de una auténtica aptitud lesiva de la acción de estos delitos, que se materialice en que la conducta posea la idoneidad objetiva para lesionar un bien jurídico ${ }^{143}$. Nos parece necesario destacar en este

que vulneraria la presunción de inocencia, que "peligro abstracto solo quiere decir que en el momento de la consumación anticipada... no están concretados o determinados los sujetos portadores del bien tutelado, cuya salud va a ser puesta en peligro o afectada por el agotamiento de la acción. Pero lo que sí es preciso es que tal peligro, como riesgo de futura lesión de aquel bien jurídico, se encuentre realmente presente en la acción". STS (ROJ: 3499/1993) de 29 de mayo de 1993. Ponente: D. Cándido Conde-Pumpido Ferreiro.

142 STS (ROJ: 4708/2003) de 4 de julio de 2003. Ponente: D. Cándido Conde-Pumpido Tourón.

143 Entre estos BACIGALUPO, Enrique. "Problemas dogmáticos del delito de tráfico ilegal de drogas". La problemática de la droga en España (análisis y propuestas políticocriminales). Ed. Edersa. Madrid. 1986, p. 100 y ss. BERDUGO GÓMEZ DE LA TORRE, Ignacio y otros. Curso de Derecho Penal. Parte General. Ed. Experiencia. Barcelona. 2004, p. 210. CORCOY BIDÁSOLO, Mirentxu. "Protección de bienes..., op. cit., p. 392. ESCRIVÁ GREGORI, J. M. La puesta en peligro de bienes jurídicos en el Derecho Penal. Ed. Bosch. Barcelona. 1976, p. 18 y ss. MAQUEDA ABREU, M‥ L. "La idea del peligro en el moderno Derecho Penal. Algunas reflexiones a propósito del Proyecto de Código Penal de 1992" en Actualidad Penal, № 26. 1994, pp. 481 y ss. MIR PUIG, Santiago. Derecho Penal. Parte general. 9a edición. REPPERTOR. Barcelona. 2011, pp. 239-241. MÉNDEZ RODRÍGUEZ, Cristina. Los Delitos de Peligro y sus Técnicas de Tipificación. Ed. Universidad Complutense. Madrid. 1993, pp. 43 y ss. QUINTERO OLIVARES, Gonzalo. Parte General del Derecho..., op. cit., pp. 284-291. RODRÍGUEZ MONTAÑÉS, Teresa. Delitos de peligro..., op. cit., pp, 298 y ss. TORÍO LÓPEZ, Ángel. "Los delitos de peligro hipotético..., op cit., pp. 827, 828 y 838. DOVAL PAIS. Antonio. Delitos de Fraude Alimentario..., op. cit., pp. 339- 341. SUAY HERNÁNDEZ, Cecilia. "Los delitos contra la salubridad..., op. ci., pp. 168, 169. En la doctrina alemana; JESCHECK, Hans-Heinrich. Tratado de Derecho Penal. Parte General. (Trad. MANZANARES SAMANIEGO, José Luis). 
momento que la discusión que se ha generado en este sentido, lamentablemente, aún no ha conducido a conclusiones reconocidas de forma general, sin embargo, se puede afirmar que existe un consenso importante sobre la necesidad de distinguir distintos grupos de casos con problemas configurados de forma diferente ${ }^{144}$.

1. Esfuerzos doctrinales por dotar de legitimidad a los delitos de peligro abstracto

Queremos señalar que dada la imposibilidad de dotar de un resultado estructural a estos delitos, se gesta una nueva línea de investigación centrada en el desvalor de la acción precisamente, en la peligrosidad de la acción como elemento característico de los delitos de peligro abstracto, resultando que lo principal a efectos del injusto es que la acción típica, valorada ex ante exprese la peligrosidad que fundamenta su criminalización y en la que radica su referencia al bien jurídico. Volz en esta dirección nos propone como criterio rector del injusto y la culpabilidad de estos delitos el principio de "asunción del riesgo", con el cual el sujeto activo asume con su comportamiento generalmente peligroso una posible lesión al bien jurídico. Dado que es la manifiesta lesividad de la conducta y no su peligrosidad en concreto, la cual puede depender de la casualidad o de otros factores, la que fundamentan los delitos de peligro abstracto. Argumentando este autor que como en estos delitos "la asunción del riesgo" representa el contenido del injusto, la exclusión del riesgo ha de excluir el injusto. En opinión de Rodríguez Montañés el principal acierto de esta teoría, pese a que la solución propuesta en su opinión no resulta satisfactoria, es que busca

Cuarta edición. Comares. Granada. 1993, pp. 238, 239. HIRSCH, Hans Joachim. "Peligro y peligrosidad"...,op. cit., pp. 83, 84 .

144 Roxin distingue cuatro grupos de peligro abstracto: A) Los clásicos delitos de peligro abstracto ("un peligro de resultado sin necesidad de un resultado de peligro"). B) Acciones masivas (sobre todo en el tráfico viario) El caso clásico de este grupo es la conducción bajo la influencia de bebidas alcohólicas u otras drogas. En estos grupos de casos por razones preventivas generales Roxin opina que se debe de sancionar dichas conductas aunque estuviera excluida totalmente una puesta en peligro. C) Delitos con bien jurídico intermedio espiritualizado (no es preciso que en el caso concreto sean puestos en peligro por una acción subsumible en los tipos respectivos. Y sin embargo ello no puede cambiar para nada la punición). D) Delitos de aptitud abstracta (abstracto concreto). ROXIN, Claus. Derecho Penal. P. G..., op. cit., pp. 407- 411. 
la fundamentación del peligro abstracto en su relación con el bien jurídico no en el resultado, de lesión o de peligro, sino en la acción ${ }^{145}$.

Rudolphi tomando como punto de partida la tesis de Volz, señala que la limitación del ámbito de aplicación de estos delitos mediante una reducción teleológica, dotándolos de un contenido de injusto material en forma de desvalor de acción, debe realizarse a través de la exigencia de "al menos imprudencia" en relación con el hecho desvalorado, postura que posteriormente desarrollará Horn fundamentando la punibilidad de estos ilícitos en "la infracción del cuidado objetivo", en relación a la lesión o el concreto peligro del bien jurídico tutelado. Este profesor llega a esta conclusión porque para él, se trata de "modalidades de delitos imprudentes" que se diferencian de los propios delitos imprudentes únicamente en que no requieren del resultado lesivo; en la misma dirección Brehm sostiene que los delitos de peligro abstracto son tentativas de delitos imprudentes de lesión que se diferencian de los delitos imprudentes, propiamente dichos, solamente en los presupuestos de responsabilidad, afirmando que la antijuricidad en estos delitos exige, además de la realización de la descripción típica, de la infracción del deber de conducta, lo cual implica que la acción ex ante debe ser apta para lesionar el bien jurídico, y que de no ser así se estarían castigando comportamientos meramente formales. Esta interpretación de la antijuricidad se traduce también en la culpabilidad, pues ha de comprobarse que al autor se le podía reprochar la infracción del deber conforme a sus facultades individuales ${ }^{146}$.

145 A la tesis defendida por Volz se le critica que su definición de "asunción del riesgo" no especifica claramente ni su contenido ni su alcance, con lo cual no se avanza en la solución del problema, sin embargo, sus planteamientos tienen el mérito de centrar el debate en el desvalor de acción y destacar el paralelismo de estos delitos con el delito imprudente. RODRÍGUEZ MONTAÑÉS, Teresa. Delitos de peligro..., op. cit., pp. 276- 281. MIR PUIG, Santiago. Derecho Penal. Parte General. 7ạ edición. Reppertor. S. L. Barcelona. 2005, pp. 231- 233. Reivindicando el papel fundamental que juega el resultado de peligro en la legitimación de la anticipación de la tutela penal. MÉNDEZ RODRÍGUEZ, Cristina. Los Delitos de Peligro..., op. cit., p. 124. PAZ Y PAZ BAILEY, Claudia. Tesis Doctoral. La protección penal de los pueblos. Especial consideración del delito de genocidio. Salamanca. 2005, pp. 296- 298. SÁNCHEZ GARCÍA DE PAZ, Isabel. "La criminalización en el ámbito..., op. cit., pp. 693-697.

Esta tesis no puede aplicársele a todos los delitos de peligro abstracto, sino sólo a aquellos que pueden ser orientados al bien jurídico y castigan acciones que no se 
Para Meyer los delitos de peligro abstracto no son delitos de puesta en peligro, sino delitos de peligrosidad, ya que desde su perspectiva todo el desvalor radica en la peligrosidad como elemento de la acción típica, y en este desvalor de la peligrosidad se encuentra la relación negativa con el bien jurídico que justifica su incriminación a partir de la idea de tutela de bienes jurídicos como fin de toda norma penal. Esta peligrosidad de la acción consiste en un juicio sobre su capacidad lesiva, el cual debe realizarse ex ante, tomando como base fáctica todas las circunstancias presentes en el momento de la acción, incluyendo los posibles conocimientos superiores que pudiera tener el autor, constituyendo su base nomológica tanto las leyes de la naturaleza como las leyes de probabilidad estadística conocidas en el momento de la acción de las que pueda concluirse que la acción puede fundamentar la posibilidad de lesión de un bien jurídico, dado que en su formulación el "desvalor de la peligrosidad" es el núcleo de la estructura del injusto de los delitos de peligro abstracto, este plantea la necesidad de una imputación subjetiva de la misma, así el sujeto activo debe haber conocido o haber podido conocer el desvalor de la peligrosidad, señalando en consecuencia que tanto en los delitos dolosos como en los imprudentes basta la imputación a título de imprudencia de la peligrosidad de la acción, incluso en los delitos denominados dolosos 147 .

diferencian de las acciones lesivas. Es preciso señalar que a favor de la tesis de la imprudencia en ciertos grupos de delitos se encuentran; Schünemann, Hoyer, Roxin, Jakobs y Silva Sánchez. RODRÍGUEZ MONTAÑÉS, Teresa. Delitos de peligro..., op. cit., pp. 281- 285. El profesor Jakobs, desde una perspectiva eminentemente funcionalista, para determinar hasta donde es correcta la legitimación de la anticipación penal señala la regla generalmente reconocida de que no es legítimo hacer responder a un sujeto de sus meros pensamientos. Afirmando que sin un comportamiento externo perturbador no se puede hacer responder a un sujeto de lo que le es interno, abarcando lo interno el entero ámbito privado, no únicamente los pensamientos. Sin embargo este autor opina que la Ley puede reducir del ámbito de lo privado lo que le corresponde a un comportamiento abstractamente peligroso, pero esto tiene que suceder sin tomar en cuenta el contexto de planificación del sujeto. JAKOBS, Günther. Estudios de Derecho JAKOBS, Günther. Derecho Penal pp. 309- 313.

147 Esta tesis ha sido acogida en la doctrina española por: Escrivá Gregori, Torío López, Gómez Pavón y Laurenzo Copello entre otros. Para Rodríguez Montañés se produce con la propuesta de Meyer una transformación contra legem de todos los delitos de peligro abstracto en delitos de aptitud, cuando la voluntad de la ley ha sido exigir sólo en ciertos tipos la expresa verificación de su aptitud lesiva ex ante RODRÍGUEZ 
Torío López señala que la teoría convencional caracteriza estos tipos penales de forma negativa introduciendo, en esta especie de "cajón de sastre", todos los delitos que no son de lesión ni de peligro concreto, que tampoco precisan de un ataque efectivo al bien jurídico, dado que la producción del peligro es sólo el motivo del legislador para sancionar penalmente dichos comportamientos ${ }^{148}$, debido a esto, se les cuestiona a éstos tipos penales el estar reñidos con el principio de lesividad, y de estricta protección de bienes jurídicos ${ }^{149}$. Ante esta situación diversos sectores de la doctrina tradicional, por la ausencia de un bien jurídico, han propuesto su desaparición (in dubio pro libertate), optando por la despenalización de tales conductas ${ }^{150}$, sin embargo el profesor Torío discrepa de tal planteamiento, pues entiende que debe de realizarse una distinción de las diferentes especies de delitos de peligro abstracto, proponiendo la siguiente:

1. Los delitos consistentes en la violación de reglas ético sociales o ético-religiosas.

2. Los delitos de peligro abstracto identificables como delitos de desobediencia, delitos de policía o injustos administrativos sometidos a pena criminal.

3. Los delitos de peligro abstracto que él define como delitos peligro hipotético, en los que el tipo penal no exige la producción de un peligro efectivo "pero sí una acción apta para producir un peligro al bien jurídico como elemento material integrante del tipo de

MONTAÑÉS, Teresa. Delitos de peligro..., op. cit., pp. 293- 297. Ver objeciones a los planteamientos de Meyer en CARO CORIA, Dino Carlos. Derecho Penal del Ambiente..., op. cit., pp. 496- 498.

TORÍO LÓPEZ, Ángel. "Los delitos de peligro hipotético..., op. cit., p. 827. Cristina Méndez afirma que los delitos de peligro abstracto se ha convertido en un concepto residual, "apto para todo lo que no sea lesión o peligro concreto para un bien jurídico", sosteniendo además que los delitos de peligro abstracto están condicionados por las fluctuaciones que se producen ya sean en sentido negativo o positivo los delitos de peligro concreto, lo cual se produce por la falta de consenso doctrinal en este sentido. MÉNDEZ RODRÍGUEZ, Cristina. Los Delitos de Peligro..., op. cit., p. 132.

Ibidem., p. 153.

150 TORÍO LÓPEZ, Ángel. “Los delitos de peligro hipotético..., op. cit., pp. 825, 826. 
delito", se trata por lo tanto de la posibilidad y no de la realidad, del peligro para el bien jurídico tutelado ${ }^{151}$.

Concluye este autor que únicamente es partidario de prescindir en la legislación penal de los dos primeros grupos, pues entiende que la idea de eliminar los denominados delitos de peligro hipotético carece de fundamento, ya que considera que estos tipos no se encuentran en contradicción con los principios rectores que legitiman al Derecho Penal, señalando que lo decisivo en los delitos de peligro, y por ende en los delitos de peligro abstracto, lo constituye "la valoración del caso

151 En los delitos de peligro hipotético "es necesaria, aunque también suficiente, la ejecución de una acción peligrosa, idónea para producir un peligro para el bien jurídico protegido". Este autor entiende que están comprendidos dentro de los delitos de peligro hipotético el abandono de niños, el cohecho activo, el falso testimonio, la amenaza simple, y algunos delitos contra la salud pública. Ibidem., pp. 827, 828, 838. En el mismo sentido. TERRADILLOS BASOCO, Juan Maria. "Peligro abstracto..., op. cit., pp. 792, 801-803. En el mismo sentido. LAURENZO COPELLO, Patricia. El resultado..., op. cit., pp. 179-181. SEQUEROS SAZATORNIL, Fernando. El tráfico de drogas ante el ordenamiento jurídico. Ed. La Ley. Madrid. 2000, p. 291. En la misma línea. STS (ROJ: 4708/2003) de 4 de julio de 2003. Ponente: D. Cándido Conde- Pumpido Tourón. STS (ROJ: 1046/1985) de 12 de noviembre de 1985. Ponente: D. Martín Jesús Rodríguez López, STS (ROJ: 1985/1993) de 25 de marzo de 1993. Ponente: D. Cándido CondePumpido Ferreiro y STS (ROJ: 1046/1985). Ponente: D. Martín Jesús Rodríguez López. En estos tipos delictivos es mucho mayor la gravedad del desvalor de acción. Para que la acción tenga relevancia penal es preciso que, desde un punto de vista ex ante, aparezca como no absolutamente improbable que de ella se derive la lesión del bien jurídico, en estos tipos penales el dolo deberá comprender consecuentemente no sólo la conciencia y voluntad de realización de la acción, sino también de su peligrosidad. CEREZO MIR, José. "Los delitos de peligro...,op. cit., p. 737. La doctrina suele citar la obra de Schröder como punto de partida en la configuración dogmática de la categoría conocida como delitos de peligro hipotético, que este profesor alemán denominaba delitos de peligro abstracto-concreto, a estos tipos penales también se les llama delitos de peligro posible o potencial, los que se caracterizan desde el punto de vista objetivo por requerir un comportamiento idóneo para producir la lesión del bien jurídico, hay que aclarar que se trata de la posibilidad y no de la realidad del peligro para el objeto de tutela. Son delitos de acción positiva que requieren establecer si la conducta reúne las condiciones materiales para determinar un menoscabo al bien jurídico. GÓMEZ TOMILLO, Manuel. "Contribución a la teoría de los delitos de peligro hipotético-aptitud abstracta. Los delitos de tenencia como paradigma de los delitos de peligro abstracto puro" en CARBONELL MATEU, Juan Carlos. DEL ROSAL BLASCO, Bernardo. MORILLAS CUEVA, Lorenzo. ORTS BERENGUER, Enrique. QUINTANAR DIEZ, Manuel (Coordinadores). Estudios penales en homenaje al profesor Cobo del Rosal. Ed. Dykinson. Madrid. 2005, pp. 465- 467. PERIS RIERA, Jaime M. "Delitos de peligro..., op. cit., pp. 703, 704. 
individual"152, constituyendo el elemento decisivo de los denominados delitos de peligro hipotético "la posibilidad del peligro" que se deduce de la realización de una acción que en relación al bien jurídico, es idónea para producirlo153.

Muestra alguna reserva a la propuesta de Torío López la profesora Méndez Rodríguez, en el entendido de que su planteamiento consiste en extender la teoría del fin de la norma y de la adecuación típica, elaborada para los tipos de resultados a todos los tipos, asumiendo no obstante que el intento de restricción que se intenta realizar es muy importante salvo en un punto: estos expedientes dogmáticos han cumplido una función clave porque han supuesto una limitación de la responsabilidad en casos en los que ya se había causado un resultado, situación que no sucede en los ilícitos propuestos, por lo que no cree que sean utilizables los criterios de la imputación objetiva a supuestos

152 TORÍO LÓPEZ, Ángel. "Los delitos de peligro hipotético..., op. cit., pp. 828, 846. Un ejemplo de peligro hipotético o bien de peligro abstracto-concreto es el supuesto de la publicidad engañosa regulado en el artículo 282 del Código Penal. MATA Y MARTíN, Ricardo M. Bienes jurídicos intermedios..., op. cit., pp. 50, 51. STS (ROJ: 1046/1985) de 12 de noviembre de 1985. Ponente: MARTÍN Jesús Rodríguez López. DEMETRIO CRESPO, Eduardo. Curso de Derecho Penal..., op. cit., pp, 213, 214.

153 En esta dirección se pronuncia también Rodríguez Montañés. RODRÍGUEZ MONTAÑÉS, Teresa. Delitos de peligro..., op. cit., p. 291. MENDOZA BUERGO, Blanca. Límites dogmáticos..., op. cit., pp. 38-52, 409- 420. PORTILLA CONTRERAS, Guillermo. "La supuesta crisis..., op. cit., pp. 918- 920. Los delitos de acción peligrosa (o de peligro abstracto-concreto y otras denominaciones alternativas), constituyen un buen instrumento político-criminal, siempre que no se recurra a ellos en exceso, para la intervención de Derecho Penal en relación con ciertas actividades vinculadas con la denominada "Sociedad de riesgo". ROMEO CASABONA, Carlos María. "La peligrosidad y el peligro en la estructura del tipo del delito imprudente". DIEZ RIPOLLES, José Luis. ROMEO CASABONA, Carlos María. GRACIA MARTÍN, Luis. HIGUERA GUIMERÁ, Juan Felipe. (Editores). La Ciencia del Derecho Penal ante el nuevo siglo. Libro homenaje al Prof. Dr. José Cerezo Mir. Ed. Tecnos. Madrid, 2002, pp. 961, 962. El profesor Romeo Casabona divide los delitos de peligro abstracto en delitos de acción peligrosa (delitos de peligro abstracto- concreto y definiciones similares) y delitos de peligrosidad (delitos de peligro abstracto propios), ambos casos considera que han quedado equiparados en su contenido desde la entrada en vigor del Código Penal de 1995, por lo cual siempre ha de verificarse la peligrosidad de la acción para considerar la relevancia pp. 77, 78. Dando argumentos sobre la peligrosidad de la conducta como mínimo de gravedad exigible para sancionar penalmente. SOLA RECHE, Esteban. "La peligrosidad de la conducta como fundamento del injusto penal" en Anuario de Derecho Penal y Ciencias Penales. 1994, 175- 177, 184, 185. Vid. STS (ROJ: 1046/1985) de 12 de noviembre de 1985. Ponente: MARTíN Jesús Rodríguez López. 
en los que se les niega la existencia material de un resultado ${ }^{154}$. Sin embargo reconociendo la labor de Torío afirma que esta propuesta es un serio intento de limitación de la responsabilidad ya que propone la descriminalización de los demás supuestos de peligro abstracto consistentes en violaciones éticas e injustos administrativos, procurando evitar de esta manera que bajo esta forma de tutela anticipada se engloben acciones que ni tan siquiera son peligrosas para el bien jurídico, y además trata de adecuar los delitos de peligro hipotético a las elaboraciones dogmáticas más recientes que han supuesto la superación de la doctrina finalista, por lo que esta construcción en su opinión adquiere el valor de constituirse en la única referente a los delitos de peligro abstracto ${ }^{155}$.

154 A favor de aplicar el primer nivel de los criterios de imputación objetiva en los delitos de peligro abstracto. MENDOZA BUERGO, Blanca. Límites dogmáticos..., op. cit., pp. 439454.

155 No le parece suficiente la exigencia de un desvalor potencial de resultado, sosteniendo que la peligrosidad de la acción y la afección a un bien jurídico no son lo mismo y que el principio de ofensividad requiere que el bien jurídico sea realmente afectado. Sin embargo pone de relieve que ni siquiera en los delitos de peligro concreto se exige la realización efectiva de un resultado de peligro, lo cual se resuelve con "la relevante probabilidad de lesión del bien jurídico". MÉNDEZ RODRÍGUEZ, Cristina. Los Delitos de Peligro..., op. cit., pp. 135-138, 153, 182- 186. "La idea de "desvalor potencial de resultado" carece de identidad propia, en el sentido de que no constituye una categoría intermedia entre el resultado de peligro y la acción peligrosa sino que se identifica con está última, por lo que constituye un mero recurso lingüístico que materialmente no aporta nada, salvo confusión, a la dogmática de los delitos de peligro". CARO CORIA, Dino Carlos. Derecho Penal del Ambiente..., op. cit., pp. 470, 471. La conversión de los delitos de peligro abstracto en delitos de peligro hipotético o presunto infringe el principio de lesividad o antijuricidad material e impide diferenciar entre infracciones administrativas y penales. CORCOY BIDÁSOLO, Mirentxu. "Protección de bienes..., op. cit., pp. 382- 386. Señala sin estar en contra de esta propuesta, algunos problemas de carácter operativo que presentan los denominados delitos de peligro hipotético. MENDOZA BUERG0, Blanca. Límites dogmáticos..., op. cit., pp. 419, 420. Muestra su desacuerdo a las teorías que partiendo de las estructuras de los delitos de peligro abstracto ven en el desvalor de resultado la idea de "potencialidad de resultado", porque desmaterializa de alguna forma el bien jurídico y se convierten sólo en proposiciones teóricas imposibles de demostración en el caso concreto. BARRIENTOS PÉREZ, Deisy Janeth. "Lesividad en los bienes jurídicos colectivos y delitos de peligro. Análisis del delito de fabricación, tráfico, porte o tenencia de armas de fuego, accesorios, partes o municiones" en Revista Nuevo Foro Penal. Vol. 11. № 84, enerojunio. 2015, pp. 104, 114. 
Queremos recalcar que debe entenderse que lo hipotético de los delitos de peligro hipotético (similar a los delitos de peligro abstractoconcreto o delitos de aptitud para producir un daño), valga la redundancia, consiste en que "el delito requiere una acción que por sus propiedades materiales sea susceptible de ser considerada según un juicio de pronóstico como peligrosa para el objeto de protección; el juez debe además verificar si en la situación concreta ha sido posible un contacto entre acción y bien jurídico, en cuya virtud hubiera podido producirse un peligro efectivo para éste". Ha de plantear, pues, la hipótesis de si la acción comprobadamente peligrosa hubiera podido determinar un resultado peligroso, siendo preciso por lo tanto acreditar la peligrosidad de la acción (desvalor real de la acción) y la posibilidad del resultado peligroso (desvalor potencial de resultado) como exigencias del tipo, lo que dota a estos ilícitos de una legitimidad político-criminal bastante consistente. Lo cual no ocurre con los delitos de peligro abstracto puros que consisten en violaciones ético-sociales o que básicamente son injustos administrativos o contravenciones al orden de la comunidad, que deberían ser objeto de descriminalización ${ }^{156}$. En este sentido Jescheck afirma que "la ausencia de toda posibilidad de puesta en concreta peligro puede servir, sin embargo, para prescindir de la punibilidad si la concurrencia del peligro para los

TORÍO LOPEZ, Ángel. "Los delitos de peligro hipotético..., op. cit., pp. 846, 847. Sobre los delitos de peligro hipotético o delitos de peligro abstracto-concreto. Los delitos de peligro hipotético se corresponden con los delitos de peligro abstracto- concreto propuestos por Schröder o los de aptitud para producir un daño propuestos por Escrivá Gregori. Estos ilícitos penales en opinión de Cerezo son delitos de peligro abstracto. CEREZO MIR, José. "Los delitos de peligro...,op. cit., p. 720, 745, 746. Los delitos de peligro hipotético se corresponden con "los delitos de aptitud para la producción de un daño" propuestos por Escrivá Gregori, sin embargo este consideraba estos ilícitos delitos de peligro concreto. ESCRIVÁ GREGORI, J. M. La puesta en peligro de bienes jurídicos en el Derecho Penal. Barcelona. Ed. Bosch. 1976, pp. 31- 32. FARALDO CABANA, Patricia. Los delitos societarios. Aspectos dogmáticos y jurisprudenciales. Ed. Tirant lo Blanch. Valencia. 2000, p. 82. LAURENZO COPELLO, Patricia. El resultado..., op. cit., pp. 177- 181. MAQUEDA ABREU, Maria Luisa. "La idea del peligro en el moderno Derecho Penal. Algunas reflexiones a propósito del proyecto de Código Penal de 1992" en Actualidad Penal. № 26. 1994, pp, 481- 488. MARTÍNEZ- BUJÁN PÉREZ, Carlos. Derecho penal Económico. Parte General. Ed. Tirant lo Blanch. Valencia. 1998, p. 110. MATA Y MARTÍN, Ricardo M. Bienes jurídicos intermedios..., op. cit., p. 54. DEMETRIO CRESPO, Eduardo. Curso de Derecho Penal..., op. cit., pp. 213, 214. 
objetos de protección conforme al tipo resulta excluida de modo absoluto" 157 .

Señala Laurenzo Copello que esta interpretación de los delitos de peligro abstracto como delitos sin resultado estructural pero con "un desvalor potencial de resultado", permite su integración a un Derecho Penal orientado a la exclusiva protección de bienes jurídicos, lo cual presupone que nos encontremos en presencia de delitos en los que es posible identificar el objeto de tutela, esto es, ilícitos en los que quepa realmente hablar de un adelantamiento de la barrera punitiva respecto a un bien jurídico determinado. De no ser así como sucede con cierta regularidad por tratarse de un delito en el que no es posible identificar con precisión el objeto de protección de la misma, entonces estaremos no únicamente frente a un ilícito sin resultado sino también, ante un comportamiento punible sin referencia alguna al desvalor de resultado, por lo tanto delitos de mera desobediencia carentes de toda legitimidad ${ }^{158}$.

Queremos poner de relieve la idea que sostiene Mir Puig de realizar un paralelismo entre la tentativa inidónea y los delitos de peligro abstracto (en todo caso peligro hipotético o posible) para establecer la fundamentación de su punición. Desde una perspectiva objetiva afirma que la tentativa inidónea es peligrosa ex ante en la medida en que para el espectador objetivo situado en el lugar del autor, hubiera podido no

157 JESCHECK, Hans-Heinrich. Tratado de Derecho Penal. Parte General. (Trad. MANZANARES SAMANIEGO, José Luis). Cuarta edición. Comares. Granada. 1993, pp. 209-212, 238, 239. "la aparición de un injusto penal requiere que desvalor de acción y desvalor de resultado se vinculen recíprocamente". LAURENZO COPELLO, Patricia. El resultado..., op. cit., pp. 180, 181. DEMETRIO CRESPO, Eduardo. Curso de Derecho Penal..., op. cit., pp. 198-200.

158 El resultado como efecto separable de la acción tiene un papel importante en los delitos de peligro, pues a partir de este elemento se pueden diferenciar los delitos de peligro concreto y de peligro abstracto, dado que la característica esencial de los primeros consiste en la exigencia típica de la efectiva producción de un peligro para un objeto determinado, mientras que la consumación de los segundos no depende de un objeto concreto en el radio de la acción peligrosa, pero al exigir un "desvalor potencial de resultado" el contenido del injusto de los delitos de peligro abstracto, si bien no es igual al de los delitos de lesión y peligro concreto, "tampoco escaparía a la perspectiva dualista de lo ilícito penal", pues aunque no exigen un resultado estructural si presuponen una cierta vinculación con el bien jurídico tutelado. LAURENZO COPELLO, Patricia. El resultado..., op. cit., pp. 27, 28, 180-183. 
concurrir en ella la inidoneidad y producirse por su virtud el delito, señalando que la apariencia de idoneidad implica la realidad de la peligrosidad estadística del hecho, lo que le lleva a concluir que se trata por ello de un peligro abstracto a diferencia del peligro concreto que concurre en la tentativa idónea, señalando que se trata de un peligro abstracto en el que basta la peligrosidad típica de la conducta, peligrosidad que se considera inherente a la acción salvo que se pruebe que en el caso concreto quedó excluida de antemano, de ahí que, en la conducción bajo la influencia de bebidas alcohólicas o estupefacientes, no sea necesaria la presencia de la víctima (tentativa inidónea por falta de objeto) ${ }^{159}$.

En la doctrina italiana cabe mencionar "la técnica de los tipos cargados" que es un intento de dotar a los delitos de peligro abstracto de una carga suficientemente ofensiva, lo cual se produce una vez que la opinión sobre la ilegitimidad de estos ilícitos fue descendiendo hasta ser minoritaria todo en aras de eliminar la aparente contradicción con el principio de ofensividad. En esta línea se ubican los trabajos de Angioni y Canestrati quienes concluyen que los elementos descriptivos usados por el legislador para delinear el tipo son tan densos de significado que parece difícil realizar una hipótesis de un hecho típico que no sea al mismo tiempo concretamente peligroso o lesivo para el bien tutelado. Estos autores se basan en la caracterización de estos ilícitos de su carga semántica: "quien causa un desastre ferroviario", "quien causa una epidemia mediante la difusión de gérmenes patógenos", afirmando que poniendo el acento en el dato lexical se asegura la tipicidad únicamente a los hechos ofensivos del interés protegido, salvando de esta manera el principio de ofensividad, sin que sea precisa la conversión de los delitos de peligro abstracto en delitos de peligro concreto, porque "el desvalor intrínseco en el dato expresaría necesariamente la sucesiva puesta en peligro del interés protegido". Se les objeta a estos juristas que la diferencia entre los delitos de peligro abstracto clásicos y los ejemplos aportados por ellos, en los que se individualizan situaciones generalmente peligrosas, no parece tan grande como para justificar su empleo e incluso promover 
su generalización, pues en ambos casos se presume que ese resultado es generalmente peligroso para el bien jurídico ${ }^{160}$.

Nos parece oportuno en este momento destacar la aportación que en este sentido realiza el profesor Hirsch, quien sostiene que la deficiente distinción del peligro en que se halla el bien jurídico y la acción o conducta peligrosa, obedece en gran medida a que en las conclusiones obtenidas de la discusión sobre el concepto de "peligro" y de los "delitos de peligro" no han sido suficientemente analizadas sistemática ni terminológicamente estabilizadas, siendo solo fraccionariamente abordadas sus consecuencias en las distintas obras que tratan el tema, objetando en este sentido que aún se sigue hablando de delitos de peligro abstracto y concreto, lo que conlleva a que se crea que se trata de un único e idéntico concepto como punto de partida para todo el entorno, y que simplemente el peligro se tiene que realizar en unos casos de forma concreta y en otros de forma abstracta ${ }^{161 .}$

Hirsch afirma que la diferencia fundamental se da entre los delitos de peligro (delitos de peligro concreto) y de peligrosidad (delitos de riesgo), dado que "peligro" significa algo transitivo, esto es, la creación de peligro para un bien, por lo cual únicamente los delitos de peligro concreto son verdaderos delitos de peligro; mientras que los delitos de peligrosidad (de riesgo) se caracterizan no por tener un "resultado de peligro", sino la peligrosidad de la conducta, siendo precisamente ésta la distinción entre lo concreto y lo abstracto. De esta forma los delitos de peligrosidad se subdividen en; 1 ) peligrosidad concreta cuando se requiere una peligrosidad real (concreta) y 2) peligrosidad abstracta cuando basta con una peligrosidad general (típica). Los denominados delitos de peligro abstracto por ello son considerados delitos de peligrosidad abstracta, porque no es el resultado de peligro sino la peligrosidad de una conducta el contenido de la abstracción ${ }^{162}$. Sobre las reservas expresadas en referencia a los delitos de peligrosidad

160 MÉNDEZ RODRÍGUEZ, Cristina. Los Delitos de Peligro..., op. cit., pp. 175.

161 HIRSCH, Hans Joachim. "Peligro y peligrosidad”...,op. cit., p. 71. Ya en el año 1961 Welzel, en su obra Imprudencia y Delitos de tráfico, se ocupa de identificar la diferencia entre peligrosidad de una conducta y el peligro como un estado de un bien jurídico. Idem, p. 81. 
abstracta por varios autores, Hirsch señala que se decanta por exigir "una peligrosidad concreta de la conducta" por ser la opción más ajustada a derecho tanto penal como procesalmente ${ }^{163}$.

Al respecto Von Hirsch y Wohlers nos proponen la siguiente clasificación: 1) Delitos preparatorios que consisten en conductas cuyo potencial de riesgo radica en que la propia persona que actuó u otra pueden apoyarse en el resultado de la conducta previa en cuestión. Se trata como vemos de comportamientos en principio inocuos que pueden servir de base para conductas lesivas de bienes jurídicos, como por ejemplo la posesión de armas o de sustancias peligrosas hasta que estas se utilizan por otras personas. 2) Los delitos acumulativos que aglutinan comportamientos que sólo pueden producir menoscabos con relevancia jurídica si se producen de forma acumulada y 3) Delitos de peligrosidad concreta: con los que se sancionan conductas potencialmente peligrosas para los bienes jurídicos en cuanto tales como la conducción de vehículos en el tráfico viario cuando se ha consumido alcohol. Para determinar la relevancia penal de los diferentes grupos de delitos proponen una serie de criterios como: el principio de responsabilidad personal, la irrelevancia de la previsibilidad o imprevisibilidad conectada, la implicación normativa, la coordinación de conductas mediante estándares de conductas vinculantes o el merecimiento de pena de comportamientos potencialmente peligrosos ${ }^{164}$.

163 Ibidem., pp. 83, 84. Cerezo en los delitos de peligro abstracto diferencia aquellos que protegen bienes jurídicos colectivos de los que protegen bienes jurídicos supraindividuales (bienes jurídicos colectivos autónomos) como los delitos contra la administración pública y delitos contra la administración de justicia, y los bienes jurídicos colectivos (bienes jurídicos con un carácter intermedio) como delitos contra la seguridad del tráfico viario y delitos contra la salud pública, que son delitos donde se lesiona el bien jurídico colectivo y se pone en peligro un bien jurídico individual. CEREZO MIR, José. “Los delitos de peligro...,op. cit., p. 746.

164 VON HIRSCH, Andrew. WHOLLERS, Wolfgang. "Teoría del bien jurídico y estructura del delito. Sobre los criterios de una imputación justa". (Trad. SPÍNOLA TÁRTALO, Beatriz) en HEFENDEHL, Roland (Ed.). La teoría del bien jurídico. ¿Fundamento de legitimación del Derecho Penal o juego de abalorios dogmático?. Ed. Marcial Pons, ediciones jurídicas y sociales, S.A. Madrid. Barcelona. 2007, pp. 288- 308. De acuerdo con la clasificación propuesta por estos autores. SEELMANN, Kurt. "El concepto de bien jurídico, el harm principle y el modelo de reconocimiento como criterios de merecimiento de pena" en HEFENDEHL, Roland (Ed.). La teoría del bien jurídico. ¿Fundamento de legitimación del 
Kurt Ralp en su obra Der Gefährdungsvorsatz del año 1933 afirma que en el Derecho Penal únicamente pueden existir tipos penales que representen un ataque material frente a intereses jurídicamente protegidos, lo que implica la exigencia en todo caso de un resultado de lesión o de peligro. Sostiene que este resultado debe producirse realmente para que se dé el tipo penal, por lo que "en todos los delitos de peligro ha de constatarse en el proceso la peligrosidad de la conducta del autor para imponer la pena", entendiendo de esta manera que en los delitos de peligro abstracto, el peligro concreto es un elemento típico no escrito que se presume por el legislador, presunción que sin embargo debe de ser comprobada en el proceso, señalando que el dolo de peligro en estos ilícitos consiste en que el autor "conozca que actúa de forma peligrosa para bienes jurídicos ajenos". Comentamos que esta formulación es criticada por adolecer de una falta de congruencia entre la parte objetiva y subjetiva del tipo al requerir en todo caso peligro concreto como elemento del tipo objetivo y conformarse con que el dolo sólo se refiera a la peligrosidad de la acción ${ }^{165}$.

Schröder planteó la existencia de un grupo de delitos de peligro mixto, denominado delito de peligro abstracto-concreto que consisten en aquellos casos en el que el peligro aparece como un elemento del tipo, pero en los que resulta dudoso que el peligro tenga exactamente el mismo significado que en los delitos de peligro concreto. En estos supuestos él intérprete sólo deberá comprobar la aptitud peligrosa de la conducta, sin entrar a determinar la medida del peligro o el ámbito de las circunstancias a las que ha de atender para su estimación, como la limitación de los criterios para la comprobación del peligro en el caso concreto que impide considerar el peligro como un resultado y, por lo tanto tratar estos delitos como de peligro concreto. Estos ilícitos también son conocidos como delitos de aptitud ${ }^{166}$. Sostiene este profesor alemán que en ciertos casos la suposición jurídica no es irrefutable, y que es tarea del juez efectuar la verificación de la

Derecho Penal o juego de abalorios dogmático?. Ed. Marcial Pons, ediciones jurídicas y sociales, S.A. Madrid. Barcelona. 2007, pp. 380, 381.

RALB, Kurt O. Der Gefärhdungsvorsatz. Strafrechtliche Abhandlungen, Tomo 312, Alfred Kurtze, Breslau- Neukirch. 1933. p. 20. Cit por RODRÍGUEZ MONTAÑÉS, Teresa. Delitos de peligro..., op. cit., pp. 267, 268, 27, 271. 
peligrosidad en el caso individual, y por lo tanto no se debe aplicar el tipo cuando se pueda constatar que el hecho no ha conducido a ningún peligro imaginable para la vida de las personas ${ }^{167}$. Para determinar en qué delitos debe realizarse la comprobación señala como pauta la siguiente: si el delito de peligro abstracto sirve a la protección de un cierto objeto determinado, respecto del que se puede afirmar con seguridad en el caso concreto sí ha sido puesto en peligro o no, es admisible la prueba en contrario (por ejemplo en los delitos de incendio, que protegen la vida). Cuando esto no sea así, sino que el peligro legalmente previsto sea indeterminado (y pone como ejemplos, la infracción de preceptos de tráfico o la tenencia ilícita de armas o sustancias explosivas...) no es admisible ${ }^{168}$.

En la doctrina española se pronuncian sobre la necesidad de comprobar la idoneidad de la acción en los delitos de peligro abstracto Barbero Santos ${ }^{169}$ y Terradillos Basoco ${ }^{170}$. Nos parece adecuado

167 SCHRÖDER, Horst. Die Gefährdungsdelikte im Srafrecht. ZStW. 1969, pp. 16- 22. Idem. "Abstrakt-Konkrete Gefährdungsdelikte". JZ.1967, pp. 522- 525. Cit por MÉNDEZ RODRÍGUEZ, Cristina. Los Delitos de Peligro..., op. cit., p. 137. En el mismo sentido. BARBERO SANTOS, Marino. "Contribución al estudio..., op. cit., p. 495. A favor de esta postura. SUAY HERNÁNDEZ, Cecilia. "Los delitos contra la salubridad..., op. cit., pp. 143146.

168 RODRÍGUEZ MONTAÑÉS, Teresa. Delitos de peligro..., op. cit., pp. 268-269. Caro Coria opina que los delitos de peligro abstracto-concreto, como sostiene la doctrina mayoritaria, son delitos de peligro abstracto, señalando que esta categoría propuesta por Schröder merece la misma crítica que los delitos de peligro hipotético, pues no debe erigirse el ilícito penal sólo en función del desvalor de acción sino también en el de resultado. CARO CORIA, Dino Carlos. Derecho Penal del Ambiente..., op. cit., pp. 471473.

169 BARBERo SANTOS, Marino. “Contribución al estudio..., op. cit., p. 493. En el mismo sentido. SUAY HERNÁNDEZ, Cecilia. "Los delitos contra la salubridad..., op. cit., pp. 143$145,168,169$. En el caso del reciente Código Penal de Nicaragua, aprobado en mayo de 2008, resulta obligada la constatación del peligro, dado que en el artículo 7 relativo al principio de ofensividad se establece que: "solo podrá ser sancionada la conducta que dañe o ponga en peligro de manera significativa un bien jurídico tutelado por la Ley penal". En igual dirección el Código Penal del Salvador en su artículo 3 relativo al principio de lesividad del bien jurídico preceptúa que: "no podrá imponerse pena o medida de seguridad alguna, si la acción u omisión no lesiona o pone en peligro efectivo un bien jurídico protegido por la Ley penal".

170 A favor de la presunción iuris tantum. TERRADILLOS BASOCO, Juan Maria. "Peligro abstracto..., op. cit., pp. 791- 794. TERRADILLOS BASOCO, Juan. Delitos de peligro..., op. cit., p. 43. Cit por MÉNDEZ RODRÍGUEZ, Cristina. Los Delitos de Peligro..., op. cit., pp. 
recordar que la clasificación realizada por Schröder no está exenta de cuestionamientos: la primera de ellas es que los delitos de peligro abstracto-concreto no representan un compendio de las características generales de ambas categorías, sino una especie de híbrido que reúne parte de las notas que definen a los dos tipos básicos. Otro señalamiento que se le hace es que no resulta nada claro las razones que le llevan a comparar y a analizar ilícitos en los que el peligro no es mencionado por el legislador, con otros en los que sí se menciona, así como que muchos de los supuestos propuestos por este profesor no son en realidad delitos de peligro abstracto-concreto, no obstante, de los diferentes señalamientos que se le hacen a la categoría propuesta por Schröder, hay que reconocer la importante contribución de este trabajo para el estudio de los delitos de peligro ${ }^{171 .}$

Gallas tomando como punto de partida el trabajo de Schröder pone en evidencia las contradicciones que se perciben entre la construcción de las categorías de peligro abstracto y concreto respecto del tipo mixto que el legislador elabora en algunos supuestos. Admite que los delitos de peligro abstracto-concreto no parecen encontrar correspondencia con ninguna de las definiciones clásicas, sin embargo sostiene que el hecho de que el legislador deje en manos del juez la verificación de la peligrosidad de la acción en el caso concreto, no los convierte en delitos de peligro concreto, ni tampoco en un tipo mixto de delitos de peligro abstracto-concreto, sino que los considera una segunda variante de los delitos de peligro abstracto, porque le resulta indiferente que sea el juez o el legislador el que decida si la acción en cuestión representa una fuente de peligro típica, pues en ambos casos

152, 152. Méndez Rodríguez opina que procurar resolver la inconsistencia de los delitos de peligro abstracto mediante la exigencia de la prueba del peligro es un intento condenado al fracaso. Idem. pp. 168-171. En el mismo sentido. CARO CORIA, Dino Carlos. Derecho Penal del Ambiente..., op. cit., pp. 490, 491.

171 Señala Méndez Rodríguez que las características esenciales sobre los delitos de peligro abstracto-concreto en las construcciones de Schröder y Gallas son las mismas, excepto en la clasificación de esta tipología ya que para Schröder se trata de delitos de peligro concreto y para Gallas de delitos de peligro abstracto, esta discrepancia se debe, fundamentalmente, al hecho que en los delitos de peligro concreto en la construcción de Gallas se exige un resultado de peligro efectivo, mientras que Schröder mantiene, también, en estos supuestos, el juicio ex ante constituido por la prognosis sobre la probabilidad de un ulterior resultado de lesión. MÉNDEZ RODRÍGUEZ, Cristina. Los Delitos de Peligro..., op. cit., pp. 188- 184, 203. 
se trata de un juicio sobre la probabilidad de una lesión que toma como base la experiencia general para establecer si con la realización de esa conducta "la probabilidad de lesión a un bien jurídico de un determinado tipo se ha incrementado de forma apreciable". A la postura sostenida por Gallas se le cuestiona que no parece acertado afirmar que estos ilícitos sean delitos de peligro abstracto en sentido estricto, dado que se produce la verificación judicial del peligro que comporta la acción, lo cual tradicionalmente se les ha negado a estos ilícitos, produciéndose de este modo una aproximación de estos últimos a los delitos de peligro concreto. Situación que lo lleva a referirse a la presencia en estos tipos de un "desvalor potencial de resultado" o de un "desvalor de puesta en peligro potencial" similar al exigido de los delitos de peligro hipotético propuesto por Torío López en la doctrina española ${ }^{172}$.

Cerezo entiende que los delitos de peligro abstracto protegen dos tipos de bienes jurídicos colectivos: el primer grupo para él está conformado por los bienes jurídicos colectivos (bienes jurídicos intermedios), en los cuales está en primera línea un bien jurídico colectivo que es afectado o lesionado por la conducta descrita en el tipo y en un segundo orden se encuentra un bien jurídico individual (mediatamente protegido), como ejemplo de estos cita los delitos contra la seguridad del tráfico viario o contra la salud pública. El segundo grupo se encuentra integrado por los "bienes jurídicos supraindividuales" que tienen un carácter autónomo, tal es el caso de los delitos contra la Administración Pública o contra la Administración de Justicia. Para solventar los problemas de legitimidad de los delitos de peligro abstracto, propone reforzar el contenido de injusto material de los mismos, lo que en su opinión se puede lograr si el legislador transforma los delitos de peligro abstracto puros en delitos de aptitud para la producción de un daño o de peligro abstracto-concreto, afirmando que el legislador en el Código Penal de 1995 ha seguido este camino, transformando los delitos de peligro abstracto contra la salud pública en delitos de aptitud para la producción de un daño o de peligro abstracto-concreto en los artículos 359, 360, 363, 364, 365, 368

172 GALLAS, Wilhelm. "Abstrakte und Konkrete Gefährdung". Festschrift für Ernst Heinitz. Berlin. 1972, pp. 173- 183. Cit por MÉNDEZ RODRÍGUEZ, Cristina. Los Delitos de Peligro..., op. cit., pp. 200- 207. 
y 371. Como se puede apreciar Cerezo sostiene que la criminalización del tráfico de precursores de drogas está legitimada por ser un delito de peligro abstracto de aptitud ${ }^{173}$. Sin embargo, es preciso puntualizar que este profesor sólo acepta dicha transformación cuando se tutelan bienes jurídicos colectivos, pues en el caso de los que él denomina bienes jurídicos supraindividuales entiende que debe ser punible la simple realización de acciones "que generalmente ponen en peligro al bien jurídico, es decir la simple realización del comportamiento descrito en el tipo, señalando como ejemplo el delito de cohecho o de falso testimonio, ya que en tales casos el sujeto no puede enjuiciar cuando la dádiva o promesa, en el delito de cohecho, pone en peligro la confianza de los ciudadanos en la pureza de la gestión administrativa, ni cuando el falso testimonio crea el peligro de que se dicten sentencias injustas ${ }^{174}$.

En opinión de Mata y Martín la protección de bienes jurídicos de carácter intermedio o de referente individual, donde se tutela un bien jurídico colectivo asociado a otro individual, produce la transformación de un delito de peligro abstracto en un delito de peligro concreto al exigirse la puesta en peligro del bien de carácter personal y la lesión del bien jurídico colectivo, pues el comportamiento debe concentrarse en un momento más próximo a los bienes de los particulares que la que pudiera representar el peligro abstracto. Ejemplo de ello es en su opinión la reforma operada en el supuesto de expedición de medicamentos deteriorados (artículo 361) en el Código Penal. Pues en el anterior texto legal (artículo 343, CP 1973) no se requería ningún peligro para las personas, bastando el mero hecho de facilitar medicamentos deteriorados o su sustitución de unos por otros para que el comportamiento punible estuviera presente, por lo que debía entenderse que estábamos frente a un delito de peligro abstracto, pero en el actual artículo $361 \mathrm{CP}$ se ha introducido la necesidad de que los que realicen el comportamiento "pongan en peligro la vida o la salud de las personas", por lo que la puesta en peligro exigida en el tipo

173 CEREZO MIR, José. “Los delitos de peligro..., op. cit., pp. 745, 746.

174 CEREZO MIR, José. "Los delitos de peligro...,op. cit., p. 746. Los delitos contra la Administración Pública y la Administración de justicia tutelan bienes jurídicos supraindividuales y son delitos acumulativos sobre los que nadie cuestiona su punibilidad. CORCOY BIDÁSOLO, Mirentxu. “Protección de bienes..., op. cit., pp. 376, 377. 
convierten al supuesto en un delito de peligro concreto ${ }^{175}$. En contra de tal planteamiento se manifiestan algunos autores que entienden que asumir tal posición niega la autonomía de los bienes jurídicos colectivos $^{176}$.

A diferencia de lo sostenido anteriormente por Mata y Martín, Doval Pais asume que la protección de los bienes jurídicos colectivos de referente individual (bienes jurídicos intermedios) se realiza a través de los delitos de peligro, y esto se hace, muchas veces mediante la técnica de peligro abstracto, negando de esta manera que la tutela de estos bienes siempre deba de realizarse mediante delitos de peligro concreto ${ }^{177}$. Carlos Coria afirma que el concepto de "bien jurídico intermedio" sostenido por Mata y Martín es similar al de bienes jurídicos colectivos orientados a la protección de bienes jurídicos individuales o suficientemente determinables, se trata por tanto de bienes colectivos tutelados de forma conjunta con bienes de los particulares, estando situados ambos en la misma línea de ataque. Entre los que se produce una relación de complementariedad, esta tesis no coincide con la construcción de Schünemann "delitos con bien

175 MATA y MARTÍN, Ricardo M. Bienes jurídicos intermedios..., op. cit., pp. 80- 82. QUINTERO OLIVARES, Gonzalo (Dir.). MORALES PRATS, Fermín (Coord.). Comentarios a la Parte Especial del Derecho Penal. Tomo II. Ed. Aranzadi-Thomson Reuters. Navarra. 2011, pp. 877-882.

176 En contra del planteamiento de Mata y Martín, Caro Coria afirma que no es correcto asumir una reconversión de los delitos de peligro abstracto que afecten a bienes jurídicos individuales en delitos de lesión contra un bien jurídico colectivo. CARO CORIA, Dino Carlos. Derecho Penal del Ambiente..., op. cit., p. 510, 513. En el mismo sentido se pronuncia Soto Navarro, afirmando que la interpretación de Mata y Martín niega la autonomía de los bienes jurídicos colectivos, además señala que la construcción propuesta por este profesor de los bienes jurídicos intermedios induce a confusión, pues no guarda relación con la tesis de los bienes jurídicos intermedios formulada por Schünemann, que se refiere a bienes jurídicos colectivos que se caracterizan precisamente por todo lo contrario, esto es, por no ser reconducibles a bienes jurídicos individuales. Para él los bienes jurídicos intermedios son inmateriales, por lo que es necesario recurrir a otro bien jurídico que los represente en un plano menos abstracto. Ese bien jurídico intermedio resultara lesionado con la mera realización de la conducta subsumible en el tipo, lo que fundamentaría por sí solo un injusto específico merecedor de pena, quedando fuera del tipo únicamente los ataques mínimos, en virtud del principio de insignificancia. SOTO NAVARRO, Susana. La protección penal..., op. cit., pp. 179- 186.

177 DOVAL PAIS. Antonio. Delitos de Fraude Alimentario..., op. cit., pp. 250, 251. 
jurídico intermedio espiritualizado", dado que al perseguirse la tutela de un bien colectivo asociado a intereses individuales, a través de delitos lesión-peligro, tan sólo se está proponiendo la instauración de delitos pluriofensivos con un desvalor múltiple, pero lo verdaderamente preocupante en su opinión, es que mediante la exigencia de un peligro concreto para bienes individuales, "se pretenda legitimar interpretaciones tributarias de la criticable teoría personalista del bien jurídico-penal de Hassemer", con lo cual se produce un retraso en la protección penal de los bienes jurídicos colectivos ${ }^{178}$.

Rodríguez Montañés sostiene que para definir el tipo del injusto y determinar el contenido del dolo y la imprudencia de los delitos de peligro abstracto, siendo coherentes con los principios informadores del Derecho Penal, se pueden extraer las siguientes conclusiones: 1) Que se trata de delitos en que lo relevante es la peligrosidad ex ante de la conducta, en la cual debe fundamentarse la antijuricidad material. 2) No es posible dar un tratamiento homogéneo a todos estos delitos, siendo preciso diferenciar clases en función del bien jurídico protegido ${ }^{179}$. 3) En los supuestos en que se tutelan bienes jurídicos

178 La tesis de Mata y Martín sólo resulta factible frente a bienes jurídico colectivos orientados a la protección de bienes individuales o suficientemente individualizables. CARO CORIA, Dino Carlos. Derecho Penal del Ambiente..., op. cit., pp. 513- 517.

179 Hay que diferenciar entre: a) los delitos orientados a la protección de bienes jurídicos individuales o suficientemente individualizables, frente a b) aquellos que tutelan bienes jurídicos colectivos no reconducibles a bienes jurídicos a bienes individuales. En los primeros se incriminan conductas potencialmente lesivas. Estos ilícitos tienen una estructura paralela a la de los delitos de peligro concreto, suponen un adelantamiento de las barreras de tutela penal, lo que, permite reconducirlos a la estructura de la tentativa imprudente (al respecto es preciso ver la imputación subjetiva de la infracción del cuidado en el delito doloso y la imputación subjetiva de la infracción del cuidado en el delito imprudente). Mientras que los segundos que protegen bienes jurídicos supraindividuales, institucionalizados o espiritualizados, o intereses difusos no reconducibles a bienes individuales, como los delitos contra la Administración de justicia, los delitos socio- económicos o inclusive los delitos contra el medio ambiente cuando se opta por su tipificación como delitos de peligro abstracto la técnica que parece más recomendable es la tipificación a través de la afectación a "un bien intermedio con función representativa". Por tanto, aquí no se trata de anticipar la protección de bienes esenciales, sino de tutelar otros bienes cuya peculiar naturaleza exige el empleo de esta técnica, que encontrará su justificación en la medida en que el bien protegido tenga suficiente entidad como para ser merecedor de tutela penal. Siendo así resulta legítima la criminalización de toda acción típica sin necesidad de comprobar la peligrosidad en relación con el bien inmaterial que mediatamente se 
esenciales individualizables, la exigencia de la antijuricidad material pasa por la reconducción a la imprudencia ${ }^{180}$. 4) En los delitos con bien jurídico intermedio con función representativa que protegen bienes jurídicos supraindividuales de carácter inmaterial o institucionalizado no es necesario comprobar su peligrosidad en relación con el bien inmaterial que mediatamente protege, dado que formalmente estamos ante delitos de lesión de este bien interpuesto con función representativa. En estos casos, sólo los ataques mínimos determinaran la atipicidad del comportamiento181. 5) En los delitos de aptitud, en los que el legislador incorpora al tipo elementos de valoración sobre la potencialidad lesiva del comportamiento, el dolo debe abarcarlos, al menos eventualmente. El autor ha de ser consciente de la aptitud lesiva de su conducta en los términos descritos en la ley.

protege, pues formalmente estamos ante delitos de lesión. Únicamente en los supuestos de ataques mínimos la conducta será atípica en virtud del principio de insignificancia. En cuanto a las exigencias del tipo subjetivo, basta con la lesión del bien representante, y con qué el dolo o la imprudencia se refieran a ella. RODRÍGUEZ MONTAÑÉS, Teresa. Delitos de peligro..., op. cit., pp. 297, 298, 299- 323.

180 A estos los denomina delitos de peligro abstracto "propios", pues forman un cuerpo homogéneo con los delitos de peligro concreto, ha de poder establecerse una relación más o menos inmediata con esos bienes que se tutelan (vida o integridad). En estos tipos "es necesaria la constatación de la efectiva peligrosidad de la conducta, que puede reconducirse a la exigencia de infracción del deber objetivo de cuidado en relación con la eventual lesión de esos bienes jurídicos (imprudencia), respondiendo, por tanto, a la misma estructura de los delitos de peligro concreto: adelantamiento de las barreras de protección a supuestos de imprudencia sin resultado lesivo. RODRÍGUEZ MONTAÑÉS, Teresa. Delitos de peligro..., op. cit., p. 339. En estos casos la admisión de los delitos de peligro abstracto depende de: "la importancia del bien jurídico individual de referencia -mayor legitimidad, por tanto, en caso de tutela de salud que del patrimonio-, la efectiva idoneidad de la regla de comportamiento que se ha establecido para su tutela, la frecuencia con que se realice la conducta de peligro y la imposibilidad de tutelar correctamente el bien jurídico a través de otras técnicas de tipificación como el peligro concreto y, especialmente el peligro hipotético". ARROYO ZAPATERO, Luis. "Derecho Penal económico..., op. cit., p. 8.

181 En el mismo sentido. CEREZO MIR, José. “Los delitos de peligro...,op. cit., p. 746. Arroyo Zapatero afirma que el legislador Español en estos casos ha desechado normalmente el uso de delitos de peligro abstracto, inclinándose, con frecuencia, a formas cercanas a los delitos de peligro hipotético, que obliga la comprobación de la efectiva idoneidad de la conducta para causar una lesión relevante al interés individual que sen ampara tras el bien jurídico. ARROYO ZAPATERO, Luis. “Derecho Penal económico..., op. cit., p. 8. 
Esta profesora opina que tomando en consideración las bases anteriormente expuestas pueden hacerse compatibles los delitos de peligro abstracto con la exigencia de antijuricidad material, con el principio de ofensividad y demás principios limitadores del ius puniendi, siempre que a través de ellos se tutele un bien jurídico suficientemente valioso para justificar la ampliación de la intervención penal. Es preciso señalar que Rodríguez Montañés admite la comisión de estos ilícitos tanto de forma dolosa como imprudente, oponiéndose de forma categórica a los delitos de peligro abstracto "con función meramente organizativa"182.

Bustos Ramírez manifiesta que afirmar la indeterminación de los bienes jurídicos colectivos carece de una fundamentación ontológica y normativa, y más aún, constituye una renuncia a la propia noción de bien jurídico penal, ya que resulta totalmente incorrecto proteger penalmente un interés cuyo contenido y lesividad se tienen por inciertos, lo cual lo conduce a sostener que "el alegato de la difícil concreción de la lesividad exigible a la conducta individual respecto del bien colectivo, no constituye más que un evidente pretexto a fin de legitimar la criminalización de las meras conductas peligrosas o de peligro abstracto", violándose de esta manera el principio de ofensividad. Bustos afirma que aunque la característica de los bienes jurídicos colectivos es su carácter complementario respecto a los bienes jurídicos individuales, ello no implica que los delitos que se configuren para su tutela hayan de ponerse en relación a éstos para definir su estructura; sin embargo, esto es lo que comúnmente sucede, pero no existe necesidad de recurrir a los delitos de peligro abstracto, que chocan con los principios garantistas del Derecho Penal, "ya que desde una debida caracterización del bien jurídico colectivo se pueden construir en relación a él, y no al bien jurídico complementado, delitos de lesión o de peligro concreto. Pues los delitos de peligro son siempre delitos de resultado que requieren de una situación peligrosa efectiva,

182 RODRÍGUEZ MONTAÑÉS, Teresa. Delitos de peligro..., op. cit., pp. 338-340. Sobre la necesidad de renunciar a las figuras de peligro abstracto imprudentes. SÁNCHEZ GARCÍA DE PAZ, María Isabel. El moderno Derecho..., op. cit., pp. 44, 45. 
por ello sostiene que los delitos de peligro abstracto donde el peligro es una presunción de derecho deben ser rechazados ${ }^{183}$.

En esta misma línea algunos autores manifiestan que la tutela de los bienes jurídicos colectivos se debe de realizar a través de delitos construidos en función de un "objeto con función representativa", el cual resultará lesionado o puesto en peligro concreto por la conducta típica individual, sin que sea necesaria la verificación de esa efectiva lesividad para el bien colectivo mediatamente tutelado, ya que la peligrosidad abstracta de la conducta típica para este último se fundamenta en la lesión o en el peligro concreto "reiterado y generalizado para el objeto representante". Consecuentemente con ello, para la realización de la imputación subjetiva bastará que el dolo o bien la imprudencia del autor comprendan únicamente el conocimiento de los elementos típicos, o sea: la afectación del objeto con función representativa inmediatamente protegido, sin que exista la exigencia de verificar el conocimiento sobre el bien jurídico colectivo ${ }^{184}$.

183 Sobre los delitos de peligro abstracto Bustos señala que el legislador no debe crear delitos de peligro sin peligro (de mera desobediencia). Afirmando que la verificación del peligro debe de realizarla el juez, caso por caso, para lo cual debe utilizar los criterios matemáticos y estadísticos con que la ciencia ha elaborado el concepto de probabilidad, teniendo que tomar en cuenta además las circunstancias propias del caso y la experiencia social sobre el tema en cuestión. BUSTOS RAMÍREZ, Juan. Control social..., op. cit., pp. 198, 327- 340. En este mismo sentido se pronuncian. MÉNDEZ RODRÍGUEZ, Cristina. Los Delitos de Peligro..., op. cit., pp. 40, 43, 154-163, 234-236. CARO CORIA, Dino Carlos. Derecho penal del Ambiente..., op. cit., pp. 406, 466-471, 508, 509, 470, 522-525. SOTO NAVARRO, Susana. La protección penal..., op. cit., pp. 178,180, 185, 186, 306, 307. PERIS RIERA, Jaime M. “Delitos de peligro..., op. cit., pp. 691, 692. ACALE SÁNCHEZ, María. El tipo de injusto..., op. cit., pp. 191- 195. Los bienes jurídicos supraindividuales, como la salud pública, deben de ser analizados desde la estructura de los delitos de peligro concreto y de lesión (peligro concreto para el referente individual y de lesión para el bien jurídico supraindividual). Entendiendo la lesión de la función que cumple el bien jurídico supraindividual por medio del peligro al referente individual. BARRIENTOS PÉREZ, Deisy Janeth. "Lesividad en los bienes..., op. cit., pp. 105, 106, 117, 118. "Sólo la lesión o puesta en peligro concreto de un bien jurídico debe de ser sancionada con una pena". MUÑOZ CONDE, Francisco. Derecho Penal..., op. cit., pp. 304, 305.

184 Por lo tanto de lo que se trata no es de anticipar la protección de los bienes jurídicos esenciales, sino de tutelar otros bienes cuya peculiar naturaleza exige el empleo de esta técnica, que estará justificada en la medida que el bien protegido tenga la suficiente 
Concluimos este repaso sobre los esfuerzos doctrinales por dotar de legitimidad a los delitos de peligro abstracto señalando que nosotros pensamos que la generalización del Derecho Penal del peligro, y especialmente del peligro abstracto, no siempre proporciona los medios adecuados para tutelar los bienes jurídicos colectivos. Protección que se puede optimizar si se parte de una correcta determinación del bien jurídico, lo cual evitaría tipificar con tanta frecuencia conductas abstractamente peligrosas, dado que la correcta determinación del bien jurídico colectivo puede permitir establecer un desvalor real capaz de fundamentar la antijuricidad material y, por ende, indicarnos las conductas que verdaderamente son merecedoras y necesitadas de pena por comportar una lesión o puesta en peligro concreto, no de los bienes jurídicos complementados (individuales), sino de los bienes jurídicos complementarios (colectivos). En todo caso nosotros reiteramos nuestra posición de que cuando se tenga que recurrir, por no existir otra opción a los delitos de peligro abstracto, debe exigirse un desvalor, al menos potencial, de resultado, solución que en nuestra opinión, es un esfuerzo importante, aunque no exento de críticas, de respetar el principio de protección de bienes jurídicos y de su correlato el principio de ofensividad.

\section{Posturas favorables a la expansión de los delitos de peligro abstracto}

El profesor Kratzsch que es un pionero en la defensa de la actual tendencia expansiva del Derecho Penal, entiende el ordenamiento penal como medio para una óptima reducción de perturbaciones "en el que no se deje ninguna posibilidad al azar". Desde su concepción el Derecho Penal es el Derecho Penal del riesgo, así la extendida tipificación de los delitos de peligro abstracto tiene en su propuesta un papel principal para conseguir una "regulación total" que posibilite una tutela efectiva de bienes jurídicos sin lagunas. La intervención penal de acuerdo con este programa, "pasa de constituir una represión puntual a convertirse en una prevención global"185. El profesor Kuhlen también

entidad como para ser merecedor de tutela penal. RODRÍGUEZ MONTAÑÉS, Teresa. Delitos de peligro..., op. cit., pp. 301, 302.

185 La protección total de bienes jurídicos propuesta por Kratzsch, desborda con creces la misión tradicional del Derecho Penal de tutelar bienes jurídicos sólo ante la lesión o puesta en peligro de bienes jurídicos de manera responsable, es decir, a costa del principio de culpabilidad. MENDOZA BUERGO, Blanca. El Derecho Penal..., op. cit., pp, 
se muestra partidario de la utilización de los delitos de peligro abstracto, justificando el empleo de los mismos por la vía de la defensa del efecto preventivo general de la amenaza penal, aunque sea limitado, como también por la vía del recurso a la idea de la prevención general positiva. Muy llamativa resulta su teoría sobre los Kumulationsdelikte en el ámbito de los delitos contra el medio ambiente, a propósito del artículo 324 del Código Penal alemán relativo a la contaminación de las aguas, argumentando que se trata de una estructura típica nueva que, en base a la relación más o menos estrecha entre acción y bien jurídico, estaría secuencialmente por debajo de los delitos de peligro abstracto, señalando que su justificación radica en el problema del gran número, esto es, en la consideración del peligro que se produciría si todos hicieran lo mismo, así Kuhlen entiende que es posible sancionar penalmente un comportamiento individual no peligroso ${ }^{186}$.

El profesor García-Pablos de Molina, sobre los delitos acumulativos, señala que la particularidad más novedosa de estas figura delictivas, es la de no exigir la lesión ni el peligro concreto para el bien jurídico, es más ni peligro abstracto, sino operar con el denominado "peligro global", que no es más que un peligro presunto o estadístico derivado del "daño acumulativo" o "efecto sumativo" que representa el temor del legislador, pero que en definitiva es una conducta inocua, en sí misma considerada, que se incrimina por el riesgo global estadístico que significaría su generalización, con la consiguiente quiebra del

131-132. Critico con la idea de una expansión desmesurada del Derecho Penal del Riesgo Prittwitz señala que "una ciencia penal orientada a las consecuencias debe considerar al menos que también en el Derecho Penal las buenas intenciones pueden originar malos resultados y que además es posible que las consecuencias inadvertidas predominen sobre las queridas. PRITTWITZ, Cornelius. "Sociedad de riesgo..., op. cit., pp. 268- 272 .

MENDOZA BUERGO, Blanca. El Derecho Penal..., op. cit., 141, 143. Dando algunas pautas sobre la evolución futura del Derecho Penal. KHULEN, Lothar. "El Derecho Penal del futuro" en ARROYO ZAPATERO, Luis. NEUMMAN, Ulfrid. NIETO MARTíN, Adán (Coord.). Crítica y justificación del Derecho Penal en el cambio de siglo. Ediciones de la Universidad de Castilla-La Mancha. Cuenca. 2003, pp. 227- 229. Tiedemann es otro de los autores que defienden el denominado "moderno Derecho Penal", asumiendo una posición favorable sin paliativos a la utilización de la técnica de los delitos de peligro abstracto para la protección de los bienes jurídicos llamados "intermedios", como los del ámbito económico. MENDOZA BUERGO, Blanca. El Derecho Penal..., op. cit., pp 151, 152. 
principio de culpabilidad, al responder el autor ex iniuria tertii ${ }^{187}$. Nosotros pensamos que tal formulación vulnera además de forma evidente el principio de lesividad y de proporcionalidad, al no exigir una valoración de la gravedad de la acción individual ${ }^{188}$.

Kindhäuser sostiene que estos tipos delictivos poseen una lesividad propia, dado que los delitos de peligro abstracto no tutelan la integridad de los bienes jurídicos, sino la disposición sin riesgo de los mismos, utilizando para fundamentar la relevancia lesiva del comportamiento del autor la perspectiva de la víctima ${ }^{189}$. A este planteamiento hay que objetarle, que aunque quien debe sentirse seguro sin lugar a dudas es la víctima, y no el incendiario o conductor que se encuentra bajo los efectos de bebidas alcohólicas u otras drogas, también lo es que al que hay que imputar el hecho es al autor y no a la víctima, quien podría incluso desconocer la existencia del peligro ${ }^{190}$. Por lo tanto lo importante aquí, es si el autor observó o no la diligencia debida para no poner en peligro a la víctima, desde la posición objetiva del observador imparcial (hombre medio) que juzgue antes del hecho y disponga de los conocimientos de un hombre inteligente del corres-

GARCÍA-PABLOS DE MOLINA, Antonio. Introducción al estudio..., op. cit., p. 577. PÉREZ CEPEDA, Ana Isabel. “De la sociedad neoliberal..., op. cit., pp. 164, 165.

FEIJOO SÁNCHEZ, Bernardo. "Sobre la administrativización del Derecho Penal en la sociedad del riesgo" en DIAZ- MAROTO Y VILLAREJO, Julio. (Dir.). Derecho y justicia penal. En homenaje al profesor Antonio González- Cuellar García. Ed. Colex. Madrid. 2006, pp. 157- 161. SOTO NAVARRO, Susana. La protección penal..., op. cit., pp. 184, 185. MENDOZA BUERGO, Blanca. Límites dogmáticos..., op. cit., pp. 61- 65, 490- 495.

En contra de entender como resultado la perturbación de las condiciones de seguridad que son imprescindibles para un disfrute despreocupado de los bienes. CEREZO MIR, José. "Los delitos de peligro...,op. cit., pp. 737, 738. PORTILLA CONTRERAS, Guillermo. "La supuesta crisis..., op. cit., p. 917. RODRÍGUEZ MONTAÑÉS, Teresa. Delitos de peligro..., op. cit., pp. 256, 257. SOTO NAVARRO, Susana. La protección penal..., op. cit., pp. 208- 211.

190 Piénsese por ejemplo en el conductor de un camión que transporta una sustancia con poder asfixiante, a una velocidad superior al límite permitido para esta actividad, por una carretera estrecha no autorizada para tal fin a altas horas de la noche. Presentándose la situación de que este conductor producto del cansancio y de las pobres condiciones de la carretera pierde el control del vehículo, saliéndose de la carretera llegando a colisionar levemente contra el muro de una vivienda, sin que se produzca ninguna fuga de la sustancia que transporta, cuando sus cinco habitantes se encuentran durmiendo por lo cual no llegan a percatarse de tal suceso. 
pondiente sector de tráfico teniendo en consideración al mismo tiempo los conocimientos especiales del autor desde una perspectiva ex ante ${ }^{191}$.

El profesor Kindhäuser clasifica los delitos de peligro abstracto en: a) supuestos de protección especial (protección de la disposición de riesgos de bienes de una persona determinada) donde se precisa de la relevancia lesiva de la conducta para legitimar su punición, y b) supuestos de protección general en los que se tutela a la colectividad, donde el fin de protección legitima la prohibición independientemente de la dañosidad de la conducta del autor, dado que la seguridad se ve perturbada por la realización de la conducta siempre que no sea segura "la no peligrosidad". Es preciso recordar que para este autor estas normas no protegen la integridad de bienes jurídicos, sino "la disposición sin riesgos sobre los mismos”, a favor de esta tesis, en relación a los delitos contra la salud pública, se pronuncia Corcoy Bidásolo ${ }^{192}$ asumiendo que estos tipos no están destinados a evitar resultados lesivos de bienes jurídico-penales, sino que comportan una lesividad sui generis que consiste en "que la acción prohibida menoscaba las condiciones de seguridad que son indispensables para la disposición sin riesgo de los bienes jurídicos", lo cual desde su

191 Al respecto, Torío señala que "una ley que no prestara atención a las medidas de seguridad adoptadas por el autor y estableciese una presunción iures et de iure de que la ejecución de la acción, externamente caracterizada, implica un peligro consumado o intentado, difícilmente podría sustraerse a la censura de injusticia”, pues entonces la pena de los de los delitos de peligro afectaría de la misma manera a la acción peligrosa y a la carente de peligrosidad. TORÍO LÓPEZ, Ángel. "Los delitos de peligro hipotético..., op. cit., p. 831.

192 RODRÍGUEZ MONTAÑÉS, Teresa. Delitos de peligro..., op. cit., pp. 257, 260. CORCOY BIDÁSOLO, Mirentxu. "Resultado de muerte y lesiones como consecuencia de un delito contra la salud pública” en Anuario de Derecho Penal y Ciencias Penales. 1989, p. 337. Siempre deberá probarse que en el caso concreto, ex post la conducta era efectivamente peligrosa, objetivamente idónea, "y lesionaba la seguridad y la confianza del ciudadano". CORCOY BIDÁSOLO, Mirentxu. Delitos de Peligro..., op. cit., pp. 24- 27, 227. CORCOY BIDÁSOLO, Mirentxu. "Protección de bienes..., op. cit., pp. 393- 395. Sostiene Kindhaüser que los delitos de peligro abstracto "no están para proteger bienes jurídicos, sino para garantizar seguridad, entendiendo que el bien jurídico no es punto de referencia ni para el reproche del injusto ni para el de culpabilidad. GOERNER, Gustavo. "Los delitos de peligro...,op. cit., p. 573. En contra de este planteamiento de Corcoy Bidásolo. SOTO NAVARRO, Susana. La protección penal de los bienes jurídicos colectivos en la sociedad moderna. Ed. Comares. Granada. 2003, pp. 208- 211. 
perspectiva dota de contenido material a los delitos de peligro abstracto. Esta tesis en nuestra opinión parece tener por pretensión librar a estos tipos delictivos de las críticas referidas a la ausencia de un desvalor de resultado que exprese la puesta en peligro de un bien jurídico ${ }^{193}$, al respecto, nosotros compartimos la opinión de quienes afirman que la "seguridad" o "disposición sin riesgo" no establece un concepto autónomo que pueda prescindir de los bienes jurídicos a los que sirve, por lo que resulta desafortunado a todas luces justificar su tutela como un fin en sí mismo, y por lo tanto la protección de la "seguridad" está condicionada a los bienes jurídicos merecedores y necesitados de pena (ya que lo contrario significaría erigir al Derecho Penal en la primera ratio del control social). Dicho esto, se puede sostener que la noción de seguridad no posee la suficiente entidad jurídica para fundamentar el injusto penal, dado que tal situación nos conduciría a establecer "un sistema de delitos de peligro con lesión presunta"194.

Hoyer desde una posición próxima a Kindhäuser, opina que mediante los delitos de peligro abstracto es preciso prohibir sin excepciones ciertas conductas con el fin de no dejar "el bien jurídico a la competencia del enjuiciamiento del autor", constituyendo por lo tanto el fundamento de la criminalización de tales conductas "el riesgo de error". Desde esta perspectiva las conductas peligrosas abstractas menoscaban la seguridad del bien jurídico en mayor intensidad en cuanto sea mayor el riesgo de que el autor fracase en el aseguramiento de su conducta, así mientras mayor número de medidas de aseguramiento tome el autor menor es su "riesgo de error", de lo cual depende la relevancia penal de la conducta 195 .

Algunos autores entre los que destacamos a Tiedemann afirman que para la protección de los bienes jurídicos colectivos (supraindividuales o intermedios), particularmente en el área de acción del Derecho Penal económico, resulta imprescindible recurrir a los delitos de peligro y fundamentalmente a los delitos de peligro abstracto, siendo partidarios

193 CARO CORIA, Dino Carlos. Derecho Penal del Ambiente..., op. cit., p. 505.

Ibidem., p. 506. La prohibición de conductas peligrosas no es, por tanto, un fin en sí mismo, como no lo es tampoco la seguridad, sino medio para otro fin: la protección de bienes jurídicos. RODRÍGUEZ MONTAÑ́́S, Teresa. Delitos de peligro..., op. cit., pp. 265- 267.

195 RODRÍGUEZ MONTAÑÉS, Teresa. Delitos de peligro..., op. cit., pp. 260, 261. 
estos juristas de una funcionalización de la protección penal señalando como fundamento de esta que el funcionamiento de los sistemas económicos únicamente puede lograrse mediante el mantenimiento de determinadas garantías que aseguran una confianza abstracta que constituiría el contenido y condición de tal funcionamiento. En atención a ello afirman que el uso de esta técnica (peligro abstracto) debe prevalecer en las legislaciones contra la "criminalidad económica", tanto por la facilidad probatoria que ofrece, como por la necesidad de tutelar bienes jurídicos colectivos, para cuya protección les resulta imprescindible esta configuración típica. Sin embargo, este profesor alemán aclara que no es únicamente la facilidad para la prueba lo que ha conducido a optar por los delitos de peligro abstracto sino fundamentalmente, la necesidad de proteger intereses jurídicos supraindividuales "para cuya efectiva tutela no resulta imaginable otra configuración típica"196. En la misma línea Fiandaca afirma que para algunos supuestos, "el instrumento más adecuado es el delito de peligro abstracto, precisamente porque la intervención penal es tanto más eficaz cuanto menos está condicionada por la verificación (en parte siempre) accidental del resultado dañoso"197. También comparte estos planteamientos Pedrazzi198; nosotros suscribimos la idea de Méndez Rodríguez quien señala que, es precisamente la comodidad y la supuesta eficacia que supone la tipificación de acciones en general y

196 TIEDEMANN, Klaus. Poder Económico y Delito. (Trad. MANTILLA VILLEGAS, Amelia). $1^{\text {a }}$ Ed. Ariel Madrid. 1985 pp, 13, 33- 36. Idem. Lecciones de Derecho Penal Económico. (comunitario, español, alemán). (Trad. MARTÍN, Teresa). 1a Ed. PPU. Barcelona, 1993, pp. 34- 35. Para Tiedemann "el delito de peligro abstracto representa el instrumento de técnica típicamente correspondiente a la esencia del bien jurídico supraindividual. CARO CORIA, Dino Carlos. Derecho Penal del Ambiente..., op. cit., pp. 506, 507. Señala que Schünemann se opone tajantemente a la anatemización de los delitos de peligro abstracto, considerando como posición reaccionaria la que critica la utilización masiva actual de este modelo delictivo por entender que se opone a la modernización del Derecho Penal. MENDOZA BUERGO, Blanca. El Derecho Penal..., op. cit., pp. 150- 152.

197 Este autor señala que "respecto a la vida y a la incolumidad pública, la creación de tipos de peligro abstracto constituye el instrumento más eficaz". FIANDACA, Giovanni. Il reato commissivo mediante omissione. Milan. 1979, p. 58. Idem. "La tipizzazione del pericolo". Dei Delitti e delle pene. 1984, pp. 445- 451. Cit. por MÉNDEZ RODRÍGUEZ, Cristina. Los Delitos de Peligro..., op. cit., pp. 81, 158, 216- 220.

198 PEDRAZZI. "Problemi di técnica legislativa". AAVV. Comportamienti economici e Legislazione penale. Ed. Giuffre. Milano. 1979, p. 33. Cit por MÉNDEZ RODRÍGUEZ, Cristina. Los Delitos de Peligro y sus Técnicas de Tipificación..., op. cit., pp. 220, 221. 
abstractamente peligrosas, el motivo de la utilización indiscriminada de los delitos de peligro abstracto en el ámbito económico, lo cual en algunas ocasiones tiene como única finalidad la protección de directrices económicas ${ }^{199}$.

Mata y Martín señala que en los casos mencionados en el párrafo anterior, la protección en vez de realizarse en el sentido de lesión para el bien jurídico colectivo y peligro para el bien jurídico individual se realiza de forma inversa, es decir, de lesión para el bien jurídico de carácter personal y únicamente peligro para el bien colectivo, produciéndose un ensanchamiento del segmento de la conducta que resulta comprendido en la prohibición penal, pues ya no se exige la lesión del bien jurídico colectivo, lo cual lógicamente entra en contradicción con el principio de intervención mínima dado que la relevancia penal de la conducta comienza en estadios muy alejados de la efectiva perturbación del bien jurídico. Además el momento final en el que la conducta se comprende en estos tipos penales se retrasa, pues la acción debe avanzar hasta producir el menoscabo real (lesión) del bien individual, y no el mero peligro, como sucedía en los anteriores supuestos de lesión-peligro, generándose de esta manera una mayor indeterminación de la conducta punible, pues si como todos sabemos existe una gran dificultad para poder fijar el momento de lesión del bien jurídico colectivo, mucho mayor problema representa poder determinar el momento de su puesta en peligro, donde la conducta se desdibuja en extremo 200 .

Este adelantamiento de la intervención penal como ya señalamos anteriormente en nuestra opinión obedece, entre otros factores, a que es una vía relativamente cómoda, barata y aparentemente rentable política y socialmente para el Estado, pero también de manera muy importante a que es demandado como el instrumento de reacción jurídica que, aparentemente, ofrece más confianza a la población, no sólo para resolver la sensación de inseguridad como potencial víctima,

199 Ibidem., p. 161. CARO CORIA, Dino Carlos. Derecho Penal del Ambiente..., op. cit., pp. 506- 510 .

200 MATA y MARTÍN, Ricardo M. Bienes jurídicos intermedios..., op. cit., pp. 85- 91. 
sino también como reacción ajustada a lo que se estima rechazable ${ }^{201}$, situación que sin embargo genera un problema de mucha trascendencia, el cual se presenta cuando, posteriormente, se demuestra su ineficacia en la prevención y la represión de los hechos que quieren prevenirse. El efecto simbólico de procurar sólo de modo aparente sensación de seguridad a la población y de estar dando respuesta a los problemas puede acabar provocando en muchos casos desconfianza hacia el propio sistema. Resultando este efecto simbólico finalmente, al menos en algunos casos, disfuncional para el conjunto del sistema penal ${ }^{202}$. Otro aspecto a destacar en este sentido es que nos encontramos, en un modelo de sociedad dirigido a "una restricción progresiva de las esferas de actuación arriesgada", lo cual puede verse reflejado en algunos casos de desarrollo doctrinal y jurisprudencial, y más aún, esto se pone de manifiesto también en la sociedad en una resistencia psicológica frente la aceptación del caso fortuito, lo cual se materializa en una creciente tendencia hacia la transformación del accidente fortuito en injusto penal provocando el incremento de infracciones de deberes de cuidado, así como de la tipificación de delitos de peligro, lo que nos lleva a un aumento significativo del ámbito de intervención del Derecho Penal ${ }^{203}$.

Para concluir este apartado queremos señalar que para justificar la ampliación de los delitos de peligro abstracto en el "moderno Derecho Penal", se ha propuesto "el principio de precaución" que trata del riesgo ciertamente sospechado pero no previsible, por ser inciertos los soportes científicos que podrían identificarlo y describirlo. Como sabemos, en la idea de prevención que justifica los delitos de peligro se parte de la idea de la previsibilidad, mientras que el principio de precaución parte de la sospecha de riesgos graves e irreversibles que puede comportar una actividad determinada, en supuestos en que se desconocen las leyes causales, se trata por tanto de una incertidumbre

201 Uno de los rasgos más significativos de la sociedad de la era postindustrial es la sensación general de inseguridad. SILVA SÁNCHEZ, Jesús María. La expansión del Derecho..., op. cit., pp. 32- 42. Francisco. GARCÍA ARÁN, Mercedes. Derecho Penal. Parte General. 8ae edición. Tirant lo Blanch. Valencia. 2010, pp. 82, 83.

203 SILVA SÁNCHEZ, Jesús María. La expansión del Derecho..., op. cit., pp. 42- 52. 
sobre los procesos causales que puedan desencadenar dichas actividades. Es preciso señalar que los principales campos de aplicación del principio de precaución serían la protección del medio ambiente y de la salud pública. Para nosotros la idea de ampliación de los delitos de peligro abstracto tomando como base el principio de precaución nos parece totalmente rechazable, pues su admisión supondría una desnaturalización de los delitos de peligro abstracto, de por sí cuestionables en muchos casos, que encuentran su sustento en el criterio de previsibilidad 204 .

\section{Crítica al uso indiscriminado de los delitos de peligro abstracto}

En opinión de Hassemer "el moderno Derecho penal" sólo de forma indirecta tiene que ver con las personas consideradas individualmente, pues este se refiere directamente a la sociedad o bien al Estado, de esta manera la tutela de bienes jurídicos es cada vez más una protección institucional, afirmando que estos bienes jurídicos colectivos se caracterizan porque son formulados de forma vaga y a grandes rasgos, citando como ejemplo de ello a la salud pública o las subvenciones públicas. Además afirma que otro elemento que utiliza "el moderno Derecho Penal" para argumentar su capacidad de intervención es la técnica de los delitos de peligro abstracto, siendo esta su forma más representativa, lo cual facilita enormemente la actividad judicial, dado que únicamente hace falta probar la acción incriminada, cuya peligrosidad no tiene que ser verificada por el juez, ya que sólo ha sido el motivo por el que el legislador la ha incriminado. Así el Derecho Penal pasa de ser un instrumento de reacción frente a las lesiones más graves de la libertad de los ciudadanos, para convertirse en un instrumento de política de seguridad 205 .

CEREZO MIR, José. “Los delitos de peligro...,op. cit., pp. 734- 736.

HASSEMER, Winfried. Persona, mundo, responsabilidad. ..., op. cit., pp. 53- 56, 68, 69. BUSTOS RAMÍREZ, Juan. HORMAZÁBAL MALARÉE, Hernán. Lecciones de Derecho Penal..., op. citpp. 251, 252. FEIJOO SÁNCHEZ, Bernardo. "Sobre la administrativización..., op. cit ., pp. 137- 148. FERRAJOLI, Luigi. Derecho y Razón..., op. cit., pp. 478, 479. En el mismo sentido GOERNER, Gustavo. "Los delitos de peligro...,op. cit., p. 584, 585. HERZOG. Felix. "Limites al control penal de los riesgos sociales. (Una perspectiva crítica ante el derecho Penal del peligro)”. (Trad. LARRAUIR PIOJAN, Elena. PEREZ ALVAREZ, Fernando) en Anuario de Derecho Penal y ciencias penales. 1993, pp. 317- 321. MENDOZA BUERGO, Blanca. Límites dogmáticos..., op. cit., pp. 340- 361. 
Este profesor alemán sostiene que el hecho de utilizar el Derecho Penal, no como última ratio sino, como primera o peor, como única ratio haciéndolo intervenir, en contra del principio de subsidiariedad, siempre que parezca rentable políticamente, coincide con la pretensión de hacer de este un elemento de transformación. Afirmando además que también en las sociedades complejas puede fundamentarse el Derecho desde un punto de vista personalista, por tanto afirma que en "el Derecho Penal, la parte que más incide en la libertad humana, los bienes jurídicos universales se deben de precisar del mejor modo posible, y funcionalizarse desde el punto de vista de los bienes jurídicos individuales"206.

Otra objeción que se realiza a los delitos de peligro abstracto es que no deben entenderse como sinónimos la peligrosidad de la acción y la afección al bien jurídico, ya que el principio de ofensividad exige que el bien jurídico sea "realmente afectado", lo cual es coherente con los lineamientos que dicta la Constitución española, en el sentido de limitar la intervención penal a la protección exclusiva de bienes jurídicos de su lesión o puesta en peligro ${ }^{207}$, condición que estimamos no se cumple al establecer simplemente la peligrosidad de la conducta tomando como base la experiencia general. Arthur Kaufmann en este sentido expresó que el injusto de los delitos de peligro abstracto encuentra su fundamento en "la probabilidad de la probabilidad" de lesión del bien jurídico ${ }^{208}$ y Cramer en un intento de compatibilizar los delitos de peligro abstracto con el principio de culpabilidad, los interpreta como tentativas de delitos de peligro concreto, lo cual lo lleva a definir los delitos de peligro abstracto como "la probabilidad de peligro concreto", por lo cual entiende que en estos casos el legislador

MUÑOZ CONDE, Francisco. GARCÍA ARÁN, Mercedes. Derecho Penal. Parte General. 6a edición. Titrant lo Blanch. Valencia. 2004, pp. 302, 303. Tomando distancia de las criticas que realiza Hassemer contra los delitos de peligro abstracto. CARO CORIA, Dino Carlos. Derecho Penal del Ambiente..., op. cit., pp. 501, 502. Critica ante la postura desarrollada por la escuela de Frankfurt. CORCOY BIDÁSOLO, Mirentxu. Delitos de Peligro..., op. cit., pp 25-27, 369-371. PERIS RIERA, Jaime M. “Delitos de peligro..., op. cit., pp. 694- 700 .

206 HASSEMER, Winfried. Persona, mundo, responsabilidad. ..., op. cit., , pp. 56, 57, 69. 
sanciona comportamientos típicamente aptos para producir un peligro concreto y ello no es "sólo el motivo del legislador, sino un presupuesto material del tipo". Sin embargo resulta poco convincente hablar de "la probabilidad de la probabilidad" o "del peligro del peligro"209. En este sentido nosotros pensamos que cuando los comportamientos no afecten verdaderos bienes jurídico-penales es mejor recurrir a las sanciones de carácter administrativo, u otras ramas del ordenamiento jurídico, que no precisan del resultado de peligro, aunque sea este al menos potencial que se ha destacado antes en este trabajo.

Queremos señalar que un importante sector en la doctrina española sostiene que para decidir si se debe optar por el Derecho Penal o el Derecho Administrativo sancionador, se deberá atender a la importancia del bien jurídico tutelado, así como a la gravedad y a la proximidad o concreción del peligro que para él suponen las conductas que lo agreden, por lo que se afirma que en términos generales debe de reservarse el Derecho Penal para los delitos de peligro concreto y de peligro abstracto denominados de peligro hipotético, de peligro abstracto-concreto o de aptitud, dejando para el Derecho Administrativo sancionador los delitos de peligro abstracto puros, así como las formas de imperfecta realización de tipos de puesta en peligro, lo cual no significa rechazar, de forma absoluta, la tipificación de los ilícitos de peligro abstracto, que en nuestra opinión deberían utilizarse para sancionar aquellos comportamientos verdaderamente graves a bienes que condicionen su utilidad para el desarrollo personal del individuo, susceptibles de lesionar bienes como la vida o la salud de las personas dentro del marco social debiendo cumplirse con las exigencias derivadas de los principios de merecimiento, necesidad e idoneidad de pena, lo cual nos lleva a concluir en este sentido que el Derecho Penal deberá seguir tutelando los bienes jurídicos más importantes (las condiciones esenciales que todas las personas consideradas tanto individual como colectivamente necesitan para su autorrealización y el

RODRÍGUEZ MONTAÑÉS, Teresa. Delitos de peligro..., op. cit., pp. 271- 275. En contra de la postura de Cramer de exigir que se dé "la probabilidad de la producción de un peligro concreto", pues supondría la introducción en el tipo de un requisito ajeno a los delitos de peligro abstracto. CEREZO MIR, José. "Los delitos de peligro...,op. cit., pp. 741, 742. El profesor Roxin es de la opinión que entender el peligro abstracto como la "probabilidad de un peligro concreto" conduce a un peligro concreto de intensidad menor de difícil determinación. ROXIN, Claus. Derecho Penal. P. G..., op. cit., p. 408. 
desarrollo de su personalidad en la vida social), de sus modalidades de ataque más graves, cuando estos no puedan protegerse a través de otro medio menos lesivo que el Derecho Penal, dándole cumplimiento a los principios de subsidiaridad, fragmentariedad y ultima ratio. En los casos que se adopte esta técnica parece razonable admitir que la presunción que estos tienen es iuris tantum, permitiendo prescindir de la punibilidad ante la ausencia de peligrosidad ${ }^{210}$.

Como se ha señalado anteriormente en este trabajo, se les cuestiona a "los delitos de peligro abstracto puros" violar el principio de estricta protección de bienes jurídicos y su correlato el principio de lesividad, puesto que en estos tipos no es necesario establecer en el caso concreto la existencia de un resultado de peligro, quedando por ende consumado el injusto con la simple ejecución de la conducta típica, por lo que se puede entender que el bien jurídico no cumple la función que le corresponde en la criminalización de estas conductas, y es por ello que se dice que la antijuricidad en los delitos de peligro abstracto, refiriéndonos a los "puros", carece de contenido material; así el injusto penal se fundamenta en la violación de reglas de comportamiento, lo cual nos conduciría a entender que la misión del Derecho Penal ya no sería la tutela de bienes jurídicos sino la de asegurar funciones o determinados valores éticos o morales ${ }^{211}$. En este sentido Bustos

210 SUAY HERNÁNDEZ, Cecilia. "Los delitos contra la salubridad ..., op. cit., pp. 168, 169. FEIJOO SÁNCHEZ, Bernardo. "Sobre la administrativización..., op. cit., pp. 139, 140, 155157. GARCIA-PABLOS DE MOLINA, Antonio. Introducción al estudio..., op. cit., pp. 575, 576. MENDOZA BUERGO, Blanca. “Gestión del riesgo..., op. cit., pp. 366- 369. SÁNCHEZ GARCÍA DE PAZ, María Isabel. El moderno Derecho..., op. cit., pp. 44- 47. SÁNCHEZ GARCÍA DE PAZ, Isabel. "La criminalización en el ámbito previo..., op. cit., pp. 706- 709, 722. El profesor Gómez Tomillo sostiene que a pesar de todas las objeciones que se le realizan a los delitos de peligro abstracto puros, y la conveniencia de su transformación en delitos de peligro hipotéticos, una política criminal realista no puede sostener la radical eliminación de estos ilícitos, que debe en su opinión someterse de forma estricta al principio de excepcionalidad. GÓMEZ TOMILLO, Manuel. “Contribución a la teoría..., op. cit 473- 478.

211 BUSTOS RAMÍREZ, Juan. Control social..., op. cit., p. 340. Caro Coria afirma que "al ser el peligro una contingencia en el hecho penalizado, entonces se espiritualiza la función de protección de bienes jurídicos". CARO CORIA, Dino Carlos. Derecho Penal del Ambiente..., op. cit., p. 486. Así se sostiene que la característica que define a los delitos de peligro abstracto es la falta de peligro en el tipo. MÉNDEZ RODRÍGUEZ, Cristina. Los Delitos de Peligro..., op. cit., p. 18, 394- 404. 
Ramírez ${ }^{212}$ sostiene en contra de los tipos de abstracta peligrosidad, que estos responden a una errónea configuración del injusto, que se realiza sobre la base de los bienes jurídicos individuales, y no en función de los bienes jurídicos colectivos que se pretende tutelar, afirmando que los delitos de peligro abstracto contradicen los principios rectores del Derecho Penal, y en definitiva no hace falta recurrir a ellos dado que "desde una debida caracterización del bien jurídico colectivo se pueden construir en relación a él (y no al bien jurídico complementado) delitos de lesión o de peligro concreto"213.

Como se afirmó al inicio de este apartado, en la parte correspondiente a la noción de los delitos de peligro abstracto, un rasgo característico de estos tipos delictivos es la supresión de la verificación judicial del peligro, dado que este ya se ha determinado en abstracto por el legislador (presunción de peligro) ${ }^{214}$, por lo que también se objeta a estos tipos penales la violación del principio de responsabilidad por el

212 BUSTOS RAMÍREZ, Juan. Control Social..., op. cit., p. 198. HORMAZÁBAL MALARÉE, Hernán. "Consecuencias político criminales y dogmáticas del principio de exclusiva protección de bienes jurídicos". PEREZ ALVAREZ, Fernando (Editor). Serta in memoriam Alexandri Baratta. Ed. Universidad de Salamanca. 2004, pp. 1085- 1087. En la misma línea se pronuncia Méndez Rodríguez afirmando que con el fin de ser coherentes con el principio de legalidad, impidiendo que el legislador, al amparo del mismo, pueda establecer como delito cualquier tipo de actividad que quiera reprimir, es necesario reconocer conjuntamente con el principio de legalidad el principio de ofensividad, ya que desde esta perspectiva, no cabe duda que la presunción de la afección al bien jurídico que los delitos de peligro abstracto implican, resulta incompatible con el principio de estricta protección de bienes jurídicos. Afirmando además esta autora que en los delitos de peligro abstracto la posibilidad de lesión es indeterminable y por ende resulta aún más indeterminable el peligro. Lo cual conduce a crear delitos de peligro abstracto "en casos que ni siquiera se tiene claro en qué consiste la lesión”. MÉNDEZ RODRÍGUEZ, Cristina. Los Delitos de Peligro..., op. cit., pp. 153,160 .

213 Ibidem., pp. 32, 159, 160. CARO CORIA, Dino Carlos. Derecho penal del Ambiente..., op. cit., pp. 227, 233, 371- 373.

214 MÉNDEZ RODRÍGUEZ, Cristina. Los Delitos de Peligro..., op. cit., p. 133. Discrepa Cerezo sosteniendo que "el contenido material de lo injusto en los delitos de peligro abstracto se cifra en el desvalor de acción, en la configuración de estos tipos penales se mantiene la referencia a los bienes jurídicos, así se castigan ciertas conductas porque generalmente ponen en peligro al bien jurídico. Por tanto se mantiene, pues una conexión, aunque de menor entidad, con el principio de lesividad". CEREZO MIR, José. "Los delitos de peligro...,op. cit., p. 737. 
hecho, y en el ámbito del Derecho Procesal Penal se habla de la presunción de culpabilidad en detrimento de la presunción de inocencia ${ }^{215}$. Queremos destacar que el señalamiento más grave que en nuestra opinión puede realizarse a los delitos de peligro abstracto radica en comprobar que "su estructura va contra toda lógica penal al establecer sanciones jurídicas que se deducen matemáticamente de la mera realización formal de las acciones típicas, sin someter ni siquiera la peligrosidad de la acción a la necesaria verificación judicial”216. Al respecto, Schröder ${ }^{217}$ manifiesta que la vía para impedir que los delitos de peligro abstracto sean delitos de mera desobediencia radica en la admisión de la prueba en contrario de la "no peligrosidad" en el caso concreto, lo que nos conduciría a la exclusión del tipo penal cuando se compruebe que el hecho no ha producido una puesta en peligro. Es preciso aclarar que esta tesis tuvo por objeto transformar la presunción iuris et de iure en una presunción iuris tantum. Sin embargo, no ha encontrado mayor aceptación, pues se considera que no es compatible con el principio in dubio pro reo, dado que si no se logra acreditar la ausencia del peligro, si el procesado corre con la carga de la prueba, la presunción operaria en perjuicio del autor, y si por el contrario como propone Schröder el juez corre con la carga de la prueba, se entiende que se estaría desnaturalizando la voluntad del legislador 218 .

215 Los delitos de peligro abstracto contienen un a presunción ipso iure relativa a la producción del peligro, presunción que no admite prueba en contrario. Esta realidad resulta claramente contraria a los principios actuales constitucionales que informan el Derecho Penal español. Violando la presunción de inocencia, garantía consagrada por la Constitución española de 1978 en su artículo 24, párrafo segundo. PEREZ ALVAREZ, Fernando. Protección penal del consumidor. Salud pública y alimentación. Ed. Praxis. Barcelona 1991, p. 60.

216 MÉNDEZ RODRÍGUEZ, Cristina. Los Delitos de Peligro..., op. cit., p. 137.

217 RODRÍGUEZ MONTAÑÉS, Teresa. Delitos de peligro..., op. cit., p. 268.

218 A la propuesta de Schröder se le objeta que si el indiciado corre con la carga de la prueba, se estaría violando el principio in dubio pro reo, siempre que no se lograra probar la ausencia del peligro. Si se exige como lo hace este profesor alemán que sea la acusación o el juez los que corran con la carga de la prueba se introduce subrepticiamente en el tipo la exigencia de un resultado de peligro, lo cual implica transformar, en contra de la voluntad de la ley, los delitos de peligro abstracto en delitos de peligro concreto. CEREZO MIR, José. “Los delitos de peligro...,op. cit., p. 741. TORÍO LÓPEZ, Ángel. “Los delitos de peligro hipotético..., op. cit., pp. 826, 827. 
La doctrina mayoritaria sostiene que los intentos de tratar de conceder un contenido de injusto propio a los delitos de peligro abstracto, así como aceptar la autonomía de las prohibiciones de poner en peligro frente a las de lesionar no satisfacen el problema de legitimación de estos tipos delictivos, ya que es aceptado de forma casi unánime que el fin de toda norma jurídica penal es la protección de bienes jurídicos, por lo cual la criminalización de actuaciones peligrosas no debe considerarse un fin en sí mismo, sino un medio para la consecución de otro fin que es la protección de bienes jurídicos ${ }^{219}$. En este sentido creemos necesario exigir la presencia de un desvalor, al menos de carácter potencial de resultado en los comportamientos constitutivos de un hecho punible no lesivo para el bien jurídico, lo cual no supone, de manera alguna, un rechazo absoluto a la técnica de los delitos de peligro abstracto, pero sí de mantener un recurso a la misma en el ámbito de lo excepcional, siendo necesario que concurran razones político-criminales que fundamenten de forma adecuada su utilización ${ }^{220}$.

En franca oposición a los delitos de peligro abstracto nos encontramos con planteamientos como los sostenidos por Herzog, quien entiende que el origen de estos se encuentra en la "inseguridad social", en "las necesidades de seguridad" y de "prevención de la esencia del Estado", lo cual transformaría al Derecho Penal en un instrumento de ordenación política, haciéndolo perder su legitimidad al abandonar los presupuestos básicos del Derecho Penal liberal221. Mendoza Buergo sostiene que actualmente existe una tendencia de sustituir o incluso evitar los delitos de peligro concreto a favor de la técnica de delito abstracto que soslaya los difíciles problemas probatorios de aquellos. Manifiesta que esta tendencia en España aún no está tan acentuada

219 RODRÍGUEZ MONTAÑÉS, Teresa. Delitos de peligro..., op. cit., pp. 267, 270. "Sólo la individualización de un resultado de peligro para el bien jurídico nos permite entender la tradicional función de anticipación que se ha atribuido siempre a los delitos de peligro. MÉNDEZ RODRÍGUEZ, Cristina. Los Delitos de Peligro..., op. cit., p. 124. SÁNCHEZ GARCÍA DE PAZ, María Isabel. El moderno Derecho..., op. cit., pp. 16, 17, 42.

221 HERZOG. Felix. "Limites al control penal de los riesgos sociales. Una perspectiva crítica ante el derecho Penal del peligro". (Trad. LARRAUIR PIOJAN, Elena. PEREZ ALVAREZ, Fernando) en Anuario de Derecho Penal y ciencias penales. 1993, pp. 317-321. RODRÍGUEZ MONTAÑÉS, Teresa. Delitos de peligro..., op. cit., pp. 262, 263. MENDOZA BUERGO, Blanca. El Derecho Penal..., op. cit., pp. 78, 79. SILVA SÁNCHEZ, Jesús María. La expansión del Derecho..., op. cit., pp. 61- 69. 
como en Alemania, pero en su opinión se trata de una cuestión de grado de evolución de sistema, por lo cual el ordenamiento jurídico penal español pronto llegará al nivel del país germano, donde prácticamente ya no se utilizan los delitos de peligro concreto en las reformas penales ${ }^{222}$.

Al moderno Derecho Penal se le cuestiona en conjunto, que con el adelantamiento de la barrera de intervención penal y con la configuración de nuevos bienes jurídicos relativos al sistema, así como con la flexibilización de las estructuras y principios del Derecho Penal consustanciales al Estado de Derecho, se está ampliando en diversos sentidos la estructura de la imputación penal orientada básicamente a la idea de daño o lesión. Creando de esta manera un derecho preventivo simbólico que a la larga resulta ineficaz y contraproducente por falta de autoridad y de suficiente legitimidad desde el punto de vista de los principios informadores del Estado de Derecho ${ }^{223}$. Resulta muy importante en nuestra opinión recordar que hay muchos autores que no forman parte de las corrientes enfrentadas en este tema que, por su carácter crítico y en parte conciliador con la necesidad de buscar soluciones a los nuevos problemas, aceptan, con algunas reservas, la asunción por el Derecho Penal de los ámbitos de regulación constituidos por los nuevos riesgos, pero defendiendo la puesta en práctica de tal tutela, en su caso, con total respeto a los principios básicos de garantía del "Derecho Penal del Estado de Derecho y a las estructuras clásicas de la imputación de la responsabilidad penal"224.

Uno de los rasgos que mejor caracteriza al moderno Derecho Penal es la creciente utilización de los delitos de peligro abstracto, así como los delitos de emprendimiento o de consumación anticipada y la punición especifica de actos preparatorios. Pretendiendo con este adelantamiento de la barrera de protección penal obtener una mejoría de la seguridad y de la propia sensación de seguridad. MENDOZA BUERGO, Blanca. El Derecho Penal..., op. cit. en la sociedad de riesgo. Ed. Civitas. Madrid. 2001, pp. 84- 91.

GARCÍA-PABLOS DE MOLINA, Antonio. Introducción al estudio..., op. cit., , pp. 577- 579. MENDOZA BUERGO, Blanca. El Derecho Penal..., op. cit., p. 111. PRITTWITZ, Cornelius. "Sociedad de riesgo..., op. cit., pp. 284- 287.

224 Entre los autores que sostienen esta posición en la doctrina alemana podemos citar a: Roxin, Hirsch, Frisch, o Köhler y a pesar de las diferencias la de Prtitwitz. Kindhäuser aunque es decidido defensor del Derecho Penal del riesgo o de la seguridad, no renuncia al respeto de las garantías y al carácter de ultima ratio del Derecho Penal. En 


\section{EL TRÁFICO DE PRECURSORES DE DROGAS COMO DELITO DE PELIGRO ABSTRACTO}

Iniciamos este apartado recordando que por delitos de peligro abstracto debemos entender aquellos en los que el legislador decide su sanción tomando como base la experiencia, la peligrosidad general de determinadas conductas (teoría de la peligrosidad general) para el bien jurídico tutelado, de tal manera que basta con la realización del comportamiento típico para cometer el delito de forma consumada, así el autor, será castigado aun cuando en el caso concreto la acción "no hubiera dado lugar a un auténtico peligro, razón por la cual se afirma que en estos delitos el peligro no constituye un elemento del tipo de injusto, por lo cual se parte de un juicio de probabilidad estadística, en el que no se pronostica un daño concreto, sino una relación estadística entre un cierto tipo de comportamientos y un resultado lesivo.

En nuestra opinión para sostener la fundamentación de la antijuricidad material de un delito de peligro abstracto no basta con un mero desvalor de acción que se materializa en la peligrosidad de la conducta, pues sin la presencia del desvalor de resultado, debiendo diferenciarse entre el resultado material que sólo concurre en los delitos de resultado y el resultado jurídico que debe estar presente en todos los ilícitos, no se cumple con el principio de lesividad de forma cabal, por ello creemos que en todo delito de peligro, la conducta realizada debe manifestarse como idónea para afectar a un bien jurídico, lo que supone no colocar a este en una situación que no quedaría explicada por la contemplación solamente de la acción, por lo tanto hay que concluir que la peligrosidad de la acción, incluso en los delitos de peligro abstracto, debe comportar un riesgo de menoscabo que, por lo menos a nivel lógico, se pueda distinguir de la acción propiamente dicha. Como todos sabemos un sector muy importante de la doctrina española exige la presencia de una auténtica aptitud lesiva de la acción de estos delitos, que se materialice en que la conducta posea la idoneidad objetiva para lesionar o poner en peligro concreto un bien jurídico colectivo. Sin embargo como todos sabemos la discusión que

la doctrina española con importantes diferencias entre ellos, podríamos agrupar aquí a: Silva Sánchez, Paredes Castañón, Rodríguez Montañés y Corcoy Bidásolo. MENDOZA BUERGO, Blanca. El Derecho Penal..., op. cit., pp, 120, 121, 129, 130. 
se ha generado en este sentido, lamentablemente, aún no ha conducido a conclusiones reconocidas de forma general, no obstante existe un consenso significativo sobre la necesidad de distinguir distintos grupos de casos con problemas configurados de forma diferente.

Nosotros queremos centrarnos particularmente en tres de las posiciones desarrolladas en la doctrina española para otorgar legitimidad a los delitos de peligro abstracto, la primera de ellas es la que planteara el profesor Bustos Ramírez que sostiene que la protección se puede optimizar si se parte de una correcta determinación del bien jurídico, lo cual evitaría tipificar conductas abstractamente peligrosas, dado que la correcta determinación del bien jurídico colectivo puede permitir establecer un desvalor real capaz de fundamentar la antijuricidad material y, por ende, indicarnos las conductas que verdaderamente son merecedoras y necesitadas de pena por comportar una lesión o puesta en peligro concreto, no de los bienes jurídicos complementados (individuales), sino de los bienes jurídicos complementarios (colectivos). Desde esta perspectiva se puede asumir que las conductas comprendidas en los delitos relativos al tráfico de drogas tipificadas en el artículo $368 \mathrm{CP}$, sobre todo las relativas al tráfico o favorecimiento del consumo ilegal de estas sustancias ilícitas tales como el almacenamiento y deposito, transporte, exportación, importación, tránsito y sobretodo la enajenación y la correlativa adquisición de la sustancia estupefaciente, la donación o bien el promover, favorecer o facilitar el consumo ilegal de drogas de otro modo pueden suponer la lesión o un peligro concreto para el bien jurídico salud pública225.

225 En el caso del cultivo y la elaboración de drogas ilícitas nos encontramos ante actividades preparatorias encaminadas a la producción de la droga, "que la previsión del legislador ha tipificado como delito en sí, en cuanto constituye antecedente necesario para la obtención del producto cuyo destino al tráfico se vislumbra". No importando que el tráfico aparezca como algo remoto si se prevé como posible. SOTO NIETO, Francisco. El delito de tráfico ilegal de drogas. Su relación con el delito de contrabando. Ed. Trivium. Madrid. 1989, p. 51. El Código Penal equipara las conductas de cultivo y elaboración de drogas a las de tráfico de drogas siempre que estas estén dirigidas a promover, favorecer o facilitar el consumo de drogas por terceras personas. MOLINA MANSILLA HUIDOBRO, Luis Fernando. El Delito de Tráfico de Drogas. Aspectos Penales y Procesales. Ed. Tirant lo Blanch. Valencia. 1999, p. 53. 
Entendemos que la protección de este bien jurídico, desde esta perspectiva, a través del artículo $371 \mathrm{CP}$ en principio no estaría justificada, pues este tipo penal sanciona la fabricación, distribución, comercio o tenencia de precursores de drogas a sabiendas de que van a utilizarse en la elaboración de drogas ilícitas o para estos fines, lo cual a pesar del plus de peligrosidad que le aportan la obligación de comprobar los elementos subjetivos "a sabiendas de" o "para estos fines" por parte del juzgador, no representa un peligro concreto para el bien jurídico tutelado. No obstante queremos poner de manifiesto que en el caso de la tenencia de precursores de los estimulantes de tipo anfetamínico tales como la efedrina, la seudoefedrina, la norefedrina, la P-2-P, el ácido fenilacético, la 3,4-MDP-2-P, piperonal, el ácido lisérgico, la ergotamina, la ergometrina, el ácido $N$-acetilantranílico o la piperidina ${ }^{226}$ en nuestra opinión la posibilidad de menoscabo del bien jurídico salud pública resulta un poco menos distante, pues estas sustancias son la materia prima principal para la elaboración de drogas de síntesis, más aún si está se realiza en emplazamiento cercanos a los laboratorios o en los propios laboratorios donde se elaborará la droga, pues equivale a tener en estos una remesa de hojas de coca, incluso pasta de coca, o el latex de la adormidera listas para proceder a fabricar cocaína o heroína, por lo tanto podrían equiparase a la fase final del cultivo de drogas o a la inicial de la elaboración de las mismas. Sin embargo queremos precisar que en el delito de tráfico de precursores de drogas se exige a través del elemento subjetivo adicional el conocimiento por parte del autor o de los autores de que dichas sustancias serán utilizadas en la fabricación ilícita de drogas o para estos fines, mientras que las conductas preceptuadas en el artículo 368 CP se requiere, algo más, que el autor o los autores

226 Estos 12 precursores (11 del Cuadro I y 1 del Cuadro II) del Convenio de Naciones Unidas de 1988 son la materia prima principal para la elaboración de los siguientes estimulantes de tipo anfetamínico: la anfetamina, la metanfetamina, el MDA (tenamfetamina o píldora del amor), MDMA (éxtasis), MDE (Eva), N-hidroxi-MDA (Hidroxilamina), ácido lisérgico, metacualona, meclocualona y fenciclidina. De las otras cinco sustancias catalogadas del Cuadro I del Convenio antes citado tres se utilizan para elaborar precursores de drogas en los laboratorios clandestinos, el safrol para fabricar isosafrol, piperonal y 3,4-MDP-2-P, el isosafrol para elaborar piperonal y 3,4MDP-2-P, y el APAAN para fabricar P-2-P. Mientras que el Anhídrido acético y el permanganato de potasio son los precursores principales para elaborar heroína y cocaína respectivamente. 
pretendan "la difusión del consumo ilegal"227. Excluyendo de esta manera aquellas conductas concernientes al autoconsumo, lo cual en nuestra opinión bebería estipularse también para el delito de tráfico de precursores de drogas en aras de solventar un poco los problemas de legitimidad que adolece este ilícito penal.

En caso del artículo 373 del CP en que sanciona; la provocación, la conspiración y la proposición del tráfico de precursores de drogas tóxicas, estupefacientes y psicotrópicos, no podemos decir otra cosa, se produce un adelantamiento de la barrera punitiva a todas luces insostenible, pues se sancionan los actos preparatorios de los actos preparatorios de tráfico de drogas o en el mejor de los casos los actos preparatorios de la tentativa del tráfico de drogas, por lo cual la posibilidad de poner en peligro concreto el bien jurídico complementario (la salud pública) es más que remota y por lo tanto carece totalmente de legitimidad.

La otra idea que queremos destacar es la sostenida por el profesor Torío López quien propuso que cuando se tenga que recurrir, por no existir otra opción, a los delitos de peligro abstracto, debe exigirse, además del desvalor de acción, un desvalor al menos potencial de resultado, de esta manera, en la medida que se correspondan con la tipología propuesta de los delitos de peligro hipotético, cumplirían, en cierta medida, con la perspectiva dualista que se reivindica para todo ilícito penal, mientras que cuando esto no ocurra se estará penalizando un acto de mera desobediencia, ajeno a los límites del Derecho Penal. Por tanto el delito requiere una acción que por sus propiedades materiales sea susceptible de ser considerada según un juicio de pronóstico como peligrosa para el objeto de tutela, estando obligado el juez a verificar si en la situación concreta ha sido posible un contacto entre acción y bien jurídico, en cuya virtud hubiera podido producirse un peligro efectivo para éste. Nosotros creemos que con esta propuesta el delito de tráfico de precursores de drogas podría en principio estar legitimado de alguna manera 228 , sobre todo si tomamos el ejemplo que

227 JOSHI JUBERT, Ujala. Los delitos de tráfico de drogas I. Un estudio analítico del art. 368. Ed. J. M Bosch Editor. Barcelona. 1999, p. 129. REY HUIDOBRO, Luis Fernando. El Delito de Tráfico de Drogas. Aspectos Penales y Procesales. Ed. Tirant lo Blanch. Valencia. 1999, p. 53.

228 TORÍO LOPEZ, Ángel. “Los delitos de peligro hipotético..., op. cit., pp. 825-828, 838, 842. 
citamos antes sobre la tenencia de los precursores de los estimulantes de tipo anfetamínico en un local cercano al laboratorio ilícito o en el mismo donde tengan previsto elaborar anfetamina, metanfetamina, éxtasis y similares, LSD, metacualona, meclocualona o fenciclidina.

En este momento cabe recordar que el artículo $371 \mathrm{CP}$ a través del elemento subjetivo adicional "a sabiendas de" o "para estos fines" exige que el sujeto activo tenga el propósito inequívoco de utilizar los precursores para elaborar las drogas él mismo o bien que proporcione estas sustancias catalogadas a una tercera persona a sabiendas de que este los usara en la fabricación de drogas. Además no hay que olvidar que los delitos de peligro nunca reclaman un grado determinado o coeficiente matemático exacto de peligrosidad del comportamiento, así como que las conductas comprendidas en el delito de tráfico de precursores de drogas la mayoría de las veces son realizadas por auténticas mafias que operan a nivel internacional (criminalidad organizada), con bastante éxito debido a su gran capacidad económica y de innovación, utilizando los mismos métodos y medios que usan para el tráfico de drogas. No obstante entendemos las reservas que un sector muy importante de la doctrina tiene al respecto, pues la incriminación de la tentativa de los delitos de peligro, bien sea este real o potencial no debe estar legitimada ${ }^{229}$ sin más, y por ende, mucho menos la de actos preparatorios de delitos de peligro"230. En el caso del artículo $373 \mathrm{CP}$ desde esta perspectiva se puede concluir que su criminalización también carece de legitimidad por el desmesurado adelantamiento que se produce del ámbito de protección penal.

Por último es preciso señalar que para las posturas que exigen para la legitimación de los delitos de peligro abstracto que la peligrosidad este presente sólo en "el desvalor de acción" o bien aquellas que desarrollan "los delitos de peligro abstracto-concreto" o "los delitos de aptitud" las conductas comprendidas en el delito de tráfico de precursores de drogas estarían justificadas sin mayores problemas. En este sentido se

230 Ibidem., 396-398, 401. La criminalización del artículo 373 CP supone castigar un acto preparatorio de un acto preparatorio $(371 \mathrm{CP})$ de un delito de peligro abstracto $(368$ CP), algo injustificado desde el principio de lesividad. CORCOY BIDÁSOLO, Mirentxu. Comentarios al Código Penal..., op. cit., p. 816. 
pronuncia un sector importante de la jurisprudencia en España afirmando que "el peligro abstracto no debe de ser confundido con el peligro presunto, de forma que cualquier acción que cumpla objetivamente la hipótesis legal, se entienda ya per se, sin admisión de prueba o estimación en contrario, integradora del delito, pues tal tipo de presunción vulneraría el esencial derecho constitucional a la presunción de inocencia. Sobre este tema la jurisprudencia mayoritaria sostiene que peligro abstracto sólo quiere decir que en el momento de la consumación anticipada, con que el legislador ha configurado el tipo, no están concretados o determinados los sujetos portadores del bien jurídico tutelado, cuya salud va a ser puesta en peligro o afectada por el agotamiento de la acción. Pero lo que si es preciso que tal peligro, como riesgo de futura lesión de aquel bien jurídico, se encuentre realmente presente en la acción para que ésta incluya en sí el contenido de la antijuricidad penal y la adecuación al tipo necesario para su ilicitud penal"231.

Una vez que hemos realizado estas puntualizaciones, queremos decir que nosotros pensamos que una política criminal de protección autónoma de bienes jurídicos colectivos, no precisa en términos de eficacia, recurrir siempre a la punición del peligro abstracto. Nos parece necesario también señalar que la tutela autónoma de los bienes colectivos no excluye de ninguna manera la relación de complementariedad con los bienes jurídicos individuales ni su exoneración de las exigencias que se derivan de los criterios de merecimiento y necesidad de pena. También es preciso recordar en este momento el papel que debe desempeñar el principio de insignificancia para la exclusión de la tipicidad de aquellas conductas que se materializan en resultados bagatelares ${ }^{232}$, así como afirmar que es incorrecto asignar a estos tipos delictivos una función reguladora, es decir, no nos parece razonable procurar regular el desarrollo ordenado

231 STS (ROJ: 3499/1993) de 29 de mayo de 1993. Ponente D. Cándido Conde-Pumpido Ferreiro. Deben quedar excluidas de sanción aquellas conductas en que a pesar de la apariencia de realizar la conducta típica, pueda descartarse totalmente la posibilidad de generación de riesgo para el bien jurídico tutelado. SEQUEROS SAZATORNIL, Fernando. El tráfico de drogas..., op. cit., p. 72.

232 "Es evidente que nada favorece tanto la criminalidad como la penalización de cualquier injusto consistente en una nimiedad". ROXIN, Claus. Problemas básicos del Derecho Penal. (Trad. LUZÓN PEÑA, Diego Manuel.). Ed. REUS, S.A. Madrid. 1976, p. 22. 
de determinadas actividades peligrosas a través de ellos, pues no es esta una función propia del Derecho Penal, y mucho menos se debe tratar de asignarle esta misión sacrificando los principios que lo legitiman ${ }^{233}$.

De lo expuesto hasta ahora en este capítulo se deduce que nos oponemos de forma categórica a la creación de delitos de peligro abstracto que tengan como base una función meramente organizativa, como ocurre en aquellos ilícitos basados en la ausencia o infracción de una autorización o control administrativo, los cuales en nuestra opinión deben cumplir con la exigencia que plantea que el núcleo de la acción punible debe consistir en algo más que una infracción de normas administrativas, dado que de no ser así se diluye notablemente el instituto de la pena, por lo cual reivindicamos que ante la ausencia de un peligro, al menos de carácter potencial, para un bien jurídico de suficiente entidad, tales supuestos deben de sancionarse en el ámbito del Derecho Administrativo sancionador, o bien en otra área del Derecho según corresponda. Igual opinión mantenemos sobre la penalización de los denominados delitos acumulativos que vulneran de forma indudable el principio de lesividad y de proporcionalidad al desentenderse totalmente de realizar la respectiva valoración de la gravedad de la acción individual.

Por todos los problemas que se han señalado sobre los delitos de peligro abstracto, consideramos que estos deben ser evitados por el legislador, siempre que sea posible, de tal manera que se recurra a esta técnica de protección de bienes jurídicos con carácter excepcional, es decir, sólo cuando razones de política criminal lo exijan. En estos casos deberá optarse por delitos de peligro abstracto que además de acreditar la peligrosidad de la conducta (desvalor de acción) comporten un desvalor de resultado, al menos potencial o intermedio, en el que si bien no se exige un resultado estructural, si sea necesaria una cierta vinculación con el bien jurídico tutelado que responda al cumplimiento del principio de exclusiva protección de bienes jurídicos, debe tratarse por tanto de delitos en los que sea posible identificar el objeto de tutela. Por lo dicho hasta aquí queremos manifestar que debe recurrirse a la técnica de los delitos de peligro abstracto como último recurso, valga la redundancia con un plus de ultima ratio, de tal manera 
que las conductas seleccionadas representen ataques realmente graves a bienes jurídicos de la mayor importancia para que esta extrema tutela esté justificada, lo que de ninguna manera significa dar la espalda a la realidad social, pues entendemos que las transformaciones económicas y tecnológicas que han hecho surgir nuevas entidades (bienes colectivos) que cumplen con los criterios anteriormente señalados deben ser objeto de protección del Derecho Penal.

Para concluir este capítulo es necesario decir que en el caso del delito de tráfico de precursores de drogas, como ya señalamos antes, pensamos que atendiendo a principios y criterios muy asentados en teoría del delito tales como: el principio de lesividad, de fragmentariedad, subsidiaridad y ultima ratio las conductas previstas en este tipo penal no tienen la suficiente entidad para su protección de forma autónoma en el Derecho Penal mediante la técnica de los delitos de peligro abstracto, a pesar de que tutela un bien jurídico de suma importancia como la salud pública, que como todos sabemos es un bien jurídico que merece protección penal, la cual se encuentra justificada en la mayoría de supuestos establecidos en los delitos relativos al de tráfico de drogas, pero no se puede decir lo mismo en el caso de las conductas contempladas en el delito de tráfico de precursores de drogas, dado que la posibilidad de afectación de este bien jurídico es más lejana. Recordemos que se trata de actos preparatorios del delito de tráfico de drogas que por decisión del legislador se elevan a la categoría de delito autónomo, de hecho estos comportamientos no son simples infracciones formales porque tienen incorporado el elemento subjetivo adicional "a sabiendas de" o "para estos fines", de no ser así el artículo 371 CP tendría que ser declarado inconstitucional en los mismos términos que lo fue el artículo 509 del anterior Código Penal. No obstante creemos que la introducción del elemento subjetivo adicional antes mencionado permite que no se pueda afirmar con propiedad que se trate de un delito de peligro presunto que castiga un acto de mera desobediencia, pues los comportamientos de fabricar, transportar, distribuir, comerciar o tener en su poder las 24 sustancias catalogadas como precursores de drogas con la finalidad de elaborar drogas ilícitas aunque no representan la producción de un peligro efectivo para el bien jurídico salud pública, sí constituyen acciones aptas para producir un peligro a este bien jurídico, se trata por lo tanto de la posibilidad y no de la realidad, del peligro para el bien jurídico tutelado, lo cual podría permitir apreciar de alguna manera un 
desvalor potencial de resultado, como señalamos antes, no libre de críticas por un sector importante de la doctrina española.

En este sentido es importante destacar que la doctrina mayoritaria sostiene, esgrimiendo argumentos de peso, que el delito de tráfico de precursores de drogas en principio no tiene la suficiente entidad para su protección de forma autónoma en el Derecho Penal al ser un acto preparatorio de los delitos relativos al tráfico de drogas y de no cumplir con la concepción dualista del ilícito penal, a pesar de proteger un bien jurídico de suma importancia como la salud pública, por lo cual afirman que es viable pensar que suprimir el artículo $371 \mathrm{CP}$, por ser una figura de poca eficacia, no reduciría de manera significativa la protección del bien jurídico tutelado por este tipo penal, puesto que en los supuestos más graves de tráfico de precursores de drogas se podría recurrir al delito de tráfico de drogas mediante el empleo, para sancionar dichas conductas, de las reglas previstas para la autoría y participación, así como las de las formas de imperfecta ejecución, pues de hecho ya se hacía antes de la aprobación de este tipo penal ${ }^{234}$ y en

234 Refiriéndose a la aprobación de 344 bis g) Rodríguez Devesa manifiesta que se adapta de esta manera el Código Penal a lo dispuesto en el artículo 3 c), ii) del Convenio de Viena de 1988. Afirmando que en "realidad estas figuras se encontraban ya tipificadas en el artículo 344 del Código Penal, pues podían perseguirse como tentativa de los tipos que ahí se recogen". RODRÍGUEZ DEVESA, José María. SERRANO GÓMEZ, Alfonso. Derecho Penal Español. Parte Especial. Decimoctava edición. Dykinson. Madrid. 1995, pp. 1086, 1087. En el $\mathrm{m}$ ismo sentido. REY HUIDOBRO, Luis Fernando. El delito de tráfico de drogas. Aspectos penales y procesales. Ed. Tirant lo Blanch. Valencia. 1999, p. 273. Morales García señala, en relación a la ejecución de los actos de elaboración ilegal de drogas preceptuado en el artículo $368 \mathrm{CP}$, que el legislador no se conforma con la tipificación del objeto material sino que adelanta la barrera punitiva hasta cualquier acto de la cadena de producción, de esta manera bastará con la realización de cualquiera de los pasos tendentes a la obtención de la droga, siendo completamente equivalente cualquier aportación a la cadena de elaboración. QUINTERO OLIVARES, Gonzalo (Dir). MORALES PRATS, Fermín (Coord.). Comentarios al Código Penal Español. Tomo II. 6a edición. Aranzadi/Thomson Reuters. Navarra. 2011, p. 935. Es preciso decir que antes de la aprobación en la legislación española del delito de tráfico de precursores de drogas en el Código Penal, artículos 344 bis g) y 344 j), a partir de la Ley Orgánica 8/1992 de 23 de diciembre, podía sancionarse por el delito de tráfico de drogas la tenencia de precursores sin que se encontraran ni siquiera residuos de alguna droga ilícita, ni materia prima básica para su fabricación, tal es el caso de la Sentencia del Tribunal Supremo del día 13 de mayo de 1996 que condena como autor de un delito de elaboración de drogas, de las que causan grave daño a la salud, a la pena de 2 años, 4 meses y 1 día de prisión menor, y al pago de la parte proporcional de las costas que le correspondan a un sujeto que en el mes de noviembre del año 1989 le 
los casos de menor relevancia podrían sancionarse, como ya se hace, con las infracciones previstas en la Ley 4/2009 de control de precursores de drogas ${ }^{235}$ (Derecho Administrativo) donde sí se encuentra plenamente justificada la protección de este bien jurídico.

Sin embargo somos conscientes de que existen muy pocas posibilidades de que se produzca un cambio de orientación en la política criminal sobre este ilícito (que tiene ya casi 25 años de vigencia), pues España está obligada a sancionar penalmente este tipo de conductas para darle cumplimiento a sus compromisos internacionales tales como el Convenio de Viena de 1988 y otras normativas comunitarias como la Decisión Marco 2004/757/JAI del Consejo, de 24 de octubre que señala de forma expresa la necesidad de que los Estados miembros sancionen con penas máximas de 5 a 10

ocuparon en un registro en su vivienda en Villagarcía de Arosa "tres hojas tamaño folio escritas a mano, en las que se describían procedimientos relativos a la transformación de diversos productos, en cocaína, mediante el uso de sustancias químicas. Encontrando después en un alpendre, una botella de ácido clorhídrico, otra de ácido sulfúrico, otra de éter etílico, un frasco de permanganato potásico (precursores de drogas), un frasco de agua fuerte y otra de amoniaco (sustancias no catalogadas). STS (ROJ: 2847/1996) de 13 de mayo de 1996. Ponente: D. José Augusto de Vega Ruiz. También el tráfico de precursores se castigaba algunas veces como un delito de tráfico de drogas en grado de conspiración. Así lo ratifico el Tribunal Supremo en su Sentencia de 30 de junio de 1995 en el caso de cinco personas que en el mes de noviembre de 1990 en Murcia tomaron la decisión de fabricar y comercializar algún o algunos de los derivados de la cocaína como el "basuco" e inclusive clorhidrato de cocaína a partir de pasta base de esta sustancia. Para lo cual se dieron a la tarea de adquirir pequeñas cantidades de algunos precursores en la zona, los que posteriormente les decomisaron, siendo estos ácido sulfúrico, acetona y ácido clorhídrico y de otras sustancias no catalogadas como el etanol, así como dos ollas express y un manuscrito donde aparecían un listado de sustancias y equipos necesarios que podrían servir para elaborar la droga. El laboratorio clandestino, rudimentario, lo pensaban montar en un remolque en las afueras de la ciudad, ahí estaban reunidos sin empezar a fabricar "basuco" o cocaína y sin tener la necesaria pasta base (materia prima), cuando fueron detenidos por dos oficiales de la Guardia Civil. Los cinco acusados fueron condenados por el Tribunal de Instancia como autores responsables de un delito contra la salud pública del artículo 344 del Código Penal, en grado de conspiración, sin la concurrencia de circunstancias modificativas de la responsabilidad criminal a la pena de cuatro meses y un día de arresto mayor y accesorias de suspensión de todo cargo público y derecho de sufragio durante el tiempo de sus condenas y con multa de 500.000 pesetas a cada uno. STS (ROJ: 3860/1995) de 30 de junio de 1995. Ponente: D. Joaquín Martín Canivell.

235 Vid., en el Anexo I la Ley 4/2009, de 15 de junio, de control de precursores de drogas. 
años los delitos de tráfico de precursores de drogas cuando se cometan en el seno de una organización criminal. Además es necesario puntualizar que quienes mayoritariamente realizan las conductas preceptuadas en el delito de tráfico de precursores de drogas son organizaciones criminales que operan a nivel internacional, con mucho éxito debido a su gran capacidad económica y de innovación, valiéndose de los mismos métodos y medios que usan para el tráfico de drogas. De hecho pese a todo el esfuerzo que se realiza a nivel mundial, haciendo uso del ordenamiento penal, del administrativo sancionador y de una parte muy importante de todos los recursos de los cuerpos y fuerzas de seguridad, sólo permite confiscar anualmente el 15\% de los precursores que se utilizan para la elaboración de la cocaína y la heroína, y el 20\% de los estimulantes de tipo anfetamínico, lo cual nos hace dudar sí podría enfrentarse esta área de la narcoactividad en buena medida sin la intervención del Derecho Penal, y de su tutela adelantada mediante un delito de peligro abstracto, sumamente cuestionado, como el preceptuado en el artículo 371 del Código Penal, y de la aplicación de medidas como la entrega vigilada, el uso de agentes encubiertos o las intervenciones telefónicas ajenas al Derecho Administrativo. En todo caso nosotros ante la imposibilidad real de derogación del delito antes mencionado nos proponemos trabajar en el capítulo correspondiente al tipo objetivo en aras de ofrecer unas pautas de interpretación lo más seguras posibles y respetuosas tanto de los principios básicos de Derecho Penal, como del Estado Social y Democrático de Derecho ${ }^{236}$, que parten de la exigencia de la

236 Somos conscientes de que es muy difícil de que este tipo penal sea suprimido, no por su evolución en la práctica jurídica, que es bastante escasa, sino más bien porque este se introdujo en el ordenamiento penal español hace 23 años para darle cumplimiento al Convenio de Viena de 1988 y demás normas comunitarias sobre el tráfico de precursores. Para que nos hagamos una idea del alcance de la aplicación de este Convenio internacional hay que decir que un total de 189 Estados o territorios del mundo sancionan estas conductas en sus ordenamientos penales internos (lo que representa el $95.45 \%$ del total de países o territorios). Precursores y sustancias químicas frecuentemente utilizados para la fabricación ilícita de estupefacientes y sustancias sicotrópicas. Informe de la Junta Internacional de Fiscalización de Estupefacientes correspondiente a 2014 sobre la aplicación del artículo 12 de la Convención de Naciones Unidas contra el Tráfico Ilícito de Estupefacientes y Sustancias Sicotrópicas de 1988. JUNTA INTERNACIONAL DE FISCALIZACIÓN DE ESTUPEFACIENTES. Ed. Naciones Unidas. New York. 2015, p. 7. Sobre la legitimidad de los delitos de peligro abstracto Roxin señala que donde "una conducta peligrosa prohibida está claramente descrita y si es claramente visible su referencia al bien 
comprobación judicial de que en la situación concreta ha sido posible un contacto entre la acción y el bien jurídico, en cuya virtud hubiera podido producirse un peligro efectivo a éste, o al menos como un mal menor un peligro de carácter potencial 237.

jurídico y tampoco se vulnera el principio de culpabilidad, entonces son inobjetables incluso los delitos de peligro abstracto", citando como ejemplo de ello el artículo 316 del Código Penal alemán que sanciona la conducción de vehículos a motor bajo la influencia de bebidas alcohólicas. ROXIN, Claus. Derecho Penal. P. G..., op. cit., p. 60. Cerezo Mir sostiene que el tráfico de precursores de drogas es un delito de "peligro abstracto de aptitud" o de "peligro abstracto concreto" por lo cual está legitimada su criminalización. CEREZO MIR, José. “Los delitos de peligro...,op. cit., pp. 745, 746.

237 TORÍO LÓPEZ, Ángel. “Los delitos de peligro hipotético..., op. cit., pp. 846, 847. 
CAPÍTULO VI

\section{CONFIGURACIÓN LEGAL DEL DELITO DE TRÁFICO DE PRECURSORES DE DROGAS}

\section{INTRODUCCIÓN}

España firmó la Convención de Naciones Unidas contra el Tráfico Ilícito de Estupefacientes y Sustancias Psicotrópicas hecha en Viena el 20 de diciembre de 1988, ratificando dicho instrumento internacional en el ordenamiento jurídico interno el día 30 de julio de 1990 (BOE núm. 270), ajustando de esta manera la legislación española a las obliga ciones internacionales que impone este Convenio, así como a los reglamentos y directivas comunitarias sobre el tema. La parte correspondiente al tráfico de precursores de este Convenio se incorporó en el ordenamiento español en el Derecho Administrativo en la Ley 3/1996, sobre medidas de control de sustancias químicas catalogadas, susceptibles de desvío para la fabricación ilícita de drogas ${ }^{1}$, y en el ordenamiento penal en los artículos 344 bis g) y 344 bis j) del Código Penal anterior (a partir de la Ley Orgánica 8/1992, del 23 de diciembre $)^{2}$, y que actualmente se encuentra preceptuado en el artículo 371 del Código Penal vigente, que establece:

1 Como antecedentes de esta norma en el ordenamiento jurídico español queremos citar por su importancia la Orden del 10 de diciembre de 1991 (RLC 11991/2969), del Ministro de Relaciones con las Cortes y de la Secretaría del Gobierno, la cual se creó con la finalidad de regular algunos aspectos de competencia, como los referidos a la designación de la autoridad competente para el otorgamiento y supervisión de las autorizaciones de exportación de las sustancias catalogadas. Esta Orden posteriormente fue derogada por la Orden del 15 de noviembre de 1994 (RLC 1994/3244), del Ministro de la Presidencia, por la que se regula el control de los precursores de drogas, donde se desarrolla ya de mejor forma los requisitos y trámites para la importación, exportación y tránsito de los precursores de drogas. Posteriormente la Ley 3/1996 fue derogada por la Ley 4/2009, de 15 de junio, de control de precursores de drogas.

2 El artículo 344 bis g) integra y literalmente dice: "El que fabricare, transportare, distribuyere, comerciare o tuviese en su poder los equipos, materiales o sustancias enumeradas en el cuadro I y Cuadro II de la Convención de Naciones Unidas, hecha en Viena el 20 de diciembre de 1988, sobre el tráfico ilícito de estupefacientes y 
“1. El que fabrique, transporte, distribuya, comercie o tenga en su poder equipos, materiales o sustancias enumeradas en el Cuadro I y Cuadro II, de la Convención de Naciones Unidas, hecha en Viena el 20 de diciembre de 1988, sobre el tráfico ilícito de estupefacientes y sustancias psicotrópicas, y cualesquiera otros productos adicionados al mismo Convenio, o que se incluya en otros futuros Convenios de la misma naturaleza, ratificados por España, a sabiendas de que van a utilizarse en el cultivo, la producción o la fabricación ilícitas de drogas tóxicas, estupefacientes o sustancias psicotrópicas, o para estos fines, será castigado con la pena de prisión de tres a seis años y multa del tanto al triplo del valor de los géneros y efectos.

2. Se impondrán las penas privativas de libertad, en su mitad superior (de cuatro años y seis meses a seis años), cuando las personas que realicen los hechos descritos en el apartado anterior pertenezcan a una organización dedicada a los fines en él señalados, y la pena superior en grado (de seis a nueve años) cuando se trate de jefes, administradores o encargados de las referidas organizaciones o asociaciones".

sustancias psicotrópicas, y cualesquiera otros productos adicionados al mismo Convenio o en otros futuros Convenios o Convenciones, ratificados por España, a sabiendas de que van a utilizarse en el cultivo, la producción o la fabricación ilícitas de drogas tóxicas, estupefacientes o sustancias psicotrópicas, o para estos fines, será castigado con las penas de prisión menor y multa de uno a cien millones de pesetas". Como se puede apreciar este artículo se corresponde al apartado 1 del actual artículo 371 , siendo los supuestos de hechos prácticamente iguales, lo cual no ocurre con la parte correspondiente a la consecuencia jurídica, pues la prisión menor consistía en la privación de libertad de seis meses y un día a seis años, así que la pena máxima a imponer era la misma (seis años), pero la pena mínima establecida era bastante menor en el Código Penal anterior seis meses y un día (actualmente tres años). También era diferente la forma de calcular la pena de multa que se debía aplicar; de 6.010,12 euros a 601.012,10 euros en el CPA y el tanto al triplo del valor de los géneros y efectos en el actual Código Penal. El artículo 344 bis j), que se corresponde con el apartado 2 del artículo 371, preceptuaba: "En los supuestos previstos en los artículos 344 bis g), 344 bis h) y 344 bis i) se impondrán las penas privativas de libertad en su grado máximo (de 4 años y 2 meses a 6 años) a las personas que pertenecieran a una organización dedicada a los fines señalados en los mismos (mientras que en la legislación actual es de 4 años y medio a 6 años), siendo la pena superior en grado (de 6 años a 9 años, tanto en el Código Penal anterior como en el actual) que correspondía a los jefes, administradores o encargados de las referidas organizaciones o asociaciones. En tales casos los Jueces o Tribunales imponían, además de las penas correspondientes, la de inhabilitación especial y las demás medidas previstas en el artículo 344 bis b)”, siendo estas: a) disolución de la organización o clausura definitiva de sus locales o de los establecimientos abiertos al público, b) suspensión de las actividades de la organización o clausura de los establecimientos abiertos al público por tiempo de seis meses a tres años, c) prohibición a la misma de realizar aquellas actividades, operaciones mercantiles o negocios, en cuyo ejercicio se haya facilitado o encubierto el delito, por tiempo de dos meses a dos años. 
En tales casos, los jueces y tribunales impondrán además de las penas correspondientes, la de inhabilitación especial del reo para el ejercicio de su profesión o industria, por un tiempo de tres a seis años, y las demás medidas previstas en el artículo 369.23. Hay que aclarar que estas medidas no se pueden aplicar porque dicho apartado fue suprimido por el artículo único 105 de la Ley Orgánica 5/2010, de 22 de junio4.

3 El apartado 2 del artículo 369 se suprime por mandato de la Ley Orgánica 5/2010, de 22 de junio, por lo cual la última parte del inciso 2 del artículo 371 que dice "y las demás medidas previstas en el artículo 369.2" no tiene ninguna validez. El artículo 369.2 establecía que debía de realizarse el comiso de los bienes objeto del delito y de los productos y beneficios obtenidos directa o indirectamente del acto delictivo y, además, la autoridad judicial podría decretar alguna de las siguientes medidas: $1^{\mathrm{a}}$ La pérdida de la posibilidad de obtener subvenciones o ayudas públicas y del derecho a gozar de beneficios o incentivos fiscales o de la seguridad social, durante el tiempo que dure la mayor de las penas privativas de libertad impuestas. $2^{2}$ La aplicación de las medidas previstas en el artículo 129 de este Código: que preceptúa que el Juez o Tribunal, en los supuestos previstos en este Código, y sin perjuicio de lo establecido en el artículo 31 del mismo, previa audiencia del Ministerio Fiscal y de los titulares y sus representantes legales podría imponer, motivadamente las siguientes consecuencias: a) clausura de la empresa, sus locales o establecimientos, con carácter temporal o definitivo. La clausura temporal no podrá exceder de cinco años, b) disolución de la sociedad, asociación o fundación, c) suspensión de las actividades de la sociedad, empresa, fundación o asociación por un plazo que no podrá exceder los cinco años, d) prohibición de realizar en el futuro actividades, operaciones mercantiles o negocios de la clase de aquellos en cuyo ejercicio se haya cometido, favorecido o encubierto el delito. Está prohibición podrá tener carácter temporal o definitivo. Si tuviere carácter temporal, el plazo de prohibición no podrá exceder de cinco años. La intervención de la empresa para salvaguardar los derechos de los trabajadores o de los acreedores por el tiempo necesario y sin que exceda de un plazo máximo de cinco años. Tanto el artículo 369.2 como el artículo 129 se corresponden a la modificación realizada por la Ley Orgánica 15/2003 la cual estuvo en vigor hasta el día 22 de diciembre del año 2010.

4 LAMARCA PÉREZ, Carmen (Coord.). Derecho Penal. Parte Especial. 6a edición. Colex. Madrid. 2011, p. 565. El último párrafo ya no será aplicable al haber quedado sin contenido el artículo 369.2 al que se remite, y además hay que señalar que la pertenencia a una organización dedicada al tráfico de precursores de drogas entra en concurso con la nueva regulación que se efectúa en el nuevo Capítulo VI del Título XXII del Libro II, que bajo la rúbrica "De las organizaciones y grupos criminales", por lo que la pena a imponer en determinados casos puede ser la establecida en este Capítulo. MARTÍNEZ PARDO, Vicente José. Los Delitos de Tráfico de Drogas: Estudio Jurisprudencial. Ed. EDISOFER S. L. Madrid. 2013, p. 306. La Ley 5/2010 afecto de forma indirecta al tráfico de precursores, por un lado, en cuanto el último párrafo ya no será aplicable al haber quedado sin contenido el artículo 369.2 al que se remite, y por otro, porque la pertenencia a una organización dedicada al tráfico de precursores entra en concurso con la nueva regulación que se efectúa en el nuevo Capítulo VI en el Título 
En una primera aproximación a este tipo penal se puede apreciar que en este se produce un claro adelantamiento de la barrera de protección penal, que sanciona comportamientos que en principio no deberían de trascender del orden administrativo, pero que en atención a los fines perseguidos, trasforman estos ilícitos administrativos en ilícitos penales $^{5}$. La doctrina mayoritaria, en esta línea, sostiene que se trata de simples actos preparatorios o a lo sumo de formas de imperfecta ejecución del delito de tráfico de drogas elevado a la categoría de delito autónomo ${ }^{6}$. Hay que decir que la inclusión de este tipo penal tanto en la legislación española como en otros ordenamientos jurídicos de nuestro entorno responde a la tendencia que en las últimas tres décadas se ha desencadenado mediante la internacionalización de la lucha contra el narcotráfico, la que en opinión de Hans-Jörg Albrecht, se ha caracterizado fundamentalmente por: a) un cambio en los supuestos clásicos de la responsabilidad penal, que está lejos de ocuparse de la afección de bienes jurídicos, cuya consecuencia inmediata es el establecimiento de

XII del Libro II, bajo la rúbrica "De las organizaciones y grupos criminales" y, por tanto la pena a imponer en determinados casos pude ser la establecida en este capítulo. Circular no 3/2011 sobre la reforma del Código Penal efectuada por la ley Orgánica 5/2010, de 22 de junio, en relacion con los delitos de tráfico ilegal de drogas y de precursores.

$5 \quad$ SEQUEROS SAZATORNIL, Fernando. El tráfico de drogas..., op. cit., p. 263.

6 MUÑOZ CONDE, Francisco. Derecho Penal. Parte Especial. 18a edición. Ed. Tirant lo Blanch. Valencia. 2010, p. 676. VIVES ANTÓN, Tomas S. y otros autores. Derecho Penal. Parte Especial. Ed. Tirant lo Blanch. Valencia. 2010, pp. 611, 612. Esta opción legislativa supone el adelantamiento de la barrera punitiva del bien jurídico colectivo salud pública mediante la creación de una figura de peligro, la cual debe ser contemplada con mucha cautela desde el punto de vista dogmático. FABIÁN CAPARRÓS, Eduardo A. "Consideraciones de urgencia..., op. cit., pp. 594, 595. LAMARCA PÉREZ, Carmen. Derecho Penal. P.E..., op. cit., p. 564. LAMARCA PÉREZ, Carmen (Coord.). Delitos y Faltas. La Parte Especial del Derecho Penal. Ed. Colex. Madrid. 2012, p. 643. En el ordenamiento jurídico penal peruano el tráfico de precursores de drogas está regulado en el artículo 296. Sobre este tipo penal Peña Cabrera señala que el legislador tipifico con carácter autónomo y específico un acto anterior a la fabricación o al tráfico de drogas. Se trata de actos preparatorios que por razones de prevención general son criminalizados de modo independiente. PEÑA CABRERA FREYRE, Alonso. R. Tráfico ilícito de drogas y delitos conexos. Perspectivas dogmáticas y político-criminales. Ed. Juristas editores. Lima. 2009, pp. 130, 131. PABÓN PARRA, Pedro Alfonso. Manual de Derecho Penal. Tomo II. Parte Especial. Octava edición. Ediciones Doctrina y Ley Ltda. Bogotá D. C. 2011, pp. 778, 779. CASTRO CUENCA, Carlos G. (Coord.). Manual de Parte Especial. Tomo II. Ed. THEMIS S. A. Bogotá. 2011, p. 603. 
los delitos de peligro abstracto como principal fórmula para dar respuesta al problema, y b) la introducción de sanciones que se desvinculan de la responsabilidad a título de culpa y que imponen la inversión de la carga de la prueba, o bien la pura responsabilidad a título de peligro ${ }^{7}$.

Como ya hemos señalado antes, las 24 sustancias catalogadas como precursores de drogas ${ }^{8}$ por el Convenio de Viena de 1988 se utilizan de forma ilícita para la elaboración o fabricación de la cocaína, heroína y de los estimulantes de tipo anfetamínico tales como: la anfetamina, la metanfetamina, el MDMA (y sustancias análogas), el LSD, el fentanilo, la metacualona y la meclocualona entre otras drogas de diseño. De hecho sin las sustancias catalogadas no se pueden fabricar estas drogas ilícitas, creemos necesario puntualizar que en el caso de la elaboración de la cocaína y la heroína estos precursores juegan un papel esencial, y en el caso de los estimulantes de tipo anfetamínico un papel principal ya que constituyen la materia prima para la elaboración de estas drogas, siendo necesario aclarar que los precursores de drogas se usan en los laboratorios clandestinos también para separar la droga de otras sustancias lícitas en que esta se encuentra enmascarada, tal es el caso del empleo de éter etílico, ácido clorhídrico y acetona para la

7 ALBRECHT, Hans- Jörg. Criminalidad Transnacional, Comercio de Narcóticos y lavado de Dinero. (Trad. GUERRERO PERALTA, Oscar Julián). Ed. Universidad Externado de Colombia. Bogotá. 2001, pp. 68, 69. Queremos destacar en este sentido que en el artículo 5.7 del Convenio de Viena de 1988 relativo al decomiso de los materiales, equipos y otros instrumentos destinados a ser utilizados en la producción de drogas, se estipula que "cada una de las partes considerara la posibilidad de invertir la carga de la prueba respecto del origen ilícito del supuesto producto $\mathrm{u}$ otros bienes sujetos a decomiso, en la medida que ello sea compatible con los principios de su derecho interno y con la naturaleza de sus procedimientos judiciales y otros procedimientos. ÁLVAREZ GARCÍA, F. Javier (Dir.). MANJÓN-CABEZA OLMEDA, Araceli. VENTURA PÜSCHEL, Arturo. (Coord.). Derecho Penal Español. Parte Especial. II. Ed. Tirant lo Blanch. Valencia. 2011, pp. 1256, 1257. CÓRDOBA RODA, Juan. GARCÍA ARÁN, Mercedes (Dir.). Comentarios al Código Penal. Parte Especial. Tomo II. Ed. Marcial Pons. Madrid. 2004, pp. 1553, 1554.

8 El 9 de octubre de 2014 el alfa-fenilacetoacetonitrilo (APAAN) y sus isómeros ópticos, por decisión unánime de la Comisión de Estupefacientes, es sustancia catalogada del Cuadro I de la Convención de 1988, por lo cual pasan a ser 24 sustancias catalogadas como precursores de drogas. Precursores y sustancias químicas frecuentemente utilizados..., correspondiente a 2014..., p. 7. Lista Roja (Decimocuarta edición). Actualizada en el mes de enero del año 2015. JIFE. Viena. Austria. 
separación de cocaína mezclada con café que se importó de Colombia a España9, o la utilización de acetona, metiletilcetona y ácido sulfúrico para la extracción de cocaína impregnada en cloruro de polivinilo flexible triturado proveniente de Venezuela ${ }^{10}$ o el uso de acetona, éter etílico, ácido clorhídrico para extraer cocaína de virutas de madera triturada11, incluso hay que puntualizar que se han incautado precursores como la acetona, el ácido clorhídrico y la metiletilcetona en laboratorios donde únicamente se dedicaban a la modificación del índice de riqueza de la cocaína (corte) para elevar su nivel de beneficios $^{12}$. No obstante, queremos recordar una vez más que todas las sustancias catalogadas como precursores juegan un papel fundamental en el desarrollo de las distintas ramas de la industria, tratándose por lo tanto de sustancias necesarias para la vida de las personas de las cuales no podemos prescindir, destacamos en este sentido: el ácido antranílico, el ácido $N$-acetilantranilico, el ácido fenilacético, el ácido lisérgico, el anhídrido acético, la efedrina, la seudoefedrina, la norefedrina, la ergometrina, la ergotamina, la piperidina y el piperonal que se utilizan en la industria farmacéutica para la elaboración de una gran variedad de medicamentos.

Desde ya queremos poner de relieve que la pena privativa de libertad establecida para el tráfico de precursores de drogas, de tres a seis años de prisión, después de la reforma realizada en el año 2010 al artículo 368 que sanciona el delito de tráfico de drogas, es superior a la preceptuada para el tráfico de las denominadas drogas blandas y la misma con la que se sanciona el tráfico de las drogas duras, lo cual evidentemente resulta desproporcionado al ser el tráfico de sustancias catalogadas un acto preparatorio del delito de tráfico de drogas, y no es

$9 \quad$ STS (ROJ: 4580/1995) de 18 de septiembre de 1995. Ponente: D. Luis Román Puerta Luis.

10 SAN (ROJ: 8185/2005) de 3 de noviembre de 2005. Ponente: D. Felix Alonso Guevara Marcos. SAN (ROJ: 6508/2006) de 21 de julio de 2006. Ponente: D. Juan Francisco Martel Rivero.

11 STS (ROJ: 583/2004) de 3 de febrero de 2004. Ponente: D. Enrique Bacigalupo Zapater. SAP de Madrid (ROJ: 15967/2005) de 17 de noviembre de 2005. Ponente: D. Juan Francisco Martel Rivero.

12 STS (ROJ: 7815/2007) de 15 de noviembre de 2007. Ponente: D. Juan Artemio Sánchez Melgar. SAP de Madrid (ROJ: 2827/2009) de 16 de marzo de 2009. Ponente: D. Jesús Ángel Guijarro López. 
que critiquemos la reducción de pena realizada por el legislador para el tráfico de drogas duras, sino que no lo haya hecho también con el tráfico de precursores donde la posibilidad de lesión del bien jurídico salud pública es mucho más distante. Por ello consideramos que esta equiparación de penas es manifiestamente desafortunada, ya que no se debería sancionar con la misma pena el tráfico de metanfetamina que el tráfico de uno de los precursores que sirven para elaborar esa droga como la efedrina. En atención a la menor gravedad objetiva de la conducta de conformidad al principio de proporcionalidad. Este tema lo desarrollaremos con mayor amplitud en el apartado correspondiente a la pena privativa de libertad.

\section{ANÁLISIS DE LOS ELEMENTOS DEL TIPO}

A.) EL BIEN JURÍDICO PROTEGIDO

Como ya señalamos en el cuarto capítulo de este trabajo, la doctrina mayoritaria sostiene que es la salud pública o colectiva el bien jurídico tutelado en los delitos relativos al tráfico de drogas ${ }^{13}$, postura que

13 En esta línea SERRANO GÓMEZ, Alfonso, SERRANO MAÍLLO, Alfonso. Derecho Penal. Parte Especial. Ed. Dykinson. Madrid. 2010, pp. 697, 715. ARROYO ZAPATERO, Luis. "Aspectos Penales del Tráfico de Droga" en Revista de la Facultad de Derecho de la Universidad Complutense de Madrid No 6 (Monográfico). Madrid. 1985, p. 32. VIVES ANTÓN, Tomas S. Derecho Penal. P.E..., op. cit., p. 608. MUÑOZ CONDE, Francisco. Derecho Penal. P.E..., op. cit., pp. 672- 674. ARROYO ZAPATERO, Luis. BERDUGO GÓMEZ DE LA TORRE, Ignacio. FERRÉ OLIVÉ, Juan Carlos. GARCIA RIVAS, Nicolás. SERRANO PIEDECASAS, José Ramón. TERRADILlOS BASOCO, Juan María (Directores). Comentarios al Código Penal. Ed. Iustel. Madrid. 2007, pp. 812, 820. BACIGALUPO, Enrique. Estudios sobre la Parte Especial del Derecho Penal. Segunda edición. Akal/iure. Madrid. 1994, p. 158. MORA ALARCÓN, José Antonio. Suma de Derecho Penal. Parte General y Parte Especial. Ed. Edisofer. S. L. Madrid. 1996, p. 526. QUINTERO OLIVARES, Gonzalo (Dir.). Comentarios a la Parte Especial del Derecho Penal. 9a Edición. AranzadiThomson Reuters. Navarra. 2011, pp. 1488, 1489. REY HUIDOBRO, Luis Fernando. El Delito de Tráfico de Drogas. ..., op. cit., p. 104. REY HUIDOBRO, Luis Fernando. El Delito de Tráfico de Estupefacientes. ..., op. cit., p. 138. JOSHI JUBERT, Ujala. Los delitos de tráfico de drogas I. Un estudio analítico del art. 368. Ed. J. M Bosch Editor. Barcelona. 1999, p. 40. GARCÍA-PABLOS de MOLINA, Antonio. "Bases para una política criminal de la droga" La problemática de la droga en España. (Análisis y propuestas políticocriminales). Edición conjunta de los Institutos Universitarios de Criminología de la Universidad de Santiago de Compostela y Universidad Complutense de Madrid. Edersa. 1986, pp. 371 y ss. LUZÓN PEÑA, Diego Manuel. "Problemas del tráfico de drogas en la jurisprudencia” Simposio sobre la droga. Aspectos Jurídicos. Ejemplar mecanografiado. 
nosotros compartimos, y por ende del tráfico de precursores de drogas, dado que el artículo 371 tiene una dependencia directa con el artículo 368 del CP. Con la particularidad que en el caso del tráfico de precursores el grado en que se afecta el bien jurídico tutelado "salud pública" es más abstracto que el que se sanciona en los artículos 368 y $369 \mathrm{CP}$, pues se trata de conductas más distantes en el tiempo al propio

Madrid 2-6 de febrero de 1981, p. 13. CARBONELL MATEU, Juan Carlos. "Consideraciones técnico-jurídicas en torno al delito de tráfico de drogas". La problemática de la droga en España. (Análisis y propuestas político criminales). Edición conjunta de los Institutos Universitarios de Criminología de la Universidad de Santiago de Compostela y Universidad Complutense de Madrid. Edersa. Madrid. 1986, pp. 337341. CORCOY BIDÁSOLO, Mirentxu. Comentarios al Código Penal...., op. cit., p. 782, 800. SAAVEDRA RUIZ, Juan (Dir.). Código Penal comentado, con jurisprudencia sistematizada y concordancias. Segunda edición. El Derecho. Madrid. 2011, p. 1139. LAMARCA PÉREZ, Carmen (Coord.). Derecho Penal. P.E..., op. cit. pp. 508, 509, 545. LAMARCA PÉREZ, Carmen (Coord.). Delitos y Faltas. ..., op. cit., pp. 619, 620. CORREA DE CARVALHO, José Theodoro. Tráfico de Drogas: Prueba Penal y Medidas Restrictivas de Derechos Fundamentales. Ed. Jurua. Lisboa. 2010, pp. 61, 62. BLANCO LOZANO, Carlos. Tratado de Derecho Penal Español. Tomo II. El Sistema de la Parte Especial. Volumen 2. Delitos contra los bienes jurídicos colectivos. J.M. Bosch. Editor. Barcelona. 2005, p. 386. SARAVIA TOlEDO, Rogelio. VILlADA, Jorge Luis. Curso de Derecho Penal. Parte Especial. Ed. Virtudes. Argentina. 2003, pp. 970, 971, 995. MORALES GARCIA, Oscar (Dir.). Código Penal con Jurisprudencia. Ed. Thomson Reuters/Aranzadi. 2013, p. 838. CLIMENT DUTANT, Carlos. Código Penal. Jurisprudencia sistematizada. 4a Edición. Tirant lo Blanch. Valencia. 2011, p. 1777. CARDONA TORRES, Juan. Derecho Penal. Parte Especial. Editorial Bosch. S.A. Barcelona. 2010, pp. 426, 437. PABON PARRA, Pedro Alfonso. Manual de Derecho Penal. Tomo II. Parte Especial. Octava Edición. Ediciones Doctrina y Ley. Ltda. Bogotá. 2011, p. 749. ÁLVAREZ GARCÍA, F. Javier. Derecho Penal Español. ..., op. cit., pp. 1258- 1264. ÁLVAREZ GARCIA, F. Javier (Dir.). El Delito de Tráfico de Drogas. Ed. Tirant lo Blanch. Valencia. 2009, pp. 21-25. TERRADILLOS BASOCO, Juan María. Lecciones materiales para el estudio del Derecho Penal. Tomo III. Derecho Penal. Parte Especial. Volumen II. Ed. Iustel. Madrid. 2011, pp. 45, 46, 55. FABIÁN CAPARRÓS, Eduardo A. "Consideraciones de urgencia sobre la Ley Orgánica 8/1992, de 23 de diciembre, de modificación del Código Penal y de la Ley de Enjuiciamiento Criminal en materia de tráfico de drogas" en Anuario de Derecho Penal y Ciencias Penales, tomo XLVI, fasc. 2. Madrid, mayo-agosto 1993, p. 594. CóRDOBA RODA, Juan. Comentarios al Código Penal..., op. cit., pp. 1554-1557. MOLINA MANSILLA, María del Carmen. El Delito de Narcotráfico..., op. cit., pp. 25, 29, 30. MOLINA MANSILLA, María del Carmen. "El delito de tráfico de drogas..., op. cit., pp. 277, 298. SUÁREZ-MIRA RODRÍGUEZ, Carlos (Coord.). Manual de Derecho Penal. Tomo II. Parte Especial. Sexta Edición. Aranzadi/Thomson Reuters. Navarra. 2011, p. 427. MORILLAS CUEVAS, Lorenzo (Dir.). Sistema de Derecho Penal. Parte Especial. 2a Edición. Dikinson, S. L. Madrid, 2016, p. 1007. COBO DEL ROSAL, Manuel. Curso de Derecho Penal Español. Parte Especial II. Ed. Marcial Pons. Madrid. 1997, p. 155. 
acto de difusión de las drogas ilícitas. Siendo precisamente el objetivo del delito de tráfico de precursores de drogas el de suprimir o al menos, en términos más prácticos, reducir la oferta de drogas ilegales en el mercado. Sin embargo es necesario subrayar que en el caso de la tenencia de precursores de los estimulantes de tipo anfetamínico tales como la efedrina, la seudoefedrina, la norefedrina, la P-2-P, el ácido fenilacético, la 3,4-MDP-2-P, piperonal, el ácido lisérgico, la ergotamina, la ergometrina, el ácido $N$-acetilantranílico o la piperidina ${ }^{14}$ en nuestra opinión la posibilidad de menoscabo del bien jurídico salud pública resulta un poco menos distante, pues estas sustancias son la materia prima principal para la elaboración de drogas de síntesis, más aún si está se realiza en emplazamientos cercanos a los laboratorios o en los propios laboratorios donde se elaborará la droga, pues equivale a tener en estos una remesa de hojas de coca (incluso pasta de coca) o el latex de la adormidera listas para proceder a fabricar cocaína o heroína, por lo tanto podrían equiparase a la fase final del cultivo de drogas (recolección) o incluso a la inicial de la elaboración de las mismas (acopio de las sustancias necesarias en el laboratorio para iniciar la producción). Sin embargo queremos destacar que en el delito de tráfico de precursores de drogas como todos sabemos se exige a través del elemento subjetivo adicional el conocimiento por parte del autor o de los autores de que dichas sustancias serán utilizadas en la fabricación ilícita de drogas o para estos fines, mientras que las conductas preceptuadas en el artículo 368 y 369 CP se requiere, algo más, que el autor o los autores pretendan con los actos de cultivo o elaboración "la difusión del consumo ilegal" de las drogas ilícitas ${ }^{15}$.

14 Estos 12 precursores (11 del Cuadro I y 1 del Cuadro II) del Convenio de Naciones Unidas de 1988 son la materia prima principal para la elaboración de los siguientes estimulantes de tipo anfetamínico: la anfetamina, la metanfetamina, el MDA (tenamfetamina o píldora del amor), MDMA (éxtasis), MDE (Eva), N-hidroxi-MDA (Hidroxilamina), ácido lisérgico, metacualona, meclocualona y fenciclidina. De las otras cinco sustancias catalogadas del Cuadro I del Convenio antes citado tres se utilizan para elaborar precursores de drogas en los laboratorios clandestinos, el safrol para fabricar isosafrol, piperonal y 3,4-MDP-2-P, el isosafrol para elaborar piperonal y 3,4MDP-2-P, y el APAAN para fabricar P-2-P. Mientras que el Anhídrido acético y el permanganato de potasio son los precursores principales para elaborar heroína y cocaína respectivamente.

15 JOSHI JUBERT, Ujala. Los delitos de tráfico..., op. cit., p. 129. REY HUIDOBRO, Luis Fernando. El Delito de Tráfico de Drogas. ..., op. cit., p. 53. 
Es preciso hacer énfasis en que es la salud pública y no la individual el bien protegido, en estas normas penales, por el riesgo que representan sus formas comisivas para la colectividad ${ }^{16}$. Bacigalupo en concordancia con lo expuesto hasta aquí, sostiene que los delitos relativos al tráfico de drogas son considerados en forma general como delitos contra la salud pública, lo cual es y ha sido plenamente compartido tanto por la jurisprudencia como por la doctrina mayoritaria sin que haya sido afectada esta postura por los diferentes textos que se han aplicado, destacando que en todos los casos la realización del tipo no ha requerido la producción de un resultado concreto lesivo del bien jurídico ${ }^{17}$.

En este momento nos parece conveniente recordar, por las similitudes que hay con la legislación sobre el tráfico de drogas, la tristemente célebre historia de la implementación de la denominada "Ley seca" o Volstead (denominada así en honor al senador Andrew Volstead) en los Estados Unidos de América, que estuvo vigente del día 17 de enero

16 Así Mora Alarcón sostiene que en los delitos relativos al tráfico de drogas no se sancionan las conductas en función del daño concreto causado a una persona determinada, en cuyo supuesto tendría que acreditarse la relación causal entre el consumo de drogas y el daño, sino que lo que se tiene en cuenta es el peligro abstracto, pues estos delitos sólo admiten formas consumadas al estar configurados como delitos de mera actividad, por lo que no se requiere de un resultado concreto. Esta postura ha sido mantenida por el Tribunal Supremo de forma reiterada en los delitos referidos a la salud pública, por lo que se fundamenta su punición en la situación de peligro que se genera por las conductas comprendidas en el tipo penal, de tal forma que la ejecución de un acto exterior correspondiente a cualquiera de las acciones típicas previstas determinaría la consumación del delito. MORA ALARCÓN, José Antonio. Suma de Derecho Penal. ..., op. cit., pp. 526, 530. CORREA DE CARVALHO, José Theodoro. Tráfico de Drogas...., op. cit., p. 61. ARROYO ZAPATERO, Luis. Comentarios al Código Penal..., op. cit., p. 820. FABIÁN CAPARRÓS, Eduardo A. “Consideraciones de urgencia..., op. cit., p. 594.

17 BACIGALUPO, Enrique. Estudios sobre la Parte Especial..., op. cit., p. 157. Sin desconocer que el delito de tráfico de drogas es un delito de peligro abstracto, de resultado cortado y consumación anticipada, es obvio que esta naturaleza debe de recaer sobre una sustancia que tenga una aptitud de provocar un riesgo a la salud pública, pues caso contrario se estaría en una situación de inexistencia de antijuricidad material por imposibilidad de ataque al bien jurídico tutelado por la norma. CORCOY BIDÁSOLO, Mirentxu, MIR PUIG, Santiago (Dir.). Comentarios al Código Penal. Reforma L.O. 5/2010. Ed. Tirant lo Blanch. Valencia 2011, pp. 803, 816. CONDE-PUMPIDO FERREIRO, Cándido. Código Penal Comentado. 3a Ed. Bosch. Barcelona. 2012, pp. 1300, 1301, 1331. STS (Roj: 2061/2010) de 20 de abril de 2010. Ponente: Joaquín Jiménez García. 
de 1920 al día 5 de diciembre de 1933. Esta norma estableció la prohibición de vender bebidas alcohólicas en todo el país. Al ser aprobada declaró Volstead: "el demonio de la bebida hace testamento. Se inicia una era de ideas claras y limpios modales. Los barrios bajos serán pronto cosa del pasado. Las cárceles y los correccionales quedarán vacíos; los transformaremos en graneros y fábricas. Todos los hombres volverán a caminar erguidos, sonreirán todas las mujeres y reirán todos los niños. Se cerraron para siempre las puertas del infierno". Lamentablemente en los trece años de vigencia de esta Ley no se logró más que propiciar que aumentara vertiginosamente el consumo de esas sustancias, además de posibilitar el desarrollo y fortalecimiento de la criminalidad organizada en ese país alrededor del tráfico ilícito de las bebidas alcohólicas. Y para colmo de males, aún y con toda la política represiva que se desarrolló para acabar con el tráfico y consumo de las sustancias antes señaladas no tuvieron más alternativa, ante el rotundo fracaso, que abolir esta prohibición sin sentido. De forma acertada Bentham mucho tiempo atrás había afirmado que no tenía ningún sentido legislar con el propósito de erradicar males tales como el alcoholismo o la fornicación. Nosotros opinamos que un ejemplo contundente de la imposibilidad real de la erradicación, o por lo menos de lograr una disminución importante, del tráfico y consumo de las denominadas drogas ilegales lo constituye el hecho irrefutable de que ni en las cárceles, donde se produce el más férreo control sobre las personas, se ha podido erradicar el tráfico y consumo de estas sustancias ilegales ${ }^{18}$.

Nils Christie señala, en nuestra opinión de forma acertada, que no se debe seguir manteniendo la idea "de que la guerra contra los estupefa-

Bentham, sobre las posibilidades de erradicar conductas no deseables como el alcoholismo manifestó que "ni siquiera todas las torturas que el ingenio puede inventar serían suficientes; y antes que haya hecho algún progreso que merezca es nombre, el castigo habrá producido una tal cantidad de daño, que excederá más de mil veces el peor agravio producido por la ofensa". BUSTOS RAMÍREZ, Juan. Manual de Derecho Penal. Parte Especial. Segunda Edición. Ariel. Barcelona. 1991, pp. 232, 233. ÁLVAREZ GARCÍA, F. Javier. Derecho Penal Español..., op. citpp. 1253, 1254. El primer decenio de la aplicación de la Ley Volstead arrojó el siguiente balance: a) medio millón de detenciones, b) penas de prisión por un total de 33.000 años, c) 2.000 muertos en la guerra del aguardiente de los gangsters y e) 35.000 víctimas de intoxicación por alcohol. CUERDA RIEZU, Antonio. "La despenalización de las drogas: tres parábolas históricas y una conclusión” en Jueces para la democracia. Año 1993. Número 19, p. 26. 
cientes legitima la adopción y puesta en práctica de cualquier tipo de medidas represivas, y lo que es más, no puede afirmarse que el Estado pueda imponer a los ciudadanos sus propios cánones de salud pública, forzándolos a un abandono involuntario del consumo de estas drogas"19. Queremos citar como un ejemplo de la irracionalidad de la lucha contra las drogas ilegales en el mundo, la legislación antidrogas de Irán, que sanciona la producción, exportación, entrega, venta, ofrecimiento de venta, o compra de opio y sus derivados cuando exceda de cinco kilos con pena de muerte, constando en los registros judiciales de ese país que se ejecutaron del año 1980 al año 2000 más de 4.000 personas, lo que arroja un promedio de 200 ejecuciones al año, por ese delito ${ }^{20}$. Es preciso recordar en este momento que los delitos relativos al tráfico de drogas ocupan gran parte del trabajo de la Administración de Justicia a todos los niveles, así como de la Policía, dado que después de los delitos contra la propiedad representan la forma de criminalidad más frecuente en el plano nacional e internacional, con una cifra negra de delitos desconocidos muy elevada, pues generalmente se afirma que no se suelen descubrir más allá del tres por ciento de los delitos que se cometen. Por lo que la actividad de narcotráfico cada vez es más grave y estamos muy lejos de encontrar alguna vía de solución a pesar de los grandes esfuerzos realizados tanto a nivel nacional como mundial, lo cual responde en gran medida, a la complejidad que se presenta en el terreno criminológico ${ }^{21}$.

Entrando propiamente en el tema que nos ocupa en este apartado queremos señalar que la doctrina mayoritaria en España considera que

19 Este autor también destaca la importancia del necesario cambio de mentalidad en la lucha contra las drogas, afirmando que la adopción de medidas de carácter no represivo no supone desentenderse del problema de las drogas, señalando que el planteamiento debe de estar orientado al control administrativo del tráfico y consumo de drogas. CHRISTIE, Nils. "The impossibility of total control" en DIEZ RIPOLLES, José Luis. LAURENZO COPELLO, Patricia (Coord.). La actual política criminal sobre drogas. Una perspectiva comparada. Ed. Tirant lo Blanch. Valencia. 1993, p. 515.

20 SHAMS NATERI, Mohammad Ebrahim. "Política criminal de Irán en materia de narcóticos, drogas y sustancias psicotrópicas”. (Trad. PIFARRE DE MONER, María José) en Revista Penal. № 7, Ed. La Ley. 2001, pp. 90-98.

21 SERRANO GÓMEZ, Alfonso. Derecho Penal. P.E..., op. cit., pp. 711-713. Es opinión generalizada que el método represivo ha sido y es un fracaso absoluto. ÁLVAREZ GARCÍA, F. Javier. Derecho Penal Español. ..., op. cit., pp. 1251, 1252. 
de lege lata, el tráfico de precursores de drogas es un acto preparatorio punible, autónomo opere legis, que en algunos supuestos podría incluso calificarse como conspiración, tentativa, o incluso como un ilícito consumado, de los delitos previstos en el artículo 368 del Código Penal español, dada la amplitud con la que son definidas las conductas típicas, de hecho cabe recordar que se hacía, en algunos casos, antes de que España ratificara el Convenio de Viena de 1988. Por ello, un sector importante de la doctrina valora de innecesario el recurso a su punición mediante el artículo 371 CP [antes 344 bis g) y 344 bis j)] $]^{22}$.

Es preciso decir que antes de la aprobación en la legislación española del delito de tráfico de precursores de drogas en el Código Penal, artículos 344 bis g) y 344 j), a partir de la Ley Orgánica 8/1992 de 23 de diciembre, podía sancionarse por el delito de tráfico de drogas la tenencia de precursores sin que se encontraran ni siquiera residuos de alguna droga ilícita, ni materia prima básica para su fabricación, tal es el caso de la Sentencia del Tribunal Supremo del día 13 de mayo de 1996 que condena como autor de un delito de elaboración de drogas, de las que causan grave daño a la salud, a la pena de 2 años, 4 meses y 1 día de prisión menor, y al pago de la parte proporcional de las costas que le correspondan a un sujeto que en el mes de noviembre del año 1989 le ocuparon en un registro en su vivienda en Villagarcía de Arosa "tres hojas tamaño folio escritas a mano, en las que se describían procedimientos relativos a la transformación de diversos productos, en cocaína, mediante el uso de sustancias químicas. Encontrando después en un alpendre, una botella de ácido clorhídrico, otra de ácido sulfúrico, otra de éter etílico, un frasco de permanganato potásico (precursores de drogas), un frasco de agua fuerte y otra de amoniaco (sustancias no catalogadas). Sustancias, respecto a las cuales, el Instituto Nacional de Toxicología, al serles remitidos con los citados folios, informo que son los indicados para la producción ilícita de cocaína". Cabe destacar que no se hace mención alguna en la sentencia a la ocupación de materia prima (hojas de coca o pasta base de cocaína), así como de materiales o equipos para su procesamiento. STS (ROJ: 2847/1996) de 13 de mayo de 1996. Ponente: D. José Augusto de Vega Ruiz. También el tráfico de precursores se castigaba algunas veces como un delito de tráfico de drogas en grado de conspiración. Así lo ratifico el Tribunal Supremo en su Sentencia de 30 de junio de 1995 en el caso de cinco personas que en el mes de noviembre de 1990 en Murcia tomaron la decisión de fabricar y comercializar algunos de los derivados de la cocaína como el "basuco" o clorhidrato de cocaína el cual elaborarían a partir de pasta base de esta sustancia. Para lo cual se dieron a la tarea de adquirir pequeñas cantidades de precursores en la zona, los que posteriormente les decomisaron, siendo estos ácido sulfúrico, acetona y ácido clorhídrico y de otras sustancias no catalogadas como el etanol, así como dos ollas express y un manuscrito donde aparecían un listado de sustancias y equipos necesarios que podrían servir para fabricar la droga. Los precursores y las sustancias no catalogadas fueron adquiridos por uno de los integrantes del grupo que trabajaba dándole mantenimiento a piscinas por lo que tenía facilidad de comprar dichas sustancias. El laboratorio clandestino, rudimentario, lo pensaban montar en un remolque en las afueras de la ciudad, ahí estaban reunidos sin 
Señalándose que este adelantamiento de la esfera de relevancia penal que consiste en criminalizar la fabricación, transporte, distribución o tenencia de las 24 sustancias químicas catalogadas como tales, con intención de fabricar o elaborar drogas de carácter ilegal, hace que en las conductas descritas en este tipo penal la posibilidad de afección del bien jurídico "salud pública", que se pretende proteger con este ilícito penal, resulte bastante distante. Lo que parece indicar que la incriminación de este tipo de comportamientos puede, en principio, estar reñido con el principio de lesividad, por lo que en opinión de una parte significativa de la doctrina española se trata de un delito de peligro presunto que encuentra su legitimidad en un acto de mera desobediencia $^{23}$. Sobre este asunto queremos recordar que el tráfico de precursores, al igual que el tráfico de drogas, en opinión de la doctrina

empezar a fabricar "basuco" o cocaína y sin tener la necesaria pasta base (materia prima), cuando fueron detenidos por dos oficiales de la Guardia Civil que tenían montado a 500 metros del lugar un puesto de vigilancia para la persecución de la caza furtiva. Los cinco acusados fueron condenados por el Tribunal de Instancia como autores responsables de un delito contra la salud pública del artículo 344 del Código Penal, en grado de conspiración, sin la concurrencia de circunstancias modificativas de la responsabilidad criminal a la pena de cuatro meses y un día de arresto mayor y accesorias de suspensión de todo cargo público y derecho de sufragio durante el tiempo de sus condenas y con multa de 500.000 pesetas a cada uno. STS (ROJ: 3860/1995) de 30 de junio de 1995. Ponente: D. Joaquín Martín Canivell. El profesor Fabián Caparrós señala que habría sido muy difícil sancionar la fabricación, transporte, distribución, comercio o tenencia de precursores en concepto de delito consumado de tráfico de drogas antes de la entrada en vigor de la Ley de 23 de diciembre de 1992. Concluyendo que únicamente una interpretación muy generosa del artículo 344 lo hubiera permitido. FABIÁN CAPARRÓS, Eduardo A. “Consideraciones de urgencia..., op. cit., p. 594.

23 REY HUIDOBRO, Luis Fernando. El delito de tráfico de estupefacientes. ..., op. cit., p. 270. QUINTERO OLIVARES, Gonzalo (Dir.). MORALES PRATS, Fermín (Coord.). Comentarios a la Parte Especial del Derecho Penal. Ed. Aranzadi. Navarra. 2002, p. 1023. ARANA, Xabier. MARKEZ, Iñaki (Coords.). Los agentes sociales ante las drogas. Ed. Dykinson. 1998, p. 260. SUÁREZ LOPEZ, José María. El tráfico de precursores. Propuestas de lege ferenda. MORILLAS CUEVA, Lorenzo (Coord.). Estudios Jurídico-penales y políticocriminales sobre tráfico de drogas y figuras afines. Ed. Dikinson. Madrid. 2003, p. 72. CORREA DE CARVALHO, José Theodoro. Tráfico de Drogas...., op. cit., p. 61. CORCOY BIDÁSOLO, Mirentxu. Comentarios al Código Penal...., op. cit., p. 816. El delito de tráfico de drogas y por ende el de tráfico de precursores no forman parte de los denominados delitos de peligro hipotético, porque el peligro ya ha sido definido por el legislador. MOLINA MANSILlA, María del Carmen. El Delito de Narcotráfico. ..., op. cit., pp. 26, 37, 38. 
y la jurisprudencia dominante es un delito de peligro abstracto, de mera actividad y de consumación anticipada, por lo cual basta con que las sustancias catalogadas se encuentren bajo el dominio funcional del sujeto activo, siempre que se cumpla con el elemento subjetivo adicional, para que se produzca la consumación. Aceptándose incluso la operatividad de la posesión mediata y la consumación de los meros tratos preliminares al acuerdo 24 .

Como ya señalamos antes el delito de tráfico de precursores de drogas, en principio, no tiene la suficiente entidad para su tutela de forma autónoma en el Derecho Penal, a pesar de proteger un bien jurídico de suma importancia como lo es la salud pública, la cual se encuentra justificada en la mayoría de supuestos establecidos en los delitos relativos al de tráfico de drogas, pero no se puede decir lo mismo en el caso de las conductas contempladas en artículo $371 \mathrm{CP}$, dado que la posibilidad de afectación o menoscabo de este bien jurídico es más distante, recordemos que se tratan de actos preparatorios del delito de

CORCOY BIDÁSOLO, Mirentxu. Comentarios al Código Penal. ...., op. cit., pp. 803, 816. CONDE-PUMPIDO FERREIRO, Cándido. Código Penal..., op. cit., p. 697. CLIMENT DUTANT, Carlos. Código Penal...., op. cit., p. 1777. Sobre el concepto de tenencia o posesión pre ordenada al tráfico de drogas, o bien la tenencia de sustancias catalogadas a sabiendas de que van a utilizarse en la elaboración de drogas ilícitas o para estos fines, se señala que con independencia del concepto civil de posesión, en los delitos contra la salud pública la tenencia material no agota los supuestos de posesión punible, pudiendo ejercerse dicha tenencia por la misma persona que tiene la cosa o disfruta el derecho, o por otra en su nombre. Se adquiere tal disponibilidad por la ocupación de la cosa o derecho poseído, o por el hecho de quedar éstos sujetos a nuestra voluntad; en consecuencia, no es necesaria la tenencia material de la droga o de las sustancias catalogadas como precursores de drogas, pudiendo la posesión ser directa e inmediata, actual, material, física o de presente, pero también mediata, indirecta e incluso a distancia, sin necesidad de contacto físico. Lo decisivo es que esté sujeta de alguna forma a la voluntad del agente (domino funcional), con posibilidad de disposición: quien tiene dominio sobre la droga es poseedor a todos los efectos, siendo suficiente la voluntad de poseer, aunque la propia persona no posea materialmente y tenga para ello la droga, o bien alguno o algunos de sus precursores, otro sujeto (servidor de la posesión). STS (Roj: 6124/2009) de 7 de octubre de 2009. Ponente: Juan Ramón Berdugo Gómez de la Torre. SAAVEDRA RUIZ, Juan. Código Penal...., op. cit., p. 1140. CARDONA TORRES, Juan. Derecho Penal...., op. cit., p. 437, 443. ÁLVAREZ GARCÍA, F. Javier. Derecho Penal Español..., op. cit., p. 1354. FABIÁN CAPARRÓS, Eduardo A. "Consideraciones de urgencia..., op. cit., pp. 594, 595. A favor de apreciar casos de tentativa o actos preparatorios en el delito de tráfico de precursores de drogas. SEQUEROS SAZATORNIL, Fernando. El tráfico de drogas..., op. cit., p. 293. 
tráfico de drogas (elaboración de drogas ilícitas) que por decisión del legislador se elevan a la categoría de delito autónomo, de hecho estos comportamientos no son simples infracciones formales porque tienen incorporado el elemento subjetivo adicional "a sabiendas de" que se van a utilizar para la fabricación ilícita de drogas o "para estos fines", de no ser así el artículo 371 CP tendría que ser declarado inconstitucional en los mismos términos que lo fue el artículo 509 del anterior Código Penal. No obstante creemos que la introducción del elemento subjetivo adicional antes mencionado propicia que no se pueda afirmar con propiedad de que se trate de un delito de peligro presunto que castiga un acto de mera desobediencia. A manera de ejemplo citamos tres casos que resultan muy ilustrativos:

1) La STS de 3 de febrero de 2004, que ratifica la condena de la SAP de Madrid a tres sujetos como autores criminalmente responsables de un delito contra la salud pública del artículo $371 \mathrm{CP}$, sin la concurrencia de circunstancias modificativas de la responsabilidad criminal, a la pena para cada uno de ellos, de cuatro años y seis meses de prisión por haber adquirido en diversas empresas del sector radicadas en Madrid, mediante una sociedad anónima pantalla, una cantidad considerable de precursores de drogas: 13,5 litros de ácido clorhídrico, 4 litros de ácido sulfúrico, 75 litros de metiletilcetona, 25 kilogramos de permanganato de potasio y 450 litros de acetona. Para vendérselos a un grupo de traficantes que tenían un laboratorio ilícito dedicado a la transformación de cocaína base en clorhidrato de cocaína y de separar la cocaína camuflada en virutas de madera proveniente de Colombia (10.152,6 gramos de cocaína pura), "a sabiendas de" que estos precursores los utilizarían para la obtención de la droga antes mencionada ${ }^{25}$. Si tomamos como referencia la cantidad de permanganato de potasio incautado, principal precursor de drogas en la elaboración de la cocaína, se podrían haber fabricado con esta sustancia aproximadamente 1.250 .000 dosis callejeras de 100 miligramos de cocaína de un 20\% o 40\% de pureza (aproximadamente 125 kilogramos de clorhidrato de cocaína) ${ }^{26}$. 
2) La STS de 16 de enero de 2003, que ratifica la SAN, sección cuarta, de 9 de julio del año 2002, que condenó a tres sujetos como autores por el delito de tráfico de precursores de drogas, que importaron un cargamento de unos 12.000 kilogramos de permanganato de potasio (envasados en bidones de 50 kilogramos), con el fin de exportarlo a Colombia. Esta remesa les fue suministrada por la empresa "Innochem" que tiene su sede en la localidad belga de Meerhort. Los condenados antes de exportar el permanganato de potasio a Colombia decidieron camuflar la mercancía y para este propósito adquirieron 6.000 kilogramos de dióxido de manganeso (sustancia no catalogada, pero que también se utiliza en la elaboración ilícita de permanganato de potasio en países de América del Sur), trasvasando para ello 40 kilos de permanganato de potasio en bolsas de basura, a cada uno de los nuevos bidones (355) recibidos, completando el peso de 50 kilos por unidad con 10 kilos de dióxido de manganeso, y tras precintar cada bidón y ponerle una nueva etiqueta referida a esta última sustancia, destruyeron las etiquetas originales del permanganato de potasio. Una vez concluido el trabajo antes mencionado, tras el llenado en las formas mencionadas de 355 bidones, estos fueron cargados el día 12 de marzo de 1999 en el contenedor con número de identificación SEAU 822620-9 de la empresa Sea-Land y transportados hasta el puerto de Algeciras, que el día 17 de marzo de 1999 se cargan en el buque Grete Maeks con destino al puerto de Cartagena de Indias en Colombia, donde llega el cargamento el día 14 de abril de 1999, siendo interceptado por la policía colombiana. Hay que puntualizar que el permanganato de potasio que se exportó a Colombia alcanzaba el peso total de 11.611 kilogramos, casi la mitad que necesitan y compran todas las empresas legales de Colombia en un mes, cantidad con la que se pudo haber elaborado aproximadamente 58.055 kilogramos de clorhidrato de cocaína ${ }^{27}$.

3) En el mismo sentido también hay que destacar que en el mes de enero del año 2011 se produjo el desmantelamiento de un laboratorio de procesamiento de cocaína, de pasta base de cocaína a clorhidrato de cocaína, en España. Este laboratorio fue el mayor y más avanzado

27 STS (ROJ: 89/2003) de 16 de enero de 2003. Ponente: D. Luis Román Puerta Luis. Características agroculturales de los cultivos de coca en Colombia. Ed. UNODC. Colombia. 2006, p. 28. 
descubierto hasta la fecha en Europa. El mismo le pertenecía a Ana María Cameno conocida como "la reina de la coca o la tetas" y estaba ubicado en una granja en Villanueva de Perales, cerca de Madrid. El operativo policial se denominó Operación Colapso. En dicho laboratorio se decomisaron 33 toneladas de sustancias químicas esenciales, entre ellas 11.345 litros de tolueno, 8.060 litros de metiletilcetona, 6.400 litros de acetona, 350 litros de ácido sulfúrico, 300 litros de ácido clorhídrico y otras sustancias no catalogadas que se utilizan en la elaboración de la cocaína. Con estos precursores podrían haberse elaborado aproximadamente unos 756 kilogramos de clorhidrato cocaína ${ }^{28}$. Durante la operación se produjo la detención de cinco personas, cuatro colombianos y un español, debiendo puntualizarse que los ciudadanos de nacionalidad colombianos fueron los encargados de montar el laboratorio, y quienes se encargarían de elaborar la cocaína (cocineros) mientras que el español se hacía cargo de la custodia de la finca ${ }^{29}$. En nuestra opinión los comportamientos realizados en estos tres casos evidencian la potencialidad de la conductas tipificadas en el delito de tráfico de precursores para crear un peligro para el bien jurídico salud pública, peligro que obviamente es menor que el generado por los sujetos que realizan la elaboración o fabricación de las drogas ilícitas, y menor aún que la que se produce en la actividad propia del narco menudeo. En este sentido queremos recordar que la jurisprudencia configura el delito previsto en el artículo $368 \mathrm{CP}$ como un delito de peligro hipotético ${ }^{30}$.

Dicho esto queremos expresar que es factible pensar, como lo hace un sector importante de la doctrina, que suprimir el artículo $371 \mathrm{CP}$ por ser una figura de poca eficacia, no reduciría de manera significativa la protección del bien jurídico protegido por este tipo penal, puesto que en los supuestos más graves de tráfico de precursores de drogas se podría recurrir al delito de tráfico de drogas mediante el empleo, para

28 Si tomamos como referencia la cantidad de tolueno ocupada. Precursores y productos químicos frecuentemente utilizados..., correspondiente a 2004..., p. 79.

29 Precursores y productos químicos frecuentemente utilizados..., correspondiente a 2011..., p. 26.

30 MUÑOZ CONDE, Francisco. Derecho Penal. P.E..., op. cit., p. 624. STS (ROJ: 278/1985) de 20 de febrero de 1985. Ponente: Juan Latour Brotons. Precursores y productos químicos frecuentemente utilizados..., correspondiente a 2000..., p. 77. 
sancionar dichas conductas, de las reglas previstas para la autoría y participación, así como las de las formas de imperfecta ejecución, de hecho ya se hacía antes, en algunos casos, de la aprobación de este tipo penal $^{31}$ o bien por la Ley de Represión del Contrabando cuando se trate de la exportación, expedición, importación o introducción de las sustancias catalogadas (cuya legitimidad también cabria cuestionar) ${ }^{32}$, y en los casos de menor relevancia podrían sancionarse, como ya se hace, con las infracciones previstas en la Ley 4/2009 de control de precursores de drogas ${ }^{33}$ (Derecho Administrativo) donde sí se encuentra plenamente justificada la protección de este bien jurídico ${ }^{34}$. Sin embargo somos conscientes de que existen muy pocas posibilidades de

31 SUÁREZ LÓPEZ, José María. “El tráfico de precursores..., op. cit., pp. 76, 77. Refiriéndose a la aprobación de 344 bis g) Rodríguez Devesa manifiesta que se adapta de esta manera el Código Penal a lo dispuesto en el artículo 3 c), ii) del Convenio de Viena de 1988. Afirmando que en "realidad estas figuras se encontraban ya tipificadas en el artículo 344 del Código Penal, pues podían perseguirse como tentativa de los tipos que ahí se recogen". RODRÍGUEZ DEVESA, José María. SERRANO GÓMEZ, Alfonso. Derecho Penal Español. Parte Especial. Decimoctava edición. Dykinson. Madrid. 1995, pp. 1086, 1087. En el $\mathrm{m}$ ismo sentido. REY HUIDOBRO, Luis Fernando. El delito de tráfico de drogas. ..., op. cit., p. 273. Sancionando la tenencia de precursores como autoria de un delito de elaboración de drogas, de las que causan grave daño a la salud. STS (ROJ: 2847/1996) de 13 de mayo de 1996. Ponente: José Augusto de Vega Ruiz. También el tráfico de precursores se castigaba algunas veces como un delito de tráfico de drogas en grado de conspiración. STS (ROJ: 3860/1995) de 30 de junio de 1995. Ponente: Joaquín Martín Canivell.

32 Morales García señala, en relación a la ejecución de los actos de elaboración ilegal de drogas preceptuado en el artículo $368 \mathrm{CP}$, que el legislador no se conforma con la tipificación del objeto material sino que adelanta la barrera punitiva hasta cualquier acto de la cadena de producción, de esta manera bastará con la realización de cualquiera de los pasos tendentes a la obtención de la droga, siendo completamente equivalente cualquier aportación a la cadena de elaboración. QUINTERO OLIVARES, Gonzalo (Dir.). MORALES PRATS, Fermín (Coord.). Comentarios al Código Penal Español. Tomo II. 6a edición. Aranzadi/Thomson Reuters. Navarra. 2011, p. 935. Ley orgánica 6/2011 de 30 de junio, por la que se modifica la Ley Orgánica 12/1995, del 12 de diciembre, de Represión del Contrabando. Vid., en el Anexo I la Ley 4/2009, de 15 de junio, de control de precursores de drogas.

34 Soto Navarro sostiene respecto de la inidoneidad de la protección penal de los bienes jurídicos colectivos, que esta no debe fundarse únicamente en el bajo nivel de persecución de estos delitos ni en la frecuencia de su comisión, sino que debería también examinarse el efecto preventivo que se produce sobre potenciales infractores. SOTO NAVARRO, Susana. La protección penal de los bienes jurídicos colectivos en la sociedad moderna. Ed. Comares. Granada. 2003, p. 175. 
un cambio de orientación en la política criminal desarrollada a mediano o incluso a largo plazo sobre este ilícito (que en el mes de diciembre de este año cumplirá 25 años de vigencia), pues España está obligada a sancionar penalmente este tipo de comportamiento por el Convenio de Viena de 1988 y otras normativas comunitarias ${ }^{35}$. Además queremos señalar que un argumento a favor de no suprimir del ordenamiento penal el delito de tráfico de precursores de drogas podemos encontrarlo en las modalidades de ataque al bien jurídico salud pública, pues quienes mayoritariamente realizan las conductas de desvío, transporte y fabricación ilícita de las 24 sustancias catalogadas son auténticas mafias que operan a nivel internacional, con mucho éxito debido a su gran capacidad económica y de innovación, utilizando los mismos métodos y medios que usan para el tráfico de drogas, lo cual dificulta aún más un cambio de orientación de la política criminal en el plano internacional (Organización de Naciones Unidas y Unión Europea), organismos donde están convencidos que no podría enfrentarse esta área de la narcoactividad en buena medida sin la intervención del Derecho Penal, y de su tutela adelantada mediante un delito de peligro abstracto, así como de la implementación de medidas tales como la entrega vigilada de precursores de drogas ${ }^{36}$, el uso de agentes encubiertos o de las intervenciones telefónicas ${ }^{37}$ propias del ordenamiento penal.

Queremos concluir este apartado manifestando que nosotros, a pesar de todas las objeciones que se le formulan con razón a este ilícito penal, pensamos que del delito de tráfico de precursores de drogas no se puede decir que sea un delito de peligro presunto que encuentre su legitimidad en un acto de mera desobediencia, pues la peligrosidad de los comportamientos preceptuados en este tipo comportan un riesgo de menoscabo del bien jurídico salud pública que, por lo menos a nivel lógico, se puede distinguir de la acción propiamente dicha y aunque lo

35 La Decisión Marco 2004/757/JAI del Consejo, de 24 de octubre que señala de forma expresa la necesidad de que los Estados miembros sancionen con penas máximas de 5 a 10 años los delitos de tráfico de precursores de drogas cuando se cometan en el seno de una organización criminal. 
ideal sería que la inclusión de los delitos de peligro abstracto deberían ser evitados por el legislador, entendemos que se recurra a esta técnica de protección de bienes jurídicos con carácter excepcional, es decir, sólo cuando razones de política criminal lo exijan. En estos casos deberá optarse por delitos de peligro abstracto que además de acreditar la peligrosidad de la conducta (desvalor de acción) comporten un desvalor de resultado, al menos potencial o intermedio, en el que si bien no se exige un resultado estructural, si sea necesaria una cierta vinculación con el bien jurídico tutelado que responda al cumplimiento del principio de exclusiva protección de bienes jurídicos y, al menos en cierta medida, a su correlato el principio de ofensividad, debiendo tratarse por tanto de delitos en los que sea posible identificar el objeto de tutela, lo cual creemos sucede en el caso del artículo $371 \mathrm{CP}$.

No debiendo obviarse además que España, al igual que el $95.45 \%$ de países del mundo, tiene la obligación de sancionar penalmente algunas de las conductas relativas al tráfico de precursores de drogas en virtud del Convenio de Viena de 1988. Así como que en el caso de la posesión de precursores de los estimulantes de tipo anfetamínico tales como la efedrina, la seudoefedrina, la norefedrina, la P-2-P, el ácido fenilacético, la 3,4-MDP-2-P, el piperonal, el ácido lisérgico, la ergotamina, la ergometrina, el ácido $N$-acetilantranílico y la piperidina la posibilidad de menoscabo del bien jurídico salud pública resulta un poco menos distante, pues estas sustancias son la materia prima principal para la elaboración de drogas de síntesis, más aún si está se realiza en emplazamiento cercanos a los laboratorios o en los propios laboratorios donde se elaborará la droga, pues equivale a tener en estos una remesa de hojas de coca, pasta de coca o el latex de la adormidera listas para proceder a fabricar cocaína o heroína, por lo tanto podrían equiparase a la fase final del cultivo de drogas o a la inicial de la elaboración de las mismas. También cabe que las conductas comprendidas en el artículo $371 \mathrm{CP}$ la mayoría de las veces son realizadas por auténticas mafias que operan a nivel internacional (criminalidad organizada), con bastante éxito debido a su gran capacidad económica y de innovación, utilizando los mismos métodos y medios que usan para el tráfico de drogas. De hecho pese a todo el esfuerzo que se realiza a nivel mundial, haciendo uso del ordenamiento penal, del administrativo sancionador y de una parte muy importante de todos los recursos de los cuerpos y fuerzas de seguridad, sólo logra confiscar anualmente el $15 \%$ de los precursores que se utilizan para la elaboración de la cocaína y la heroína, y el $20 \%$ de los estimulantes de 
tipo anfetamínico, lo cual nos lleva al convencimiento de que no podría enfrentarse esta área de la narcoactividad en buena medida sin la intervención del Derecho Penal, y de su tutela adelantada mediante un delito de peligro abstracto, sumamente cuestionado, como el tráfico de precursores de drogas, que precisa de la aplicación de medidas como la entrega vigilada, el uso de agentes encubiertos o las intervenciones telefónicas, ajenas al Derecho Administrativo. Por lo dicho hasta aquí sostenemos que no es conveniente proponer la despenalización de este delito, por lo que a nos proponemos trabajar en aras de ofrecer unas pautas de interpretación lo más seguras posibles y respetuosas de los principios básicos de Derecho Penal a continuación.

\section{B.) NATURALEZA JURÍDICA}

El delito de tráfico de precursores de drogas tipificado en el artículo 371 del Código Penal español es un delito de peligro abstracto, de mera actividad y de consumación anticipada o en la que la respuesta penal se adelanta al momento de realización de los actos preparatorios del delito de tráfico de drogas, específicamente de la elaboración de drogas ilícitas. Sobre la naturaleza del peligro de este tipo delictivo la jurisprudencia mayoritaria sostiene que el peligro abstracto, al que se hace referencia en este tipo de delito, no debe de confundirse con el peligro presunto, de forma que cualquier acción que cumpla objetivamente la hipótesis legal se entienda ya, per se, sin admisión de prueba o estimación en contrario, integradora del delito pues tal tipo de presunción vulneraría el derecho constitucional a la presunción de inocencia. En su opinión peligro abstracto sólo quiere decir que en el momento de la consumación anticipada, con que el legislador ha configurado el tipo, no están concretados o determinados los sujetos portadores del bien jurídico protegido, cuya salud va a ser puesta en peligro o afectada por el agotamiento de la acción. Pero lo que sí es preciso es que tal peligro, como riesgo de futura lesión de aquel bien jurídico, se encuentre realmente presente en la acción para que ésta incluya en sí el contenido de la antijuricidad material y la adecuación al tipo necesarios para su ilicitud penal (STS del 29 de mayo de 1993) ${ }^{38}$.

38 CONDE-PUMPIDO FERREIRO, Cándido. Código Penal..., op. cit., p. 1300. STS (ROJ: 3499/1993) de 29 de mayo de 1993. Ponente: Cándido Conde-Pumpido Ferreiro. CORCOY BIDÁSOLO, Mirentxu. Comentarios al Código Penal..., op. cit., pp. 803, 816. 
Los homólogos más próximos al artículo 371 CP podrían encontrarse en el desaparecido delito de tenencia de útiles para el robo del artículo 509 del antiguo CP, por lo cual, de no haberse introducido la exigencia del elemento subjetivo "a sabiendas de" o "para estos fines", cabría aplicarle los criterios deducibles de la sentencia del Tribunal Constitucional del 8 de junio de 1988 al artículo 37139, o en el artículo 400 CP

LAMARCA PÉREZ, Carmen (Coord.). Derecho Penal. P.E..., op. cit., pp. 508, 509. ÁLVAREZ GARCIA, F. Javier. El Delito de Tráfico..., op. cit., pp. 25-29.

CONDE-PUMPIDO FERREIRO, Cándido. Código Penal..., op. cit., pp. 1328-1331. Sobre el artículo $509 \mathrm{CP}$ "se han enfrentado dos posible variantes de la interpretación del precepto sobre las que nuestro análisis deberá versar, sin excluir la posibilidad de otras diferentes, que no es posible enjuiciar, porque no han sido objeto de debate: a) ..., la sola tenencia de instrumentos idóneos para ejecutar un delito de robo hace presumir el especial destino a tal ejecución, a menos que el acusado facilite mediante el correspondiente descargo la prueba en contrario, b) ..., la posesión de los instrumentos, como la idoneidad de estos para un delito de fuerza en las cosas, y la especial destinación o destino por su poseedor a la ejecución de delitos de tal tipo, corresponde siempre probarlas, como cualquier otro elemento inculpatorio, a la parte acusadora, sin que por exigencia de la Ley tenga el acusado que realizar prueba alguna. En esta interpretación, la idea de descargo suficiente posee un sentido distinto. No es una actividad necesaria del acusado, sino una actividad libre de este, que alguna de las tesis mantenidas en el presente recurso considera como una especial causa de justificación, aun cuando probablemente sea más exacto calificarla de libertad del acusado para alegar y probar una destinación diferente. Tras lo dicho, resulta, como necesaria conclusión del análisis que se realiza, que la primera de las interpretaciones cuestionadas, es decir la que antes ha sido expuesta bajo la letra a), es contraria a los dictados del art. 24.2 de la Constitución y al derecho fundamental de la presunción de inocencia, lo que no ocurre en cambio, con la segunda de las interpretaciones. La primera de ellas, es como decíamos, contraria al art. 24.2 Contiene una presunción en contra del reo que es la presunción del mal uso o la presunción de la tendencia o finalidad, que se considera además como iuris tantum, produciendo una traslación o inversión de la carga de la prueba, de suerte que la destrucción o desvirtuación de tal presunción corresponde al acusado a través del descargo. Llegados a este punto parece obligado concluir que la disposición de la Ley enjuiciada no es en sí misma inconstitucional, pero que si lo es alguna de las interpretaciones de que ha sido y puede ser todavía objeto. Ello impone la conveniencia de llegar a una sentencia constitucional de carácter interpretativo, que tome, sobre todo, en consideración el principio de conservación de las disposiciones legales, en cuanto a las mismas pueden ser interpretadas y aplicadas de conformidad con la Constitución. En virtud de todo lo expuesto, el Tribunal Constitucional, por la autoridad que le confiere la Constitución española, ha decidido declarar inconstitucional el art. 509 del Código Penal en cuanto se interprete que la posesión de instrumentos idóneos para ejecutar el delito de robo presume que la finalidad y el destino que les da su poseedor es la ejecución de tal 
vigente (otro acto preparatorio elevado a la categoría de delito autónomo) que sanciona la fabricación, recepción, obtención o tenencia de útiles, materiales, instrumentos, sustancias, datos y programas informáticos, aparatos, elementos de seguridad, u otros medios específicamente destinados a la comisión de los delitos de fabricación de monedas, efectos timbrados, documentos públicos, oficiales y de comercio, así como privados y certificados ${ }^{40}$.

Valle Muñiz y Morales García afirman que el problema de legitimidad del delito de tráfico de precursores no se resuelve con el recurso a la exigencia de específicos elementos subjetivos para la conformación del injusto, como son en ésta sede los fines de cultivo, producción o fabricación ilícita de drogas. En este sentido señalan que si la apertura de las conductas contenidas en el artículo 368 del Código Penal merecen ya un juicio negativo de valoración sobre su desmesurado alcance, con mayor motivo lo suscita la retracción del reproche penal hasta conductas que en sí mismas ni siquiera son capaces de promover, favorecer o facilitar el consumo ilegal, como la fabricación de equipos y materiales, supuestos de los que ya se hacía difícil predicar su vinculación al objeto jurídico de tutela, manifestando además que posiblemente hubiese resultado más acertado, de lege ferenda, el mantenimiento de las conductas enunciadas en el artículo 371 del Código Penal en la órbita de la cooperación necesaria para la realización, únicamente, de algunos comportamientos del tipo básico (concretamente, en cuanto a la elaboración de drogas tóxicas) si bien para ello hubiera sido igualmente necesaria la construcción de éste en torno a

delito". STC (105/1988) de 8 de junio de 1988. Ponente: D. Luis Díez-Picazo y Ponce de León.

40 SEQUEROS SAZATORNIL, Fernando. El tráfico de drogas..., op. cit., p. 290. El artículo 400 del Código Penal no es un delito formal ni de mera sospecha ya que el tipo requiere de forma expresa que la tenencia o fabricación lo sean de útiles destinados a la comisión de falsedades punibles, por lo que las acusaciones deben probar la finalidad delictiva de los instrumentos enumerados. Además hay que decir que en lo concerniente al tipo subjetivo, se integra por el dolo, que debe abracar la aptitud de los medios y útiles para la realización de falsificaciones y al elemento finalista de tener intención de utilizarlos o de proporcionarlos para su uso ilícito. CONDE-PUMPIDO FERREIRO, Cándido. Código Penal..., op. cit., pp. 1421, 1422. CORCOY BIDÁSOLO, Mirentxu. Comentarios al Código Penal...., op. cit., p. 816. STS (ROJ: 2497/2001) de 26 de marzo de 2001. Ponente: D. José Jiménez Villarejo. STS (ROJ: 2484/1999) de 14 de abril de 1999. Ponente: D. Eduardo Moner Muñoz. 
estructuras ajenas a la evidente equiparación entre autoría y participación ${ }^{41}$. Queremos señalar que en nuestra opinión la fabricación, transporte, distribución, comercio o tenencia de equipos y materiales no está comprendida en el artículo 371 del Código Penal por no estar enumeradas en el Cuadro I y II de la Convención de Naciones Unidas del 20 de diciembre de 1988.

El Tribunal Supremo en su sentencia del 26 de marzo del año 2001 describe de forma clara el adelantamiento de la barrera de protección penal que se produce con el delito de tráfico de precursores de drogas. Sobre este tema señala en su fundamento jurídico número cuatro: "que en este precepto, con el que sustancialmente coincide el art. $371.1 \mathrm{CP}$ 1995 (RCL 1973/3170 y RCL 1996/777), se castiga entre otros actos, la posesión de los equipos, materiales o sustancias enumeradas en los cuadros I y II de la Convención de Naciones Unidas de 20 de diciembre de 1988 (RCL 1990/2309), a sabiendas de que se van a utilizar en el cultivo, la producción o la fabricación ilícitas de drogas tóxicas, estupefacientes o sustancias psicotrópicas, o para estos fines. Se trata de un tipo delictivo de mera actividad, puesto que su elemento objetivo se realiza por el mero hecho de tener en propio poder los equipos, materiales o sustancias referidos, en el que el dolo no sólo debe cubrir la acción típica sino otras a las que ésta sirve de antesala o presupuesto. A esto se refiere el precepto cuando exige, para la integración del tipo, que el poseedor actúe «a sabiendas» de que los equipos, materiales o sustancias van a ser utilizados en el cultivo, la producción o la fabricación de tóxicos, estupefacientes o psicotrópicos. No estamos, pues, ante un delito de «sospecha» porque la mera posesión, aún no autorizada, no es suficiente para la incriminación. Y como difícilmente se puede «saber»-no solamente sospechar- cuál va a ser el destino de una cosa sino cuándo dicho destino se lo va a dar quien posee u otra persona con la que aquél está concertado, puede decirse que el delito descrito en la norma cuestionada es un tipo «de imperfecta realización», esto es, un tipo en que la respuesta penal se adelanta al momento de la realización de actos meramente

41 QUINTERO OLIVARES, Gonzalo. Comentarios a la Parte Especial..., op. cit., p. 1524. En el mismo sentido. VIDALES RODRÍGUEZ, Catalina. "La última reforma del Código Penal en materia de drogas" en Revista general de Derecho, núm. 583. Valencia. 1993, p. 2731. ARANA, Xabier. MARKEZ, Iñaki (Coords.). Los agentes sociales ante las drogas. Ed. Dykinson. 1998, p. 260. 
preparatorios- inspirados por una determinada finalidad de su autorque quedarían impunes de no ser por la previsión legal. La «ratio» del precepto no puede ser más clara: el legislador ha tipificado en este caso actos preparatorios, en relación con el cultivo y la fabricación de productos tóxicos o estupefacientes o sustancias psicotrópicas, porque ha querido concertar con la comunidad internacional los instrumentos jurídicos orientados a la represión de determinadas actividades definidas como singularmente amenazadoras y perjudiciales para el bienestar de los pueblos. El adelantamiento de la protección penal ha supuesto, en este caso, considerar como objeto de delito no sólo las drogas ya elaboradas sino los productos que se denominan sus «precursores». Ahora bien, así como la posesión de drogas sólo es punible cuando está acompañada del propósito de difundirlas, la posesión de los precursores sólo lo es cuando se tiene conciencia de que van a ser ilícitamente utilizados en el cultivo, la producción o la fabricación de drogas cuyo consumo se quiere atajar" 42 .

Muñoz Conde afirma al respecto que, al igual que en el delito de tráfico de drogas, en el de tráfico de precursores se presenta una extensión desmesurada del tipo, en el que se consideran delitos consumados lo que en puridad de principio serían formas imperfectas de ejecución o incluso simples actos preparatorios, y como autoría lo que conforme a los principios generales son actos de complicidad, señalando que este adelantamiento de la barrera punitiva hace que los límites entre la infracción criminal y el comportamiento penalmente irrelevante por atípico queden así muy difuminados, haciendo intervenir en muchas

STS (ROJ: 2497/2001) de 26 de marzo de 2001. Ponente: D. José Jiménez Villarejo. CORCOY BIDÁSOLO, Mirentxu. Comentarios al Código Penal. ...., op. cit., pp. 816, 817. TERRADILLOS BASOCO, Juan María. Lecciones materiales..., op. cit., p. 63. Algunas leyes penales modernas han puesto el acento en sancionar la posesión de objetos, lo cual plantea considerables problemas, entre ellos podemos citar la posesión de explosivos, armas de fuego, de drogas, de precursores de drogas, de pornografía infantil y de otros muchos objetos. En el Derecho Penal alemán existen más de cien preceptos que conminan con pena la posesión de objetos. Es preciso decir que sancionar este tipo de conductas no es una novedad, como ejemplo de ello se puede citar la Ley romana contra bandidos y envenenadores del año 81 antes de Cristo que castigaba con la pena de muerte la tenencia de veneno; siendo poco claro si debía de probarse la existencia de la intensión homicida. SCHROEDER, Friedrich-Christian. "La posesión como hecho punible" (Trad. Polaino-Orts, Miguel) en Revista de Derecho Penal y Criminología, 2o Época, número 14, pp. 155, 156. 
ocasiones al Derecho Penal en estadios muy alejados de la simple puesta en peligro del bien jurídico tutelado, situación que se incrementa si se tiene en cuenta que en la lucha contra este tipo de criminalidad se emplean medios de dudosa legalidad como la figura del agente provocador o agentes policiales infiltrados que intervienen en momentos de ambigua punibilidad ${ }^{43}$.

Por todo lo antes expuesto entendemos que es razonable pensar que el tráfico de sustancias catalogadas como precursores en atención al principio de lesividad no comporta la suficiente entidad para su protección en el orden penal como delito autónomo, por lo cual las conductas sancionadas por este tipo penal no deberían trascender del ámbito administrativo o a lo sumo algunas de estas conductas deberían sancionarse como formas de imperfecta ejecución o actos preparatorios del delito de tráfico de drogas ${ }^{44}$. En este sentido se pronuncia la doctrina de forma mayoritaria, sin embargo somos conscientes de que es muy difícil que este tipo penal sea suprimido, no por su evolución en la práctica jurídica, que es bastante escasa, sino más bien porque este se introdujo en el ordenamiento penal español hace 24 años para darle cumplimiento al Convenio de Viena de 1988 y demás normas comunitarias relativas a el tráfico de precursores ${ }^{45}$. Para que nos hagamos una idea del alcance de la aplicación de este convenio internacional hay que decir que un total de 189 Estados o territorios del mundo sancionan estas conductas en sus ordenamientos penales internos (lo que representa el $95.45 \%$ del total de países o territo-

43 MUÑOZ CONDE, Francisco. Derecho Penal. P.E..., op. cit., p. 676. VIVES ANTÓN, Tomas S. Derecho Penal. P.E..., op. cit., pp. 611, 612.

44 Manjón-Cabeza Olmeda afirma que el elemento fundamental para diferenciar el delito previsto en el artículo $371 \mathrm{CP}$ de las simples infracciones administrativas relativas al transporte o la distribución de estas sustancias catalogadas al margen de lo autorizado, es el subjetivo de saber que los precursores que se poseen o se manejan están destinados a la ulterior producción, propia o de un tercero, de drogas ilícitas en el marco del delito de tráfico de drogas, o sea para el consumo ilícito. ÁLVAREZ GARCÍA, F. Javier. Derecho Penal Español. ..., op. cit., pp. 1355, 1356.

45 El tráfico de precursores se incorpora al Código Penal español mediante la Ley Orgánica 8/1992, de 23 de diciembre, de modificación del Código Penal y de la Ley de Enjuiciamiento Criminal, en los artículos 344 bis g) y 344 bis j) del ACP. 
rios $)^{46}$. En todo caso queremos terminar este apartado manifestando que resulta evidente que la situación se vuelve insostenible con la incorporación del artículo 373 del Código Penal que sanciona la provocación, la conspiración y la proposición para cometer el tráfico de precursores de drogas. Castigando de esta forma "los actos preparatorios de los actos preparatorios del tráfico de drogas, es decir la preparación de la preparación" dado que además de criminalizar el tráfico de precursores, también se sanciona los actos preparatorios de este $^{47}$. Es preciso señalar que sobre la necesidad imperiosa de eliminación de este despropósito legislativo hay unanimidad en la doctrina española, situación que dudamos se produzca en la práctica legislativa, a mediano e inclusive a largo plazo, pues la tendencia va en sentido opuesto. Afortunadamente podemos decir que no conocemos de la existencia de ninguna sentencia sobre la provocación, la conspiración o la proposición para fabricar, transportar, distribuir, comerciar o tener en su poder precursores de drogas en todos los años de vigencia de esta norma.

\section{C.) EL OBJETO MATERIAL}

El objeto material del tipo delictivo está constituido según el artículo 371 del Código Penal español, por los equipos, materiales o sustancias enumeradas en el Cuadro I y Cuadro II de la Convención de Naciones Unidas celebrada en Viena el día 20 de diciembre de 1988, sobre el tráfico ilícito de estupefacientes y sustancias psicotrópicas, y cualesquiera otros productos adicionados al mismo Convenio o que se incluyan en otros futuros convenios de la misma naturaleza, ratificados por España. El Tribunal Supremo en su sentencia del día 16 de enero de 2003, sostiene que el tráfico de precursores es una norma penal en blanco; señalando en su fundamento de derecho quinto que "el artículo 371 del Código Penal castiga con las correspondientes penas, entre otras conductas, una serie de actividades (fabricación, transporte,

46 Únicamente no son estados partes de la Convención de 1988 un total de nueve, de los 198 Estados que existen, siendo estos: Guinea Ecuatorial, Somalia, Sudán del Sur, Estado de Palestina, Islas Salomón, Kiribati, Palau, Papua Nueva Guinea y Tuvalu. Precursores y sustancias químicas frecuentemente utilizados..., correspondiente a 2014..., pp. 7, 45-50.

47 REY HUIDOBRO, Luis Fernando. El delito de tráfico de estupefacientes. ..., op. cit., p. 274. 
distribución, comercio, etc.) relacionadas con materiales o sustancias enumeradas en el Cuadro I y Cuadro II de la Convención de Naciones Unidas, hecha en Viena el 20 de diciembre de 1988, (...), y cualesquiera otros productos adicionados al mismo Convenio o que se incluyan en futuros Convenios de la misma naturaleza ratificados por España, a sabiendas de que van a utilizarse en el cultivo, la producción o la fabricación ilícitas de drogas tóxicas, estupefacientes o sustancias psicotrópicas, o para estos fines,..., de modo que constituye, por una parte, una norma penal en blanco, que ha de ser integrada con las correspondientes normas extrapenales, y, por otra, es un delito de mera actividad" 48 .

De la redacción de la parte que establece el objeto material de este tipo penal hay que decir que resulta bastante confusa, pues se hace referencia a equipos, materiales o sustancias enumeradas en los Cuadros I y II de la Convención de Naciones Unidas de 1988, cuando en realidad estos cuadros no contienen ninguna lista de materiales o equipos, sino únicamente de sustancias. La única referencia que hace el Convenio a los materiales y equipos destinados a la producción o fabricación ilícita de estupefacientes y sustancias psicotrópicas se encuentra el artículo 13 de la Convención, que literalmente dice: "las partes adoptarán las medidas que consideren adecuadas para impedir el comercio y la desviación de materiales y equipos destinados a la producción o fabricación ilícita de estupefacientes y sustancias psicotrópicas y cooperarán a este fin". Por lo que se plantea la duda de si el legislador se refiere a esos materiales y equipos, al mismo tiempo que las sustancias catalogadas que figuran en los Cuadros I y II, o sólo exclusivamente a estas últimas. Sobre este tema existen diferentes opiniones, Sequeros Sazatornil señala que es necesario destacar la diferencia existente en la naturaleza de los objetos que conforman el objeto material del delito. Mientras que las sustancias, constituyen en sí la razón primera de la sanción de la conducta al recaer sobre los precursores propiamente dichos, los equipos y materiales que también lo integran hacen alusión a las herramientas con la cual se pueden blanco. LAMARCA PÉREZ, Carmen (Coord.). Derecho Penal. P.E..., op. cit., p. 508. CORREA DE CARVALHO, José Theodoro. Tráfico de Drogas...., op. cit., p. 62. CÓRDOBA RODA, Juan. Comentarios al Código Penal..., op. cit., pp. 1660- 1662. 
producir o fabricar drogas ilícitas ${ }^{49}$. Mientras que Rey Huidobro sostiene que el legislador ha querido incluir tanto los materiales y equipos a que se hace referencia en el artículo 13 del Convenio, como las sustancias de los Cuadros I y II, pero al haber efectuado una redacción legal inadecuada, no ha sabido plasmarlo en la letra de la Ley, por lo que en base al respeto de los principios de legalidad y seguridad jurídica, la interpretación restrictiva es la que debería prevalecer en este tema, con lo cual se evitaría caer en posibles interpretaciones extensivas o analógicas en perjuicio del reo en tal caso los equipos y materiales quedarían fuera de la órbita del artículo

49 SEQUEROS SAZATORNIL, Fernando. El tráfico de drogas..., op. cit., p. 285. Fabián Caparrós señala que "en principio, el tipo objetivo no establece ninguna clase de limitación en relación con los «equipos» y los «materiales», aspecto que nos hace temer por un campo de aplicación potencial de este precepto excesivamente amplio. Sólo la exposición de motivos de la Ley indica que han de resultar «indispensables» para el cultivo, producción y fabricación ilícita de drogas, criterio que debería de haber sido incorporado a la redacción del precepto. Si lo hace con respecto a las «sustancias», para las cuales exige su previa inclusión en la propia Convención de Viena o en cualquier otro Tratado internacional del que pueda ser parte nuestro Estado". Este autor considera que la inclusión del elemento subjetivo "a sabiendas de" o "para estos fines en la artículo $371 \mathrm{CP}$ ayuda a solventar la absoluta indeterminación con la que son mencionados los equipos y materiales. Afirmando que de este modo, no podrá ser objeto del delito todo bien susceptible de ser utilizado de cualquier modo para el cultivo, la producción o la fabricación ilícita de estupefacientes como fertilizantes, combustibles, etc. Sino únicamente aquellos que sean especialmente idóneos para tal objetivo (instrumental especializado, etc.). Lo que confirma la interpretación del criterio antes mencionado recogido en la exposición de motivos. FABIÁN CAPARRÓS, Eduardo A. "Consideraciones de urgencia..., op. cit., pp. 595, 596. El concepto de precursor puede dar lugar fácilmente a una ampliación sin fin de las listas a ellos alusivas, y los equipos y materiales, al no constituir un catálogo cerrado, permiten abarcar cualquier cosa a partir exclusivamente de la siempre problemática referencia subjetiva. Como los equipos y materiales no se encuentran enumerados en las listas hace falta realizar una interpretación teleológica para comprender este defectuoso precepto. DIEZ RIPOLLES, José Luis. "Tendencias político-criminales en materia de drogas" en Jueces para la democracia. Año 1993. Número 19, pp. 39, 46. CÓRDOBA RODA, Juan. Comentarios al Código Penal pp. 1660-1662. Vid., en el Anexo IV la lista de precursores de drogas, así como sus características y uso legales e ilegales.

50 REY HUIDOBRO, Luis Fernando. El delito de tráfico de estupefacientes. ..., op. cit., pp. 276, 277. CORCOY BIDÁSOLO, Mirentxu. Comentarios al Código Penal. ...., op. cit., pp. $815,816$. 
371, posición que nosotros compartimos plenamente. Lo que no ocurre en otras legislaciones como la costarricense ${ }^{51}$.

Para poner de manifiesto la excesiva amplitud que se puede producir con los materiales o equipos en la legislación española queremos poner como ejemplo la tenencia de equipos y materiales que se pueden usar en el cultivo marihuana (Cannabis sativa), los arbustos de coca (Erythroxylum coca) o de la adormidera (Papaver somniferum). Prácticamente cualquier material de labranza estaría comprendido como equipo siempre que se demostrara el elemento subjetivo del tipo, por lo tanto palas, picos, azadones, machetes, barretones, escardillas, guadañas, horcas, hoces, hachas, rastrillos, regaderas, tijeras, transplantadores y toda una gran variedad de abonos, fertilizantes y plásticos serían precursores de drogas.

También hay que decir que algunas sentencias no hacen más que sembrar confusión sobre el objeto material del tráfico de precursores de drogas, como en el caso de la SAP de Madrid de 14 de junio de 2010 que integra y literalmente dice: "a propósito de los precursores debe de señalarse que son sustancias utilizadas como reactivos, disolventes o catalizadores, en los procesos químicos necesarios para la producción o elaboración de drogas tóxicas, estupefacientes o sustancias psicotrópicas, enumeradas en los Cuadros I y II de la Convención de Naciones Unidas hecha en Viena el 20 de diciembre de 1988, sobre

Que en su artículo número 73 preceptúa que "se impondrá pena de prisión de ocho a quince años a quien produzca, fabrique, prepare, distribuya, transporte, almacene, importe o exporte precursores $u$ otros productos químicos incluidos en esta regulación, además de máquinas y accesorios, para utilizarlos en la comisión de alguno de los delitos tipificados en esta Ley. La pena será de ocho a veinte años de prisión cuando el delito se cometa mediante la constitución o el empleo de una organización delictiva". Sobre los precursores señala, al igual que en la legislación española, que son las sustancias enumeradas en los Cuadros I y II de la Convención de Viena de 1988 y las que incluyan en otros convenios de la misma naturaleza. Mientras que en el caso de los materiales o equipos no se refiere a ningún Cuadro o lista señalando que "además, se controlarán la importación, comercialización y fabricación de máquinas y accesorios que se utilicen para el entabletado, encapsulado y comprimido de estupefacientes, sustancias psicotrópicas u otras de efecto semejante", que únicamente deben de cumplir la condición de ser utilizados en la comisión de alguno de los delitos tipificados en esta Ley. Ley 7786 sobre estupefacientes, sustancias psicotrópicas, drogas de uso no autorizado, legitimación de capitales y actividades conexas de 30 de abril de 1998, reformada íntegramente por la Ley 8204 de 26 de diciembre de 2001. 
el tráfico ilícito de estupefacientes y sustancias psicotrópicas y cualesquiera otros productos adicionados al mismo Convenio o en otros futuros Convenios ratificados por España, y entre ellos se encuentran por ejemplo, el ácido clorhídrico y la fenacetina"52. Como todos sabemos el ácido clorhídrico es un precursor que se encuentra en Cuadro II de dicho Convenio. Pero la fenacetina no se encuentra en ninguno de los cuadros. De hecho es un analgésico muscular, similar al paracetamol, que fue retirado del mercado europeo en el año 1984 porque afecta gravemente los riñones y el hígado. La fenacetina se añade como adulterante para potenciar el sabor amargo de la cocaína y mejorar su aspecto, dándole un tono más brillante a la droga. Por lo tanto es una sustancia de corte o adulterante de la cocaína muy utilizado en España al igual que el levamisol, la cafeína, la lidocaína y el manitol. Es necesario precisar que la tenencia o tráfico de fenacetina no es subsumible en el artículo $371 \mathrm{CP}$ pues como hemos señalado antes no es ninguna de las 24 sustancias catalogadas como precursores de drogas por Naciones Unidas. Lo mismo ocurre con la Sentencia de la Audiencia Provincial de Murcia de 16 de diciembre de 2011 que incluye el benceno y el ácido amino-P-benzoico BP 98 como precursores de drogas aunque no se encuentran en ninguno de los cuadros de la Convención de Viena de 1988, sin embargo este Tribunal afirma que se encuentran incluidos en el Cuadro II53.

Sobre los materiales o equipos antes señalados Suárez López cree que es necesario que se realice una enumeración exhaustiva que debe incluirse en el Convenio de Viena de 1988, como un nuevo anexo, o mejor por una remisión a un cuadro al efecto en una Ley interna, como puede ser la Ley 3/1996, sobre medidas de control de sustancias químicas catalogadas, susceptibles de desvío para la fabricación ilícita de drogas (norma que fue derogada por la Ley 4/2009, de 15 de junio, de control de precursores de drogas), lo que exigiría una modificación del artículo 371 del Código Penal54. En la misma dirección parece Mir.

$53 \quad$ SAP de Murcia (ROJ: 2858/2011) de 16 de diciembre de 2011. Ponente: D. José Manuel Nicolás Manzanares. El error es reproducido en la sentencia de casación. STS (ROJ: 232/2013) de 18 de enero de 2013. Ponente: D. Alberto Gumersindo Jorge Barreiro.

54 La propuesta de Suárez López es la siguiente: "El que fabrique, transporte, distribuya, comercie o tenga en su poder alguna de las sustancias u objetos recogidos en las leyes, 
apuntar Morales García al señalar que la remisión a los Cuadros del Convenio de 1988 plantea un problema de orden político criminal, pues no entiende acertado que el tipo limite su extensión al ámbito de los convenios internacionales, restringiendo de esta manera el paso a posibles regulaciones contenidas en nuestro derecho interno cuyo objeto abarca sustancias igualmente susceptibles de ser utilizadas como precursores para la elaboración de drogas tóxicas ${ }^{55}$. Nosotros creemos, como ya lo hemos señalado antes, que al no encontrarse enumerado ningún equipo o material en el Convenio antes citado o en sus anexos, la tenencia, transporte, distribución o comercio de cualquier equipo o material idóneo para cultivar, fabricar o elaborar drogas ilícitas no podrá subsumirse en el artículo 371, pero sin embargo entendemos que este tipo de conductas si pueden tener cabida en el artículo 368 por la excesiva amplitud con que esta redactadas las conductas punibles, lo cual también puede ocurrir con las denominadas sustancias no catalogadas que se utilizan para la elaboración de drogas ilícitas. En todo caso es preciso decir que afortunadamente, el término "precursores" establecido en la Decisión Marco 2004/757/JAI del Consejo, de 25 de octubre de 2004, es más restringido, ya que excluye tales "equipos o materiales", limitando el concepto a las referidas "sustancias", ahora delimitadas por la disciplina comunitaria en el desarrollo del referido artículo número $12^{56}$.

u otras disposiciones de carácter general, sobre las medidas de control de sustancias químicas catalogadas susceptibles de desvío para la fabricación ilícita de drogas, o en los cuadros I y II de la Convención de Naciones Unidas, hecha en Viena el 20 de diciembre de 1988, sobre el tráfico ilícito de estupefacientes y sustancias psicotrópicas, a sabiendas de que van a utilizarse en el cultivo, la producción o la fabricación ilícitas de drogas tóxicas, estupefacientes o sustancias psicotrópicas, o para estos fines será castigado con la pena de prisión de seis meses a tres años". El artículo 2 del artículo 371 mantiene su redacción actual. SUÁREZ LÓPEZ, José María. El tráfico de precursores..., op. cit., p. 74. "Son equipos o materiales las balanzas de precisión o dinamómetros, alambiques, pequeñas prensas, molinillos de café con restos de sustancias ilícitas, bolsitas de plástico y cualesquiera otros objetos o productos empleados en la fabricación, corte, mezcla o fragmentación de las drogas". LAMARCA PÉREZ, Carmen (Coord.). Derecho Penal. P.E..., op. cit., p. 564. LAMARCA PÉREZ, Carmen (Coord.). Delitos y Faltas. ..., op. cit., p. 643.

55 QUINTERo OLIVARES, Gonzalo. Comentarios a la Parte Especial..., op. cit., p. 1524.

56 FABIAN CAPARROS, Eduardo A. “El tráfico ilícito..., op. cit., p. 5. Señala Fabián Caparrós que la remisión normativa que se realiza en el artículo 371 del CPE es poco afortunada, puesto que se realiza, a los Cuadros I y II de la Convención de Naciones Unidas, del 20 
Hay que recordar que producto de las imprecisiones antes señaladas en la redacción de este tipo penal algunos autores como Queralt Jiménez llegaron a considerar, en algún momento, que si aparecieran nuevas sustancias que pudieran cumplir el cometido de los denominados precursores de drogas, estas podrían considerarse como tales sin necesidad de esperar un consenso internacional ${ }^{57}$. Sin embargo tal situación no es posible ya que el artículo 371 del Código Penal español se refiere exclusivamente a los equipos, materiales o sustancias incluidas en los Cuadros I y II de la Convención de Viena de 1988, y cualesquiera otros productos adicionados al mismo Convenio o a otros futuros convenios de la misma naturaleza ratificados por España. Es decir, que de esta manera no sólo se declara la automática aplicación en el ordenamiento jurídico interno de las sustancias contenidas en este Convenio o futuros convenios internacionales, sino que se priva al legislador español de la posibilidad de incluir sustancias en el artículo 371 que no se hallen reconocidas previamente como precursores en el ámbito internacional ${ }^{58}$. Para poder hacerlo el

de diciembre de 1988, y cualesquiera productos agregados al mismo Convenio u otros convenios de la misma naturaleza, ratificados por España, sin recurrir en ningún caso a la normativa interna. De esta manera el tipo objetivo no establece de forma clara, la necesaria limitación de los "equipos" y "materiales" comprendidos en el tipo penal, lo cual propicia que el ámbito de aplicación de este precepto sea excesivamente amplio e impreciso; con ello, "el legislador ha demostrado su inequívoca voluntad de incorporarse a un programa de lucha al narcotráfico que supera las fronteras internas; pero también ha formalizado una suerte de autolimitación a la hora de determinar cuáles han de ser en el futuro esas sustancias. FABIAN CAPARROS, Eduardo A. "Consideraciones de urgencia..., op. cit., p. 595. CORDOBA RODA, Juan. GARCIA ARAN, Mercedes (Dir.). Comentarios al Código Penal. Parte Especial. Tomo II. Ed. Marcial Pons. Madrid. 2004, p. 1661. Afirma que se trata de una norma penal abierta, que no peca, pese a ello de inconstitucionalidad. LAMARCA PÉREZ, Carmen (Dir.). Derecho Penal. Parte Especial. 3a edición. Colex. Madrid. 2005, p. 516. En el mismo sentido que Fabián Caparrós. SUÁREZ LÓPEZ, José María. “El tráfico de precursores. ..., op. cit., pp. 72, 73.

57 QUERAlT JIMÉnEZ, J. J. Derecho Penal Español. Parte Especial. Tercera edición. J. M. Bosch. Barcelona. 1996, p. 814.

$58 \quad$ REY HUIDOBRO, Luis Fernando. El delito de tráfico de estupefacientes. ..., op. cit., p. 278. En el mismo sentido Fabián Caparrós señala que el legislador además de mostrar su inequívoca intensión de incorporarse a un programa de ámbito internacional, "ha formalizado una suerte de autolimitación a la hora de determinar cuáles han de ser en el futuro esas sustancias". FABIÁN CAPARRÓS, Eduardo A. "Consideraciones de urgencia..., op. cit., p. 595. SUÁREZ LÓPEZ, José María. El tráfico de precursores..., op. cit., p. 73. SEQUEROS SAZATORNIL, Fernando. El tráfico de drogas..., op. cit., p. 286. El 
legislador español tendría que reformar este artículo. Afortunadamente no conocemos de la existencia de ninguna sentencia que sancione por el delito de tráfico de precursores de drogas la fabricación, distribución, comercio o tenencia de materiales o equipos que puedan utilizarse para la elaboración de drogas ilícitas.

Díez Ripollés en su momento censuró la desmesurada extensión que otorga el precepto al objeto material de este tipo penal, pues no se conforma con aludir a las sustancias químicas incluidas en las listas de la Convención, o con sumar a éstas las que se añadan en un futuro a dichas listas según el procedimiento previsto en el mismo, sino que, ampliando de por sí la peligrosa técnica de la ley penal en blanco hasta límites desconocidos hasta ahora, incluye también aquellos productos que se adicionen en otros futuros convenios de la misma naturaleza ratificados por España. Esto en su opinión posibilita que se pueda producir una ampliación sin fin de las listas de las sustancias catalogadas como precursores, lo que conlleva, según esta tesis, una grave indeterminación del tipo, afectando con ello al principio de certeza y seguridad jurídica ${ }^{59}$. Dichosamente en los 26 años de vigencia

Tribunal supremo absuelve como autor de un delito intentado contra la salud pública a un sujeto colombiano sin residencia legal en España que se le ocuparon 0.96 gramos de cocaína con una pureza base de $12.9 \%$ que no consta que no fuera para autoconsumo, así como 5 kilogramos de sustancias de corte (fenacetina, lidocaína, levamisol y ácido borico) y una balanza de cocina en su domicilio, porque ninguna de esas sustancias son drogas o estupefacientes abarcados por el artículo 368 del Código Penal, además se señala que tampoco lo pueden sancionar por tráfico de precursores porque ninguna de las cuatro sustancias pertenecen al listado de las 23 sustancias catalogadas en los Cuadros I y II del Convenio de Viena de 1988. También hay que decir que no se hace ninguna referencia sobre la posibilidad de considerar la balanza de cocina como un instrumento que se usa para elaborar drogas. STS (ROJ: 4232/2010), de 23 de junio de 2010. Ponente: Adolfo Prego de Oliver Tolivar.

DIEZ RIPOLLES, José Luis. “Tendencias político-criminales..., op. cit., p. 46. REY HUIDOBRO, Luis Fernando. El delito de tráfico de estupefacientes. ..., op. cit.,. 1987, p. 278. Sobre este tema Mendoza Buergo sostiene que en el artículo 371 se realiza una remisión hacia el futuro, cuando menos sorprendente desde el punto de vista del principio de legalidad, a cualquier otro producto que pueda adicionarse a este Convenio o que pueda incluirse en otros futuros Convenios o Convenciones, de la misma naturaleza, ratificados por España. BAJO FERNÁNDEZ, Miguel (Dir.). Compendio de Derecho Penal. Parte Especial. Vol. II. Ed. Centro de Estudios Ramón Areces, S.A., Madrid. 1998, pp. 688, 689. En el mismo sentido. VIDALES RODRÍGUEZ, Catalina. "La última reforma del Código Penal en materia de drogas" en Revista General de Derecho, 
que tiene el Convenio de Viena de 1988 sólo se ha pasado de las 12 sustancias originales contenidas en los cuadros a las 24 que están catalogadas actualmente, lo cual aunque representa un aumento notable $(100 \%)$, en nuestra opinión no se puede tildar de desmesurado. Por el contrario también se le cuestionaba a esta técnica legislativa que esta remisión internacional puede resultar excesivamente lenta, lo cual pone entre dicho que el legislador recurriera a la técnica de la Ley penal en blanco, que tiene la función esencial de impedir en determinados aspectos el anquilosamiento del Derecho Penal superado por la rapidez $\mathrm{y}$ frecuencia de los cambios sociales ${ }^{60}$, lo cual efectivamente sucede, ejemplo de ello es que para trasladar el ácido fenilacético del Cuadro II al Cuadro I del Convenio, y por ende incrementar las medidas de control sobre esta sustancia a nivel mundial, se demoraron cuatro años ${ }^{61}$. Situación que ha ido mejorando en alguna medida pues para incorporar el APAAN al Cuadro I de la Convención solo demoraron un año y siete meses ${ }^{62}$.

Queremos citar a manera de ejemplo, con una redacción bastante diferente a la legislación española sobre el tráfico de precursores de drogas, la Ley de control de insumos químicos y productos fiscalizados, Ley № 28305 de la República del Perú, del 29 de julio del año 2004 que en su artículo número 4 establece una lista de 27 sustancias que son consideradas insumos químicos o productos fiscalizados (precursores de drogas). De estas sustancias sólo 12 pertenecen a los cuadros incluidos en la Convención de Viena de 1988 (5 del Cuadro I y 7 del Cuadro II). Las otras 15 sustancias enumeradas en la lista son sustancias no catalogadas que se usan frecuentemente en la elaboración de drogas tóxicas, estupefacientes y psicotrópicos. Es importante destacar que en este mismo artículo se establece que esta lista se

núm. 583, Valencia, abril 1993, p. 2731. CORREA DE CARVALHO, José Theodoro. Tráfico de drogas..., op. cit., p. 62. SUÁREZ LOPEZ, José María. El tráfico de precursores. ..., op. cit., pp. 73, 74.

61 Precursores y sustancias químicas frecuentemente utilizados..., correspondiente a 2010..., p. 1 .

62 El alfa-fenilacetoacetonitrilo (APAAN) es un precursor inmediato de otro precursor la 1-fenil-2-propanona (P-2-P) que se utiliza en la fabricación ilícita de anfetamina y metanfetamina. Precursores y sustancias químicas frecuentemente utilizados..., correspondiente a $2014 \ldots$, p. 7. 
podrá modificar, retirando o incluyendo nuevos precursores o mezclas de estos, mediante Decreto Supremo para el cual se requiere un informe técnico del Comité de Coordinación Interinstitucional e informe favorable del Ministerio de la Producción y del Ministerio del Interior. El citado Decreto Supremo debe ser refrendado por los titulares de ambos ministerios ${ }^{63}$. En Argentina la Ley 23.737 en su artículo número 24 establece que los precursores, y productos químicos serán determinados en listas que, por decreto, el Poder Ejecutivo Nacional debe elaborar a ese fin y actualizar periódicamente. Esta lista actualmente tiene catalogada como precursores de drogas un total de 60 sustancias, 23 sustancias de los Cuadros I y II del Convenio de Viena y 37 sustancias no catalogadas que normalmente se utilizan en la elaboración de drogas ilícitas ${ }^{64}$. Lo mismo ocurre en la legislación penal colombiana que en el artículo 382 del Código Penal establece que son precursores de drogas las sustancias "contempladas en los Cuadros I y II de la Convención de Naciones Unidas contra los Estupefacientes y sustancias Psicotrópicas y las que según concepto previo del Consejo Nacional de Estupefacientes se utilicen con el mismo fin" 65 .

\section{D.) LA CONDUCTA TÍPICA}

Las conductas típicas preceptuadas en el artículo 371 del Código Penal consisten en la fabricación, transporte, distribución, comercio o tenencia de equipos, materiales o sustancias enumeradas en el Cuadro I y Cuadro II, de la Convención de Naciones Unidas, celebrada en Viena el día 20 de diciembre de 1988, sobre el tráfico ilícito de estupefa-

63 Las sustancias de los Cuadros que se consideran precursores en el Perú son: anhídrido acético, permanganato de potasio, piperonal, safrol e isosafrol (Cuadro I) y acetona, ácido sulfúrico, ácido clorhídrico, éter etílico, metiletilcetona, tolueno y ácido antranílico (Cuadro II). "Se trata de un precepto penal parcialmente en blanco, con un elemento normativo que se integra por remisión a la normativa internacional". La Ley № 28305, fue modificada por la Ley 29037 del uno de junio del 2007, se encuentra desarrollada por el Reglamento de la Ley 28305 Ley de control de insumos químicos y productos fiscalizados. Reglamento que fue aprobado mediante el Decreto supremo № 053-2005-PMC, del 27 de julio del año 2005. PEÑA CABRERA FREYRE, Alonso. R. Tráfico ilícito de drogas..., op. cit., pp. 443, 444, 467-543.

64 SARAVIA TOLEDO, Rogelio. Curso de Derecho...., op. cit., pp. 975, 976, 1005, 1006.

65 Se usa la versión actualizada del artículo 382 del Código Penal de Colombia. PABON PARRA, Pedro Alfonso. Manual de Derecho...., op. cit., p. 778. 
cientes y sustancias psicotrópicas, y cualesquiera otros productos adicionados al mismo Convenio, o que se incluyan en otros futuros convenios de la misma naturaleza, ratificados por España, a sabiendas de que van a utilizarse en el cultivo, la producción o la fabricación ilícita de drogas tóxicas, estupefacientes o sustancias psicotrópicas o para estos fines ${ }^{66}$. El antecedente de este tipo penal es el artículo 344 bis g) y 344 bis j) del Código Penal anterior, artículos que entraron en vigor a partir de la Ley Orgánica 8/1992, del 23 de diciembre, del cual el actual artículo $371 \mathrm{CP}$ es una reproducción bastante fiel. En una primera aproximación a este ilícito penal se puede apreciar que sujeto activo de este delito puede serlo cualquier persona, pues se trata de un delito común, mientras que sujeto pasivo es la colectividad, ya que ella es la titular del bien jurídico salud pública. Además hay que decir que la comisión de este ilícito debe de realizarse de forma dolosa, que no caben comportamientos omisivos, y además debe conocerse que el tráfico de estas sustancias está destinado a la elaboración ilícita de drogas, también hay que decir que no hace falta demostrar en el proceso el ánimo de lucro dado que este tipo penal no lo exige.

Como ya señalamos antes el delito de tráfico de precursores de drogas está integrado por cinco verbos rectores: "fabricar", "transportar", "distribuir", "comerciar" y "tener" las sustancias catalogadas para la elaboración ulterior de drogas ilícitas, careciendo de relevancia que el sujeto lleve a cabo uno o varios de los actos típicos. Debiendo ajustarse su interpretación jurídica a la dimensión semántica de su significado, por lo tanto:

1) Por "fabricar" habrá que entender la producción de objetos en serie, usando generalmente medios mecánicos. Está conducta consiste

66 En opinión de Díez Ripollés el legislador fue más allá de lo que exigía la Convención de Viena de 1988 en su artículo 3.1 a) iv) que obliga a las partes a tipificar como delitos: "la fabricación, el transporte o la distribución de equipos, materiales o de las sustancias enumeradas en el Cuadro I y Cuadro II, a sabiendas de que van a utilizarse en el cultivo, la producción o la fabricación ilícitos de estupefacientes o sustancias sicotrópicas o para dichos fines", porque incluye el castigo de la posesión de precursores, lo cual no venía necesariamente obligado por dicha Convención, pues la punición de la posesión queda a reserva de los principios constitucionales y de los conceptos fundamentales de cada ordenamiento jurídico, lo cual así se establece en el artículo 3.1 c) ii) de este Convenio. DÍEZ RIPOLLÉS, José Luis. "Tendencias político criminales en materia de drogas" en Jueces para la democracia. Información y debate, no 19, 2/1993, p. 46. 
en la elaboración o fabricación mediante un conjunto de operaciones de síntesis químicas, pudiendo utilizar para ello diversos métodos, de cualquiera de las 24 sustancias catalogadas como precursores de drogas en los cuadros I y II del Convenio de 1988. En el caso de que el resultado no se lograse por razones ajenas a la voluntad del autor o los autores, es decir que no se haya concluido el proceso de fabricación ilícita, por ejemplo de la efedrina o el permanganato de potasio al tenor de la redacción del tipo podrían apreciarse formas de imperfecta ejecución a pesar del desmesurado adelantamiento de la barrera punitiva que se produce al sancionar de esta manera la tentativa de un acto preparatorio, elevado al categoría de delito autónomo, del delito de tráfico de drogas propiamente dicho ${ }^{67}$. Es necesario señalar que el proceso de fabricación ilegal de precursores generalmente se realiza en emplazamientos cercanos a los laboratorios ilícitos o bien en los propios laboratorios. Cuando se produce este último supuesto generalmente una vez que se termina la elaboración del precursor se procede casi de forma inmediata a la fabricación de la droga ilícita, de esta manera se presenta la particularidad de que el acto de fabricar la sustancia catalogada, que en principio sería la conducta más distante a la de elaboración de drogas ilegales, pasa a ser la más cercana. Queremos subrayar que se sancionara por el delito de tráfico de precursores cuando se ocupen estas sustancias, siempre que no se haya iniciado la elaboración de la droga, en el caso de los estimulantes de tipo anfetamínico, o bien cuando en el laboratorio se encuentren precursores pero no materia prima (latex de adormidera, opio, pasta de coca o cocaína base) para la elaboración de drogas o alguna cantidad significativa de estupefacientes ya terminados.

2) Por "transportar" debe comprenderse la acción de trasladar las sustancias catalogadas en los cuadros I y II del Convenio de Viena de

67 JOSHI JUBERT sostiene que sólo deben apreciarse formas de imperfecta ejecución en las conductas de tráfico, promoción, facilitación y favorecimiento del artículo $368 \mathrm{CP}$ pues estos comportamientos lesionan efectivamente el bien jurídico "salud pública", lo cual en su opinión no es legítimo en las conductas de cultivo, elaboración y posesión, del mismo precepto penal, ya que en estas fases sólo se pone en peligro el bien jurídico salud pública al ser fases previas a la consumación material, especialmente previstas en la parte especial, lo cual en nuestra opinión cobra aún más sentido en el caso de las conductas previstas en el tráfico de precursores donde la puesta en peligro al bien jurídico antes señalado es más remoto. JOSHI JUBERT, Ujala. Los delitos de tráfico..., op. cit., pp. 244, 245. 
1988 de un lugar a otro dentro del territorio nacional, de este a un tercer país, de un tercer país al territorio nacional o simplemente de tránsito por el Estado. Esta actividad se puede ejecutar usando cualquier medio de transporte (aéreo, naval o terrestre), inclusive se puede realizar a pie (porteadores) o a través de servicios postales. Cabe recordar que la mayoría de las veces para transportar los precursores de drogas estos se enmascaran o camuflan dentro de diversos objetos de uso cotidiano o en sustancias no sometidas a fiscalización para evitar su detección por los Cuerpos y Fuerzas de seguridad, así como que muchas veces, con el mismo fin, los traficantes utilizan rutas por países distintos de aquellos por los que el envío está destinado a transitar, realizando operaciones de importación y reexportación de las mismas a través de terceros países ${ }^{68}$. Es necesario puntualizar que si quien lleva a cabo el transporte desconoce que está transportando precursores de drogas y que estos están destinados a la elaboración ilícita de drogas estaríamos ante un caso de autoría mediata, en el cual el comportamiento del autor material debe quedar impune por ausencia de dolo y del elemento subjetivo adicional que contiene el artículo 371CP.

3) Por "distribuir" debe entenderse dar a cada sustancia su oportuna colocación o el destino conveniente para su posterior utilización en la elaboración ilícita de drogas. Se trata de hacer llegar los precursores a distintos puntos de almacenamiento o bien a los propios laboratorios clandestinos donde serán utilizados para la elaboración ilícita de drogas.

4) Por "comerciar" deberá comprenderse el acto de comprar, vender o permutar géneros, en el caso que nos ocupa los precursores de drogas. Debiendo aclarase en este sentido que no se requiere la validez y eficacia civil de estas operaciones, pues como todos sabemos para la adquisición de estas sustancias los traficantes normalmente utilizan una serie de subterfugios como el uso sociedades ficticias o documentación falsificada de empresas o instituciones reales. Sin embargo entendemos que no se debería sancionar el simple "acuerdo consensuado" respecto del precursor y el precio, aunque ni la una ni el otro

$68 \quad$ Al ser el bien jurídico tutelado la salud pública en general es irrelevante que el tráfico de precursores este destinado a la elaboración de drogas ilícitas en España o en un tercer país. 
hubiesen sido entregados. En el caso de que se pueda demostrar que el vendedor legitimo desconociera la finalidad ilícita que se le va a dar a las sustancias catalogadas, también cabe la posibilidad de apreciar casos de autoría mediata, así como de sancionarlo, si corresponde, administrativamente por infringir alguna de las normas de la Ley 4/2009, de 15 de junio, de control de precursores de drogas ${ }^{69}$.

5) La "tenencia" debe de ser entendida según la terminología penalística, no en el sentido de que el sujeto activo deba tener la cosa (el o los precursores) en una inmediata relación con el cuerpo, sino que es suficiente con que posea la disponibilidad de hecho de la sustancia a través de la atracción de la misma al ámbito de la propia esfera de custodia, sin que sea necesaria la presencia del sujeto en el lugar en que se encuentra la cosa y mucho menos que tal lugar le pertenezca. Se debe destacar que las conductas antes señaladas para que adquieran relevancia penal deben de realizarse a sabiendas de que se utilizarán para la elaboración de drogas ilícitas o para estos fines de no ser así pueden apreciarse casos de autoría mediata, así como que la posesión puede ser bastante prologada pues un método utilizado por los traficantes de estas sustancia es dejar los precursores de drogas, como ha ocurrido en muchas ocasiones, en almacenes durante un largo periodo de tiempo, ya que son conscientes de que las autoridades tienen unos recursos limitados y no pueden mantener indefinidamente un envío bajo observación, o bien muy corta cuando la tenencia se lleva a cabo en emplazamientos o locales cercanos a los laboratorios o en los propios laboratorios donde se elaboran las drogas. Es necesario destacar que el castigo de la posesión de precursores no venía necesariamente obligado por la Convención de Viena de 1988, pues la punición de la posesión queda a reserva de los principios constitucionales y de los conceptos fundamentales de cada ordenamiento jurídico, lo cual así se establece en el artículo 3.1 c) ii) de este Convenio.

Como se puede observar el legislador al hacer alusión de forma expresa a los actos de fabricación, transporte, distribución, comercio y posesión, otorga al ámbito de los comportamientos típicos una gran generalidad, que hace que sea punible a título de autor, prácticamente todo comportamiento relacionado con aquellos. Así hasta la más 
mínima contribución a la producción o difusión de una sustancia incluida en los cuadros, siempre que se tenga conocimiento de que va a ser utilizada en la elaboración ilícita de drogas, estupefacientes o sustancias psicotrópicas, estará sin más comprendida en el artículo 371 CP. Queremos recordar una vez más que ninguna de las 24 sustancias catalogadas se utiliza en el cultivo de drogas ilegales, así como que en nuestra opinión los materiales o equipos a que hace alusión el artículo antes citado, producto de la desafortunada redacción realizada por el legislador están fuera de la órbita de este tipo penal. Lo que no niega la importancia que puedan tener para fundamentar en los procesos judiciales la responsabilidad de los autores por la comisión de este ilícito penal.

Como todos sabemos a este tipo penal, al igual que el artículo 368, relativo al tráfico de drogas, estupefacientes y psicotrópicos, la doctrina mayoritaria les critica su excesiva amplitud, al entender que tan amplia y ambigua redacción podría vulnerar los principios constitucionales de legalidad y seguridad jurídica. En primer lugar se señala que podría entenderse que, siendo los hechos constitutivos de tráfico de precursores susceptibles de ser calificados como una tentativa del delito previsto en el artículo 368 (especialmente, habida cuenta de la amplitud con la que se encuentra descrita la conducta típica en dicho precepto), la inclusión del tráfico de precursores es innecesaria, dado que las conductas en él descritas podrían castigarse como una forma de imperfecta ejecución del delito de tráfico de drogas (elaboración o fabricación de drogas ilícitas) ${ }^{70}$.

Se cuestiona también que el artículo 373 del CP sancione la provocación, la conspiración y la proposición para cometer entre otros, el tráfico estas sustancias catalogadas, resultando con ello, que se castigan "los actos preparatorios de los actos preparatorios del tráfico de drogas", es decir, "la preparación de la preparación", sancionándose de esta manera no sólo el tráfico de precursores de drogas, sino

70 En este sentido SUÁREZ LOPEZ, José María. El tráfico de precursores. ..., op. cit., p. 72. Vidales Rodríguez sostiene que la introducción del artículo 344 bis g) y 344 bis j), actual artículo 371, resultaba innecesaria al tenor del contenido del artículo 344 (artículo 368). VIDALES RODRÍGUEZ, Catalina. "La última reforma..., op. cit, p. 2731. QUINTERO OLIVARES, Gonzalo. Comentarios a la Parte Especial..., op. cit., p. 1524. 
también de forma específica, los actos preparatorios a él referidos ${ }^{71}$, con lo que "parece que tal regulación renuncia a los principios penales básicos, algunos constitucionales, aceptados de forma general por la doctrina y la jurisprudencia"72. En este sentido con razón se afirma que dicho precepto opera como excepción al modelo de incriminación de los actos preparatorios consagrados en los artículos 16 (tentativa), 17 y 18 (actos preparatorios) del Código Penal73. Es necesario recordar que el legislador español incorpora la sanción de la conspiración, la proposición y la provocación para cometer el delito de tráfico de precursores de drogas en el Código Penal en atención al artículo 3.1 c) de la Convención de Naciones Unidas de $1988^{74}$.

Sequeros Sazatornil señala que del artículo $371 \mathrm{CP}$ no es correcto decir que contenga un tipo delictivo descrito en forma abierta que propicie o facilite el arbitrio judicial en detrimento de la seguridad jurídica y del principio de legalidad, ya que su núcleo central está constituido por dos factores que se encuentran bien definidos, como son: el de la posesión de los instrumentos idóneos para cometer el delito básico de tráfico de drogas y la especial destinación que su poseedor va a dar a los mismos, requisitos de los cuales el primero es de eminente carácter objetivo mientras que el segundo es de carácter subjetivo o intencional, debiendo además destacarse que uno y otro deben situarse dentro del marco del artículo 6 del Código Penal que exige para todo tipo de delito la concurrencia de dolo o culpa, al igual que para la imposición de una

71 REY HUIDOBRO, Luis Fernando. El delito de tráfico de estupefacientes. ..., op. cit., pp. 273, 274. ÁlVAREZ GARCÍA, F. Javier. Derecho Penal Español..., op. cit., p. 1353. MORILlAS CUEVAS, Lorenzo (Coord.). Sistema de Derecho Penal Español. Parte Especial. Ed. Dikinson, S. L. Madrid, 2011, pp. 824, 825.

72 JOSHI JUBERT, Ujala. "Sobre el concepto de organización en el delito de tráfico de drogas en la jurisprudencia del Tribunal Supremo" en Anuario de Derecho Penal y Ciencias Penales, tomo XLVIII, fasc. II, mayo-agosto. 1995, p. 658.

73 CORCOY BIDÁSOLO, Mirentxu. Comentarios al Código Penal. ...., op. cit., p. 816.

74 Que estipula que cada una de las partes adoptará las medidas que sean necesarias para tipificar como delitos penales en su derecho interno, cuando se cometan intencionalmente, a reserva de sus principios constitucionales y de los conceptos fundamentales de su ordenamiento jurídico: La participación en la comisión de alguno de los delitos tipificados de conformidad con lo dispuesto en el presente artículo, la asociación y la confabulación para cometerlos, la tentativa de cometerlos, y la asistencia, la incitación, la facilitación o el asesoramiento en relación con su comisión. 
pena la exige el artículo número 575 . Consecuentemente con lo expuesto anteriormente sostiene que sólo existe una forma de entender el artículo 371 del CP de acuerdo con la cual, la posesión de instrumentos y sustancias en él descritos, como su idoneidad para la comisión del delito de tráfico a través de su desvío, y su especial destinación por su poseedor para la ejecución de éste, corresponderá siempre probarlas como cualquier otro elemento inculpatorio a la parte acusadora, sin que por exigencias de la ley tenga el acusado que realizar prueba alguna sobre dichos particulares, siendo libre el procesado de emitir en su descargo exculpación alguna así como de alegar y probar una finalidad diferente ${ }^{76}$. Sin embargo no parece ser ese siempre el criterio que mantiene el Tribunal Supremo, a manera de ejemplo citamos la sentencia del 14 de abril de 1999 que anuló la sentencia absolutoria dictada por la Audiencia Provincial de San Sebastián en que se absolvía a dos sujetos tanto de los delitos contra la salud pública, en la modalidad de sustancias que causan grave daño a la salud y en cantidad de notoria importancia de los artículos y 369.3 del Código Penal, y contrabando, de los artículos 2.1 d) y 3.1 párrafo $2^{\circ}$, inciso $2^{\circ}$ de la Ley de Contrabando, como del artículo 371. 1ํo del Código Penal. Sancionando a estos dos sujetos por el delito de tráfico de precursores de drogas ${ }^{77}$.

Este mismo autor señala que el artículo $371 \mathrm{CP}$ castiga a los que con las conductas descritas agoten los preliminares al tráfico de drogas tóxicas, estupefacientes y sustancias psicotrópicas, no especificando el tipo básico sobre si dichos actos de tráfico se pueden realizar por el infractor inicial o por un tercero. Posiblemente la actividad más común 2497/2001) de 26 de marzo. Ponente: José Jiménez Villarejo.

76 SEQUEROS SAZATORNIL, Fernando. El tráfico de drogas ..., op. cit., p. 291. Una vez más queremos señalar que en los Cuadros I y II del Convenio de Viena de 1988 no se hace referencia a materiales o equipos que sirvan para elaborar drogas ilícitas.

77 Fundamento de Derecho Tercero: "Igualmente las remisiones de dinero efectuadas por "A" mediante transferencias bancarias a Colombia, la última el 22 de junio de 1996, por un importe de 1.398 .382 pesetas (8.404 euros con 45 céntimos), sin que su explicación sea convincente, al no concretar la causa de las mismas, pues no se envían dichas sumas importantes, aunque sea un amigo el receptor de aquéllas". STS (ROJ: 2484/1999) de 14 de abril de 1999. Ponente: D. Eduardo Móner Muñoz. MOLINA MANSILLA, María del Carmen. El Delito de Narcotráfico. ..., op. cit., p. 229. 
corresponderá a quienes además de manipular los precursores lo hagan con el fin de producir o fabricarse la droga ellos mismos. En este caso señala que deberá de distinguirse el tipo de droga de que se trate: en concreto si es de las que causan grave daño a la salud o no, ya que este artículo no prevé esa alternativa. Es necesario aclarar que las 24 sustancias catalogadas en los Cuadros I y II del Convenio del 20 de diciembre de 1988 se utilizan para elaborar las denominadas drogas duras. En opinión de Sequeros normalmente el supuesto más común corresponderá a las drogas más gravemente dañosas que necesitan de procesos químicos o sintéticos para su fabricación. No obstante, aunque el proceso para producir las drogas blandas suele ser natural como el de la marihuana, en otras se hace imprescindible el uso de materiales y equipos (prensa y aprietes), como ocurre con sus derivados el hachís o el aceite de hachís. En este sentido queremos recordar, una vez más, que en los Cuadros I y II del Convenio de 1988 no existe ninguna lista de materiales y equipos, ni tampoco ninguna sustancia catalogada que se use en el procesamiento de las sustancias antes señaladas ${ }^{78}$, razón por la cual creemos que si se encontraran los materiales o equipos en el curso de una investigación, sin hallar ninguna de las sustancias catalogadas, no podría sancionarse a quienes las tuviesen como autores del delito de tráfico de precursores de drogas ilegales, lo cual no niega que si pueda hacerse, dada la amplitud de la redacción del tipo, por el articulo 368 en grado de tentativa o incluso de autoría, si se realiza una interpretación muy generosa de este artículo ${ }^{79}$.

Lo mismo ocurre con las denominadas sustancias no catalogadas, que pueden ser desde un total de 52 si se toman en cuenta las que se encuentran incluidas en la lista limitada de vigilancia especial internacional de sustancias no incluidas en los cuadros hasta 150 sustancias de las cuales tiene conocimiento la JIFE que varios estados realizan diversos tipos de fiscalización por su uso frecuente en la

79 Sobre la posibilidad de castigar otros actos preparatorios que no estén recogidos en los Cuadros I y II del Convenio de Viena de 1988, mediante tentativa del artículo 368. SERRANO GÓMEZ, Alfonso. Derecho Penal. ..., op. cit., p. 734. 
elaboración de drogas ilícitas ${ }^{80}$. A manera de ejemplo citamos la Sentencia del Tribunal Supremo de 23 de junio de 2010 que absuelve como autor de un delito intentado contra la salud pública a un sujeto colombiano sin residencia legal en España al que se le ocuparon una bolsa de 0.96 gramos de cocaína con una pureza base del $12.9 \%$ que no consta que no fuera para autoconsumo, así como 5 kilogramos de sustancias de corte (fenacetina, lidocaína, levamisol y ácido bórico) y una balanza de cocina en su domicilio. Señalando el Tribunal que ninguna de esas sustancias son drogas o estupefacientes abarcados por el artículo 368 del Código Penal, además se expresa en esta sentencia que tampoco lo pueden sancionar por tráfico de precursores porque ninguna de las cuatro sustancias pertenecen al listado de las 24 sustancias catalogadas en los Cuadros I y II del Convenio de Viena de 198881. Sin embargo dada la amplitud del artículo 368 CP pudieron condenar a una persona como autor de un delito de tráfico de drogas a cuatro años de prisión y multa de 18.000 euros por venderles a unos traficantes unos cuantos kilos de fenacetina para cortar cocaína teniendo pleno conocimiento de su destino, señalando el Tribunal "que no obstante la inocuidad de la fenacetina (sustancia no catalogada como precursor de drogas), esta era adquirida por el recurrente para entregarla a los otros condenados, a sabiendas que era destinada por ellos como sustancia de corte de la cocaína, que tenían y les fue ocupada, para incrementar su peso y por tanto sus ganancias. En este escenario es claro que el recurrente actuaba como promovedor del ilícito de tráfico, vista la amplitud del tipo penal del artículo 368 del Código Penal, y por tanto no puede cuestionarse, desde el respeto de los hechos probados la aplicación del tipo penal" 82 . Lo que pone de

Precursores y productos químicos frecuentemente utilizados..., correspondiente a 2011..., p. 35. La lista de vigilancia internacional especial limitada de sustancias no incluidas en los cuadros se creó dándole cumplimiento a la resolución 1996/29 del Consejo Económico y Social, paso de tener 26 sustancias en el año 1998, cuando fue creada, a 52 sustancias en el año 2012. Precursores y sustancias químicas frecuentemente utilizados..., correspondiente a 2012..., pp. 35, 36. Vid., en el Anexo V la lista de sustancia químicas no catalogadas que más se utilizan a nivel mundial en la elaboración de drogas ilícitas. Tolivar.

82 STS (ROJ: 3941/2009) de 3 de junio de 2009. Ponente: D. Joaquín Giménez García. 
manifiesto que el tráfico o la tenencia de una sustancia no catalogada, aunque se cumpla el elemento subjetivo "a sabiendas de" o "para estos fines", no puede subsumirse en el artículo $371 \mathrm{CP}$.

Para terminar este apartado queremos señalar que en el caso de fármacos como el Rohipnol, Buprex (este opiáceo ha tenido diferente tratamiento en la jurisprudencia), Trankimanzin, o las benzodeacepinas en general, que de forma mayoritaria son considerados como psicotrópicos que no causan grave daño a la salud por el Tribunal Supremo Español ${ }^{83}$, no tenemos conocimiento de que se utilicen ninguna de las 24 sustancias catalogadas como precursores de drogas en su elaboración, por lo que tampoco el tráfico de las sustancias que se utilizan para elaborar dichos fármacos debe sancionarse como un delito de tráfico de precursores de drogas.

\section{E.) EL DOLO Y EL ELEMENTO SUBJETIVO DEL INJUSTO}

En la vertiente subjetiva del tipo, el dolo en este caso exige que el sujeto activo tenga conocimiento de que las sustancias que fabrica, transporta, distribuye, comercie o posee, sean precursores de drogas tóxicas, estupefacientes o psicotrópicos, y no obstante de esta comprensión, realice voluntariamente los actos prohibidos. Hay que puntualizar que se trata de un tipo de injusto que, además del elemento

83 STS (ROJ: 8957/1992) de 9 de diciembre 1992. Ponente: D. José Antonio Martín Pallin, STS (ROJ: 3187/1998) de 18 de mayo de 1998. Ponente: D. Gregorio García Ancos. STS (ROJ: 9361/1992) de 24 de diciembre de 1992. Ponente: D. Joaquín Delgado García. STS (ROJ: 2644/1998) de 27 de abril de 1998. Ponente: D. José Antonio Martín Pallín. STS (ROJ: 4886/1998) de 20 de junio de 1998. Ponente: D. José Augusto de la Vega Ruiz. STS (ROJ: 6427/1998) de 4 de Noviembre. Ponente: D. Eduardo Moner Muñoz. STS (ROJ: 6816/1998) de 17 de Noviembre de 1998. Ponente: D. José Jiménez Villarejo. Ver criterio adoptado en el pleno de la Sala segunda del TS que considera al Rohipnol, y en general a las benzodiacepinas, como drogas que no causan grave daño a la salud de las personas, modificando la doctrina anterior. Las razones que se exponen para no considerar estas sustancias como no causantes de grave daño a la salud son las siguientes: 1. Se trata de fármacos que pueden ser dispensados sin apenas contraindicaciones y efectos secundarios, 2. No producen adicción específica, 3. No alteran la personalidad de quienes las consumen, 4. La peligrosidad de estas sustancias no viene determinada por la composición intrínseca sino por su uso incontrolado. Joshi Jubert sostiene que deben considerarse sustancias que causan daño a la salud en forma no grave pero penalmente relevante los sedantes, los hipnóticos o ansiolíticos antes citados. JOSHI JUBERT, Ujala. Los delitos de tráfico..., op. cit., pp. 86-91, 98. 
subjetivo general integrado por el dolo, se caracteriza por ser portador de un particular elemento subjetivo adicional, consistente en que las sustancias relacionadas en el artículo 371 sean fabricadas, transportadas, distribuidas, poseídas o comercializadas, "a sabiendas" de que van a utilizarse en el cultivo, la producción o la fabricación ilícita de drogas tóxicas, estupefacientes o sustancias psicotrópicas, "o para esos fines". Es importante destacar que la doctrina mayoritaria, a la que nosotros nos adherimos, sostiene que el tipo exige siempre la existencia de un dolo directo ${ }^{84}$. Aunque a juicio de algunos autores como Díez Ripollés se trata de un defecto de técnica legislativa, pues se reiteran de un modo incongruente las exigencias subjetivas en un mismo tipo respecto a las mismas conductas, primero la posibilidad de cometerse con dolo eventual "a sabiendas de" y luego con dolo directo de primer grado "para estos fines" y consecuentemente se castiga, de un modo poco realista, la posesión en supuestos de dolo eventual ${ }^{85}$.

Sobre este tema, Morales García afirma, en nuestra opinión con razón, que tal redacción responde a que las conductas de fabricación, transporte, distribución, comercio o tenencia se proyecten sobre el

REY HUIDOBRo, Luis Fernando. El Delito de Tráfico de Drogas. ..., op. cit., p. 279. SUÁREZ LOPEZ, José María. El tráfico de precursores..., op. cit., pp. 74, 75. El elemento subjetivo del injusto distinto del dolo, únicamente podrá quedar demostrado a través de la prueba por indicios, es decir, deduciéndolo el juzgador a partir del conjunto de datos objetivos concurrentes. ARROYO ZAPATERO, Luis. Comentarios al Código Penal. ..., op. cit., p. 820. Mendoza Buergo rechaza la posibilidad de apreciar dolo eventual en el delito de tráfico de precursores como consecuencia del elemento subjetivo del tipo. BAJO FERNÁNDEZ, Miguel. Compendio de Derecho..., op. cit., p. 689. Sobre la imposibilidad de apreciar dolo eventual. FABIÁN CAPARRÓS, Eduardo A. "Consideraciones de urgencia..., op. cit., pp. 595, 596. Los casos de dolo eventual quedan excluidos de este tipo penal. ÁLVAREZ GARCÍA, F. Javier. Derecho Penal Español. ..., op. cit., pp. 1355,1356. BLANCO LOZANO, Carlos. Tratado de Derecho...., op. cit., p. 408. No se admite en este tipo penal el dolo eventual. TERRADILLOS BASOCO, Juan María. Lecciones materiales..., op. cit., p. 64. CÓRDOBA RODA, Juan. Comentarios al Código Penal..., op. cit., p. 1662. MOLINA MANSILLA, María del Carmen. El Delito de Narcotráfico. ..., op. cit., pp. 229, 230. En la legislación peruana el tráfico de precursores de drogas (artículo 296 del Código Penal), al igual que en España, el tipo subjetivo requiere siempre la concurrencia de dolo, dado que el sujeto activo debe actuar a sabiendas que los insumos o materias primas serán empleados en la elaboración de drogas tóxicas, estupefacientes o sustancias psicotrópicas. PEÑA CABRERA FREYRE, Alonso. R. Tráfico ilícito de drogas..., op. cit., p. 133. 
hecho propio o de un tercero ${ }^{86}$. En el primer supuesto, el sujeto activo realiza los comportamientos descritos con el fin de la utilización del objeto material en el cultivo, producción o fabricación ilícita de drogas, de manera que esta finalidad asume la condición de elemento subjetivo del injusto, lo que permite la exclusión del círculo de relevancia penal de simples incumplimientos de la Ley 4/2009, como la caducidad de las licencias, la ausencia de la declaración de las sustancias comercializadas, etc., cuando la aludida finalidad no consiga inferirse del conjunto de circunstancias que rodeen el hecho. En el segundo de los casos sostiene que tales fines deben integrar el elemento cognitivo del dolo siendo suficiente, en tal caso, la simple prognosis sobre la probabilidad de utilización de las sustancias catalogadas como precursores en la fabricación ilícita de drogas, admitiendo de esta manera este autor la comisión de este delito con dolo eventual ${ }^{87}$.

Por lo tanto la simple posesión de las sustancias recogidas en este tipo penal, no es delictiva per se en ningún caso, sino únicamente si esa tenencia está pre ordenada a la producción de drogas ilícitas. Así, los actos a que hace referencia el artículo $371 \mathrm{CP}$, desligados de las finalidades legalmente determinadas, son actos que no comportan ninguna relevancia penal. Ello planteará a veces especiales dificultades probatorias a la hora de su incriminación, pues los órganos que ejercen la acusación deberán demostrar que concurre el elemento subjetivo antes mencionado ${ }^{88}$, lo cual normalmente se acredita mediante prueba

Ver STS (ROJ: 2484/1999) de 14 de abril de 1999. Ponente: D. Eduardo Moner Muñoz. STS (ROJ: 1849/2004) de 17 de marzo de 2004. Ponente: D. Joaquín Giménez García. CLIMENT DUTANT, Carlos. Código Penal...., op. cit., p. 487. CRUZ DE PABLO, José Antonio (Coord.). Comentarios al Código Penal. Vol 2. Ed. Difusión Jurídica. Madrid. 2008, pp. 1859, 1860. SAAVEDRA RUIZ, Juan. Código Penal comentad...., op. cit., p. 1168. MOLINA MANSILlA, María del Carmen. El Delito de Narcotráfico. ..., op. cit., p. 230. GRANADOS PÉREZ, Carlos. Jurisprudencia del Tribunal Supremo sobre el delito de tráfico de drogas. Ed. La Ley. Madrid. 2007, pp. 458, 459.

QUINTERO OLIVARES, Gonzalo. Comentarios a la Parte Especial..., op. cit., pp. 1524, 1525.

88 Se debe de reconocer el riesgo que supone centrar, como en este caso ocurre, la determinación de la tipicidad o atipicidad del acto exclusivamente en un dato psíquico del sujeto activo como son sus intenciones. MUÑOZ CONDE, Francisco. Derecho Penal. P.E..., op. cit., p. 687. En la legislación colombiana también se exige que la introducción al país, sacarlas del mismo, transportar o la tenencia de precursores se realice "a sabiendas de" que dichas sustancias se utilizaran en la elaboración de drogas ilícitas. 
indiciaria, de la cual el Tribunal deduce el destino a la fabricación ilícita de drogas a través de un juicio de inferencia ${ }^{89}$. Conde-Pumpido señala

CASTRO CUENCA, Carlos G. (Coord.). Manual de Parte Especial. ..., op. cit., p. 603. Se absuelve por no poder establecer con certeza el elemento subjetivo a los cuatro procesados del delito de tráfico de precursores de drogas (dos británicos y dos españoles), por haber introducido a España 1.495 kilogramos de efedrina siendo su posterior destino una empresa radicada en Marruecos, utilizando para ello su empresa "Alborán Farma" sin tener las preceptivas autorizaciones. Hay que decir que aunque se absuelve a los procesados, los 1.495 kilogramos de efedrina se decomisaron y se destruyeron. Señalando el Tribunal que al ser "la efedrina una sustancia sometida a control en sus distribución, independientemente del pronunciamiento absolutorio, pero al no constar las preceptivas autorizaciones, ni su utilización a fines legítimos, procede acordar el comiso y destrucción". SAN (ROJ: 3347/2013) de 3 de julio de 2013. Ponente: D. Fernando Grande-Marlaska Gómez. Sobre el decomiso de los 1.500 kilogramos de efedrina que se produjo en España. Las autoridades que investigaban irregularidades y discrepancias en los documentos descubrieron una sociedad ficticia en Marruecos que se dedicaba a importar cantidades considerables de efedrina para luego enviarlas de contrabando a Marruecos. España informo sobre el incidente a través del sistema PICS y, tras recibir la alerta, las autoridades del Canadá entablaron contacto con las autoridades españolas mediante el sistema PICS para intercambiar información relativa a un caso parecido de efedrina en el que parecía estar involucrado el Canadá. Precursores y productos químicos frecuentemente utilizados..., correspondiente a 2013..., pp. 13-15. De esta investigación judicial hay que decir que se puede valorar de "muy pobre" dada la cantidad exorbitante de efedrina ocupada a los procesados: 1.495 kilogramos en diciembre del año 2011 en el puerto de Algeciras. Cuando la cantidad de "efedrina necesaria o movilizada en España durante el periodo de un año no sería superior a 45 kilogramos". Se echa en falta los resultados de las coordinaciones con las autoridades correspondientes de Canadá y Marruecos, así como con la JIFE para establecer la naturaleza de los destinatarios finales en Marruecos, máxime cuando se tiene constancia que la empresa Alboran Farma unos meses antes de la incautación ya había realizado una importación de más de 500 kilogramos de este precursor de drogas proveniente siempre de Halifax (Canadá) y la había despachado para Marruecos. Siendo la efedrina uno de los precursores más controlados internacionalmente por la importancia que tiene en la producción mundial de metanfetamina. Era de esperarse un mejor desarrollo de la investigación tomando en cuenta que se trató de la mayor incautación de efedrina en Europa en ese año, que representó el $65 \%$ de las incautaciones realizadas por 18 países.

89 "La afirmación del elemento subjetivo no puede ser, ni en este caso ni en ningún otro, resultado de la apreciación de una prueba directa sino de una inferencia del Tribunal o, como se ha llamado tradicionalmente, de un juicio de valor que puede ser revisado en esta sede". STS (ROJ: 2497/2001) de 26 de marzo de 2001. Ponente: D. José Jiménez Villarejo. STS (ROJ: 8986/2000) de 5 de diciembre del año 2000. Ponente: D. Cándido Conde-Pumpido Touron. STS (ROJ: 89/2003) de 16 de enero de 2003. Ponente: D. Luis Román Puerta Luis. En el mismo sentido STS (ROJ: 5856/2011) de 27 de septiembre de 2011. Ponente: D. Juan Ramón Berdugo Gómez de la Torre. Sobre el juicio de inferencia 
que debido a la similitud del delito de tráfico de precursores de drogas con el antiguo delito de tenencia de útiles para el robo (artículo 509 del anterior Código Penal), cabe también aplicar los criterios deducibles de la Sentencia del Tribunal Constitucional de 8 de junio, sobre dicho artículo $^{90}$. En este sentido pensamos que el artículo 371 si no tuviera incorporado el elemento subjetivo adicional "a sabiendas de" o "para estos fines" tendría que ser declarado inconstitucional en los mismos términos que lo fue el artículo 509 del anterior código Penal.

Es necesario precisar que valorar el móvil anímico exigido por el tipo, como un elemento subjetivo del injusto, en cuanto resulta imprescindible para determinar la antijuricidad de la conducta legalmente descrita en el artículo 371 del CP, forma parte, dentro de la clasificación que de estos delitos se hace, de los denominados "delitos de intención", también denominados "de tendencia interna trascendente", y dentro de estos, de los llamados "de resultado cortado", porque el tipo exige una finalidad o motivo, el saber que las

realizado por el Tribunal Supremo para demostrar el elemento subjetivo "a sabiendas de", por un sujeto que transporto en dos ocasiones en una furgoneta un total de 1.000 kilogramos de acetona (precursor), cloruro de metileno y alcohol metílico (sustancias no catalogadas) de Madrid a Barcelona a cambio de 1.500 euros por viaje para su uso por terceras personas en un laboratorio clandestino donde extraían la cocaína impregnada en pedidos de polivinilo flexible triturado que importaban desde Venezuela. SAN (ROJ: 6508/2006) de 21 de julio de 2006. Ponente: D. Juan Francisco Martel Rivero. Schroeder señala que los delitos de posesión que exigen junto a la posesión, una intensión de utilización del objeto, merecen menos críticas que los delitos puros de posesión. Sobre los primeros afirma que la intensión debe constatarse en el proceso. Sin embargo, como ningún sospechoso reconocerá que tenía la intención de cometer un delito, la intensión se debe deducir en el proceso penal mediante indicios externos, y como tal indicio sirve de nuevo a la posesión. Con ello, le proporciona el elemento de la intensión al sospechoso únicamente la posibilidad de refutar tal efecto indiciario de la posesión a través de la referencia a otro fin distinto. SCHROEDER, Friedrich-Christian. “La posesión..., op. cit., p. 163.

CONDE-PUMPIDO FERREIRO, Cándido. Código Penal..., op. cit., pp. 1293, 1330. RODRÍGUEZ RAMOS, Luis. Código Penal comentado y con jurisprudencia. Segunda edición. La Ley. Madrid. 2007, pp. 868, 869. El elemento subjetivo del injusto, distinto al dolo, únicamente podrá demostrarse a través de la prueba por indicios, es decir, deduciéndolo el juzgador a partir de los datos objetivos concurrentes. TERRADILLOS BASOCO, Juan María. Lecciones materiales..., op. cit., p. 63. STC 105/1988, de 8 de junio de 1988. Ponente: Luis Díez-Picazo y Ponce de León. STS (ROJ: 2484/1999) de 14 de abril de 1999. Ponente: D. Eduardo Moner Muñoz. STS (ROJ: 7737/2003) de 3 de diciembre de 2003. Ponente: D. Miguel Colmenero Menéndez de Luarca. 
sustancias van a utilizarse en el cultivo, la producción o la fabricación ilícita de drogas, que va más allá de la realización del hecho típico, y que el sujeto no precisa alcanzar para la consumación del delito ${ }^{91}$. Sería muy positivo que este tipo penal exigiera para su consumación, en su elemento subjetivo adicional, que la elaboración de las drogas ilícitas lo fuese necesariamente para la difusión de estas, pues pensamos que si el tráfico de precursores es para el auto consumo no debería tener relevancia penal, igual que ocurre con las conductas sancionadas en el $368 \mathrm{CP}$.

Sobre la Ley 4/2009, de 15 de junio, de control de precursores queremos destacar que en su artículo 8 f) se establece como infracción muy grave "realizar operaciones con sustancias catalogadas sobre las que se tenga certeza o sospecha razonable de que dichas sustancias pueden desviarse hacia la fabricación ilícita de estupefacientes o de sustancias psicotrópicas, sin haber notificado tal certeza o sospecha a las autoridades competentes, o antes de que éstas hayan respondido a la notificación previa del operador". Sobre este inciso deseamos puntualizar que si la conducta consiste en realizar operaciones, bien puede ser una sola o varias, con sustancias catalogadas teniendo la certeza de que dichas sustancias "pueden desviarse" para la fabricación ilícita de drogas, sin haber notificado tal certeza a las autoridades competentes, posiblemente en la práctica judicial podría subsumirse, aunque no sería correcto, en el artículo 371.1 del Código Penal que sanciona la comercialización de dichas sustancias "a sabiendas de" que van a utilizarse en el cultivo, la producción o la fabricación ilícita de drogas, pues la frontera en este tipo de comportamientos entre la norma administrativa y penal es a veces muy tenue. Hay que recordar que estamos hablando de "certeza" y no de "sospecha", lo cual podría llegar a interpretarse como una conducta dolosa de comercializar precursores de drogas con una persona física o jurídica que va a elaborar drogas con dichas sustancias. Es preciso recordar que el delito de tráfico de precursores de drogas no exige la obtención de un lucro especial o excepcional en este sentido, por lo cual las sustancias podrían facturarse incluso a precio de mercado. Sin embargo la 
diferencia entre la conducta que sanciona en este caso la norma administrativa y la norma penal es que en la primera se tiene la certeza de que la sustancia catalogada "se puede utilizar" por un tercero (el comprador) para la elaboración de drogas ilícitas (dolo eventual) y en la norma penal se sabe "que se va a utilizar" la sustancia por un tercero en la elaboración de drogas ilícitas" (dolo directo). Queremos señalar que esta es la conducta de la Ley 4/2009 más próxima al ilícito penal regulado en el artículo 371, las restantes tienen un claro contenido formal, propio de los ilícitos administrativos. Creemos preciso recordar, en este momento, que en la tramitación parlamentaria del artículo 344 bis g) el grupo parlamentario IU-IC propuso incluir este artículo un tercer apartado en el que se sancionara las conductas vinculadas al manejo de precursores de drogas "cuando se realizaran con manifiesta ausencia del cuidado o previsión normalmente exigible" (imprudencia), afortunadamente esta enmienda fue rechazada, pues su aprobación habría sido un auténtico despropósito jurídico ${ }^{92}$.

Sobre el delito del tráfico de precursores de drogas queremos señalar que la jurisprudencia es bastante escasa, nosotros hemos logrado encontrar un total de 17 sentencias (siete del Tribunal Supremo, tres de la Audiencia Nacional y siete de Audiencias Provinciales en el periodo 1993-2016) ${ }^{93}$. A continuación abordamos el estudio de dos

93 STS (ROJ: 2484/1999) de 14 de abril de 1999. Ponente: Eduardo Moner Muñoz. STS (ROJ: 2497/2001) de 26 de marzo de 2001. Ponente: D. José Jiménez Villarejo. STS (ROJ: 89/2003) de 16 de enero de 2003. Ponente: D. Luis Román Puerta Luis. STS (ROJ: 583/2004) de 3 de febrero de 2004. Ponente: D. Enrique Bacigalupo Zapater. STS (ROJ: 1748/2009) de 18 de marzo de 2009. Ponente: D. Carlos Granados Pérez. STS (ROJ: 232/2013) de 18 de enero de 2013. Ponente: D. Alberto Gumersindo Jorge Barreiro. STS (ROJ: 5672/2016) de 23 de diciembre de 2016. Ponente: D. Andrés Palomo del Arco. SAN (ROJ: 4326/2002) de 9 de julio de 2002. Ponente: Dña. Raimunda de Peñafort Lorente Martínez. SAN (ROJ: 6508/2006) de 21 de julio de 2006. Ponente: D. Juan Francisco Martel Rivera. SAN (ROJ: 3347/2013) de 3 de julio de 2013. Ponente: D. Fernando Grande- Marlaska Gómez. SAP de Madrid (ROJ: 1659/2003) de 10 de febrero de 2003. Ponente: D. Adrián Varillas Gómez. Absuelven porque no se demuestra el elemento subjetivo. SAP de Guadalajara (ROJ: 71/2007) de 7 de marzo de 2007. Ponente: Dña. María Ángeles Martínez Domínguez. Absuelven porque no se puede demostrar el elemento subjetivo. SAP de Madrid (ROJ: 15967/2005) de 17 de noviembre de 2005. Ponente: D. Juan Francisco Martel Rivero. SAP de Madrid (ROJ: 2827/2009) de 16 de marzo de 2009. Ponente: Jesús Ángel Guijarro López. SAP de Madrid (ROJ: 1011/2014) de 28 de enero de 2014. Ponente: Dña Adoración María 
resoluciones judiciales que evidencian lo compleja que es la prueba del dolo y del elemento subjetivo adicional "a sabiendas de" o "para estos fines" en este tipo penal.

La primera es la STS de 14 de abril de 1999, que versa sobre dos sujetos, Francisco de nacionalidad española (con antecedentes penales por tráfico de drogas en Francia) y Jorge Omar de nacionalidad colombiana de quienes la policía tenía información de que podrían tener montado en la localidad de Irún un laboratorio para transformar pasta de coca en clorhidrato de cocaína a los que les fueron registrados dos inmuebles en localidades ubicadas en el municipio de Irún por la policía. En el primer inmueble, se incautaron una placa con dos lámparas infrarrojas, un horno microondas, dos pesas electrónicas (instrumentos), dos bidones de hexano (sustancia no catalogada) y dos bidones de metiletilcetona y otro de ácido clorhídrico (sustancias catalogadas), tres botes de manitol, un bote de etanol (sustancias no catalogadas) diferentes barreños, cinco papeles secantes blancos, una garrafa con disolvente, una malla metálica, vasos de medida, así como una piel de vaca (instrumentos), tomándose de algunos de estos objetos diversas muestras que pericialmente analizadas resultaron tener un compuesto no cumplidamente acreditado. En el segundo inmueble registrado se encontraron cinco garrafas de ácido clorhídrico, cinco garrafas de ácido sulfúrico, cuatro garrafas de acetona, cinco garrafas de éter etílico (todas sustancias catalogadas), tres botes de carbón activo, dos botes de ácido oxálico 2-hidrato, tres bidones de metilcetona, tres bidones de hexano, un bote de manitol (comúnmente usado para adulterar cocaína), un bote de hidróxido de sodio y un bote de cinco kilogramos de carbón activo (todas sustancias no catalogadas). Un paquete casi entero de papeles de filtro, diversos trapos blancos, una espátula, una brocha, un cuchillo, una llana, una malla metálica, tres recipientes pequeños de plástico, una probeta graduada, dos vasos de plástico graduados, un colador, dos rodillos metálicos, dos cubos y un microscopio (instrumentos). Como ya señalamos en el desarrollo del proceso, los materiales anteriormente relacionados fueron analizados, resultando que contenían "un 
compuesto no debidamente acreditado". Además incautaron en la casa de habitación de Francisco un total 485.000 pesetas (2.914 euros). Estando detenido el Juez de Instrucción se enteró que Francisco le pidió a su mujer que cogiera un dinero que tenía debajo de la televisión en la casa de su padre y que le pidiera a este que se lo guardara en la cocina, por lo cual ordenó un registro en la casa del padre de este procesado, donde encontraron 5.700 .000 pesetas (34.257 euros) y 52.000 francos franceses (7.927 euros), sumando un total de 45.098 euros la cantidad que le fue ocupada a Francisco. Los encausados en sus respectivas declaraciones alegaron que poseían los materiales que les fueron incautados porque estaban trabajando en la elaboración de un disolvente para eliminar manchas.

En su Sentencia, la Audiencia Provincial de San Sebastián admitió que los productos químicos elaborados en el factum, estaban catalogados como susceptibles de desvío para la fabricación ilícita de drogas, pero sin embargo no estimó probado que en el cobertizo de referencia se hallara montado un laboratorio para la transformación de pasta de coca en clorhidrato de cocaína, ni que los productos encontrados en el otro inmueble fueran a utilizarse con tal fin. Sin embargo, estimaron que dichas sustancias pudieron servir para "crear un disolvente específico para quitar manchas de ante", por lo que ambos procesados fueron absueltos de los delitos contra la salud pública, en la modalidad de sustancias que causan grave daño a la salud y en cantidad de notoria importancia de los artículos 368 y 369.3 del Código Penal, y contrabando, de los artículos $2.1 \mathrm{~d}$ ) y 3.1 párrafo $2^{\circ}$, inciso no 2 de la Ley de contrabando, como del artículo 371.1 del Código Penal, en relación con el Convenio de Naciones Unidas del 20 de diciembre de 1988, que se les imputaba por el Ministerio Fiscal, acordando en la inmediata puesta en libertad de los procesados, así como la devolución a sus titulares de todo lo intervenido en la causa. Esta sentencia fue recurrida por el Ministerio Fiscal en recurso de casación por infracción de Ley (única y exclusivamente por infracción del artículo 371.1 del Código Penal).

La Sala Segunda del Tribunal Supremo declaró procedente el recurso, dictando segunda sentencia que impuso pena de prisión de tres años para ambos acusados por el delito contra la salud pública tipificado en el artículo 371.1 del CP. Como argumento esencial, el Tribunal valoró como prueba directa la posesión de las sustancias aptas para la fabricación de drogas, así como el destino de los efectos intervenidos por la pluralidad 
de indicios tales como: llamadas telefónicas a Colombia, remisiones de dinero a ese país, alto nivel de vida de uno de los procesados, así como que los imputados no pudieron demostrar que estaban elaborando un disolvente para eliminación de manchas, en este sentido cabe preguntarse porque tendrían que demostrar los procesados tal extremo ${ }^{94}$, a partir de ello esta Sala concluyó que la inferencia efectuada por el Tribunal de instancia fue contraria al criterio humano, a la lógica, y a los principios de común experiencia, pues en conjunción todos los elementos de prueba directa e indiciaria conducen al convencimiento de que la tenencia de materiales y productos químicos intervenidos, elementos de probable utilización para el tratamiento de pasta de cocaína, en la ocasión, lugar y circunstancias de secreto y ocultación en que se produjeron, acreditan el destino de producción y elaboración de cocaína para el tráfico ilícito ${ }^{95}$.

94 Sobre este asunto se pronunció el Tribunal Constitucional: "el problema que plantean las cuestiones de inconstitucionalidad adquiere un cariz completamente distinto si la disposición de Ley contenida en el art. 509 del Código Penal se examina a la luz de los dictados del art. 24.2 de la Constitución y, en especial, desde el punto de vista del principio de que todos los ciudadanos tienen derecho a la presunción de inocencia. Este derecho fundamental ha sido definido y desarrollado por una extensa jurisprudencia de este Tribunal que no es necesario reiterar aquí con detalle. Baste señalar que, como es manifiesto, el art. 24.2 de la Constitución significa que se presume que los ciudadanos no son autores de hechos o conductas tipificadas como delito y que la prueba de la autoría y la prueba de la concurrencia de los elementos de tipo delictivo, corresponden a quienes, en el correspondiente proceso penal, asumen la condición de parte acusadora, sin que pueda imponerse al acusado o procesado una especial actividad probatoria, que dependerá siempre de la libre decisión que se adopte respecto de su defensa, pues la Constitución le reconoce también al acusado el derecho a no declarar contra sí mismo. Significa, además, la presunción de inocencia que en los procesos en que se enjuician acciones delictivas debe existir una prueba de cargo suficiente, realizada a través de medios de prueba que merezcan un enjuiciamiento favorable desde el punto de vista de su legitimidad constitucional. Desde esta perspectiva hay que examinar el art. 509 del Código Penal que aquí se debate". STC 105/1988 de 8 de junio de 1988. Ponente: D. Luis Díez y Picazo y Ponce de León.

95 Sobre los juicios de inferencia el Tribunal Supremo señala: "No siempre se dispone de prueba directa, de modo que en algunos casos es preciso recurrir a la llamada prueba indirecta o indiciaria, en la cual, mediante un mecanismo lógico complejo se puede llegar a afirmar la realidad de un hecho mediante el razonamiento construido sobre la base de otros hechos, los indicios, que estén suficientemente acreditados. Los requisitos del mecanismo racional a emplear por el Tribunal han sido reiteradamente descritos por la jurisprudencia, con mayor o menor amplitud. Así, por ejemplo, la STS 
La segunda sentencia que queremos poner de ejemplo para demostrar la complejidad que entraña demostrar el elemento subjetivo adicional del artículo $371 \mathrm{CP}$ es la SAN de 3 de julio de 2013 en la que son procesados dos ciudadanos británicos (Fructuoso y Manuel) y dos ciudadanos españoles (Romualdo y Luis Manuel), por haber introducido en España 1.495 kilogramos de efedrina en el mes de diciembre del año 2011 provenientes del puerto de Halifax (Canadá), siendo su posterior destino la empresa TRIMIDEX SARL radicada en Marruecos de la cual son titulares los dos ciudadanos británicos, utilizando para ello la empresa "Alborán Farma S. L." de la cual es dueño Luis Manuel y Administrador Fructuoso sin tener las preceptivas autorizaciones para operar con este precursor de drogas. Cabe destacar que en el mes de julio del año 2011 había realizado la misma operación con 500 kilogramos de efedrina, así como que las necesidades legítimas de España de esta sustancia en un año es sólo de 45 kilogramos y la empresa de mayor implantación no requiere de más de 19 kilogramos

de 23 de noviembre de 1998, según la cual como prueba objetiva de cargo se admite la llamada prueba de indicios por la que a partir de determinados hechos o datos base cabe racionalmente deducir la realidad del hecho consecuencia. Para ello son precisos determinados requisitos exigidos reiteradamente por esta sala, y compendiados en las sentencias de 23 de mayo y 5 de octubre de 1997, en términos reiterados en las sentencias de 14 de mayo, 8 de junio y 30 de noviembre de 1998. Tales requisitos son: A) que los indicios estén plenamente acreditados; sean plurales, o excepcionalmente sea único pero de una singular potencia acreditativa; sean concomitantes al hecho que se trata probar; y estén interrelacionados, cuando sean varios, reforzándose entre sí (sentencias de 12 de julio y 16 de diciembre 1996, entre otras). B) Que a partir de esos indicios se deduzca el hecho consecuencia como juicio de inferencia razonable, es decir, que no solamente no sea arbitrario, absurdo o infundado, sino que responda plenamente a las reglas de la lógica y de la experiencia, de manera que de los hechos base acreditados fluya, como conclusión natural, el dato precisado de demostración, existiendo entre ambos un enlace preciso y directo según las reglas del criterio humano (sentencias de 18 de octubre 1995; 19 de enero y 13 de julio 1996, etc.). Y C) Que la sentencia exprese cuáles son los hechos base o indicios en que apoye el juicio de inferencia, y que explique el razonamiento a través del cual partiendo de los indicio se llega a la convicción sobre el acaecimiento del hecho punible y la participación del acusado. En definitiva, se exige que el razonamiento se apoye en elementos de hecho y que éstos sean varios, estén debidamente acreditados, se relacionen reforzándose entre sí, así como que el juicio de inferencia pueda considerarse razonable y que la sentencia lo exprese". STS (ROJ: 7737/2003) de 3 de diciembre de 2003. Ponente: D. Miguel Colmenero Menéndez de Luarca. STS (ROJ: 2484/1999) de 14 de abril de 1999. Ponente: D. Eduardo Moner Muñoz. En el mismo sentido SAN (ROJ: 3347/2013) de 3 de julio de 2013. Ponente: D. Fernando Grande- Marlaska Gómez. 
de efedrina. Este caso fue instruido por el Juzgado Central de Instrucción número 2 de la Audiencia Nacional, calificando el Ministerio Fiscal los hechos de un delito de tráfico de precursores de drogas previsto y penado en el artículo 371.1.2 del Código Penal (apreciando la agravante de pertenencia a organización), pidiendo para cada uno de los procesados la pena de 5 años de prisión, multa de 48.000 euros, así como la pena de inhabilitación especial por un periodo de tres años para el ejercicio de cualquier profesión relacionada con actividades comerciales, así como la disolución de la empresa "Alborán Farma" de conformidad a lo dispuesto en el artículo 129 CP. Resolviendo la Sala de lo Penal de la Audiencia nacional absolver a los cuatro procesados, bajo el argumento de que aunque "la cantidad de efedrina aprehendida era importante, difícilmente compatible con un uso normalizado, pero igualmente lo fue meses atrás sin que saltaran las alarmas, y ante un vacío complementario sobre su destino final, no podemos concluir con la necesaria certeza que fuera el de concurrir a la elaboración de drogas y/o sustancias estupefacientes. $Y$ en este sentido, no en base a la ausencia de pruebas, sino a que la existente no permite concluir un juicio en grado de certeza jurídica, conformándose dudas razonables, y en aplicación del principio in dubio pro reo, procede dictar un pronunciamiento absolutorio". No obstante los 1.495 kilogramos de efedrina se decomisaron y se destruyeron. Señalando el Tribunal que al ser "la efedrina una sustancia sometida a control en sus distribución, independientemente del pronunciamiento absolutorio, pero al no constar las preceptivas autorizaciones, ni su utilización a fines legítimos, procede acordar el comiso y destrucción" 96 . Hay que subrayar que esta fue la mayor incautación de efedrina en Europa en ese año, que representó el $65 \%$ de las incautaciones realizadas por 18 países de Europa, así como que con la cantidad incautada se hubiese podido elaborar aproximadamente una tonelada de metanfetamina, lo que representa unos 30 millones de dosis callejeras de 30 miligramos $^{97}$.

En todo caso hay que señalar que la Empresa Alboran Farma cometió una infracción muy grave de conformidad al artículo 8 b) de la Ley 4/2009, de 15 de junio, de control de precursores de drogas al realizar Gómez.

97 Precursores y productos químicos frecuentemente..., correspondiente a 2013..., pp. 13-15. 
actividades con sustancias catalogadas sin haber obtenido la licencia de actividad requerida. Por lo cual debió ser sancionada al tenor del artículo 13, de la misma Ley, con una multa de entre 6.000 y 60.000 euros, así como con la retirada o la no concesión de la licencia de actividad y la cancelación de la inscripción en el Registro General de Operadores de Sustancias Químicas Catalogadas y/o el Registro de Operadores de Comercio de Sustancias Químicas Catalogadas por un periodo de hasta cinco años.

Queremos terminar este apartado señalando que en el delito de tráfico de precursores en la vertiente subjetiva del tipo, el dolo en este caso exige que el sujeto activo tenga conocimiento de que las sustancias que fabrica, transporta, distribuye, comercie o posee, sean precursores de drogas tóxicas, estupefacientes o psicotrópicos, y no obstante de esta comprensión, realice voluntariamente los actos prohibidos. Debiendo puntualizarse que se trata de un tipo de injusto que, además del elemento subjetivo general integrado por el dolo, se caracteriza por ser portador de un particular elemento subjetivo adicional, consistente en que las sustancias relacionadas en el artículo 371 sean fabricadas, transportadas, poseídas o comercializadas, a sabiendas de que van a utilizarse (por un tercero) en el cultivo, la producción o la fabricación ilícita de drogas tóxicas, estupefacientes o sustancias psicotrópicas, o para esos fines (por el propio sujeto activo). Exigiendo en ambos casos el tipo penal que estas conductas se realicen con dolo directo ${ }^{98}$.

\section{F.) El ERROR EN EL DELITO DE TRÁFICO DE PRECURSORES DE DROGAS}

Como todos sabemos resulta verdaderamente difícil apreciar cualquier clase de error, ya sea este de tipo o de prohibición, en los delitos relativos al tráfico drogas principalmente por la notoriedad de la prohibición sobre las drogas ilícitas. Lo que hace verdaderamente complicado que el autor pueda demostrar, no que desconocía la prohibición, sino que no podía conocerla. Nosotros pensamos que debería resultar quizás un poco menos complicado en el caso del tráfico de precursores de drogas, pues estas sustancias no son tan conocidas por la mayoría de las personas como lo son las drogas, 
estupefacientes o psicotrópicos, además hay que recordar que las 24 sustancias catalogadas como precursores tienen múltiples usos lícitos. Así como que este ilícito incluye el elemento subjetivo adicional que exige que el sujeto activo debe de actuar con el ánimo de fabricar, transportar, distribuir, comerciar o tener en su poder los precursores de drogas para elaborar él mismo las drogas ilícitas o bien para proporcionárselas a un tercero a sabiendas de que este las utilizará para elaborar las mismas. Lamentablemente en la práctica la posibilidad de que los tribunales aprecien error es bastante difícil, pero no imposible. A manera de ejemplo queremos citar la sentencia del Tribunal supremo de 16 de enero de $2003^{99}$.

La misma trata de dos ciudadanos españoles (Gaspar y José Ignacio) que tenían constituida una empresa importadora "Quindifar S.A." a través de la cual adquirieron un total de 12.000 kilogramos de permanganato de potasio (precursor de drogas) proveniente de Bélgica con el fin de enviarla a Colombia para vendérsela a un cartel de ese país que se dedicaba a la fabricación ilícita de cocaína. Gaspar y José Ignacio antes de exportar el permanganato de potasio a Colombia decidieron camuflar la mercancía y para este propósito adquirieron 6.000 kilogramos de dióxido de manganeso (sustancia no catalogada, pero que también se utiliza en la elaboración ilícita de permanganato de potasio en países de América del Sur), Y a los mismo fines de camuflaje encargaron a Miguel (tercer sujeto condenado en esta sentencia), hijo de José Ignacio, trasvasar 40 kilos de permanganato de potasio en bolsas de basura, a cada uno de los nuevos bidones (355) recibidos, completando el peso de 50 kilos por unidad con 10 kilos de dióxido de manganeso, y tras precintar cada bidón ponerle una nueva etiqueta referida a esta última sustancia, destruyera las etiquetas originales del permanganato de potasio. Para que le ayudara en esta tarea Miguel contrató a su amigo Rubén, quien no tenía conocimiento de que estaba trabajando con una sustancia catalogada como precursor de droga ni el propósito para él cual se realizaba tal trasvase. Una vez concluido el trabajo antes mencionado, tras el llenado en las formas mencionadas de 355 bidones, que fueron cargados el día 12 de marzo de 1999 en el contenedor con número de identificación SEAU 8226209 de la empresa Sea-Land y transportados hasta el puerto de Algeciras, 
que el día 17 de marzo de 1999 se cargan en el buque Grete Maeks con destino al puerto de Cartagena de Indias en Colombia, donde llega el cargamento el día 14 de abril de 1999, siendo interceptado por la policía colombiana.

Los cuatro sujetos fueron condenados por la Sección Cuarta de la Sala Penal de la Audiencia Nacional como autores del delito de tráfico de precursores de drogas. Sin embargo Tribunal Supremo en su sentencia absolvió a Rubén por que no existía ninguna prueba de cargo que acreditara que conociera la naturaleza de las sustancias que trasvaso ni la concurrencia del elemento subjetivo del tipo del artículo $371 \mathrm{CP}$, que requiere que las actividades recogidas se realicen "a sabiendas" del destino del producto para el narcotráfico. Nosotros creemos que igualmente, de haber sido condenados, hubiesen sido absueltos los empleados que transportaron en los camiones los bidones al puerto de Algeciras, pues actuaron convencidos de estar realizando una actividad lícita. La de transportar 18.000 kilogramos de dióxido de manganeso (una sustancia no catalogada debidamente etiquetada en 355 bidones) por encargo de una empresa legal.

Es preciso recordar que el error sobre cualquiera de los elementos típicos, ya sean descriptivos, o normativos, dará lugar a un error de tipo, en el que la vencibilidad o no del mismo va a dar lugar a la impunidad, pues no procede castigar esta modalidad delictiva en su forma imprudente. Este tipo de error puede provenir de una deficiente percepción sensorial o de una incorrecta valoración jurídica ${ }^{100}$. Mientras que el error de prohibición puede referirse a la existencia de la norma prohibida como tal (error de prohibición directo) o bien a la existencia, límites o presupuestos objetivos de una causa de justificación (error de prohibición indirecto) que permita tal comportamiento, generalmente prohibido ${ }^{101}$.

100 TERRADILLOS BASOCO, Juan María. Lecciones materiales..., op. cit., p. 64. En el mismo sentido. CÓRDOBA RODA, Juan. GARCÍA ARÁN, Mercedes. Comentarios al Código Penal. Parte General (incorporada reforma producida por la Ley Orgánica 5/2010, de 22 de junio). Ed. Marcial Pons. Madrid. 2011, p. 113. CÓRDOBA RODA, Juan. Comentarios al Código Penal..., op. cit., pp. 1593-1595. QUINTERO OLIVARES, Gonzalo. Comentarios al Código Penal..., op. cit., pp. 147-150.

MUÑOZ CONDE, Francisco. Derecho Penal. P.G..., op. cit., pp. 410, 411. Hay que señalar que el conocimiento de la antijuricidad del hecho no debe corresponderse con un 


\section{G.) FORMAS DE IMPERFECTA REALIZACIÓN}

En materia de tentativa y consumación la jurisprudencia configura el delito previsto en el artículo 368 como un delito de peligro abstracto hipotético que requiere la potencialidad de la conducta para crear un peligro al bien jurídico (STS del 20 de febrero de 1985), y como un delito de consumación anticipada, por lo que generalmente no aprecia formas imperfectas de ejecución ${ }^{102}$. Sin embargo parte de la doctrina opina que deben apreciarse casos de tentativa ${ }^{103}$, existiendo además

conocimiento estricto y pormenorizado de los procedimientos legales, sino con una valoración paralela en la esfera del profano sobre el carácter de la ilicitud de la conducta. Más particularmente, la valoración que exige el error de prohibición debe centrase en un juicio de "recognoscibilidad" de la antijuricidad del hecho, tratándose por lo tanto de valorar si el sujeto pudo, en una circunstancia concreta y respecto de una determinada prohibición penal, reconocer la antijuricidad del hecho. Siendo necesario para enjuiciamiento del error de prohibición tener en cuenta las condiciones psicológicas y culturales del procesado, así como las posibilidades que se le ofrecieran de instrucción y asesoramiento o de acudir a medios que le permitieran conocer la trascendencia jurídica de su comportamiento. QUINTERO OLIVARES, Gonzalo (Dir.), MORALES PRATS, Fermín (Coord.). Comentarios al Código Penal..., op. cit..., pp. 151, 152. No basta con alegar la existencia del error sino que éste ha de quedar suficientemente acreditado, empleándose para ello criterios que se refieren básicamente a la posibilidad del autor de informarse sobre el derecho. STS (ROJ: 758/2005) de 10 de febrero de 2005. Ponente: Juan Saavedra Ruiz.

102 STS (ROJ: 278/1985) de 20 de febrero de 1985. Ponente: D. Juan Latour Brotons. STS (ROJ: 1748/2009) de 18 de marzo de 2009. Ponente: D. Carlos Granados Pérez. CONDE-PUMPIDO FERREIRO, Cándido. Código Penal..., op. cit., pp. 1294, 1295. SAAVEDRA RUIZ, Juan. Código Penal comentado...., op. cit., p. 1140. LAMARCA PÉREZ, Carmen (Coord.). Derecho Penal. P.E..., op. cit., pp. 560, 561. LAMARCA PÉREZ, Carmen (Coord.). Delitos y Faltas. ..., op. cit., p. 638. SUÁREZ-MIRA RODRÍGUEZ, Carlos (Coord.). Manual de Derecho Penal. Tomo II. Parte Especial. Sexta Edición. Aranzadi/Thomson Reuters. Navarra. 2011, pp. 434, 435.

103 MORILLAS CUEVAS, Lorenzo. Sistema de Derecho..., op. cit., p. 828. SERRANO GÓMEZ, Alfonso. Derecho Penal. ..., op. cit., p. 734. VAZQUEZ IRUZUBIETA, Carlos. Comentario al Código Penal. Actualizado por LO 5/2010. Ed. La Ley. Madrid. 2010, p. 815. MOLINA MANSILLA, María del Carmen. El Delito de Narcotráfico..., op. cit., pp. 122, 123. También a favor de apreciar casos de tentativa o actos preparatorios incluso en el delito de tráfico de precursores de drogas. SEQUEROS SAZATORNIL, Fernando. El tráfico de drogas..., op. cit., p. 293. En contra de esta posición se afirma que por razones políticocriminales, y no estrictamente dogmáticas, la sanción de los tipos de imperfecta ejecución no estaría legitimada desde el prisma del principio de fragmentariedad y de ultima ratio. CÓRDOBA RODA, Juan. Comentarios al Código Penal ..., op. cit., pp. 1580, 1581. 
algunas sentencias del Tribunal Supremo como la de 4 de febrero de 1985 , de 3 de junio de $1986^{104}$, de 5 de diciembre del año 2000 o 13 de marzo del mismo año ${ }^{105}$, de 23 de febrero de 2010, de 19 de noviembre de 2009, de 16 de octubre de 2009, de 8 de enero de 2009, de 10 de junio de 2008, de 12 de diciembre del año 2001, de 5 de marzo de 2001, de 21 de junio de 1999, de 10 de marzo de 2010 y de 29 de junio de 2010, que si lo hacen, castigando como tentativa los supuestos en los que él acusado no ha llegado a tener disponibilidad sobre la droga, que no ha estado en su posesión de forma mediata o inmediata; bastando la acción de concurrir al lugar donde se debía recoger la droga, en ejecución de un plan previamente concertado, cuando la tenencia no se alcanza por razones ajenas a su voluntad ${ }^{106}$, debiendo encuadrarse en los supuestos punibles de tentativa, los casos que podrían calificarse de idoneidad relativa, es decir, aquellos en que los medios utilizados "objetivamente valorados ex antes y desde una

104 STS (ROJ: 45/1985) de 4 de febrero de 1985. Ponente: D. José Hermenegildo Moyna Menguez. STS (ROJ: 2995/1986) de 3 de junio. Ponente: D. Ramón Montero Fernández.

105 STS (ROJ: 8986/2000) de 5 de diciembre del año 2000. Ponente: D. Cándido CondePumpido Touron, STS (ROJ: 1966/2000) de 13 de marzo de 2000. Ponente: D. Enrique Bacigalupo Zapater.

106 STS (ROJ: 1148/2010) de 23 de febrero de 2010. Ponente: D. Alberto Gumersindo Jorge Barreiro. STS (ROJ: 1155/2009) de 19 de noviembre de 2009. Ponente: D. Miguel Colmenero Menendez de Luarca. STS (ROJ: 6447/2009) de 16 de octubre de 2009. Ponente: D. Juan Ramón Berdugo Gómez de la Torre. STS (ROJ: 99/2009) de 8 de enero de 2009. Ponente: D. Francisco Monterde Ferrer. STS (ROJ: 2633/2008) de 10 de junio de 2008. Ponente: D. Juan Ramón Berdugo Gómez de la Torre. STS (ROJ: 9770/2001) de 12 de diciembre de 2001. Ponente: D. Cándido Conde-Pumpido Touron. STS (ROJ: 1701/2001) de 5 de marzo de 2001. Ponente: D. José Jiménez Villarejo. STS (ROJ: 4373/1999) de 21 de junio de 1999. Ponente: D. Cándido Conde-Pumpido Touron. STS (ROJ: 1413/2010) de 10 de marzo de 2010. Ponente: D. Andrés Martínez Arrieta. STS (ROJ: 4065/2010) de 29 de junio de 2010. Ponente: D. Carlos Granados Pérez. STS (ROJ: 1112/1995) de 27 de febrero de 1995. Ponente: D. Ramón Montero FernándezCid. "Si la intervención del acusado tiene lugar después de que la droga se encuentre ya en nuestro país, habiéndose solicitado su colaboración por un tercero, sin haber participado en la operación previa, sin ser destinatario de la mercancía y sin llegar a tener la disponibilidad efectiva de la droga intervenida por ser detenido antes de hacerse cargo efectivo de la misma, o justamente en ese momento, se trata de un delito intentado. STS (ROJ: 7691/2003) de 2 de diciembre de 2003. Ponente: D. Enrique Abad Fernández. 
perspectiva general, son abstracta y racionalmente aptos para ocasionar el resultado típico (de lesión o de peligro) ${ }^{107}$.

Queremos destacar en este sentido la Sentencia del Tribunal Supremo de 5 de diciembre del año 2000, esta sentencia condena por tráfico de drogas en grado de tentativa idónea a dos personas que en el mes de junio de 1993 se trasladan desde Barcelona a Estambul en coche para recoger 60 kilogramos de heroína para luego introducir dicha sustancia a España. Todo esto por encargo de una tercera persona y a cambio de diez millones de pesetas (60.000 euros). Resultando que por razones ajenas a su voluntad la entrega de la droga no se llevó a cabo y los dos ciudadanos españoles regresaron a España sin la droga. Por esta actividad ambos fueron condenados como autores responsables de un delito contra la salud pública en la modalidad de tráfico de drogas que causan grave daño a la salud, en grado de tentativa, con la circunstancia de notoria importancia, y pertenencia a organización, imponiéndoseles la pena de dos años, cuatro meses y un día de prisión menor y multa de un millón de pesetas (6.000 euros), sin declarar responsabilidad civil derivada del delito. La defensa de los imputados en su recurso sostuvo que al haber resultado frustrado el viaje a Turquía y no haberse llegado a posesionar los recurrentes de la droga, no cabía apreciar tentativa sino unos meros deseos o intenciones que son jurídicamente irrelevantes, señalando además que atendiendo a criterios civiles la tentativa sólo es posible cuando se ha perfeccionado la posesión de la droga. Hay que destacar que durante el proceso los imputados negaron tener conocimiento de que lo que tenían que recoger en Turquía era heroína (elemento subjetivo), sosteniendo que ellos creían que iban a transportar algún objeto de contrabando. El Tribunal Supremo a través de un juicio de inferencia más la declaración inculpatoria de otro procesado que los acompañó en parte del viaje, llegó a la conclusión de que dicha actividad constituye una operación que supera ampliamente las meras intenciones o deseos, configurándose claramente como una colaboración voluntaria y efectiva al tráfico de drogas, manifestada directamente por actos exteriores, recordando la sentencia que se ha admitido de forma reiterada por la jurisprudencia que "el intento de lograr la tenencia de 
la droga, materializado en acciones próximas a su obtención, es punible como tentativa cuando dicha tenencia no se alcanza por razones ajenas a la voluntad del autor". Además señala el Tribunal que "cabe admitir excepcionalmente la tentativa cuando el acusado no ha llegado en momento alguno a tener disponibilidad, ni aun potencial, sobre la droga, que no ha estado en su posesión, ni mediata ni inmediata". Siendo este el criterio aplicado de forma benévola en este caso por el Tribunal de instancia. En la sentencia para desestimar el recurso se argumenta que el artículo 16 del Código Penal ha redefinido la tentativa, añadiendo la expresión objetivamente (practicando todos o parte de los actos que objetivamente deberían producir el resultado). Por lo tanto se trata de supuestos en los que la sanción penal está justificada porque el autor ha decidido vulnerar el bien jurídico protegido, a través de una acción que no resulta ajena a la órbita del tipo y utilizando medios generalmente idóneos aun cuando no lo sean en el caso concreto, razón por la que no cabe apreciar la inidoneidad de la conducta aunque no conste efectivamente en el proceso que la heroína hubiese llegado a estar en Estambul a disposición de los recurrentes ${ }^{108}$. Sobre esta sentencia Córdoba Roda y García Arán opinan que las conductas enjuiciadas "no constituyen ni siquiera el inicio de actos de ejecución ${ }^{109}$.

Otra sentencia digna de mención es la del 13 de marzo del año 2000, en ella se sanciona a tres ciudadanos españoles como autores de un delito intentado, sin circunstancias modificativas, a las penas de seis años de prisión menor del Código Penal de 1973 (a uno de ellos) y de cuatro años de prisión menor a los dos restantes y multa de 50 millones de pesetas (300.500 euros con 5 céntimos) a cada uno de ellos por participar en una operación fallida de tráfico de drogas, en el que les entregaron cuatro paquetes, de un kilogramo cada uno, que supuestamente contenían cocaína y resultaron ser libros. La defensa alegó que de ninguna manera cabría construir una tentativa de delito contra la salud pública en cantidad de notoria importancia cuando no se ocupó cantidad alguna de drogas, quedando en este caso en el terreno de las intenciones. El Tribunal Supremo desestimó los recursos

108 STS (ROJ: 8986/2000) de 5 de diciembre del año 2000. Ponente: D. Cándido CondePumpido Tourón.

109 CÓRDOBA RODA, Juan. Comentarios al Código Penal..., op. cit., pp. 1584, 1585. 
argumentando que "el juicio sobre la idoneidad en un delito de actividad o de peligro abstracto, sólo se debe referir a la aptitud de la acción para la realización del tipo, sin ninguna vinculación a un posible resultado proveniente causalmente de la acción"..., "es decir, que obrando con un dolo completo, realizaron acciones que les hubieran permitido conseguir la droga, si el proveedor se la hubiera proporcionado", señalando que la tentativa inidónea era expresamente punible en el artículo 52 del código Penal de 1973 y sigue siéndolo, en la medida que la punibilidad de la tentativa no está excluida en el artículo $62 \mathrm{CP}^{110}$.

Afortunadamente, en la jurisprudencia del Tribunal Supremo español, de la Audiencia Nacional o de las Audiencias Provinciales no hemos encontrado ninguna sentencia que aprecie formas de imperfecta realización del artículo $371 \mathrm{CP}^{111}$, lo cual tiene lógica, pues se trata de actos preparatorios elevados a la categoría de delito, por lo tanto se trataría de la tentativa de un acto preparatorio, lo que a todas luces sería un adelantamiento desmesurado de la barrera de intervención penal112. Aunque pensamos que por los criterios que mantiene la

110 STS (ROJ: 1966/2000) de 13 de marzo de 2000. Ponente: D. Enrique Bacigalupo Zapater.

111 Sin embargo encontramos una sentencia en que el Tribunal Supremo que absuelve como autor de un delito intentado contra la salud pública a un sujeto colombiano sin residencia legal en España que se le ocuparon una bolsa de 0.96 gramos de cocaína con una pureza base del $12.9 \%$ que no consta que no fuera para autoconsumo, así como 5 kilogramos de sustancias de corte (fenacetina, lidocaína, levamisol y ácido bórico) y una balanza de cocina en su domicilio, porque ninguna de esas sustancias son drogas o estupefacientes abarcados por el artículo 368 del Código Penal, además se señala en esta sentencia que tampoco lo pueden sancionar por tráfico de precursores porque ninguna de las cuatro sustancias pertenecen al listado de las 23 sustancias catalogadas en los Cuadros I y II del Convenio de Viena de 1988. STS (ROJ: 4232/2010) de 23 de junio de 2010. Ponente: D. Adolfo Prego de Oliver Tolivar. Sobre la tentativa en el Derecho Penal español. MIR PUIG, Santiago. Derecho Penal..., op. cit., pp. 353-364

112 JOSHI JUBERT sostiene que sólo deben apreciarse formas de imperfecta ejecución en las conductas de tráfico, promoción, facilitación y favorecimiento del artículo 368 CP pues estos comportamientos lesionan efectivamente el bien jurídico "salud pública". Lo cual en su opinión no es legítimo en las conductas de cultivo, elaboración y posesión, del mismo precepto penal, ya que en estas fases sólo se pone en peligro el bien jurídico salud pública al ser fases previas a la consumación material, especialmente previstas en la parte especial. Lo cual en nuestra opinión cobra aún más sentido en el caso de las conductas previstas en el tráfico de precursores donde la 
jurisprudencia nada impide apreciarlos al ser un delito autónomo. A favor de poder configurar casos de tentativa o actos preparatorios en el delito de tráfico de precursores se pronuncia Sequeros Sazatornil113. Para poder valorar tal situación elaboramos los siguientes ejemplos: 1) Un sujeto que se dedica a la elaboración de metanfetamina a pequeña escala en su casa ubicada en los alrededores de Madrid viaja a Filipinas y ahí adquiere 20 litros de aceite de sasafrás (que contiene safrol), y que se usa bastante en los laboratorios clandestinos de metanfetamina de ese país, el cual envía por correo a un primo que reside en Ávila sin que este tenga conocimiento del envío ni de la actividad ilegal que realiza el sujeto en mención. Una vez de vuelta en España, este sujeto se pone en contacto con su primo explicándole que él elabora metanfetamina y que le realizó un envío de 20 litros de aceite de sasafrás desde Filipinas que utiliza para la elaboración de la droga antes mencionada. Su primo acepta ir a retirar el paquete a correos a cambio de 300 euros, así lo hace y es detenido por la policía cuando se lo entregan o cuando acude a correos a retirar dicha sustancia. En este caso pensamos que puede ser sancionado este último, de conformidad con los criterios mantenidos por a la jurisprudencia mayoritaria, por el delito de tráfico de precursores de drogas en grado de tentativa, pues su intervención tiene lugar después de que esta sustancia que tiene un contenido rico de safrol (precursor de drogas) se encuentre ya en nuestro país, habiéndose solicitado su colaboración por un tercero, sin haber participado en la operación previa y sin llegar a tener disponibilidad efectiva del precursor intervenido por ser detenido justo cuando le habían entregado el paquete o cuando se lo iban a entregar, queremos destacar que aunque el sujeto propuesto en este ejemplo era el destinatario la sustancia que contenía el precursor de drogas no tenía conocimiento previo de ello ${ }^{114}$. 2) Otro ejemplo podría ser el de una persona, que tiene una pequeña empresa que comercializa fertilizantes, que intenta comprar en una empresa, digamos SILMAR S.A., ubicada en la localidad de Igualada (Barcelona)

puesta en peligro al bien jurídico antes señalado es más remoto. JOSHI JUBERT, Ujala. Los delitos de tráfico..., op. cit., pp. 244, 245.

113 SEQUEROS SAZATORNIL, Fernando. El tráfico de drogas..., op. cit., p. 293.

114 Para elaborar este ejemplo utilizamos la STS (ROJ: 7691/2003) de 2 de diciembre de 2003. Ponente: D. Enrique Abad Fernández. 
un total de 40 kilos de permanganato de potasio, para luego exportarla de forma enmascarada, con otra sustancia como el manganato de potasio a Ecuador donde la utilizarían para elaborar cocaína, sin lograr comprar la sustancia, porque en dicha empresa sospecharon de él, por no ser cliente habitual y resultarles sospechoso su comportamiento, por lo cual informaron a la policía quien procedió a detenerlo, por error, antes de adquirir el precursor en la tienda. Creemos que este supuesto se podría llegarse a sancionar como tentativa porque el sujeto activo no tuvo disponibilidad efectiva sobre los 40 kilogramos de permanganato de potasio ${ }^{115}$. 3) El caso de un sujeto que teniendo conocimiento de que en su barrio hay un grupo de personas que trafican cocaína, que él cree que además realizan el proceso de transformación de pasta base a clorhidrato de cocaína, se decide acopiar una gran cantidad de frascos de acetona (unos treinta litros) que compra en diferentes supermercados y tiendas de chinos, con la esperanza de lograr contactar con estos para vendérselas a un precio superior al que ha pagado, para obtener así algún beneficio económico. Siendo detenido cuando contacta de forma infructuosa con los traficantes de cocaína en el puesto de venta ilícito, lográndose establecer por las autoridades que estos no se dedican a la fabricación ni refinamiento de la droga sino únicamente a traficar con cocaína (narcomenudeo), de manera que solo necesitan sustancias para cortar esta droga como la fenacetina, levamisol, cafeína, lidocaína y manitol, por lo cual no tenían ningún interés en adquirir acetona. Como se puede apreciar en este caso el sujeto activo tiene disponibilidad real sobre el precursor y piensa que su destino será la elaboración de cocaína, por lo que cumpliría con el elemento subjetivo que exige el artículo 371, razón por la cual podría llegar a justificarse que se sancionase como una tentativa acabada del delito tráfico de precursores de drogas, bajo el argumento de que el sujeto activo ha decidido vulnerar el bien jurídico tutelado, mediante una acción que no resulta ajena a la órbita del tipo y utilizando medios generalmente idóneos aun cuando no lo sean en el caso concreto ${ }^{116}$. 4) Una persona

115 Para crear este caso usamos la STS (ROJ: 89/2003) de 16 de enero de 2003. Ponente: D. Luis Román Puerta Luis

116 El argumento para sancionar un comportamiento similar lo obtuvimos de la STS (ROJ: 8986/2000) de 5 de diciembre del año 2000. Ponente: D. Cándido Conde-Pumpido Tourón. 
que por encargo de un amigo, que tiene un pequeño laboratorio ilegal en su piso del barrio San José de Salamanca donde elabora metanfetamina, viaja de Salamanca a Pontevedra, bajo la promesa de la remuneración de 1.500 euros, para encontrarse con un sujeto que trabaja en una farmacia el cual le debe entregar 500 gramos de seudoefedrina a cambio de 2.500 euros, conociendo el sujeto en mención que dicha sustancia se utilizara en la elaboración de drogas ilícitas. Resultando que en Pontevedra lo estafan y le entregan unas cajas que contienen comprimidos de un medicamento para el dolor de cabeza denominado TYLENOL que ni siquiera contiene seudoefedrina. Esta persona regresa a Salamanca a entregar el supuesto precursor al domicilio de quien se lo encargó cuando ambos son detenidos por la policía, ocupando la policía en el inmueble 300 gramos de metanfetamina con una riqueza del $82,4 \%$, utensilios para la fabricación de dicha droga con restos de ácido clorhídrico y seudoefedrina por lo que condenan al amigo por tráfico de drogas que causan grave daño a la salud y al sujeto en mención por tentativa de trafico de precursores de drogasi17. 5) A un sujeto que tiene un pequeño laboratorio ilícito de metanfetamina en el barrio Tejares de Salamanca la policía en un registro en dicho inmueble lo detiene cuando se disponía a elaborar APAAN (precursor de drogas) manipulando para tal efecto 800 gramos de fenilacetonitrilo y 500 gramos de acetato de etilo (sustancias no catalogadas) con las que se elabora el alfa-fenilacetoacetonitrilo más conocido como APAAN que se utiliza frecuentemente en los laboratorios clandestinos en la elaboración de 1-fenil-2-propanona (P-2-P) sustancia catalogada que es la materia prima con la cual se fabrica tanto anfetamina como metanfetamina, sin que las autoridades encuentren en el local ninguna de estas drogas ilícitas. Por lo que en el Juzgado de Instrucción es condenado por el delito de tráfico de precursores de drogas en grado de tentativa a la pena de un año y seis meses de prisión En todo caso reiteramos que es muy difícil que se aprecien casos de tentativa en el delito de tráfico de precursores de drogas pues prácticamente cualquier comportamiento: fabricar, transportar, distribuir, comerciar o tener en su poder equipos, materiales o sustancias enumerados en los Cuadros I y II del Convenio de Naciones Unidas de 1988 siempre 
que mediante un juicio de inferencia se pueda deducir que la conducta se realizaba a sabiendas de que las sustancias van a utilizarse en el cultivo (ningún precursor sirve para ello), la producción, o la fabricación ilícita de drogas tóxicas, estupefacientes o sustancias psicotrópicas, o para estos fines, será sancionado como un comportamiento consumado. No obstante queremos poner de manifiesto, que en cualquiera de los casos, resultara más beneficioso para el reo ser sancionado por el delito de tráfico de precursores de drogas en grado de tentativa (pena inferior en uno o dos grados a la señalada como delito consumado), aunque suponga un adelanto desmesurado de la barrera punitiva sancionar la tentativa de un acto preparatorio, elevado a la categoría de delito autónomo, del delito de tráfico de drogas (elaboración). Queremos recordar que el Convenio de Viena de 1988 en su artículo 3.1 C) inciso IV) señala que cada una de las Partes adoptará las medidas que sean necesarias para tipificar como delito penal el tráfico de precursores de drogas en su derecho interno, cuando se cometa intencionalmente y a reserva de sus principios constitucionales y de los conceptos fundamentales de su ordenamiento jurídico deberá también sancionarse la asociación y la confabulación para cometerlo, la tentativa de cometerlo, y la asistencia, la incitación, la facilitación o el asesoramiento en relación con su comisión.

\section{H.) AUTORÍA Y PARTICIPACIÓN}

Para iniciar este apartado queremos recordar, de forma muy breve porque ya lo hicimos en el apartado II inciso D.) de este capítulo, referido a las conductas típicas, que autores del delito de tráfico de precursores de drogas, estupefacientes y psicotrópicos serán los sujetos que realicen las conductas de fabricación, transporte, distribución, comercio o tenencia de las sustancias enumeradas en el Cuadro I y Cuadro II, de la Convención de Naciones Unidas del 20 de diciembre de 1988, sobre el tráfico ilícito de estupefacientes y sustancias psicotrópicas, y cualesquiera otros productos adicionados al mismo Convenio, o que se incluyan en otros futuros convenios de la misma naturaleza, ratificados por España, "a sabiendas de" que van a utili- 
zarse la producción o la fabricación ilícita de drogas tóxicas, estupefacientes o sustancias psicotrópicas o "para estos fines"118.

En lo que se refiere a la diferenciación entre autoría y participación en el delito de tráfico de drogas, hay que decir que por la amplitud de términos empleados por el legislador para definir la conducta típica, la jurisprudencia, prácticamente de forma unánime, durante muchos años sanciono a autores y partícipes con la misma pena, estableciendo de esta manera un "concepto unitario de autor", mediante el cual se consideraba como tal a todo el que contribuyera de alguna manera en la realización del delito. Es precisamente hasta la entrada en vigor del Código Penal de 1995 empezó a cambiar esta tendencia119, tal situación

Vid supra sobre tipos y casos de autoría en el delito de tráfico de precursores de drogas apartado II inciso D) de este mismo capítulo, pp. 25-35.

119 STS (ROJ: 133/1995) de 19 de enero de 1995. Ponente: D. Enrique Bacigalupo Zapater. "Todo acto de auxilio al poseedor de la droga con destino al tráfico encaja en alguno de los supuestos del artículo 344 (hoy 368) del Código Penal en calidad de autoría directa (...), pues constituyen actos que de algún modo promueven, favorecen o facilitan el consumo ilegal. STS (ROJ: 2712/2002) de 17 de abril de 2002. Ponente: D. Miguel Colmenero Menéndez de Luarca. MUÑOZ CONDE, Francisco. Derecho Penal. P.E..., op. cit., pp. 678, 679. "Tiene declarado esta sala, como son exponentes las sentencias de 2 de noviembre de 1988 y 28 de noviembre de 1994, que todo acto de auxilio al poseedor de la droga con destino al tráfico encaja en alguno de los supuestos del artículo 368 del Código Penal, en calidad de autoría directa, dado en los amplios términos en que aparece configurada esta clase de infracción penal, pues constituyen actos que de algún modo promueven, favorecen o facilitan el consumo ilegal de sustancias estupefacientes. Es cierto que algunas sentencias han admitido la complicidad en casos de colaboración mínima de favorecimiento al favorecedor del tráfico tales como la mera indicación y el acompañamiento hasta el lugar donde se vendía la droga, pero no cuando existe un previo acuerdo seguidos de actos que facilitan la venta de tales sustancias estupefacientes, lo que, según reiterada doctrina de esta sala, convierte en autores a todos los concertados para la actividad de tráfico de droga, cualquiera que sea el rol concreto, siempre que su colaboración contribuya, como establece el artículo 368 del Código Penal, a promover, favorecer o facilitar el tráfico ilícito de drogas tóxicas o estupefacientes o de sustancias psicotrópicas". STS (ROJ: 2126/2003) de 27 de marzo de 2003. Ponente: D. Carlos Granados Pérez. "Estamos ante un concepto extensivo de autor, que excluye prácticamente las formas accesorias de participación, donde son autores todos los que ostentan el dominio del hecho dentro de la acción conjunta planeada de modo que el previo acuerdo convierte a todos los intervinientes en autores". STS (Roj: 7500/2005) de 28 de noviembre de 2005. Ponente: José Manuel Maza Martín. LAMARCA PÉREZ, Carmen (Coord.). Derecho Penal P.E..., op. cit., pp. 558- 560. LAMARCA PÉREZ, Carmen (Coord.). Delitos y Faltas. ..., op. cit., pp. 636, 637. Durante muchos años la jurisprudencia ha castigado a autores y partícipes con la misma pena, pues entendía que existía un concepto unitario de autor. 
asumimos que es perfectamente trasladable al tráfico de precursores de drogas. De hecho nada impide al tenor del artículo 29 del Código Penal que se puedan apreciar casos de complicidad ${ }^{120}$, pero hasta la fecha no conocemos de la existencia de alguna sentencia que lo haga. Resultando obvio que la mayor dificultad se puede presentar al tratar de distinguir entre cooperación necesaria y cooperación no necesaria. En este sentido hay que decir que Cooperador necesario es quien coopera en la ejecución de un hecho delictivo con un acto sin el cual no se hubiera efectuado (aportación esencial). El autor ejecuta el hecho (solo, en unión de otros o por medio de otro); en cambio, el cooperador es un colaborador que precisa de la existencia de un hecho ajeno al que aporta algún elemento relevante. Mientras que para determinar los casos de cooperación no necesaria, deberá tenerse en cuenta que se trata de conductas auxiliares que benefician a aquel que es el verdadero traficante, "es decir que no favorecen directamente al tráfico aunque favorecen al favorecedor". Para establecer el tipo de complicidad es preciso examinar las conductas enjuiciadas desde la doble perspectiva de los bienes escasos y del dominio funcional del hecho, con el objetivo de verificar si la conducta aparece en el caso como claramente periférica y de mínima colaboración o bien si trata de una aportación esencial ${ }^{121}$.

A partir del año 1995 con la aprobación del Código Penal se empezó a distinguir a efecto de penas entre autores y partícipes. ARROYO ZAPATERO, Luis. Comentarios al Código Penal. ..., op. cit., p. 812. TERRADILLOS BASOCO, Juan María. Lecciones materiales..., op. cit., p. 56. SUÁREZ-MIRA RODRÍGUEZ, Carlos (Coord.). Manual de Derecho Penal. Tomo II. Parte Especial. Sexta Edición. Aranzadi/Thomson Reuters. Navarra. 2011, pp. 433, 434. MORILLAS CUEVAS, Lorenzo. Sistema de Derecho..., op. cit., p. 828.

120 A la imputada, compañera sentimental del principal condenado por tráfico de precursores de drogas, se le atribuye el papel de auxiliar de este al atender algunas llamadas telefónicas de los traficantes de drogas a los que les proporcionaban los precursores. Al no obtenerse pruebas suficientes de su participación criminal le absuelven. SAP de Madrid (Roj: 15967/2005) de 17 de noviembre de 2005. Ponente: Juan Francisco Martel Rivero.

121 CORCOY BIDÁSOlO, Mirentxu. Comentarios al Código Penal. ...., op. cit., pp. 803, 816. CONDE-PUMPIDO FERREIRO, Cándido (Coord.). Código Penal..., op. cit., p. 1305. SERRANO GÓMEZ, Alfonso. Derecho Penal. ..., op. cit., p. 723. STS (ROJ: 6202/2001) de 16 de julio de año 2001. Ponente: Cándido Conde-Pumpido Tourón. STS (ROJ: 5207/2000) de 26 de junio de 2000. Ponente: Joaquín Giménez García. STS (ROJ: 7672/2000) de 24 de octubre 2000. Ponente: Enrique Abad Fernández. STS (ROJ: 
Creemos que es posible sancionar como cooperadores necesarios, y por ende a la misma pena que a los autores, de este delito a miembros de los cuerpos de seguridad, así como a funcionarios de puertos, aeropuertos, puestos fronterizos, retenes y aduanas, entre otros, que estando encargados de enfrentar el tráfico de precursores no lo hagan por estar confabulados con los traficantes de estas sustancias. Pensamos que estas conductas pueden tener cabida fundamentalmente en las conductas referidas al transporte y tenencia de precursores. Ejemplo de ello pueden ser: a) el policía que estando encargado en el aeropuerto de Bilbao de revisar el equipaje de pasajeros sospechosos de transportar drogas, sus precursores u otras sustancias u objetos ilícitos no lo haga a conciencia, con un sujeto que trae dos maletas con dos kilos de efedrina en cada una de ellas (ocultos en cartones de cigarrillos) que van a utilizar en la elaboración de metanfetamina en un pequeño laboratorio situado en las afueras de Barkaldo, al haber sido sobornado previamente, o b) el funcionario encargado de ir a verificar si en un deposito aduanero del puerto de Vigo la empresa SILMAR S.L. tiene oculto un lote de 1.000 kilogramos de anhídrido acético, que está destinado a la elaboración ilícita de heroína en unos laboratorios ilícitos en Estambul. Si una vez realizada la inspección, el funcionario declara que no existe tal lote en este almacén, pese a haberlo encontrado, por haber recibido la cantidad de 3.000 euros de parte del operador encargado del depósito aduanero.

Para valorar la posibilidad de apreciar casos de complicidad en el tráfico de precursores de drogas utilizaremos la Sentencia del Tribunal Supremo del 16 de enero del año 2003122, se trata de la sentencia recurrida de la Audiencia Nacional, sección cuarta del 9 de julio del año

7500/2005) de 28 de noviembre de 2005. Ponente: José Manuel Maza Martín. STS (ROJ: 1748/2009) de 18 de marzo de 2009. Ponente: Carlos Granados Pérez. SAAVEDRA RUIZ, Juan. Código Penal comentado..., op. cit., pp. 1141, 1142. La jurisprudencia ha reducido la complicidad a los casos de participación accesoria accidental no necesaria, de quien no tiene el dominio del hecho o es fácilmente sustituible al no tratarse de un bien escaso, de manera que los hechos se hubieran producido de la misma manera sin su colaboración. LAMARCA PÉREZ, Carmen (Coord.). Derecho Penal. P.E..., op. cit., pp. 559, 560. VAZQUEZ IRUZUBIETA, Carlos. Comentario al Código Penal. Actualizado por LO 5/2010. Ed. La Ley. Madrid. 2010, p. 815. BLANCO LOZANO, Carlos. Tratado de Derecho...., op. cit., pp. 386, 387.

122 STS (ROJ: 89/2003) del 16 de enero de 2003. Ponente: Luis Román Puerta Luis. 
2002 en la que se condenaron a tres sujetos como autores por el delito de tráfico de precursores de drogas, siendo estos Gaspar y José Ignacio (los dos primeros) que importaron un cargamento de unos 12.000 kilogramos de permanganato de potasio (envasados en bidones de 50 kilogramos), con el fin de exportarlo a Colombia. Esta remesa les fue suministrada por la empresa "Innochem" que tiene su sede en la localidad belga de Meerhort. Gaspar y José Ignacio antes de exportar el permanganato de potasio a Colombia decidieron camuflar la mercancía y para este propósito adquirieron 6.000 kilogramos de dióxido de manganeso (sustancia no catalogada, pero que también se utiliza en la elaboración ilícita de permanganato de potasio en países de América del Sur), dicha remesa se las proporciono la empresa R. Orts Simo S.A. de Aldaya (Valencia), ajena a estos hechos, así como 365 etiquetas y 144 bidones de plástico opaco con sus correspondientes precintos comprados a la empresa Reyde S.A, de Sant Boi de Llobregat (Barcelona) también ajena a estos hechos, para realizar el camuflaje encargaron a Miguel (tercer sujeto condenado en esta sentencia), hijo de José Ignacio, trasvasar 40 kilos de permanganato de potasio en bolsas de basura, a cada uno de los nuevos bidones recibidos, completando el peso de 50 kilos por unidad con 10 kilos de dióxido de manganeso, y tras precintar cada bidón y ponerle una nueva etiqueta referida a esta última sustancia, destruyendo las etiquetas originales del permanganato de potasio. Para que le ayudara en esta tarea Miguel contrató a su amigo Rubén. Una vez concluido el trabajo antes mencionado, tras el llenado en las formas mencionadas de 355 bidones, que fueron cargados el día 12 de marzo de 1999 en el contenedor con número de identificación SEAU 822620-9 de la empresa Sea-Land y transportados hasta el puerto de Algeciras, que el día 17 de marzo de 1999 se cargaron en el buque Grete Maeks con destino al puerto de Cartagena de Indias en Colombia, donde llega el cargamento el día 14 de abril de 1999, siendo interceptado por la policía colombiana. Hay que puntualizar que el permanganato de potasio que se exportó a Colombia alcanzaba el peso total de 11.611 kilogramos y su valor económico ascendía a la suma de 3.607.491 pesetas es decir 21.681 euros con 46 céntimos.

La Audiencia Nacional condenó como coautores por el delito de transporte de sustancias destinadas a la elaboración de drogas a Gaspar y José Ignacio a la pena de cuatro años y seis meses de prisión y multa de 30.000 euros e inhabilitación especial para ejercer el derecho de sufragio pasivo durante el tiempo de condena. A Miguel también lo 
condenaron como coautor por el mismo delito a tres años de prisión, multa de 30.000 euros e inhabilitación especial para ejercer el sufragio pasivo durante el tiempo de condena, además se condenó al pago, cada uno, de una cuarta parte de las costas causadas. A Rubén se le absolvió del delito de tráfico de precursores de drogas con toda clase de pronunciamientos favorables, y declarando de oficio una cuarta parte de las costas. El Tribunal Supremo ratifico esta sentencia el día 16 de enero del año $2003^{123}$. A Rubén se le absolvió porque su participación únicamente consistió en trasvasar el permanganato de potasio a los nuevos bidones (40 kilogramos en cada bidón) con diez kilogramos de dióxido de manganeso. Y porque en el proceso no se acredito que conociera que estaba trasvasando una sustancia catalogada (permanganato de potasio), así como que supiera que esta sustancia estaba destinada a la elaboración de cocaína en Colombia. Si en el caso de Rubén se hubiese establecido que tenía conocimiento de que estaba trasvasando una sustancia catalogada a otros bidones para camuflarla con el dióxido de manganeso, a sabiendas de que se utilizarían para la elaboración de cocaína, perfectamente podría haber sido condenado como cómplice del delito de tráfico de precursores de drogas. No obstante hay que aclarar que en la práctica es muy probable que lo pudieran condenar como coautor o cooperador necesario de un delito tipificado en el artículo 371.1 del Código Penal.

Otro ejemplo que podemos utilizar es la sentencia de la Audiencia Provincial de Madrid del día 17 de noviembre de 2005124. En esta causa el Ministerio Fiscal solicitó que a María Teresa una mujer de origen africano, cónyuge de Luis Enrique, ciudadano español que fue condenado por el delito de tráfico de precursores de drogas ${ }^{125}$, se le sancionara como autora del mismo delito, solicitando una pena de 4 años de prisión, accesorias y costas. El compañero sentimental de esta señora era titular de una empresa denominada Laboratorio Técnico Labortec S. L. con sede en Collado de Villalba y posteriormente en Becerril de la Sierra (domicilio de la pareja). Esta "empresa pantalla" obtenía una gran cantidad de sustancias químicas (precursores y

STS (ROJ: 89/2003) del 16 de enero del año 2003. Ponente: Luis Román Puerta Luis. SAP de Madrid (ROJ: 15967/2005) de 17 de noviembre de 2005. Ponente: Juan Francisco Martel Rivero.

STS (ROJ: 583/2004) de 3 de febrero de 2004. Ponente: Enrique Bacigalupo Zapater. 
sustancias no catalogadas) y material de laboratorio en diversas empresas del sector radicadas en Madrid por encargo de "Guillermo" de nacionalidad colombiana, quien en compañía de otros sujetos, recogían las sustancias y materiales del Chalet de becerril de la Sierra, después que Víctor Manuel y Gerardo (también condenados por el mismo delito), empleados de la pareja de María Teresa, quitaran las etiquetas de origen de la mercancía y las cambiaran por otras en blanco donde sólo figuraba el nombre del producto en cuestión, para trasladarlas a un chalet situado en La Navata (Galapagar) donde Guillermo un laboratorio ilícito para la extracción de cocaína que se encontraba camuflada en viruta de madera para su posterior distribución en el mercado ilícito de drogas.

El Ministerio Fiscal deduce el conocimiento y participación de María Teresa en las actividades ilícitas que se desarrollaban en el domicilio familiar: su pareja Luis Enrique y sus dos empleados, por la convivencia que la pareja mantenía desde hace 20 años, por el elevado nivel de vida que llevaban y del tenor de las conversaciones telefónicas intervenidas, las autoridades de la Policía "llegaron al convencimiento acerca del conocimiento por la acusada de la actividad delictiva que realizaba su compañero sentimental, adoptando ella la posición de auxiliar de él, pues bajo sus órdenes contactaba con los clientes y les decía cuando podían venir a recoger la mercancía encargada previamente". Sin embargo, del resultado de la práctica probatoria desplegada no se llega a la conclusión condenatoria interesada por la parte acusadora, porque aunque la acusada contactaba telefónicamente con los clientes que requerían los precursores, sustancias no catalogadas y equipos, y les indicaba a estos cuando podían llegar a retirarlos, de las declaraciones de los policías que intervinieron en las investigación y demás pruebas presentadas en el proceso no pudo deducirse de manera categórica la contribución criminal de la acusada, por lo que la absuelven del delito contra la salud pública, en su modalidad de tráfico de precursores ${ }^{126}$. Nosotros pensamos que si en el

126 Ningún testigo vio o escucho a María Teresa encargar productos destinados a ser utilizados como precursores, ni transportar los mismos, ni comerciar con estos, ni quitar las etiquetas de los productos adquiridos en el mercado lícito establecido para mutarlos en el mercado clandestino, como tampoco se le vio o escucho realizar tratos ilícitos con las personas implicadas en el negocio criminal descubierto, ya que el dato de ponerlas en contacto si cogía el teléfono y del dato de mantener conversaciones con 
juicio se hubiera podido demostrar que María Teresa en las llamadas telefónicas hubiera acordado el precio de los precursores, por orientaciones de Luis Enrique, con los traficantes de drogas, o bien les realizara recomendaciones de seguridad para llegar a buscar las sustancias catalogadas o recibiera pedidos de estas sustancias por los traficantes, siempre que se estableciera el conocimiento de contri-bución al acto ilícito, perfectamente habrían podido condenarla como cómplice de un delito contra la salud pública del artículo 371 del Código Penal. Queremos señalar que la posibilidad de apreciar casos de cooperación no necesaria en el delito de tráfico de precursores de drogas es, sin lugar a dudas, favorable al reo pues el artículo 63 del Código Penal establece que a los cómplices de un delito consumado o intentado se les impondrá la pena inferior en grado a la fijada por la Ley para los autores del mismo delito.

Queremos destacar que últimamente, algunos años después de la aprobación del Código Penal de 1995, se observa cierta tendencia jurisprudencial que diferencia la complicidad de la autoría en los delitos relativos al tráfico de drogas. Calificando como complicidad los comportamientos de menor relevancia, los casos de colaboración mínima o de favorecer o facilitar el favorecimiento, cuando se realiza una aportación de escasa entidad, o de carácter ocasional, sin formar parte que quienes ejecutan la operación de tráfico de drogas. En tal sentido citamos las sentencias del Tribunal Supremo de 18 de septiembre de 1995, 26 de junio del año 2000, de 24 de octubre del año 2000, de 10 de julio del año 2001, de 16 de julio del año 2001, de 21 junio del año 2002, de 30 de diciembre del año 2002, de 27 de marzo del año 2003, de 3 de diciembre del año 2003, de 17 de marzo del año 2004, de 13 de septiembre del año 2004, de 28 de noviembre de 2005, de 20 de abril del año 2007, de 7 de mayo de 2010, de 22 de junio del año 2010, de 27 de septiembre del año 2011 y la SAP de 14 de octubre de 2009127. En dichas sentencias, de forma general, se han

ellas, no se extraen consecuencias punitivas en el acto enjuiciado. SAP de Madrid (Roj: 15967/2005) de 17 de noviembre de 2005. Ponente: Juan Francisco Martel Rivero.

127 STS (ROJ: 4580/1995) de 18 de septiembre de 1995. Ponente: Luis Roman Puerta Luis, STS (ROJ: 5207/2000) de 26 de junio de 2000. Ponente: Joaquín Giménez García, STS (ROJ: 7672/ 2000) de 24 de octubre de 2000. Ponente: Enrique Abad Fernández, STS (ROJ: 6024/2001) de 10 de julio de 2001. Ponente: Eduardo Moner Muñoz, STS (ROJ: 6202/2001) de 16 de julio de 2001. Ponente: Cándido Conde-Pumpido Tourón, STS 
sancionado como cómplices a: a) quien realiza la mera indicación y acompañamiento hasta el lugar donde se vendía la droga, siempre que no exista un acuerdo previo y se trate de actos que faciliten la venta, b) quien recibe y descifra los mensajes en clave en una operación de narcotráfico, c) quien realiza la ocultación ocasional y de poca duración de una pequeña cantidad de droga que otro poseía, d) la cesión del domicilio a los autores por pura amistad para no levantar sospechas, e) la facilitación del domicilio de venta y precio de la droga, f) la realización de llamadas telefónicas para convencer y acordar con un tercero el transporte de la droga, g) acompañar y trasladar en su vehículo a un familiar o amigo en sus contactos $\mathrm{y}$ h) encargarse de los pasos previos para la recepción de la droga enviada desde el extranjero, sin ser destinatario ni tener la disponibilidad efectiva de la misma ${ }^{128}$.

Los requisitos que establece el Tribunal Supremo para apreciar complicidad en los delitos contra la salud pública son los siguientes: a) la comisión del ilícito delictivo por una o varias personas que con su conducta asuman el papel principal de autoría, frente a otros que desarrollen una participación secundaria, b) el conocimiento por parte del cómplice de su contribución a un acto ilícito, pues de otra forma su participación sería impune, c) que su comportamiento sea de naturaleza secundaria y sometida a los actos principales de tráfico, que realiza el autor o coautores, d) que, por ello, no tenga carácter imprescindible en la ejecución del delito, e) que la colaboración del

(ROJ: 4600/2002) de 21 de junio de 2002. Ponente: Carlos Granados Pérez, STS (ROJ: 8929/2002) de 30 de diciembre de 2002. Ponente: José Ramón Soriano Soriano, STS (Roj: 2126/2003) de 27 de marzo de 2003. Ponente: Carlos Granados Pérez, STS (ROJ: 7737/2003) de 3 de diciembre de 2003. Ponente: Miguel Colmenero Menéndez de Luarca, STS (ROJ: 1849/2004) de 17 de marzo de 2004. Ponente: Joaquín Giménez García, STS (ROJ: 5639/2004) de 13 de septiembre de 2004. Ponente: Luis Román Puerta Luis, STS (ROJ: 7500/2005) de 28 de noviembre de 2005. Ponente: José Manuel Maza Martín. STS (ROJ: STS 2398/2007) de 20 de abril de 2007. Ponente: José Ramón Soriano Soriano, STS (ROJ: 2804/2010) de 7 de mayo de 2010. Ponente: Alberto Gumersindo Jorge Barreiro, STS (ROJ: 4208/2010) de 22 de junio de 2010. Ponente: Julián Antonio Sánchez Melgar. STS (ROJ: 5856/2011) de 27 de septiembre de 2011. Ponente: Juan Ramón Berdugo Gómez de la Torre y SAP (ROJ: SAP TO 865/2009) de 14 de octubre de 2009. Ponente: Urbano Suarez Sánchez. 
cómplice sea fácilmente reemplazable y f) que tal aportación sea, en sí misma, esporádica y de escasa consideración ${ }^{129}$.

También hay que decir que el encubrimiento es muy difícil de apreciar en los delitos relativos al tráfico de drogas, más aún que la cooperación no necesaria o complicidad. En este sentido se afirma que la figura del encubrimiento es de difícil construcción en relación con delitos de esta naturaleza ya que al ser de carácter permanente toda intervención tiene lugar durante la comisión y nunca con posterioridad a la misma, por lo cual este tipo de participación menor normalmente se debe de considerar como como complicidad en cuanto auxilia al o los autores con actos anteriores o simultáneos ${ }^{130}$. No obstante pueden existir supuestos de hecho muy concretos en los que cabría construir la figura del encubrimiento en la modalidad de ocultar o inutilizar los efectos o instrumentos del delito para impedir su descubrimiento, relegando a esta modalidad aquellas conductas consistentes en destruir la droga, o bien los precursores de drogas, con el fin de frustrar o dificultar la intervención de las autoridades encargadas de la investigación. Y ello siempre que el delito principal se hubiera ya consumado. Es necesario tener presente que el encubrimiento implica siempre una actuación a posteriori, esto es cuando la acción encubierta ha sido ya ejecutada ${ }^{131}$.

129 SAP (ROJ: SAP TO 865/2009) de 14 de octubre de 2009. Ponente: Urbano Suarez Sánchez. SAP de Madrid (ROJ: 11904/2010) de 14 de junio de 2010. Ponente: Pascual Fabia Mir.

130 Se condena como cómplice de un delito contra la salud pública a un ciudadano de nombre Alberto a la pena de cuatro años y seis meses de prisión. El condenado estuvo presente en una nave industrial donde pudo comprobar, sin tener ninguna participación previa, la extracción de unos paquetes de cocaína de unas lavadoras industriales importadas desde Venezuela, acompañando a otro de los condenados (como autor del delito) a un vehículo donde introdujeron en el maletero una bolsa que contenía cinco paquetes de cocaína con un peso bruto de 5.500 gramos con un grado de pureza del 77\%, no observándose en la investigación la existencia de un relevante beneficio o lucro económico derivada de su aportación al tráfico. STS (ROJ: 5008/2001) de 12 de junio de 2001. Ponente: José Antonio Martín Pallín. Ver también STS (ROJ: 7737/2003) de 3 de diciembre de 2003. Ponente: Miguel Colmenero Menéndez de Luarca. STS (ROJ: 6737/1996) de 28 de noviembre de 1996. Ponente: José Luis Manzanares Samaniego.

131 En este caso se sanciona a dos personas Regina y Luis Manuel como responsables de un delito de encubrimiento con causa en un delito contra la salud pública, en su modalidad de sustancias que causan grave daño a la salud, en concepto de encubridores a un año de prisión. Ambos fueron sorprendidos junto con otros dos 
Vamos a usar el mismo ejemplo de Luis Enrique, que tenía una "empresa pantalla" con sede en su propio domicilio en Becerril de la Sierra y suministraba precursores de drogas, sustancias no catalogadas y equipos a un grupo de traficantes que en un chalet situado en La Navata (Galapagar), que tenían un laboratorio ilícito para la extracción de cocaína que se encontraba camuflada en viruta de madera y su posterior distribución en el mercado. Para ello nos situamos en el día 24 de junio de 1999 a las 14:20 horas en el chalet de Becerril de la Sierra cuando se procede a practicar la entrada y registro en dicho inmueble, donde se ocuparon 7,5 litros de ácido clorhídrico, cuatro litros de ácido sulfúrico y 75 litros de metiletilcetona, así como otras sustancias no catalogadas que se utilizan para transformar la pasta base de cocaína en clorhidrato de cocaína ${ }^{132}$. En dicho inmueble fueron capturados, y posteriormente condenados por tráfico de precursores, Luis Enrique y sus dos empleados Víctor Manuel y Gerardo. Supongamos que si además de estas personas se hubiese encontrado en el chalet un sujeto de nombre Mario, íntimo amigo de Luis Enrique, que no tenía ninguna participación en la actividad ilícita antes mencionada, pero si conocimiento de la misma por su amistad con Luis Enrique. Nosotros pensamos que si Mario en el momento en que se percatan de la presencia de las autoridades, accede por petición de su amigo, a tirar por el váter de la habitación de invitados los cuatro litros de ácido sulfúrico y es detenido por la policía justo en el momento en que se dispone a tirar la sustancia antes mencionada podría haber sido condenado como responsable de un delito de encubrimiento en un delito de tráfico de precursores, pues su conducta consiste en destruir el precursor de drogas, con el fin de frustrar o dificultar la intervención de las autoridades competentes en un delito que ya se había consumado.

acusados cuando intentaban sacar al exterior desde un garaje varios paquetes y bolsas de gran tamaño, en cuyo interior se encontró hachís, cocaína y moldes para prensar drogas, así como diversos productos químicos para la mezcla y adulteración. El Ministerio Fiscal cuestiono que el Tribunal de Instancia calificara tal comportamiento como un delito de encubrimiento, pues se trata de actos de autoría, al tratarse de un acto de ocultación encaminado a favorecer al autor de un delito contra la salud pública. Pero el Tribunal Supremo mantiene la calificación de encubrimiento por la ausencia de impugnación por parte del Fiscal ante el Tribunal de Instancia. Lo cual obliga a mantener una calificación jurídica equivocada. STS (ROJ: 3893/2014) de 22 de septiembre de 2014. Ponente: Manuel Marchena Gómez.

132 STS (ROJ: 583/2004) de 3 de febrero de 2004. Ponente: Enrique Bacigalupo Zapater. 


\section{LA PENALIDAD}

\section{A.) Pena PRivativa de Libertad}

El legislador ha establecido como pena básicas para las conductas descritas en el tipo del artículo 371 CP la pena privativa de libertad de prisión de tres a seis años, y una multa del tanto al triplo del valor de los géneros o efectos (probablemente en consideración a la circunstancia de que estos delitos están por lo general determinados por móviles de lucro), así como el comiso de las sustancias por imperativo del artículo $374 \mathrm{CP}$. Es necesario recordar que la pena básica que establecía el delito de tráfico de precursores drogas era intermedia en relación con la doble sanción que efectuaba el articulo 368 CP, según se tratare de drogas catalogadas como causantes de grave daño a la salud (también llamadas drogas duras) y no causantes de ese grave daño a la salud (denominadas además drogas blandas). No obstante, y como ya se ha señalado antes, la doctrina ha destacado la desproporcionalidad de las penas señaladas en relación con la lesividad de las conductas que la generan. En este sentido, se criticaba el hecho de que, en virtud de este precepto, correspondía un mayor castigo a quien trafica con precursores de drogas que a quien lo hace con drogas blandas, cuando cabe suponer que, desde el punto de vista de la tutela de la salud pública, la posibilidad de lesión de este bien jurídico es mayor en el delito de tráfico de drogas que en el tráfico de precursores de drogas (aunque estos lo sean de drogas duras), y desde el punto de vista económico también es más rentable. Por ello, se afirmaba, que políticocriminalmente este desfase en la penalidad distaba mucho de ser acertado ${ }^{133}$, entendiendo que de esta manera se atentaba contra el principio de proporcionalidad. Además era destacable que cuando se trataba de los jefes, administradores o encargados de las referidas organizaciones se imponía la pena superior en grado, que era de seis a nueve años de prisión, pena que concordaba con el límite máximo establecido por el artículo $368 \mathrm{CP}$ para los sujetos que traficaban con drogas duras.

La desproporcionalidad que se produce en la pena a imponer por el delito de tráfico de precursores en el ordenamiento español se vio 
incrementada con la aprobación de la Ley Orgánica 5/2010 del 22 de junio, que redujo la pena de prisión del tipo básico del tráfico de drogas que causan grave daño a la salud establecida en el artículo 368 del Código Penal de tres a seis años, manteniéndose la multa del tanto al duplo del valor de la droga objeto del delito (inferior a la del tráfico de precursores que es del tanto al triplo del valor de los géneros y efectos) ${ }^{134}$. De esta manera en la actualidad la pena privativa de libertad es exactamente la misma prevista para el artículo $371 \mathrm{CP}$. Equiparando por tanto la conducta del tráfico de drogas duras con la del tráfico de sus precursores, es decir se sanciona igual el tráfico de cocaína, heroína, éxtasis, anfetaminas y metanfetaminas, que el tráfico de sus precursores: la acetona, el ácido clorhídrico, el ácido sulfúrico, el éter etílico, la metiletilcetona, el permanganato de potasio, el tolueno, el anhídrido acético, el ácido fenilacético, la norfedrina, la P-2-P, la efedrina, la seudoefedrina, el piperonal, el safrol o la 3,4-MDP-2-P. Pero este despropósito legislativo va más allá, pues en esta reforma se preceptúa que los tribunales, en el caso de los delitos tipificados en el 368, podrán imponer la pena inferior en grado (de un año y medio a tres años) a las señaladas en atención a la escasa entidad del hecho y a las circunstancias personales del culpable, lo cual no se encuentra previsto para el artículo $371^{135}$, con lo cual se puede presentar el caso de que inclusive se sancione con una pena menor a las personas que trafican con drogas duras, que aquellas que trafican con los precursores de estas drogas, aunque en este tipo delictivo la puesta en peligro del bien jurídico salud pública sea mucho más distante. Queremos aclarar que para nosotros la reducción de penas realizada para el delito de tráfico de drogas debe tener sin lugar a dudas una

VIVES ANTÓN, Tomas S. Derecho Penal. P.E..., op. cit., p. 611. SAAVEDRA RUIZ, Juan. Código Penal comentado...., op. cit., pp. 1138, 1139. Debe reconocerse que la rebaja de pena del tipo básico cuando se trata de drogas que causan grave daño a la salud producirá efectos muy beneficiosos para alcanzar penas menos desproporcionadas, no sólo en el tipo básico, sino también en los tipos agravados de los artículos 369 y 370 (no así en el caso del artículo 369 bis). ÁLVAREZ GARCÍA, F. Javier. Derecho Penal Español..., op. cit., p. 1257. MORILLAS CUEVAS, Lorenzo. Sistema de Derecho..., op. cit., p. 829. No sólo es necesario que pueda culparse al autor del delito de aquello que motiva la pena, sino que además que la gravedad de esta resulte proporcionada al hecho cometido. MIR PUIG, Santiago. Derecho Penal..., op. cit., pp. 127, 128. 
valoración positiva, lo que es difícil de asimilar es que dicha reducción no abarcara también a las penas establecidas para el tráfico de precursores de drogas.

El inciso número 2 del artículo $371 \mathrm{CP}$ establece que se impondrá la pena en su mitad superior (de cuatro años y medio a seis años) cuando las personas que realicen los hechos descritos en el apartado anterior pertenezcan a una organización dedicada a los fines en él señalados ${ }^{136}$ y la pena superior en grado (de seis a nueve años) cuando se trate de los jefes, administradores o encargados de las referidas organizaciones o asociaciones. En tales casos, los jueces o tribunales impondrán, además de las penas correspondientes, la de inhabilitación especial del reo para el ejercicio de su profesión o industria por tiempo de tres a seis años, y las demás medidas previstas en el artículo 369.2, que

136 Los elementos que integraban la nota de organización de forma sintetizada son los siguientes: a) existencia de una estructura más o menos normalizada y establecida; b) empleo de medios de comunicación no habituales; c) pluralidad de personas previamente concertadas; d) distribución diferenciada de tareas o reparto de funciones; e) existencia de una coordinación; f) debe tener finalmente la estabilidad temporal suficiente para la efectividad del resultado jurídico apetecido. Señala esta sentencia que la organización requiere que "los autores hayan actuado dentro de una estructura caracterizada por un centro de decisiones y diversos niveles jerárquicos, con posibilidad de sustitución de unos u otros mediante una red de reemplazos que asegura la supervivencia del proyecto criminal con cierta independencia de las personas integrantes de la organización y que dificultan de manera extraordinaria la persecución de los delitos cometidos, aumentando al mismo tiempo el daño posible causado". STS (ROJ: 1905/2000) de 10 de marzo de 2000. Ponente: D. Adolfo Prego de Oliver Tovar. STS (ROJ: 4580/1995) de 18 de septiembre de 1995. Ponente: D. Luis Román Puerta Luis. STS (ROJ: 3020/2003) de 5 de mayo de 2003. Ponente: D. José Antonio Marañón Chavarri. Aplica la agravante de organización. SAP de Ciudad Real (ROJ: 617/2011) de 20 de julio de 2011. Ponente: D. Alfonso Moreno Cardoso. En casación elimina la agravante de organización de la Audiencia Provincial de Ciudad Real modificando la sentencia. STS (ROJ: 4207/2012) de 29 de mayo de 2012. Ponente: D. Miguel Colmenero Menéndez de Luarca. SAP de Madrid (ROJ: 11904/2010) de 14 de junio de 2010. Ponente: D. Pascual Fabia Mir. STS (ROJ: 5856/2011) de 27 de septiembre de 2011. D. Ponente: Juan Ramón Berdugo Gómez de la Torre. No puede afirmarse que exista una situación de red jerarquizada con cierta vocación de continuidad sino un concierto de voluntades encaminadas a la ejecución de un acto de tráfico ilícito de sustancias destinadas a la elaboración de cocaína (precursores), con el lógico reparto de roles propio de la coautoría criminal pero lejos de la "organización". SAN (ROJ: 4326/2002) de 9 de julio de 2002. Ponente: Dña. Raimunda de Peñafort Lorente Martínez. SAN (ROJ: 8185/2005) de 3 de noviembre de 2005. Ponente: Felix Alonso Guevara Marcos. 
establecía que debía de realizarse el comiso de los bienes objeto del delito y de los productos y beneficios obtenidos directa o indirectamente del acto delictivo y, además, la autoridad judicial podría decretar alguna de las siguientes medidas: $1^{\text {a }}$ La pérdida de la posibilidad de obtener subvenciones o ayudas públicas y del derecho a gozar de beneficios o incentivos fiscales o de la seguridad social, durante el tiempo que dure la mayor de las penas privativas de libertad impuestas; 2 a la aplicación de las medidas previstas en el artículo 129 de este Código dirigidas a sancionar a las personas jurídicas ${ }^{137}$.

Pero como todos sabemos el artículo 369.2 CP fue suprimido por el artículo centésimo quinto del artículo único de la Ley Orgánica 5/2010 del día 22 de junio, por lo cual este no tiene ninguna vigencia. Lo que

137 El artículo 129 de este Código: preceptúa que el Juez o Tribunal, en los supuestos previstos en este Código, y sin perjuicio de lo establecido en el artículo 31 del mismo, previa audiencia del Ministerio Fiscal y de los titulares y sus representantes legales podrá imponer, motivadamente las siguientes consecuencias: a) clausura de la empresa, sus locales o establecimientos, con carácter temporal o definitivo. La clausura temporal no podrá exceder de cinco años, b) disolución de la sociedad, asociación o fundación, c) suspensión de las actividades de la sociedad, empresa, fundación o asociación por un plazo que no podrá exceder los cinco años, d) prohibición de realizar en el futuro actividades, operaciones mercantiles o negocios de la clase de aquellos en cuyo ejercicio se haya cometido, favorecido o encubierto el delito. Está prohibición podrá tener carácter temporal o definitivo. Si tuviere carácter temporal, el plazo de prohibición no podrá exceder de cinco años. La intervención de la empresa para salvaguardar los derechos de los trabajadores o de los acreedores por el tiempo necesario y sin que exceda de un plazo máximo de cinco años. El texto anterior a dicha modificación operada por la Ley Orgánica 15/2003 estipulaba que: "en tales casos, los jueces y tribunales impondrán además de las penas correspondientes, la de inhabilitación especial del reo para el ejercicio de su profesión o industria, por un tiempo de tres a seis años, y las demás medidas previstas en el artículo 370". Dicho artículo establecía que: "los Jueces o Tribunales impondrían las penas privativas de libertad superiores en grado a las señaladas en el artículo anterior y multa del tanto al séxtuplo cuando las conductas en él definidas sean de extrema gravedad, o cuando se trate de los jefes, administradores o encargados de las organizaciones o asociaciones mencionadas en su número 6. En este último caso, así como cuando concurra el supuesto previsto en el número 2 del mencionado artículo, la autoridad judicial podrá decretar, además alguna de las medidas siguientes: a) disolución de la organización o clausura definitiva de sus locales o de los establecimientos abiertos al público, b) suspensión de las actividades de organización o clausura de los establecimientos abiertos al público por tiempo no superior a cinco años, c) prohibición de la misma a realizar aquellas actividades, operaciones mercantiles o negocios, en cuyo ejercicio se haya facilitado o encubierto el delito, por tiempo no superior a cinco años". 
directamente comporta un incumplimiento de la Decisión Marco 2004/757/JAI del Consejo de 24 de octubre de 2004, ya que esta exige establecer, igual que para el delito de tráfico de drogas, la responsabilidad de las personas jurídicas. Este incumplimiento parece deberse a un error, ejemplo de la precipitada y defectuosa elaboración de la reforma, que ha llevado a incluir en el ámbito de aplicación del artículo 369 bis CP, a estos efectos, únicamente los delitos recogidos en los dos artículos anteriores, y no, por tanto, el que tipifica este artículo $371 \mathrm{CP}$, obviamente posterior ${ }^{138}$, del que se suprimieron dichas sanciones por la LO 5/2010 al eliminar el artículo 369.2. Sin embargo hay que decir que el tráfico de precursores si contempla sanciones para las personas jurídicas en el ámbito de la Ley de contrabando. Esta situación creemos que debe de solventarse cambiando la redacción del segundo párrafo del artículo 371.2 que podría quedar de la siguiente manera: en tales casos, los jueces y tribunales impondrán además de las penas correspondientes, la de inhabilitación especial del reo para el ejercicio de su profesión o industria, por un tiempo de dos a cinco años, y las demás medidas previstas en el tercer párrafo del artículo 369 bis $^{139} \mathrm{o}$

138 CONDE-PUMPIDO FERREIRO, Cándido. Código Penal..., op. cit., pp. 1329-1331. Una vez más se pone de manifiesto la miopía del legislador, por cuanto, con la reforma llevada a cabo por la Ley 5/2010, se ha suprimido el apartado 2 del artículo 369, y luego se mantiene aún su aplicación en el artículo 371 al remitir a dicho precepto ya derogado. Lógicamente, si ya no existe dicho precepto, resulta sin sentido la remisión a él. Lo correcto hubiera sido suprimir también dicha referencia y aplicar aquí el nuevo artículo 31 bis sobre la responsabilidad penal de las personas jurídicas y el artículo 129 , en el que se prevé la aplicación de las consecuencias accesorias que pretendía el artículo 371, quedando ahora sin efectividad alguna su publicación. CARDONA TORRES, Juan. Derecho Penal...., op. cit., p. 444. TERRADILLOS BASOCO, Juan María. Lecciones materiales..., op. cit., pp. 64, 65. Lo que se ha producido, de facto, es un beneficio no deseado por el legislador al desaparecer, sin ser sustituidas, algunas de las medidas antes contempladas para el delito de tráfico de precursores de drogas agravado. ÁLVAREZ GARCÍA, F. Javier. Derecho Penal Español..., op. cit., p. 1351.

139 Cuando de acuerdo con lo establecido en el artículo 31 bis una persona jurídica sea responsable de los delitos recogidos en los dos artículos anteriores, se le impondrán las siguientes penas:

a) Multa de dos a cinco años, o del triple al quíntuple del valor de la droga cuando la cantidad resultante fuese más elevada, si el delito cometido por la persona física tiene prevista una pena de prisión de más de cinco años. b) Multa de uno a tres años, o del doble al cuádruple del valor de la droga cuando la cantidad resultante fuese más elevada, si el delito cometido por la persona física tiene prevista una pena de prisión de más de dos años no incluida en el anterior inciso. Atendidas las reglas establecidas en 
bien reformando el tercer párrafo de este artículo que quedaría redactado de la siguiente forma: Cuando de acuerdo con lo establecido en el artículo 31 bis una persona jurídica sea responsable de los delitos recogidos en los dos artículos anteriores y en el artículo 371, se le impondrán las siguientes penas.

Manjón-Cabeza Olmeda señala que sobre el concepto de organización al que se refiere el inciso número 2 del artículo $371 \mathrm{CP}$, para imponer la pena en su mitad superior (de cuatro años y medio a seis años) deberá estarse al más estricto, respecto del construido con la legislación anterior a la LO 5/2010, del nuevo artículo 570 bis Código Penal que literalmente establece que: "a los efectos de este Código se entiende por organización criminal la agrupación formada por más de dos personas con carácter estable o por tiempo indefinido, que de manera concertada y coordinada se repartan diversas tareas o funciones con el fin de cometer delitos, así como de llevar a cabo la perpetración reiterada de faltas". Para imponer la pena superior en grado (de 6 a 9 años) a los "jefes, administradores y encargados" de las referidas organizaciones o asociaciones, hay que entender que se trata de la cúspide de la organización criminal responsable de su dirección, y de las personas que siendo subordinadas reciben el encargo de dirigir y tienen capacidad de decidir, y las personas que aun no ocupando la cúspide, sin embargo llevan el día a día de la organización ${ }^{140}$.

Sin embargo, es preciso esclarecer, como ya señalamos antes, que cuando el delito de tráfico de precursores se realiza perteneciendo a una organización dedicada estos fines se produce un concurso de normas con el delito de pertenencia a una organización criminal

el artículo 66 bis, los jueces y tribunales podrán asimismo imponer las penas recogidas en las letras b) a g) del apartado 7 del artículo 33.

140 ÁLVAREZ GARCÍA, F. Javier. Derecho Penal Español. ..., op. cit., pp. 1332, 1333, 1356, 1357. La Decisión Marco 2004/757/JAI del Consejo de 25 de octubre de 2004 relativa al establecimiento de disposiciones mínimas de los elementos constitutivos de delitos y las penas aplicables en el ámbito del tráfico ilícito de drogas en el apartado número 4 del artículo 4 establece que cada uno de los Estados miembros adoptará las medidas necesarias para garantizar que la fabricación, el transporte o la distribución de precursores, a sabiendas de que van a utilizarse en la producción o la fabricación ilícitas de drogas o para dichos fines. Se castiguen con penas máximas de 5 a 10 años de privación de libertad, como mínimo, cuando el delito se haya cometido dentro de una organización delictiva en el sentido de la Acción Común 98/733/JAI. 
tipificado en el artículo 570 bis, el cual se ha de resolver mediante la aplicación de la regla de alternabilidad prevista en el artículo 8.4 del Código Penal, y por tanto, constatar cuál de las dos disposiciones tiene señalada la pena de mayor gravedad. Debiendo tenerse en cuenta que el tipo penal del artículo 570 bis no sanciona la conducta de tráfico de precursores, por lo que para hacer la comparación de penas con el artículo 371, es necesario añadir a las penas fijadas por aquél, las que procedan por esta actividad delictiva ${ }^{141}$. Como sabemos la pertenencia a una organización se sanciona en el artículo 371.2 con la aplicación de la pena en su mitad superior (de cuatro años y medio y un día a seis años) y la pena superior en grado (de seis a nueve años) cuando se trate de los jefes, administradores o encargados de las referidas organizaciones o asociaciones. Mientras que el artículo 570 bis en su inciso 1 castiga a quienes promovieren, constituyeren, organizaren, coordinaren o dirigieren una organización criminal con la pena de cuatro a ocho años si se trata de delitos graves (penados con más de cinco años) y de tres a seis años si se tratare de delitos menos graves (penados con menos de cinco años). Y a quienes participaren activamente en la organización, formaren parte de ella o cooperaren económicamente o de cualquier otro modo con la misma serán castigados con las penas de prisión de dos a cinco años si tuviere como fin la comisión de delitos graves, y con la pena de prisión de uno a tres años en los demás casos. Preceptuando en su inciso número 2 que cuando la organización: a) esté formada por un elevado número de personas, b) disponga de armas o instrumentos peligrosos o c) disponga de medios tecnológicos avanzados de comunicación o transporte que por sus características resulten especialmente aptos

141 El legislador ha decidido que en el ámbito de las organizaciones y grupos criminales el mayor desvalor de pertenecer a una organización criminal justifica la aplicación de la sanción más grave, con el objeto de evitar sanciones atenuadas derivadas de la eventual existencia de discordancias punitivas entre los distintos tipos penales. Aunque el expresado concurso de normas entre los artículos 371.2 y 570 bis se produce porque la pertenencia a una organización está tipificada en ambas disposiciones, sin embargo, hay que tener en cuenta que el primero de estos dos artículos castiga conjuntamente dos conductas: la de traficar, transportar, distribuir o la tenencia de equipos, materiales o sustancias enumeradas en el Cuadro I y Cuadro II de la Convención de Viena de 1988 y la de pertenecer a una organización, mientras que el artículo 570 bis solamente tipifica esta última conducta. Circular no 3/2011 sobre la reforma del Código Penal efectuada por la Ley Orgánica 5/2010, de 22 de junio, en relacion con los delitos de tráfico ilegal de drogas y de precursores. 
para facilitar la ejecución de delitos o la impunidad de los culpables se impondrá a quienes fueren dirigentes de la organización la pena prevista en el número anterior en su mitad superior lo que supone de seis a ocho años si se trata de delitos graves y de cuatro años y seis meses a seis años si se trata de delitos menos graves, y en el caso de los miembros de la organización de tres años y seis meses a cinco años si se trata de delitos graves y de dos a tres años si se trata de delitos menos graves. Estableciendo además este inciso que si concurrieran más de dos circunstancias, de las señaladas anteriormente, se impondrán las penas superiores en grado, de 8 a 12 años si se trata de delitos graves y de 6 a 9 años si se trata de delitos menos graves a los dirigentes de la organización, y de 5 años a 7 años y 6 meses si se trata de delitos graves y de 3 años a 4 años y 6 meses en los demás casos. Señalando el artículo 570 quáter que cuando las conductas previstas en los artículos 570 bis y 570 ter estuvieren comprendidas en otro precepto de este código, será de aplicación lo dispuesto en la regla $4^{\mathrm{a}}$ del artículo 8 que establece que el precepto penal más grave excluirá los que castiguen el hecho con pena menor.

Por lo cual, cuando se trate de los jefes, administradores o encargados de las referidas organización que realicen el delito de tráfico de precursores la pena máxima a imponer puede llegar hasta los 14 años de prisión, pero en el caso de que se cumplan dos de las circunstancias agravantes del artículo 570 bis inciso 2 la pena privativa de libertad sería de hasta 18 años, lo que supone nueve años más (el doble) que la establecida antes de la aprobación de la LO 5/2010142. Lo que excede en gran medida lo dispuesto en la Decisión Marco 2004/757/JAI del Consejo, de 24 de octubre, relativa al establecimiento de disposiciones mínimas de los elementos constitutivos de delitos y de las penas aplicables en el ámbito del tráfico de drogas, que el artículo 4 señala de forma expresa la necesidad de que los Estados miembros sancionen con penas máximas de 5 a 10 años el tráfico de precursores de drogas que se haya cometido dentro de una organización delictiva.

Hay que señalar que en los supuestos en que la coparticipación en el delito de tráfico de precursores no alcance el grado de organización y sí

142 Circular no 3/2011 sobre la reforma del Código Penal efectuada por la Ley Orgánica 5/2010, de 22 de junio, en relacion con los delitos de tráfico ilegal de drogas y de precursores. 
de grupo criminal, se produce un concurso real de delitos en el que se plantea la misma problemática anteriormente analizada que determina la imposición acumulada de las penas señaladas para ambos delitos. Como el delito de tráfico de precursores de drogas no contempla la participación en un grupo criminal habrá que adicionar a estas las penas que preceptúa el artículo 570 ter que prevé en su inciso 1 para quienes constituyeren, financiaren o integraren un grupo criminal la pena 6 meses a 2 años de prisión si la finalidad es cometer cualquier otro delito grave, y con la pena de 3 meses a 1 año de prisión cuando se trate de cometer uno o varios delitos menos graves o la perpetración reiterada de delitos leves. El inciso 2 establece que las penas previstas en el número anterior se impondrán en su mitad superior cuando el grupo: a) esté formado por un elevado número de personas, b) disponga de armas o instrumentos peligrosos o c) disponga de medios tecnológicos avanzados de comunicación o transporte que por sus características resulten especialmente aptos para facilitar la ejecución de delitos o la impunidad de los culpables, lo que supone una pena de prisión de 1 año y 3 meses si se trata de delitos graves, y de 7 meses y 15 días a 1 año si se trata de delitos menos graves. Preceptuando además que si concurrieran dos o más de dichas circunstancias se impondrán las penas superiores en grado, o sea de 2 años a 3 años si se trata de delitos graves y de 1 año a 1 año y 6 meses si se trata de delitos menos graves. Como vemos para la diferenciación de organización criminal y grupo criminal, el legislador ha construido el concepto de este último sobre las notas negativas de no concurrencia de alguna o algunas de las circunstancias de la organización criminal, por lo que se puede concluir que los caracteres "transitorio y ocasional" expresados en el subtipo agravado del derogado artículo 369.1.2. ${ }^{\text {a }} \mathrm{CP}$, en la actualidad se incardinan en el concepto de grupo criminal, toda vez que se corresponde con una agrupación de personas no suficientemente estructurada para perpetuarse en el tiempo ${ }^{143}$.

143 Circular no 3/2011 sobre la reforma del Código Penal efectuada por la Ley Orgánica 5/2010, de 22 de junio, en relacion con los delitos de tráfico ilegal de drogas y de precursores. La organización y el grupo criminal tienen en común la unión o agrupación de más de dos personas y la finalidad de cometer delitos concertadamente. Pero mientras que la organización criminal requiere, además, la estabilidad o constitución por tiempo indefinido, y que se repartan las tareas o funciones de manera concertada y coordinada (necesariamente ambos requisitos conjuntamente: estabilidad y reparto de tareas), el grupo criminal puede apreciarse cuando no concurra ninguno de estos dos 
Considerando el Ministerio Público que la mera codelincuencia se produciría en aquellos casos en los que la unión o agrupación fuera únicamente de dos personas o cuando estando integradas por más de dos personas, la agrupación se hubiera formado fortuitamente para la comisión inmediata de un delito ${ }^{144}$.

Méndez Rodríguez señala que la desastrosa definición de grupo criminal que contiene nuestro Código Penal se caracteriza por la finalidad que guía a quienes se conciertan, sin precisar requisitos materiales que permitan conceptuar estas modalidades de agrupaciones como criminalidad organizada, lo que ha propiciado una jurisprudencia plural, muchas veces confusa, que se ve obligada a recurrir a elementos que literalmente no contempla la Ley tanto para responder al sentido de estas tipificaciones como modalidades menores de criminalidad organizada, como para permitir su delimitación de las organizaciones criminales y de la codelincuencia. Expresando que en definitiva se puede concluir que los grupos criminales no constituyen modalidades de criminalidad organizada en sentido estricto, por lo que carecen de los elementos que fundamentan su punición autónoma y por ello debería de desaparecer el delito de pertenencia a grupo criminal, dado que la expansión punitiva que representa su inclusión junto al delito de pertenencia a organización criminal no se puede fundamentar materialmente, respondiendo

requisitos, o cuando concurra uno solo. De esta manera, se reserva el concepto de organización criminal para aquellos supuestos de mayor complejidad de la estructura organizativa, pues es, precisamente, la estabilidad temporal y la complejidad estructural lo que justifica una mayor sanción en atención al importante incremento en la capacidad de lesión. Pues se trata de la delincuencia organizada transnacional, caracterizada por su profesionalización, tecnificación e integración en estructuras legales. Mientras que para la pequeña criminalidad organizada de ámbito territorial más limitado y cuyo objetivo es la realización de actividades delictivas de menor entidad, se diseña como figura especifica el grupo criminal. STS (ROJ: 3131/2014) de 18 de julio de 2014. Ponente. D. Cándido Conde-Pumpido Tourón. STS (ROJ: 1840/2013) de 1 de abril de 2013. Ponente: Miguel Colmenero Menéndez de Luarca. STS (ROJ: 5580/2013) de 11 de diciembre de 2013. Ponente: D. Cándido CondePumpido Tourón, STS (ROJ: 6211/2013) de 5 de diciembre de 2013. Ponente: D. Julián Artemio Sánchez Melgar, STS (ROJ: 220/2014) de 9 de enero de 2014. Ponente: D. Alberto Gumersindo Jorge Barreiro, STS (ROJ: 1622/2014) de 7 de mayo de 2014. Ponente: Miguel Colmenero Menéndez de Luarca.

144 STS (ROJ: 3131/2014) de 18 de julio de 2014. Ponente: D. Cándido Conde-Pumpido Tourón. 
únicamente a una línea político criminal que no tiene correspondencia además, con los instrumentos internacionales suscritos por España ${ }^{145}$.

Queremos puntualizar que también en muchos países de nuestro entorno jurídico las penas por el delito de tráfico de precursores de drogas son bastante elevadas, incluso en algunos es mayor que en España. Por ejemplo en Italia, las penas privativas de libertad pueden alcanzar los 22 años y en Portugal los 12 años. Las penas en América Latina también son bastante altas: Argentina de 4 a 15 años; Bolivia de 5 a 15 años a quienes fabricaran precursores y de 10 a 25 años a quienes traficaran con estos; Brasil de 10 a 15 años; Chile de 3 a 10 años; Colombia de 5 a 15 años; Costa Rica de 8 a 20 años; Ecuador de 8 a 12 años; El Salvador de 5 a 15 años; Guatemala de 12 a 20 años; Honduras de 3 a 6 años; México de 5 a 15 años, Nicaragua de 5 a 10 años; Panamá de 5 a 15 años; Perú de 5 a 10 años; República Dominicana de 2 a 5 años; Uruguay de 20 meses a 10 años y la República Bolivariana de Venezuela de 8 a 25 años. Nos parece importante destacar que en la "Ley de supervisión de precursores" alemana la pena puede llegar hasta 5 años de conformidad al artículo 19.1, resultando llamativo que en su artículo 19.2 establece hasta un año de prisión para la tentativa del tráfico de precursores, además en el artículo 19.4 sanciona hasta con un año de privación de libertad o multa a quien comete los hechos de forma imprudente. Conducta que no se contempla en España, al admitirse únicamente la comisión de tales comportamientos de forma dolosa. Es importante decir que en Austria la pena máxima por el delito de tráfico de precursores de drogas también es de 5 años ${ }^{146}$.

145 MÉNDEZ RODRÍGUEZ, Cristina. "Los delitos de pertenencia a organización criminal y grupo criminal y el delito de tráfico de drogas cometido por persona que pertenece a una organización delictiva. Crónica de un conflicto normativo anunciado y análisis jurisprudencial" en Estudios Penales y Criminológicos, vol. XXXIV (2014). Ed. Universidad de Santiago de Compostela, pp. 535-540, 555, 556, 558, 559.

146 Ley № 23.737 Tenencia y tráfico de estupefacientes de Argentina de 21 de septiembre de 1989; Ley del Régimen de la coca y sustancias controladas, Ley 1008 de Bolivia de 19 de julio de 1988; Ley de Drogas 11.343 de Brasil de 23 de agosto de 2006; Ley 19.366 Sanciona el tráfico ilícito de estupefacientes y sustancias psicotrópicas, y modifica diversas disposiciones legales y deroga la Ley 18.403 de Chile de 4 de enero de 1995; Ley 30 de 1986 por la cual se adopta el Estatuto Nacional de Estupefacientes de Colombia de 31 de enero de 1986; Ley 7786 sobre estupefacientes, sustancias psicotrópicas, drogas de uso no autorizado, legitimación de capitales y actividades 
Es necesario señalar que el inciso número 4 del artículo 570 quáter CP del Código Penal español estipula que los jueces o tribunales, razonándolo en la sentencia, podrán imponer a él o los responsables de cualquiera de los delitos previstos en este capítulo la pena inferior en uno o dos grados, siempre que el sujeto haya abandonado de forma voluntaria sus actividades delictivas y haya colaborado activamente con las autoridades o sus agentes, bien para obtener pruebas decisivas para la identificación o captura de otros responsables o para impedir la actuación o el desarrollo de las organizaciones o grupos a que haya pertenecido, bien para evitar la consumación de un delito que se tratara de cometer en el seno o a través de dichas organizaciones o grupos. Sobre las dificultades que plantea la introducción del Capítulo VI relativo a las organizaciones y grupos criminales, mediante la LO 5/2010, hace un estudio pormenorizado Méndez Rodríguez quien señala, en nuestra opinión de forma muy acertada, que "la falta de técnica legislativa, la pretensión de no dejar ni un solo fenómeno asociativo al margen del Derecho Penal y la voluntad de que la sanción sea la máxima de las posibles, ha conducido a una situación

conexas de 30 de abril de 1998 de Costa Rica, reformada íntegramente por la Ley 8204 de 26 de diciembre de 2001; Ley de sustancias estupefacientes y psicotrópicas, codificación de Ecuador, Registro oficial suplemento 490 de 27 de diciembre de 2004; Ley Reguladora de las actividades relativas a las drogas de El Salvador. Decreto № 153 de 2 de octubre de 2003; Ley contra la Narcoactividad. Decreto número 48-92 de Guatemala de 24 de septiembre de 1992; Ley de uso indebido y tráfico ilícito de drogas y sustancias psicotrópicas de Honduras. Decreto número 126-89 de 5 de septiembre de 1989; Código Penal para el Distrito Federal en materia común y para toda la República en materia de Fuero Federal de México; Ley de Reforma y adiciones a la Ley 177, Ley de estupefacientes psicotrópicos y sustancias controladas. Ley 285 de 6 de abril de 1999 de Nicaragua; Código Penal de Panamá de 22 de septiembre de 1982; Código Penal de Perú. Decreto Legislativo № 635 de 3 de abril de 1991; Ley № 50-88 de República Dominicana de 5 de mayo de 1988; Ley № 17.016 estupefacientes de Uruguay de 7 de octubre de 1998; Ley Orgánica de Drogas G.O. (37510) 05/09/2010 de la República Bolivariana de Venezuela; Decreto- Ley № 15/93 de 22 de enero sobre Situación jurídica del tráfico y consumo de estupefacientes y psicotrópicos de Portugal; Ley para controlar el tráfico de precursores, que pueden ser mal utilizados para la fabricación ilícita de estupefacientes (Ley de Supervisión de Precursores) de Alemania del 11 de marzo del año 2008; Decreto del Presidente de la República de Italia de 9 de octubre de 1990, № 309 de "Las Leyes relativas a la regulación de los estupefacientes y sustancias psicotrópicas, prevención, tratamiento y rehabilitación la drogadicción" (DO n 62 de 15.3.2006-... Supl. Ordinario 62). Ley de Sustancias Estupefacientes (SMG) de Austria de 20 de diciembre de 2008. 
insostenible teóricamente y difícilmente manejable en la práctica por nuestros tribunales" 147 .

El artículo $372 \mathrm{CP}$, contiene una cualificación por razón del sujeto activo del delito, señala que si los hechos previstos en este capítulo fueran realizados por empresario, intermediario en el sector financiero, facultativo, funcionario público, trabajador social, docente o educador, en el ejercicio de su cargo, profesión u oficio, se le impondrá, además de la pena correspondiente, la de inhabilitación especial para empleo o cargo público, profesión u oficio, industria o comercio, de 3 a 10 años. Se sancionara con la pena de inhabilitación absoluta de 10 a 20 años cuando los referidos hechos fueren realizados por autoridad o agente de la misma, en el ejercicio de su cargo ${ }^{148}$. Establece además este artículo quiénes deben ser considerados facultativos: los médicos, psicólogos, las personas en posesión de título sanitario, los veterinarios, los farmacéuticos y sus dependientes. En el caso de los trabajadores sociales, docentes o educadores entendemos que no tienen ninguna relación especial con tráfico de precursores, sino más bien con el tráfico de drogas. Hay que recordar que este precepto reproduce casi literalmente el artículo 344 bis c) del anterior Código Penal, añadiendo como sujetos a los empresarios e intermediarios en el sector financiero y estableciendo un límite temporal en las penas de inhabilitación.

También hay que destacar que en el artículo 376 del Código Penal se establecen dos supuestos atenuados, con una posible rebaja de la pena en uno (de año y medio a tres años de prisión) o dos grados (de 9 a 18 meses de prisión). Siendo estos supuestos los siguientes: 1) cuando el sujeto haya abandonado voluntariamente la actividad delictiva y haya colaborado activamente con las autoridades o sus agentes bien para impedir la producción del delito, bien para obtener pruebas decisivas para la identificación o captura de otros responsables o para impedir la actuación o el desarrollo de las organizaciones o asociaciones a las que

MÉNDEZ RODRÍGUEZ, Cristina. “Los delitos de pertenencia..., op. cit., pp. 513-521.

148 La pena de inhabilitación absoluta que se impone tanto a las autoridades como a sus agentes, encuentra su fundamento en el mayor desvalor de acción presente en el delito de tráfico de drogas cuando es perpetrado por estos sujetos que deben de cumplir una serie de deberes especiales que son negados con la comisión del delito. TERRADILLOS BASOCO, Juan María. Lecciones materiales..., op. cit., pp. 65, 66. ÁLVAREZ GARCÍA, F. Javier. Derecho Penal Español. ..., op. cit., pp. 1357-1359. 
haya pertenecido o con las que haya colaborado. 2) Cuando el reo, siendo drogodependiente en el momento de los hechos, acredite suficientemente que ha finalizado con éxito un tratamiento de deshabituación, siempre que la cantidad de drogas tóxicas, estupefacientes o sustancias psicotrópicas no fuese de notoria importancia o extrema gravedad. En principio no parece existir ningún impedimento para aplicar esta rebaja de pena a un sujeto que trafique con precursores de drogas, sin embargo hay que señalar que los criterios de "notoria importancia" o "extrema gravedad" no se utilizan por nuestros tribunales al enjuiciar el tráfico de estas sustancias catalogadas ${ }^{149}$.

Cabe recordar que siguiendo el criterio marcado por el acuerdo plenario de la Sala Segunda del Tribunal Supremo de 27 de diciembre de 2007 "el Tribunal no puede imponer pena superior a la más grave de las pedidas por las acusaciones, siempre que la pena solicitada se corresponda con las previsiones legales al respecto, de modo que cuando la pena se omite o no alcanza el mínimo previsto en la ley, la sentencia debe imponer, en todo caso, la pena mínima establecida para el delito objeto de condena". La STS de 11 de febrero de $2008^{150}$ estableció la necesidad de imponer, en todo caso, la pena mínima establecida para el delito objeto de condena en el supuesto de imposición de pena de multa no solicitada oportunamente por la acusación pública.

En relación a la cuantificación de la pena de multa, es necesario valorar el precio de las sustancias dentro de un mercado ilícito, la STS de 17 de diciembre de $2008^{151}$ admite la posible fijación por remisión a la publicación oficial de la página web del Observatorio Español sobre Drogas y las Adicciones (http://www.pnsd.msssi.gob.es), actualizada semestralmente, cuyos parámetros son remitidos con esta misma periodicidad a los órganos judiciales. Además resulta obligatorio que

149 SAP de Guadalajara (ROJ: 234/2010) de 23 de junio de 2010. Ponente: D. Manuel Eduardo Regalado Valdés.

150 STS (ROJ: 1186/2008) de 11 de febrero de 2008. Ponente: D. Julián Artemio Sánchez Melgar.

151 El Tribunal Supremo modifica el monto de la multa establecida por el Tribunal de Instancia. STS (ROJ: 3303/2003) de 16 de mayo de 2003. Ponente: D. José Aparicio Calvo-Rubio. STS (ROJ: 7312/2008) de 17 de diciembre de 2008. Ponente: D. Manuel Marchena Gómez. 
en los hechos probados se determine el valor de la droga, o en el caso que nos ocupa de sus precursores, no siendo aceptable diferir la delimitación de su cuantía a la fase de ejecución de la sentencia ${ }^{152}$.

En nuestra opinión sería muy conveniente reformar las penas establecidas en el artículo $371 \mathrm{CP}$, en atención a la menor gravedad objetiva de las conductas. En este sentido creemos que sería razonable que las penas para el tráfico de precursores continúen, al menos, siendo una pena intermedia entre la establecida para el tráfico de drogas blandas y drogas duras, de tal manera que la penalidad para este tipo de conductas sea de dos a cinco años de prisión y no de tres a seis años que es la misma pena establecida para el tráfico de drogas duras, lo cual sin lugar a dudas es un despropósito jurídico. Siguiendo con esta lógica debería imponerse la pena en su mitad superior (de tres años y seis meses a cinco años) cuando los procesados pertenezcan a una organización dedicada al tráfico de precursores, y la pena superior en grado (de cinco a siete años y seis meses) cuando se trate de los jefes, administradores o encargados de las referidas organizaciones. Propuesta que cumpliría con lo dispuesto en la Decisión Marco 2004/757/JAI del Consejo, de 24 de octubre que señala de forma expresa la necesidad de que los Estados miembros sancionen con penas máximas de cinco a diez años los delitos de tráfico de precursores de drogas cuando se cometan en el seno de una organización criminal, lo cual implicaría reformar en este sentido la redacción del artículo 570 bis y la supresión del artículo 570 ter, del que ya un sector de la doctrina ha recomendado suprimirlo por todas las dificultades que presenta tanto en el plano teórico como en su aplicación práctica en los tribunales ${ }^{153}$. Como asumimos que esta reforma legislativa es bastante difícil que se produzca pensamos, por la actual tendencia legislativa, que por lo menos debería de contemplarse para el tráfico de precursores, al igual que se hace en el párrafo segundo del artículo 368, la posibilidad de que los tribunales puedan imponer "la pena inferior en grado a las señaladas en atención a la escasa entidad y a las circunstancias personales del culpable". Creemos de la Torre. 
que para la aplicación de esta reducción se podría tomar como referencia los criterios establecidos para determinar las cantidades de "notoria importancia", "extrema gravedad" o un criterio intermedio de dichas cantidades que se utilizan en el delito de tráfico de drogas, en aras de establecer un umbral en las diferentes sustancias catalogadas en concordancia de su capacidad para la elaboración de dosis de drogas ilegales, debiendo tenerse en cuenta que para la fabricación de cualquier droga se pueden utilizar varios precursores ${ }^{154}$. Entendemos que la racionalidad de tal planteamiento obedece a que si es conveniente aplicar esta reducción de pena para el delito de tráfico de droga, mucho más lo es para el tráfico de precursores de drogas en

154 A continuación detallamos la cantidad de precursores de drogas tóxicas, estupefacientes y psicotrópicos que normalmente se utilizan para la elaboración de las dosis callejeras de las principales drogas ilícitas: Anfetamina: La dosis callejera es de $10 \mathrm{mg}$ a $250 \mathrm{mg}$ : con 1 kilogramo de ácido fenilacético se pueden fabricar de $1.000 \mathrm{a}$ 25.000 dosis, con un litro de 1-fenil-2-propanona se pueden fabricar de 2.000 a 50.000 dosis, con un kilogramo de norefedrina se pueden elaborar de 2.500 a 70.000 dosis. Cocaína: la dosis callejera es de $100 \mathrm{mg}$ a $200 \mathrm{mg}$ : con un kilogramo de permanganato de potasio se pueden fabricar de 25.000 a 50.000 dosis, con un litro de acetona, éter etílico, metiletilcetona o tolueno se pueden elaborar de 250 a 500 dosis. Heroína: la dosis callejera es de $100 \mathrm{mg}$ a $500 \mathrm{mg}$ : con un litro de anhídrido acético se pueden fabricar de 800 a 4.000 dosis, con un litro de acetona, éter etílico, metiletilcetona o tolueno se pueden elaborar de 100 a 500 dosis. LSD: la dosis callejera es de $50 \mathrm{mg}$ a 80 mg: con un kilogramo de ergometrina o ergotamina se pueden fabricar 25.000 .000 a 40.000.000 dosis, con un kilogramo de ácido lisérgico se pueden elaborar de 85.000.000 a 13.000 .000 dosis. Metanfetamina: la dosis callejera es de $30 \mathrm{mg}$ a $250 \mathrm{mg}$ : con un kilogramo de efedrina o seudoefedrina se pueden fabricar 2.500 a 21.000 dosis. Metacualona: la dosis callejera es de $250 \mathrm{mg}$ : con un kilogramo de ácido antranílico se pueden elaborar 4.000 dosis, con un kilogramo de ácido $\mathrm{N}$ - acetilantranílico se pueden elaborar 3.200 dosis. MDA y sustancias análogas: la dosis callejera es de $100 \mathrm{mg}$ : con un kilogramo de safrol se pueden fabricar 1.000 dosis, con un kilogramo de isosafrol se pueden elaborar 2.000 dosis, con un kilo de piperonal se pueden fabricar 2.000 dosis y con un litro de 3,4-metiledioxifenil-2-propanona se pueden elaborar 4.000 dosis. Es preciso aclarar que para el MDMA o MDEA se pueden fabricar el doble de dosis que con las cantidades de los precursores anteriormente citados. Fenciclidina: la dosis callejera es de $1 \mathrm{mg}$ a $10 \mathrm{mg}$ : con un kilogramo de piperidina se pueden elaborar de $100.000 \mathrm{a}$ 1.000 .000 de dosis. Precursores y productos químicos frecuentemente utilizados para la fabricación ilícita de estupefacientes y sustancias sicotrópicas. Informe de la Junta Internacional de Fiscalización de estupefacientes correspondiente a 2000 sobre la aplicación del artículo 12 de la Convención de Naciones Unidas contra el Tráfico Ilícito de Estupefacientes y Sustancias Sicotrópicas de 1988. JUNTA INTERNACIONAL DE FISCALIZACIÓN DE ESTUPEFACIENTES. Ed. United Nations Publication. New York. 2001, p. 77. 
atención al importante adelantamiento de la esfera de tutela que se produce en este tipo penal.

Como ya señalamos antes en el caso de que se produzca un concurso entre el delito de tráfico de drogas y tráfico de precursores de drogas debemos de remitirnos al concurso de normas, dado que en ambos delitos se protege el mismo bien jurídico "la salud pública", el cual está regulado en el artículo 8 del Código Penal, más específicamente en su tercer apartado que desarrolla el principio de consunción o absorción; que establece que el precepto penal más amplio o complejo, en este caso el artículo 368, absorberá a los que castiguen las infracciones consumidas en aquel (artículo 371). Así lo afirma Rey Huidobro: "si el tráfico de precursores está organizado por el traficante del estupefaciente, es patente la consunción por el artículo 368", por lo que únicamente se castigara por el tipo básico, o agravado en su caso, del delito de tráfico de drogas al estar ante una conducta de elaboración, no procediendo de ninguna manera sancionar por la elaboración de dichas sustancias y separadamente por el tráfico de precursores, pues de hacerlo se estaría incurriendo en la vulneración del principio non bis in ídem. Por lo tanto la existencia de sustancias químicas catalogadas además de la droga, incluso en pequeñas cantidades, es un elemento indiciario de pre ordenación al tráfico. En la práctica esto ocurre con bastante frecuencia, y la jurisprudencia de forma unánime siempre sanciona por el delito de tráfico de drogas. Hay que recordar, una vez más, que antes la pena por el tráfico de drogas que causan grave daño a la salud era mayor que la del tráfico de sus precursores, sin embargo posterior a la reforma operada por la Ley Orgánica 5/2010 la pena tanto para el delito de tráfico de drogas duras como para el delito de tráfico de precursores es la misma: de tres a seis años de prisión y multa del tanto al triplo del valor de la droga o bien de los géneros o efectos, pudiendo incluso ocurrir que la pena para el tráfico de las drogas antes señaladas sea menor por cuanto se contempla la posibilidad de imponer la pena inferior en grado (de un año y seis meses a tres años) en atención a la escasa entidad del hecho y las circunstancias personales del culpable, lo cual no se contempla para el tráfico de precursores. En los supuestos de tráfico de drogas blandas en el que se encuentren precursores, no de drogas blandas pues ya hemos dicho anteriormente que no se encuentran en los Cuadros I y II del Convenio de Viena, nos encontramos que la pena del artículo 368 es inferior a la del artículo 371, al castigarse éste con privación de libertad de uno a tres años y multa del tanto al duplo del valor de la 
droga, por lo que la aplicación del concurso de normas antes señalado conduce paradójicamente a castigar más levemente la conducta más grave que absorbe los actos preparatorios (pero del tráfico de drogas duras). Lo cual, sin lugar a dudas, es atribuible a la falta de tino que ha mostrado el legislador en las últimas reformas al Código Penal ${ }^{155}$.

Como señalamos anteriormente siempre que las autoridades ocupen a cualquier sujeto precursores de drogas y drogas aunque sea en cantidades muy pequeñas o incluso residuos, se sanciona aplicando el concurso de normas por infracción del artículo 368. Es preciso decir que antes de la incorporación en la legislación española del delito de tráfico de precursores de drogas en el Código Penal, artículos 344 bis g) y 344 j), a partir de la Ley Orgánica 8/1992 de 23 de diciembre, se sancionaba, en algunos casos, por el delito de tráfico de drogas la

155 REY HUIDOBRO, Luis Fernando. El Delito de Tráfico de Drogas. ..., op. cit., p. 276. SEQUEROS SAZATORNIL, Fernando. El tráfico de drogas..., op. cit., pp. 292, 293. CORCOY BIDÁSOLO, Mirentxu. Comentarios al Código Penal. ...., op. cit., pp. 43, 44, 217. CÓRDOBA RODA, Juan, GARCÍA ARÁN, Mercedes (Dir.). Comentarios al Código Penal. Parte General. Ed. Marcial Pons. Madrid. 2011, pp. 59-64. QUINTERO OLIVARES, Gonzalo. Comentarios al Código Penal..., op. cit., pp. 91-105. CONDE PUMPIDOFERREIRO, Cándido (Dir.). Código Penal Comentado. 3a Edición. Con concordancias y jurisprudencia. Actualizado a la LO 5/2010 de 23 de junio de 2010. Tomo I. 3a edición. Bosch S.A. Barcelona. 2012, pp. 30-32. CUELLO CONTRERAS, Joaquin, MAPELLI CAFFARENA, Borja. Curso de Derecho Penal. Parte General. Ed. Tecnos. Madrid. 2011, pp. 228-233. A dos sujetos que se les ocuparon en su vehículo y en un inmueble: una bolsa pequeña que contenía una piedra de cocaína que pesaba 61.40 gramos , un bolsa pequeña con 0.19 gramos de cocaína, una bolsa pequeña con 1.76 gramos de cocaína, una bolsa pequeña con 7.76 gramos de hachís, un frasco con 88 milímetros de ácido sulfúrico, un frasco que contenía 1 litro de ácido clorhídrico, una garrafa vacía de metiletilcetona, una bolsa de plástico que contenía 249.8 gramos de permanganato de potasio, así como otras sustancias no catalogadas y materiales y equipos que usaban para la elaboración de cocaína. Se les condena (a ambos) por un delito contra la salud pública por tráfico de drogas que causan grave daño a la salud a la pena de 3 años de prisión y multa de 2.704 euros con 55 céntimos. STS (ROJ: 3303/2003) de 16 de mayo de 2003. Ponente: D. José Aparicio Calvo Rubio. En el mismo sentido: STS (ROJ: 2847/1996) de 13 de mayo de 1996. Ponente: D. José Augusto de Vega Ruiz. STS (ROJ: 7815/2007) de 15 de noviembre de 2007. Ponente: D. Julián Artemio Sánchez Melgar. STS (ROJ: 3732/2002) de 25 de mayo de 2002. Ponente: D. Gregorio García Ancos. STS (ROJ: 7714/2001) de 9 de octubre de 2001. Ponente: José Ramón Soriano Soriano. STS (ROJ: 2497/2001) de 26 de marzo de 2001. Ponente: D. José Jiménez Villarejo. STS (ROJ: 5856/2011) de 27 de septiembre de 2011. Ponente: D. Juan Ramón Berdugo Gómez de la Torre. SAP de Madrid (ROJ: 7718/2010) de 25 de mayo de 2010. D. Ponente: Dña. Adoración María Riera Ocariz. 
tenencia de precursores sin que se encontraran ni siquiera residuos de alguna droga ilícita, ni materia prima básica para su fabricación, tal es el caso de la Sentencia del Tribunal Supremo del día 13 de mayo de 1996 que condena como autor de un delito de elaboración de drogas, de las que causan grave daño a la salud, a la pena de 2 años, 4 meses y 1 día de prisión menor, y al pago de la parte proporcional de las costas que le correspondan a un sujeto que en el mes de noviembre del año 1989 le ocuparon en un registro en su vivienda en Villagarcía de Arosa "tres hojas tamaño folio escritas a mano, en las que se describían procedimientos relativos a la transformación de diversos productos en cocaína, mediante el uso de sustancias químicas. Encontrando después en un alpendre, una botella de ácido clorhídrico, otra de ácido sulfúrico, otra de éter etílico, un frasco de permanganato potásico (precursores de drogas), un frasco de agua fuerte y otra de amoniaco (sustancias no catalogadas). Sustancias, respecto a las cuales, el Instituto Nacional de Toxicología, al serles remitidos con los citados folios, informo que son los indicados para la producción ilícita de cocaína". Cabe aclarar que no se hace mención alguna en la sentencia a la ocupación de materia prima (hojas de coca, pasta de cocaína o cocaína base), así como de materiales o equipos para su procesamiento ${ }^{156}$. Nosotros estamos convencidos, sin lugar a dudas, que si estos hechos se hubieran producido después del mes de diciembre del año 1992, se hubieran sancionado como un delito de tráfico de precursores de drogas regulado en los artículos 344 bis g) y 344 bis j).

\section{B.) DETERMinACIÓN DE LA CUANTÍA DE LA PENA DE MULTA}

El artículo 377 señala que para la determinación de la cuantía de las multas que se impongan en aplicación de los artículos 368 a 372, el valor de la droga objeto del delito o de los géneros o efectos intervenidos será el precio final del producto o, en su caso, la recompensa o ganancia obtenida por el reo, o que hubiera podido obtener. En la jurisprudencia del Tribunal Supremo el precio final es el criterio precedente (STS del 6 de octubre del año 2006) ${ }^{157}$. Cuando se desconoce el valor, se aplica el valor de la ganancia obtenida (STS del 4

\footnotetext{
156 STS (ROJ: 2847/1996) de 13 de mayo de 1996. Ponente: D. José Augusto de Vega Ruiz. 
de marzo del año 2009) ${ }^{158}$. Para tal efecto se debe de diferenciar dos situaciones previstas por el legislador: 1) que el sujeto condenado por el delito de tráfico de precursores de drogas, es el propietario de estas sustancias y 2) que el condenado por el mismo delito, se dedique al tráfico de estas sustancias por encargo de un tercero que es el dueño de los precursores de drogas. En este caso resultaría desproporcionado imponerle al reo la multa en relación al precio de mercado de las sustancias catalogadas con que trafica159. Hay que señalar que el principio de culpabilidad obliga a que el valor de la recompensa o ganancia que se hubiera podido obtener se acredite de forma correcta por la acusación, pudiendo objetivarse por la valoración pericial. Un sector de la doctrina cuestiona que la multa se pueda establecer a partir de parámetros que se escapan del dominio del autor en el momento de realización de la conducta delictiva ${ }^{160}$. En este sentido se pronuncia Fernández Palma, quien afirma que estos criterios suscitan bastantes interrogantes en relación a su legitimación en el ámbito penal, si se piensa en la ruptura de principios básicos cuya repercusión excede las fronteras de la disciplina para afectar directamente la estructura de su fundamento constitucional. En efecto, la valoración del precio de salida en función de parámetros que escapan al dominio del autor en el momento de la realización de la conducta para instalarse en futuribles que pertenecen a la esfera de control de terceros ajenos al hecho del autor, implica una quiebra del principio de culpabilidad por el hecho propio de difícil justificación incluso en sectores delincuenciales como éste en los que el nivel de beneficio escapa de toda lógica previsible. A ello se añade la incoherencia sistemática evidenciada con el comiso de los bienes, efectos y ganancias del delito. Dicho decomiso priva al autor del monto patrimonial relacionado de cualquier modo con el delito y, sin embargo, la pena proporcional de multa partirá del valor real del mercado de los efectos, y lo que es más importante, de los objetos materiales del delito. Lo que inhibe, desde luego, la cláusula de proporcionalidad contenida en el artículo 52 del $\mathrm{CP}$, pues por más que se quiera limitar el grado de su imposición en función de la capacidad económica del sujeto su cuantía inicial 
desborda del mentado principio de culpabilidad cualquier lógica de proporcionalidad. Lo cual tal vez podría evitarse recurriendo a la aplicación excepcional de los baremos relativos al precio final del producto y a la previsión de futurible ganancias, en favor de la más sensata referencia a la recompensa o ganancia efectivamente obtenida, criterio que está contenido en el precepto, que pese al tono imperativo mantiene potestades de discrecionalidad judicial sobre la preferencia por uno u otro factor de valoración ${ }^{161}$.

En relación a la cuantificación de la pena de multa es necesario valorar el precio de las sustancias dentro de un mercado ilícito, la STS de 17 de diciembre de $2008^{162}$ admite la posible fijación por remisión a la publicación oficial de la página web del Observatorio Español sobre Drogas (http://www.pnsd.msc.es/home.htm), página que se actualiza semestralmente, cuyos parámetros son remitidos con esta misma periodicidad a los órganos judiciales. Además resulta obligatorio que en los hechos probados se determine el valor de la droga, o en el caso que nos ocupa de sus precursores, no siendo aceptable diferir la delimitación de su cuantía a la fase de ejecución de la sentencia163. En la sentencia de la Audiencia Provincial de Madrid de 10 de febrero 2003 condenan al acusado por el delito de tráfico de drogas a la pena

161 Fernández de Palma a manera de ejemplo señala que si el valor de las drogas incautadas hubiera podido alcanzar los diez millones de euros una vez adulteradas y distribuidas. A pesar de que el comiso privará al sujeto de las drogas, instrumentos, ganancias, etc., del delito, la cifra inicial de la que deberá partir la multa proporcional se sitúa, precisamente en la cifra anteriormente aludida, lo que inhibe desde luego la cláusula de proporcionalidad contenida en el artículo 52 CP. QUINTERO OLIVARES, Gonzalo. Comentarios a la Parte Especial..., op. cit., pp. 1549, 1550. STS (Roj: 522/2001) de 30 de enero de 2001. Ponente: Joaquín Giménez García. Son dos las situaciones previstas por el legislador, la primera es que el condenado por el delito sea el propietario de las drogas o precursores de estas, y segundo que el condenado por este tipo de delitos se dedique al tráfico por encargo de un tercero. En este caso sería desproporcionado imponerle la multa en relación al precio del mercado de las sustancias con las que trafica. ARROYO ZAPATERO, Luis. Comentarios al Código Penal. ..., op. cit., pp. 830, 831. CÓRDOBA RODA, Juan. Comentarios al Código Penal p. 1684.

162 STS (ROJ: 7312/2008) de 17 de diciembre de 2008. Ponente: D. Manuel Marchena Gómez.

163 STS (ROJ: 3318/2009) de 1 de junio de 2009. Ponente: D. Juan Ramón Berdugo Gómez de la Torre. SAP de Guadalajara (ROJ: 234/2010) de 23 de junio de 2010. Ponente: D. Manuel Eduardo Regalado Valdés. 
de un euro de multa, aunque le ocuparon en su domicilio 6 frascos de ácido clorhídrico con un peso de 10.602 gramos, 2 bidones de acetona y tolueno con un peso de 15.799 gramos, así como otro bidón de acetona con un peso de 7.055 gramos y un cubo infantil con restos de cocaína con procaína, porque seguramente no se estableció en el proceso el precio de estas sustancias catalogadas ${ }^{164}$.

En todo caso, la jurisprudencia lamenta que en multitud de ocasiones las multas millonarias impuestas se conviertan en la práctica en declaraciones vacías de contenido ante la inexistencia de responsabilidad subsidiaria en penados de más de cinco años de prisión, lo que usualmente superará ese límite, y cuando esto no ocurre hay que recordar que se debe atender al límite de un año de duración máxima de dicha responsabilidad personal subsidiaria, por lo que se interpreta que se debe potenciar la discrecionalidad judicial prevista en dicho artículo, que también prevé un criterio más personalizado, consistente en la ganancia que en concreto pudiera haber obtenido el reo. En su imposición han de tenerse en cuenta las especificas reglas de determinación de la pena, no sujetas sólo a la gravedad del hecho y a la personalidad del delincuente, sino también a los beneficios obtenidos o que se pensaban obtener, así como a las condiciones establecidas en el artículo 52 del código Penal ${ }^{165}$.

164 SAP de Madrid (ROJ: 1659/2003) de 10 de febrero de 2003. Ponente: D. Adrián Varillas Gómez.

165 1) No obstante lo dispuesto en los artículos anteriores y cuando el Código así lo determine, la multa se establecerá en proporción al daño causado, el valor del objeto del delito o el beneficio reportado por el mismo. 2) En estos casos, los jueces y tribunales impondrán la multa dentro de los límites fijados para cada delito, considerando para determinar en cada caso su cuantía, no sólo las circunstancias atenuantes y agravantes del hecho, sino principalmente la situación económica del culpable. 3) Si, después de la sentencia, empeorase la situación económica del penado, el juez o tribunal, excepcionalmente y tras la debida indagación de dicha situación, podrá reducir el importe de la multa dentro de los límites señalados por la ley para el delito de que se trate, o autorizar su pago en los plazos que se determinen. 4) En los casos en los que este Código prevé una pena de multa para las personas jurídicas en proporción al beneficio obtenido o facilitado, al perjuicio causado, al valor del objeto, o a la cantidad defraudada o indebidamente obtenida, de no ser posible el cálculo en base a tales conceptos, el Juez o Tribunal motivará la imposibilidad de proceder a tal cálculo y las multas previstas se sustituirán por las siguientes: a) Multa de dos a cinco años, si el delito cometido por la persona física tiene prevista una pena de prisión de 


\section{C.) El DECOMISO}

El nuevo artículo 374 establece que en los delitos previstos en los artículos 301.1, párrafo segundo y 368 a 372, además de las penas que corresponda por el delito cometido, serán objeto de decomiso las drogas tóxicas estupefacientes o sustancias psicotrópicas, los equipos materiales y sustancias a que se refiere el artículo 371, así como los bienes, medios, instrumentos y ganancias con sujeción a lo dispuesto en los artículos 127 a 128 del Código Penal ${ }^{166}$ y a las siguientes normas especiales:

1. ${ }^{\mathrm{o}}$ Las drogas, estupefacientes y sustancias psicotrópicas serán destruidas por la autoridad administrativa bajo cuya custodia se encuentre, una vez realizados los informes analíticos pertinentes y guardadas muestras suficientes de las mismas, salvo que la autoridad judicial competente haya ordenado su conservación integra. Una vez que la sentencia sea firme, se procederá a la

más de cinco años. b) Multa de uno a tres años, si el delito cometido por la persona física tiene prevista una pena de prisión de más de dos años no incluida en el inciso anterior. c) Multa de seis meses a dos años, en el resto de los casos. Número 4 del artículo 52 introducido por el apartado decimotercero del artículo único de la L.O. 5/2010, de 22 de junio, por la que se modifica la L.0. 10/1995, de 23 de noviembre, del Código Penal (B.O.E. 23 junio).Vigencia: 23 diciembre 2010. Artículo 52 redactado por el apartado decimocuarto del artículo único de la L.O. 15/2003, de 25 de noviembre, por la que se modifica la L.0. 10/1995, de 23 de noviembre, del Código Penal (B.O.E. 26 noviembre). Vigencia: 1 octubre 2004.

166 Como se puede observar, el artículo $374 \mathrm{CP}$ se remite expresamente al artículo 127 (incluyendo los artículos: 127 bis, 127 ter, 127 quater, 127 quinquies, 127 sexies, 127 septies y 127 octies) y al artículo 128 CP. A diferencia de la situación actual, la redacción del artículo 374 anterior a la L.0. 1/2015 no se refería al artículo 128. Con todo, autores como Manjón-Cabeza Olmedo sostenían que ello no debía impedir su aplicación, toda vez que este precepto contiene la regla de proporcionalidad que permite no decretar el decomiso o decretarlo parcialmente cuando los efectos o instrumentos sean de lícito comercio su valor no guarde relación con la gravedad o naturaleza del delito o cuando las responsabilidades civiles ya estén satisfechas. Señala esta autora que la doctrina y jurisprudencia mayoritaria consideran que la regla de proporcionalidad es aplicable a los casos del artículo 374 CP. ÁLVAREZ GARCÍA, F. Javier. Derecho Penal Español. ..., op. cit., pp. 1360, 1361. “El Comiso, aunque no incluido en el catálogo de las penas contenidas en el artículo 33 del Código Penal, constituye una sanción sometida a los principios de culpabilidad, proporcionalidad, pertinencia y legalidad". STS (ROJ: 6008/2002) de 20 de septiembre de 2002. Ponente: Enrique Abad Fernández. 
destrucción de las muestras que se hubieran apartado, o a la destrucción de la totalidad de lo incautado, en el caso de que el órgano judicial competente hubiera ordenado su conservación.

2. - A fin de garantizar la efectividad del decomiso, los bienes, medios, instrumentos y ganancias podrán ser aprehendidos o embragados y puestos en depósito por la autoridad judicial desde el momento de las primeras diligencias.

3. - La autoridad judicial podrá acordar que, con las debidas garantías para su conservación y mientras se sustancia el procedimiento, el objeto del decomiso, si fuere de lícito comercio, pueda ser utilizado provisionalmente por la Policía Judicial encargada de la represión del tráfico de drogas.

4. $-\mathrm{Si}$, por cualquier circunstancia, no fuera posible el decomiso de los bienes y efectos señalados en el párrafo anterior, podrá acordarse el de otros por un valor equivalente.

5. - Cuando los bienes, medios, instrumentos y ganancias del delito hayan desaparecido del patrimonio de los presuntos responsables, podrá acordarse el decomiso de su valor sobre otros bienes distintos incluso de origen lícito, que pertenezcan a los responsables.

Los bienes decomisados podrán ser enajenados, sin esperar el pronunciamiento de firmeza de la sentencia en los siguientes casos:

1. ${ }^{-}$Cuando el propietario haga expreso abandono de ellos.

2. ${ }^{-}$Cuando su conservación pueda resultar peligrosa para la salud o seguridad pública, o dar lugar a una disminución importante de su valor, o afecte gravemente a su uso y funcionamiento habitual. Se entenderán incluidos los que, sin sufrir deterioro material, se deprecien por el transcurso del tiempo. Lo cual puede ocurrir con algunos precursores de drogas cuya conservación puede resultar peligrosa. A modo de ejemplo, valga citar la acetona o el éter etílico, que son altamente inflamables; el ácido clorhídrico o el ácido sulfúrico, que son sustancias muy corrosivas; o bien el ácido lisérgico, el permanganato de potasio o el tolueno, que son sustancias muy tóxicas.

En opinión de Muñoz Conde, lo más importante de este artículo es que, de conformidad con el artículo $127 \mathrm{CP}$, se permite el decomiso de las 
ganancias obtenidas de los delitos relativos al tráfico de drogas y de sus precursores independientemente de las transformaciones que haya podido experimentar. La finalidad no es otra que acabar con el blanqueo de las ganancias obtenidas con estos delitos, que normalmente se invierten en negocios legales. Sin embargo, la transformación jurídica de la titularidad y el respeto a los derechos de terceros no responsables del delito, así como las dificultades para probar que determinados bienes o negocios proceden de estas ganancias, dificultarán en gran medida la aplicación de este precepto. Es necesario destacar que el pleno de la Sala de lo Penal del Tribunal Supremo acordó, en sesión del día 5 de octubre de 1998, que también cabe el comiso de las ganancias procedentes de operaciones anteriores a la concreta operación descubierta y enjuiciada, siempre que se tenga probada dicha procedencia y se respete en todo caso el principio acusatorio. Este criterio ha sido seguido por las SSTS de 1 de abril de 1999167, de 2 de junio del 2008, de 20 de septiembre del año 2005, de 16 de enero de 2003, de 20 de febrero del año 2001 y de 15 de julio de $2003^{168}$.

MUÑOZ CONDE, Francisco. Derecho Penal. P.E..., op. cit., pp. 688-690. CORCOY BIDÁSOLO, Mirentxu. Comentarios al Código Penal...., op. cit., pp. 820, 821. QUINTERO OLIVARES, Gonzalo. Comentarios a la Parte Especial..., op. cit., pp. 1530- 1532. STS (ROJ: 2290/1999) de 1 de abril de 1999. Ponente: D. Joaquín Martín Canivell.

168 STS (ROJ: 2970/2008) de 2 de junio de 2008. Ponente: D. Francisco Monterde Ferrer, STS (ROJ: 5385/2005) de 20 de septiembre de 2005. Ponente: D. Julián Artemio Sánchez Melgar, STS (ROJ: 102/2003) de 16 de enero de 2003. Ponente: D. Andrés Martínez Arrieta, STS (ROJ: 1209/2001) de 20 de febrero de 2001. Ponente: D. Adolfo Prego de Oliver Tolivar y STS (ROJ: 5022/2003) de 15 de julio de 2003. Ponente: D. Juan Saavedra Ruiz. Ver también sobre el comiso de estos bienes: STS (ROJ: 7190/2009) de 29 de octubre de 2009. Ponente: D. Enrique Bacigalupo Zapater, STS (ROJ: 6914/2007) de 31 de octubre de 2007. Ponente: D. Juan Ramón Berdugo Gómez de la Torre, STS (ROJ: 3391/2007) de 25 de abril de 2007. Ponente: D. Juan Ramón Berdugo Gómez de la Torre, STS (ROJ: 793/2007) de 7 de febrero de 2007. Ponente: D. Juan Ramón Berdugo Gómez de la Torre, STS (ROJ: 2650/2006) de 2 de mayo de 2006. Ponente: D. Juan Ramón Berdugo Gómez de la Torre, STS (ROJ: 8785/2006) de 10 de febrero de 2006. Ponente: D. Juan Ramón Berdugo Gómez de la Torre, STS (ROJ: 14/2005) de 10 de enero de 2005. Ponente: D. Juan Ramón Berdugo Gómez de la Torre. 
D.) PRELaCión EN Pago

Finalmente, el artículo $378 \mathrm{CP}$ establece que los pagos que se efectúen por el penado por uno o varios delitos a que se refieren los artículos 368 al 372 CP se imputaran por el orden siguiente:

1. - A la reparación del daño causado e indemnización de perjuicios.

2.․ A la indemnización al Estado por el importe de los gastos que se hayan hecho por su cuenta en la causa.

3. $\quad$ A la multa.

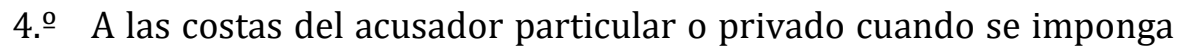
en la sentencia su pago.

5. - A las demás costas procesales, incluso las de la defensa del procesado, sin preferencia entre interesados.

\section{OTRAS DISPOSICIONES DEL CÓDIGO PENAL RELACIONADAS CON EL TRÁFICO DE PRECURSORES}

\section{A.) LA PROVOCACIÓN, LA CONSPIRACIÓN Y LA PROPOSICIÓN}

Un elemento muy controvertido, que ya se ha tratado en este capítulo, es que el artículo $373 \mathrm{CP}$ sanciona la provocación, la conspiración y la proposición para cometer el delito de tráfico de precursores de drogas, que se castiga con la pena inferior en un grado (de un año y seis meses a tres años) o la pena inferior en dos grados (de nueve meses a un año y seis meses), a la pena prevista para el tráfico de sustancias catalogadas. La sanción de este tipo de comportamiento es a todas luces un adelantamiento totalmente desmesurado de la barrera de protección penal, pues sanciona los actos preparatorios de los actos preparatorios (tráfico de precursores) de un delito de peligro abstracto (tráfico de drogas), razón por lo cual en este trabajo no podemos hacer otra cosa que recomendar su supresión del ordenamiento penal, entendiendo sin embargo que esto es muy difícil que se produzca por que la tendencia legislativa actualmente va en sentido opuesto. No obstante queremos señalar que afortunadamente no tenemos conocimiento de la existencia de ninguna sentencia en el Tribunal Supremo, la Audiencia Nacional o las Audiencias Provinciales por conspiración, provocación o proposi- 
ción de tráfico de precursores de drogas ${ }^{169}$. De acuerdo a la propuesta que hicimos antes, para las conductas tipificadas en el artículo $371 \mathrm{CP}$, la pena establecida para la provocación, la conspiración y la proposición para cometer el delito de tráfico de precursores de drogas sería de un año a dos años (pena inferior en un grado) y de seis meses a un año (pena inferior en dos grados).

Creemos necesario recordar que antes de la aprobación del delito de tráfico de precursores de drogas en el ordenamiento penal español, conductas que se podían sancionar por este delito, se castigaban algunas veces como un delito de tráfico de drogas en grado de conspiración. Así lo ratificó el Tribunal Supremo en su sentencia de 30 de junio de 1995 en el caso de cinco personas que en el mes de noviembre de 1990 en Murcia tomaron la decisión de fabricar y comercializar algunos de los derivados de la cocaína como el "basuco" e inclusive clorhidrato de cocaína a partir de pasta base de esta sustancia. Para lo cual se dieron a la tarea de adquirir pequeñas cantidades de algunos precursores en la zona, siendo estos ácido sulfúrico, acetona y ácido clorhídrico y de otras sustancias no catalogadas como el etanol, así como de dos ollas expréss, teniendo además un manuscrito donde aparecían un listado de sustancias y equipos necesarios que podrían servir para elaborar la droga. Los precursores y las sustancias no catalogadas fueron adquiridos por uno de los integrantes del grupo que trabajaba dándole mantenimiento a piscinas por lo que tenía facilidad de comprar dichas sustancias. El laboratorio clandestino, rudimentario, lo pensaban montar en un remolque en las afueras de la ciudad, ahí estaban reunidos sin empezar

169 "Ha de quedar excluida la calificación jurídica de conspiración que postula la defensa, dado que la anticipación de la calificación delictiva que se prevé en el artículo 371 del Código Penal dificulta sobremanera la posibilidad de aplicación de los actos meramente preparatorios, al sancionar el propio precepto la mera tenencia de precursores sin necesidad de que se lleguen siquiera a distribuir, y mucho menos todavía se exige la elaboración de la sustancia estupefaciente. Ambos aspectos objetivos no son exigidos por el tipo penal, circunstancia que imposibilita que prospere la tesis que postula la defensa visto el margen estrechísimo que deja abierto el legislador para que opere la tipificación de la cooperación delictiva. STS (Roj: 232/2013) de 18 de enero de 2013. Ponente: Alberto Gumersindo Jorge Barreiro. CORCOY BIDÁSOlo, Mirentxu. Comentarios al Código Penal...., op. cit.,. pp. 818, 819. QUINTERO OLIVARES, Gonzalo. Comentarios a la Parte Especial..., op. cit., pp. 1527, 1528. DIEZ RIPOLLES, José Luis. “Tendencias político-criminales..., op. cit., p. 40. 
a fabricar "basuco" o cocaína y sin tener la necesaria pasta base (materia prima), cuando fueron detenidos por dos oficiales de la Guardia Civil que tenían montado a 500 metros del lugar un puesto de vigilancia para la persecución de la caza furtiva. Los cinco acusados fueron condenados por el Tribunal de Instancia como autores responsables de un delito contra la salud pública del artículo 344 del Código Penal, en grado de conspiración, sin la concurrencia de circunstancias modificativas de la responsabilidad criminal a la pena de cuatro meses y un día de arresto mayor y accesorias de suspensión de todo cargo público y derecho de sufragio durante el tiempo de sus condenas y con multa de 500.000 pesetas $(3.005,06$ euros) a cada uno de los procesados. Sentencia que fue ratificada por el Tribunal Supremo señalando que el Tribunal sentenciador contó para formar su convicción con tres informes sobre el destino y la susceptibilidad de lo encontrado para elaborar cocaína, el último de los cuales señala la posibilidad de que con lo encontrado se podían elaborar perfumes y no cocaína, pero, en conjunción con otros elementos de prueba, ha llegado lógicamente el Tribunal al convencimiento de que la tenencia de esos, concretos elementos de posible utilización para el tratamiento de pasta de cocaína, en la ocasión, lugar y circunstancias de secreto y ocultación en que se produjeron, merecía inequívocamente ser estimada como la realización de actos previos, configurables como conspiración, de la comisión de un delito de tráfico de drogas ${ }^{170}$.

Tomando como referencia jurisprudencia más reciente nos encontramos la STS de 23 de julio de 2010 que condenó a un sujeto, modificando la condena del Tribunal de Instancia que sentenció a Arcadio como autor de un delito contra la salud pública tipificado en el artículo 368, por conspiración (artículo 373) a la pena de un año y cinco meses de prisión, inhabilitación especial para el ejercicio del sufragio pasivo durante el tiempo de condena y multa de 30.732 euros. Para modificar la condena el Tribunal Supremo se basó en que Arcadio lo que hizo fue contactar telefónicamente con Víctor Manuel para encargarle un kilogramo de cocaína, fijándole este el precio de 30.000 euros, acudiendo Arcadio a los alrededores del apartamento, donde se encontraba Víctor Manuel, con el dinero para comprar la droga cuando fue detenido por la policía. Señala el Tribunal que a partir de estos hechos 
no cabe dudas de que el acusado, Arcadio, no llegó a dar comienzo a la ejecución de la alternativa típica de la tenencia de drogas para el tráfico del artículo 368 CP. Consecuentemente debió ser aplicado el artículo 373 CP y la pena debió de ser reducida en dos grados, dado que el acusado no dio inicio a la ejecución del delito y su conducta sólo es consecutiva de una resolución manifestada (conspiración) ${ }^{171}$. Creemos que este Tribunal podría haber aplicado el mismo criterio con cualquier procesado si en las mismas circunstancias lo que hubiera ido a comprar al apartamento de Víctor Manuel hubiese sido permanganato de potasio, efedrina o piperonal, lo que los llevaría a condenarlo por conspiración del artículo $371 \mathrm{CP}$, lo cual como ya señalamos antes produciría un adelantamiento desmesurado de la barrera punitiva.

En todo caso queremos puntualizar que existirá conspiración cuando dos o más personas se concierten para cometer el delito de tráfico de precursores de drogas y resuelvan ejecutarlo, siendo necesario que además tengan la aptitud suficiente para cometer el delito ${ }^{172}$. Mientras

171 STS (ROJ: 4713/2010) de 23 de julio de 2010. Ponente: D. Enrique Bacigalupo Zapater.

172 "Respecto a este tipo delictivo, siguiendo una línea jurisprudencial poco discutida, hemos de indicar primeramente y con carácter general lo siguiente: 1) Se trata de un delito de características híbridas, pues si bien se le ha considerado en muchas ocasiones como un delito de «dinámica propia», no es fácil olvidar que, al mismo tiempo y de una forma indefectible es subsidiario o «dependiente» de otro que podemos llamar «principal», o lo que es lo mismo, podríamos decir que se trata de un delito simplemente «mediato», de características parecidas, según una parte de la doctrina, a lo que se ha dado en llamar una tentativa de peligro. 2) Por tanto, la independencia tipológica de estos delitos es más aparente que real porque, de un lado, el artículo 17.1 nos indica que la conspiración siempre habrá de ir dirigida a la «ejecución de un delito» y, de otra porque el módulo cuantitativo de la pena que pueda corresponder se hace depender de la que haya de aplicarse al delito pretendido, delito «matriz», en este caso concreto, la tratarse de tráfico de precursores de drogas, con la pena inferior en uno o dos grados a los previstos para aquél (artículo 373). 3) Es necesario que este delito de pura intención no se haya iniciado en su ejecución, pues (obvio es decirlo) de así ocurrir entraríamos en el campo de la tentativa, figura jurídica distinta a la de la conspiración, de ahí que en múltiples ocasiones sea muy difícil diferenciar este tipo delictivo de las formas imperfectas de ejecución. 4) Se requiere el concierto de dos o más personas para la ejecución delictiva de que se trate y que todas ellas tengan el ánimo de llevar a cabo esta coautoría anticipada que ha de inferirse de «condicionamientos eminentemente sicológicos para su vivencia» cual son, no sólo de carácter previo o «pactum scaleris» entre esas formas sino también la decisión de su efectividad o «resolutio finis»". STS (ROJ: 4446/2002) de 18 de junio de 2002. Ponente: D. Gregorio García Ancos. En el mismo sentido. STS (RJ: 3417/2003) de 20 de mayo de 2003. Ponente: D. Gregorio García Ancos. STS (Roj: 5514/2004) de 24 de julio de 2004. 
que la proposición se produce cuando la persona que ha resuelto realizar los comportamientos comprendidos en el artículo 371 CP invita a otra u otras personas a ejecutar dicho ilícito ${ }^{173}$. Finalmente la provocación se realiza cuando el sujeto activo incita directamente por medio de la prensa, la radiodifusión o cualquier otro medio de eficacia semejante, que facilite la publicidad, o ante una concurrencia de personas a la perpetración del delito de tráfico de precursores de drogas, debiendo puntualizarse que cuando a la provocación le sigue la producción del delito se castiga como inducción. En el caso de la regulación de las organizaciones y grupos criminales introducida por la LO 5/2010 de 22 de junio hay que realizar un esfuerzo complementario para establecer su diferencia con la conspiración tipificada en el artículo 373 y la realización de uno de los delitos contenidos en los artículos 570 bis y 570 ter, especialmente en este último, para lo cual habrá que atender al grado de concreción en la premeditación delictiva, de modo que nos hallaríamos ante un supuesto de conspiración si se trata de realizar una concreta acción típica, mientras que si el concierto se produce en términos más indefinidos, como montar un negocio de tráfico de precursores de drogas, estaríamos ante un supuesto de organización o grupo criminal, según el grado de estabilidad con que lo implicados aborden ese propósito delictivo ${ }^{174}$.

Ponente: Julián Artemio Sánchez Melgar. SANCHEZ MELGAR, Julian. Código Penal. Comentarios y Jurisprudencia. II. 2º Edición. Sepin. Madrid. 2006, pp. 2023, 2024. MOLINA MANSILlA, María del Carmen. El Delito de Narcotráfico. ..., op. cit., pp. 120, 121. MIR PUIG, Santiago. Derecho Penal..., op. cit., pp. 343-350.

173 STS (ROJ: 5626/2004) de 10 de septiembre de 2004. Ponente: D. Carlos Granados Pérez. Al tenor de esta sentencia entendemos que se podría sancionar por el delito de proposición a un sujeto que solicitara por diferentes medios: verbal, por correo, por correo electrónico, redes sociales, teléfono etc., a otra persona que le suministrase cualquier sustancia catalogada como precursor, para la elaboración de drogas ilegales, a los que este tiene acceso por trabajar en una empresa química, sin que este último acceda a realizar tal conducta. STS (ROJ: 4744/2004) de 2 de julio de 2004. Ponente: D. Enrique Bacigalupo Zapater. MIR PUIG, Santiago. Derecho Penal..., op. cit., pp. 350, 351.

174 CONDE-PUMPIDO FERREIRO, Cándido. Código Penal..., op. cit., pp. 1332-1334. Sobre la conspiración en los delitos relativos al tráfico de drogas, ver la STS (ROJ: 2855/1998) de 5 de mayo de 1998. Ponente: D. José Antonio Martín Palllín. 


\section{B.) LA REINCIDENCIA INTERNACIONAL}

Al tenor del artículo $375 \mathrm{CP}$ las condenas de los jueces o tribunales extranjeros por delitos de la misma naturaleza que los previstos en los artículos 368 a 372 de este capítulo producirán los efectos de reincidencia, salvo que el antecedente penal haya sido cancelado o pueda serlo con arreglo al Derecho español. Los presupuestos de aplicación de la reincidencia internacional son: a) la existencia de una condena que tendrá que ser firme en aplicación del régimen general del artículo 22.8 del Código Penal español, b) que la condena sea por un delito de la misma naturaleza que los previstos en los artículos 368-372 del CPE175 y c) que el antecedente penal no se haya cancelado o no pueda ser cancelado conforme al Derecho español. En este sentido se pronuncian las sentencias de Tribunal supremo del 13 de mayo del año 2004, del 12 de septiembre del año 2003 y del 20 de diciembre de $1996^{176 .}$

Como todos sabemos la denominada reincidencia internacional ha sido objeto de modificaciones en su incorporación al artículo $375 \mathrm{CP}$. Destacamos en este sentido la sustitución de los términos "de igual

175 Por lo tanto las condenas extrajeras por proposición, provocación, conspiración o similares no tienen cabida, dado que estos comportamientos están regulados en el artículo $373 \mathrm{CP}$ que queda fuera del ámbito de la reincidencia internacional. ÁLVAREZ GARCÍA, F. Javier. Derecho Penal Español..., op. cit., pp. 1363- 1365.

176 STS (ROJ: 3252/2004) de 13 de mayo de 2004. Ponente: D. Miguel Colmenero Menéndez de Luarca, STS (ROJ: 5465/2003) de 12 de septiembre de 2003. Ponente: D. Joaquín Delgado García y STS (ROJ: 7393/1996) de 20 de diciembre de 1996. Ponente: D. Cándido Conde-Pumpido Touron. Aprecia la circunstancia agravante de reincidencia del artículo 375 por estar el acusado ejecutoriamente condenado por sentencia firme desde el 5 de febrero de 1993 por un Tribunal de la República Federal de Alemania por un delito de elaboración, tenencia o tráfico de drogas a la pena de siete años de prisión mayor. SAP de Santa Cruz de Tenerife (ROJ: 1299/2002) de 20 de mayo de 2002. Ponente: D. Esteban Solaz Solaz. Estima aplicable la circunstancia agravante de reincidencia internacional porque el acusado fue condenado por el Tribunal de Gran Instancia número 16 de Bobigny (Francia) en sentencia firme de fecha de 20 de abril de 1993 como autor de un delito de elaboración, tenencia o tráfico de drogas a la pena de siete años de prisión mayor. SAN (ROJ: 1959/2001) de 27 de marzo de 2001. Ponente: Dña Elizabeth Cardona Minguez. Aplica la agravante de reincidencia internacional por haber sido el culpable condenado mediante sentencia dictada por el Tribunal del Distrito Judicial de Amsterdam (Holanda) el 9 de noviembre de 1994 por un delito de tráfico de estupefacientes, a la pena de cuatro años de prisión menor. SAP de Málaga (ROJ: 3036/1999) de 24 de septiembre de 1999. Ponente: D. Ignacio Escribano Cobo. 
entidad" por el más adecuado de "delitos de la misma naturaleza" a raíz de la reforma realizada en 1988 sobre los delitos de tráfico de drogas, de esta manera se centra la exasperación de la pena en el dato cualitativo del fundamento del delito y no en meramente cuantitativo de la pena en que aquella referencia podría incurrir. La remisión al artículo $22.8 \mathrm{CP}$, mantiene, sin embargo, la polémica en torno a las dudas de constitucionalidad cuando su aplicación, exclusivamente fundamentada en la realización de un hecho ya desvalorado y sancionado, puede sobrepasar el grado culpabilidad del sujeto. De la nueva regulación también hay que decir que resuelve algunas carencias que presentaba la normativa anterior, 344 bis f), como la de resolver la discusión sobre la determinación del derecho aplicable para la cancelación de las penas, decantándose por el derecho interno español, lo que obliga, en aras a la constatación de la identidad de la naturaleza de los delitos, a la confrontación no sólo de los tipos de injusto correspondientes (en cuanto a identidad de bien jurídico y acción desvalorada) sino de la sanción que por ellos se impone. Por lo cual la imposición en el extranjero de penas privativas de libertad superiores a los marcos abstractos contemplados en el artículo 36 en relación al 70.2.1으 del CP, conllevará la imposibilidad de apreciación de identidad pues tales penas se inscribirán ya en el seno de órdenes cualitativas diversas, lo que también ocurrirá, cuando la pena prevista para el hecho realizado fuera de España no tuviera correlativo en el ordenamiento interno, por ejemplo trabajos forzados o reclusión perpetua ${ }^{177}$.

\section{C.) COLABORACiÓN CON LA JUSTICIA}

En lo concerniente al premio por delación el artículo 376 del Código Penal preceptúa que los casos previstos en los artículos 368 al 372, los jueces o tribunales razonándolo en sentencia, podrán imponer la pena inferior en uno o dos grados a la señalada por la ley para el delito que se trate. En el caso del tráfico de precursores la pena inferior en un

177 QUINTERo OLIVARES, Gonzalo. Comentarios a la Parte Especial..., op. cit., pp. 1533, 1534. La aplicación de la reincidencia internacional no es fácil, en la práctica por la inexistencia de un Registro Universal donde consten todas las condenas. Esta carencia se ha tratado de suplir con acuerdos relativos a aquellos países con los que existe una mayor relación. CONDE-PUMPIDO FERREIRO, Cándido. Código Penal..., op. cit., pp. 1339, 1340. ARROYO ZAPATERO, Luis. Comentarios al Código Penal. ..., op. cit., p. 827. 
grado será de un año y seis meses a tres años de prisión, y la pena inferior en dos grados de nueve meses a un año y seis meses de prisión. Siempre que el sujeto haya abandonado voluntariamente sus actividades delictivas y hubiese colaborado activamente con las autoridades o sus agentes, bien para impedir la producción del delito, bien para obtener pruebas decisivas para la identificación o captura de otros responsables o para impedir la actuación o el desarrollo de las organizaciones o asociaciones a las que haya pertenecido o con las que haya colaborado. Hay que decir que para la doctrina mayoritaria se trata de una institución propia del derecho promocional, entre el delator y el arrepentido, con los riesgos constitucionales que entraña la figura del arrepentido coimputado (Sentencia del Tribunal Constitucional de 22 de mayo de 2006$)^{178}$, pero con una clara finalidad políticocriminal (sentencia del Tribunal Supremo del 29 de enero del año 2008) ${ }^{179}$. Es preciso aclarar que la decisión de "rebajar o no hacerlo únicamente en un grado no es revisable en casación, porque la aplicación del artículo 376 queda al libre arbitrio del órgano judicial sentenciador $\mathrm{y}$, también entra dentro de la discrecionalidad del juzgador decidir si, de aplicar el precepto, la pena se reduce en uno o dos grados" 180 .

Para que pueda aplicarse la atenuación facultativa del primer inciso del artículo 376 se deben cumplir tres requisitos: 1) que el sujeto haya abandonado voluntariamente sus actividades delictivas, 2) que se haya presentado a las autoridades confesando los hechos y 3) que haya colaborado activamente con las autoridades para alguna de las tres finalidades siguientes: a) para impedir la producción del delito, b) para obtener pruebas decisivas para la identificación o captura de otros responsables del delito y c) para impedir la actuación o el desarrollo de las organizaciones o asociaciones a las que haya pertenecido o con las ZAPATERO, Luis. Comentarios al Código Penal. ..., op. cit., pp. 828, 829. STS (ROJ: 669/2008) de 29 de enero de 2008. Ponente: Juan Ramón Berdugo Gómez de la Torre. Ver también STS (ROJ: 3552/2003) de 26 de mayo de 2003. Ponente: Luis Román Puerta Luis y STS (ROJ: 527/2004) de 31 de enero de 2004. Ponente: Enrique Bacigalupo Zapater.

STS (ROJ: 2083/2000) de 15 de marzo de 2000. Ponente: D. José Antonio Marañón Chavarri. 
que haya colaborado. Del propio texto del artículo antes mencionado, por la conjunción "y" repetidamente utilizada, está claro que deben concurrir estos tres elementos para que el Tribunal pueda, de modo facultativo, aplicar la rebaja de pena en uno o dos grados que en el mismo se prevé181.

En opinión de Fernández Palma en la lucha contra el tráfico de drogas uno de los mayores obstáculos es la proliferación de las estructuras delictivas organizadas, normalmente estables y con sólidas conexiones internacionales, que dificultan en gran medida el acceso al último peldaño de la pirámide organizativa y por ende su completa desarticulación. En esta línea el artículo 376 parece responder a la idea, de que en el enfrentamiento al narcotráfico es necesario utilizar todos los medios y estrategias posibles, incluido el recurso a la colaboración-delación de quienes, precisamente por dedicarse a esas actividades delictivas, pueden contribuir a su debilitamiento, que premia no tanto el propio arrepentimiento o confesión sino la posible eficacia práctica de la colaboración. Señalando que se trata de una normativa contradictoria o de doble vía que responde a una cuestionable política legislativa, en definitiva utilitarista, en sintonía con la elegida por el resto de la comunidad internacional, aparentemente inoperante si atendemos al progresivo incremento de dicha actividad delictiva ${ }^{182}$.

También se establece en el segundo inciso de este artículo el mismo tratamiento, reducción de pena en uno dos grados, al reo que siendo drogodependiente en el momento de comisión de los hechos, acredite suficientemente que ha finalizado con éxito un tratamiento de deshabituación, siempre que la cantidad de drogas tóxicas, estupefacientes o sustancias psicotrópicas no fuere de notoria importancia o extrema gravedad. En principio esta disminución de pena podría aplicarse a los condenados por el artículo $371 \mathrm{CP}$, sin

181 STS (ROJ: 508/2001) de 29 de enero de 2001. Ponente: D. Joaquín Delgado García. SAP de Guadalajara (ROJ: 234/2010) de 23 de junio de 2010. Ponente: D. Manuel Eduardo Regalado Valdés.

182 QUINTERO OLIVARES, Gonzalo. Comentarios a la Parte Especial..., op. cit., pp. 15351548. 
embargo no tenemos constancia de que exista alguna sentencia que lo haya hecho ${ }^{183}$.

\section{D.) LA CIRCULACIÓN O ENTREGA VIGILADA DE DROGAS O DE SUS PRECURSORES}

La entrega vigilada tiene por finalidad permitir que las sustancias, equipos o materiales que pueden ser objeto de esta medida, así como los bienes y ganancias procedentes del blanqueo de capitales circulen por territorio español o entren o salgan de él sin ser interceptados por las autoridades competentes, para descubrir e identificar a todas las personas involucradas en estos delitos. Sobre este tema hay que recordar que la Ley Orgánica 8/1992, de 23 de diciembre, de modificación del Código Penal y de la Ley de Enjuiciamiento Criminal en materia de tráfico de drogas, introdujo entre otras novedades importantes la de autorizar la circulación o entrega vigilada de drogas tóxicas, estupefacientes o sustancias psicotrópicas, así como de otras sustancias prohibidas como las denominadas sustancias catalogadas o precursores de drogas (artículo 263 bis, 1 LECrim). Las modificaciones realizadas por la Ley Orgánica 5/1999, de 13 de enero, y la Ley Orgánica 5/2010, de 22 de junio, han hecho posible que esta circulación o entrega vigilada se pueda aplicar además a todos los delitos a los que se refiere el artículo 301 del Código Penal (blanqueo de capitales) y en los relacionados con el tráfico de animales y vegetales, falsificación de monedas, falsificación de tarjetas de crédito, así como de tenencia y depósito de armas y municiones. Con ello se le otorga legitimidad a un método que había sido muy cuestionado en los últimos años. No obstante hay que señalar que el artículo 263 bis LECrim impone determinadas precauciones que procuran evitar los abusos que en la práctica anterior se habían producido. Pero su redacción aún deja mucho que desear y el amplio margen de discreción permite a las autoridades policiales y judiciales cometer abusos, así como justificar los que se han cometido con anterioridad ${ }^{184}$.

183 ARroyo ZAPATERO, Luis. Comentarios al Código Penal. ..., op. cit., p. 829. Se aplica atenuante analógica que conlleva una respuesta penológica aminorada con respecto al tipo aplicable (tráfico de drogas). SAP de Guadalajara (Roj: 234/2010) de 23 de junio de 2010. Ponente: Manuel Eduardo Regalado Valdés. 
La STS de 16 de enero de 2003 nos muestra un caso claro de entrega vigilada, se trata de la sentencia recurrida de la Audiencia Nacional, sección cuarta del 9 de julio del año 2002 en la que se condenaron a tres sujetos como autores por el delito de tráfico de precursores de drogas, siendo estos Gaspar y José Ignacio (los dos primeros) que importaron un cargamento de unos 12.000 kilogramos de permanganato de potasio (envasados en bidones de 50 kilogramos), con el fin de exportarlo a Colombia. Esta remesa les fue suministrada por la empresa "Innochem" que tiene su sede en la localidad belga de Meerhort, y transportada en un camión articulado con tractora matrícula belga FEF 282 y el remolque con matrícula UDR 535 perteneciente a Transportes R-Helsen de Westeleo (Bélgica), hasta la nave ubicada en la calle Llanos del Castillo no 30 de El Higuerón (Córdoba) donde llegó el día 26 de noviembre de 1998, habiendo sido arrendada dicha nave a su propietaria el 1 de noviembre de 1998 por José Ignacio. Como empresa importadora de ese cargamento figuraba la empresa española "Cendivega" con domicilio social en la calle Ramón y Cajal de Villanueva (Córdoba), siendo la verdadera importadora la empresa "Quindifar S.A." domiciliada en la referida nave y que estaba en trámites de constitución siendo sus gestores los señores Gaspar y José Ignacio.

Gaspar y José Ignacio, antes de exportar el permanganato de potasio a Colombia, decidieron camuflar la mercancía y para este propósito adquirieron 6.000 kilogramos de dióxido de manganeso (sustancia no catalogada, pero que también se utiliza en la elaboración ilícita de permanganato de potasio en países de América del Sur). Dicha remesa se las proporcionó la empresa R. Orts Simo S.A. de Aldaya (Valencia), ajena a estos hechos, así como 365 etiquetas y 144 bidones de plástico opacos con sus correspondientes precintos comprados a la empresa

5/1999, de 13 de enero, de modificación de la Ley de Enjuiciamiento Criminal" en aidpespana.uclm.es/pdf/criminalidad/rrodriguez.pdf, pp. 117, 118. Sobre los requisitos de validez de este mecanismo de seguimiento de la droga o de sus precursores: STS (ROJ: 4906/2009) de 6 de julio de 2009. Ponente: D. Julián Artemio Sánchez Melgar, STS (ROJ: 4628/2009) de 18 de junio de 2009. Ponente: D. Manuel Marchena Gómez, STS (ROJ: 99/2009) de 8 de enero de 2009. Ponente: D. Francisco Monterde Ferrer, STS (ROJ: 5941/2008) de 3 de octubre de 2008. Ponente D. Manuel Marchena Gómez. STS (ROJ: 51/2002) de 10 de enero de 2002. Ponente: D. Joaquín Giménez García. STS (ROJ: 822/2015) de 5 de marzo de 2015. Ponente: D. Juan Ramón Berdugo Gómez de la Torre. 
Reyde S.A, de Sant Boi de Llobregat (Barcelona) también ajena a estos hechos, recibiéndose estas mercancías el día 26 de febrero de 1999, en la nave antes señalada donde seguía almacenado el permanganato de potasio. Y a los mismo fines de camuflaje encargaron a Miguel (tercer sujeto condenado en esta sentencia), hijo de José Ignacio, trasvasar 40 kilos de permanganato de potasio en bolsas de basura, a cada uno de los nuevos bidones (355) recibidos, completando el peso de 50 kilos por unidad con 10 kilos de dióxido de manganeso, y tras precintar cada bidón ponerle una nueva etiqueta referida a esta última sustancia, destruyera las etiquetas originales del permanganato de potasio. Para que le ayudara en esta tarea Miguel contrató a su amigo Rubén. Una vez concluido el trabajo antes mencionado, tras el llenado en las formas mencionadas de 355 bidones, que fueron cargados el día 12 de marzo de 1999 en el contenedor con número de identificación SEAU 822620-9 de la empresa Sea-Land y transportados hasta el puerto de Algeciras, que el día 17 de marzo de 1999 se cargan en el buque Grete Maeks con destino al puerto de Cartagena de Indias en Colombia, donde llega el cargamento el día 14 de abril de 1999, siendo interceptado por la policía colombiana. Esta exportación a Colombia fue gestionada por Gaspar ante el transitario de Algeciras "Tránsito 2000 S.L.", declarando que el contenedor llevaba 20 pallets de dióxido de manganeso en 355 bidones de 50 kilogramos cada uno, siendo la empresa embarcadora "Quindifar S.L." y el destinatario "Tomas" con domicilio en la avenida NUM000-NUM 001 de Santa Fe de Bogotá (Colombia). Hay que puntualizar que el permanganato de potasio que se exportó a Colombia alcanzaba el peso total de 11.611 kilogramos y su valor económico ascendía a la suma de 3.607491 pesetas es decir 21.681 euros con 46 céntimos. Esta remesa estuvo vigilada por las autoridades competentes desde su salida de Bélgica hasta su llegada al puerto de Cartagena de Indias. En opinión del Tribunal Supremo la entrega vigilada se desarrolló conforme a derecho ${ }^{185}$.

Nos parece importante señalar que la LO 5/1999 introduce dos novedades importantes: la primera es que la entrega vigilada deberá acordarse siempre, en resolución fundada, estableciendo cuando fuera posible, el objeto de la autorización y el tipo y cantidad de sustancia de que se trate. Esta obligación se deriva del derecho/deber de motivar 
las resoluciones judiciales (derecho del justiciable, deber del órgano judicial); es decir, del derecho de todo ciudadano de obtener de los Tribunales una resolución fundada en derecho como parte integrante del derecho a la tutela judicial efectiva. Y de una manera especial, por afectar derechos fundamentales (el derecho al secreto de la correspondencia consagrado en el artículo 18.3 de la Constitución Española). El deber constitucional de motivación de las resoluciones judiciales que limitan derechos fundamentales es una exigencia formal del principio de proporcionalidad, de tal manera que el órgano judicial deba de realizar un juicio de ponderación entre el derecho o derechos fundamentales afectados y los intereses que tal afectación procura proteger. La segunda novedad es que en el caso de que la resolución fuera adoptada por el Juez Instructor, este deberá remitir copia de la misma al Juzgado decano de su jurisdicción, el cual llevará un registro de las mismas (se supone que con el objeto de tener el CGPJ una estadística nacional de estas resoluciones) ${ }^{186}$.

Queremos destacar que aunque el artículo 263 bis LECrim establece que la realización de la entrega vigilada se debe decidir caso por caso y teniendo en cuenta su necesidad a los fines de la investigación en relación con la importancia del delito y con las posibilidades de vigilancia, la propia dinámica del narcotráfico imprime a esta actividad un riesgo que no se puede ocultar. Decimos esto porque existen algunas inconcreciones en esta norma como que no se establezca a quien se le pueden entregar las drogas u otras sustancias, ni la procedencia que deben tener las sustancias que se empleen para tal fin. Otro elemento a tener en cuenta es que la autorización de las entregas

186 La doctrina jurisprudencial reiterada de la Sala Segunda del Tribunal Supremo llega a las siguientes conclusiones: 1) El secreto a la inviolabilidad de las comunicaciones, que consagra el artículo 18.3 CE, debe de hacerse extensivo a los paquetes postales, sean enviados a través de las oficinas de Correos o de empresas privadas que ofrezcan servicios análogos. 2) No están amparados por este derecho fundamental los paquetes previstos con etiqueta verde, los abiertos y aquellos en que se hace constar en el exterior su contenido. En el mismo sentido, se equiparán las maletas y bolsos de viaje. 3) La apertura de paquetes exige autorización judicial, mediante un auto motivado, que debe ponderar la adopción de la medida en razón de la gravedad del delito perseguido. RODRÍGUEZ FERNÁNDEZ, Ricardo. "El agente encubierto y la entrega vigilada. (Comentarios a la LO 5/1999, de 13 de enero, de modificación de la Ley de Enjuiciamiento Criminal" en aidpespana.uclm.es/pdf/criminalidad/rrodriguez.pdf, pp. 108-110, 122, 123. 
vigiladas pueden realizarla, además del juez de instrucción competente y el Ministerio fiscal, los jefes de unidades orgánicas de la Policía Judicial central o de ámbito provincial o sus mandos superiores, que son autoridades administrativas, debiendo de dar cuenta inmediata al Ministerio Fiscal, o al Juez de Instrucción competente si existiera un procedimiento judicial abierto. Se le cuestiona a tal situación que la policía no posee otro principio inspirador en sus actuaciones que su propia eficacia, lo cual puede propiciar el deterioro del Estado de derecho, sin que con ello se logre la eficacia pretendida187. Además hay que señalar que la circulación o entrega vigilada de drogas ilegales o de sus precursores opera como causa de justificación, para los agentes que participan en esta, por obrar en cumplimiento de un deber o en el ejercicio legítimo de un oficio o cargo (artículo $20.7 \mathrm{CP}$ ). No se admiten otras causas de justificación por ser el bien jurídico tutelado un bien colectivo superior a cualquier bien individual ${ }^{188}$.

\section{E.) EL AGENTE ENCUBIERTO}

El Tribunal Supremo sostiene mayoritariamente que la actuación del agente encubierto en la investigación judicial es correcta, y por lo tanto no existe delito provocado, cuando los agentes de la autoridad sospechan o conocen la existencia de una actividad delictiva y se infiltran entre quienes la lleven a cabo, en busca de información o pruebas que posibiliten impedir o castigar el delito. En estos supuestos, la determinación de delinquir ya ha surgido firmemente en él o los sujetos con independencia de la intervención del agente encubierto, que, enmascarado bajo una falsa personalidad, se limita a comprobar la actuación de él o los delincuentes e incluso a realizar algunas actividades de colaboración con el mismo, en la actualidad reguladas, desde la entrada en vigor de la Ley Orgánica, de 13 de enero, en el artículo 282 bis de la Ley de Enjuiciamiento Criminal, que se refiere específicamente a adquirir y transportar los objetos, instrumentos o efectos del delito. Pudiendo producirse la intervención policial en cualquier fase del iter criminis, en el momento que ya se ha cometido o RODRÍGUEZ FERNÁNDEZ, Ricardo. "El agente encubierto..., op. cit., pp. 107, 108, 118121.

188 LAMARCA PÉREZ, Carmen (Coord.). Delitos y Faltas. ..., op. cit., pp. 635, 636. 
se está cometiendo el delito, especialmente en los delitos de tracto sucesivo como los de tráfico de drogas, y aún en sus fases iniciales de elaboración o preparación, siendo lícita siempre que permita la evolución libre de la voluntad del sujeto y no suponga una inducción a cometer el delito que de alguna forma la condicione. "En estos casos, la actuación policial no supone una auténtica provocación, pues la decisión del sujeto activo siempre es libre y anterior a la intervención puntual del agente encubierto, aunque éste, siempre por iniciativa del autor de la infracción criminal, llegue a ejecutar labores de adquisición o transporte de los efectos del delito". Se trata en definitiva de una "provocación policial para descubrir delitos ya cometidos"189.

Hay que señalar que la utilización del agente encubierto está prevista sólo para aquellas investigaciones que afecten a actividades propias de la delincuencia organizada tales como: los delitos relativos al tráfico de drogas, de secuestro bajo condición, de prostitución, de robo con fuerza en las cosas, con violencia o intimidación, delitos de extorción, delitos de robo y hurto de vehículos, delitos de estafa, delitos de receptación, delitos contra la seguridad de los trabajadores, delitos de tráfico de especies de flora o fauna amenazadas, delitos de tráfico de material nuclear y radioactivo, delitos de falsificación de monedas, delitos de tráfico y depósito de armas, municiones y explosivos, todos los delitos de terrorismo y delitos contra el patrimonio histórico. Siendo necesario puntualizar que ningún policía judicial podrá ser obligado a actuar como agente encubierto, y que la autorización para actuar como tal debe concederla el Juez de Instrucción o el Ministerio Fiscal, dando en este caso cuenta inmediata al Juez, quien podrá revocarla. Su concesión deberá realizarse en resolución fundada y guardando proporcionalidad con el fin perseguido. Es necesario poner de manifiesto que si en el transcurso de una investigación es indispensable la violación de un derecho fundamental por parte del

189 Sobre la aplicación de esta figura ver STS (ROJ: 1242/2009) de 6 de febrero de 2009. Ponente: D. José Manuel Maza Martin. STS (ROJ: 99/2009) de 8 de enero de 2009. Ponente: D. Francisco Monterde Ferrer, STS (ROJ: 7815/2007) de 15 de noviembre de 2007. Ponente: D. Julián Artemio Sánchez Melgar. STS (ROJ: 3705/2003) de 30 de mayo de 2003. Ponente: D. José Manuel Maza Martín. STS (ROJ: 1230/2002) de 22 de febrero de 2002. Ponente: D. José Jiménez Villarejo entre otras. En el mismo sentido se pronuncia RODRÍGUEZ FERNÁNDEZ, Ricardo. "El agente encubierto..., op. cit., y pp. 99, 100. 
agente encubierto, por ejemplo entrada y registro de un domicilio, deberá solicitarse la correspondiente autorización judicial de la autoridad competente, que podrá denegarla ${ }^{190}$.

A manera de ejemplo citamos el caso de un grupo de sujetos que se dedicaban a la introducción de cocaína en España para luego distribuirla, una vez mezclada con productos químicos que disminuyeran su grado de pureza y aumentaran su peso para obtener mayores beneficios económicos. De dicha actividad tuvo conocimiento el Departamento de Narcotráfico de la Unidad Central Operativa de la Guardia Civil en el año 2005 a través del testigo protegido "Ovidio" a quien el jefe de la organización criminal "Bartolomé" le encargará la compra de algunos precursores como ácido clorhídrico, acetona y otras sustancias no catalogadas en Madrid y su posterior traslado a Tenerife donde estaba ubicado su laboratorio de modificación del índice de riqueza de la cocaína. El testigo protegido recibe la orientación de la Guardia Civil de proponerle a Bartolomé que dicha tarea la cumpla una tercera persona que tiene facilidades de comprar dichas sustancias por estar vinculado a ese tipo de negocios y gozar de su entera confianza. El jefe de este grupo criminal accede y así entra en escena el agente encubierto "Eduardo" autorizado debidamente por el Juzgado de Instrucción número 1. Este recibe el dinero de "Ovidio" quien previamente lo había recibido de "Bartolomé", compra las sustancias químicas, las traslada a Tenerife y se las entrega a "Bartolomé". Una vez que las autoridades proceden a desarticular la red son ocupados en diferentes inmuebles y en un coche una cantidad importante de cocaína tasada en 338.207, 66 euros, cuatro botellas de un litro de ácido clorhídrico, 13 botes de un litro de acetona y otras sustancias no catalogadas que se usan para cortar cocaína, así como algunos instrumentos que usaban para tal fin. La Audiencia de Instancia condenó a cinco miembros de la banda (Bartolomé, Imanol, Leonardo, José Manuel y Ángel de Jesús) como responsables en concepto de autor de un delito contra la salud pública, en relación con sustancias que causan daño a la salud, en cantidad de notoria importancia y en el seno de una organización delictiva, a las penas de nueve años y un día de prisión, multa de 388.207,66 euros e inhabilitación especial para el ejercicio del sufragio pasivo durante el tiempo de la condena, además del abono de 
una octava parte de las costas procesales generadas. Absolviendo además a tres procesados por falta de pruebas en su contra.

Tres de los condenados presentaron recursos en el cual se quejaban de la actuación del testigo protegido "Ovidio" y su falta de cobertura legal por no ser funcionario policial. Además de reprochar su actuación provocadora, a quien acusan de poner en marcha todo el entramado criminal, solicitando se declare la nulidad del proceso por tratarse de un delito provocado. Este motivo fue desestimado al entender el Tribunal Supremo que "Ovidio" lo que hizo es dar la "notitia criminis" a las autoridades competentes, sin cometer una auténtica provocación, pues la actividad criminal ya estaba en marcha, dado que la cocaína ya estaba en Tenerife y lo que le solicitaron al testigo protegido era la adquisición de precursores y otras sustancias no catalogadas para cortar la droga y obtener mayores beneficios económicos, señalando el Tribunal que el modo de introducir al agente encubierto "Eduardo" en la organización, se hace con la respectiva autorización judicial de conformidad al artículo 282 bis de la Ley de Enjuiciamiento Criminal sin conculcar derechos constitucionales. "Exclusivamente se ha solicitado la colaboración del denunciante, para que, bajo el control judicial, realice una indicación al tenido por jefe de la organización y le sugiera la intervención de un tercero, que será precisamente el agente encubierto.., pues de alguna manera se tiene que producir la infiltración, que en definitiva es una simulación que permite la Ley.., que autoriza el ordenamiento jurídico para introducirse en las organizaciones criminales, en donde el agente ha de desempeñar un papel, que confunda a los integrantes de la organización, y les permita suponer que se trata de uno de ellos..., en consecuencia, respetados los derechos fundamentales en tal infiltración, cualquier otra actuación (simulación) para la penetración en la trama organizada, debe de considerase legal. Por tanto, el motivo no puede prosperar"191.

191 STS (ROJ: 7815/2007) de 15 de noviembre de 2007. Ponente: Julián Artemio Sánchez Melgar. La figura del agente encubierto supone una evolución en la lucha contra la delincuencia organizada. Consiste en que el funcionario policial con una identidad falsa se infiltre en la estructura de una organización criminal para, desde dentro de la misma, obtener pruebas que posibiliten la condena penal de sus integrantes, así como la desarticulación de dicha organización. La acción del agente encubierto "excede la del confidente (que se limita, desde fuera, a recabar información) y la del agente provocador (que intenta descubrir la realidad de la comisión de un delito y la obtención de pruebas de esa actividad), introduciéndose en una organización criminal, 
Hay que señalar que "no es pacífica en la doctrina penal la admisión de la figura del agente encubierto, y cierto sector de la misma propugna la prohibición de estos medios de actuación policial porque lesionan los principios inspiradores del Estado de Derecho y vulneran la interdicción de la arbitrariedad de los Poderes Públicos que garantiza el artículo 9.3 de la Constitución Española". De este criterio radical se han hecho eco algunas resoluciones de esta Sala, pero el criterio que ha prevalecido es el que admite la figura expresada cuando no hay quebranto para el principio de legalidad, lo que sucede cuando se trata de descubrir delitos ya cometidos, generalmente de trato sucesivo como suelen ser los de tráfico de drogas, porque en tales casos los agentes policiales no buscan y provocan la comisión del delito, sino poner al descubierto los canales por lo que fluye y se realiza este tráfico ilícito, tratando, en definitiva, de obtener pruebas de una actividad sobre la que abrigan fundadas sospechas"192.

Es necesario aclarar que en el delito provocado la voluntad de cometer el delito surge en el sujeto, no por su propia voluntad, sino como consecuencia de la actividad de otra persona, quien generalmente es un agente o bien un colaborador de los Cuerpos o Fuerzas de Seguridad, que guiado por la intensión de detener a los sospechosos o de facilitar su detención, provoca mediante su actuación engañosa la ejecución de una conducta delictiva que no había sido planeada ni decidida por aquél, y que de otra forma no hubiera realizado, adoptando dicho agente además las medidas de precaución correspondientes para evitar la efectiva lesión o puesta en peligro del bien jurídico protegido. Tal forma de proceder es manifiestamente contraria a los principios inspiradores del Estado Derecho193. "Esta clase de delito provocado, tanto desde el punto de vista de la técnica penal por el carácter imposible de su producción- como desde el más fundamental principio constitucional de la interdicción de la arbitrariedad de los poderes públicos (artículo 9.3 C.E.) y hasta desde el de la

pudiendo actuar entonces tanto como confidente o como agente provocador". RODRÍGUEZ FERNÁNDEZ, Ricardo. “El agente encubierto..., op. cit., p. 100.

192 STS (ROJ: 3198/1993) de 21 de mayo de 1993. Ponente: D. José Hermenegildo Moyna Menguez.

193 STS (ROJ: 4107/2003) de 13 de junio de 2003. Ponente: D. Julián Artemio Sánchez Melgar. 
lícita obtención de la prueba (artículo 11.1 L.O.P.J.) debe considerarse como penalmente irrelevante, procesalmente inexistente $\mathrm{y}$, por todo ello, impune"194. Como principio general el agente policial estará exento de responsabilidad criminal por todas sus actuaciones en el desarrollo de la investigación, sin embargo si este se hubiera excedido o hubiera incurrido en provocación al delito podrá incurrir en responsabilidad. Para determinar la misma el Juez competente deberá en primer lugar solicitar un informe relativo a la actuación del agente encubierto del órgano que hubiera autorizado la actuación ${ }^{195}$.

\section{B.) CONCURSO CON OTROS DELITOS}

\section{Concurso con el tráfico de drogas}

Es preciso aclarar que en el caso de que se le ocupen drogas y precursores de drogas a un sujeto o grupo de personas, el delito de tráfico de precursores queda absorbido, en virtud de la regla $3^{\underline{a}}$ del artículo 8 del Código Penal, por el de tráfico de drogas (368 y 369 CP), por ser el comportamiento más amplio y acabado, pero puede conducir a un absurdo cuando se trata de drogas que no causan grave daño a la salud que solo se sanciona con prisión de uno a tres años (inferior a la pena preceptuada en el artículo 371 de tres a seis años). Esta incongruencia es a todas luces considerable por que el tráfico de precursores es un acto preparatorio del tráfico de drogas, aunque de drogas duras, y siendo un acto preparatorio material, su castigo

194 STS (ROJ: 5911/1993) de 15 de septiembre de 1993. Ponente: D. Cándido CondePumpido Ferreiro. La defensa de uno de los imputados alega la existencia de una infracción del derecho a la tutela judicial efectiva del recurrente (art. 24.2 CE), porque el buque tripulado por los agentes encubiertos partió del puerto de Southampton, transportando drogas ilícitas, dos días antes de ser autorizado para ello por el titular del Juzgado Central no 5, que estaba a cargo de la Instrucción. Señala el Tribunal que el comportamiento de los "agentes encubiertos" sería, como queda dicho, irregular, incluso quizá hasta sancionable, pero en modo alguno priva de valor a las diligencias de investigación y acreditación de los hechos enjuiciados en este procedimiento. STS (ROJ: 1242/2009) de 6 de febrero de 2009. Ponente: D. José Manuel Maza Martin. En estos casos puede resultar difícil eximir de responsabilidad al agente provocador, de hecho no faltan especialistas que propugnan su castigo penal, con las atenuaciones que pudieran proceder atendiendo los móviles que lo impulsaron. RODRÍGUEZ FERNÁNDEZ, Ricardo. “El agente encubierto..., op. cit., pp. 95-99.

195 Ibidem.,. 106. 
únicamente es posible porque el legislador lo ha elevado a delito autónomo, pero esa autonomía no debe suponer que la pena sea mayor o igual a la del comportamiento más avanzado y por ende más peligroso para el bien jurídico tutelado. El absurdo se incrementó con la reforma realizada al artículo 368 por la Ley Orgánica 5/2010, por la que se rebaja la pena del tipo básico referido a las drogas que causan grave daño a la salud, pasando la pena de prisión de tres a nueve años a la de tres a seis años, equiparando el castigo del tipo básico del tráfico de precursores y la del tipo básico de tráfico de las denominadas drogas duras, situación que amerita que el Legislador revise las discordancias que se derivan de castigar los comportamientos sin atender al principio de proporcionalidad, y sin revisar las relaciones entre unas y otras penas ${ }^{196}$. Es necesario señalar que la jurisprudencia de forma prácticamente unánime cuando se incautan drogas ilícitas y precursores de drogas se decanta por sancionar por el delito de tráfico de drogas ${ }^{197}$. Sin embargo hay que decir que en algunos casos cuando

196 ÁlVAREZ GARCÍA, F. Javier. Derecho Penal Español..., op. cit., pp. 1354, 1355. En los supuestos muy habituales en que el delito de tráfico de precursores concurre con el de tráfico de drogas, se produce una absorción por éste de aquel, toda vez que el primero constituye un adelantamiento de la barrera punitiva, que determina la sanción penal de actos preparatorios del delito de tráfico de drogas. MARTíNEZ PARDO, Vicente José. Los Delitos de Tráfico..., op. cit., p. 306. CORCOY BIDÁSOLO, Mirentxu. Comentarios al Código Penal. ...., op. cit., p. 817.

197 STS (ROJ: 4580/1995) de 18 de septiembre de 1995. Ponente: D. Luis Román Puerta Luis. STS (ROJ: 7714/2001) de 9 de octubre de 2001. Ponente: D. José Ramón Soriano Soriano. STS (ROJ: 3732/2002) de 25 de mayo de 2002. Ponente: D. Gregorio García Ancos. STS (ROJ: 3020/2003) de 5 de mayo de 2003. Ponente: D. José Antonio Marañón Chavarri. STS (ROJ: 1849/2004) de 17 de marzo de 2004. Ponente: D. Joaquín Giménez García. STS (ROJ: 3303/2003) de 16 de mayo de 2003. Ponente: D. José Aparicio CalvoRubio. STS (ROJ: 4700/2004) de 2 de julio de 2004. Ponente: D. José Antonio Martín Pallin. STS (ROJ: 7500/2005) de 28 de noviembre de 2005. Ponente: D. José Manuel Maza Martín. STS (ROJ: 5856/2011) de 27 de septiembre de 2011. Ponente: D. Juan Ramón Berdugo Gómez de la Torre. STS (ROJ: 4207/2012) de 29 de mayo de 2012. Ponente: D. Miguel Colmenero Menéndez de Luarca. STS (ROJ: 3131/2014) de 18 de julio de 2014. Ponente: D. Cándido Conde-Pumpido Tourón. SAN (ROJ: 8185/2005) de 3 de noviembre de 2005. Ponente: D. Felix Alonso Guevara Marcos. SAN (ROJ: 6088/2009) de 21 de enero de 2009. Ponente: Dña. María Teresa Palacios Criado. SAP de Ciudad Real (ROJ: 617/2011) de 20 de julio de 2011. Ponente: D. Alfonso Moreno Cardoso. SAP de Guadalajara (ROJ: 234/2010) de 23 de junio de 2010. Ponente: D. Manuel Eduardo Regalado Valdés. SAP de Madrid (ROJ: 8039/1999) de 8 de junio de 1999. Ponente: D. Adrián Varillas Gómez. SAP de San Sebastián (ROJ: 835/2016) de 3 de octubre de 2016. Ponente: D. Jorge Juan Hoyos Moreno. SAP de Guadalajara (ROJ: 
en el ilícito se puede diferenciar claramente que la participación de él o algunos de los procesados esta únicamente referida a la fabricación, transporte, distribución, comercio o tenencia de precursores de drogas se puede aplicar el artículo $371 \mathrm{CP} 198$, siempre que no se aprecie la agravante de organización o bien si el poseedor de los precursores está a su vez, integrado en un grupo organizado dedicado a la elaboración y distribución de la sustancia estupefaciente, siendo su papel dentro del grupo, precisamente el suministro de aquellos productos, el delito del artículo 371, como acto preparatorio, queda absorbido por el delito del artículo 368 del Código Penal, en virtud del artículo 8 CP199.

\section{Pertenencia a organización o grupo criminal}

Es más complicada la situación que se produce cuando el delito de tráfico de precursores se realiza perteneciendo a una organización dedicada estos fines, pues en términos similares a los relativos a los delitos de tráfico de drogas, se produce un concurso de normas con el delito de pertenencia a una organización criminal tipificado en el

206/2016) de 23 de julio de 2016. Ponente: Dña. Isabel Serrano Frias. SAP de Palencia (ROJ: 129/2016) de 11 de abril de 2016. Ponente: D. Carlos Miguelez del Rio. SAP de Madrid (ROJ: 4062/2016) de 31 de marzo de 2016. Ponente: Dña. María del Pilar de Prada Bengoa. Sin embargo si se incautan precursores y pequeños restos no cuantificables de drogas se sanciona por el delito de tráfico de precursores. SAP de Madrid (ROJ: 1011/2014) de 28 de enero de 2014. Ponente: Dña. Adoración María Riera Ocariz. SAP de Salamanca (ROJ: 348/2004) de 3 de junio de 2004. Ponente: D. Ildefonso García del Pozo. Ver Circular no 3/2011 sobre la reforma del Código Penal efectuada por la Ley Orgánica 5/2010, de 22 de junio, en relacion con los delitos de tráfico ilegal de drogas y de precursores.

198 STS (ROJ: 1748/2009) de 18 de marzo de 2009. Ponente: D. Carlos Granados Pérez. STS (ROJ: 583/2004) de 3 de febrero de 2004. Ponente: D. Enrique Bacigalupo Zapater.

199 "Si el poseedor de sustancias o productos considerados como precursores está a su vez, integrado en un grupo organizado dedicado a la elaboración y distribución de la sustancia estupefaciente, siendo su papel dentro del grupo, precisamente el suministro de aquellos productos, el delito del artículo 371, como acto preparatorio, queda absorbido por el delito del artículo 368 del Código Penal, en virtud del artículo 8 CP como aconteció en el caso presente en el que fueron intervenidos más de 14 kilogramos de cocaína. STS (ROJ: 5856/2011) de 27 de septiembre de 2011. Ponente: D. Juan Ramón Berdugo Gómez de la Torre. STS (ROJ: 2774/2016) de 9 de junio de 2016. Ponente: D. Juan Ramón Berdugo Gómez de la Torre. SAN (ROJ: 6508/2006) de 21 de julio de 2006. Ponente: D. Juan Francisco Martel Rivero. SAN (ROJ: 6088/2009) de 21 de enero de 2009. Ponente: Dña. María Teresa Palacios Criado. 
artículo 570 bis, el cual se ha de resolver mediante la aplicación de la regla de alternabilidad prevista en el artículo 8.4 del Código Penal, y por tanto, constatar cuál de las dos disposiciones tiene señalada la pena de mayor gravedad, debiendo tenerse en cuenta que el tipo penal del artículo 570 bis no sanciona la conducta de tráfico de precursores, por lo que para hacer la comparación de penas con el artículo 371, es necesario añadir a las penas fijadas por aquél, las que procedan por esta actividad delictiva. Hay que señalar que en los supuestos en que la coparticipación en el delito de tráfico de precursores no alcance el grado de organización y sí de grupo criminal, se produce un concurso real de delitos entre el artículo 371 y el artículo 570 ter en el que se plantea la misma problemática anteriormente analizada que determina la imposición acumulada de las penas señaladas para ambos delitos, debiendo puntualizarse que tanto el artículo 570 bis como el artículo 570 ter castigan únicamente a los que participen activamente en "la organización criminal" o "grupo criminal", formaren parte o cooperaren económicamente o de cualquier otro modo con las mismas, sin exigir ninguno de estos tipos penales para su aplicación que se haya cometido ningún otro delito ${ }^{200}$.

MARTínEZ PARDO, Vicente José. Los Delitos de Tráfico P.E..., op. cit., p. 307. Una de las novedades más importantes introducidas por la Ley Orgánica 5/2010, de 22 de junio es la creación de un nuevo capítulo VI en el título XXII del libro II, que bajo la rúbrica "de la organizaciones criminales y grupos criminales", establece un concepto de organización criminal en el artículo 570 bis del Código Penal, definiéndola como la agrupación formada por dos o más personas con carácter estable o por tiempo indefinido, que de manera concertada y coordinada se repartan diversas tareas o funciones con el fin de cometer delitos, así como de llevar a cabo la perpetración reiterada de faltas. También se introdujo el concepto de grupo criminal, definiéndolo en el artículo 570 ter 1 in fine como la unión de más de dos personas que, sin reunir alguna o algunas de las características de la organización criminal definida en el artículo anterior, tenga por finalidad o por objeto la perpetración concertada de delitos o la comisión concertada y reiterada de faltas. Como vemos para la diferenciación de organización y grupo criminal, el legislador ha construido el concepto de este último sobre las notas negativas de no concurrencia de alguna o alguna de las circunstancias de la organización criminal, por lo que se puede concluir que los caracteres "transitorio y ocasional" expresados en el subtipo agravado del derogado artículo 369.1.2. a CP, en la actualidad se incardinan en el concepto de grupo criminal, toda vez que se corresponde con una agrupación de personas no suficientemente estructurada para perpetuarse en el tiempo. Circular $n^{\circ}$ 3/2011 sobre la reforma del Código Penal efectuada por la Ley Orgánica 5/2010, de 22 de junio, en relacion con los delitos de tráfico ilegal de drogas y de precursores. La reforma introducida por la LO 5/2010, si 
Sin embargo, creemos que plantea mayores dificultades la diferenciación entre el delito de pertenencia a un grupo criminal y otras formas de codelincuencia ocasional para delinquir, siendo muy

bien ha suprimido la circunstancia $2^{\underline{a}}$ del art 369.1 , no ha eliminado la agravación específica, en cuanto ha incorporado un nuevo art 369 bis, castigando con penas de nueve a doce años y multa a "quienes realizaren los hechos descritos en el art. 368, respecto de sustancias o productos que causen grave daño a la salud y pertenecieren a una organización delictiva..", aunque ya no se habla del carácter transitorio o del modo ocasional de la actividad de distribución. Según ha expuesto esta Sala en las sentencias 207/2012, de 12 de marzo, y 334/2012, de 25 de abril, la reforma obliga a tener en cuenta las siguientes consideraciones: a) La agravación se produce exclusivamente cuando quienes ejecutan las conductas descritas en el art 368 pertenecen a una organización criminal. b) Ha de operarse con la definición legal de organización que ahora se plasma en el nuevo art. 570 bis: "A los efectos de este Código, se entiende por organización criminal la agrupación formada por más de dos personas con carácter estable por tiempo indefinido, que de manera concertada y coordinada se repartan diversas tareas o funciones con el fin de cometer delitos, así como..." c) La organización ha de estar integrada, en consecuencia, por un mínimo de tres personas, no siendo suficiente con dos (art. 570 bis del C. Penal ). d) Se ha suprimido de la agravación para la ejecución del delito el consorcio meramente transitorio u ocasional, ajustándose así el subtipo a la exigencia de estabilidad que impone el nuevo art. 570 bis del C. Penal al definir la organización. e) La agravación no comprende a quienes simplemente formen parte de un grupo criminal, tal como aparece definido en el art 570 ter. f) Se amplían las conductas que se especificaban en el antiguo 369.1.2º, pues allí se exigía la pertenencia del culpable a una organización que tuviera como finalidad difundir tales sustancias y productos, mientras que la actual redacción de la agravación del art. 369 bis cubre la totalidad de las conductas previstas en el art 368 (actos de cultivo, elaboración o tráfico, así como promover, favorecer o facilitar su consumo ilegal), que van más allá de la simple distribución material. Se recogen, pues, sustancialmente en la definición legal los caracteres que asumía la jurisprudencia supra citada, en cuanto que se requiere una pluralidad de personas (tres o más), estabilidad en el tiempo, y una actuación concertada y coordinada con distribución de tareas y reparto de roles o funciones entre sus distintos componentes. g) Ha de sopesarse también que el nuevo art. 570 bis 1 del C. Penal equipara punitivamente a quienes participan activamente en la organización con los que forman parte de ella o cooperan económicamente o de cualquier otro modo . h) El nuevo subtipo agravado de organización previsto en el art. 369 bis del C. Penal suscita complejos problemas concursales con la nueva regulación de las organizaciones criminales en el art. 570 bis, dada la posibilidad de que se dé un concurso de normas entre el nuevo subtipo agravado de organización (art. 369 bis), de una parte, y de otra el concurso del delito contra la salud pública (arts. 368 y 369) con el nuevo tipo de organización criminal, con sus relevantes agravaciones específicas de penas (art. 570 bis, apartados 1 y 2). Tal concurso de normas habrá de dirimirse, en principio, con arreglo al art. 570 quáter.2, aplicando el supuesto que tenga asignada una mayor pena (art. 8.4 del C. Penal). STS (ROJ: 6803/2012) de 1 de octubre de 2012. Ponente: Alberto Gumersindo Jorge Barreiro. 
importante la diferencia entre ambas figuras pues es distinto su régimen jurídico. Mientras que los supuestos de codelincuencia no tienen trascendencia penológica al margen de los delitos que se cometan, la pertenencia a un grupo criminal constituye un delito autónomo respecto de las infracciones penales que eventualmente se cometan, que deben castigarse separadamente dando lugar a un concurso real de delitos ${ }^{201}$.

Queremos concluir este apartado señalando que la vigilancia que ejercen tanto los órganos de la policía como de la Guardia Civil sobre operaciones sospechosas con las empresas que comercializan los precursores, así como la colaboración de la industria química y farmacéutica en este sentido, han permitido la detección y desmantelamiento de varios laboratorios clandestinos de elaboración, extracción o refinamiento (corte) de drogas, así como el procesamiento y condena de los miembros que operan los mismos. Investigaciones que frecuentemente se inician por el delito de tráfico de precursores de drogas y se concluyen por el delito de tráfico de drogas propiamente dicho 202.

\section{Represión del contrabando de precursores de drogas}

Es importante señalar que las conductas relacionadas con el tráfico de precursores de drogas también son sancionadas por la Ley orgánica 6/2011 de 30 de junio, por la que se modifica la Ley Orgánica 12/1995, del 12 de diciembre, de Represión del Contrabando. Esta norma en el inciso 15 del artículo 1 define a los precursores de drogas como "las

201 Sobre la reforma penal en relación con las organizaciones y grupos criminales los señores Fiscales valorarán la concurrencia de circunstancias que revelen la voluntad de continuidad en otras actividades criminales de la misma clase, que normalmente se pondrá de manifiesto por los medios comisivos utilizados para delinquir, y de los que a su vez se desprenderá la existencia de una planificación o coordinación con un cierto reparto de papeles que favorezca la eficacia de su actividad criminal, su capacidad ofensiva y la impunidad de sus miembros. Circular $n^{0} 3 / 2011$ sobre la reforma del Código Penal efectuada por la Ley Orgánica 5/2010, de 22 de junio, en relacion con los delitos de tráfico ilegal de drogas y de precursores.. https://www.fiscal.es/fiscal/PA_WebApp_SGNTJ_NFIS/descarga/memoria2012_vol1_c ircu_03.pdf?idFile=77180d36-49d0-4841-8af4-b1a3baed5109, p. 1419.

202 STS (ROJ: 5856/2011) de 27 de septiembre de 2011. Ponente: Juan Ramón Berdugo Gómez de la Torre. SAP de Murcia (ROJ: 2858/2011). Ponente: José Manuel Nicolás Manzanares. 
sustancias y productos susceptibles de ser utilizados en el cultivo, la producción o la fabricación de drogas tóxicas, estupefacientes o sustancias psicotrópicas, enumeradas en los cuadros I y II de la Convención de Naciones Unidas hecha en Viena el 20 de diciembre de 1988, sobre el tráfico ilícito de estupefacientes y sustancias psicotrópicas y cualesquiera otros productos adicionados al mismo Convenio, o en cualesquiera tratados o convenios internacionales sobre el mismo objeto suscritos por España". Como vemos este precepto abarca las mismas sustancias que el artículo 371 del Código Penal Español, estando supeditada la modificación de la lista de sustancias al Convenio de 1988 u otros Convenios de la misma naturaleza ratificados por España ${ }^{203}$. La Ley de Represión del Contrabando establece en su artículo 2 inciso 2 "que cometen el delito de contrabando, siempre que el valor de los bienes, mercancías, géneros o efectos sea igual o superior a 50.000 euros, los que realicen alguno de los siguientes hechos: ... c) importen, exporten, introduzcan, expidan 204 o realicen cualquier otra operación sujeta al control previsto en la normativa correspondiente referido a las mercancías sometidas al mismo por alguna de las disposiciones siguientes: ... $3^{\circ}$ la normativa reguladora del comercio exterior de precursores de drogas sin las autorizaciones a las que se refiere el Reglamento (CE) $\mathrm{n}^{-}$ 111/2005 del Consejo, de 22 de diciembre de 2004, por el que se establecen normas para la vigilancia del comercio de precursores de drogas entre la Comunidad y terceros países, o habiéndolas obtenido bien mediante su solicitud con datos o documentos falsos en relación con la naturaleza o el destino de tales productos o bien de cualquier otro modo ilícito".

FARALDO CABANA, Patricia. Comentarios a la Legislación Penal Especial. Ed. Lex Nova/Thomson Reuters. Valladolid. 2012, p. 100.

204 Este Reglamento en su artículo 1 realiza las siguientes definiciones: a) importación: la entrada de mercancías no comunitarias en el territorio español comprendido en el territorio aduanero de la Unión Europea, así como en el ámbito territorial de Ceuta y Melilla. Se asimila a la importación la entrada desde áreas exentas, b) introducción: la entrada en territorio español de mercancías comunitarias procedentes de otros Estados miembros de la Unión Europea, c) exportación: la salida de mercancías del territorio español. No se considerará exportación la salida de mercancías comunitarias del territorio español comprendido en el territorio aduanero, d) expedición: la salida de mercancías del territorio español con destino final a otros Estados miembros de la Unión Europea. 
Sin embargo Alicia Rodríguez Núñez afirma que el contrabando de drogas tóxicas, estupefacientes, sustancias psicotrópicas y de las sustancias catalogadas como sus precursores o de cualquiera otros bienes cuya tenencia constituya delito está castigado en el artículo 2.3 de la Ley Orgánica 12/1995, de 12 de diciembre, de Represión del Contrabando modificada por la LO 6/2011, de 30 de junio con independencia del valor de los bienes mercancías géneros y efectos ${ }^{205}$. Nosotros tenemos ciertas dudas sobre tal afirmación porque el artículo 2.3 lo que señala es que "cometen, asimismo, delito de contrabando quienes realicen alguno de los hechos descritos en los apartados 1 y 2 de este artículo, si concurre alguna de las circunstancias siguientes: a) cuando el objeto del contrabando sean drogas tóxicas, estupefacientes, sustancias psicotrópicas, armas, explosivos, agentes biológicos o toxinas, sustancias químicas tóxicas y sus precursores, o cualesquiera otros bienes cuya tenencia constituya delito, o cuando el contrabando se realice a través de una organización, con independencia del valor de los bienes, mercancías o géneros, pues parece que a los precursores a que se refiere este inciso del artículo 2 es a los de "las sustancias químicas tóxicas", por lo que se trataría de las sustancias enumeradas en las listas 1, 2 y 3 de la Convención sobre la prohibición del Desarrollo, la Producción, el Almacenamiento y el Empleo de Armas Químicas y sobre su Destrucción, hecha en París el 13 de enero de 1993, definidas al efecto en su artículo II. Hay que destacar, que antes de la reforma de la LO 6/2011, estaba más claro que se hacía referencia a los precursores de drogas, así la LO 12/1995 en su artículo 3 a) establecía que cometen asimismo delito de contrabando quienes realicen alguno de los hechos descritos en el apartado 1 de este artículo, si concurre alguna de las circunstancias siguientes: a) Cuando el objeto del contrabando sean drogas tóxicas, estupefacientes, sustancias psicotrópicas, sustancias catalogadas como precursores, armas, explosivos o cualesquiera otros bienes cuya tenencia constituya delito o cuando el contrabando se realice a través de una organización, aunque el valor de los bienes, mercancías, géneros o efectos sea inferior a 3.000 .000 de pesetas.

En todo caso es evidente que tendría relevancia sobre los precursores de drogas, del artículo 3 a), en el mismo sentido, la parte que señala "o 
cuando el contrabando se realice a través de una organización", pues en tales casos quienes importen, exporten, introduzcan, expidan o realicen cualquier otra operación sujeta a control previsto en la normativa con cualquiera de las sustancias contenidas en los Cuadros I y II de la Convención de Viena de 1988, con independencia del valor de estas sustancias comete el delito de contrabando sin tener las debidas autorizaciones que establece el Reglamento (CE) 111/2005 del Consejo, de 22 de diciembre de 2004, o habiéndolas obtenido bien mediante su solicitud con datos o documentos falsos en relación con la naturaleza o el destino de tales productos o bien de cualquier otro modo ilícito.

El artículo 3 de la Ley Orgánica 6/2011 preceptúa que quienes cometan el delito de contrabando serán castigados con las penas de prisión de uno a cinco años y multa del tanto al séxtuplo del valor de los bienes, mercancías, géneros o efectos. Estableciendo que en el caso del contrabando de precursores de drogas las penas se impondrán en su mitad superior (de tres a cinco años), y la pena superior en grado (de cinco a siete años y seis meses) cuando el delito se cometa por medio o en beneficio de personas, entidades $u$ organizaciones cuya naturaleza o actividad pudiera derivarse una facilidad especial para la comisión del mismo. Un aspecto a destacar es que las conductas antes señaladas serán igualmente punibles cuando se cometan de forma imprudente, aplicándose en tales casos la pena inferior en un grado (de seis meses a un año). El inciso 3 de este artículo establece que cuando proceda la exigencia de responsabilidad penal de una persona jurídica de acuerdo a lo establecido en el artículo 2.6206, y tras aplicar los criterios establecidos en los apartados 1 y 2 de este artículo, se impondrá la pena siguiente: a) en todos los casos, multa proporcional del duplo al cuádruplo del valor de los bienes, mercancías, géneros o efectos objeto del contrabando, y prohibición de obtener subvenciones

206 Las personas jurídicas serán plenamente responsables en relación con los delitos tipificados en los apartados anteriores cuando en la acción u omisión en ellas descritas concurran las circunstancias previstas en el artículo 31 bis de la Ley Orgánica 10/1995, del Código Penal y en las condiciones en él establecidas. Asimismo, cuando el delito se cometa en el seno, en colaboración, a través o por medio de empresas, organizaciones o grupos, entidades o agrupaciones carentes de personalidad jurídica, le será de aplicación lo previsto en el artículo 129 de La Ley Orgánica 10/1995, de 23 de diciembre del Código Penal. 
y ayudas públicas para contratar con las Administraciones públicas y para gozar de beneficios e incentivos fiscales o de la Seguridad Social por un plazo entre uno y tres años, b) adicionalmente, en los supuestos previstos en el artículo 2.2 (tráfico de precursores), suspensión por un plazo de entre seis meses y dos años de las actividades de importación, exportación o comercio de la categoría de bienes, mercancías, géneros o efectos objeto del contrabando. Llegados a este punto queremos recordar que el artículo 371 del Código Penal sanciona el tráfico de precursores siempre que se realice de forma dolosa (exigiendo dolo directo) y que se realice a sabiendas de que tales sustancias van a ser utilizadas en el cultivo, la producción o la fabricación ilícitas de drogas tóxicas, estupefacientes o sustancias psicotrópicas, o para estos fines, mientras que en la Ley de represión del contrabando no se exigen esas dos condiciones.

También debe señalarse que el Tribunal Supremo tradicionalmente consideraba que mientras en el tráfico de drogas y por ende de precursores de drogas se tutelaba el bien jurídico "salud pública", en el delito de contrabando de estas drogas o sus precursores el bien jurídico que se protegía es "el interés de la Administración pública en controlar el tráfico de géneros sujetos al arancel de aduanas, estancados o prohibidos"207, decantándose posteriormente hacia una doctrina unitaria del bien jurídico tutelado "la salud pública". En todo caso hay que poner de manifiesto que la jurisprudencia más reciente del Tribunal Supremo, aun sometiéndose a la doctrina tradicional reconoce de forma expresa la existencia de "notables argumentos" en favor del concurso de normas y por ende su sanción como un único delito. Una vez abandonada la tesis de la dualidad de bienes jurídicos tutelados el concurso de normas se plantea como la solución más correcta, siendo el criterio finalmente adoptado. Para refrendar tal postura se argumenta que en los supuestos de introducción de la droga en España desde el exterior el artículo 368 CP alcanza toda la ilicitud del hecho, "pues no existe un interés fiscal defraudado en la medida en la que aunque el autor lo hubiera querido satisfacer ello no hubiera

207 Sobre la dualidad de bienes jurídicos y por consiguiente el concurso ideal de delitos: STS (ROJ: 1927/1993) de 24 de marzo de 1993. Ponente: D. Luis Román Puerta Luis. STS (ROJ: 1566/1994) de 9 de marzo de 1994. Ponente: D. José Hermenegildo Moyna Menguez. STS (ROJ: 9640/1994) de 30 de mayo de 1994. Ponente: D. José Augusto de Vega Ruiz. 
sido posible. Asimismo, tampoco existe en estos casos un mayor peligro para la salud pública, toda vez que todo el peligro proviene de la tenencia de la droga dentro del territorio. Precisamente lo que crea el peligro es la introducción de la droga en España y no su introducción por sí misma" 208. En todo caso hay que decir que esta solución no es válida para el tráfico de precursores de drogas, pues como todos sabemos las 24 sustancias que son consideradas como tales son de lícito comercio, por lo cual habría que entender que la Ley de Represión del Contrabando además de tutelar el bien jurídico "salud pública" podría proteger otro bien jurídico "los intereses económicos del Estado".

Sobre el iter criminis hay que señalar que de acuerdo con la Junta de la Fiscalía Especial para la Prevención y Represión del Tráfico ilegal de drogas, de los días 18 y 19 de noviembre del año 2004, ratificada por la Circular 2/2005 del día 31 de marzo, de la Fiscalía General del Estado, se acoge el criterio aduanero conforme al cual en la figura de importación de estupefacientes, lo cual asumimos también vale para sus precursores, el delito queda consumado cuando se ha pasado el control aduanero o cuando, inexistente éste, se ha colocado la mercancía en territorio protegido por las barreras aduaneras españolas. Tomando como base esta interpretación se puede afirmar que son admisibles las formas imperfectas de ejecución cuando se han iniciado las actividades inmediatamente dirigidas al paso de la frontera, pero no se ha

CONDE-PUMPIDO FERREIRO, Cándido. Código Penal..., op. cit., pp. 1296, 1306. La línea jurisprudencial del Tribunal Supremo venía estimando la concurrencia de normas y no de delitos entre el contrabando y el tráfico de drogas, cuando el culpable introducía o sacaba la sustancia del territorio nacional (Acuerdo del Pleno de la Sala Segunda de 19 de julio de 2000). Esta duplicidad se ha resuelto con la modificación del Código Penal operada por la LO 5/2010 que ha suprimido el apartado 10 del artículo 369.1. LAMARCA PÉREZ, Carmen (Coord.). Derecho Penal. P.E..., op. cit., p. 572. CARDONA TORRES, Juan. Derecho Penal...., op. cit., pp. 446, 447. Sobre la doctrina unitaria del bien jurídico protegido y el concurso de normas: STS (ROJ: 2094/1996) de 8 de abril de 1996. Ponente: D. Cándido Conde-Pumpido Tourón. STS (ROJ: 1757/1997) de 11 de marzo de 1997. Ponente: D. Cándido Conde-Pumpido Tourón. STS (ROJ: 7303/1997) de 2 de diciembre de 1997. Ponente: D. Cándido Conde-Pumpido Tourón. STS (ROJ: 7272/1997) de 1 de diciembre de 1997 Ponente: D. Enrique Bacigalupo Zapater. A través del artículo 2.3 a) de la Ley Orgánica de Represión del Contrabando se protege el bien jurídico salud pública al igual que en el artículo 368 CP. FARALDO CABANA, Patricia. Comentarios a la Legislación..., op. cit.,pp. 98, 99. BLANCO LOZANO, Carlos. Tratado de Derecho...., op. cit., pp. 383, 384. 
producido la introducción en territorio español o de la Unión Europea, como es lógico debe regir el mismo criterio con los supuestos de exportación $^{209}$. En lo que se refiere a la autoría y participación entendemos que estamos ante un delito común que no presenta especiales particularidades en esta materia. En el caso de que las conductas descritas fueran realizadas por una persona jurídica, tal como lo establece el artículo 2.6 LORC se estará a lo dispuesto por el artículo 31 bis CP; si fueran cometidos en el seno, en colaboración, a través o por medio de empresas, organizaciones, grupos, entidades o agrupaciones sin personalidad jurídica, se les deberá aplicar el artículo 129 CP (artículo 2.7 LORC) ${ }^{210}$.

Queremos puntualizar que en los procedimientos por el delito de contrabando la responsabilidad civil comprenderá la totalidad de la deuda tributaria y aduanera no ingresada, que la Administración Tributaria no haya podido liquidar por prescripción, caducidad o cualquier otra causa legal prevista en la Ley General Tributaria o en la normativa aduanera de la Unión Europea, incluidos sus intereses de demora. Para la ejecución de la pena de multa y de responsabilidad civil, los jueces y tribunales recabarán el auxilio de los servicios de la Administración Tributaria, que las exigirá por el procedimiento administrativo de apremio en los términos establecidos en la Ley General Tributaria. Sobre el comiso hay que decir que toda pena que se impusiere por un delito de contrabando llevará consigo el comiso de los siguientes bienes, efectos o instrumentos: a) las mercancías que constituyan el objeto del delito, b) los materiales instrumentos o maquinaria empleados en la fabricación, elaboración, transformación o comercio de los géneros estancados o prohibidos, c) los medios de transporte con los que se lleve a efecto la comisión del delito, salvo que pertenezcan a un tercero que no haya tenido participación en el delito, d) las ganancias obtenidas del delito, cualesquiera que sean las transformaciones que hubieran podido experimentar, e) cuantos bienes y efectos, de la naturaleza que fueren, hayan servido de

209 El criterio que debe de aplicarse es el de alternabilidad en virtud del cual en el caso concreto, tal como establece el artículo 8.4 del Código Penal, "el precepto penal más grave excluirá los que castiguen el hecho con pena menor" FARALDO CABANA, Patricia. Comentarios a la Legislación..., op. cit., pp. 101- 106. 
instrumento para la comisión del delito. Si por cualquier circunstancia, no fuera posible el comiso de los bienes o instrumentos señalados anteriormente, se acordará el comiso por un valor equivalente de otros bienes que pertenezcan a los criminalmente responsables del delito. 


\section{CONCLUSIONES DE LA PRIMERA PARTE}

PRIMERA.- Sobre la Fiscalización internacional de precursores de drogas hay que decir que en los 28 años de funcionamiento ha tenido avances muy notables, entre ellos hay que destacar que actualmente han ratificado, aprobado o se han adherido la Convención de Viena de 1988 un total de 189 Estados o territorios, incluida la Unión Europea, lo cual constituye el $95.45 \%$ de todos los Estados o territorios del mundo. Siendo suscriptores del Convenio todos los países fabricantes de precursores, así como la inmensa mayoría de los Estados exportadores e importadores de estas sustancias, de hecho de los tres tratados internacionales sobre fiscalización de drogas es el que tiene mayor número de adhesiones tiene. Además hay que señalar que se han registrado progresos en todos los mecanismos de que dispone para el control de los canales internacionales comercio lícito de estas sustancias. Tal es el caso del sistema de notificaciones previas a la exportación que cuenta actualmente con un total de 108 estados o territorios (el 54.5\% del total) que son usuarios de este sistema, que como todos sabemos es uno de los medios más eficaces para poder determinar la legitimidad de cualquier transacción de sustancias catalogadas. Lamentablemente hay que destacar que en algunas regiones la mayoría de países no han invocado todavía su derecho a ser informados, dejando de esta manera amplias zonas vulnerables a la desviación de precursores de drogas. Además hay que decir que en la práctica sólo el $40 \%$ de los países exige algún tipo de notificación, y apenas el $21 \%$ de los países de bajos recursos exigen notificaciones previas a la exportación, frente al $66 \%$ y el $40 \%$ de los países de mayores y medianos ingresos, respectivamente, lo que propicia que los países de bajos ingresos se encuentren en una situación mucho más vulnerable a los intentos de desviación por parte de los traficantes de precursores de drogas.

SEGUNDA.- Una situación similar ocurre con el sistema PEN Online, que es un sistema automatizado del que disponen las autoridades competentes de los países importadores y exportadores para confirmar la legi- 
timidad de cada operación en tiempo real, y así tener la posibilidad de suspender o detener las remesas sospechosas de forma muy ágil. Actualmente se han inscrito en este sistema 150 países y territorios (el $75.7 \%$ del total). Los que por término medio envían mensualmente 2.600 notificaciones previas a la exportación, frente a unas 600 notificaciones mensuales que se enviaban cuando empezó a funcionar el sistema en el año 2006. Es necesario precisar que aunque la mayoría de países que tienen un comercio importante de sustancias catalogadas utilizan de forma activa el sistema PEN Online, hay algunos gobiernos registrados en este sistema que prácticamente no lo usan. Agravando el problema el hecho de que entre los países que aún no se han inscrito en el sistema PEN Online, se encuentran regiones utilizadas especialmente por los traficantes como zonas de tránsito o de destino de sustancias catalogadas. En tal situación se hallan partes importantes de África, zonas de Europa Sudoriental y gran parte de Asia Central, de hecho únicamente el $43 \%$ de los países de bajos recursos se han registrado en el sistema, frente al 85\% de países de mayores recursos o del $65 \%$ de países medianos ingresos que hace uso de este valioso recurso que también se utiliza con bastante éxito en las operaciones internacionales que desarrolla de forma periódica la JIFE.

TERCERA.- Es necesario poner de manifiesto que algunos gobiernos importadores que hacen uso del sistema PEN Online no siempre toman las medidas con carácter inmediato al recibir las notificaciones previas a la exportación a fin de determinar si las transacciones en cuestión son o no legítimas, Otro aspecto negativo a reseñar es que siempre que se realiza una comparación de las remesas de precursores notificadas previamente a través del sistema PEN Online de un año con las importaciones reportadas mediante el formulario D que envían anualmente todo los países a la Junta se encuentran discrepancias apreciables en ambos sentidos, las cuales son mayores en las sustancias incluidas en el Cuadro II. Pudiendo concluirse que siempre las exportaciones reales de sustancias catalogadas superan a las reportadas por cualquiera de las dos vías antes señaladas.

CUARTA.- En el caso del sistema de comunicación de incidentes relacionados con precursores (PICS) que es una plataforma de comunicación segura para el intercambio rápido de información entre los cuerpos y fuerzas de seguridad nacionales y las autoridades de reglamentación, sobre remesas sospechosas, incautaciones, desviaciones y tentativas de 
desviación, remesas de precursores detenidas, en tránsito e incautaciones de laboratorios y equipos clandestinos. Sistema que en definitiva facilita el intercambio de inteligencia en tiempo real y permite poner en marcha investigaciones bilaterales y regionales sin retraso, hay que decir que presenta las mismas limitaciones que el sistema PEN Online, ya que sólo están registrados un total de 90 países y territorios (el $45.4 \%$ del total mundial), y además los países de pocos recursos económicos hacen un uso muy limitado de este recurso.

QUINTA.- Por otra parte hay que destacar que lamentablemente el incremento de los gobiernos que presentan el formulario D (sobre el comercio lícito y tráfico ilícito de precursores) no ha sido el esperado, pues se ha pasado de los 104 gobiernos que presentaron dicho informe en 1990 a 117 que presentaron el informe correspondiente al año 2014 (el 59\% de todos los Estados miembros). Presentándose la deficiencia de que la mayoría de esos gobiernos, no proporcionan información detallada sobre los métodos de desviación y fabricación ilícita de dichas sustancias. Resultando que aproximadamente un $21 \%$ de los países miembros incumple con su obligación de presentar los informes requeridos a la JIFE, lo cual dificulta seriamente el establecimiento de las pautas de desviación, y de fabricación ilícita de precursores de drogas y de otras sustancias no catalogadas.

SEXTA.- Desde que se inició la lucha contra el desvío de precursores de drogas, los instrumentos de que disponen los gobiernos para detectar estas sustancias son cada vez mejores, pero a pesar de ser lo suficientemente sencillos para que puedan ser utilizados por todas las autoridades nacionales competentes, nunca se ha logrado su aplicación de forma generalizada, pues no se han producido los mismos avances en todos los países, ya que los estados o territorios más pobres o menos desarrollados, y de hecho regiones enteras, están quedando rezagadas, por lo cual el alcance de las medidas de fiscalización de los precursores de drogas y sustancias no catalogadas dista mucho de ser mundial al no haberse dado la prioridad requerida a la asistencia técnica, situación de la que los traficantes de precursores se aprovechan para desarrollar sus actividades con muy poca dificultad en regiones donde las medidas de fiscalización son prácticamente inexistentes o muy débiles, y los organismos de represión tienen una capacidad muy limitada. Lo cual sucede en países de Africa, América Central y el Caribe, Asia Central, Asia 
Sudoriental y Europa Oriental, o países muy inestables como Afganistán, Irak o Siria.

Otro elemento a tener en cuenta es que las operaciones internacionales del Proyecto Prisma (sobre precursores de estimulantes de tipo anfetamínico y del Proyecto Cohesión (sobre los precursores de la heroína y la cocaína) han ayudado mucho a brindar asistencia a los países de medianos y pocos recursos, sin embargo hay que decir que están progresando a un ritmo diferente. En el caso del Proyecto Cohesión las actividades centradas contra la producción de heroína obtienen mejores resultados, aunque aún no son los deseados, que los relativos a los productos químicos utilizados en la fabricación ilícita de cocaína. En este sentido la JIFE ha reconocido que la comprensión acerca de las fuentes de productos que se utilizan en la fabricación ilícita de esa droga, y las pautas conexas de su desviación y tráfico son insuficientes. Además hay que añadir que el nivel de participación e intercambio de información en los dos proyectos antes citados sigue siendo reducida, dándose el caso de que algunas consultas sobre operaciones con precursores sospechosas no son respondidas.

SÉPTIMA.- Paulatinamente se han registrado menos desvíos de precursores de drogas del comercio internacional, gracias, en parte, a los resultados logrados mediante la aplicación de las medidas de fiscalización del Convenio de 1988, pero también al hecho constatado de que los traficantes elaboran en laboratorios ilícitos las sustancias catalogadas más importantes del Cuadro I (el permanganato de potasio, el anhídrido acético, la efedrina, la seudoefedrina, la P-2-P, la 3.4-MDP-2-P, el safrol y el ácido fenilacético), y del Cuadro II (el ácido sulfúrico, el ácido clorhídrico, la metiletilcetona y el éter etílico), cantidad que representa justamente la mitad de los precursores de drogas contenidos en los Cuadros, lo cual también ocurre con una serie de sustancias no catalogadas que se utilizan en la elaboración ilícita de la cocaína, la heroína y estimulantes de tipo anfetaminico. Además hay que añadir que a lo largo de los últimos años los traficantes de sustancias catalogadas, utilizan cada vez más sustancias sucedáneas de los precursores o bien los denominados pre-precursores (que sirven para elaborar las sustancias catalogadas), precisamente a partir del año 2010 se sabe que obtienen estas sustancias preparadas por encargo a empresas de la industria química de diferentes países del mundo, para luego transformarlas en precursores de drogas. 
OCTAVA.- Actualmente, la mayoría de los casos de desvío de tráfico de precursores que se producen se desvían de los canales internos de distribución, que cuando no se realizan en el propio país en que se fabrica la droga, se pasan luego de contrabando a través de las fronteras hasta llegar a los laboratorios de producción ilícita de drogas. En este sentido nos encontramos con el problema de que en muchos Estados y territorios no se conocen bien los fabricantes lícitos de precursores de drogas, ni las sustancias que se producen ni los niveles de producción de las mismas y mucho menos las necesidades legítimas de importación de sustancias catalogadas de sus países. Por lo que hace falta mejorar el marco de colaboración voluntaria con la industria química y la farmacéutica para poder enfrentar de mejor manera el desvío de precursores de drogas. Existen para ello las directrices para la elaboración de un código de práctica voluntario destinado a la industria química y la lista de vigilancia internacional especial limitada de sustancias no incluidas en los cuadros que la Junta pone a disposición de todos los gobiernos de forma gratuita

NOVENA.- Existe una tendencia de los traficantes de disminuir sus intentos de desviar sustancias catalogadas del comercio internacional, sin embargo para hacerlo se han dado a la tarea de modificar las rutas de desviación, siendo estas cada vez más complejas, además para evadir las medidas de fiscalización han optado por procurarse cada vez estas sustancias en formas de preparados farmacéuticos sobre todo en el caso de la efedrina y seudoefedrina y en menor medida en otras sustancias que sirven para elaborar estimulantes de tipo anfetaminico, utilizando también la modificación química o disimulación química usando bisulfito P-2-P o bisulfito 3,4-MDP-2-P para enmascarar la P-2-P o la 3,4-MDP-2-P respectivamente.

DÉCIMA.- En los últimos años se han multiplicado a un ritmo sin precedentes las nuevas sustancias psicoactivas, que están fuera del alcance de los tratados de fiscalización internacional de drogas. Las categorías más comunes han sido los cannabinoides sintéticos, las catinonas sintéticas y los opiodes sitéticos. Según el Obsevatorio Europeo para las Drogas y las Toxicomanias (OEDT), el número de notificaciones de nuevas sustancias psicoactivas fue de cinco sustancias por año en el perido 2000-2005. Pero en el año 2011 esa cifra había aumentado a 49 sustancias, lo que significa que casi todas las semanas había salido al mercado una nueva sustancia. Cantidad que se duplico en el año 2014. 
Siendo sumamente complicado conocer el número exacto de nuevas sustancias psicoactivas que circulan en el mercado mundial, así como que precursores se utilizan para elaborar las mismas. De estas nuevas drogas hay que decir que han propiciado el aumento del número de consumidores que han sufrido graves consecuencias para la salud, o que incluso han fallecido por haberse expuesto a su acción.

UNDÉCIMA.- Han aparecido precursores de diseño que los traficantes encargan a empresas legales, y se transforman en precursores de drogas realizando procedimientos muy simples. Estas sustancias por sus características químicas, generalmente, no están sujetas a ningún tipo de control.

DUODÉCIMA.- Veintiocho años de fiscalización internacional de precursores han demostrado la capacidad de las organizaciones de tráfico de sustancias químicas para adaptarse rápidamente a las presiones ejercidas por los órganos de reglamentación y de aplicación de la ley. Concretamente, sus posibilidades de obtener sustancias intermedias, de elaborar ellos mismos los precursores que necesitan, así utilizar métodos más complejos para la fabricación de drogas, como lo manifiesta la posibilidad que tienen de utilizar otras materias primas y otros métodos que anteriormente se consideraban demasiado complejos y costosos como para emplearlos en entornos ilícitos. Debiéndose tener en cuenta que todo esto, se ve agravado por el aumento continuo de las clases y cantidades de drogas sintéticas, no obtenidas de plantas, y la velocidad sin precedentes con que se producen ahora los cambios de una sustancia a otra, habida cuenta de la flexibilidad con que actúan los traficantes en lo que respecta a la obtención de precursores y la fabricación ilícita.

DECIMOTERCERA.- A pesar de los colosales esfuerzos, normativos, judiciales, policiales, administrativos y financieros, realizados por los gobiernos de prácticamente todo el mundo por erradicar el tráfico de drogas ilegales, y en el caso que nos atañe de los precursores de estas drogas, continúa siendo una meta inalcanzable, debiendo señalarse que lamentablemente tampoco se ha logrado reducir la oferta ni la demanda de las mismas, además los precios finales de las drogas en el mercado ilegal o bien se mantienen estables o peor aún, han bajado y su grado de pureza a nivel general se mantiene. Por otra parte desafortunadamente las organizaciones delictivas que trafican con precursores de drogas 
son cada vez más grandes y más hábiles, están mejor organizadas, son más adapatables y están en condiciones de eludir el creciente número de medidas de fiscalización que se han establecido, lo que hace necesario una profunda reflexión sobre la estrategia a seguir sobre este tema en el plano internacional, porque lo que se ha hecho hasta ahora, en nuestra opinión, no ha producido los resultados deseados. Ya que los informes más optimistas afirman que las autoridades competentes logran incautar anualmente hasta $20 \%$ de los precursores que se utiliza para elaborar los estimulantes de tipo anfetamínico y aproximadamente $15 \%$ de las sustancias catalogadas que se emplean para elaborar cocaína, heroína y sus productos derivados.

\section{CONCLUSIONES DE LA SEGUNDA PARTE}

PRIMERA.- Es función del Estado la protección de bienes jurídicos, para lo cual este dispone de diferentes medios de control (formalizados y no formalizados). Entre éstos, cuenta con las diferentes ramas del ordenamiento jurídico del cual es parte integrante el Derecho Penal, al que siendo consecuentes con los principios de fragmentariedad, subsidiaridad, y última ratio no le corresponde la tutela de todos los bienes jurídicos, sino sólo de aquellos esenciales para posibilitar la participación de las personas individualmente consideradas en el sistema social de tal forma que si la tutela de determinados bienes jurídicos puede dispensarse por cualquier otra rama del ordenamiento jurídico u otro medio de control social no formalizado, debe preferirse éste, pues, el Derecho Penal está llamado a proteger los bienes más importantes para el desarrollo de las personas en el marco social, frente a las modalidades de ataque más graves, lo que pone de manifiesto que el concepto de bien jurídico es mucho más amplio que el de bien jurídico penal. Por ello nos oponemos a las leyes penales de carácter simbólico que no sirven para la protección de bienes jurídicos, sino que persiguen fines extrapenales, como la tranquilidad del electorado o la de procurarle una buena imagen al Estado.

SEGUNDA.- Optamos por un concepto de bien jurídico de corte sociológico y constitucionalmente orientado, pues entendemos que "la concurrencia entre las posiciones sociológicas y constitucionales no es sólo posi- 
ble, sino absolutamente necesaria", lo que nos conduce a concluir que la Constitución es un marco de referencia (compatibilidad) imprescindible pero insuficiente para la determinación de los bienes jurídicopenales dada la complejidad y dinamismo de las relaciones sociales que existe en la actualidad, las cuales, bajo ningún concepto pueden ser ignoradas (dañosidad social). Otro criterio que no podemos dejar de observar es la necesaria orientación personal en el entendido de que el Derecho existe por y para los individuos considerados tanto individual como colectivamente, siendo necesario además recurrir a los criterios de merecimiento, necesidad e idoneidad de pena para poder determinar qué realidades deben de ser objeto de tutela jurídico penal.

TERCERA.- Por ello, la protección de los bienes jurídicos penales colectivos, independientemente de que puedan tener un carácter autónomo con relación a los bienes jurídicos individuales y que necesiten un tratamiento acorde con su diversidad, estará condicionada a su utilidad para el desarrollo personal del individuo dentro del marco social, así como a las exigencias derivadas de los principios de merecimiento, necesidad e idoneidad de pena, lo cual nos lleva a concluir en este sentido que el Derecho Penal deberá seguir tutelando los bienes jurídicos más importantes (las condiciones esenciales que todas las personas consideradas tanto individual como colectivamente necesitan para su autorrealización y el desarrollo de su personalidad en la vida social), de sus modalidades de ataque más graves, cuando estos, no puedan protegerse por otro medio menos lesivo que el Derecho Penal, dándole cumplimiento a los principios de subsidiaridad, fragmentariedad y ultima ratio.

CUARTA.- Lo sostenido hasta aquí nos lleva a entender que bienes jurídicos son las condiciones esenciales que todas las personas consideradas tanto de forma individual como colectivamente necesitan para su autorrealización y el desarrollo de su personalidad en la vida social. En este concepto se advierte la orientación personal del bien jurídico, lo cual de ninguna manera niega la protección de bienes jurídicos colectivos, siempre que la lesión o puesta en peligro de estos, afecte la realización personal de los individuos que integran la sociedad, siendo imprescindible para ello, sin duda alguna, el reconocimiento de la dignidad humana y por consiguiente, el libre desarrollo de la personalidad. Queremos hacer la aclaración de que las condiciones esenciales a las que nos referimos pueden consistir tanto en objetos materiales como inmateriales, relaciones, intereses o derechos que necesariamente deben 
ser socialmente valiosos, así como que las condiciones antes aludidas requieren tener además un titular concreto (las personas consideradas tanto individual como colectivamente).

QUINTA.- Partimos de la idea comúnmente aceptada por la doctrina de que el legislador no crea los bienes jurídicos, sino que estos surgen del desarrollo social y al Derecho lo que le compete es reconocerlos, otorgarles tal categoría. Así el concepto material de delito es previo al Código Penal y éste, dota al legislador de un criterio político-criminal para determinar las conductas o comportamientos que deben criminalizarse. Asumida esta idea nos pronunciamos a favor de un concepto de bien jurídico trascendente al sistema, en los términos antes señalados, rechazando de forma tajante aquellas concepciones inmanentes que dejan relegado al bien jurídico a un simple problema interpretativo, lo cual nos obligaría a buscar el contenido de este en la misma norma, situación que consideramos nos conduciría a un círculo vicioso, pues bastaría con la simple desobediencia a la norma para justificar la protección penal. De esta manera la mera desobediencia al Estado justificaría sobradamente la criminalización de cualquier conducta, de lo cual se infiere que un presupuesto que reviste vital importancia en la búsqueda del concepto material del bien jurídico-penal, es precisamente que este no debe perder la vinculación con la realidad social en la cual debe operar. De esto, se deduce que para que pueda cumplir con la función crítica limitando al legislador y a los jueces en los procesos de criminalización primaria y secundaria, tiene que ser coherente y funcional a un sistema de valores que están relacionados de forma directa con la realidad histórica que se vive y la que se pretende alcanzar.

SEXTA.- Resulta necesario, de conformidad con el principio de proporcionalidad, realizar una ponderación de intereses entre las libertades creadas o protegidas por el Estado y las que se restringen con la imposición de las penas y medidas de seguridad. El Estado, irremediablemente, para poder crear seguridad, se ve en la obligación de restringir libertad, por lo cual se propone la exigencia de que entre la seguridad creada y la libertad restringida se produzca un saldo positivo. Además, el Estado está obligado a elegir siempre la medida menos ofensiva, de tal forma que se obtenga la máxima protección al mínimo coste que supone a su vez, el máximo de libertad, por lo que el bien lesionado o puesto en peligro, debe ser más importante o al menos semejante al bien restringido, lo que expresado en forma coloquial podría explicarse 
de la siguiente manera: no puede de ninguna manera resultar más grave para las personas el remedio que la propia enfermedad.

SÉPTIMA.- Todo lo dicho hasta aquí, como no puede ser de otro modo, es válido para los bienes jurídicos colectivos, más aún cuando su protección se realiza generalmente mediante la tipificación de delitos de peligro abstracto, que es la técnica de tutela penal más anticipada, por lo que opinamos debe recurrirse en estos casos a su protección mediante el Derecho Penal como último recurso, valga la redundancia con un plus de ultima ratio, de tal manera que las conductas seleccionadas representen ataques realmente graves a bienes jurídicos de la mayor importancia para que esta extrema tutela esté justificada, lo que de ninguna manera, significa dar la espalda a la realidad social, pues entendemos que las transformaciones económicas y tecnológicas que han hecho surgir nuevas entidades (bienes colectivos) que cumplen con los criterios anteriormente señalados deben ser objeto de protección del Derecho Penal.

OCTAVA.- La ausencia de un bien jurídico que tutelar despoja a la norma penal de su contenido material y por tanto de su legitimidad, y aún más, posibilita la realización de abusos por parte del Estado sobre las personas y la comunidad en general, por lo cual en nuestra opinión resulta acertado afirmar que el concepto de bien jurídico racionaliza al Derecho Penal. No obstante, estimamos necesario destacar en este momento que el principio de estricta protección de bienes jurídicos no constituye el único límite que nos ofrece la dogmática jurídico-penal frente al ius puniendi estatal. Este, ha de complementarse con el principio de lesividad, el principio de intervención mínima y en atención al mismo con los criterios de merecimiento de pena, necesidad de pena, y de proporcionalidad, sin olvidar el principio de intervención legalizada, así como otros criterios señalados anteriormente.

NOVENA.- Como en el delito de tráfico de precursores de drogas la posibilidad de lesionar o menoscabar el bien jurídico salud pública resulta más distante que en los delitos relativos al tráfico de drogas (elaboración o fabricación de drogas ilícitas y más aún de su tráfico propiamente dicho), la doctrina mayoritaria cuestiona su legitimidad por estar reñido con el principio de lesividad, de fragmentariedad, subsidiaridad y de ultima ratio y por consiguiente constituir un delito de peligro presunto que encuentra su legitimidad en un acto de mera desobediencia, 
que no debería trascender del orden administrativo. Constituyendo su inclusión en el ordenamiento jurídico penal un claro ejemplo del afán de control total preventivo del legislador, pues tipifica conductas donde el bien jurídico protegido resulta impreciso, por lo cual no es patente que sea merecedor de tutela penal producto del incierto contenido lesivo que comportan las distintas conductas que sanciona este tipo penal. Afirmándose además que esta pretensión de crear preceptos omnímodos provoca una redacción tortuosa de los tipos, con remisiones entre ellos, conceptos indeterminados, reenvíos tremendamente generales a normas extrapenales, incluso hacia el futuro que entran en contradicción con principios sumamente asentados en el Derecho Penal.

DÉCIMA.- A pesar de las objeciones citadas, de las cuales no se puede predicar que sean infundadas, queremos puntualizar que en el caso de la tenencia o fabricación de precursores de drogas que se utilizan para la elaboración de las drogas de diseño, donde no hace falta ni la hoja de coca ni las capsulas verdes de la adormidera para elaborar cocaína o heroína, tales como la efedrina, seudoefedrina, la P-2-P o la 3,4-MDP-2$\mathrm{P}$, el ácido lisérgico o la piperidina, la posibilidad de menoscabo del bien jurídico salud pública, más aún si está se realiza en emplazamientos cercanos a los laboratorios o en los propios laboratorios donde se fabricara la droga, parece un poco menos distante, pues equivale a tener la materia prima (principal) para elaborar anfetamina, metanfetamina, éxtasis, LSD o fenciclidina, dado que sólo hace falta realizar unos procedimientos bastantes sencillos con equipos muy rudimentarios y otras sustancias esenciales para obtener dichas drogas. La introducción de los elementos subjetivos, en el artículo 371 CP, "a sabiendas de" o "para estos fines" (elaboración de drogas ilícitas) no evita el uso de la técnica de los delitos de peligro abstracto para su tutela, pero sí impide afirmar con propiedad que se trate de un delito presunto que castiga un acto de mera desobediencia. Además, el tráfico de estas sustancias catalogadas cuando consiste en la realización de acciones imprudentes o bien del incumplimiento de normas de carácter administrativo se encuentra sancionado por la Ley 4/2009, de 15 de junio, de control de precursores de drogas.

UNDÉCIMA. - Los delitos de peligro abstracto son aquellos en los que el legislador decide su sanción tomando como base la experiencia, la peligrosidad general de determinadas conductas (teoría de la peligrosidad 
general) para el bien jurídico tutelado, de tal manera que basta con la realización del comportamiento típico para cometer el delito de forma consumada, así el autor, será castigado aun cuando en el caso concreto la acción no hubiera dado lugar a un auténtico peligro, razón por la cual se afirma que en estos delitos el peligro no constituye un elemento del tipo de injusto, por lo cual se parte de un juicio de probabilidad estadística, en el que no se pronostica un daño concreto, sino una relación estadística entre un cierto tipo de comportamientos y un resultado lesivo. Queremos subrayar que esta definición de delitos de peligro abstracto se corresponde claramente con los denominados "delitos de peligro abstracto puros", que son actos de mera desobediencia.

DUODÉCIMA.- Para sostener la fundamentación de la antijuricidad de un delito de peligro abstracto no basta con un mero desvalor de acción que se materializa en la peligrosidad de la conducta, pues sin la presencia del desvalor de resultado, debiendo diferenciarse entre el resultado material que sólo concurre en los delitos de resultado y el resultado jurídico que debe estar presente en todos los ilícitos, no se cumple con el principio de lesividad de forma cabal. Por ello creemos que en todo delito de peligro la conducta realizada debe manifestarse como idónea para afectar a un bien jurídico, lo que supone no colocar a este en una situación que no quedaría explicada por la contemplación solamente de la acción, por lo tanto hay que concluir que la peligrosidad de la acción, incluso en los delitos de peligro abstracto, debe comportar un riesgo de menoscabo que, por lo menos a nivel lógico, se pueda distinguir de la acción propiamente dicha. En esta línea un sector muy importante de la doctrina española exige la presencia de una auténtica aptitud lesiva de la acción de estos delitos, que se materialice en que la conducta posea la idoneidad objetiva para lesionar un bien jurídico. Sin embargo hay que decir que la discusión que se ha generado en este sentido, lamentablemente, aún no ha conducido a conclusiones reconocidas de forma general, sin embargo si existe un consenso significativo sobre la necesidad de distinguir distintos grupos de casos con problemas configurados de forma diferente.

DECIMOTERCERA.- Lo ideal sería que el legislador evitara los delitos de peligro abstracto, siempre que fuera posible, de tal manera que se recurra a esta técnica de protección de bienes jurídicos con carácter excepcional, es decir, sólo cuando razones de política criminal lo exijan. En estos casos deberá optarse por delitos de peligro abstracto que 
además de acreditar la peligrosidad de la conducta (desvalor de acción) comporten un desvalor de resultado, al menos potencial o intermedio, en el que si bien no se exige un resultado estructural, si sea necesaria una cierta vinculación con el bien jurídico tutelado que responda al cumplimiento del principio de exclusiva protección de bienes jurídicos y, al menos en cierta medida, a su correlato el principio de ofensividad. Debe tratarse por tanto de delitos en los que sea posible identificar el objeto de tutela. Por lo dicho hasta aquí queremos manifestar que debe recurrirse a la técnica de los delitos de peligro abstracto como último recurso, valga la redundancia con un plus de ultima ratio, de tal manera que las conductas seleccionadas representen ataques realmente graves a bienes jurídicos de la mayor importancia para que esta extrema tutela esté justificada, lo que de ninguna manera significa dar la espalda a la realidad social, pues entendemos que las transformaciones económicas y tecnológicas que han hecho surgir nuevas entidades (bienes colectivos) que cumplen con los criterios anteriormente señalados deben ser objeto de protección del Derecho Penal.

DECIMOCUARTA.- De lo expuesto hasta ahora se deduce que nos oponemos de forma categórica a la creación de delitos de peligro abstracto que tengan como base una función meramente organizativa, como ocurre en aquellos ilícitos basados en la ausencia o infracción de una autorización o control administrativo, los cuales en nuestra opinión deben cumplir con la exigencia que plantea que el núcleo de la acción punible debe consistir en algo más que una infracción de normas administrativas, dado que de no ser así se diluye notablemente el instituto de la pena, por lo cual reivindicamos que ante la ausencia de un peligro, al menos de carácter potencial, para un bien jurídico de suficiente entidad, tales supuestos deben de sancionarse en el ámbito del Derecho Administrativo sancionador, o bien en otra área del Derecho según corresponda. Igual opinión mantenemos sobre la penalización de los denominados delitos acumulativos que vulneran de forma indudable el principio de lesividad y de proporcionalidad al desentenderse totalmente de realizar la respectiva valoración de la gravedad de la acción individual.

DECIMOQUINTA.- Nos centramos particularmente en tres de las posiciones desarrolladas en la doctrina española para dotar de legitimidad a los delitos de peligro abstracto, la primera de ellas es la que planteara el profesor Bustos Ramírez que sostiene que la protección se puede op- 
timizar si se parte de una correcta determinación del bien jurídico, lo cual evitaría tipificar conductas abstractamente peligrosas, dado que la correcta determinación del bien jurídico colectivo puede permitir establecer un desvalor real capaz de fundamentar la antijuricidad material $\mathrm{y}$, por ende, indicarnos las conductas que verdaderamente son merecedoras y necesitadas de pena por comportar una lesión o puesta en peligro concreto, no de los bienes jurídicos complementados (individuales), sino de los bienes jurídicos complementarios (colectivos). Desde esta perspectiva se puede asumir que las conductas comprendidas en los delitos relativos al tráfico de drogas tipificadas en el artículo $368 \mathrm{CP}$, sobre todo las relativas al tráfico o favorecimiento del consumo ilegal de estas sustancias ilícitas tales como el almacenamiento y depósito, transporte, exportación, importación, transito, así como la enajenación y la correlativa adquisición de la sustancia estupefaciente, la donación o bien el promover, favorecer o facilitar el consumo ilegal de drogas de otro modo, pueden suponer la lesión o un peligro concreto para el bien jurídico salud pública. Pero entendemos que la protección de este bien jurídico a través del artículo 371 CP en principio no estaría justificada, pues este tipo penal sanciona la fabricación, distribución, comercio o tenencia de precursores de drogas a sabiendas de que van a utilizarse en la elaboración de drogas ilícitas o para estos fines, lo cual a pesar del plus de peligrosidad que le aportan la obligación de comprobar los elementos subjetivos "a sabiendas de" o "para estos fines" por parte del juzgador, no parece representar un peligro concreto para el bien jurídico tutelado.

DECIMOSEXTA.- No obstante queremos poner de manifiesto que en el caso de la tenencia de precursores de los estimulantes de tipo anfetamínico tales como la efedrina, la seudoefedrina, la norefedrina, la P-2-P, el ácido fenilacético, la 3,4-MDP-2-P, piperonal, el ácido lisérgico, la ergotamina, la ergometrina, el ácido $\mathrm{N}$-acetilantranílico o la piperidina en nuestra opinión la posibilidad de menoscabo del bien jurídico salud pública resulta un poco menos distante, pues estas sustancias son la materia prima principal para la elaboración de drogas de síntesis, más aún si está se realiza en emplazamiento cercanos a los laboratorios o en los propios laboratorios donde se elaborará la droga, pues equivale a tener en estos una remesa de hojas de coca, pasta de coca o el latex de la adormidera listas para proceder a fabricar cocaína o heroína, por lo tanto podrían equiparase a la fase final del cultivo de drogas o a la ini- 
cial de la elaboración de las mismas. Sin embargo queremos precisar que mientras en el delito de tráfico de precursores de drogas se exige a través del elemento subjetivo adicional el conocimiento por parte del autor o de los autores de que dichas sustancias serán utilizadas en la fabricación ilícita de drogas o para estos fines, en las conductas preceptuadas en el artículo 368 CP se requiere, algo más, que el autor o los autores pretendan "la difusión del consumo ilegal" lo que obviamente marca una diferencia importante.

DECIMOSÉPTIMA. - La otra idea que queremos destacar es la sostenida por el profesor Torío López quien propuso que cuando se tenga que recurrir, por no existir otra opción, a los delitos de peligro abstracto, debe exigirse, además del desvalor de acción, un desvalor al menos potencial de resultado, de esta manera, en la medida que se correspondan con la tipología propuesta de los delitos de peligro hipotético, cumplirían, al menos en cierta medida, con la perspectiva dualista que se reivindica para todo ilícito penal, mientras que cuando esto no ocurra se estará penalizando un acto de mera desobediencia, ajeno a los límites del Derecho Penal. Por tanto el delito requiere una acción que por sus propiedades materiales sea susceptible de ser considerada según un juicio de pronóstico como peligrosa para el objeto de tutela, estando obligado el juez a verificar si en la situación concreta ha sido posible un contacto entre acción y bien jurídico, en cuya virtud hubiera podido producirse un peligro efectivo para éste. Nosotros creemos que con esta propuesta el delito de tráfico de precursores de drogas podría en principio estar legitimado de alguna manera, sobre todo si tomamos el ejemplo que citamos antes sobre la tenencia de los precursores de los estimulantes de tipo anfetamínico en un local cercano al laboratorio ilícito o en el mismo donde tengan previsto elaborar anfetamina, metanfetamina, éxtasis y similares, LSD, metacualona, meclocualona o fenciclidina. En este momento cabe recordar que los delitos de peligro nunca reclaman un grado determinado o coeficiente matemático exacto de peligrosidad del comportamiento, así como que las conductas comprendidas en el artículo $371 \mathrm{CP}$ la mayoría de las veces son realizadas por auténticas mafias que operan a nivel internacional (criminalidad organizada), con bastante éxito debido a su gran capacidad económica y de innovación, utilizando los mismos métodos y medios que usan para el tráfico de drogas. No obstante entendemos las reservas que un sector muy importante de la doctrina tiene al respecto, pues la incriminación de la 
tentativa de los delitos de peligro, bien sea este real o potencial no debe estar legitimada sin más, y por ende, mucho menos la de actos preparatorios de delitos de peligro". En el caso del artículo $373 \mathrm{CP}$, en que sanciona la provocación, la conspiración y la proposición del tráfico de precursores de drogas, desde esta perspectiva también se puede concluir que su criminalización carece de legitimidad por el desmesurado adelantamiento que se produce del ámbito de protección penal.

DECIMOOCTAVA.- Por último es preciso señalar que para las posturas doctrinales que exigen para la legitimación de los delitos de peligro abstracto que la peligrosidad este presente sólo en "el desvalor de acción" o bien aquellas que desarrollan "los delitos de peligro abstractoconcreto" o "los delitos de aptitud" las conductas comprendidas en el delito de tráfico de precursores de drogas estarían justificadas sin mayores problemas. En este sentido se pronuncia un sector importante de la jurisprudencia en España afirmando que "el peligro abstracto no debe de ser confundido con el peligro presunto, de forma que cualquier acción que cumpla objetivamente la hipótesis legal, se entiende ya per se, sin admisión de prueba o estimación en contrario, integradora del delito, pues tal tipo de presunción vulneraría el esencial derecho constitucional a la presunción de inocencia". Por lo tanto peligro abstracto sólo quiere decir que "en el momento de la consumación anticipada, con que el legislador ha configurado el tipo, no están concretados o determinados los sujetos portadores del bien jurídico protegido, cuya salud va a ser puesta en peligro o afectada por el agotamiento de la acción. Pero lo que sí es preciso es que tal peligro, como riesgo de futura lesión de aquel bien jurídico, se encuentre realmente presente en la acción para que ésta incluya en sí el contenido de la antijuricidad material y la adecuación al tipo necesarios para su ilicitud penal".

DECIMONOVENA.- Atendiendo a principios y criterios muy asentados en teoría del delito tales como: el principio de lesividad, de fragmentariedad, subsidiaridad y ultima ratio, cabría afirmar que el tráfico de precursores de drogas no tienen la suficiente entidad para su protección de forma autónoma en el Derecho Penal mediante la técnica de los delitos de peligro abstracto, a pesar de que tutela un bien jurídico de suma importancia como es la salud pública, merecedor de protección penal. Ésta se encuentra justificada en la mayoría de supuestos establecidos en los delitos relativos al de tráfico de drogas, pero no se puede decir lo mismo en el caso de las conductas contempladas en el delito de tráfico 
de precursores, dado que la posibilidad de afectación de este bien jurídico es más lejana. Se trata de actos preparatorios del delito de tráfico de drogas que por decisión del legislador se elevan a la categoría de delito autónomo. De hecho, estos comportamientos no son simples infracciones formales, porque tienen incorporado el elemento subjetivo adicional "a sabiendas de" o "para estos fines". De no ser así, el artículo 371 CP tendría que ser declarado inconstitucional en los mismos términos que lo fue el artículo 509 del anterior Código Penal. No obstante, creemos que la introducción del elemento subjetivo adicional antes mencionado permite que no se pueda afirmar con propiedad de que se trate de un delito de peligro presunto que castiga un acto de mera desobediencia, pues los comportamientos de fabricar, transportar, distribuir, comerciar o tener en su poder las 24 sustancias catalogadas como precursores de drogas con la finalidad de elaborar drogas ilícitas, aunque no representan la producción de un peligro efectivo para el bien jurídico salud pública, sí constituyen acciones aptas para producir un peligro a este bien jurídico, se trata por lo tanto de la posibilidad y no de la realidad, del peligro para el bien jurídico tutelado, lo cual podría permitir apreciar de alguna manera un desvalor potencial de resultado.

VIGÉSIMA.- Sin embargo, somos conscientes de que es improbable que se produzca un cambio de orientación en la política criminal sobre este ilícito, que tiene ya casi 25 años de vigencia. España está obligada a sancionar penalmente este tipo de conductas para dar cumplimiento a sus compromisos internacionales tales como el Convenio de Viena de 1988 y otras normativas comunitarias como la Decisión Marco 2004/757/JAI del Consejo, de 24 de octubre, que señala de forma expresa la necesidad de que los Estados miembros sancionen con penas máximas de 5 a 10 años los delitos de tráfico de precursores de drogas cuando se cometan en el seno de una organización criminal. Además, quienes suelen realizar las conductas preceptuadas en el delito de tráfico de precursores de drogas son organizaciones criminales que operan a nivel internacional con mucho éxito, debido a su gran capacidad económica y de innovación, valiéndose de los mismos métodos y medios que usan para el tráfico de drogas. De hecho pese a todo el esfuerzo que se realiza a nivel mundial, haciendo uso del ordenamiento penal, del administrativo sancionador y de una parte muy importante de todos los recursos de los cuerpos y fuerzas de seguridad, sólo logra confiscar anualmente el 15\% de los precursores que se utilizan para la 
elaboración de la cocaína y la heroína, y el 20\% de los estimulantes de tipo anfetamínico, lo cual nos lleva al convencimiento de que no podría enfrentarse esta área de la narcoactividad en buena medida sin la intervención del Derecho Penal, y de su tutela adelantada mediante un delito de peligro abstracto, sumamente cuestionado, como el tráfico de precursores de drogas, que precisa de la aplicación de medidas como la entrega vigilada, el uso de agentes encubiertos o las intervenciones telefónicas, ajenas al Derecho Administrativo. Por lo dicho hasta aquí sostenemos que no es conveniente proponer la despenalización de este delito, pero si trabajar en aras de ofrecer unas pautas de interpretación lo más seguras posibles y respetuosas de los principios básicos de Derecho Penal, para lo cual nos permitimos realizar las recomendaciones que se expresan en las conclusiones siguientes.

VIGESIMOPRIMERA.- En atención al principio de legalidad, por la redacción defectuosa del artículo 371, las conductas que consistan en fabricar, transportar, distribuir, comerciar o tener en su poder equipos y materiales a sabiendas de que van a utilizarse en el cultivo, la producción o la fabricación ilícita de drogas tóxicas, estupefacientes o psicotrópicos no pueden subsumirse en este tipo penal. Por ello, si el legislador desea que sí lo sean, es necesario que reforme este artículo especificando con mejor criterio los equipos o materiales que se consideran precursores a efectos de esta infracción, elaborando un catálogo exhaustivo como se ha hecho en los Cuadros I y II del Convenio de 1988, $\mathrm{o}$ al menos delimitando mejor a que equipos y materiales se refiere.

VIGESIMOSEGUNDA.- En la vertiente subjetiva del tipo, el dolo exige que el sujeto activo tenga conocimiento de que las sustancias que fabrica, transporta, distribuye, comercie o posee, sean precursores de drogas tóxicas, estupefacientes o psicotrópicos $y$, a pesar de esta comprensión, realice voluntariamente los actos prohibidos. Se trata de un tipo de injusto que, además del elemento subjetivo general integrado por el dolo, se caracteriza por ser portador de un particular elemento subjetivo adicional, consistente en que las sustancias relacionadas en el artículo 371 sean fabricadas, transportadas, poseídas o comercializadas, a sabiendas de que van a utilizarse (por un tercero) en el cultivo, la producción o la fabricación ilícita de drogas tóxicas, estupefacientes o sustancias psicotrópicas, o para esos fines (por el propio sujeto activo). Ello implica la exigencia en ambos casos del dolo directo. En consecuencia, este delito requiere una acción que, por sus propiedades ma- 
teriales, sea susceptible de ser considerada según un juicio de pronostico como peligrosa para el bien jurídico salud pública, por lo que el juez además debe comprobar si en el caso concreto ha sido posible un contacto entre la acción y el bien jurídico tutelado, en el cual hubiera podido producirse un peligro efectivo para este o al menos un peligro de carácter potencial. Además, sería recomendable que, al igual que se hace en el delito de tráfico de drogas, se exigiera que el tráfico de precursores estuviese destinado a la elaboración de drogas para la difusión del consumo ilegal, con el fin de excluir la relevancia penal de quienes realicen las conductas comprendidas en el artículo $371 \mathrm{CP}$ para el autoconsumo de drogas.

VIGESIMOTERCERA.- La fabricación, transporte, distribución, comercio o tenencia de precursores de drogas comprendidos en el artículo $371 \mathrm{CP}$, como su idoneidad para la comisión del delito de tráfico (elaboración de drogas ilícitas), y su especial destinación por él o los procesados para la ejecución de éste ilícito, corresponderá siempre probarlas como cualquier otro elemento inculpatorio a la parte acusadora. Ello supone que la ley no podrá exigir al acusado que aporte prueba de descargo al respecto, aunque le ampare el derecho de hacerlo o de alegar y probar una finalidad diferente. De esta manera, los juicios de inferencia realizados por los tribunales para demostrar el elemento subjetivo del tráfico de precursores de drogas, en los cuales se recurre a la llamada prueba indirecta o indiciaria, se deben cumplir los siguientes requisitos: 1) que los indicios estén plenamente acreditados; sean plurales, o excepcionalmente sea único pero de una singular potencia acreditativa; sean concomitantes al hecho que se trata probar, y estén interrelacionados, cuando sean varios, reforzándose entre sí; 2) que, a partir de esos indicios, se deduzca el hecho consecuencia como juicio de inferencia razonable, es decir, que no solamente no sea arbitrario, absurdo o infundado, sino que responda plenamente a las reglas de la lógica y de la experiencia, de manera que de los hechos base acreditados fluya, como conclusión natural, el dato precisado de demostración, existiendo entre ambos un enlace preciso y directo según las reglas del criterio humano; 3) que la sentencia exprese cuáles son los hechos base o indicios en que apoye el juicio de inferencia, y que explique el razonamiento a través del cual partiendo de los indicios se llega a la convicción sobre el acaecimiento del hecho punible y la participación del acusado. En definitiva, se exige que el razonamiento se apoye en elementos de 
hecho y que éstos sean varios, estén debidamente acreditados, se relacionen reforzándose entre sí, así como que el juicio de inferencia pueda considerarse razonable y que la sentencia lo exprese.

VIGESIMOCUARTA.- Sería muy conveniente reformar las penas establecidas en el artículo 371, pues una cosa es elevar un acto preparatorio a la categoría de delito, ya sea para darle cumplimiento a un compromiso internacional o por razones de política criminal, y otra muy distinta es equiparar este en pena al delito que le da vida. En este sentido, creemos que sería razonable que las penas para el tráfico de precursores continúen, al menos, siendo una pena intermedia entre la establecida para el tráfico de drogas blandas y drogas duras, de tal manera que la penalidad para este tipo de conductas sea de dos a cinco años de prisión y no de tres a seis años que es la misma pena establecida para el tráfico de drogas duras, lo cual sin lugar a dudas es un despropósito jurídico contrario a todo criterio de proporcionalidad. Siguiendo con esta lógica, debería imponerse la pena en su mitad superior (de tres años y seis meses a cinco años) cuando los procesados pertenezcan a una organización dedicada al tráfico de precursores, y la pena superior en grado (de cinco a siete años y seis meses) cuando se trate de los jefes, administradores o encargados de las referidas organizaciones. Esta propuesta cumpliría lo dispuesto en la Decisión Marco 2004/757/JAI del Consejo, de 24 de octubre, que señala de forma expresa la necesidad de que los Estados miembros sancionen con penas máximas de 5 a 10 años los delitos de tráfico de precursores de drogas cuando se cometan en el seno de una organización criminal. Lo cual implicaría reformar en este sentido la redacción del artículo 570 bis.

VIGESIMOQUINTA.- Sobre el artículo 570 ter hay que señalar que la definición de grupo criminal que contiene se caracteriza por la finalidad que guía a quienes se conciertan, sin precisar requisitos materiales que permitan conceptuar estas modalidades de agrupaciones como criminalidad organizada, esta redacción verdaderamente deficiente, ha repercutido generando una jurisprudencia plural, muchas veces confusa, que se ve obligada a recurrir a elementos que literalmente no contempla la Ley tanto para responder al sentido de estas tipificaciones como modalidades menores de criminalidad organizada, como para permitir su delimitación de las organizaciones criminales y de la codelincuencia. Por ello se puede concluir que los grupos criminales no constituyen modalidades de criminalidad organizada en sentido estricto, por lo que 
carecen de los elementos que fundamentan su punición autónoma y por ello sería recomendable suprimir el delito de pertenencia a grupo criminal, dado que la expansión punitiva que representa su inclusión junto al delito de pertenencia a organización criminal no se puede fundamentar materialmente, respondiendo únicamente a una línea político criminal que no tiene correspondencia además, con los instrumentos internacionales suscritos por España. En todo caso si no se elimina este tipo penal, que es lo más probable, es urgente que se haga un estudio a conciencia del mismo para mejorar, aunque sea un poco, las incoherencias manifestadas.

VIGESIMOSEXTA.- La supresión del artículo 369.2 por el artículo centésimo quinto del artículo único de la Ley Orgánica 5/2010 del día 22 de junio ha generado un incumplimiento sobrevenido de la Decisión Marco 2004/757/JAI del Consejo de 24 de octubre de 2004, que exige expresamente establecer para el tráfico de precursores, al igual que para el delito de tráfico de drogas, la responsabilidad penal de las personas jurídicas. Esta situación debe solventarse cambiando la redacción del segundo párrafo del artículo 371.2 que podría reformarse en el siguiente sentido: "En tales casos, los jueces y tribunales impondrán además de las penas correspondientes, la de inhabilitación especial del reo para el ejercicio de su profesión o industria, por un tiempo de dos a cinco años, y las demás medidas previstas en el tercer párrafo del artículo 369 bis". Otra solución podría ser la reforma del tercer párrafo de este artículo, redactándose de la siguiente forma: "Cuando de acuerdo con lo establecido en el artículo 31 bis una persona jurídica sea responsable de los delitos recogidos en los dos artículos anteriores y en el artículo 371, se le impondrán las siguientes penas...".

VIGESIMOSÉPTIMA.- El tráfico de precursores es un acto preparatorio del delito de tráfico de drogas elevado a la categoría de delito autónomo. Por ello, resulta cuestionable la admisión de las formas imperfectas de ejecución, toda vez que ello supondría un adelantamiento desmesurado del ámbito de protección penal. En consecuencia, la realización de dichas conductas no debería tener relevancia penal. Con todo, asumimos que la autonomía formal del tipo ofrece razones técnico-jurídicas para aceptarlas, coherentes con los criterios que mantiene la jurisprudencia respecto de los delitos relativos al tráfico de drogas, y entendemos que sería peor que se sancionara como delito consumado, y por ende con mayor pena, conductas que claramente serian casos de tentativa. 
VIGESIMOOCTAVA.- Los Tribunales no deberían establecer un concepto unitario de autor en el delito de tráfico de precursores de drogas, mediante el cual se considere como tal a todo el que contribuyera de alguna manera en la realización del delito, como ocurrió por mucho tiempo con el delito de tráfico de drogas, pues entendemos que no existe ningún obstáculo para apreciar casos de complicidad (cooperación necesaria, cooperación no necesaria e inclusive casos de encubrimiento), al tenor del artículo 29 del Código Penal, lo que obviamente permitiría racionalizar las penas que se deben aplicar en atención al nivel de contribución de los partícipes en la consumación del delito.

VIGESIMONOVENA.- En materia de tráfico de drogas, la jurisprudencia es bastante parca a la hora de conceder relevancia al error en cualquiera de sus formas. En el caso del delito de tráfico de precursores de drogas, creemos que puede ser admisible el error de tipo cuando se trate de sustancias respecto de la cuales no exista un conocimiento notorio sobre su cualidad de precursores, debiendo referirse la calificación a los criterios establecidos en el artículo $14.1 \mathrm{CP}$, esto es, atendiendo a las circunstancias del hecho y las personales del autor. Ello podría ocurrir especialmente con alguna sustancia recién incorporada en los Cuadro I y II de la Convención de Viena de 1998, como puede ser el caso del alfafenilacetoacetonitrilo, más conocido como APAAN, que fue agregado en el Cuadro I en el mes de octubre de 2014; con la efedra, el acetite de sasafrás, o bien con precursores enmascarados en otras sustancias no catalogadas, como es el caso de la 3,4-MDP-2-P camuflada en 3,4-MDP-2$\mathrm{P}$ glicidato de metilo, o bien de la P-2-P enmascarada en bisulfito P-2-P o bisulfito BMK.

TRIGÉSIMA.- Sobre el artículo $373 \mathrm{CP}$, que sanciona los actos preparatorios punibles en los delitos previstos en los artículos 368 al 372, hay que decir que en el caso del artículo 371 CP la situación es verdaderamente insostenible, pues se sanciona la provocación, la conspiración y la proposición de fabricar, transportar, comerciar o simplemente la tenencia de las sustancias clasificadas como precursores de drogas, criminalizando de esta manera un acto preparatorio de un acto preparatorio del delito de tráfico de drogas. Por lo que resulta ineludible proponer la eliminación del tráfico de precursores del artículo 373 del ordenamiento penal. 
TRIGÉSIMOPRIMERA.- Para finalizar, es importante señalar que los resultados obtenidos hasta el día de hoy en la lucha contra el tráfico de precursores de drogas, tanto en el ámbito internacional como en España, distan mucho de poder considerarse satisfactorios. Mientras continúe siendo tan rentable el negocio del narcotráfico, estarán a la orden obreros, campesinos, empleados, desempleados, transportistas, químicos, intermediarios, pistoleros, repartidores, camellos, asesores, encubridores, empresarios, entidades financieras, políticos, funcionarios corruptos, jueces, fiscales, policías, guardias civiles y militares para hacer cuanto haga falta para mantener en funcionamiento el negocio mundial del tráfico de drogas ilegales y, por ende, el del tráfico de sus precursores.

En el caso de España apenas tenemos constancia de la existencia de 17 sentencias sobre este delito a lo largo de casi un cuarto de siglo desde que fue tipificado por vez primera. A ello se añade que la importancia de los decomisos de sustancias catalogadas en dichos expedientes no ha sido relevante en la mayoría de los casos. Sin embargo, hay que destacar que los casi 14 millones de kilogramos de precursores incautados, durante el transcurso de este periodo de tiempo en España podrían haber sido utilizados para la elaboración de drogas ilícitas en cantidades muy importantes, fundamentalmente de cocaína, heroína, anfetamina, metanfetamina, metcatinona, fenciclidina, MDMA (éxtasis), MDA (tenamfetamina o píldora del amor), MDE (Eva), N-hidroxi-MDA (Hidroxilamina), así como de otros precursores de drogas tales como: ácido fenilacético, isosafrol, piperonal, P-2-P y 3,4-MDP-2-P, sustancias que también se utilizan en la elaboración de las drogas antes citadas. El volumen de precursores decomisados hasta la fecha nos permite suponer, tomando como referencia que se incauten el $20 \%$ del total de las sustancias catalogadas que se desvían o se fabrican ilícitamente, que el tráfico ilícito de precursores mensual en España podría ser de 265.151 kilogramos, y por ende, el de aproximadamente de 3.181.815 kilogramos al año. Siendo los precursores que más se desviarían los siguientes: el tolueno, el ácido sulfúrico, la acetona, la metiletilcetona, el éter etílico, el anhídrido acético, el permanganato de potasio, el ácido clorhídrico, efedrina y piperonal, lo cual en nuestra opinión supone un problema de gran envergadura, tanto para los cuerpos y fuerzas de seguridad como para el poder judicial y para el poder legislativo de cara a poder plantearse la descriminalización de las conductas previstas en el artículo $371 \mathrm{CP}$ y del enfrentamiento de esta área de la narcoactividad 
746 EL TRÁFICO DE PRECURSORES DE DROGAS TÓXICAS, ESTUPEFACIENTES Y...

únicamente con las medidas y sanciones administrativas de la Ley 4/2009 de control de precursores de drogas. 


\section{BIBLIOGRAFÍA CONSULTADA}

ABANTO VÁSQUEZ, Manuel A. "Acerca de la teoría de bienes jurídicos" en Revista Penal. Julio de 2006. № 18. La Ley.

ALBRECHT, Hans-Jörg. Criminalidad transnacional, comercio de narcóticos y lavado de dinero. (Trad. GUERRERO PERALTA, Oscar Julián). Ed. Universidad Externado de Colombia. Bogotá. 2001.

ACALE SÁNCHEZ, María. El tipo de injusto en los delitos de mera actividad. Ed. Comares. Granada. 2000.

ALLINGER, Norman. CAVA, Michael. DE JONGH, Don. JOHNSON, Carl. LEBEL, Norman. STEVENS, Calvin. Química orgánica. Segunda edición. Editorial Reverte S.A. Barcelona, Bogotá, Buenos Aires, Caracas, México, Río de Janeiro. 1978.

ÁLVAREZ GARCÍA, Francisco Javier: "Bien jurídico y Constitución". Cuadernos de Política Criminal n. 043 (1991).

- (Dir.). El Delito de Tráfico de Drogas. Ed. Tirant lo Blanch. Valencia. 2009.

- "La necesidad de un cambio de paradigmas en el tráfico de drogas: la urgencia de su legalización" en Cuadernos de Política Criminal, n.․105, (2011).

ÁLVAREZ GARCÍA, F. Javier (Dir). MANJÓN-CABEZA OLMEDA, Araceli. VENTURA PÜSCHEL, Arturo (Coord.). Derecho Penal Español. Parte Especial. II. Ed. Tirant lo Blanch. Valencia. 2011.

ARANA, Xabier. MARKEZ, Iñaki (Coord.). Los agentes sociales ante las drogas. Ed. Dykinson. Madrid. 1998.

ARANGUEZ SÁNCHEZ, Carlos. ALARCón NAVIO, Esperanza. El Código Penal Francés. Traducido y anotado. Ed. Comares. Granada. 2000.

- "Principales características de la regulación francesa sobre los delitos relativos al tráfico de drogas" en MORILLAS CUEVA, Lorenzo (Coord.). Estudios jurídico-penales y político-criminales sobre tráfico de drogas y figuras afines. Ed. Dykinson. Madrid. 2003. 
ARROYO ZAPATERO, Luis. "Aspectos penales del tráfico de droga" en Revista de la Facultad de Derecho de la Universidad Complutense de Madrid, n. 6 (Monográfico) (1985).

- "Derecho Penal Económico y Constitución" en Revista Penal. N. 1 (1998).

ARROYO ZAPATERO, Luis. BERDUGO GÓMEZ DE LA TORRE, Ignacio. FERRÉ OLIVÉ, Juan Carlos. GARCIA RIVAS, Nicolás. SERRANO PIEDECASAS, José Ramón. TERRADILLOS BASOCO, Juan María (Directores). Comentarios al Código Penal. Ed. Iustel. Madrid. 2007.

BACIGALUPO ZAPATER, Enrique. "Problemas dogmáticos del delito de tráfico ilegal de drogas" en FERNÁNDEZ ALBOR y otros autores. La problemática de la droga en España (análisis y propuestas político- criminales). Ed. Edersa. Madrid. 1986.

- Estudios sobre la Parte Especial del Derecho Penal. Segunda edición. Akal/iure. Madrid. 1994.

BAIGÚN, David. "El bien jurídico orden económico" en BAIGÚN, David (Et. Al.). Estudios sobre Justicia Penal. Homenaje al Profesor Julio B. J. Maier. Ed. Editores del Puerto. Buenos Aires. 2005.

BAJO FERNÁNDEZ, Miguel (Dir.). Compendio de Derecho Penal. Parte Especial. Vol. II. Ed. Centro de Estudios Ramón Areces, S.A., Madrid. 1998.

BARATTA, Alessandro. "Fundamentos ideológicos de la actual política criminal sobre drogas" en DÍEZ RIPOLLÉS, José Luis. La actual política criminal sobre drogas. Una perspectiva comparada. Ed. Tirant lo Blanch. Valencia. 1993.

BARBERO SANTOS, Marino. “Contribución al estudio de los delitos de peligro abstracto" en $A D P C P, 1973$.

- "La reforma penal de la Monarquía Constitucional española" en VVAA. Reforma política y Derecho. Ed. Centro de publicaciones del Ministerio de Justicia Madrid. 1985.

BARRIENTOS PÉREZ, Deisy Janeth. "Lesividad en los vienen jurídicos colectivos y delitos de peligro. Análisis del delito de fabricación, tráfico, porte o tenencia de armas de fuego, accesorios, partes o municiones" en Nuevo Foro Penal. Vol. 11, no 84 (2015).

BERDUGO GÓMEZ DE LA TORRE, Ignacio. Reflexiones sobre la problemática del bien jurídico. Salamanca. Versión dactilográfica. 1990. 
BERDUGO GÓMEZ DE LA TORRE, Ignacio y otros autores. Lecciones de Derecho Penal. Parte General. Ed. Praxis. Barcelona. 1996.

- Curso de Derecho Penal. Parte General. Ed. Experiencia. Barcelona. 2004.

BERNAL CONTRERAS, Héctor Hernando. Las sustancias químicas y el tráfico de estupefacientes. Ed. Ministerio de Justicia y del Derecho. Bogotá. 2003.

- Las Sustancias Químicas y el Tráfico de Estupefacientes. Tercera Edición. Ministerio del Interior y de Justicia. Dirección Nacional de Estupefacientes. Bogotá. 2006.

BlanCo LOZANo, Carlos. Tratado de Derecho Penal Español. Tomo II. El Sistema de la Parte Especial. Volumen 2. Delitos contra los bienes jurídicos colectivos. J.M. Bosch. Editor. Barcelona. 2005.

BOTTKE, Wifried. “¿Roma locuta causa finita? ¿Adiós a la exigencia de protección de los bienes jurídicos?" en LUZÓN PEÑA, Diego Manuel (Dir.). Derecho Penal del Estado Social y Democrático de Derecho. Libro homenaje a Santiago Mir Puig. Ed. La Ley. Madrid. 2010.

BROND, Leonardo G. "Ley de estupefacientes alemana (BtMG)" en Revista de Derecho Penal Argentina, n. $\mathrm{o} 1$ (2004).

BUNZEL, Michael. SCHMIDT, Juana. STOLLE, Peer. "Primera sesión. Teoría del bien jurídico y harm principle". (Trad. ÁLCACER GUIRAO, Rafael) en HEFENDEHL, Roland (Ed.). La teoría del bien jurídico. ¿Fundamento de legitimación del Derecho Penal o juego de abalorios dogmático?. Ed. Marcial Pons, ediciones jurídicas y sociales, S.A. Madrid. Barcelona. 2007.

BUSTOS RAMÍREZ, Juan. Control Social y Sistema Penal. Ed. PPU. Barcelona. 1987.

- Manual de Derecho Penal. Parte General. Ed. Ariel. Barcelona. 1989.

- Derecho Penal. Parte Especial. Segunda Edición. Ariel. Barcelona. 1991.

BUSTOS RAMÍREZ, Juan. HORMAZÁBAL MALARÉE, Hernán. Lecciones de Derecho Penal. Parte General. Ed. Trotta. Madrid. 2006.

- Lecciones de Derecho Penal. Volumen I. Ed. Trotta. Madrid. 1997.

- Lecciones de Derecho Penal volumen II. Ed. Trotta. Madrid. 1999. 
BUSTOS VALENCIA, Alirio. La Ley del Monte. Ed. Intermedio. Santa Fe de Bogotá. Colombia. 1999.

CADAVID QUINTERO, Alfonso. Introducción a la Teoría del Delito. Ed. Biblioteca Jurídica Dike. Medellín. 1998.

CALDERÓn CEREZO, Ángel, CHOCLÁn MONTALVO, José Antonio. Derecho Penal. Tomo II. Parte Especial. Ed. Bosch. Barcelona. 1999.

CARBONELL MATEU, Juan Carlos. "Consideraciones técnico-jurídicas en torno al delito de tráfico de drogas" en FERNÁNDEZ ALBOR Y otros autores. La problemática de la droga en España. (Análisis y propuestas político criminales). Edersa. Madrid. 1986.

- "Reflexiones sobre el abuso del Derecho Penal y la banalización de la legalidad" en ARROYO ZAPATERO, Luis A. BERDUGO GÓMEZ DE LA TORRE, Ignacio (Dir). NIETO MARTÍN, Adán. (Coord.). Libro homenaje al Dr. Marino Barbero Santos in memorian. Vol. I. Ed. Universidad de Castilla La Mancha. Universidad de Salamanca. Cuenca. 2001.

CARDONA TORRES, Juan. Derecho Penal. Parte Especial. Editorial Bosch. S.A. Barcelona. 2010.

CARMONA CUENCA, Encarnación. El Estado Social de Derecho en la Constitución. Ed. Consejo Económico y Social. Madrid. 2002.

CARO CORIA, Dino Carlos. La estabilidad del Ecosistema como Bien jurídico penal y su protección mediante la técnica de los Delitos de peligro. Tesis Doctoral. Universidad de Salamanca. 1997.

- "Sociedades de riesgo y Bienes jurídicos colectivos" en Themis Revista de Derecho, n. 37 (segunda época) (1998).

- Derecho Penal del Ambiente. Delitos y Técnicas de Tipificación. Ed. Gráfica Horizonte. S.A. Lima. 1999.

CASCAJO CASTRO, José Luis. "La voz Estado social y democrático de Derecho: Materiales para un léxico constitucional español", en Revista del Centro de Estudios Constitucionales, n. 12 (1992).

CASTRO CUENCA, Carlos G. (Coord.). Manual de Parte Especial. Tomo II. Ed. THEMIS S. A. Bogotá. 2011.

CEREZO MIR, José. Curso de Derecho Penal Español. Parte General. I. Introducción. Quinta edición. Tecnos. Zaragoza. 1996. 
- "Los delitos de peligro abstracto" en Revista de Derecho Penal, n. 1 (2001).

CLIMENT DUTANT, Carlos. Código Penal. Jurisprudencia sistematizada. 4a Edición. Tirant lo Blanch. Valencia. 2011.

CHRISTIE, Nils. "The impossibility of total control" en DIEZ RIPOLLES, José Luis. LAURENZO COPELLO, Patricia (Coord.). La actual política criminal sobre drogas. Una perspectiva comparada. Ed. Tirant lo Blanch. Valencia. 1993.

COBO DEL ROSAL, Manuel. "Consideraciones generales sobre el denominado tráfico ilegal de drogas tóxicas o estupefacientes" en Delitos contra la salud pública. Tráfico ilegal de drogas tóxicas o estupefacientes. Ed. Universidad de Valencia. 1977.

- Curso de Derecho Penal Español. Parte Especial II. Ed. Marcial Pons. Madrid. 1997.

CONDE-PUMPIDO FERREIRO, Cándido (Dir.). "El tratamiento penal del tráfico de drogas: las nuevas cuestiones" en FERNÁNDEZ ALBOR y otros autores. La problemática de la droga en España (análisis y propuestas político- criminales). Edersa. Madrid. 1986.

- Código Penal comentado. Tomo II. Ed. Bosch. Barcelona. 2004.

- Código Penal Comentado. Con concordancias y jurisprudencia. Actualizado a la LO 5/2010 de 23 de junio de 2010. Tomo I. $3^{\text {a }}$ Ed. Bosch. Barcelona. 2012.

- Código Penal Comentado. 3a Edición. Con concordancias y jurisprudencia. Actualizado a la LO 5/2010 de 23 de junio de 2010. Tomo II. 3ª Ed. Bosch. Barcelona. 2012.

CORCOY BIDASOLO, Mirentxu. "Resultado de muerte y lesiones como consecuencia de un delito contra la salud pública" en Anuario de Derecho Penal y Ciencias Penales. 1989.

- Delitos de Peligro y protección de bienes jurídico-penales supraindividuales. Nuevas formas de delincuencia y reinterpretación de tipos penales clásicos. Ed. Tirant lo Blanch. Valencia. 1999.

- "Protección de bienes jurídico-penales supraindividuales y Derecho Penal mínimo" en MIR PUIG, Santiago (Dir.). Derecho Penal del siglo XXI. Ed. Consejo del Poder Judicial. Madrid. 2008. 
CORCOY BIDÁSOLO, Mirentxu. MIR PUIG, Santiago (Dir.). Comentarios al Código Penal. Reforma L.O. 5/2010. Ed. Tirant lo Blanch. Valencia 2011.

CÓRDOBA RODA, Juan. "Les delits de mis en danger" en Informe nacional presentado al coloquio preparatorio del X congreso internacional de Derecho Penal, Revue International de Droit Pénal (1969).

CÓRDOBA RODA, Juan. GARCÍA ARÁN, Mercedes (Dir.). Comentarios al Código Penal. Parte Especial. Tomo II. Ed. Marcial Pons. Madrid. 2004.

- Comentarios al Código Penal. Parte General (incorporada reforma producida por la Ley Orgánica 5/2010, de 22 de junio). Ed. Marcial Pons. Madrid. 2011.

CORREA DE CARVALHO, José Theodoro. Tráfico de Drogas: Prueba Penal y Medidas Restrictivas de Derechos Fundamentales. Ed. Juruá. Lisboa. 2010.

CRUZ BLANCA, María José. "Las sustancias estupefacientes en la legislación penal italiana" en MORILLAS CUEVA, Lorenzo (Coord.). Estudios jurídico-penales y político-criminales sobre tráfico de drogas y figuras afines. Ed. Dykinson. Madrid. 2003.

CRUZ DE PABLO, José Antonio (Coord.). Comentarios al Código Penal. Vol 2. Ed. Difusión Jurídica. Madrid. 2008.

CUELLO CONTRERAS, Joaquín, MAPELLI CAFFARENA, Borja. Curso de Derecho Penal. Parte General. Ed. Tecnos. Madrid. 2011.

CUERDA RIEZU, Antonio. "La despenalización de las drogas: tres parábolas históricas y una conclusión" en Jueces para la democracia, n. 19 (1993).

DE LA CUESTA ARZAMENDI, José L. "Legislación penal europea occidentalcomunitaria y comparada sobre drogas" en Doctrina Penal Teoría y práctica de las Ciencias penales, año 14. 1991b (1991).

DEMETRIO CRESPO, Eduardo. "Crítica al funcionalismo normativista" en Revista de Derecho Penal y Criminología (3. época), n.o 3 (2010).

DEMETRIO CRESPO, Eduardo, RODRÍGUEZ YAGÜE, Cristina (Coord.). Curso de Derecho Penal. Parte General. Ediciones Experiencia, S. L. Barcelona. 2016.

DÍEZ RIPOLLÉS, José Luis. Los delitos relativos a drogas tóxicas, estupefacientes y sustancias psicotrópicas. Ed. Tecnos. Madrid. 1989. 
- La actual política criminal sobre drogas. Una perspectiva comparada. Ed. Tirant lo Blanch. Valencia. 1993.

- "Tendencias político criminales en materia de drogas" en Jueces para la Democracia. Información y Debate, no 19 (1993).

- "El bien jurídico protegido en un Derecho Penal garantista", en Nuevo Foro Penal. Revista del Centro de Estudios Penales de la Universidad de Antioquia, n. 60 (1999).

- Derecho Penal Español. Parte General. 4a edición. Tirant lo Blanch. Valencia. 2016.

DONNA, Edgardo Alberto. "La sociedad de riesgos y los delitos de peligro abstracto" en GARCÍA VALDÉS, Carlos, MARTÍNEZ ESCAMILLA, Margarita, ALCÁCER GUIRAO, Rafael, VALLE MARISCAL DE GANTE, Margarita (Coord.). Estudios Penales en homenaje a Enrique Gimbernat. Tomo I. EDISOFER. Madrid. 2008.

DOVAL PAIS, Antonio. "Estructura de las conductas típicas con especial referencia a los Fraudes Alimentarios. Intereses Difusos y Derecho Penal", en Cuadernos de Derecho Judicial. Ed. Consejo General del Poder Judicial. Madrid. 1995.

- Delitos de fraude alimentario. Análisis de sus elementos esenciales. Ed. Aranzadi. Pamplona. 1996.

- "Los delitos de fraude alimentario nocivo en el contexto de los delitos contra la seguridad colectiva" en ZÚÑIGA RODRÍGUEZ, Laura. MÉNDEZ RODRÍGUEZ, Cristina. DIEGO DÍAZ-SANTOS, María del Rosario (Coord.). Derecho Penal, sociedad y nuevas tecnologías. Ed. Colex. Madrid. 2001.

EIRANOVA EnCinAS, Emilio (Coord.). Código Penal Alemán StGB. Código Procesal Penal Alemán StPO. Ed. Marcial Pons. Madrid. 2000.

ESCRIVÁ GREGORI, J. M. La puesta en peligro de bienes jurídicos en el Derecho Penal. Ed. Bosch. Barcelona. 1976.

ESER, Albin. “Consideraciones finales” en ESER, Albin. HASSEMER, Winfried. BURKHARDT, Björn. (Coordinadores de la versión alemana). MUÑOZ CONDE, Francisco. (Coordinador de la versión española). La Ciencia del Derecho Penal ante el nuevo milenio. Ed. Tirant lo Blanch. Valencia. 2004. 
ESPINOZA V. Manuel. Delito de Narcotráfico. Ed. Rodas. Segunda edición. Lima. 1998.

FABIÁN CAPARRÓS, Eduardo A. “Consideraciones de urgencia sobre la Ley Orgánica 8/1992, de 23 de diciembre, de modificación del Código Penal y de la Ley de Enjuiciamiento Criminal en materia de tráfico de drogas" en Anuario de Derecho Penal y Ciencias Penales, tomo XLVI, fasc. 2 (1993).

- El Delito de Blanqueo de Capitales. Ed. Colex. Madrid. 1998.

- "El tráfico ilícito de drogas en el Derecho de la Unión Europea. Comentario a la Decisión Marco 2004/757/JAI del Consejo de 25 de octubre de 2004, relativa al establecimiento de disposiciones mínimas de los elementos constitutivos de delitos y las penas aplicables en el ámbito del tráfico ilícito de drogas", en iustel.com, Revista General de Derecho Penal, n.․ 7 (2005).

FARALDO CABANA, Patricia. Comentarios a la Legislación Penal Especial. Ed. Lex Nova/Thomson Reuters. Valladolid. 2012.

- Los delitos societarios. Aspectos dogmáticos y jurisprudenciales. Ed. Tirant lo Blanch. Valencia. 2000.

FEIJOO SÁNCHEZ, Bernardo. "Sobre la administrativización del Derecho Penal en la sociedad del riesgo" en DÍAZ- MAROTO Y VILLAREJO, Julio. (Dir.). Derecho y justicia penal. En homenaje al profesor Antonio González-Cuéllar García. Ed. Colex. Madrid. 2006.

FERRAJOLI, Luigi. Derecho y Razón. Teoría del garantismo penal (Trad. IBÁÑEZ, Perfecto Andrés. RUIZ MIGUEL, Alfonso. BAYÓN MOHINO, Juan. TERRADILLOS BASOCO, Juan. CANTARERO BANDRÉS, Rocío). Segunda edición. Trotta. Madrid. 1997.

FERNÁNDEZ, Gonzalo D. Bien jurídico y sistema del delito. Ed. B de F. Buenos Aires. 2004.

GALÁN PACHÓN, Juan. GUERRERO, Lech Julián. “La legalización de las drogas ilícitas en Colombia: elementos para una discusión" en GALÁN, Juan Manuel. THOUMI, Francisco. RAMÍREZ, William. VARGAS, Ricardo. $L a$ batalla perdida contra las drogas: ¿legalizar es la opción?. Ed. Intermedio Editorial Ltda. Bogotá. 2008.

GARBerí llobregat, J. (Dir.). Práctica jurisprudencial del Código Penal. Tomo III. Ed. BOSCH. Barcelona. 
GARCÍA ALBERO, Ramón. "La relación entre ilícito penal e ilícito administrativo: texto y contexto de las teorías sobre la distinción de ilícitos" en QUINTERO OLIVARES, Gonzalo. MORALES PRATS, Fermín (Coords.). El nuevo Derecho Penal Español. Estudios penales en memoria del profesor José Manuel Valle Muñiz. Ed. Aranzadi. Navarra. 2001.

GARCÍA ARÁN, Mercedes. "Constitución y Derecho Penal veinte años después" en ARROYO ZAPATERO, Luis. BERDUGO GÓMEZ DE LA TORRE, Ignacio (Dir). NIETO MARTÍN, Adán (coord.). Libro homenaje al Dr. Marino Barbero Santos in memoriam. Volumen I. Ed. Universidad de Castilla la Mancha- Universidad de Salamanca. Cuenca. 2001.

GARCÍA-PABLOS de MOLINA, Antonio. "Bases para una política criminal de la droga" en FERNÁNDEZ ALBOR y otros autores. La problemática de la droga en España. (Análisis y propuestas político-criminales). Edersa. 1986.

- Tratado de Criminología. Ed. Tirant lo Blanch. Valencia. 1999.

- "Tendencias actuales del Derecho Penal" en Modernas tendencias en la Ciencia del Derecho Penal y la Criminología. Ed. UNED. Madrid. 2001.

- Introducción al Derecho Penal. Editorial Universitaria Ramón Areces. Madrid. 2005.

GARCÍA RIVAS, Nicolás. Contribución al estudio del tipo de peligro y aplicación a los delitos contra la salud pública y el medio ambiente. Inédito. Albacete 1995.

- Delito ecológico. Estructura y aplicación judicial. Ed. Praxis: Wolters Kluwer. Barcelona. 1998.

GIL Y GIL, Alicia y otros autores. Curso de Derecho Penal. Parte General. Ed. Dykinson. Madrid. 2011.

GIMBERNAT ORDEIG, Enrique. Concepto y método de la ciencia del Derecho Penal. Ed. Tecnos. Madrid. 1999.

GOERNER, Gustavo. "Los delitos de peligro abstracto y las garantías constitucionales" en Revista de Derecho Penal, n. 2 (2002).

GÓMEZ BENÍTEZ, José Manuel. "Sobre la Teoría del Bien Jurídico (aproximación al ilícito penal)", en Revista de la Facultad de Derecho de la Universidad Complutense de Madrid, n.ㅇ 69 (1983). 
GOMÉZ PAVÓN, Pilar. El delito de conducción bajo la influencia de bebidas alcohólicas, drogas tóxicas y estupefacientes. Ed. Bosch. Barcelona. 1998.

GOMÉZ RUFO, Antonio. "El futuro ya está aquí" en El Mundo. Madrid. 17 de mayo de 2008.

GÓMEZ TOMILLO, Manuel. “Contribución a la teoría de los delitos de peligro hipotético-aptitud abstracta. Los delitos de tenencia como paradigma de los delitos de peligro abstracto puro" en CARBONELL MATEU, Juan Carlos. DEL ROSAL BLASCO, Bernardo. MORILLAS CUEVAS, Lorenzo. ORTS BERENGUER, Enrique. QUINTANAR DÍEZ, Manuel (Coordinadores). Estudios penales en homenaje al profesor Cobo del Rosal. Ed. Dykinson. Madrid. 2005.

GONZÁLEZ RUS, Juan José. Bien jurídico y Constitución (bases para una teoría). Ed. Fundación Juan March. Madrid. 1983.

GRACIA MARTÍN, Luis. “Qué es modernización del Derecho Penal?” en DÍEZ RIPOLLÉS, José Luis. ROMEO CASABONA, Carlos María. GRACIA MARTÍN, Luis. HIGUERA GUIMERÁ, Juan Felipe (Editores). La Ciencia del Derecho Penal ante el nuevo siglo. Libro homenaje al Profesor. Doctor. Don José Cerezo Mir. Ed. Tecnos. Madrid. 2002.

- Prolegómenos para la lucha por la modernización y expansión del Derecho Penal y para la crítica del discurso de resistencia. Ed. Tirant lo Blanch. Valencia. 2003.

- "Contribución al esclarecimiento de los fundamentos de legitimidad de la protección penal de los bienes jurídicos colectivos por el Estado Social y Democrático de Derecho" en HORMAZÁBAL MALARÉE (Coord.). Estudios de Derecho Penal en memoria del Profesor Juan José Bustos Ramírez. Ed. Ubijus. México DF. 2011.

GRANADOS PÉREZ, Carlos. Jurisprudencia del Tribunal Supremo sobre el delito de tráfico de drogas. Ed. La Ley. Madrid. 2007.

GUERRERO AGRIPINO, Luis Felipe. La Delincuencia Organizada. Repercusiones en la Autoría y Participación. Problemas de Tipificación. Regulación en el Sistema Penal Mexicano. Tesis Doctoral. Universidad de Salamanca. 2000.

GUISASOLA LERMA, Cristina. "Principio de legalidad y estructura de los delitos de peligro abstracto. A propósito de la STC 42/1999" en Revista de Derecho Penal, n.․ 7 (2002). 
HASSEMER, Winfried. "Derecho Penal simbólico y protección de Bienes jurídicos”, en Nuevo foro penal, número 51. 1991.

- Crítica al Derecho Penal de hoy. (Trad. ZIFFER, Patricia S.). Ed. Universidad del Externado de Colombia. Bogotá. 1997.

- Persona, mundo y responsabilidad. (Trad. MUÑOZ CONDE, Francisco y DÍAZ PITA, María del Mar). Ed. Temis, Santa Fe de Bogotá. 1997.

- "Bienes jurídicos en el Derecho Penal". (Trad. ZIFFER, Patricia S.) en BAIGÚN, David (Et. al.). Estudios sobre Justicia Penal. Homenaje al Profesor Julio B. J. Maier. Ed. Editores del Puerto. Buenos Aires. 2005.

- “¿Puede haber delitos que no afecten a un bien jurídico penal?”. (Trad. SPÍNOLA TÁRTALO, Beatriz) en HEFENDEHL, Roland (Ed.). La teoría del bien jurídico. ¿Fundamento de legitimación del Derecho Penal o juego de abalorios dogmático?. Ed. Marcial Pons. Madrid. Barcelona. 2007.

HASSEMER, Winfried. MUÑOZ CONDE, Francisco. La responsabilidad por el producto en el Derecho Penal. Ed. Tirant lo Blanch. Valencia. 1995.

HEFENDEHL, Roland. "El bien jurídico como eje material de la norma penal". (Trad. MARTÍN LORENZO, María) en HEFENDEHL, Roland (Ed.). La teoría del bien jurídico. ¿Fundamento de legitimación del Derecho Penal o juego de abalorios dogmático?. Ed. Marcial Pons, ediciones jurídicas y sociales, S.A. Madrid. Barcelona. 2007.

- "El bien jurídico: imperfecto, pero sin alternativa". (Trad. MARTÍN LORENZO, María), en GARCÍA VALDÉS, Carlos, MARTÍNEZ ESCAMILLA, Margarita, ALCÁCER GUIRAO, Rafael, VALLE MARISCAL DE GANTE, Margarita (Coord.). Estudios Penales en homenaje a Enrique Gimbernat. Tomo I. EDISOFER. Madrid. 2008.

HEINE, Günter. "La Ciencia del Derecho Penal ante las tareas de futuro" en ESER, Albin. HASSEMER, Winfried. BURKHARDT, Björn. (Coordinadores de la versión alemana). MUÑOZ CONDE, Francisco. (Coordinador de la versión española). La Ciencia del Derecho Penal ante el nuevo milenio. Ed. Tirant lo Blanch. Valencia. 2004.

HERZOG, Félix. "Límites al control penal de los riesgos sociales. Una perspectiva crítica ante el Derecho Penal del peligro" (Trad. LARRAUIR PIJOAN, Elena. PÉREZ ÁLVAREZ, Fernando) en Anuario de Derecho Penal y Ciencias Penales (1993).

- "Sociedad del riesgo, Derecho Penal del riesgo, regulación del riesgoperspectivas más allá del Derecho Penal" (Trad. DEMETRIO CRESPO, 
Eduardo) en ARROYO ZAPATERO, Luis. NEUMANN, Ulfrid, NIETO MARTÍN, Adán. (Coord.). Crítica y justificación del Derecho Penal en el cambio de siglo. Ediciones de la Universidad de Castilla- La Mancha. Cuenca. 2003.

HIGUERA GUIMERÁ, Juan Felipe (Editores). "El sistema de medidas y el erróneo criterio en la formulación del principio de proporcionalidad en el Código Penal de 1995" en DIEZ RIPOLLES, José Luis. ROMEO CASABONA, Carlos María. GRACIA MARTÍN, Luis. HIGUERA GUIMERÁ, Juan Felipe (Editores). La ciencia del Derecho Penal ante el nuevo siglo. Libro homenaje al Profesor. Doctor. Don José Cerezo Mir. Ed. Tecnos. Madrid. 2002.

HIRSCH, Hans Joachim. "Peligro y peligrosidad". (Trad. SOLA RECHE, Esteban). Derecho Penal. Obras completas. Tomo I. Ed. Rubinzabal- Culzoni Editores. Buenos Aires. 1999.

- "Acerca del estado actual de la discusión sobre el concepto de bien jurídico". (Trad. PASTOR, Daniel R.) en Modernas tendencias en la ciencia del Derecho Penal y la Criminología. Ed. UNED. Madrid. 2001.

- "Los conceptos de desvalor de acción y desvalor de resultado o sobre el estado de las cosas". (Trad. DEMETRIO CRESPO, Eduardo) en DÍEZ RIPOLLÉS, José Luis. ROMEO CASABONA, Carlos María. GRACIA MARTÍN, Luis. HIGUERA GUIMERÁ, Juan Felipe (Editores). La ciencia del Derecho Penal ante el nuevo siglo. Libro homenaje al Profesor. Dr. D. José Cerezo Mir. Ed. Tecnos. Madrid. 2002.

- "Problemas actuales de la legislación penal propia de un Estado de Derecho". (Trad. GUZMÁN DALBORA, José Luis) en FIGUEREIDO DIAS, Jorge. SERRANO GÓMEZ, Alfonso. POLITOFF LIFSCHITZ, Sergio. ZAFARONI, Raúl Eugenio (Dir.). GUZMÁN DALBORA, José Luis (Coord.). Homenaje a Manuel de Rivacoba y Rivacoba. El penalista liberal. Controversias nacionales e internacionales en Derecho Penal, Procesal Penal y Criminología. Ed. Hammurabi. Buenos Aires. 2004.

HOMS SANZ DE LA GARZA, Joaquín. Trastorno mental transitorio y drogas que inciden en la imputabilidad. Ed. Bosch, editor, S.L. Barcelona. 1996.

HORMAZÁBAL MALARÉE, Hernán. Bien Jurídico y Estado Social y Democrático de Derecho (el objeto protegido por la norma penal). Ed. PPU. Barcelona. 1991.

- "Consecuencias político criminales y dogmáticas del principio de exclusiva protección de bienes jurídicos" en PÉREZ ÁLVAREZ, Fernando 
(Coord.). Serta in memoriam Alexandri Baratta. Ed. Universidad de Salamanca. 2004.

HUERTA TOCILDO, Susana. Sobre el contenido de la antijuricidad. Ed. Tecnos. Madrid. 1984.

JAKOBS, Günther. Sociedad, norma y persona en una teoría de un Derecho Penal funcional. (Trad. CANCIO MELIÁ, Manuel y FEIJOO SÁNCHEZ, Bernardo). Segunda edición. Civitas. Madrid. 1996.

- Derecho Penal. Parte General. Fundamentos y teoría de la imputación. (Trad. CUELLO CONTRERAS, Joaquín. SERRANO GONZÁLEZ DE MURILLO, José Luis). Segunda edición. Marcial Pons. Madrid. 1997.

- Estudios de Derecho Penal. (Trad. PEÑARANDA RAMOS, Enrique). Ed. Civitas. Madrid. 1997.

- Bases para una teoría funcional del Derecho Penal. (Trad. CANCIO MELIÁ, Manuel. FEIJOO SÁNCHEZ, Bernardo. PEÑARANDA RAMOS, Enrique. SANCINETTI, Marcelo. SUÁREZ GONZÁLEZ, Carlos). Ed. Palestra Editores. Lima. 2000.

JAREBORG, Nils. "Derecho Penal e ideología" en ESER, Albin. HASSEMER, Winfried. BURKHARDT, Björn. (Coordinadores de la versión alemana). MUÑOZ CONDE, Francisco. (Coordinador de la versión española). La Ciencia del Derecho Penal ante el nuevo milenio. Ed. Tirant lo Blanch. Valencia. 2004.

JESCHECK, Hans-Heinrich. Tratado de Derecho Penal. Parte General. (Trad. MAZANARES SAMANIEGO, José Luis). Cuarta edición. Comares. Granada.1993.

JOSHI JUBERT, Ujala. Los delitos de tráfico de drogas I. Un estudio analítico del art. 368. Ed. J. M Bosch Editor. Barcelona. 1999.

- "Sobre el concepto de organización en el delito de tráfico de drogas en la jurisprudencia del Tribunal Supremo" en Anuario de Derecho Penal y Ciencias Penales, tomo XLVIII, fasc. II (1995).

KARGL, Walter. "Protección de bienes jurídicos mediante protección del Derecho" (trad. RAGUÉS i VALLÉS, Ramón) en ROMEO CASABONA, Carlos María (Dir). La insostenible situación del Derecho Penal. Ed. Comares. Granada. 2000.

KHULEN, Lothar. "El Derecho Penal del futuro" en ARROYO ZAPATERO, Luis. NEUMANN, Ulfrid. NIETO MARTÍN, Adán (Coord.). Crítica y justifi- 
cación del Derecho Penal en el cambio de siglo. Ediciones de la Universidad de Castilla-La Mancha. Cuenca. 2003.

LAMARCA PÉREZ, Carmen (Coord.). (Dir.). Derecho Penal. Parte Especial. 3a edición. Colex. Madrid. 2005.

- (Coord.). Derecho Penal. Parte Especial. 6ª edición. Colex. Madrid. 2011.

- Delitos y Faltas. La Parte Especial del Derecho Penal. Ed. Colex. Madrid. 2012.

LASCURAÍN SÁNCHEZ, Juan Antonio. "Bien jurídico y objeto protegible" en Anuario de Derecho Penal y Ciencias Penales, vol. LX. (2007).

LAURENZO COPELLO, Patricia. El resultado en el Derecho Penal. Ed. Tirant lo Blanch. Valencia. 1992.

LEGANÉS GÓMEZ, Santiago, ORTOLÁ BOTELLA, María Ester. Criminología. Parte Especial. Ed. Tirant lo Blanch. Valencia. 1999.

LORENZO SALGADO, José M. “Título XIV: Delitos contra la seguridad colectiva. Capitulo III. De los delitos contra la salud pública", en Documentación jurídica, n. $37 / 40$ (Monográfico dedicado a la propuesta de anteproyecto del nuevo Código Penal) (1983).

- "Reforma de 1983 y tráfico de drogas" en FERNÁNDEZ ALBOR y otros autores. La problemática de la droga en España (análisis y propuestas político- criminales). Ed. Edersa. Madrid. 1986.

LUZÓN PEÑA, Diego Manuel. "Problemas del tráfico de drogas en la jurisprudencia" en Simposio sobre la droga. Aspectos Jurídicos. Ejemplar mecanografiado. Madrid 2-6 de febrero de 1981.

- Curso de Derecho Penal. Parte General I. Editorial Universitas. S. A. Madrid. 1996.

MAGRO SERVET, Vicente. Guía práctica de la casuística existente en los delitos contra la salud pública. Ed. La Ley. Madrid. 2004.

MANNA, Adelmo. "La Actual Política Criminal sobre la Droga en Italia" en DÍEZ RIPOLLÉS, José Luis, LAURENZO COPELLO, Patricia (Coord.). La Actual Política Criminal sobre Drogas. Una perspectiva comparada. Ed. Tirant lo Blanch. Valencia 1993.

MANTOVANI, Ferrando. "Droga: oscuro mal de la vida y de la libertad". (Trad. BENÍTEZ ORTÚZAR, Francisco) en Cuadernos de Política Criminal, N. $\mathrm{o} 100$ (2010) 
MAQUEDA ABREU, María Luisa. "La idea del peligro en el moderno Derecho Penal. Algunas reflexiones a propósito del proyecto de Código Penal de 1992" en Actualidad Penal, n.o 26 (1994).

MARCHENA GÓMEZ, Manuel. Código Penal de 1995. Un año de vigencia en la doctrina del Tribunal Supremo, Audiencias Provinciales y Fiscalía General del Estado. Ed. Comares. Granada. 1997.

MARTÍNEZ- BUJÁN PÉREZ, Carlos. Derecho penal Económico. Parte General. Ed. Tirant lo Blanch. Valencia. 1998.

MARTÍNEZ PARDO, Vicente José. Los Delitos de Tráfico de Drogas: Estudio Jurisprudencial. Ed. EDISOFER S. L. Madrid. 2013.

MATA Y MARTÍN, Ricardo M. Bienes jurídicos intermedios y Delitos de peligro. Aproximación a los presupuestos de la técnica de peligro para los delitos que protegen bienes jurídicos intermedios (- tutela penal del medio ambiente, delitos económicos, seguridad de tráfico-). Ed. Comares. Granada. 1997.

MAZZACUVA, Nicola. "El futuro del Derecho Penal". (Trad. RODRÍGUEZ ARIAS, Miguel Ángel) en ARROYO ZAPATERO, Luis. NEUMANN, Ulfrid. NIETO MARTÍN, Adán (Coord.). Crítica y justificación del Derecho Penal en el cambio de siglo. Ediciones de la Universidad de Castilla- La Mancha. Cuenca. 2003.

MÉNDEZ RODRÍGUEZ, Cristina. Los Delitos de Peligro y sus Técnicas de Tipificación. Ed. Universidad Complutense. Madrid. 1993.

- "Los delitos de pertenencia a organización criminal y grupo criminal y el delito de tráfico de drogas cometido por persona que pertenece a una organización delictiva. Crónica de un conflicto normativo anunciado y análisis jurisprudencial" en Estudios Penales y Criminológicos, vol. XXXIV (2014).

MENDOZA BUERGO, Blanca. El Derecho Penal en la sociedad de riesgo. Ed. Civitas. Madrid. 2001.

- Límites dogmáticos y político-criminales de los delitos de peligro abstracto. Ed. Comares. S. L. Granada. 2001.

- "Gestión del riesgo y política criminal de seguridad en la sociedad del riesgo" en DÍAZ- MAROTO Y VILLAREJO, Julio. (Dir.). Derecho y justicia penal. En homenaje al profesor Antonio González- Cuellar García. Ed. Colex. Madrid. 2006. 
MERTON, Robert. Teoría y estructuras sociales. Fondo de Cultura Económico. México. 1984.

MIR PUIG, Santiago. Introducción a las bases del Derecho Penal. Ed. Bosch. Barcelona. 1976.

- "Bien jurídico y Bien jurídico penal como límites del ius puniendi" en Estudios Penales y Criminológicos, vol. XIV (1991).

- El Derecho Penal en el Estado Social y Democrático de Derecho. Ed. Ariel. Barcelona. 1994.

- Derecho Penal. Parte General. 7̣a edición. Reimpresión. Reppertor. Barcelona. 2005.

- "Límites del normativismo en el Derecho Penal" en MIR PUIG, Santiago (Dir.). Derecho Penal del siglo XXI. Ed. Consejo General del Poder Judicial. Madrid. 2008.

- Derecho Penal. Parte general. 9a edición. REPPERTOR. Barcelona. 2011.

MOCCIA, Sergio. "De la tutela de bienes a la tutela de funciones. Entre ilusiones postmodernas y reflujos liberales". (Trad. RAGUÉS VALLÉS, Ramón) en SILVA SÁNCHEZ, Jesús María. Política Criminal y nuevo Derecho Penal. Libro homenaje a Claus Roxin. Ed. Bosh. Barcelona. 1997.

MOJÓN, D. J. Curso analítico de química. Trad. CARBONEL y BRAVO, Antonio. Ed. D. Antonio Brusi impresor de cámara de S. M. Barcelona. 1918.

MOLINA MANSILLA, María del Carmen. "El delito de tráfico de drogas: el tipo básico y los subtipos agravados" en Anuario de derecho Penal y Ciencias Penales, Vol. LIX (2006).

- $\quad$ El Delito de Narcotráfico. Ed. Bosh, S. A. Barcelona. 2008.

MORA ALARCóN, José Antonio. Suma de Derecho Penal. Parte General y Parte Especial. Ed. Edisofer. S. L. Madrid. 1996.

MORALES GARCÍA, Oscar (Dir.). Código Penal con Jurisprudencia. Ed. Thomson Reuters/Aranzadi. 2013.

MORALES VALDÉS, Hugo. "Bien jurídico, principio de ofensividad e idoneidad lesiva. Análisis crítico del concepto strict liability en el Derecho Inglés". Tesis Doctoral. Universidad de Salamanca. 2004.

MORILLAS CUEVA, Lorenzo (Coord.). Estudios jurídico-penales y políticocriminales sobre tráfico de drogas y figuras afines. Ed. Dykinson. Madrid. 2003. 
- (Dir.). Sistema de Derecho Penal. Parte Especial. 2ª Edición. Dikinson, S. L. Madrid, 2011.

MUÑOZ CONDE, Francisco y GARCÍA ARÁN, Mercedes. Derecho Penal. Parte General. 6a edición. Tirant lo Blanch. Valencia. 2004.

- Derecho Penal. Parte General. Segunda edición. Tirant lo Blanch. Valencia. 1996.

- Derecho Penal. Parte General. 8ª edición. Tirant lo Blanch. Valencia. 2010.

- Derecho Penal. Parte General. 9a edición. Tirant lo Blanch. Valencia. 2015.

MUÑOZ CONDE, Francisco. Derecho Penal y Control Social. Ed. Fundación Universitaria. Jerez de la Frontera. 1985.

- "Protección de bienes jurídicos como límite constitucional del Derecho Penal" en QUINTERO OLIVARES, Gonzalo. MORALES PRATS, Fermín (Coord.). El nuevo Derecho Penal Español. Estudios penales en memoria del profesor José Manuel Valle Muñiz. Ed. Aranzadi. 2001.

- Derecho Penal. Parte Especial. Decimoquinta edición. Tirant lo Blanch. Valencia. 2004.

- Derecho Penal. Parte Especial. 18 edición, revisada y puesta al día. Ed. Tirant lo Blanch. Valencia. 2010.

- Derecho Penal. Parte Especial. 19 edición, completamente revisada y puesta al día. Ed. Tirant lo Blanch. Valencia. 2013.

MÜSSIG, Bernd. "Desmaterialización del bien jurídico y de la Política Criminal. Sobre las perspectivas y los fundamentos de una teoría del bien jurídico crítica hacia el sistema". (Trad. Manuel Cancio Meliá y Enrique Peñaranda Ramos) en Revista de Derecho Penal y Criminología (2. época), n. 9 (2002).

NAVARRO CARDOSO, Fernando. "El Derecho Penal del riesgo y la idea de seguridad. Una quiebra del sistema sancionador" en PÉREZ ÁLVAREZ, Fernando (Ed.). Serta in memoriam Alexandri Baratta. Ed. Universidad de Salamanca. 2004.

NESTLER, Cornelius. "El principio de protección de bienes jurídicos y la punibilidad de la posesión de armas de fuego y de sustancias estupefacientes". (Trad. BENLLOCH PETIT, Guillermo) en ROMEO CASABONA, 
Carlos María (Dir.). La insostenible situación del Derecho Penal. Ed. Comares. Granada. 2000.

NEUMAN, Elías. La legalización de las drogas. Segunda edición. Depalma. Buenos Aires. 1997.

NEUMANN, Ulfrid. "Alternativas: Ninguna. Sobre la crítica más reciente a la teoría personal del bien jurídico". (Trad. RUIZ, Carmen Eloísa) en Cuadernos de Política Criminal, n.o 93 (2007).

OCTAVIO DE TOLEDO Y UBIETO, Emilio. "Algunas cuestiones sobre autoría, participación, tentativa, peligro e imprudencia, a propósito de la responsabilidad penal por el producto" en OCTAVIO DE TOLEDO Y UBIETO, Emilio. GURDIEL SIERRA, Manuel. CORTÉS BECHIARELLI, Emilio (Coordinadores). Estudios penales en recuerdo del profesor Ruiz Antón. Ed. Tirant lo Blanch. Valencia. 2004.

- "Función y límites del principio de exclusiva protección de Bienes jurídicos", en Anuario de Derecho Penal y Ciencias Penales. Ed. Centro de publicaciones del Ministerio de Justicia. Madrid. 1990.

OCTAVIO DE TOLEDO Y UBIETO, Emilio. HUERTA TOCILDO, Susana. Derecho Penal. Parte General. Segunda edición. Madrid. 1986.

ORTS BERENGUER, Enrique. GONZÁLEZ CUSSAC, José L. Compendio de Derecho Penal. (Parte General y Parte Especial). Ed. Tirant lo Blanch. Valencia. 2004.

PABÓN PARRA, Pedro Alfonso. Manual de Derecho Penal. Tomo II. Parte Especial. Octava Edición. Ediciones Doctrina y Ley. Ltda. Bogotá. 2011.

PAREDES CASTAÑóN, José Manuel. El riesgo permitido en el Derecho Penal (Régimen jurídico-penal de las actividades peligrosas). Ed. Ministerio de Justicia e Interior. Secretaria General Técnica. Centro de publicaciones. Madrid. 1995.

PARMA. Carlos. "El pensamiento de Günther Jakobs" en El Derecho Penal del siglo XXI. Ed. Cuyo. Segunda reimpresión. Mendoza. 2004.

PARSON, Talcott. La estructura de la acción social I y II. Madrid. Ediciones Guadarrama. Madrid. 1968.

PAZ Y PAZ BAILEY, Claudia. Tesis Doctoral. La protección penal de los pueblos. Especial consideración del delito de genocidio. Salamanca. 2005.

PEÑA CABRERA, Raúl. Tratado de Derecho Penal. Tomo IV (Tráfico de drogas y lavado de dinero). Ediciones jurídicas. Lima. 1995. 
PEÑA-CABRERA FREYRE, Alonso. R. Tráfico ilícito de drogas y delitos conexos. Perspectivas dogmáticas y político criminales. Ed. Juristas editores. Lima. 2009.

PÉREZ ÁLVAREZ, Fernando. Protección penal del consumidor. Salud pública y alimentación. Ed. Praxis. Barcelona. 1991.

- "La regulación del delito alimentario nocivo", en Anuario de Derecho Penal y Ciencias Penales, tomo XLVI, fascículo III (1993).

- "Alimentos transgénicos y Derecho Penal. Apuntes para una reflexión" en ARROYO ZAPATERO, Luis, BERDUGO GÓMEZ DE LA TORRE, Ignacio (Dir.) NIETO MARTÍN, Adán (Coord.). Homenaje al Profesor Marino Barbero Santos. Volumen II. Ed. Universidad de Castilla la Mancha. Universidad de Salamanca. Cuenca. 2001.

PÉREZ CEPEDA, Ana Isabel. "De la sociedad neoliberal del riesgo a la expansión de Derecho Penal" en MUÑOZ CONDE, Francisco José. Problemas actuales del Derecho Penal y de la Criminología. Estudios Penales en memoria de la Profesora. Dra. María del Mar Díaz Pita. Ed. Tirant lo Blanch. Valencia. 2008.

PÉREZ ROYO, Javier. Curso de Derecho Constitucional. Décima edición. Marcial Pons. Madrid. 2005.

PERIS RIERA, Jaime M. "Delitos de peligro y sociedad de riesgo: una constante discusión en la dogmática penal de la última década" en CARBONELL MATEU, Juan Carlos. DEL ROSAL BLASCO, Bernardo. MORILLAS CUEVAS, Lorenzo. ORTS BERENGUER, Enrique. QUINTANAR DIEZ, Manuel (Coord.). Estudios penales en homenaje al profesor Cobo del Rosal. Ed. Dykinson. Madrid. 2005.

POLAINO NAVARRETE, Miguel. El bien jurídico en el Derecho Penal. Ed. Publicaciones de la Universidad de Sevilla. 1974.

- "La controvertida legitimación del Derecho Penal en las sociedades modernas. ¿Más Derecho Penal" en CARBONELL MATEU. Juan Carlos. DEL ROSAL BLASCO, Bernardo. MORILLAS CUEVAS, Lorenzo. ORTS BERENGUER, Enrique. QUINTANAR DÍEZ, Manuel (Coordinadores). Estudios en homenaje al profesor Cobo del Rosal. Ed. Dykinson. Madrid. 2005.

- "Protección de bienes jurídicos y confirmación de la vigencia de la norma: ¿dos funciones excluyentes?" en Cuadernos de Política Criminal, n. 93 (2007). 
- "Recensión de AMELUNG, Knut. Rechtsgüterschutz und Schutz der Gesellschaft". Frankfurt am Main. 1972, en Anuario de Derecho Penal y Ciencias Penales, vol. XXVI (1973).

PORTILLA CONTRERAS, Guillermo. "La supuesta crisis de la teoría del bien jurídico: la tensión entre el iuspositivismo y positivismo, entre la necesidad de referencias externas y la inmanencia del Derecho. Especial atención a la legitimidad de ciertos bienes colectivos" en OCTAVIO DE TOLEDO Y UBIETO, Emilio. GURDIEL SIERRA, Manuel. CORTÉS BECHIARELLI, Emilio (Coords.). Estudios penales en recuerdo del profesor Ruiz Antón. Ed. Tirant lo Blanch. Valencia. 2004.

- "Principio de intervención mínima y Bienes jurídicos colectivos", en Cuadernos de Política Criminal, n.. 39 (1989).

PRIETO RODRÍGUEZ, Javier Ignacio. El Delito de tráfico y el consumo de drogas en el ordenamiento jurídico penal español. Ed. Aranzadi. Segunda edición. Pamplona. 1993.

PRITTWITZ, Cornelius. "Sociedad de riesgo y Derecho Penal" en ARROYO ZAPATERO, Luis. NEUMANN, Ulfrid. NIETO MARTÍN, Adán (Coord.). Crítica y justificación del Derecho Penal en el cambio de siglo. Ediciones de la Universidad de Castilla- La Macha. Cuenca. 2003, pp. 268- 273.

QUERALT JIMÉNEZ, J. J. Derecho Penal Español. Parte Especial. Tercera edición. J. M. Bosch. Barcelona. 1996.

QUINTERO OLIVARES, Gonzalo. (Dir.). Manual de Derecho Penal. Parte General. Ed. Aranzadi. Pamplona. 1999.

- Parte General del Derecho Penal. Cuarta edición. Aranzadi/Thomson Rehuters. Navarra. 2010.

- "Los delitos de riesgo en la política criminal de nuestro tiempo" en ARROYO ZAPATERO, Luis. NEUMANN, Ulfrid. NIETO MARTÍN, Adán (Coords.). Crítica y justificación del Derecho Penal en el cambio de siglo. Ediciones de la Universidad Castilla-La Mancha. Cuenca. 2003.

QUINTERO OLIVARES, Gonzalo (Dir.) MORALES PRATS, Fermín (Coord.). Parte General del Derecho Penal. Ed. Thomson-Aranzadi. Navarra. 2005.

- Comentarios al nuevo Código Penal. Ed. Aranzadi. Navarra. 2005.

- Comentarios al Código Penal Español. Tomo I. Ed. Aranzadi/Thomson Reuters. Navarra. 2011. 
- Comentarios al Código Penal Español. Tomo II. 6a edición. Aranzadi/Thomson Reuters. Navarra. 2011.

- Comentarios a la Parte Especial del Derecho Penal. 9a Edición. AranzadiThomson Reuters. Navarra. 2011.

QUINTERO OLIVARES, Gonzalo (Dir.). VALLE MUÑIZ, José Manuel (Coord.). Comentarios a la Parte Especial del Derecho Penal. Ed. Aranzadi. Pamplona. 1996.

REY HUIDOBRO, Luis Fernando. El Delito de Tráfico de Estupefacientes. Su inserción en el ordenamiento penal español. Ed. Bosch. Barcelona. 1987.

- El Delito de Tráfico de Drogas. Aspectos Penales y Procesales. Ed. Tirant lo Blanch. Valencia. 1999.

RODRÍGUEZ DEVESA, José María. SERRANO GÓMEZ, Alfonso. Derecho Penal Español. Parte Especial. 18. ${ }^{\text {a }}$ edición. Dikynson. Madrid. 1995.

RODRÍGUEZ FERNÁNDEZ, Ricardo. "El agente encubierto y la entrega vigilada. (Comentarios a la LO 5/1999, de 13 de enero, de modificación de la Ley de Enjuiciamiento Criminal" en http://aidpespana.uclm.es/pdf/criminalidad/rrodriguez.pdf

RODRÍGUEZ MONTAÑES, Teresa. Delitos de peligro, dolo e imprudencia. Ed. Centro de estudios judiciales de la Universidad Complutense de Madrid. 1994.

RODRÍGUEZ RAMOS, Luis. Compendio de Derecho Penal. Parte General. Ed. Dykinson. S. L. Madrid. 2006.

- Código Penal comentado y con jurisprudencia. Segunda edición. La Ley. Madrid. 2007.

ROMEO CASABONA, Carlos María. "La peligrosidad y el peligro en la estructura del tipo del delito imprudente" en DIEZ RIPOLLES, José Luis. ROMEO CASABONA, Carlos María. GRACIA MARTÍN, Luis. HIGUERA GUIMERÁ, Juan Felipe. (Editores). La Ciencia del Derecho Penal ante el nuevo siglo. Libro homenaje al Prof. Dr. José Cerezo Mir. Ed. Tecnos. Madrid, 2002.

ROMERAL MORALEDA, Antonio. GARCÍA BLÁZQUEZ, Manuel. Tráfico y consumo de drogas. Aspectos penales y médico-forenses. Ed. Comares. Granada. 1993.

ROXIN, Claus. Problemas básicos del Derecho Penal. (Trad. LUZÓN PEÑA, Diego Manuel.). Ed. REUS, S.A. Madrid. 1976. 
- "La problemática de la imputación objetiva". (Trad. CASAS BARRERO, Enrique) en Cuadernos de Política Criminal, n.o 39 (1989).

- Derecho Penal. Parte General. Tomo I. Fundamentos. La estructura de la teoría del delito. (Traducción de la segunda edición alemana por LUZON PEÑA, Diego Manuel y otros autores). Ed. Civitas. Madrid. 1997.

- La evolución de la política Criminal, el Derecho penal y el proceso penal. (Trad. GÓMEZ RIVERO, Carmen. GARCÍA CANTIZANO, María del Carmen). Ed. Tirant lo Blanch alternativa. Valencia 2000.

ROXIN, Claus. “¿Es la protección de bienes jurídicos una finalidad del Derecho penal?". (Trad. ORTIZ DE URBINA GIMENO, Íñigo) en HEFENDEHL, Roland (Ed.). La teoría del bien jurídico. ¿Fundamento de legitimación del Derecho Penal o juego de abalorios dogmático? Ed. Marcial Pons, ediciones jurídicas y sociales, S.A. Madrid. Barcelona. 2007.

ROXIN, Claus. ARZT, Günther. SCHÜNEMANN, Bernd. "Sobre la dogmática y la política criminal del Derecho Penal del medio ambiente" en SCHÜNEMANN, Bernd. Temas actuales y permanentes del Derecho Penal después del milenio. Ed. Tecnos. Madrid. 2002.

ROXIN, Claus. ARZT, Günther. TIEDEMANN, Klaus. Introducción al Derecho Penal y al Derecho Procesal. (Trad. ARROYO ZAPATERO, Luis. GÓMEZ COLOMER, Juan-Luis). Ed. Ariel. Barcelona. 1989.

RUDOLPHI, Hans Joachim: "Los diferentes aspectos del concepto de Bien Jurídico", en Nuevo Pensamiento Penal, año 4 (1975).

SAAVEDRA RUIZ, Juan (Dir.). Código Penal comentado, con jurisprudencia sistematizada y concordancias. Segunda edición. El Derecho. Madrid. 2011.

SÁNCHEZ GARCÍA DE PAZ, María Isabel. El moderno Derecho Penal y la anticipación de la tutela penal. Ed. Universidad de Valladolid. 1999.

- "La criminalización en el ámbito previo como tendencia políticacriminal contemporánea" en QUINTERO OLIVARES, Gonzalo. MORALES PRATS, Fermín (Coordinadores). El nuevo Derecho Penal español. Estudios penales en memoria del profesor José Manuel Valle Muñiz. Ed. Aranzadi. Navarra. 2001.

SÁNCHEZ TOMÁS, José Miguel. Derecho de las drogas y de las drogodependencias. Ed. FAD. Madrid. 2002. 
SANTANA VEGA, Dulce María. "La fundamentación del injusto a la luz de sus teorías y de los principios informadores del Derecho Penal" en LUZÓN PEÑA, Diego Manuel. Derecho Penal del Estado Social y Democrático de Derecho. Libro homenaje a Santiago Mir Puig. Ed. La Ley. Madrid. 2010.

- La protección penal de los Bienes jurídicos colectivos. Ed. Dykinson. Madrid. 2000.

SÁNCHEZ MELGAR, Julián. Código Penal. Comentarios y Jurisprudencia. II. 2oㅡ Edición. Sepin. Madrid. 2006

SARAVIA TOLEDO, Rogelio. VILlADA, Jorge Luis. Curso de Derecho Penal. Parte Especial. Ed. Virtudes. Argentina. 2003.

SCHROEDER, Friedrich-Christian. "La posesión como hecho punible" (Trad. Polaino-Orts, Miguel) en Revista de Derecho Penal y Criminología, 2o Época, número 14.

SCHÜNEMANN, Bernd. Consideraciones críticas sobre la situación espiritual de la ciencia Jurídico- Penal alemana. (Trad. CANCIO MELIÁ, Manuel), Ed. Universidad Externado de Colombia. Centro de Investigaciones de Derecho Penal y Filosofía del Derecho. Santa Fe de Bogotá. 1996.

- "Sobre la dogmática y la Política Criminal del medio ambiente" (Trad. SACHER, Marina) en SCHÜNEMANN, Bernd. Temas actuales y permanentes del Derecho Penal después del milenio. Ed. Tecnos. Madrid. 2002.

SEELMANN, Kurt. "El concepto de bien jurídico, el harm principle y el modelo de reconocimiento como criterios de merecimiento de pena" en HEFENDEHL, Roland (Ed.). La teoría del bien jurídico. ¿Fundamento de legitimación del Derecho Penal o juego de abalorios dogmático?. Ed. Marcial Pons, ediciones jurídicas y sociales, S.A. Madrid. Barcelona. 2007.

SEQUEROS SAZATORNIL, Fernando. El Tráfico de Drogas ante el Ordenamiento Jurídico. Evolución normativa, doctrinal y jurisprudencial. Ed. La Ley. Madrid. 2000.

SERRANO GÓMEZ, Alfonso, SERRANO MAÍLLO, Alfonso. Derecho Penal. Parte Especial. Ed. Dykinson. Madrid. 2010.

SHAMS NATERI, Mohammad Ebraim. "Política criminal de Irán en materia de narcóticos, drogas y sustancias psicotrópicas". (Trad. PIFARRE DE MONER, María José) en Revista Penal, n.o 7 (2001). 
SILVA SÁNCHEZ, Jesús María. Aproximación al Derecho Penal Contemporáneo. Ed. Bosh. Barcelona. 1992.

- ¿¿Protección penal del medio ambiente? Texto y contexto del artículo I y II" en La Ley. 1997-3.

- La expansión del Derecho Penal. Aspectos de la política criminal en las sociedades postindustriales. Segunda edición. Civitas. Madrid. 2001.

SOLA RECHE, Esteban. "La peligrosidad de la conducta como fundamento del injusto penal" en Anuario de Derecho Penal y Ciencias Penales (1994).

SOTO NAVARRO, Susana. La protección penal de los bienes jurídicos colectivos en la sociedad moderna. Ed. Comares. Granada. 2003.

- "Concreción y lesión de los bienes jurídicos colectivos. El ejemplo de los delitos ambientales y urbanísticos" en Anuario de Derecho Penal y Ciencias Penales, Vol. LVII (2005).

SOTO NIETO, Francisco. El delito de tráfico ilegal de drogas. Su relación con el delito de contrabando. Ed. TRIVIUM. Madrid. 1989.

STRATENWERTH, Günter. Derecho Penal. Parte General. I. El hecho punible. (Traducción de la segunda edición alemana de 1976. ROMERO, Gladis). Ed. EDERSA D.L. Madrid. 1982.

- "La criminalización en los delitos contra bienes jurídicos colectivos". (Trad. ORTIZ DE URBINA GIMENO, Íñigo. VALLE MARISCAL DE GANTE, Margarita) en HEFENDEHL, Roland (Ed.). La teoría del bien jurídico. ¿Fundamento de legitimación del Derecho Penal o juego de abalorios dogmático?. Ed. Marcial Pons, ediciones jurídicas y sociales, S.A. Madrid. Barcelona. 2007.

SUÁREZ GONZÁLEZ, Carlos J. "Derecho Penal y riesgos tecnológicos" en ARROYO ZAPATERO, Luis. NEUMANN, Ulfrid. NIETO MARTÍN, Adán (Coord.). Crítica y justificación del Derecho Penal en el cambio de siglo. Ediciones de la Universidad Castilla-La Mancha. Cuenca. 2003.

SUÁREZ LÓPEZ, José María. "El tráfico de precursores. Propuestas de lege ferenda" en MORILLAS CUEVA, Lorenzo (Coord.). Estudios Jurídicopenales y político-criminales sobre tráfico de drogas y figuras afines. Ed. Dikinson. Madrid. 2003. 
SUÁREZ-MIRA RODRÍGUEZ, Carlos (Coord.). Manual de Derecho Penal. Tomo II. Parte Especial. Sexta Edición. Aranzadi/Thomson Reuters. Navarra. 2011.

SUAY HERNÁNDEZ, Cecilia. "Los delitos contra la salubridad y seguridad del consumo en el marco de las relaciones entre el Derecho Penal y el Derecho Administrativo sancionador" en PICÓ LORENZO, Celsa. Las fronteras del Código Penal y el Derecho Administrativo sancionador. Ed. Consejo General del Poder Judicial. Madrid. 1997.

TERRADILLOS BASOCO, Juan. "La satisfacción de necesidades como criterio de determinación del objeto de tutela jurídico penal”, en Revista de la Facultad de Derecho de la Universidad Complutense de Madrid. 1981.

- "Peligro abstracto y garantías penales" en QUINTERO OLIVARES, Gonzalo. MORALES PRATS, Fermín (Coord.). El nuevo Derecho Penal Español. Estudios en memoria del Profesor José Manuel Valle Muñiz. Ed. Aranzadi. Navarra. 2001.

- Lecciones materiales para el estudio del Derecho Penal. Tomo III. Derecho Penal. Parte Especial. Volumen II. Ed. Iustel. Madrid. 2011.

TIEDEMANN, Klaus. Introducción al Derecho Penal y al Derecho Procesal. (Trad. ARROYO ZAPATERO, Luis. GÓMEZ COLOMER, Juan-Luis). Ed. Ariel. Barcelona. 1989. TIEDEMANN, Klaus. Poder económico y delito. (Trad. MANTILLA VILLEGAS, Amelia). 1aㅡ Ed. Ariel. Madrid. 1985.

- Lecciones de Derecho Penal Económico. (Trad. MARTín, Teresa). 1a Ed. PPU. Barcelona. 1993.

TORÍO LÓPEZ, A. "Los delitos de peligro hipotético", en Anuario de Derecho Penal y Ciencias Penales. 1981.

VÁZQUEZ IRUZUBIETA, Carlos. Comentario al Código Penal. Actualizado por LO 5/2010. Ed. La Ley. Madrid. 2010.

VELASCO MARTÍN, Alfonso. ÁLVAREZ GONZÁLEZ, Francisco Javier. Compendio de psiconeurofarmacia. Ediciones Díaz de Santos. S.A. Madrid. 1988.

VELÁSQUEZ VELÁSQUEZ, Fernando. Derecho Penal. Parte General. Ed. Temis. Santa Fe de Bogotá. 1997.

- Las Drogas. Aspectos: histórico, sustantivo y procesal. Ed. Librería Colegas. Medellín. 1989. 
VIVES ANTÓN, Tomás (Coord.). Derecho Penal. Parte Especial. Segunda edición. Tirant lo Blanch. Valencia. 1996.

- Derecho Penal. Parte Especial. Ed. Tirant lo Blanch. Valencia. 2010.

VIDALES RODRÍGUEZ, Catalina. "La última reforma del Código Penal en materia de drogas" en Revista General de Derecho, n.o 583 (1993).

VON HIRSCH, Andrew. "El concepto de bien jurídico y el principio del daño". (Trad. ALCÁCER GUIRAO, Rafael). HEFENDEHL, Roland (Ed.). La teoría del bien jurídico. ¿Fundamento de legitimación del Derecho Penal o juego de abalorios dogmático?. Ed. Marcial Pons, ediciones jurídicas y sociales, S.A. Madrid. Barcelona. 2007.

VON HIRSCH, Andrew. WHOLLERS, Wolfgang. "Teoría del bien jurídico y estructura del delito. Sobre los criterios de una imputación justa". (Trad. SPÍNOLA TÁRTALO, Beatriz) en HEFENDEHL, Roland (Ed.). La teoría del bien jurídico. ¿Fundamento de legitimación del Derecho Penal o juego de abalorios dogmático?. Ed. Marcial Pons, ediciones jurídicas y sociales, S.A. Madrid. Barcelona. 2007.

WADE, L.G. Jr. (Trad. MONTAÑA PEDRERO, Ángel Manuel. BATALLA GARCÍA, Consuelo). Química Orgánica. Quinta edición. Pearson Prentice Hall. Madrid. 2004.

WOLTER, Jürgen. “Derechos humanos y protección de bienes jurídicos en un sistema Europeo del Derecho Penal". (Trad. BALDÓ LAVILLA, Francisco) en SCHÜNEMANN, B., FIGUEREIDO DIAS (Coord.). SILVA SÁNCHEZ, Jesús María (Ed.). Fundamentos de un sistema Europeo del Derecho Penal. Ed. J.M. Bosch Editor, S.A. Barcelona, 1995.

ZAFFARONI, Raúl Eugenio. "El funcionalismo sistémico y sus respectivas jurídico- penales" en Estudios penales en memoria del profesor Agustín Fernández- Albor. Ed. Universidad de Santiago de Compostela. 1989.

ZODER, Isabel. La protección personal del Nasciturus. Tesis Doctoral. Universidad de Salamanca. Salamanca 1997.

ZÚÑIGA RODRÍGUEZ, Laura. Libertad Personal y Seguridad Ciudadana. Estudio del tipo penal de injusto del delito de detenciones ilegales practicadas por funcionarios públicos. Ed. PPU. 1993. 


\section{ÍNDICE DE JURISPRUDENCIA CONSULTADA}

\section{A.) TRIBUNAL CONSTITUCIONAL}

- $\quad$ STC 11/1983, de 21 de febrero de 1983. Ponente: Francisco Pera Verdaguer (utilización de agentes encubiertos y entrega vigilada).

- STC 145/1985, del 28 de octubre de 1985. Ponente: D.a Gloria Begué Cantón (conducción bajo la influencia de bebidas alcohólicas).

- STC 148/1985, del 30 de octubre de 1985. Ponente: D.a Gloria Begué Cantón (conducción bajo la influencia de bebidas alcohólicas).

- STC 65/1986, de 22 de mayo de 1986. Ponente: D. Ángel Latorre Segura (bien jurídico y Constitución).

- $\quad$ STC 22/1988, del 18 de febrero de 1988. Ponente: D. Fernando García-Mon y González (conducción bajo la influencia de bebidas alcohólicas).

- STC 105/1988, de 8 de junio de 1988. Ponente: D. Luis Díez-Picazo y Ponce de León (posesión de instrumentos idóneos para ejecutar el delito de robo).

- STC 111/1993, de 25 de marzo de 1993. Ponente: D. Álvaro Rodríguez Bereijo (delito de intrusismo, bienes jurídicos y Constitución).

- STC 136/1999, de 20 de julio de 1999. Ponente: D. Carles Viver Pi-Sunyer (principio de lesividad).

- STC 188/2002, de 14 de octubre del 2002. Ponente: D. - María Emilia Casas Baamonde (conducción bajo la influencia de bebidas alcohólicas).

- STC 200/2004, de 15 de noviembre del 2004. Ponente: D. Eugeni Gay Montalvo (conducción bajo la influencia de bebidas alcohólicas).

- STC 160/2006, de 22 de mayo de 2006. Ponente: D. Pascual Sala Sánchez (colaboración con la justicia).

\section{B.) TRIBUNAL SUPREMO}

- $\quad$ STS (ROJ: 1494/1966) de 23 de diciembre de 1966. Ponente: D. Enrique Cid y Ruiz Zorrilla (concepto de salud pública).

- STS (ROJ: 1680/1969) de 28 de octubre de 1969. Ponente: D. Ángel Escudero Coral (concepto de salud pública).

- $\quad$ STS (ROJ: 2750/1970) de 11 de marzo de 1970. Ponente: D. Fidel de Oro Pulido (concepto de salud pública). 
- $\quad$ STS (ROJ: 1910/1971) de 9 de marzo de 1971. Ponente: D. Ángel Escudero del Coral (concepto de salud pública).

- STS (ROJ: 3310/1972) de 27 de junio de 1972. Ponente: D. José Espinosa Herrera (concepto de salud pública).

- STS (ROJ: 4399/1978) de 6 de noviembre de 1978. Ponente: D. Luis Vivas Marzal (concepto de salud pública).

- STS (ROJ: 4296/1980) de 19 de diciembre de 1980. Ponente: D. Mariano Gómez de Liaño Cobaleda (delitos de peligro abstracto).

- $\quad$ STS (ROJ: 4252/1981) de 22 de junio de 1981. Ponente: D. Juan Latours Brotons (drogas ilícitas, convenios internacionales).

- STS (ROJ: 4704/1981) de 8 de junio de 1981. Ponente: D. Manuel García Miguel (drogas ilícitas, convenios internacionales).

- STS (ROJ: 5086/1981) de 2 de octubre de 1981. Ponente: D. Mariano Gómez de Liaño Cobaleda (delitos de peligro abstracto).

- STS (ROJ: 1507/1982) de 24 de febrero de 1982. Ponente: D. Martín Jesús Rodríguez López (concepto de salud pública).

- STS (ROJ: 1154/1983) de 2 de Marzo de 1983. Ponente: D. Juan Latour Brotóns (principio de lesividad).

- $\quad$ STS (ROJ: 1516/1983) de 8 de febrero de 1983. Ponente: D. Juan Latour Brotóns (bien jurídico).

- STS (ROJ: 1615/1983) de 20 de enero de 1983. Ponente: D. Mariano Gómez de Liaño Cobaleda (delitos de peligro abstracto).

- STS (ROJ: 1007/1984) de 24 de mayo de 1984. Ponente: D. Mariano Gómez de Liaño Cobaleda (delitos de peligro abstracto).

- $\quad$ STS (ROJ: 1383/1984) de 22 de marzo de 1984. Ponente: D. José Hijas Palacios (drogas ilícitas, convenios internacionales).

- STS (ROJ: 45/1985) de 4 de febrero de 1985. Ponente: D. José Hermenegildo Moyna Ménguez (tentativa de tráfico de drogas).

- STS (ROJ: 278/1985) del 20 de febrero de 1985. Ponente: D. Juan Latours Brotóns (delitos de peligro abstracto).

- STS (ROJ: 1111/1985) de 18 de marzo de 1985. Ponente: D. Benjamín Gil Sáez (delitos de peligro abstracto).

- $\quad$ STS (ROJ: 1131/1985) de 25 de octubre de 1985. Ponente: D. José Hijas palacios (concepto de salud pública).

- STS (ROJ: 1161/1985) de 29 de junio de 1985. Ponente: D. José augusto de Vega Ruiz (concepto de salud pública). 
- $\quad$ STS (ROJ: 1046/1985) del 12 de noviembre de 1985. Ponente: D. Martín Jesús Rodríguez López (delitos de peligro abstracto).

- STS (ROJ: 2995/1986) de 3 de junio. Ponente: D. Ramón Montero Fernández (tentativa de tráfico de drogas).

- $\quad$ STS (ROJ: 1344/1987) de 26 de febrero de 1987. Ponente: D: José Jiménez Villarejo (drogas ilícitas, convenios internacionales).

- STS (ROJ: 6617/1987) de 22 de octubre de 1987. Ponente: D. Fernando Díaz Palos (conducción bajo la influencia de bebidas alcohólicas).

- STS (ROJ: 7902/1987) de 9 de diciembre de 1987. Ponente: D. José Hermenegildo Moyna Ménguez (conducción bajo la influencia de bebidas alcohólicas).

- STS (ROJ: 8150/1989) de 19 de mayo de 1989. Ponente: D. José Hermenegildo Moyna Ménguez (conducción bajo la influencia de bebidas alcohólicas).

- STS (ROJ: 4052/1989) de 7 de julio del 1989. Ponente: D. Luis Román Puerta Luis (conducción bajo la influencia de bebidas alcohólicas).

- STS (ROJ: 1437/1992) de 24 de febrero del 1992. Ponente: D. Fernando Díaz Palos (conducción bajo la influencia de bebidas alcohólicas).

- STS (ROJ: 8957/1992) de 9 de diciembre 1992. Ponente: D. José Antonio Martín Pallín (drogas que no causan grave daño a la salud).

- STS (ROJ: 9361/1992) de 24 de diciembre de 1992. Ponente: D. Joaquín Delgado García (drogas que no causan grave daño a la salud).

- STS (ROJ: 20999/1992) de 23 de abril de 1992. Ponente: D. Enrique Bacigalupo Zapater (caso Colza).

- STS (ROJ: 1927/1993) de 24 de marzo de 1993. Ponente: D. Luis Román Puerta Luis (bien jurídico tutelado en los delitos relativos al tráfico de drogas y en el delito de contrabando de drogas).

- STS (ROJ: 1985/1993) de 25 de marzo de 1993. Ponente: D. Cándido CondePumpido Ferreiro (delitos de peligro abstracto, principio de lesividad).

- $\quad$ STS (ROJ: 3198/1993) de 21 de mayo de 1993. Ponente: D. José Hermenegildo Moyna Ménguez (agente provocador).

- STS (ROJ: 3499/1993) de 29 de mayo de 1993. Ponente: D. Cándido CondePumpido Ferreiro (tráfico de drogas, naturaleza de los delitos de peligro abstracto).

- STS (ROJ: 5911/1993) de 15 de septiembre de 1993. Ponente: D. Cándido Conde-Pumpido Ferreiro (agente encubierto). 
- $\quad$ STS (ROJ: 1566/1994) de 9 de marzo de 1994. Ponente: D. José Hermenegildo Moyna Ménguez (bien jurídico tutelado en los delitos relativos al tráfico de drogas y en el delito de contrabando de drogas).

- STS (ROJ: 2086/1994) de 28 de marzo de 1994. Ponente: D. José augusto de Vega Ruiz (error en el delito de tráfico de drogas).

- STS (ROJ: 9640/1994) de 30 de mayo de 1994. Ponente: D. José Augusto de Vega Ruiz (bien jurídico tutelado en los delitos relativos al tráfico de drogas y en el delito de contrabando de drogas).

- $\quad$ STS (ROJ: 133/1995) de 19 de enero de 1995. Ponente: D. Enrique Bacigalupo Zapater (tráfico de drogas, autoría y participación).

- STS (ROJ: 1112/1995) de 27 de febrero de 1995. Ponente: D. Ramón Montero Fernández-Cid (tentativa de tráfico de drogas).

- STS (ROJ: 2216/1995) de 17 de abril de 1995. Ponente: D. Joaquín Martín Canivell (error en el delito de tráfico de drogas).

- STS (ROJ: 3860/1995) de 30 de junio de 1995. Ponente: D. Joaquín Martín Canivell (condena por tráfico de drogas en grado de conspiración el tráfico de precursores).

- STS (ROJ: 4580/1995) de 18 de septiembre de 1995. Ponente: D. Luis Román Puerta Luis (utilización de precursores para adulterar drogas).

- STS (ROJ: 5861/1995) de 21 de noviembre de 1995. Ponente: D. Joaquín Delgado García (error en el delito de tráfico de drogas).

- STS (ROJ: 2094/1996) de 8 de abril de 1996. Ponente: D. Cándido CondePumpido Tourón (bien jurídico tutelado en los delitos relativos al tráfico de drogas y en el delito de contrabando de drogas).

- STS (ROJ: 2847/1996) de 13 de mayo de 1996. Ponente: D. José Augusto de Vega Ruiz (condenaban por tráfico de drogas el tráfico de precursores).

- STS (ROJ: 6737/1996) de 28 de noviembre de 1996. Ponente: D. José Luis Manzanares Samaniego (participación en el tráfico de drogas).

- STS (ROJ: 7393/1996) de 20 de diciembre de 1996. Ponente: D. Cándido Conde-Pumpido Tourón (reincidencia internacional).

- STS (ROJ: 1757/1997) de 11 de marzo de 1997. Ponente: D. Cándido CondePumpido Tourón (bien jurídico tutelado en los delitos relativos al tráfico de drogas y en el delito de contrabando de drogas).

- STS (ROJ: 5661/1997) de 26 de septiembre de 1997. Ponente: D. Gregorio García Ancos (caso Colza). 
- $\quad$ STS (ROJ: 7272/1997) de 1 de diciembre de 1997 Ponente: D. Enrique Bacigalupo Zapater (bien jurídico tutelado en los delitos relativos al tráfico de drogas y en el delito de contrabando de drogas).

- $\quad$ STS (ROJ: 7303/1997) de 2 de diciembre de 1997. Ponente: D. Cándido CondePumpido Tourón (bien jurídico tutelado en los delitos relativos al tráfico de drogas y en el delito de contrabando de drogas).

- $\quad$ STS (ROJ: 2644/1998) de 27 de abril de 1998. Ponente: D. José Antonio Martín Pallín (drogas que no causan grave daño a la salud).

- $\quad$ STS (ROJ: 2855/1998) de 5 de mayo de 1998. Ponente: D. José Antonio Martín Palllín (conspiración para el delito de tráfico de drogas).

- $\quad$ STS (ROJ: 3187/1998) de 18 de mayo de 1998. Ponente: D. Gregorio García Ancos (drogas que no causan grave daño a la salud).

- $\quad$ STS (ROJ: 4886/1998) de 20 de junio de 1998. Ponente: D. José Augusto de la Vega Ruiz (drogas que no causan grave daño a la salud).

- $\quad$ STS (ROJ: 6427/1998) de 4 de Noviembre de 1998. Ponente: D. Eduardo Moner Muñoz (drogas que no causan grave daño a la salud).

- $\quad$ STS (ROJ: 6816/1998) de 17 de Noviembre de 1998. Ponente: D. José Jiménez Villarejo (drogas que no causan grave daño a la salud.

- $\quad$ STS (ROJ: 2290/1999) de 1 de abril de 1999. Ponente: D. Joaquín Martín Canivell (decomiso en los delitos relativos al tráfico de drogas).

- $\quad$ STS (ROJ: 2484/1999) de 14 de abril de 1999. Ponente: D. Eduardo Moner Muñoz (tráfico de precursores).

- $\quad$ STS (ROJ: 4373/1999) de 21 de junio de 1999. Ponente: D. Cándido CondePumpido Tourón (tentativa de tráfico de drogas).

- $\quad$ STS (ROJ: 1905/2000) de 10 de marzo de 2000. Ponente: D. Adolfo Prego de Oliver Tovar (elementos que integraban el concepto de organización).

- STS (ROJ: 1966/2000) de 13 de marzo de 2000. Ponente: D. Enrique Bacigalupo Zapater (tentativa de tráfico de drogas).

- $\quad$ STS (ROJ: 2083/2000) de 15 de marzo de 2000. Ponente: D. José Antonio Marañón Chávarri (colaboración con la justicia).

- $\quad$ STS (ROJ: 5207/2000) de 26 de junio de 2000. Ponente: D. Joaquín Giménez García (autoría y participación en el tráfico de drogas).

- $\quad$ STS (ROJ: 7672/2000) de 24 de octubre 2000. Ponente: D. Enrique Abad Fernández (autoría y participación en el tráfico de drogas). 
- STS (ROJ: 8986/2000) de 5 de diciembre del año 2000. Ponente: D. Cándido Conde-Pumpido Tourón (prueba de elementos subjetivos mediante juicio de inferencia).

- STS (ROJ: 9063/2000) de 11 de diciembre de 2000. Ponente: D. Adolfo Prego de Oliver (tráfico de drogas y antijuricidad material).

- STS (ROJ: 508/2001) de 29 de enero de 2001. Ponente: D. Joaquín Delgado García (colaboración con la justicia).

- STS (ROJ: 1209/2001) de 20 de febrero de 2001. Ponente: D. Adolfo Prego de Oliver Tolivar (el decomiso en los delitos relativos al tráfico de drogas).

- $\quad$ STS (ROJ: 1701/2001) de 5 de marzo de 2001. Ponente: D. José Jiménez Villarejo (tentativa de tráfico de drogas).

- STS (ROJ: 2497/2001) de 26 de marzo de 2001. Ponente: D. José Jiménez Villarejo (tráfico de precursores).

- STS (ROJ: 5008/2001) de 12 de junio de 2001. Ponente: D. José Antonio Martín Pallín (la participación en el tráfico de drogas).

- STS (ROJ: 5898/2001) de 29 de julio de 2001. Ponente: D. Alfredo Prego de Oliver (tráfico de drogas y antijuricidad material).

- STS (ROJ: 6024/2001) de 10 de julio de 2001. Ponente: D. Eduardo Moner Muñoz (autoría y partición en el tráfico de drogas).

- STS (ROJ: 6202/2001) de 16 de julio de año 2001. Ponente: D. Cándido CondePumpido Tourón (autoría y participación en el tráfico de drogas).

- STS (ROJ: 7714/2001) de 9 de octubre de 2001. Ponente: D. José Ramón Soriano Soriano (concurso entre tráfico de drogas y tráfico de precursores).

- STS (ROJ: 9770/2001) de 12 de diciembre de 2001. Ponente: D. Cándido Conde-Pumpido Tourón (tentativa de tráfico de drogas).

- STS (ROJ: 1230/2002) de 22 de febrero de 2002. Ponente: D. José Jiménez Villarejo (agente encubierto).

- STS (ROJ: 2632/2002) de 15 de abril de 2002. Ponente: D. Julián Artemio Sánchez Melgar (conducción bajo la influencia de bebidas alcohólicas).

- STS (ROJ: 2712/2002) de 17 de abril de 2002. Ponente: D. Miguel Colmenero Menéndez de Luarca (tráfico de drogas, autoría y participación).

- STS (ROJ: 3732/2002) de 25 de mayo de 2002. Ponente: D. Gregorio García Ancos (concurso entre tráfico de drogas y tráfico de precursores).

- STS (ROJ: 4446/2002) de 18 de junio de 2002. Ponente: D. Gregorio García Ancos (conspiración del delito de tráfico de drogas). 
- STS (ROJ: 4600/2002) de 21 de junio de 2002. Ponente: D. Carlos Granados Pérez (tráfico de drogas, autoría y participación).

- STS (ROJ: 51/2002) de 10 de enero de 2002. Ponente: D. Joaquín Giménez García (entrega vigilada).

- STS (ROJ: 8929/2002) de 30 de diciembre de 2002. Ponente: D. José Ramón Soriano Soriano (tráfico de drogas, autoría y participación).

- STS (ROJ: 89/2003) del 16 de enero de 2003. Ponente: D. Luis Román Puerta Luis (tráfico de precursores).

- STS (ROJ: 102/2003) de 16 de enero de 2003. Ponente: D. Andrés Martínez Arrieta (decomiso en los delitos relativos al tráfico de drogas).

- STS (ROJ: 1317/2003) de 27 de febrero de 2003. Ponente: Miguel Colmenero Menéndez (error en el delito de tráfico de drogas).

- STS (ROJ: 2126/2003) de 27 de marzo de 2003. Ponente: D. Carlos Granados Pérez (tráfico de drogas, autoría y participación).

- STS (ROJ: 3020/2003) de 5 de mayo de 2003. Ponente: D. José Antonio Marañón Chavarri (concurso entre tráfico de drogas y tráfico de precursores).

- STS (ROJ: 3303/2003) de 16 de mayo de 2003. Ponente: D. José Aparicio Calvo-Rubio (concurso entre tráfico de drogas y tráfico de precursores).

- STS (ROJ: 3417/2003) de 20 de mayo de 2003. Ponente: D. Gregorio García Ancos (conspiración para el delito de tráfico de drogas).

- STS (ROJ: 3705/2003) de 30 de mayo de 2003. Ponente: D. José Manuel Maza Martín (agente encubierto).

- STS (ROJ: 4107/2003) de 13 de junio de 2003. Ponente: D. Julián Artemio Sánchez Melgar (agente encubierto).

- $\quad$ STS (ROJ: 4125/2003) de 13 de junio de 2003. Ponente: D. Juan Saavedra Ruiz (tráfico de drogas y antijuricidad material).

- STS (ROJ: 4318/2003) de 20 de junio de 2003. Ponente: D. Carlos Granados Pérez (tráfico de drogas y antijuricidad material).

- STS (ROJ: 4335/2003) de 21 de junio de 2003. Ponente: D. Enrique Bacigalupo Zapater (tráfico de drogas y antijuricidad material).

- STS (ROJ: 4483/2003) de 26 de junio de 2003. Ponente: D. Miguel Colmenero Menéndez de Luarca (tráfico de drogas y antijuricidad material).

- STS (ROJ: 4708/2003) de 4 de julio de 2003. Ponente: D. Cándido CondePumpido Tourón (tráfico de drogas y antijuricidad material).

- STS (ROJ: 5093/2003) de 17 de julio de 2003. Ponente: D. Perfecto Agustín Andrés Ibáñez (tráfico de drogas y antijuricidad material). 
- $\quad$ STS (ROJ: 5022/2003) de 15 de julio de 2003. Ponente: D. Juan Saavedra Ruiz (decomiso en los delitos relativos al tráfico de drogas).

- STS (ROJ: 5254/2003) de 21 de julio de 2003. Ponente: D. Julián Artemio Sánchez Melgar (tráfico de drogas, peligro abstracto).

- STS (ROJ: 5465/2003) de 12 de septiembre de 2003. Ponente: D. Joaquín Delgado García (reincidencia internacional).

- $\quad$ STS (ROJ: 7691/2003) de 2 de diciembre de 2003. Ponente: D. Enrique Abad Fernández (tentativa de tráfico de drogas).

- STS (ROJ: 7737/2003) de 3 de diciembre de 2003. Ponente: D. Miguel Colmenero Menéndez de Luarca (Prueba de elementos subjetivos mediante juicio de inferencia).

- STS (ROJ: 583/2004) de 3 de febrero de 2004. Ponente: D. Enrique Bacigalupo Zapater (tráfico de precursores).

- STS (ROJ: 931/2004) de 13 de febrero de 2004. Ponente: D. Enrique Bacigalupo Zapater (concepto de salud pública).

- STS (ROJ: 1849/2004) de 17 de marzo de 2004. Ponente: D. Joaquín Giménez García (concurso entre tráfico de drogas y tráfico de precursores).

- STS (ROJ: 3127/2004) de 10 de mayo de 2004. Ponente: D. Carlos Granados Pérez (tráfico de drogas, bien jurídico salud pública).

- STS (ROJ: 3252/2004) de 13 de mayo de 2004. Ponente: D. Miguel Colmenero Menéndez de Luarca (reincidencia internacional).

- STS (ROJ: 3843/2004) de 3 de junio de 2004. Ponente: D. Miguel Colmenero Menéndez de Luarca (tráfico de drogas, peligro abstracto).

- STS (ROJ: 4700/2004) de 2 de julio de 2004. Ponente: D. José Antonio Martín Pallín (concurso entre tráfico de drogas y tráfico de precursores).

- STS (ROJ: 4744/2004) de 2 de julio de 2004. Ponente: D. Enrique Bacigalupo Zapater (proposición para el delito de tráfico de drogas).

- STS (ROJ: 5514/2004) de 24 de julio de 2004. Ponente: D. Julián Artemio Sánchez Melgar (conspiración para el delito de tráfico de drogas).

- STS (ROJ: 5626/2004) de 10 de septiembre de 2004. Ponente: D. Carlos Granados Pérez (proposición para el delito de tráfico de drogas)

- STS (ROJ: 5639/2004) de 13 de septiembre de 2004. Ponente: D. Luis Román Puerta Luis (tráfico de drogas, autoría y participación).

- STS (ROJ: 6197/2004) de 5 de octubre de 2004. Ponente: D. Diego Antonio Ramos Gancedo (tráfico de drogas, peligro abstracto). 
- STS (ROJ: 8114/2004) de 15 de diciembre de 2004. Ponente: D. Carlos Granados Pérez.

- STS (ROJ: 14/2005) de 10 de enero de 2005. Ponente: D. Juan Ramón Berdugo Gómez de la Torre (decomiso en los delitos relativos al tráfico de drogas).

- STS (ROJ: 672/2005) de 7 de febrero de 2005. Ponente: D. Andrés Martínez Arrieta (tráfico de drogas, salud pública).

- STS (ROJ: 676/2005) del 7 de febrero de 2005. Ponente: D. Miguel Colmenero Menéndez de Luarca (tráfico de drogas, peligro abstracto).

- STS (ROJ: 758/2005) de 10 de febrero de 2005. Ponente: D. Juan Saavedra Ruiz (error en el delito de tráfico de drogas).

- STS (ROJ: 999/2005) de 18 de febrero de 2005. Ponente: D. Juan Ramón Berdugo Gómez de la Torre (tráfico de drogas, principio de lesividad).

- STS (ROJ: 3967/2005) de 17 de junio del 2005. Ponente: D. Diego Antonio Ramos Gancedo (tráfico de drogas, peligro abstracto).

- STS (ROJ: 5385/2005) de 20 de septiembre de 2005. Ponente: D. Julián Artemio Sánchez Melgar (decomiso en los delitos relativos al tráfico de drogas).

- STS (ROJ: 6272/2005) de 7 de febrero de 2005. Ponente: D. Andrés Martínez Arrieta (tráfico de drogas, principio de lesividad).

- STS (ROJ: 6801/2005) de 7 de noviembre de 2005. Ponente: D. Juan Ramón Berdugo Gómez de la Torre (delitos de peligro abstracto, principio de lesividad).

- STS (ROJ: 7500/2005) de 28 de noviembre de 2005. Ponente: D. José Manuel Maza Martín (concurso entre tráfico de drogas y tráfico de precursores).

- STS (ROJ: 1957/2006) de 31 de marzo de 2006. Ponente: D. José Ramón Soriano Soriano (sustancias que causan grave daño a la salud).

- STS (ROJ: 2650/2006) de 2 de mayo de 2006. Ponente: D. Juan Ramón Berdugo Gómez de la Torre (decomiso en los delitos relativos al tráfico de drogas).

- STS (ROJ: 5324/2006) de 15 de septiembre de 2006. D. Andrés Martínez Arrieta (conducción bajo la influencia de bebidas alcohólicas).

- STS (ROJ: 5738/2006) de 6 de octubre de 2006. Ponente: D. José Ramón Soriano Soriano (determinación de la cuantía de la pena de multa).

- STS (ROJ: 8785/2006) de 10 de febrero de 2006. Ponente: D. Juan Ramón Berdugo Gómez de la Torre (decomiso en los delitos relativos al tráfico de drogas).

- STS (ROJ: 793/2007) de 7 de febrero de 2007. Ponente: D. Juan Ramón Berdugo Gómez de la Torre (decomiso en los delitos relativos al tráfico de drogas). 
- STS (ROJ: 2398/2007) de 20 de abril de 2007. Ponente: D. José Ramón Soriano Soriano (tráfico de drogas autoría y participación).

- STS (ROJ: 3391/2007) de 25 de abril de 2007. Ponente: D. Juan Ramón Berdugo Gómez de la Torre (decomiso en los delitos relativos al tráfico de drogas).

- STS (ROJ: 6914/2007) de 31 de octubre de 2007. Ponente: D. Juan Ramón Berdugo Gómez de la Torre (decomiso en los delitos relativos al tráfico de drogas).

- STS (ROJ: 7815/2007) de 15 de noviembre de 2007. Ponente: D. Juan Artemio Sánchez Melgar (uso de precursores para adulterar drogas, agentes encubiertos).

- STS (ROJ: 1186/2008) de 11 de febrero de 2008. Ponente: D. Julián Artemio Sánchez Melgar (imposición de multa no solicitada por el Fiscal).

- STS (ROJ: 2633/2008) de 10 de junio de 2008. Ponente: D. Juan Ramón Berdugo Gómez de la Torre.

- STS (ROJ: 2970/2008) de 2 de junio de 2008. Ponente: D. Francisco Monterde Ferrer (decomiso en los delitos relativos al tráfico de drogas).

- STS (ROJ: 5941/2008) de 3 de octubre de 2008. Ponente D. Manuel Marchena Gómez (entrega vigilada).

- STS (ROJ: 6795/2008) de 16 de diciembre de 2008. Ponente: D. Juan Ramón Berdugo Gómez de la Torre (tentativa de tráfico de drogas).

- $\quad$ STS (ROJ: 7312/2008) de 17 de diciembre de 2008. Ponente: D. Manuel Marchena Gómez (determinación de la cuantía de la pena de multa).

- STS (ROJ: 99/2009) de 8 de enero de 2009. Ponente: D. Francisco Monterde Ferrer (tentativa de tráfico de drogas).

- STS (ROJ: 957/2009) de 4 de marzo de 2009. Ponente: D. Andrés Martínez Arrieta (determinación de la cuantía de la pena de multa).

- STS (ROJ: 1155/2009) de 19 de noviembre de 2009. Ponente: D. Miguel Colmenero Menéndez de Luarca (tentativa de tráfico de drogas).

- STS (ROJ: 1242/2009) de 6 de febrero de 2009. Ponente: D. José Manuel Maza Martín (agente encubierto).

- STS (ROJ: 1748/2009) de 18 de marzo de 2009. Ponente: D. Carlos Granados Pérez (tráfico de precursores).

- STS (ROJ: 3318/2009) de 1 de junio de 2009. Ponente: D. Juan Ramón Berdugo Gómez de la Torre (determinación de la cuantía de la pena de multa).

- STS (ROJ: 3941/2009) de 3 de junio de 2009. Ponente: D. Joaquín Giménez García (tráfico de drogas, sustancias no catalogadas como precursores). 
- STS (ROJ: 4628/2009) de 18 de junio de 2009. Ponente: D. Manuel Marchena Gómez (entrega vigilada).

- STS (ROJ: 4906/2009) de 6 de julio de 2009. Ponente: D. Julián Artemio Sánchez Melgar (entrega vigilada).

- STS (ROJ: 6447/2009) de 16 de octubre de 2009. Ponente: D. Juan Ramón Berdugo Gómez de la Torre (tentativa de tráfico de drogas).

- STS (ROJ: 7190/2009) de 29 de octubre de 2009. Ponente: D. Enrique Bacigalupo Zapater (decomiso en los delitos relativos al tráfico de drogas).

- STS (ROJ: 1148/2010) de 23 de febrero de 2010. Ponente: D. Alberto Gumersindo Jorge Barreiro (tentativa de tráfico de drogas).

- STS (ROJ: 1413/2010) de 10 de marzo de 2010. Ponente: D. Andrés Martínez Arrieta (tentativa de tráfico de drogas).

- STS (ROJ: 2061/2010) de 20 de abril de 2010. Ponente: D. Joaquín Jiménez García (bien jurídico protegido en los delitos relativos al tráfico de drogas).

- STS (ROJ: 2804/2010) de 7 de mayo de 2010. Ponente: D. Alberto Gumersindo Jorge Barreiro (tráfico de drogas, autoria y participación).

- STS (ROJ: 4065/2010) de 29 de junio de 2010. Ponente: D. Carlos Granados Pérez (tentativa de tráfico de drogas).

- STS (ROJ: 4208/2010) de 22 de junio de 2010. Ponente: D. Julián Antonio Sánchez Melgar (tráfico de drogas, autoría y participación).

- STS (ROJ: 4232/2010) de 23 de junio de 2010. Ponente: D. Adolfo Prego de Oliver Tolivar (tenencia o tráfico de sustancias no catalogadas como precursores).

- STS (ROJ: 4713/2010) de 23 de julio de 2010. Ponente: D. Enrique Bacigalupo Zapater (conspiración para el delito de tráfico de drogas).

- STS (ROJ: 5856/2011) de 27 de septiembre de 2011. Ponente: D. Juan Ramón Berdugo Gómez de la Torre (concurso entre tráfico de drogas y tráfico de precursores).

- STS (ROJ: 4207/2012) de 29 de mayo de 2012. Ponente: D. Miguel Colmenero Menéndez de Luarca (concurso entre tráfico de drogas y tráfico de precursores).

- STS (ROJ: 232/2013) de 18 de enero de 2013. Ponente: D. Alberto Gumersindo Jorge Barreiro (tráfico de precursores).

- STS (ROJ: 1840/2013) de 1 de abril de 2013. Ponente: D. Miguel Colmenero Menéndez de Luarca (pertenencia a grupo criminal). 
- STS (ROJ: 5580/2013) de 11 de diciembre de 2013. Ponente: D. Cándido Conde- Pumpido Tourón (pertenencia a grupo criminal).

- STS (ROJ: 220/2014) de 9 de enero de 2014. Ponente: D. Alberto Gumersindo Jorge Barreiro (pertenencia a grupo criminal).

- STS (ROJ: 3131/2014) de 18 de julio de 2014. Ponente: D. Cándido CondePumpido Tourón (concurso entre tráfico de drogas y tráfico de precursores).

- STS (ROJ: 3893/2014) de 22 de septiembre de 2014. Ponente: D. Manuel Marchena Gómez (participación en el tráfico de drogas).

- STS (ROJ: 822/2015) de 5 de marzo de 2015. Ponente: D. Juan Ramón Berdugo Gómez de la Torre (entrega vigilada).

- STS (ROJ: 2774/2016) de 9 de junio de 2016. Ponente: D. Juan Ramón Berdugo Gómez de la Torre (concurso entre tráfico de drogas y tráfico de precursores).

- STS (ROJ: 5672/2016) de 23 de diciembre de 2016. Ponente: D. Andrés Palomo del Arco (tráfico de precursores).

\section{C.) AUDIENCIA NACIONAL}

- SAP de Málaga (ROJ: 3036/1999) de 24 de septiembre de 1999. Ponente: D. Ignacio Escribano Cobo (reincidencia internacional).

- SAN (ROJ: 1959/2001) de 27 de marzo de 2001. Ponente: D. Elizabeth Cardona Mínguez (reincidencia internacional).

- SAN (ROJ: 4326/2002) de 9 de julio de 2002. Ponente: D. ${ }^{a}$ Raimunda de Peñafort Lorente Martínez (tráfico de precursores).

- SAN (ROJ: 8185/2005) de 3 de noviembre de 2005. Ponente: D. Félix Alfonso Guevara Marcos (concurso entre tráfico de drogas y tráfico de precursores).

- SAN (ROJ: 6508/2006) de 21 de julio de 2006. Ponente: D. Juan Francisco Martel Rivera (tráfico de precursores).

- SAN (ROJ: 6088/2009) de 21 de enero de 2009. Ponente: D. a María Teresa Palacios Criado (concurso entre tráfico de drogas y tráfico de precursores).

- SAN (ROJ: 3347/2013) de 3 de julio de 2013. Ponente: D. Fernando GrandeMarlaska Gómez (tráfico de precursores).

\section{D.) AUDIENCIAS PROVINCIALES}

- SAP de Madrid (ROJ: 8039/1999) de 8 de junio de 1999. Ponente: D. Adrián Varillas Gómez (concurso entre tráfico de drogas y tráfico de precursores). 
- SAP de Santa Cruz de Tenerife (ROJ: 1299/2002) de 20 de mayo de 2002. Ponente: D. Esteban Solaz Solaz (reincidencia internacional).

- SAP de Madrid (ROJ: 1659/2003) de 10 de febrero de 2003. Ponente: D. Adrián Varillas Gómez (tráfico de precursores).

- SAP de Salamanca (ROJ: 348/2004) de 3 de junio de 2004. Ponente: D. Ildefonso García del Pozo (tráfico de precursores).

- SAP de Madrid (ROJ: 15967/2005) de 17 de noviembre de 2005. Ponente: D. Juan Francisco Martel Rivero (tráfico de precursores).

- SAP de Guadalajara (ROJ: 71/2007) de 7 de marzo de 2007. Ponente: D. ${ }^{a}$ María Ángeles Martínez Domínguez (tráfico de precursores).

- SAP de Madrid (ROJ: 2827/2009) de 16 de marzo de 2009. Ponente: D. Jesús Ángel Guijarro López (tráfico de precursores).

- SAP de Toledo (ROJ: 865/2009) de 14 de octubre de 2009. Ponente: D. Urbano Suárez Sánchez (tráfico de drogas, autoría y participación).

- SAP de Madrid (ROJ: 7718/2010) de 25 de mayo de 2010. D. Ponente: D.a Adoración María Riera Ocariz (concurso entre tráfico de drogas y tráfico de precursores).

- SAP de Madrid (ROJ: 11904/2010) de 14 de junio de 2010. Ponente: D. Pascual Fabia Mir (objeto material del tráfico de precursores).

- SAP de Guadalajara (ROJ: 234/2010) de 23 de junio de 2010. Ponente: D. Manuel Eduardo Regalado Valdés (concurso entre tráfico de drogas y tráfico de precursores).

- SAP de Ciudad Real (ROJ: 617/2011) de 20 de julio de 2011. Ponente: D. Alfonso Moreno Cardoso (concurso entre tráfico de drogas y tráfico de precursores).

- SAP de Murcia (ROJ: 2858/2011) de 16 de diciembre de 2011. Ponente: D. José Manuel Nicolás Manzanares (tráfico de precursores).

- SAP de Madrid (ROJ: 1011/2014) de 28 de enero de 2014. Ponente: D. a Adoración María Riera Ocariz (concurso entre tráfico de drogas y tráfico de precursores).

- SAP de Madrid (ROJ: 4062/2016) de 31 de marzo de 2016. Ponente: D. - María del Pilar de Prada Bengoa (concurso entre tráfico de drogas y tráfico de precursores).

- SAP de Palencia (ROJ: 129/2016) de 11 de abril de 2016. Ponente: D. Carlos Miguélez del Río (concurso entre tráfico de drogas y tráfico de precursores).

- SAP de Guadalajara (ROJ: 206/2016) de 23 de julio de 2016. Ponente: D. ${ }^{a}$ Isabel Serrano Frías (concurso entre tráfico de drogas y tráfico de precursores). 
- SAP de San Sebastián (ROJ: 835/2016) de 3 de octubre de 2016. Ponente: D. Jorge Juan Hoyos Moreno (concurso entre tráfico de drogas y tráfico de precursores). 
ANEXOS 



\section{DISPOSICIONES GENERALES}

\section{JEFATURA DEL ESTADO}

9973

Ley 4/2009, de 15 de junio, de control de precursores de drogas.

JUAN CARLOS I

REY DE ESPANA

A todos los que la presenten vieren y entendieren. Ley.

Sabed: Que las Cortes Generales han aprobado y Yo vengo en sancionar la siguiente

PREÁMBULO

El articulo 12 del Convenio de las Naciones Unidas contra el tráfico ilicito de estupefacientes y sustancias psicotrópicas, adoptado en Viena el 19 de diciembre de 1988 . del que España es parte, contempla la adopción de medidas adecuadas para controlar la fabricación y distribución de precursores entre los Estados miembros.

Estas sustancias quimicas, que se desvian de su curso legal y se utilizan para la elaboración de distintos tipos de drogas, se producen fundamentalmente en paises desarrollados, motivo por el cual dichos paises adquieren compromisos derivados de la adhesión a Convenios Internacionales como el mencionado, a través de los cuales adoptan normativas y legislan para conseguir una armonización adecuada y eficaz, que facilite e control de los precursores desde su fabricación hasta su destino final, al objeto de evitar su desvio para fines ilicitos.

Sin embargo, ha de tenerse en cuenta que dichas sustancias se destinan fundamentalmente a la fabricación industrial de importantes derivados muy corrientes y necesarios en nuestra sociedad y que, por io tanto, su control debe dirigirse únicamente necer evitar su desvio para laelaboración ilicita de drogas, sin interferir en el normal funcionamiento
de su fabricación y comercio.

En el ámbito de la Unión Europea, el establecimiento de medidas adecuadas a tal fin ha venido desarrollándose a través de Reglamentos y de Directivas, que han desembocado en disposiciones nacionales, como es, en el caso español, la Ley 3/1996, de 10 de enero, sobre medidas de control de sustancias químicas catalogadas susceptibles de desvio para la fabricación ilicita de drogas, asi como su Reglamento de desarrollo, aprobado por el Real Decreto 865/1997, de 6 de junio.

El Parlamento Europeo y el Consejo de la Unión Europea, tras la evaluación de las experiencias y logros obtenidos en materia de control de precursores de drogas, y sin olvidar en ningún momento que, en principio, el comercio de las sustancias empleadas en la industria quimica y farmacéutica es legal, ha llegado a la conclusión de que es más adecuado en este momento un Reglamento, que garantice la aplicación directa de normas armonizadas, en lugar de utilizar como instrumento normativo una Directiva, máxime tras la ampliación del número de miembros de la Unión Europea a 27 Estados.

Por ello, el Parlamento Europeo y el Consejo de la Unión Europea han aprobado el Reglamento (CE) 273/2004, de 11 de febrero, sobre precursores de drogas; el Reglamento (CE) 111/2005, del Consejo, de 22 de diciembre de 2004, por el que se establecen normas para la vigilancia del comercio de precursores de drogas entre la Comunidad y terceros paises; y el Reglamento (CE) 1277/2005, de la Comisión, de 27 de julio, por el que se establecen normas de aplicación de los dos primeros.

Si bien dichos Reglamentos son de carácter obligatorio en todos sus elementos y directamente aplicables los Estados miembros, éstos ordenan a cada Estado determinar 
el régimen de sanciones aplicables a las infracciones a cada uno de estos Reglamentos, así como adoptar las medidas necesarias para garantizar su aplicación. Las sanciones que, en su caso, se prevean deberán ser eficaces, proporcionadas y disuasorias.

En cumplimiento de dicho mandato se ha elaborado esta Ley cuyo contenido se limita a regular aquellos aspectos esenciales para poder aplicar en nuestro pais las medidas que se recogen en cada uno de los tres Reglamentos comunitarios y poder sancionar todo hecho contrario a las obligaciones contenidas en los mismos.

La Ley se divide en tres Capitulos, cinco Disposiciones Adicionales, una Transitoria, una Derogatoria y cuatro Disposiciones Finales.

En el Capitulo I se define como objeto de la Ley establecer el sistema de otorgamiento de licencias de actividad, así como el régimen de sanciones que será de aplicación en caso de infracción de las disposiciones contempladas en los referidos Reglamentos.

En este sentido la Ley se inserta en el articulo $149.1 .100^{\circ}$ y $29 .{ }^{\circ}$ de la Constitución que asigna al Estado competencia exclusiva en materia de comercio exterior, aduanas y seguridad pública.

El Ministerio del Interior y el Ministerio de Economia y Hacienda serán las autoridades competentes, en relación con el incumplimiento de las obligaciones establecidas en los Reglamentos comunitarios, en el ámbito de sus respectivas competencias.

En el Ministerio del Interior existirá un Registro General de Operadores de Sustancias Quimicas Catalogadas y, en el Ministerio de Economia y Hacienda, existirá un Registro de Operadores de Comercio Exterior de Sustancias Quimicas Catalogadas.

Ambos Registros serán únicos para todo el territorio nacional. lo que supone una novedad respecto al Registro General

Las licencias de actividad se concederán por el Ministerio del Interior para las operaciones intracomunitarias y por el Ministerio de Economia y Hacienda para las operaciones extracomunitarias.

El Capitulo II está dedicado a las infracciones, relacionándose todos aquellos hechos que puedan ser calificados como infracciones graves o muy graves a las obligaciones establecidas por los Reglamentos comunitarios.

Se determinan sus respectivos plazos de prescripción que será a los 4 años, 2 años y 1 año, para las infracciones muy graves, graves y leves respectivamente, a contar desde el dia en que la infracción se hubiera cometido o en el caso de una actividad continuada desde la finalización de la actividad o la fecha del último acto con el que la infracción se consume.

Se rebaja de cinco años a cuatro el plazo para las infracciones muy graves, y se amplia el plazo de las infracciones leves de seis meses a un año.

El Capitulo III se refiere a las sanciones que podrán ser de multa cuando se imponga por infracciones leves o, en el caso de infracciones graves o muy graves, podrá imponerse, de forma conjunta o alternativa, las sanciones de multa o la suspension de la licencia o licencias de actividad por el periodo de tiempo que se determine $y$, en el caso de las muy graves, además la retirada de la licencia.

Siguiendo la recomendación de la Unión Europea a los Estados miembros en el sentido de disponer en sus normativas nacionales en la materia de un régimen sancionador que garantice su aplicación y que responda a los principios de eficacia, proporcionalidad y disuasión, se ha aplicado una rebaja sustancial del importe de las multas, así como del tiempo de suspensión de la licencia de actividad.

Asimismo, la dualidad multa/suspensión o retirada se mantiene, pero ahora bien de forma conjunta o bien de forma alternativa.

Además se incluyen varios preceptos en relación con el procedimiento sancionador como la posibilidad de adoptar medidas provisionales, la competencia para imponer las sanciones o su publicidad.

También se establecen aquellos supuestos en los que la sanción que se imponga por la comisión de alguna de las infracciones tipificadas en la Ley, conlleva el comiso de determinados bienes, efectos o instrumentos, e incluso la posible enajenación de los mismos, tanto por la autoridad administrativa, ya sean los Ministros o los Secretarios de 
Estado a los que esta Ley les reconoce esta competencia, como por la autoridad judicial en el supuesto de que se interponga recurso contencioso-administrativo contra las resoluciones dictadas por esas autoridades administrativas.

Las cinco Disposiciones Adicionales atienden a los regimenes especiales, la promoción de la colaboración voluntaria, el destino de las multas y ganancias decomisadas, el deber de colaboración de autoridades y funcionarios, y el intercambio de información internacional.

La Disposición Transitoria única establece un plazo de tres meses para que los Registros Delegados, al quedar suprimidos, transfieran todos los datos de que dispongan al Registro General de Operadores de Sustancias Quimicas Catalogadas, al ser único en todo el territorio nacional.

La Disposición Derogatoria única deroga expresamente la Ley 3/1996, de 10 de enero.

Las cuatro Disposiciones Finales se refieren al titulo competencial en virtud del cual se dicta la presente Ley, a la autorización al Gobierno para la actualización de las sanciones, asi como para dictar las normas necesarias para su desarrollo reglamentario, y, por último. a su entrada en vigor.

CAPITULO

Disposiciones generales

Artículo 1. Objeto.

El objeto de esta Ley es establecer el sistema de otorgamiento de licencias de actividad así como el régimen sancionador aplicable en caso de infracción de las disposiciones contempladas en el Reglamento 273/2004, del Parlamento Europeo y del Consejo, de 11 de febrero, sobre precursores de drogas; el Reglamento 111/2005, del Consejo, de 22 de diciembre de 2004, por el que se establecen normas para la vigilancia del comercio de precursores de drogas entre la Comunidad y terceros paises; y el Reglamento 1277/2005 de la Comisión, de 27 de julio, por el que se establecen normas de aplicación de los dos anteriores.

Articulo 2. Autoridades competentes

A los efectos de esta Ley serán autoridades competentes:

a) El Ministerio de Economia y Hacienda en relación con el incumplimiento de las obligaciones establecidas en el Reglamento 111/2005, del Consejo, de 22 de diciembre de 2004

b) El Ministerio del Interior en relación con el incumplimiento de las obligaciones establecidas en el Reglamento 273/2004, del Parlamento Europeo y del Consejo, de 11 de febrero.

El Reglamento 1277/2005, de la Comisión, de 27 de julio, que tiene carácter complementario de los anteriores, se aplicará por cada Ministerio en función de la distribución de competencias expresada en los párrafos anteriores.

Articulo 3. Registros de Operadores.

1. En el Ministerio del Interior existirá un Registro General de Operadores de Sustancias Quimicas Catalogadas en el que se inscribirán en la forma que se determine reglamentariamente, las personas fisicas y juridicas que realicen operaciones con sustancias catalogadas, conforme se establece en el Reglamento 273/2004, del Parlamento Europeo y del Consejo, de 11 de febrero

2. En el Ministerio de Economía y Hacienda existirá un Registro de Operadores de Comercio Exterior de Sustancias Quimicas Catalogadas en el que se inscribirán en la 


\section{EOE BOLETÍN OFICIAL DEL ESTADO

forma que se determine reglamentariamente, las personas fisicas y jurídicas que realicen operaciones con sustancias catalogadas conforme se establece en el Reglamento 111/2005. del Consejo, de 22 de diciembre de 2004, y en el Reglamento 1277/2005, de la Comisión. de 27 de julio.

3. Ambos Registros serán únicos para todo el territorio nacional.

4. Cualquier modificación de los datos que consten en dichos Registros que se produzca durante el tiempo que dure la actividad o actividades para las que se hayan inscrito, deberá comunicarse al mismo en el plazo de quince dias a contar desde el momento en que se haya producido.

Articulo 4. Licencias de actividad.

1. Las licencias de actividad se concederán por el Ministerio del Interior para las operaciones que asi lo requieran conforme a lo dispuesto en el Reglamento 273/2004, del Parlamento Europeo y del Consejo, de 11 de febrero, y por el Ministerio de Economia y Hacienda para las operaciones que asi lo requieran conforme a lo dispuesto en el Reglamento $111 / 2005$, del Consejo, de 22 de diciembre de 2004, y tendrán la vigencia que Reglamento 111/2005, del Consejo, de 22 de diciembre de 2004, y tendrán la vigencia que
reglamentariamente se determine.

2. Para obtener una licencia de actividad se estará a lo dispuesto en el Reglamento 1277/2005, de la Comisión, de 27 de julio.

3. Para suspender, retirar o renovar una licencia de actividad, se atenderá a lo dispuesto en el Reglamento 1277/2005, de la Comisión, de 27 de julio, y en el Reglamento 111/2005 del Consejo, de 22 de diciembre de 2004.

CAPITULO ॥

De las infracciones

Articulo 5. Infracciones en materia de precursores de drogas.

1. Constituyen infracciones administrativas en materia de precursores de drogas las acciones y omisiones, incluso a titulo de simple negligencia, que sean contrarias a las obligaciones y deberes establecidos en el Reglamento 273/2004, del Parlamento Europeo y del Consejo, de 11 de febrero; en el Reglamento 111/2005, del Consejo, de 22 de diciembre de 2004, y en el Reglamento 1277/2005, de la Comisión, de 27 de julio.

2. Serán responsables de las infracciones administrativas en materia de precursores de drogas las personas fisicas o juridicas que por acción u omisión incurran en los supuestos tipificados como infracciones.

Articulo 6. Infracciones leves.

Constituyen infracciones leves los incumplimientos de las obligaciones recogidas en el Reglamento 273/2004, del Parlamento Europeo y del Consejo, de 11 de febrero; en el Reglamento 111/2005, del Consejo, de 22 de diciembre de 2004, y en el Reglamento $1277 / 2005$, de la Comisión, de 27 de julio, siempre que no constituyan infracciones graves o muy graves, conforme a lo dispuesto en esta Ley.

Articulo 7. Infracciones graves.

Constituyen infracciones graves las siguientes conductas:

a) Nocomunicar en la formaque se establezca reglamentariamente, las modificaciones de los datos que deban constar en el Registro General de Operadores de Sustancias Quimicas Catalogadas o en el Registro de Operadores de Comercio Exterior de Sustancias Quimicas Catalogadas.

b) No designar a un agente responsable del comercio de sustancias catalogadas cuando dicha designación sea preceptiva. 
c) Suministrar sustancias catalogadas de la Categoria 1 del Anexo I de Reglamento 273/2004, del Parlamento Europeo y del Consejo, de 11 de febrero, o de Reglamento 111/2005, del Consejo, de 22 de diciembre de 2004, sin comprobar de modo diligente que la persona fisica o juridica destinataria de las mismas posee licencia de actividad para operar con tales sustancias.

d) No obtener de los clientes la declaración de uso o usos especificos de las sustancias catalogadas suministradas.

e) Incumplir las obligaciones relativas a la documentación que deba acompañar a las operaciones con sustancias catalogadas, asi como en lo referido a su etiquetado.

f) No informar inmediatamente a las autoridades competentes acerca de los pedidos y transacciones de sustancias catalogadas, sobre los que se tenga certeza o sospecha razonable de que dichas sustancias pueden desviarse hacia la fabricación ilicita de estupefacientes o de sustancias psicotrópicas.

g) Carecer de las medidas de protección o de los protocolos de actuación para la realización de actividades con sustancias catalogadas, en la forma que se determine reglamentariamente, sin que dichas carencias hubiesen dado lugar a la sustracción o retirada no autorizada de sustancias catalogadas.

Articulo 8. Infracciones muy graves.

Constituyen infracciones muy graves de las obligaciones impuestas por la presente Ley las siguientes conductas:

a) Realizar actividades con sustancias catalogadas sin haber obtenido la inscripción en el Registro General o en el Registro de Operadores de Comercio Exterior de Sustancias Quimicas Catalogadas requerida para tales actividades.

b) Realizar actividades con sustancias catalogadas $\sin$ haber obtenido la licencia de actividad requerida, en su caso, para tales actividades o habiendo sido suspendida o habiendo expirado el plazo de vigencia de la misma.

c) Aportar datos o documentos, falsos o manifiestamente inexactos, para obtener la inscripción en el Registro General o en el Registro de Operadores de Comercio Exterior de Sustancias Quimicas Catalogadas o para obtener una licencia de actividad.

d) Suministrar sustancias catalogadas de la Categoria 1 del anexo I del Reglamento 273/2004, del Parlamento Europeo y del Consejo, de 11 de febrero, o del Reglamento 111/2005, del Consejo, de 22 de diciembre, a sabiendas de que la persona fisica o juridica destinataria de las mismas carece de la licencia de actividad para operar con tales sustancias.

e) La resistencia, obstrucción, o negativa a las actuaciones de los órganos de la Administración que resulten competentes en cada caso y, en particular:

No facilitar el examen de documentos, informes, antecedentes, libros, registros, ficheros, facturas, justificantes y asientos de contabilidad principal o auxiliar, programas y archivos informáticos, sistemas operativos y de control, y cualquier otro dato con trascendencia para el control.

Negar o impedir indebidamente la entrada o permanencia en fincas o locales a los funcionarios autorizados de la Administración o el reconocimiento de locales, máquinas, instalaciones y explotaciones que se utilicen para el desempeño de actividades en relación con las sustancias catalogadas.

No atender algún requerimiento debidamente notificado.

f) Realizar operaciones con sustancias catalogadas sobre las que se tenga certeza sospecha razonable de que dichas sustancias pueden desviarse hacia la fabricación ilicita de estupefacientes o de sustancias psicotrópicas, $\sin$ haber notificado tal certeza o sospecha a las autoridades competentes, o antes de que éstas hayan respondido a la notificación previa del operador. 


\begin{tabular}{lcr} 
EO10. & BOLETÍN OFICIAL DEL ESTADO \\
\hline Núm. 145 & Martes 16 de junio de 2009 & Sec. I. Pág. 50514 \\
\hline
\end{tabular}

g) Carecer de las medidas de protección o de los protocolos de actuación para la realización de actividades con sustancias catalogadas, en la forma que se determine reglamentariamente, siempre que tales carencias hubiesen dado lugar a la sustracción o retirada no autorizada de sustancias catalogadas.

h) Realizar actividades con sustancias catalogadas sin la autorización de exportación o sin la autorización de importación cuando fueran preceptivas o si hubiese expirado el periodo de validez de las mismas.

i) Realizar acciones tipificadas como graves cuando durante los cinco años anteriores el sujeto infractor hubiera sido condenado en sentencia firme por un delito contra el tráfico ilicito de drogas, tipificado en el Código Penal, o sancionado en firme al menos por dos infracciones administrativas graves de las establecidas en la presente Ley. En este supuesto, en ningún caso se podrá tener en cuenta la reincidencia como criterio para graduar la sanción a imponer.

Artículo 9. Concurso con otros procedimientos.

1. No podrán sancionarse con arreglo a esta Ley las conductas que lo hubieran sido penal o administrativamente, cuando se aprecie identidad de sujeto, hecho y fundamento.

2. Cuando los hechos motivo del expediente pudieran ser constitutivos de delito, se ordenará, si se hubiese incoado, la suspensión del procedimiento sancionador, dándose traslado de aquéllos al Ministerio Fiscal. Terminado el procedimiento penal se reanudará la tramitación del procedimiento sancionador contra los sujetos obligados que no hubiesen sido condenados en via penal. No podrá reanudarse el procedimiento administrativo sancionador sobre los mismos fundamentos ya considerados en el proceso penz podr resolución que se dicte deberá respetar en todo caso la declaración de hechos probados
en dicho procedimiento penal.

Articulo 10. Prescripción de infracciones.

1. Las infracciones muy graves prescribirán a los 4 años, las graves a los 2 años y las leves al año.

2. El plazo de prescripción se contará desde la fecha en que la infracción hubiera sido cometida. En las infracciones derivadas de una actividad continuada la fecha inicial del cómputo será la de la finalización de la actividad o la del último acto con el que la infracción se consume. La prescripción se interrumpirá por la iniciación, con conocimiento del interesado, del procedimiento sancionador, volviendo a correr el plazo si el expediente quedara paralizado durante un mes por causa no imputable a aquéllos contra quienes se dirija. También se interrumpirá por la iniciación de un proceso penal por los mismos hechos. o por otros cuya separación de los sancionables con arreglo a esa Ley sea racionalmente imposible.

CAPITULO III

De las sanciones y del procedimiento sancionador

Articulo 11. Sanciones por infracciones leves. Las in
euros.

Articulo 12. Sanciones por infracciones graves.

Las infracciones graves serán sancionadas, de forma conjunta o alternativa, con:

a) Multas desde 601 euros hasta 6.000 euros.

b) Suspensión de la licencia o licencias de actividad por un periodo de hasta seis meses. 
Articulo 13. Sanciones por infracciones muy graves.

Las infracciones muy graves serán sancionadas, de forma conjunta o alternativa con:

a) Multas desde 6.000 hasta 60.000 euros

b) Retirada de la licencia o licencias de actividad o la suspensión de las mismas por un periodo de hasta cinco años. La retirada de la licencia conllevará la cancelación de la inscripción en el Registro General de Operadores de Sustancias Quimicas Catalogadas o en el Registro de Operadores de Comercio Exterior de Sustancias Quimicas Catalogadas. correspondiente.

Artículo 14. Graduación de las sanciones

Las sanciones aplicables en cada caso por la comisión de infracciones se graduarán considerándose, además de los criterios establecidos en el artículo 131.3 de la Ley 30/1992, de 26 de noviembre, de Régimen Juridico de las Administraciones Públicas y del Procedimiento Administrativo Común, por:

a) El riesgo para la salud pública y el daño causado a la salud de los ciudadanos, en su caso, como consecuencia de la infracción.

b) El alcance de la sustracción o de la retirada no autorizada.

c) El volumen de actividad comercial del infractor con sustancias catalogadas.

d) El beneficio ilicito obtenido, en su caso, como consecuencia de la infracción.

e) Las sanciones firmes por infracciones graves o muy graves de las previstas en esta Ley impuestas al sujeto obligado en los últimos cinco años.

f L La reincidencia, por comisión u omisión, en el término de un año, de más de una infracción de la misma naturaleza, cuando así haya sido declarado por resolución firme.

Articulo 15. Prescripción de las sanciones.

Las sanciones muy graves, graves y leves prescribirán, respectivamente, a los 4 años, 2 años y 1 año, a contar desde el dia siguiente a aquel en que hubiera adquirido firmeza la resolución por la que se impuso la sanción.

Articulo 16. Competencia para la imposición de sanciones.

1. Para la imposición de sanciones por la comisión de infracciones muy graves serán competentes los Ministros del Interior y de Economia y Hacienda en el ámbito de sus respectivas competencias.

2. Para la imposición de sanciones por la comisión de infracciones graves y leves serán competentes el Secretario de Estado de Seguridad y el Secretario de Estado de Hacienda y Presupuestos, en el ámbito de sus respectivas competencias.

3. Las resoluciones sancionadoras pondrán fin a la via administrativa, siendo recurribles ante el orden jurisdiccional contencioso-administrativo.

Artículo 17. Instrucción del procedimiento.

La iniciación e instrucción del procedimiento sancionador corresponderá a los Ministerios del Interior y de Economia y Hacienda, en el ámbito de sus respectivas competencias, en la forma que reglamentariamente se establezca, y, en todo caso, de acuerdo con lo dispuesto en la Ley 30/1992, de 26 de noviembre.

Articulo 18. Adopción de medidas provisionales.

1. En cualquier momento de la instrucción del procedimiento sancionador por infracción grave o muy grave, el órgano competente que haya ordenado su incoación podrá adoptar mediante acuerdo motivado las siguientes medidas de carácter provisional, de forma conjunta 0 alternativa: 


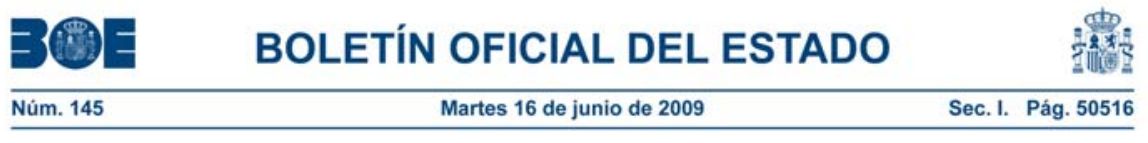

a) La inmovilización de sustancias catalogadas relacionadas con la presunta infracción

b) La suspensión temporal del ejercicio de actividades con sustancias catalogadas.

2. La adopción de tales medidas se comunicará a la mayor brevedad posible al órgano competente para imponer la sanción, quien, en el plazo de diez dias hábiles desde que fueron acordadas, deberá ratificarlas o dejarlas sin efecto. Si no lo hiciera, las medidas se entenderán levantadas al finalizar este plazo.

3. Las medidas provisionales adoptadas tendrán una duración máxima de tres meses en caso de infracción grave, y de seis meses en caso de infracción muy grave.

Articulo 19. Comiso y enajenación cautelar.

1. Toda sanción que se impusiere por la comisión de las infracciones tipificadas en esta Ley llevará consigo el comiso de los siguientes bienes, efectos e instrumentos:

a) Las mercancias que constituyan el objeto de la infracción.

b) Los materiales, instrumentos o maquinaria empleados en la fabricación, elaboración, transformación o comercio de las sustancias quimicas catalogadas.

c) Las ganancias obtenidas, cualesquiera que sean las transformaciones que hubieran podido experimentar.

d) Cuantos bienes y efectos de la naturaleza que fueren, hayan servido de instrumento para la comisión de la infracción.

2. No se procederá al comiso de los bienes, efectos e instrumentos mencionados en el apartado anterior, cuando éstos sean de licito comercio y hayan sido adquiridos por un tercero de buena fe.

3. Incoado un procedimiento administrativo sancionador, podrán intervenirse los bienes o derechos que puedan ser objeto de comiso.

4. El órgano competente para acordar el comiso podrá disponer en cualquier momento del procedimiento la enajenación de los bienes o derechos intervenidos, en los supuestos siguientes:

a) Cuando su propietario haga expreso abandono de ellos, y

b) Cuando su conservación pueda resultar peligrosa para la salud o seguridad pública o dar lugar a disminución importante de su valor. Se entenderán comprendidos en este apartado las mercancias, géneros o efectos que sin sufrir deterioro material se deprecian por transcurso del tiempo.

El producto de la enajenación se depositará con las debidas garantias.

El acuerdo de enajenación pondrá fin a la via administrativa, se notificará a los interesados y será susceptible de recurso.

5. Cuando por la interposición de un recurso administrativo se acuerde la suspensión de las resoluciones sancionadoras que lleven consigo el comiso, podrá disponerse que con carácter cautelar se proceda a la enajenación de los bienes o derechos intervenidos, en los supuestos del apartado anterior.

Artículo 20. Ejecución de las sanciones.

1. Las sanciones serán ejecutivas desde que se dicte la resolución que ponga fin a la via administrativa.

2. Cuando la sanción sea de naturaleza pecuniaria, la autoridad que la imponga señalará el plazo para satisfacerla, que no será inferior a quince dias hábiles ni superior a treinta, pudiendo acordarse el fraccionamiento del pago, en la forma que se determine reglamentariamente.

3. En los casos de suspensión temporal o retirada de una licencia de actividad, la autoridad sancionadora señalará un plazo de ejecución adecuado, que no será inferior a los quince dias hábiles ni superior a treinta, previa audiencia de la persona física o del representante de la persona juridica, titulares de la licencia y de los terceros que pudieran resultar afectados. 
4. Para la ejecución forzosa de las sanciones se seguirá el procedimiento previsto en la normativa vigente.

Articulo 21. Publicidad de las sanciones.

Las resoluciones sancionadoras de los procedimientos por infracciones muy graves se harán públicas por las autoridades competentes para imponer las sanciones, una vez sean firmes en via administrativa, en la forma que reglamentariamente se determine.

Disposición Adicional Primera. Especialidades de determinados operadores.

1. Deberán inscribirse en el Registro General de Operadores de Sustancias Quimicas Catalogadas que se contempla en el apartado 1 del articulo 3 de esta Ley, las farmacias, los dispensarios de productos veterinarios, los laboratorios de las Fuerzas Armadas y de los Cuerpos y Fuerzas de Seguridad, y cualesquiera otros tipos de autoridades o instituciones que reglamentariamente se determine, para el uso de las sustancias catalogadas de las Categorias 1 y 2 del Anexo I del Reglamento 273/2004, del Parlamento Europeo y del Consejo, de 11 de febrero, en el ámbito de sus actividades profesionales $u$ oficiales.

2. También deberán obtener la licencia de actividad a que se refiere el artículo 4 de esta Ley, las farmacias, los dispensarios de productos veterinarios, los laboratorios de las Fuerzas Armadas y de los Cuerpos y Fuerzas de Seguridad, y cualesquiera otros tipos de autoridades o instituciones que reglamentariamente se determine, para el uso de las sustancias catalogadas de la Categoria 1 del Anexo I del Reglamento 273/2004, del Parlamento Europeo y del Consejo, de 11 de febrero, en el ámbito de sus actividades profesionales $u$ oficiales.

3. Las farmacias, los dispensarios de productos veterinarios, las aduanas, Ios laboratorios de las Fuerzas Armadas y de los Cuerpos y Fuerzas de Seguridad y cualesquiera otros tipos de autoridades o instituciones que reglamentariamente se determine, estarán exentos de las obligaciones que se determinan en el Reglamento 1277/2005, de la Comisión, de 27 de julio.

Disposición Adicional Segunda. Promoción de la colaboración voluntaria.

1. El Gobierno promoverá convenios de colaboración voluntaria entre la industria quimica y farmacéutica y los Departamentos ministeriales competentes, especialmente en lo relativo a las sustancias quimicas no catalogadas, entendiéndose por tales cualquier sustancia que haya sido identificada por ser utilizada en la fabricación ilicita de estupefacientes o de sustancias psicotrópicas.

2. Asimismo, se instrumentarán los mecanismos de colaboración y los oportunos cauces de coordinación con las Comunidades Autónomas para la puesta en práctica con eficacia de aquellas medidas previstas en esta Ley que deban, en su caso, llevarse a cabo por las policías autonómicas.

Disposición Adicional Tercera. Destino de las multas y de las ganancias decomisadas.

Al importe de las multas y de las ganancias decomisadas, acordadas en la resolución sancionadora, se les dará el destino previsto en la Ley 17/2003, de 29 de mayo, por la que se regula el Fondo de bienes decomisados por tráfico ilicito de drogas y otros delitos relacionados

Disposición Adicional Cuarta. Deber de colaboración de autoridades y funcionarios.

Sin perjuicio de lo establecido en las leyes penales y en la Ley de Enjuiciamiento Criminal, toda autoridad o funcionario, incluidos los de arancel, que descubran hechos que puedan constituir indicios o pruebas de desvio ilicito de sustancias quimicas catalogadas, deberán informar de los mismos a las autoridades competentes.

El incumplimiento de esta obligación por los funcionarios públicos podrá ser sancionado disciplinariamente con arreglo a la legislación especifica que les sea de aplicación. 


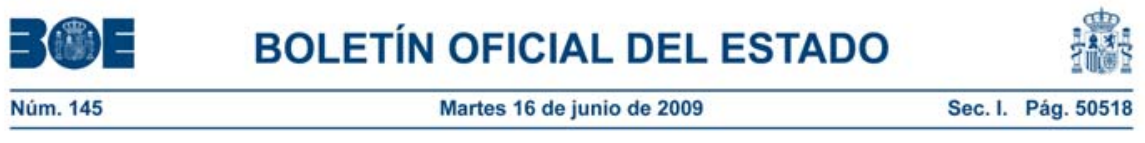

Disposición Adicional Quinta. Intercambio de información internacional.

El intercambio de información con organismos internacionales y con otros Estados se condicionará a lo dispuesto en la normativa comunitaria, en los Convenios y Tratados Internacionales 0 , en defecto de los anteriores, al principio general de reciprocidad, asi como al sometimiento de dichas autoridades extranjeras a las mismas obligaciones de secreto profesional que rigen para las españolas.

Disposición Transitoria Única. Traspaso de datos al Registro General de Operadores de Sustancias Quimicas Catalogadas.

Los Registros Delegados transferirán todos los datos de que dispongan al Registro General de Operadores de Sustancias Quimicas Catalogadas que se regula en el articulo 3.1 de esta Ley, en el plazo de tres meses desde su entrada en vigor.

Disposición Derogatoria Única. Derogación normativa.

Queda derogada la Ley $3 / 1996$, de 10 de enero, sobre medidas de control de sustancias quimicas catalogadas susceptibles de desvio para la fabricación ilicita de drogas, y cuantas disposiciones de igual o inferior rango se opongan a lo establecido en esta Ley.

Disposición Final Primera. Titulo competencial.

La presente Ley se dicta al amparo de lo dispuesto en el articulo $149.1 .10{ }^{\text {a }}$ y $29 .{ }^{\text {a }}$ de la Constitución española, que atribuye al Estado la competencia exclusiva en materia de régimen aduanero, comercio exterior y seguridad pública.

Disposición Final Segunda. Actualización de las sanciones.

Se autoriza al Gobierno para que, mediante Real Decreto, actualice la cuantia de las sanciones pecuniarias previstas en la presente Ley, de acuerdo con las variaciones del Índice de Precios al Consumo.

Disposición Final Tercera. Desarrollo reglamentario.

El Gobierno, a propuesta de los Ministros del Interior y de Economia y Hacienda, aprobará las normas necesarias para su desarrollo reglamentario.

Disposición Final Cuarta. Entrada en vigor.

La presente Ley entrará en vigor el dia siguiente al de su publicación en el «Boletin Oficial del Estadom.

Por tanto,

Mando a todos los españoles, particulares y autoridades, que guarden y hagan guardar esta Ley.

Madrid, 15 de junio de 2009.

JUAN CARLOS R.

El Presidente del Gobierno

JOSE LUIS RODRIGUEZ ZAPATERO 


\section{ANEXO II \\ USO DE SUSTANCIAS INCLUIDAS EN LOS CUADROS PARA LA FA- BRICACIÓN ILÍCITA DE ESTUPEFACIENTES Y SUSTANCIAS PSICO- TRÓPICAS}

En los gráficos I a IV se muestra el uso de sustancias incluidos en los Cuadros para la fabricación ilícita de estupefacientes y sustancias psicotrópicas.

Las cantidades aproximadas que se indican corresponden a los métodos de elaboración utilizados más comúnmente. Existen otros métodos de fabricación, además de los que se muestran, en los que se usan sustancias incluidas en los Cuadros, e incluso sustancias no catalogadas en ellos, en lugar o además de las que sí lo están, según la zona geográfica de que se trate. 
GRÁFICO I. Fabricación ilícita de cocaína y heroína: sustancias incluidas en los Cuadros y cantidades aproximadas necesarias para la elaboración ilícita de 100 kilogramos de clorhidrato de cocaína o de heroína.
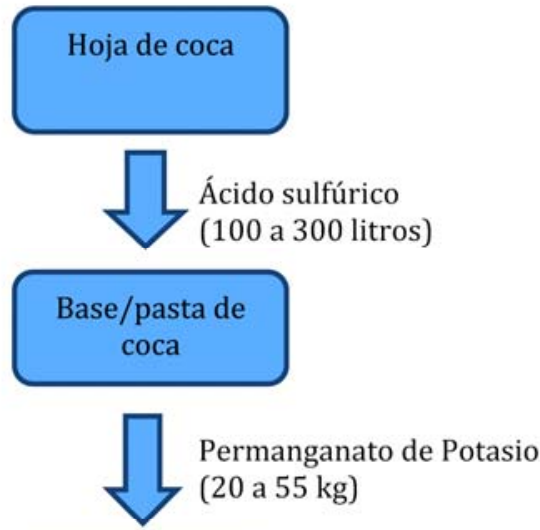

\section{Cocaína}

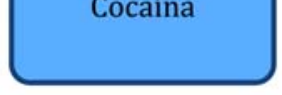

Acetona/éter etílico metiletilcetona/tolueno (1.000 a 2.000 litros) Ácido clorhídrico (20 a 40 litros)

\section{Clorhidrato de} cocaína (100 kg)
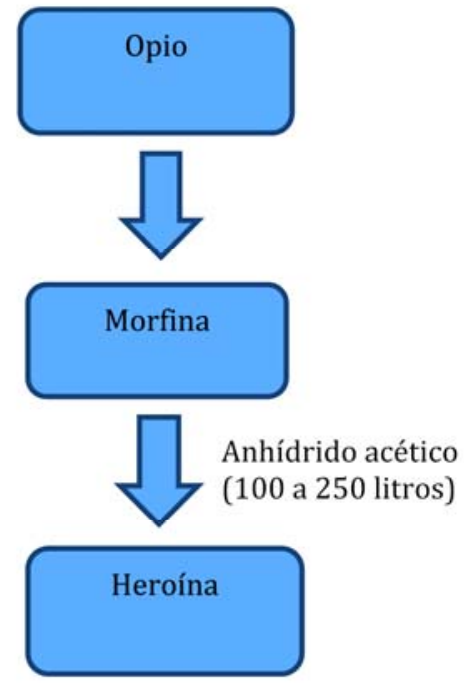

Acetona/éter etílico (10 a 100 litros) Ácido clorhídrico (30 a 40 litros)

Clorhidrato de heroína (100 kg)

Nota: Para la extracción de cocaína de la hoja de coca, así como para la purificación de la pasta de coca y los productos básicos en bruto de la cocaína y la heroína se necesitan disolventes, ácidos y bases. En todas las etapas de la fabricación de drogas se utiliza una amplia variedad de esas sustancias químicas. 
GRÁFICO II. Fabricación ilícita de anfetamina y metanfetamina: sustancias incluidas en los Cuadros y cantidades aproximadas necesarias para la elaboración ilícita de 100 kilogramos de sulfato de anfetamina y de clorhidrato de metanfetamina.

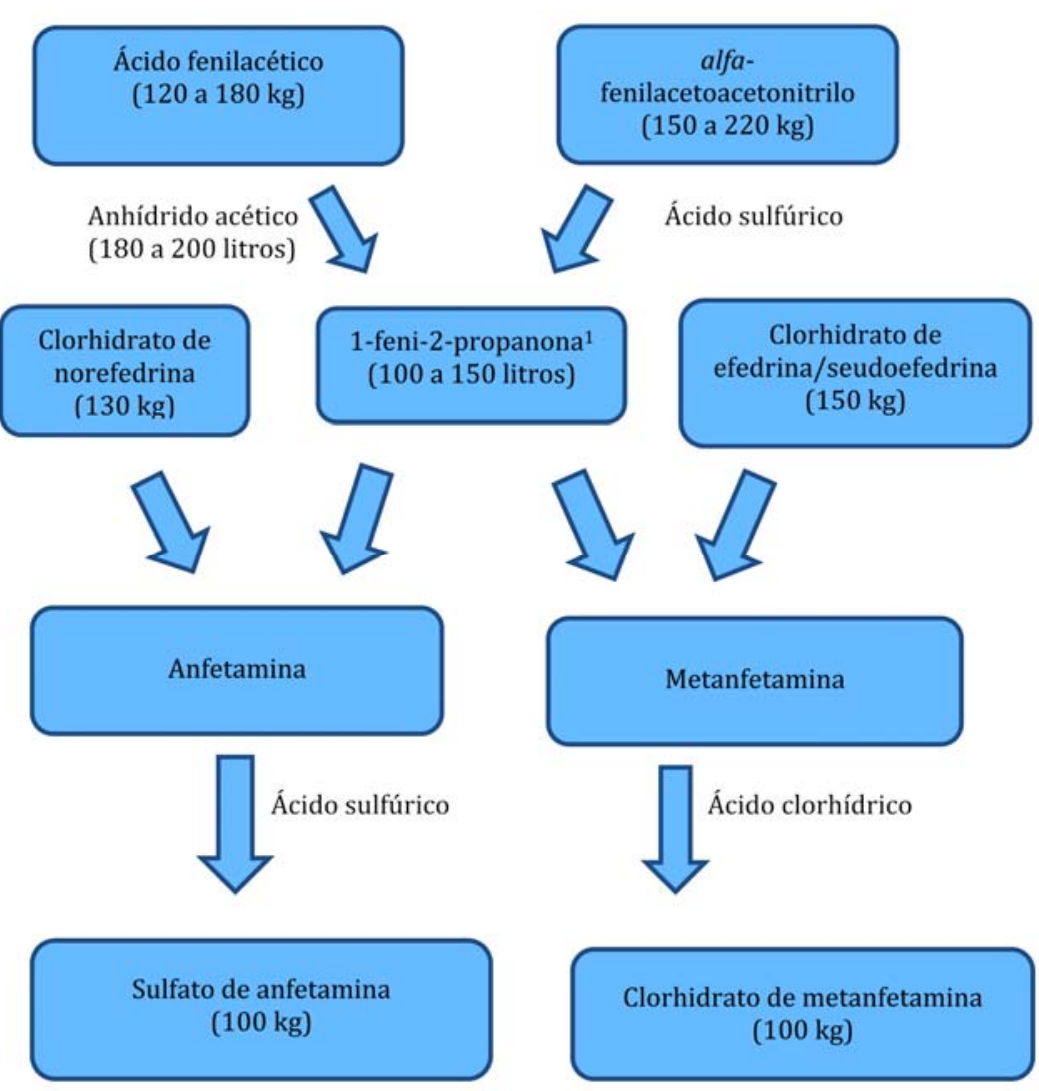

Nota: Con clorhidrato de efedrina/seudoefedrina puede fabricarse metcatinona, estimulante de tipo anfetamínico menos común, y se necesitan las mismas cantidades aproximadas que en el caso de la metanfetamina para obtener 100 kilogramos de sal clorhídrica.

1 Empleando 1-fenil-2-propanona se obtiene $d, l$-anfetamina/metanfetamina racémica, en tanto que empleando efedrina, seudoefedrina o norefedrina se obtiene $d$-anfetamina /metanfetamina. 
GRÁFICO III. Fabricación ilícita de 3,4-metilendioximetanfetamina (MDMA) y sustancias conexas: sustancias incluidas en los Cuadros y cantidades aproximadas de esas sustancias necesarias para la elaboración ilícita de 100 kilogramos de MDMA.

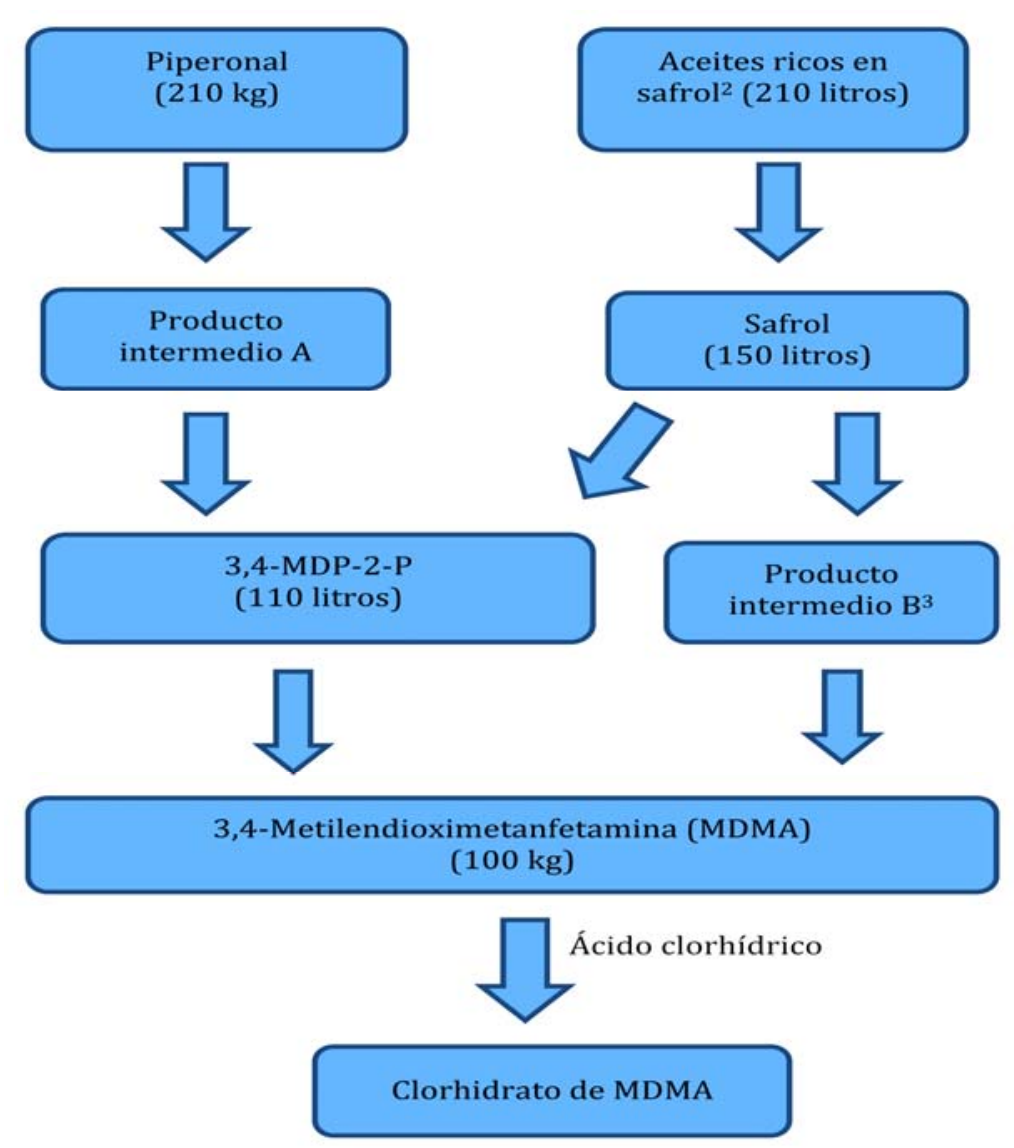

Nota: En este gráfico no se incluye el isosafrol, otro precursor de la MDMA sometido a fiscalización internacional, ya que comúnmente no se encuentra como materia prima. El isosafrol es un producto intermedio en otros métodos de elaboración de MDMA a partir de safrol; se necesitan aproximadamente 300 litros de safrol para fabricar 100 kilogramos de MDMA.

2 Partiendo del supuesto de que los aceites ricos en safrol tienen un contenido de safrol del 75\% como mínimo.

3 Para fabricar 100 kilogramos de MDMA a partir del producto intermedio B se necesitan 200 litros de safrol. 
GRÁFICO IV. Fabricación ilícita de dietilamida del ácido lisérgico (LSD), fenciclidina y metacualona: sustancias incluidas en los Cuadros y cantidades aproximadas necesarias para la fabricación ilícita de 1 kilogramo de LSD y 100 kilogramos de fenciclidina y metacualona.

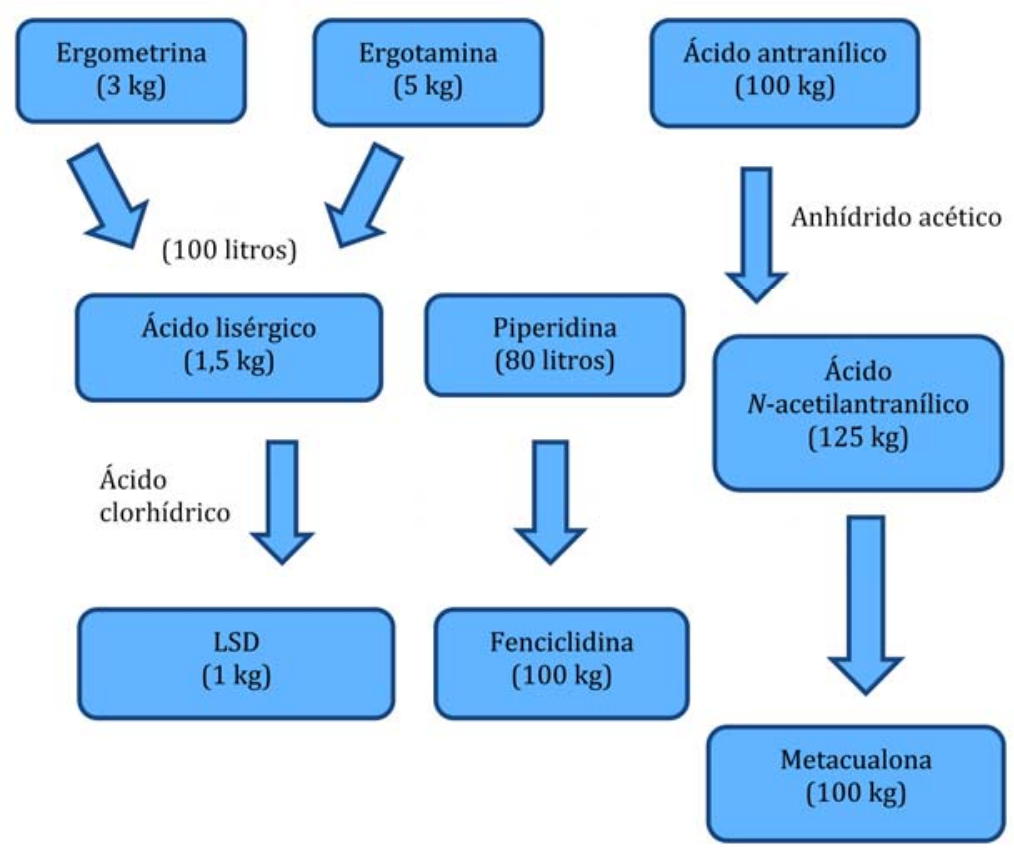





\section{ANEXO III}

INCAUTACIONES DE PRECURSORES DE LOS CUADROS I Y II REALIZADAS EN ESPAÑA DEL AÑO 1993 AL AÑO 2014

\begin{tabular}{|c|c|c|c|c|c|c|c|c|c|}
\hline 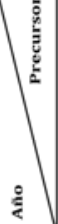 & 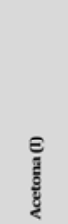 & 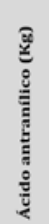 & 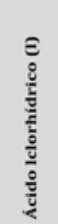 & 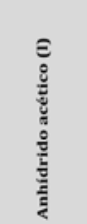 & 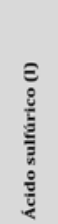 & 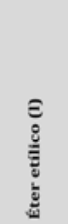 & 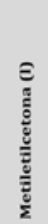 & 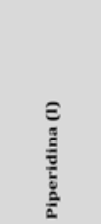 & 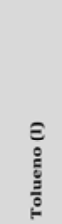 \\
\hline 1993 & 17 & 6 & 16 & 57 & & & & 6 & 16 \\
\hline \multicolumn{10}{|l|}{1994} \\
\hline 1995 & 288 & 13 & & 173 & 200 & & 10 & 13 & \\
\hline 1996 & 75 & 50 & 48 & 184 & & & & 50 & 48 \\
\hline 1997 & 254 & 3 & & 3 & & & 5 & 3 & \\
\hline 1998 & 276 & 24 & 17 & 101 & & & 12 & 24 & 17 \\
\hline 1999 & 610 & 19 & 6 & 300 & 75 & & & 19 & 6 \\
\hline 2000 & 151 & 311 & 26 & 203 & 533 & 4 & & 311 & 26 \\
\hline 2001 & 4.694 & 151 & 42 & 6.829 & 5.930 & & 365 & 151 & 42 \\
\hline 2002 & 246 & 6 & 12 & 12 & 50 & & & 6 & 12 \\
\hline 2003 & 1.714 & 106 & 206 & 1 & & & & 106 & 206 \\
\hline 2004 & 59 & 40 & 1 & 1 & 2 & 7 & 9 & 40 & 1 \\
\hline 2005 & 1.197 & 12 & 10 & 5 & 131 & & & 12 & 10 \\
\hline 2006 & 401 & & 15 & & 37 & 205 & & & 401 \\
\hline 2007 & 567 & & 57 & 259 & 72 & 872 & & 1 & 567 \\
\hline 2008 & 862 & & 77 & 106 & 104 & 2.083 & & 1 & 862 \\
\hline 2009 & 3.705 & & 207 & 93 & 74 & 256 & & 42 & 3.705 \\
\hline 2010 & 442 & & 55 & 35 & 66 & 43 & & 4 & 442 \\
\hline 2011 & 1 & & 1 & 1 & & 1 & & & 1 \\
\hline 2012 & 425 & & 990 & 30 & 287 & 123 & 50 & 33 & 425 \\
\hline 2013 & 1.190 & & 490 & 1.086 .979 & 297 & 2.197 & & 11.511 .987 & 1.190 \\
\hline 2014 & 85 & & 159 & 1 & 20 & 1 & & 2 & 85 \\
\hline Total & 17.259 & 0 & 2.792 & 1.087 .888 & 8.826 & 12.702 & 61 & 11.512 .471 & 17.259 \\
\hline
\end{tabular}




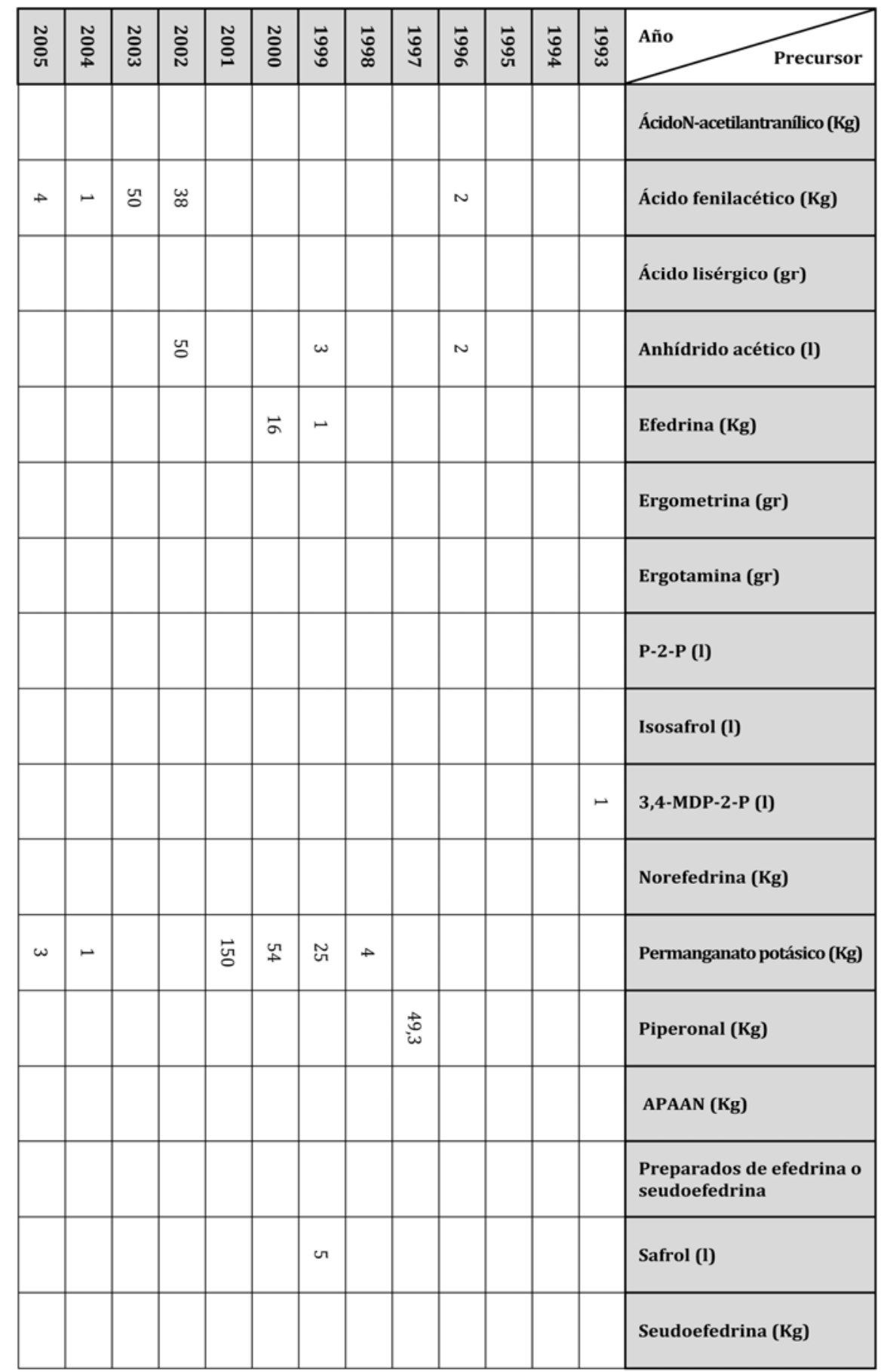




\begin{tabular}{|c|c|c|c|c|c|c|c|c|c|c|}
\hline $\overrightarrow{\stackrel{0}{\Xi}}$ & $\stackrel{\text { N }}{\stackrel{\Gamma}{\rightleftharpoons}}$ & $\underset{\omega}{\stackrel{N}{\omega}}$ & $\stackrel{N}{\stackrel{N}{N}}$ & $\stackrel{N}{\varrho}$ & $\stackrel{N}{\circ}$ & : & ๕ั & ¿ั่ & ڤั. & Año Precursor \\
\hline o & & & & & & & & & & ÁcidoN-acetilantranílico (Kg) \\
\hline ஃ & & & & & & $\leftarrow$ & & & & Ácido fenilacético (Kg) \\
\hline ○ & & & & & & & & & & Ácido lisérgico (gr) \\
\hline فั & $\vec{\diamond}$ & $\stackrel{\circ}{\stackrel{\leftrightarrow}{*}}$ & $\Xi$ & & & u & & & & Anhídrido acético (I) \\
\hline ث્ّ & & & 䓈 & & & & & & & Efedrina (Kg) \\
\hline ○ & & & & & & & & & & Ergometrina (gr) \\
\hline- & & - & & & & & & & & Ergotamina (gr) \\
\hline 0 & & & & & & & & & & P-2-P (I) \\
\hline 0 & & & & & & & & & & Isosafrol (I) \\
\hline 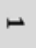 & & & & & & & & & & 3,4-MDP-2-P (1) \\
\hline ○ & & & & & & & & & & Norefedrina (Kg) \\
\hline : & & 岕 & $\overrightarrow{0}$ & $r$ & N & & & $v$ & & Permanganato potásico $(\mathrm{Kg})$ \\
\hline 它 & & $\stackrel{\vec{A}}{\dot{\Delta}}$ & & & & & & & & Piperonal (Kg) \\
\hline ○ & & & & & & & & & & APAAN (Kg) \\
\hline 0 & & & & & & & & & & $\begin{array}{l}\text { Preparados de efedrina o } \\
\text { seudoefedrina }\end{array}$ \\
\hline $\boldsymbol{u}$ & & & & & & & & & & Safrol (1) \\
\hline 0 & & & & & & & & & & Seudoefedrina (Kg) \\
\hline
\end{tabular}





\section{ANEXO IV \\ SUSTANCIAS CATALOGADAS}

1. Acetona o propanona, también es conocida como formaldehído de dimetilo, dimetilacetal, dimetilcetona, propano, cetona, 2-propanona, beta-ceto propano, metilcetona y ácido o éter piroacético. Es un compuesto químico cuya apariencia es de un líquido incoloro, muy volátil, de olor penetrante y característico, su fórmula empírica es $\mathrm{CH}_{3} \mathrm{COCH}_{3}$ y su fórmula molecular $\left(\mathrm{CH}_{3}\right)_{2} \mathrm{CO}$ del grupo de las cetonas que se encuentra naturalmente en el medio ambiente. Se puede obtener por fermentación del almidón de maíz y de la melaza. Por síntesis química, a partir del cumeno. Subproducto de la obtención del fenol. Por oxidación del propeno. Se fabrica de forma industrial en los Estados Unidos de América, Alemania, España, Finlandia, Francia, Italia, los Países Bajos, el Reino Unido de Gran Bretaña e Irlanda del Norte, Corea del Sur, Japón, Taiwán, México, Argentina, Brasil, Ecuador, la República Bolivariana de Venezuela y Australia. En España se dedican a la fabricación de acetona las siguientes empresas: Cepsa Química, Química farmacéutica Bayer. S.A., Rhodia Iberia S.A., Cor Química S.L., Proquibasa y Quality Chemicals S.L., entre otras. La acetona se evapora fácilmente, es inflamable y es soluble en agua. Al ser una sustancia fácilmente inflamable arde en presencia de una llama, de una fuente de calor (superficie caliente) o de una chispa. La acetona sintetizada se usa en la fabricación de plásticos, fibras, cosméticos, removedores de esmalte para las uñas, medicamentos y otros productos químicos, como solvente en procesos que involucran resinas, lacas, grasas, ceras, adhesivos, tintas de impresión, en la manufactura de barnices, removedores de barniz, en la manufactura de caucho sintético y productos químicos de fotografía, así como disolvente de uso generalizado en la industria química y farmacéutica. También es utilizado como intermediario en la fabricación de cloroformo y en la fabricación de aceites lubricantes. Es un precursor que se necesita para elaborar cocaína y heroína, de hecho es el solvente más utilizado en la elaboración de la cocaína y tiene gran importancia en la producción de heroína, además se usa en la elaboración de metanfetamina. Esta sustancia catalogada se fabrica en los laboratorios clandestinos de cocaína a partir del alcohol isopropílico, y se conocen casos de su sustitución como solvente en la elaboración de cocaína por sustancias no catalogadas como el acetato de etilo y el acetato de butilo.

2. Alfa-fenilacetoacetonitrilo, más conocido como APAAN es un compuesto orgánico químico que prácticamente no tiene usos lícitos conocidos (no hay aplicaciones industriales conocidas en que se utilice APAAN), pues no existe comercio lícito documentado de esta sustancia salvo, en pequeñas cantidades que se destinan a actividades de investigación y desarrollo y en análisis de laboratorio. El APAAN se elabora utilizando dos sustancias no catalogadas el fe- 
nilacetonitrilo y el acetato de etilo. Este precursor contiene un grupo de nitrilo y un anillo de benceno (fenilo), su fórmula es $\mathrm{C}_{10} \mathrm{H}_{9} \mathrm{NO}$ y se presenta en forma de cristales. El alfa-fenilacetoacetonitrilo existe en forma de dos isómeros ópticos, que se prestan igualmente para su transformación en la 1-fenil-2propanona (P-2-P), por lo cual se utiliza en los laboratorios clandestinos para elaborar P-2-P, del cual es un precursor inmediato, y por ende anfetamina y metanfetamina.

3. Ácido $\mathbf{N}$-acetilantranílico, también conocido como: ácido 2-aminobenzóico, aminobenzóico, ácido orto, acetilamenobenzóico y 2-carboxiacetanilida. Sobre sus características podemos decir que es un polvo cristalino fino, de color blanco o amarillento y sabor dulzón, es una sustancia de solubilidad moderada en la mayoría de los solventes orgánicos que tiene poca solubilidad en el agua y que es peligroso si es aspirado, su fórmula molecular es $\left(\mathrm{CH}_{3} \mathrm{CONH}\right) \mathrm{C}_{6} \mathrm{H}_{4}(\mathrm{COOH})$. Se puede conseguir por reacción del ácido antranílico con el anhídrido acético (otros precursores de drogas). El ácido $\mathrm{N}$ acetilantranílico se fabrica en los siguientes países: Alemania, Bélgica, el Reino Unido de Gran Bretaña e Irlanda del Norte, Suiza. Sobre sus usos legales señalamos los siguientes: como materia prima para la síntesis de analgésicos y antipiréticos del tipo de ácido mefenámico y ácido flufenámico que forman parte de algunos medicamentos para el tratamiento del dolor y la fiebre, así como en la manufactura de plásticos y productos químicos refinados. Esta sustancia se utiliza de forma ilícita para la elaboración de metacualona y meclocualona. Es necesario señalar, como ya lo hicimos antes, que el ácido $\mathrm{N}$ acetilantranílico se prepara a menudo a partir del ácido antranílico (sustancia catalogada).

4. Ácido antranílico tiene los siguientes sinónimos: ácido 2-aminobenzóico, ácido orto-aminobenzóico, 1-amino-2-carboxibenceno, ortocarboxilina, NCICO 1730 vitamino L1, este ácido es un polvo cristalino blanco o amarillento de sabor dulce, es peligroso si se aspira, irritante a los ojos y al tracto respiratorio. Su fórmula molecular es $\left(\mathrm{NH}_{2}\right) \mathrm{C}_{6}(\mathrm{COOH})$. Se puede obtener por reacción del anhídrido isatoico con álcalis o por reducción del ácido orto-nitrobenzóico. Se fabrica en los Estados Unidos de América, Alemania, Dinamarca y Japón. Se utiliza de forma legal como materia prima para la síntesis de analgésicos y antipiréticos del tipo de ácido mefenámico y ácido flufenámico que forman parte de algunos medicamentos para el tratamiento del dolor y la fiebre, también se usa en la fabricación de tintes y perfumes, así como en la preparación de repelentes de pájaros e insectos. Este precursor se utiliza de forma ilegal para la síntesis del ácido $N$-acetilantranílico, que luego se emplea para la elaboración de metacualona y meclocualona.

5. Ácido clorhídrico también llamado ácido muriático por su extracción de la sal marina en América, cloruro de hidrógeno y ácido hidroclórico, su fórmula empírica es HCL, se puede obtener industrialmente por reacción del cloruro de sodio (sal de mesa) con el ácido sulfúrico (otro precursor), también a partir 
del cloruro de sodio, dióxido de azufre, aire y vapor de agua. Es subproducto de la síntesis de los hidrocarburos clorados. Sobre sus características podemos decir que es una solución acuosa de hidrogeno gaseoso, corrosiva, incolora (pero a veces amarillenta, por la presencia de rastros de hierro, cloro y materia orgánica) y fumante. Sus fabricantes se encuentran en: los Estados Unidos de América, Alemania, Austria, Bélgica, España, Finlandia, Francia, Grecia, Irlanda, Italia, Noruega, los Países Bajos, Portugal, el Reino Unido de Gran Bretaña e Irlanda del Norte, Suecia, Suiza, Corea del Sur, Filipinas, Indonesia, Japón, Malasia, Singapur, Tailandia, Taiwán, México, Estado Plurinacional de Bolivia y Colombia. Sobre sus usos lícitos se puede afirmar que es un compuesto utilizado en muchas reacciones como medio de reacción o bien como compuestos de catálisis ácida. Se usa para limpiar, tratar y galvanizar metales, curtir cueros, procesamiento de alimentos, activación de pozos de petróleo y en la refinación y manufactura de una amplia variedad de productos, también se utiliza como un agente de limpieza en una solución al 18\%, en la fabricación de cloruros y clorhidratos, para la neutralización de sistemas básicos. Como catalizador y disolvente en síntesis orgánicas. Este precursor se utiliza de forma ilícita en la producción de heroína, cocaína, metanfetamina, MDMA y fenciclidina. Es una sustancia muy corrosiva que daña los tejidos vivos y ataca igualmente a otras materias. La reacción puede deberse a la presencia de agua o humedad. El ácido clorhídrico también está clasificado como una sustancia peligrosa para el medio ambiente.

6. Ácido fenilacético o ácido 2 -fenilacético, ácido acético 2-fenil, ácido phenyl ethanols. Es un ácido carboxílico derivado del ácido acético mediante la sustitución de un hidrógeno del carbono 2 (alfa) por un radical fenilio. Se puede obtener mediante hidrólisis de cianuro de bencilo por medio de ácido sulfúrico o clorhídrico (otras sustancias catalogadas). Su fórmula molecular es $\mathrm{C} 6 \mathrm{H} 5(\mathrm{CH} 2 \mathrm{COOH})$ es un polvo blanco cristalino de olor penetrante y muy desagradable. Se fabrica en los siguientes países: Alemania, Dinamarca, España, Francia, el Reino Unido e Gran Bretaña e Irlanda del Norte y Japón. Esta sustancia catalogada es la materia prima para la preparación de analgésicos y antipiréticos del tipo ibuprofeno (hay muchos medicamentos que contienen este compuesto y se utilizan para el tratamiento del dolor y la fiebre), para síntesis de penicilinas, además se usa como aromatizante de bebidas, alimentos, para la fabricación de perfumes y en soluciones de limpieza. Este precursor se utiliza de forma ilegal para producir anfetaminas, metanfetaminas y otro precursor de drogas la fenilacetona (P-2-P) más conocida como 1-fenil-2-propanona.

7. Ácido lisérgico $\mathrm{C}_{16} \mathrm{H}_{16} \mathrm{~N}_{2} \mathrm{O}_{2}$ se puede obtener por hidrólisis alcalina de los alcaloides del cornezuelo, como la ergotamina o ergonovina más conocida como ergometrina (ambas sustancias catalogadas). Por fermentación de cultivos de claviceps purpurea o de aspergillus clavatus. El ácido lisérgico es un polvo blanco cristalino, poco soluble en agua y en solventes orgánicos, altamente toxico, su ingestión produce vómito, diarrea, confusión e inconsciencia. Esta 
sustancia se utiliza en síntesis orgánicas y de ergonovina, medicamento que usualmente se suministra a las mujeres para detener el sangrado fuerte que se produce después del parto, así como en investigaciones médicas. Se puede usar como materia prima para la elaboración de drogas relacionadas con el LSD. En algunos países como Canadá se usa en psicoterapia como droga legal bajo prescripción médica, y en Suiza se ha autorizado su investigación para valorar su aplicación en la psiquiatría. En países como la Federación de Rusia y el Reino Unido de Gran Bretaña e Irlanda del Norte se discute actualmente su legalización para uso terapéutico.

8. Ácido sulfúrico, aceite de vitriolo, espíritu de vitriolo, licor de vitriolo, ácido de batería, dihidrógeno sulfato, electrolito ácido, espíritu de azufre o tetraoxosulfato (VI) de hidrógeno cuya fórmula molecular es $\mathrm{H}_{2} \mathrm{SO}_{4}$. Es un líquido aceitoso incoloro o café, inodoro, pero concentrado es sofocante e higroscópico. Es un compuesto químico muy corrosivo que dañan los tejidos vivos. Se puede conseguir por oxidación catalítica del dióxido de azufre en trióxido de azufre, que a su vez se convierte en ácido sulfúrico por el "método de contacto" (reacción con el agua). Por reacción entre el dióxido de azufre, oxigeno, vapor de agua y óxidos de nitrógeno en cámaras de plomo. Se fabrica en los siguientes países: los Estados Unidos de América, Alemania, Austria, Bélgica, Dinamarca, España, Finlandia, Francia, Grecia, Italia, Noruega, los Países Bajos, Portugal, el Reino Unido de Gran Bretaña e Irlanda del Norte, Suecia, Suiza, Corea del Sur, Indonesia, Japón, Tailandia, Taiwán, Colombia, el Estado Plurinacional de Bolivia, Perú y Siria. Hay que destacar que esta sustancia es el compuesto químico que más se produce en el mundo, por eso se utiliza como uno de los medidores de la capacidad industrial de los países. Una gran parte de la producción de este precursor se emplea en la obtención de fertilizantes, además se utiliza para fabricar productos orgánicos, pinturas, pigmentos, explosivos, alcoholes, tintas, detergentes sintéticos, caucho sintético y natural, pulpa, papel, celulosa rayón y fibras textiles. También se usa para la síntesis de otros ácidos y sulfatos y en la industria petroquímica para refinar petróleo, así como para procesar y limpiar metales. Es utilizado además en la manufactura de fosfato y sulfato de amonio. El ácido sulfúrico tiene una gran importancia en la producción ilícita de cocaína, heroína y metanfetamina. Es preciso mencionar que este precursor es una sustancia peligrosa para el medio ambiente.

9. Anhídrido acético, también conocido como óxido acetílico, anhídrido de ácido acético, oxido de acetilo y anhídrido etanóico. El anhídrido acético es el anhídrido, derivado de ácido carboxílico, más importante, el ácido acético. Se puede conseguir por deshidratación del ácido acético o por carbonalización del acetato de metilo. Según estadísticas del año 2004 se producían aproximadamente unos dos millones de toneladas al año de este precursor. El anhídrido acético es una sustancia líquida de color incoloro y de olor astringente, su fórmula molecular es $\left(\mathrm{CH}_{3} \mathrm{CO}\right)_{2} \mathrm{O}$. Se fabrica en los siguientes países: los Estados Unidos de América, Alemania, Francia, el Reino Unido de Gran Bretaña e Irlanda del Norte, Suiza, Japón, México y Brasil. La mayor parte de la produc- 
ción de anhídrido acético va a parar a la producción de acetato de celulosa (plásticos y fibras textiles), también tiene otras aplicaciones como la síntesis de la tetraacetiletilenodiamina en la industria de detergentes, y la síntesis de fármacos tales como el ácido acetil salicílico (aspirina) o paracetamol. También encuentra aplicación en la producción de polimetilacrilimida (espuma dura), plastificantes acetilados, explosivos, ciertos fluidos para frenos hidráulicos, fluidos de perforación, tintes, herbicidas, aromas, fragancias y para la limpieza de metales. El anhídrido acético es una sustancia indispensable para la fabricación de la heroína, además es un precursor difícilmente sustituible en la elaboración de esta droga, que también se utiliza en la fabricación de drogas de tipo anfetamínico (metanfetamina y anfetamina) y de la metacualona. El anhídrido acético también se puede utilizar para obtener otros precursores como el P-2-P y el ácido fenilacético. Este precursor es una sustancia corrosiva que daña los tejidos vivos y ataca igualmente a otras materias. La reacción puede deberse a la presencia de agua o humedad.

10. La efedrina, que también tiene otros nombres Eciphin, efedrato, ephedramal, ephedrina anhidra entre otros, consiste en cristales blancos o incoloros, higroscópicos, tiene un punto de fusión de 79 C.․ㅡ, un olor desagradable a pescado, y se oxida en presencia del aire. Su fórmula molecular es $\left(\mathrm{C}_{6} \mathrm{H}_{5}\right) \mathrm{CH}(\mathrm{OH}) \mathrm{CH}\left(\mathrm{NHCH}_{3}\right) \mathrm{CH}_{3}$. Se fabrica fundamentalmente en los siguientes países: Alemania, República Checa, India, Japón y China. Es un compuesto que forma parte de muchos medicamentos para el tratamiento del asma y otros procesos respiratorios como el catarro, así como alergias. Forma parte igualmente de gotas nasales para descongestionar la nariz. Además, se ha promovido como la sustancia natural perfecta para bajar de peso porque acelera el metabolismo, aumenta la energía física y quita el hambre. Muchos atletas y fisicoculturistas toman efedrina y puede usarse de forma ilegal como materia prima para la elaboración de drogas de diseño como anfetaminas y metanfetaminas. Es preciso señalar que la efedrina es la sustancia precursora que más se emplea en los Estados Unidos de América para obtener la metanfetamina, por reducción del ácido yodhídrico en presencia del fósforo rojo. Hay que destacar que los preparados farmacéuticos que contienen efedrina suelen ser utilizados por los narcotraficantes como precursores para la fabricación ilícita de metanfetamina. Por ello muchos de los gobiernos interesados, entre ellos los de Australia, los Estados Unidos de América, la Federación de Rusia, México, República Checa y Tailandia, han tomado medidas para fiscalizar el comercio internacional y la distribución interna de estos productos. Esta sustancia también se usa para elaborar metcatinona.

11. Ergometrina $\mathrm{C}_{19} \mathrm{H}_{23} \mathrm{~N}_{3} \mathrm{O}_{2}$ también conocida como ergonovina. Tiende a formar cristales solvatados incoloros, tiene propiedades y estructuras similares a la ergotamina. Se fabrica de forma industrial en Suiza e India. Se utiliza para la prevención y tratamiento de la hemorragia posparto o del aborto debida a atonía uterina, es además un poderoso estimulante uterino (oxitócico) em- 
pleado en la obstetricia, también se utiliza como vasoconstrictor, especialmente en el tratamiento de la migraña. Es también un derivado del ácido lisérgico, por lo tanto puede utilizarse de manera ilegal como materia prima en la obtención de drogas relacionadas con el LSD.

12. Ergotamina $\mathrm{C}_{33} \mathrm{H}_{35} \mathrm{~N}_{5} \mathrm{O}_{5}$ también denominada 12-hidroxi-2-metil-5alfa(fenilmetil)-ergotam-3,6,18-triona, ergoton-a, bellegral, cafergot, cormutamin, effergot, wigrine, escupan, secagyn, migwell, migril y migretamina. En su forma básica se presenta como cristales afines a la humedad (higroscópicos). Como tartrato polvo cristalino blanco poco higroscópico a veces cristales incoloros e inodoros. La ergotamina se puede obtener por extracción del cornezuelo del centeno. Se fabrica de forma industrial en Suiza e India. Esta sustancia catalogada es un compuesto que forma parte de algunos medicamentos utilizados para el tratamiento del dolor de cabeza de tipo migraña y como oxitóxico en obstetricia. Por su estructura (es un derivado del ácido lisérgico) puede usarse de forma ilegal para la elaboración de drogas de tipo LSD (dietilamina del ácido lisérgico).

13) Éter etílico o dietil éter, éter dietílico, éter sulfúrico, éter anestésico, etilóxido, dietil óxido, óxido de etilo o éter es un líquido incoloro, muy inflamable, con un bajo punto de ebullición, de sabor acre y ardiente, de olor dulce y penetrante. Su fórmula empírica es $\mathrm{C}_{4} \mathrm{H}_{10} \mathrm{O}$ y su fórmula molecular es $\left(\mathrm{C}_{2} \mathrm{H}_{5}\right)_{2} \mathrm{O}$. Al ser una sustancia fácilmente inflamable arde en presencia de una llama, de una fuente de calor (superficie caliente) o de una chispa. Es más ligero que el agua, su densidad es de $736 \mathrm{Kg} . / \mathrm{m} 3$, sin embargo su vapor es más denso que el aire $(2,56 \mathrm{~kg} / \mathrm{m} 3)$. El éter etílico hierve con el calor de la mano (34,5으 $\mathrm{C}$ y se solidifica a $-116^{\circ}$ C. Este precursor se puede producir por deshidratación del etanol (alcohol etílico). Por hidratación del etileno. En ambos métodos la reacción se efectúa en presencia de otro precursor: el ácido sulfúrico. Existen productores industriales de esta sustancia controlada en los Estados Unidos de América, Alemania, España, Francia, Noruega, Japón y Taiwán. De sus usos lícitos podemos decir que el éter etílico es un buen disolvente de las grasas, azufre, fósforo, se utiliza como extractante de aceites, ceras y resinas, en la fabricación de plásticos y perfumes, en medicina como anestésico general. Además tiene aplicaciones industriales como disolvente de usos generalizado en laboratorios químicos y en industrias químicas y farmacéuticas, y en las fábricas de explosivos y municiones. Esta sustancia se usa de forma ilícita para la fabricación de cocaína y heroína.

14) Isosafrol cuya fórmula es $\mathrm{C}_{10} \mathrm{H}_{10} \mathrm{O}_{2}$ que también es conocido como: 1,2 (metilenedioxi)-4-propenil-benceno, 5-(1-propenil)-1,3-benzodioxol presenta como características que es un líquido incoloro de olor a anís, moderadamente tóxico por ingestión, venenoso cuando se inyecta, carcinógeno y tumorígeno experimental es irritante para piel, soluble en etanol, etil éter y benceno, insoluble en agua. El isosafrol se puede conseguir por reacción del safrol (otro precursor de drogas) con hidróxido potásico alcohólico. El isosafrol se usa co- 
múnmente en la preparación de perfumes, fragancias y sabores de bebidas gaseosas, jabones perfumados, pesticida, en pequeñas cantidades junto con saliciliato de metilo en aromatizantes de cerveza de raíces y zarzaparrilla, en diversas síntesis orgánicas y en la manufactura de otras sustancias catalogadas como el piperonal y la 3,4-MDP-2-P. Por ende este precursor se usa para fabricar MDA y sustancias análogas como el MDMA.

15. Metiletilcetona o butanona, MEC, MEK, 2-butanona, etilmetilcetona. Es un líquido claro incoloro de olor agradable parecido a la acetona, la fórmula empírica de la metiletilcetona es $\mathrm{CH}_{3} \mathrm{COCH}_{2} \mathrm{CH}_{3}$. Se puede obtener por deshidrogenación del alcohol butílico secundario o bien por oxidación de los butenos normales. Se fabrica en los siguientes países: Alemania, Francia, los Países Bajos, el Reino Unido de Gran Bretaña e Irlanda del Norte, Japón, Taiwán y los Estados Unidos de América. Esta sustancia catalogada es un disolvente que se utiliza de forma legal en algunas reacciones químicas. Es un producto industrial, usado como base disolvente en diversas aplicaciones, solvente para pinturas, barnices y lacas de nitrocelulosa, como intermediario de síntesis del peróxido de metiletilcetona, utilizado en la catálisis de algunas reacciones de polimerización, producción de disolventes para revestimientos, adhesivos, cintas magnéticas, separación de la cera de aceites lubricantes, cuero sintético, papel transparente, papel de aluminio, quita grasas, extracción de grasas, aceites, ceras, resinas sintéticas y naturales y pólvora sin humo. Este precursor se usa de forma ilícita para la fabricación de heroína y cocaína. Es una sustancia irritante por lo que el contacto repetido con este producto provoca reacciones inflamatorias en la piel y las mucosas.

16. Norefedrina o fenilpropanolamina, cuya fórmula molecular es $\left(\mathrm{C}_{6} \mathrm{H}_{5}\right) \mathrm{CH}(\mathrm{OH}) \mathrm{CH}\left(\mathrm{NH}_{2}\right) \mathrm{CH}_{3}$ tiene como propiedades que es un material cristalino de olor parecido al ácido benzoico, con frecuencia se halla en forma de clorhidrato. Esta sustancia se puede conseguir por reacción de la propiofenona con un alquilnitrito, seguida por hidrogenación en presencia de un catalizador de paladio o platino. Se fabrica de forma industrial en los siguientes países: Alemania y Suiza. La norefedrina es comúnmente utilizada como descongestionante nasal y como inhibidor del apetito, en veterinaria se emplea para controlar la incontinencia urinaria de los perros. De forma ilegal se utiliza para producir anfetaminas, metanfetaminas y del 4-metil-aminorex. La norefedrina se añadió al Cuadro I de la Convención de 1988 en el mes de noviembre del año 2000 en cumplimiento de una recomendación de la JIFE.

17. Permanganato potásico. Tiene diferentes sinónimos: sal de potasio de ácido permangánico, camaleón mineral y permanganato de potasa, su fórmula estructural es $\mathrm{KMnO}_{4}$, su apariencia es de cristales color violeta con lustre metálico. Se puede obtener por oxidación de electrolítica del manganato de potasio, que a su vez se prepara por fusión de la pirolusita (mineral de óxido de man- 
ganeso) con el hidroxido de potasio. Este precursor se fabrica fundamentalemente en los siguientes países: Alemania, España, Japón, Taiwán y los Estados Unidos de América. El permanganato de potasio es un compuesto inorgánico con propiedades oxidantes, útil en diferentes procesos de oxidación de compuestos orgánicos, reactivo en química analítica, desinfectante, ingrediente para tintura, agente en el tratamiento médico de algunos venenos, también se usa para remover de una solución hierro y manganeso, blanqueo de resinas, ceras, grasas, aceite, paja, algodón, seda y diversas fibras, colorante pardo de maderas, estampado de telas, fabricación de aguas minerales, fotografía, fabricación de insecticidas, curtido de cueros, purificación del agua, desinfectantes, en medicina se usa como bactericida y fungicida, para el tratamiento de eccema y de las alergias a la planta rhus radicans y similares, para el tratamiento oral de barbitúricos, hidrato cloral y muchos alcaloides. Se utiliza de forma ilícita en la producción de cocaína. Se emplea para extraer la cinamoilcocaína y otros alcaloides oxidables de la cocaína, es la sustancia más empleada con este fin, puesto que su color violeta en la solución sirve como indicador. En Colombia por las dificultades que tienen los productores de drogas para conseguir esta sustancia, debido a los severos controles a los que está sometido su tráfico, se realiza un proceso rústico para la producción de permanganato de potasio en laboratorios clandestinos utilizando como precursor el dióxido de manganeso y el manganato de potasio. El permanganato de potasio también se utiliza de manera ilegal para elaborar metcatinona (efedrona) y otras drogas de tipo anfetaminico. El permanganato de potasio es una sustancia química tóxica que, incluso en pequeñas cantidades, presenta un peligro para la salud, puede penetrar en el organismo por inhalación, ingestión o a través de la piel. La combustión de este precursor necesita de una materia combustible, oxígeno y de una fuente de inflamación. Es una sustancia peligrosa para el medio ambiente, resulta muy tóxica para los organismos acuáticos, para la fauna, así como para la capa de ozono.

18. Piperidina cuya fórmula es $\left(\mathrm{CH}_{2}\right)_{5} \mathrm{NH}$, también conocida como hexahidropiridina y pentametilenamina, es un líquido incoloro, inflamable de olor a pimienta y tacto jabonoso, las sales (clorhidrato, nitrato, bitartrato y fosfato) son cristalinas. Es posible la obtención de esta sustancia por reducción catalítica de la piridina, por reacción al calor de la piperina con el hidróxido potásico alcohólico, también se puede extraer en pequeñas cantidades de la pimienta negra. La piperidina se fabrica en los siguientes países: Alemania, Francia, el Reino Unido de Gran Bretaña e Irlanda del Norte, Japón y los Estados Unidos de América. Esta sustancia catalogada es un producto que se usa de forma lícita como disolvente y reactivo de uso generalizado en laboratorios químicos y en industrias químicas y farmacéuticas, puede formar parte de compuestos con propiedades antihistamínicas y neurolépticas, así como en la preparación de anestésicos locales, analgésicos y otros fármacos, humectantes y germicidas, también se usa como intermedio en la aceleración de la vulcanización del caucho, en el curado de resinas expoxídicas, como solvente, catalizador en re- 
acciones de condensación, se emplea también en la producción de plásticos. Esta sustancia se utiliza de forma ilícita en la fabricación de fenciclidina.

19. Piperonal cuya fórmula es $\left(\mathrm{CH}_{2} \mathrm{OO}\right) \mathrm{C}_{6} \mathrm{H}_{3}(\mathrm{CHO})$ está constituido por cristales o agujas incoloras de olor a heliotropo y es moderadamente tóxico. Se puede obtener por oxidación del isosafrol con bricomato sódico y ácido sulfúrico también a partir de la vainilla, por reacción el cloruro de alumino y dicloromerato (o dibrometano) en presencia de la dimetilformamida (o el sulfóxido de dimetilo). Se fabrica en los siguientes países: Austria, Francia, el Reino Unido de Gran Bretaña e Irlanda del Norte, Japón, Taiwán y los Estados Unidos de América. Se usa en la producción de perfumes, así como en la confección de aromas de cereza y vainilla, en síntesis orgánica y como componente para los repelentes de mosquitos. Además es un compuesto que de forma ilícita se utiliza en la elaboración de las drogas de diseño como el éxtasis y el polvo de ángel, MDA entre otras, siendo el precursor de MDMA más comercializado, el piperonal es también materia prima, o precursor secundario, para la elaboración de otra sustancia catalogada 3,4-MDP-2-P. Hay que señalar, por la importancia que tiene, que China es un gran exportador de piperonal.

20. Safrol $\left(\mathrm{CH}_{2} \mathrm{OO}\right) \mathrm{C}_{6} \mathrm{H}_{5}\left(\mathrm{CH}_{2} \mathrm{CH}=\mathrm{CH}_{2}\right)$, se conoce además con otros nombres: 1,2(metilendioxi)-4-alibenceno, 5-alil-1,3-benzodioxol, alicatecol metilenedieter, 5-(2-propenyl)-1-3-benzodioxol, shimokol, shikimole, safrole MF, rhyuno oil. Esta sustancia catalogada es un líquido incoloro algo amarillento de olor a sasafrás, también puede presentar cristales. Se puede obtener por la separación de varios aceites esenciales, como el de sasafrás o el de alcanfor o bien a partir del 3,4-metilenodioxibenceno, vía un intermediario bromado. El safrol se fabrica de forma industrial en Taiwán y los Estados Unidos de América entre otros países. Esta sustancia catalogada es moderadamente tóxica por ingestión, venenosa cuando se inyecta. Hay que decir que este precursor se usa de forma lícita en la producción de perfumes, aromas, insecticidas y jabones. El safrol presenta la característica de servir en la síntesis de otros precursores de drogas como el piperonal, el isosafrol y la 3,4- metilendioxifenil-2-propanona que se utilizan de forma ilícita para producir MDA (tenamfetamina o píldora del amor). MDE (Eva), MDMA (Éxtasis) y N-hidroxi-MDA (Hidroxilamina).

21. Seudoefedrina, también conocida como isoephefedrina o d-efedrina su fórmula base es $\mathrm{C}_{10} \mathrm{H}_{15} \mathrm{NO}$ y su fórmula molecular es $\left(\mathrm{C}_{6} \mathrm{H}_{5}\right) \mathrm{C}(\mathrm{OH}) \mathrm{HCH}\left(\mathrm{NHCH}_{3}\right) \mathrm{CH}_{3}$. Esta sustancia consiste en cristales blancos o polvo cristalino inodoros, su inhalación es peligrosa y debe evitarse su contacto con la piel y con los ojos. Se puede realizar su obtención por extracción de varias plantas del género Ephedra, también a partir de la efedrina (otro precursor). La seudoefedrina se fabrica en Alemania y los Estados Unidos de América. Es un agente farmacológico con acción agonista adrenérgica, utilizado en medicina por sus propiedades como descongestivo sistémico; frecuentemente indicado para tratar la congestión nasal, de senos y de la trompa de Eustaquio. Se usa para la elaboración de metanfetaminas y anfetaminas. Es 
preciso señalar que los preparados farmacéuticos que contienen seudoefedrina suelen ser utilizados por los narcotraficantes como precursores para la fabricación ilícita de metanfetamina. Por ello muchos de los gobiernos interesados, entre ellos los de Australia, los Estados Unidos de América, la Federación de Rusia, México, República Checa y Tailandia, han tomado medidas para fiscalizar el comercio internacional y la distribución interna de estos productos.

22. Tolueno o metilbenceno, metilbenzol, fenilmetano, toluol, cuya fórmula empírica es $\mathrm{C}_{6} \mathrm{H}_{5} \mathrm{CH}_{3}$, se puede producir por la destilación del aceite de alquitrán o del petróleo. Sobre su apariencia podemos decir que es un líquido incoloro de olor penetrante similar al benceno, es una sustancia química toxica que, incluso en pequeñas cantidades, presenta un peligro para la salud. Se fabrica de forma industrial en: Alemania, Austria, Bélgica, España, Francia, Italia, los Países Bajos, Portugal, el Reino Unido de Gran Bretaña e Irlanda del Norte, Corea del Sur, Japón, Singapur, Taiwán, los Estados Unidos de América, Argentina, Brasil, Colombia y Chile. Sobre sus usos lícitos señalamos que el tolueno es la materia prima a partir de la cual se obtienen derivados del benceno, el ácido benzoico, el fenol, la caprolactama, la sacarina, el TDI (diisocianato de tolueno) materia prima para la elaboración de poliuretano, medicamentos, colorantes, perfumes, explosivos, pinturas, lacas, resinas, limpiadores, pegamentos, detergentes y como aditivo de la gasolina. También se utiliza de forma ilegal en la elaboración de cocaína, heroína, metacualona y metanfetamina.

23. 1-fenil-2-propanona, su fórmula molecular es $\mathrm{CH}_{3} \mathrm{COCH}_{2}\left(\mathrm{C}_{6} \mathrm{H}_{5}\right)$ también conocida como P-2-P, fenilacetona o BMK, es un líquido transparente y algo viscoso. Se puede obtener de los ácidos fenilacético y acético. A partir del cianuro de bencilo, a través del alfa-fenilacetoacetonitrilo (APAAN). Por reacción del benzaldehido con el nitropropeno, obtenido a su vez del nitroetano. También se puede sintetizar a partir del ácido fenilacético (método más utilizado en la actualidad). El precursor 1-fenil-2-propanona se fabrica en los Estados Unidos de América y Francia. Como usos lícitos se utiliza en la producción de propilhexedrina que se usa para tratamiento de la obesidad, también en síntesis orgánicas y en la fabricación de productos de limpieza y desinfección. Además se utiliza de manera ilegal en la fabricación de anfetaminas y metanfetaminas. En los Estados Unidos de América el 1-fenil-2-propanona era la sustancia precursora que se usaba con mayor frecuencia en la producción de anfetaminas y metanfetaminas, hasta que dicha sustancia fue incorporada en la lista II de la Ley estadounidense de sustancias fiscalizadas en 1980. En la actualidad es más común que se use la efedrina, pero el 1-fenil-2-propanona se encuentra aún en la tercera parte de los laboratorios clandestinos de anfetamina y metanfetamina. Por lo general esos laboratorios sintetizan ellos mismos este precursor o bien utilizan como sucedáneo de este el benzaldehído que es una sustancia química no catalogada.

24. 3,4-metilendioxifenil-2-propanona conocida también como 3,4-MDP-2-P o PMK cuya fórmula es (CH2O0)C6H3 (CH2COCH3), también es conocido como 
3,4-metilenodioxifenilacetona y piperonilmetilcetona. De este precursor de drogas hay que decir que es un líquido incoloro amarillento y que se puede obtener por reacción del isosafrol con ácido fórmico, peróxido de hidrogeno y ácido sulfúrico. Además son precursores de este precursor, valga la redundancia, otras dos sustancias catalogadas (el safrol y el piperonal). La 3,4-MDP-2-P se fabrica industrialmente en Alemania. Esta sustancia se usa de forma lícita en la producción de fragancias y como reactivo en síntesis orgánica, y se utiliza de forma ilegal para producir MDA, MDMA, MDE y (N-hidroxi-MDA). Es preciso señalar que la 3,4-metilendioxifenil-2-propanona es el reactivo principal en la síntesis de estas drogas ilícitas. 



\section{ANEXO V \\ SUSTANCIAS NO CATALOGADAS QUE SE UTILIZAN EN LA ELABORACIÓN DE DROGAS ILÍCITAS}

1. El acetato de butilo o ácido butílico normal que tiene como sinónimos los siguientes: éster butílico del ácido acético, acetato $N$-butilo o etanoato de butilo. $\mathrm{Su}$ fórmula empírica es $\mathrm{CH}_{3} \mathrm{CO}_{2}\left(\mathrm{CH}_{2}\right)_{3}$, esta sustancia se utiliza en la elaboración de lacas, cuero artificial, películas fotográficas, plásticos y vidrios de seguridad. De manera ilícita se usa como solvente en la conversión de cocaína en clorhidrato de cocaína. Esta sustancia no catalogada se encuentra fiscalizada en Colombia y Costa Rica.

2. El acetato de etilo, otros nombres por los que se conoce a esta sustancia son: aceto de etilo, éter acético, éster etílico del ácido acético, éster etiloacético y etonoato de etilo. Su fórmula empírica es $\mathrm{C}_{4} \mathrm{H}_{8} \mathrm{O}_{2}$ y se utiliza como solvente de diversas sustancias (nitrocelulosa, barnices, lacas), en la preparación de aromas artificiales de frutas, en la fabricación de pólvora sin humo, de cuero y sedas artificiales, y de perfumes. De forma ilegal se usa como solvente en la transformación de la cocaína básica en clorhidrato de cocaína. Esta sustancia no catalogada esta fiscalizada en Argentina, Colombia, Ecuador, Perú, Jamaica y está comprendida en los cuadros del Reglamento Modelo de sustancias químicas que se utilizan para la fabricación ilícita de drogas de la OEA.

3. El acetato de isopropilo también se conoce con los nombres de acetato 2propílico, éster isopropílico del ácido acético, 2-propil acetato, acetato npropilo. Su fórmula empírica es $\mathrm{C}_{5} \mathrm{H}_{10} \mathrm{O}_{2}$, como usos lícitos se pueden mencionar los siguientes: como solvente para derivados de la celulosa, plásticos, alcoholes y grasas, también es utilizado en la industria de la perfumería. De manera ilegal se usa para la transformación de cocaína en clorhidrato de cocaína. Esta sustancia esta fiscalizada en Argentina, Colombia, Costa Rica y está comprendida en los cuadros del Reglamento Modelo de sustancias químicas que se utilizan para la fabricación ilícita de drogas de la OEA.

4. El acetato de plomo, también conocido como azúcar de plomo, diacetato de plomo, sal de Saturno y fuerza de Goulard. Su fórmula es $\mathrm{Pb}\left(\mathrm{C}_{2} \mathrm{H}_{3} \mathrm{O}_{2}\right)_{2}$. Es un compuesto químico cristalino de color blanco con un sabor ligeramente dulce. De forma lícita se usa como reactivo para generar otros compuestos de plomo y como fijador para algunos tintes. En bajas concentraciones (del 1\%), es el principal ingrediente activo en una variada gama de tinturas progresivas para el cabello, que va tomando progresivamente un color castaño debido a la combinación del plomo con el azufre, más abundante en las proteínas del cabello que en la piel. También se utiliza como mordiente en impresión, tinte 
textil y desecante en pinturas y barnices. De forma ilegal se usa en la elaboración de estimulantes de tipo anfetamínico.

5. El acetato de sodio, también llamado etanoato de sodio, es la sal de sodio del ácido acético (otra sustancia no catalogada). Su fórmula es $\mathrm{NaCH}_{3} \mathrm{COONaC}_{2} \mathrm{H}_{3} \mathrm{O}_{2}$. Esta sustancia es utilizada en la industria textil para neutralizar las corrientes residuales de ácido sulfúrico, y como foto resistente cuando se usan colorantes de anilina. También se usa como agente de encurtido en el curtido con cromo, ayuda a retardar la vulcanización del cloropreno en la producción sintética del caucho. Además es el compuesto químico que da sabor a las patatas fritas y se suele añadir a los alimentos como conservante. De forma ilegal se utiliza en la elaboración de anfetamina y metanfetamina.

6. El ácido acético asimismo denominado ácido etanoico, ácido metanocarboxílico y ácido del vinagre. Su fórmula es $\mathrm{CH}_{3} \mathrm{COOH}$, entre sus usos lícitos podemos señalar la fabricación de acetato de vinilo, acetato de celulosa, anhídrido acético, fibra de acetato, plásticos y caucho, en curtidurías, en el estampado del percal y teñido de la seda, en la conservación de alimentos, solvente de gomas, resinas, aceites esenciales y muchas otras sustancias, en diversas síntesis orgánicas. De forma ilícita se utiliza como precursor secundario en la preparación clandestina de la fenilcetona (1-fenil-2-propanona o P-2-P), que a su vez se emplea en la síntesis de la anfetamina y metanfetamina. También se utiliza como precursor secundario para preparar anhídrido acético, o se mezcla con este, con el fin de elaborar heroína. El ácido acético esta fiscalizado por la OEA, Kirguistán, Polonia, Tailandia y Afganistán.

7. El ácido acético glacial cuya fórmula es $\mathrm{CH}_{3} \mathrm{COOH}$, conocido también como ácido metacalboxílico o ácido etanóico. Es un compuesto puro (99,8\% mínimo), que lo diferencia de las soluciones acuosas frecuentemente halladas y que reciben el nombre de ácido acético. Se dice que no es más que ácido acético concentrado al $98.8 \%$ y que se le llama glacial porque al congelarse forma cristales. Esta sustancia es líquida, tiene un fuerte olor a vinagre, no posee agua, es inflamable y es infinitamente soluble. Se utiliza en la limpieza de manchas. En medicina se aplica como tinte en colonoscopias, como auxiliar en la detección del papiloma humano, fabricación de acetato de vinilo, rayón, acetato de celulosa. En apicultura se utiliza para controlar la plaga de polillas en la cera. Está incluido en la lista de vigilancia internacional especial limitada de sustancias no incluidas en los Cuadros de la Convención de 1988, debido a su posible utilización directa en laboratorios de heroína y como tapadera para ocultar anhídrido acético de contrabando.

8. El ácido fórmico que se conoce además como ácido metanóico, ácido hidrógeno carboxílico y ácido amínico. Su fórmula molecular es $\mathrm{HCOH}$, de forma lícita se utiliza como agente desencalador, agente reductor en el teñido indeleble de lana, en curtidos, en la depilación e hinchamiento de los pellejos, en galvanizado, en la coagulación del látex natural, en la regeneración del caucho usado y en análisis químico. De manera ilícita se usa en la producción de anfe- 
tamina, metanfetamina y MDA. Esta sustancia no catalogada se encuentra fiscalizada en Argentina y Costa Rica.

9. El ácido fosfórico también denominado ácido ortofosfórico es un compuesto químico ácido de formula $\mathrm{H}_{3} \mathrm{PO}_{4}$ esta sustancia tiene un aspecto líquido transparente, ligeramente amarillento. Normalmente el ácido fosfórico se almacena y distribuye en disolución. Se obtiene mediante el tratamiento de rocas de fosfato de calcio con ácido sulfúrico, filtrando posteriormente el líquido resultante para extraer el sulfato de calcio. Otra manera de obtención consiste en quemar vapores de fósforo y tratar el óxido resultante con vapor de agua. De forma lícita se emplea como ingrediente de bebidas no alcohólicas como por ejemplo la gaseosa (aditivo alimentario E-338), como pegamento de prótesis dentales, como catalizador, en metales inoxidables y para fosfatos que se utilizan como ablandadores de agua, fertilizantes y detergentes. También es bastante usado en laboratorios químicos en la preparación de disoluciones tampón o reguladoras del PH. De forma ilícita se usa como sustituto del ácido sulfúrico en la elaboración de cocaína.

10. El ácido hidriódico es la solución acusa del yoduro de hidrogeno. Se obtiene en estado de gas mediante la destilación de una parte de fósforo con 8 de yodo, y un poco de agua. Este gas no tiene color; tiene un olor análogo al del ácido hidroclórico, y un sabor muy ácido; al contacto del aire forma vapores visibles por la humedad que atrae; su densidad es la del aire, como 4,4 es á I,0; contiene la mitad de su volumen de gas de hidrógeno. De forma lícita se utiliza en la fabricación de yoduro, medicamentos, tintes, elaboración de sabores, como desinfectante y compuesto de yodo orgánico. De forma ilícita se usa en la elaboración de estimulantes de tipo anfetamínico.

11. El ácido hipofosforoso se puede escribir $\mathrm{H}_{3} \mathrm{PO}_{2}$ pero una presentación más adecuada es $\mathrm{HOP}(0) \mathrm{H}_{2}$ que pone de relieve su carácter monopróctico. Esta sustancia se utiliza de forma lícita en la fabricación de productos farmacéuticos, decoloración de los polímeros, tratamiento de aguas, en la recuperación de metales preciosos o no ferrosos. Su uso principal es para el recubrimiento electrolítico. Como uso ilícito de esta sustancia hay que decir que puede reducir yodo elemental para formar el ácido yodhídrico (precursor secundario), que es un agente eficaz para reducir efedrina y seudoefedrina que se utilizan para la elaboración de metanfetamina. El ácido hipofosforoso y sus sales están fiscalizados en los Estados Unidos de América y el Canadá.

12. El ácido mandélico o ácido fenilglicólico es un hidrocarburo aromático cuya fórmula química es $\mathrm{C}_{8} \mathrm{H}_{8} \mathrm{O}_{3}$. Es blanco, cristalino y parcialmente soluble en agua. Tiene numerosas aplicaciones en la industria cosmética, especialmente en el tratamiento de imperfecciones en la piel, la hiperpigmentación y tratamientos antienvejecimiento. Como fármaco se emplea en el tratamiento de infecciones del tracto urinario. De forma ilícita se utiliza en la elaboración del ácido fenilacético y por ende de la P-2-P, ambos precursores de drogas. 
13. El ácido nítrico también conocido como trioxonitrato $(V)$ de hidrógeno. Su fórmula química es $\mathrm{HNO}_{3}$ es un líquido corrosivo y tóxico que puede ocasionar graves quemaduras. Sobre sus propiedades físicas podemos decir que es un líquido viscoso, incoloro e inodoro, en muchas ocasiones distintas impurezas lo colorean de amarillo-marrón. Es utilizado como reactivo de laboratorio, para fabricar explosivos como la nitroglicerina y trinitrotolueno (TNT), así como fertilizantes como el nitrato de amonio. Tiene usos adicionales en la metalurgia y en refinado, ya que reacciona con la mayoría de los metales y en la síntesis química. De manera ilícita se usa como sustituto del ácido sulfúrico en la elaboración de cocaína. Esta sustancia está fiscalizada en Perú.

14. El ácido tartárico también conocido como ácido dihidroxisuccínico o ácido 2,3 dihidroxibutanodioico, cuya fórmula molecular es (CO$\mathrm{OH})(\mathrm{OH}) \mathrm{HCCH}(\mathrm{OH})(\mathrm{COOH})$, se utiliza de manera lícita en la elaboración de gaseosas, dulces, pan, postres de gelatina, en fotografía, curtiduría, alfarería, en la preparación de tartratos, en productos farmacéuticos y como tampón, además hay que decir que esta sustancia es un subproducto de la industria de la elaboración del vino. De forma ilícita se usa en la purificación de la morfina básica antes de su conversión en heroína y en la preparación de tartratos de heroína. Hay que señalar que esta sustancia no es indispensable para la elaboración de la heroína, pero sirve para aumentar la pureza del producto final, de hecho se ha encontrado en algunos laboratorios clandestinos. Lo mismo puede ocurrir con la fabricación ilegal de metilanfetamina, es decir que aunque no se utilice en la síntesis directa de esta droga, se puede usar para aumentar el nivel de pureza de la misma.

15. El ácido yodhídrico o yoduro de hidrógeno en solución acuosa, cuya fórmula molecular es HI. Tiene los siguientes usos lícitos: síntesis de compuestos orgánicos e inorgánicos del yodo, desinfectante, en química como reactivo, en farmacia como suplemento, jarabe de ácido yodhídrico, de las dietas deficientes en yodo. De manera ilegal se utiliza como reductor en la preparación de la metanfetamina, en los laboratorios clandestinos es frecuente que se prepare el ácido yodhídrico por reacción a partir de fósforo rojo, yodo y agua. Esta sustancia no catalogada está fiscalizada en Argentina y los Estados Unidos de América.

16. El alcohol butílico normal también denominado alcohol butílico, 1-butanol, n-butanol, hidróxido butílico, 1-hidroxibutano y n-propilcarbinol. La fórmula molecular de esta sustancia es $\mathrm{CH}_{3}\left(\mathrm{CH}_{2}\right)_{3} \mathrm{OH}$, se utiliza de forma lícita como: solvente de grasas, ceras, resinas, gomas laca, barnices y gomas, se usa en la fabricación de lacas, rayón y detergentes. Como uso ilícito podemos decir que se utiliza como solvente de la cocaína básica y del ácido clorhídrico en la conversión de la cocaína básica en clorhidrato de cocaína. Esta sustancia se encuentra fiscalizada en Colombia.

17. El alcohol butílico secundario o 2-butanol, 2-hidroxibutano y metiletilcarbinol tiene por fórmula $\mathrm{CH}_{3} \mathrm{CH}_{2} \mathrm{CH}(\mathrm{OH}) \mathrm{CH}_{3}$ se utiliza de forma legal en síntesis 
de la metiletilcetona (sustancia catalogada), en preparación de agentes de flotación, sabores, perfumes, tintes, humectantes, fabricación de detergentes industriales, como quita pinturas, como solvente de resinas naturales y de aceites de linaza y ricino. De forma ilícita se utiliza en la producción de cocaína y de la metiletilcetona.

18. El alcohol etílico conocido asimismo como etanol, alcohol, alcohol anhidro, hidróxido de etilo y metilcarbinol, cuya fórmula molecular es $\mathrm{CH}_{3} \mathrm{CH}_{2} \mathrm{OH}$ y se usa de manera lícita en la producción de bebidas alcohólicas, solvente industrial, aditivo antidetonante de la gasolina, en perfumería, síntesis orgánica y en la elaboración de productos farmacéuticos. De forma ilícita se utiliza como solvente en la transformación de la cocaína básica en el clorhidrato de cocaína. Esta sustancia se encuentra fiscalizada por la OEA.

19. El alcohol isobutílico también conocido como isobutanol, 2-metil-1propanol, isopropilcarbinol, y 1-hidroximetilpropano. Su fórmula molecular es $\left(\mathrm{CH}_{3}\right)_{2} \mathrm{CHCH}_{2} \mathrm{OH}$. Se utiliza de forma legal en la síntesis de ésteres para preparar aromas sintéticos de frutas, como solvente en la fabricación de quita pinturas y quita barnices. De forma ilegal se usa en la conversión de cocaína básica en clorhidrato de cocaína. En este proceso es empleado para disolver el ácido clorhídrico, hay que señalar que no es indispensable en este procedimiento ya que puede sustituirse por otros alcoholes. Esta sustancia se encuentra fiscalizada en Argentina, Colombia y Ecuador.

20. El alcohol isopropílico o isopropanol, isopropilo alcohol, 2-propanol, dimetil carbinol, petrohol, alcohol propílico secundário, IPA. Su fórmula molecular es $\left(\mathrm{CH}_{3}\right)_{2} \mathrm{CHOH}$ tiene como usos lícitos los siguientes: solvente, extractador, deshidratante, descongelante y desinfectante. Se emplea como materia prima en la producción de acetona, por lo tanto es un precursor secundario, y de otros compuestos. El alcohol isopropílico de primera calidad se utiliza para componer productos higiénicos, como, cremas para la piel, preparados para el cabello y esmalte para uñas. De forma ilícita se utiliza para la conversión de la cocaína básica en clorhidrato de cocaína. Esta sustancia no catalogada está fiscalizada en Argentina, Colombia, Costa Rica, Ecuador y Jamaica.

21. El alcohol metílico conocido también como metanol; carbinol, alcohol de madera, cuya fórmula molecular es $\mathrm{CH}_{3} \mathrm{OH}$ es un líquido movedizo, transparente e incoloro; al arder produce una llama azulada. De forma lícita se usa como solvente industrial, anticongelante; aditivo antidetonante de la gasolina; para la desnaturalización del alcohol etílico (etanol), materia prima para la producción de formaldehído, y de los ésteres metílicos de los ácidos orgánicos e inorgánicos y como solvente de uso farmacéutico. De forma ilícita se utiliza como solvente en la conversión de la cocaína básica en el clorhidrato. Esta sustancia está fiscalizada en Colombia y está comprendida en los cuadros del Reglamento modelo para el control de sustancias químicas que se utilizan en la elaboración ilícita de drogas de la OEA. 
22. El amoníaco o amoníaco anhidro, álcali volátil cuya fórmula es $\mathrm{NH}_{3}$, se usa de forma lícita como: fertilizante, para preparar fertilizantes, para la elaboración de compuestos que contienen nitrógeno tanto orgánicos como inorgánicos, como refrigerante, catalizador de reacciones de condensación, fibras sintéticas, agente neutralizante y preparación de explosivos. De manera ilegal se utiliza para la elaboración de cocaína y para la conversión del clorhidrato de cocaína en crack, además se usa en la elaboración de metanfetamina. Esta sustancia está fiscalizada en Arabia Saudita, Argentina, Colombia, Costa Rica, Ecuador, Perú y la República Bolivariana de Venezuela.

23. El anhídrido isatóico $\mathrm{C}_{8} \mathrm{H}_{5} \mathrm{NO}_{3}$ es un polvo blanco cristalino de color amarillo. Como usos lícitos podemos señalar los siguientes: intermediarios de colorantes, intermedios farmacéuticos. Se utiliza de forma ilícita para elaborar metacualona.

24. El anhídrido propiónico o anhídrido del ácido propiónico, anhídrido propanóico y anhídrido metilacético, cuya fórmula molecular es $\left(\mathrm{CH}_{3} \mathrm{CH}_{2} \mathrm{CO}\right)_{2}$. Se usa de forma lícita como esterificante de la celulosa, los aceites de perfumería, las grasas, en la producción de resinas alquídicas, tintes y fármacos, rehidratante en reacciones de sulfonación y nitración. De forma ilegal se usa en la producción de fentanilo, la meperidina y sustancias análogas. Esta sustancia no catalogada está fiscalizada en Bahamas, los Estados Unidos de América y Suiza.

25. El benceno es también denominado benzol o ciclohexanotrieno. Su fórmula molecular es C6H6. Como usos lícitos se conocen los siguientes: solvente de ceras, resinas, aceites, preparación del etilbenceno, cumeno, ciclohexano, fabricación de barnices y lacas, como ingrediente de ciertos combustibles motores. De manera ilegal se utiliza como solvente en la conversión de la cocaína básica en clorhidrato de cocaína y en la elaboración de la fenciclidina. Esta sustancia está fiscalizada por la OEA.

26. El benzaldehído es conocido a la vez como aldehído benzoico y aceite sintético de almendras amargas, y su fórmula molecular es $\mathrm{C}_{6} \mathrm{H}_{5} \mathrm{CHO}$. Es un compuesto químico que consiste en un anillo de benceno con un sustituyente aldehído. Es el representante más simple de los aldehídos aromáticos y uno de los miembros industrialmente más usados de esta familia de compuestos. Se usa de forma legal en la fabricación de tintes y perfumes, en la obtención de ácidos cinámico y mandélico, como solvente en la preparación de aromatizantes, fármacos y productos para la agricultura. De sus usos ilícitos se puede decir que se emplea en la elaboración de anfetaminas, metanfetaminas y como sucedáneo de un precursor de drogas, del Cuadro I, el 1-fenil-2-propanona (P2-P). El benzaldehído se encuentra fiscalizado en Arabia Saudita, Argentina, Costa Rica, los Estados Unidos de América, la Unión Europea y Suiza.

27. El bicarbonato de sodio denominado también carbonato ácido sódico o sosa de cocer. Su fórmula molecular es $\mathrm{NaHCO}_{3}$. Entre su múltiples usos lícitos ci- 
tamos los siguientes: obtención de sales de sodio, generación de dióxido de carbono, preparación de polvos de cocer, sales y bebidas efervescentes, en extintores de incendios y material de limpieza, en medicina veterinaria, como antiácido (alcalificante) sistémico y de la orina. De forma ilícita se utiliza como material alcalino en la producción de pasta de coca y cocaína básica. También se usa en la elaboración de heroína. Esta sustancia está fiscalizada en Costa Rica y Ecuador.

28. El bricomato de potasio conocido asimismo como dicromato potásico y cromato potásico rojo. Su fórmula molecular es $\mathrm{K}_{2} \mathrm{Cr}_{2} \mathrm{O}_{7}$. De forma lícita se emplea como oxidante en la fabricación de productos químicos orgánicos, en el curtido del cuero, para colorear, pintar y decorar porcelanas, en pigmentos para la imprenta, teñido de maderas, pirotecnia y fósforos de seguridad, en el blanqueo de aceite de palma, cera y esponjas, para impermeabilizar telas y en acumuladores eléctricos para despolarizar pilas secas. Se usa de forma ilegal como oxidante en la preparación de metcatinona.

29. El bricomato de sodio o dicromato sódico, es una sustancia cuya fórmula molecular $\mathrm{Na}_{2} \mathrm{Cr}_{2} \mathrm{O}_{7}$, de manera legal se utiliza como oxidante en la preparación de colorantes, productos químicos orgánicos y tintas, en el curtido al cromo de cueros, en acumuladores eléctricos, en el blanqueo de grasas, aceites, esponjas y resinas, en el refinado de petróleo, en la fabricación de ácido crómico, cromatos y pigmentos de cromo, en preventivos de la corrosión y pinturas anticorrosivas, en el tratamiento de metales, en el electro grabado del cobre, como mordiente en tintorería, para endurecer la gelatina, en la defoliación del algodón y otras plantas. De forma ilícita se utiliza como oxidante en la preparación de la metcatinona.

30. El butanol conocido también como: alcohol butílico, propilcarbinol, N-butil alcohol, 1-butanol, n-butanol que tiene por fórmula $\mathrm{CH}_{3} \mathrm{CH}_{2} \mathrm{CH}_{2} \mathrm{CH}_{2} \mathrm{OH}$, se usa de forma legal como: solvente grasas, resinas, barnices, elaboración de lacas, rayón, detergentes, otros compuestos butílicos, fluidos hidráulicos y como agentes de deshidratación. Esta sustancia se utiliza de forma ilegal para la extracción de base de cocaína, se encuentra fiscalizada en Colombia y Costa Rica.

31. La cafeína también conocida como 1,3,7-trimetilxantina cuya fórmula molecular es $\mathrm{C}_{8} \mathrm{H}_{10} \mathrm{~N}_{4} \mathrm{O}_{2}$ es un alcaloide del grupo de las xantinas, sólido cristalino, blanco y de sabor amargo, que actúa como una droga psicoactiva, levemente disiosativa y estimulante por su acción antagonista no selectiva de los receptores de adenosina. Fue descubierta en 1819 por el químico alemán Friedrich Ferdinand Runge, quien acuñó el término Koffein, un compuesto químico en el café, el cual pasaría posteriormente al español como cafeína. Esta sustancia recibe también otros nombres relativos a los productos que la contienen, como la guaranina (encontrada en la gauraná), mateína (encontrada en el mate) y teína (encontrada en el té), las cuales contienen además algunos alcaloides adicionales como los estimulantes cardíacos teofilina y teobromina y a menu- 
do otros compuestos químicos como plifenoles, los cuales pueden formar complejos insolubles con la cafeína. Esta sustancia de forma ilícita se utiliza en la elaboración de heroína.

32. El carbonato de calcio o sal de calcio del ácido carbónico se presenta en la naturaleza en formas de dos minerales: aragonita y calcita. Su fórmula molecular es $\mathrm{CaCO}_{3}$, se usa de manera legal en la fabricación de pintura, caucho, plásticos, papel, insecticidas y tinta. Como rellenador en la producción de adhesivos, fósforos, lápices, lápices de tiza, linóleo, compuestos aislantes y varillas para soldadura. Como antiácido y complemento dietético del calcio, desacidificante de los vinos, en productos cosméticos, fármacos y antibióticos. De manera ilegal se usa como material alcalino en la elaboración de cocaína básica y también se utiliza en la fabricación de heroína. Esta sustancia se encuentra fiscalizada en el Ecuador y Afganistán.

33. El carbonato de potasio también conocido como cenizas de perla y sal tártara. Su fórmula molecular es $\mathrm{K}_{2} \mathrm{CO}_{3}$. Esta sustancia se usa de forma lícita en la fabricación de jabón, champú líquido, vidrio, loza, obtención de sales potásicas, grabado y litografía, curtido y acabado del cuero, deshidratante de líquidos orgánicos y alcalificante. De manera ilegal se utiliza como alcalificante en la preparación de pasta de coca y base de cocaína. Esta sustancia no catalogada esta fiscalizada por la OEA y Arabia Saudita.

34. El carbonato de sodio tiene los siguientes sinónimos: soda calcinada, ceniza de sosa, soda ASH, carbonato sódico, sequiocarbonato sódico, sosa de cocer, sosa carbonatada, carbonato liviano y sosa de solvay. Su fórmula empírica es $\mathrm{Na}_{2} \mathrm{CO}_{3}$, sobre sus usos lícitos podemos mencionar los siguientes: como suavizante del agua, agente limpiador, aditivo para alimentos, procesamiento de textiles, refinación del petróleo, en la industria fotográfica, fabricación de vidrio, detergente de uso general, preparación de sales de sodio y en química analítica. Este material alcalino se puede usar de forma ilícita para preparar pasta de coca, cocaína básica, heroína, anfetamina y metanfetamina. Esta sustancia se encuentra fiscalizada por la Organización de Estados Americanos (OEA) y Arabia Saudita.

35. El cianuro de bencilo denominado del mismo modo acetonitrilo de benceno, 2-fenilacetonitrilo, alfatoluinitrilo y cianotolueno, cuya fórmula molecular es $\mathrm{C}_{6} \mathrm{H}_{5} \mathrm{CH}_{2} \mathrm{CN}$, se utiliza de forma legal en la síntesis del ácido fenilacético (sustancia catalogada), que se emplea para obtener la penicilina, entre otras síntesis orgánicas. Como usos ilícitos podemos decir que el cianuro de bencilo es un precursor secundario, dado que se usa para producir dos precursores primarios: 1-fenil-2-propanona (P-2-P) y el ácido fenilacético. Esta sustancia no catalogada se encuentra fiscalizada por la OEA, la Unión Europea y Arabia Saudita.

36. El cianuro de potasio llamado del mismo modo sal de potasio del ácido cianhídrico. Su fórmula molecular es KCN y tiene por usos lícitos los siguientes: en 
galvanizado, endurecimiento de superficies metálicas, síntesis orgánica e inorgánica, extracción de oro y de plata de sus minerales, como fumigante de los cítricos y otros árboles frutales. De manera ilegal se utiliza para la preparación de la fenciclidina (PCP) y sustancias análogas.

37. El cianuro de sodio o sal de sodio del ácido cianhídrico, cuya fórmula molecular es NaCN. Esta sustancia tiene como usos lícitos los siguientes: extracción de oro y plata de sus minerales, fumigación de cítricos y otros árboles frutales, preparación del ácido cianhídrico y de muchos cianuros y síntesis orgánicas. Se utiliza de manera ilegal para elaborar fenciclidina y sustancias análogas.

38. El ciclohexano además denominado hexahidrobenceno, hexametileno y hexanafteno, cuya fórmula molecular es $\left(\mathrm{CH}_{2}\right)_{6}$ [cíclica]. Esta sustancia se utiliza de forma legal en la producción de nylon, como disolvente y agente químico intermedio. En la industria del calzado se usa como disolvente. De forma ilícita se emplea como solvente en la preparación de cocaína ya que tiene propiedades similares al tolueno (sustancia catalogada).

39. La ciclohexanona también llamada cetoxametileno o cetona pimélica. Su fórmula molecular es $\left(\mathrm{CH}_{2}\right)_{5} \mathrm{CO}$ [cíclica]. Tiene como usos lícitos los siguientes: solvente del acetato de celulosa, nitrocelulosa, resinas naturales, resinas vinílicas, caucho bruto, ceras, goma laca, DDT y en la obtención de ácido adípico para la producción de nylon. De forma ilícita se utiliza para la elaboración clandestina de fenciclidina. Esta sustancia está fiscalizada en Argentina y Suiza.

40. El cloroformo también conocido como tricloruro de formilo, tricloruro de metano, triclorometano, tricloroformo, cuya fórmula estructural es $\mathrm{CHCL}_{3}$ y que tiene como usos lícitos los siguientes: la producción de fluorocarbono 22 (refrigerante), como solvente de grasas, aceites, caucho, alcaloides, ceras y resinas, como ingrediente en la formulación de medicamentos, cosméticos y como intermediario en la producción de tintas y pesticidas. De forma ilícita se puede utilizar como solvente de uso en la producción de cocaína y heroína. Esta sustancia está fiscalizada por la OEA, Arabia Saudita, China, Kirguistán y Tailandia.

41. El cloruro de acetilo o cloruro de etanoílo cuya fórmula molecular es $\mathrm{CH}_{3} \mathrm{COCL}$, tiene como usos lícitos la síntesis de fármacos y tintes, la determinación de la proporción de agua en líquidos orgánicos, fabricación de lubricantes, de caucho y en reacciones de polimerización. De manera ilegal se utiliza como acetilante en la conversión de morfina en heroína, como todos sabemos el reactivo más común para la transformación de morfina en heroína es el anhídrido acético, el cloruro de acetilo se puede usar en su lugar pero por el inconveniente de su alta peligrosidad se emplea raras veces. Esta sustancia esta fiscalizada en Argentina, el Estado Plurinacional de Bolivia, Costa Rica, Egipto, Honduras, Hong Kong (RAE de China), Pakistán, Paraguay, Polonia, Tailandia y Afganistán. 
42. El cloruro de amonio, cloruro amoniaco o sal amoníaco cuya fórmula molecular es $\mathrm{NH}_{4} \mathrm{Cl}$, tiene como usos lícitos los siguientes: fundente para recubrir el hierro de zinc, en estañado, en pilas secas, tintorería, mezclas anticongelantes, galvanoplastia, limpieza de soldadores, para teñir, para dar lustre al algodón, en polvos detergentes, y para retardar la fusión de la nieve en las pistas de esquí. De forma ilegal se utiliza para ajustar la acidez $(\mathrm{pH})$ en la extracción de la morfina del opio y para la conversión de esta en heroína, esta sustancia catalogada no es indispensable porque en su lugar se pueden utilizar otros ácidos, como el ácido acético. El cloruro de amonio está fiscalizado en Arabia Saudita, Argentina, China, Perú y Afganistán.

43. El cloruro de bencilo también conocido como clorometilbenceno o alfaclorotolueno. Su fórmula molecular es $\mathrm{C}_{6} \mathrm{H}_{5} \mathrm{CH}_{2} \mathrm{Cl}$. Esta sustancia tiene como usos lícitos los siguientes: obtención de plastificantes, alcohol bencílico y ácido fenilacético, en la obtención de sales cuaternarias de amonio (usadas para producir desinfectantes y catalizadores), ésteres de bencilo (ingredientes de aromatizantes y perfumes), tintes de la serie del trifenilmetano, disulfuro de bencilo (antioxidante de lubricantes), bencifenol y bencilaminas. De forma ilícita esta sustancia no catalogada se usa como precursor secundario para producir dos precursores: el ácido fenilacético y 1-fenil-2-propanona, que se usan para producir anfetaminas y metanfetaminas. Esta sustancia se encuentra fiscalizada por la OEA, la Unión Europea y Suiza.

44. El cloruro de tionilo conocido también como oxicloruro de azufre cuya fórmula molecular es $\mathrm{SOCl}_{2}$, se usa de forma lícita para la preparación de cloruros de acilos (como el cloruro de acetilo), para sustituir a los grupos-OH o-SH por átomos de cloro, con los reactivos de Grinard forma sulfoxidos, en las baterías de litio-tionilo. En la industria militar se utiliza en el "di-di", método de producción de agentes nerviosos del tipo G. De manera ilícita se utiliza en la elaboración de la metanfetamina. Esta sustancia fue incluida en el año 2006 en la lista de precursores y productos químicos esenciales fiscalizados en Filipinas.

45. El cornezuelo de centeno o ergot (claviceps purpúrea) es un hongo del grupo de los acomicetos parasito del centeno, pero también de otros cereales. El género claviceps contiene más de 50 especies, todas ellas parasitas de cereales. Se le conoce como el rey de los alucinógenos naturales, pues es la base del LSD y además posee una inusitada complejidad química. El ergot puede llegar a contener hasta 300 alcaloides distintos. Los principales alcaloides con propiedades psicoactivas son: el ácido lisérgico, la ergotamina, la ergometrina (sustancias catalogadas), la ergocristina y la ergocriptina (sustancias no catalogadas), cada una de estas sustancias tiene unas acciones farmacológicas bien diferenciadas, pero todas sirven para elaborar LSD. El cornezuelo de centeno o ergot contiene alcaloides muy tóxicos, así como otros con propiedades medicinales como la ergonovina que tiene utilidad como uterotónica y hemostática. Esta sustancia está fiscalizada en Argentina y Costa Rica. 
46. El diacetato de etilideno, asimismo denominado 1,1-diacetoxietano, diacetato de 1,1-etanodiol y diacetato del acetaldehido. Su fórmula molecular es $\left(\mathrm{CH}_{3} \mathrm{COO}\right)_{2} \mathrm{CHCH}_{3}$. De forma legal se utiliza como fungicida de uso agrícola e intermedio en la fabricación de acetato de vinilo. De manera ilegal su usa para la acetilación de la morfina para producir heroína. Esta sustancia se encuentra fiscalizada en Pakistán y Tailandia.

47. La diacetona alcohol también conocida como: pyranton, 4-hidroxi-4-metil-2pentanona, 4-hidroxi-2-ceto-4-metilpentanona, cuya fórmula empírica es $\mathrm{C}_{6} \mathrm{H}_{12} \mathrm{O}_{2}$, tiene como usos lícitos los siguientes: solvente de diferentes sustancias (acetato de celulosa, nitrocelulosa, grasas, aceites, resinas, ceras), en la conservación de fármacos, en soluciones anticongelantes, fluidos hidráulicos, intermedio en la preparación de óxido de mesitilo, metilsobutilcetona y hexilenglicol. Esta sustancia no catalogada es un precursor secundario, pues se usa de forma ilegal para la producción de acetona y por ende para la fabricación de cocaína. Esta sustancia se encuentra fiscalizada en Colombia.

48. El diaclorometano, llamado además cloruro de metileno o bicloruro de metileno. Su fórmula molecular es $\mathrm{CH}_{2} \mathrm{C}_{12}$, se usa de forma legal como solvente de acetato de celulosa, fluido desengrasador y detergente, solvente usado en la elaboración de alimentos (por ejemplo el café), en quita pinturas y quita barnices. De forma ilegal se usa como solvente en la producción de clorhidrato de cocaína. Esta sustancia se encuentra fiscalizada por la OEA.

49. La dietilamina o amina dietílica cuya fórmula molecular es $\left(\mathrm{C}_{2} \mathrm{H}_{5}\right)_{2} \mathrm{NH}$. De forma lícita se utiliza en la producción de aceleradores de la vulcanización, agentes de flotación, resinas, tintes y fármacos. Como usos ilícitos podemos señalar que se utiliza en la obtención de la dietiltriptamina (DET) que es un alucinógeno sintético y de la dietilamina del ácido lisérgico (LSD). Esta sustancia está fiscalizada en Arabia Saudita, Argentina y Suiza.

50. El dióxido de manganeso u óxido de manganeso cuya fórmula es $\mathrm{MnO}_{2}$ conocido también como pirolusita, es el óxido más importante del manganeso, pero no el más estable. Se utiliza de forma lícita en la elaboración de pinturas y barnices, para pintar cristales y cerámica, en la obtención de cloro de yodo, como agente oxidante en síntesis orgánica y como despolarizador en pilas secas. De manera ilegal se transforma en manganato de potasio y posteriormente en permanganato de potasio en laboratorios clandestinos de Colombia, que a su vez abastecen a laboratorios ilícitos que se dedican a fabricar cocaína.

51. La ergocristina es uno de los alcaloides extraídos del cornezuelo de centeno o ergot (del género claviceps) que es un hongo del grupo de los acomicetos, parásito del centeno, pero también de otros cereales, se conoce como el rey de los alucinógenos naturales pues es la base del LSD. Tiene una mezcla de alcaloides extremadamente variable, de estos los principales alcaloides con propiedades psicoactivas son: el ácido lisérgico, la ergotamina, la ergometrina (sustancias catalogadas), la ergocristina y ergocriptina (sustancias no catalo- 
gadas). La fórmula química de la ergocristina es $\mathrm{C}_{35} \mathrm{H}_{39} \mathrm{~N}_{5} \mathrm{O}_{5}$ es un precursor del LSD no sometido a fiscalización internacional. Se empieza a darle seguimiento a raíz del descubrimiento de unas desviaciones de esta sustancia y de ergotamina en Eslovaquia en el año 2003.

52. El éter de petróleo también denominado nafta, nafta de petróleo, petróleo y bencina. De su fórmula podemos decir que es una mezcla de las fracciones ligeras del petróleo, compuesta principalmente de pentanos $\left(\mathrm{C}_{5} \mathrm{H}_{12}\right)$ y hexanos $\left(\mathrm{C}_{6} \mathrm{H}_{14}\right)$. Esta sustancia se utiliza principalmente por las compañías farmacéuticas como solvente en el proceso de formación de fármacos. De forma ilícita se usa como solvente para producir aceite de hachís a partir de la marihuana, también se utiliza en la producción de cocaína. Esta sustancia esta fiscalizada en Ecuador y Perú.

53. La etilamina conocida como monoetilamina, aminoetano y etanoamina. Su fórmula molecular es $\mathrm{CH}_{3} \mathrm{CH}_{2} \mathrm{NH}_{2}$ y su fórmula condensada es $\mathrm{C}_{2} \mathrm{H}_{7} \mathrm{~N}$, la etilamina es gaseosa a temperatura ambiente pero se licua por debajo de $161 / 4 \mathrm{C}$. Es un gas fuerte con olor amonical. Se usa de forma lícita en la producción de herbicidas, estabilizante del látex del caucho, en la producción de tintes, fármacos y resinas. De sus usos ilícitos podemos decir que sirve, junto con la fenilacetona (P-2-P), para la síntesis de la N-etilanfetamina, junto con la 3,4metilenodioxifenil-2-propanona, para la síntesis de la 3,4-metilenodioxi-Netil-anfetamina (MDE). Esta sustancia no catalogada está fiscalizada en Bahamas, Costa Rica, los Estados Unidos de América, la Unión Europea y Suiza.

54. La fenilacetamida conocida también como acetanilida tiene por fórmula química $\mathrm{C}_{8} \mathrm{H}_{9} \mathrm{NO}$ es una sustancia química sólida e inodora con apariencia de hoja o copo. Esta sustancia no catalogada se usa como inhibidor en el peróxido de hidrogeno y para estabilizar barnices de éster de celulosa, como acelerador de la síntesis del caucho, tintes y síntesis intermedia de tinte y síntesis de alcanfor. De forma ilícita se utiliza en la elaboración de metanfetamina.

55. El fenilacentronilo tiene por fórmula química $\mathrm{C}_{8} \mathrm{H}_{7} \mathrm{~N}$ es un líquido aceitoso, incoloro y de un olor característico, se puede usar como materias primas para su elaboración el cloruro de bencilo y cianuro de sodio. El fenilacentronilo de forma legal se utiliza como intermediario en la síntesis de otros productos químicos y como reactivo de laboratorio. De forma ilícita se usa en la elaboración de metanfetamina. Esta sustancia esta fiscalizada en Japón.

56. El fenilacetato de etilo también conocido como etil fenilacetato o éster etílico del ácido fenilacético es un líquido transparente ligero cuya fórmula es $\mathrm{C}_{10} \mathrm{H}_{12} \mathrm{O}_{2}$. Es un producto destinado para uso industrial como ingrediente en la fabricación de mezclas, también se utiliza en la elaboración de sabores y fragancias para cosméticos y jabones. De forma ilícita se utiliza para obtener ácido fenilacético para elaborar metanfetamina. La sustancia en cuestión se ha encontrado en laboratorios clandestinos de drogas en México. 
57. El fenilacetilcarnibiol conocido como l-fenilacetilcarnibiol(l-PAC) o 1hidroxi-1-fenil-propan-2-ona tiene por fórmula química $\mathrm{C}_{9} \mathrm{H}_{10} \mathrm{O}_{2}$ es un compuesto organico derivado del benzaldehído. De su apariencia podemos decir que es un polvo ligeramente amarillento. El fenilacetilcarnibiol es sintetizado mediante el benzaldehído y glucosa. La gran mayoría de la fabricación de esta sustancia se realiza en grandes industrias farmacoquímicas en la India, país que ha logrado perfeccionar el método de producción, reduciendo considerablemente los costes de producción. Esta sustancia no catalogada se utiliza principalmente para la elaboración de dos sustancias la efedrina y la seudoefedrina (precursores de drogas).

58. La formamida o metanamida cuya fórmula molecular es $\mathrm{HCONH}_{2}$, se usa de forma legal como solvente ionizante, en la preparación de ésteres fórmicos, reblandecedor del papel, en colas animales y gomas solubles en agua. De forma ilegal se utiliza en la producción de anfetaminas y MDA. Esta sustancia está fiscalizada en Argentina, Bulgaria y la Unión Europea.

59. El formiato de amonio o formiato amónico también sal de amonio del ácido fórmico, tiene por fórmula $\mathrm{HCOONH}_{4}$, se utiliza en el análisis químico, especialmente para precipitar los metales ordinarios de las sales de los metales nobles (como oro o platino). De manera ilegal se usa en la producción de anfetaminas y MDA.

60. El fósforo rojo cuyo símbolo atómico es $\mathrm{P}$, se utiliza de forma lícita en la pirotecnia, en la fabricación de fósforos, en síntesis orgánica, obtención del ácido fosfórico, fosfina, anhídrido fosfórico, tricloruro y pentacloruro de fósforo, fabricación de fertilizantes, plaguicidas, granadas incendiarias, bombas fumígenas y balas trazadoras. De forma ilícita se usa en la producción de la metanfetamina y otros estimulantes de tipo anfetamínico, como la desomorfina o Krokodil. Esta sustancia está fiscalizada en Canadá, México, los Estados Unidos de América y la Federación de Rusia.

61. La gamma-butirolactona (GBL) también conocida como butirolactona tiene por fórmula química C4H6O2 y es un higroscópico líquido incoloro aceitoso con una característica débil olor y es soluble en agua. El GBL es un común disolvente y reactivo en química y se usa como un compuesto de aroma, como eliminador de manchas, como pegamento removedor, como separador de pintura, y como disolvente en algunos condensadores electrolíticos de aluminio de mojado. En los seres humanos actúa como un profármaco para $\mathrm{GBH}$, y se utiliza como un intoxicante de recreo con efectos similares al alcohol. Si al GBL se le añade hidróxido sódico se obtiene la droga ácido gamma-hidroxibutírico GBH la cual también se puede sintetizar a través del tetrahidorfurano. La gamma-butirolactona está fiscalizada en la Unión Europea y los Estados Unidos de América. Es necesario puntualizar que a través del acuerdo del pleno no jurisdiccional de la sala de lo penal del Tribunal Supremo español se establece que a la GBL debe dársele el mismo tratamiento que a la GBH, es decir debe ser con- 
siderada como droga que causa grave daño a la salud. Este criterio es seguido por la sentencia del Tribunal Supremo del 15 de diciembre del 2004.

62. La gasolina, espíritu de motor o gasolina automotor libre de plomo, además de ser el combustible de vehículos a motor, se utiliza de forma ilícita en la elaboración de cocaína y desomorfina. Esta sustancia está fiscalizada en Colombia mediante la resolución 001 del 13 de mayo de 1996 del Consejo Nacional de Estupefacientes (CNE) y las resoluciones (del mismo organismo) 0005 a 0015 de octubre del 2001 por medio de la cual se estableció que las personas naturales o jurídicas que vendan, distribuyan, compren o almacenen gasolina, diésel y kerosene en cantidades superiores a 55 galones al día deberán llevar un registro diario de esas transacciones. Hay que destacar que por mandato de las resoluciones 001 a 011 del mes de noviembre del 2002 del CNE los controles sólo se deben llevar en algunos departamentos y municipios del país. Se deben ver las resoluciones 014, 015, 018 y 0017 del 3 de diciembre del año 2004, así como la resolución 005 del 10 de febrero del 2006. Donde se establece que la gasolina se encuentra actualmente en la "lista de sustancias químicas sometidas a control especial", esta sustancia también está fiscalizada en Bolivia.

63. El hexano o diopropil, conocido también como N-exilhidruro, caproil hidruro, $\mathrm{N}$-hexano, hidrido de caproílo e hidrido hexílico, su fórmula empírica es $\mathrm{C}_{6} \mathrm{H}_{14}$, como usos lícitos señalamos los siguientes: constituyente de solventes, preparación de adhesivos de secado rápido, industria del caucho y extracción de aceites vegetales. En la industria petrolera es muy utilizado como solvente, también se usa para determinar el índice de refrigeración de minerales. De forma ilegal se usa para transformar cocaína en clorhidrato de cocaína. El hexano se ha descubierto en muestras de clorhidrato de cocaína confiscadas en los Estados Unidos de América y en América Latina. Esta sustancia no catalogada está fiscalizada en Argentina, el Estado Plurinacional de Bolivia, Colombia, Costa Rica, Ecuador, Perú y Jamaica.

64. El hidróxido de amonio también conocido como agua amoniacal, amoniaco acuso o monohidrato de amonio, cuya fórmula es $\mathrm{NH}_{4} \mathrm{OH}$ y tiene los siguientes usos lícitos: en la industria textil, fabricación de rayón, caucho, fertilizantes, refrigeración, condensación, polimerización, fotografía en el revelado de imágenes latentes, productos farmacéuticos, jabones amoniacales, lubricantes, tratamiento de maderas para hacerlas incombustibles, fabricación de tintas, explosivos, cerámica, compuestos amónicos, saponificación de grasas y aceites, detergente, aditivo de alimentos, limpiador doméstico y en síntesis orgánica. Esta sustancia no catalogada se utiliza en la producción de pasta de coca, cocaína básica y heroína. Se encuentra fiscalizada por la OEA y Arabia Saudita.

65. El hidróxido de calcio también denominado hidrato cálcico, hidrato de cal, cal hidratada y cal apagada tiene como fórmula $\mathrm{Ca}(\mathrm{OH})_{2}$. Esta sustancia no catalogada se usa de forma legal en diversos materiales para la construcción y pavimentación, como argamasas, cementos y yesos, en lubricantes, fluidos de 
perforación, plaguicidas, recubrimientos incombustibles, pintura al agua, en el tratamiento de aguas y en la fabricación de pulpa de papel. Se utiliza de forma ilícita como material alcalino en la producción de pasta de coca, cocaína básica y morfina. Esta sustancia se encuentra fiscalizada en Argentina, Bolivia y Perú.

66. El hidróxido de potasio llamado además hidrato de potasio, potasa cáustica y lejía de potasa, cuya fórmula es KOH. Tiene por usos lícitos los siguientes: fabricación de jabón líquido, quita pinturas, quita barnices, en galvanoplastia y fotograbado, alcalificante (en farmacia), para tintas de imprenta, absorbente del $\mathrm{CO}_{2}$ y mordiente de madera. De manera ilícita se utiliza como material alcalino en la producción de pasta de coca y cocaína básica, también se utiliza en la elaboración de metanfetamina. Esta sustancia no catalogada esta fiscalizada por la OEA y Arabia Saudita.

67. El hidróxido de sodio asimismo denominado sosa cáustica, lejía de sosa y cáustico blanco tiene por fórmula $\mathrm{NaOH}$. Esta sustancia se usa de forma lícita en las soluciones que se utilizan para neutralizar ácidos y preparar sales de sodio, por ejemplo en el refinado del petróleo para extraer los ácidos sulfúricos y orgánicos. Se emplea para tratar la celulosa en la fabricación del rayón por el método de la viscosa y para la fabricación de la celofana, en la disolución de telas para la recuperación del caucho, en la fabricación de plásticos, en la hidrólisis de grasas, para formar jabones en la precipitación de alcaloides y de muchos metales de las soluciones acuosas de sus sales y en la preparación de supositorios de glicerina. De manera ilegal se puede utilizar en la producción de pasta de coca y de cocaína básica, además se utiliza en la elaboración de metanfetamina. Esta sustancia no catalogada está fiscalizada por la OEA.

68. El hipoclorito de sodio o sódico igualmente llamado lejía y agua de labarraque tiene por fórmula $\mathrm{NaClO}$. Se usa de forma legal en la producción de lejía, germicida, desinfectante y desodorante. De forma ilícita se utiliza como oxidante en la elaboración de cocaína como sustituto del permanganato de potasio. Esta sustancia no catalogada se encuentra fiscalizada en Costa Rica, Ecuador y Perú.

69. El kerosene también llamado keroseno, kerosina y petróleo lampante se usa de forma legal como combustible para cocinas y lámparas, desengrasador y limpiador, también como solvente para la preparación de cosméticos e insecticidas. Como todos sabemos esta sustancia no catalogada es el líquido orgánico que más se usa en la extracción de la cocaína de las hojas de coca. Se pueden emplear otros líquidos, como la gasolina, pero suelen ser menos adecuados que el kerosene, esto porque la gasolina es demasiado volátil e inflamable. El Kerosene esta fiscalizado en Argentina, Bolivia, Costa Rica, Paraguay y Perú.

70. El manganato de potasio cuya fórmula molecular es $\mathrm{K}_{2} \mathrm{MnO}_{4}$ es un compuesto químico cristalino rombito, además es higroscópico, corrosivo y estable en condiciones ambientales secas. Esta sal de color verde es un intermedio en la síntesis industrial del permanganato de potasio, también se utiliza en la indus- 
tria textil, así como en el tratamiento de aguas residuales, como agente oxidante en síntesis orgánica y el control de olores y bacterias. De forma ilícita se usa en laboratorios clandestinos de Colombia, junto con el dióxido de manganeso, para producir permanganato de potasio para abastecer a los laboratorios clandestinos de cocaína.

71. El metabisulfito sódico cuya fórmula es $\mathrm{Na}_{2} \mathrm{~S}_{2} \mathrm{O}_{5}$ es una sustancia química antioxidante también conocida como pirosulfito sódico. Se suele comercializar como un polvo blanco soluble en agua, y a menudo en combinación con el bisulfito sódico. Su uso más popular es como conservante de alimentos, siendo fácil encontrarlo como elemento para el tratamiento de aguas como agente tensoactivo o en la industria química como un agente reductor. De forma ilícita se utiliza en la elaboración de cocaína.

72. La metilamina también denominada monometilamina y aminometano, tiene la siguiente fórmula $\mathrm{CH}_{3} \mathrm{NH}_{2}$. Entre sus usos lícitos podemos citar los siguientes: la producción de bactericidas, insecticidas, explosivos y de Nmetilpirrolidina (solvente y aditivo de aceites lubricantes). De manera ilegal se utiliza junto con la P-2-P en la producción de metanfetamina y junto con la 3,4-MDP-2-P en la fabricación de la 3,4-metilenodioximetanfetamina (MDMA), así como en la elaboración de otros estimulantes de tipo anfetamínico. Esta sustancia se encuentra fiscalizada en Arabia Saudita, Argentina, Bahamas, Costa Rica, La Unión Europea, los Estados Unidos de América, México y Suiza.

73. La metilisobutilcetona o isopropilacetona, hexona, 4-metil-2-pentanona, MIBK su fórmula estructural es $\mathrm{CH}_{3} \mathrm{COCH}_{2} \mathrm{CH}\left(\mathrm{CH}_{3}\right)_{2}$, esta sustancia tiene como usos lícitos los siguientes: disolvente de pinturas, de barnices, lacas de nitrocelulosa, procesos de extracción, incluida la extracción de uranio a partir de productos de fisión, síntesis orgánicas, desnaturalizante del alcohol, fabricación de alcohol amílico de metilo y como solvente de laboratorio. Se utiliza de forma ilícita como solvente en la producción de cocaína. Esta sustancia no catalogada está fiscalizada en Arabia Saudita, Argentina, el Estado Plurinacional de Bolivia, Colombia, Costa Rica, Ecuador, los Estados Unidos de América, Jamaica y Perú.

74. La N-etilefedrina también denominada etaefedrina o 1-N-etilefedrina. Su fórmula molecular es $\left(\mathrm{C}_{6} \mathrm{H}_{5}\right) \mathrm{CH}(\mathrm{OH}) \mathrm{CH}\left(\mathrm{N}\left[\mathrm{CH}_{3}\right]\left[\mathrm{C}_{2} \mathrm{H}_{5}\right]\right) \mathrm{CH}_{3}$, se utiliza de forma lícita para la elaboración de fármacos de la clase terapéutica de los expectorantes y broncodilatadores. De forma ilícita se utiliza para la elaboración de la N-etil-N-metilanfetamina. Esta sustancia no catalogada estuvo fiscalizada en los Estados Unidos de América hasta el día 16 de abril de 1994.

75. La N-eteilseudoefedrina cuya fórmula molecular es $\left(\mathrm{C}_{6} \mathrm{H}_{5}\right) \mathrm{C}(\mathrm{OH}) \mathrm{HCH}\left(\mathrm{N}\left[\mathrm{CH}_{3}\right]\left[\mathrm{C}_{2} \mathrm{H}_{5}\right]\right) \mathrm{CH}_{3}$. De manera ilegal esta sustancia se utiliza en la preparación de La N-etil-N-metilanfetamina. Fue retirada de la lista de sustancias fiscalizadas en los Estados Unidos de América el día 14 de abril de 
1994. Hay que destacar que en este país no existen productores ni distribuidores de esta sustancia no catalogada.

76. El nitroetano cuya fórmula molecular es $\mathrm{CH}_{3} \mathrm{CH}_{2} \mathrm{NO}_{2}$ se utiliza de forma lícita como solvente de nitrócelulosas, grasas, ceras y tintes, en síntesis orgánica, experimentalmente como líquido propulsor. De manera ilícita se usa para producir 1-fenil-2- propanona (precursor de drogas), anfetaminas, MDA y MDMA. Esta sustancia no catalogada se encuentra cada vez más en los laboratorios clandestinos de drogas de síntesis. Se encuentra fiscalizada por Arabia Saudita, Argentina, Costa Rica, la Unión Europea, los Estados Unidos de América y Suiza.

77. La N-metilefedrina denominada además: 2-dimetilamino-1-fenil-1-propanol, metilefedrina, alfa-[1-(dimetilamino)etil]bencenometanol, alcohol alfa[1- (dimetiamino)etil]bencílico, 1-fenil-1-hidroxi-2-dimetilaminopropano, N, Ndimetinorefedrina. Cuya fórmula es $\left(\mathrm{C}_{6} \mathrm{H}_{5}\right) \mathrm{CH}(\mathrm{OH}) \mathrm{CH}\left(\mathrm{N}\left[\mathrm{CH}_{3}\right]_{2}\right) \mathrm{CH}_{3}$. Esta sustancia se utiliza de manera lícita en síntesis orgánica. De manera ilícita en combinación con él ácido yodhídrico sirve para obtener la N,Ndimetilanfetamina (N,N-DMA). Esta sustancia no catalogada está fiscalizada por los Estados Unidos de América.

78. La N-metilseudoefedrina es una sustancia cuya fórmula molecular es $\left(\mathrm{C}_{6} \mathrm{H}_{5}\right) \mathrm{C}(\mathrm{OH}) \mathrm{HCN}\left(\mathrm{N}\left(\mathrm{CH}_{3}\right)_{2}\right) \mathrm{CH}_{3}$. De forma ilícita en presencia del ácido yodhídrico se convierte en N,N-dimetilanfetamina (N,N DMA). Esta sustancia se encuentra fiscalizada en Bahamas y los Estados Unidos de América. Hay que señalar que aunque la N-metilseudoefedrina se podría utilizar, como señalamos anteriormente, para sintetizar $\mathrm{N}, \mathrm{N}$ dimetilanfetamina, prácticamente nunca se ha encontrado en los laboratorios clandestinos.

79. La orto-toluidina conocida por otros nombres tales como: ortoaminotolueno, o-toluidina, orto-metilanilina o 2-aminotolueno, cuya fórmula es $\left(\mathrm{CH}_{3}\right) \mathrm{C}_{6} \mathrm{H}_{4}\left(\mathrm{NH}_{2}\right)$. Esta sustancia se utiliza de forma legal en la fabricación de diversos tintes, estampado de tejidos en azul oscuro y para hacer inalterables los colores a la acción de los ácidos. De forma ilícita se emplea en la elaboración de la metacualona. Esta sustancia está fiscalizada en Costa Rica.

80. El óxido de calcio conocido también como cal viva, cal o cal fundente cuya fórmula es CaO. Se utiliza de manera legal en materiales para la construcción, en la preparación de productos químicos industriales, en la producción de acero, aluminio y manganesio, en la fabricación de vidrio, fungicidas, insecticidas, fluidos de perforación, lubricantes y tratamiento de aguas. De forma ilícita se usa en la preparación de pasta de coca, cocaína básica y morfina, aunque hay que señalar que se puede sustituir por otras en tales procesos. Esta sustancia está fiscalizada en Argentina, el Estado Plurinacional de Bolivia y Perú.

81. El permanganato de sodio también conocido como permanganato sódico es un compuesto inorgánico cuya fómula es $\mathrm{NaMnO}_{4}$. Es la sal sódica del ácido per- 
manganésico. En esta sal el manganeso actúa con su mayor estado de oxidación, +7. El ion permanganato MnO4 actúa como un poderoso oxidante. Está estrechamente relacionado con el más común permanganato de potasio, pero en general es menos deseable, ya que es más caro de producir. Es principalmente disponible en forma de monohidrato. El permanganato de sodio se comporta de manera similar al permanganato de potasio. Se disuelve fácilmente para dar soluciones de color púrpura oscuro. Se puede elaborar por la reacción del dióxido de manganeso con hipoclorito de sodio. Debido a su alta solubilidad, sus soluciones acuosas se utilizan como agentes de ataque en la fabricación de circuitos impresos y está ganando popularidad en el tratamiento del agua. De forma ilícita se puede usar como sustituto del permanganato de potasio (precursor de drogas) en la elaboración de cocaína, metcatinona y otras drogas de tipo anfetamínico.

82. El peróxido de hidrógeno denominado igualmente agua oxigenada, dióxido de hidrógeno o bióxido de hidrógeno tiene por fórmula $\mathrm{H}_{2} \mathrm{O}_{2}$. Como usos lícitos de esta sustancia no catalogada podemos señalar los siguientes: en la propulsión de cohetes, blanqueante y oxidante de alimentos, en la industria de la pulpa y del papel, como antiséptico y agente limpiador tópico, en preparados farmacéuticos, enjuagues y lociones sanitarias. De manera ilegal se utiliza para sustituir al permanganato de potasio en la oxidación de la cinamoilcocaína. Como esta sustancia es incolora resulta más difícil de dosificar, a pesar de ello, se ha encontrado en algunos laboratorios clandestinos.

83. El sulfato de sodio se conoce de igual manera como: sulfato sódico anhidro, sulfato sódico desecado, torta de sal, thenardita, sulfato sódico decahidratado, sal de Glauber y mirabilita. La fórmula de esta sustancia no catalogada es $\mathrm{Na}_{2} \mathrm{SO}_{4}$ (forma anhidra). El sulfato de sodio se utiliza de forma lícita para colorear y estampar tejidos, normalización de tintes, mezclas frigoríficas, reactivo de laboratorio, fabricación de vidrio, pulpa de papel, secante de líquidos orgánicos. Esta sustancia se usa de forma ilegal en la producción de cocaína. Se ha encontrado con cierta frecuencia en laboratorios clandestinos de América del Sur, aunque no es una sustancia indispensable en la preparación de cocaína, se usa para secar solventes (acetona, éter, etc.) a fin de aprovecharlos de nuevo (reciclaje). Esta sustancia está fiscalizada por la OEA.

84. El thinner (diluyente en español) igualmente denominado solvente stoddard, adelgazante de pinturas o espíritu mineral. Es una mezcla de disolventes de naturaleza orgánica derivados del petróleo. El thinner tiene como disolvente principal al tolueno (sustancia catalogada) y como solvente al benceno (sustancia no catalogada), también se encuentra entre sus componentes: alcohol metílico, cetona o acetona (sustancia catalogada), hexano (sustancia no catalogada), alcoholes, xileno y ésteres. Su composición varía según el fabricante. Se utiliza de forma lícita para diluir pinturas de autos, de aviones o sea recubrimientos caros, además se usa para diluir pegamentos, pinturas de aceite y barnices. Hay que destacar que esta sustancia es en sí misma una droga mar- 
ginal (inhalante) muy nociva que lesiona la estructura del sistema nervioso central, y afecta el organismo humano en muchos aspectos. Se utiliza para la elaboración de la droga sintética conocida como "cristal" (MDMA o éxtasis). Esta sustancia se encuentra fiscalizada en Colombia y Costa Rica.

85. El tiosulfato de sodio también conocido como hiposulfito de sodio, anticloro, hipo o subsulfito sódico, tiene por fórmula $\mathrm{Na}_{2} \mathrm{~S}_{2} \mathrm{O}_{3}$. Sus usos lícitos son los siguientes: extrae el cloro en disolución, sirve de anticloro para el blanqueo de la pulpa del papel, como fijante en fotografía, en la extracción de la plata de los minerales, mordiente en el teñido y estampado de tejidos, reductor en el teñido al cromo, en la fabricación de cuero, en el blanqueo del hueso, la paja y el marfil. De manera ilícita se utiliza en la elaboración de la metanfetamina por reducción de la efedrina (precursor de drogas) con el ácido yodhídrico.

86. El tricloroetileno cuya fórmula es $\mathrm{ClHC}=\mathrm{CCl}_{2}$. Se usa como solvente de grasas, ceras, resinas, aceites, caucho, pinturas, barnices, solvente de ésteres y éteres de celulosa, se utiliza en muchas industrias tales como la del café y especias para la extracción de solventes, en lavado en seco y como quita grasas, en la fabricación de productos orgánicos químicos y farmacéuticos y como ácido en el cloroacético. De forma ilícita se usa solo o con otros solventes en la conversión de cocaína básica en clorhidrato de cocaína. Esta sustancia se encuentra fiscalizada por la OEA.

87. La urea o carbamida tiene por fórmula $\mathrm{CO}\left(\mathrm{NH}_{2}\right)_{2}$, de sus uso lícitos podemos decir lo siguiente: la mayor parte de la urea (el $73 \%$ de la producción) se usa como abono, el resto se dedica a piensos, fabricación de resinas, plásticos, fabricación de papel y como diurético. Esta sustancia no catalogada se utiliza en la producción de pasta de coca, cocaína básica y para la síntesis del ácido barbitúrico.

88. El xileno también denominado dimetilbenceno, xilol, xilenos mixtos. Hay tres xilenos que se diferencian entre sí en su estructura molecular: orto-xileno (1,2-dimetilbenceno), meta-xileno (1,3-dimetilbenceno) y para-xileno (1,4dimetilbenceno). La fórmula de esta sustancia no catalogada es $\mathrm{C}_{6} \mathrm{H}_{4}\left(\mathrm{CH}_{3}\right)_{2}$. Los xilenos mixtos se emplean como antidetonantes en la gasolina y los combustibles de aviación. El orto-xileno se emplea en la producción de anhídrido ftálico (para producir fibras de poliéster) y la fabricación de plaguicidas. El meta-xileno se emplea en la obtención del ácido asoftálico, que a su vez se usa en la fabricación de pinturas, acabados y resinas y en la obtención del nitrilo isoftálico (de uso en productos agroquímicos). El para-xileno (el más importante de los tres comercialmente) se emplea principalmente en la obtención del ácido tereftálico (que se usa en la fabricación de poliésteres), en menor escala se emplea también como solvente para la fabricación de revestimientos y plaguicidas. El xileno se utiliza de forma ilícita como solvente en la conversión de cocaína básica en clorhidrato de cocaína. Esta sustancia se encuentra fiscalizada en Argentina, Colombia, Costa Rica, Ecuador, Jamaica y Perú. 
89. El yodo cuya fórmula es $I_{2}$ se utiliza de forma legal en la producción de soluciones de yodo, germicidas, fungicidas, antisépticos, para reducir la fricción de superficies duras (acero inoxidable, vidrio), como reactivo importante en química analítica y en la obtención de sales de yodo. De manera ilegal se usa en la producción de metanfetamina y fenciclidina (PCP). Esta sustancia está fiscalizada en Argentina y los Estados Unidos de América.

90. El 1-fenil-1-propanona o propiofenona cuya fórmula molecular es $\mathrm{C}_{9} \mathrm{H}_{10}$. Es un líquido de una tonalidad entre incoloro y amarillo pálido, que es insoluble en agua pero miscible con metanol, etanol, éter dietílico, benceno y tolueno. Se utiliza en la síntesis de la efedrina y derivados de la propiofenona como catinona y metcatinona. Es un intermedio útil para la preparación de medicamentos que actúan sobre el sistema nervioso, tales como productos farmacéuticos ansiolíticos y los hipnóticos. De forma ilícita se utiliza para fabricar un precursor de drogas: la P-2-P. 

